\title{
CULTURA MATERIAL, CONSTRUCCIÓN DE IDENTIDADES Y TRANSFORMACIONES SOCIALES EN EL VALLE DE AMBATO DURANTE EL PRIMER MILENIO D. C.
}

Tesis a ser presentada en la Facultad de Ciencias Naturales y Museo

Universidad Nacional de La Plata para optar por el grado de Doctor en Ciencias Naturales

\author{
Autor \\ Marcos Román GASTALDI \\ Director \\ Dr. Andrés G. LAGUENS \\ Codirectora \\ Dra. Bárbara BALESTA
}

Año 2010 


A Guillo por lo compartido... 



AMO las cosas loca,

locamente.

Me gustan las tenazas,

las tijeras,

adoro

las tazas,

las argollas,

las soperas,

sin hablar, por supuesto,

del sombrero.

Amo

todas las cosas,

no sólo

las supremas,

sino

las

infinita-

mente

chicas,

el dedal,

las espuelas,

los platos,

los floreros.

(...).

Yo voy por casas,

calles,

ascensores,

tocando cosas,

divisando objetos

que en secreto ambiciono:

uno porque repica,

otro porque

es tan suave

como la suavidad de una

cadera,

otro por su color de agua

profunda,

otro por su espesor de

terciopelo.

Oh río

irrevocable

de las cosas,

no se dirá

que sólo

amé

los peces,

o las plantas de selva y de

pradera, que no sólo

amé

lo que salta, sube, sobrevive,

suspira.

No es verdad:

muchas cosas

me lo dijeron todo.

No sólo me tocaron

o las tocó mi mano,

sino que acompañaron

de tal modo

mi existencia

que conmigo existieron

y fueron para mí tan existentes

que vivieron conmigo media

vida

y morirán conmigo media

muerte.

Oda a las Cosas

("Odas Elementales" Pablo

Neruda) 
Muchas son las personas que de diversas maneras contribuyeron a que esta tesis pueda ser realizada. En primer lugar quiero agradecer a mi director Andrés Laguens, quien no solo guió el trabajo en un contexto de calidez, libertad y aguda exigencia, si no que también fue una fuente de apoyo permanente. Él, junto a Mirta Bonnin desde mí llegada a Córdoba, propiciaron en el Museo de Antropología un lugar de estímulo y amistad permanente.

En segundo lugar, quiero agradecer a mi codirectora Bárbara Balesta, quien a la distancia me apoyó, proporcionándome consejos, respaldo y orientación académica.

Durante los más de cinco años que duró la elaboración de esta tesis gocé de una beca FONCyT y una beca doctoral otorgada por el Consejo Nacional de Investigaciones Científicas y Técnicas con lugar de trabajo en el Museo de Antropología.

También quiero agradecer a todos los miembros del equipo Ambato: Pepe Pérez Gollán no sólo me envió desde Buenos Aires parte de la bibliografía utilizada en esta tesis, sino que también me ha contagiado su pasión y entusiasmo por la arqueología y me inspiró hondamente oyéndolo relatar sus vivencias en el Ambato. En este mismo sentido agradezco a Sofía Juez y Susana Assandri las largas charlas a través de las cuales pude no sólo conocer más, sino también, y fundamentalmente, acercarme afectivamente al Proyecto Ambato. También quiero agradecer, a todos los compañeros que cotidianamente compartimos mañanas, tardes y noches en el laboratorio y en el Ambato: Andrés Barale, Rita Bargas; Silvia Burgos, Mariana Dantas, German Figueroa, Pepe Hierlin, Quique Lindskoug, Bernarda Marconetto, Verónica Mors, Francisco Pazzarelli, Soledad Salega, José Siles, Gisela Vargas y Emilio Villafañe. Además, con Francisco Pazzarelli, mantuvimos largas disquisiciones sobre las historias de las vasijas analizadas; a su vez leyó las distintas versiones del manuscrito proporcionado ideas y su mirada crítica. Bernarda Marconetto, desde mi incorporación al proyecto me ayudó continuamente en el aprendizaje y conocimiento de las distintas excavaciones realizadas en los años 90, además me enseñó a utilizar la MOTI CAM para observar las huellas de uso. Rita Bargas, en el marco de una ayudantía, me ayudó a procesar mucho del material analizado. Mariana Fabra me aclaró muchas ideas sobre la cerámica del valle. Darío Quiroga me ayudo con los materiales del depósito. En definitiva agradezco a todos los compañeros del Museo de Antropología (FFyH, UNC) por hacer de él un lugar ameno y divertido. 
También quiero agradecer a todas aquellas otras personas además de las nombradas que participaron en los diferentes trabajos de campo: Javier, Marina., Claudina, Gabriel, Valeria, Clara, Agustina, Canela, Micaela, Walter y Alan.

Gabriela Granizo, Marcos Quesada, Enrique Moreno, Leandro D’amore y Claudio Revuelta, a la distancia pero siempre presentes me aportaron bibliografía, consejos, charlas y su inmensa amistad.

Varias personas se interesaron en esta investigación y con ellos mantuve interesantes diálogos que sin duda enriquecieron esta tesis: Inés Gordillo, Cynthia Pizarro; Gustavo Sorá, Ludmila Catela, Axel Lázzari, Almudena Hernando Gonzalo, Alfredo Gonzáles Rubial, Benjamín Alberti, Carlos Fígari, Rafael Curtoni, Carina Jofre, Carolina Lema, Roxana Cattaneo, Andrés Izeta, Sebastián Muñoz, Mariana Mondini, Gustavo Martínez, Eduardo Pautasi, Gisela Osorio y Humberto Mamaní.

Inés Gordillo además me facilitó el acceso a piezas cerámicas del sitio La Rinconada que se hallaban en la dirección de Antropología de Catamarca.

Quiero agradecer también a la familia Allosa de Colpes -Ana y Jorge- y a Justina Seco de Los Castillo por su hospitalidad. A mis compadres Lico y Federico, a mi comadre Lidia, a Pablo, Tomasa y Anita de Tumballa por enseñarme e iniciarme en los caminos de la chicha.

También agradezco a Alejandra Granizo directora de Patrimonio Cultural de la Municipalidad de San Fernando del Valle de Catamarca por permitirme acceder a analizar los materiales Aguda de Ambato que se encuentran en el Museo Adán Quiroga. A la directora de Patrimonio de la Provincia de Catamarca, Natalia Ponferrada, le agradezco por dejarme acceder a analizar los materiales de los sitios Martínez y La Rinconada que se hallan en los depósitos de la Dirección de Antropología de Catamarca. También agradezco al director del departamento de arqueología, Sergio Álvarez, por facilitarme las instalaciones del laboratorio de arqueología de dicha institución.

En mi familia encontré la contención y el estímulo que me mantuvieron en marcha. Mis padres Raquel y José, mis hermanas Laura y Carina, mi abuela Lela y mi tío Te me animaron permanentemente. También conté con el apoyo de mi familia política los Espósitos: Julio, Alejandra, Nico, Luci, Lucas, Bauti, Cande, Pochocha me adoptaron como hijo y me apoyaron siempre. Por último, quiero agradecer a una personas que, desde el inicio, ha sido muy importante en esta historia y en mi vida, Guillermina Espósito, quien no solo participó en esta tesis a través de charlas, críticas, sugerencias, lecturas del 
manuscrito, si no que también y principalmente con su estímulo constante e inmenso amor. A ella está dedicada esta tesis por todo lo compartido.

Todo lo provechoso que de esta tesis pudiese surgir, a ellos. El resto, es de mi exclusiva responsabilidad. 


\section{ÍNDICE GENERAL}

RESUMEN

ABSTRACT 5

$\begin{array}{ll}\text { INTRODUCCIÓN } & 9\end{array}$

CAPÍTULO 1. SUJETOS Y CULTURA MATERIAL: UNA MIRADA DESDE LA ARQUEOLOGÍA DEL VALLE DE AMBATO

La Cultura Material como Símbolo: Figuras Draconianas, Simbología e Identidad Calchaquí en los Orígenes de la Nación

La Cultura Material Como Reflejo: Migraciones Contactos e Influencias "Extranjeras"

I-Figuras Draconianas, Rasgos, Raza y Civilización en la Órbita de Tiahuanaco

II-Lo Draconiano se Transforma: ¿Restos Materiales del Pueblo de los Barriales?, ¿Civilización Material de la Antigua Civilización de los Barriales o ¿Patrimonio de la Cultura de los Barreales

III-La Cultura de los Barreales se Fragmenta: Lo Draconiano como Patrimonio de la Cultura de La Aguada.

La Cultura Material como Indicador: Proceso de Integración Regional y Producción de lo Local

Notas

CAPITULO 2. SUJETOS Y CULTURA MATERIAL RECONSIDERADOS

Su Objetualidad

Su Representación

De la Mutua Constitución de las Cosas y las Personas: Alcanzando la Cosa como Cosa

Notas

Objetos como Sujetos: sus Biografías 
Notas

CAPÍTULO 4. METODOLOGÍA Y TÉCNICA EN EL CAMPO Y EN EL LABORATORIO

Procedencia de la Muestra y Actividades Realizadas en el Campo

Técnicas de Obtención de Datos

Caracterización de las Vasijas para la Reconstrucción de Trayectorias Biográficas

Tratamiento de los Cuerpos

Técnicas de Análisis de los Datos

Notas

CAPÍTULO 5. EL VALLE DE AMBATO

Notas

CAPÍTULO 6. VASIJAS COMO SUJETOS: SUS BIOGRAFÍAS

I Parte. Convirtiéndose en Vasijas...

Las Arcillas Utilizadas

Vasijas de Clase E

Preparando la Pasta

Dándoles Forma

Tamaños Alcanzados

Terminado de las Vasijas

Vasijas de Clase A1

Preparado de la Pasta

Dándoles Forma

Tamaños Alcanzados 
II Parte. Las vasijas una vez terminadas...

¿Dónde son Distribuidas?

Las Vasijas Haciendo: Rastros, Huellas, Contextos y Prácticas...

a) Huellas y Rastros...

Vasijas de Clase E

Vasijas de Clase A1

b) Contextos y Prácticas

Los Contextos del Sitio Martínez 1

Los Contextos del Sitio Martínez 4

Los Contextos del Sitio Martínez 2

279

Los Contextos del Sitio Piedras Blancas

296

Los Contextos del Sitio Iglesia de los Indios

Recapitulando: Vasijas, Contextos y Prácticas

III Parte. Las Vasijas al Romperse...

Notas

Fragmentando los Cuerpos...

Conservando los Cuerpos...

Notas

Mediaciones entre Contingencia y Estructura: las Interfacies como Limen 
CAPÍTULO 9. MEMORIA Y SENTIDO COMÚN: LOS MONTÍCULOS Y LA FIJACIÓN DE SIGNIFICADOS EN EL LARGO TÉRMINO

Los Montículos de Ambato y la Apropiación del Pasado

II- Los Montículos: Sedimentación, Visualización y Monumentalización de un Paisaje

Los Montículos y el Período de Integración Regional

Lo Particular Universalizado: la Fijación de un Pasado y la Constitución de "Una" Memoria Social

Notas

CAPÍTULO 10. DESANDANDO CAMINOS

REFERENCIAS BIBLIOGRÁFICAS

ANEXO 1: EXCAVACIÓN POR UNIDAD ESTRATIGRÁFICA

ANEXO 2: DESCRIPCIÓN DE LOS ATRIBUTOS Y ESTADOS DE ATRIBUTO DE LA CLASIFICACIÓN DEL MATERIAL CERÁMICO

ANEXO 3: DESCRIPCIÓN DE CLASES CERÁMICAS ANALIZADAS

ANEXO 4: VARIABLES PARA LA DESCRIPCIÓN DE LOS MODOS DE USO DE VASIJAS CERÁMICAS

ANEXO 5: RECONSTRUCCIONES ESTRTIGRÁFICAS DEL RECINTO H Y F DEL SITIO PIEDRAS BLANCAS

I Parte. Reconstrucción de Contextos Depositacionales en el RH 
En esta investigación nos interrogamos por las formas de participación de la cultura material en los procesos de construcción de identidades sociales en la segunda mitad del primer milenio de la era en el Valle de Ambato -Catamarca, Argentina-. Este interrogante se vincula a problemáticas mayores, que desde hace al menos 30 años el Proyecto Arqueológico Ambato viene desarrollando en la zona, relacionadas con el surgimiento en el valle -alrededor del cuarto o quinto siglo del primer milenio- de relaciones sociales con mayor grado de exclusión que las formas organizativas anteriores. Estas nuevas relaciones habrían producido la institucionalización de desigualdades sociales inéditas para la región y la época. Concretamente, en este contexto, nos interesa dilucidar las formas específicas en que la cultura material participó en la constitución, legitimación y reproducción de la identidades sociales surgidas como parte del proceso de transformación social mencionado.

El interés de focalizarnos en la participación de la cultura material en los procesos de construcción de identidades responde a la inquietud de que la misma no sólo conforma el registro visible con el que trabajamos los arqueólogos, sino que puede ser considerada un elemento activo -y podríamos plantear un "agente" más- de dicho proceso. Esta posición nos permite marcar ciertas limitaciones, pero también retomar los aportes del lugar históricamente ocupado por la cultura material en las investigaciones que se abocaron a estudiar los procesos de cambio señalados en el Valle de Ambato. La misma fue considerada como reflejo de la influencia de pueblos evolucionados de los Andes Centrales o como indicadora de procesos locales de cambios.

Por otro lado, dentro de un panorama teórico más general, nos permite discutir aquellas posiciones esencialistas, materialistas y constructivistas de la constitución de las identidades y su relación con las cosas, en las que los objetos y sujetos quedaron ubicados en laderas opuestas, permitiéndonos establecer ciertos puentes entre ambos. En este sentido, extraemos a los objetos de aquellos marcos según los cuales éstos se transforman en espejos de esencias reificadas - la cultura en las posiciones normativas-; de aquellos donde éstos adquieren sentido sólo en relación al plexo funcional donde participan, siendo sólo productos de necesidades de los individuos que los preceden -posiciones materialistas 
vinculadas a la Nueva Arqueología- y de aquellos enfoques que pretenden encontrar al sujeto detrás del artefacto, siendo este último solo producto de un red intersubjetiva de significados -visiones constructivistas-.

Retomando la serie de investigaciones producidas recientemente en el Valle de Ambato donde la cultura material fue adquiriendo cada vez más un rol activo, planteamos una posición alternativa donde sujetos y objetos se coproducen activamente en el tiempo.

Así, a nivel metodológico realizamos una inversión de perspectiva: los objetos son analizados como si fueran personas con particulares trayectorias biográficas y los sujetos se analizan como si fueran artefactos, haciendo énfasis en la producción del cuerpo. Ambas perspectivas por sí solas resultan insuficientes para comprender los procesos de construcción de identidades sociales y su vinculación con la cultura material, por lo que finalmente, estas dos perspectivas invertidas son imbricadas construyendo una serie de cartografías donde se observan los encuentros, conjunciones y diseminaciones de estas biografías y los sujetos a los cuales dichos objetos se vincularon.

Un conjunto de objetos son los protagonistas de las biografías que reconstruimos: vasijas de cerámica. Objetos que se mueven por distintas manos y contextos y de esta forma acumulan determinadas historias y diferentes significados sociales. Así, al ir delineando las trayectorias biográficas reconstruidas de estas vasijas iremos transitando por diferentes espacios, escalas y contextos a lo largo de toda la temporalidad señalada.

Las trayectorias biográficas trazadas de estos objetos, son entrecruzadas con las formas materiales en que las personas fueron producidas. Particularmente hacemos hincapié en el cuerpo como ámbito de acción central, tanto en un sentido genético (socialización) como crónico (práctica cotidiana) de la subjetivación.

Las cartografías reconstruidas nos marcan las sendas seguidas por estos objetos y sujetos en el espacio social del Valle de Ambato a lo largo de la temporalidad abarcada, y de esta forma nos permiten mostrar de qué manera en el valle las múltiples agencias humanas y no humanas - continuamente se constituyeron unas a otras en redes de percepción y acción, haceres y saberes, representaciones y prácticas. Por otro lado el análisis de las cartografías reconstruidas en el largo término nos permite comprender de qué forma las mismas lograron producirse y reproducirse a lo largo de al menos siete siglos. 
This research raises questions about the forms of participation of material culture in the construction process of social identities in the Ambato Valley, Catamarca, Argentina during the second half of the first millennium A.D. This question is linked to various issues, which has been investigated for more than 30 years by the "Ambato Archaeological Project" in the Ambato Valley. This in turn is related to the rise in the valley, around the fourth or fifth century of the first millennium of social relations with a greater degree of exclusion in the previous organizational forms, which would have produced the unprecedented institutionalization of social inequality, both in the region and the era. Specifically, in this context, we are interested in elucidating the specific ways in which the material culture involved in the creation, legitimation and reproduction of social identities emerged as part of the process of social transformation mentioned.

The need to focus on the participation of material culture in identity construction processes responded to the concern that it not only shapes the visible record that the archaeologists works with, but could be considered an active element and could us plant another "agent" in that process. This position enables us to highlight some limitations, but also resume the contributions, which historically were occupied by the material culture, in the investigations attempting to study the processes of change identified in the Ambato Valley. It was seen as reflecting the influence of societies evolved in the Central Andes or as an indicator of local processes of change.

On the other hand, within a broader theoretical landscape can allows us to discuss different positions (essential, materialist and constructivist), of the constitution of identities and their relationship to things in which objects and subjects were placed on opposite sides, allowing us to establish bridges between them. In this sense, we extract the objects from the frameworks under which they transformed to reified essences mirrors, the culture in normative positions; from those where they make sense only in relation to an functional plexus where they participate, merely products of the needs of individuals that they precede -materialistic positions linked to the New Archeology-, and those approaches that 
pretends to seek the subject behind the artifact, the latter being the product of a single inter-subjective network of meanings -constructivist views-.

Launching of, within the series of recently produced research in the Ambato Valley, where the material culture is taking an increasingly active role, we propose an alternative position, where subjects and objects are actively co-producing in time.

Thereby, in a methodological level we are realizing a venture in perspective: the objects are analyzed as if they were people with particular biographies and the subjects as if they were like artifacts, emphasizing the production of the body. Both approaches alone are insufficient to understand processes in the construction of social identities and its relationship to material culture, so that ultimately, these two inverted perspectives are interwoven, building a series of maps where they observed the encounters, conjunctions and disseminations of these biographies and subjects to which these objects are linked.

A set of objects are the protagonists of the biographies that we rebuild: ceramic vessel. Objects that move through different hands and contexts and thus accumulate determinant histories and different social meanings. So, when outlining the biographical trajectories reconstructed of these vessels, we are transiting different spaces, scales and contexts throughout the whole marked temporality. The biographical trajectories drawn of these objects are intertwined with the material forms in which people were produced. In particular we stress the body as central scope, both in a genetic sense (socialization) and chronic (daily practice) of subjectivity.

The mapping, reconstructed marks the paths followed scarred by these objects and subjects in the social space in the Ambato Valley along with the temporality covered, and thus allow us to show how the many agencies in valley, both human and nonhuman, continually were forming each other in networks of perception and action, tasks and knowledge, representation and practices. Furthermore the analysis of the reconstructed mapping, in the long term, allows us to understand in what ways these archived to produce and reproduce themselves, throughout at least seven centuries. 


\section{INTRODUCCIÓN}

Para principios de la era cristiana, en el Valle de Ambato -Catamarca, Argentina- se planteó la existencia de cambios profundos en los modos de vida hasta ese momento conocidos (Assandri 2007; Assandri et al 1991; González 1977, 1998; Gordillo 1990, 1995, 2006, 2009; Heredia 1998; Laguens 2002, 2005, 2006a, 2006b; Laguens y Bonnin 1996; Laguens y Juez 1999; Marconetto 2008; Pazzarelli 2006; Pérez Gollán 1986, 1991, 1994, 2000a, 2000b; Pérez et al 1996-97; Pérez et al 2000). Las investigaciones llevadas a cabo en el lugar durante más de 30 años plantearon el surgimiento de una sociedad en la que se habrían institucionalizado nuevas relaciones de poder, inéditas a las entabladas en momentos anteriores. Estas relaciones habrían producido la aparición de desigualdades sociales al interior de los grupos que habitaron el valle en particular y la región del NOA en general. Dichas desigualdades se habrían reproducido gracias al abrigo que cierta ideología religiosa proporcionaba a las "elites" emergentes para su reproducción (Pérez y Heredia 1975; Heredia 1998; Pérez Gollán 1986, 1991, 2000a, 2000b; Pérez Gollán et al 1996-97; Gordillo 1990, 1995, 2006, 2009). En dicho proceso la cultura material adquiriría nuevas dimensiones simbólicas, en función de esa ideología dominante. Las nuevas dimensiones sociales y materiales, que se habrían ido conformando en este proceso, a la vez que formarían un nuevo conjunto de "recursos" -basado en relaciones políticas, activado y manipulado en la ideología- habrían implicado la aparición de nuevas prácticas y estrategias sociales, a través de y por medio de las cuales se habrían reconfigurado las relaciones entre los grupos que habitaban el valle (Laguens 2002, 2005, 2006a, 2006b; Laguens y Bonnin 2005). Este proceso, que para la misma época también se habría dado en otras parte del Noroeste Argentino, fue colocado como un marcador temporal que permitía separar dos períodos históricos, el fin del Período Temprano (González 1961-64, 1977, 1998) o Formativo inferior (Núñez Regueiro 1974) y el comienzo del Período Medio (Gonzáles 1961-64, 1977, 1998) o el Período de Integración Regional (Núñez Regueiro y Tartusi 1990; Pérez Gollán 1986, 1991; Pérez y Heredia 1987), donde las “atomizadas" sociedades formativas se habrían integrado bajo ciertas formas más centralizadas de poder.

Insertándonos en esta discusión, en esta investigación nos interrogamos específicamente por el rol que protagonizó la cultura material en la producción, reproducción y legitimación de las nuevas identidades sociales que habrían surgido como parte de ese proceso de reconfiguración señalado. Partimos del planteo según el cual la cultura material, lejos de ser un elemento pasivo que refleja influencias de pueblos 
evolucionados de los Andes Centrales (Gonzáles 1977, 1998; Gonzáles y Pérez 1976), o que acompaña e indica procesos locales de cambios (Assandri 2007; Gordillo 1990, 1995; Heredia 1998; Pérez y Heredia 1975; Laguens y Bonnin 1996; Pérez Gollán 1986, 1991, 1994; Pérez et al 1996-97; Pérez et al 2000), es un agente activo en la producción y reproducción no sólo de la nuevas relaciones de poder entabladas sino también de los nuevos grupos sociales establecidos (Espósito 2006, 2009; Gastaldi 2007b y 2007c; Gordillo 2006, 2009; Haber et al 1996-97; Laguens 2002, 2005, 2007; Laguens et al 2007; Laguens y Pazzarelli 2007; Pazzarelli 2006; Pérez 2000a y 2000b).

Esta investigación plantea que para llegar a una comprensión más profunda de los procesos de construcción de nuevas relaciones de poder y la conformación de nuevos grupos sociales antes inexistentes, que parecen acontecer en el Valle de Ambato durante el primer milenio, es necesario fusionar la antigua brecha teórica que ubicaba a las cosas y las personas en laderas opuestas de una profunda quebrada. Sostenemos que es necesario considerarlas como constituidas por relaciones recursivas que sostienen a lo largo de sus vidas. Además de esto debemos colocar en el centro de la escena a la constitución de los sujetos. Concretamente cómo estos construyen sus subjetividades e identidades sociales, trazando un puente entre los procesos de construcción ideológica y de subjetivación de las personas. Sólo después de comprender las maneras específicas en que en el Valle de Ambato las personas construyeron sus identidades sociales, y la forma en que la cultura material participó en la conformación, producción, reproducción y legitimación de estas "nuevas" construcciones identitarias, es que podremos acercarnos a las maneras concretas en que determinados grupos de personas se habrían diferenciado del resto y de cómo dichas diferencias pudieron perdurar al menos siete siglos.

Dada la problemática señalada estructuramos la tesis en diez capítulos.

En el capítulo uno abrimos la discusión mostrando los lugares ocupados por la cultura material y, en relación a éstos, el lugar de los sujetos en las distintas investigaciones realizadas en el valle para dar cuenta de este proceso de cambio señalado. Particularmente, nos centramos en discutir las dos visiones que predominaron acerca de la cultura material y que produjeron ciertas limitaciones a la hora de comprender los procesos de transformación de las relaciones sociales: aquella que la comprendió como reflejo de pueblos evolucionados de los Andes Centrales y aquella que la percibió como indicadora de procesos locales de cambio. Ambas visiones le otorgaron un rol pasivo en dichos procesos. Al mismo tiempo, en estas explicaciones los sujetos no sólo tuvieron un lugar pasivo frente a las transformaciones sociales, en tanto se los consideró como reproductores 
de un orden social ya establecido, sino que quedaron ubicados en la ladera opuesta de donde fue colocada la cultura material. Una vez que mostramos los aportes y limitaciones de las perspectivas utilizadas, y retomando algunos planteos recientes sobre los procesos de cambio que estudiamos y su vinculación con la cultura material, en la que ésta comienza a participar más activamente, introducimos en el capítulo dos una propuesta teórica alternativa. Esta propuesta nos brinda la posibilidad de pensar, en primer lugar, a la cultura material como un agente activo en la constitución de la vida social; y en segundo lugar, más vinculado ya con la construcción de las identidades sociales, nos abre la posibilidad teórica de repensar a los objetos y los sujetos como mutuamente constituidos. Para esto, discutimos dos visones particulares de la cultura material -donde entran tanto aquella que la vio como reflejo o como indicadora-: por un lado discutimos la perspectiva que piensa a las cosas desde su objetualidad en sí -visiones normativas y materialistas de la misma-, y por otro lado, aquella que las piensa desde el representar de las personas -visiones interpretativas o constructivitas. Una vez que planteamos esta alternativa, apuntamos ciertos elementos acerca de los procesos de construcción de identidades sociales, que nos llevan a replantear a los sujetos ya no sólo como meros reproductores de un orden social establecido, sino como agentes estructurados y estructurantes de dicho orden.

Desde una posición no esencialista, consideramos a los procesos de construcción identitaria como actos de poder donde la "unidad" que se proclama y se vive como tal nunca es completamente cerrada o suturada; siempre es amenazada por aquello que deja afuera, aquello de lo cual dicha unidad fue recortada produciendo un efecto de frontera. Este efecto nos abre la posibilidad de repensar las transformaciones sociales ocurridas en relación a aquello que en las nuevas configuraciones sociales quedó en el espacio fronterizo, amenazando a las nuevas construcciones. Así, planteamos que las identidades no se construyen solo desde la mismidad, sino que la "mismidad" o "unidad" tiene un horizonte de recorte que no le pertenece pero que le es fundamental para su existencia. Es decir, al tiempo en que puede señalar aquello que no es, se sabe continuamente amenazada por eso mismo: el cierre o sutura de esta unidad, entonces, siempre será, necesariamente, incompleto.

El establecimiento de un puente de encuentro en donde sujetos y objetos se coproducen, como un proceso de constitución que no está completamente cerrado y fijado sino que es amenazado por otras formas de producción que se dan en el mismo espacio social y que se definen como un afuera constitutivo, nos lleva, en el capítulo tres a discutir un enfoque teórico metodológico que nos permita dos cosas. Por un lado, acercarnos, desde 
la arqueología, a quebrar con las dos visiones de la cultura material -desde su objetualidad en sí y desde el representar de las personas- y observar las formas recursivas en que ésta y los sujetos se coproducen; por otro lado, que nos brinde herramientas para observar de qué formas se producen esos efectos de frontera y las maneras concretas en que logran perdurar por un lapso temporal prolongado, a pesar de la continua amenaza recibida por aquello de lo cual se recorta. Así, proponemos realizar, en primer lugar un ejercicio analítico en el que los objetos y las personas sufran un cambio en sus estatutos ontológicos: las cosas serán analizadas como si fueran personas con particulares trayectorias biográficas y las personas serán analizadas como si fueran objetos. Estos nos permitirá, en el caso de los primeros, extraerlos de su aparente participación en redes funcionales desprovistas de sentidos, y en el caso de los sujetos nos posibilitará desmitificar su carácter subjetivo, es decir que su constitución deviene sólo de las representaciones que los sujetos se hacen de sí mismos, más allá de sus intervenciones en el mundo.

Un conjunto de objetos son los protagonistas de las biografías que reconstruimos, todos ellos pertenecientes a un tipo de material específico: cerámico. Los objetos seleccionados se corresponden con dos clases cerámicas identificadas para el valle: la alfarería oxidante de paredes gruesas para grandes vasijas tricolor o lisas, y aquella reductora de tradición Ciénaga-Aguada. El que hayamos elegido trazar las trayectorias biográficas de las vasijas que se fabrican con estas dos clases cerámicas, se debe a que la primera de ellas se señaló como representante de una larga tradición cerámica en el Valle; se utilizaría desde inicios del primer milenio hasta los primeros siglos del segundo milenio. Estas vasijas, entonces, estuvieron presentes desde los primeros momentos de producción de las transformaciones sociales señaladas. Por lo cual con ellas podremos cubrir todo el lapso temporal considerado. La segunda clase, si bien al igual que la anterior puede asociarse con una tradición de larga data, sufrió un cambio importante alrededor del siglo IV o V: se abandonaron las formas decorativas anteriores y se incorporó como decoración en su superficie la iconografía "Aguada". Este hecho, sumado a que dicha icnografía fue planteada como representante de los procesos ideológicos ocurridos -y en tanto tal, enmascaradora de las relaciones de poder-, torna relevante que observemos las diferentes biografías de estos objetos en dicho lugar. Por otro lado, ambas clases cerámicas están conspicuamente representadas en todos los sitios excavados en el valle, datados en el período que estamos considerando. Inclusive, estos objetos aparecen en diferentes clases de sitios que han sido señalados como representantes de diferentes "jerarquías". Así, al ir delineando las trayectorias biográficas reconstruidas de estas vasijas iremos transitando por diferentes espacios, escalas y contextos a lo largo de toda la temporalidad señalada. 
Las trayectorias biográficas trazadas de estos objetos, son entrecruzadas con las formas materiales en que las personas fueron producidas. Particularmente hacemos hincapié en el cuerpo como ámbito de acción central, tanto en un sentido genético (socialización) como crónico (práctica cotidiana) de la subjetivación. Si bien desde la arqueología puede parecer un problema acercarse a esta producción del cuerpo y con ella de las personas -en tanto éstas no están vivas-, el tratamiento que recibió el cuerpo al momento de la disolución del sujeto como "tal", al momento de su muerte, es un punto que nos abre la posibilidad de observar parte del proceso. Por otro lado estas formas de producción corporal son comparadas con otras que se hallan plasmadas en la cerámica a la cual le trazamos las biografías. La rica iconografía presente nos habla de particulares formas de representación del cuerpo y las personas, las cuales nos sirven de contraposición con las otras formas de producción mencionadas.

Una vez producido este cambio de estatuto ontológico, realizamos las imbricaciones de las trayectorias biográficas de los objetos cerámicos con las personas, con lo que obtenemos una serie de cartografías en las que se conjugan las intersecciones entre ambas trayectorias y las formas en las que ambos se coproducen. Pero estas intersecciones nos dejarán en un ámbito en donde dichos encuentros -entre objetos y personas- se producen en la contingencia de la práctica presente, por lo cual pueden ser cuestionados; si nos quedáramos en ese lugar, no podríamos comprender porqué las relaciones que se consolidaron en el valle en el primer milenio lograron perdurar al menos siete siglos. Por lo que conjugamos estas cartografías con el largo término, analizándolas en toda la temporalidad abarcada.

El análisis de las cartografías en el largo término nos lleva a realizar otra intersección particular, aquella posible de establecer entre las biografías de estas vasijas y los sujetos con los cuales se vincularon, con una serie de estructuras que están representadas desde los primeros años del primer milenio en todo el valle, los montículos, también denominados "basureros". Algunos de ellos fueron resignificados posteriormente en plataformas ceremoniales, lugares en donde terminaron depositados muchos de los objetos y personas que analizamos aquí, sea al momento de romperse los primeros o de morir las segundas. Su vinculación con los montículos, nos abre paso para pensar la historia de más largo término, de las relaciones entre personas y cosas, y de cómo estas relaciones particulares que se afincan en la contingencia subvierten su estado transformándose en universales; contingencia y estructura son los tópicos a través de los cuales transcurriremos. 
En el capítulo cuatro desarrollamos los elementos metodológicos técnicos para la reconstrucción de las trayectorias biográficas de los objetos, la producción del cuerpo de los sujetos y la reconstrucción de las cartografías de intersección de las trayectorias seguidas por vasijas y sujetos.

En el quinto capítulo caracterizamos el valle a nivel geográfico y nos acercamos a su paisaje arqueológico.

A partir del sexto capítulo hasta el capítulo nueve inclusive realizamos el desarrollo del camino que trazamos en la metodología. En el capítulo seis analizamos a las vasijas pertenecientes a las dos clases cerámicas seleccionadas como si fueran sujetos y mostramos las diferentes sendas biográficas recorridas por éstas; en el capítulo siete analizamos a las personas como objetos, comparamos por lo menos dos formas de tratamiento corporal que reciben los individuos al morir -fragmentación del cuerpo o conservación del cuerpo entero-, lo que nos lleva a trazar relaciones con otras formas de tratamiento corporal: el recibido por los camélidos, que en algunos aspectos y situaciones es idéntico la de los humanos; en el capítulo ocho trazamos las cartografías de intersección de las trayectorias seguidas por las vasijas y los sujetos humanos y no humanos; y en el capítulo nueve realizamos el análisis de los montículos, el que nos permitirá proponerlos como estructuras que por la dinámica de su formación, las inclusiones materiales halladas y su larga temporalidad se fueron constituyendo, a lo largo del primer milenio de la era, como lugares donde determinadas prácticas sociales y ciertas construcciones identitarias, al ir sedimentando y monumentalizándose, pretendieron ser ahistorizadas, es decir naturalizadas, llegando a conformar parte del sentido común de los que vivieron allí. En este sentido, discutimos este proceso en relación a la universalización de determinados significados, que en el caso de los montículos nos lleva a analizar las formas de constitución de cierta/as memoria/as social/es y los procesos de lucha hegemónicos en donde dichas construcciones se hallan inmersas. Esta discusión, posteriormente, nos abre la posibilidad de repensar la aparente fijeza de dichas prácticas e identidades, generada por estas estructuras que provocan el desplazamiento de aquello que se produce en la contingencia y en este sentido originan un cierre o sutura, pero que sólo es aparente. Así, por último, planteamos ciertas hipótesis sobre por qué, hacia fines del primer milenio y comienzos del segundo, este desplazamiento y suturas de ciertas construcciones identitarias se cancelaron precipitando un nuevo espacio para la luchas por sentido en los albores de lo que se dio en llamar Período de Desarrollos Regionales. 
Por último en el capítulo diez, a manera de cierre realizamos una recapitulación de los distintos planteos realizados. Esto nos permitirá retomar los interrogantes iniciales y plantear las distintas respuestas que hemos dado a los mismos. 


\section{CAPÍTULO 1}

SUJETOS Y CULTURA MATERIAL: UNA MIRADA DESDE LA ARQUEOLOGÍA

DEL VALLE DE AMBATO

En este capítulo articularemos una discusión sobre dos visiones de la cultura material, que predominaron en las investigaciones realizadas en el valle, y que produjeron que objetos y sujetos quedaran en ámbitos separados y pasivos en relación a las transformaciones sociales señaladas: aquella que la observó como reflejo de influencias de pueblos evolucionados de los centros nucleares de los Andes, y aquella que la colocó como indicadora de procesos locales de cambio. Una vez que mostremos ciertos límites, pero también los aportes que tuvieron ambas perspectivas para comprender en profundidad dichas trasformaciones, nos adentraremos en discutir las últimas investigaciones realizadas en el valle, donde la cultura material fue colocándose cada vez más en una posición activa. Insertándonos en las discusiones planteadas por estas últimas investigaciones comenzaremos a delimitar una propuesta alternativa donde objetos y sujetos ya no sean situados en laderas opuestas de una profunda quebrada, sino que puedan concebirse como mutuamente constituidos.

El interés por la arqueología del valle de Ambato surge tardíamente en la arqueología regional, a principios de la década del setenta del siglo XX, aunque existían algunas referencias dispersas: Lafone Quevedo (1888) en su paso por el lugar a fines del siglo XIX describe la existencia de un sitio tardío, Pucarilla, que se encontraría en la ladera occidental de la sierra del Ambato que delimita el angosto valle al oeste; el hallazgo dado a conocer por Adán Quiroga y reinterpretado por Ambrosetti (1906) del hacha de Huaycama, pueblo ubicado a unos pocos quilómetros al sur desde donde se sitúa el comienzo del valle; la vasija tricolor dada a conocer por Lorandi (1967). Es a partir de las investigaciones realizadas en los '70 por el equipo dirigido por Heredia y Pérez -que se inscriben dentro del proyecto más amplio dirigido por Rex González sobre la Cultura de la Aguada para todo el Noroeste Argentino (Heredia 1998:71)- que, a esta porción norte del Valle Central de Catamarca, se la empieza a conocer como Valle de Ambato. Es decir, cuando hablamos del Valle de Ambato debemos reconocer en él no solo una definición geográfica sino una categoría histórica específica que se fue construyendo a través de las sucesivas investigaciones realizadas en el lugar. De hecho, la primera denominación que tuvo este proyecto fue la de "Investigaciones Arqueológicas en los Valles de Catamarca y Singuil” (Bonnín 2007) ${ }^{\mathrm{i}}$.

No obstante, si bien no recibió atención por los arqueólogos estuvo sujeto a sucesivas excavaciones realizadas por coleccionistas. Uno de las colecciones más grandes existentes es 
la que Aroldo Rosso (coleccionista de Córdoba) fue juntado a través de diferentes excavaciones y donaciones en la Región de Rodeo Grande en el valle (Bedano, Juez y Roca 1974). Dicha colección poseía un cúmulo muy importante de piezas de cerámica negra gris grabada de estilo Aguada asociada a lo que González (1977) define como facie Aguada oriental, y que en su trabajo de 1961-64 asociaba con un origen diferente de los otros estilos relacionado con el Complejo $X$. Es debido al interés generado por estos materiales que comienzan las primeras investigaciones en el valle (Pérez y Heredia 1975) y se realiza un estudio tipológico exhaustivo de la colección antes mencionada que culmina siendo una tesis de licenciatura (Bedano et al 1993).

Bonnín (2007) realiza un análisis histórico de los planteos iniciales del Proyecto Ambato entre 1973 y 1976, y señala que para los comienzos de las investigaciones, en el proyecto que hemos mencionado más arriba, Heredia y Pérez reconocen las particularidades estéticas y técnicas diferentes de la cerámica hallada en el valle respecto a las consideradas como expresiones típicas de la Cultura de la Aguada remarcado la importancia de:

“...emprender trabajos sistemáticos en estos lugares a fin de poder en primer lugar establecer (una secuencia) el contenido de una serie de contexto culturales correspondientes a facies arqueológicas muy poco o nada conocidas (...) Un plan metódico como el que proponemos contribuirá, a no dudarlo, en forma muy clara y definida al conocimiento de una de las culturas más importantes por su desarrollo tecnológico y artístico que habitara el N.O. argentino; cultura que sirve de hito o jalón demarcador en la secuencia y el proceso histórico de las etnías autóctonas de nuestro país” (Heredia y Pérez citado por Bonnín 2007:7)

La relevancia de emprender investigaciones en el valle se enmarca claramente en la perspectiva utilizada por los mismos en el programa propuesto por González para establecer la secuencia cultural del Noroeste Argentino y específicamente retoma el lugar otorgado por este autor a la Cultura de la Aguada en la historia regional. Aguada que, a la misma vez que caracterizaba al Período Medio lo definía, marcaba para González los más altos logros alcanzados por los pueblos prehispánicos de la región. Su acabada y refinada alfarería, su carga iconográfica, así como la producción de objetos de metal -principalmente las placas y los discos- permitían observar no solo la destreza desarrollada por los artesanos sino la existencia de especialistas. La perfección técnica que demostraban estos artefactos resaltaba los avances tecnológicos y sociales de los pueblos de la región. Sin embargo estos planteos eran acompañados, en parte, por un descreimiento en la posibilidad de que estos mismos 
pueblos los llevaran a cabo sin la intervención, ya sea de manera directa o indirecta, de la luz irradiada hacia los márgenes o territorios de frontera de los centros nucleares de los Andes. Para el caso del NOA Tiahuanaco era uno de éstos:

"La Aguada debió representar un lapso de tiempo de varios siglos. Tuvo que existir un momento de comienzo, en que las ideas y elementos que la integran empiezan a infiltrarse en el N.O., luego un momento de auge y estabilización de la cultura, por último, uno de desintegración. El aspecto tipológico de los materiales sugiere esta evolución. Si parte de los elementos Aguada deriva de Ciénaga, su elaboración esencial se hizo a expensas de los elementos persistentes de esta cultura, como el caso de la alfarería, la que debió enriquecerse por aportes progresivos llegados de otros centros. Presumiblemente, algunos de los situados en la olla del Titicaca, los que quizá no llegaron de manera directa, si no indirecta a través de puntos intermedios situados en la Puna Chilena. De manera que su origen no debió ser por conquista o invasión rápida, como habíamos supuesto, si no por infiltración progresiva” (González 1961-64:232)

Las infiltraciones eran observadas principalmente en los estilos cerámicos. La cultura material en este contexto fue considerada como el reflejo de dichas migraciones, contactos o influencias (González 1961-64, 1977, 1979, 1992, 1998).

La cultura material vista como reflejo de influencias posee una larga tradición en la arqueología del NOA en general, y específicamente en las interpretaciones que se realizaron de los materiales que luego comenzaran a conformar parte del patrimonio de la Cultura de la Aguada y que jugarán un rol fundamental en la definición del Período de Integración Regional y en los comienzos de la arqueología del Valle. La infiltración, ya sea de manera directa o indirecta de elementos (como la alfarería mencionada por González), desde otros centros que enriquecen las culturas locales y producen cambios, es una temática en el NOA que proviene de larga data; desde mucho antes que González defina a Aguada y establezca la secuencia cultural del NOA. Como señalan Politis y Pérez Gollán (2004) González amplió y sistematizó la secuencia cultural del Noroeste Argentino, y obtuvo una cronología absoluta que quizás constituya el mejor ejemplo de la arqueología historicista norteamericana en Latinoamérica a partir de las ideas de Bennett et al (1948). Pero además, su visión de los materiales que formarán parte de la cultura de la Aguada y con ellos de la cultura material, posee un anclaje histórico y teórico más profundo en la arqueología regional. Este se vincula a cierto quiebre que se produce en las consideraciones de los materiales que luego conformarán 
parte de la Cultura de la Aguada - esto es el "estilo cerámico o cultura draconiana" o "cultura de los Barreales"- respecto de las interpretaciones que de ellos se venía realizando en los inicios de la disciplina e inclusive en su etapa formativa (Haber 1994) ${ }^{\mathrm{ii}}$. En dicha etapa, la cultura material no reflejaba las migraciones, contactos, e influencias de Tiahuanaco, como lo pasarán a hacer posteriormente sino que eran "símbolos" de las tradiciones, mitos y leyendas de los pueblos que los produjeron, en este caso asociados a lo Diaguita-Calchaquí. Esta visión

llegó a coexistir en diálogo contrapuesto con aquella otra donde esos objetos como "espejos,"iii reflejaban esas influencias.

Empezaremos así discutiendo estas dos primeras visiones, sus relaciones, sus contraposiciones, el lugar otorgado por ellas a los objetos y con ellos a los sujetos. Discutir este anclaje, la particular propuesta de González sobre Aguada y su influencia en la arqueología del Valle de Ambato, nos ubicará en una posición muy adecuada para analizar y comprender la importancia y el cambio de visión que significa el planteo de la cultura material como "indicadora" de procesos locales de cambio. Pero si pretendemos comprender en profundidad la manera en que se fueron articulando las narrativas alrededor de estos materiales, y su influencias en narrativas posteriores, es muy importante que en esta sección no articulemos la discusión sólo desde un diálogo entablado por sujetos que enuncian teorías o entre enunciados teóricos sin vincularlos a la manera en que en esos momentos formativos e iniciales de la disciplina y con ella de los sujetos que la practicaron -arqueólogos, folcloristas etc.- se definieron a sí mismos. Si nos quedáramos sólo con lo primero no podríamos observar específicamente cómo a pesar de las críticas y redefiniciones que se darán de estos materiales en momentos posteriores, ciertas consideraciones realizadas en estos momentos iniciales quedarán incorporadas como supuestos naturalizados que influenciarán fuertemente en las narrativas que de la cultura material de la Aguada y del Período de Integración Regional se vayan articulando.

\section{La cultura material como símbolo: figuras draconianas, simbología e identidad calchaquí en los orígenes de la nación}

González (1961-64:205) cita a Lafone Quevedo (1892) como el primero en dar informaciones sobre los materiales que va a colocar como formando parte del patrimonio de la cultura Aguada: una “...teja finísima y bien pulimentada...” donde aparecen figuras que el autor califica entre otras designaciones como "...dragones o medusas, con cola de serpiente coral y pies de lagartijas" (Lafone Quevedo 1892; 15, 20 y 23 citado en González 1961-64: 
205). Para Lafone Quevedo, quien acuña el nombre draconiano, si bien esta decoración podría ser más antigua que las otras que caracterizaban al arte calchaquí, conformaba parte de éste (Lafone Quevedo 1905:8) ${ }^{\mathrm{iv}}$. En este sentido lo draconiano constituía una variedad del mismo $\operatorname{arte}^{\mathrm{v}}$. A su vez el arte calchaquí y sus variedades expresaban el simbolismo de sus creadores: "Yo entiendo que el americano no daba una pincelada ni una cincelada sin reproducir algún símbolo de su fe, ya convencional, ya significativo (Lafone Quevedo 1890:11 citado en Haber 1994). Un ejemplo claro de este pensamiento es el análisis que realiza de un objeto hallado en la zona de Chaquiago en Andalagalá:

"De los mejores es el objeto, lámina XII, que casi parece una tetera cuyo mango es la cola y su pico la cabeza. Esto dos detalles establecen que se trata de un huanaco, pero de un huanaco que encierra otro ser animado; este a lo que se ve representa una avestruz, aunque todos los detalles sean convencionales. La costumbre de formar un vaso con el cuerpo de una figura zoomorfa es muy del lugar y de la época (...); pero en este caso tenemos algo más, porque se representa una de las leyendas conservadas en el folk-lore local, la metamorfosis de la avestruz en huanaco..." (Lafone Quevedo 1905:11).

Lafone Quevedo, en este sentido, establece una fuerte conexión entre el "arte calchaquí" y lo folklórico -las creencias y leyendas actuales de la región-. Esta perspectiva del autor fue señalada como el acercamiento filológico de Lafone Quevedo al pasado indígena y particularmente a la historia calchaquí (Haber 1994, Haber y Delfino 1995-1996). Cada información que este autor obtenía, “... así fuera una leyenda popular, una ruina arqueológica, la decoración de una vasija, el relato de un cronista de indias, un antiguo documento de encomienda, un apellido indígena o el nombre de un lugar, era considerado por Lafone como un fragmento de un texto al que había que transcribir, traducir, interpretar, y combinar de tal modo de construir una narrativa histórica" (Haber 1994:43-44). Un ejemplo interesante que Haber (1994) trae a colación es la interpretación que realiza Lafone Quevedo del disco que adquirió en una población cercana a Pilciao ${ }^{\text {vi }}$. Según Haber el disco le lleva a interpretar en sus diseños símbolos míticos incaicos combinados con "letras" que representan deidades locales catamarqueñas: "La curva de los lagartos y los ganchos de sus pies dan un $\mathrm{Cu}$; los círculos con punto, el disco todo, la patenta en la frente, pueden ser $a$, las cruces ó crucero son la $t$, porque son dos, ó porque tiene los dos círculos floreados encima, hacen $t i$ " (Lafone Quevedo 1892:11 citado en Haber 1994: 44). En este modelo filológico es muy importante la noción de símbolo y su vinculación con los objetos; en términos de Lafone podríamos decir, 
más precisamente, con los gestos -pincelada, cincelada- que quedan plasmados en los objetos. Pero ¿qué es un símbolo -“convencional” o "significativo” de su fe- para este autor? Y ¿cómo se vinculan estos símbolos con los objetos y los gestos que en ellos están representados? Una pista que nos permite comprender el sentido que Lafone Quevedo le otorga al símbolo la econtramos en la etimología de esta palababra: "Etimológicamente debería significar una cosa unida (...) los griegos usaron "unir" (symballein) muy frecuentemente para significar el hacer un contrato o convenio. Ahora bien, con frecuencia y desde antiguo encontramos símbolo (symbolon) usado para significar un contrato o convenio. Aristóteles llama al nombre un "símbolo", esto es, un signo convencional. En griego, la fogata que se enciende para avisar es un "símbolo", esto es, una señal sobre la que se está de acuerdo; una bandera o estandarte es un "símbolo"; un santo y seña es un "símbolo"; un distintivo es un "símbolo"; (...)." (Pierce 2005: 297). Es en este sentido de unión por convención que Lafone Quevedo entiende al símbolo. Las pinceladas y las cinceladas en Lafone Quevedo se hallan guiadas por estas convenciones, y él a través del conocimiento y estudio de las tradiciones folclóricas poseía las herramientas, las "cláusulas" de ese convenio que le permiten vincular los gestos plasmados en los objetos con lo que simbolizan. Un claro ejemplo de este procedimiento puede ser observado en la interpretación que Lafone Quevedo realiza de dos hachas halladas por él en la zona de Andalgalá: "De las piezas en piedra hay seis, que son: un mortero hondo con dibujos convencionales, dos chatos antropomorfos, un ídolo y dos hachas ó toquis" (Lafone Quevedo 1905:8). Mas adelante cuando describe más profundamente cada objeto señala: "Hacha o cuña de piedra, (...) de las que suelen llamarse toqui y que deben considerarse como símbolo de autoridad.” En este caso Lafone Quevedo puede unir el hacha de piedra con el significado autoridad, al conocer las "cláusulas del convenio" toqui. El pensamiento de Lafone Quevedo, se ve reflejado también en otro autor, más joven que éste, pero muy influyente en la época: Adán Quiroga.

En Quiroga lo draconiano está asociado a los dioses del aire o Huairapucas; un ejemplo que nos muestra su pensamiento es la interpretación que realiza de la olla de barro de Capayán, que después comenzará a formar parte del repertorio clásico iconográfico de la Cultura Aguada:

"Más en las Huayrapucas hasta hora reproducidas no aparece el símbolo de la Cruz, que vamos estudiando en los dioses meteorológicos, hasta que damos con el grupo meteorológico atmosférico Capayán, en las fronteras del valle de Londres (...). Como se ve en el desarrollo del grupo mítico de la olla, al centro del mismo, aparece un ser de interesantísima formas humanas. Este ser como los dioses 
mexicanos del aire, lleva en la cabeza un penacho de seis anchas plumas de ave. En su cara humana -de la que caen pendientes- dos serpientes que tatúan sus mejilla, sobre la que descansan sus cabezas, forman la nariz del ídolo en su punto de intersección, y sus colas arqueadas las cejas; la boca es ovalada. De su barba, despréndense la caja geométrica del cuerpo, saliendo para adentro del cuadro, de cada una de las cuatro esquinas del mismo, cuatro cabezas de serpientes, con ojos y bocas, provistas de sus cuellos. Estas cuatro cabezas forman el símbolo de la Cruz (...). Del ángulo inferior del cuadro desprérndense las pata zoomorfas del mítico ser, el que aparecen en medio de las nubes y de la tormenta, provistos de grandes ojos dobles, con los zig-zags. El caso que acabamos de ofrecer es elocuentemente típico, y salta a la vista la intención del artista que grabó la cruz, formada por cuatro cabezas de serpientes rayos, que insinúan lluvia. Esa Cruz ocupa el centro mismo de todo ese animado y viviente grupo mítico de la tormenta, como símbolo de alto valor meteorológico (...) todo en este grupo habla de lluvia, de agua del cielo...” (Quiroga 1977 [1901]:83-84)

Ambrosetti, es otro que se halla dentro de esta línea de investigación. Este autor creyó ver en esta decoración la imagen del tigre. Pero al estudiar un plato de Santa María sostuvo que tales figuras se refieren a un culto de un dios llamado "Catequil" (Ambrosetti 1906). Bregante (1926:105) señala que Ambrosetti asoció la existencia de un pájaro en el plato con la representación de Piguerao, el hermano de Catequil, que en la leyenda viene a ser la mistificación del relámpago.

Los dos primeros autores señalados compartieron, no sólo esta visón sobre la posibilidad de narrar la historia calchaquí, la cual podía ser leída en los objetos arqueológicos a través de los mitos y leyendas, planteando una continuidad de las tradiciones indígenas, sino que también los unía cierta mirada política sobre la arqueología. Para Quiroga, la arqueología, la historia oral y las tradiciones populares conformaban las fuentes de las cuales se nutriría el poeta épico para la construcción de un relato de fuerte intención nacionalista (Haber 1994), en donde: "La historia de las razas indias es, pues nuestra historia; su tradición, la tradición de nuestra tierra y de nuestra raza (...). Apartar al indio de la historia, es desdeñar nuestra tradición y renegar de nuestro nombre de americanos" (Quiroga 1893:38-39 citado en Haber 1994). Lafone Quevedo, casi unos 20 años después de Quiroga, escribía en su justificación de ciertas crítica que realizaba a algunos postulados realizados por el padre Antonio Larrouy (acerca del grado de sujeción a los incas en que los diaguitas y calchaquíes se hallaban cuando entraron los españoles y a la época en que la lengua del Cuzco se introdujo en Tucumán): “... 
me limitaré a dos de los puntos que el autor toca y que son trascendentales por lo que respecta á los orígenes de la historia patria" (1914:359). En Lafone Quevedo, a diferencia de Quiroga que resaltaba la epopeya calchaquí principalmente por ser un pueblo de guerreros y héroes, la admiración se dirigía a un pueblo de hábiles artesanos, conocedores de mitos y leyendas (Haber 2004).

Así Lafone Quevedo y Quiroga, a sus modos, incorporan como parte fundamental de la definición del estado nación a las tradiciones indígenas: lo diaguita, lo calchaquí como parte fundante de ésta no debía ser alejado de la narrativa épica de la nación. Además, estaba ahí para ser develado y ellos conocían las claves para comprender su significado y simbolismo.

El discurso "nacionalista", particularmente de Quiroga se distingue del esbozado desde Buenos Aires particularmente del discurso liberal "occidentalizante" de Sarmiento, que como señala Escolar (2007:134) al referirse a Calibar aquel baqueano cuyano que en "Facundo", aparecía como icono de la cultura gaucha, en "Recuerdos de provincia" su habilidad constituye "otra costumbre [huarpe que] sobrevive, hija de la antigua y fatigosa caza de pie" (Sarmiento, 1966:33 citado en Escolar 2007:134). "El paisano que casaba guanacos, a la usanza antigua, evita las rodadas y arroja con destreza sus boleadoras, puede ser considerado en esta perspectiva como "criollo", gaucho, "huarpe" o "indio" (...). Esta posibilidad de indistinción cultural abre paso al tema sarmientino de la civilización como proceso inacabado y críticamente amenazado en el seno de la sociedad criolla" (Escolar 2007:134). Así Sarmiento, y podríamos decir la perspectiva de nación enfocada desde Buenos Aires, a diferencia de Quiroga y Lafone Quevedo, funda en un distanciamiento radical las bases de la nación, en una construcción de un otro expresado en su premisa básica: Barbarie o Civilización. El establecimiento de esta "cronopolítica" o "negación de coetaneidad" (Gnecco 2006:223) por parte de Sarmiento, produce que lo "huarpe", lo indio, lo gaucho, el folclore, las leyendas, el arte calchaquí cobre un doble sentido: se constituye en ese "otro" del cual se recorta la nación argentina civilizada, lo que produce un doble alejamiento: temporal barbarie y civilización en los clásicos términos morganianos- y espacial -relacionado al provincianismo donde habita la otredad. Es en este contexto político e intelectual, donde se producen las luchas hegemónicas por la conquista del sentido común (Isla 2002), en este caso del sentido de lo indígena por parte de las elites intelectuales provinciales o porteñas, donde lo "indio", "lo calchaquî", lo "diaguita”, "lo draconiano", los discos de bronce con sus palabras está en disputa, ya sea que se plantearan como una otredad radical a la nación, ya sea como fundante, como "origen", tradición o complemento; además, permanecen inalterables, 
inmutables como esencias que deben, o ser barridas del imaginario y de la realidad recordemos las conquistas al desierto-, o incorporadas en discursos nacionalistas tendiente a fundar las raíces de la nación.

A pesar de las transformaciones sociales que a fines del siglo XIX y principios del XX se producían en el naciente Estado Nación, que afectaban a intelectuales, indios, gauchos, criollos, y que suponían una creciente proletarización de las poblaciones indígenascampesinas y la delimitación de las fronteras externas e internas, "lo calchaquî" se mantenía inalterable en su esencia. Lo "draconiano", a pesar de su quizás mayor antigüedad, tal cual lo percibe Lafone Quevedo, podía aún ser leído, las cláusulas de los convenios se hallaban a su alrededor: en la gente que habitaba Pilciao, en su folclore, leyendas y mitología. La misma gente que iba incorporándose como proletario a los emprendimientos comerciales que se desarrollaban en Catamarca -integrante de la región calchaquí-, y en el caso de Lafone Quevedo incorporándose como fuerza de trabajo a su ingenio minero. Así con Lafone Quevedo y Quiroga los símbolos “calchaquí” y sus cláusulas, al permanecer inalterables, quedaron monumentalizados en las obras del poeta épico, conformando el fundamento de donde lo nación debía beber. No importaba la desestructuración de las poblaciones indígenas, de sus parcialidades, de sus pueblos durante la colonia, o la incorporación de estas poblaciones a la nueva economía floreciente de las provincias del interior: esa dinámica no alteraba la esencia, el monumento donde yacían inmutables los "símbolos" del arte calchaquí se mantenía inmune.

Es en esta configuración particular sobre los discursos de lo indígena durante la conformación del Estado Nación, enraizados en discursos evolucionistas de la época, en donde la diferencia se temporalizaba y se creaba una política de espacialización de la alteridad, donde el otro se hallaba lejos. Comienza a surgir, además, un interés en discutir el “origen" de estos pueblos, surgiendo fuertemente dos categorías con las cuales se abordará esta problemática: “cronología” y "difusión”. Las figuras draconianas, en este contexto cobran una importancia fundamental, en tanto que por su estilo, podían asociarse a una de las grandes “civilizaciones” de los Andes Centrales: Tiahuanaco.

\section{La cultura material como reflejo: migraciones, contactos e influencias "extranjeras"}

I- Figuras draconianas, caracteres, rasgos, raza, cultura y civilización en la órbita de Tiahuanaco. 
La visión de la cultura material, en donde los objetos se pensaron como símbolos de las convenciones utilizadas por la sociedad para comunicar un signo o significado, como el caso del toqui que simboliza autoridad, sufre una profunda modificación cuando comienza a vincularse lo draconiano con culturas del antiguo Perú y Bolivia, particularmente con Tiahuanaco. Máx Ulhe (1912) propuso que lo draconiano estaba fuertemente vinculado con las culturas peruanas y era anterior a la cultura que él denominó calchaquí. Pero es Debenedetti uno de los primeros que dirige la atención sobre la posibilidad de vincular a las "viejas culturas aborígenes del noroeste" y a lo draconiano con Tiahuanaco. Abiertamente en discusión con otros autores como Boman, para quien, en términos de Debenedetti (1912:7) "nuestra cultura aborigen" la hacía "derivar de la incaica directamente", o con aquellos autores -Ambrosetti, Lafone Quevedo, Quiroga- que "sostuvieron una autonomía más o menos relativa y su desarrollo más o menos independiente" señalaba que :

“...los estudios arqueológicos practicados en Perú, Bolivia, Chile y República Argentina demuestran de una manera evidente que no es posible admitir tales hipótesis (...) Me propongo desentrañar del material descubierto hasta hoy los elementos que á mi juicio, son exóticos en nuestras extinguidas culturas del noroeste argentino y ver si es posible referirlos al período en que floreció en el altiplano de Bolivia la avanzada civilización de Tiahuanaco, civilización que llegó á su mayor desarrollo mucho tiempo antes del dominio incaico." (Debenedetti 1912:7)

Debenedetti en este trabajo proponía una nueva agenda para la arqueología como disciplina, demarcando no sólo su objeto sino también su campo:

"Determinar las correlaciones que pueden existir entre las culturas, seguir paso a paso sus desarrollos despojándolo de lo que en ellos hubiere de exótico, restituir a su verdadera procedencia los elementos que han determinado una modificación en un arte dado y desarticular los componentes que han servido para dar carácter a una cultura en un determinado tiempo, constituye una de las finalidades en que está empeñada nuestra arqueología. Sabido es que por tal camino se llegará más o menos pronto á determinar la cronología de los largos períodos de nuestras antiguas culturas aborígenes.” (Debenedetti 1912:5) 
En el programa propuesto por Debenedetti, lo "draconiano", y la cultura material comienza a cobrar sentido en relación a un núcleo de representación un tanto diferente del esbozado por los autores que venimos tratando. La importancia de lo draconiano como símbolo del arte Calchaquí, aunque más antiguo, comienza a participar de otras relaciones, otras cláusulas articuladas alrededor de categorías como: cultura, raza, rasgo, evolución, estados de cultura, influencia/difusión y cronología. Si bien estas categorías venían siendo utilizadas anteriormente por los autores mencionados, Debenedetti las combina y redefine de maneras distintas. En primer lugar, desde una perspectiva impregnada de una idea de progreso decimonónica, conjugaba la idea de cultura con estados de desarrollo. Es decir diferencias culturales implican estados de cultura diferentes, estos estados se corresponden con una escala evolutiva. Estas escalas y estados no eran fijos, poseían un movimiento perpetuo, lo que cambiaba eran las velocidades de movimiento, siempre en ascenso. Pero en algunos casos, dichas velocidades podían permanecer con movimientos tan lentos e imperceptibles que parecían detenidas:

"Muchos estados de cultura en América parecen estar estacionados y en las mismas condiciones que hace siglos. Precisamente son aquellos que no han sido influidos por otras culturas más avanzadas y que, dado su estado de aislamiento, cuentan con escasos elementos para evolucionar”. Naturalmente es que así sea porque á nuestro juicio, cuanto menos elementos dispone una cultura mayores son las probabilidades para su detención ó su lentísimo desarrollo. En tal estado se encuentran los indígenas del centro de la América del sur sin que haya todavía para ello un asomo de mejoramiento de sus condiciones de cultura." (Debenedetti 1912:8)

La cinética podía acelerarse, siempre y cundo se recibieran poderosas "influencias" que determinaran movimientos ascendentes que imprimieran carácter y solidez al desarrollo "natural" o local, tal cual como sucedió en el NOA, según este autor, con la influencia de Tiahuanaco: "en nuestra región del noroeste, en época en que la cultura se halla en un nivel inferior, vino de otras partes una influencia poderosa que determinó un movimiento ascendente y fue poco a poco imprimiéndole carácter y solidez.” (Debenedetti 1912:7)

Lo draconiano y la cultura material en el pensamiento de Debenedetti sufren un proceso de redefinición profunda, se transforman en el significante, junto con otros "elementos", de las influencias de Tiahuanaco. Pero ¿qué es un elemento para Debenedetti? Para comprender el significado debemos relacionarlo a una tríada: carácter, cultura/raza y civilización. 
"Elemento", es utilizado por el autor para designar muchas cosas: desde distintos objetos y las formas específicas de éstos -vasos, platos, ollas de cerámica, tabletas de madera, discos de metal, hachas, etc.-, las figuras que representan o se hallan representadas en ellos -serpientes de dos cabezas, o serpientes de cabeza triangular con o sin meandros anexos-, tipos de decoración -draconiana, antropomorfa-. La posibilidad de asociación de todos estos elementos viene dada porque cada uno de ellos expresa un "carácter": "Si consideramos la alfarería por el carácter de sus forma, veremos que ello constituye una prueba para el estudio de las correlaciones" (Debenedetti 1912:16). Ahora bien, ¿quién o que imprime ese carácter?, y aquí debemos traer la noción de cultura junto con la de raza y civilización. La relación entre cultura/raza y civilización debe colocarse en los siguientes términos: la civilización para Debenedetti es utilizada como un marcador del máximo estado alcanzado por una cultura/raza dentro de la escala evolutiva, pero además marca también el máximo estado alcanzado y posible de alcanzar por las culturas/razas que se hallan en un área y tiempo determinado. Así, Tiahuanaco alcanzó este estado y luego los Incas, antes de Tiahuanaco fueron Ica y Nazca. Raza y cultura hablan ya no de escala evolutiva universal, si no de particulares y es aquí donde entra el "carácter". Cada cultura/raza poseía un carácter, que se expresaba en todo lo que hacían. Los "caracteres" de las raza o culturas no permanecían aislados sino que se relacionaban, se influenciaban: así en las "antiguas culturas de NOA" él podía rastrear las "influencias", a través de cómo se expresaban los caracteres particulares de cada cultura/raza en los objetos. Ahora bien la pregunta sería, si uno quiere rastrear el origen de esas influencias, ¿cómo saber que carácter influyó al otro? Aquí entra a jugar la "civilización" como estado de desarrollo: "la única razón que explica estas correlaciones [ejemplo: la decoración draconiana que caracterizó a Tiahuanaco se halla en el NOA] debe buscarse en que una de las cultura mencionadas ha influido poderosamente en la otra y, en este caso, la cultura influyente ha sido Tiahuanaco por las razones siguientes:..." (Debenedetti 1912:25, mi resaltado).

Entre las cinco razones esgrimidas por Debenedetti -la gran expansión de Tiahuanaco en todo el altiplano hasta Colombia, además de ser su arte el más característico, superior y puro lo cual hace más eficaz poder determinar lo que a él verdaderamente pertenece-, señala: “...porque es más lógico afirmar que una cultura superior influya más poderosamente á una inferior que no ésta á aquella" (Debenedetti 1912:26). Así, los discos, la decoración draconiana, la figura de serpientes, etc., se transforman en elementos, rasgos, expresión de caracteres de una cultura/raza, y lo que la arqueología debía hacer es ya no leer su significado y simbolismo, si no seguir la huella de su origen, de donde provenía, a quien pertenecía. 
Un ejemplo interesante es cuando se refiere a los objetos de cobre y bronce que aparecen en el NOA: "Los tumis ó tajaderas, discos, hachas de bronce llamadas toqui, topos, tan comunes en nuestra región andina, son propios del período de Tiahuanaco" (Debenedetti 1912:22). Aquí toqui, no refiere al convenio que Lafone pudo establecer entre hacha de bronce y el significado de autoridad, sino comienza a cobrar sentido en relación a otro ámbito de significación donde el hacha de bronce, ya sea por el carácter de su forma, o por el carácter de la figura que se halla esbozada en ella, etc. se vincula con el carácter de la cultura/raza de Tiahuanaco, y además significa la influencia que esta civilización realizó a una cultura determinada. Con ello, los convenios que permanecían aún suturados en Ambrosetti, en Lafone Quevedo y en Quiroga, se rompen para siempre, hay una escisión, una grieta, un abismo que se pierde en lo profundo de ese movimiento perpetuo y de diferentes velocidades en los que las "viejas culturas del Noroeste" se hallan totalmente comprometidas. A pesar de la invocación de huairapuca de Quiroga, o el conjuro que la inscripción que Lafone lee en su disco, o la súplica de Ambrosetti para que Catequil venga a su socorro, la poderosas influencias, traídas por Debenedetti desde Tiahuanaco lograron su cometido: por un lado, y de un solo golpe, rompieron las suturas y las arrojaron a un abismo evolutivo profundo, a un tiempo muy anterior a la llegada de los Incas, separándolas de las convenciones actuales por un largo período de tiempo; por otro lado, y como efecto de ese mismo impulso, las arrancaron del fondo del abismo, de ese estado de naturaleza en donde las culturas aborígenes del NOA se hallaban, para arrastrarlas velozmente a ese estado superior que sólo Tiahuanaco podía ofrecerles, como "raza" conquistadora que era:

"tales fueron las civilizaciones de Nazca é Ica cuyo desarrollo es tan completo y evolucionado y su asilamiento tan grande que ha hecho suponer que sean producto de importaciones de la América Central (...) Nada ni el más mínimo vestigio de estas civilizaciones se ha encontrado ahora en Argentina ni se encontrará por razones fundamentales: esas culturas no tuvieron desarrollos locales ni expansión; actuaron dentro de un relativo aislamiento y no fue la conquista el carácter de las razas que las sostuvieron” (Debenedetti 1912: 11).

En el caso de Debenedetti la delimitación del objeto de la arqueología presuponía ya una delimitación del sujeto. La determinación del "origen" y de las influencias que produjo la conquista, producían una doble fijación: por un lado, se producía una naturalización de los procesos "civilizatorios" de conquista, alguno de los cuales se estaba llevando a cabo en los mismos años que el autor escribía sus textos -específicamente en el Gran Chaco-, en tanto 
que aparecían como naturales y ahistóricos, estableciendo una continuidad histórica con los eventos difusionistas del pasado y los eventos difusionistas civilizatorios del presente y del futuro (Gnecco 2004:121). Por otro lado, la utilización del concepto de raza unido a caracteres culturales, creaba un otro fijo: así podían asociarse el "carácter" de las raza indígenas de hoy con nuestras "viejas culturas del noroeste" y el "carácter" de las razas de Tiahuanaco con el “carácter de la razas que sostienen" la "civilización" nacional. En esa interacción se coproducía, no solo él mismo como sujeto/arqueólogo, si no el sujeto nacional junto con aquél otro que debía, por medio del proceso civilizatorio, ser impulsado a estadios más avanzados de cultura ${ }^{\text {vii }}$.

En este contexto cobra mucha relevancia la cronología, y, como ya mencionamos, el origen. Estos dos problemas se transformaron en puntos de fuerte discusión y de encendidos debates. Pero la visión de Debenedetti también se enfrenta explícitamente con la propuesta expresada por Boman, principalmente, y también por Greslebin. En el caso de las figuras draconianas, la vinculación que podía hacer Debenedetti con Tiahuanaco fue rechazada por Boman y Greslebin (1923), quienes vuelve a sugerir la idea de coetaneidad en los estilos draconianos y otros estilos de la "región diaguita", particularmente el santamariano, que se definía por contraposición al anterior: "el estilo santamariano es contemporáneo con el draconiano, diferenciándose estos dos estilos decorativos por sus dispersión geográfica y no por sus épocas distintas. Los dos estilos han existido durante los dos últimos siglos inmediatamente anteriores a la conquista y aun han perdurado cierto tiempo después de ella" $(1923: 49)$

Aquí lo draconiano convivía con lo santamariano, inclusive hasta después de la conquista. Esta perduración, según los autores, se evidenciaba en hallazgos estratigráficos una urna de estilo santamariano se encontró apoyada en la tapa de una císta que poseía objetos pertenecientes a la colonia-; y en el caso de lo draconiano, su supervivencia hasta la colonia e inclusive posteriormente, se evidenciaba en tanto que en Bañado de los Pantanos (aquel fuerte fundado en 1633 por José Luís de Cabrera para pacificar al Valle de Paccipas y donde había reunido a unos 1200 indios), la cerámica indígena que aparecía era de indudable estilo draconiana. En resumen, se señalaba que la antigüedad de las poblaciones indígenas del NOA no iba más allá de dos siglos antes de la conquista, arriesgando llevar el estilo draconiano hasta un máximo de cinco siglos antes de la conquista, alrededor del mil de la era cristina (en total oposición a las relaciones que proponía Debenedetti con Tiahuanaco).

No obstante, a pesar de la discusión planteada con la perspectiva de Debenedetti (y también con otros, como Max Uhle, que planteaba su asociación con Tiahuanaco y su mayor 
antigüedad) y de proponer junto con Quiroga, Lafone y Ambrosetti la continuidad de las tradiciones indígenas prehispánica hasta la colonia e inclusive más allá, la perspectiva de Boman y Greslebin se alejaba más de estos últimos tres autores que del primero, con quien estaban en abierta contraposición. Pues señalaban que hasta el momento nadie había definido el estilo draconiano, que puede ser relacionado con el "carácter" de Debenedetti, aunque no es necesariamente lo mismo como veremos. Boman y Greslebin definen al estilo draconiano de la siguiente manera (1923:12):

"El estilo draconiano consiste en la representación de un monstruo ("dragón”) de cuerpo serpentiforme, ornado de manchas ovaladas y provisto de patas con garras. Así como de una o varias cabezas antropo o zoomorfas, más o menos estilizadas, destacándose generalmente en las últimas, fuera de los ojos y la lengua, las fuertes mandíbulas con dientes puntiagudos. Las estilizaciones que tienen su origen en este monstruo se componen de los cuatro elementos siguientes: ÓVALOS con o sin relleno, originados en las manchas del cuerpo; BANDAS CURVILÍNEAS o a veces, en las estilizaciones grabadas, ROMBOS, representando el cuerpo; ASERRADOS derivados de las mandíbulas dentadas; GARFIOS O GANCHOS procedente de las garras.”

Luego señalan: "el estilo draconiano prefiere las líneas curvas, mientras que el santamariano con predilección emplea las líneas rectas.” (Boman y Greslebin 1923:12)

Es interesante que para Boman y Greslebin, a diferencia de Debenedetti, el estilo o el “carácter" de lo draconiano, en términos del último autor, se defina de maneras distintas. Más allá de lo que concretamente asocian con lo draconiano, que para cada uno de estos autores es una cosa diferente ${ }^{\text {viii }}$, nos muestran dos formas de definir y pensar al estilo. Boman los concibe cómo parte del arte diaguita, es decir los asocia a una categoría más inclusiva, semejante al de arte calchaquí manejada por Lafone, Quiroga o Ambrosetti. A su vez, cada estilo posee una distribución geográfica -dispersión- particular. Pero lo interesante es que puede definirlos como estilos, y marcar sus límites, identificarlos, caracterizarlos, al contraponerlos uno con el otro, y establecer oposiciones: uno maneja líneas curvas, el otro prefiere las rectas; en uno hay representaciones de avestruces, pájaros, sapos, serpientes con cabezas bipartitas etc., en el otro no. Así el estilo no esta definido como núcleo cerrado o mismidad sino con relación a otra cosa. Lo que les permite a Boman y Greslebin poder unirlos en una categoría como arte calchaquí no son los estilos 'en sí mismos', si no el que se 
distribuyan en un ámbito geográfico particular que corresponde al de la cultura diaguita de habla cacana. Aquí, geografía y lengua funcionan como amalgamas de estos estilos, en tanto que para estos autores no hay profundidad temporal. La vinculación entre un estilo y una cultura particular en estos autores es más lábil que en Debenedetti: dentro de una cultura y un mismo arte pueden convivir estilos contrapuestos, muy poco vinculables salvo por las relaciones de oposición posibles de realizar entre ellos. En Debenedetti la cultura/raza, expresa su "carácter" en todo lo que hace, esto produce que el carácter de una decoración o en términos de Boman y Greslebin el estilo, esté más vinculado a una idea de centro, núcleo cerrado, por lo que la posibilidad de poder relacionar estilos diferentes al interior de un mismo carácter de una raza/cultura particular se trasforma en una tarea difícil sino imposible.

Ahora bien, a pesar de las diferencias sobre cómo intepretar el estilo, estos autores, al igual que Debenedetti, se vuelven a distanciar de las versiones de lo draconiano de Lafone, Quiroga y Ambrosetti en tanto que las antiguas convenciones (rotas por Debenedetti) no se vuelven a suturar. A pesar del planteo sobre la perduración de los dos estilos hasta tiempos posteriores a la colonia, los mitos, leyendas y tradiciones se dejan de lado: no son códigos ni cláusulas válidas para poder acercarse a los significados de la cultura material. Sin embargo, a diferencia de Debenedetti, no dejan de lado el interés en poder realizar cierta lectura sobre lo que expresan estos estilos, pero la búsqueda de estas herramientas de lecturas no estaban en las tradiciones ni en la arqueología, sino en el arte y particularmente en la "composición artística".

El proceso de composición artística, no debía ser la simple copia o alineamientos de figuras antiguas arreglados al azar sin conciencia estética. No sólo que se necesitaba aplicar las reglas de la estética, sino que además se debía poseerse un profundo conocimiento de los estilos prehispánicos empleados y de la arqueología de las regiones y pueblos al que pertenecen (Boman y Greslebin 1923: 59). Los autores al final del texto, en un apéndice, comentan dos composiciones realizadas por Greslebin en dos tapices, una con las características del estilo draconiano y al otra con características del estilo santamariano. Los comentarios: “...servirán para ilustrar las definiciones que hemos dado y demostrar en síntesis las diferencias entre uno y otro de los dos estilos" (Boman y Greslebin 1923: 60). Así, con respecto a la composición draconiana señalaban:

"toda la composición del tapiz está dispuesta sobre un fondo gris que recuerda el tono general de la cerámica draconiana grabada. El conjunto de la composición toma una armonía de color por el contraste de tonos, siguiendo el 
ejemplo de los originales indígenas, salvo en los detalle de las manchas del dragón que por ausencia de otros colores típicos están en armonía de escala con el fondo del cuerpo. El todo presenta una impresión inquieta, indefinida, característica del estilo draconiano" (resaltado en el original).

Al describir al santamariano señalan: "Nuestra composición santamariana, aún cuando no carece de complicaciones, ofrece cierta calma al lado del efecto que causa el tapiz de estilo draconiano. Es la calma que se adquiere con el uso preferentes de motivos geométricos." (Boman y Greslebin 1923: 60). Así estos autores lograban realizar por medio de la composición artística, en un juego de relaciones de oposición, una lectura del significado donde lo geométrico y lo no geométrico, lo lineal y lo no lineal, permitían definir e interpretar a dichos estilos en términos de lo inquietante y lo calmo.

A pesar de las formas diferentes en que estos autores definen lo draconiano y piensan al estilo o carácter, e inclusive a lo cultural (diferencias que trascenderán a sus planteos produciendo debates que perdurarán en la disciplina por mucho tiempo), la forma de comprender a lo draconiano, a lo diaguita, a Tiahuanaco, etc. se recorta de un trasfondo muy similar. El mismo del cual se recortaba el pensamiento de Sarmiento, de Lafone Quevedo, de Quiroga y de Ambrosetti. Si uno piensa en las preocupaciones de Sarmiento al pensar lo indio, lo gaucho, lo criollo como amenaza a la civilización, o al reclamo de Quiroga de incorporar lo indio -entendido como epopeya calchaquí- como fundante de la nación, o el interés de Lafone por aclarar procesos ocurridos antes de la conquista española -como lo que le discute a Laruy, en tanto eran muy importantes para comprender la "historia patria"-, lo “indio" es un problema para la conformación del Estado Nación, ya sea para su incorporación diferencial o su no incorporación.

Ahora, al pensar las preocupaciones de Debenedetti por buscar el origen del carácter que expresaban determinadas alfarerías, y otros objetos del NOA, en lugares distantes, como Tiahuanaco, o la negación por parte de Boman y Greslebin de cierta antigüedad de la poblaciones indígenas que habitaban la región y su inclusión dentro de una cultura "Diaguita"; lo "indio", lo draconiano, lo diaguita, lo calchaquí, no aparece como una amenaza al proceso civilizatorio de la Nación o como soporte de la historia nacional. Lo "indio" ya no es un problema, pues ambos procesos de incorporación y de no incorporación ya se habían producido o se estaban ya produciendo. La arqueología, como disciplina ya institucionalizada, había realizado ambos procesos: "lo indio" fue incorporado como su objeto de conocimiento, pero en esa misma incorporación existía una apropiación y una total no incorporación, en 
tanto que la arqueología era la "única" autorizada para hablar sobre su objeto. Así, los discursos establecidos desde la arqueología comenzaba a recortarse de un trasfondo un tanto distinto donde "lo draconiano", lo "indígena", lo "diaguita", el "carácter de las extintas y antiguas culturas del NOA" comenzaron a representar aquello que la arqueología como disciplina debía y podía, por medio de ciertas herramientas, narrar.

Un autor que se inserta en esta discusión realizando una propuesta algo diferente a lo que se venía desarrollando es Leviller (1927). La propuesta de este autor retoma ciertos postulados del programa de Debenedetti, pero difiere notablemente en la concepción de los draconiano, no sólo porque propone que en realidad se tratan de figuras felinizadas, sino porque se acerca más a las concepciones de Lafone, Quiroga y Ambrosetti. Siguiendo a Debenedetti -y también los planteos de Uhle- acepta cierta vinculación de lo draconiano con Tiahuanaco, discutiendo de esta forma con la propuesta de Boman. A su vez relaciona a este estilo con otra cultura más antigua que Tiahuanaco, la Cultura Recuay. Pero el interés de Levillier no es establecer relaciones o encontrar los orígenes de rasgos o caracteres con el objeto de establecer cronologías, sino plantear la existencia de cierta "unidad mitológica" entre las culturas indígenas, no solamente andinas, si no compartida por varios pueblos de las tierras bajas. Al comparar la cerámica Recuay (que Tello asocia a la representación de un dios felino) con la alfarería draconiana, encuentra similitudes notables que le llevan a señalar que “...no era concebible que los diaguitas escaparan a la unidad tan claramente patentizada en las naciones vecinas del norte, ni era aceptable que donde las demás representaban al dios felino, particularmente al jaguar, ellos imaginaran un dragón.” (Levillier 1927:61)

Levillier, veía en las representaciones más que una imagen de fantasías, tal cual lo expresara el término draconiano (concebida por Lafone Quevedo, Quiroga y Ambrosetti), observaba una imagen realista que los atributos mitológicos de ese felino a veces desfiguraban y que “...la unión de estos con figura humanas, serpentiformes y astrales, no puede apreciarse como una fantasía o una fe aislada en lo monstruoso imaginado, sino como la asociación de elementos naturales divinizados y la conjunción de múltiples creencias, adoraciones o temores..." (Levillier 1927:61). Lo mitológico en Levillier es la forma de lidiar con aquellos sentimientos que ciertos aspectos de la naturaleza, como el felino, producían a los indígenas. Al igual que para Quiroga, Lafone y Ambrosetti, en los objetos se podían "leer" esas percepciones y ciertas convenciones utilizadas para simbolizarlas. Pero a diferencia de estos autores, el "mito" ocupa un lugar diferente, como una forma de representación que mediaría entre la naturaleza no comprendida, indómita: 
"En rigor de verdad, nada tiene de extraño que siendo el tigre la fiera más difundida y cruel del continente, actuara en forma de obsesión sobre la sensibilidad primitiva aterrorizada, hasta el punto de establecerse en las divinidades y ocupar un lugar esencial en las imágenes de las obras de arte. El indio de la región serrana del callejón de los Mochicas y de la región Diaguita, veneraron a lo que adoraban, por bueno; y lo que temían por malo. A ambas fuerzas respetaron y sirvieron y a ambas dirigieron sus holocaustos interesados. La esperanza como el espanto dilatan los ojos y mueven la fantasía, al desequilibrar el juicio. De allí las fábulas, las creencias y supersticiones transmitidas de padres a hijos, transportadas después a la cerámica y a los enseres de uso diario.” (Leviller 1927:74)

Estas percepciones se materializarían en los objetos, en la cultura material. Esos aspectos mitológicos que desfiguran la realidad, podríamos decir el mito, las leyendas trasmitidas y su representación en los objetos, intervienen como un mecanismo de clasificación de los fenómenos y fuerzas naturales, y del mundo:

“En sus monumentos, en sus tejidos, en su cerámica, pueden leerse como un libro de sociología los capítulos de su capacidad creadora, de su talento estilizador, de sus hábitos privados, de su grado de progreso, de sus enfermedades, de su indumentaria, de sus vicios, por fin, los animales, las plantas, y los comestibles de cada región. Lo predominante, las imágenes más reiteradas, son escenas de las leyendas preferidas, símbolos de fuerzas mitológicas unidas o en pugna unas con otras...”. (Levillier 1927:62)

Estas formas de clasificación se hallarían presentes hasta hoy. En un sentido metodológico se diferencia de Debenedetti, Boman y Greslebin, acercándose a Quiroga, Lafone y Ambrosetti. Para Levillier, los aspectos mitológicos del felino perduran en el presente y pueden ser interpretados analizando los mitos y leyendas en relación con este animal, para luego compararlos con las representaciones que quedaron plasmadas en los objetos. El autor utiliza una categoría metodológica para unir estas creencias y representaciones de los felinos: "ideografías”. La ideografía, que puede ser definida como la representación de una idea a través de un conjunto de caracteres (Diccionario de la Real Academa Española 2001), es la clave que le permite leer en los objetos esos aspectos 
mitológicos. Así, realizando un amplio recorrido por distintas leyendas donde participan felinos -jaguares- en diferentes pueblos indígenas, desde las tierras bajas hasta los andes, encuentra una asociación recurrente entre el felino y los astros -especialmente la luna-, lo que le lleva a proponer la existencia de una unidad mitológica sobre la base del dios-felino-sol. Una vez conocidas las asociaciones de esos caracteres con las ideas, estas pueden se leídas. Los indígenas: "Con su afán realista copiaron lo que vieron. Bajo el ardor de la inquietud, imaginaron escenas, pintaron, esculpieron representaciones de los mitos, y evocaron a los dioses-penates de la tribu. Así es como pululan espléndidos ejemplares de jaguares naturales, jaguares estilizados, jaguares-hombres, jaguares dioses, jaguares-demonios, jaguar-hombresol, jaguar-mujer-luna, y luego la unión de esos personajes principales entre sí, con los atributos de rayos, serpientes, frutos." (Levillier 1927:74). Cada una de estas representaciones o ideografías conforman índices de esa unidad mitológica dios-felino-sol.

A pesar de todas las propuestas de Levillier, desde el ámbito de la arqueología sólo se rescatan algunas de ellas: la propuesta de que lo draconiano es un felino, la relación planteada entre lo draconiano con la cultura Recuay, y la proposición de que la representación debe verse no como fantasías imaginadas sino como elementos naturales divinizados. Estos tres aspectos conformarán la base para que lo draconiano se transforme definitivamente (el término será usado ya sólo de forma marginal), y comience a integrarse estos materiales no como un estilo particular dentro del arte calchaquí, ni como ideografías que representan aspectos de una unidad mitológica compartida por pueblos que se enfrentaron con el jaguar: se convierten definitivamente en patrimonio de una cultura específica. La posibilidad de lectura en las representaciones de mitos y leyendas quedará, después del trabajo de Levillier, conformando un espacio casi de frontera de la arqueología como disciplina; lo folclórico se irá conformado como ese afuera, que permanecerá hasta la actualidad en ámbitos no disciplinares. Sólo muy tardíamente, y asociado a un núcleo de sentido totalmente distinto, la idea de una unidad mitológica compartida por distintos pueblos será retomada como punto de discusión e interpretación de algunos aspectos de estos materiales, algo que desarrollaremos cuando analicemos la cultura material utilizada como indicador

Más allá de los planteos de Leviller, las posiciones de Debenedetti, Boman y Greslebin establecieron un debate que perduró mucho tiempo. Dichos diálogos no sólo pueden seguirse a través de los textos escritos por esos autores, sino que se transformaron en posiciones que plantearon un debate en la misma disciplina, durante varias décadas; particularmente, en lo que respecta al planteo de Boman y Greslebin sobre la cronología. Según González (1961-64) sus ideas tuvieron honda gravitación sobre los arqueólogos 
argentinos y frenaron por décadas todo intento de carácter cronológico. Por otro lado, el programa de Debenedetti, a pesar de las críticas de Boman, se logra instalar en la arqueología argentina y permeará los trabajos que se realicen posteriormente. La arqueología comenzará así a limitar definitivamente su campo, y lo draconiano comienza a participar de un núcleo más cerrado del que venía siendo asociado ahora a la idea de "pueblo" de los Barreales (Casanova 1930), de "Civilización de los Barreales" (Debenedetti 1931) y luego de "Cultura de los Barreales" (Bennett et al 1948).

II- Lo draconiano se transforma: ¿restos materiales del pueblo de los Barreales?, ¿"civilización material” de la antigua Civilización de los Barreales? o ¿patrimonio de la Cultura de los Barreales?

A pesar de los planteos de Boman y Greslebin, alrededor de los años treinta y en torno a los trabajos de Casanova (1930) y de Debenedetti (1931) comienza a instalarse la idea de que lo draconiano conforma parte de un núcleo cultural más antiguo que lo santamariano; aunque todavía no se halla asociado totalmente con la idea de cultura, a la que posteriormente quedará totalmente vinculado. Casanova (1930) realiza una serie de excavaciones, específicamente tumbas, en el cementerio de Huilische -Dpto. Belén, Catamarca- en la que encuentra cerámica típica draconiana asociada a otros materiales con motivos que más simples y rudimentarios y con otros motivos zoomorfos y antropomorfos. Además de objetos de cerámica, encuentran asociados objetos de metal, de cobre y mica. Acuerda con Debenedetti y Levillier en la antigüedad de dichos restos respecto de la conquista española. A su vez está de acuerdo con este último respecto de considerar a lo draconiano como representación de un felino de base realista y la vinculación que realiza con la cultura Recuay. Sin embargo deja de lado una de las propuestas principales realizadas por Levillier, la idea de unidad mitológica compartida por muchos pueblos. Como señala González (1961-64), Casanova habla por primera vez de “... pueblo de los Barreales” (Casanova 1930:143 citado en González 196164). Pero como también señala González (1961-64:206) el término cultura de los Barreales tenía ya carácter definitorio en la obra póstuma de Debenedetti (1931). Sin embargo debemos hacer un aclaración, Debenedetti en dicho trabajo no se refiere a Cultura de los Barreales, si no que la define como: "L’Ancienne Civilisations des Barreales du Nord-ouest Argentin: La Ciénega et La Aguada". En este trabajo no utiliza el término cultura, sino que específicamente habla de "Civilización de los Barriales". La utilización de este término se relaciona con el programa propuesto por él mismo unos diecinueve años antes: 
"Considérés d'un point de vue exclusivement archéologique, les gisements de La Ciénega sont d'une importante primordiale, parce qu'ils prouvent complétement l'existence d'un stade de civilisation avancée chez les peuples qui vécurent dans les vallées de la province de Catamarca á una époque, selon nous, trés antérieure au temps de la conquête et de l'occupationespagnole et qui dura longtemps.” (Debenedetti 1931: 11).

La definición de Debenedetti incluye a la propuesta realizada por Casanova, pero a su vez posee en su definición un marcador evolutivo, la civilización. En el antiguo trabajo de 1912 no utilizaba esta categoría para referirse a las culturas del NOA, solo señalaba que habían recibido las influencias de Tiahuanaco, influencias que habrían servido para arrancarlas de un estado de naturaleza (a las culturas del NOA), imprimiéndoles solidez a su desarrollo. Los hallazgos realizados en La Ciénaga y en La Aguada le permitían utilizar este marcador para caracterizar a la cultura productora de esos materiales como civilización, en tanto señala que se está ante la presencia de los restos materiales de un pueblo en donde el arte, en un momento determinado de su desarrollo, fue homogéneo, y que se hallaba diseminado en otros puntos del Noreste Argentino (Debenedetti 1931:11-12). A su vez, señala que se trata de una colección que nos revela, en toda su plenitud, la existencia de una "civilisation matérialle", que en lo concerniente a la cerámica rompe radicalmente con el canon clásico del estilo calchaquí ampliamente conocido (Debenedetti 1931:12). Además, señala que la piezas pueden ser identificadas, en función de todos sus caracteres, con el estilo que otros han denominado draconiano, pero dado que las deducciones realizadas sobre el mismo provienen de piezas aisladas y raras, sin conocer tampoco su extensión territorial, los cementerios de La Ciénaga y La Aguada proveen por primera vez en Argentina un conjunto arqueológico completo en donde el estudio completo permitirá mantener o rechazar el supuesto estilo draconiano vagamente definido (Debenedetti 1932:14).

El término civilización material utilizado por el autor lleva incorporado dos aspectos: por un lado, estos objetos conforman los restos materiales de un pueblo que habitó los lugares denominados barreales -por los lugareños-, tal cual lo expresa Casanova, y que produjo dichos objetos imprimiéndoles un carácter particular a los mismos. El otro aspecto, es que representan el grado o estado evolutivo alcanzado por ese pueblo: la civilización, que, como ya hemos señalado, para Debenedetti marca el mayor grado posible de alcanzar por un pueblo en una época determinada. Así, lo draconiano se une con otros elementos para transformarse 
definitivamente en representantes del patrimonio de un pueblo que alcanzó el máximo grado evolutivo en el noroeste: la civilización ${ }^{\text {ix }}$.

Definida específicamente como Cultura de los Barreales también aparece en el trabajo de Bennett y colaboradores (1948), pero esta propuesta difiere de la idea de pueblo de Casanova y de la idea de Civilización de Debenedetti; concretamente, está asociada más a la idea de área cultural norteamericana. El reclamo de Uhle y Debenedetti sobre la importancia de establecer una cronología tomaba cuerpo en la obra de estos autores, y desde ese momento las disputas con Boman sobre la antigüedad de las culturas del NOA comienzan a ser discutidas. En esa obra (Bennett et al 1948), los autores se propusieron realizar una síntesis de la arqueología del Noreste Argentino $^{\mathrm{x}}$, y lo perteneciente al pueblo de lo Barreales y a la antigua Civilización de los Barreales aparece definido ahora como Cultura de los Barreales. Esta definición, si bien se relaciona con los anteriores planteos de Casanova, y Debenedetti, gira en torno a un núcleo de sentido más específico, que predominará durante los siguientes treinta años, dada su influencia en la obra posterior de Rex González; perdurará también hasta la actualidad, superpuesto a otras cosas: el de la historia cultural norteamericana. La organización del libro que realizaron estos autores nos permite vislumbrar cuales son estos núcleos. Áreas culturales, sub-áreas, estilos, culturas, complejos, períodos, interrelaciones, cronología, serán los conceptos que articulan esta propuesta. La obra comienza con una introducción en donde se definen las distintas áreas culturales de la Argentina, una vez definidas las cuatro áreas mayores se adentran en la caracterización de área del Noroeste Argentino, primero a nivel geográfico: “es la región montañosa que se extiende desde Bolivia en el norte hasta Mendoza en el sur, y de la frontera de chilena a las planicies de la pampa y el chaco" (Bennett et al 1948:15 la traducción es nuestra). Más adelante señalan que esta extensa región, en muchas formas, es un área cultural en sí misma, marcando contrastes con otras secciones de Argentina. Así, comienzan a caracterizarla en términos generales, haciendo hincapié en los aspectos compartidos:

"todos las períodos y culturas conocidas dependieron de una horticultura sedentaria complementada con el pastoreo de llamas. Grandes sitios son comunes, y presentan construcciones arquitectónicas de piedras o adobe. La cerámica estuvo bien desarrollada, la metalurgia fue asociada con la mayoría de las culturas, y, donde la buena preservación nos permite, el trabajo en madera, el trabajo en piedras, la tejeduría y una artesanía similar se ponen en evidencia. Hay indicadores de una formalizada organización religiosa y política. En otras 
palabras, las culturas del Noroeste son generalmente similares al patrón básico andino encontrado a través de Bolivia y Perú” (Bennett et al 1948:15-16)

A pesar de estas homogeneidades al interior de la región pueden hacerse subdivisiones, "sub-áreas" que según los autores responden más a patrones culturales que a factores ambientales. Reconociendo las otras divisiones realizadas por otros autores, optan por dividir el Noroeste en cuatro sub-áreas: sub-área Norte (Jujuy y parte adyacente a esta de Salta), Centro (Salta, Tucumán y Norte de Catamarca), Sur (Catamarca, La Rioja, San Juan y Mendoza) y Este (santiago del Estero). A su vez señalan que estas divisiones son en parte definidas por conveniencia de separar un área tan vasta, pero que responde a unidades culturales válidas. Una vez definidas estas sub-áreas, comienzan con la caracterización de cada una de ellas, la cultura de Los Barreales se encuentra en la sub-área sur. La descripción de cada sub-área se estructura de la siguiente manera: se la caracteriza a nivel geográfico, se realizan algunas divisiones, se enumeran algunas de los aspectos compartidos, y luego se adentran en los estilos que se presentan en ella. Los estilos serán el núcleo principal sobre el cual posteriormente se definirán las culturas, y se asociarán a ella el resto de elementos que la caracterizan. En nuestro caso, los estilos que forman la Cultura de los Barreales serán el Huiliche monocromo, el Ciénaga Policromo y en parte, el Calingasta Inciso. La descripción de cada estilo se realiza en primer lugar con una descripción general: "Huliche monocromo es una cerámica gris oscura o negra, combinado quizás con grafito, decorado por incisiones". En éste entra el estilo draconiano aunque en ningún momento lo refieran con ese nombre. Luego se describen las formas a las cuales se asocian para después adentrarse más específicamente en la descripción de los diseños: "Los diseños son geométricos y figurativos. La ornamentación geométrica es caracterizada sobre el balance de los elementos que en textura y motivo se asemejan a patrones textiles. (...). Los diseños figurativos incluyen llamas con cuerpos triangulares, largas orejas, y pequeñas cabezas, sapos romboidales, pájaros rectilíneos grabados o en finas incisiones curvilíneas, figuras antropomorfas y jaguares.”(Bennett et al 1948:101). Una vez definidos los estilos, pasan a describir los sitios donde aparecen representados. Los sitios son el nexo entre los estilos y demás elementos que van a forma parte y caracterizar a las culturas. El espacio unido al estilo funciona como una fuerza centrípeta que permite aglutinar un conjunto de características que, a su vez, permitirán definir una cultura particular. Esta unión entre espacio/estilo/elementos asociados, posteriormente pasará a definirse como "contexto cultural". Así, cuando realizan la descripción de la cultura, aparecen otros elementos junto a los estilos cerámicos; al caracterizar a la cultura de los Barreales señalan: 
"Los sitios La ciénaga, Huiliche, Chañarmuyo, y Barrealito B sirven para aislar a la cultura de los Barreales que tiene una amplia distribución en el sur. Aunque no existen restos superficiales asociados en la Ciénaga, hay cercanas casas de barro y unidades con bajos muros de piedras. Los cementerios son simples, tumbas pozo no alineadas, algunas de las cuales se reportaron como muy profundas. Grandes jarros planos son utilizados para enterrar infantes." (Bennett et al 1948: 117).

El otro paso es ordenar cronológicamente a estas culturas y realizar una periodificación. Una vez que han definido a las culturas de esta sub-área las ordenan en cuatro períodos, siguiendo la periodificación clásica de los Andes Centrales: Temprano, Medio, Tardío e Inca. La deducción utilizada para ubicar cronológicamente a los culturas es en cierta forma simple, partiendo del conocimiento que la cultura Inca es más tardía que las otras y a que, según los autores, todos los datos apuntan a que la Cultura de los Barreales es una de las más tempranas (tal como hemos vista fue señalado casi desde el principio en relación a lo draconiano) ubican al resto de las culturas definidas en el área -Cultura Belén, Cultura Aimogasta, y lo que llaman misceláneas -estilo Condorhuasi Polícromo- en el medio de estas dos. A Condorhuasi Polícromo lo ubican más tardíamente que la cultura de los Barreales en tanto que se asemeja más a Yocavil Polícromo. El estilo aquí vuelve a aparecer como fuerza centrípeta en tanto permite atraer al estilo Condorhuasi por similitud hacia el Yocavil y de esta forma adquirir identidad temporal, en tanto puede ocupar una posición determinada en el cuadro de periodificación.

Esta metodología la desarrollan en cada una de las sub-áreas, y en el final de la obra realizan un cuadro síntesis de la cronología del área, marcando las interrelaciones posibles de establecer, las "Interna" y las "Externas". Es decir al interior del área como "núcleo", unidad geográfico-cultural, y al exterior del área como otros núcleos unidades geográfico-culturales. Recordemos que este procedimiento se realiza también en una escala más pequeña al interior de las sub-regiones -relaciones entre las divisiones-. Pero algunas pueden llegar a entrar en áreas aún mayores como el caso del Noroeste Argentino con el área andina de Perú y Bolivia.

Así tenemos una fuerza centrípeta, que va aglutinando todo lo hallado alrededor de determinados núcleos, que se contienen unos a otros. Dicha fuerza se compone de dos parámetros: uno es espacial, el otro es el principio de similitud. Otra fuerza que interviene es el tiempo, que es lineal y constante. Pero a diferencia del tiempo de Debenedetti, de Boman y 
Greslebin, y de los otros autores que hemos discutido, no cumple una función de variable en el modelo, sólo participa como parámetro constante y fijo que permite la ordenación de dichos núcleos. En el caso de los otros autores, el tiempo es una variable muy importante, que en algunos casos determina el modelo (por ejemplo en Debenedetti), en tanto que forma parte constitutiva de la fuerza del "progreso", la evolución cultural en los términos evolucionistas clásico. En estos planteos en realidad el tiempo es progreso. Si pensamos en el marcador evolutivo de Debenedetti, sería imposible definir la idea de civilización sin la idea de progreso. Y por lo tanto sería imposible ubicar temporalmente a cada cultura-raza, en tanto que no se podrían reconstruir las influencias para restituirlas a su origen. En el modelo de Bennett y colaboradores (1948), el tiempo es lineal, al igual que en los otros autores, pero no forma parte de la idea de progreso decimonónica clásica.

En esta obra se puede observar, un principio administrativo, ordenador, que permite articular un gran cúmulo de información, otorgándole un lugar en cierta forma preciso. El arqueólogo así, no sólo es el sujeto de conocimiento del pasado (y como hemos señalado más arriba quien puede y debe dar cuenta del él), si no que también se transforma en su administrador. Si pudiéramos representar la obra de Bennett y colaboradores (1948) en una imagen podría ser la del depósito de un museo, el arqueólogo como administrador del pasado puede circular libremente por los pasillos, donde se hallan las estanterías y dentro de ellas, los objetos arqueológicos. Los estantes pueden ampliarse, se les puede cruzar una tablita al medio, se puede cambiar de lugar los objetos, se pueden armar nuevas estanterías, pero los soportes sobre los cuales descansan permanecerán inalterables, así como la geometría particular que ellos expresan.

III- La cultura de los Barreales se fragmenta: Lo draconiano como patrimonio de la cultura de La Aguada.

El programa lanzado por el trabajo sistematizador de estos autores conforma, como ya hemos dicho, uno de los soportes sobre los que González producirá una nueva sistematización de la arqueología del NOA, creando, como señala Bonnin (2007) un modo de hacer arqueología que influirá decisivamente no sólo en los comienzos de las investigaciones en el Valle de Ambato, si no en toda la arqueología del Noroeste Argentino ${ }^{\text {xi }}$

En los trabajos realizados por González se nota la influencia de la obra de Bennett et al (1948) particularmente en la tendencia hacia un principio administrativo y en el objetivo de armar una "secuencia", en sus propios términos -"periodificación", en términos de los otros 
autores-. En el año en que es publicada la obra de estos tres autores -a fines de 1948-, González está volviendo de realizar sus estudios en Estados Unidos, en la Universidad de Columbia -de la mano de Julián Steward- (Bianciotti: 2005:170). Se trata de una coyuntura particular para la antropología en esa universidad: por una lado los discípulos de Boas conforman parte de los profesores con los cuales González toma clases (por ejemplo, Ruth Benedict), por otro lado, existen críticas muy fuertes a las posiciones historicista y culturalista Boasiana, que suponen cambios de profesores y el resurgimiento, de la mano del Julian Steward, de una perspectiva neoevolucionista, como la ecología cultural. La combinación entre el historicismo culturalista norteamericano y una posición evolucionista serán parte de los sustentos que González utilizará para delinear su enfoque. El otro aspecto que influyó profundamente en su perspectiva fue lo que aprendió en la escuela de campo de Arizona.

La propuesta que González, a su vuelta, planteaba como agenda para la arqueología argentina fue el establecimiento de una secuencia histórica para el NOA. En este sentido compartía los viejos intereses en establecer cronología de Uhle y Debenedetti. Más adelante señala "Yo me di cuenta que hacía falta eliminar la idea de que todo lo que se encontraba en el noroeste era diaguita porque evidentemente, había una secuencia que era necesario establecer. Esa era la problemática fundamental" (Bianciotti 2005:172). Resalta en el mismo párrafo que Max Uhle lo vio claramente, en tanto que estableció una secuencia y con un criterio muy particular: de la época del salvajismo, es decir cazadores recolectores, luego la cultura de los vasos draconianos, después la cultura Belén y finalmente, los incas. Pero a diferencia de Uhle y Debenedetti la visión de González era un tanto diferente, se trataba de la propuesta metodológica del historicismo culturalista norteamericano. Es aquí donde adquiere relevancia para González la obra de Bennett et al (1948), en tanto que había establecido una secuencia bien fundada, aunque podía ampliarse mucho y completarse (Bianciotti 2005:173). Para esto, según González, se debía excavar, obtener muchos fechados radiocarbónicos y trabajar con colecciones como la de Muñiz Barreto, que contaban con una documentación muy sólida sobre el valle de Hualfin: "Si yo lograba hacer una cronología maestra para el centro del noroeste después iba ha ser relativamente más fácil encontrar las secuencias de las áreas aledañas en las cuatro direcciones.” (Bianciotti 2005:173). En este sentido, el trabajo de González se acerca mucho a la posición tomada por Bennett et al (1948), donde la secuencia (periodificación) conforma la estantería o el esqueleto sobre la cual montar luego una historia cultural. Con González (1950-55) también aparece fuertemente la importancia de establecer los contextos culturales. Éstos, como mencionamos, comienzan a tener importancia en la obra de Bennett et al (1948), pero será González quien los proponga como un aspecto fundamental, un primer paso, para poder realizar una secuencia en el NOA. En este sentido, se aleja un 
tanto Bennett et al (1948) ya que para estos autores los contextos de asociación conforman un aspecto más vale marginal a la periodificación, siendo los estilos el factor más importante de definición de una cultura y de su posición cronológica.

González en la biografía autorelatada parafraseando a un alumno señala “...una vez, cuando yo buscaba armar los contextos de las culturas del noroeste, me dijo: <yo sé lo que usted busca; usted busca las cosas que van juntas>. Así describió en dos palabras, de una manera muy gráfica, la organización de los contextos que para entonces carecían totalmente de interés, no habían sido ensayados salvo en parte por el libro de Bennett pero no como organización de contextos si no de culturas a través de distintos estilos." (Bianciotti 2005:172). Cual es esa diferencia que señala el autor, ¿Qué son los contextos culturales para González? Señalamos que en el trabajo de Bennett et al (1948) en primer lugar se definían los estilos, luego se describían los sitios donde ellos aparecían, juntos con los materiales asociados, para luego definir la cultura. González en su trabajo de 1950-55, "Contextos culturales y cronología relativa en el área central del N. O. Argentino" cuando se refiere a las culturas agro-alfareras señala: "La formación de los cuadros cronológicos en lo que se refiere a las culturas agroalfareras ha presupuesto la formación de los contextos culturales respectivamente de su ubicación en el tiempo. Estos contextos se han formado especialmente con el estudio de los sitios aislados, de los basureros y del patrimonio de las tumbas" (González 1950-55:14). Con respecto a la cronología señala: "en primer lugar ha sido necesario la identificación correcta de los numerosísimo tipos de alfarería que aparecen en la zona." Aquí de la misma forma que Bennett et al (1948) toma como principio y punto de partida los estilos (tipos alfareros), es decir el principio de similitud, con su fuerza centrípeta. Pero cuando se refiere a los cuadros cronológicos señala en la nota (5) "Debemos hacer notar una diferencia entre los cuadros cronológicos de Bennett y el nuestro. En el primero se exponen la sucesión de estilos cerámicos que se agrupan en culturas (...) nosotros no exponemos si no la cultura o la etapa correspondiente. La mención de los tipos de alfarería fundamentales de esas etapas van en los textos" (González 1950-55:14). ¿Que implica esta diferencia remarcada por González, entre sucesión de estilos cerámicos agrupados en culturas y sucesión de culturas o etapa correspondiente? ¿Cómo se vincula con su definición de los contextos culturales?

Los contextos culturales en parte son como le señaló un alumno a González "las cosas que van juntas", y son estas cosas que van juntas las que luego le permiten definir un cultura específica y posteriormente ordenarlas temporalmente, armar la secuencia de desarrollo cultural en el NOA. La crítica realizada por González a Bennett et al (1948), es la 
marginalidad en su textos y cuadros de estas otras cosas que van juntas con los estilo cerámicos -tipos cerámicos-. Dentro de la propuesta de González el estilo sería un aspecto más del "patrimonio" o "elementos" (1961-64) de una cultura particular, es por eso que señala que no los coloca en su cuadro cronológico si no dentro del texto (González 1950-55:14).

Aunque no se halla definido específicamente en dicho trabajo, podemos observar qué significa para González el patrimonio, en la estructura elegida para describir la Cultura de la Aguada (1961-64): en primer lugar establece la dispersión geográfica utilizando de base un mapa confeccionado por Bregante (1926). Luego de establecida la dispersión en el espacio se sumerge en la descripción de la economía, la tecnología (alfarería -aquí describe a los estilos alfareros-, material de piedra, metalurgia y objetos de madera), las habitaciones y el patrón de poblamiento, la funebria, la armas, el vestido y los adornos, la sociedad, la religión y el arte, la cronología y por último el origen de esta cultura. El "contexto cultural" descrito para Aguada amplía notablemente las salas y estanterías del depósito que Bennett y colaboradores (1948) habían construido para la arqueología del NOA. No solo debían correrse tablas de lugar para que entrara una cultura nueva, o mover de un lugar a otro los objetos en tanto algunas cultura desaparecían y otras cambiaban de posición en la secuencia, sino que debían ampliarse las estanterías, en tanto que junto a los estilos cerámicos entraban un cúmulo muy grande de otras cosas que, como elementos o patrimonio, formaban parte de una cultura. Pero a pesar de esta ampliación y cierto desplazamiento, el lugar ocupado por el estilo, y con él el lugar ocupado por los demás objetos del patrimonio de la cultura, no sufre ningún cambio.

Es sugerente que González en el trabajo donde define a la Cultura de la Aguada y caracteriza el patrimonio de esta (su contexto cultural) comience analizando y mostrando la "dispersión geográfica" de las piezas de la cultura de la Aguada utilizando y ampliando un mapa confeccionado por Bregante (1926), donde la autora utiliza los estilos cerámicos (más cercano a la definición de Debenedetti del carácter de una cultura/raza) para trazarlo. De vuelta, el estilo como fuerza centrípeta junto a su matriz conectiva, el espacio, delimita el área ocupada por la cultura de La Aguada. En este sentido si bien en la geografía del texto de González el estilo ocupa un lugar diferente, de menor visibilidad, sigue siendo el sustento a través del cual es posible delimitar y definir una cultura y su patrimonio, su contexto cultural. Así la geometría de los depósitos construidos por Bennett et al (1948) se mantiene intacta y el estilo junto al espacio, fijados en un mapa crean y recrean a la cultura Aguada como unidad. En este punto, el estilo, el espacio, el mapa, los objetos, el patrimonio, es decir la "cultura" y la "cultura material" se autoreflejan y vuelve a reafirmarse el cambio que Debenedetti (1912) había comenzado a producir, respecto de los planteos de Lafone Quevedo, Quiroga y 
Ambrosetti, de lo draconiano y de la cultura material. Estos ya no eran símbolos posibles de ser leídos a través de las cláusulas que aún permanecían en el folclore, sino que eran el "significante" de una cultura particular.

No obstante, hay un punto en donde González se aleja notablemente de Bennett et al (1948): su noción de tiempo. Esto nos lleva de vuelta a la definición de "La Civilización de los Barriales" por Debenedetti (1931).

Como ya hemos señalado la "Civilización" para Debenedetti es el máximo grado alcanzado y por alcanzar por un cultura/raza en un lugar y período determinado. Por otro lado, si pensamos en el trabajo de 1912 son estas civilizaciones las que impulsan y aceleran por medio de la conquista a las otras culturas, como lo que habría ocurrido en el NOA con la Influencia de Tiahuanaco. Esta afirmación de Debenedetti, pasará a conformar un supuesto indiscutido que permanecerá en la arqueología regional por décadas y que creemos influye en la propuesta de González. Conformará a su vez una de las bases sobre las cuales se sustenta la definición de la cultura de la Aguada como la marcadora de un hito en la secuencia cultural del NOA, no alcanzado por otros sociedades que se sucedieron con anterioridad a esta e inclusive luego de su desaparición: "El período medio está jalonado por la cultura que se denomina de La Aguada. Desde el punto de vista cultural es el momento de mayor desarrollo en todo el Noroeste o, por lo menos uno de los más altos exponentes de las manifestaciones técnicas y artística" (González y Pérez 1976:63, las itálicas son del original). Inclusive, antes de que González dedique un texto a la definición de la cronología y contexto de la cultura de la Aguada (1961-64), en el trabajo donde define los contextos culturales y la cronología relativa en el área central de N. O. Argentino (1955:14) señala "En nuestra cronología, como en la de Bennett (op. cit: 141), (5) la aparición de las culturas ceramistas y agrícolas en el área central y gran parte del N. O. parece se produjo por invasión, con la llegada de una cultura de alto desarrollo técnico y artístico que conocía la metalurgia, los animales domésticos y cuya cerámica no ha sido sobrepasada en belleza y finura.”. En este último trabajo, la primera facie cultural definida es la de La Aguada. En el trabajo de Bennett et al (1948), si bien se reconoce la existencia de influencias entre culturas que le llaman interna y externa, no se recurre a explicaciones y mecanismos como la conquista, o conceptos evolutivos como desarrollo técnico o artístico: la idea de "progreso" no se halla expresada allí. Aquí es donde González se acerca mucho al planteamiento de Debenedetti, en tanto que la conquista (invasión en González) fue uno de los mecanismos apelados por este autor para observar las influencias en el NOA de culturas más desarrolladas. Por otro lado esas invasiones o conquistas producen la aparición de la cultura más desarrollada del NOA (la civilización de los Barreales en 
Debenedetti y la Cultura de la Aguada en González). Aunque González posteriormente modificará la posición cronológica de la Aguada, discutirá el mecanismo esgrimido sobre el origen -la invasión-, proponiendo la "infiltración" desde los oasis chilenos de aquellos elementos que permiten que surja Aguada, y que se imponen y desplazan a los de la cultura Ciénaga. La posición de La Aguada en la escala evolutiva de la culturas del NOA, y su desarrollo a partir de influencias de sociedades más desarrolladas ubicadas en los centros nucleares de los Andes -que ya había sido propuesto por Max Ulhe y Debenedetti- no será discutido. El siguiente pasaje de González ilustra esta forma de pensar:

"Si existen algunos momentos de detención cultural o retroceso (Hualfín, San José, etc.) la recuperación se establece de cualquier forma y si esta no ocurriera por sí misma, las influencias de los centros andinos vuelven a elevar el nivel. La invasión imperial incaica es clara en ese sentido. Es decir que los «accidentes históricos» (influencias del este) no pudieron cambiar el rumbo de las etapas del proceso cultural que se cumplía bajo la influencia de los centros nucleares [...] Pudieron cambiar algunos detalles del contenido o alterar los lapsos de tiempo, década, etapa pero no impidieron que se movilizara la cultura hacia niveles de mayor complejidad" (González 1979: 14).

Durante los años posteriores, para González el NOA quedará como un área de desarrollo marginal a la gran corriente de la civilización Andina, tal como lo señalara posteriormente Pérez Gollán (1994). Esto nos trae de vuelta al principio de este capítulo y a los inicios de las investigaciones en el Valle de Ambato.

\section{La Cultura Material como Indicador: Proceso de Integración Regional y la Producción de lo local.}

Señalamos al principio de este capítulo que uno de los intereses por desarrollar investigaciones en el Valle de Ambato fue la presencia de la cerámica negra gris grabada. Originalmente, si bien fue colocada como una facie dentro del desarrollo de la cultura de la Aguada, González la vinculó a un Complejo X, proponiendo como hipótesis un origen diferente. Específicamente, se trataba de un centro independiente en Bolivia, no conocido aún, desde donde irradiaron influencias que, por un lado, cristalizaron a orillas del Titicaca y, por otro, alcanzaron independientemente al NOA (González 1961-64:251). Así el comienzo de las investigaciones en Ambato, tal cual lo indicaran Pérez y Heredia (1975), permitiría no sólo 
conocer una facie aún desconocida de la Aguada, sino que también ampliaría y profundizaría el conocimiento de su contexto cultural.

Las investigaciones que se fueron concretando en el lugar -hasta ese momento denominado como sector norte del Valle Central de Catamarca (Pérez y Heredia 1975)-, es decir las primeras prospecciones y excavaciones de sitios en diferentes partes del Valle, comenzaron a mostrar un panorama particular que paulatinamente, junto a un conjunto de sentidos diferentes acerca de la producción del cambios social, cambiarán la forma de pensar a Aguada como cultura, le dará identidad al Valle en la arqueología regional y producirá un quiebre con cierta perspectiva de la cultura material que desde los planteos de Debenedetti (1912) permanecía como sustento inalterable de la interpretación de los materiales asociados a Aguada.

En primer lugar se observó la presencia de "cerámicas negras o rojizas que portaban los típicos felinos de la cultura de la Aguada (...) [que] si bien podían ser filiadas como piezas ciertamente Aguada (...), todas las alfarerías presentaban formas y (...) motivos decorativos que ofrecían un estilo diferente a los de aquella área (...) con características regionales bien marcadas" (Heredia 1976:3). En segundo lugar, se pudo determinar la asociación de estas cerámicas con “...sitios de viviendas que presentaban rasgos inéditos para Aguada (...). [se trataban de] sitios de viviendas no agrupados cuyas paredes habían sido construidas con barro pero teniendo una columna formada con piedras planas superpuestas, colocadas a una distancia de 70-100 cm una de otra. Este rasgo resultaba significativo ya que solo había sido relevado para la temprana cultura de Alamito..." (Heredia 1976:3). En tercer lugar, en estas viviendas aparecían otros materiales como las grandes vasijas de cuerpo subglobular pintadas en negro, blanco y rojo, delineando motivos geométricos, aunque muy frecuentemente aparecían figuras antropomorfas de guerreros, complementadas con representaciones felínicas vinculadas al complejo Aguada; aunque por su motivos y colores sugerían alguna relación con la alfarería Condorhuasi -aspecto que mostraría cierta continuidad de algunos rasgos desde el período temprano- y que aparecían también en los sitios de Alamito -Alumbrera Tricolor- ${ }^{\text {xii }}$. En cuarto lugar, y vinculado al período temprano en el valle, se excavó el sitio el Altillo (Federici 1991), un montículo basurero artificial que en toda su estratigrafía presentaba cerámica del estilo Condorhuasi, y que señalaba una ocupación del valle anterior a Aguada vinculada a esta cultura. A su vez, las excavaciones realizadas en un sitio habitacional y específicamente en un montículo basurero adosado a este -sitio Martínez I (Assandri 1991)arrojó la asociación de cerámica Aguada con fragmentos que poseían rasgos de la cultura temprana Ciénaga, esto les llevó a plantear un nuevo momento de ocupación del área que 
venía a ensamblarse a los dos ya conocidos de Condorhuasi y Aguada (Heredia 1976). Pero a su vez, sobre este nuevo momento señalan que hasta ese instante “...no fue posible localizar otros restos pertenecientes a Ciénaga, donde ésta aparezca como única manifestación o como un componente aislado de un asentamiento" (Heredia 1976:6-7). Estas apreciaciones iniciales llevaron a plantear ciertas hipótesis de trabajo: a) la localidad de Los Castillos constituye un centro de desarrollo de la cultura de la Aguada, diferente a los otros conocidos -Valle de Hualfín y Norte de la Rioja-; b) la vinculación con culturas más tempranas como la de Alamito y Condorhuasi y la aparición de Ciénaga en contextos donde también aparecía Aguada sugerían una antigüedad probablemente mayor para este centro de Aguada que cualquiera de las otras manifestaciones de esta cultura en el NOA (Heredia 1976).

El lugar ocupado por la cultura material en esta interpretaciones sigue siendo por el momento el reflejo de las culturas que habitaron el valle en distintos momentos, un ejemplo de esto es lo que se indica cuando aparece cerámica de estilo Ciénaga en el montículo del sitio Martínez I: “...no fue posible localizar otros restos pertenecientes a Ciénaga, donde ésta aparezca como única manifestación o como un componente aislado de un asentamiento" (Heredia 1976:6-7). Es decir, lo que se está indicando es que no habían hallado el "contexto cultural" de Ciénaga. En este sentido sigue existiendo una fuerte relación entre estilo y cultura; la cultura material de Aguada aún no fue desplazada desde el locus donde González la ubica en sus trabajos.

Pero la idea de que Aguada en el Valle de Ambato posee una mayor profundidad temporal respecto a las otras áreas irá abriendo el camino para un planteo más vinculado a un desarrollo local de esta cultura que a infiltración de elementos de las áreas nucleares a través de los oasis de puna. Este proceso de trasformación no se encuentra desacoplado de las fuerzas macroregionales, sino más bien en un activo y creciente proceso de integración, aunque iniciado y concretado a través de una serie de trasformaciones internas de las relaciones sociales de la sociedad que habitó el valle durante el primer milenio.

La fuerte vinculación establecida con Alamito, más la presencia de estos estilos asociados o formando parte de culturas más tempranas, llevan a proponer que:

“En algún momento entre el 400 y 500 d.C, se asientan en el valle de Ambato comunidades Alamito-ciénaga probablemente venidas del Campo del Pucará cuando los asentamientos de Alumbrera fueron abandonados y Ciénaga influía de forma neta sobre la cultura local (...) Al instalarse en Ambato estas comunidades Alamito-Ciénagas, que debían tener un fuerte énfasis de pastoreo 
en su base económica, ya sea porque incorporaron un nuevo cultígeno de más alto rendimiento económico (variedad nueva de Zea mays?), o bien porque comenzaron a practicar una agricultura con sistemas más complejos de riego, o por algún otro factor que por el momento desconocemos, iniciaron una transformación social de importancia y en un lapso de tiempo relativamente corto. Este cambio tal como lo entendemos, se operó en las relaciones internas de comunidades instaladas en un ámbito geográfico determinado, las transformó cualitativamente y abrió el camino para el pasaje a una cultura distinta que los arqueólogos denominamos Aguada la que posteriormente, tal vez por su efectividad económica, ocupa otros medios ambientes y adquiere notable preponderancia.” (Pérez y Heredia 1975:67)

En esta cita se conjugan dos aspectos que irán imprimiendo ciertos sentidos y desplazando otros de lo que se conocía y se sustentaba para el desarrollo de Aguada: en primer lugar la relación entre desarrollo tecnológico -como la incorporación de una nueva variedad de cultivo- y vinculada a esto la reestructuración de las relaciones sociales al interior del las comunidades que adquieren dichos productos.

La relación entre tecnología y cambio social, tal cual la están expresando los autores, podría ser puesta en éstos términos: existe una avance en las fuerzas productivas al incorporarse nuevas tecnología, esta avance produce tensiones en los modos de relación al interior de las comunidades que se instalaron en el valle que llevan, en un proceso “dialéctico" (Heredia 1976), a que se reconfiguren las relaciones sociales de producción infraestructura-. El segundo aspecto que comienza a tomar fuerza es que esto cambios en la infraestructura son acompañados por cambios super-estructurales, surgiendo la ideología como un factor de importancia en la explicación de la reproducción de las nuevas relaciones sociales que generarían dichos cambios en las relaciones de producción:

“Un de los aspectos manifiestos del cambio es la temática decorativa: comienza el predominio de la representación felínica, que si bien está presente ya en Tafí, Condorhuasi, Alamito y Ciénaga en relación a estructuras del denominado complejo de transformación shamánico” y ligado al uso de drogas alucinógenas (...) es con Aguada que adquiere un carácter de reflejo iconográfico de las relaciones internas de la sociedad que comienza a diferenciarse en sus status, aunque de modo muy incipiente. Surge un grupo de guerreros sacerdotes que asume la dirección de la comunidad, probablemente por la apropiación del 
excedente económico posibilitado por una explotación más efectiva del medio Ambiente. Aquí aparecerían las construcciones [plataformas ceremoniales] denominadas "Iglesia de los Indios" y "Bordo de los Indios” y que pueden ser expresión del status de guerreros sacerdotes...” (Pérez y Heredia 1975:67)

En esta cita existe un cambio notable del lugar ocupado por las figuras draconianas que desde los planteos de Levillier (1923) que retomaron Casanova y González, no habían sido desplazadas. Como hemos señalado más arriba, estas figuras fueron observadas por estos autores como la asociación de elementos naturales divinizados; y en este sentido como lo señalara Levillier, las figuras draconianas, en tanto expresión de mitos que utilizaron para lidiar con aquellos "sentimientos" que producían ciertos aspectos de la naturaleza -como el felino-, se transformaron en mediadoras con aquellas fuerzas no comprendidas e indómitas. La religión era expresión de este proceso. En cambio, en Pérez y Heredia (1975) estas figuras son expresión, más que del proceso de mediación a través del cual se incorpora la naturaleza a la cultura, de un proceso de cambio en las relaciones sociales, transformándose en productos ideológicos que sustentan relaciones de dominación, en este caso la aparición de una elite de guerreros sacerdotes. González, en el trabajo donde define el patrimonio de la cultura de la Aguada, ya había adelantado la observación de ciertas diferencias, particularmente en el ajuar de las tumbas, señalando la posibilidad de la existencia de status diferentes. Pero serán Pérez y Heredia (1975), quienes incorporen al interior de la problemática de Aguada ciertos elementos que hasta el momento no se habían esbozado, o se los había interpretado en un plano de la historia regional más amplio y de mayor profundidad temporal (y que también que influyó en la perspectiva de estos autores) como en el caso de Núñez Regueiro (1974). Lo que en el planteo de González (1961-64) quedaba separado en casilleros diferentes que caracterizaban el patrimonio de Aguada, aquí será conjugado al interior de determinadas relaciones vinculadas a la conformación de una ideología dominante: lo que González define separadamente como "Economía”, "Sociedad”, “Arte y Religión”, comienzan a participar de otras relaciones, más allá de ser expresiones y contexto de una cultura particular.

Si bien, y volviendo a la metáfora del depósito de museo, las tablas más gruesas y espesas que dividen los compartimentos culturales y en donde se produce un efecto reflejo entre cultura y cultura material aún permanecerán en su lugar, las otras tablitas agregadas por González que subdividieron y ampliaron notablemente las estanterías creadas por Bennett et al (1948) comenzarán a desmaterializarse, los objetos colocados ahí aprovecharán para cruzarse de estante y visitar a los vecinos. Es en este cruce que la cultura material irá 
perdiendo su poder reflectivo de la cultura, tempranamente otorgado por Debenedetti, y adquirirá más visiblemente su rol de indicador de procesos de cambios internos en las relaciones sociales de los grupos que habitaron el Valle.

Los objetos -vasijas, discos de metal-, las edificaciones -casas, plataformas, montículosetc. dejarán de ser patrimonio de la facie Aguada de Ambato para transformarse en "evidencias", "indicios", "huellas" de procesos de cambios internos en las relaciones socioeconómicas y del surgimiento de una ideología dominante, fuertemente arraigada en tradiciones anteriores. La transparencia que poseían los símbolos para Lafone y Quiroga; la claridad de la imagen especular entre cultura y cultura material de Debenedetti, Boman y Greslebin, Casanova, Leviller, Bennett y González se comenzarán a opacar. La "ideología" entendida desde una posición Marxista como inversión y mistificación de la realidad aparecerá en escena. La cultura material estará atravesada por este proceso.

Un claro ejemplo de esto los conforma el lugar que se otorga a los sitios Iglesia de los Indios y Bordo de los Indios en la interpretación de la historia del valle. La presencia de plataformas escalonadas y espacios abiertos adosados a ellas a manera de plazas públicas, serán entendidos como la materialización de cambios en los rituales de tinte familiar, característicos de momentos anteriores -como los que se realizaban en Alamito o en el sitio el Altillo- hacia otros de carácter más colectivos, que evidenciaría la aparición de una elite religiosa:

“En Ambato este ritual o ceremonialismo familiar parece estar ausente. No solo no hay indicios de construcciones ceremoniales para uso de pequeños grupos [como los sitios de Alamito] si no por el contrario, está presentes los muchos más imponentes complejos arquitectónicos de pirámides-plaza para la participación comunitaria (...) resulta claro que en Ambato a partir de este momento se produjo un cambio en la organización social. Las familias extensas de los tiempos de Alamito dejaron de vivir agrupadas en torno a una vivienda, probablemente autosuficiente y de cumplir sus rituales religiosos familiares casi individualmente, para pasar a participar de una vida comunal con relaciones que ya reconocían otros vínculos sociales, no solo de parentesco inmediato, y a practicar una religión o rituales administrados por individuos más o menos especializados en esas funciones." (Pérez y Heredia 1987:174) 
Esta interpretación da el paso para plantear que fue en esta región del Ambato donde “...se consiguió formalizar una nueva estructura socioeconómica e ideológica específica que resultó de la conjunción de una serie de procesos ya en marcha, pero que son retomados y modificados, o bien de otros que se elaboraron internamente por primera vez y que, con posterioridad, constituirán un acto de integración regional para gran parte del NOA." (Pérez y Heredia 1987:167). A su vez, se plantea que tal integración se llevó a cabo sobre las diversas sociedades locales que, en sus modos de vida, poseían los elementos, materiales y simbólicos, que serán integrados en Ambato en un nuevo orden:

“Nuestro punto de partida es que más allá de apelar a un mecanismo difusionista para dar cuenta del proceso histórico del NOA (...) es necesario enfocar el problema en términos surandinos. Pensando de esta manera, el NOA se integra a una dinámica ideológica más abarcativa. Tal dinámica gira en torno al culto solar (Punchao), cuyo eje se sitúa en la isla Titicaca. Este espacio geográfico (que en términos generales correspondería, posteriormente al collasuyu incaico) comparte, desde épocas muy tempranas, una ideología que es posible de rastrar desde épocas muy tempranas a través de la iconografía (...) En consecuencia, en este momento que llamamos de integración regional del NOA se desarrollan proceso ideológicos -profundamente enraizados en el tejido social de la épocaque son compartidos por un sin número de sociedades surandinas y no que derivan de una sola de ellas, v. gr. Tiwanaku; es más ésta última es una de las tantas sociedades que comparten esa ideología surandina. El eje de la problemática explicativa se traslada entonces, desde la difusión lisa y llana hacia un proceso interno de transformación social.” (Pérez y Heredia 1987:173)

El NOA, como región, comenzará a ser desplazado del margen de "la corriente de civilización andina", pasando a formar un punto de articulación importante en la conformación de un espacio regional integrado, en el que el flujo de ideas y bienes con un alto valor simbólico jugará un papel fundamental (Pérez y Heredia 1987, Pérez Gollán 1991). El Valle de Ambato adquirirá relevancia en tanto será uno de los lugares en donde se consolida, más tempranamente, ese proceso en el NOA. Pero el desplazamiento que sufre el valle, y que lo transforma en un afluente más de dicha corriente, produce una reubicación o reposicionamiento en el espacio teórico e histórico de los centros nucleares de los Andes y, en relación a ellos de los márgenes. El área del Titicaca, y específicamente Tiahuanaco, dejarán de tener la preeminencia de fuerzas centrífugas que influyen en el desarrollo cultural de NOA 
y, como diría Debenedetti, le impriman su carácter, para transformarse en una de las tantas sociedades que comparten esta ideología, es decir este "núcleo mítico simbólico de antigua raigambre surandina".

Por otro lado el discurso de la "integración regional", produce un cambio de lugar de las narrativas que la arqueología articula sobre el pasado, y específicamente sobre aquellas cosas con las que lo estudia, es decir los objetos materiales. Habíamos señalado anteriormente que la arqueología -los arqueólogos-, fue colocada como único sujeto de enunciación válido del pasado. Si bien, las narrativas seguirán participando de este privilegio hasta el presente, sufrirán un desplazamiento de sentido, en tanto que estas últimas, serán puestas como un discurso que puede llevar a desandar los caminos que conduzcan a una "utopía”: ¿Cuál es esta?:

"Hasta la fecha no hemos registrado evidencias de una ocupación tardía del valle de Ambato, y lejos estamos de tener una explicación para esta circunstancia. Pero lo real es que la ideología que cristalizó en este pequeño valle catamarqueño persistió, en gran parte en las sociedades indígenas posteriores, y existen claras pistas que nos llevan a pensar que, además sirvió de sustento a las rebeliones anticoloniales que estallaron en el NOA, en los siglos XVI y XVII. Parecería que los arqueólogos vamos construyendo una propia teoría de los indicios que da cuenta, finalmente de la utopía.” (Pérez y Heredia 1987:176)

La “integración regional” así comprendida, produce una conexión muy fuerte entre pasado y presente, la memoria larga ${ }^{\text {xiii }}$ (Rivera 1984) que condensa y que fue sustento de procesos emancipatorios en el pasado, una que en el presente se encuentra diluía y dispersa, sólo en indicios ocultos bajo tierra; se transforma en la posibilidad de que hoy, nuevamente, la arqueología pueda dar cuenta de un nuevo proceso ideológico de "integración" y emancipación. Ambos términos son claves para comprender estos planteos, pero es en la experiencia de la persecución, el exilio y la construcción de una arqueología que, no sólo de cuenta de la situación social y política de esos años en Latinoamérica ${ }^{\text {xiv }}$, si no que permita la inserción activa de las arqueólogos en la construcción de nuevas realidades, donde pueden ser plenamente comprendidos, y donde la "integración regional” actúa y se trasforma en combustible para la construcción utópica. Así la circulación de ideas en el pasado, fuente del planteo de esta perspectiva, y la re-ubicación de los márgenes respecto de las áreas nucleares como centros que aportan elementos a la construcción "civilizatoria" de los Andes, tiene su imagen especular en la construcción intelectual de una arqueología social latinoamericana. El 
espacio geopolítico desde donde se enuncia la teoría cobra relevancia fundamental, como lo señalará Pérez Gollán (1981) -unos años antes de que escribiera este artículo con Herediacuando presenta su libro en el que se traducen una serie de artículos de Vere Gordon Childe, que conforman uno de los sustentos teóricos fundamentales para la realización de una arqueología social (Lumbreras 1984, 2006). Allí expresaba, citando a Lorenzo et al (1976:23, citado en Pérez Gollán 1981:14): “... pensamos que la arqueología es una ciencia social, pero que las Ciencias Sociales o están presididas por la Historia o no tienen existencia propia (...) y en nuestro caso está el compromiso histórico y social... . El Hombre no puede ser sin raíz, sin pasado". Para luego acotar: "Para ser más explícito: es la intención salir al paso de las tendencias neopositivistas tan de moda en la arqueología de hoy en día. Lentamente estas tendencias se van filtrando desde el Norte y algunas veces, para colmo, al pasar el Río Bravo se las empaqueta con la envoltura de una fraseología materialista, circunstancia que genera confusión y conduce a una vía muerta.” (Pérez Gollán 1981:14). La “civilización”, a pesar de seguir fuertemente arraigada a una concepción evolucionista, aquí cobra relevancia más que como un estadio evolutivo último, como fuerza de lucha que empodera un discurso antagónico al vertido por el status quo. Así en la "corriente de civilización andina" habitan múltiples sentidos: "autoctonismo" -como lo denominara recientemente Pérez Gollán (2007)e "influencias extranjeras" serán dos discursos que tensionan y confluyen en dicho concepto. Y a la vez activan los antagonismos en el presente, así las teorías que se filtran desde el Norte al sur del Río Bravo, o aquellas que plantean el desarrollo del NOA empujado por fuerzas centrífugas emanadas desde los centros nucleares, encuentran resistencia en los planteos de una arqueología social fuertemente domiciliada, latinoamericana.

En síntesis el centro de la explicación se traslada desde un carácter "marginal" o "subdesarrollado" a uno con características propias que habría aportado elementos originales a la gran corriente de civilización andina (Pérez Gollán 1991:163). Desde esta perspectiva, se propuso al NOA y particularmente al Valle de Ambato como un área con características propias y con un desarrollo histórico local de los procesos de complejización y con ellos de diferenciación social (Assandri et al 1991; Heredia 1998; Laguens 2002, 2005; Laguens y Bonnin 1996; Pérez Gollán 1991, 1994). A partir de estos planteos, la complejización social, los procesos de diferenciación social y las desigualdades sociales serán los tropos en los que se concentrarán las investigaciones en el valle.

Los planteos iniciales sobre la complejidad social irán cambiando a medida que continúen las investigaciones en el valle, esto producirá cierto reubicación de la participación de la cultura material en ellos. Al inicio, la sociedad que se consolidó en el valle durante el 
período de integración regional denominada entidad sociocultural de Ambato, comienza a ocupar un lugar específico dentro de los estadios evolutivos de las sociedades propuestas desde el neoevolucionismo: se la definió como "jefatura” (Pérez Gollán 1991:172). Las jefaturas para este autor, siguiendo la propuesta de Carneiro (1981 citado en Pérez Gollán 1991:172), son "una unidad política autónoma que comprende a un número de aldeas o comunidades bajo el control permanente de un jefe supremo". A su vez las jefaturas, según Pérez Gollán (1991:172), se caracterizan por la aparición del rango como principio de integración de sociedades multicomunitarias y el ejercicio político del cargo de "jefe", quien además cumple la función de sacerdote principal, no existiendo una verdadera estratificación de clases. La base económica del jefe reside en su papel redistribuidor de bienes, puesto que en estas sociedades las especialidades están muy desarrolladas. Aparece un nuevo tipo de asentamientos que es el centro o la capital; allí se levanta el templo, la residencia del jefe y la morada de los servidores (Sanders y Marino 1973:157 citado en Pérez Gollán 1991:172). A su vez señala, siguiendo a Service (1984:320 citado en Pérez Gollán 1991:173), que las sociedades de jefaturas crean sobre los niveles de los cultos segmentarios familiares y locales un recubrimiento religioso que comprende al conjunto de la sociedad, abarcando todas las actividades. Así señala que:

"uno de los indicadores más impactantes es la aparición del complejo ceremonial plaza-pirámide que es una innovación absoluta con respecto a las normas sociales, políticas y religiosas de la época; por un lado, esto habla del encumbramiento de un grupo social diferenciado y de la aparición de la desigualdad hereditaria; y por otro del surgimiento de la sede que coordina las actividades de la sociedad. Es necesario agregar que en el mismo contexto ocurre la estructuración de una elaborada ideología solar” (Pérez Gollán 1991:172).

La interpretación de este tipo de arquitectura "monumental" pueden ser encuadradas en cierto marco según el cual “...la "arquitectura” más prominentes en los Andes centrales y meridionales, tales como las plataformas piramidales, es la arena donde se ejerce la violencia ritual o simbólica de las elites. El poder sagrado está focalizado en el centro, axis mundi del complejo ritual, que es activado por la elite para la realización de ritos de consumo que se juzgan cruciales para el éxito agrícola y la reproducción del orden socio cósmico" (Swenson 2003:257.) A pesar de que en esta nueva interpretación la cultura material ya no reflejara de manera directa la cultura, y presentando una relación de la ideología como inversión de la 
realidad, al apelar a ciertos tipos universales que posen límites y propiedades muy definidas (tales como las escalas evolutivas del neoevolucionismo) se vuelve a colocar otro reflejo sin velo sobre la cultura material, en el contraste entre el tipo y los hechos; es en este tipo de relación donde la aparición de estructuras monumentales, por ejemplo, se transforma en indicador de la aparición de una elite gobernante.

Si bien al principio es definido como jefatura, posteriormente, haciéndose eco de las críticas recibidas a las posiciones neoevolucionistas al interior de la arqueología (por Blanton 1995; McGuire 1983; Yoffe 1993 entre otros) existe un cambio en la conceptualización de la complejidad social y de las formas de analizarla al interior del valle. Esto producirá una modificación también en la forma de pensar a la cultura material. La complejidad social será extraída de la tipificación propuesta por el neoevolucionismo, la que como señala MCguire (1983: 92):

“...juntan todos los aspectos de una sociedad en un tipo, y las sociedades se convierten en "cajas negras", en los análisis arqueológicos. [...]Podemos especificar cambios en las variables materiales externas, tales como el ambiente y el tamaño de la población, e identificar el movimiento de las sociedades entre etapas, pero no podemos delinear una conexión causal entre la variable material y el cambio. Esto es debido a que la aproximación tipológica no se ocupa de los mecanismos internos de los sistemas culturales. Y más importante no podemos ocuparnos directamente de las fuerzas dentro de las sociedades, tales como competencia entre y dentro de grupos sociales, que pueden ser causales de la evolución." [La traducción es nuestra].

Este autor propone descomponer el concepto de complejidad en sus elementos constituyentes: la desigualdad y la heterogeneidad, transformando a estos elementos en variables explicativas. La heterogeneidad se refiere a la distribución de las poblaciones en grupos sociales. La desigualdad trata con el acceso diferencial a los recursos materiales y sociales dentro de una sociedad. Estas dos variables especifican los ejes vertical y horizontal de la estructura social, que es concebida como la distribución de la gente ente diferentes posiciones y sus asociaciones sociales. Estos dos ejes abren la posibilidad de medir los grados de heterogeneidad y desigualdad de una sociedad específica. Retomado los planteos de este autor la sociedad compleja, que aparece en el Valle de Ambato durante el primer milenio, pasará a considerarse como un sistema social caracterizado por patrones marcados e 
institucionalizados de desigualdad y heterogeneidad (Assandri 2007; Laguens 2002, 2005; Pérez Gollán y Laguens 2001; Pérez Gollán et al 2000).

Este replanteo de la complejidad social, producirá que se comience a criticar la manera en la cual desde la arqueología se argumentaba la existencia o no de estos procesos. Laguens (2006a) señalará que históricamente la caracterización de Aguada como una sociedad compleja - y por transición, diferenciada - fue siempre una inferencia que estuvo basada fuertemente en la calidad de su producción artesanal, principalmente la cerámica, que impacta por una gran riqueza y complejidad iconográfica en el estilo decorativo. El supuesto señalado por el autor, es que la maestría artesanal sólo sería alcanzable dados ciertos grados de complejidad social, que por definición suponen la división del trabajo en especialidades, ya sea de dedicación parcial o completa. Este supuesto, sustentado entonces a partir de lo tecnológico y estilístico, ha sido luego punto de partida para proyectar por extensión hacia otros aspectos materiales una idea de organización compleja, que puede variar tanto desde lo referente a las prácticas funerarias, la organización política, la economía o la arquitectura, hasta otras producciones materiales que, en definitiva, realimentaron circularmente una caracterización - que si bien muy probablemente fuera acertada resultaba altamente intuida (Laguens 2006a). Específicamente, planteaba que si se quería estudiar un proceso social, cuyo resultado fue un estado de cosas que puede caracterizarse como una organización de bases socialmente heterogéneas y desiguales, no podía partirse de un supuesto: era necesario primero optar por el establecimiento de los alcances de la complejidad, luego determinar si dicha sociedad era compleja o no y, si así lo era, con qué criterio y cómo podríamos caracterizar la complejidad de su organización y materialidad. En función de este planteo, el acento será puesto en determinar de qué manera dichos procesos de cambio y establecimientos de las diferencias y desigualdades sociales podían observarse en diferentes esferas de lo social: la arquitectura, la producción artesanal especializada, el procuramiento y uso de los recursos, la tecnología y la ideología. Si bien al principio la cultura material pudo haber indicado de manera casi directa la aparición de sociedades complejas, facilidad otorgada por los tipos evolutivos a los cuales se apelaba, luego esta indicación se va a plantear como opaca y no evidente. Se necesitaba para responder dichos interrogantes, hacerle preguntas al registro arqueológico. Así, partiendo de determinadas consideraciones teóricas, como la definición de las dos ejes -vertical y horizontal- para evaluar el proceso de complejización, la generación de expectativas sobre como debería comportarse el registro arqueológico en caso de que Ambato se tratara de una sociedad compleja, y la utilizando determinadas métodos y técnicas, podía llegarse a responder por ejemplo si era o no compleja y las grados de diferenciación y heterogeneidad que presentaba. 
En este sentido, se realizaron análisis de la arquitectura y los asentamientos que permitieron inferir la existencia de espacios jerarquizados (Assandri 2007; Assandri y Laguens 1999); a través del análisis de la cerámica se evaluó la especialización de la producción (Fabra 2008; Laguens y Juez 1999); el cambio en el manejo de recursos -como por ejemplo la leña- evidenció accesos diferenciales a los mismos (Marconetto 1999, 2008), las capacidades de almacenamiento entre sitios de diferentes jerarquías era distinta (Pazzarelli 2006), la inversión de trabajo en la arquitectura fue diferencial (Barale 2006), entre otros. Así la cultura material, entendida más como registro arqueológico se trasformó en fuente para la búsqueda de indicadores que dieran cuenta que en Ambato existió y se instaló un sociedad heterogénea y diferenciada. Pero también, al igual que en casi toda la historia de las investigaciones que venimos desarrollando, la cultura material ocupó un lugar pasivo.

Ahora bien, los aportes de estas investigaciones establecieron un marco de interpretación que permitió observar el carácter local de los cambios en las esferas de lo social, lo político, lo religioso, lo tecnológico, y establecer un "antes" y un "después" (Laguens 2005). En este sentido se lograron identificar los distintos elementos por los cuales se podían interpretar a las nuevas formas sociales establecidas como sociedades con una creciente desigualdad social. Sin embargo, quedan todavía, a nuestro entender, un grupo de importantes interrogantes aún no resueltos sobre el surgimiento y consolidación de sociedades jerarquizadas en el NOA, y particularmente en el Valle de Ambato durante el primer milenio. Por un lado ciertas cuestiones vinculadas al proceso de establecimiento de los "nuevos" modos de vidas, tales como: ¿de qué manera se produjeron los cambios?, ¿cómo se produjeron y reprodujeron las nuevas configuraciones de poder que se establecieron?, ¿cómo determinados grupos sociales se fueron consolidando como grupos de elite diferenciados del resto?, ¿de qué manera esa forma inédita de configuraciones de poder se produjo y reprodujo durante tanto tiempo?

Si bien en este marco la "ideología" cumplió un rol fundamental, no sólo a nivel histórico-social sino como fuente explicativa de la reproducción de las nuevas relaciones y los nuevos grupos establecidos, en tanto enmascaradora de las relaciones sociales de poder, la explicación no se adentró en los procesos mismos o mecanismos específicos a través de los cuales esas nuevas relaciones se lograron consolidar en Ambato. En parte esto se debe a la visión de ideología utilizada, la que se vincula más a una propuesta ortodoxa del materialismo histórico, en la que la ideología se observa como episteme falsa o ilusoria de la realidad. En este sentido al ser una especie de cámara obscura que invierte la realidad se transforma, como diría Treherne (1995), en una variable a ser removida de la ecuación, tales 
como los procesos tafonómicos, para acceder a una representación "verdadera" de la sociedad. Sin embargo la distinción entre realidad social e ideología no es tan clara. Como lo señalaran Shanks y Tilley (1987) la ideología no solo subyuga a los sujetos si no que los crea. Althuser (2003) argumentó que las personas viven en una "relación imaginaria con sus condiciones reales de existencia" por medio de las cuales la ideología tiene una existencia material en toda práctica humana, el mediador entre conciencia y acción, y como tal la gente de manera subconsciente o prerreflexiva vive su ideología como real. A pesar de que Bourdieu no hable de Ideología sino de Doxa, esta posición es semejante a la noción de que la ideología está inscripta en las acciones cotidianas de los individuos, las que son generadas por disposiciones prerreflexivas como el habitus -la incorporación de lo social en los cuerpos(Bourdieu y Wacuant 1995). Es decir la ideología es naturalizada como evidente en sí misma, "no reconocida" y tomada como dada en tanto entalla una "fe práctica", una indisputada, prerreflexiva, ingenua, natural conformidad con las presuposiciones fundamentales de una forma de vida dada, es decir la doxa (Bourdieu 1991). La ideología permeando todo el tejido social es un componente de toda la práctica humana, y no solo un producto conspirativo de un grupo. Volviendo a Althusser la ideología interpela a los individuos como sujetos, es decir la ideología es central a la construcción de la subjetivada e identidad del yo (Treherne 1995). En este sentido creemos que en Ambato debemos poner atención en el proceso mismo por el cual los sujetos llegaron a constituirse como tales y con él los nuevos grupos sociales que parecen surgir en el valle. La constitución de los sujetos y con ellos de las identidades sociales, posee un rol fundamental en este proceso.

Otro de los aspectos de la noción de Ideología tal cual fue entendida en Ambato, que debemos considerar es que, como señala Treherne (1995) siguiendo a Weber, es uno de esos conceptos generales que en virtud de la perspectiva de este último nos conducen lejos de la riqueza de la realidad, ya que debe ser tan abstracto como sea posible y por lo tanto desprovisto de contenido. Aquí pueden entrar la comprensión e intervención de los bienes de prestigio como competencia y exhibición de la autoridad o el poder -tal como lo discutiera Espósito (2009), para el caso de los metales en Ambato y de la metalurgia como "Tecnologías del Poder"-. El problema diría Treherne (1995) de la idea de "competencia por prestigio" radica en la generalidad; por ejemplo, el tratamiento de los bienes y prácticas exóticas como funcionalmente prestigiosos no da cuenta del carácter sociohistórico específico de esos objetos y prácticas.

En los términos que venimos discutiendo, la ideología, y con ella la constitución de los sujetos, opera más efectivamente en la rutina, en los niveles no discursivos de la práctica 
humana, particularmente a través de su objetivación en los objetos materiales que median activamente la acción social (Hodder 1988, 1992; Shanks y Tilley 1987). Es por esto que nos parece que en las interpretaciones que se vienen realizando de los procesos de cambio en el Valle queda por resolver aún la participación de la cultura material en los mismos, dado el rol pasivo otorgado en las investigaciones reseñadas hasta el momento.

Vinculado a este punto se nos presentan estos interrogantes: ¿puede considerarse a la cultura material un elemento activo en la producción y reproducción de la "nueva" vida social que se estableció en el valle a partir del siglo IV de la era? O, como históricamente fue considerada en las investigaciones que se llevaron a cabo para estudiar dichos cambios, ¿sólo puede ser concebida como un elemento que refleja o indica tales procesos? A su vez, si tenemos en cuenta los planteos de dicha investigaciones que señalan que los cambios sociales producidos llevaron a que se conformen nuevos grupos sociales al interior del valle, diferentes a los que se articularon anteriormente ¿puede considerarse a la cultura material un componente activo en la construcción de esa "nuevas" identidades sociales? Y si, como proponemos en esta investigación, le otorgamos a la cultura material la posibilidad de transformarse en "agente” de dichas construcciones ¿cuáles serían las maneras específicas de participación - de agencia- de la misma en la conformación, reproducción y legitimación de las identidades sociales? En otras palabras ¿qué lugar ocupó la misma en el interjuego de dichas construcciones?

En recientes investigaciones desarrolladas en el valle para estudiar estos procesos de cambio la cultura material fue ocupando una posición cada vez más activa (Espósito 2006, 2009; Gastaldi 2007b, 2007c; Gordillo 2006, 2009; Laguens 2002, 2005, 2006b, 2007; Laguens et al 2007; Laguens y Pazzarelli 2007; Pérez Gollán 2000a, 2000b). Es a partir de éstas que comenzaremos a plantear una propuesta alternativa para concebir a la cultura material como un agente activo, no sólo en la producción y reproducción de determinadas relaciones sociales, sino también en la constitución misma de la subjetividad de las personas que se vincularon con ella. En estas investigaciones, la cultura material dejó de ser indicadora del establecimiento de desigualdades sociales para transformarse en un participante activo de dicho proceso.

Laguens (2002:12) parte de ciertos interrogantes, semejantes a los formulados por nosotros: “¿cómo participa la cultura material en el proceso de conformación de las desigualdades sociales en el valle? ¿acentúa las diferencia, las enmascara, las estructura, puede ser fuente de diferenciación, reflejo pasivo o aún medio activo de negociación y poder?”, y señala que: 
“...la cerámica de estilo Aguada, [que] con su alto grado de inversión artesanal, su producción especializada, su calidad y su complicada carga iconográfica, podría ser interpretada como un bien de prestigio, de circulación restringida en grupos de mayor jerarquía (...) Sin embargo su distribución y uso no estaba restringido a un sector particular de la sociedad, si no que por el contrario, aparece tanto en los asentamientos pequeños como en los grandes sitios ceremoniales. (...) nos encontramos ante un recurso homogeneizante, que actúa desdibujando las diferencias entre las personas. (Laguens 2002:12)

Aquí la cultura material, no sólo refiere a la idea de prestigio sino a la ambigüedad que ésta expresa dada su distribución generalizada en el valle; funciona no sólo como forma de legitimación y enmascaramiento de las relaciones sociales desiguales; no solo indica, sino que también produce activamente dichas diferencias.

En una línea similar, el análisis espacial del sitio Iglesia de los Indios, uno de los más grandes hallado en el valle, le permitió observar a Gordillo $(2006,2009)$ cómo los espacios se hallaban demarcando y restringiendo el acceso a espacios públicos, semipúblicos y privados. En este sentido la arquitectura y las formas de circulación se hallaban activamente implicadas en la determinación de las relaciones de la gente que habitaba y circulaba por ellos. Espósito (2006, 2009), analizando los objetos de metal de distintos contextos del valle que se encuentran asociados a diferentes prácticas (tales como la producción cerámica -cinceles-, como ajuar de difuntos humanos -anillo- y no humanos, como el entierros de camélidos hachas-), pretende trascender las definiciones a priori otorgadas clásicamente a estos objetos al ubicarlos en el polo de objetos utilitarios y objetos suntuarios. Específicamente, se propone acercarse a los significados que éstos poseen, no sólo por ser objetos de metal, ni por poseer determinadas características intrínsecas, sino por su participación en determinadas prácticas sociales:

“...nuestra perspectiva nos permitió comprender que "lo metálico” como componente material del conjunto de objetos que analizamos, es un elemento que los unifica como una categoría particular de objeto, sólo al inicio de sus trayectorias biográficas. Al momento en que se los confecciona, todos participan en una dimensión donde convergen las mismas escalas temporales, espaciales y sociales. Pero cuando sus biografías divergen, y cada uno de los objetos comienza a participar en prácticas interactivas concretas con otros objetos, en diversos 
espacios y tiempos y con diversos agentes sociales, se constituyen en categorías particulares no ya por compartir el atributo de "ser de metal", sino por asociaciones específicamente vinculadas a los contextos en los que se integran” (Espóstio 2009:69).

Así, los cinceles que participaron en los contextos productivos de alfarería, se constituyeron en categorías particulares vinculadas a las grandes vasijas ordinarias y a los alfareros que las construyeron, pero que en nada se vinculan a, por ejemplo, el anillo dispuesto en la tumba del infante o el fragmento de hacha depositado en el montículo de Piedras Blancas: "Vimos de este modo el papel que jugó un grupo de objetos en el refuerzo de la identidad social de un pequeño enterrado bajo el piso de un recinto, del mismo modo que pudimos comprender el rol que jugó un grupo de cinceles en la reproducción de la escala social que significó la especialización artesanal de cerámica en la sociedad que entre el 600 y el 1200 de la era, vivió en el Valle Ambato" (Espóstio 2009:70).

La aproximación activa a la cultura material, queda plasmada como una línea teórica metodológica en posteriores trabajos de Laguens junto a otros investigadores (Laguens 2007; Laguens et al 2007; Laguens y Pazzarelli 2007). Influenciados por los planteos de la ANT Teoría del Actor-Red o Actor Network Theory) (Latour 1996, 1998; Law 1992); los artefactos, en este enfoque, son considerados como efectos de relaciones. Los efectos de los objetos dependen de las redes de relaciones en las que están inmersos, existiendo algunas relaciones fijas e inmutables, que se mantienen más allá de estas redes -en el caso de una vasija pueden ser ciertas propiedades que se les otorgan a partir del diseño, tales como forma, pasta, etc.- y otras que cambian según las redes de relaciones o del "fibrado" en donde participan. Para esta perspectiva, a diferencia de las relaciones lineales o en un solo plano, tales como las que pone en juego un modelo de flujo clásico, las relaciones arqueológicas se presentan como un bollo de papel donde cosas que en un plano estaban separadas, ahora están próximas o se superponen, una infinidad de planos que se chocan y se entrecruzan, infinidad de líneas de relaciones, más cortas, más largas, cientos de puntos de intersección y una multiplicidad de relaciones que antes no existían (Laguens y Pazzarelli 2007:3). Como señalan los autores se podrá intentar estirar el papel nuevamente, pero las arrugas siguen, las redes se pusieron en evidencia. Los autores antes que red prefieren "fibrado" en tanto implica algo más que la idea de una red que se une a través de distintos nodos. Un fibrado es una figura más pertinente en cuanto posee una apariencia más desordenada, con relaciones en muchas direcciones, con más de un punto de contacto sobre una misma fibra, con variados puntos de cruce, intersticios y distintas intensidades de ligazón, en contraste con una red fija de nodos y conexiones 
(Laguens y Pazzarelli 2007:3). La agencia de la cultura material, lo objetos, así como los otros participantes de las redes, humanos y no humanos, interactúan influenciándose a través de sus efectos, productos de la red de relaciones en las que se encuentran inmersos, siendo imposible pensarlos por fuera de este "fibrado". En esta perspectiva se produjo un simetrización ${ }^{\mathrm{xv}}$ de las relaciones entre humanos y no humanos: ambos definen sus formas, sus relaciones, sus identidades en esa multiplicidad de escalas en la que se hallan inmersos.

Teniendo en cuenta estos planteos, particularmente la imposibilidad de pensar a las personas y los objetos por fuera de sus mutuas vinculaciones en distintos planos (Laguens 2007; Laguens y Pazzarelli 2007; Laguens et al 2007); la dialéctica (Espóstio 2006, 2009) que se produce entre ellos a lo largo de sus vidas; donde las identidades de ciertos grupos humanos -como por ejemplo los especialistas en la fabricación de las grandes vasijas y los cinceles que intervienen en su confección- son impensables e indefinibles si no las colocamos en los contextos prácticos de la acción. Nos adentraremos, ahora, en nuestra propuesta.

\section{Notas}

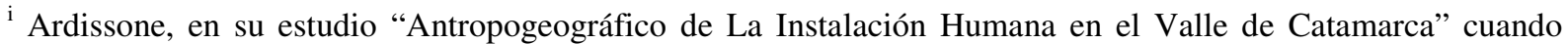
analiza el ambiente humano del Valle y cuando habla de las Instalaciones Indígenas del sector norte pone una cita del Padre Larrouy: "Entre todos, los pueblos que conozco son 16. En el Valle de Paclín, uno solo a ciencia cierta: el Paquilingasta, hoy Amadores. En el Valle de Sínguil, cuatro: Sínguil, Colpes, Guaycama y Pomangasta (hoy La Puerta)." (Larrouy citado en Ardissone 1941:59). En esta cita lo que hoy conocemos como Valle de Ambato o sector septentrional del Valle de Catamarca figura como valle de Sínguil. Los cuatro pueblos señalados cubren todo el valle de Ambato tal cual hoy se lo define e inclusive llega hasta más al sur hasta la localidad de La Puerta. Actualmente desde la geología y la geografía al Valle de Ambato no se lo conoce de este forma y su identidad geográfica tampoco esta bien delimitada, se lo presenta como área de la Cuenca del Río de los Puestos formada por la cuenca del Río Ambato y la Cuenca del Río Huañumil (Mariot et a 2001).

ii Es una etapa liminar, prediciplinaria que se plantea alrededor de los últimos 25 años del siglo XIX y los primeros años del siglo XX. Ver para una discusión más profunda de la conformación de esta etapa Haber 1994.

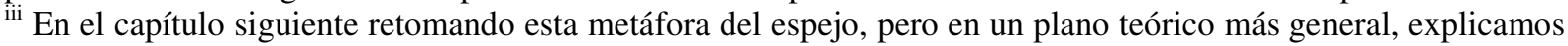
como la visión "normativa" de la cultura y de la cultura material produce una separación tajante entre sujetos y objetos.

${ }^{\text {iv }}$ Su asociación al arte calchaquí queda claro cuando señala en uno de los primeros trabajo que publica material pertenecientes a este estilo -"Viaje arqueológico a la región de Andalgalá": "Los objetos se dividen en dos grupos: los de piedra y los de alfarería; unos y otros pueden considerarse como representativos y me llevarán a tratar otras curiosidades del arte calchaquí, a saber las alfarería draconianas negras y grises que son grabadas y las de colores claros que son pintadas..." (Lafone Quevedo 1905:8).

${ }^{v}$ Queda claro esto cuando el autor, al introducir los materiales arqueológicos hallados en la zona, explicita porqué se propuso realizar estos estudios: “...pero siendo el caso que de Europa llegan expediciones para estudiar la arqueología de nuestra región calchaquina, y vista la tendencia de inventar culturas nuevas, donde acaso no se trata más que de diferencia locales, me ha parecido conveniente iniciar una serie de estudios geográficos arqueológicos, al objeto de presentar a los estudiantes de la materia un cuerpo de datos que le sirvan de cotejo." (Lafone Quevedo 1905: 8).

${ }^{v i}$ Posteriormente, a 1 disco se lo denomina con su nombre y se lo asocia a la cultura del Aguada junto con otros discos hallados en la región (Pérez Gollán 1986; González 1992).

vii La coacción como fuerza de cambio y movimiento ascendente no fue patrimonio de este autor en el discurso sobre lo indígena, se viene elaborando de hace más tiempo en relación con discursos de soberanía estatal, no entendida "...como relación de exterioridad que regula las relaciones entre estados sino como de dominio al interior del mismo estado" (Escolar 2007:31), esto es de lo que incluye, pero esto que es inclusivo nunca es definitivo ni se "...dirime en el plano territorial y jurídico en terreno clásico, como inscribe la ficción del estado
} 
moderno, si no a través de prácticas, ámbitos y estructuras sociales" (Escolar 2007:31). Estas técnicas de gobierno no solo implican prácticas de coerción, si no también tecnologías del Yo, disciplinas de subjetivación, creación de identidades, autoconciencia y consentimiento de los individuos (Foucault 1991 citando a Escolar 2007:31).

viii Según Boman y Greslebin , Debenedetti: "En cuanto a lo que se refiere al estilo draconiano, confunde la cabeza de "dragón" de este estilo con la clásica cabeza de puma del estilo de Tiahuanaco, cuando difícilmente pueda haber dos clases de cabezas estilizadas más diferentes que estas" (1923:52).

${ }^{\text {ix }}$ Por otro lado en el trabajo de Casanova y Debenedetti comienza a tomar cuerpo, aunque no de manera definida, la asociación contextual y la integridad de los registro. Es decir la asociación ya no sólo viene dada por el carácter de un objeto, sino porque conforma parte de una misma unidad contextual: se los encuentra en el interior de una tumba asociado a otros objetos, a su vez esas tumbas se hallan en un cementerio ubicado en un lugar geográfico particular como es el paisaje de los Barreales. Esto queda claro tanto en la primera parte del trabajo de Debenedetti, en tanto que no solo describe el lugar donde provienen los objetos, si no que se dedica a caracterizar el paisaje natural a nivel geológico, geomorfológico, fitográfico etc. Es decir lo primero que hace es definir naturalmente a los Barreales para luego describir la civilización que se desarrolló en ellos. Por su parte cundo se refiere a las tumbas las describe minuciosamente recalcando el lugar in situ de los hallazgos.

${ }^{\mathrm{x}}$ Esta propuesta fue parte de un programa mayor originado en un seminario de la Universidad de Yale para toda la Argentina donde participaban otros arqueólogos norteamericanos comprometidos con otras áreas de la Argentina.

xi Aquí nos referiremos a los trabajos de González en relación a la Cultura de la Aguada, hasta que comienzan a realizarse investigaciones en el valle -principios de la década del 70-, en tanto que nos interesa comprender particularmente como influenció su perspectiva en la visón de los materiales hallados en el valle y en las investigaciones posteriores realizadas sobre ellos. Por otro lado la obra de González continúa hasta la actualidad, por lo que si bien, parte de lo desarrollado durante esos momentos representa en gran medida el pensamiento de este autor, en tanto que algunos de sus planteos iniciales los continúa manteniendo, su perspectiva fue cambiando con los años incorporando no sólo nuevas discusiones, si no que también enfoques diferentes.

xii Estas vasijas también fueron relacionadas con cerámicas santiagueñas como Cortaderas y las Mercedes (González y Pérez 1976, Núñez Regueiro 1998). Estos tipos de recipientes cerámicos son retomadas por nosotros en la reconstrucciones biográficas -ver capítulo 6 vasijas de clase E forma "a"-.

xiii El concepto de memoria larga es definido por Silvia Rivera para comprender las luchas campesinas en el horizonte histórico boliviano, referido a las luchas indígenas anticoloniales simbolizadas en la figura de Tupak Katari.

${ }^{\text {xiv }}$ Las investigaciones arqueológicas en el Valle de Ambato comienzan en el año 1973, cuando Osvaldo Heredia y José Antonio Pérez Gollán realizan una primera prospección del área de Los Castillos. Desde esa fecha y hasta 1976 se realizaron cuatro campañas arqueológicas con apoyo financiero del CONICET. La dictadura militar del año 1976 interrumpe abruptamente las investigaciones, y provoca persecuciones académicas, el asesinato y desaparición de tres miembros del grupo, y el exilio obligado de la mayoría de los miembros del equipo de investigación. Hacia 1986 y, según lo manifiestan los propios miembros del equipo, gracias al decidido apoyo del Dr. Alberto Rex González, se reanudan las investigaciones en el Valle de Ambato, ya en el año 1987 bajo la dirección de Heredia y Pérez Gollán.

${ }^{\mathrm{xv}}$ En parte comparte la visión con lo que se dio en llamar Arqueología Simétrica (Shanks 2006; Webmoor 2006; Witmore 2006) 


\section{CAPÍTULO 2}

\section{SUJETOS Y CULTURA MATERIAL RECONSIDERADOS}

En este capítulo nos acercaremos a una propuesta que permita pensar las relaciones de recursividad que mantienen objetos y sujetos a lo largo de sus vidas. Para esto reflexionaremos críticamente acerca de uno de los supuestos más profundamente arraigado en la Arqueología. Este supuesto está presente tanto en las visiones que consideran a la cultura material como reflejo de cambios y/o migraciones, así como en aquellas en donde ésta se piensa como indicadora o acompañante de los cambios: la separación tajante entre objetos producidos y sujetos productores. Esta separación, que se dio tempranamente en las ciencias sociales y que la arqueología como tal abrazó en sus investigaciones, produjo que los objetos quedaran "sujetados" a las formas materiales de reproducción de la vida, como produjo también que las personas quedasen "sujetadas" a su propia, aislada y solitaria subjetividad. Esta dicotomía logró ocultar y casi borrar de la memoria la forma de la naturaleza dialéctica de dicha relación. Es decir, la manera en que los objetos y los sujetos interactuamos construyendo mutuamente nuestras identidades.

La separación entre personas y cosas forma parte de una confusión en la interpelación que se realizó sobre las últimas. Nunca se llegó a preguntar realmente sobre la "naturaleza" de las cosas. Intentando aclarar esta confusión, partimos de una pregunta que guiará la exposición: ¿Qué es una cosa?. Para responder este interrogante en este apartado, retomamos reflexivamente un ejemplo expuesto por Heidegger (1994) que nos permitirá discurrir en la deconstrucción del supuesto de separación artificiosa entre personas y cosas. Nos concentraremos en deconstruir un objeto específico: una jarra.

Podríamos responder que una cosa:

“...es la jarra [pero] ¿Qué es la jarra?. Decimos: un recipiente; algo que acoge en sí algo distinto de él. En la jarra lo que acoge son el fondo y las paredes. Esto que acoge se puede a su vez coger por el asa. Como recipiente, la jarra es algo que está en sí. El estar-en-sí caracteriza a la jarra como algo autónomo. Como posición autónoma [...] de algo autónomo, la jarra se distingue de un objeto... Algo autónomo puede convertirse en objeto si lo ponemos ante nosotros, ya sea en la percepción sensible inmediata, ya sea en el recuerdo que lo hace presente. (Heidegger 1994: sin paginación) 
Definir a la cosa de esta forma nos lleva a pensar que la cosidad de la cosa - su naturaleza- descansa en el hecho de que podamos pensarla como objeto (como ante-puesto a nosotros), y en este caso "la cosidad de la cosa" se encontraría en el representar de las personas, es decir en su sumergida y aislada subjetividad. De otro modo, podemos pensar que "la cosidad de la cosa" puede estar determinada desde su objetualidad, desde su estar en sí, al distinguirse de otra autónoma, de otro objeto. Estas dos formas de definir a las cosas, desde el representar o desde su objetualidad, fueron los puntos de partida desde los cuales la arqueología acometió el estudio de la cultura material. Adentrémonos en ellos para entender sus limitaciones y poder trascender la división artificial entre cosas y personas. De aquí surgirá la posibilidad teórica de que la cultura material pueda ser extraída de su pasividad, para ser convertida en una agente activo en la producción y reproducción de la vida social.

\section{Su Objetualidad}

¿Qué significa que la cosa se defina desde su estar en sí?. En primer lugar, el objeto, al estar en sí, adquiere autonomía, se diferencia de otros objetos que también son autónomos. La jarra está en sí como recipiente y al estar como recipiente se diferencia de un cuchillo que está como otra cosa y que también es autónomo. Esta definición de la cosa a través de su objetualidad se observa tanto en las visiones llamadas normativas ${ }^{\mathrm{i}}$ de la cultura material como en aquellas que criticaron fuertemente a esta última, las posiciones materialistas ${ }^{\mathrm{ii}}$.

En la visión normativa, que en parte hemos discurrido en el capítulo 1, la cultura material se encuentra muy vinculada al concepto de cultura, como conjunto de normas compartidas. Este conjunto de normas y valores, que caracteriza a un determinado grupo o sociedad, se refleja y toma cuerpo en la cultura material a través de objetos semejantes (Llamazares y Slavutsky 1990; Shanks y Tilley 1987; Trigger 1994). En esta concepción, al situar a la cultura dentro de una especie de envase de rasgos, normas y valores compartidos se desdibuja el sentido del concepto de "sociedad" y la cultura es reificada como una identidad propia que parece existir más allá de los hombres que la sustentan (Llamazares y Slavutsky 1990). Lo mismo sucede con la cultura material, puesto que se transforma en significante del grupo de personas que la poseía. El objeto, la jarra en nuestro caso, es significante de una cultura, sus rasgos la reflejan, adquiriendo así la jarra 
identidad por sí misma, al diferenciarse de otros significantes-jarra que reflejan a otra cultura. Los individuos y sus representaciones están por fuera de la relación especular entre "cultura" y cultura material. De esta manera la jarra se transforma en una entidad autónoma y su naturaleza es expresada en ella objetivamente.

Sin embargo, a pesar de las fuertes críticas disparadas a esta clásica visión desde las posiciones materialistas vinculadas a la Nueva Arqueología, en ellas también se mantuvo la separación entre objetos producidos y sujetos productores. Esto se observa claramente en uno de los campos de estudio más importantes investigados por esta escuela: el de las tecnologías prehistóricas.

Desde hace al menos dos décadas, se empezó a criticar la noción de "tecnología" manejada tradicionalmente en los estudios prehistóricos, principalmente en las visiones materialistas de la cultura material. (Dobres 2000; Dobres y Hoffman 1994, 1999; Gastaldi 2007d; Ingold 1999; Lechtman 1993; Lechtman y Soldi 1985; Lemonnier 1992; Schlanger 1994).

La tecnología se define actualmente como un término totalmente contrapuesto al de arte (Dobres 2000; Ingold 1999; Thomas 1996). Al observar la etimología de la palabra tecnología vemos que ésta se deriva de la raíz griega tekhnê (Corominas y Pascual 1992, Ingold 1999, Dobres 2000), mientras que la palabra arte se deriva del francés antiguo ars (Ingold 1999). Pero lo cierto es que ambas, en un momento de la historia, tuvieron esencialmente el mismo significado, relacionado con la habilidad artesanal (Ingold 1999:8). Originalmente, la raíz griega tekhnê significó no sólo el momento de la ejecución práctica, sino también una inseparable combinación de arte, habilidad, artesanía, principios, conocimientos y entendimiento (Dobres 2000:50). La progresiva diferenciación que sufrió esta sintética definición de tekhnê, produjo que quedara, por un lado, el concepto de "técnica" (en el sentido de "habilidad artesanal") y por el otro, que el significado se preservara en términos de "artificioso" (artful), "artífice", "artista" y por supuesto de "artefacto" (Ingold 1999:8). En el pensamiento occidental moderno, la tecnología quedó asociada a la replicación mecánica de algo dado, en lugar de referirse a la producción creativa de innovaciones, más relacionada con el arte. De esta manera la tecnología quedó definida como objetiva y determinada, en lugar de subjetiva y espontánea (Ingold 1999:8). Esta separación de la noción original de tecnología produjo que los marcos analíticos utilizados para los análisis tecnológicos la pensaran más vinculada a objetos que a prácticas, y a herramientas y artefactos más que a los procesos en los cuales los mismos están incorporados (Dobres 2000, Gastaldi 2007d; Ingold 1999). Éste es el 
sentido del concepto de tecnología que las posiciones materialistas y funcionalistas en arqueología adoptaron. Así, la tecnología quedó fijada como un concepto ahistórico y fue pasible de ser aplicado a cualquier tiempo y lugar (Dobres 2000, Dobres y Hoffman 1994, 1999; Gastaldi 2007d, Ingold 1999; Lechman y Soldi 1985). Estas perspectivas, además, definían a la tecnología como íntimamente relacionada con el ambiente, como la variable interpuesta entre éste y el hombre, como aquellos utensilios y herramientas que permitían la adaptación al entorno (Binford 1962, 1965). La tecnología comunicaba la "variedad" del sistema ambiental al resto de los subsistemas (Clark 1984).

Dentro de estos estudios, la cultura -concepto que incluye la cultura material y la tecnología- fue definida como el medio extrasomático de adaptación. Inclusive se definieron categorías de artefactos, cada una de las cuales se relacionaba con un subsistema del sistema cultural total (Binford 1962, 1965) y eran definidas por su contexto funcional primario, es decir, por la función que cumplían en el mantenimiento de un subsistema. Así, los artefactos tecnómicos, sociotécnicos e ideotécnicos eran los que mantenían los subsistemas económico, social e ideológico respectivamente, del sistema cultural total (Binford 1962). Los objetos fueron, entonces, extraídos de la relación especular con la cultura y colocados en una relación de necesidad, en donde la producción de los mismos se explicaba por la satisfacción de necesidades anteriores.

Volvamos ahora, para entender mejor dónde reside la confusión en la pregunta acerca de las cosas, al ejemplo de la jarra. Preguntamos otra vez: ¿dónde descansa la cosidad de la jarra? Planteamos anteriormente que la jarra es un recipiente, algo que acoge en sí algo distinto de él y que lo que acoge de la jarra son las paredes y el fondo. Pero, según Heidegger (1994), cuando llenamos la jarra de vino, por ejemplo, el fondo y las paredes -lo impermeable de la jarra- no es en realidad lo que se encarga de acoger, sino que cuando llenamos la jarra, el líquido entra en la jarra vacía. Entonces lo que acoge del recipiente es el vacío, “...esta nada de la jarra es lo que es la jarra como recipiente que acoge" (Heidegger 1994). Pero ¿está realmente vacía la jarra? Según el autor, la física nos dice que la jarra está llena de aire y de todos los componentes que constituyen al aire. Entonces, cuando vertemos vino en la jarra, lo único que ocurre es que sacamos el aire que llena la jarra y lo sustituimos por un líquido. Pero esta forma de definir lo que acoge de la jarra -cambiar un contenido por otro- nos fuerza a olvidar al vino que es acogido por la jarra; esto nos lleva de vuelta a la noción clásica de tecnología en donde se expresa la dicotomía entre el carácter objetivo, mecánico y objetual de la jarra, enunciado en su definición como concavidad donde se expande un líquido, y los saberes y conocimientos 
en donde los objetos se hallan, es decir la jarra llena de vino, y el conjunto de prácticas con las cuales se vincula. Esto nos lleva al segundo punto a analizar: ¿la cosidad de la cosa se halla en el representar de las personas?

\section{Su Representación}

¿Qué significa que la cosidad de la cosa se encuentre en las formas de representación que hacen las personas de ella? Esta pregunta nos lleva a analizar cómo la cosa llega a un estar en sí, el proceso a través del cual la cosa llega a tener una posición autónoma respecto a otro objeto, también autónomo. Volviendo a nuestro ejemplo, la cosa, la jarra, para llegar a un estar en sí tiene que ser producida por alguien, un alfarero. El alfarero prepara la arcilla, le da forma, la cocina, etc., es decir, la produce. La jarra por medio de este producir, este emplazar desde, en relación a determinada representación que se realiza de ella, hace que la jarra entre a estar en sí (Heidegger 1994). Pero este entrar a estar en sí ¿es la naturaleza de la jarra como jarra?, ¿es la cosidad de la cosa?.

Existe una serie de trabajos que interpretan la cultura material del Período de Integración Regional en el NOA desde una definición de los objetos que parte del representar de las personas (González 1974, 1977, 1992; González y Baldini 1991; Gordillo y Kusch 1987; Kusch 1990; Kusch y Valko 1997; Pérez Gollán 1986, 1991).

Dichos trabajos tratan de resolver un antiguo dilema planteado en la arqueología en general y particularmente en la arqueología del primer milenio en el NOA: aquel de “...si por las dificultades inherente debíamos abandonar por completo el intento de interpretación del simbolismo de esa iconografía [expresada en la cerámica decorada y/o modelada de la culturas del NOA, en los recipientes y monolitos de piedras, y en la placas metálicas] o si por lo contrario se podía en algún momento empezar a establecer cierta sistematización de signos que permitiera en el futuro elaborar una verdadera semiología arqueológica de esos materiales"iii (González 1974:9). Así, por ejemplo, Pérez Gollán (1986) y posteriormente González (1992), interpretan al disco Lafone Quevedo como parte integrante de un conjunto de placas circulares de bronce halladas en el NOA, norte de Chile y Bolivia que representan un personaje cuyos atributos coincidirían con el Punchao "personaje de las manos vacías", según lo denomina González-. El Punchao, personaje con claras connotaciones solares, vinculado al consumo del cebil, no sería sólo una deidad exclusivamente incaica sino que, en opinión de Pérez Gollán $(1986,1991)$, se estaría frente a un antiquísimo núcleo mítico-simbólico, que perdura y es revitalizado por los incas 
(Pérez Gollán 1986:67). Esto es la matriz ideológica que hemos analizado en el capítulo anterior. En esta misma línea de investigación, González y Baldini (1991) analizaron un ceramio perteneciente al Museo de Arte Precolombino de Santiago de Chile asociado a la cultura de la Aguada, intentando una interpretación de su función y significado. Luego de analizar la iconografía de la vasija, que se referiría al "personaje de las manos vacías", y de plantear su parecido morfológico e iconográfico con vasijas encontradas en entierros de párvulo de individuos posiblemente sacrificados, concluyeron que: “...la función de la pieza considerada se relaciona con el sacrificio de niños y [que] su uso era contener a los cadáveres o acompañarlos como parte del rito de sacrificio. La figura desplegada en ambas caras del ceramio (...), se relacionaría (...) con la deidad solar a la que estaba destinado el sacrificio (González y Baldini 1991:51). Por su parte, Kusch (1990) investiga la evolución de la figura humana a través de los diferentes estilos cerámicos del NOA - Condorhuasi, Ciénaga, Aguada y Santamaría, respectivamente-, en relación a las no-humanas, particularmente el felino. La autora propuso que en principio era posible hablar de dos momentos "estilísticos": uno primero zoomórfico, vinculado a Condorhuasi, en el que no tendrían espacio las formas semi-humanas orientadas verticalmente, y un segundo momento antropomórfico relacionado con Ciénaga- Aguada, sustentado en la existencia de personajes humanos en posición vertical, interpretación que apoyaría el carácter de deidad antropomorfa que le reconoce González en sus trabajos.

En todos estos trabajos, los objetos analizados dejaron de ser el "significante" de grupos de personas y se transformaron en signos, producto de una imbricada red de significados, relacionados, en el caso de Pérez Gollán y González, con la antigua ideología de raigambre surandina vinculada al culto del Punchao. El significado de los objetos, en este sentido, podía ser interpretado en relación al marco cosmológico de representación del que eran producto, quedando subsumidos como expresión simbólica de la representación cosmogónica que realizaba la sociedad de ella misma y del mundo. Los sujetos, en cambio, quedaban abandonados a su mundo interno, aislado y solitario.

En las definiciones de la cultura material expresadas en esto trabajos, existe un supuesto básico: los sujetos se relacionan con el mundo -actúan en él- a través de las representaciones sociales y simbólicas que realizan del mismo. Esta división entre la comunicación de información cultural y la alteración del mundo físico por la cultura material, descansa sobre la suposición de que los agentes humanos habitan mundos de significados intersubjetivos, o están sujetos a redes de significación, por encima, y más allá de, sus intervenciones materiales (Haber y Gastaldi 2006; Ingold 1999). Es decir, implica 
una inicial separación de la mente y el mundo, de los niveles de realidad "etic" y "emic" (Ingold 1999: xi).

Volvamos ahora al ejemplo de la jarra. Dijimos que la jarra está en sí, producto de un producir, de un emplazar desde. Pero al pensar de esta forma, estamos pensando a la jarra desde el momento de su producción, es decir, desde el momento en que el alfarero se la representa como la cosa que tiene que ser producida. Al situar el significado de la cosa, su naturaleza, en el producir, en el emplazar desde, los individuos y sus marcos de significados terminaron preexistiendo a la producción de las cosas. Otra vez los objetos y los sujetos quedaron aislados. Entonces ¿Cómo alcanzamos a la cosa como cosa?

\section{De la Mutua Constitución de las Cosas y las Personas: Alcanzando la Cosa como Cosa}

Sólo alcanzamos a la cosa como cosa al no tomar posición por ninguna de las formas descriptas anteriormente, y trascendiendo lo dicotómico que hay en ellas. Nos situamos así en una dimensión donde cosas y personas se pertenecen mutuamente. ¿Cuál es esta dimensión? se la puede situar en el momento de la práctica. Con relación al ejemplo de la jarra, sería en el momento en que vierte su contenido. Este momento práctico no debe ser entendido, como en el caso de las visiones constructivistas de la cosa, como ocurriendo en relación a las representaciones del mundo que poseemos, más allá de nuestras intervenciones en él. Al situarnos en el momento práctico, como dimensión donde hallamos la naturaleza de la cosa, las representaciones del mundo y las intervenciones que realizamos en él, se fusionan. Es decir, las visiones del mundo que poseemos son tomadas en relación a las intervenciones que realizamos en él, y estas últimas se constituyen también a través de las representaciones sociales del mundo (Ingold 1999; Thomas 1996, 2001).

Cuando la jarra vuelca su contenido, no sólo se vierte un líquido, a la manera en que se define el verter desde la físca, sino que en ese momento práctico está fusionado el significado de la bebida que se vierte. Es decir, el significado, lejos de estar adjuntado a la acción -como el significante al significado-, está más bien inmanente en las relaciones entre las personas y el mundo que las rodea, entre los objetos y los sujetos (Ingold 1999:xi).

Las personas, desde su nacimiento, se encuentran en un activo lazo perceptual con los componentes de su ambiente, en el que también se encuentran las cosas. Como señala Thomas (1996) siguiendo a Heidegger al señalar como los humanos encontramos las cosas 
en el mundo: "Mundo" -o ambiente- no intenta sugerir un planeta particular, o colección de objetos, o totalidad de todas las cosas físicas que existen. Por el contrario, usamos la palabra como estructura de inteligibilidad. Cuando los seres humanos encuentran los fenómenos en el día-a-día, les pueden otorgar sentidos por asignación de ellos a un contexto de significación" (Thomas 1996:65, la traducción es nuestra). Es decir que cuando nosotros nos encontramos con un objeto físico; su red de significados contextuales permite que se haga inteligible: "las cosas "aparecen" ante nosotros siendo siempre inteligibles." (Thomas 1996:65). Como dice Bourdieu: "La mente nacida del mundo de objetos no surge como una subjetividad confrontando a una objetividad: el universo objetivo está construido de objetos que son el producto de operaciones de objetivación estructuradas de acuerdo a las mismas estructuras que la mente aplica a aquel" (Bourdieu 1977:91, la traducción es nuestra). Es en este sentido en que se puede comprender la afirmación de Shanks y Tilley (1987) de que la cultura material es estructurada y estructurante.

No podemos comprender acabadamente a los objetos si no los analizamos en el marco de las prácticas sociales en las que participan, ya que es en éstas donde adquieren significado (Gastaldi 2007d; Shanks y Tilley 1987; Tilley 1989; Hodder 1982, 1988, 1989, 1990; Miller y Tilley 1996; Pérez Gollán 1999). Por otro lado, no podemos entender la constitución del sujeto si no es en relación con los objetos con los cuales convive durante su vida (Gastaldi 2007b, 2007c, 2007d, Gosden 1994; Gosden y Marshall 1999; Haber y Gastaldi 2006; Ingold 1999; Laguens 2007, Laguens y Pazzarelli 2007, Laguens et al 2007; Spector 1996; Thomas 1996). Es en esta relación dialéctica que los individuos y las cosas se constituyen mutuamente, es en esta dimensión donde hallamos a la cosa como cosa. Así la constitución del sujeto, como persona, como individuos sociales, es imposible pensarla sin las intervenciones que estos realizan en el mundo.

Ahora bien, nuestro interés desde el comienzo del trabajo, no solo fue repensar las relaciones entre los objetos y los sujetos, si no que también estuvo puesto en dilucidar los procesos de construcción de identidades sociales en el valle. ¿Que relaciones podemos establecer entre éstas y aquellos? Y ¿Cómo concebimos a las mismas en esta investigación?

Desde hace unas décadas la problemática de la identidad y su desarrollo plural -las identidades- (Arfuch 2005; Hall 2003; Restrepo 2004) han vuelto a surgir con mucha fuerza en la discusión de las ciencias sociales en general y en la arqueología en particular (Jones 1996; Gosden 2001; Hernando 2002; Meskell 2001; Shenan 1994; Treherne 1995, 
Thomas 1996). Esto se produjo en un contexto de creciente surgimiento y reivindicación de minorías sexuales, étnicas, políticas, lingüísticas, religiosas, entre otras. A medida que se registraba esta explosión en los estudios sobre la identidad, la misma, desde distintos sectores de las ciencias sociales, fue sometida a un crítica profunda. Esta crítica se dio en varias disciplinas y tendencias teóricas, pero un aspecto compartido fue el cuestionamiento, de una manera u otra, a la noción de una identidad integral, originaria y unificada (Hall 2003:13).

Se comenzó planteando una fuerte crítica a la idea de un sujeto autónomo, central, omnipresente, tal cual fue definido por la metafísica postcartesiana (Thomas 1996; Hall 2003; Laclaud 1996). Se produjo en este sentido un descentramiento del sujeto. Ya no podía pensarse en los términos cartesianos clásicos donde existe un cuerpo sometido a las leyes de la naturaleza y una mente alojada en él siendo algo distinto de este (Thomas 1996:46). Ni pensar a la persona enteramente definida por estos dos aspectos. Como señala este último autor la entrada en escena de las estructuras lingüísticas, y el reconocimiento de que el significado y el significante no son idénticos produce un quiebre en esa visión totalizadora y unificada del sujeto en tanto que solo puede conocerse y reconocerse a si mismo por medio del lenguaje (Thomas 1996:46). Así el sujeto no se forma totalmente por un proceso conciente, no es una conciencia totalizadora que viene al mundo y toma al lenguaje como medio de expresión de su pensamientos y experiencias primordiales. Más bien, para el sujeto es necesario ser insertado en el leguaje en orden de desarrollar una identidad de si (Thomas 1996: 46, siguiendo al pensamiento de Lacan). Esta crítica centra la atención en la construcción de la subjetividad y los procesos inconcientes de su formación. Por otro lado marca la necesidad de una externalidad al sujeto, absolutamente necesaria para su formación. Laclau (1996:45) señala esto mismo cuando plantea que la posibilidad misma de la distinción entre sujeto/objeto -clásica del pensamiento moderno“... es el simple resultado de la imposibilidad de constituir ninguno de sus dos términos. Soy un sujeto precisamente porque no puedo ser una conciencia absoluta, porque soy enfrentado por algo constitutivamente ajeno; y no puede haber un puro objeto en razón de esta opacidad/alienación que muestra las huellas del sujeto en el objeto". Para Thomas (1996:47) la paradoja de la existencia humana es que la subjetividad está al mismo tiempo dispersa, y fuera del si mismo, situada-embodied-y localizada espacial y temporalmente. A su vez ese proceso de devenir sujeto, no es fijo, si no que la construcción del yo es un proceso incesantemente performativo, es decir se halla en un proceso de continua formación, es histórico y contingente (Thomas 1996; Hall 2003; Meskell 2001). 
La identidad y las identidades, a través de estas críticas, serán extraídas de la concepción según la cual son unidades totalizadoras y esenciales. Empezará a tomar cuerpo la idea que las mismas si bien proclaman una "unidad" son el resultado, no de una totalidad natural, inevitable o primordial, sino de un proceso naturalizado $\mathrm{y}$ sobredeterminado de "cierre" (Hall 2003:17). Como señala Laclau (1996:53) lo "universal" -en nuestro caso la "unidad" proclamada- no es otra cosa que un particular que en cierto momento subvierte su estado y pasa a ser dominante. De modo que las "unidades" proclamadas las identidades "emergen en el juego de modalidades específicas de poder y, por ello, son más el producto de la marcación de las diferencias y la exclusión que signo de una unidad idéntica y naturalmente constituida: una identidad en su significado tradicional (es decir, una mismidad omniabarcativa, inconsútil y sin diferenciación interna) (Hall 2003:17). Así, dentro de esta perspectiva las identidades se construyen a través de la diferencia, no al margen de ella. "Esto implica la admisión radicalmente perturbadora de que el significado "positivo" de cualquier término -y con ello su "identidad"- solo puede construirse a través de la relación con el Otro, la relación con la que él no es, con lo que justamente le falta, con lo que se ha denominado su afuera constitutivo" (Hall 2003:17). Así, según este autor, a lo largo de sus trayectorias las identidades pueden funcionar como puntos de identificación y adhesión sólo debido a su capacidad de excluir, de omitir, de dejar "afuera", abyecto: "toda identidad tiene como "margen" un exceso, algo más. La unidad, la homogeneidad interna que el término trata como fundacional, no es una forma natural sino construida de cierre y toda identidad nombra como su otro necesario, aunque silenciado y tácito aquello que le "falta" (Hall 2003:17). De esta forma la constitución de una identidad social siempre es un acto de poder (Laclau 1990 citado en Hall 2003).

En resumen la perspectiva desde la cual pensamos a los procesos de construcción identitaria, pone énfasis en los proceso de constitución de los sujetos sociales, donde los objetos como partes del "mundo", entendido como "estructura de inteligibilidad" forman parte inseparable de dicho proceso; a su vez, las identidades de los sujetos se definen y constituyen en un juego específico de relaciones de poder (no sólo como expresión de éstas sino en un sentido generativo). Aquí es donde constitución de identidades y desigualdad social se encuentran. Investigar cómo se produjeron y reprodujeron los procesos de diferenciación social en el valle de Ambato, es interpretar la manera en que las identidades de los individuos fueron construidas. Sólo después podremos comprender las formas a través de las cuales determinados grupos sociales se fueron consolidando como grupos 
diferenciados del resto y de qué formas esta nueva configuración se produjo y reprodujo en el Valle de Ambato durante al menos siete siglos.

\section{Notas}

\footnotetext{
${ }^{\text {i } A s i ́ ~ f u e ~ l l a m a d a ~ p o r ~ s u s ~ c r i ́ t i c o s ~ m a ́ s ~ f u e r t e s ~ d e ~ l a ~ N u e v a ~ A r q u e o l o g i ́ a . ~}$

ii Ver Hodder (1988).

iii González en este artículo se hace eco de las críticas realizadas a la arqueología tradicional por las perspectivas funcionalistas. A su vez, retoma las propuestas planteadas por el estructuralismo en la antropología y en la arqueología para interpretar el arte prehispánico.
} 
Hasta aquí planteamos que personas y cosas no pueden ser comprendidas si no entendemos que su constitución deviene de una historia mutuamente entrelazada, habiéndonos apartado de esta manera de las dicotomías planteadas por las perspectivas normativista, materialistas y constructivistas de la cultura material. Nos acercamos así a un enfoque multidimensional y dialéctico de la relación entre los seres humanos y los objetos, donde la construcción de las identidades es el eje para comprender los cambios identificados en el Valle de Ambato durante el primer milenio de la era. Ahora nos preguntamos ¿cómo podemos desde la arqueología acceder a los modos a través de los cuales fueron entabladas las relaciones sujetos/ objetos y construidas dichas identidades?

Proponemos cuatro fases de análisis: en la primera extraeremos a los objetos de su aparente operación dentro de redes funcionales desprovistas de sentidos, para ello adoptamos una perspectiva fetichista metodológica: los consideraremos como si fueran personas con particulares trayectorias biográficas. En la segunda desplazaremos a los sujetos del lugar históricamente ocupados por ellos, donde su subjetividad se construye sólo de las representaciones que ellos hacen de sí mismos, es decir de la perspectiva según la cual el sentido se superpone a los objetos a posteriori de su inclusión en redes funcionalmente activas y que, en definitiva, sea necesario buscar a las personas detrás de los artefactos. Adoptamos para esto una perspectiva objetivista sobre ellos, analizándolos como objetos. En tercera, conjugaremos ambas perspectivas construyendo las cartografías en las que las trayectorias biográficas de los objetos -vasijas- y de las personas se intersectan o diseminan. Mostraremos de qué manera las agencias humanas y no humanas, continuamente se constituyen unas a otras en redes de percepción, acción, haceres y saberes, representaciones y prácticas (Gastaldi 2007a, 2007b; Haber y Gastaldi 2006). En la cuarta nos inmiscuiremos en el largo término, observando cómo estas cartografías que se producen en la contingencia del presente logran perdurar en el tiempo.

\section{Objetos como sujetos: sus biografias}

Tomar a los objetos como si fueran personas nos permitirá, en un primer nivel de análisis, desvincularlos de aquellas posiciones en las cuales son analizados sólo en relación a su operación dentro del plexo funcional donde participan. Es decir, de la perspectiva en donde los objetos son creados para satisfacer necesidades de los individuos que preexisten a ellos. En esta sección centramos nuestro análisis en los objetos mismos, ya que es a través de sus 
formas, usos y trayectorias que podremos averiguar los intereses que los animan. Desde una perspectiva metodológica son las cosas en movimiento las que iluminan su contexto social y humano (Appadurai 1991). En este nivel analizaremos a los objetos como si fueran individuos con determinadas trayectorias biográficas. Pero ello no implica caer en un fetichismo de los objetos, ya que en su uso, los instrumentos entran en relaciones específicas con quienes los usan. Y es en esta relación, y no en los instrumentos por sí solos, donde se determina la particularidad histórica de una tecnología (Marx 1978; Meillassoux 1984; Sahlins 1983; Vicent García 1991a). Por ello tomaremos a los objetos mismos como unidades de análisis, evaluando su biografía, o sus biografías posibles, pero enfocada desde las prácticas sociales donde participan.

No hace más de una década que la perspectiva biográfica de las cosas fue planteada como un enfoque muy útil para la interpretación arqueológica (D’Amore 2002; Gastaldi 2007b, 2007d; Gerristen 1999; Gosden y Marshall 1999; Haber y Gastaldi 2006; Saunders 1999; Tringham 1995). El enfoque biográfico de los objetos se propuso en la arqueología en un momento donde la cultura material iba adquiriendo un rol activo en la conformación de las relaciones sociales. El concepto de biografía se opuso al de «vida de uso»-use life-, debido a que este último focaliza su análisis en los cambios de las características morfológicofuncionales de un objeto o artefacto, por ejemplo, en los estudios de tecnología lítica donde se analiza la reducción de los instrumentos a través de sucesivos episodios de lascado observando principalmente los cambios de las formas y usos. Los objetos aquí son pasivos, el material inerte es transformado en una cosa con la que se realizan actividades. Estos análisis no dirigen su atención a la interacción que se produce entre la gente y los objetos, y como en dicha relación se crean significados (Gosden y Marshall 1999).

El enfoque biográfico de los objetos, surge primero en el seno de la antropología económica. Para establecer las trayectorias biográficas de las cosas, a los objetos se le hicieron el mismo tipo de preguntas realizadas a las personas: “¿Cuáles son las posibilidades biográficas inherentes a su "estatus", período o cultura, y cómo se realizan tales posibilidades?, ¿De dónde proviene la cosa y quién la hizo?, ¿Cuál ha sido su carrera hasta ahora, y cuál es de acuerdo con la gente su trayectoria ideal?, ¿Cuáles son las edades y períodos reconocidos en la vida de la cosa, y cuáles los indicadores culturales de estos?, ¿Cómo ha cambiado el uso de la cosa debido a su edad, y qué sucederá cuando llegue al final de su vida útil?" (Kopytoff 1991: 92). Esta transposición del enfoque biográfico hacia las cosas se realizó puesto que, según quienes lo proponen, la biografía de una cosa podría alumbrar aquellas relaciones y procesos que de otro modo quedarían oscuros. Por ejemplo, en situaciones de contacto cultural, puede mostrar lo que los antropólogos han enfatizado con frecuencia: que lo significativo de la adopción de objetos -y de conceptos- extranjeros no es el hecho de que sean adoptados, sino la forma en que son redefinidos culturalmente y puestos en uso: "La biografía de un automóvil 
revela una abundante información cultural: el modo en que se adquiere, cómo y de quiénes proviene el dinero reunido para comprarlo, la relación entre el comprador y el vendedor, los usos que le dan a los automóviles, la identidad de los pasajeros y la de aquellos a quienes se lo presta, la frecuencia del préstamo, los talleres donde se repara, el vínculo de los propietarios con los mecánicos, el paso del automóvil de mano en mano a través de los años y, por último, cuando ya no funciona, la disposición de sus partes. Todos estos detalles habrán de mostrar una biografía completamente distintas de aquella del automóvil empleado por la clase media estadounidense, los navajo o los franceses." (Kopytoff 1991:93). El enfoque biográfico de las cosas permite así observar, como es señalado en la biografía de un automóvil, el conjunto de relaciones sociales entabladas por las personas con relación a la producción y uso de un determinado objeto.

Variedades de objetos arqueológicos fueron analizadas desde el punto de vista biográfico: casas (D’Amore 2002; Gerristen 1999; Tringham 1995), collares (Gosden y Marshall 1999), perlas (Saunders 1999), herramientas agrícolas (Gastaldi 2007d; Haber y Gastaldi 2006), etc. Estas investigaciones mostraron la potencialidad del enfoque biográfico para acceder a aquellos aspectos de la cultura material que durante mucho tiempo quedaron en la penumbra de la interpretación arqueológica, es decir, la manera en que la producción y uso de objetos interviene en el establecimiento y reproducción de determinadas relaciones sociales. En una investigación anterior (Gastaldi 2007d), realizamos la reconstrucción de las distintas biografías que tuvieron ciertas herramientas, palas líticas, en el oasis de Tebenquiche Chico. El trazado de sus trayectorias biográficas nos permitió mostrar de qué forma, los implementos analizados, además de cumplir una función determinada -mover sedimentos-, al participar en las actividades agrícolas -roturar, sembrar, regar, etc.- construían activamente las relaciones sociales de producción en el oasis. Y que no podíamos comprender cómo se construían las identidades en este lugar, si no interpretábamos las formas en que los sujetos se definían a sí mismos. En este caso, la manera en que con la utilización de las palas, los sujetos se definían como apropiador/ras de los medios de producción. Y como a través de esta identificación de los sujetos como apropiador/ras se producía y reproducía no solo la unidad doméstica, sino también el oasis de Tebenquiche Chico.

Las diversas investigaciones desarrolladas en el valle, han señalado algunas características de ciertos objetos, que nos permiten proponerlos como categorías relevantes a ser analizadas (Fabra 2008; Laguens 2005; Pérez Gollán et al 2000). Se ha establecido la vigencia en la producción tecnológica de ciertas variedades de objetos cerámicos desde el inicio de la ocupación agroalfarera local hasta el final de la ocupación Aguada, como por ejemplo la alfarería oxidante de paredes gruesas para grandes vasijas tricolor o lisas, y aquella reductora de tradición Ciénaga-Aguada (Fabra 2008; Laguens 2005). Ambas clases cerámicas demuestran una continuidad notable en el tipo de materia prima utilizada y en los 
procedimientos de manufactura, trascendiendo la funcionalidad de diferentes clases de formas y la distribución en distintas clases de sitios en el tiempo y en el espacio (Laguens 2005). Ambas clases nos brindan, por un lado, representatividad temporal, en tanto están presentes desde los inicios de las transformaciones sociales referidas. Pero además ninguna de ellas continúa de la misma forma en momentos posteriores a la producción de las transformaciones sociales; la cerámica gris negra si bien es representante de una larga tradición, en el nuevo contexto social - a partir del 500 d.C-, adquiere otro rol: mientras que se mantendrían idénticos procedimientos de manufactura para producir una variedad más acotada de objetos, se transforma en vehículo de una información novedosa como es el estilo Aguada. En el caso de las grandes vasijas oxidantes, aumentan notablemente su representatividad. Trazar las biografías de estos objetos que fueron resignificados en el nuevo contexto social es un punto importante a la hora de evaluar la producción y reproducción de las relaciones sociales en las que participaban activamente estos objetos en las nuevas configuraciones sociales. Otro punto que hacen que nos interesemos en estas clases es que se hallan conspicuamente representadas en diversidad de sitios pertenecientes a diferentes "jerarquías", hecho que nos posibilita, una vez que tracemos sus biografías, que podamos transitar por variedad de contextos, escalas y espacios obteniendo un panorama más completo de las trayectorias biográficas seguidas por estos objetos en todo el valle en el lapso temporal considerado.

Uno de los problemas metodológicos que posee el enfoque biográfico en nuestro caso, es el hecho de que, a diferencia de los antropólogos, los arqueólogos no contamos con las personas para entrevistarlas, y así conocer las formas, usos y movimientos que poseen los objetos. Entonces ¿cómo reconstruir la trayectoria biográfica de un objeto o un conjunto de ellos desde ellos mismos?

La reconstrucción de las biografías de las cosas requiere de mucha creatividad por parte del arqueólogo para desarrollar un enfoque metodológico-técnico que permita realizarla. Estos modelos dependen del o los tipos de objetos analizados -casas, monumentos, herramientas, etc.-, del o los contextos históricos donde se inserta el objeto, de las prácticas a las cuales se vincula/n, y del tipo de información contextual con el que cuenta el investigador. Pero existen otras cuestiones que deben ser tenidas en cuenta. La perspectiva biográfica implica la obtención de la mayor cantidad de información posible acerca de los objetos de los que se quiere trazar su biografía. Debemos analizar desde la materialidad más esencial del objeto: los materiales usados para su fabricación, su proveniencia, las características de los mismos, etc., pasando por las técnicas de fabricación, formas, funciones, modo y lugares de usos, si son conservados, cuándo se los deja de usar, porqué, dónde se los tira, etc.; hasta las prácticas sociales donde intervienen y los contextos económico-sociales estructurados y reestructurados por éstas. Es relacionando todos estos datos que podremos reconstruir la o las diferentes trayectorias biográficas que tuvo un determinado objeto. 
Para la reconstrucción de las biografías seguiremos en primera instancia un modelo secuencial, por lo que comenzaremos por describir los procesos de manufactura de las vasijas: tipos de materias primas utilizadas, posibles lugares de proveniencia, lugares de fabricación de las vasijas, secuencias de producción de las mismas, etc. Luego evaluaremos las propiedades técnicas y formales que les fueron concedidas a estos objetos para ser utilizadas en diferentes actividades prácticas. Posteriormente observaremos qué sucede con ellas una vez fabricadas con determinadas características y en determinados lugares. Con respecto a esto último trataremos de responder las siguientes preguntas: ¿Dónde son distribuidas?; ¿Se las utiliza en los mismos lugares en donde son fabricadas o en otros lados? ¿Cómo se las usa en esos lugares?; ¿Quiénes las usan?; ¿Coinciden o no las propiedades formales y técnicas, concedidas para que sean utilizadas en alguna actividad particular, con los usos concretos a los que fueron sometidas? Es decir ¿se las usa en aquellas actividades que nos marcan estas características o se las usa para algo más u otra cosa?; ¿Qué cosas específicas se están haciendo con estas vasijas en esos lugares? ¿Con qué objetos y lugares se vinculan estas actividades? ¿Dónde se las almacena o guarda?. Luego nos acercaremos al tiempo de vida de éstas, para intentar responder si ¿se espera de ellas un tiempo de vida prolongado o corto, o es indistinto? Y una vez que se rompen ¿se las repara? O ¿se las deja de usar?, ¿se las transforma en otro objeto?, y si se las repara ¿siguen siendo utilizadas para realizar las mismas cosas o se utilizan para realizar otras cosas?, ¿se dejan de usar sólo cuando se rompen?, ¿Qué pasa cuando se rompen? ¿Quedan en el mismo lugar? O ¿Se las descarta o tira en otros lugares? ¿Son en algún momento posterior recicladas? ¿Sufren algún proceso de transformación que marque su estado de abandono?

Las trayectorias que reconstruiremos respondiendo a estos interrogantes, según el modo en que las vamos a ir describiendo, siguen una secuencia lineal, a la manera de un modelo de flujo clásico. En este sentido, si el análisis terminara aquí, no trascenderíamos los cinco procesos en que fue dividida la historia de vida -contexto sistémico- de un elemento duradero: obtención, manufactura, uso, mantenimiento y descarte (Schiffer 1972, 1987, 1995). Estas cinco etapas se podrían asociar con una biografía, ya que establecen una secuencia en el tiempo a la manera de los antropólogos cuando preguntan acerca de la trayectoria laboral de una persona, pero: ¿conformaría esto una biografía cultural?; ¿trascenderíamos la visión según la cual el objeto opera dentro de redes funcionales con sentidos otorgados a priori?; ¿habríamos producido ese mencionado cambio en el estatuto ontológico de las cosas trasformándolas en sujetos?. La respuesta es no. Kopyttof (1991) señala que uno puede realizar diferentes trayectorias biográficas de los objetos -tecnológicas, sociales, económicas, etc.pero que esto no basta para que estas biografías sean biografías culturales: "Una biografía económica culturalmente configurada concibe al objeto como una entidad culturalmente construida, cargadas de significados culturalmente especificados, y clasificada y reclasificada 
de acuerdo con categorías culturalmente constituidas" (1991:94). Por lo que luego de responder a todos estos interrogantes, que nos brindarán un conjunto de datos muy importantes sobre la vida de estos objetos, y focalizándonos en las prácticas sociales donde intervienen y los contextos económico-sociales estructurados y reestructurados por éstas, realizaremos una reconstitución de estas trayectorias lineales, es decir ordenadas en una forma secuencial a priori por nosotros, en biografías culturales.

En síntesis, con el enfoque biográfico de las vasijas accederemos a una de las dimensiones temporales del objeto: la de su historia de vida, que se sitúa en el marco de las prácticas sociales en las cuales los mismos se constituyen significativamente. Además, las trayectorias biográficas de los objetos nos mostrarán de qué manera los individuos se apropiaron física y simbólicamente de ellos construyendo mutua y activamente sus identidades. Es decir, accederemos al marco de las relaciones establecidas entre sujetos y objetos a través del seguimiento de la trayectoria vital de un objeto en particular.

Sin embargo, la dimensión temporal de la vida de un objeto no coincide necesariamente con la dimensión temporal de la vida de un individuo, y si no comprendemos la manera en que los sujetos llegaron a representarse a sí mismos en la interacción con los objetos durante el transcurso de su vida, no lograremos comprender la totalidad de la relación establecida entre las cosas y las personas, y, en última instancia, no podremos acceder al modo a través del cual se constituyeron activamente las distintas maneras en que se entablaron las relaciones sociales en el Valle de Ambato durante el primer milenio. Adentrémonos, entonces, en la dimensión temporal de la vida del sujeto.

\section{Sujetos como Objetos: sus cuerpos}

Pensar a la persona como objeto, nos permitirá desvincularnos de aquellas perspectivas en las cuales la identidad de la persona se constituye sólo a través de su subjetividad, en relación a determinados marcos de significados discursivos o simbólicos, insertos en un particular contexto socio-histórico. Esto nos lleva a tratar las formas en que fue concebida la construcción de la subjetividad del individuo y su identificación como tal. Como eje de la discusión tomaremos al cuerpo y su participación en la constitución de los sujetos sociales.

La separación entre personas y cosas, que tratamos anteriormente, produjo otra escisión artificial: la del cuerpo con el "yo", separación que atravesó casi todas las consideraciones que se realizaron en distintos campos sobre la constitución de la subjetividad individual (Thomas 1996, 2001; Treherne 1995). Esta división produjo que se planteara que el "yo" -individual- se construye en el plano de lo discursivo y lo simbólico, quedando el cuerpo subsumido pasivamente en las representaciones sociales realizadas del mismo. Esta perspectiva situó la generación de la subjetividad del individuo fuera del ámbito del cuerpo, lo que provocó que no 
se tratase satisfactoriamente la relación fundamental entre aquél y la subjetividad de una persona (Treherne 1995). A partir de las críticas realizadas a estas posiciones, desplazaremos al individuo desde su representación de sí mismo hacia su corporeidad, situando al cuerpo como eje para la interpretación de la construcción de la subjetividad de los sujetos.

El supuesto que se esconde detrás de las separaciones del cuerpo y el "yo", es que una cultura o acción de lo social obra sobre una naturaleza que se supone como una superficie pasiva, exterior a lo social, pero contrapartida necesaria de aquél (Butler 2002). Así, el cuerpo se transforma en una superficie de inscripción, de esta forma la construcción de la subjetividad de los individuos no se origina o ni es inherente al cuerpo sino que está impuesta externamente. Butler (2002:28) propone que en vez de pensar en términos de estas concepciones de construcción del cuerpo, volvamos a la noción de materia, “...no como sitio o superficie, sino como un proceso de materialización que se estabiliza a través del tiempo para producir el efecto de frontera, de permanencia y de superficie que llamamos materia". Así la construcción no es un acto único, ni un proceso causal iniciado por un sujeto que culmina en una serie de efectos fijados. La construcción, no sólo se realiza en el tiempo, sino que es en sí misma un proceso temporal que opera a través de la reiteración de "normas"; en el curso de esta reiteración el cuerpo (Butler habla de sexo, del cuerpo heterosexual) se produce y a la vez se desestabiliza (Butler 2002:29).

Aquí hay que traer a la discusión la idea de performatividad discutida por esta autora, la que no debe considerarse como una repetición de actos, como si éstos permanecieran intactos e idénticos a sí mismos a medida que se los repite en el tiempo, entendiendo a su vez al tiempo como algo exterior a los actos. Como señala la autora, un acto es en sí mismo una repetición, una sedimentación y un congelamiento del pasado (Butler 2002:29). Una descripción precisa de cómo el tiempo no puede ser considerado más allá de los actos prácticas- la encontramos en el pensamiento de Bourdieu. No podemos separar la idea de tiempo, de este autor, de la de habitus (Bourdieu 1977, 1988). Para este autor el habitus es el mecanismo estructurante que opera desde dentro de los agentes, no es ni estrictamente individual ni por sí solo completamente determinante. Lo define como un sistema socialmente constituido de disposiciones estructuradas y estructurantes, adquiridas mediante la práctica y siempre orientada a funciones básicas. Además, afirma que son sistemas perdurables y transponibles de esquemas de percepción, apreciación y acción resultante de la institución de lo social en los cuerpos (Bourdieu y Wacquant 1995) ${ }^{\mathrm{i}}$. Es el generador de las prácticas, es el que nos permite actuar en determinados campos. Pero a su vez es generado en la misma práctica. O sea, se temporaliza en el acto mismo en el que se realiza la práctica:

«El tiempo se origina en la ejecución misma del acto (o pensamiento) como actualización de una potencialidad que es por definición, actualización de lo no 
actual y desactualización de lo actual [...] La actividad práctica, en la medida que tiene un sentido, en que es sensata, razonable, es decir, generada por habitus ajustados a las tendencias inmanentes del campo, trasciende el presente inmediato por medio de la movilización práctica del pasado y la anticipación práctica del futuro inscripto en el presente en un estado de potencialidad objetiva» (Bourdieu y Wacquant 1995:95).

En esta idea de Bourdieu claramente el tiempo se produce en la práctica y no por fuera de ella, en este sentido se acerca mucho y nos da una definición más precisa que Butler acerca de cómo este se produce. No obstante, la idea de performatividad tal cual la comprende esta autora nos abre otra posibilidad, que la propuesta de Bourdieu no nos aclara y nos deja en un ámbito demasiado reproductivista: al producirse el acto, al mismo tiempo que se materializa y fija -en términos de Bourdieu, vuelve a ser incorporado como habitus-, se desestabiliza, en tanto depende para su fijación, en el caso del cuerpo, de la producción simultánea de una esfera de seres abyectos -cuerpos abyectos-, que marcan el límite o la frontera de aquello que deja de ser sujeto, pero que es constitutivo de éste. "Lo abyecto designa aquellas zonas "invivibles", "inhabitables" de la vida social, que sin embargo están densamente pobladas por quienes no gozan de la jerarquía de los sujetos, pero cuya condición de vivir bajo el signo de lo "invivible" es necesaria para circunscribir la esfera de los sujetos" (Butler 2002:19-20). Este proceso de construcción de frontera ya lo hemos mencionado cuando tratamos la construcción de identidades sociales, por lo que ambos procesos están inextricablemente unidos. Este planteo nos brinda una caja de herramientas teóricas y metodológicas muy operativas para que al no dar por sentado la existencia de un cuerpo con límites precisos -natural- sobre los cuales se inscribe lo social, nos centremos en observar los procesos productivos que hacen que se materialicen determinados cuerpos y con ellos determinados sujetos, y a su vez que otros cuerpos y sujetos simultáneamente sean colocados en la frontera de esta producción.

Desde esta perspectiva, el origen de la subjetivación no puede ser comprendida si la focalizamos sólo desde las representaciones que se realizan en el plano discursivo o simbólico, sino que debemos tomar al cuerpo -visto como un proceso de materialización- como un ámbito de acción. El cuerpo es central tanto en un sentido genético (socialización) como crónico (práctica cotidiana), a la subjetivación. Llegamos de esta manera a una noción activa del cuerpo, en donde el mismo se nos presenta como un eje central en torno al cual el sujeto construye su identidad. En este momento logramos salirnos de la idea del sujeto como producto del mero representar desde lo discursivo y simbólico, y nos adentramos en su corpórea fisicalidad ${ }^{\mathrm{ii}}$, en su mera "objetualidad".

Otro problema, al igual que el de la reconstrucción biográfica, se nos presenta a los arqueólogos a la hora de interpretar de qué manera se construyeron las subjetividades 
individuales y grupales en el pasado; lo único que tenemos presente ante nosotros es la manera en que los cuerpos de las personas fueron tratados al momento de su disolución como tal, es decir, en el momento de su muerte.

En el Valle de Ambato se han hallado por lo menos dos formas diferentes en el tratamiento de los cuerpos de los individuos muertos. Por un lado, se conserva el cuerpo entero, existiendo enterratorios de un solo individuo. La otra "actitud" hacia los cuerpos encontrada en el valle, es el de la dislocación y/ o fragmentación de las partes corporales del individuo. En este sentido, se encontraron en varios sitios fragmentos óseos humanos dispersos, muy fragmentados, con evidencias de impactos violentos en el cráneo, y algunos quemados. En otros casos, los huesos se utilizaron para funciones prácticas, posiblemente como herramientas (Baffi y Torres 1996). Los cuerpos, en las dos actitudes dadas hacia los mismos no se hallaron despojados, sino que todos fueron encontrados en asociación con otros objetos, formando parte de un mismo contexto significativo, entre ellos objetos de metal, cerámicos, líticos y huesos de animales. (Herrero y Ávila 1991; Juez 1991; Pérez Gollán 2000 et al). Estos contextos significativos de asociación nos remiten al contexto de vida de los individuos, y también a la manera en que los objetos se encuentran co-construyendo activamente la subjetividad del individuo, hasta en su muerte. Esto nos conduce hacia el momento práctico rutinario, a los contextos cotidianos en los cuales estos objetos entraron en contacto e interactuaron con los sujetos.

\section{Cartografías: Intersecciones, Diseminaciones y Encuentros.}

El establecimiento de las cartografías se realizará entrecruzando todas las sendas biográficas del sujeto trasmutado en objeto, y de los objetos trasmutados en sujetos. La cartografía biográfica resultante, nos permitirá establecer los distintos encuentros, y desencuentros, conjunciones y diseminaciones entre las distintas trayectorias seguidas.

Aquí debemos realizar una consideración sobre la relación tiempo y espacio. En el acápite anterior planteamos al tiempo no como externo a las prácticas, sino como producido en ellas mismas. Ahora vamos a trazar cierta relación entre la temporalidad de las prácticas y su vinculación con la producción de espacios o lugares, donde éstas no solo se desarrollan como si el espacio fuera un escenario fijo e inmutable sino que se encuentran activamente involucradas en su producción. Una propuesta relevante en el marco del planteo que venimos realizando es la de la geografía-tiempo de Giddens (1995).

El autor, retoma críticamente los planteos de la geografía histórica del geógrafo sueco Hägerstrand. Esta toma como punto de partida el carácter rutinizado de la vida diaria y el carácter finito de la vida individual. Para esta perspectiva es de fundamental importancia las intersecciones en el espacio y en el tiempo de las sendas cotidianas y de las sendas vitales, 
dándole un rol muy importante al ser humano como "proyecto biográfico". Basándose en esta propuesta Giddens (1995) la reelabora proponiendo una particular forma de pensar la geografía-tiempo que consideramos relevante a la hora de analizar las intersecciones, encuentros, desencuentros y diseminaciones de las biografías de las vasijas y de los sujetos.

En primera instancia, Giddens (1995) critica el concepto de "lugar", señalando que en teoría social no se puede emplear simplemente en términos de un punto en el espacio, así como también señala que tampoco se puede hablar de puntos en el tiempo como una sucesión de "ahoras". Esto significaría que el concepto de presencia -o, más bien, la mutualidad de presencia ausencia- debe explicarse tanto en términos de su espacialidad como de su temporalidad (Giddens 1995). La separación del espacio y el tiempo es una de las principales características de la modernidad (Giddens 1995:29) y a su vez esta separación es acompañada de un vaciamiento de estas categorías en tanto se alejan de la especificidad de la localización. El mapamundi en el que no existe un lugar privilegiado -puesto que es una proyección universal-, es el correlato simbólico del reloj en el vaciamiento del espacio (Giddens 1995: 29). Dos nociones le permiten reformular la categoría de "lugar": "sedes" - y regionalizaciones dentro de estas-, es decir el uso del espacio para proveer las ambientaciones de interacción que especifican su contextualidad y la disponibilidad-presencia, es decir el 'estar juntos' de la copresencia que demandan los medios para ser capaz de 'juntarse'. La constitución de sedes se vincula con fenómenos tales como el cuerpo, sus elementos de movilidad, de comunicación, en relación con las propiedades físicas del mundo circundante. Las sedes proveen buena parte de la "fijeza" de instituciones situadas. Por lo común es posible definir sedes en los términos de sus propiedades físicas, sea como rasgos del mundo material o, más generalmente, como una combinación de esos rasgos y artefactos humanos. Pero definir las sedes sólo en estos términos es erróneo en tanto que, por ejemplo, una casa se aprehende como tal únicamente si el observador reconoce que es una "morada" con un espectro de otras propiedades especificadas por los modos de su utilización en una actividad humana (Giddens 1995:151). La regionalización no se debe entender sólo como localización en el espacio, si no como referida a una zonificación de un espacio-tiempo en relación con prácticas sociales rutinizadas. Así el espacio y el tiempo en la propuesta de este autor quedarían vinculados a una localización, una que sería no sólo estructurante de las prácticas allí realizadas y proveería la ambientación y los contextos necesarios de co-presencia para la interacción sino que indisolublemente se hallaría estructurada por dichas interacciones, producto de prácticas situadas espacio-temporalmente.

Aquí debemos traer a la discusión tres conceptos que nos permitirán acceder, desde la arqueología, a la estructuración de estas geografías-tiempos creadas y recreadas en las rutinas diarias de las prácticas sociales, en donde objetos y sujetos se coproducen: el de unidad estratigráfica, secuencia estratigráfica y el de interfacie (Harris 1991; Carandini 1997). La unidad estratigráfica se considera la mínima unidad elemental de excavación, puede ser 
definida como una acción o un conjunto de ellas (Carandini 1997). Para Harris (1991:73) "tres factores principales determinan la acumulación de restos culturales durante el proceso de estratificación arqueológica: la superficie del terreno ya existente, las fuerzas de la naturaleza y la actividad humana". En relación a la actividad humana señala que: "a diferencia de las fuerzas de la naturaleza como la gravedad que hace que los depósitos tiendan a la horizontalidad, o a depositarse uno sobre otro respetando lo límites impuestos por la superficie anterior, los estratos antrópicos se derivan de una selección cultural: el hombre puede crear estratos a voluntad que respondan a un plan abstracto y no al devenir de la naturaleza (...) La historia de la humanidad, desde los primeros campamentos alrededor de un fuego, hasta las modernas metrópolis, es, en gran medida, la historia de la constitución de nuevas cuencas de deposición, de nuevos límites topográficos de, por así decirlo, los límites de propiedad estratigráfica" (Harris 1991: 74). En este sentido la unidad estratigráfica es el resultado de acciones naturales y culturales. Es en este punto donde se puede trazar una vinculación entre la noción de acción iii , más específicamente "actividad humana" que propone Harris y la noción de práctica social (D’amore 2002, 1998; Gastaldi 2007a; 2007d; Haber 1996, 2006). La noción de práctica social, que en parte ya le hemos definido al tratar la noción de habitus de Bourdieu, refiere a la multiplicidad de actividades prácticas (Giddens 1991, 1995) que los agentes de un grupo social determinado realizan cotidianamente en el curso de sus vidas. Estas prácticas se realizan en el marco que las posibilita; esto es, deben ser entendidas en relación a las estructuras encarnadas en tradiciones y reglas sociales, que son no sólo el medio sino también el resultado de tales prácticas. Así, la unidad estratigráfica, producto de acciones realizadas por individuos situados en relación a determinadas estrategias y estructuras sociales, nos permite tomar a la secuencia estratigráfica "reconstruida" como marco interpretativo a través del cual podríamos caracterizar a los objetos en las prácticas sociales concretas donde estaban involucrados y con ellas acercarnos a los significados que estos tuvieron en un determinado momento. La secuencia estratigráfica es la secuencia de acciones -unidades estratigráficas- que le fueron dando forma al depósito arqueológico. Uno de los elementos más importantes que permiten identificar las unidades estratigráficas, es decir que permite dividir a la tierra en dos, diferenciar dos acciones o conjunto de ellas y, establecer entre ellas una relación estratigráfica es la interfacie.

Según sean de depositación o de destrucción, las interfacies se clasifican como elementos interfaciales -horizontales y verticales- si son de destrucción de un depósito; o interfacies de estrato - horizontales o verticales- si son producto de depositación. Las interfacies de estrato horizontal son las superficies de estrato que se han creado y depositado más o menos horizontalmente, teniendo una extensión igual a la del estrato. Las interfacies de estratos verticales forman la superficie de un estrato vertical, generalmente un muro. Cuando un grupo de estas interfacies conforman una gran superficie se habla de interfacie de período. 
Según Harris, las interfacies de períodos son el equivalente a la suma de las interfacies de estratos horizontales y verticales que conformaron niveles de uso coetáneos (Harris 1991:100). La identificación de estas superficies nos permitirá acceder a la estructuración de las geografías temporales en donde objetos y sujetos, vasijas y personas producían sus encuentros y desencuentros (Gastaldi 2007a). Las interfacies nos permiten observar las vinculaciones entre distintas escalas de espacio-tiempo, son claves para comprender las intersecciones de estructuras y acciones (D’amore 2002; Haber 2006; Gastaldi 2007a, 2007d).

Es necesario aquí que hagamos explícita nuestra consideración de las escalas que tomaremos en nuestra investigación. En las cartografías biográficas, se entrecruzan una multiplicidad de escalas espaciales, temporales y sociales. Se conjuga el tiempo de vida de un individuo con el tiempo vital de un objeto, que podrá exceder o no la vida de la persona, se conjugan diferentes espacialidades vinculadas a sendas biográficas distintas, así como distintas escalas sociales, como las vinculadas a las prácticas domésticas y a la de los espacios públicos, entre otras. Estas múltiples escalas de ninguna manera pueden ser consideradas como "macro" o "micro" escalas, ni tampoco como escalas diferentes, debido a que se encuentran relacionadas dialécticamente. El análisis de escalas múltiples considera simultáneamente las diferentes escalas en las cuales existen las relaciones, y los vínculos entre las diferentes escalas. Reconoce explícitamente que la reproducción social tiene lugar tanto dentro como fuera de los límites de la escala bajo consideración (Cobb y Garrow 1996; Haber 2006; Bintliff 1991).

Ahora planteamos otra inquietud: si la constitución de las cosas y los individuos se produce en el momento de la práctica, en la conjunción de la multiplicidad de dimensiones en las que los objetos y los sujetos permanecen unidos, es decir en la contingencia de lo presente, ¿cómo es que perduran a través del tiempo dichas constituciones?, ¿cómo es que no son cuestionadas? En el caso particular de la historia de Ambato, ¿cómo es que perduraron durante casi siete siglos las relaciones sociales establecidas en el nuevo modo de vida que en determinado momento parece surgir? Debemos referirnos aquí, entonces, a la posibilidad de la fijación de significados en estructuras que superen lo contingente de la práctica presente.

\section{Descontextualizando significados: su fijación en el largo término}

En este punto del análisis entramos en una dimensión temporal que supera el tiempo biográfico de un objeto o un sujeto. Nos introducimos en la dimensión del largo término de las prácticas, en las estructuras de larga duración (Braudel 1980; Bintliff 1991; Hodder 1987a, 1987b). La dimensión del tiempo largo es el tiempo de las sociedades, donde un año o quizá un siglo, no signifique gran cosa (Braudel 1980:30). Es en esta dimensión temporal donde 
podemos encontrar la perdurabilidad de determinadas estructuras sociales durante lapsos de tiempo considerables. Es en esta temporalidad donde son fijados los significados de las prácticas al ser extraídos de sus contextos de producción. Aquí los significados son naturalizados más allá de la contingencia de la práctica misma, situándolos en categorías ahistóricas muy difíciles de cuestionar por su durabilidad, aparentemente inconmovible (Espósito 2009, Gastaldi 2007c, 2007d; Haber 2006; Quesada 2001, 2007). Esto nos lleva, por un lado, a analizar las cartografías, observando sus cambios y continuidades a lo largo de toda la temporalidad pertinente a nuestra investigación. Y por otro lado, nos conduce al plano en donde las geografías-temporales que dichas cartografías nos muestran pretenden ser ahistorizadas, transformándose en categorías naturalizadas de significación.

Algunos de los tipos de objetos que hemos seleccionado -individuos fragmentados, la cerámica gris-negra grabada- fueron hallados formando parte de la matriz estratigráfica de un cierto tipo de estructura: los montículos. Dada la dinámica de formación de estas estructuras -la que se fue produciendo progresivamente por depositación periódicas de materiales-, las inclusiones halladas en su matriz -representantes de todas las cosas y actividades realizadas por las personas en los viviendas y aldeas asociadas a éstas-, y su larga temporalidad - su formación comienza en los inicios del primer milenio-, los propondremos como aquellos "lugares" donde determinadas prácticas sociales pretendieron ser ahistorizadas, es decir naturalizadas, llegando a conformar parte del sentido común de los que vivieron allí. Dos categorías nos servirán para analizar estas estructuras: sedimento y monumento.

El sedimento implica la extracción de los objetos de los circuitos cotidianos y su posterior depositación, un proceso en el que cada depositación se superpone a otras -de las cuáles sólo de alguna se conserva memoria-, llegando a conformar verdaderas estratigrafías (D'amore 2002; Gastaldi 2007a y d; Haber 2006; Haber y Gastaldi 2006). De esta forma, las sendas espacio-temporales de la rutina diaria y las biografías individuales de personas y objetos, se inscriben en sucesiones diacrónicas de un tiempo más largo, el de la historia de estas sucesivas depositaciones. Es en esta instancia donde las prácticas de sedimentación vinculan estructura y agencia, es en este proceso donde las interfacies como superficies creadas y recreadas en la rutina diaria se unen a los sedimentos. Así la sincronicidad de la vida diaria es reducida a una sucesión "natural”, a un proceso de sedimentación. En el caso de los montículos esta reducción de la sincronicidad implica otro proceso que refuerza, o doblemente estructura y fija los significados: el de monumentalización. Podríamos decir que el sedimento es el alimento del monumento. El monumento en general ha sido interpretado como un acto de fundación, un acontecimiento que se conforma en estructurador de prácticas futuras, al ser altamente visible y duradero, está oriento hacia el futuro. Criado Boado (1991) señala, cuando analiza el megalitismo europeo, que una de las características de las tumbas megalíticas es precisamente ser monumento: construcción de grandes proporciones concebidas para resistir el 
tiempo, y ser visibles, resaltar del espacio circundante. Lo importante para Criado Boado del megalito es la articulación que realiza del monumento con el tiempo y el espacio haciéndose visible y duradero en uno y en otro (1991:93). En los Andes, las chullpas podrían se interpretadas como monumentos, en tanto se inscriben visible y duraderamente en el paisaje; de esta forma, como monumento originado en generaciones pasadas naturaliza la genealogía de las generaciones del presente. En el caso de los montículos, a diferencia de los megalitos o las chullpas, se trata de monumentos visibles y duraderos, pero dichas propiedades, más que concedidas por un evento fundacional como puede ser la construcción de un megalito o una chullpa, fueron adquiriéndose paulatinamente, a través del proceso de sedimentación. Es éste, y no solo la visibilidad y durabilidad, lo que produce que el montículo se transforme en monumento, imprimiendo de esta forma a las sendas biográficas de sujetos, objetos y a las identidades sociales constituidas en ellas, un temporalidad no histórica, descontextualizada. Con el análisis de los montículos arribaremos al modo en que se fijaron los significados en el Valle de Ambato, más allá del tiempo cotidiano, en un lugar donde el tiempo casi se detiene, en donde el montículo se transformó en tiempo y se ahistorizó.

\section{Notas}

\footnotetext{
${ }^{\text {i }}$ El habitus es el resultado de la interiorización de una multiplicidad de estructuras externas históricamente constituidas que les permite a los actores sociales enfrentar distintas situaciones de manera sistemática y coherente. Los individuos no son pasivos, o sea «... los agentes sociales determinan activamente, mediante categorías de percepción y apreciación social e históricamente constituidas, las situaciones que los determinan. Se puede decir incluso que los agentes sociales están determinados solamente en la medida en que se autodeterminan; pero las categorías de percepción y apreciación que forman la base de esta autodeterminación están en si mismas determinadas en gran parte por las condiciones económicas y sociales de su constitución.» (Bourdieu y Wacquant 1995:94).

ii Esto, como señala Treherne (1995), no quiere decir que reduzcamos el cuerpo a un mero componente biológico, a la manera de la sociobiología, sino darle a este último, un rol más activo en la constitución de la identidad individual.

iii Para Carandini (1997:137) actividad hace referencia a grupos de unidades estratigráficas, a acciones insistentes o a un grupo secuencial de acciones que tienen el mismo fin.
} 


\section{CAPÍTULO 4}

\section{METODOLOGÍA Y TÉCNICA EN EL CAMPO Y EN EL LABORATORIO}

En esta sección se describen las actividades que se desarrollaron para la recolección de la muestra a investigar, las técnicas de obtención de datos y las técnicas de análisis de los mismos.

\section{Procedencia de la muestra y actividades realizadas en el campo}

Se trabajó, por un lado con material que ya había sido recolectado en anteriores excavaciones realizadas en diferentes sitios de valle desde los años 70 (Martínez 1, Martínez 2, Martínez 4 y Piedras Blancas) -figura 4.1-; por otro lado se realizaron nuevas excavaciones durante la ejecución de la investigación. Específicamente fueron realizadas tres campañas arqueológicas -2004, 2005 y 2008- donde se amplió la excavación de tres recintos pertenecientes al sitio Piedras Blancas, con el objetivo de obtener información contextual más precisa que la que se había obtenido en las anteriores excavaciones (ver anexo I).

Los sitios seleccionados respondieron a dos criterios distintos: por una lado, a un criterio de representatividad temporal de los materiales a analizar, es decir, que las dataciones de los sitios cubra todo el rango temporal aquí abarcado. Por otro lado, a un criterio de representatividad de la variabilidad que presentan los sitios en el valle en relación a tamaño, complejidad y jerarquía. Es decir, los sitos seleccionados cubren todo el rango en términos de esas dos variables, lo que nos brinda variedad de situaciones y contextos para producir comparaciones. Además de los objetos procedentes de las excavaciones, incorporamos al análisis objetos cerámicos provenientes de tres colecciones: de la colección Rosso, del Museo Ambato de la Falda, de la colección del Museo Adán Quiroga de la Municipalidad de San Fernando del Valle de Catamarca y de la colección de la Dirección de Antropología de la Provincia de Catamarca. La incorporación de este material al análisis respondió a la posibilidad de acceder a piezas enteras o con alto grado de completitud. 


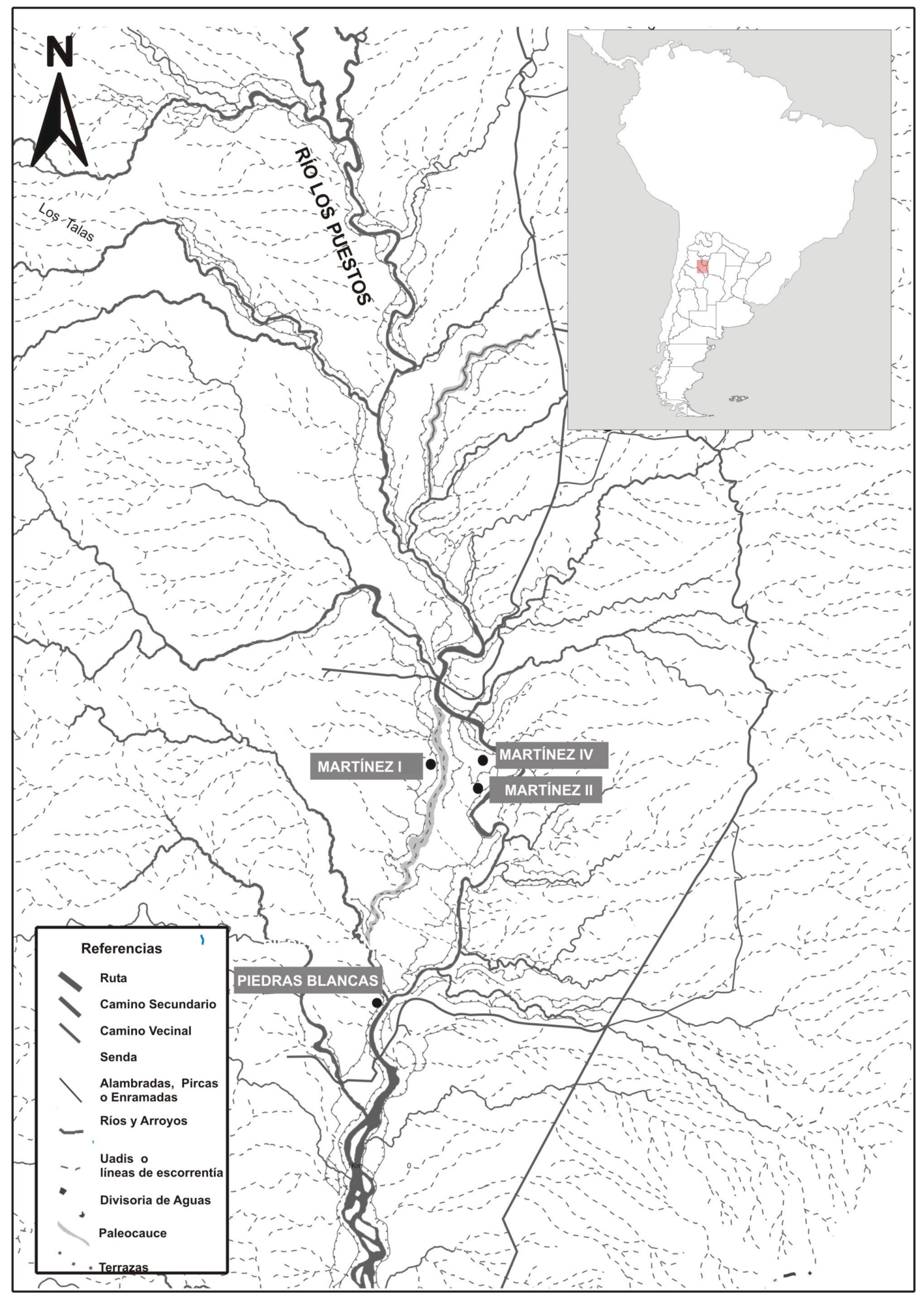

Figura 4.1: Mapa de los sitios de donde proviene la muestra analizada. La carta fue realizada mediante fotografías aéreas sin restitución ortogonal (Escala 1:27500) 


\section{Técnicas de obtención de los datos}

Se utilizaron variables tanto cualitativas como cuantitativas que nos permitieron obtener el corpus de datos necesario para caracterizar, con la mayor cantidad de información posible, a los materiales analizados.

\section{Caracterización de las vasijas para la reconstrucción de trayectorias biográficas}

En función de obtener la mayor cantidad de datos necesarios para establecer las diferentes trayectorias biográficas se diseñaron dos fichas de registros, que luego fueron incorporadas a una base de datos relacional en Microsoft Access 2003. El enfoque que se utilizó para el establecimiento de las variables de análisis del material considera a la vasija como unidad de análisis y al fragmento como unidad de observación. En nuestro caso es fundamental centrarnos en la vasija como unidad de análisis, puesto que es ésta y no los fragmentos los que se categorizan significativamente durante su vida, y es justamente esta biografía la que nos interesa indagar. No obstante, esto no significa que los fragmentos no pueden constituirse en algún momento en un objeto significativo, por ejemplo al incorporarse como antiplástico a la arcilla, o al reciclarse y usarse como otro objeto -fichas, torteros o recipientes entre otros-. Por eso, veremos que las variables definidas también permiten acercarnos a estas otras trayectorias y categorías de objetos. Centrarnos en la vasija como unidad de análisis, requiere, por un lado, poseer algunas formas conocidas, pero además, poder reconstruirlas a partir de los fragmentos que potencialmente llegaran a formar parte de la misma. Esto se fundamenta en la simetría rotacional que guardan las vasijas a partir del eje vertical central, lo que les permite ser tratadas como sólidos de revolución, aún sin estar fabricadas a torno (Granizo 2001; Orton et al 1993). En este enfoque los fragmentos se consideran equivalentes de vasijas estimados -eve- (Orton et al 1993: 35 y 196). Este concepto parte de la idea de que todo fragmento es una determinada proporción de una vasija entera, es decir, es una fracción del total de la misma; por lo que es posible reconstruir la forma y tamaño original de la misma por medio de la combinación de varios fragmentos, pertenecientes a las distintas partes de la vasija, y de los cuales se tiene registrado el radio y porcentaje de arco. Para ello, una condición es que los fragmentos deben poder orientarse según la posición original que ocupaban dentro de la vasija. Pero, además, cada clase cerámica particular puede poseer distintas formas y tamaños; teniendo en cuenta estos aspectos teóricos-metodológicos expliquemos el diseño específico de la base de datos: 
La base de datos se ha orientado a (anexo II):

a-Reconstruir los contextos depositacionales donde se encuentran incluidos los fragmentos analizados. Por tanto, a todos los fragmentos se les tomaron variables de identificación (código de siglado) y de georeferenciación (coordenadas X, Y, Z). Con esto pudimos relacionar a los distintos fragmentos entre sí y con otros objetos. Es decir, estas variables permitieron contextualizar a los fragmentos analizados y, a través de la reconstrucción de dichos contexto, acercarnos a las prácticas sociales en las que estuvieron involucrados.

b-Realizar un catálogo de tamaños y formas de las vasijas representadas. Para la selección de los fragmentos analizados se tuvieron en cuenta los siguientes criterios que responden, principalmente, a la necesidad de caracterizar nuestra unidad de análisis, la vasija: en primer término, se determinó como condición que el fragmento pudiera ser orientado según su posición original en la vasija, que pudiera ser asociado a alguna forma ya conocida para el valle (Bedano et al 1993; Fabra 2008; Pazzarelli 2006; Zaburlín 1999), o que, por presentar determinados rasgos formales, pudiera reconstruirse su forma y en última instancia obtenerse al menos el radio y el porcentaje de arco. Este criterio selectivo no actuó sobre una muestra a priori; por el contrario, fue aplicado a la totalidad del material presente de los distintos sitios mencionados, con lo que aseguramos una máxima representatividad.

Para el establecimiento de los tamaños de las vasijas, se midió -en milímetros- el largo y ancho del fragmento cuando se orientaba según la posición original que ocupaba en la pieza; además, se midió el radio y el porcentaje de circunferencia, lo cual nos permitió acercarnos a los tamaños reales de las vasijas con las que contamos. Para el caso de las vasijas enteras o con alto grado de completitud se siguieron los lineamientos de la Primera Convención Nacional de Antropología (1966).

Para el establecimiento del catálogo de formas se utilizó una combinación de estudios descriptivos de las formas cerámicas (Bedano et al 1993; Primera Convención Nacional de Antropología 1966; Fernández y Martínez 1998) que centraron la caracterización en los aspectos formales de las vasijas. En cuanto a la forma, se definieron los siguientes criterios de discriminación y caracterización: en el caso de las vasijas enteras y en aquellas que poseían un alto porcentaje de completitud, se las clasificó según los tipos formales definidos para la cerámica del Valle de Ambato (Bedano et al 1993): Forma de $\underline{\text { Vasija }}$. En los casos en que la vasija no se pudo asociar a ninguna forma ya definida, se la 
caracterizó siguiendo los planteos de Fernández y Martínez (1998) para describir la forma global de la vasija. Por otro lado, para las partes constituyentes de la vasija - $\underline{\text { borde, cuello, }}$ asa, cuerpo y base - se utilizó los criterios definidos por la Primera Convención Nacional de Antropología (1966). A los fragmentos cerámicos se los caracterizó formalmente identificando la parte de la vasija a la que pertenecen: Borde, Cuello, Asa, Cuerpo, Base, y se caracterizó a cada una siguiendo como en el caso de las vasijas enteras o con alto grado de completitud la Primera Convención Nacional de Antropología (1966).

c- Identificar los fragmentos con las clases cerámicas que ya fueron definidas tecnológicamente en el valle de Ambato para el período considerado (Fabra 2008) -anexo III-. Fabra logró establecer las clases cerámicas a través de variables tales como: composición de la pasta (tamaño u tipo de antiplástico utilizado, análisis de las cavidades, tipo de arcilla), tratamiento de las superficies internas y externas, temperaturas de cocción, tipo de cocción, técnicas de confección, etc. -ver anexo III-. Las clases que se definieron pueden poseer diferentes formas y tamaños. Se creó un campo, clase cerámica, que nos permitió una primera discriminación de los datos ingresados. Para aquellos casos que no pudieron ser asociados, en tanto podrían conformar otra clase cerámica, se los analizó siguiendo la propuesta de esta autora. La identificación de los fragmentos con la clase nos proporcionó información no solo referente a las formas de confección de las vasijas analizadas, materias primas utilizadas, etc. sino que nos proporcionaron datos que pudimos utilizar posteriormente para el análisis de la función de estos objetos.

d-Reconstrucción de los usos concretos en los que estuvieron involucradas: los análisis de los modos de uso de los implementos cerámicos se han focalizado en dos grandes planos: por un lado, los estudios que se concentran en determinar las característica de performance que posee una vasija cerámica para realizar una o varias clases de actividades y, por otro lado, aquellos que se dedican a inferir los usos concretos a los que fueron sometidos dichos objetos (Rice 1987, Skibo 1992). Nos concentramos en el primer plano y en los análisis de alteraciones por uso -atrittions- del segundo plano mencionado. A pesar de no concentrarnos en los análisis químicos de residuos orgánicos, hicimos referencia a algunos resultados de un conjunto de análisis realizados a estos objetos (Pazzarelli 2006) -anexo IV-. Las propiedades de performance no determinan las prácticas concretas donde estas vasijas participarán en un futuro (Skibo 1992; Sillar 1996), sino que nos permitieron conjuntamente y fundamentalmente con los análisis posteriores de huellas de uso y contextos de uso, acercarnos a las prácticas específicas donde estos objetos estuvieron 
involucrados en el Valle de Ambato en el momento considerado. La significatividad o no de estas propiedades dependerá de la historia posterior de la vasija y no de la propiedad en sí. Es decir la/s prácticas concretas serán las que podrán activar, desactivar o ignorar estas propiedades. Esto se acerca a una comprensión más relacional, cercana a la propuesta de Laguens (2007), Laguens y Pazzarelli (2007) y Laguens et al (2007) en donde los objetos se conciben como efectos de redes de relaciones, donde las propiedades efectivas o potenciales que, a partir del diseño y de la creación le otorga un artesan@ (y que perduran hasta que el objeto se rompe) adquieren significación según las conexiones de distinto alcance que realiza a lo largo de su biografía con otros objetos, sujetos -humanos y no humanos-, usos y espacios. La utilización de los objetos en una actividad particular depende en gran medida, además de las propiedades de performance, de los contextos sociales en los que están inmersos esos objetos, las personas que los usan y la actividad concreta que se está desarrollando con ellos (Sillar 1996, 2000; Sillar y Tite 2000).

e-Observación de la reactivación y comportamientos de reciclaje y descarte de las vasijas. Una vez reconstruidos los modos de uso, se observó si las vasijas enteras y fragmentos de vasijas poseían reparaciones, identificando los agujeros de reparación (Anexo II) o "costura"; además, se observó si, luego de su rotura, pasaban a conformar otros objetos, tales como torteros, fichas o platos, prácticas de reciclaje muy frecuente en el sitio Piedras Blancas (Zaburlin 2001). Por otro lado, se observó si las fracturas se hallaban o no erosionadas, lo que puede indicarnos procesos posdepositacionales a los que estuvieron sometidos esos fragmentos, lo que nos acerca tanto a observar la integridad de los contextos de hallazgos, como las prácticas de reclamación de objetos de otros contextos donde sufrieron procesos erosivos. También se observó si poseían pintura postcocción, el color de la misma y la extensión -ver anexo II-.

\section{Tratamiento de los cuerpos}

En el caso del material óseo humano, se utilizaron datos ya recolectados de los mismos (Baffi y Torres 1996, Cruz 2005, 2007, Gordillo 2009; Gordillo y Solari 2009); particularmente analizamos las diferentes formas en que se presentan estos restos en el registro arqueológico del valle, observando los tratamientos que recibieron. Para esto, se tuvo en cuenta, por un lado, datos contextuales, es decir asociaciones significativas con otros objetos y particularmente con las vasijas analizadas aquí. En ese sentido tratamos de establecer contextos de asociaciones significativas, evaluando en qué momentos de la 
biografía de dichos objetos se producen esos encuentros (al inicio, al final, etc.). A su vez, se analizaron los patrones funerarios utilizados en los casos en que pudieron ser identificados -si fueron enterrados enteros, o fosas excavadas directamente en el piso, o en otros lugares más preparados; en el caso de los fragmentados, si estuvieron arrojados en el piso de una habitación, de un patio, en los montículos, o si pudieron estar colgados de los postes de los techos de las habitaciones o galerías, etc.-. Por otro lado, se contemplaron aquellos datos bioantropológicos que indicaran las conductas asumidas hacia los cuerpos vivos y muertos de las personas (causa de muerte, fragmentación intencional de los restos, evidencias de violencia como descarnado, golpes y desarticulación, etc.). También se observó si con dichos restos se confeccionaron instrumentos o no, y si así fue, qué clases de instrumentos. Además, se tuvieron en cuenta otras variables como son el sexo biológico y la edad de los individuos, que relacionadas con las anteriores nos permitieron discernir diferencias significativas en el tratamiento según estos últimos dos parámetros. También, se buscó establecer relaciones entre las conductas seguidas por los humanos con las recibidas por otros animales, como los camélidos, que por lo que se conoce de la arqueología del Valle en algunas situaciones poseen tratamiento similar (Cruz 2007, Laguens y Gastaldi 2008).

\section{Técnicas de análisis de los datos}

Los datos recolectados fueron ingresados en bases de datos relacionales (Access 2000) y analizados en planilla de cálculo (Excel 2000). Luego, cada uno de los objetos analizados -en aquellos casos en que existía información espacial precisa: coordenadas, plantas, perfiles estratigráficos, etc.- fueron ingresado a otra base de datos relacional a nivel geográfico (Arcview 9 - Sistema de Información Geográfico), que nos posibilitó, a través de técnicas estadístico-matemáticas y análisis cualitativos de los datos espaciales, identificar los espacios significativos de asociación contextual en los cuales se entrecruzan las trayectorias biográficas de la totalidad de los objetos y sujetos analizados aquí. En aquellos casos en que no poseíamos información espacial precisa -como es el de los sitios Martínez 1, Martínez 2, Martínez 4- reconstruimos los espacios analizando los datos presentes en las libretas de campo, informes y publicaciones que han llegado hasta nuestros días. Por último, relacionamos la información cronológica de cada uno de los sitios para observar los cambios y las continuidades de las cartografías de intersección en el largo término. 


\section{Notas}

iEs interesante la categoría utilizada por Sillar (1996, 2000) "embedded" para referirse a la situación en la
que está cualquier tecnología. Esta categoría trata de enfatizar que toda técnica esta inserta y se produce en
un amplio contexto de artefactos, estructuras ideológicas y contextos económico-sociales. En este sentido, se
acerca a los planteos de Dobres (2000), Dobres y Hofman (1994, 1999), Lemonier (1992) entre otros,
respecto de la concepción de la tecnología. Sillar, en sus trabajos entnoarqueológicos en los Andes bolivianos
sobre la utilización de combustible para la fabricación de objetos de cerámica y para el uso de estos en otras
actividades, muestra claramente cómo las estructuras sociales e ideológicas se encuentran mediando estas
actividades. 
En este capítulo nos adentramos a caracterizar en términos generales el paisaje arqueológico donde las vasijas y las personas que analizamos desarrollaban su vida cotidiana. Conformará una primera entrada, en tanto que a medida que desarrollemos las biografías de las vasijas y con ellas de los sujetos, iremos observando de qué maneras estas ayudaron también a configurarlo.

El Valle de Ambato está ubicado en el Departamento de Ambato, Provincia de Catamarca, siendo parte de la provincia geológica de las Sierras Pampeanas Noroccidentales -figura 5.1-. Esta provincia geológica ocupa el centro- sur del territorio catamarqueño y se caracteriza por poseer estrechos valles y bolsones, alternando con bloques o cordones elevados. En general los cordones montañosos poseen una dirección NNO-SSE. Uno de estos valle estrechos es el Valle de Ambato, situado entre los $27^{\circ} 54^{\prime}$ y los $28^{\circ} 03^{\prime}$ de latitud sur y entre los $65^{\circ} 45^{\prime}$ y $65^{\circ} 55^{\prime}$ de longitud oeste, constituyendo la porción septentrional del valle de Catamarca. Posee una superficie de $1797 \mathrm{~km} 2$, estando bordeado al este por el macizo Balcozna-Lampazo de la sierra de La Graciana, que tiene una altura máxima de unos 1900 msnm, y al oeste por el macizo de Humaya (2278m) de la sierra del Ambato-Manchado, siendo la altura máxima la del cerro Manchado, de 4351 msnm. El límite sur lo constituye el Valle de Catamarca, y hacia el norte los Altos de Singuil (Ardissone 1941). En la llanura aluvial del fondo del valle, y en el mismo sentido de los cordones montañosos que la delimitan, corre el Río de los Puestos o Nacimientos, que nace en los Altos de Singuil (1250 m.s.n.m.) y cambia su nombre al llegar al sector meridional, pasando a ser el Río del Valle.

El área de la cuenca del río Los Puestos tiene características muy particulares. Mientras el río principal escurre a lo largo de un amplio valle en dirección norte-sur, con una pendiente suave a moderada teniendo un caudal permanente sólo en su tramo inferior (Gonzáles Bonorino 1978), sus afluentes, que se desplazan en dirección oeste-este y del este-oeste, son todos de régimen torrencial con fuertes pendientes y con gran arrastre de sedimentos. La red de drenaje de los afluentes provenientes de la Sierra de Graciana, son muy torrenciales, de fuerte pendiente y de corta trayectoria, mientras que los afluentes que provienen del sistema de Ambato recorren largas distancias sobre terrenos muy quebrados y atravesando serranías bajas con dirección norte-sur por medio de angostos cañones que 
ellos mismos supieron excavar aprovechando las fallas existentes. Como veremos, esta particularidad será un punto importante de articulación en la ocupación del valle.

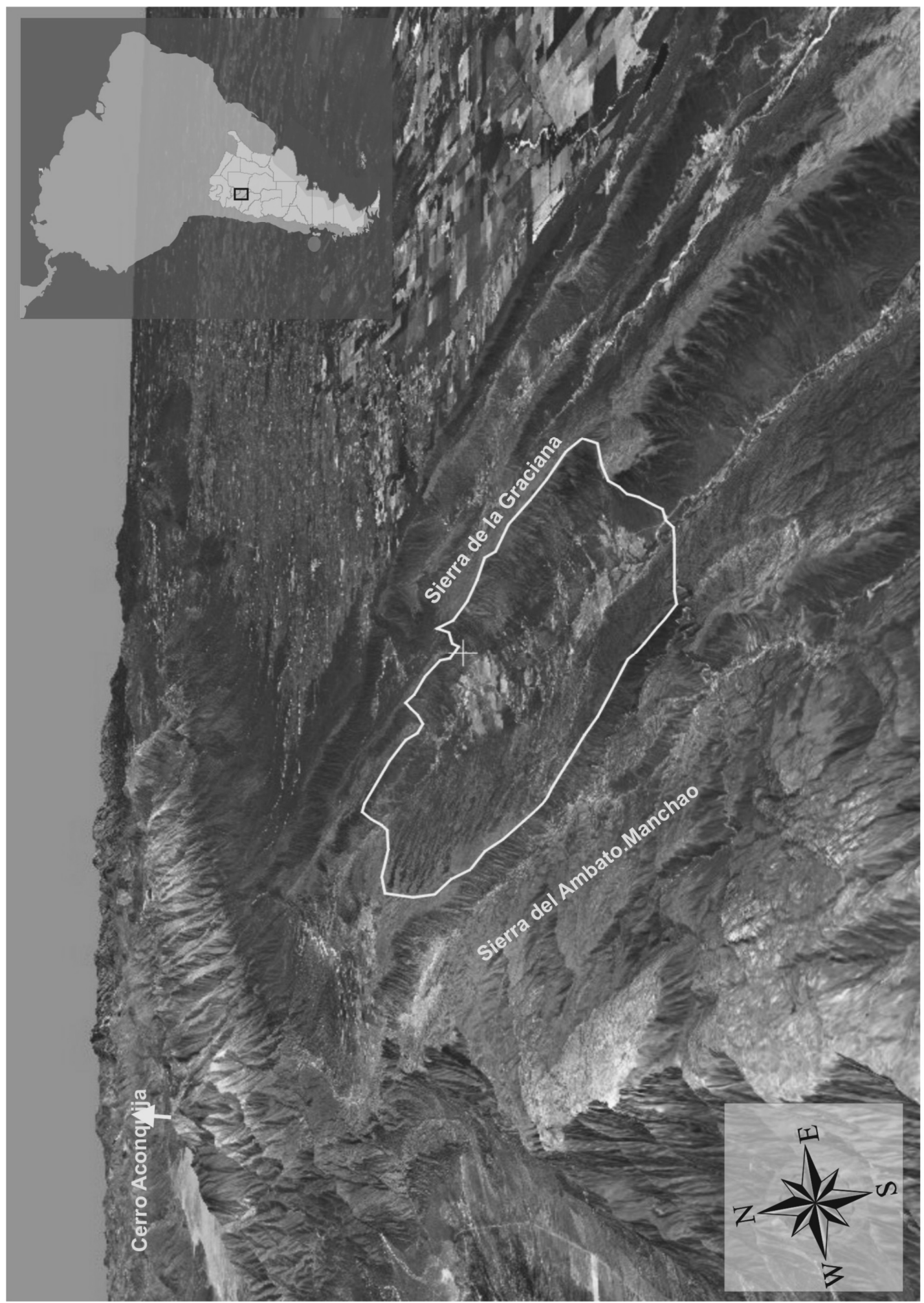

Figura 5.1: Ubicación geográfica del Valle de Ambato.Imágen satelital de falso color Landsat 7 (NASA World Win 1.4). 
En general, los sitios arqueológicos están distribuidos en toda la superficie del valle, tanto en los sectores de fondo de valle -donde se halla la mayor concentración de éstos- como en las laderas -figura 5.2-. Describiremos en primer lugar las diferentes clases de sitios de habitación identificados y su emplazamiento en el valle, para luego pasar a la descripción de las estructuras vinculadas a la producción agrícola que, junto a las residenciales, son las más abundantes en el lugar. Estas estructuras han modelado materialmente el paisaje conservándose su visibilidad hasta hoy día, siendo algunas de ellas aún utilizadas ${ }^{\mathrm{i}}$.

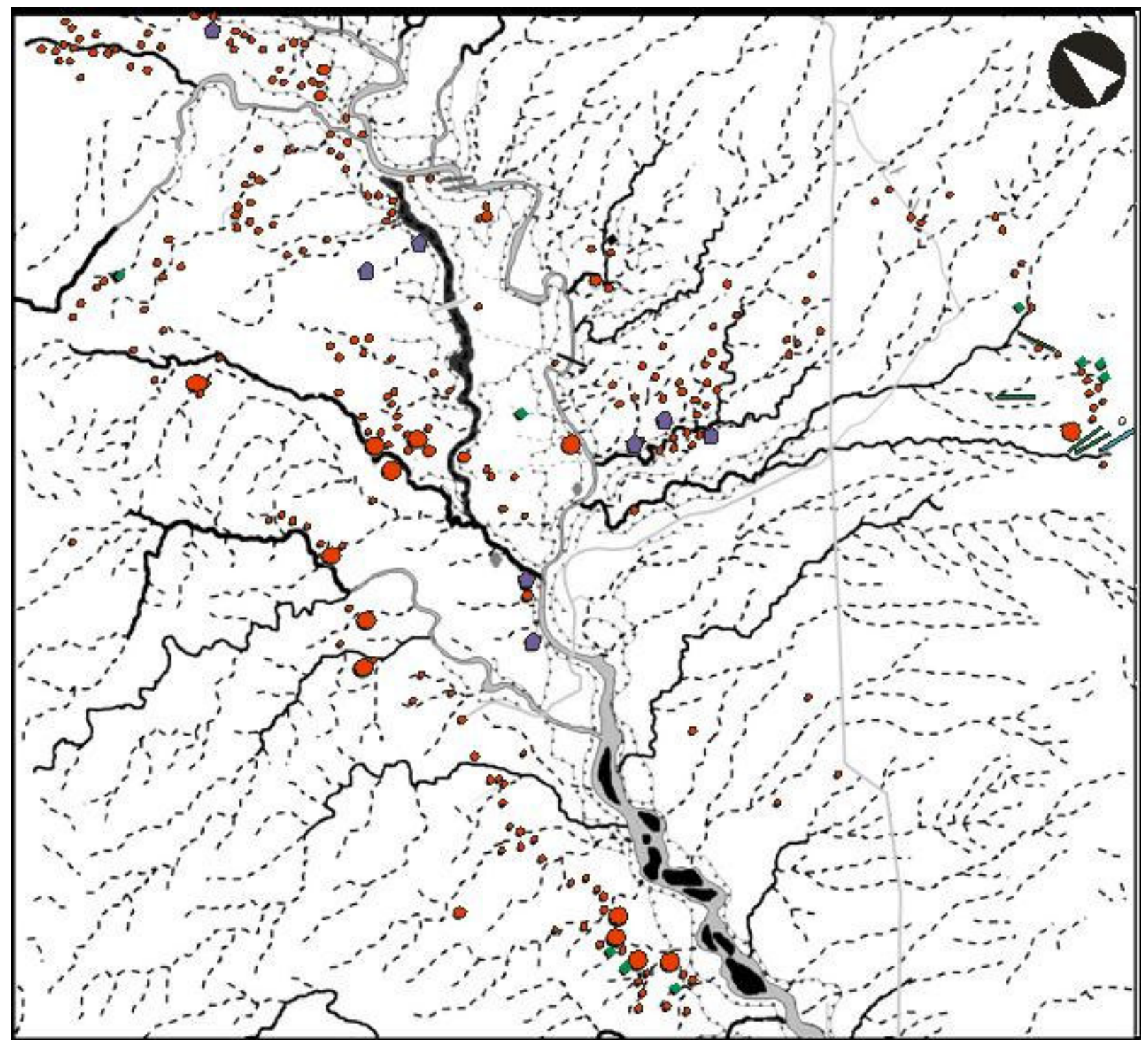

Figura 5.2: obsérvese la distribución en el espacio de los sitios, cercanos a los arroyos y torrentera. Se muestra el cauce principal, los arroyos en línea continua, y las torrenteras en línea entrecortada. Los círculos rojos de tamaño pequeño -clase P y M (Assandri 2007)- y de tamaño grande clases -G, MG y MSG- (Assandri 2007)Las líneas grises que atraviesan gran parte del mapa son caminos actuales. Las líneas verdes más cortas y las celestes son andenes y canales respectivamente. Los rombos de color lila son montículos -basureros y plataformas-. La carta fue realizada mediante fotografías aéreas sin restitución ortogonal (Escala 1:27500) 
Los sitios hallados en el fondo del valle se encuentran repartidos en tres terrazas fluviales (Assandri 2007). Dichas terrazas integran una franja que va de los $1050 \mathrm{msnm}$ a los 1090 msnm en el inicio del piedemonte. Las unidades dentro de estas terrazas varían en su frecuencia de aparición: de las 139 unidades analizadas por la autora, la mayoría -114se ubican en la primera terraza, 22 en la segunda y sólo 3 en la tercera junto al río. A su vez, la primera y segunda terrazas están surcadas por los arroyos y torrenteras que alimentan al Río de los Puestos. En éstas, las unidades se ubican en zonas altas, a más de $300 \mathrm{~m}$ de distancia del cauce principal.

Las unidades de habitación se caracterizan por tener como base un módulo subrectangular, subdividido en dos o tres recintos, que pueden aparecer solos o combinados con patios y corrales (Assandri 2007:52), y fueron clasificados en cuatro grupos:

a) Unidades pequeñas (clase P): de un solo módulo dividido internamente en dos o tres recintos; de hasta $200 \mathrm{~m} 2$ de superficie, de forma rectangular, cuadrangular o trapezoidal. Es la clase más numerosa, representada por sitios como Martínez 4 -figura 6.8-sitio que incorporamos al análisis- (Herrero y Ávila 1991), La Rinconada 047 y Cerco de Palos 065, entre otros.

b) Unidades medianas (clase M): estructuras compuestas por dos o tres módulos de base contiguos, con un espacio amplio adosado, tipo patio o corral, abarcando una superficie que varía entre los $230 \mathrm{~m} 2$ y $500 \mathrm{~m} 2$. Un sitio característico de este grupo es Martínez 1 -figura 6.9- -sitio de donde también proviene parte de la muestra analizada en esta tesis-. (Assandri 1991).

c) Unidades grandes (clase G): presentan dos componentes enfrentados, cada uno con subdivisiones compuestas por tres o más módulos y un espacio abierto o patio entre ambos componentes, o bien a un lado. La superficie ocupada varía entre los $540 \mathrm{~m} 2$ y $1.000 \mathrm{~m} 2$. Un sitio representante de este grupo es Martínez 2 -figura 6.7- - de donde proviene también parte de la muestra analizada- (Juez 1991).

d) Unidades muy grandes (clase MG): el módulo constructivo de base se repite formando estructuras complejas de distintas formas y tamaños, con módulos internos, adosados o no. Constituyen unidades muy grandes, a veces separadas en sectores cercanos (de ello surge una sub-categoría de sitios muy grandes con sectores, MGS -figura 6.103). 
Las superficies oscilan entre los $1.000 \mathrm{~m} 2$ hasta los casi $13.000 \mathrm{~m} 2$, llegando hasta los $54.000 \mathrm{~m} 2$ en los sitios con sectores. Esta clase corresponde a sitios tales como Iglesia de los Indios (Gordillo 1995), Bordo de los Indios, Huañumil (Cruz 2005, Laguens y Bonnin 2005) y Piedras Blancas -figura 6.76- - sitio de donde proviene parte de la muestra analizada-.

Otra clasificación de las estructuras de habitación realizada sobre sitios hallados en prospecciones posteriores a las analizadas por Assandri (Cruz 2005), dividió a las estructuras de habitación en dos: simple y complejas. Los primeros corresponderían a las unidades clase P, M y G de Assandri y los segundos a la clase MG y MGS de la misma autora.

Dejando el fondo del valle, ya en el piedemonte occidental, al igual que del lado oriental de la Sierra de la Graciana y a lo largo de las quebraditas donde nacen los arroyos que luego recorren el fondo del valle, se detectaron una serie de endicamientos de piedra, canales, corrales, terrazas de cultivos y unidades habitacionales (Cruz 2005; Figueroa 2008).

Sobre las estructuras agrícolas, que conjuntamente con las de habitación son las que están más representadas en todo el valle, Cruz (2005) y Figueroa (2008) realizaron amplias prospecciones en las laderas occidentales y orientales, habiéndolas caracterizado tanto a nivel arquitectónico como de distribución espacial. Retomando la clasificación propuesta por Donkin (1979) y Treacy (1994), tanto Cruz (2005) como Figueroa (2008), realizan una adaptación de la misma a las particularidades observadas en el valle, teniendo en cuenta el emplazamiento en el terreno de las estructuras. De esta manera, ambos autores identifican:

a) Terrazas de ladera emplazadas en los flancos interfluviales -las más frecuentes(Figueroa 2008: 316 y 315), que a su vez se dividen en dos subtipos: rectas y de contorno figura 5.3-.

b) Terrazas de cauce (Figueroa 2008) o de contención (Cruz 2005) -figura 5.4-, que fueron construidas sobre los fluvios colectores del río Los Puestos. Son considerablemente menos abundantes que las anteriores, y están asociadas al control de la erosión. La distancia de separación entre cada terraza, así como la altura y largo del muro dependen de la topografía, siendo más cercanas cuando la pendiente es mayor y más lejanas cuando ésta disminuye (Cruz 2005; Figueroa 2008; Pérez et al 2000). 
Terrasses de Cárdenez. Bassin de Los Puestos - Vallée d'Ambato

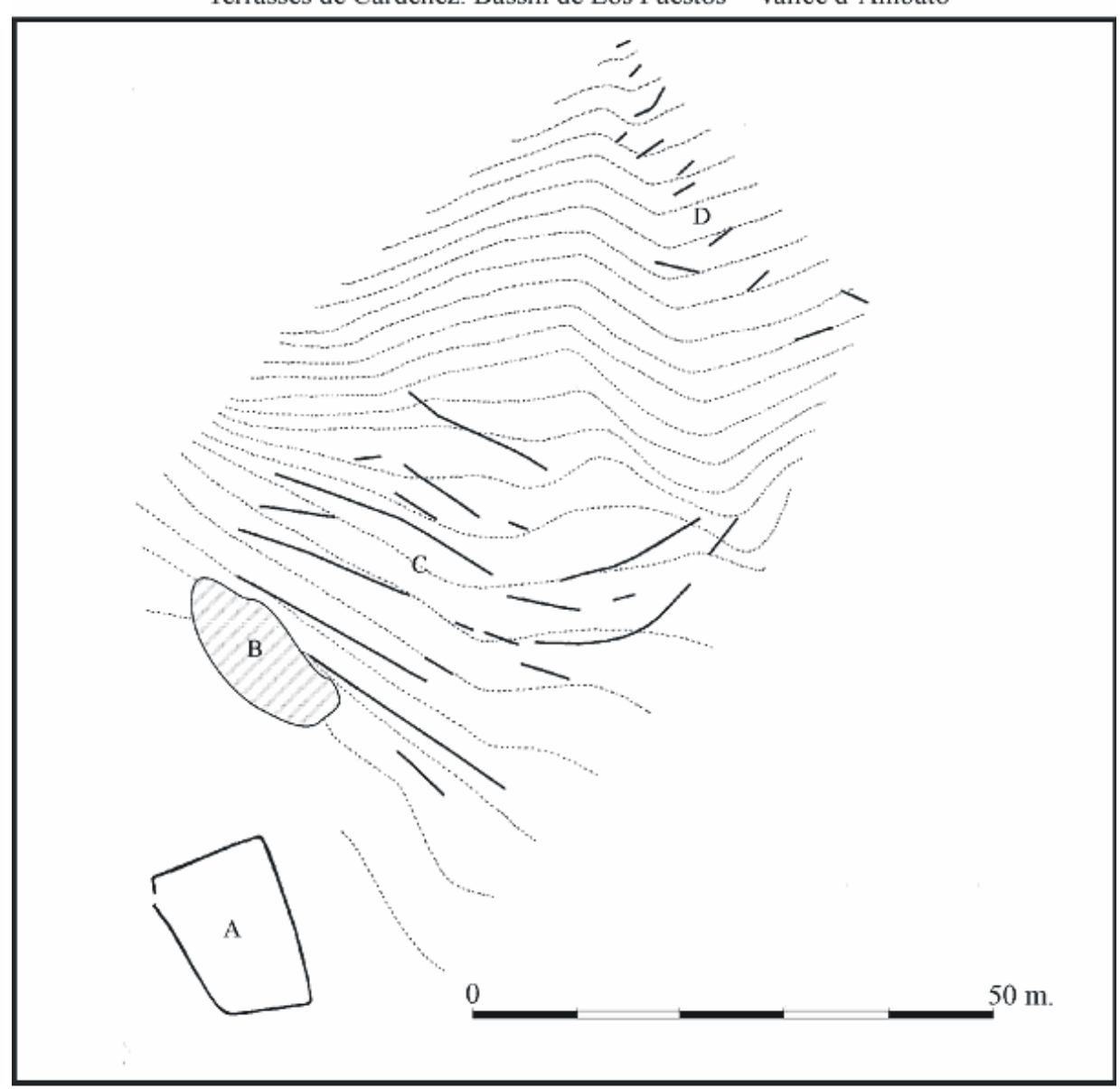

$\mathrm{A}=$ Enclos

$\mathrm{B}=$ Affleurement de quartz

Figura 5.3: Canchones (A), Alfloramiento de Cuarzo (B), $\mathrm{C}=$ Terrasses linéaires Terrazas de ladera (C) y Cross-Channels (D), del sitio Cárdenas, $\mathrm{D}=$ Cross-channels ubicado en la ladera occidental del valle. Extraído de Cruz (2005)

----- courbes de niveaux à $1 \mathrm{~m}$

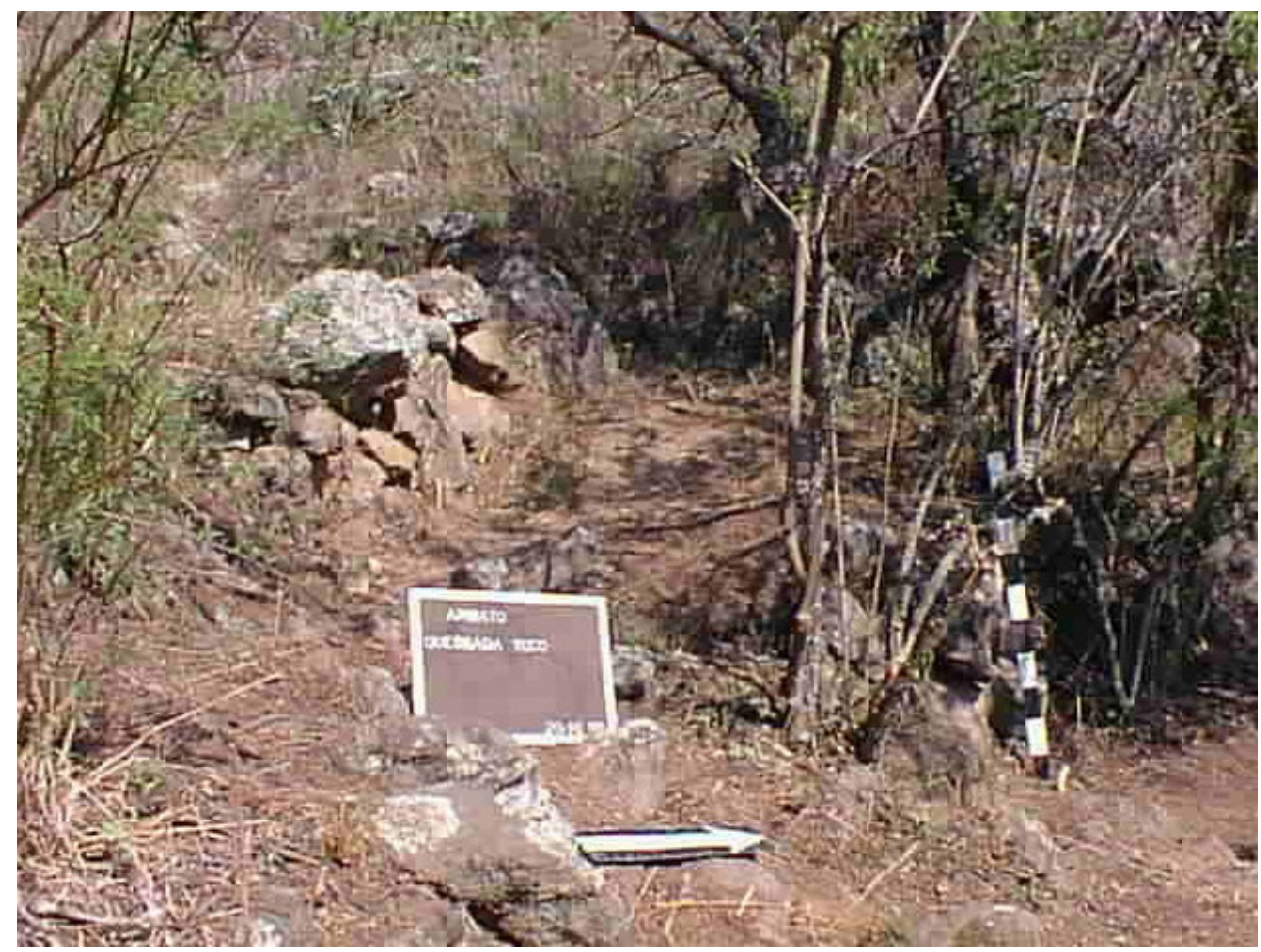

Figura 5.4: fotos de terrazas de cauce o cross-chanel del sitio Tuco, ubicado en la ladera occidental del Valle 
c) Cruz (2005) además de estas dos clases, agrega otra que denomina terrazas de gran superficie (canchones), ubicadas en sectores de pendiente suave como los conos de deyección de las quebradas que bajan de las laderas en donde la superficie recoge un aporte de sedimentos importante. Aparecen mayormente representadas en las laderas orientales, asociadas a canales de irrigación, pero también en sectores de las laderas occidentales donde también existen canales de irrigación.

Figueroa (2008:315) resalta la gran cantidad de terrazas halladas en los faldeos de la sierra del Ambato, identificando unas 2742 (Figueroa 2007: 5), siendo las más abundantes las de ladera recta, que representan 46\%, siguiéndoles en proporción las terrazas de ladera de contorno con un $36,1 \%$, y el $15,9 \%$ restante a terrazas de cauce (Figueroa 2008:315). En relación a los canchones, Cruz (2005) encuentra unas 21 de estas estructuras.

En relación a las estructuras de irrigación -figura 5.5-, de menor frecuencia que las terrazas agrícolas, Figueroa (2008) encuentra 11 estructuras de canalización en la ladera del Ambato. Cruz (2005) menciona el hallazgo de por los menos 12 canales tanto de la ladera del Ambato como de la Graciana. Estas estructuras aparecen en la superficie como hileras de piedras relativamente planas paralelas que se pueden seguir por varios metros, dependiendo de su estado de conservación. De la excavación de una de estas estructuras, se conoce que están revestidas con piedras planas tanto las paredes laterales como las del fondo, lo cual probablemente evite la pérdida por infiltración permitiendo conducir el agua a mayor distancia y sin pérdida de caudal (Cruz 2005, Figueroa 2008) -figura 5.5-. A su vez, se han hallado endicamientos (Cruz 2005) o represas (Figueroa 2008). Éstas, al igual que las estructuras de canalización, no son abundantes, hallándose en los sectores más elevados y explayados de los arroyos, alcanzando algunas los 2,25 m de alto; levantándose donde aflora la roca madre a escasos metros de las terrazas del cauce (Figueroa 2008:316). En general, por su disposición y ubicación, los canales acarrean agua de los sectores de vertientes ubicados en las laderas hacia sectores de menor pendiente donde se hallan canchones de cultivos, e inclusive hacia el fondo del valle. En el fondo del valle, se han reportado canales que tomarían el agua de la cuenca del Río de los Puestos, siendo sin embargo muy escasos. En otros casos, se han hallado terrazas de cauce o de contención en los fondos de los arroyos secundarios (Assandri 2007). Cruz (2005) realizó una serie de sondeos en el área de los sitios Martínez (cercano a los sitios Martínez 1, 2, 3 y 4) ubicada en el fondo del valle. Los sondeos fueron realizados cercanos a cuatro sitios pequeños $(050,051,052$ y 053$)$ que se hallan totalmente alineados en lo que para el autor podría ser 

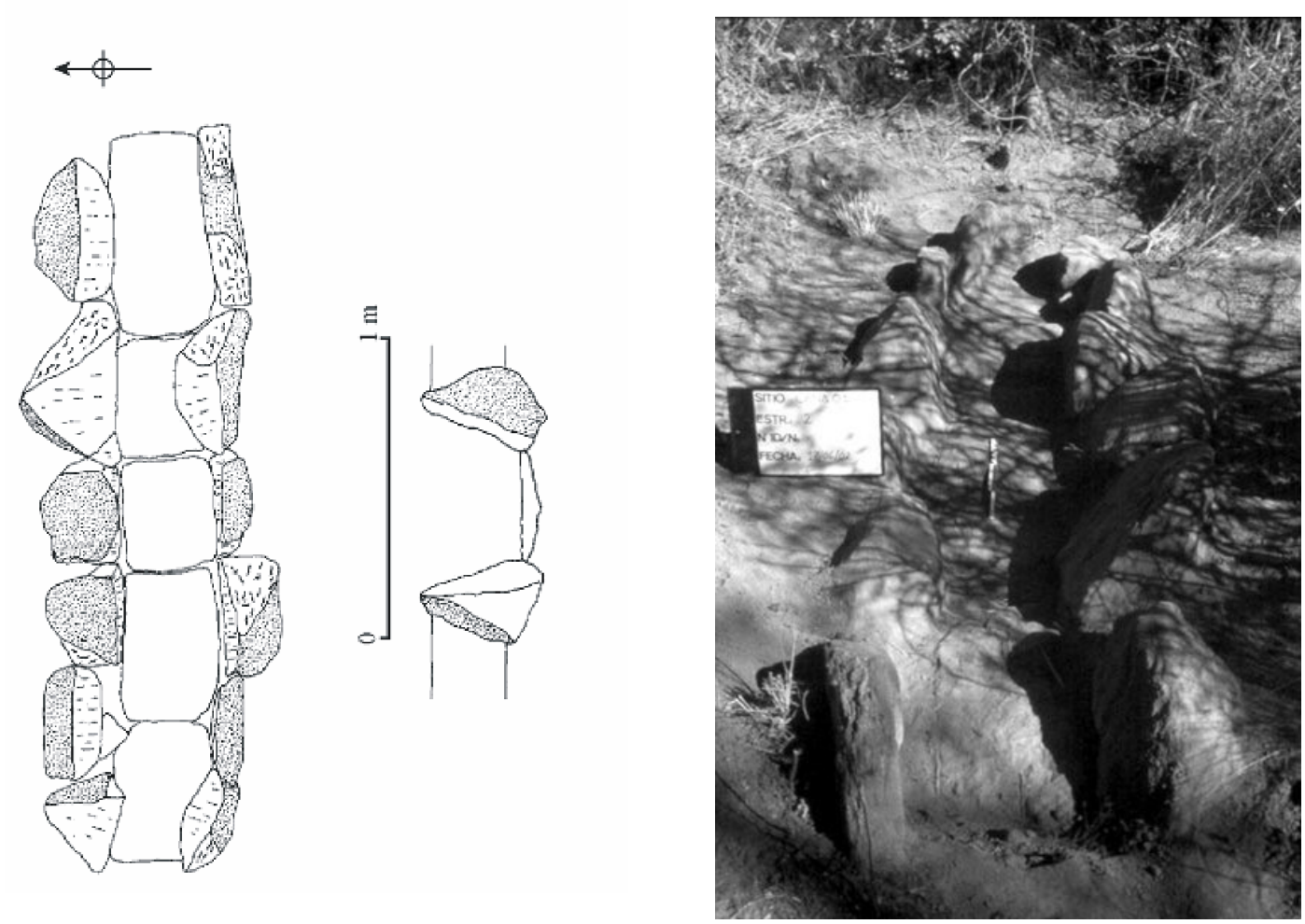

Figura 5.5: estructura de canalización para riego.

un canal. Sólo en uno de los sondeos halló la posible traza de un canal, aunque sin estructuras de piedras. La presencia de estructuras agrícolas en el fondo del valle, no ha sido hasta el momento constatada, salvo que consideremos la presencia de estos canales y algunos de estas estructuras de contención como indicadores, pero aún no se puede establecer dicha correlación. Cruz (2005) señala que dada la alta acumulación de sedimento (entre 0,70 y 1,20 m) que posee el fondo del valle desde la época de ocupación de los sitios, las estructuras de contención podrían estar invisibilizadas. Según Figueroa (2008: 316) "se puede afirmar que la agricultura desarrollada habría dependido exclusivamente de los aportes pluviales estacionales y del manejo de aguas de escorrentía. Muestra de ello es la construcción de represas, terrazas de ladera rectas, y de cauce, todas ellas ubicadas sobre relieve negativo del terreno, lo cual estaría ligado al manejo de agua de escorrentía. Además, la totalidad de los canales registrados se hallan vinculados al transporte del agua hacia los sectores deprimidos del valle y no la irrigación de las superficies aterrazadas".

Hasta el momento hemos descrito los sitios residenciales, las estructuras agrícolas y otras estructuras vinculadas a la contención de la erosión. Relacionando todas estas estructuras, tenemos una primera representación del paisaje arqueológico demarcado materialmente por éstas durante el período abarcado. Si realizamos una mirada sobre la distribución de los sitios en la topografía del valle podemos observar lo siguiente. En el 
caso de los sitios residenciales, tal cual lo observa Assandri (2007), los mismos se hallan ubicados a los largo de las zonas altas de las torrenteras que alimentan al Río de los Puestos, al igual que los sitios de habitación de las zonas de laderas (Figueroa 2008). En el caso de las estructuras agrícolas, estas forman terrenos apropiados para los cultivos, canalizando el agua hacia sectores más bajos del fondo de valle, reteniendo el agua para ser distribuida posteriormente y conteniendo los procesos erosivos en lugares donde hay fuertes pendientes. Por otro lado, estas estructuras ocupan las cuencas definidas por las torrenteras que alimentan al río que corre en el fondo de la quebrada en sentido norte-sur. El aprovechamiento del agua del río principal, no se observa tanto como el aprovechamiento, manipulación del agua de escorrentía y de las vertientes que nacen en los sectores de ladera. En el río principal no existe una intervención e inversión en el paisaje como se puede observar en otros sectores (Assandri 2007). Quizás esto se debe a que en algunos sectores, el río corre por cañadas profundas que dificultan notablemente el transporte del agua -figura 5.6-.

La utilización del agua de escorrentía producto de lluvias estivales, implica que la misma deba ser acumulada -por ejemplo en represas- y desde ahí ser distribuidas a otros sectores, o retenida por medio del control de la velocidad de esta, interponiéndose estructuras -terrazas de cauce- que detengan su escurrimiento, tales como las que se hallan en los sectores negativos de las quebraditas que bajan desde la sierra del Ambato. Esto permite que por infiltración o percolación pueda ser utilizarla para regar y humedecer

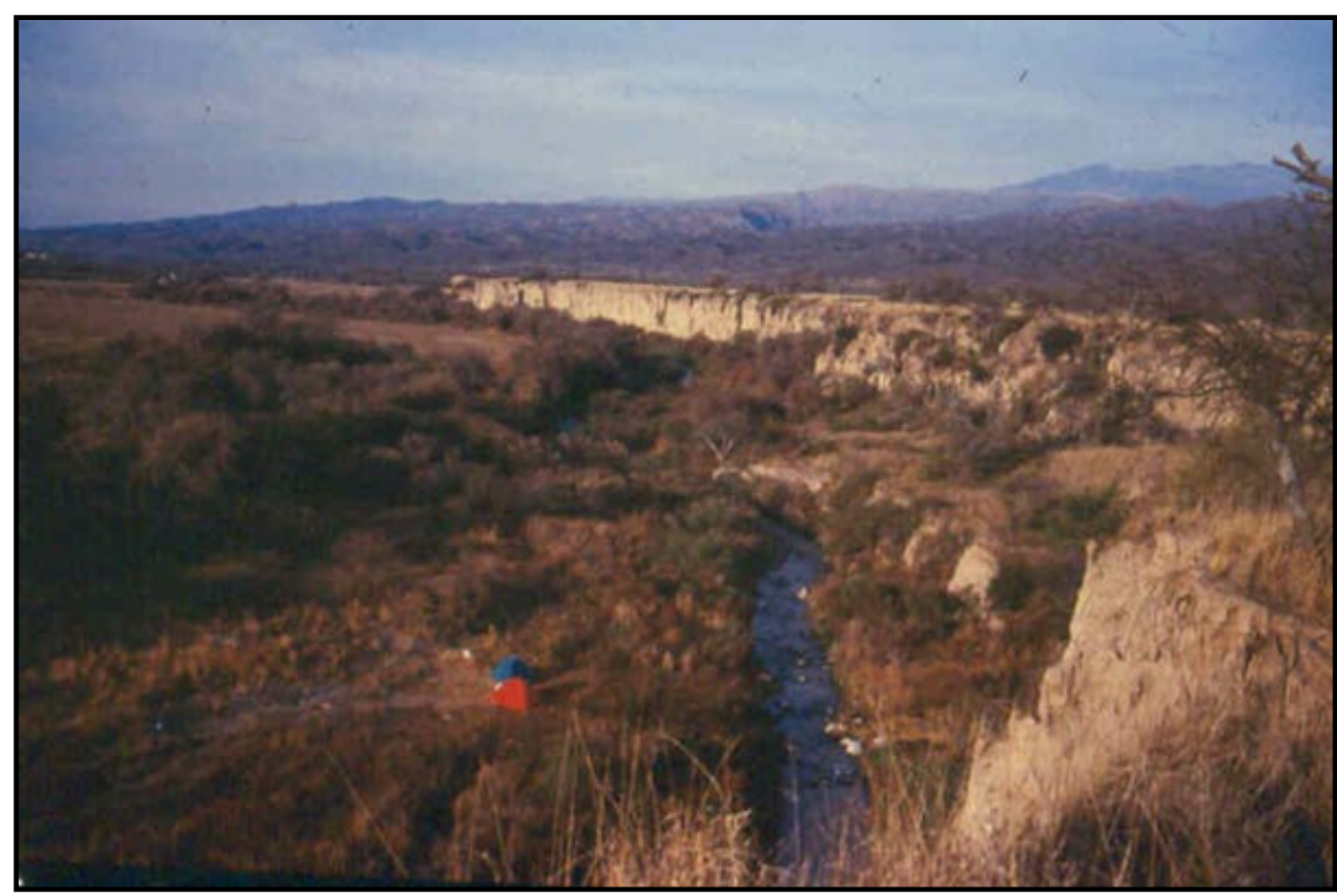

Figura 5.8: barrancas del río de los puestos. 
sectores de cultivos, como las terrazas lineales y de contorno. En el caso del agua de vertiente, esta debe ser canalizada hacia los sectores donde se desea transportarla, requiriendo una inversión continua y un compromiso duradero para evitar los procesos de erosión, que pondrían en peligro los cultivos. Lo mismo ocurre con el transporte de agua de las vertientes hacia sectores del fondo del valle. Así, el recorrido que hace el agua para llegar al Río de los Puestos se nos presenta como un elemento significativo en la ordenación y gestión de ese paisaje: este recorrido se da en dos sentidos: bajando desde el Este hasta llegar al cauce principal o bajando desde el oeste hasta el mismo cauce -figura 5.2-. De esta forma, la disposición de los sitios y su estructuración espacial no seguiría la pendiente del cauce principal sino la de las torrenteras y arroyos secundarios.

$\mathrm{Si}$ emplazamos los diferentes sitios hallados en este recorrido del agua, comenzando desde las torrenteras hasta la desembocadura de los arroyos en el cauce principal, obtenemos el siguiente panorama. Al inicio del recorrido, las unidades se caracterizan principalmente por terrazas de laderas -rectas o de contornos- y terrazas de cauces -cross channels-, pudiendo haber también canchones. Dependiendo de la existencia de vertientes en este sector, también se pueden encontrar las bocatomas de acequias que llevan el agua hacia abajo. En estos sectores, las estructuras agrícolas se asocian a sitios pequeños y medianos. Si existen unidades residenciales grandes, están ubicadas preferentemente en el quiebre de pendiente entre ladera y fondo de valle. Ya en las pendientes más suaves del fondo del valle, hay andenes y algunos endicamientos en el lecho tanto de arroyos como de torrenteras. Aparecen también sitios pequeños, medianos, grandes y muy grandes. Estos últimos preferentemente asociados a arroyos, no a torrenteras, que desembocan en el Río de los Puestos. Incluso algunos se hallan en las partes altas de las barrancas donde desembocan los arroyos al cauce principal -tal es el caso de Piedras Blancas, Iglesia de los Indios o Cerco de Palo 69 -.

La inversión en la manutención y gestión de la infraestructura que venimos desarrollando, para el aprovechamiento y manipulación del agua de escorrentía y vertientes, sea para realizar la práctica agrícola, o para la apropiación del agua en general, genera un compromiso a largo plazo. Esto en tanto que, por un lado, el trabajo queda inmovilizado en ella (Vicent García 1991a, Quesada 2001, 2007; Barale 2006), y por otro, como diría Vicent García (1991a) en el caso de las prácticas agrícolas (una de las principales prácticas económicas desarrolladas en el valle), al tratarse de una actividad económica que depende de la “...inversión de un esfuerzo de rendimiento diferido, el problema no es sólo asegurar el éxito técnico de ese esfuerzo, sino garantizar el acceso a sus resultados" (Vicent García: 1991a:45). En este sentido, la distribución de los sitios a lo 
largo y en lo alto de las quebraditas y torrenteras por donde baja el agua, más toda la infraestructura utilizada para manejarla y manipularla, que como dijimos se da desde las laderas hacia el centro del valle, produce fuertes vinculaciones entre aquellos grupos que comparten el agua que baja desde las laderas hacia el río. Dentro de este paisaje y de la lógica de apropiación del agua, debemos incorporar a los camélidos.

La gestión de estos animales es virtualmente inseparable de la apropiación y gestión del paisaje agrícola (Figueroa et al 2009), no solo por la asociación espacial entre las estructuras de cultivo y los corrales, si no también por el tipo de alimentación recibida por estos animales que arrojaron los análisis de isópotos estables (Izeta et al 2009). Los resultados obtenidos producen un contraste entre la alimentación en períodos formativos, respecto del considerado por nosotros. Por un lado, en el sitio formativo, El Altillo, los valores de $\delta^{13} \mathrm{C}$ hallados (entre $-11,8 \%$ y $-17,1 \%$ o) evidencian que los camélidos estaban alimentándose con plantas con patrones fotosintéticos $\mathrm{C}_{3}$ y $\mathrm{C}_{4}$, las que se distribuyen en varios pisos vegetales del valle. En cambio, en el sitio Piedras Blancas, los valores de $\delta^{13} \mathrm{C}$ registrados varían entre $-9,5 \%$ y $-13,1 \%$, es decir, se aproximan a los presentados para maíz, en el área de los Andes Centro Sur, alejándose significativamente de los valores registrados para los recursos herbáceos locales. Esto para Figueroa et al (2009:12) “...resulta en un hecho totalmente novedoso para la región, que apunta a una alimentación dirigida de los animales del rebaño, siendo alimentados con maíz en una alta proporción, a partir de los restos agrícolas. Ello contrasta con las prácticas previas de alimentación del ganado, que habían estado basadas en el pastoreo a campo abierto". En este sentido del éxito técnico y de la apropiación del trabajo invertido para la gestión del agua de escorrentía y vertientes, depende en parte también la reproducción de los camélidos.

Pero a su vez, los sitios de vivienda se hallan en diversas cantidades, asociaciones y relaciones en el fondo del valle, lo que introduce otro parámetro ordenador de la ocupación del mismo. Assandri (2007) utilizando técnicas de análisis espacial ( $K$-means y vecino más cercano), llegó a agrupar las unidades residenciales del fondo del valle en tres concentraciones que define como aldeas -figura 5.9-. Cada una de estas agrupaciones presentaría un sitio MGS, seguidos de vecinos de primer orden de tamaño G, luego por vecinos de segundo orden de tamaño $\mathrm{M}$ y de tercer orden de tamaño P. Podría existir una cuarta concentración hacia el sur en relación a un sitio MSG -Huañumil- (Cruz 2005). La cantidad de cada una de las clases de sitios según la autora, varía de acuerdo al tamaño, estando representados en mayor cantidad los más pequeños y habiendo solo uno de los más grandes. Todos los sitos comparten las mismas variedades de materias primas y técnicas constructivas y una orientación solar semejante $-4^{\circ}$ al norte-. A su vez, al interior de cada 


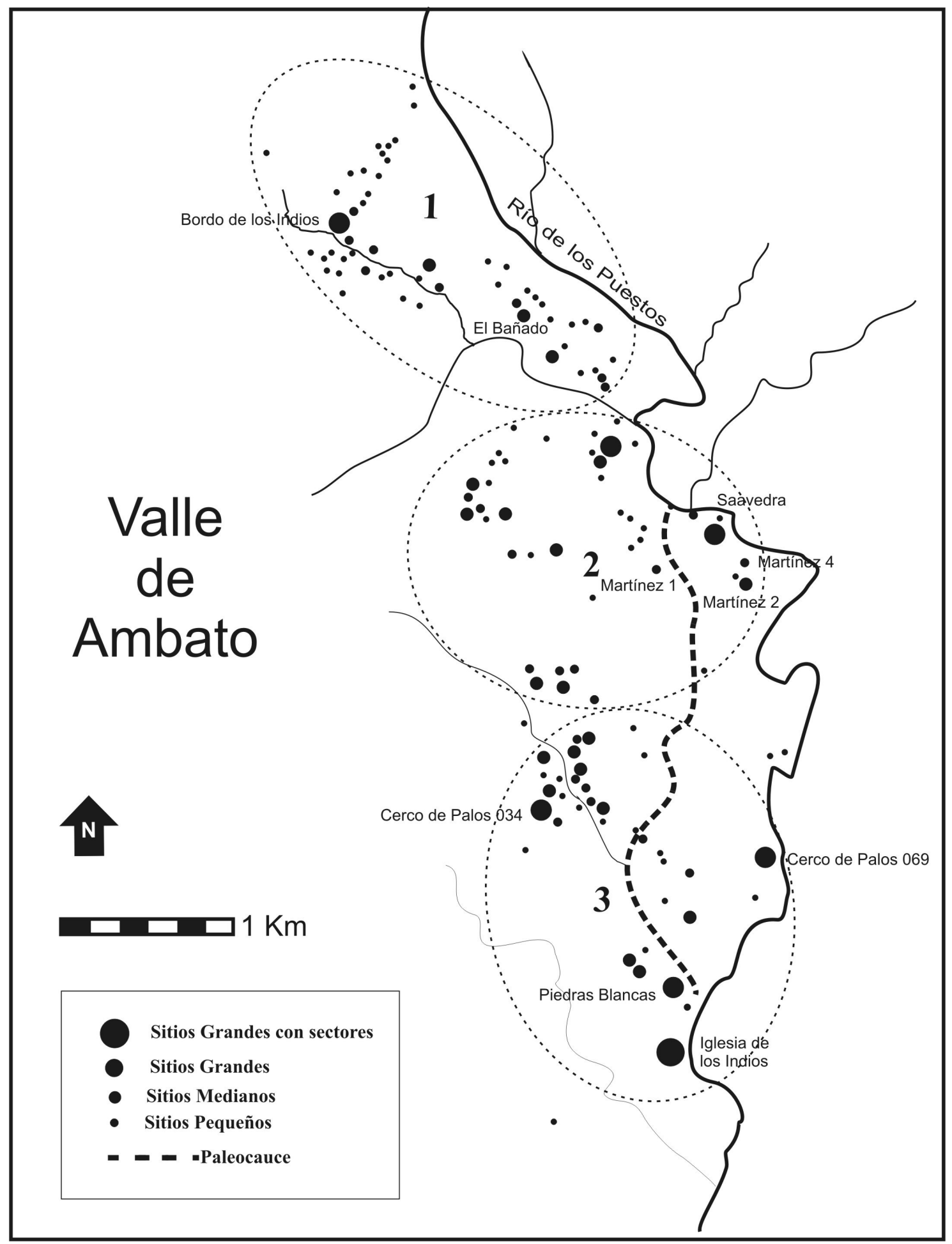

Figura 5.9: mapa de las concentraciones de sitios en el fondo del valle, según agrupaciones por tamaño, jerarquía y vecino más cercano.

una de las concentraciones, pueden distinguirse agrupaciones más pequeñas de sitios $\mathrm{P}$ en relación a sitios $\mathrm{M}, \mathrm{G}$ y $\mathrm{MG}$, vinculados a determinadas torrenteras o arroyos. Assandri (2007:101) retomando los planteos de McGuire (1983) sobre la posibilidad de diferenciar en la arquitectura los grupos residenciales y las instituciones, señala que las distribuciones observadas en Ambato podrían considerase de la siguiente manera: las unidades más pequeñas $(\mathrm{P})$ que a su vez se les otorga según los análisis del vecino más cercano una 
jerarquía 1 -menor- correspondería a lo que este autor denomina household cluster: un cuarto o una casa con un fogón, cuartos de almacenamiento y áreas de actividad. Luego las unidades de un módulo con patio y corral (M, jerarquía 2) y aquellas de dos módulos (G, jerarquía 1) serían subgrupos del family cluster: agrupamiento de las unidades mínimas en otras mayores. Estas forman las unidades de patio que son varias unidades domésticas conectadas por puertas o patios comunes. En tanto que los MG y MGS (jerarquía 4) corresponderían a instituciones para albergar actividades que representan y simbolizan a todo el grupo social, sin descartar la pasibilidad de residencia en estos lugares. La agrupación de todos ellos forman las aldeas. Esto muestra un nivel de agrupación mayor al que puede observarse de la apropiación del agua de escorrentía y vertiente, en tanto aglutina a varios de estos sistemas. En este sentido entran en juego relaciones más amplias y colectivas. Repensemos estas agrupaciones y formas de apropiación del agua con otro de las prácticas recurrentemente observas en los sitios y que tiene cierta implicancia a la hora de la producción de las vasijas que analizamos aquí, la gestión y apropiación de los "recursos forestales".

En el valle, las prácticas de recolección son abundantes (Marconetto 2008; Figueroa y Dantas 2006; Gordillo 2009; Gordillo y Ares 2005). En las galerías de los sitios Piedras Blancas e Iglesia de los Indios se han hallado grandes vasijas (en algunos casos más de 5 vasijas con más 250 litros de volumen) almacenando frutos de chañar -Geoffroea(Gordillo 2009; Gordillo y Ares 2005). A su vez, Marconetto (2008) pudo observar elecciones diferentes en cuanto a las leñas utilizadas para la combustión: mientras que los fogones domésticos presentan variedad de leñas pertenecientes a diferentes especies Acacia, Aspidosperma, Celtis, Condalia, Geoffroea, Jodina, Lithrea, Prosopis, Schinopsis, Schinus y Ziziphus- (tratándose en general de ramas producto de la poda natural del monte), para otras actividades vinculadas a prácticas artesanales, como el recocido de metales, se eligen maderas más duras como el algarrobo -Prosopis alba y nigra- y quebracho -Aspidosperma quebracho blanco- de mayor grosor, e inclusive quizás con algún proceso previo de transformación en carbón de leña, que permiten llegar a altas temperaturas y conservar durante más tiempo el calor (Marconetto 2008, Espósito y Marconetto 2008). En relación a las maderas que intervienen en la construcción de los techos de las viviendas, se hallaron algunas que crecen en las inmediaciones de los sitios como los algarrobos - prosopis- principalmente usadas como postes para sostén del techo y para la enramada. Pero también se han recuperado especies alóctonas, como el laurel de la falda -Phoebe sp- y el cebil -Anadenanthera colubrina- (cuya semilla se usaba a su vez como sustancia psicotrópica, Pérez Gollán 1991, 1986), utilizadas como tirante en los 
techos. Salvo estas dos últimas especies, todas las demás crecen en las inmediaciones de los sitios (Marconetto 2008). Esto nos lleva a pensar en la articulación del paisaje vinculado al aprovechamiento y apropiación de las aguas de escorrentía, y las aldeas con lo que Marconetto y Mors (sin fecha) llamaron el "monte" haciendo referencia al aprovechamiento de los recursos forestales.

De la Orden y Quiroga (1997) dividen al valle en tres grandes "unidades fisiográficas mayores" o "Gran Paisaje": vertiente rocosa superior, pie de monte y llanura fluvial. A su vez, cada una está subdividida en paisajes y éstos en unidades vegetacionales. Marconetto (2008: 52) señala que:

“..las unidades que presentan mayor diversidad de especies leñosas, son en primer lugar el bosque en galería del fondo de valle del río Los Puestos; seguido por el bosque abierto del piedemonte inferior occidental de la sierra de Balcozna; con una riqueza similar encontramos, el bosque de la vertiente oriental de la sierra de Humaya, que corresponde al gran paisaje de la vertiente rocosa superior; en tercer orden mencionaremos el bosque abierto de la llanura del fondo de valle, y el mosaico de bosque y arbustal del piedemonte occidental superior de la sierra Balcozna. Estos datos (...) dan cuenta de la existencia de diversidad de microclimas: como vemos hay bosques con alta diversidad florística tanto en el fondo de valle, en los piedemontes y en las vertientes rocosas más altas, así como en ambas vertientes. La disposición de la vegetación decreciendo con la altura, y de Este a Oeste, en este caso, si bien es una tendencia no están marcada debido a la diversidad microambiental”.

Las prácticas de apropiación del "monte" se diferencian de las prácticas de apropiación del agua en el valle. En la gestión del monte, no se requiere la inversión en infraestructura como sí la posee la apropiación del agua de escorrentía y de las vertientes. Según los estudios antracológicos y de distribución de especies leñosas descriptos hasta ahora, el monte está presente en las inmediaciones de las casas. Es decir que las casas están insertas en él. Esta articulación de "la casa en el monte" y el ingreso del "monte en la casa" (Marconetto y Morse, en prensa), nos permite pensar, en principio, en los recursos del monte con un acceso no restringido o por lo menos no materialmente restringido. Pero si pensamos en las prácticas concretas en donde participan las cosas del monte, su incorporación al interior es realizada por medio de ciertas valoraciones sociales que pueden producir cierta tensión. Por un lado, tenemos la clasificación que hace Marconetto (2008) 
de las leñas involucradas en las prácticas de combustión: la "leña firme" (algarrobo y quebracho), utilizada principalmente en las actividades artesanales de recocido de metales, y las distintas especies de "leña blanda" utilizadas en los fogones domésticos, provenientes de la poda natural del monte. Por otro lado, tenemos cierta clasificación de las maderas que se consideran mejores para la construcción de los techos, algunas obtenidas del monte cercano y otras provenientes de lugares más lejanos. Estas formas de apropiación podrían haber generado tensiones a la hora del acceso a aquellas, en tanto las presiones sobre el monte circundante a las casas podrían ocasionar problemas de acceso futuro, tensionando las relaciones entre vecinos. Esto habría requerido la existencia de ciertos tipos de mediaciones en esferas supradomésticas, activándose determinadas relaciones más allá de los que habitaban las casas en el monte.

Los agrupamientos observados por Assandri, estas aldeas, quizás se vinculen a esta esfera de construcción más colectiva, en donde la apropiación de "monte”, y del "agua de escorrentía" entrarían en diálogo, regulando las relaciones sociales entre los grupos constituidos, tanto como la producción y reproducción del particular paisaje del Valle de Ambato descrito hasta el momento.

Este primer acercamiento nos sirve de puntapié inicial para enmarcar las trayectorias biográficas de las vasijas que analizamos y en donde los sujetos desarrollaban sus rutinas diarias. Pero solo es un punto de inicio, porque una vez que hayamos reconstruido las trayectorias biográficas de las vasijas y de los sujetos, y esbozado las cartografías y su reproducción en el largo término, volveremos sobre el paisaje y observaremos de que maneras específicas esté llegó a ser construido por ellas. Con ello, esperamos demostrar al final de esta tesis que pensar al paisaje arqueológico del valle solo como "escenario" donde se ejecutaban las prácticas en las que los objetos y sujetos se vinculaban, es parte de la misma confusión que llevó a que los sujetos y objetos, el cuerpo y la subjetividad, quedaran en laderas opuestas sin vinculación.

\section{Notas}

\footnotetext{
${ }^{\mathrm{i}}$ La estancia La Rinconada ha reutilizado una de estas acequias para conducir agua de una vertiente de la zona de la Graciana al este del valle hacia sectores del fondo del valle donde tiene plantaciones de Nogales.
} 


\section{CAPÍTULO 6}

\section{VASIJAS COMO SUJETOS: SUS BIOGRAFÍAS CULTURALES}

En este capítulo reconstruimos las trayectorias biográficas seguidas por lo objetos que hemos seleccionado, pertenecientes a dos grandes grupos: la alfarería oxidante de paredes gruesas para grandes vasijas tricolor o lisas, y la cerámica reductora de tradición Ciénaga-Aguada (Fabra 2008, Laguens 2005). Como hemos señalado, reconstruir las trayectorias biográficas requiere que analicemos y relacionemos la materialidad más esencial del objeto con las prácticas sociales donde intervinieron y los contextos económico- sociales estructurados y reestructurados por éstas.

Como forma de ordenar y describir los datos, elegimos una manera secuencial de exposición. En primer lugar -I parte- describiremos los procesos por los cuales estos objetos llegan a convertirse en vasijas. Así, comenzaremos por especificar los procesos de manufactura: tipos de materias primas utilizadas, posibles lugares de proveniencia y acceso a ellas, lugares de fabricación de las vasijas y sus secuencias de producción. En este último caso veremos los tipos de arcilla y antiplásticos utilizados, las diferentes proporciones y pastas logradas, y las diferentes formas y tamaños. Asimismo analizaremos las relaciones entre las pastas, los tamaños y formas de las vasijas, con el objetivo de hallar patrones que nos puedan indicar diferentes tipos de preferencias y elecciones. También describiremos, para cada tipo de forma, su secuencia de modelado, los tratamientos y acabados superficiales internos y externos, las formas de decoración, y finalmente, analizaremos sus formas de cocción: posibles combustibles utilizados, temperaturas y atmósferas. Por último, evaluaremos las propiedades técnicas y formales que les fueron concedidas para ser utilizados en diferentes actividades prácticas (ver anexo VI). En segundo lugar -II parteobservaremos en qué actividades son usadas estas vasijas una vez que son fabricadas con determinadas características y en determinados lugares. Para ello, analizaremos en primer lugar los rastros de usos, para luego adentraremos a especificar sus contextos de hallazgos. Esto nos permitirá observar los lugares donde se las usaba, almacenaba y/o guardaba, acercándonos así a conocer en qué otras actividades intervenían como objetos y qué relaciones entablaba con otros, observando las prácticas en las que participaron. De esta manera, en esta sección trataremos de responder a los siguientes interrogantes: una vez que las vasijas se fabricaron con determinadas características ise las utiliza en los mismos lugares donde son fabricadas o van hacia otros lados?; ¿quiénes las usan?; ¿qué actividades específicas se hacen con estas vasijas en esos lugares?, ¿coinciden las intenciones 
funcionales con los usos concretos a los que fueron sometidas?, es decir, ¿se las usa en aquellas actividades que nos marcan las características de performance o tienen otro destino práctico?, ¿se las utiliza en varias actividades o en una sola?, a su vez ¿un mismo objeto puede ser utilizado para realizar distintas cosas?. Una vez que a una vasija determinada se la ha destinado a alguna actividad, ¿siempre se la usa para realizarla?; ¿Con qué objetos y lugares se vinculan en estas actividades?; ¿con qué otros lugares y objetos no entran en contacto?; ¿dónde se las almacena o guarda?, ¿existen lugares especiales para guardarlas?. En tercer lugar -III parte- nos acercaremos al tiempo de vida de las vasijas, instancia en la que trataremos de responder: ¿cuál es el tiempo esperado de vida de una vasija o, parafraseando a Kopytoff (1991), una "vida bien vivida"?; una vez que se rompen ¿se las repara o se las deja de usar?; ¿se las transforma en otro objeto?; ¿se dejan de usar sólo cuando se rompen o dejan de ser utilizadas antes?; ¿qué pasa cuando se rompen?: ¿quedan en el mismo lugar o se las descarta en otros lugares?; ¿hay algún lugar especial donde son depositadas una vez rotas o existen varios lugares?; en el/los lugar/es donde se depositan los fragmentos de la vasija rota, ¿hay también objetos de otras clases?; los fragmentos ¿son en algún momento reciclados?, Si las vasijas se dejan de usar antes de romperse ¿se las desacarta?, ¿se las guarda en algún lugar diferente de donde se arrojan los fragmentos?, tanto las vasijas rotas y aquellas que son dejadas de usar ¿sufren algún proceso de transformación que marque un estado de abandono?. En cuarto lugar -IV parte- conjugaremos todos estos datos con el objetivo de sintetizar las distintas trayectorias biográficas seguidas por las vasijas analizadas. 


\section{Parte}

\section{Convirtiéndose en vasijas...}

Fabra (2008) determinó que para el período que consideramos en este trabajo -siglos IV a X/ XI de la era-, en el valle de Ambato se hallan representadas doce clases tecnológicas diferentes de vasijas cerámicas. Cada clase fue definida por esta investigadora por una combinación de variables. La autora distinguió los procesos de formatización primaria y secundaria. Para el proceso de formatización primaria, tuvo en cuenta atributos de pasta, tales como el tipo, tamaño y densidad del antiplástico; la densidad, el tamaño y la forma de las cavidades, así como las técnicas de preparación y de remoción de la pieza. Para el proceso de formatización secundaria, fueron descriptas las técnicas de acabado, corte y decoración que presentaban las superficies, los tratamientos precocción y el tipo de cocción que presentaban los materiales (Fabra 2008). Dentro de estas doce clases, a nosotros nos interesa la clase E (subclase E1, E2, E3, E4, E5 y E6) y la clase A1 (para la descripción de cada clase según los criterios definidos por la autora ver el Anexo III) puesto que los dos grandes grupos de alfarería analizados aquí se corresponden con estas clases, respectivamente. A su vez, la autora determinó que para el período anterior al que tomamos en este trabajo -Período Formativo, siglos I a IV de la era- existió una variedad mayor de clases tecnológicas -43 clases respecto de las 12 del período posterior-. Por lo que al comienzo del Período de Integración Regional -siglos V a IV de la era- existe una reducción en la variabilidad de las clases tecnológicas. Durante este proceso, algunas de las clases utilizadas en el período formativo del valle desaparecieron, otras continuaron, algunas aumentaron su representatividad y otras sufrieron ciertos cambios. Así, las clases tecnológicas que tomamos en esta investigación se vienen utilizando y fabricando desde comienzos del primer milenio. Durante el Período de Integración Regional, si bien continúan dichas tradiciones, se observan cambios en la representatividad respecto del período anterior, aumentando en el caso de la clase A1 un 33\% y en el caso de la clase E un $100 \%$ (ver tabla 6.1 y 6.2). Esto nos indica no sólo que existe una continuidad en las tradiciones tecnológicas -es decir determinadas formas de hacer que perduran casi 1000 años- sino que, a su vez, ciertas formas de hacer logran consolidarse en el tiempo y, como en el caso de las dos clases analizadas, aumentar notablemente su representatividad respecto a otras clases que desaparecen. En el caso de la clase tecnológica A1 (Negro Pulido) si bien continúa produciéndose de la misma forma que las clases Gris Negro Pulido y Negro Pulido del Período Formativo, sufre una modificación en relación a la decoración 
de la superficie externa, en tanto se le incorpora, por medio de la técnica del inciso y grabado, el repertorio iconográfico clásico del estilo Aguada (Fabra 2008; Laguens 2002).

Aunque en esta investigación retomamos la clasificación realizada por Fabra (2008), en una primera instancia desarticularemos estas clases y las expresaremos en términos del proceso secuencial de producción, a fin de ir observando y describiendo las trayectorias de estas vasijas.

En primer lugar observamos los tipos de materias primas utilizadas en la fabricación de las vasijas y los lugares de extracción de las mismas, empezando por las arcillas utilizadas.

\begin{tabular}{|l|l|}
\hline \multicolumn{1}{|c|}{ Período Formativo } & \multicolumn{1}{c|}{$\begin{array}{c}\text { Período de Integración } \\
\text { Regional }\end{array}$} \\
\hline $\begin{array}{l}\text { Gris/Negro Pulido } \\
\text { Negro Pulido }\end{array}$ & A1 (Negro Pulido) \\
\hline $\begin{array}{l}\text { Ordinario con mica dorada } \\
\text { Ordinario con mica plateada } \\
\text { Ordinario con mica dorada y plateada }\end{array}$ & E (variedades 1 a 6) \\
\hline
\end{tabular}

Tabla 6.1: Correspondencia entre clases tecnológicas. Modificado de Fabra (2008)

\begin{tabular}{|l|c|c|c|}
\hline \multicolumn{1}{|c|}{ Período Formativo } & $\%$ & $\%$ & \multicolumn{1}{c|}{$\begin{array}{c}\text { Período de Integración } \\
\text { Regional }\end{array}$} \\
\hline $\begin{array}{l}\text { Gris/Negro Pulido } \\
\text { Negro Pulido }\end{array}$ & $7.62 \%$ & $19.61 \%$ & A1 (Negro Pulido) \\
\hline $\begin{array}{l}\text { Ordinario con mica dorada } \\
\text { Ordinario con mica plateada } \\
\text { Ordinario con mica dorada y } \\
\text { plateada }\end{array}$ & $14.09 \%$ & $35 \%$ & E (variedades 1 a 6) \\
\hline
\end{tabular}

Tabla 6.2: Porcentaje de representatividad de las clases tecnológicas en cada sitio. Modificado de Fabra (2008)

\section{La/s arcilla/as utilizadas}

A nivel geológico, el valle presenta un basamento rocoso, principalmente rodeado por gnéis, migmatitas y afloramientos de esquistos (Blasco et al 1994 en Bertolino y Fabra 2003). Estos poseen intrusiones de cuerpos de pegantitas y granodiorita-tonalita. A su vez, poseen sedimentos del cuaternario con relicto de rocas sedimentarias del terciario que fueron erosionadas por el Río de los Puestos y sus afluentes (Blasco et al 1994 en Bertolino y Fabra 2003). En estos relictos del terciario, asociados a sedimentos del 
cuaternario, se han hallado dos probables fuentes de arcilla (Bertolino y Fabra 2003; Fabra 2008). Se trata de dos canteras con diferentes propiedades. Una se caracteriza por la presencia de arcilla roja, mientras que la otra es de arcilla blanca con afloramiento de feldespato (Fabra 2008). Ambas se encuentran ubicadas en los faldeos de la sierra de La Graciana, en el límite este del sector norte del valle de Ambato, a $3 \mathrm{Km}$. del pueblo de Los Castillos (figura 6.1 y 6.2). Se presentan como una pared de unos $5 \mathrm{~m}$. de altura y $9 \mathrm{~m}$. de largo en una pequeña cañada por donde corre el arroyo de Los Escobales. Según Fabra (2008) la arcilla roja es muy pigmentada, de consistencia muy compacta y formación laminar en algunos puntos de su extensión, presentándose en otros granos más grandes e inclusiones de mica y feldespato.

Con el objetivo de observar la procedencia de las arcillas utilizadas para la confección de las distintas clases tecnológicas utilizadas en el valle, Bertolino y Fabra (2003) compararon los composición mineralógica y química de las arcilla utilizando distintos métodos experimentales ${ }^{\mathrm{i}}$. La mineralogía de las fuentes de arcilla está caracterizada por cuarzo, calcita, albita, microclino, mica, caolinita y hematita; ambas se diferencian porque presentan, en el caso de la arcilla roja, caolinita e illita, y en el caso de la arcilla blanca, cuarzo, albita, mica, anfíboles y cristobalitas, con pura esmectita. A partir de los análisis de muestras de las diferentes clases tecnológicas identificadas para el Período Formativo y para el Período de Integración Regional, se supone que se utilizaron ambas arcillas: al comparar la mineralogía y composición química de las muestras de las canteras con el material arqueológico de ambos períodos se observa claramente un uso predominante de la arcilla roja, mezclado en alguna proporción con la arcilla blanca (Bertolino y Fabra 2003:31). La arcilla roja refleja excelentes propiedades plásticas, sugiriéndose la incorporación de la arcilla blanca en forma de arenisca (grit), como antiplástico (Bertolino y Fabra 2003:31-32). Particularmente, todo esto ha sido observado en las clases que nos interesan aquí (clase G del Período Formativo -equivalente a clase $\mathrm{E}$ y sus subvariedades- y a la case A1 -Negro Pulido- del Período de Integración Regional).

Para la fabricación de las dos clases cerámicas, entonces, se utilizarían fuentes locales y las mismas clases de arcillas en proporciones diferentes, se coloca más arcilla roja que blanca. Hasta este punto, las vasijas que se confeccionan con estas arcillas comparten un mismo origen. 


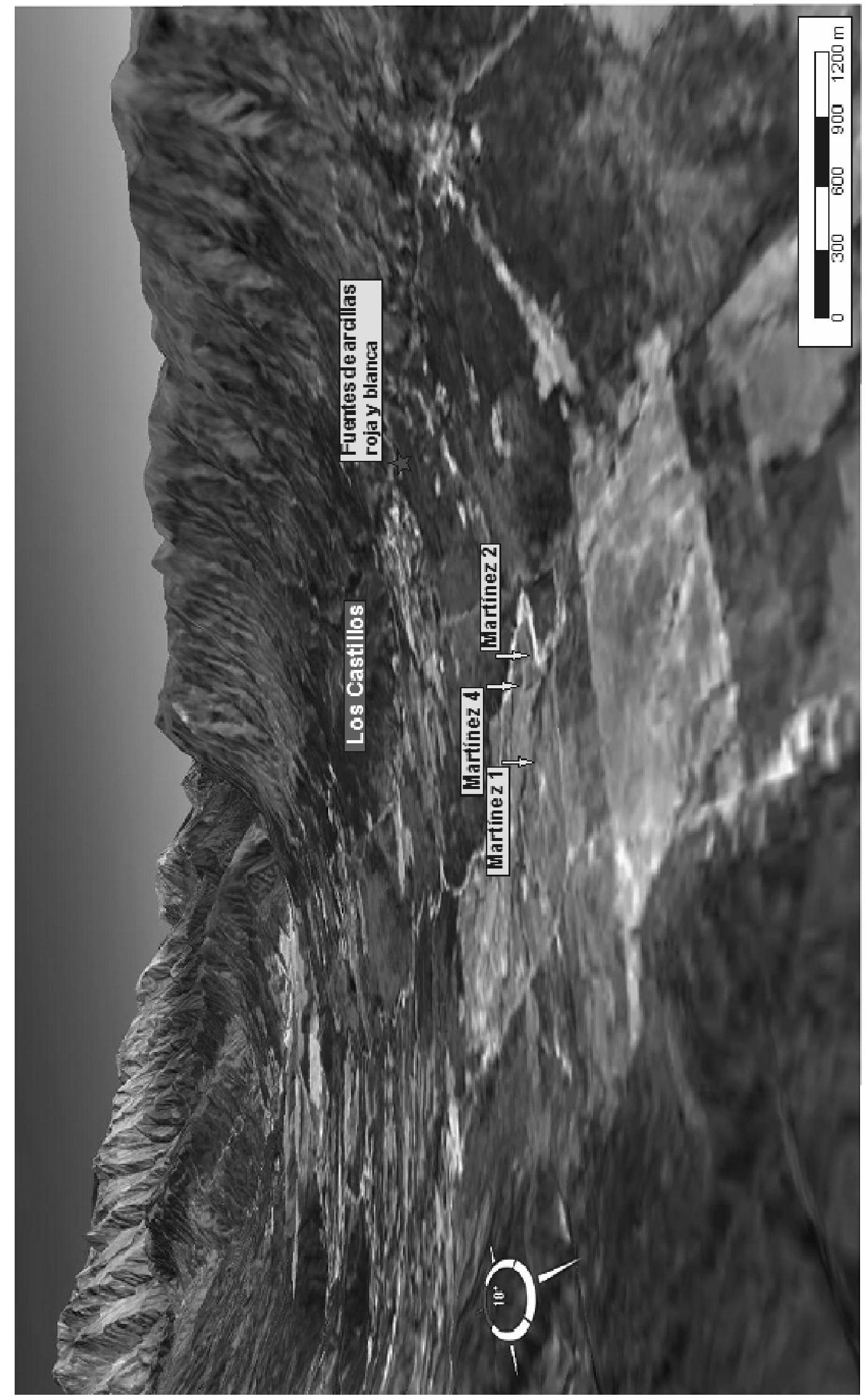

Figura 6.1: mapa en el que se observa la ubicación de las canteras y los sitios donde existen ciertas evidencias de producción cerámica. 
Consideremos ahora otras serie de estudios realizados sobre la clase A1 (Negro-Pulido) que tuvieron como objetivo determinar la procedencia de las arcillas usadas mediante análisis de activación neutrónica -INAA- (Laguens et al 2004, Laguens et al 2006) ${ }^{\mathrm{ii}}$. Los resultados de estos análisis contradicen, en parte, lo observado por Bertolino y Fabra (2003); específicamente sobre la procedencia de las arcillas utilizadas en la confección de la clase A1, no así aquello sobre los tipos de arcillas -rojas y blancas- utilizadas. En un primer momento se analizaron 20 fragmentos cerámicos pertenecientes a la clase A1 provenientes de dos sitios del Valle de Ambato: Piedras Blancas y Bordo de los Indios (Laguens et al 2004) ${ }^{\text {iii }}$. Junto a ello se analizaron cuatro muestras de arcilla provenientes de las dos canteras antes descriptas -dos de la blanca y dos de la roja-. Los primeros resultados obtenidos sugieren (Laguens et al 2004): a) la existencia y prominencia de un grupo de referencia con alta homogeneidad $-84 \%$ de los fragmentos analizados-; b) el uso de una única fuente de arcilla para este grupo; c) el usos de al menos otras seis fuentes de arcilla para el resto de las muestras; d) ninguna de estas fuentes utilizadas se corresponden con las cuatro muestras analizadas extraídas de las canteras de arcilla roja y blanca identificadas en el valle.

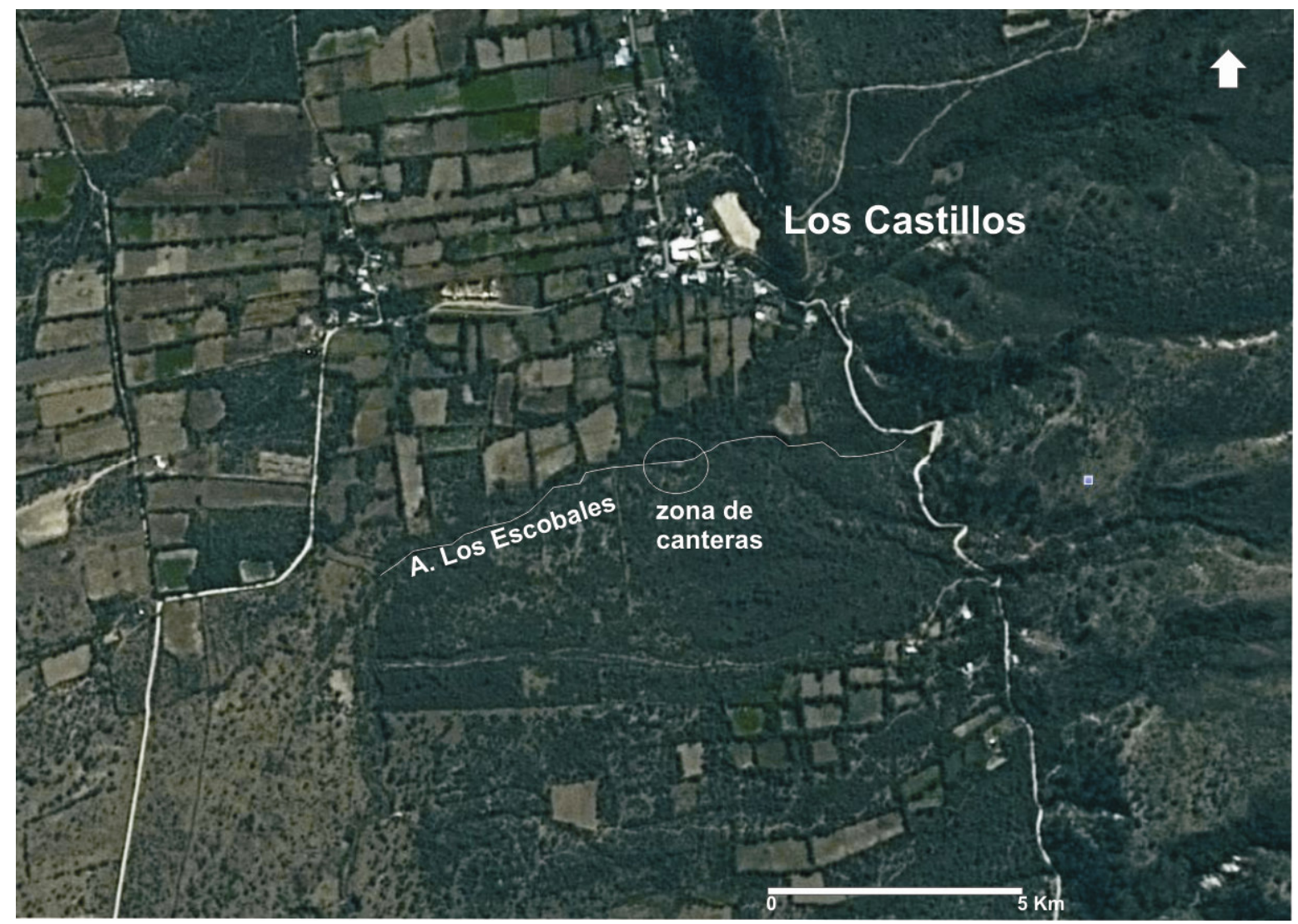

Figura 6.2: canteras de arcilla blanca y roja en el arroyo Los Escobales.

En un segundo análisis la muestra se amplió a 60 fragmentos y a 6 muestras de arcilla. En esta ocasión los fragmentos provinieron -figura 6.3- por una lado, del Valle de 
Ambato (37 muestras -61,7\% del total-) seleccionadas de los sitios: Bordo de los Indios, Piedras Blancas, Martínez 2, 3 y 4, sitios 107, 121, 125 y 126, y el sondeo H-. Otros 23 fragmentos provinieron de áreas exteriores al valle de Ambato (38,3\% del total): del valle de Catamarca 10 fragmentos: sitios Peschiutta 1, Los Ángeles, Pueblo Perdido de la Quebrada y Salvat 1; tres fragmentos del sitio El Rincón al sureste de Tucumán y de dos sitios en el sector este de la zona de la sierra del Ancasti: Baviano y Sicha. En esta ocasión el interés que guió a los autores fue averiguar si la producción de este grupo con alta homogeneidad fue producida localmente en el valle, o si existieron varias áreas de manufactura. Al análisis de los fragmentos se sumaron seis muestras más de fuentes de arcilla, cuatro pertenecientes a las analizadas por Bertolino y Fabra (2003). Las otras dos muestran provienen de la localidad de Humaya (figura 6.3), una de color roja y otra de color amarilla ${ }^{\mathrm{iv}}$.

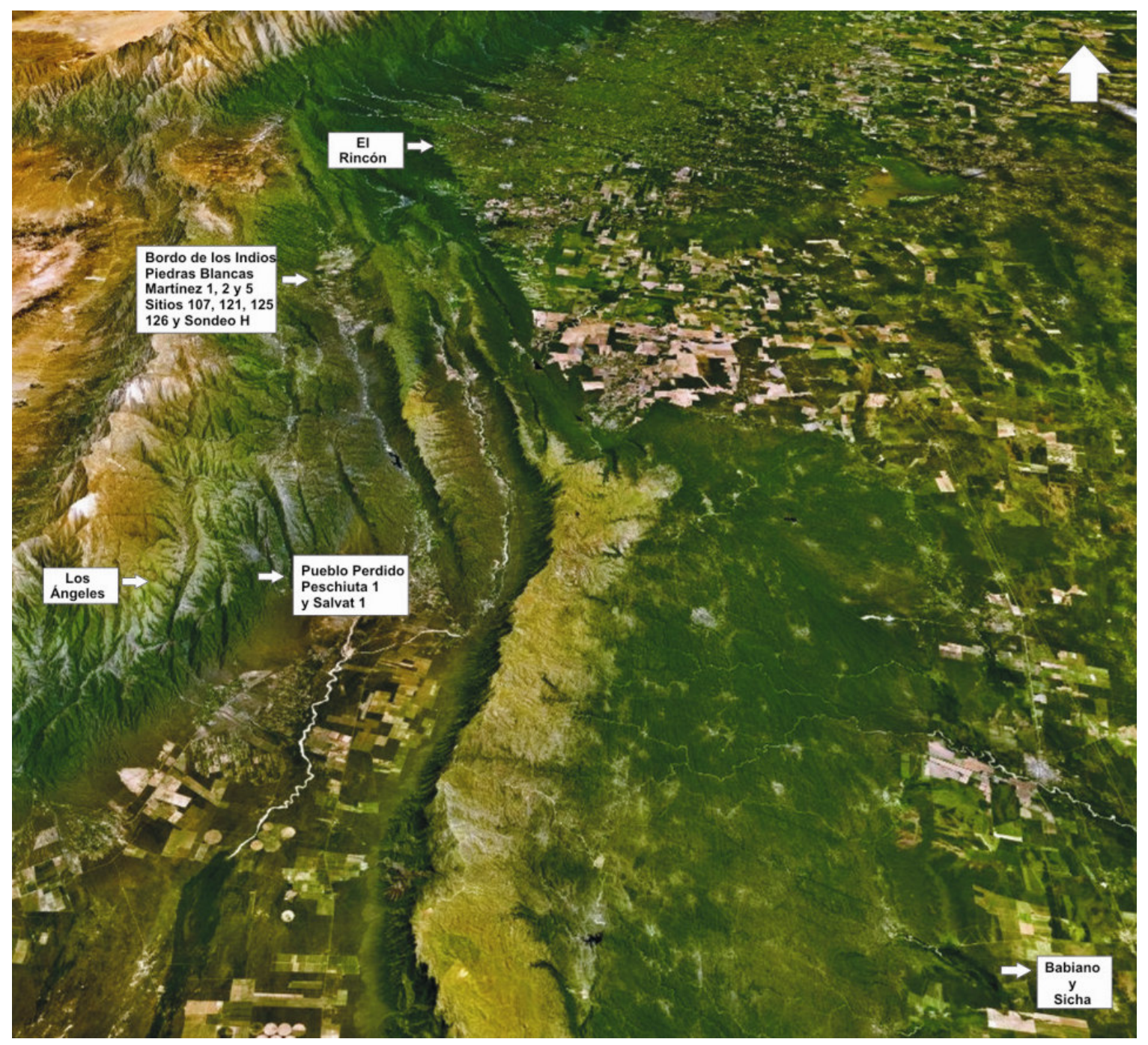

Figura 6.3: proveniencia de las muestras analizadas. 
Los resultados obtenidos refieren que la estructura básica del grupo con alta homogeneidad determinada por Laguens et al (2004) no sufriría cambios, determinándose que: a) la mayor cantidad de las muestras analizadas corresponden al mismo grupo de referencia y b) ninguna de las muestras de fuentes de arcilla analizadas pueden ser asignadas al grupo de referencia de Ambato. En relación con las muestras provenientes de fuera del valle, se determinó que la mayoría pertenece al grupo de referencia del Valle de Ambato. Acorde a los valores que se observan en la tabla 6.3 el $80 \%$ de la muestra se corresponde con el grupo con alta homogeneidad del Valle de Ambato, mientras que el $20 \%$ restante no asignable a dicho grupo se distribuye diferencialmente en cada región de la siguiente manera: en Ambato -figura 6.4- el 13, 5\% (5 fragmentos de 37), en Catamarca 60\% (6 fragmentos de 10). En Alberdi, de los tres fragmentos analizados todos pertenecen al grupo de referencia de Ambato, mientras que en Ancasti el 10\% (1 fragmento de 9). Si se comparan las muestras que provienen de fuera del valle $(n=23)$ el $70 \%$ (16 fragmentos) se corresponde con el grupo de referencia, mientras que el resto $-30 \%$ (7 fragmentos)proviene de otras fuentes de arcilla (Laguens et al 2006). A su vez, estas muestras fueron comparadas con otras 19 fuentes de arcilla provenientes de Catamarca obteniéndose que la mayoría de estas arcillas poseen pocas probabilidades de corresponder al grupo de referencia Aguada. Tres muestras de Potrero de Santa Lucía, -Andalgalá- posee un posibilidad mínima apenas excediendo el $1 \%$ de probabilidad y una muestra en particular de este lugar, según los investigadores, posee buenas posibilidades. A su vez, dos muestras provenientes del sitio Martínez 3 pertenecientes a clases tecnológicas del formativo equivalente a la A1 analizada aquí, pero con decoración Ciénaga, pertenecería a un tercer grupo, al igual que una muestra de Pueblo Perdido.

Como conclusión, los autores señalan que: a) la cerámica analizada fue manufacturada usando diferentes fuentes de arcilla probablemente en diversas localidades; b) que por lo menos hay tres grupos de referencia: el de Ambato, el de los fragmentos Ciénaga y el del Valle de Catamarca; c) de todos los grupos, el más homogéneo es el del Valle de Ambato, d) la mayoría de las muestras analizadas corresponden al grupo de referencia de Ambato; e) existe una probabilidad de que el grupo de referencia fuera manufacturado con arcilla provenientes de la región de Andalgalá.

A la hora de pensar en las arcillas utilizadas para la confección de las clases tecnológicas analizadas, esto resultados nos brindan datos interesantes. Con respecto a la clase tecnológica E (sub variedades 1 a 6) la información obtenida hasta el momento nos indica que las arcillas utilizadas provendrían de dos fuentes del valle de Ambato, siendo 


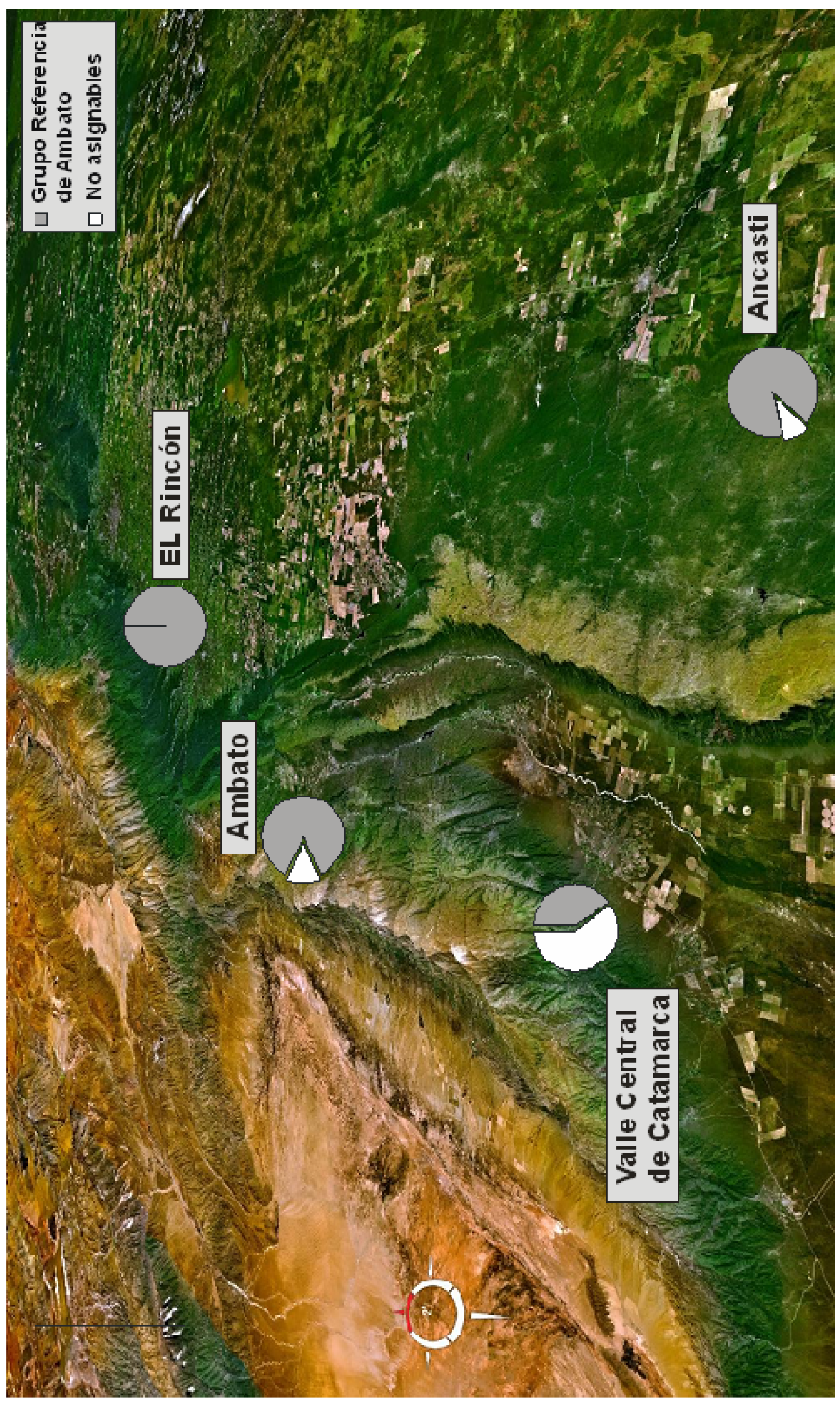

Figura 6.4: Mapa que muestra los gráficos de porcentajes por región, de las muestras asignables al grupo de referencia y las no asignables. 
utilizada una combinación de ambas en diferentes proporciones, la roja por sus propiedades de plasticidad y la blanca agregada en menor proporción como antiplástico. En relación a la clase tecnológica A1, si bien los datos de los análisis de activación neutrónica para determinar la procedencia contradicen los primeros resultados obtenidos por Bertolino y Fabra (2003), refuerzan a su vez la existencia de cierta homogeneidad en la preparación de la pasta: en el caso de Bertolino y Fabra (2003) al determinar la utilización de arcilla roja en su mayoría mezclada con blanca, y en el caso de Laguens et al (2004) y Laguens et al (2006) por la alta homogeneidad del grupo de referencia de Ambato. Como señalan Laguens et al (2006) "Cuando consideramos la organización espacial de la producción, la variedad de cerámicas en el valle sugiere varios lugares de manufactura, pero la identificación de un grupo de referencia con alta homogeneidad, tal como el Grupo de Referencia Ambato, implica que la preparación de la pasta -con o sin inclusiones, mezclando arcilla o no- está de acuerdo con un patrón estandarizado”. Para nuestro caso, es importante no sólo tener en cuenta este grupo de alta homogeneidad, que nos puede estar refiriendo a un "modo de hacer" de larga temporalidad, sino también prestar atención a la variabilidad que nos marcan los datos de procedencia. En el caso de la cerámica A1, existe una diversidad en su producción y utilización. Los resultados nos muestran la existencia de varios lugares de procedencia de las arcillas utilizadas, marcándonos diferencias en el inicio de sus trayectorias biográficas. Esta variabilidad le lleva a Laguens et al (2006) a proponer que no se puede plantear una producción centralizada en el Valle de Ambato. Fuentes con buena calidad de arcilla no son un recurso escaso ni en el valle ni en la región, por lo que pensar en un control centralizado de las fuentes sería dificultoso. Los autores se inclinan a pensar en restricciones sobre los procesos de manufactura, que estarían estructurados de manera fuertemente estandarizada, tal cual lo sugieren también Fabra (2008) respecto a las clases tecnológicas y, Laguens y Juez (1999) ${ }^{\mathrm{v}}$ respecto a las escudillas de clase A1. Al observar las fuentes de arcilla identificadas en el valle (Bertolino y Fabra 2003; Fabra 2008), no se presentan señales materiales de restricción en el acceso a las mismas: no hay paredes ni sitios cercanos que demarquen límites o restrinjan su acceso, por lo que si existía algún tipo de restricción, éste no fue demarcado materialmente, lo que en cierta forma se condice con la propuesta de Laguens et al (2006). Volveremos sobre este aspecto cuando analicemos la posibilidad de acceso a los combustibles necesarios para la cocción de las vasijas.

En relación a el/los lugar/es específico/s de procedencia de las arcillas, el único dato obtenido es que una de las muestras del grupo de referencia posee una alta probabilidad de 
proveniencia de Potrero de Santa Lucía en Andalgalá, a más de $50 \mathrm{Km}$ de distancia del sector norte del valle de Ambato. Aunque falta realizar más análisis para confirmar o rechazar este dato, posee implicancias a la hora de pensar la interacción a nivel regional, tanto como las biografías específicas de los objetos que aquí analizamos, en tanto que podrían haber tenido un recorrido inicial distinto de aquellos fabricados en el valle. Si pensamos en los modelos construidos por las investigaciones etnoarqueológicas, sobre las distancias a las fuentes de materias primas para la obtención de arcilla que señalan la corta distancias existentes entre estas y los lugares donde se las confecciona (Arnold 1985). Pero en Ambato, la distancia a recorrer para obtener elementos "deseados" no ha sido un inconveniente; tenemos, por ejemplo, el caso de la explotación de madera: los postes de techumbre utilizados en algunos sitios fueron traídos de más de $50 \mathrm{Km}$ de distancia -laurel de la falda (Phoebe sp) de las yungas, o el Cebil (Anadenanthera colubrina) también utilizada como madera para la techumbre y posiblemente sus chauchas como alucinógeno(Marconetto 2008; Pérez Gollán 1991). Otro caso es la utilización del cobre arsenical, para la fabricación de objetos de metal; el mismo ingresaba en forma de lingotes traídos desde fuera del valle (Espósito 2009). Podríamos pensar, entonces, que distancias similares podrían haberse recorrido para la búsqueda de $\operatorname{arcillas}^{\mathrm{vi}}$.

En los sitios Martínez 1, Martínez 2 y Martínez 4, se han hallado contextos de asociación de objetos vinculados a actividades artesanales de producción alfarera (Assandri 1991; Juez 1991; Herrero y Ávila 1991). En zonas de recintos techados, galerías y patios se han recuperado cinceles de metal, panes de pintura roja o blanca, panes de arcilla cruda, espátulas de huesos, pulidores de piedra, placas de mica y en algunos casos cerámica sin cocer o con fallas en su elaboración. La descripción de estos contextos nos permitirá apoyar la idea de una producción local (aunque esto no invalide, como lo señalan los estudios de activación neutrónica, que objetos ya fabricados de otros lugares -como los de clase A1- pudieran haber ingresado al lugar) y observar las condiciones en que se habrían fabricado las vasijas aquí analizadas: lugares de manufactura, objetos participantes, formas de producción, etc.

En el sitio Martínez 2 ha aparecido un fragmento de cuerpo de $140 \mathrm{~mm}$ de alto por $180 \mathrm{~mm}$ de ancho, con un $13 \%$ de porcentaje de arco y un radio de $180 \mathrm{~mm}$. Pertenece a una vasija pintada negra sobre blanco, posiblemente de forma "a" (figura 6.5) (sensu Bedano et al 1993) aparentemente cocida a una temperaturas inferior a la necesaria para que se produzca el cambio fisco-químico necesario para que adquiera las propiedades de la cerámica -entre $500^{\circ}$ y $800^{\circ}$ según los tipos de arcillas (Rice 1987; Rye 1988; Schiffer y 
Skibo 1987)-. El cuerpo se encuentra muy fragmentado y se desgrana fácilmente. Las propiedades de fragilidad -softness- y la friabilidad han sido señaladas como dos de los indicadores de la no cocción o de la falta de cocción de una pieza (Rye 1988:111).
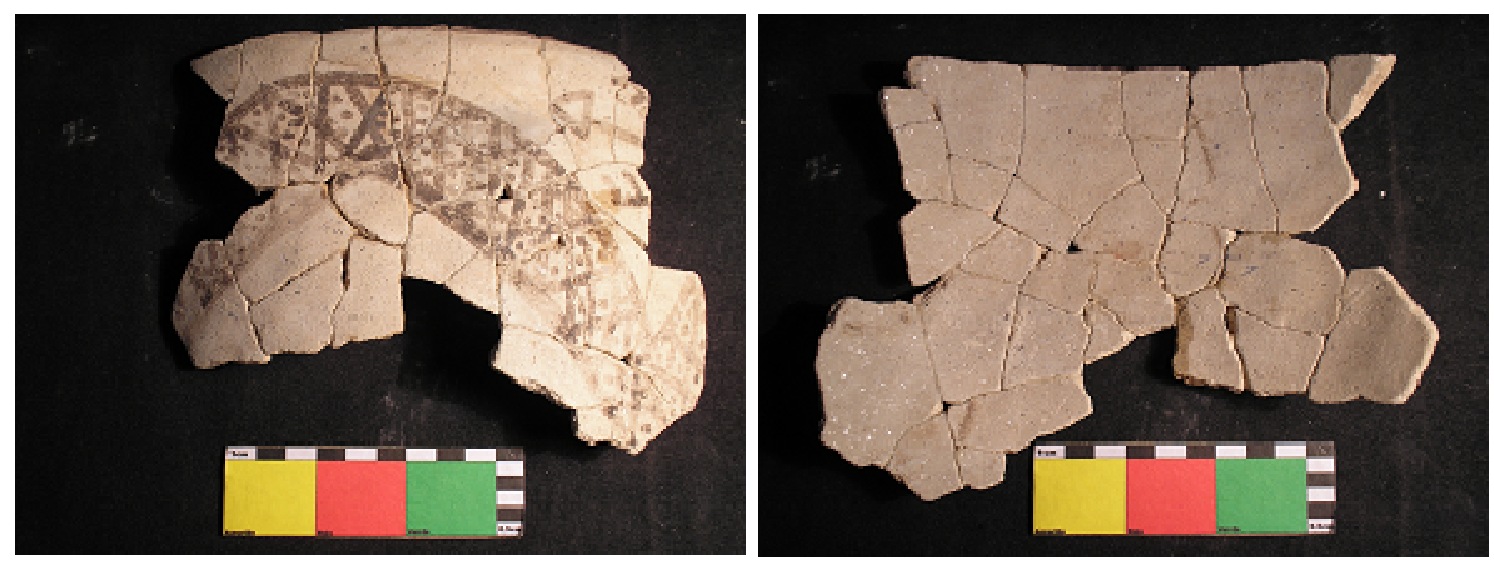

Figura 6.5: fragmento de cuerpo de vasija de clase E de forma "a", probablemente cocida a muy baja temperatura.

Otro de los objetos hallados es una escudilla -puco- (sensu Bedano et al 1993) fragmentada, gris liso pulido, que muestra fallas en su elaboración y en su cocción (figura 6.6). Posee grandes dimensiones, una altura de $160 \mathrm{~mm}$ y un diámetro máximo de $360 \mathrm{~mm}$ en la boca y una base de $120 \mathrm{~mm}$. Es notable cómo varían los espesores en el labio, al igual que en el cuerpo, oscilando entre los 4 y los $6 \mathrm{~mm}$ en distinto sectores de la pieza. En aquellas partes de la vasija donde el espesor es menor a $3 \mathrm{~mm}$, la pieza se ha deformado hacia adentro alterando la circunferencia que normalmente poseen las bocas de estas piezas, con lo que falla el sostén estructural de la misma; se trata de un típico indicador de exceso de cocido (Rye 1988:112). Fue encontrada en el sector oeste del sitio, en la habitación $\mathrm{n}^{\circ} 2$ ubicada contigua hacia el norte de la habitación $\mathrm{n}^{\circ} 1$-figura 6.7-. Ambas habitaciones se asocian a un sector de galería que corre paralelo al este, donde se hallaron dos banquetas (Juez 1991). Los contextos presentes en estos espacios han permitido interpretarlos como vinculados con la producción de alfarería.

En la habitación $\mathrm{n}^{\circ} 2$ se hallaron cuatro concentraciones de materiales -a, b, c y d-, que evidencian estas actividades artesanales - 'a' y 'b'-. En la concentración 'b' aparece esta vasija con defectos de cocción, asociada a grandes vasijas de tipo negro y blanco sobre rojo (clase E, formas "a" -ver más adelante-) y vinculadas a huesos humanos y de camélidos, aparentemente contenidos en su interior. La concentración 'a' reúne a tres vasijas cuyos fragmentos se mezclan con piezas óseas humanas y de camélidos -una vasija 
grande ( $70 \mathrm{~cm}$ de alto) con borde evertido, otra de características similares pero con base plana y una tercera gris lisa pulida de contorno complejo asimilable, de forma $\mathrm{b}$ (sensu Bedano et al 1993) (Juez 1991). Asociado a este contexto aparecen tres pequeñas lajas de filita con retoque en algunos de sus bordes, un núcleo de cuarzo blanco, trozos de mica, un pan de arcilla cruda, un cincel de metal y un pancito de pintura blanca; estas asociaciones permitieron interpretar a este sector como un lugar de almacenamiento de materia primas e instrumentos vinculados a la producción de alfarería (Juez 1991: 98).
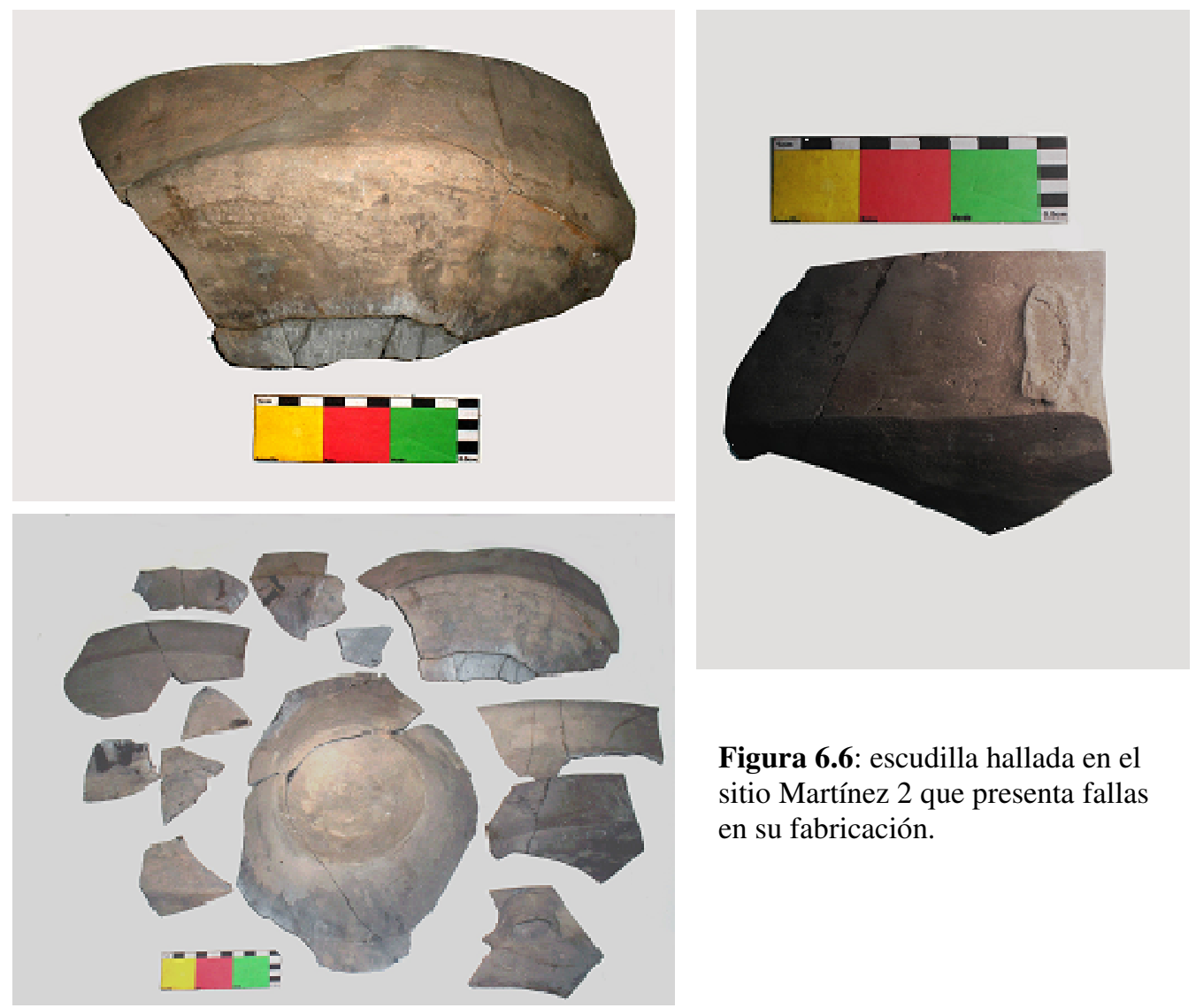

Figura 6.6: escudilla hallada en el sitio Martínez 2 que presenta fallas en su fabricación.

En el sitio Martínez 4, Herrero y Ávila (1991) describen otro contexto asociado a prácticas artesanales y producción de alfarería, específicamente a la fabricación y/ o decoración de cerámica. Nos referimos a la habitación cerrada y a la galería probablemente techada que se extiende en sentido E-O descrito en el capítulo anterior -figura 6.8-. En este sector -específicamente en la cuadrícula 2B-, aparece un conjunto de hallazgos que es interpretado por los autores como un área de molienda, dada la presencia de una mano de moler y dos molinos planos. Pero a su vez aparecen asociados a éstos un cincel de metal, una aguja de metal, pequeños panes de pintura roja, arcilla cruda, espátulas de material óseo, lo que permite proponer que se trata de un área de actividad vinculada a la fabricación y/o decoración de cerámica. 


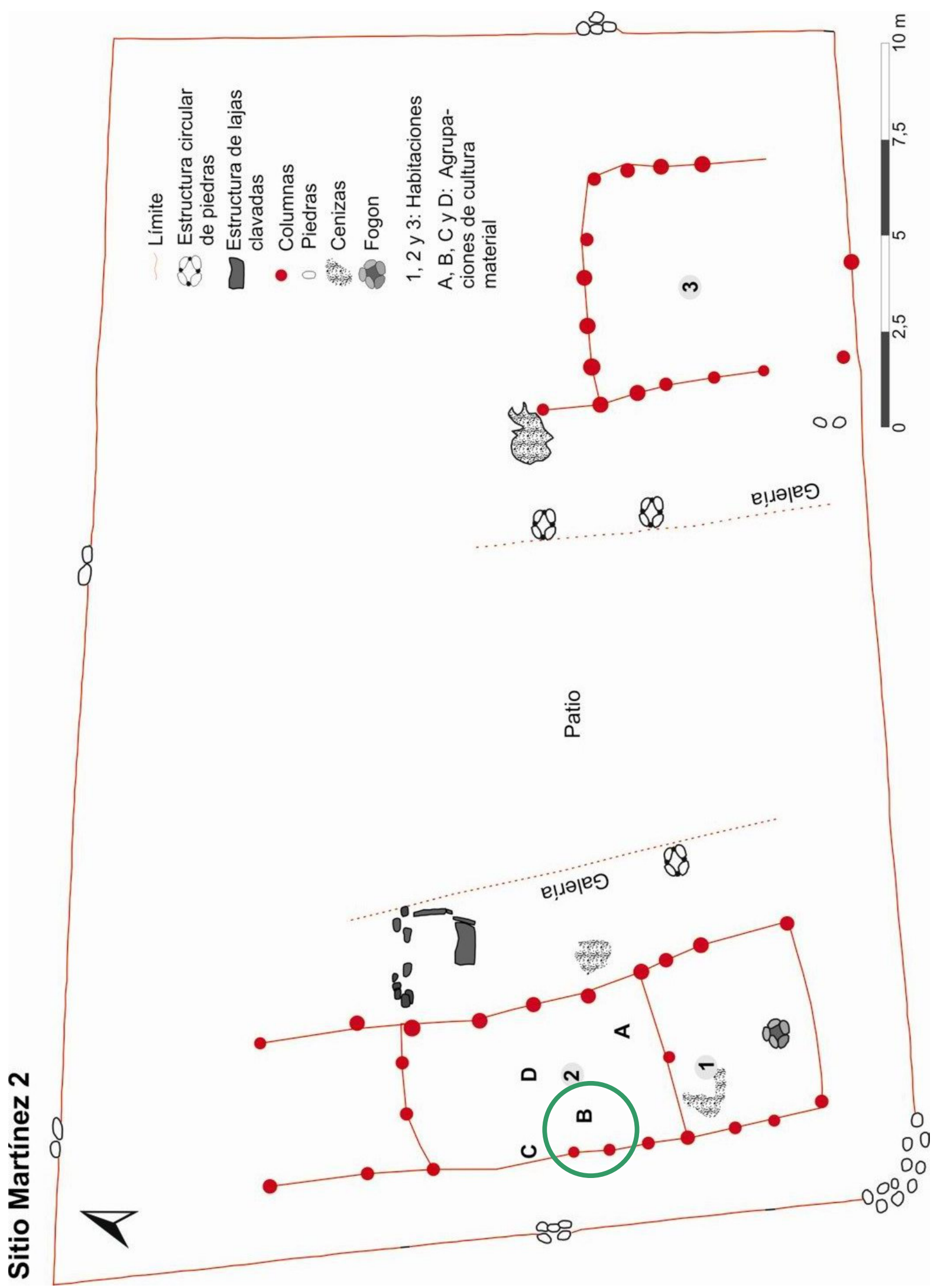

Figura 6.7: zona donde se halló la escudilla con defectos de confección y cocción. Se observan también las concentraciones. Existe una descripción más detallada de las distribuciones más adelante cuando, se analicen los contextos de usos de las vasijas a las que les trazamos las biografías 


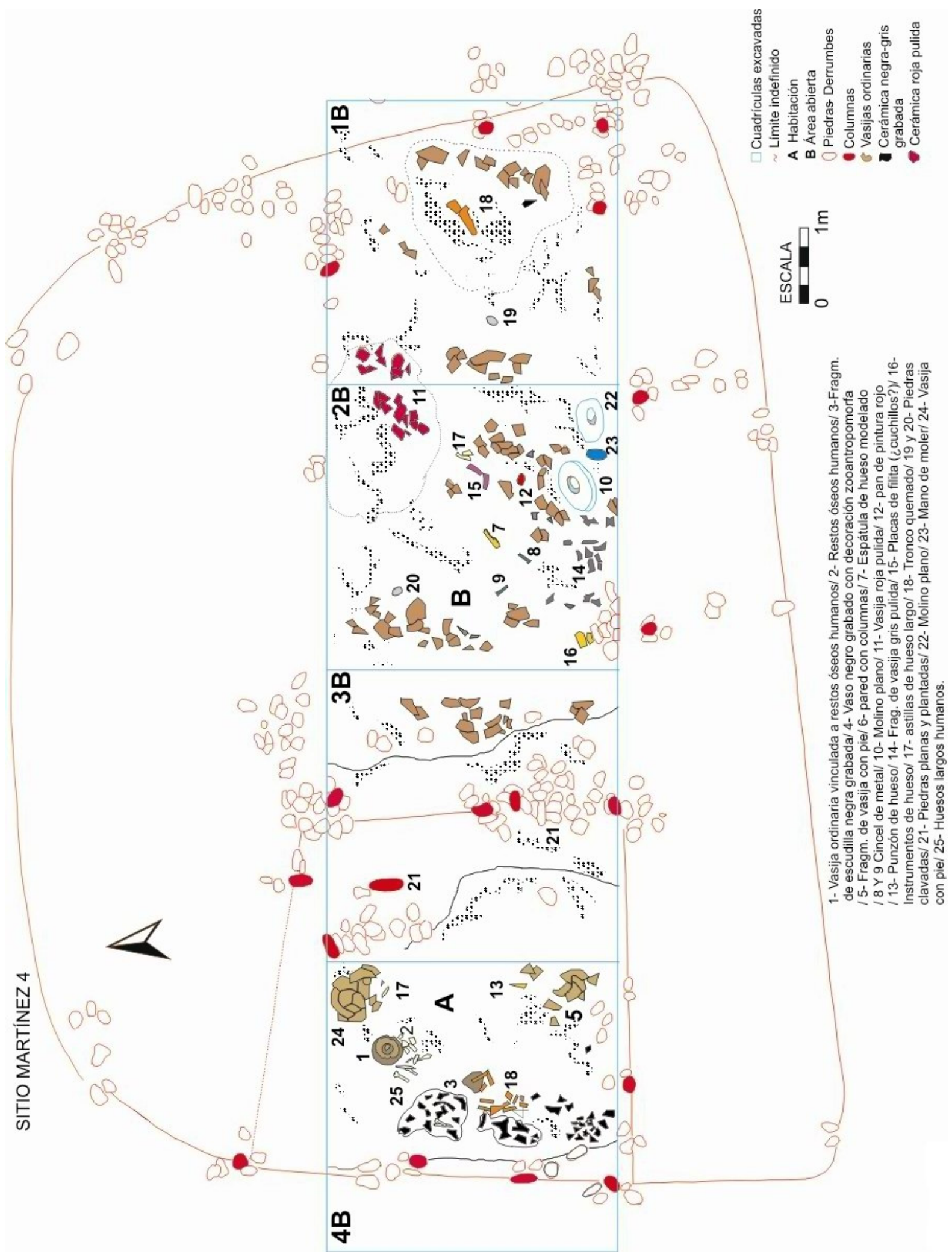

Figura 6.8: sitio Martínez 4: existe una descripción más detallada de los contextos más adelante. 
En el sitio Martínez 1 se excavaron dos sectores, uno contra el muro sur, y otro junto al muro perimetral norte del sitio. Las cuadrículas excavadas en el sector sur -figura 6.9cubren una parte fuera del muro y otra dentro de sitio. Hacia el interior se hallaron cuatro concentraciones de material denominadas a, b y c. En la concentración a-cuadrículas 1C y 1D- se hallaron asociados tres vasijas grandes -forma a- (Bedano et al 1993) junto a un punzón de hueso, planchas de mica y panes de pintura roja. A la concentración b (cuadrículas 1A, 1B y 2B) se asocian vasijas de gran tamaño clase E, un cincel, un hachita de metal y una laja de filita con retoque. En la concentración c (cuadrícula 1 E) aparecen una cuenta de concha de Borus Oblongus, una ollita calceiforme clase E, pequeñas planchas de mica, un pulidor de piedra y una piedra para honda. Las concentraciones d, e y f se hallan al norte del recinto. Este sector habría estado techado, estimación efectuada a partir de los restos de techos carbonizados que se encontraron en esta área, y por la presencia de una estructura central de sostén de poste (Assandri 1991). La concentración 'd' está próxima a la estructura de poste formada por cuatro grandes piedras calzadas con otras más pequeñas, y la conforman tres cinceles de metal, una espátula de hueso confeccionada sobre un hueso largo de camélido, un pulidor de piedra, restos de una vasija grande clase E (ordinario sensu Assandri 1991) similar a la del sector sur, y una pequeña escudilla subglobular de ante liso pulido de $7.5 \mathrm{~mm}$ de altura. La concentración 'e' la conforman fragmentos de escudillas negras gris grabadas, una vasija ante pulida, un hornillo de pipa con decoración modelada y pintada, fragmentos de una vasija grande clase E, un fragmento de tubo de pipa y parte de otro hornillo de pipa con pintura postcoción roja y amarilla. Además, se encontraron tres espátulas de hueso y un pulidor para cerámica del mismo material, un tortero de piedra y lajas de pizarra con filo. La concentración 'f' está conformada por un cincel de metal, una espátula de hueso confeccionada sobre una escápula de camélido, una lanzadera de telar de hueso, un pan de pintura roja, dos cuentas de collar de concha subcirculares y fragmentos cerámicos de clase E, Negro y gris liso pulido (clase A1), Negro y gris grabado (clase A1) y Ante liso pulido (clase A2 sensu Fabra 2008). En el sector norte junto a la pared se recuperó además otro cincel de metal. Por la manera en que se distribuyen las concentraciones de material dentro de la habitación y por la composición de las mismas, Assandri (1991: 70) interpretó este sector de Martínez 1 como un lugar donde se guardaban instrumentos de trabajo -espátulas, cinceles, pulidores, pintura, etc.- y donde se almacenaban productos para el consumo. Esta interpretación se apoya en la presencia de vasijas grandes, aunque es de suponer también que estas vasijas sean piezas terminadas y en depósito, aún sin usar. Según la autora, la relación entre el sector norte de la habitación y el área abierta del sector sur, se daría de la 
siguiente manera: en el sector norte, techado y sin luz, se guardan los implementos utilizados en las tareas artesanales desarrolladas en el sector sur del sitio, área abierta en donde se llevan a cabo las actividades relacionadas con la producción cerámica. A pesar de no haberse encontrado arcilla cruda ni piezas sin cocer o cocidas a baja temperatura (o mal confeccionadas tales como en los sitios Martínez 2 y Martínez 4), la asociación de panes pintura, espátulas de hueso, pulidores de piedras, cinceles de metal, comparado con los otros contextos descriptos, apoyan la idea de Assandri (1991).

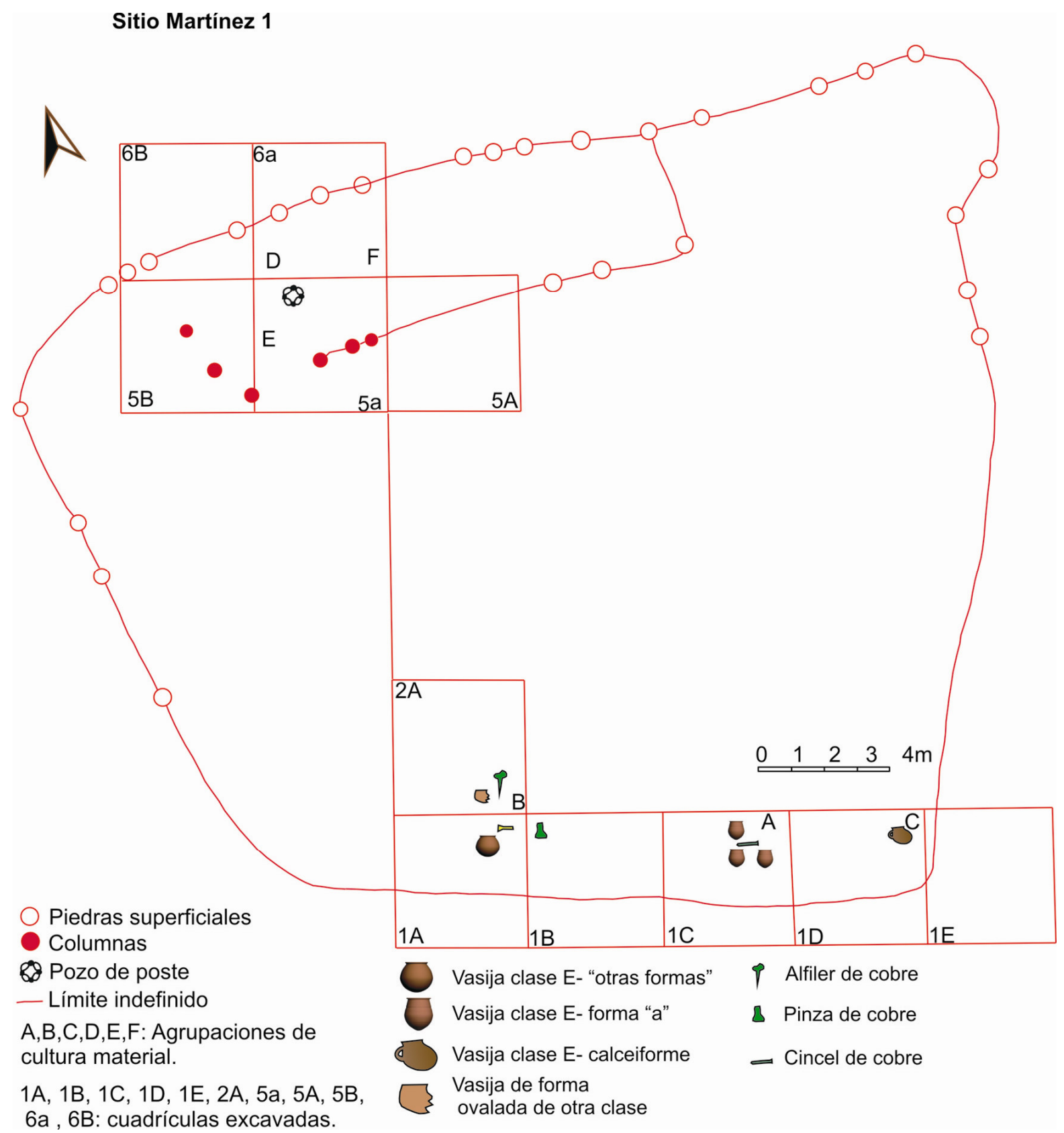

Figura 6.9: sitio Martínez 1. Existe una mayor descripción de contextos, particularmente los de la habitación techada-cuadrículas 6a, 6B, 5a, 5B-más adelante. 
En el recinto $\boldsymbol{H}$ del sitio Piedras Blancas fue encontrada una estructura que podría estar vinculada a la elaboración de cerámica. Por sus relaciones estratigráficas -cortada por un elemento interfacie horizontal (ver anexo 2)- y su asociación de materiales, es probable que haya sido construido durante el período Formativo, y que posteriormente haya sido cortado para construirse el recinto en cuestión. Se trata de un pozo de forma subcircular de unos 0,7 de diámetro y $0,50 \mathrm{~m}$ de profundidad -figura 6.10-. Una vez excavado el sedimento que lo rellenaba, en el que no apareció ningún hallazgo, se observaron remanentes de varias capas de arcillas superpuestas. Estas capas indicaban procesos sucesivos de depositación y extracción de una mezcla acuosa de arcilla y agua, pudiendo conformar un lugar de mezcla de las arcilla/as utilizadas. Muy cercanos a este pozo, se hallaron otros dos pozos más pequeños que contenían una mezcla de arena gruesa, cuarzo y mica molidos en distintos tamaños, típicos antiplásticos utilizados en varias clases de cerámicas tanto del Período Formativo como del Período de Integración Regional, lo que nos informaría sobre posibles formas de realizar el preparado de la arcilla, que podría corresponder al que se utilizó y perduró durante ambos períodos.

Recapitulando lo expuesto hasta aquí, vemos que las dos clases tecnológicas analizadas son representativas de 'formas de hacer' con una larga temporalidad en el valle -inclusive la clase E aumenta su representatividad notablemente- mientras que otras desaparecen. En el caso de la clase A1, si bien se sigue produciendo de la misma forma, se le incorporan modificaciones, apareciendo en su superficie exterior los motivos iconográficos típicos del estilo Aguada. Con respecto a las arcillas utilizadas para confeccionar ambas clases, se utiliza una mezcla de arcilla roja con una proporción de arcilla blanca. Para el caso de la clase E, probablemente estas arcillas fueran extraídas de canteras locales, aunque falta realizar análisis de INAA. Estas canteras forman parte de las barrancas de los arroyos que circulan por el valle, en sectores donde afloran relictos de rocas sedimentarias del terciario y sedimentos del cuaternario. El acceso a estas canteras no habría sido restrictivo, o al menos no se trató de una restricción demarcada materialmente. En relación a la Clase A1, hasta el momento no han aparecido fuentes de arcilla al interior del valle que se correlacionen con los estudios de INAA. Existe un grupo de alta homogeneidad, probablemente producido con arcillas provenientes de una sola fuente, aunque también existen grupos provenientes de otras fuentes. A su vez, este grupo con alta homogeneidad aparece representado fuera del valle: hacia el noreste en la zona de Alberdi -Tucumán-, al sureste al pie de la serranía del Ancasti y al suroeste en la Quebrada del Tala, donde ésta desemboca en el valle central de Catamarca, lo que nos mostraría cierta 


\section{Recinto H de Piedras Blancas}
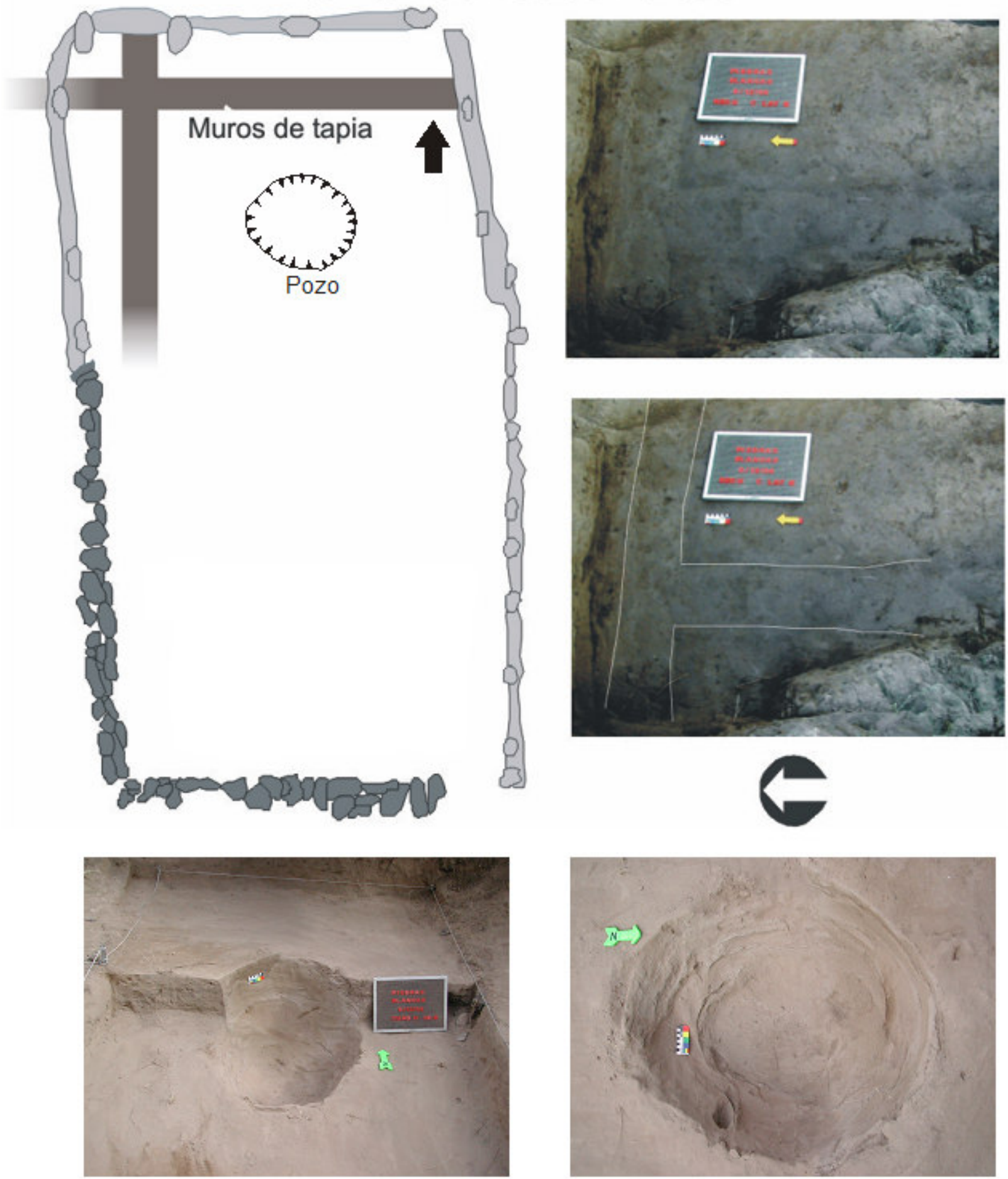

Figura 6.10: las dos fotos inferiores muestran la estructura que habría sido utilizadas para mezclar las arcillas. Obsérvese las capas de arcillas sucesivas que muestran episodios recurrentes de extracción de una mezcla de arcilla y agua. En las dos fotos de la derecha se observan las paredes de tapia de la ocupación anterior cortada por el recinto $\mathrm{H}$. El plano de la izquierda muestra la ubicación de la estructura con respecto a los muros de tapia.

interacción social entre estas regiones. Según los datos de INAA obtenidos hasta el momento, estos objetos se vinculan más a los sectores sureste y noreste del Valle, en tanto que la mayor representatividad en las muestras de estos lugares la posee el grupo de referencia de Ambato. A su vez, aunque falte confirmación, el grupo de referencia posee vinculaciones con una cantera de arcilla ubicada al noroeste del valle, al pie del cerro 
Aconquija, en Potrero de Santa Lucía. No conocemos si los objetos provendrían ya confeccionados desde este lugar o si por el contrario la arcilla de esta fuente fue requerida por los habitantes del valle de Ambato. Se han hallado objetos del clásico estilo Aguada de Ambato en lugares muy distantes del valle y de las fuentes mencionadas, como en el caso del sitio Tebenquiche Chico, en la Puna de Atacama (Granizo 2001).

A pesar de existir varias posibilidades en cuanto a la proveniencia de las arcillas y/o los lugares de fabricación de la cerámica, tenemos por el contrario cierta homogeneidad en los proceso de producción, con ciertas arcilla más utilizadas que otras -como las que se usan en el grupo de alta homogeneidad y en la utilización de arcillas rojas y blancas- y en la estandarización de algunos tipos de formas (Laguens y Juez 1999, Fabra 2008). Recordemos la reducción de la variabilidad de clases observadas por Fabra (2008) en el paso del Período Formativo al Período de Integración Regional, lo que quizás nos esté indicando que estas "formas de hacer" con una larga temporalidad se transforman en "más deseadas" que otras. Sin embargo también en el mismo espacio social circulan objetos fabricados con arcillas que no pertenecen al grupo homogéneo de Ambato, tal como los objetos de Martínez 3, que nos permiten entrever la convivencia de "formas de hacer" variadas aunque con una tendencia a predominar algunas más que otras.

Focalicemos ahora en nuestra unidad de análisis, las vasijas de las clases tecnológicas A1 y E. La muestra analizada se compone de 95 piezas enteras y 521 fragmentadas -en las que se incluyen desde piezas con alto grado de completitud hasta fragmentos que cumplen la condición de caso señalada en el capítulo tres-. Si repartimos estos valores según la clase tecnológica, tenemos que de las 95 piezas enteras analizadas, $69(72,63 \%)$ pertenecen a la clase A1, y $26(27,37 \%)$ a la clase E. En el caso de las fragmentadas, $317(60,84 \%)$ pertenecen a la clase A1 y $204(39,15 \%)$ a la clase E. Es decir que en total entre vasija enteras y fragmentadas con respecto a las clases tecnológicas tenemos 230 de la clase E y 386 de la clase A1.

\section{Vasijas de clase $\mathbf{E}$ :}

\section{Preparado de la pasta:}

En el caso de la clase tecnológica E, las arcillas rojas y blancas aparecen combinadas, con un antiplástico compuesto de arena, cuarzo y mica. En general, la 
densidad de antiplástico es alta -de 30 a 50\% de la superficie (Fabra 2008)-, al igual que las cavidades -de 30 a 50\% de la superficie (Fabra 2008)-. Estas últimas son de tamaño pequeño a mediano. Al interior de esta clase, se pueden distinguir cinco tipos de mezclas distintas -figura 6.11-. La diferencia entre estas solo está dada por el tamaño de los antiplásticos utilizados -mica y cuarzo- y, en una de ellas, además, por la cantidad relativa de mica:

a) Mezcla 1 -subclases E1 y E4-: en la que se usó antiplástico molido de tamaño grande (figura 6.11).

b) Mezcla 2 -subclase E3- donde se utilizó un antiplástico molido de tamaño variado -pequeño, mediano y grande- (figura 6.11).

c) Mezcla 3 donde se utilizó un antiplástico molido de tamaño también variado pero más grande -pequeño, mediano, grande y muy grande- (figura 6.11).

d) Mezcla 4 -subclases E5 y E6- donde se usó antiplástico molido de tamaño pequeño y mediano (figura 6.11).

e) Mezcal 5 -subclase E2- donde se utilizó antiplástico molido de tamaño mediano y pequeño al igual que la mezcla 4 , aunque con mayor cantidad de mica que el resto (figura $6.11)$.

En cuanto a los porcentajes de cada tipo de mezcla, las que poseen mayor representación son la Mezcla 1 y la Mezcla 5 con 45,45\% y 31,10 \% ( $\mathrm{n}=230)$ respectivamente. El resto apenas llega a sobrepasar el 10\% (ver gráfico 6.1).

El preparado de la pasta se podría describir de la siguiente manera: primero, desde los sitios donde se las fabricaba -sitios residenciales de tamaño pequeño, medianos y grandes: Martínez 1, Martínez 2, Martínez 4-, los artesanos irían a recoger las arcillas blanca y roja a las fuentes que se hallan en las barrancas. También se dirigirían a buscar cuarzo y mica en las canteras ubicadas en los faldeos de la sierra del Ambato, desde donde volverían a los sitios para empezar el proceso de fabricación. Teniendo en cuenta los hallazgos del recinto $\mathrm{H}$ del sitio Piedras Blancas, probablemente se procedía a mezclar las arcillas en un pozo, colocando mayor cantidad de arcilla roja que blanca. Mientras tanto el cuarzo y la mica se molía en por lo menos cuatro medidas de tamaño relativo: pequeño, mediano, grande y muy grande, que se almacenaban en distintos pozos ubicados en las 


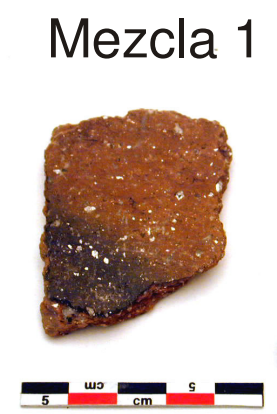

\section{3}

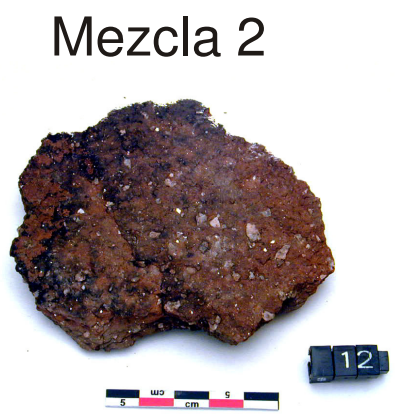

\section{Mezcla 5}

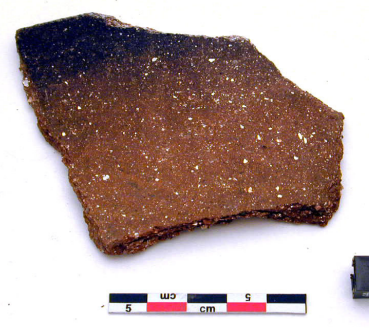

111

Figura 6.11: variedad de pastas con las que se fabrican las vasijas de clase E.
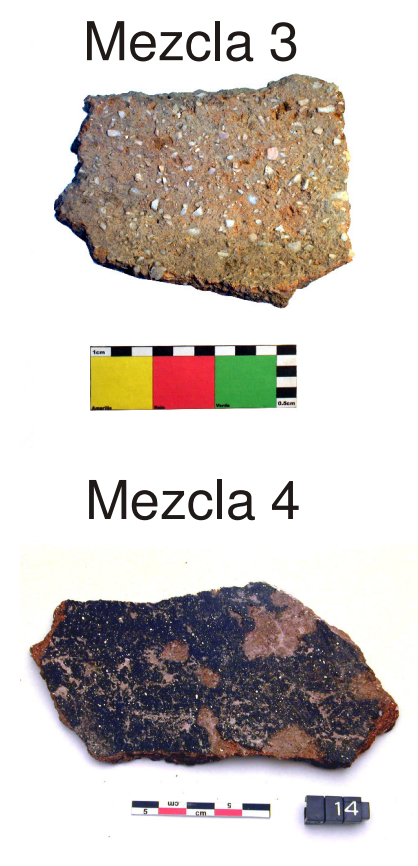

Porcentaje por tipos de mezcla según tamaño y densidad del antiplástico

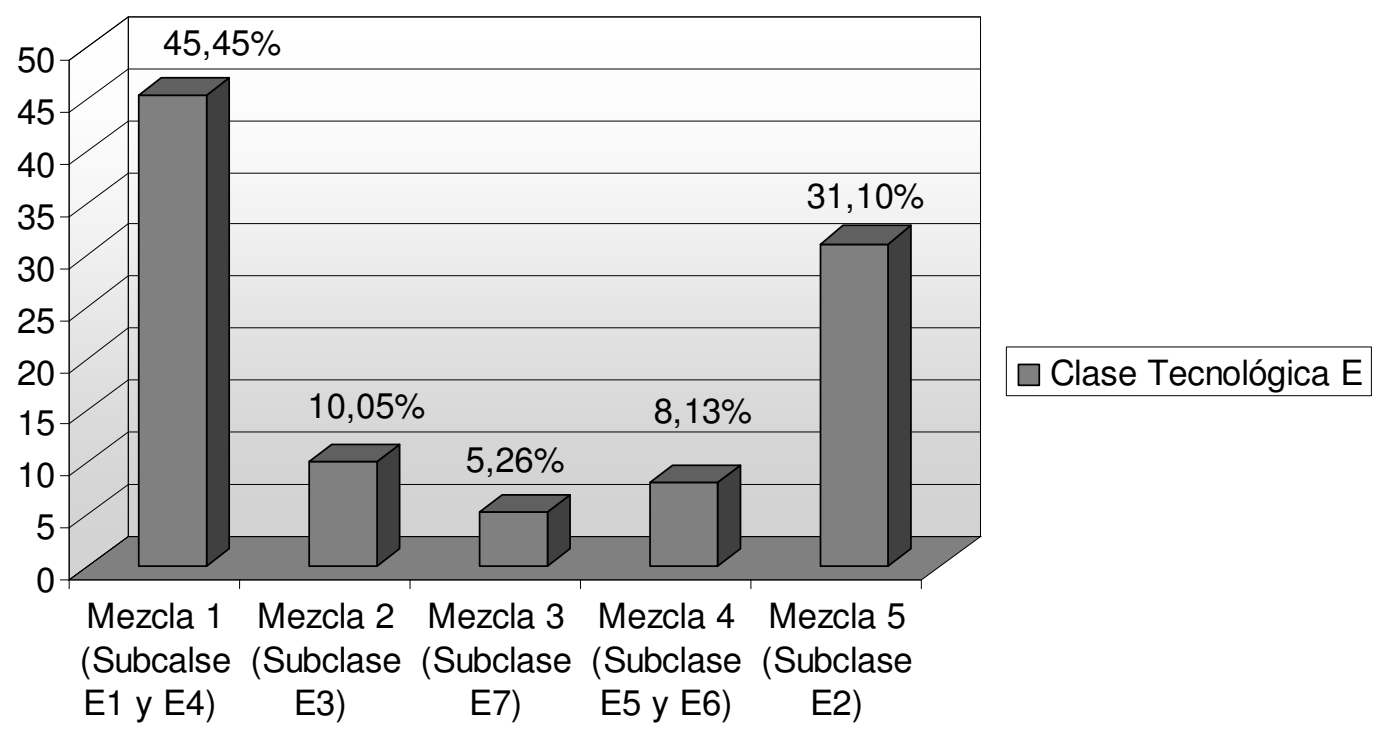

Gráfico 6.1: porcentaje de representación de las diferentes mezclas en la clase E. se preparaba la arcilla. Luego el antiplástico molido, junto con un poco de arena, se mezclaba en diferentes proporciones con las arcillas para realizar, por lo menos, cinco mezclas distintas, lo que da comienzo a la bifurcación de las trayectorias de las futuras vasijas. También existe la posibilidad de que distintas vasijas sean fabricadas con distintas mezclas. Además, con esta variedad de mezclas se fabricaban al menos siete clases de formas (figura 6.12), que podían adquirir diferentes tamaños y tratamientos, siendo algunas decoradas y otras no. 
Forma "a"
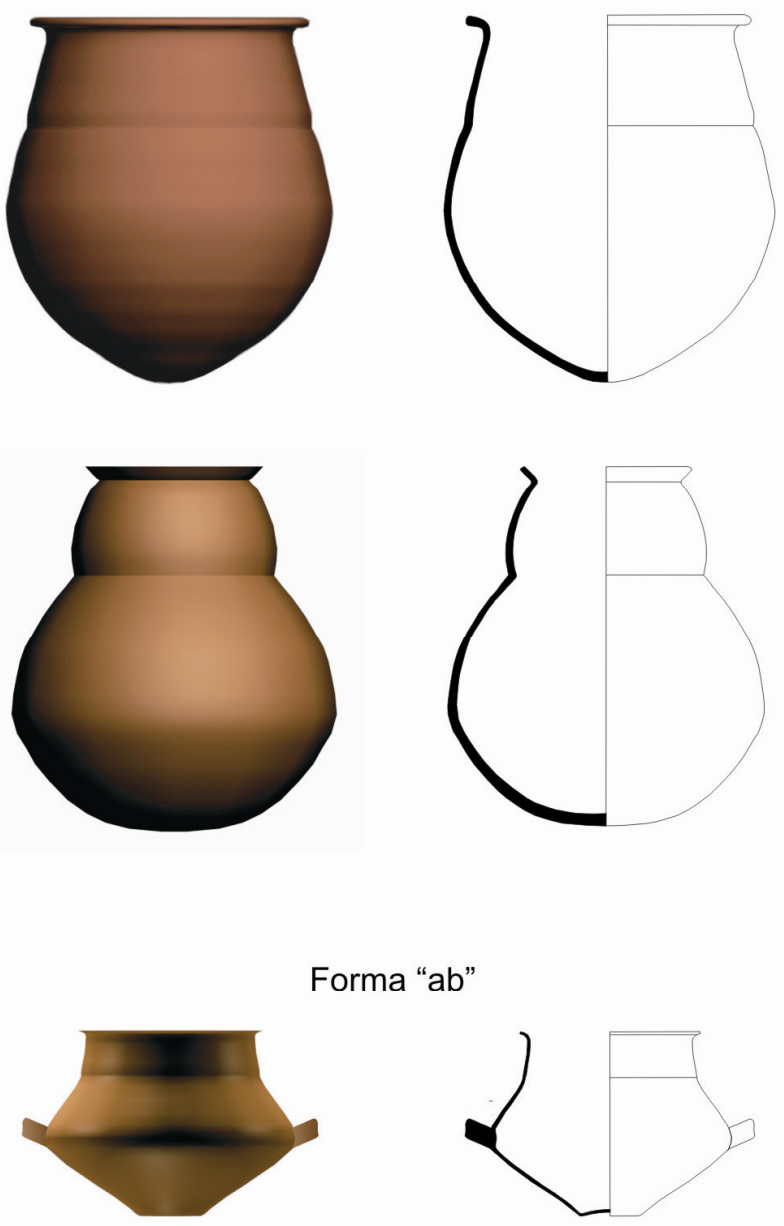

Forma "ab"

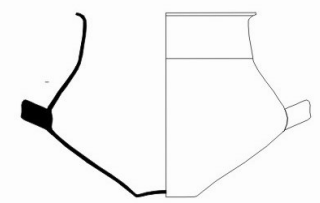

Calceiforme

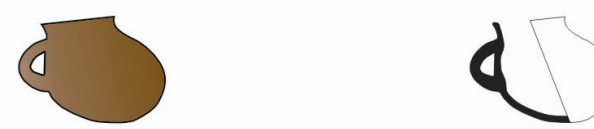

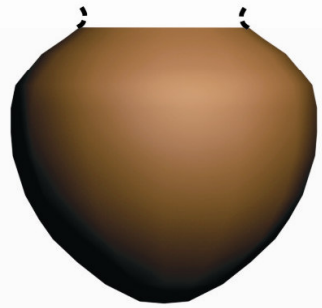
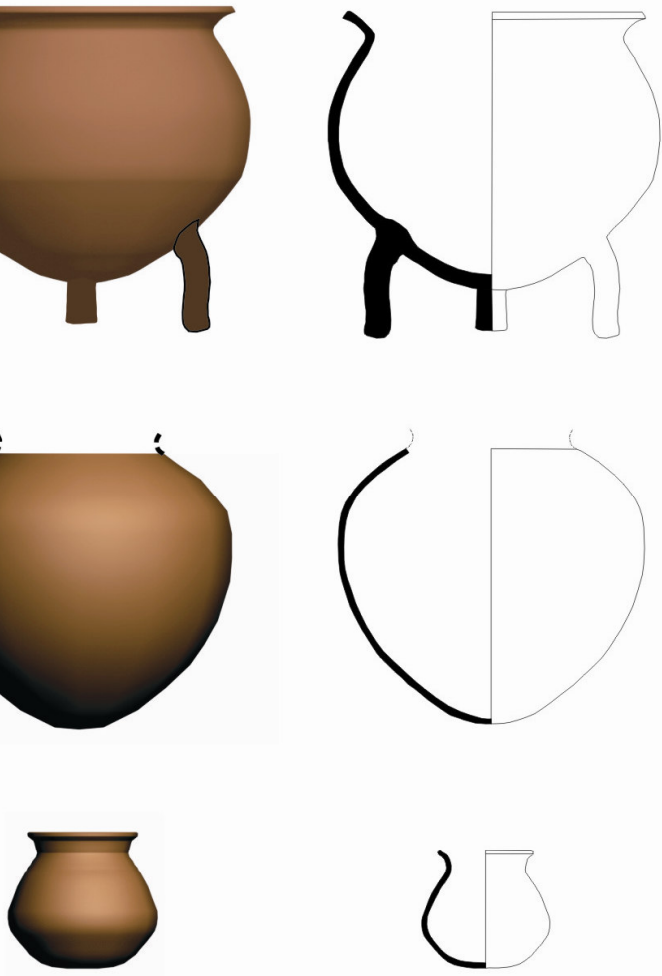

Vasos o Jarras
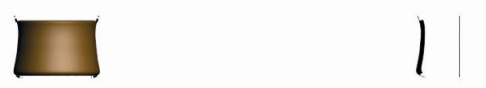

"otras formas"
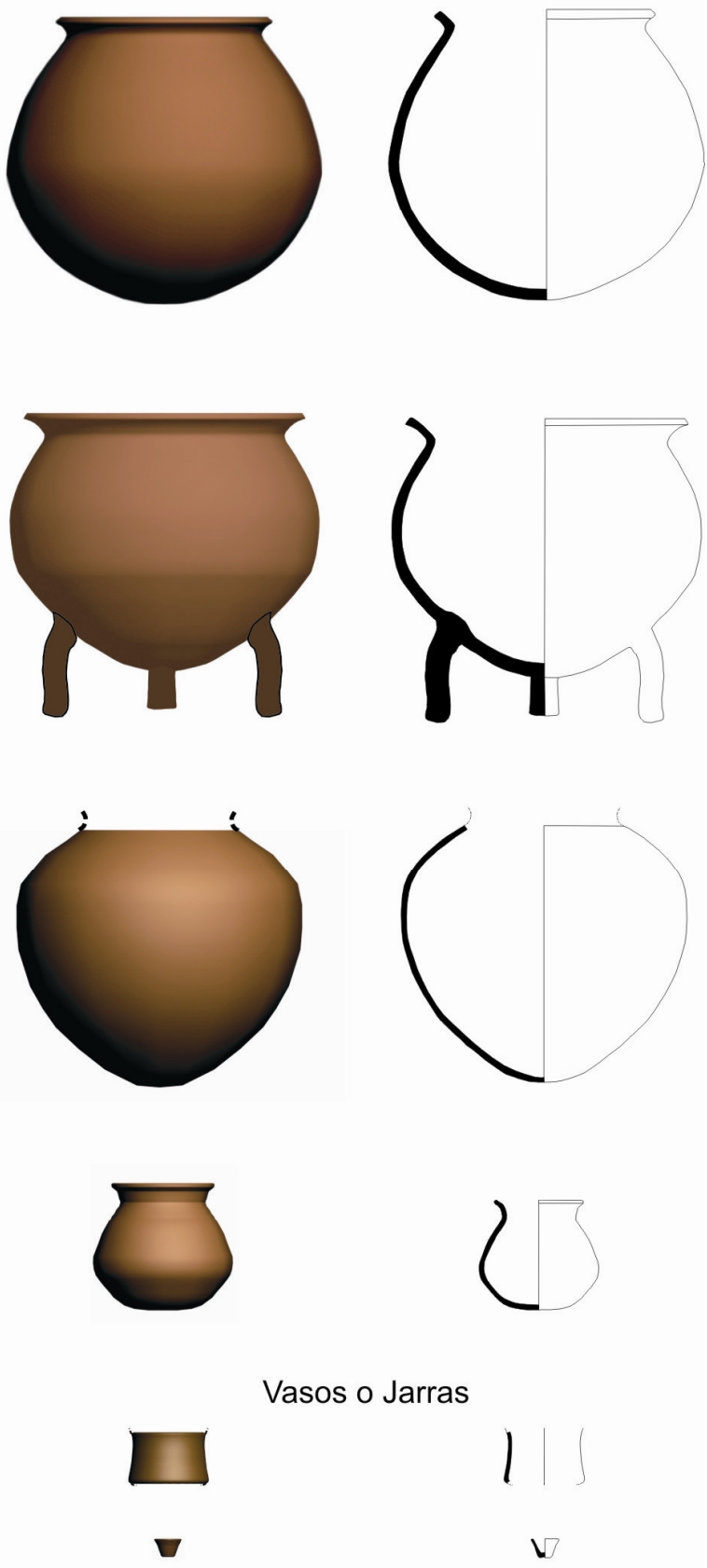

Restringida compuesta

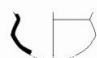

Figura 6.12: variedad de formas dentro de la clase E 


\section{Dándoles Forma}

De las siete formas identificadas para la clase $\mathrm{E}$, seis se corresponden con las clasificaciones realizadas para el valle por Bedano et al (1993) y Zaburlín (2001), y una corresponde a nuevas identificaciones.

Forma “a” (sensu Bedano et al 1993): se trata de vasijas restringidas de contorno compuesto o inflexionado, con sección inferior subglobular de base cónica y una superior subcilíndrica, de paredes convergentes o subtroncocónicas de paredes convergentes. Poseen puntos angulares en la separación cuerpo y cuello, o puntos de inflexión. Esto hace que en algunas de las vasijas, la sección superior quede sobresaltada. Poseen el labio recto y no tienen asas.

Forma "ab" (sensu Bedano et al 1993): son vasijas restringidas de contorno complejo, con una sección inferior subtroncocónica, separada por un punto angular de una intermedia subglobular, esta última separada de la sección superior por otro punto angular. La sección superior es de forma subcilíndrica de paredes convergentes. En la parte media se hallan ubicadas dos asas acintadas en forma de semianillo horizontal remachadas a la pieza. Al igual que la forma "a" el labio es recto. Las bases de estas vasijas son cóncavo-convexas.

Calceiformes: vasijas restringida de contorno inflexionado, con un asa de forma de semianillo vertical remachada, localizada en uno de los lados. La boca de estas vasijas se ubica en el costado donde se inserta el asa, el labio es redondeado. Poseen bases convexas.

Vasijas restringidas subglobulares de cuello evertido (de ahora en más las llamaremos "otras formas"): como su nombre lo indica son vasijas restringidas subglobulares de cuello evertido y labio recto o redondeado, que pueden presentar asas horizontales o verticales remachadas. Poseen un punto de inflexión que separa el cuello del cuerpo. Las bases recuperadas poseen formas más cónicas y también convexas. Algunas son tetrápodas.

Platos: vasija de contorno no restringido simple, de paredes rectas divergentes, labio recto o redondeado y base cóncavo-convexa o cónica. 
Vasos o jarras: vasijas subcilíndricas de forma no restringida de paredes rectas divergentes, de base plana o cóncava-convexa.

Vasija restringida compuesta dependiente de borde evertido: pose un punto angular que separa la parte media de la superior. Al tener solo un caso sin base, no conocemos su forma.

En relación a la representatividad de estas formas al interior de la clase E, la que posee mayor representación es la forma "a" con un 38,42\%. Luego le sigue la forma "restringida subglobular de borde evertido" (de ahora en más "otras formas") con 25,26 \%; los "platos" con el 20,52\%; la forma "ab" con 8,94\%; las "calceiformes" con 6,31\%, y el resto de las formas que no llegan al $1 \%$ en tanto solo poseemos un solo ejemplar de cada una -figura 6.13-. Estos porcentajes pueden ajustarse si representamos en el mismo gráfico el número mínimo de vasijas por forma. Al número mínimo de vasijas -MNV- lo estimamos calculando los porcentajes de arcos, principalmente de los bordes y de las bases. En la -figura 6.13- podemos observar los valores de porcentajes representados de los bordes y base, y su correspondientes EVE de cada uno. Para los cálculos sumamos el MNV de cada forma a las cantidades de vasijas enteras de cada forma. Los porcentajes arrojan un leve corrimiento respecto de los cálculos anteriores $-\mathrm{MNV}=50-$. En algunas formas como las vasijas calceiformes duplican su porcentaje -12,17\%-, mientras que en otras disminuyen, como es el caso de los platos, que descienden a un $12,77 \% \quad(7,75 \%$ menos).

Para la fabricación de algunas de estas formas -gráfico 6.2- se utiliza un sólo tipo de mezcla -como en el caso de las vasijas calceiformes que son fabricadas con la mezcla 5 $(n=12)$-. Otras formas son realizadas con variedades de mezclas: en el caso de la forma "a" se hallan representadas las cinco mezclas aunque predomina la mezcla 1 con un porcentaje de $61 \%(\mathrm{n}=74)$. En el caso de la forma "ab" tiene predominancia las mezclas $1-35,29 \%$ - y la $5-41,17 \%$ - $(\mathrm{n}=17)$. En el caso de los platos predomina la mezcla 2 -38\%-y la mezcla 1 $30,70 \%-(n=39)$. Con respecto a las formas subglobulares restringidas de cuello evertido hay un predominio de las mezclas 1 y 2 con 52,08\% la primera y 43,75\% la segunda $(\mathrm{n}=48)$. Los dos vasos o jarras pertenecen a la mezcla 4 y la vasija restringida compuesta dependiente de borde evertido pertenece a la mezcla 1.

Por lo que vemos hasta aquí a la hora de seleccionar una mezcla específica para confeccionar la vasija interviene, en algunos casos, la forma que se va a fabricar, específicamente en las calceiformes. En los otros casos donde se hallan representadas las 
Forma "a"
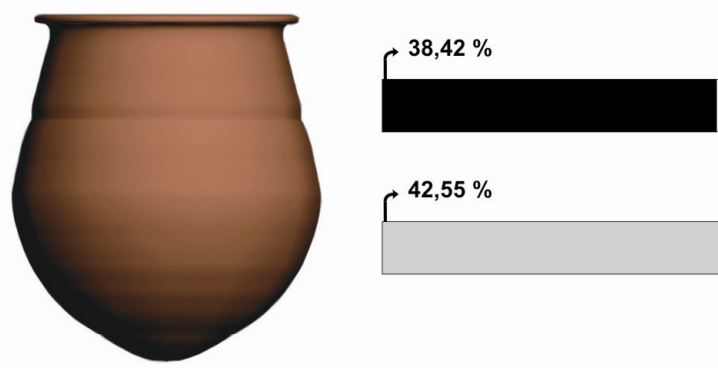

Forma "ab"
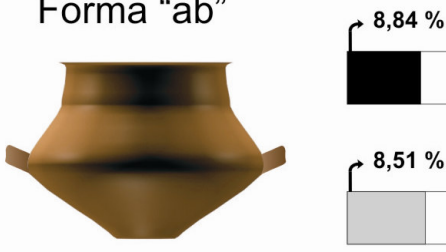

Calceiforme

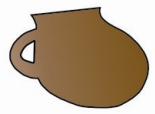

"Otras formas"
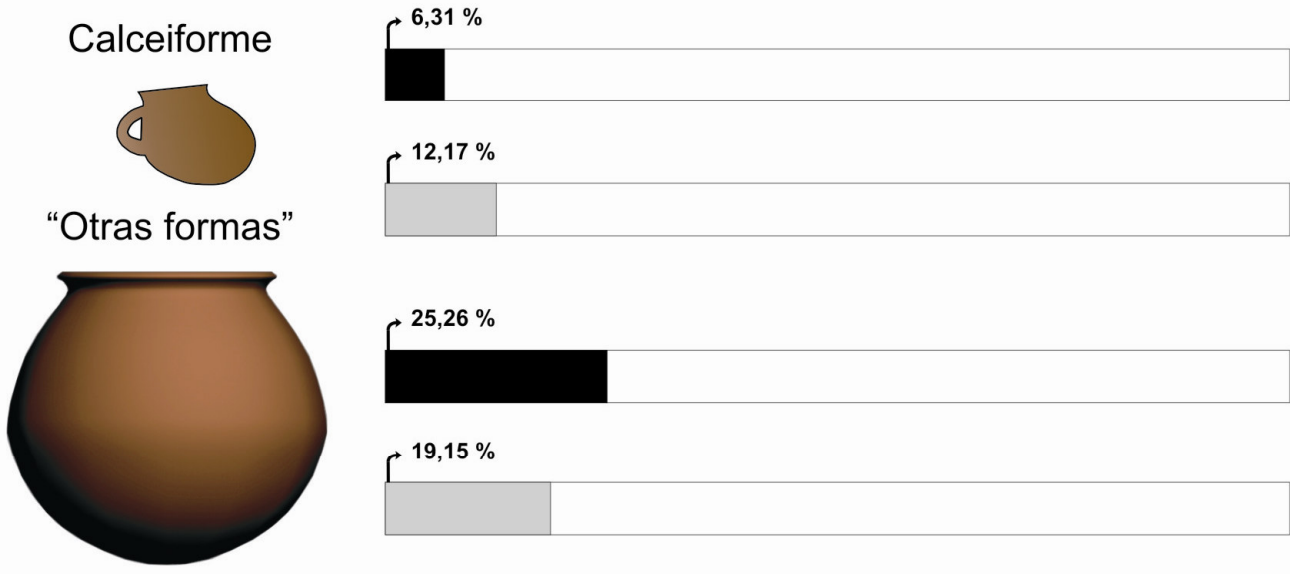

$19,15 \%$

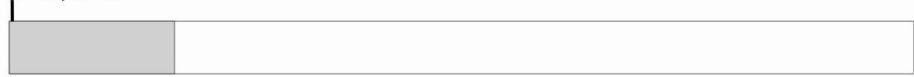

Platos

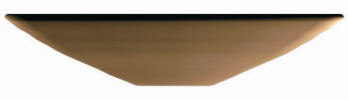

$12,77 \%$
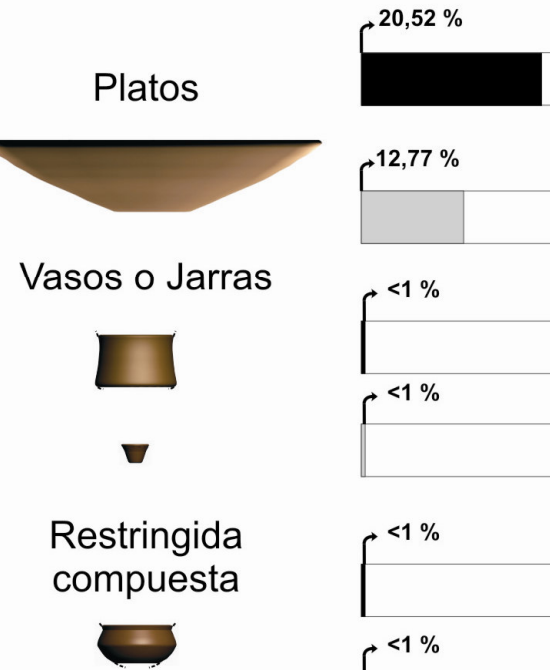

$$
\overbrace{}^{<1 \%}
$$

\section{$<<1 \%$}
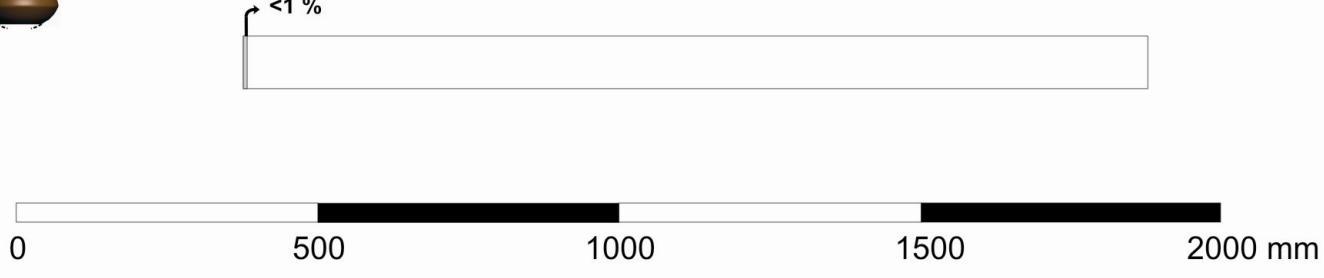

Porcentaje de formas de la clase $\mathrm{E}$ (sumando enteras y fragmentadas sin cálculo de NMV)

Porcentaje de formas de la clase $E$ (sumando enteras y cálculo de NMV)

Figura 6.13: porcentajes de cada forma en la clase E. El n es de 193 y el NMV total es de 50 
cinco mezclas, aunque predominando casi siempre una o dos de ellas, la forma no estaría interviniendo. A continuación, veremos que otras variables vinculadas a parámetros formales como el tamaño -altura de la vasija, diámetro máximo de la vasija, relación altura/ancho de la vasija, espesores de muros- pueden influenciar a la hora de seleccionar alguna de estas mezclas.

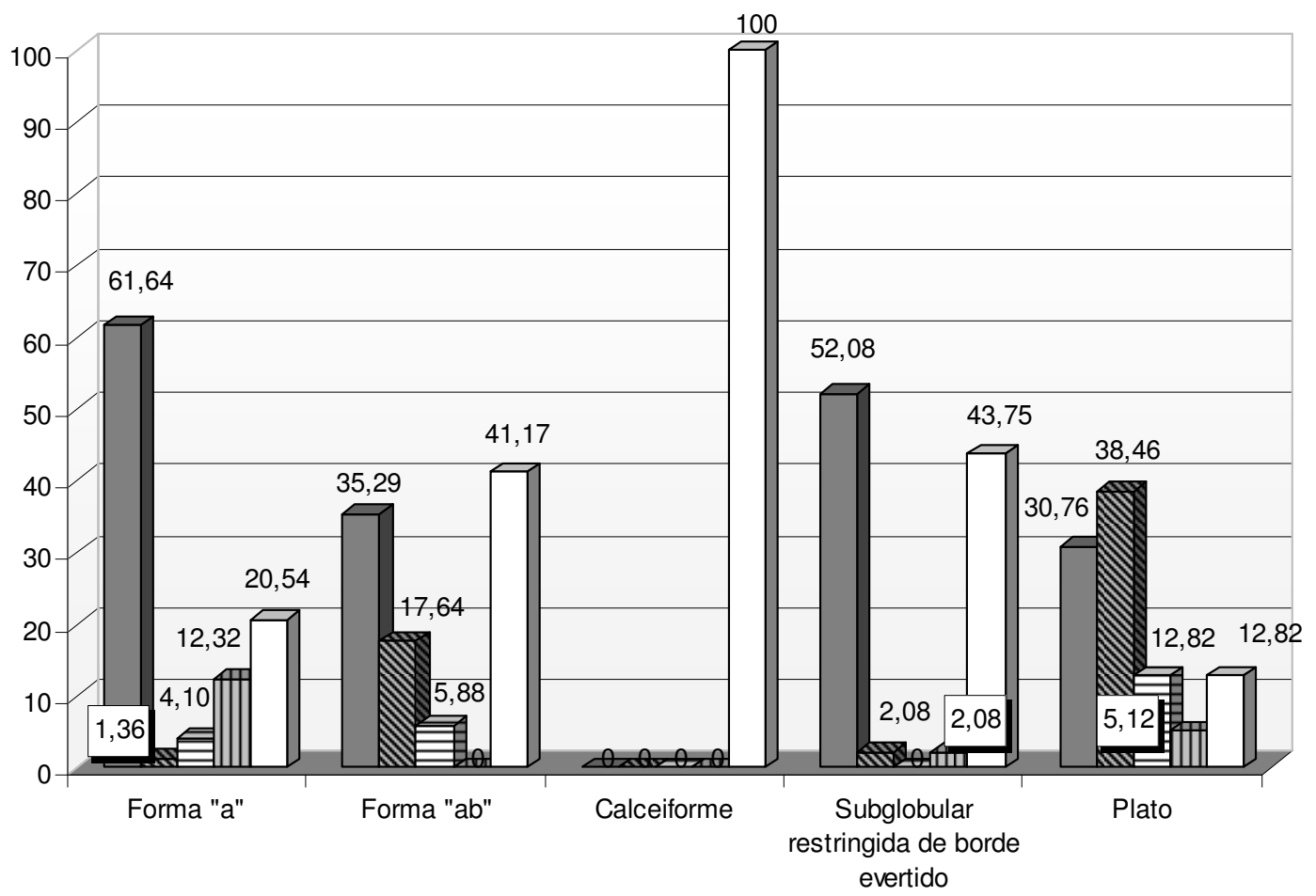

Gráfico 6.2: porcentajes de cada mezcla al interior de las distintas formas (n=192). La vasija restringida compuesta al ser sólo un ejemplar no fue incorporada al gráfico pertenece a la mezcla 1.

Altura. En el gráfico 6.3 podemos observar que las alturas, sin tener en cuenta la forma, se reparten diferencialmente entre las distintas mezclas. La que posee mayor altura es la mezcla 4 , siguiéndole la 1 , luego la 2 , la 5 y por último la 3 . Los diagramas de caja muestran que al interior de cada mezcla existe cierta variabilidad. Vemos solo un valor outlayer en la mezcla 1. Existe una superposición entre las mezcla 1 y 4 en el rango de valores que van de $525 \mathrm{~mm}$ a $550 \mathrm{~mm}$. Si observamos las medianas de cada una de las mezclas -que dividen la mitad de los valores para arriba y la mitad de los valores para abajo- vemos que en la mezcla 4 es bastante más elevada que en la mezcla 1, poseyendo esta última la mitad de los valores por encima de $705 \mathrm{~mm}$, mientras que la mezcla 1 los posee por encima de los $514 \mathrm{~mm}$. A su vez, la diferencia entre el umbral superior -pared superior de la caja- y la mediana -línea transversal- en la mezcla 4 es mucho más pequeña que la diferencia entre el umbral inferior y la mediana. Esto nos indica que en la mezcla 4, los valores superiores a la mediana están bastante cerca, entre los 700 y los $750 \mathrm{~mm}$. En el caso de la mezcla 1 los valores se hallan más distribuidos pero la diferencia entre el umbral 
superior y la mediana es menor en valores superiores a ésta, concentrándose los casos entre los $514 \mathrm{~mm}$ y los $575 \mathrm{~mm}$. La mezcla 1 a su vez comparte un rango de altura con la mezcla 2 entre los $425 \mathrm{~mm}$ y los $450 \mathrm{~mm}$, pero las medianas son bastante diferentes.

En la mezcla 2 es de 297 mm, estando repartidos de manera bastante homogénea, en tanto que las diferencias entre la mediana y el umbral superior e inferior son casi idénticas. La mezcla 2 comparte, en mayor medida, un rango de altura con la mezcla 5, en tanto que esta última se encuentra comprendida por las mezcla 2 en el intervalo que va de los 175 $\mathrm{mm}$ a los $350 \mathrm{~mm}$, salvo por los valores extremos -aún dentro de una dispersión centralde la mezcla 5 , que alcanza los $550 \mathrm{~mm}$ y $\operatorname{los} 75 \mathrm{~mm}$. En cuanto a la mediana de la mezcla 5 , está en los $253 \mathrm{~mm}$ siendo las diferencias entre la mediana y los umbrales superiores e inferiores casi iguales. La mezcla 3 no comparte ningún intervalo de altura con las otras, estando la mediana en $32 \mathrm{~mm}$ de altura.

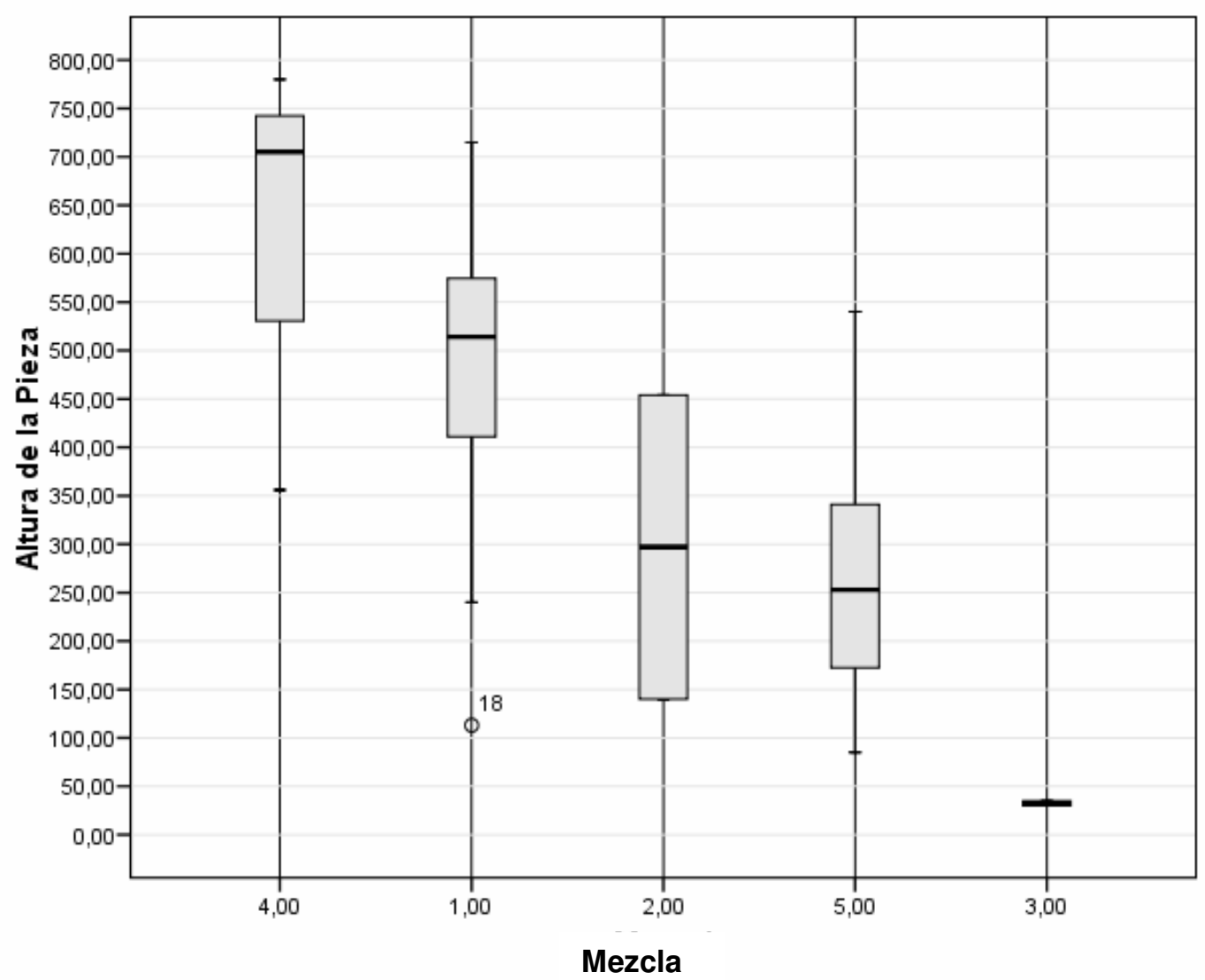

Gráfico 6.3: de tallo y hoja donde se comparan la altura de las vasijas analizadas de clase E y la mezcla. Obsérvese que la mezcla 4 y 1 son las que alcanzan mayores alturas, mientras que las mezclas 5 y 3 poseen las menores alturas. La mezcla 2 se encuentra en el medio compartiendo en mayor medida con la mezcla 5 . El $\mathrm{n}=37$. 
Es decir, existe cierta tendencia a utilizar la mezcla 4 por encima de los $550 \mathrm{~mm}$ de altura, y especialmente cuando son mayores a $700 \mathrm{~mm}$. Hay que resaltar que existen valores extremos -aún dentro de una dispersión central- de la mezcla 1 en este rango de alturas, aunque es ocasional. Entre los $525 \mathrm{~mm}$ y $575 \mathrm{~mm}$ se utilizan de forma alternativa la mezcla 1 y 4, siendo más frecuente la utilización de la mezcla 1. Por debajo de los 550 y hasta los $450 \mathrm{~mm}$ se utilizaría la mezcla 1. Pero también tenemos ocasionalmente casos extremos del uso de la mezcla 5 en este rango. Por debajo de estas medidas, hasta los 400 $\mathrm{mm}$, podrían usarse la mezcla 2 y 1 . La mezcla 1 podría ocasionalmente usarse para valores menores, en tanto que tenemos casos extremos de su uso en $250 \mathrm{~mm}$. La mezcla 2 se utilizaría en las medidas de entre 350 y $400 \mathrm{~mm}$, compartiendo con la mezcla 5 desde los $350 \mathrm{~mm}$ hasta los $175 \mathrm{~mm}$. Por debajo de este valor se utiliza también la mezcla $2 \mathrm{y}$, por debajo de los $35 \mathrm{~mm}$ se utilizaría la mezcla 3. Hay que agregar que tenemos un caso outlayer en la mezcla 1 que llega hasta los $100 \mathrm{~mm}$.

Al aplicar un test ANOVA para determinar la significatividad de estas diferencias test que permite comparar varias muestras y es muy potente para variables numéricas de escala como la que manejamos- a un nivel de significación del 95\% vemos que: el valor de significación a nivel inter-grupo e intra-grupo es 0,00, por lo que, al ser menor que 0,05, nos informa que existen diferencias entre los grupos, pero no nos dice entre qué grupos. Un test que nos puede indicar éstas diferencias, es la prueba de comparación múltiple de Bomferroni: en la tabla 6.4 si observamos los límites superiores e inferiores del intervalo de confianza veremos números negativos y positivos. Los grupos difieren al no encontrarse el 0 entre esos valores. Así, vemos que cuando comparamos la mezcla 1 con las demás, ésta difiere con las mezclas 3 y 5, mientras que no lo hace con las mezclas 2 y 4 . La mezcla 2 no difiere de ninguna. En el caso de la mezcla 3, difiere de la 1 y la 4, no haciéndolo de la 2 y la 5 . La mezcla 4 no difiere de la 1 y 2 pero sí de la 3 y 5 . Por último, la mezcla 5 difiere de la 1 y no de la 2, 3 y 4 . La mezcla 2 es la que presenta relaciones con todas las mezclas en relación a la altura. Es decir que podemos confirmar que las mezclas 4 y 1 se utilizan para las vasijas de mayor altura. La mezcla 2 ocupa el rango más variables de todas, y las mezclas 3 y 5 se vincularían a piezas de menor altura.

Diámetro máximo. Se comparó el diámetro máximo por cada mezcla sin tener en cuenta la forma -gráfico 6.4-. Las mezclas 4 y 2 son las que poseen diámetros más altos, solapándose entre los $475 \mathrm{~mm}$ y los $600 \mathrm{~mm}$. La mezcla 4 posee la mediana en $600 \mathrm{~mm}$, lo que indica que posee la mitad de los valores por encima de $600 \mathrm{~mm}$ hasta los $625 \mathrm{~mm}$. La mezcla 2 


\section{Comparaciones múltiples}

Variable dependiente: Altura de la Pieza

\begin{tabular}{|c|c|c|c|c|c|c|}
\hline \multirow[b]{2}{*}{ I) Mezcla } & \multirow[b]{2}{*}{ J) Mezcla } & \multirow[b]{2}{*}{$\begin{array}{l}\text { Diferencia de } \\
\text { medias (لل-ال-ل }\end{array}$} & \multirow[b]{2}{*}{ Frror típico } & \multirow[b]{2}{*}{ Sig. } & \multicolumn{2}{|c|}{$\begin{array}{c}\text { Intervalo de confianza al } \\
95 \%\end{array}$} \\
\hline & & & & & Límite inferior & $\begin{array}{l}\text { Límite } \\
\text { superior }\end{array}$ \\
\hline \multirow[t]{4}{*}{1} & 2 & 178,94737 & 115,25258 & 1,000 & $-168,5333$ & 526,4280 \\
\hline & 3 & $443,44737^{*}$ & 115,25258 & ,005 & 95,9667 & 790,9280 \\
\hline & 4 & $-137,71930$ & 96,31784 & 1,000 & $-428,1127$ & 152,6741 \\
\hline & 5 & $204,94737^{*}$ & 58,73816 & 014 & 27,8548 & 382,0399 \\
\hline \multirow[t]{4}{*}{2} & 1 & $-178,94737$ & 115,25258 & 1,000 & $-526,4280$ & 168,5333 \\
\hline & 3 & 264,50000 & 155,03610 & ,977 & $-202,9259$ & 731,9259 \\
\hline & 4 & $-316,66667$ & 141,52795 & ,323 & $-743,3662$ & 110,0329 \\
\hline & 5 & 26,00000 & 119,17720 & 1,000 & $-333,3132$ & 385,3132 \\
\hline \multirow[t]{4}{*}{3} & 1 & $-443,44737^{*}$ & 115,25258 &, 005 & $-790,9280$ & $-95,9667$ \\
\hline & 2 & $-264,50000$ & 155,03610 & ,977 & $-731,9259$ & 202,9259 \\
\hline & 4 & $-581,16667^{*}$ & 141,52795 & ,003 & $-1007,8662$ & $-154,4671$ \\
\hline & 5 & $-238,50000$ & 119,17720 &, 539 & $-597,8132$ & 120,8132 \\
\hline \multirow[t]{4}{*}{4} & $\overline{1}$ & 137,71930 & 96,31784 & 1,000 & $-152,6741$ & 428,1127 \\
\hline & 2 & 316,66667 & 141,52795 & ,323 & $-110,0329$ & 743,3662 \\
\hline & 3 & $581,16667^{*}$ & 141,52795 & ,003 & 154,4671 & 1007,8662 \\
\hline & 5 & $342,66667^{*}$ & 100,98105 & 019 & 38,2140 & 647,1194 \\
\hline \multirow[t]{4}{*}{5} & 1 & $-204,94737^{*}$ & 58,73816 &, 014 & $-382,0399$ & $-27,8548$ \\
\hline & 2 & $-26,00000$ & 119,17720 & 1,000 & $-385,3132$ & 333,3132 \\
\hline & 3 & 238,50000 & 119,17720 &, 539 & $-120,8132$ & 597,8132 \\
\hline & 4 & $-342,66667^{*}$ & 100,98105 & 019 & $-647,1194$ & $-38,2140$ \\
\hline
\end{tabular}

${ }^{*}$. La diferencia de medias es significativa al nivel .05.

Tabla 6.4: prueba de comparaciones múltiples de Bonferroni. Obsérvese los límites inferiores y superiores del intervalo de confianza donde aparecen números negativos y positivos. Los distintos grupos difieren si el 0 no se encuentra entre esos valores.

posee su mediana en $510 \mathrm{~mm}$, estando la mitad de sus valores entre esta medida y los 600 $\mathrm{mm}$, siendo más amplia la distancia entre el umbral inferior y la media. Las mezclas 2 y la 4 comparten además con la mezcla 1 los valores de $480 \mathrm{~mm}$ y los $550 \mathrm{~mm}$, siendo la mediana de esta mezcla 455, existiendo distancias semejantes desde la media a los umbrales inferiores y superiores. Las mezclas 2 y 1 comparten con la 5 y 3 , los diámetros entre $375 \mathrm{~mm}$ y los $450 \mathrm{~mm}$ la primera, y de los 375 a los $425 \mathrm{~mm}$ la segunda. Hacia valores más bajos se extienden las mezclas 5 y la 3, teniendo la 3 la mitad de los valores por debajo de $200 \mathrm{~mm}$ y la 5 por debajo de $292 \mathrm{~mm}$. Si observamos las distancias entre las medias y los umbrales superiores e inferiores, la mitad de sus valores los ubica entre los 200 y $425 \mathrm{~mm}$. 


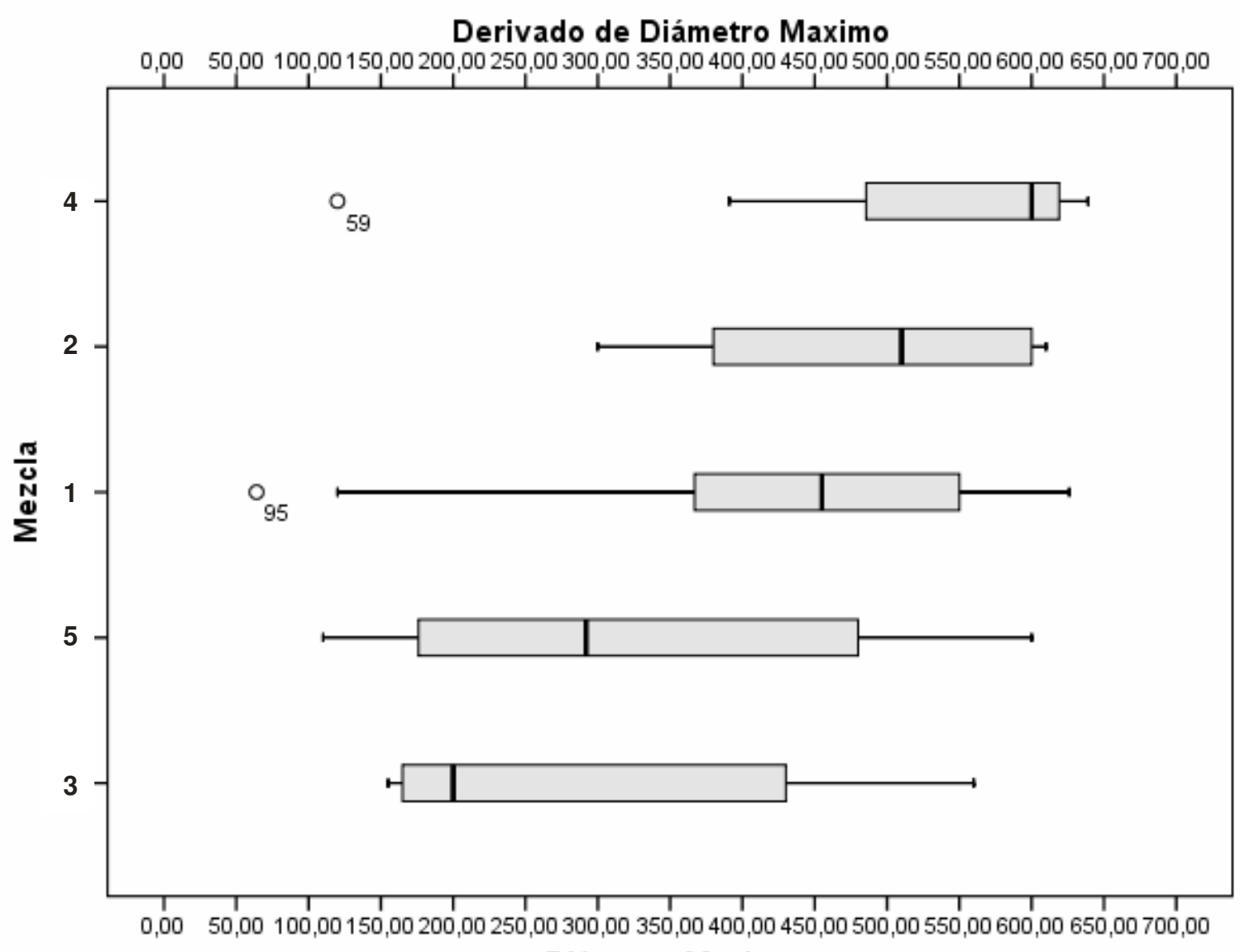

Diámetro Maximo

Gráfico 6.4: de tallo y hoja donde se comparan el diámetro máximo de las vasijas analizadas de clase E y la mezcla. Obsérvese que la mezcla 4 y 2 son las que alcanzan mayores diámetros, mientras que las mezclas 5 y 3 poseen las menores. La mezcla 2 se encuentra en el medio compartiendo en mayor medida con la mezcla 2 . El $n=96$.

Si realizamos un test de significación ANOVA con un nivel de significación del 95\%, tenemos que a nivel intra e inter grupo existen diferencias significativas -valor de significación 0,02-. Cuando realizamos comparaciones múltiples (test de Bonferroni) observamos que -tabla 6.5- la mezcla 1 no difiere de ninguna de las otras, es decir que comparte un rango de diámetros semejantes con todas. La mezcla 2 difiere de la 5, dado que la 5 tiende a valores inferiores y la 2 hacia superiores. La mezcla 3 no difiere de ninguna, por lo que, al igual que la 1, comparte con el resto el rango de diámetros posibles. La mezcla 4 difiere de la 5 probablemente por los valores menores de esta última. La mezcla 5 difiere de la mezcla 2 y 4 y no de la 1 y 3 , lo que confirma que la mezcla 5 se utiliza para especímenes de menor diámetro, la mezcla 2 y 4 para valores mayores y las mezclas 1 y 3 pueden usarse para todo el rango de valores. 


\section{Comparaciones múltiples}

Variable dependiente: Diámetro Maximo

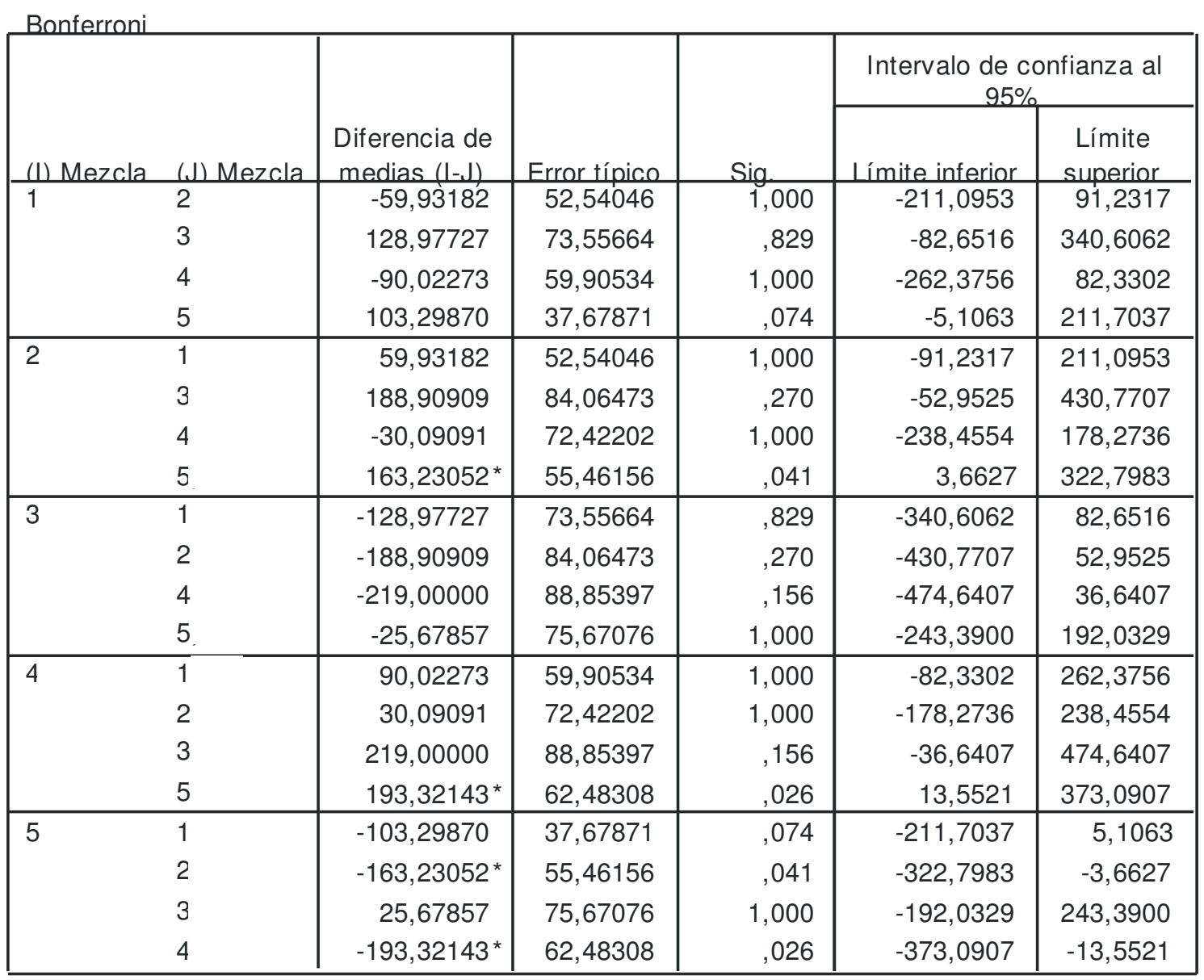

${ }^{*}$. La diferencia de medias es significativa al nivel .05.

Tabla 6.5: prueba de comparaciones múltiples de Bonferroni. Obsérvese los límites inferiores y superiores del intervalo de confianza donde aparecen números negativos y positivos. Los distintos grupos difieren si el 0 no se encuentra entre esos valores.

Altura sobre diámetro máximo. Si combinamos estos valores realizando una división entre el alto y el diámetro máximo y evaluamos su distribución entre las mezclas podríamos informarnos sobre si éstas se usan para vasijas con mayor altura que diámetro o con menor altura y mayor diámetro. Realizaremos este cálculo sobre las 37 vasijas de clase E, a las que se les ha podido medir estas dos medias.

La mezcla 1 arrojó una media de 1,09, es decir que el alto y el ancho son proporcionales, pero con cierta dispersión en tanto tiene una desviación típica de 0,21 y un máximo y mínimo de 0,67 y 1,41. La mezcla 2 se mantiene por debajo de 1 , por lo que son más anchas que altas, con una media de 0,52, una desviación de 0,32 y un mínimo y máximo de 0,28 y 0,74. La mezcla 3 posee un media de 0,24 con una desviación de 0,031 y un mínimo y máximo de 0,18 y 0,26 , por lo que las vasijas realizadas con esta mezcla 
son muy anchas y de baja altura. La mezcla 4 se comporta de manera semejante a la 1 con una media de 1,07 y una desviación de 0,157 con mínimos y máximos de 0,910 y 1,13: las vasijas realizadas con esta mezcla poseen alturas y diámetros semejantes. La muestra 5 es la que junto a la 3 presenta menos variabilidad. Su media es de 0,95 , con una desviación de 0,09 y un máximo y mínimo de 0,99 y 0,74. Es decir que las vasijas realizadas con esta mezcla son apenas más anchas que altas. De esta forma, vemos que las mezclas 4, 5 y 1 se utilizan para vasijas que poseen casi el mismo alto que ancho, mientras que las mezclas 2 y 3 se usan para vasijas de menor altura y mayor diámetro, pudiéndose utilizar en este caso también la mezcla 1.

Espesores. El otro parámetro que podría influir en la elección de una mezcla es el espesor de las paredes de las piezas. Si observamos el gráfico de caja 6.5 a simple vista se perciben algunos valores outlayer de las mezclas 5, 1 y 4 siempre hacia valores más espesos. La mezcla 1 es la que posee mayor variabilidad desde los $2 \mathrm{~mm}$ a los $16 \mathrm{~mm}$ repartiéndose los valores alrededor de la mediana $8 \mathrm{~mm}$ de igual manera. No obstante, la mayoría comparte el rango de medidas. Las medianas tienden a ser inferiores en las mezclas 5 y 2 y, superiores en las 4 y 3 .

Si aplicamos un test de significación ANOVA observamos que a un nivel de $95 \%$ nos arroja diferencias significativas a nivel intra e inter grupo -valor de significación 0,009-. Para observar donde se hallan las diferencias aplicamos como en los casos anteriores el test de comparaciones múltiple de Bonferroni -tabla 6.6- que nos señala que existen diferencias significativas entre la mezcla 5 y 4 ; no existiendo diferencias entre con respecto a las otras tres mezclas. Es de resaltar que las mezclas 4 y 5 poseen el mismo tamaño de antiplástico -mediano y pequeño-, salvo que a la 5 se le agrega mayor cantidad de mica. Las vasijas confeccionadas con ésta última mezcla tienden a tener paredes menos espesas que la 4. La mezcla 4 comparte los espesores con las otras pero en rangos más espesos que la 5. Estas diferencias podrían vinculase a que las vasijas de mezcla 4 alcanzan mayores alturas que las de la mezcla 5, por la cual necesitan un soporte estructural mayor, siendo el espesor de los muros una variable importante para lograrlo 


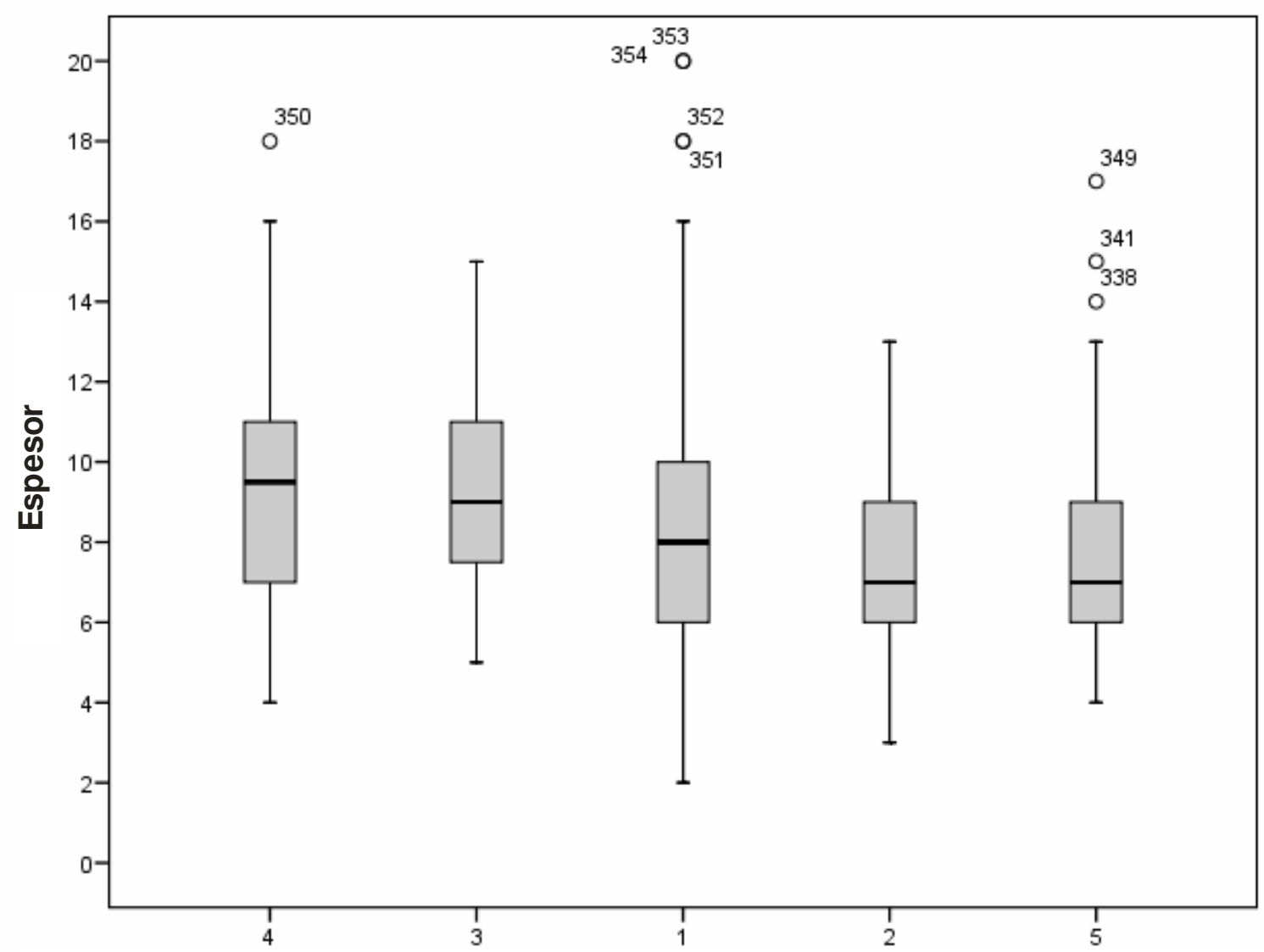

Gráfico 6.5: gráfico de caja donde se comparan los espesores de los muros de las vasijas analizadas de clase $\mathrm{E}$-sin importar la parte de la pieza considerada- y el tipo de mezcla. A simple vista nos se observan tantas diferencias. $\mathrm{N}=354$.

Según lo analizado hasta aquí para la selección de la mezcla, el tamaño de las piezas influye positivamente. Si consideramos por separado el diámetro máximo y la altura vemos que: la altura de la pieza puede jugar cierto rol en la selección de las mezclas 4 y 1 utilizadas en piezas más altas, mientras que la mezcla 2 podría utilizarse para diferentes rangos de altura, y las mezclas 3 y 5 para piezas más bajas. La mezcla 2 se utilizaría indistintamente aunque no alcanzaría valores tan altos como los de la mezcla 4 ni tan bajos como los de la mezcla 3. En cuanto al diámetro en relación a la altura, sabemos que existe cierta relación entre estas dos medidas. Cuando observamos las relaciones entre ambas, vemos que las mezclas 1, 4 y 5 se utilizan para vasijas de alto y ancho semejantes, mientras que las mezclas 2 y 3 , se usan para vasijas más anchas que altas, siendo la mezcla 3 la que presenta mayores diámetros en relación a la altura. A su vez, la mezcla 1 podría usarse en algunos casos para vasijas más anchas que altas, aunque dicha relación es menor a aquellas de las mezclas 2 y 3. Es decir, lo que tenemos aquí nos informa que la elección de las pastas puede estar influida por el tamaño de las vasijas y por las relaciones entre las alturas y los diámetros máximos, y también por determinadas formas particulares. El espesor de las paredes influye relativamente. Sólo existen diferencias entre mezclas del mismo tamaño 
de antiplástico pero una de ellas con mayor agregado de mica, tendiendo esta última a ser menos espesas que las otras. No obstante, la selección no es absolutamente restrictiva, puesto que al interior de las mezclas existe variabilidad. Sólo una forma se limita al uso de una mezcla, el de la vasija calceiforme, que utiliza la mezcla 5.

\section{Comparaciones múltiples}

Variable dependiente: Espesor

\begin{tabular}{|c|c|c|c|c|c|c|}
\hline \multirow[b]{2}{*}{ (I) Mezcla } & \multirow[b]{2}{*}{ (J) Mezcla } & \multirow[b]{2}{*}{$\begin{array}{l}\text { Diferencia de } \\
\text { medias (I-J) }\end{array}$} & \multirow[b]{2}{*}{ Error típico } & \multirow[b]{2}{*}{ Sig. } & \multicolumn{2}{|c|}{$\begin{array}{c}\text { Intervalo de confianza al } \\
95 \%\end{array}$} \\
\hline & & & & & Límite inferior & $\begin{array}{l}\text { Límite } \\
\text { superior }\end{array}$ \\
\hline \multirow[t]{4}{*}{1} & 2 & 819 &, 516 & 1,000 &,- 64 & 2,28 \\
\hline & 3 &,- 781 & ,678 & 1,000 & $-2,70$ & 1,13 \\
\hline & 4 & $-1,146$ &, 585 &, 511 & $-2,80$ &, 51 \\
\hline & 5 &, 652 & ,356 & ,677 &,- 35 & 1,66 \\
\hline \multirow[t]{4}{*}{2} & 1 &,- 819 &, 516 & 1,000 & $-2,28$ & ,64 \\
\hline & 3 & $-1,600$ & ,789 & ,434 & $-3,83$ &, 63 \\
\hline & 4 & $-1,964$ & ,712 & ,061 & $-3,97$ & ,05 \\
\hline & 5 &,- 167 &, 539 & 1,000 & $-1,69$ & 1,36 \\
\hline \multirow[t]{4}{*}{3} & 1 & ,781 & ,678 & 1,000 & $-1,13$ & 2,70 \\
\hline & 2 & 1,600 & ,789 & ,434 &,- 63 & 3,83 \\
\hline & 4 &,- 364 & ,836 & 1,000 & $-2,73$ & 2,00 \\
\hline & 5 & 1,433 & ,696 & ,401 &,- 53 & 3,40 \\
\hline \multirow[t]{4}{*}{4} & 1 & 1,146 & , 585 &, 511 &,- 51 & 2,80 \\
\hline & 2 & 1,964 & ,712 &, 061 &,- 05 & 3,97 \\
\hline & 3 & ,364 & ,836 & 1,000 & $-2,00$ & 2,73 \\
\hline & 5 & $1,798^{*}$ & ,606 & ,032 & ,09 & 3,51 \\
\hline \multirow[t]{4}{*}{5} & 1 &,- 652 & ,356 & ,677 & $-1,66$ & ,35 \\
\hline & 2 &, 167 & ,539 & 1,000 & $-1,36$ & 1,69 \\
\hline & 3 & $-1,433$ & ,696 & ,401 & $-3,40$ &, 53 \\
\hline & 4 & $-1,798$ * & ,606 & ,032 & $-3,51$ &,- 09 \\
\hline
\end{tabular}

${ }^{*}$. La diferencia de medias es significativa al nivel .05.

Tabla 6.6: prueba de comparaciones múltiples de Bonferroni. Obsérvese los límites inferiores y superiores del intervalo de confianza donde aparecen números negativos y positivos. Los distintos grupos difieren si el 0 no se encuentra entre esos valores. Se observan diferencias entre las mezcla 5 y 4.

\section{Tamaños alcanzados}

Adentrémonos ahora en los tamaños que adquieren cada una de las formas realizadas con las diferentes mezclas. 


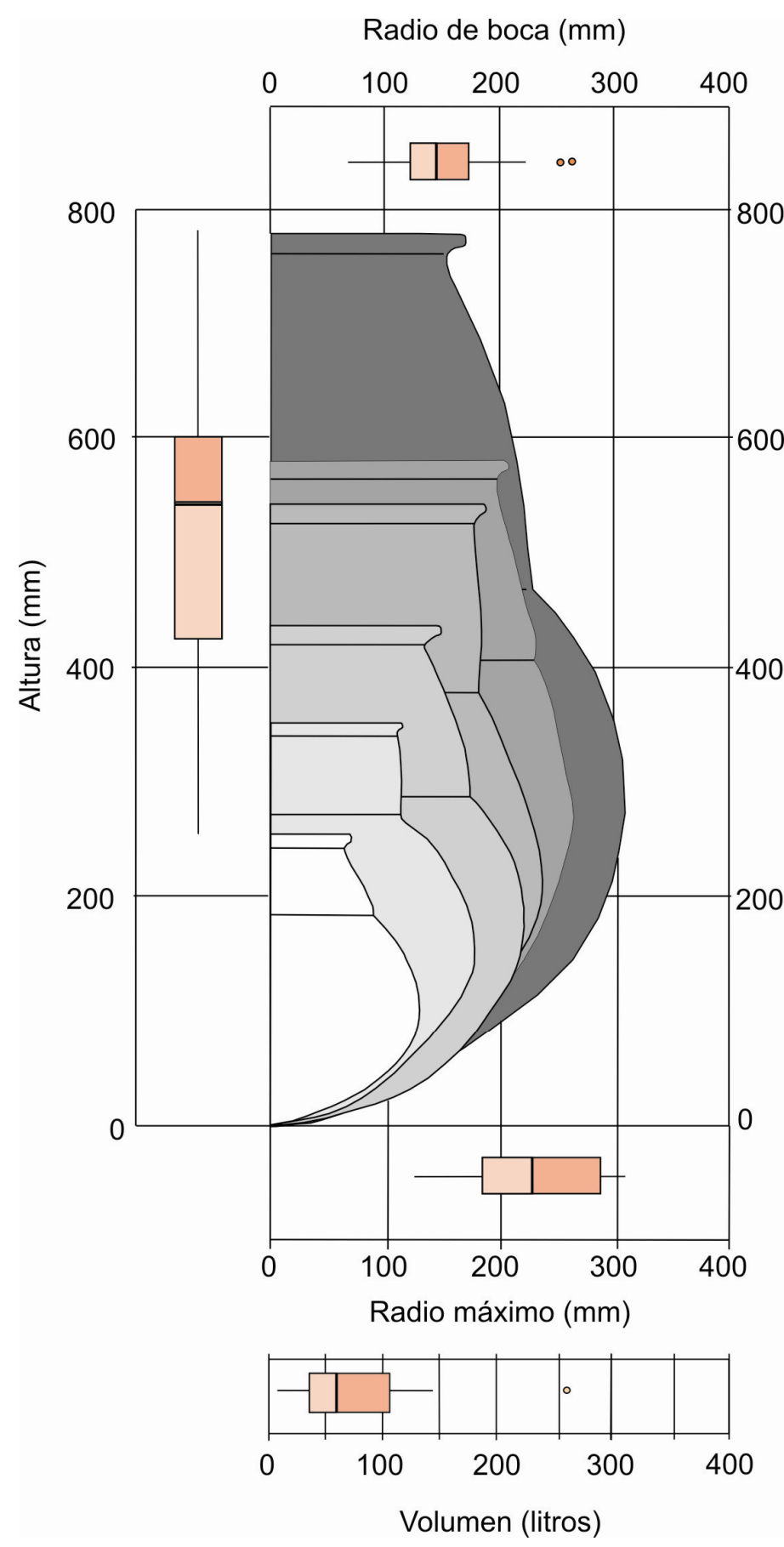

Gráfico 6.6: combinación de gráficos de tallo y hoja de tamaño y volumen de las vasijas de forma "a". Los n son los siguientes: altura $n=17$, radio máximo $n=22$, radio de boca $\mathrm{n}=57$, volumen $\mathrm{n}=17$. La línea más gruesa de las cajas indica la mediana. Los círculos rosas son valores outlayer.
Tamaños de la forma " $a$ ": con respecto a la altura poseen un promedio de $535,80 \mathrm{~mm}$ con una desviación típica de 158,80 mm y un máximo y mínimo de $780 \mathrm{~mm}$ y 253mm -n=17-. La dispersión de los valores alrededor de la mediana $-540 \mathrm{~mm}$ - tal cual se observa en el gráfico 6.6 es diferencial encontrándose la mitad de los valores entre esta última y los 600 milímetros, mientras que el resto se distribuye en un rango más amplio. En cuanto al diámetro máximo, tenemos una media de 464,18 mm con una desviación típica de 117,1 y un mínimo y máximo de 255 y $639-n=22-. \quad$ Los valores se dispersan diferencialmente -gráfico 6.6-. La mitad está entre 375 mm umbral inferior- y la mediana -460 $\mathrm{mm}$ - y el resto entre esta última y los $580 \mathrm{~mm}$ del umbral superior. Sin embargo las diferencias son leves. Si comparamos la altura en relación al ancho dividiendo la primera por la segunda, observamos que en general los valores son cercanos a 1, lo cual indica que estas piezas tienen las mismas proporciones de alto y ancho, o son más altas que anchas. En términos de porcentajes, podemos decir que un $33 \%$ se corresponden a un valor 1 , y un $66 \%$ se halla por encima de este valor $-\mathrm{n}=17$-. En relación al diámetro de la boca, los valores promedios son 297,52 mm con una desviación típica de 81,36 con máximos y mínimos de 131 y 375 $(\mathrm{n}=57)$. El gráfico 6.6 muestra dos valores outlayer, repartidos de manera homogénea 
alrededor de la mediana $297 \mathrm{~mm}$ siendo el umbral inferior de $240 \mathrm{~mm}$ y el superior de 340 mm. En relación a los volúmenes de contención, tenemos un valor promedio de 76,57 litros con una desviación de 32,6 y un mínimo y máximo de 7,86 litros y 261 litros (n=17). El volumen muestra cierta variabilidad. Si observamos el diagrama de caja del gráfico 6.6, podemos observar que la mediana es de 59,29 litros, con una distancia más corta hasta el umbral inferior que desde ésta al umbral superior. Esto nos dice que la mitad de los volúmenes medidos de estas vasijas están entre los 38 litros y los 59 litros, y el resto se halla entre este último y los 110 ó 120 litros. Tenemos también dentro de los valores máximos y mínimos unos 4 ó 5 litros y 140 ó 145 litros, y los valores outlayer de 260 litros. Esta forma de vasija es la que mayores volúmenes alcanza, junto con las "otras formas" con las que comparte un rango semejante.

Tamaños de la forma “ab”-gráfico 6.7-: poseen muy poca representación en la muestra total de la clase E, superando apenas el $8 \%$. Hemos medido la altura de cuatro piezas que poseen un mínimo de $113 \mathrm{~mm}$ de altura; las otras tres van de los $294 \mathrm{~mm}$ a los $317 \mathrm{~mm}$.

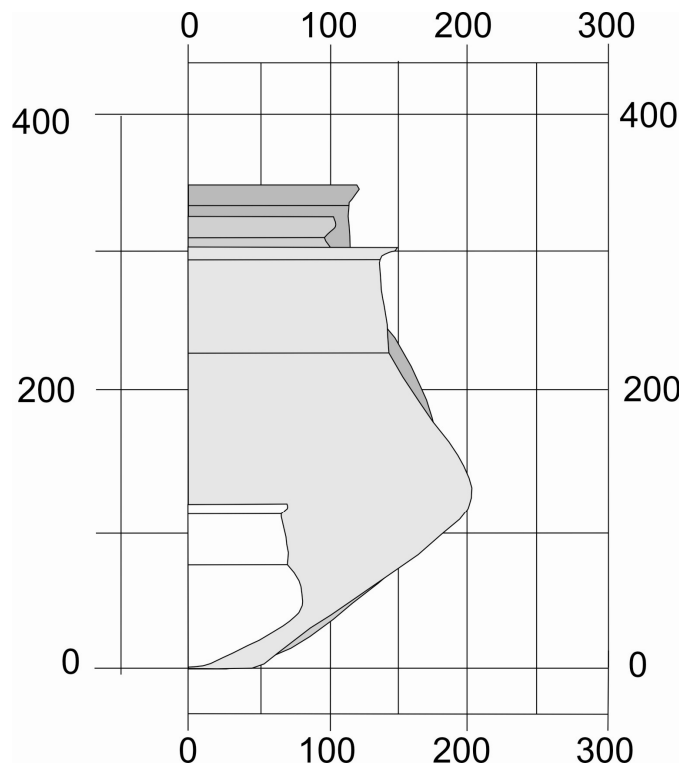

Gráfico 6.7: tamaños de las vasijas de forma "ab" Con respecto al diámetro máximo de estas vasijas, hemos medido 8 casos que poseen una media de 300,8 mm con una desviación estándar de 105,37 y un mínimo y máximo de 160 mm y $440 \mathrm{~mm}$. En relación al diámetro de la boca, hemos podido medir 9 casos, que poseen una media de $215 \mathrm{~mm}$ con una desviación típica de 75,60 mm y un mínimo y máximo de 120 y 350 mm. Pudimos medir los volúmenes en cuatro de estas vasijas, tres de las cuales se hallan alrededor de los 20 litros y uno muy alejado, con 1,5 litros.

Tamaños de las "otras formas -gráfico 6.8-: en relación a la altura poseemos 8 casos medidos, que arrojan un promedio de 439,5 mm con una desviación de 103,12mm y mínimos y máximos de $240 \mathrm{~mm}$ y $569 \mathrm{~mm}$. En cuanto a los diámetros máximos, los 20 casos poseen una media de $405 \mathrm{~mm}$ con una desviación de 148 y un mínimo y máximo de $120 \mathrm{~mm}$ a $626 \mathrm{~mm}$. Estos datos nos marcan una dispersión bastante grande de las medidas. 


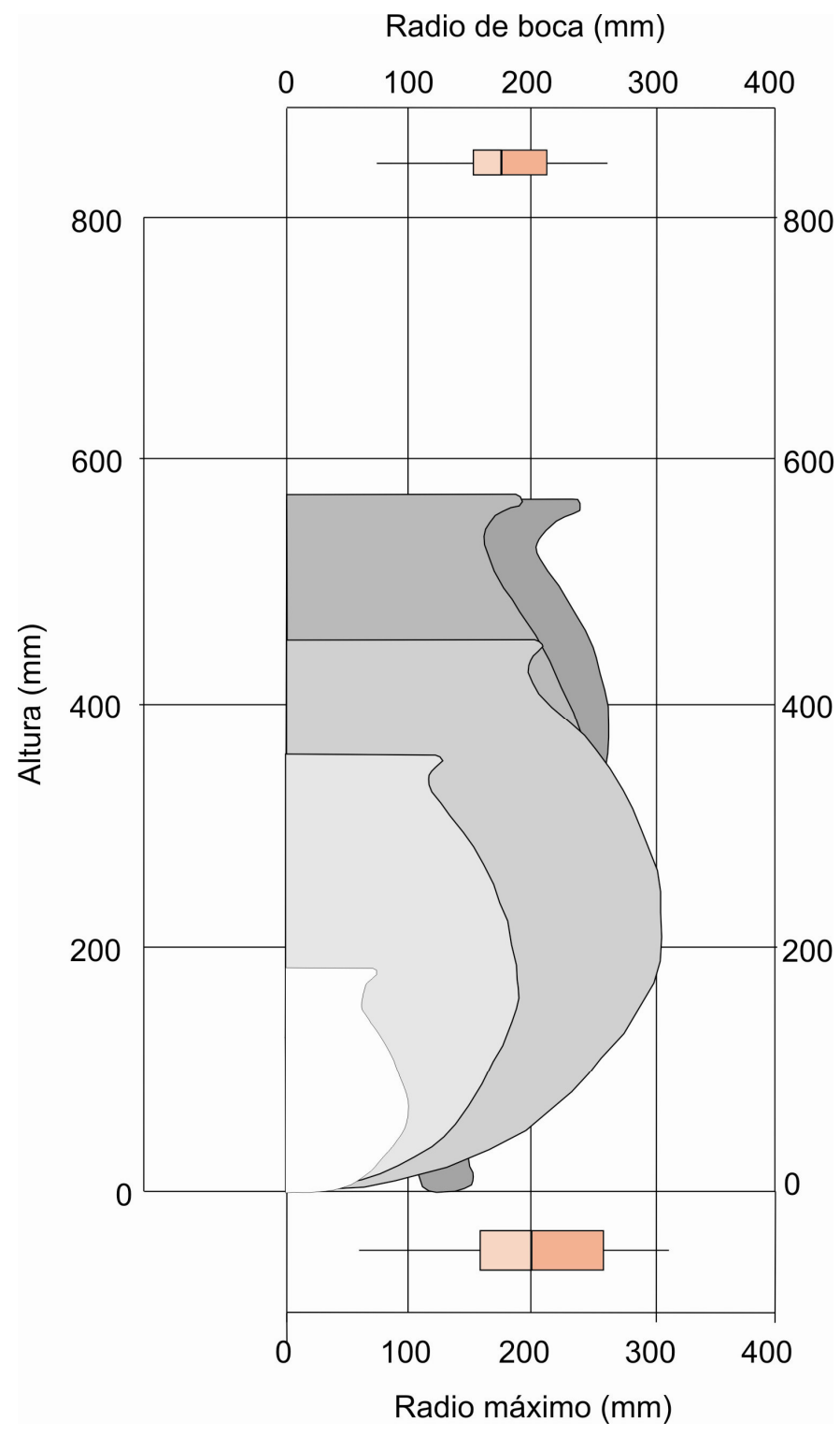

Gráfico 6.8: combinación de gráficos de tallo y hoja de tamaño y volumen de las vasijas de "otras formas". Los $\mathrm{n}$ son los siguientes: radio máximo $\mathrm{n}=20$, radio de boca $\mathrm{n}=34$.
Si observamos el diagrama de tallo y hoja podemos observar la siguiente distribución: la mediana es de 400 $\mathrm{mm}$. Por encima de ésta, hasta los $500 \mathrm{~mm}$, se distribuye la mitad de las mediciones. Por debajo de la mediana hasta los $275 \mathrm{~mm}$ se ubican los casos restantes, a excepción de los valores extremos. Hay una tendencia leve de agrupación hacia valores por debajo de la mediana. Si sobre los 8 casos medidos completos dividimos la altura por el diámetro, observamos valores cercanos a 1 con un promedio de 0,950 y una desviación de 0,22. Es decir que estas piezas poseen en general dimensiones muy parecidas en alto y ancho. En relación a los diámetros de boca, de los 34 casos medidos tenemos un promedio de 291,70 $\mathrm{mm}$ con una desviación de 93,8 mm, un máximo de 460 y un mínimo de 80 mm. La desviación no es tan elevada, los valores máximos y mínimos no son representativos de la dispersión en tanto que las medidas se concentran entre los $250 \mathrm{~mm}$ y los $300 \mathrm{~mm}$ estando la media en $285 \mathrm{~mm}$. Las distancias desde esta última a los umbrales inferior y superior es casi la misma con una leve tendencia a concentrarse entre la mediana y los $250 \mathrm{~mm}$. Esta forma es la que junto con las vasijas 'a' presenta mayores volúmenes, con una media de 62,78 litros, con una desviación de 38 litros y un mínimo y máximo de 4,89 y 101,07 litros $(n=8)$. Estas medidas nos hablan de una elevada dispersión, desde volúmenes muy pequeños hasta otros muy altos. 


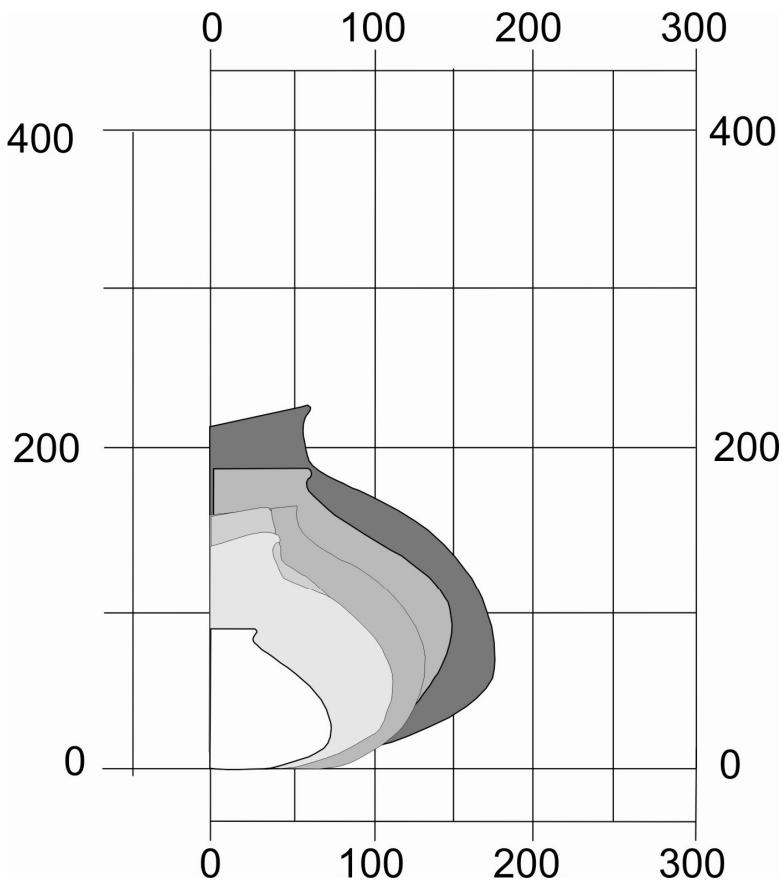

Gráfico 6.9: tamaños de las vasijas de forma calceiforme. Se representan los mínimos y máximos, mas algunos valores intermedios que representan la media.
Tamaños de las formas calceiformes gráfico 6.9-: los seis casos en donde hemos podido medir la altura, arrojan un promedio de $153 \mathrm{~mm}$ con una desviación de 49 mm y mínimo y máximos de $80 \mathrm{~mm}$ y $205 \mathrm{~mm}$. En relación al diámetro máximo, pudimos medir 8 casos que poseen un promedio de $182,37 \mathrm{~mm}$ con una desviación de 54 y un mínimo y máximo de 110 y $270 \mathrm{~mm}$. La relación alto/ancho nos arroja que son vasijas más anchas que altas, estando el valor por debajo de $1-0,86$ con una desviación de 0,17- En relación al diámetro de la boca pudimos medir 9 casos, que poseen una media de 121,33 mm con una desviación

de 56,3 y mínimo y máximos de $50 \mathrm{~mm}$ y $280 \mathrm{~mm}$. Vemos una dispersión bastante grande: por encima de la mediana $116 \mathrm{~mm}$ hasta los $120 \mathrm{~mm}$, se concentra el $50 \%$ de la mediciones, estando el resto entre ésta y los $90 \mathrm{~mm}$. Hay una leve tendencia a agruparse en valores alrededor de la mediana y la media. Con respecto a los volúmenes, de los 5 casos medidos no hemos calculado un promedio debido a la presencia de valores extremos de 0,5 litros a 13 litros, valores que al ser tan pequeña la muestra, alteran mucho las medidas de tendencia central. Los otros tres casos medidos se encuentran entre los 2, 70 litros y los 3,5 litros.

Tamaño de los platos -gráfico 6.10-: con respecto a la altura, pudimos medir 3 casos, dos de ellos tienen entre $30 \mathrm{~mm}$ y $35 \mathrm{~mm}$, y uno tiene $140 \mathrm{~mm}$, valores bastantes extremos. Con respecto a los diámetros también se observan diferencias, los 38 casos medidos -3 el diámetro, 35 el radio con promedio de porcentaje de arco entre 5\% y 10\%-tienen una media de 488,53 con una desviación de 148,5 y mínimo y máximos de 155 y $630 \mathrm{~mm}$. Si observamos el diagrama de caja podemos ver las diferencias entre las distancias entre la mediana $560 \mathrm{~mm}$ y el umbral inferior y superior. El 50\% de los casos está ente la mediana y los $600 \mathrm{~mm}$, el 50\% restante se encuentra entre los $390 \mathrm{~mm}$ y la mediana. Los dos casos de poca altura poseen diámetros mucho más bajos que la media, entre 155 y $165 \mathrm{~mm}$. Esto 


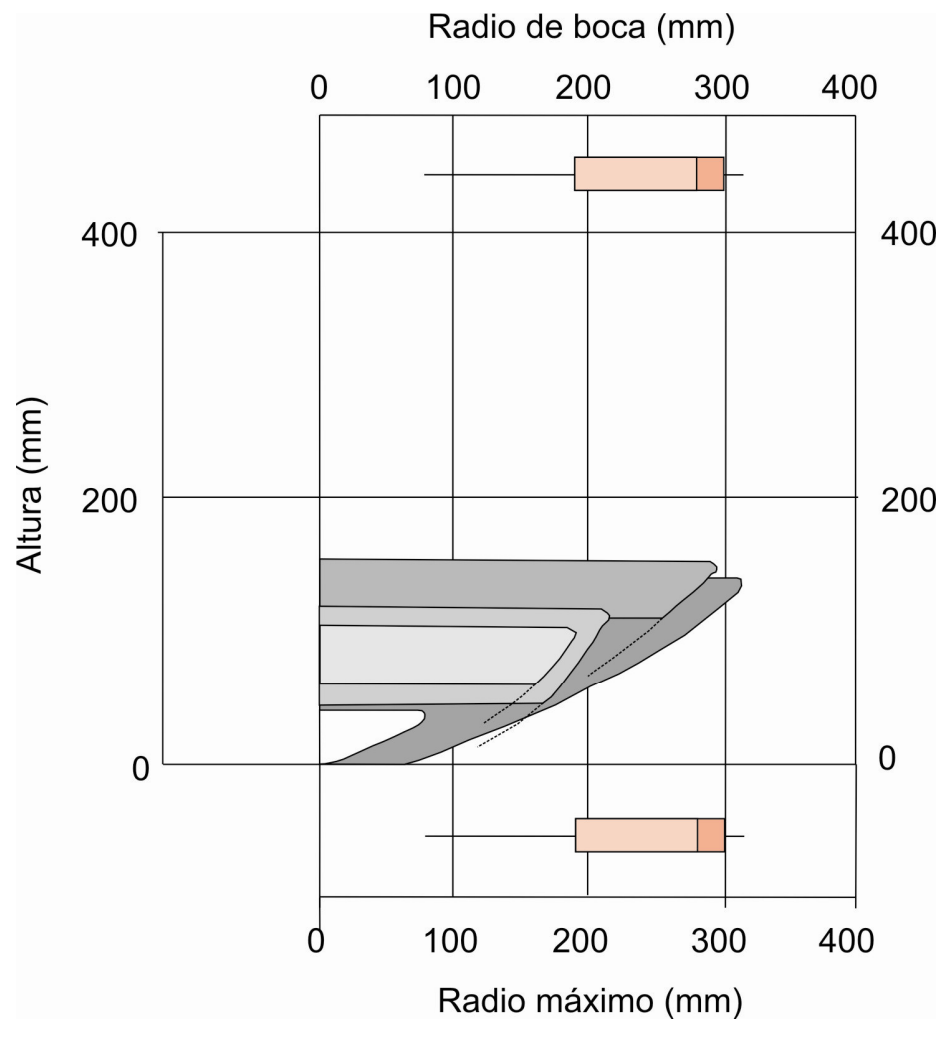

Gráfico 6.10: combinación de gráficos de tallo y hoja de tamaño y volumen de los platos. Los $\mathrm{n}$ son los siguientes: radio máximo y de boca -coincidentes en esta forma-, el $n=38$. nos permitiría plantear la existencia de un tamaño de plato muy grande y otro muy pequeño, existiendo cierta variedad entre los pequeños y la mediana. Los platos pequeños poseen bases diferentes a los más grandes, son cónicas, mientras que el resto presenta bases cóncavoconvexas. No hace falta sacar un índice para decir que son mucho más anchos que altos.

De las otras tres formas presentes, tenemos vasos o jarras figura 6.12- con un diámetro máximo de $180 \mathrm{~mm}$, junto con otro muy pequeño de $60 \mathrm{~mm}$ de diámetro

máximo y de boca y una altura de $40 \mathrm{~mm}$; y una vasija restringida compuesta dependiente de cuello evertido -figura 6.12-, con un diámetro de boca de $80 \mathrm{~mm}$ y un diámetro máximo de $120 \mathrm{~mm}$.

\section{Terminado de las vasijas}

Una vez que estas vasijas han adquirido la forma y tamaño deseado por el artesano, sufren diferentes tratamientos:

Formas " $a$ ": Estas piezas, como ya lo señalaran Bedano et al 1993 y Zaburlín 2001, se habrían realizado por partes dado su gran tamaño, necesitando que la arcilla húmeda se seque para servir de sostén a lo que se le va a adosar encima (García 1990, Rye 1987), a partir de la técnica de rodillo. Por otro lado, como también lo observara Zaburlín (2001), en algunas de estas vasijas se observa la unión de las diferentes planchas, en algunas de ellas siendo visible la línea de fractura -figura 6.14- . Por lo que la técnica de modelado de estas piezas podría haber sido por ahuecamiento de la base de forma cónica, luego confección por medio de rodetes o rodillos de diferentes partes, luego ensamble de las 


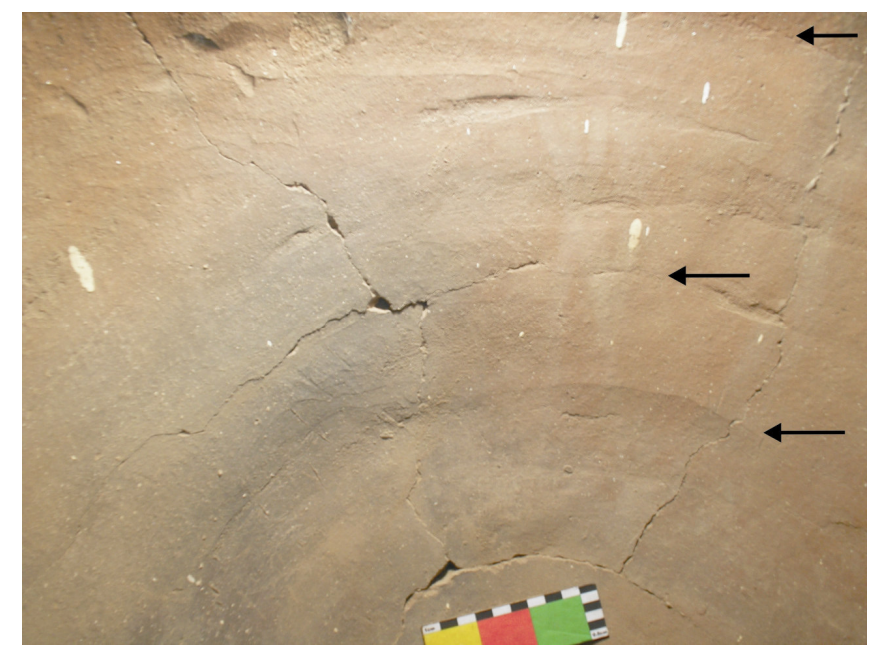

Figura 6.14: vasija de forma "a" donde se observan las uniones de las planchas.

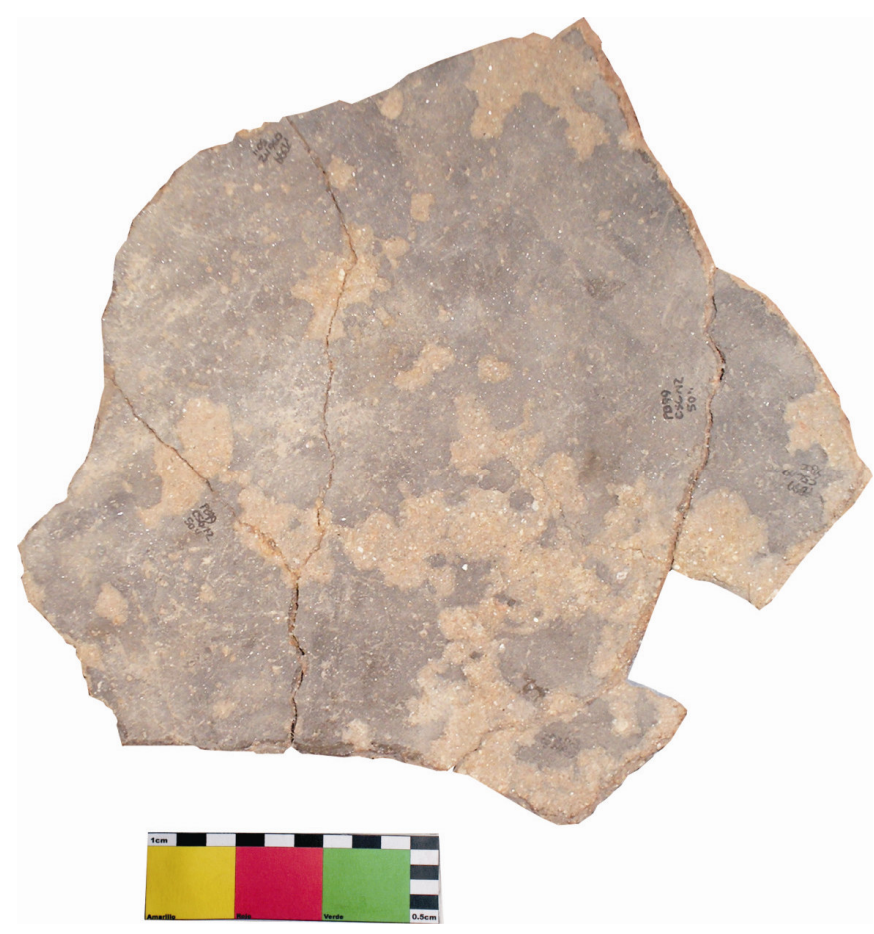

Figura 6.15: fragmento de vasija "a" -mezcla 5- con baño negro. distintas partes y pegado con una arcilla líquida. Una vez modelada su forma y otorgado el tamaño deseado, se las alisa probablemente con los cinceles y espátulas de hueso hallados en los contextos vinculados a la producción artesanal. En algunos casos $(8 \% \quad \mathrm{n}=74)$ a las paredes interiores se les coloca un baño negro -figura 6.15- . Este baño solo se encuentra en las vasijas con mezcla 5. Luego, a algunas vasijas se les colocan aplicaciones al pastillaje para formar en la parte del cuello un rostro antropomorfo -figura 6.16a-. Estos rostros se componen de cejas, ojos, nariz, boca, orejas y en algunos casos mentón -figura 6.16b-. Las cejas casi siempre conforman un semi-arco por encima de los ojos, que se afina hacia los extremos del rostro, y están unidas al centro de la cara, encima de la nariz. Hay casos en que no se colocan cejas y presentan sólo ojos. En algunos casos estos son de forma ovalada recorridos en su porción
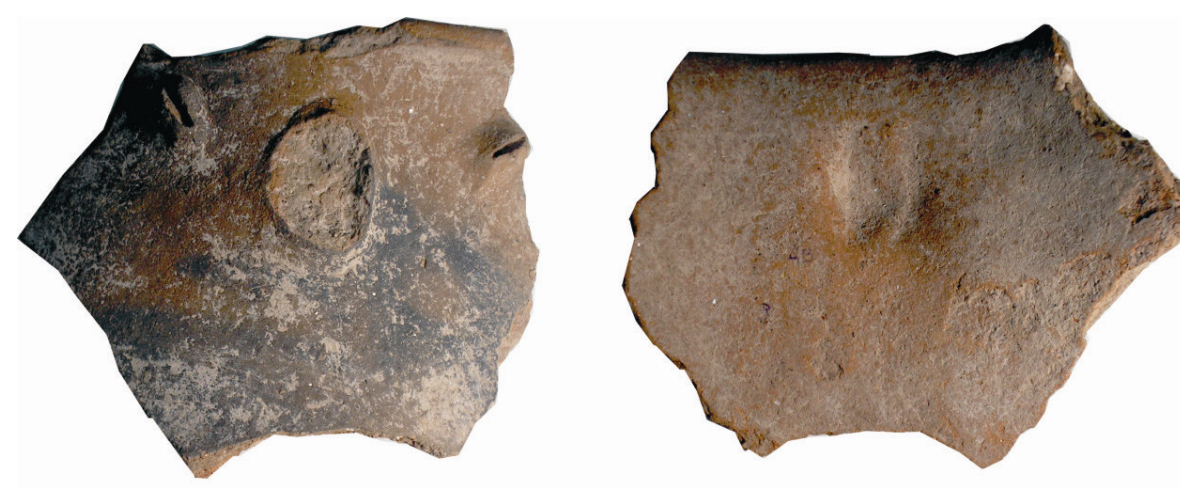

Figura 6.16a: fragmento que muestra el modelado al pastillaje del rostro. Obsérvese en la imagen derecha la huella dejada producto de la presión ejercida para pegar la

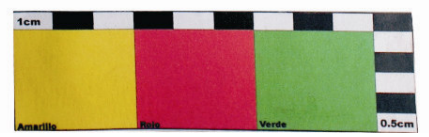
nariz. 

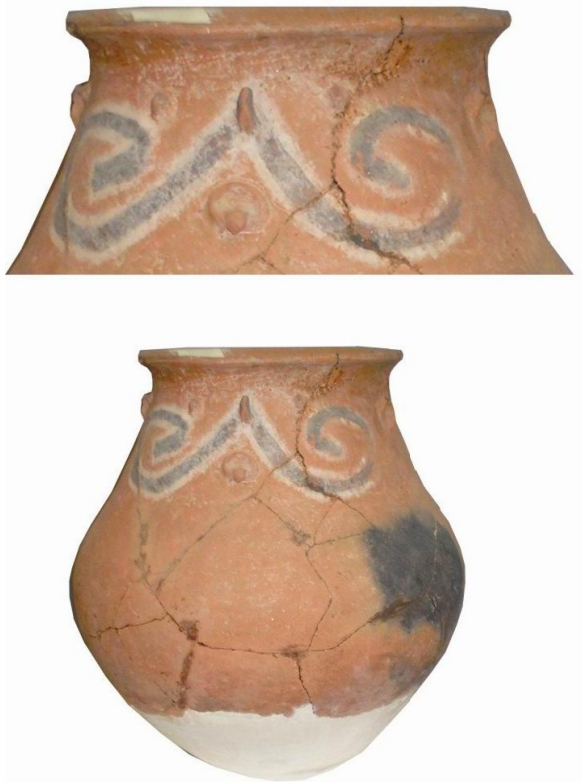

111
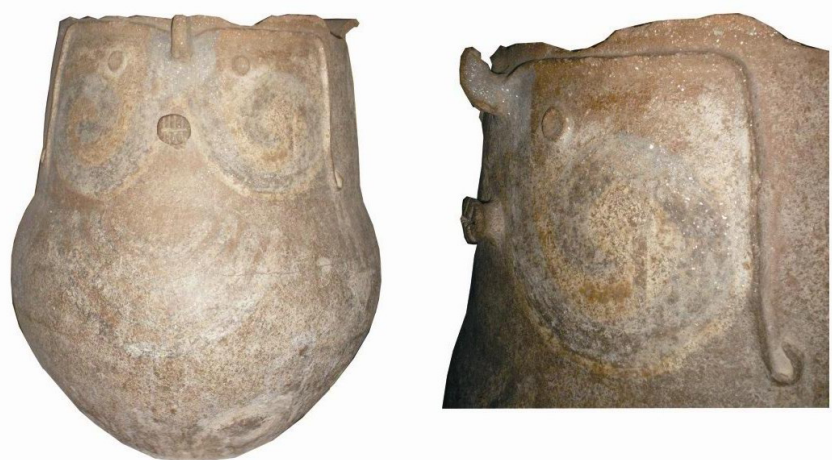
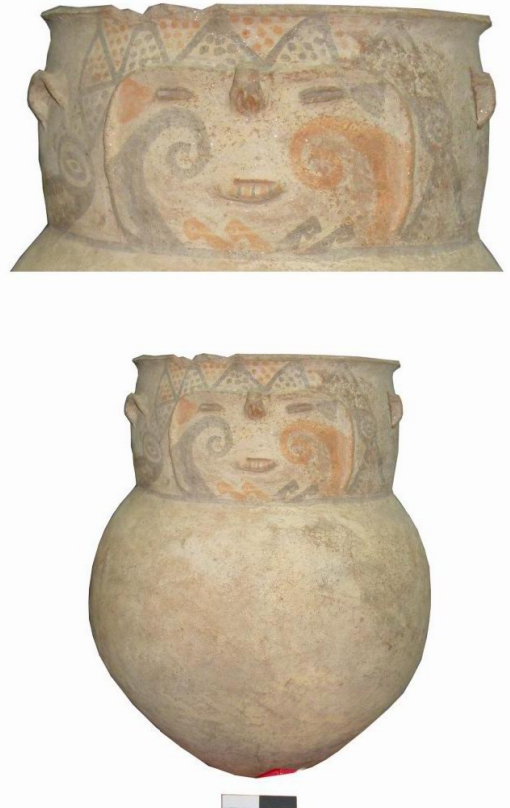

IIII
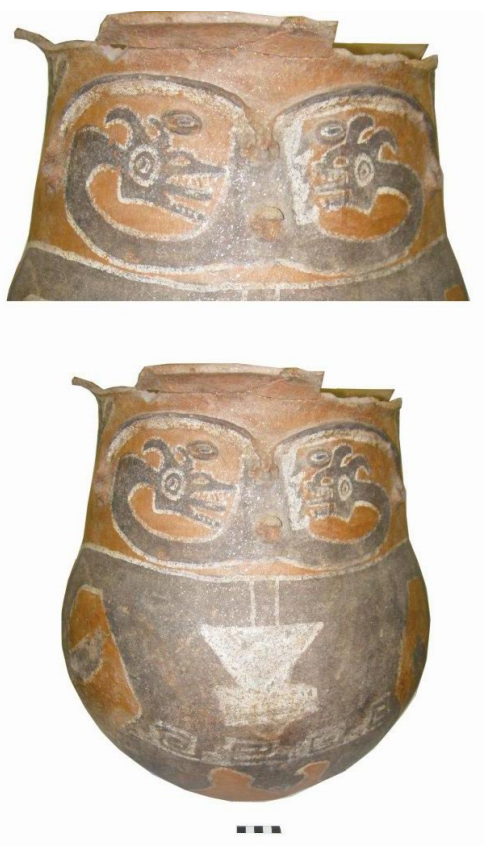

$\ldots$
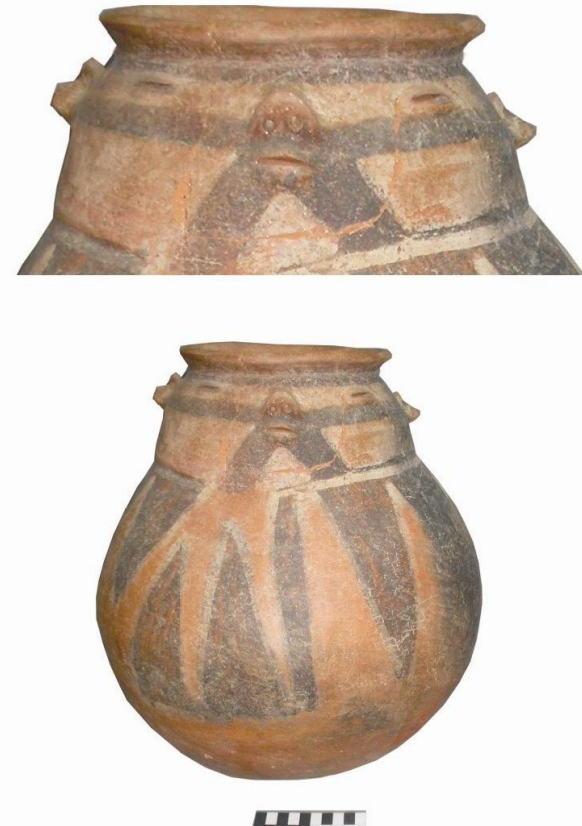

1010

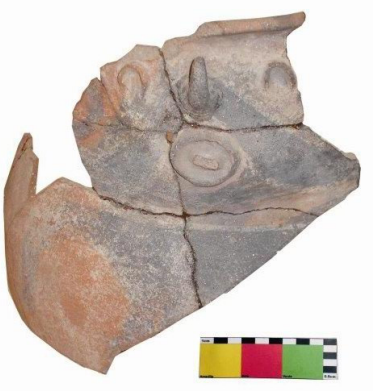

Figura 6.16b: fotografías de vasijas de forma "a" donde se observan los rostros modelados y pintados en distintos coleros. Fila superior de imágenes: vasijas pertenecientes a la Colección Rosso (C.R.). Fila inferior: primeras dos vasijas pertenecen a la Colección del Museo Adán Quiroga (C.M.A.Q) y, la última proviene de las excavaciones del Proyecto Ambato. 
sentido del diámetro máximo por otro surco. Con respecto a la nariz, estas vasijas presentan las típicas narices en ganchos invertidas, pero también presentan narices más "comunes" (a nuestra percepción anatómica del rostro humano). La boca puede ser circular u ovalada. En algunos casos poseen una lengua que sale hacia afuera. Los mentones son aplicados al pastillaje o son esbozados al momento de modelar el cuello, estando siempre muy cercanos al punto angular que divide cuello y cuerpo. Las orejas pueden estar ubicadas al terminar las cejas o bien solas. Estos modelados pueden combinarse luego con motivos pintados en rojo, blanco y negro, aunque en algunos casos no presentan ningún tipo de pintura.

En todas las vasijas estudiadas que presentan rostros modelados y pintados, la pintura se utiliza para marcar ciertas particularidades de las caras que no fueron modeladas. En algunos casos su aplicación denota que el rostro se halla pintado y se muestra el diseño delineado por la aplicación de pintura. En otros casos, en la parte del cuerpo de las vasijas que no presenta aplicaciones al pastillaje, se pinta el resto del cuerpo antropomorfo. Existe una variedad notable en el modelado de los rostros, y si bien hay determinados atributos compartidos, estos se representan de distintas maneras. Existen otras vasijas que no poseen rostro modelados al pastillaje pero sí se hallan pintadas en rojo, negro y blanco o sólo con dos de estos colores -figura 6.17-. En algunos casos se trata de los clásicos motivos "draconiformes", en otros casos geométricos, y en otras ocasiones combinados.

Las vasijas de forma "ab": al igual que en las de forma "a", a estas vasijas se le observan los ensanchamientos del rodete. Estas vasijas presentan cuellos bastante evidentes, algunos separados por puntos angulares o de inflexión muy marcados. Hemos observado fracturas que corren por estas uniones, que fueron pegadas con una arcilla más diluida. Esto nos muestra que estas vasijas fueron fabricabas al igual que las de forma "a", por partes: primero se el cuerpo y después el cuello, para luego pegarlos. Una vez dada la forma y tamaño deseados, se les realizan dos agujeros en la sección media del cuerpo para insertar las asas y remacharlas -figura 6.18-. Las asas se fabrican aparte, son de forma acintadas y se la coloca en posición horizontal para luego ser alisadas. Estas vasijas, conjuntamente con las de la forma "a", son las únicas de la clase E que son decoradas, siendo en general la decoración pintada y/o modelada al pastillaje en la zona del cuello -figura 6.19-. Los colores utilizados son: negro, blanco y rojo. En general, la pintura se encuentra en la parte superior del cuerpo y en todo el cuello. También hemos relevado vasijas que están pintadas sólo en el cuello. En todas ellas observamos motivos, zoomorfos y geométricos. 


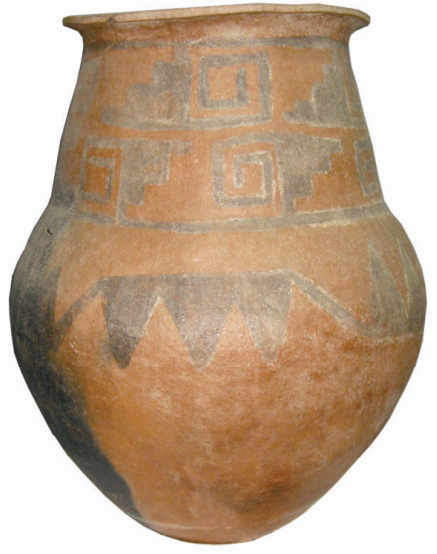

in

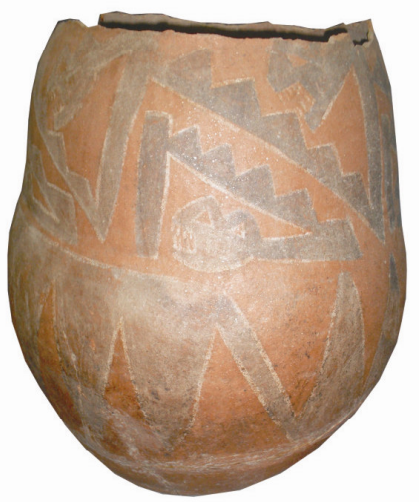

민

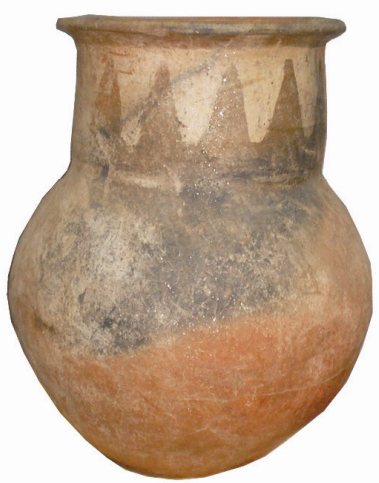

IIII
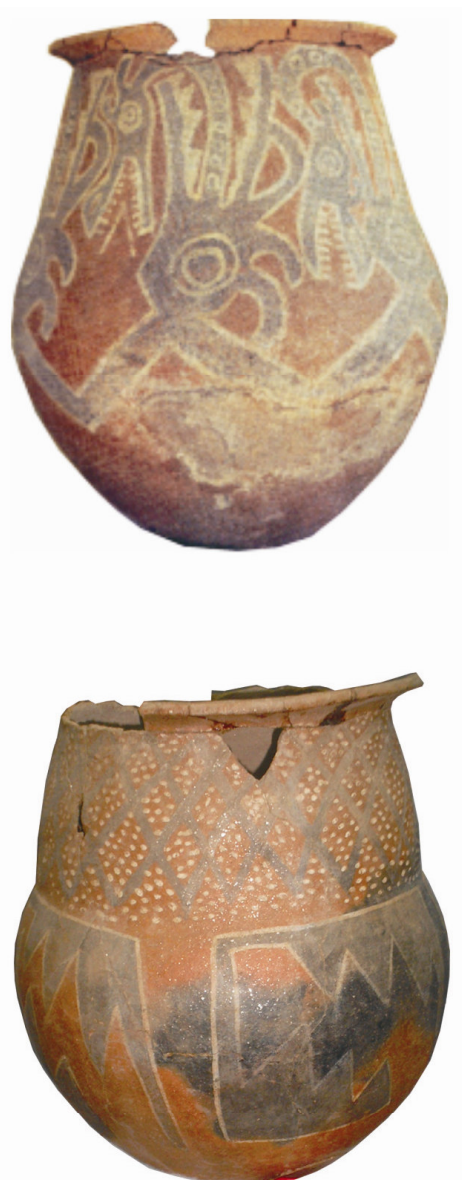

IIII

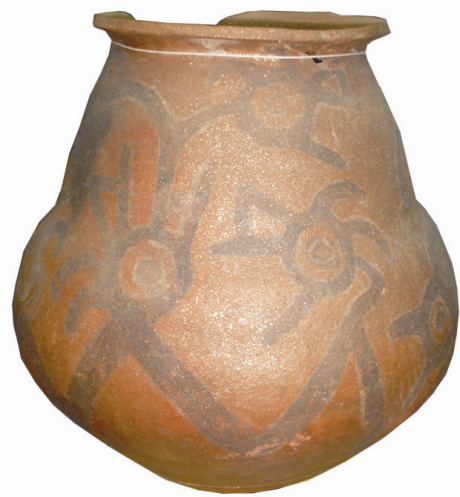

IIII

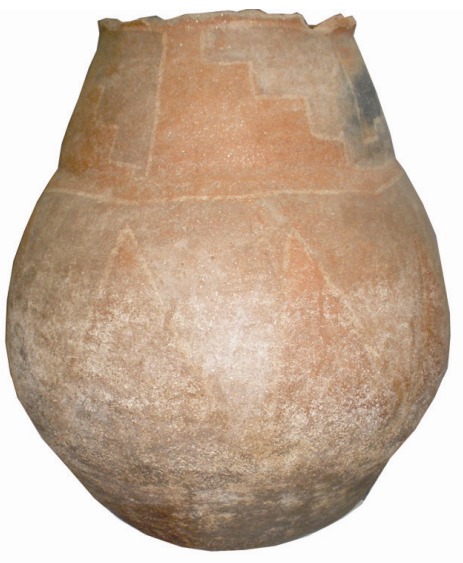

UII
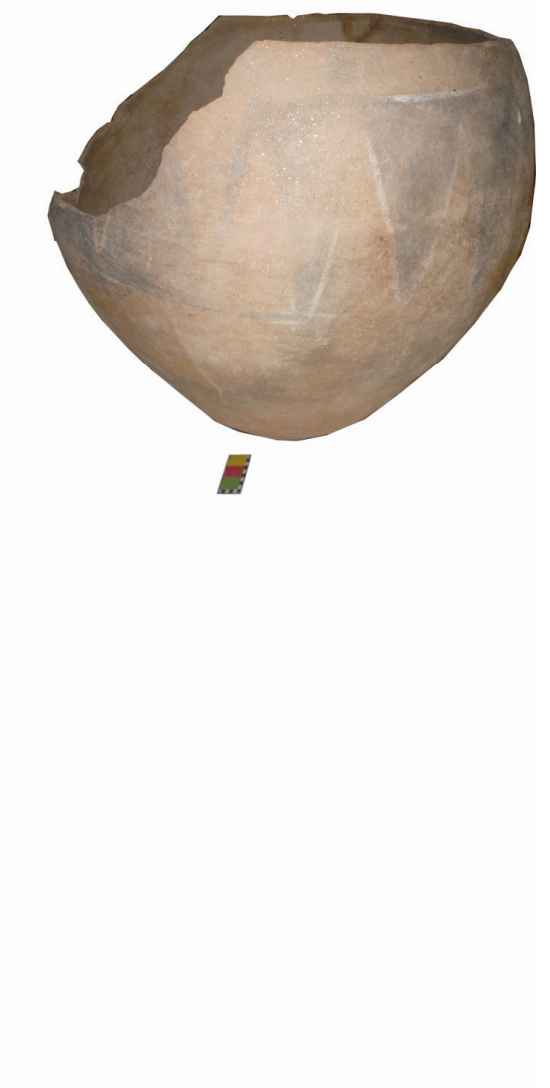


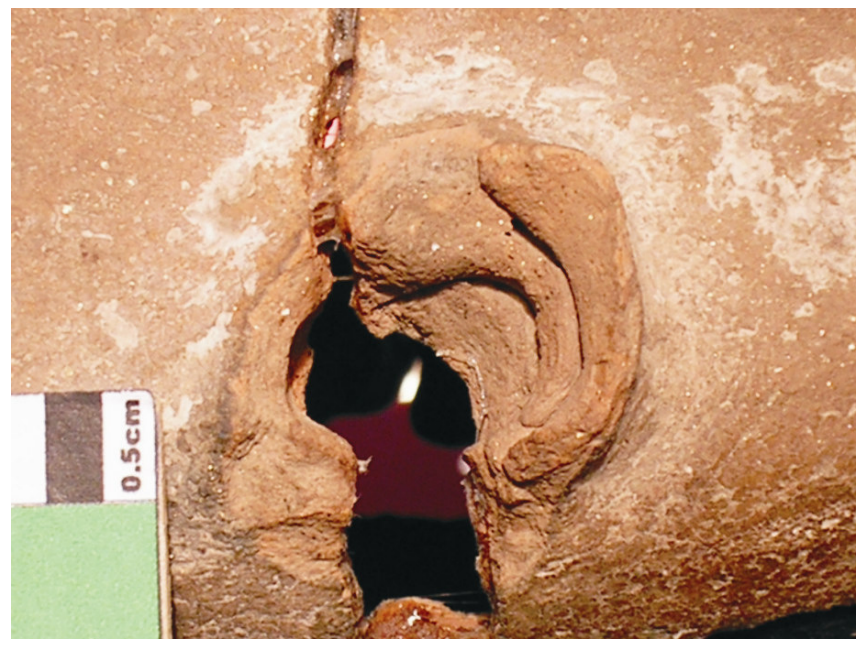

Figura 6.18: fotografía que muestra el remachado de un asa en una vasija de forma "ab". Se observa la perforación para la inserción del asa.

Figura 6.19: decoración presenta en las vasijas de forma "ab". Se observan pintados motivos geométricos, combinados algunas veces con motivos zoomorfos pintados o modelados al pastillaje en colores negro sobre ante, negro y rojo sobre la pasta natural y negro y blanco sobre la pasta natural. Pieza completa de arriba proviene del sitio Martínez 2. Piezas completas inferiores pertenecen a la C.R.
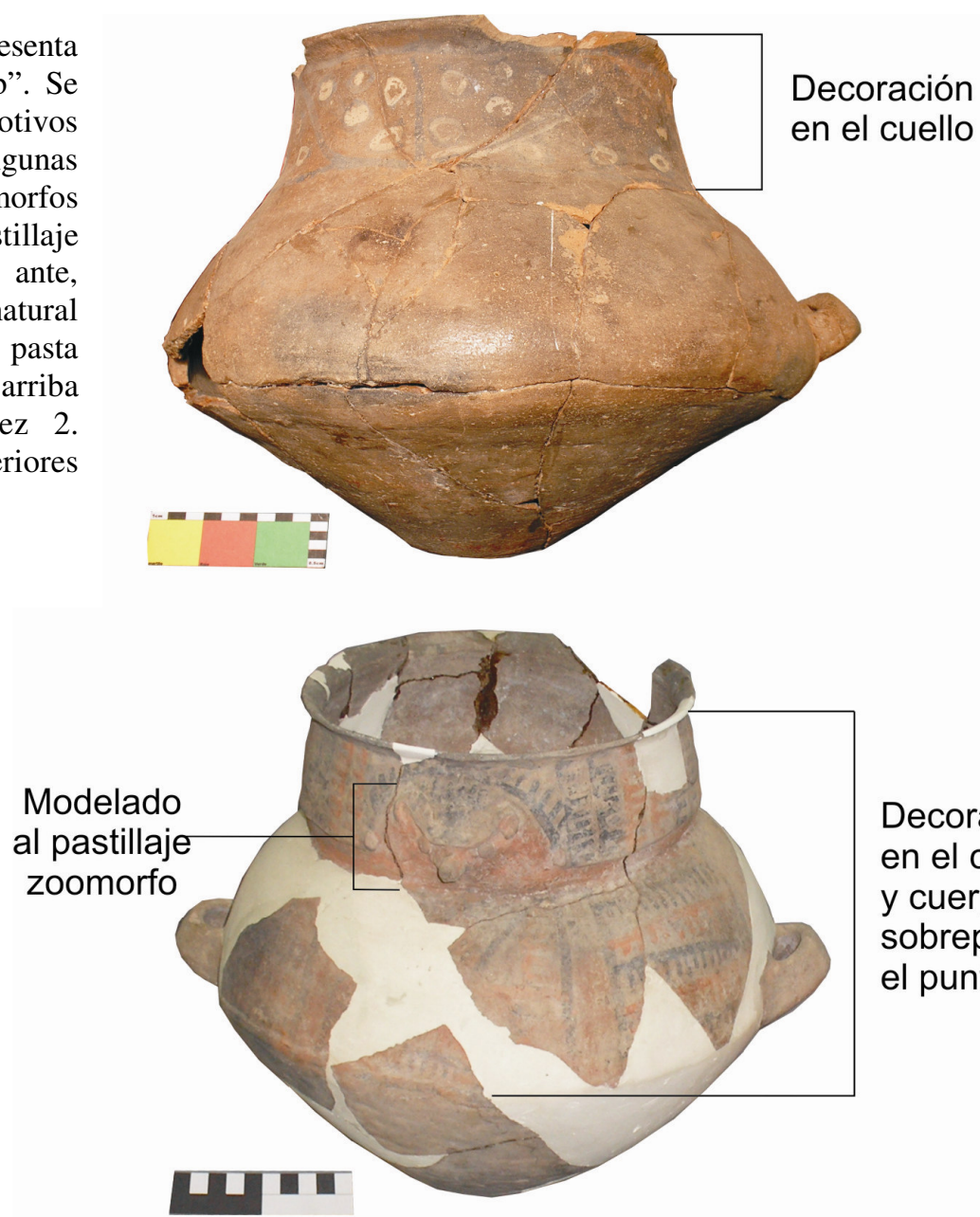

Decoración en el cuello y cuerpo, no sobrepasando el punto angular

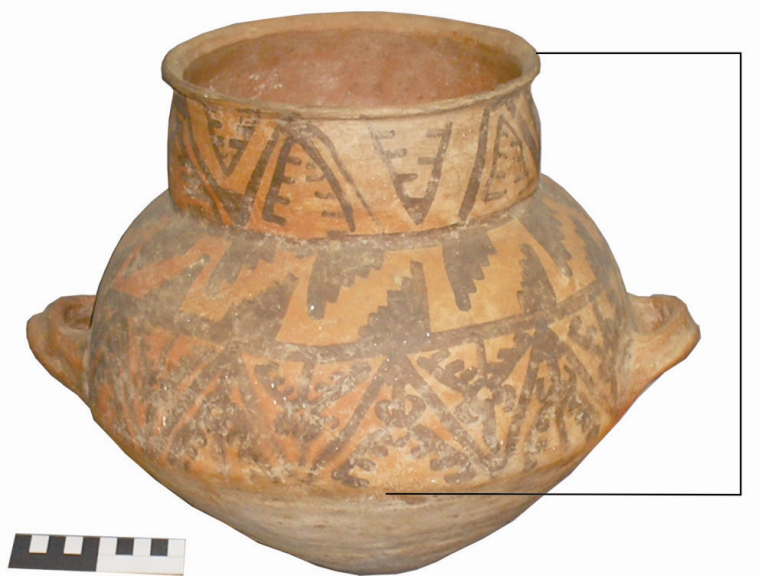

Decoración en el cuello y cuerpo, no sobrepasando el punto angular 
Las vasijas calceiformes, las “otras formas”, los platos, los vasos o jarras, la vasija restringida compuesta dependiente y cuello evertido: una vez que se les dio el tamaño y la forma deseados, se las alisa con instrumentos. Ninguna de estas formas presenta decoración alguna, ni modelado ni pintado. En todas estas formas se observan sinuosidades y engrosamientos que marcan su confección con la técnica del rodete -figura 6.20-. En el caso de las vasijas de mayor tamaño de las "otras formas", no se han observado las uniones de las planchas, aunque probablemente las más grandes se hayan realizado por partes. Aquellas vasijas de "otras formas" que presentan asas fueron remachadas -figura 6.21-. Lo mismo sucede con las vasijas de esta misma forma que presentan patas -figura $6.22-$.

La descripción del proceso de cocción de las piezas lo realizaremos más adelante, conjuntamente con las vasijas de clase A1.

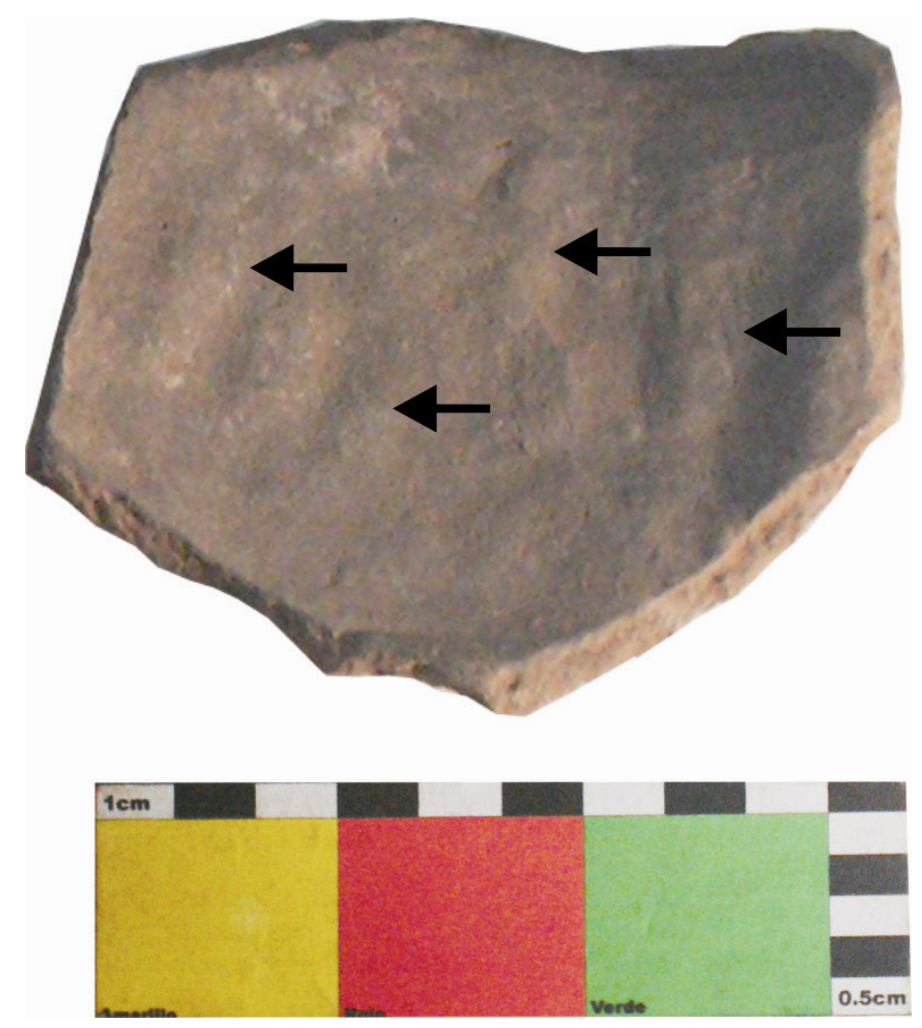

Figura 6.20: fragmento de cuerpo de una vasija perteneciente a las "otras formas" donde se observan las rugosidades dejadas por la superposición y pegado de los rodillos. 

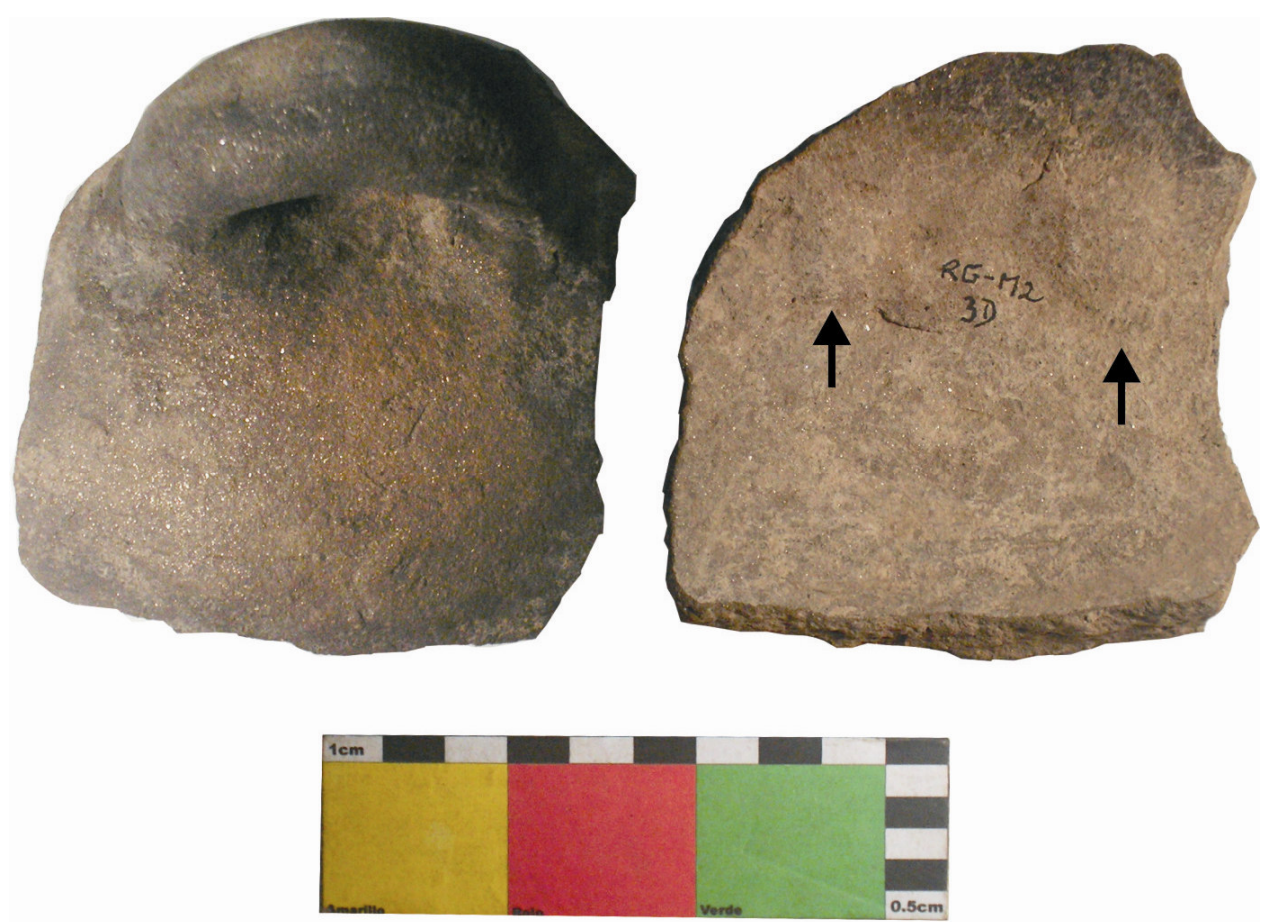

Figura 6.21: fragmento de cuerpo con asa de una vasija perteneciente a las "otras formas". Obsérvese las protuberancias en la superficie interna -imagen derecha- de la inserción del asa.

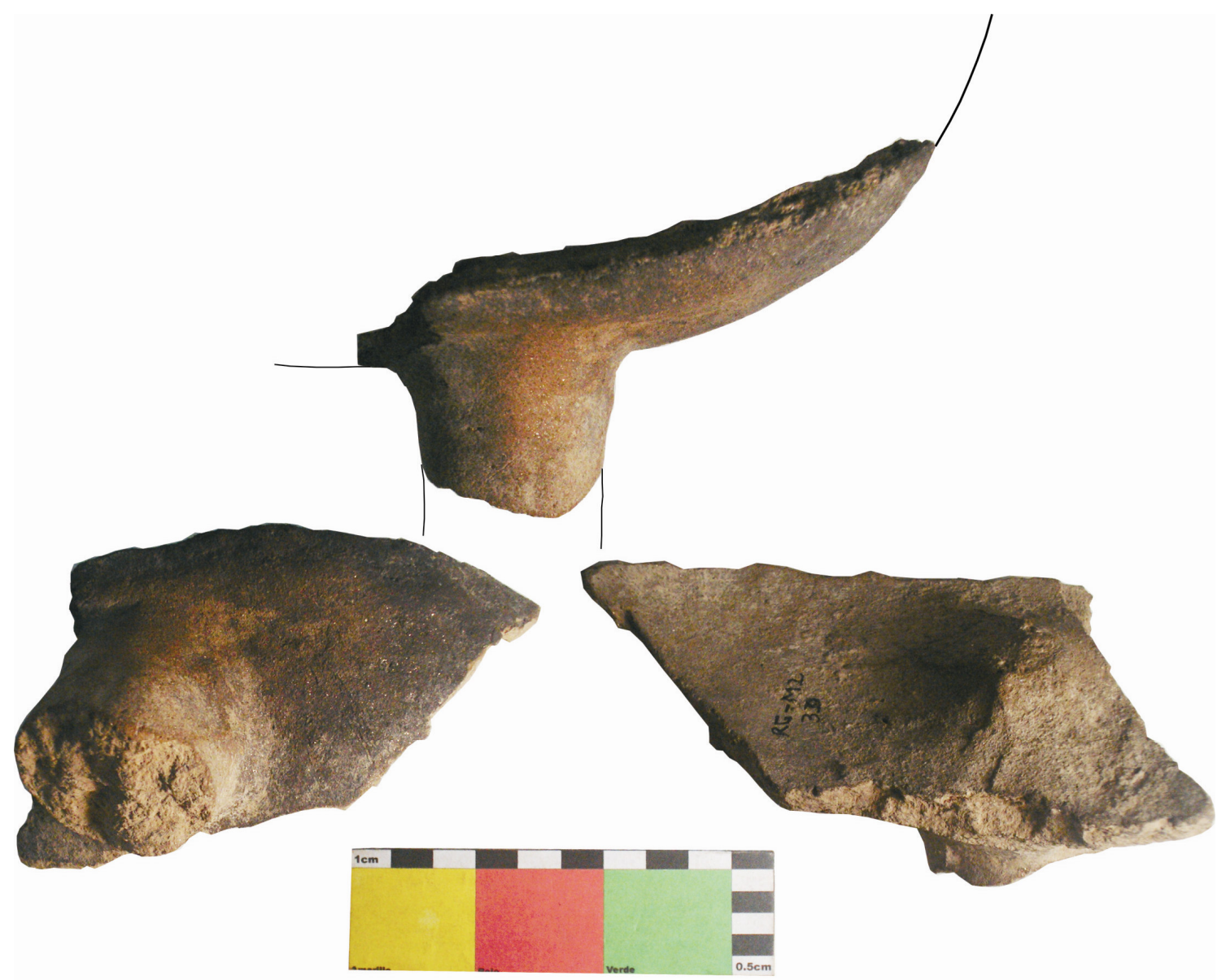

Figura 6.22: fragmento del fondo y para de una vasija tetrápoda pertenecientes a las "otras formas". Obsérvese la protuberancia dejada por la inserción de la pata. 


\section{Vasijas de clase A1}

\section{Preparado de la pasta:}

En esta clase, en términos de secuencia de producción, las arcillas rojas y blancas se combinan con antiplástico formado por arena o tiesto molido, de tamaño pequeño, cuya densidad es mínima o no se observa -ver anexo 3-. Las mismas características de tamaño presentan las cavidades en las pastas; se trata de un pasta muy fina, diferente a la clase E. La secuencia del preparado de estas pastas compartiría en parte los mismos procedimientos que la clase E, específicamente de aquellas vasijas producidas localmente. Ya hemos mencionado las implicancias de los datos arrojados por los análisis de activación neutrónica para interpretar el inicio de las trayectorias biográficas de estas vasijas. Hemos señalado que algunas podrían ingresar al valle ya fabricadas, y de aquellas fabricadas localmente hay cierta probabilidad que algunas fueran fabricadas con arcillas provenientes de Andalgalá.

\section{Dándoles Forma}

Algunas de las formas que describimos a continuación se corresponden con las definidas para el valle por Bedano et al (1993) y Zaburlín (2001) -figura 6.23-:

Forma " $b$ " (sensu Bedano et al 1993): es una de las formas más representativa de la cultura de la Aguada de la zona de Ambato (Bedano et al 1993, González 1998). Se trata de vasijas restringidas de contorno complejo, con una sección inferior subtroncocónica, una intermedia subglobular y otra superior subtroncocónica de paredes convergentes, subcilíndricas de paredes ligeramente convergentes o rectas. Generalmente poseen asas acintadas en forma de semianillo horizontal remachadas a la pieza en la parte media. Existe un caso en que estas asas adoptan la forma de una pierna y pie humano. La sección inferior se une con la intermedia con un punto angular y éste con la superior a través de otro punto angular situado a la mitad de la altura de la pieza.

Forma "c": son vasijas no restringidas de contorno compuesto, con una parte inferior subtroncocónica y una superior de paredes cóncavas. Ambas secciones se unen con un punto angular ubicado por debajo de la altura media de la pieza. Pueden presentar asas 
acintadas en forma de semianillo horizontal, estando remachadas por debajo de la altura media de la pieza.

Escudillas: normalmente conocidas como pucos (Bedano et al 1993, Fabra 2008, Zaburlín 2001), se presentan de forma restringida y no restringida. En general ambas formas poseen contornos compuesto y un punto angular que divide una sección inferior subtroncocónica y una superior que en los casos de las restringidas es levemente convergente o marcadamente convexa; en el otro caso son rectas. Raramente pueden presentar un asa en forma de cuello y cabeza de camélido, estando esta última adosada y no remachada. También pueden presentar un asa acintada en forma de semianillo horizontal, como el caso de la escudilla 'mal fabricada' hallada en el sitio Martínez 2, adosada a la pieza. En otros casos, en el borde -que en general es recto- pueden presentar adosados al pastillaje pequeñas cabezas modeladas zoomorfas.

Calceiformes o Asimétricas: la misma descripción que para las identificadas en la clase E, salvo que la base es de forma cóncava convexa.

“otras formas": la misma descripción que para las identificadas en la clase E.

Vasos: hemos registrado dos formas. Una es subcilíndrica, de contorno simple con paredes divergentes o levemente convergentes. Presentan un asa acintada adosada en posición vertical, en general por encima de la altura media de la pieza. También se presentan vasos subcuadrangulares de paredes rectas divergentes sin asas.

Vasijas restringidas compuestas. Poseen una parte inferior subtroncocónica separada por un punto angular de la superior, de paredes convexas; no presentan asas y el labio en general es redondeado.

Vasijas modeladas: se presentan en variedad de formas: batracios, rostros humanos y de camélidos, tortugas, murciélagos, aves, y personas de cuerpo entero sentadas.

Bols: vasijas no restringidas simples de base cóncavo-convexa y labio redondeado, no presentan asas. 
Escudillas
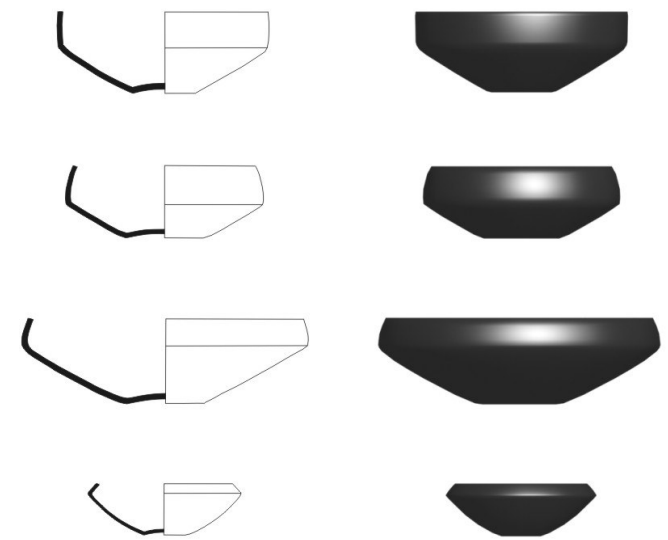

Restringidas compuestas
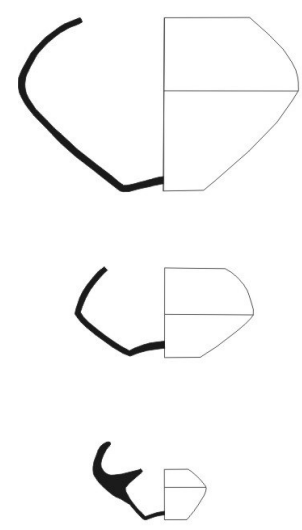

Vasos o Jarras
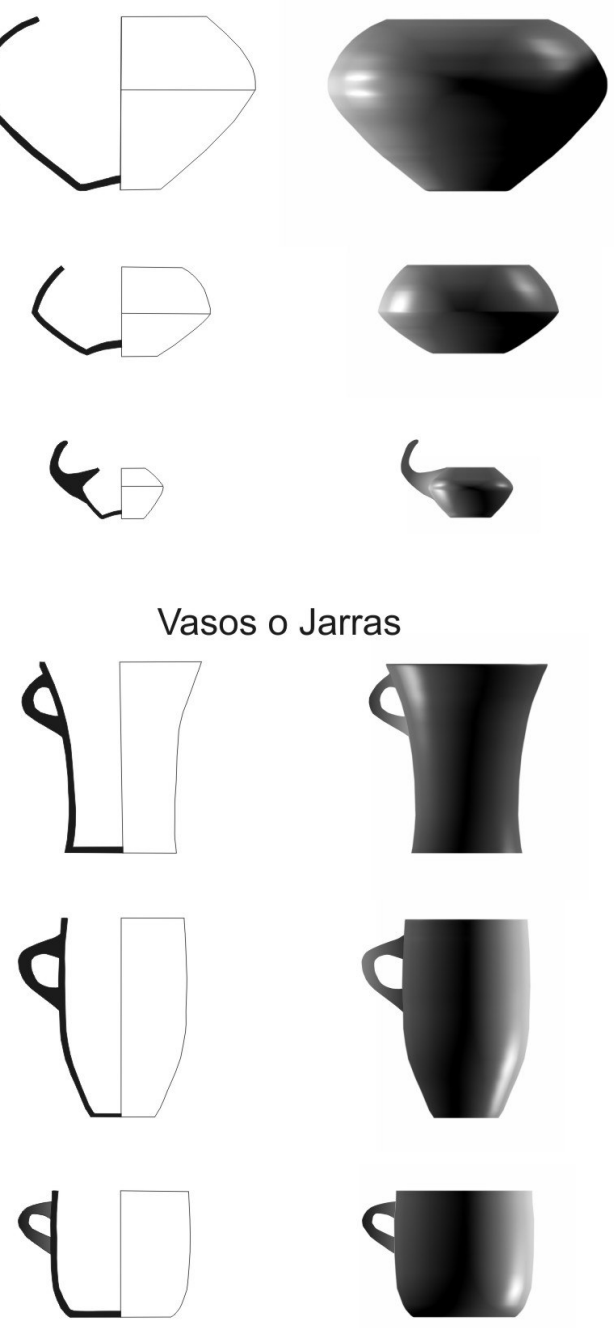

Bol
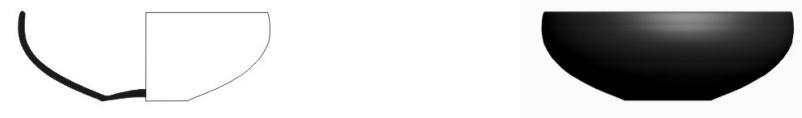

Forma "b"
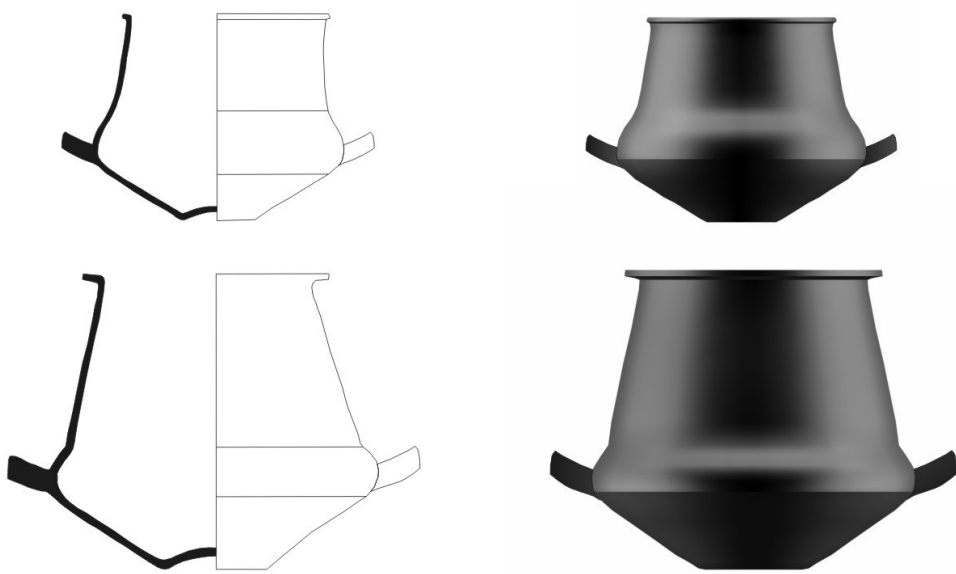

Forma "c"
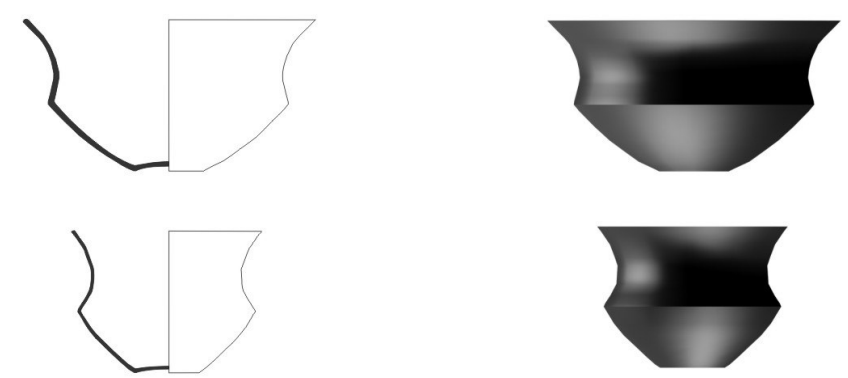

"Otras formas"
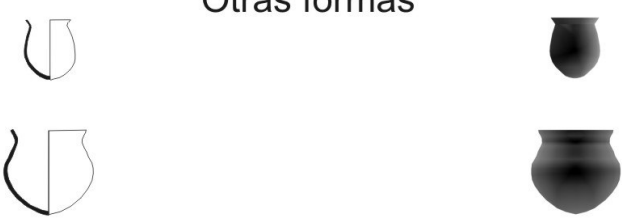

Calceiforme

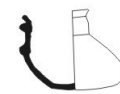

Modeladas
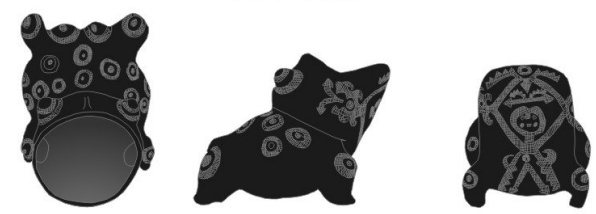

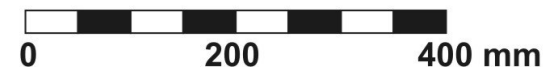

Figura 6.23: formas de las vasijas de clase A1. 
En relación a los porcentajes de representación de las formas dentro de la clase A1, si observamos el gráfico 6.11 tenemos que el mayor porcentaje, sin considerar el MNV, lo poseen las escudillas $(48,70 \%, \mathrm{n}=386)$, la forma " $\mathrm{b}$ " $(22,55 \%)$ y los bols $(10,62 \%)$; estando el resto alrededor o por debajo del 5\%. Si medimos esto en relación al NMV, los porcentajes cambian levemente -gráfico 6.11-: las escudillas bajan a 44\% (n=100), la forma "b" asciende a $32 \%$ y los bols disminuyen al 6\%. El resto de las formas quedan por debajo del $5 \%$.

\section{Tamaños alcanzados}

En relación a los tamaños que adquieren estas vasijas en cada forma, los análisis arrojan los siguientes datos:

Forma “b” -gráfico 6.12-

En general son piezas más altas que anchas, cuando se divide la altura por el diámetro máximo nos da una media de 0,786 con una desviación de 0,107 con un mínimo y máximo de 0,518 y $0,938(n=26)$.

Con respecto a la altura de estas piezas, las mismas poseen un promedio de 166,23 mm ( $\mathrm{n}=26)$, con una desviación típica alta de $72,48 \mathrm{~mm}$. Presentan un máximo y mínimo de $375 \mathrm{~mm}$ y $85 \mathrm{~mm}$, siendo la mediana de $140 \mathrm{~mm}$. Dada la alta desviación típica, la media no representa bien la muestra medida, por lo que conviene analizar la dispersión de los valores: si observamos el diagrama de caja vemos que tenemos un valor outlayer de $375 \mathrm{~mm}$. Dentro de la dispersión central, el resto de valores se distribuye en proporciones diferentes, estando el 50\% de los valores entre la mediana y el umbral inferior de $110 \mathrm{~mm}$, con un extremo de $85 \mathrm{~mm}$; y por encima de la mediana los valores van hasta casi $200 \mathrm{~mm}$ con un valor extremo de $295 \mathrm{~mm}$. Es decir que hay un amplio rango de tamaños que pueden adquirir estas piezas, exceptuando el valor outlayer, van desde los $85 \mathrm{~mm}$ de altura hasta casi los $300 \mathrm{~mm}$, concentrándose principalmente entre los 110 y $140 \mathrm{~mm}$, y de manera más dispersa entre los 140 y $200 \mathrm{~mm}$.

En relación a los radios de boca, de las 26 piezas enteras -diagrama de caja superiortenemos una media de 78,3 (diámetro 156,60 mm) con una desviación de 23,37 (diámetro $46,75 \mathrm{~mm}$ ) y un mínimo y máximo de $41,5 \mathrm{~mm}$ (diámetro $83 \mathrm{~mm}$ ) y $130 \mathrm{~mm}$ (diámetro $260 \mathrm{~mm}$ ), siendo la mediana de 74,25 mm (diámetro 148,50 mm). La dispersión de los valores es diferencial como se observa en el diagrama de caja, estando el 50\% entre los 60 mm ( diámetro $120 \mathrm{~mm}$ ) y la mediana, y el 50\% restante, bastante más distribuidos, entre 
Forma "b"
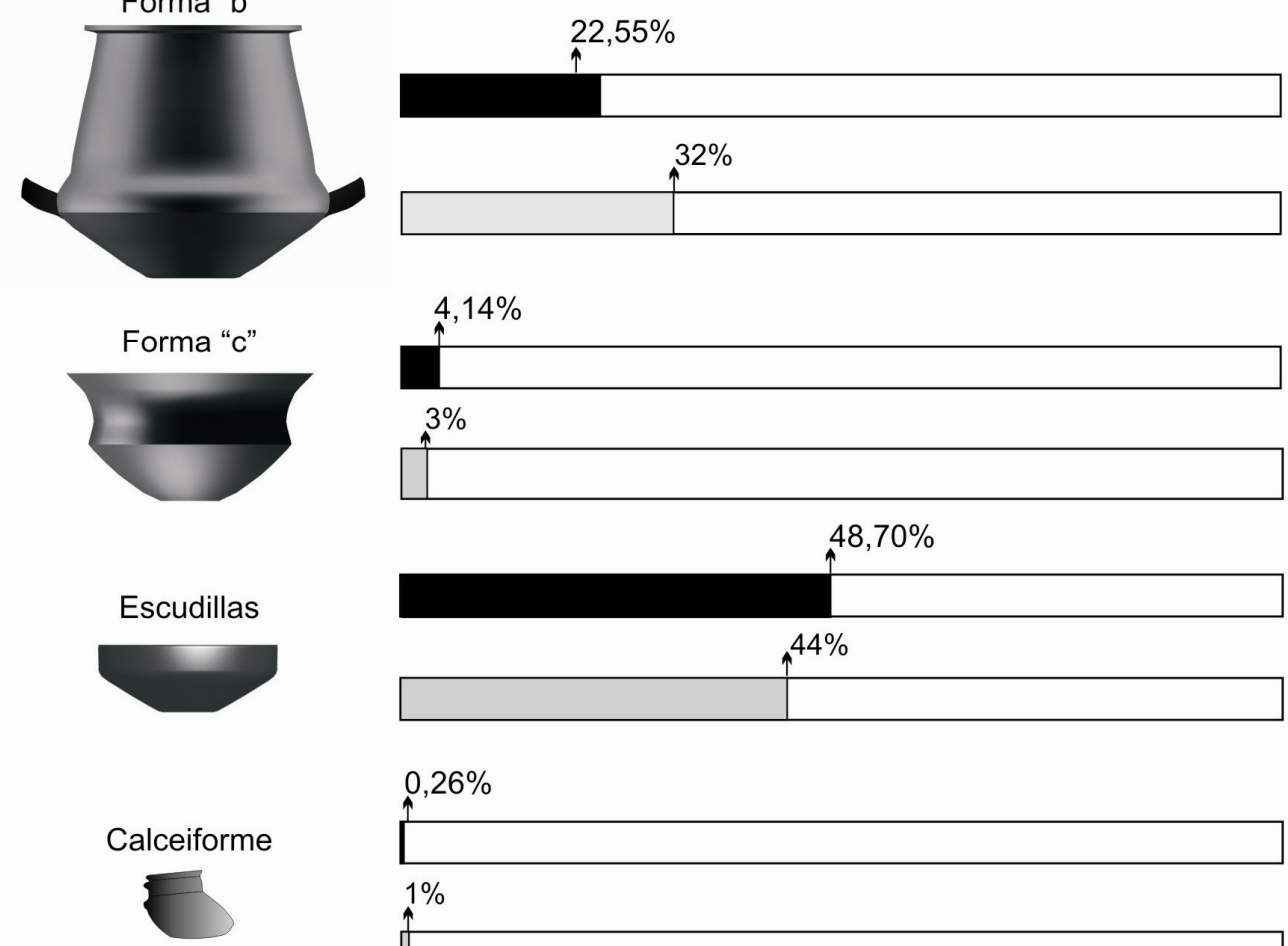

"Otras formas"

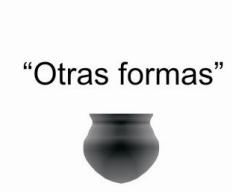


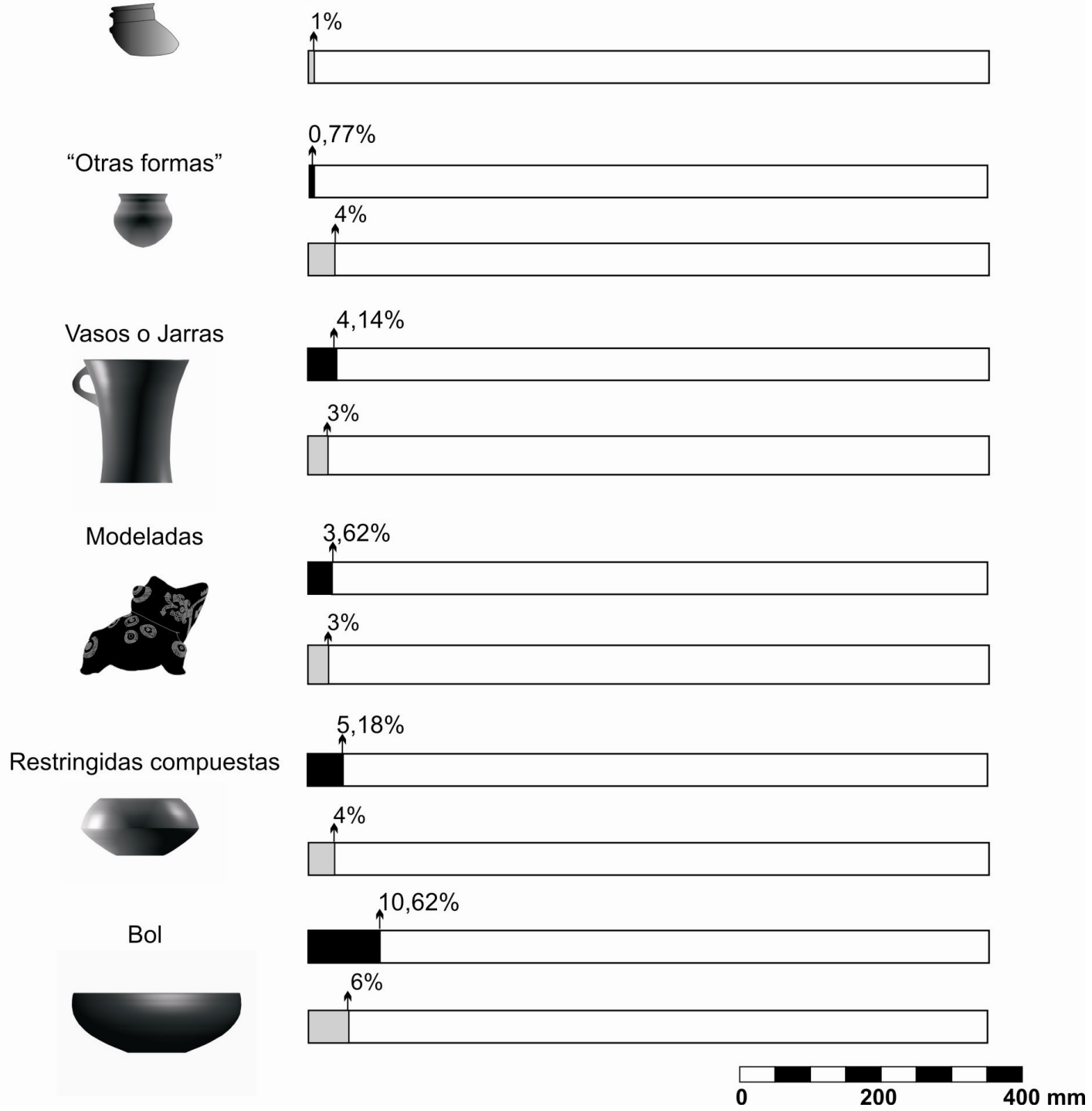

Gráfico 6.11: porcentaje de representación de las distintas formas en la clase A1. El las barras color negro representan el porcentaje sin tener en cuenta el NMV $-n=386$. Las barras de color gris representan el porcentaje teniendo en cuenta las vasijas enteras más el NMV -n=100-. En general las proporciones se mantienen existiendo leves cambios. 


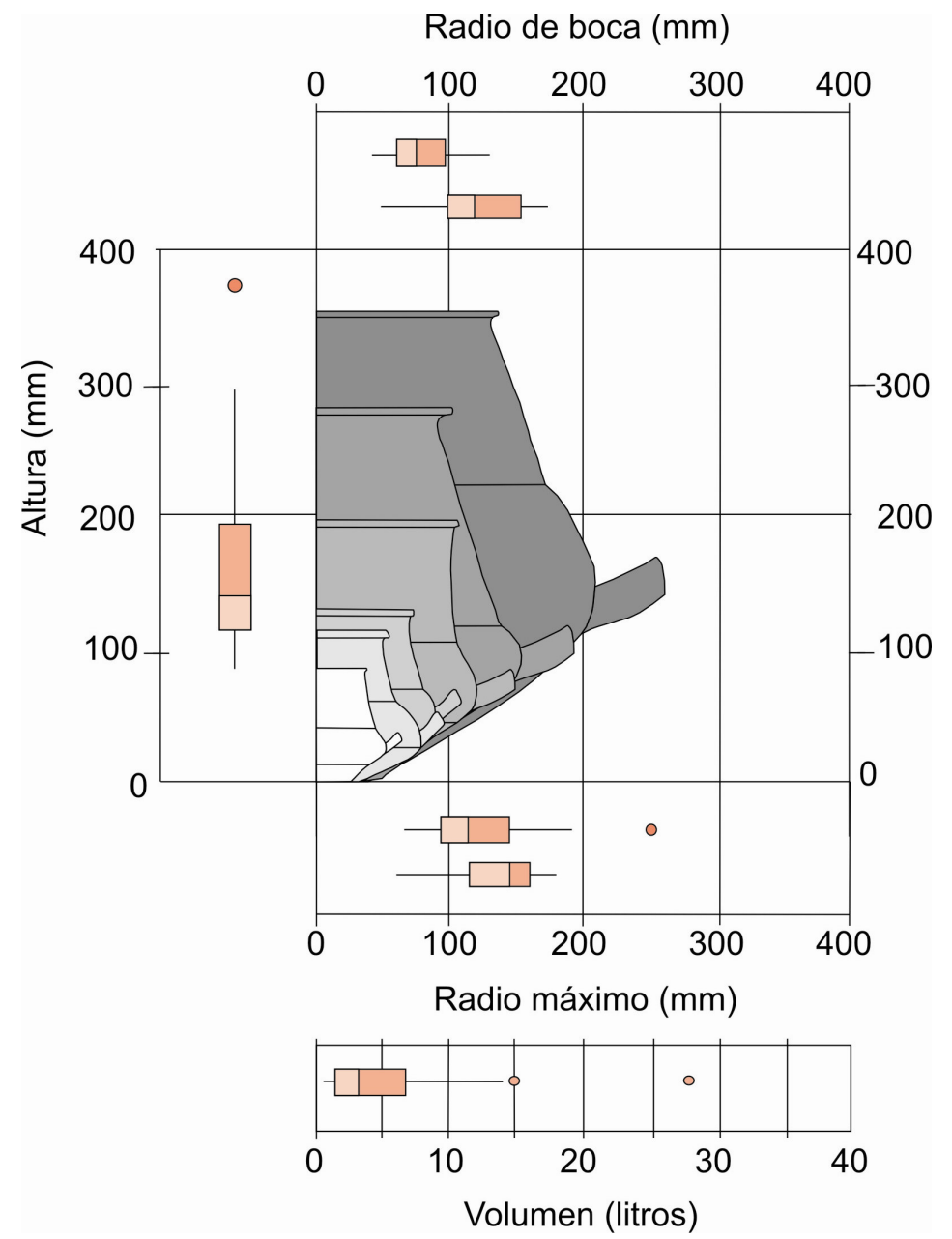

Gráfico 6.12: se combinan gráficos de caja de las diferentes medidas de las vasijas de forma "b" de clase A1. En el caso del radio de boca el gráfico de caja superior corresponde a los radios de vasijas enteras $-\mathrm{n}=26$-, el inferior a los radios de las fragmentadas con $5 \%$ o más de porcentaje de radio - la mediana y $97,5 \mathrm{~mm}$ (diámetro $195 \mathrm{~mm})$; existiendo valores extremos de $41 \mathrm{~mm}$ (diámetro 82) y $130 \mathrm{~mm}$ (diámetro 260 $\mathrm{mm})$. Cuando observamos los radios medidos de la boca diagrama de caja inferior- $(n=33$, iguales o superiores al $5 \%$ de porcentaje de arco), vemos que arroja una media bastante superior a los valores de las piezas enteras de $122 \mathrm{~mm}$ (diámetro $=244 \mathrm{~mm})$ con una desviación de $35,89 \mathrm{~mm}$ (diámetro $=71,78)$ y un mínimo y máximo de $50 \mathrm{~mm}$ (diámetro $=100 \mathrm{~mm}$ ) y $175 \mathrm{~mm}$ (diámetro $=350 \mathrm{~mm}$ ), siendo la mediana $120 \mathrm{~mm}$ (diámetro= 240). Si observamos la dispersión en el diagrama de caja vemos lo

siguiente: no existen valores outlayer y la dispersión es diferencial: tenemos la mitad de los valores entre la mediana y $100 \mathrm{~mm}$ (diámetro $=200 \mathrm{~mm}$ ) con un extremo de $50 \mathrm{~mm}$ (diámetro $=100 \mathrm{~mm}$ ), y la mitad de los valores restantes ente la mediana y $150 \mathrm{~mm}$ (diámetro $=300$ ), con un valor extremo de $175 \mathrm{~mm}$ (diámetro $=350$ ). Es decir que al igual que la altura, el diámetro de la boca en estas piezas presenta un rango de variabilidad bastante elevado, exceptuando los casos extremos tanto de los radios máximos de las enteras como de aquellas fragmentadas, irían desde los $120 \mathrm{~mm}$ a $300 \mathrm{~mm}$ de diámetro.

En relación a los radios máximo alcanzados por estas piezas, vemos que las vasijas enteras -diagrama de caja superior- $(\mathrm{n}=26)$ arrojan un promedio de 137, 5 (diámetro 275 $\mathrm{mm}$ ) con una desviación de 34,61 mm (diámetro 69,23 mm) y un mínimo y máximo de $55 \mathrm{~mm}$ (diámetro $110 \mathrm{~mm}$ ) y 207,5 (diámetro $415 \mathrm{~mm}$ ), siendo la mediana de 94,27 mm (diámetro $188,50 \mathrm{~mm}$ ). Al igual que con respecto a las alturas y diámetros de boca de las piezas, existe una dispersión amplia de los valores. Si observamos cómo se comporta dicha 
dispersión en el diagrama de caja, vemos que existe un valor outlayer de 207,5 mm (diámetro $415 \mathrm{~mm}$ ) y que la distribución alrededor de la mediana es diferencial: la mitad de los valores se encuentran entre los 77,5 mm (diámetro $155 \mathrm{~mm}$ ) y la mediana y la mitad restante un poco más dispersa entre la mediana y los casi $120 \mathrm{~mm}$ (diámetro $240 \mathrm{~mm}$ ), teniendo valores extremos de $155 \mathrm{~mm}$ (diámetro $310 \mathrm{~mm}$ ) y $55 \mathrm{~mm}$ ( diámetro $110 \mathrm{~mm}$ ). En cuanto a los radios máximo de las fragmentadas -diagrama de caja inferior- $(n=20$, iguales o mayores al 5\% de porcentaje de arco) vemos que poseen una media de 137,55 $\mathrm{mm}($ diámetro $=275,1)$ con una desviación de 30,79 (diámetro $=61,58)$ y un mínimo y máximo de $60 \mathrm{~mm}($ diámetro $=120 \mathrm{~mm})$ y $180 \mathrm{~mm}($ diámetro $=360 \mathrm{~mm})$, siendo la mediana de $145 \mathrm{~mm}$ (diámetro $=290$ ). Si observamos la manera en que se distribuyen los valores en el diagrama de caja, vemos una distribución diferencial, la mitad de los valores se encuentra entre la mediana y $160 \mathrm{~mm}$ (diámetro $=320$ ), con un valor extremo de 180 diámetro $=360)$, y el $50 \%$ restante entre la mediana y los $110 \mathrm{~mm}($ diámetro $=220 \mathrm{~mm})$ con un valor extremo de $60 \mathrm{~mm}$ (diámetro $=120)$. Existe un grupo bastante cercano $(50 \%$ de los casos) entre los $290 \mathrm{~mm}$ y $320 \mathrm{~mm}$, y otro grupo (50\%) que se dispersa entre los 220 $\mathrm{mm}$ y los $290 \mathrm{~mm}$. Analizando tanto los valores medidos de las piezas enteras y los valores medidos de radio de las fragmentadas, tenemos respecto al diámetro máximo cuatro grupos de intervalos: uno de ellos está concentrado entre los $130 \mathrm{~mm}$ y $152 \mathrm{~mm}$ de diámetro, otro entre los $152 \mathrm{~mm}$ y $220 \mathrm{~mm}$, un tercero que está entre los 222 y 290, y un último que se encontraría ente los 290 y 320. Estos dos últimos son los que poseen mayor representatividad.

En relación a los diámetros de las bases tenemos una media de 71,73 $\mathrm{mm}$ con una desviación de 19,54 mm, un máximo y un mínimo de $45 \mathrm{~mm}$ y $100 \mathrm{~mm}$, siendo la mediana de $70 \mathrm{~mm}(\mathrm{n}=29)$.

Los espesores de las bases $(\mathrm{n}=31)$ arrojan un promedio de 5,47 con una desviación de 1,12, con un mínimo y máximo de $4 \mathrm{~mm}$ y $8 \mathrm{~mm}$ y una mediana de $5 \mathrm{~mm}$. En relación al espesor de las paredes del cuerpo $(n=60)$ tenemos una media de 4,95 con una desviación típica de 1,19 con un mínimo y máximo de 3 y $8 \mathrm{~mm}$, siendo la mediana de $5 \mathrm{~mm}$. En relación al espesor del cuello, hemos podido medir 46 casos que arrojaron una media de 5,06 con una desviación típica de 1,12 con mínimos y máximos de $3 \mathrm{~mm}$ y 7mm, siendo la mediana de $5 \mathrm{~mm}$. Los valores en el diagrama de caja se reparten de manera homogénea estando entre los $4 \mathrm{~mm}$ y $6 \mathrm{~mm}$ de espesor. El espesor del borde $(\mathrm{n}=46)$ arrojó una media de 4,56 mm con una desviación de $0,84 \mathrm{~mm}$ con un mínimo y máximo de 3 y 6 , siendo la 
mediana de 4,50. Podemos decir hasta aquí que los espesores de las distintas partes presentan valores semejantes, tendiendo el borde a ser menos espeso.

Los volúmenes -gráfico 6.12- de estas piezas, varían notablemente, llegando al punto en que la desviación típica supera a la media, teniendo valores mínimos y máximo de 0,5 litros y 28,17 litros. Si observamos la dispersión de los valores en el diagrama de caja n=26-, vemos que existen dos valores outlayer, mientras que el resto de los valores se distribuyen diferencialmente, estando el $50 \%$ de los valores entre 1,5 y 3 litros, y el 50\% restante entre la mediana 1,5 litros y casi 7 litros.

Para resumir, podemos decir que en la relación de tamaños y volúmenes, estas piezas son en general más altas que anchas, presentando gran variabilidad de tamaño, entre los $85 \mathrm{~mm}$ de alto a los $375 \mathrm{~mm}$ y 110 de diámetro máximo hasta los $415 \mathrm{~mm}$. Presentan un rango de volúmenes que cubre desde los 0,5 litros a los 28 litros. La variabilidad en los tamaños contrasta con la homogeneidad en los espesores de estas piezas, que tienden a estar entre los $5 \mathrm{~mm}$ y $6 \mathrm{~mm}$.

Forma c -gráfico 6.13-

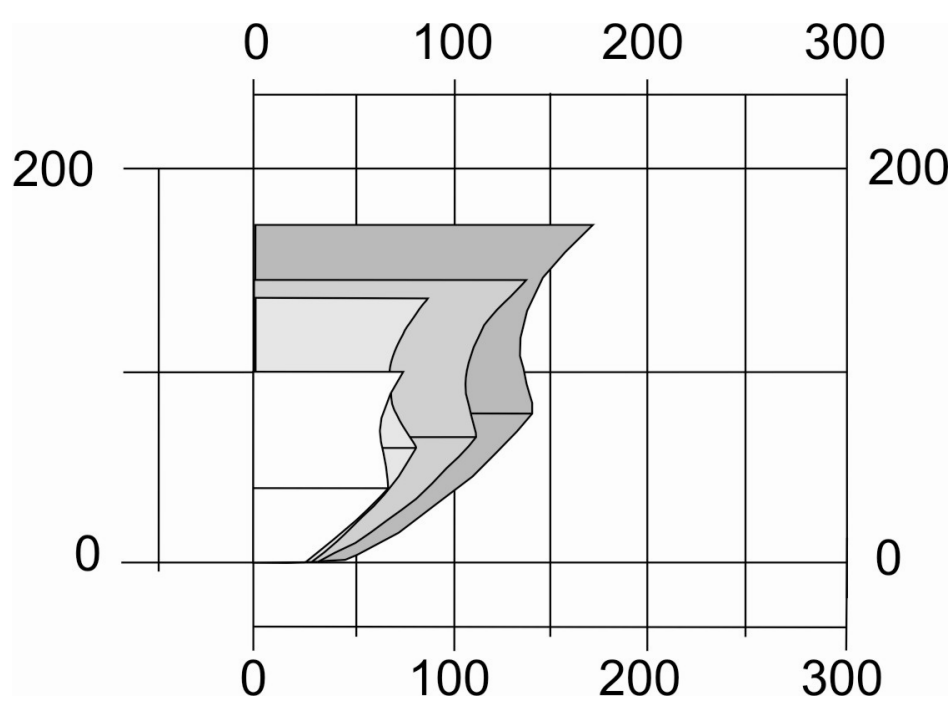

Gráfico 6.13: tamaño de las vasijas de forma c de clase A1. Las medidas están expresadas en mm.
Son en general más altas que anchas. Las alturas medidas en tres vasijas enteras van desde los $111 \mathrm{~mm}$ a los $141 \mathrm{~mm}$. El diámetro de la boca de estos tres ejemplares va de los 145 a los 282. Pudimos medir 8 radios de boca, que arrojaron un promedio de $150,75 \mathrm{~mm}$ (diámetro=351) con una desviación de $\quad 39,63$ (diámetro=79,26) y un máximo y mínimo de $215 \mathrm{~mm}$

$($ diámetro=430) y $94 \mathrm{~mm}($ diámetro $=188)$. Esto nos muestra cierta variabilidad en los diámetros de bocas de estas vasijas. En relación al diámetro máximo, en la mayoría de los casos coincide con el de la boca, por lo cual los valores de los diámetros y radios de la 
boca son los valores del diámetro máximo. Existe un sólo caso en donde la boca es de $111 \mathrm{~mm}$ de diámetro de boca, contra los $190 \mathrm{~mm}$ de diámetro máximo que se encuentra en el punto angular que suelen presentar los cuerpos de estas vasijas. El diámetro de la base va desde los $63 \mathrm{~mm}$ a los $81 \mathrm{~mm}(\mathrm{n}=3)$. Los espesores de la base se encuentran entre los $11 \mathrm{~mm}$ y $12 \mathrm{~mm}(\mathrm{n}=3)$. En relación al espesor del cuerpo $(\mathrm{n}=12)$, el mismo posee una media de $5 \mathrm{~mm}$ con una desviación de 1,04 y un máximo y mínimo de 3 y $7 \mathrm{~mm}$, por lo cual los cuerpos poseen menos espesor que las bases. Con respecto al espesor de los bordes $(\mathrm{n}=9)$, poseen una media de 4,67 mm con una desviación típica de $0,88 \mathrm{~mm}$ y un máximo y mínimo de $4 \mathrm{~mm}$ y $6 \mathrm{~mm}$, con casi el mismo espesor que el cuerpo.

En cuanto al volumen, los tres casos medidos se encuentran entre los 1,86 litros y 4,93 litros, con un valor intermedio de 2,32 litros. A partir de estos datos, podemos decir que, al igual que la forma $b$, estas piezas poseen cierta variabilidad, junto a una poca variabilidad en sus espesores.

Escudillas -gráfico 6.14-

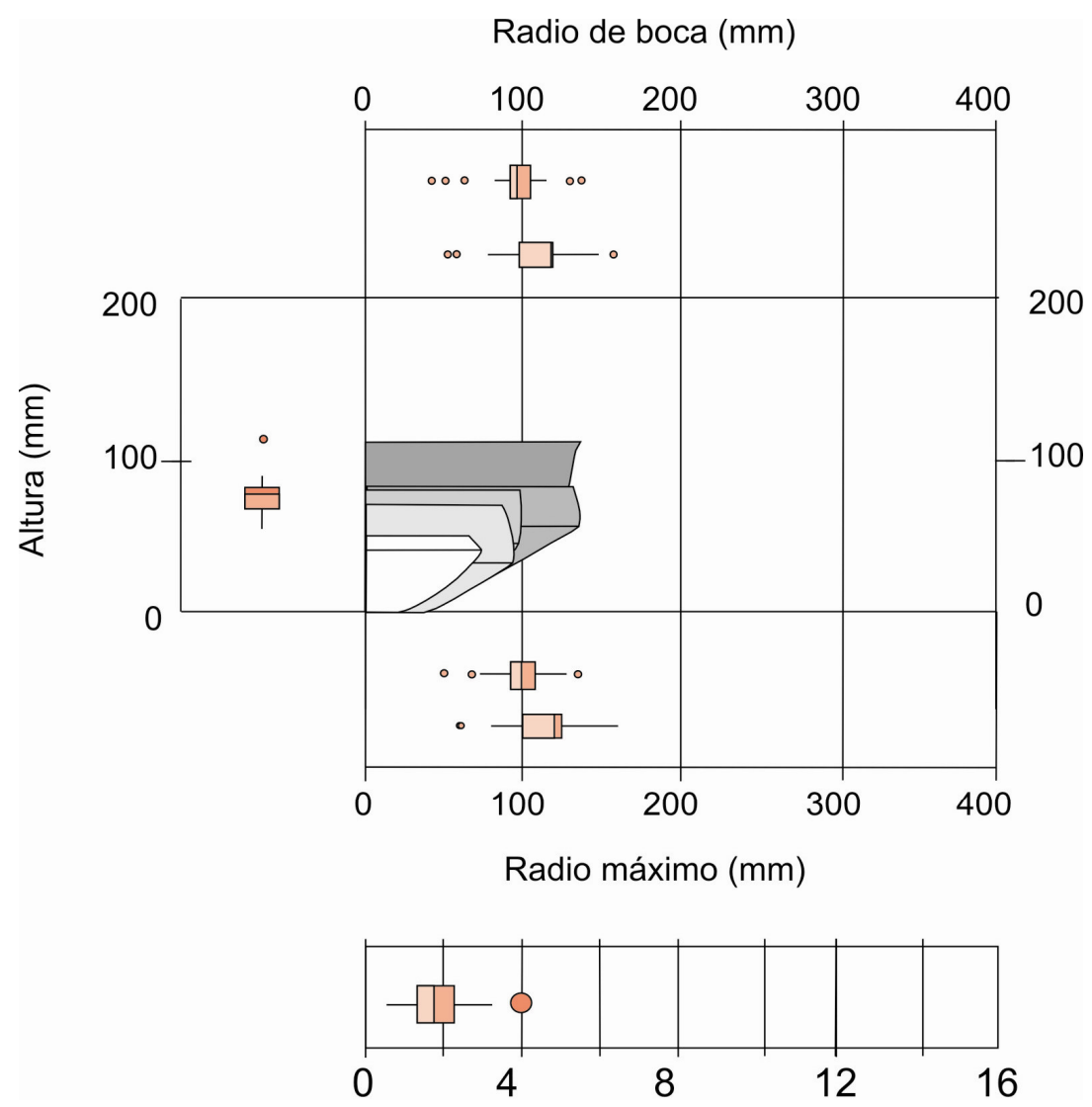

Anteriores investigaciones (Laguens y Juez 1999) han señalado la estandarización en la fabricación de las escudillas. Si bien los autores señalan la existencia de variabilidad en sus tamaños, las proporciones entre las distintas partes de las piezas se mantienen similares. Los autores no proponen una fabricación en serie pero sí indican la presencia de cierto canon de manufactura.

Hemos

Gráfico 6.14: se combinan gráficos de caja de las diferentes medidas de las escudillas de clase A1. En el caso del radio de boca, el gráfico de caja superior corresponde a los radios de vasijas enteras $-\mathrm{n}=25-$, el inferior a los radios de las fragmentadas con 5\% o más de porcentaje de radio $-\mathrm{n}=112-$. En el caso del radio máximo el diagrama de caja superior corresponde a las enteras $-\mathrm{n}=25$ - y el inferior a las fragmentadas con porcentajes de arcos del $5 \%$ o mayores $-n=112$-superior. En el caso de las altura y el volumen el $n=25$. 
pertenecen a la medidas por Laguens y Juez (1999)- y 175 fragmentos de escudillas $(\mathrm{MNV}=14)$ fabricadas con la clase A1. Se trata de piezas más anchas que altas.

En cuanto a la altura poseen una media de 72,84 mm ( $\mathrm{n}=25)$, con una desviación de 11,90 mm y un mínimo y máximo de 52 y $110 \mathrm{~mm}$. Si observamos la dispersión de estos valores, tenemos un valor outlayer de $110 \mathrm{~mm}$, mientras que el resto se encuentra entre los $70 \mathrm{~mm}$ y $80 \mathrm{~mm}$.

En relación a los radios de boca, en las piezas enteras tenemos una media de 95,94 mm (diámetro 191,88 mm) con una desviación típica de 20,85 mm (diámetro 41,7 mm) y un máximo y mínimo de 42,5 mm (diámetro $85 \mathrm{~mm}$ ) y 137,5 (diámetro $275 \mathrm{~mm}$ ). Hay 5 valores outlayer, y el resto está entre $92,5 \mathrm{~mm}$ (diámetro $185 \mathrm{~mm}$ ) y $105 \mathrm{~mm}$ (diámetro $210 \mathrm{~mm}$ ) con dos valores extremos de 82,5 mm (diámetro $165 \mathrm{~mm}$ ) y $115 \mathrm{~mm}$ (diámetro $230 \mathrm{~mm})$. Si observamos los radios de los bordes medidos $(\mathrm{n}=112)$-iguales o mayores al $5 \%$ de porcentaje de arco- tenemos un promedio de 113,99 $\mathrm{mm}$ (diámetro $=227,98)$ con una desviación de 20,49 (diámetro = 40,98) y un mínimo y máximo de $55 \mathrm{~mm}$ (diámetro $=110 \mathrm{~mm}$ ) y $195 \mathrm{~mm}$ (diámetro =390). El diagrama de caja nos muestra cuatro valores outlayer, estando el resto entre los $100 \mathrm{~mm}$ (diámetro $200 \mathrm{~mm}$ ) y $120 \mathrm{~mm}$ (diámetro 240) con valores extremos de $80 \mathrm{~mm}$ (diámetro $160 \mathrm{~mm}$ ) y $150 \mathrm{~mm}$ (diámetro $300 \mathrm{~mm}$ ). Es notable que el 50\% de los valores dentro de una dispersión central se hallen en los $120 \mathrm{~mm}$ (diámetro $240 \mathrm{~mm}$ ), puesto que nos indica una clara tendencia en los radios de las bocas a tener $240 \mathrm{~mm}$ de diámetro.

Con respecto al radio máximo de estos recipientes, vemos que las 25 piezas enteras arrojan un promedio de 98,5 mm (diámetro 197,28 mm) con una desviación de 18,45 mm (diámetro $36,89 \mathrm{~mm}$ ) y un mínimo y máximo de $50 \mathrm{~mm}$ (diámetro $100 \mathrm{~mm}$ ) y $135 \mathrm{~mm}$ (diámetro $270 \mathrm{~mm}$ ). La dispersión de estos valores en el diagrama de caja se presenta con tres valores outlayer, estando el resto entre los 92,5 mm (diámetro $185 \mathrm{~mm}$ ) y $100 \mathrm{~mm}$ (diámetro $200 \mathrm{~mm}$ ) con valores extremos de $75 \mathrm{~mm}$ (diámetro $150 \mathrm{~mm}$ ) y $125 \mathrm{~mm}$ (diámetro $250 \mathrm{~mm}$ ). En relación a los radios máximos medidos en el cuerpo -punto angular de las escudillas- $(\mathrm{n}=112)$ arrojaron una media de 114,12 (diámetro 228,24 mm) con una desviación típica de 19,11 (diámetro = 38,22 mm) y un mínimo y máximo de $60 \mathrm{~mm}$ $($ diámetro $=120 \mathrm{~mm})$ y $160 \mathrm{~mm}($ diámetro $=160 \mathrm{~mm})$. Si observamos en el diagrama de caja la dispersión vemos dos valores outlayer, estando el resto distribuido entre los 100 $\mathrm{mm}($ diámetro $=200 \mathrm{~mm})$ y $\operatorname{los} 125 \mathrm{~mm}($ diámetro $=250 \mathrm{~mm})$ con valores extremos de 80 $\mathrm{mm}$ (diámetro $=160 \mathrm{~mm}$ ) y $160 \mathrm{~mm}$ (diámetro =320). A su vez, existe una gran concentración $(50 \%)$ entre la mediana $-120 \mathrm{~mm}($ diámetro = 240)- y $125 \mathrm{~mm}($ diámetro = 
250). Es decir que la mayoría se encuentra alrededor de los $240 \mathrm{~mm}$ o $250 \mathrm{~mm}$ de diámetro. Si embargo, existe dispersión de los casos hacia valores más bajos, entre la mediana y $100 \mathrm{~mm}$ (diámetro $=200 \mathrm{~mm}$ ).

En cuanto a los diámetros de las bases $(\mathrm{n}=45)$ tenemos un promedio de $72,20 \mathrm{~mm}$ con una desviación típica de 15,79 mm y un máximo y mínimo de $45 \mathrm{~mm}$ y $120 \mathrm{~mm}$. En relación a los espesores, vemos que la base posee un promedio de 5,09 $\mathrm{mm}(\mathrm{n}=45)$ con una desviación de 0,76 mm y un mínimo y máximo de $3 \mathrm{~mm}$ y $7 \mathrm{~mm}$.

El espesor del cuerpo $(\mathrm{n}=173)$ posee un promedio de 4,43 con una desviación típica de 0,935 , con un mínimo de $2 \mathrm{~mm}$ y un máximo de $8 \mathrm{~mm}$. El espesor del borde $(\mathrm{n}=135)^{\mathrm{vii}}$ posee un promedio de 4,10 $\mathrm{mm}$ con una desviación típica de $0,86 \mathrm{~mm}$ y un mínimo y máximo de $4 \mathrm{~mm}$ y $6 \mathrm{~mm}$.

Con respecto al volumen de las escudillas $(\mathrm{n}=25)$ tenemos un promedio de 1,738 litros con una desviación típica de 0,81 litros y un máximo y mínimo de 0,50 y 3,92 litros. Si observamos la dispersión de los valores en el diagrama de caja, vemos que tenemos un valor outlayer (el máximo) y el resto se distribuye homogéneamente entre los 1,5 litros y los 2,5 litros, estando la mediana de 1,69 litros a la misma distancia de los umbrales inferiores y superiores de la caja.

Calceiforme -figura 6.12-

Tenemos un solo caso registrado que tiene una altura de $80 \mathrm{~mm}$, con un diámetro de boca de $65 \mathrm{~mm}$ y un diámetro máximo de $100 \mathrm{~mm}$. Estos valores son muy semejantes a la vasija calceiforme más pequeña registra para la clase tecnológica E. El espesor de los muros posee en la base $5 \mathrm{~mm}$ al igual que en el cuerpo, mientras que en el borde mide 4 $\mathrm{mm}$. En cuanto al volumen posee menos de medio litro.

\section{"Otras formas" -figura 6.12-}

Fueron registradas tres enteras y tres fragmentadas. Las piezas enteras poseen una altura mínima de $51 \mathrm{~mm}$ y máximo de $95 \mathrm{~mm}$. Difieren notablemente con respecto a los tamaños de las "otras formas" de la clase E. En relación a los diámetros de boca medidos, tenemos que las enteras van de los $44 \mathrm{~mm}$ a los $80 \mathrm{~mm}$ y el diámetro máximo se extiende entre los $50 \mathrm{~mm}$ y los $120 \mathrm{~mm}$. Los fragmentos son bordes que van desde los $75 \mathrm{~mm}$ a los $140 \mathrm{~mm}$. Los espesores de las bases están entre los $4 \mathrm{~mm}$ y $8 \mathrm{~mm}$, los del cuerpo de 3 a 8 
$\mathrm{mm}$ y, los del borde de $2 \mathrm{~mm}$ a $6 \mathrm{~mm}$. El volumen medido en las tres enteras va de los 0,07 a los 0,64 litros, es decir que tienen muy bajo volumen, con respecto a las demás.

Vasos o Jarras -gráfico 6.15-

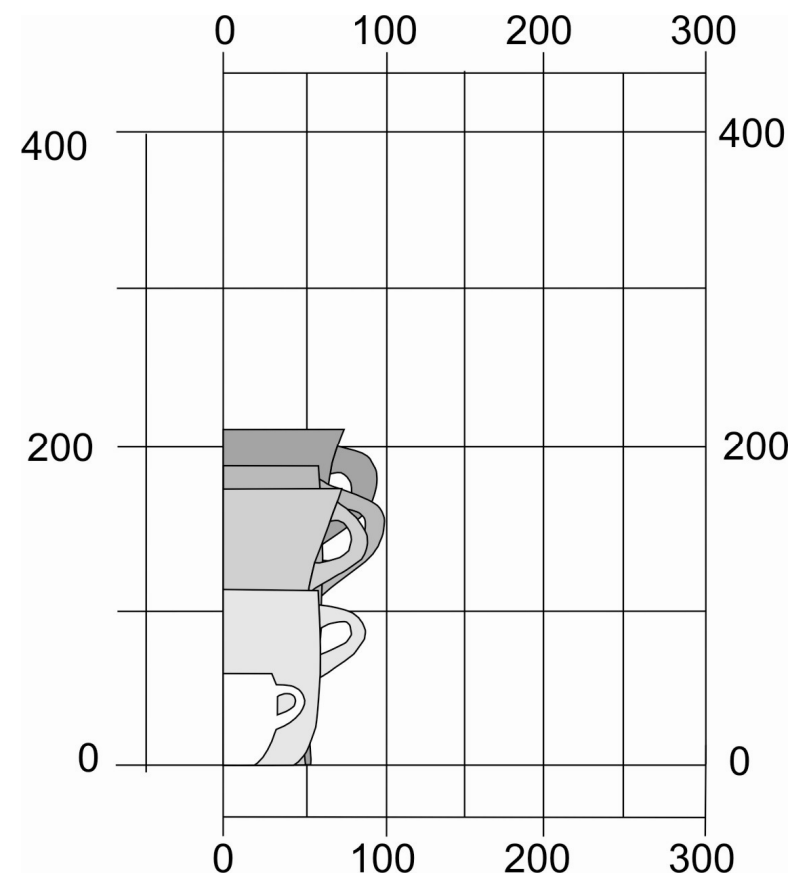

Gráfico 6.15: tamaño de los vasos o jarras de clase A1. Las medidas están expresadas en mm.

Relevamos cinco enteras y 6 fracturadas $(\mathrm{MNV}=2)$. Con respecto a la altura de las piezas, tenemos una de $56 \mathrm{~mm}$ de altura, otra de $100 \mathrm{~mm}$ y las tres restantes están entre los $170 \mathrm{~mm}$ y $210 \mathrm{~mm}$ de altura. En relación a los diámetros de la boca, que siempre coinciden con el diámetro máximo, tenemos el más pequeño de $66 \mathrm{~mm}$ y los otros cuatro entre los 116 $\mathrm{mm}$ y $145 \mathrm{~mm}$. Los radios de las bocas $(\mathrm{n}=6)$ están entre los $60 \mathrm{~mm}$ y $140 \mathrm{~mm}$. Los diámetros de base medidos $(n=9)$ van desde los $50 \mathrm{~mm}$ a los $95 \mathrm{~mm}$. En relación a los espesores de la base tenemos que en general todos se hallan entre los $5 \mathrm{~mm}$ y $6 \mathrm{~mm}(\mathrm{n}=9)$. El espesor del cuerpo $(\mathrm{n}=11)$ va desde los 3 a los $6 \mathrm{~mm}$ predominando aquellos que van de los $5 \mathrm{~mm}$ a los $6 \mathrm{~mm}$. El espesor del borde va de los 3 a los $5 \mathrm{~mm}(\mathrm{n}=11)$, predominando los de $5 \mathrm{~mm}$. En relación a los volúmenes, de los 5 casos medidos tenemos uno con una capacidad de 0,40 litros, mientras que los otros cuatro van de los 1,5 litros a los 2,19 litros.

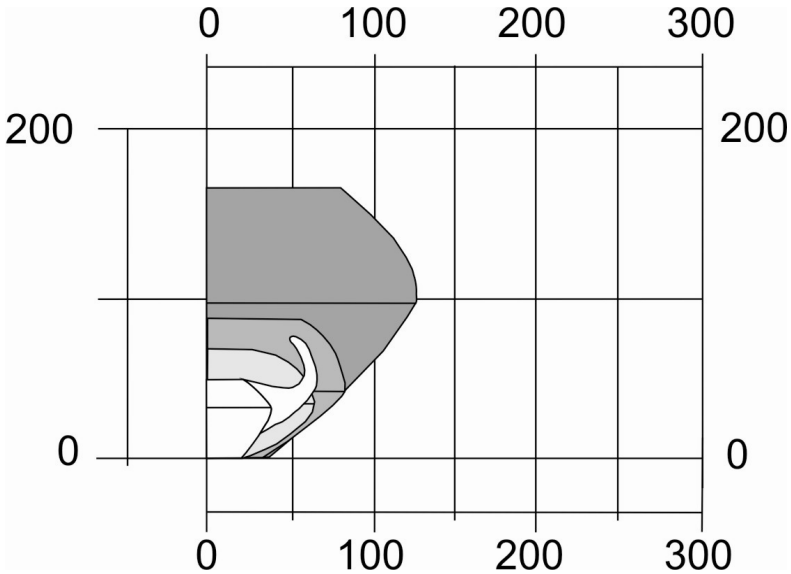

Gráfico 6.16: tamaño de las vasijas restringidas compuestas de clase A1. Las medidas están expresadas en $\mathrm{mm}$.
Vasijas restringidas compuestas -gráfico 6.16-

Hemos medido 5 vasijas enteras y 8 fragmentadas $(M N V=1)$. Las alturas varían de los 55 a los $148 \mathrm{~mm}$. En relación al diámetro de la boca también son variables, desde los $45 \mathrm{~mm}$ a los $165 \mathrm{~mm}$ $(n=5)$. En el caso de las fragmentadas, los radios del borde medidos $(\mathrm{n}=7)$ van de los 
$35 \mathrm{~mm}$ (diámetro $=70 \mathrm{~mm}$ ) a los $135 \mathrm{~mm}$ (diámetro $=270 \mathrm{~mm}$ ). Los diámetros máximos se registran en el punto angular: en los casos de las vasijas enteras van desde los $95 \mathrm{~mm}$ a los $268 \mathrm{~mm}$ y, en el caso de las fragmentados, arrojan un valor de $96 \mathrm{~mm}$ (diámetro $=192$ $\mathrm{mm}$ ) y $112 \mathrm{~mm}$ (diámetro $=224 \mathrm{~mm}$ ). El diámetro de la base va de los $40 \mathrm{~mm}$ a los $86 \mathrm{~mm}$ $(n=5)$. Según estos valores, puede observarse cierta variabilidad a pesar de lo pequeño de la muestra. En relación a los espesores medidos, vemos que las bases van desde los $5 \mathrm{~mm}$ a los $6 \mathrm{~mm}$ de espesor $(\mathrm{n}=5)$. En relación al espesor de los cuerpos $(\mathrm{n}=13)$, poseen un promedio de 4,90 con una desviación de 1,01 y un máximo y mínimo de $3 \mathrm{~mm}$ y $7 \mathrm{~mm}$. El borde tiene un promedio de 4,3 con una desviación típica de 0,53 y un máximo y mínimo de $4 \mathrm{~mm}$ y $5 \mathrm{~mm}$. En relación a los volúmenes, estos van desde los 0,17 litros a los 6 litros, con valores medios que van desde los 0,6 litros a 1,30 litros.

\section{Modeladas}

Presentan tamaños muy variados. Hemos registrado 3 piezas enteras y 13 fragmentadas (NMV=13). Diez de los fragmentos no permiten conocer la forma que tenían el modelado, pero dada la curvatura que presentan podemos saber que pertenecen a este tipo de piezas. Dos de las fragmentadas se encuentran con mayor grado de completitud por
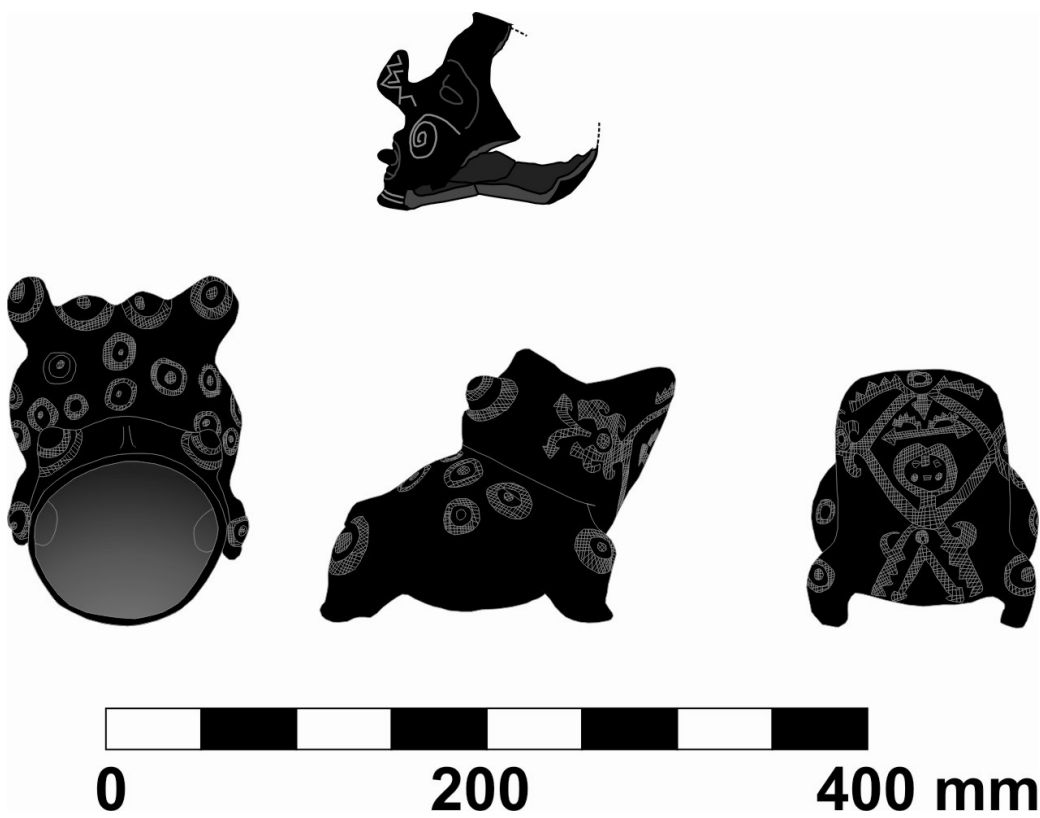

Figura 6.24: tamaño de las vasijas modeladas. lo cual podemos conocer su forma y tamaño. En uno de los casos se trata de un rostro modelado -figura 6.24-, muy semejante a algunos de los modelados que presentan la forma a: se trata de un rostro que posee una nariz en gancho prominente hacia arriba, los ojos se encuentran hendidos y están delineados por los párpados y las cejas que aparentemente convergen en la nariz. Posee los pómulos bien marcados, al igual que la boca ovalada; en su interior se observan dientes y del centro sale una lengua. También se halla demarcado el mentón. 
La altura de esta pieza es de $70 \mathrm{~mm}$ aproximadamente, la boca es de $60 \mathrm{~mm}$, y el diámetro máximo $95 \mathrm{~mm}$ al igual que la base. En relación a los espesores, en la base -que es de forma plana- posee $6 \mathrm{~mm}$ y en el cuerpo y borde $4 \mathrm{~mm}$. El otro caso de las vasijas fragmentadas posee un rostro esbozado con nariz apenas sobresaliente. A su vez presenta cejas que se juntan en la nariz y que sirven para demarcar la extensión del rostro. Posee ojos convexos, probablemente haya tenido boca pero por la fractura no se observa. El borde de la pieza posee una forma irregular sinuosa. No conocemos la forma completa pero aparentemente se extendía más que lo que ocupa el rostro modelado. El fragmento posee un alto de unos $90 \mathrm{~mm}$ y un ancho de $70 \mathrm{~mm}$; medimos la curvatura y el diámetro aproximado es de $150 \mathrm{~mm}$. En cuanto a las piezas enteras se trata de dos batracios y un suri. Ambos batracios poseen la boca abierta, que también forma la boca de las vasijas figura 6.24-. Estas son más bien ovaladas, si se las mira de perfil el contorno marca una "V" abierta asimétrica. En una de las piezas la boca mide $75 \mathrm{~mm}$, en otra mide $100 \mathrm{~mm}$. La altura de los batracios es de $110 \mathrm{~mm}$. En cuanto al diámetro máximo del cuerpo en el que posee la boca más pequeña es de $137 \mathrm{~mm}$ y en el otro es de $125 \mathrm{~mm}$. Poseen cuatro patas que le sirven de apoyo, y como fondo se les marca una pequeña base cóncava convexa de $50 \mathrm{~mm}$. Ambos se encuentran mirando hacia arriba con la boca abierta como esperando que se le vierta un contenido, pero a la misma vez ofreciéndolo para escanciar -figura 6.24. En cuanto al largo de los batracios, el primero mide $180 \mathrm{~mm}$ y el segundo unos $170 \mathrm{~mm}$, si se consideran las patas un tanto más. El suri se halla modelado en una vasija subglobular asimétrica. Opuesto a la boca surge una prolongación en forma de cuello y cabeza de suri. Posee una base ligeramente cóncava. Tiene una altura de $98 \mathrm{~mm}$, la boca tiene un diámetro de $48 \mathrm{~mm}$, siendo el diámetro máximo del cuerpo $137 \mathrm{~mm}$. La base posee un diámetro de $67 \mathrm{~mm}$.

\section{Bol-gráfico 6.17-:}

Hemos registrado fragmentos de estas formas $(n=39, N M V=4)$. No poseemos datos de la altura alcanzada por estas piezas. En relación al diámetro de la boca registramos los siguientes valores de radio $(\mathrm{n}=22)$ : un promedio de 107,27 $\mathrm{mm}$ (diámetro $=214,54 \mathrm{~mm}$ ) con una desviación de 30,80 $\mathrm{mm}$ (diámetro $=61,60 \mathrm{~mm}$ ) y un mínimo y máximo de 32 $\mathrm{mm}($ diámetro $=64)$ y $156 \mathrm{~mm}($ diámetro $=312 \mathrm{~mm})$. Si observamos la dispersión de los valores, se observa una distribución diferencial estando el $50 \%$ de los valores entre la mediana $90 \mathrm{~mm}$ (diámetro $=180 \mathrm{~mm}$ ) y $115 \mathrm{~mm}$ (diámetro $230 \mathrm{~mm}$ ) con un valor máximo de $140 \mathrm{~mm}$ (diámetro $=280 \mathrm{~mm}$ ) y el resto entre la media y los $80 \mathrm{~mm}$ (diámetro $=160$ 


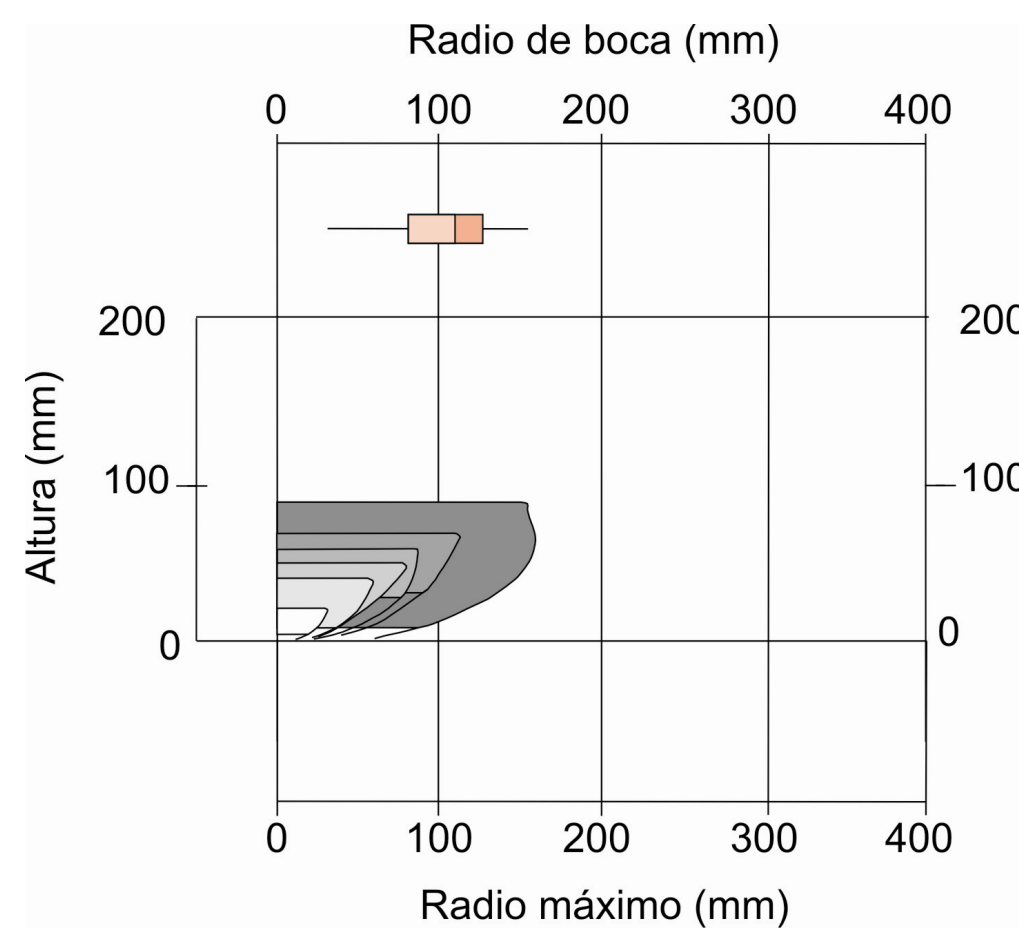

Gráfico 6.17: gráficos de caja de las diferentes medidas de fragmentos con $5 \%$ o más de los bols de clase A1 n=22. $\mathrm{mm}$ ) con un valor extremo de $35 \mathrm{~mm}$ (diámetro $=70 \mathrm{~mm}$ ). En relación al diámetro máximo en esta forma, coincide con el diámetro de la boca. El diámetro de la base pudimos medirlo en dos casos: uno tiene $50 \mathrm{~mm} \mathrm{y}$ otro $110 \mathrm{~mm}$. En relación a los espesores de la base, en los dos casos miden $6 \mathrm{~mm}$. El espesor del cuerpo $(n=39)$ tiene un promedio de 4,13 mm con una desviación de 0,81 mm y un mínimo y máximo de $3 \mathrm{~mm}$ y $6 \mathrm{~mm}$.

Con respecto al espesor del borde tenemos un promedio de $4 \mathrm{~mm}(\mathrm{n}=28)^{\mathrm{viii}}$ con una desviación de $0,81 \mathrm{~mm}$ y un máximo de $2 \mathrm{~mm}$ y $6 \mathrm{~mm}$. Suponiendo que los bol podrían presentar, dependiendo de su tamaño, volúmenes semejantes a las escudilla, podría sugerirse que dadas sus formas, alcanzarían volúmenes levemente mayores, siempre que se comparen objetos de tamaños semejantes.

\section{Terminado de las vasijas}

Una vez que estas vasijas han adquirido la forma y tamaño deseados por el artesan@, sufren diferentes tratamientos, particularmente dos procesos: el pulido de las superficies externas e internas, y la incisión -sensu Rye (1981:90)- en diferentes estados de sequedad de la pasta. Bedano et al (1993) lo denominan "grabado", dado que en general las incisiones se realizan cuando la pasta se encuentra bastante seca y dura. Esto está indicado porque en general no quedan márgenes sobreelevados al lado del surco de la incisión, presentando en algunos casos cierto astillado que indicaría que la pieza estaba ya seca. Gordillo (2009) describe para la Rinconada la existencia de grabados e incisiones. Dado los proceso de pulido y alisado de las superficies de estas vasijas, no se pudo observar la técnica de modelado de las misma, salvo algunas indicaciones de su fabricación por partes, 
particularmente en la forma "b" que posee un cuello diferenciado del cuerpo por un punto angular marcado. Se pudo observar en algunos casos que el cuello y el cuerpo se modelaron por separado y que fueron luego pegados; esto se observa específicamente en las superficies internas donde quedaron las marcas de la arcilla que se usó para pegarlos, la que luego se alisó -figura 6.25-.
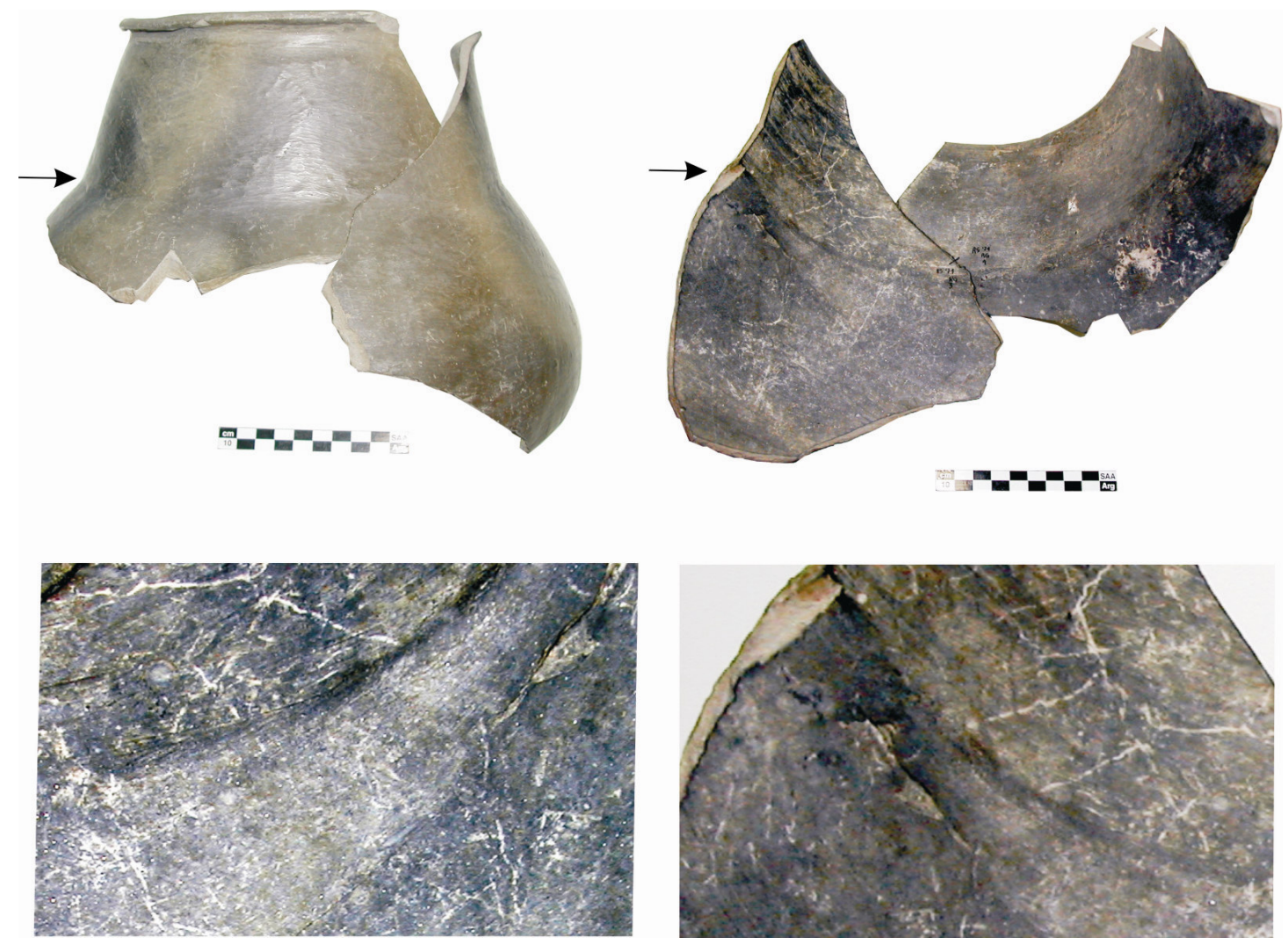

Figura 6.25: imágenes que muestran la forma de modelado de las vasijas de forma b de clase A1. Obsérvese el sobreborde dejado de la unión del cuello y el cuerpo.

Forma " $b$ ": una vez que se le dio la forma y el tamaño, se pule la superficie externa dejándole, como a casi todas las vasijas de la clase A1, un brillo muy intenso -figura 6.26-. El pulido en general se extiende hasta la parte interna del borde, culminando en el punto angular, que marca la separación entre el borde y el cuello -figura 6.26-. La superficie interior de las piezas se encuentra alisada -figura 6.26-. Una vez que está pulida, a algunas se les graba en la superficie diferentes motivos, en general en el cuello y parte del cuerpo, teniendo como límite la altura del diámetro máximo. Los motivos grabados en general son figurativos -figura 6.27-: felinos, humanos convertidos en felinos o a la inversa. Estos personajes en general portan armas en sus manos, González (1961, 1977, 1998) le denomina sacrificador. En aquellas variedades que no tienen asas, se representan las típicas 
cabezas estilizadas de felinos de las que brotan otras cabezas (clásicamente llamadas draconiformes). En un caso hallamos un asa incisa con un motivo serpentiforme. En un ejemplar de la colección Rosso registrada por Bedano et al (1993), una de esta vasijas posee en el cuerpo un rostro modelado de camélido con hocico y ojos, que sobresalen formando un pequeño domo y están demarcados por grabado. A su vez, superpuestos al modelado en el cuerpo y en el cuello se representaron dos felinos.
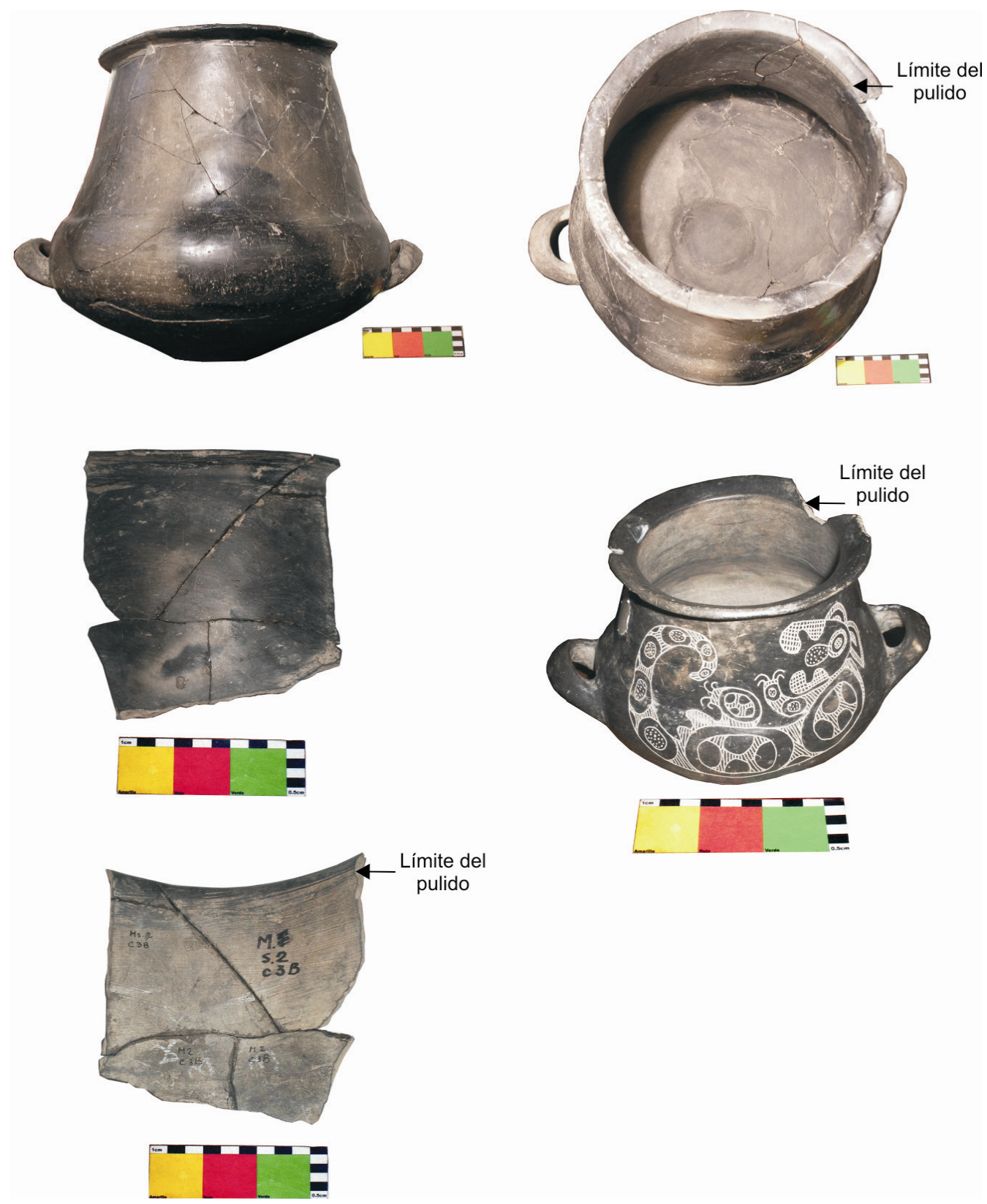

Figura 6.26: imágenes que muestran la extensión del pulido en las vasijas de forma b. Obsérvese el pulimento de la superficie exterior, mientras que la interior sólo se encuentra alisada. La vasija con grabado pertenece a la CR. El resto proviene de excavaciones del Proyecto Ambato. 

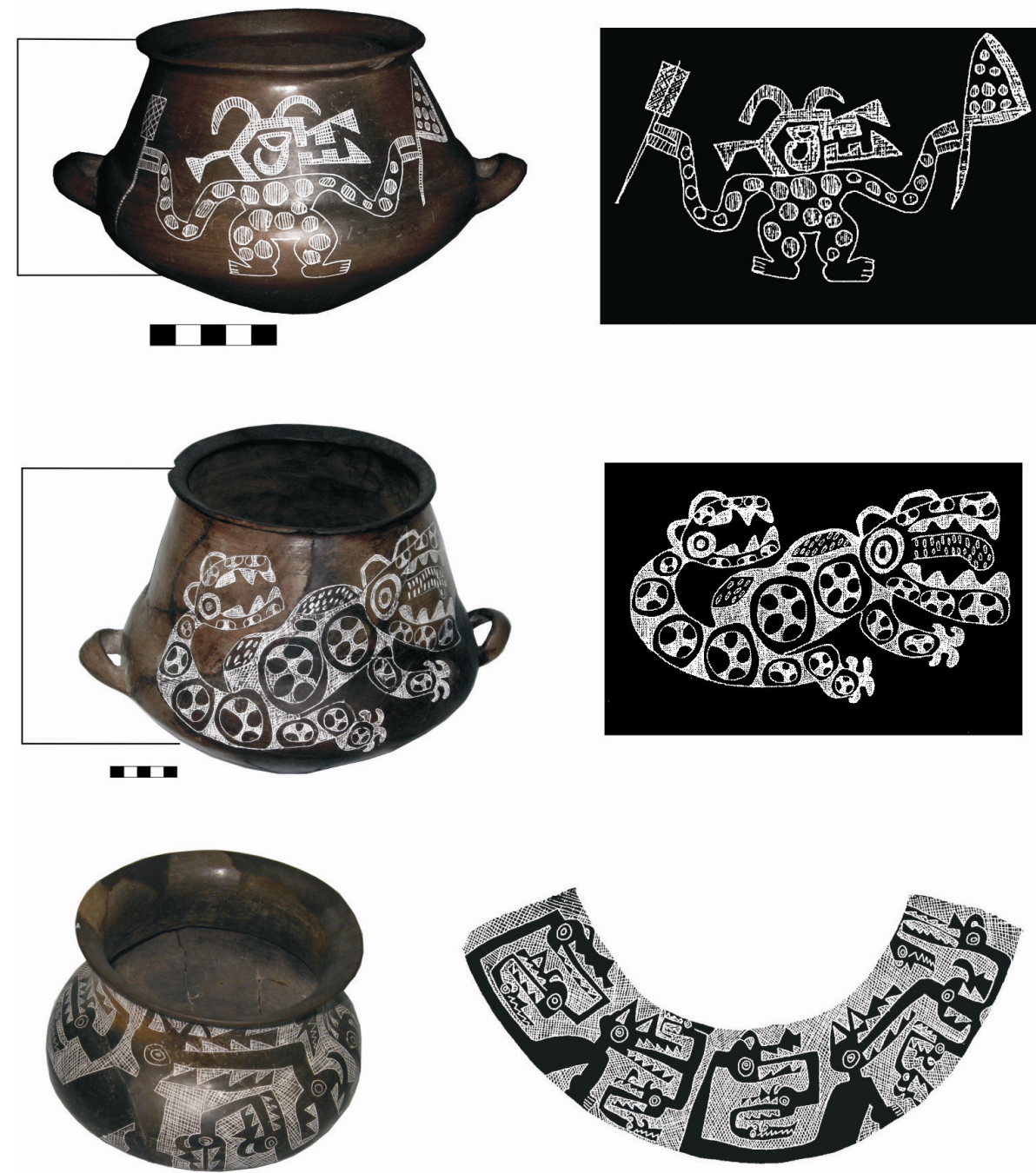

口1
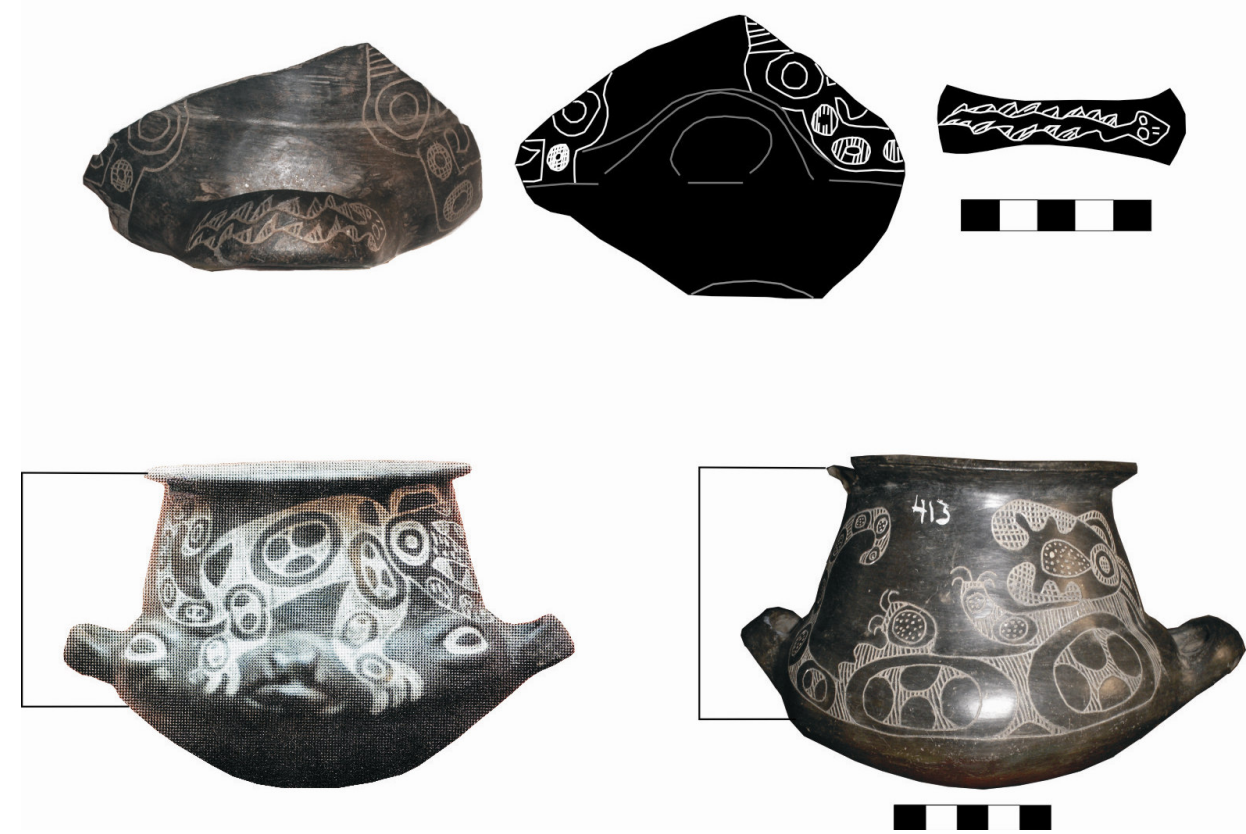

Figura 6.27: imágenes que muestra los motivos incisos en las vasijas de forma b. En la primera imagen (superior) se observa un personaje con rasgos felínicos que porta armas en sus manos -Personaje del Sacrificador según González (1961, 1977, 1998). La segunda imagen y las dos últimas muestran por un lado felinos naturalistas en distintas posiciones y el modelado de un rostro de camélido. Obsérvese en este último caso que las incisiones también se usaron para resaltar parte del rostro modelado -ojos-. Las vasijas del centro muestran los típicos motivos “draconiformes". Las vasijas primera, segunda y quinta pertenecen a la C.R. La tercera a la C.M.A.Q. y el fragmento proviene de excavaciones realizadas por el Proyecto Ambato. 
Forma c: son piezas pulidas o bruñidas en toda la superficie externa incluyendo la base -figura 6.28-. El pulido se extiende hacia el interior de los cuellos, que son evertidos. En general el pulido llega hasta el punto angular o de inflexión que separa el cuello del cuerpo, mientras que la superficie interior está alisada. Luego se las graba; como en la forma "b", el grabado se desarrolla en la superficie del cuello y el cuerpo hasta el punto que marca el diámetro máximo -figura 6.28-. Los motivos representados son muy semejantes a la de forma $\mathrm{b}$. Al igual que en éstos, no se observan motivos geométricos.

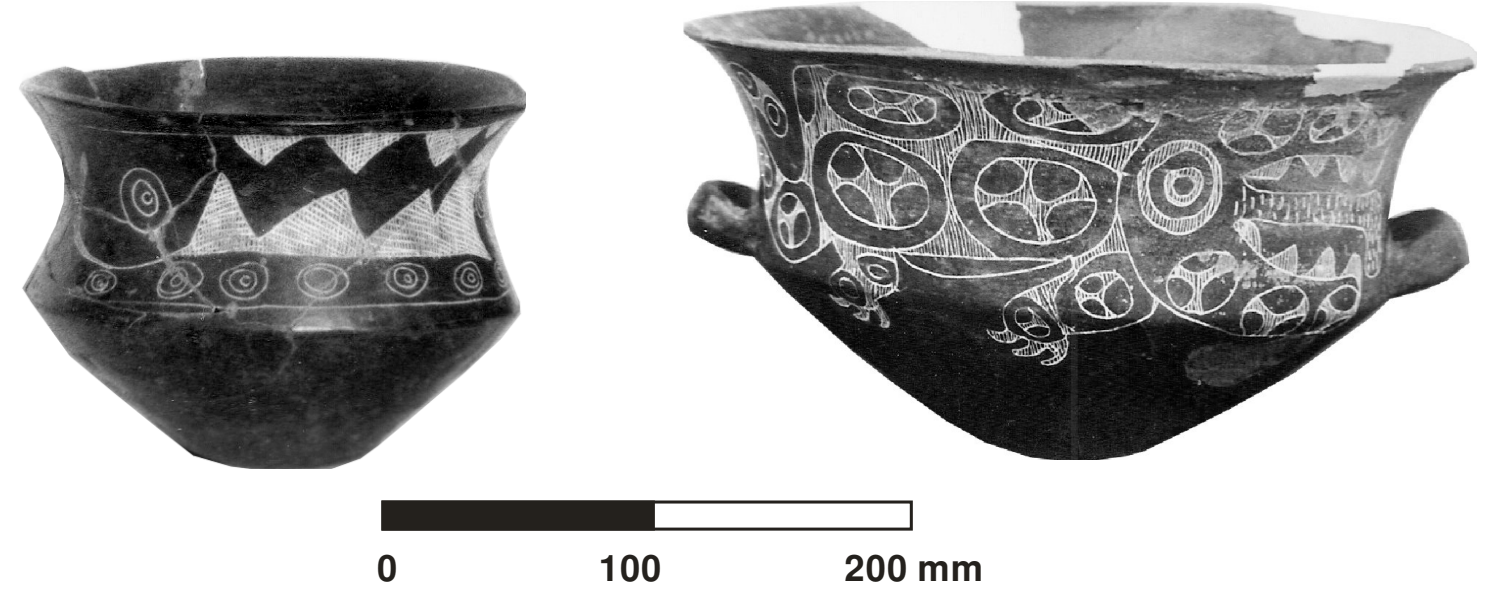

Figura 6.28: vasijas de forma "c" pertenecientes a la C.R.

Escudillas: a las escudillas se las pule en sus superficies interna y externa. La parte de la pieza elegida para realizar el grabado siempre coincide con la sección superior desde el borde hasta el punto angular -figuras 6.29 y 6.30-. Dichas zonas pueden llegar a estar delimitadas por un rectángulo que demarca el área donde se van a grabar los motivos. A veces se presentan dos paneles rectangulares divididos por espacios vacíos -figura 6.30-. Los motivos que suelen grabarse son geométricos, contrastando de esta forma con las forma "b" y "c" -figura 6.29-; mientras que a veces se les graban motivos figurativos figura 6.30-. Estos últimos pueden ser felinos o humanos transformados en felinos y viceversa. Pueden representarse también cabezas triangulares de humanos (algunas con máscaras), de las que se ha indicado que son representaciones de cabezas trofeos (Bedano et al 1993; González 1977, 1998). También se representan los motivos típicos "draconiformes" de cabezas, de las cuales emergen otras cabezas. 

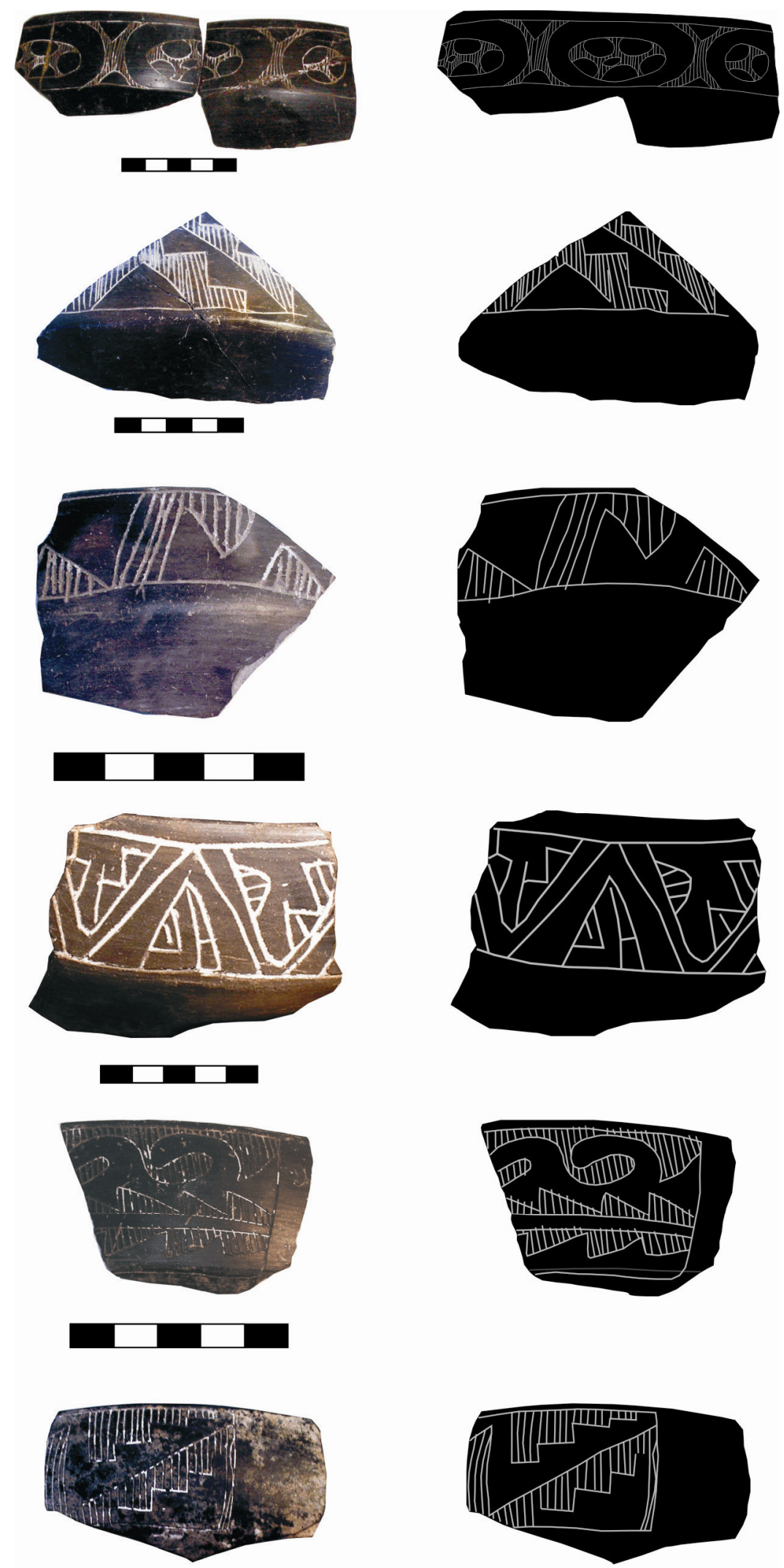

Figura 6.29: imágenes y dibujos que muestra los motivos incisos geométricos en las escudillas. 

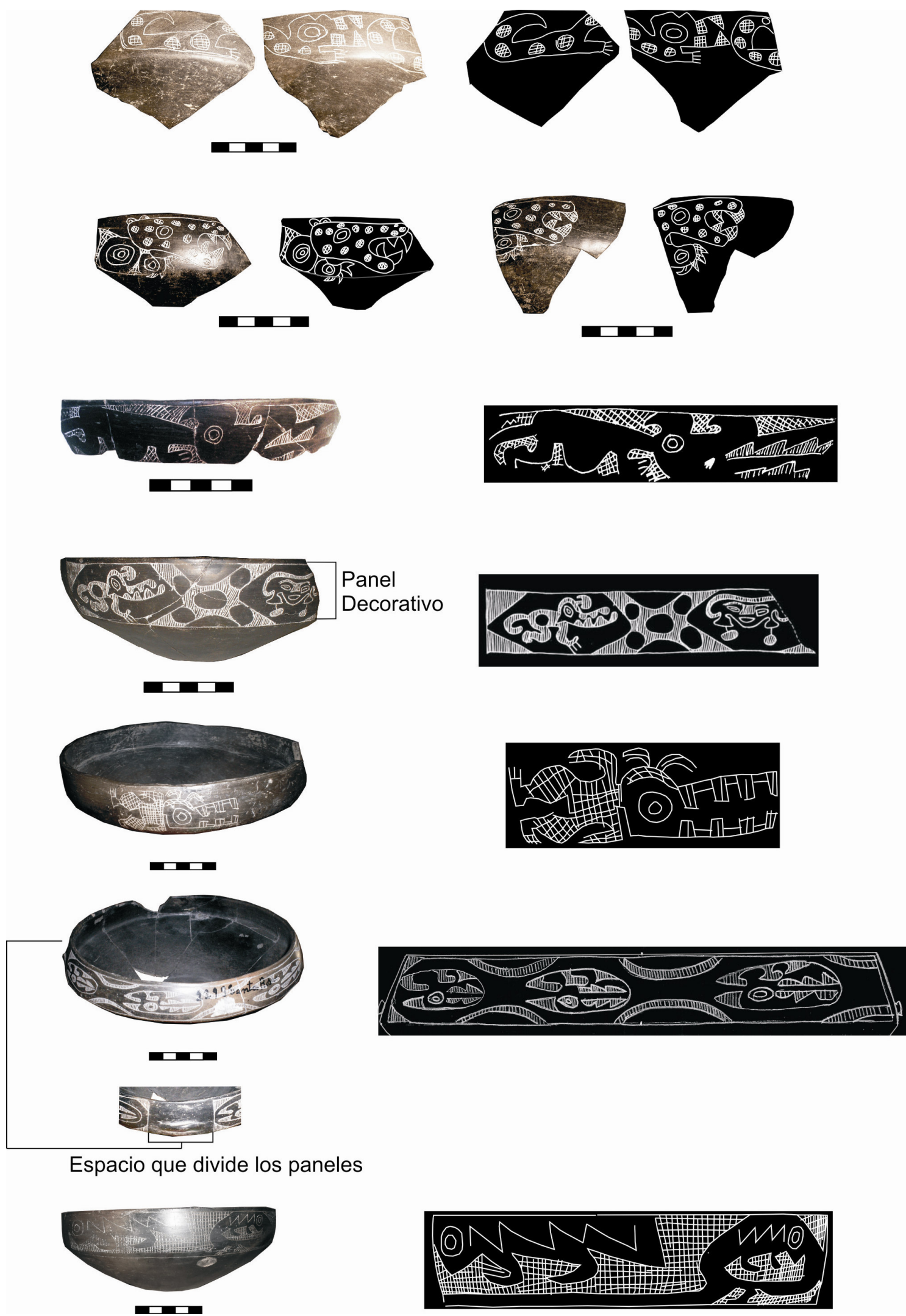

Figura 6.30: imágenes y dibujos que muestra los motivos incisos figurativos en las escudillas. Los Fragmentos de provienen de excavaciones realizadas por el Proyecto Ambato. La escudilla cuarta de la C.D.A.C. y las escudillas quinta, sexta y séptima de la C.M.A.Q. 
Calceiforme: la pieza está pulida en su superficie externa y se encuentra solo alisada en la interna. Posee un grabado geométrico en su cuerpo -figura 6.31-.
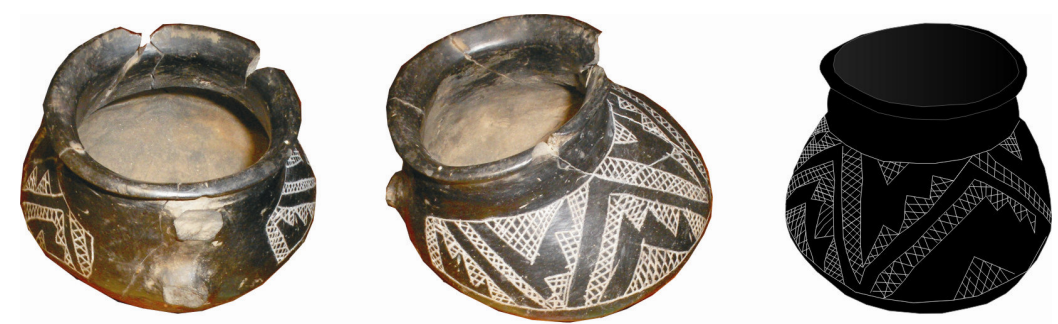

Figura 6.31: fotos y dibujos que muestra los motivos incisos geométricos de la vasija calceiforme. Obsérvese que el pulido solo se encuentra en la superficie exterior llegando hasta el punto angular que divide el borde del cuello. La pieza pertenece a la C.M.A.Q.

"otras formas": a éstas se las pule en toda la superficie exterior -figura 6.32-. El pulido en la parte interior llega hasta el punto de inflexión que divide el cuello del cuerpo, aunque en un caso se extiende un poco más, conformando en general la parte visible. Pueden presentar grabados. En la figura 6.32 se trata de un felino recostado sobre su espalda, con las patas hacia arriba.

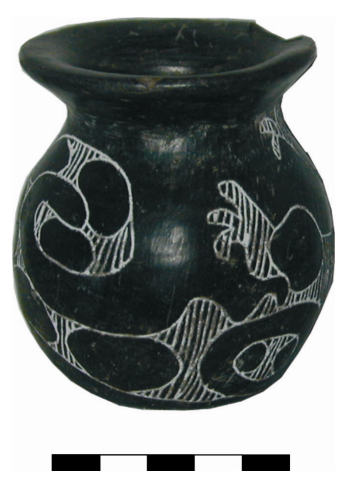

Figura 6.32: fotos de una vasija de "otras formas" que posee inciso un felino recostado sobre su espalda. Motivo que también hemos observado que aparece en las de forma "b". La pieza proviene la C.R.

Vasos o Jarras: se hallan pulidos tanto en el exterior como en el interior al igual que las escudillas -figura 6.33-. Pueden presentar en el asa algún modelado zoomórfico adherido al pastillaje. Una de las registradas posee dos felinos parados atados a una especie de lanza -figura 6.33-. La decoración se desarrolla a lo largo del cilindro del vaso o jarra. El felino puede aparecer parado con el cuerpo de frente y la cabeza de perfil -figura 6.33-. En otro caso se grabó un motivo zoomórfico, que podría representar un chelco (lagartija). También se pueden presentar cabezas felínicas de las que emergen otras cabezas draconiforme-. Un vaso registrado de forma cuadrangular posee en su superficie un grabado antropomórfico felinizado que portaría en su mano izquierda dos flechas o lanzas 
y en la derecha un cuchillo o hacha, conformando la clásica figura del sacrificador -figura 6.33- (González 1961, 1977, 1998).
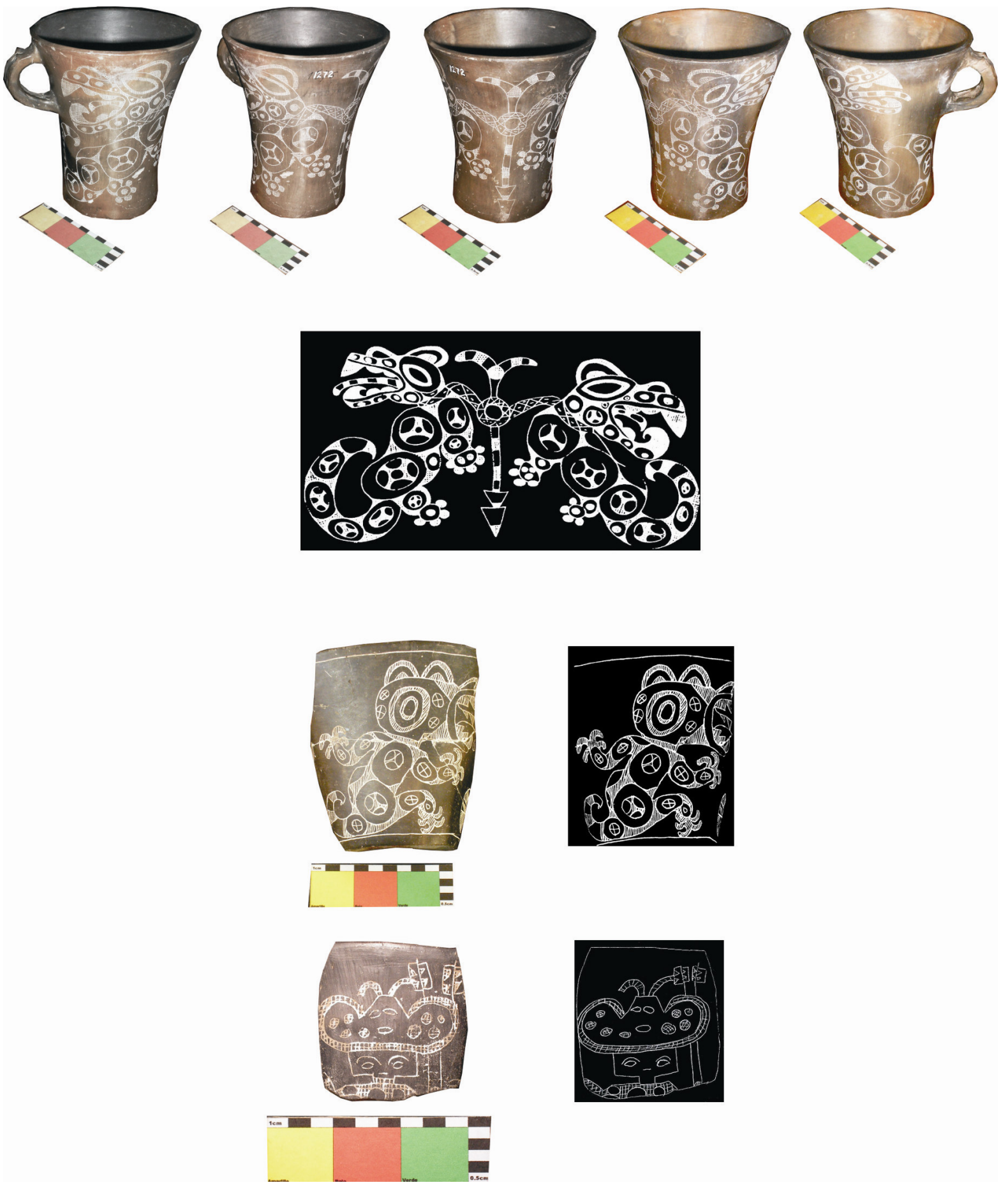

Figura 6.33: fotografía y dibujos de los motivos incisos en los vasos o jarras.

Vasijas restringidas compuestas: son piezas pulidas en su superficie externa y en parte de su superficie interna. Es en esta forma donde más se nota el juego que establece el artesano con la visibilidad de la zona pulida. En general el pulido llega hasta el borde de la pieza que, como hemos dicho, es bien restringido. En la parte interna, la zona pulida comienza 
en la zona donde se proyectan las líneas de la visual cuando la vasija se mira desde arriba. En relación a las representaciones grabadas, se las realiza en la parte superior convexa por encima del punto angular que presenta la pieza -figura 6.34-. Se representan felinos, cabezas de felino muy estilizadas, las típicas cabezas triangulares romboidales y motivos geométricos, pudiendo estar enmarcadas por rectángulos -figura 6.34-.
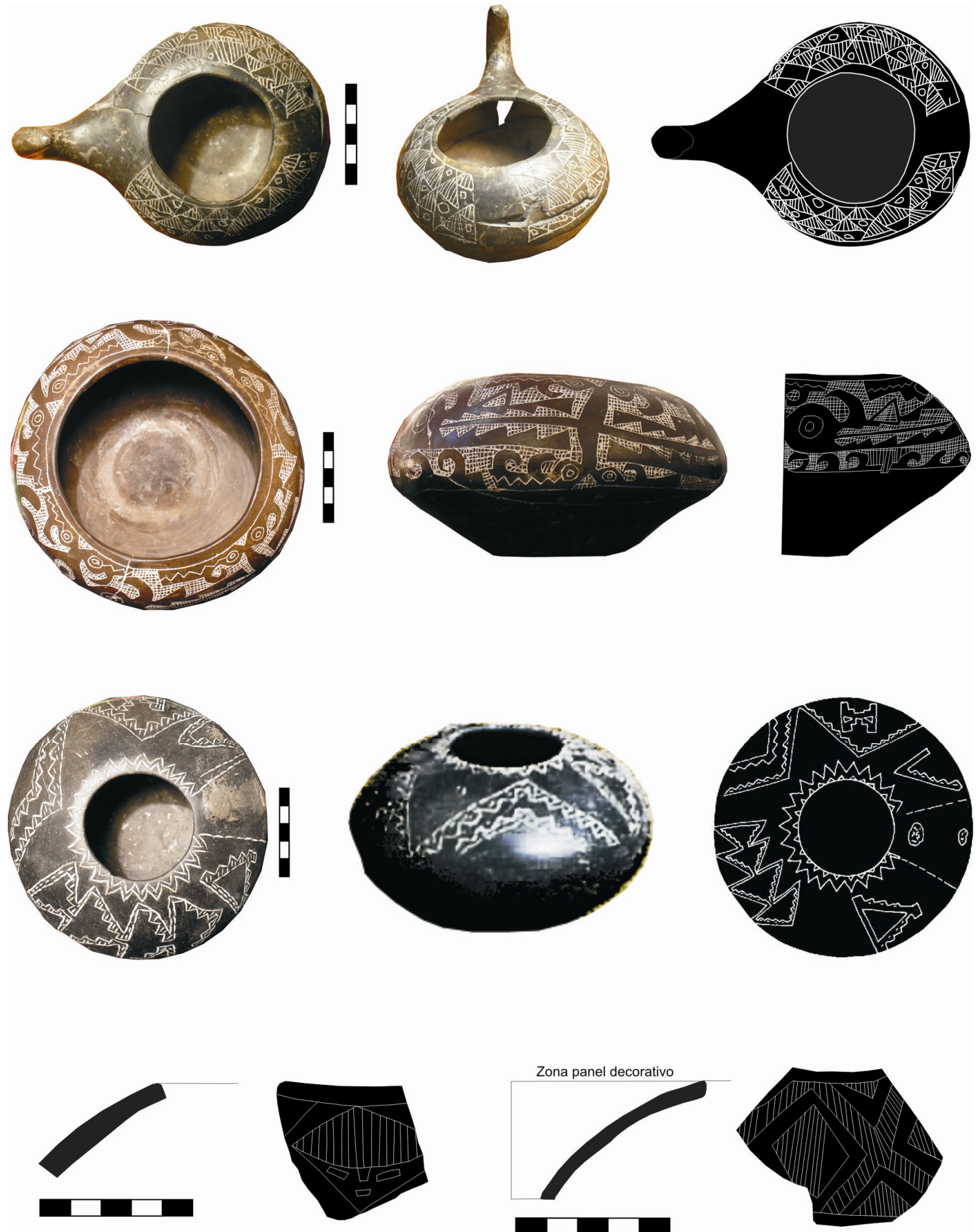

Figura 6.34: fotografía y dibujos de los motivos incisos en las vasijas restringidas compuestas. El pulido se realiza en la superficie interna y en el caso de la interna sólo en la zona que se observa cunado se las mira desde arriba -fotografías de la izquierda- . Las vasijas de la primera y segunda tira de imágenes pertenecen a la C.M.A.Q. Las restantes provienen de excavaciones realizadas por el Proyecto Ambato. 
Modeladas: son vasijas pulidas en su superficie exterior, sin observarse el juego de visuales señalado con anterioridad. Se tratan de dos batracios, un suri, mientras que otra se tratan de rostros modeladas, algunos con nariz en gancho -figura 6.35-. Todas se encuentran alisadas sólo en su superficie interior. En algunos casos, los motivos grabados remarcan algún aspecto del modelado, tales como los ojos -figura 6.35-. En otros casos el grabado se superpone al modelado, representándose en general motivos felínicos u antropofelínicos -ver batracio y suri en Figura 6.35-.
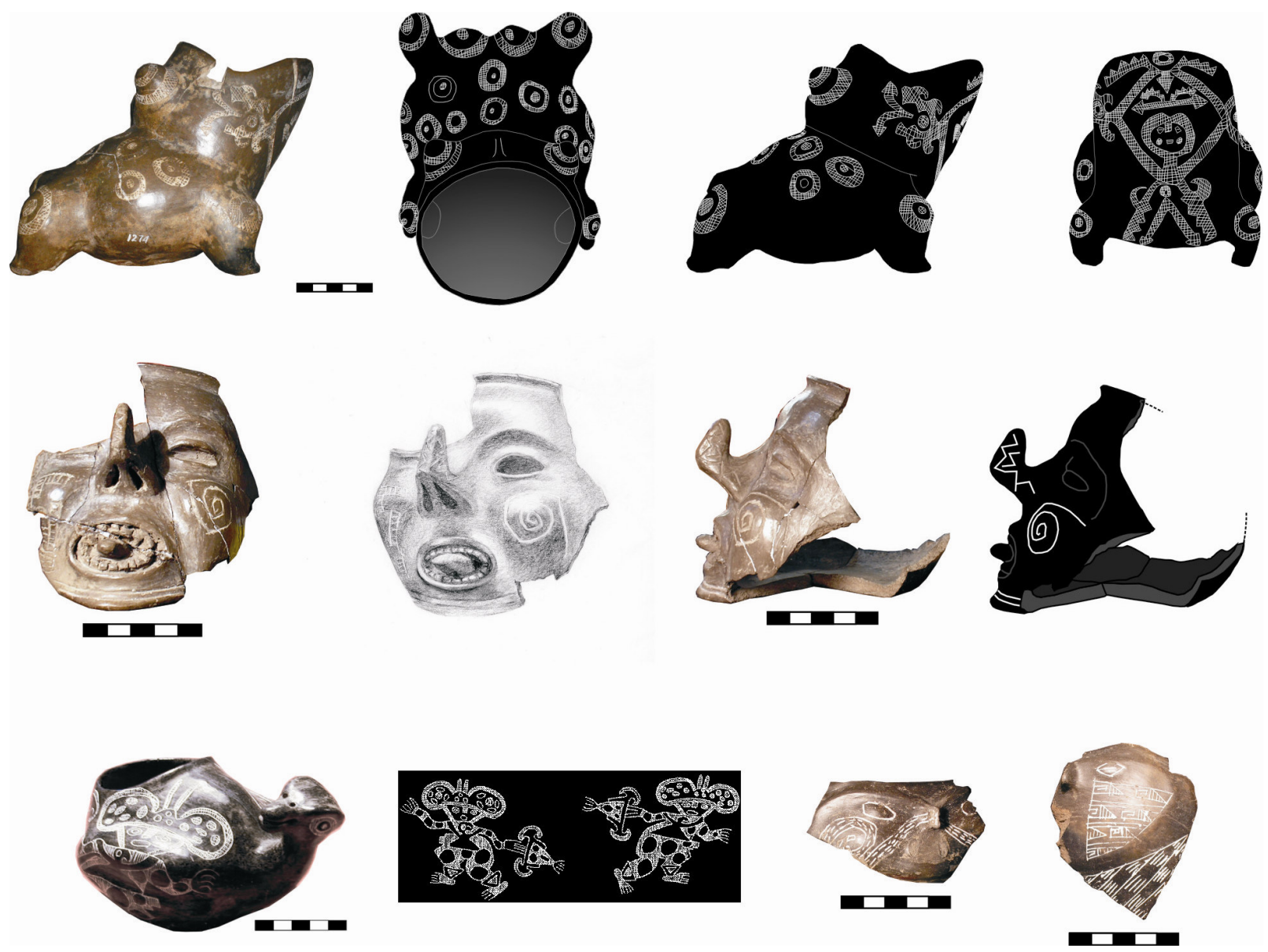

Figura 6.35: fotografía y dibujos de los motivos incisos en las vasijas modeladas. Tenemos batracios, rostros y suri. Obsérvese que las incisiones en algunos casos se hallan remarcando algunos rasgos del rostro que podrían ser tatuajes o pinturas faciales.

Bol: éstos, al igual que las escudillas, son pulidos en su superficie externa e interna, probablemente debido a la forma de estas piezas, que poseen una alta visibilidad hacia el interior. Estas piezas no presentan grabados en sus superficies. 
Una vez que las vasijas de ambas clases son alisadas, pulidas, pintadas, etc. se las cocina. Pasaremos ahora a analizar los datos que poseemos con respecto a las técnicas y formas de cocción para cada una de ellas.

\section{Combustibles, formas y temperaturas de cocción}

Para la Arqueología, averiguar los tipos de combustibles utilizados para la producción de vasijas cerámicas conlleva ciertos problemas. En primer lugar no puede ser inferida desde el análisis de los fragmentos cerámicos y, en segundo lugar, por lo general es muy difícil hallar las estructuras de cocción de las piezas de alfarería, sean éstas hornos o espacios a cielo abierto (Orton et al 1997; Rice 1987; Rye 1988). Como señala Rye (1988: 96), el propósito de cocinar las piezas, con suficiente calor y tiempo, es lograr la destrucción de los cristales minerales arcillosos. Según el autor, la temperatura mínima necesaria varía para diferentes arcillas, la más baja es alrededor de $500^{\circ}$ y las más alta alrededor de $800^{\circ}$. Cuando el calor alcanza dichas temperaturas, la arcilla adquiere las propiedades que necesita la cerámica: dureza, porosidad y estabilidad, bajo un amplio rango de condiciones químicas y físicas (Rye 1988:96). Las cerámicas que no alcanzan esta temperatura, como señalan Schiffer y Skibo (1987), suelen en general desintegrarse cuando posteriormente son sumergidas en agua. Varios autores coinciden en que las principales variables controladas por el ceramista a la hora de la cocción de las piezas son el rango de calor, la temperatura máxima y la atmósfera que rodea a los objetos (Rye 1988, Rice 1987, Orton et al 1997). El rango de calor es muy importante porque se necesita el suficiente tiempo para completar las reacciones química necesarias (Rye 1987:96). Pero un tiempo muy lento de cocción produce mayor consumo de combustible, y un exceso de la temperatura óptima de cocción puede producir daños como rajaduras. La atmósfera dependerá de la entrada de aire y contacto de la vasija con el oxígeno. Los tipos de combustibles usados pueden modificar el rango de temperatura, la producción rápida o más lenta de calor, no así la atmósfera que depende más de la disposición de las vasijas en relación a la entrada de aire. Sin embargo, algunos combustibles pueden producir una menor oxidación de las vasijas. Combustibles como el guano quema despacio y de manera uniforme, en cambio la paja quema rápidamente produciendo mayor calor en menor tiempo, pero se consume rápidamente (Rye 1988:98). Según este autor, combustibles como la paja son utilizados al inicio para extraer los restos de humedad que puedan mantener las 
piezas. La utilización de maderas es mejor para hornos que alcancen altas temperaturas $\left(1100^{\circ}\right.$ por ejemplo) (Rye 1988:98).

Algunos estudios etnoarqueológicos y etnográficos con ceramistas de la puna de Jujuy señalan la utilización de guano -oveja y burro- y leña -tola (Parastrephia lepidophylla)- para la cocción de vasijas en una estructuras a cielo abierto (García 1988). Según la autora, la leña y la bosta de burro sólo se utilizan como iniciadores del fuego: el combustible que más participa en la cocción de las vasijas es la bosta de oveja. Rodríguez (2002) para la zona de Casira en la puna jujeña, también señala la utilización de bosta de burro, de oveja y de llama. Otros estudios realizados en el Chaco con ceramistas tobas, que en general utilizan estructuras a cielo abierto para el cocido de las piezas, señalan que hay un repertorio de combustibles que se utiliza, compuesto por: palo flojo -Albizia inundata-, brea, -Cercidium praecox, bosta de vaca, cardón -Stetsonia coryne, duraznillo -Ruprechtia triflora- y cortezas de algarrobo -Prospis- (Montani 2004:111). Palavecino (1944) señaló que los wichí prefieren "cortezas de árboles y maderas podridas muy secas, o bien, excremento de vaca" como combustible. Arenas (2003:228) señaló para los Tobas que, "como combustible se estima la bosta de vaca; a falta de ella, especialmente en tiempos pasados, se usaba como leña corteza de 'quebracho blanco' juntos con ramas secas de ‘cardón', corteza de 'algarrobo' también sirve. El 'cardón' solo no sirve, debe ir mezclado con un combustible adecuado, por ejemplo con un poco de bosta". Montani (2004:112). señala además que la utilización de los elementos de este repertorio de combustibles no es excluyente. Las alfareras prefieren una u otra leña, y en muchos casos están condicionadas por factores situacionales - abundancia o escasez temporal y espacial de cada tipo de leñano siendo extraño que en una misma quema se usen leñas de más de un tipo.

Hasta el momento, en Ambato no han sido halladas estructuras de cocción de vasijas, por lo que no conocemos las técnicas de cocimiento. Lo que sí se conoce es la atmósfera a la que fueron cocidas las vasijas aquí analizadas: oxidantes las de clase E y reductora la clase A1. Además, por los experimentos realizados (difracción de rayos X) se pudo conocer que las temperaturas de cocción que llegan a tener ambas clases, no superan los $700^{\circ}$ (Bertolino y Fabra 2003). Esta temperatura no abría requerido, como lo ha señalado Rye (1988) madera o leña gruesas. Teniendo en cuenta que en la mayoría de los caso etnoarqueológicos y etnográficos citados la utilización de guano es una práctica habitual, y que casi siempre se utiliza una mezcla de combustibles, sumado a la categorización de Marconetto (2008) sobre las elecciones de maderas utilizadas en Ambato, plantemos como hipótesis que para la cocción de la alfarería analizada, la "leña falsa" fue combinada con 
otro combustible como el guano de camélido, obtenido de los corrales junto a las terrazas de cultivos (Figueroa et al 2009). La "leña firme" se habría dejado para otras actividades como la producción de carbón para el recocido de metales como hemos señalado en el capítulo cinco requiere temperaturas superiores.

A continuación, con el fin de adentrarnos en la caracterización de lo que sucede con las vasijas una vez terminadas, analizaremos las propiedades técnicas y formales que poseen de manera potencial para ser utilizadas en diferentes actividades.

\section{Propiedades de performance}

Estas propiedades nos permitirán comprender parte de la variedad de posibilidades que observamos al comienzo de las trayectorias biográficas de estas vasijas -ver anexo IV-. Como hemos señalado en el capítulo tres, estas propiedades no determinan las prácticas donde estas vasijas participarán en un futuro (Skibo 1992; Sillar 1996, 2000) La significatividad de estas propiedades dependerá de la historia posterior de la vasija y no de la propiedad en sí. Es decir las prácticas concretas serán las que podrán activar, desactivar o ignorar estas propiedades.

\section{Vasijas de clase E:}

Existen tres propiedades técnicas relacionadas con las pastas utilizadas, que son compartidas por todas las formas: la resistencia al shock térmico, el comportamiento térmico y la permeabilidad/ porosidad/ densidad -ver anexo IV- (Bronitsky y Hamer 1986; Rice 1987; Rye 1988; Tite 1999; Tite et al 2001). La clase tecnológica E posee una concentración muy alta de cuarzo, superando el $20 \%$ del volumen. Según lo que planteamos en el anexo IV sobre características de performance asociadas a la resistencia al shock térmico, este volumen no permitiría que se produzcan fracturas inestables, otorgándole mayor rigidez a la pasta, propiedad señalada como más óptima para resistir la carga de estrés rápido que se produce cuando son expuestas al fuego (Tite 1999; Tite et al 2001). Señalamos además que formas planas como la mica, muy presente en la clase $\mathrm{E}$ en general y en la mezcla 5 en particular, combinadas con la red de microfracturas producidas por la alta concentración de cuarzo, producen aún una mayor rigidez. En relación al planteo de Tite (1999), las pastas con estas propiedades resistirían de manera más adecuada 
los cambios rápidos de temperatura puesto que se vincularían más a fracturas estables que inestables. Recordemos que en general, las fracturas estables implican la absorción, deflexión y bifurcado de las fracturas impidiendo que se propague por toda la pieza. La mezcla 5 es la que presenta mejores propiedades para soportar el shock térmico, y posee un buen comportamiento térmico, con un tamaño de antiplástico mediano y pequeño lo cual hace que disminuya la influencia del coeficiente de expansión térmica elevado del cuarzo (Bronitsky y Hamer 1986; Rice 1987; Tite 1999). La mezcla 5 posee, además, mayor cantidad de mica que el resto de las mezclas. En la clase E, las cavidades son de tamaño pequeño a mediano y en la pasta se presentan con una alta densidad $-30 \%$ a $50 \%-$, por lo que se puede señalar que todas las mezclas que forman la clase E son relativamente porosas. Recordemos que también los poros producen deflexión, absorción, bifurcación de las fracturas, otra característica importante para soportar el estrés térmico.

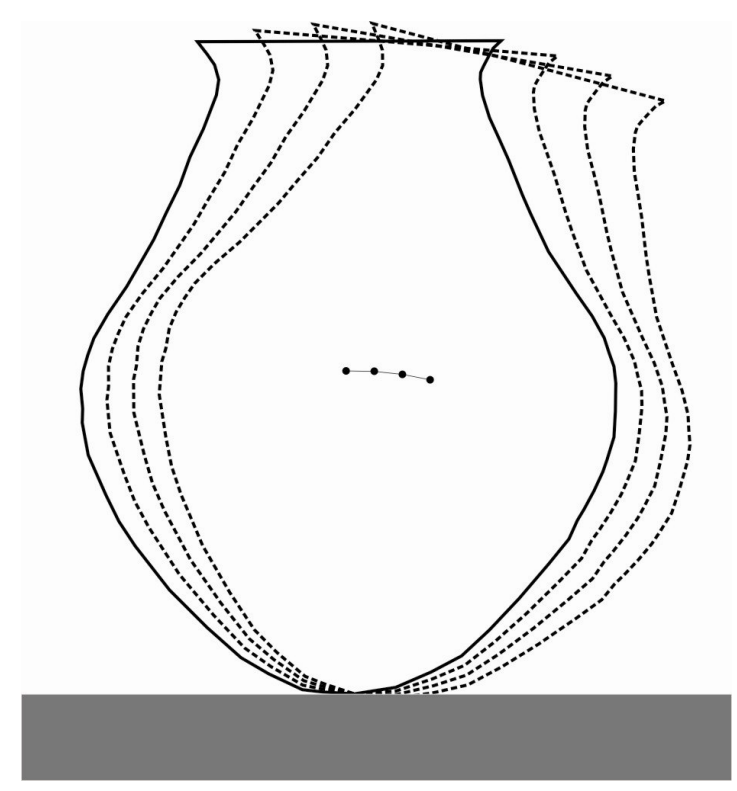

Figura 6.36: dibujo que muestra como el centro de gravedad desciende cuando se la inclina, marcándonos inestabilidad de la pieza y dificultad para mantenerse erguida. Por otro lado, debido a la base cónica necesitan de algún soporte para mantenerlas en pie.
Forma " $a$ ": en relación a la capacidad de estos contenedores, los volúmenes de estas vasijas oscilan entre los 50 litros y los 120 litros, habiendo casos de 260 litros. Con respecto a la estabilidad, la altura del centro de gravedad, sin importar el tamaño de la pieza, desciende cuando se la inclina -figura 6.36-. Poseen bases cónicas, por lo que la estabilidad es muy baja. Considerando esto y sus tamaños promedio, es indispensable la utilización de soportes para mantenerlas erguidas. En relación con la accesibilidad, las vasijas poseen bocas amplias por lo que su contenido es de fácil acceso. Este índice es relativamente elevado, hallándose un tanto por encima de la mitad del valor que puede adquirir una vasija que posee un índice de accesibilidad absoluto -valor absoluto=1- (estadísticos: media 0,64, desviación estándar 0,14, máximo 0,78, mínimo $0,48, \mathrm{n}=18$ ). Con respecto a la transportabilidad, estas vasijas no poseen las formas secundarias necesarias para ser transportadas -tales como asas o apéndices-. Si a esto le sumamos el gran tamaño de algunas de ellas, se puede señalar que son poco transportables y manipulables. Con respecto al espesor, esta forma posee paredes 
bastante espesas en los cuerpos, desde los $8 \mathrm{~mm}$ a los $12 \mathrm{~mm}(\mathrm{n}=24)$. Espesores de estas características, han sido vinculados a la necesidad de sostén estructural y actividades de almacenamiento (Rice 1987). Por otro lado, los muros espesos no son buenos para propagar rápidamente el calor por toda la superficie de la pieza, fenómeno requerido en actividades de cocción de alimentos. En relación a este punto, si bien por las características de las pastas de las formas 'a' se esperaría que se le produzcan fracturas estables propiedad importante a la hora de soportar estrés térmico- su forma, que a pesar de ser globular, presenta puntos angulares y de inflexión marcados, hace que la resistencia al shock térmico de estas vasijas disminuya. Sintetizando, podemos decir que son vasijas con volúmenes altos (los mayores presentes en el valle), inestables, con un alto índice de accesibilidad, baja transportabilidad, baja resistencia al shock térmico y alta porosidad en la pasta. Quizás los baños negros presentes en alguna de las formas de estas vasijas estén impermeabilizándolas. Dadas estas propiedades, se puede decir que son potencialmente aptas para contener líquidos que necesiten de respiración -para mantenerse frescos-, y también sólidos. También son potencialmente aptas para realizar tareas de procesamiento que no impliquen su sometimiento al fuego.

Forma "ab": En relación a la capacidad de estos contenedores, señalamos que tenemos un valor medido muy bajo -1,5 litro- y tres bastante más altos que en promedio

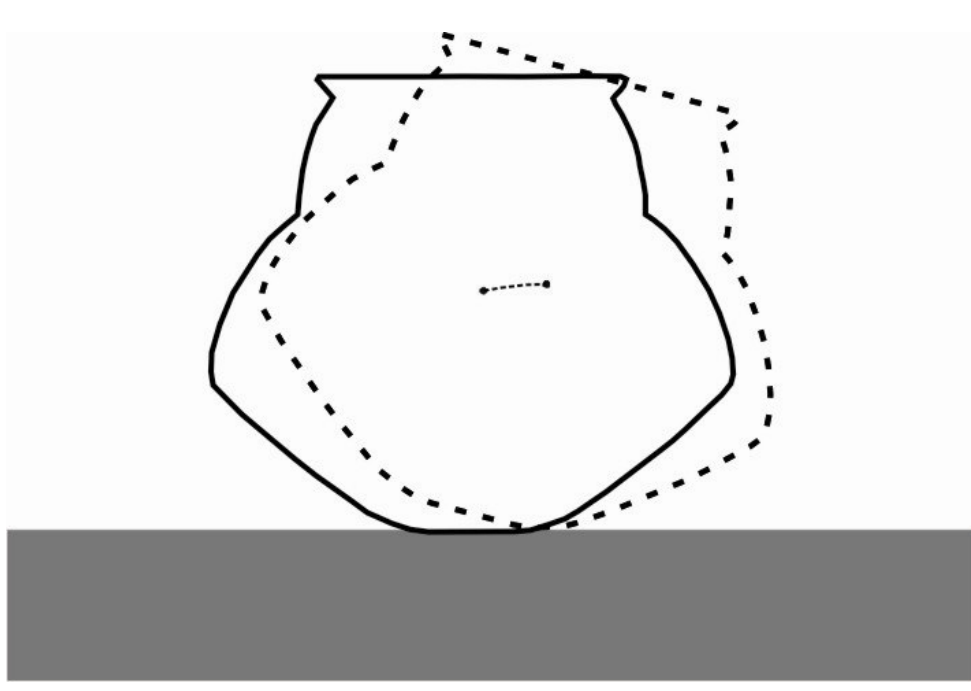

Figura 6.37: dibujo que muestra como el centro de gravedad se eleva cuando se la inclina, marcándonos estabilidad de la pieza para mantenerse erguida. poseen unos 20 litros. $\mathrm{Si}$ comparamos las medidas de los radios de bordes y los diámetros máximos de cuerpos, pueden asociarse a un volumen levemente más amplio que el promedio mencionado, en tanto el diámetro máximo medido de $440 \mathrm{~mm}$ es más amplio que el diámetro máximo medido en las vasijas enteras de $395 \mathrm{~mm}$. La altura del centro de gravedad se eleva cuando la vasija sale de una posición de equilibrio estable y se inclina, por lo que son estables -figura 6.37-. Sumado a esto, la forma "ab", posee bases de forma cóncavas (exterior) y convexas (interior), lo que les proporciona una superficie de apoyo estable. Al poseer asas remachadas en la parte media del cuerpo, son fáciles y apropiadas 
para transportar. La accesibilidad a los contenidos es buena, el índice arroja valores que alcanzan un mínimo de 0,53 y un máximo de 0,81 (n=5). En relación al comportamiento térmico y resistencia al shock térmico, si bien el mayor porcentaje de estas vasijas $(41,17 \%$ $\mathrm{n}=23)$ se confeccionan con la mezcla 5 , entre otras mezclas $(35,9 \%$ con la mezcla $1,17,64$ $\%$ con la mezcla 2 y $5,88 \%$ con la mezcla 3 ), su forma, con puntos angulares y de inflexión marcados, hacen que las características de la mezcla 5 para resistir el estrés térmico se anulen o disminuyan notablemente. En relación al espesor de las paredes de la vasija, vemos que para el cuerpo ronda entre $\operatorname{los} 5 \mathrm{~mm}$ a $7 \mathrm{~mm}(\mathrm{n}=16)$, con muros no muy espesos. Podemos decir entonces que son vasijas con volúmenes medios o bajos, estables, con un alto índice de accesibilidad, alta transportabilidad, baja resistencia al shock térmico y alta porosidad en la pasta. Dadas estas propiedades se puede decir que son potencialmente aptas para contener líquidos y sólidos y para transportarlas.

Forma calceiforme: los cinco casos en que hemos podido medir el volumen muestran cierta variabilidad. Uno de los ejemplares posee 0,5 litros, otro en el extremo de 13 litros, mientras que los intermedios están entre 2,5 a 3,5 litros. En cuanto a la accesibilidad a los contenidos, dada la forma asimétrica y la apertura de la boca, se puede plantear que el acceso a los mismos es dificultoso. En cuanto al espesor de los muros del cuerpo, son vasijas que tienen un mínimo de $5 \mathrm{~mm}$ y un máximo de $9 \mathrm{~mm}$, con una moda de $9 \mathrm{~mm}$ $(n=12)$. Es decir, los espesores de muros son variables, pero teniendo en cuenta la moda en general, tienden a ser muros espesos. En cuanto a la estabilidad, si bien no pudimos obtener el centro de gravedad dada la asimetría de la pieza, por sus bases de forma convexa logran mantenerse erguidas -figura 6.38-. Poseen además formas secundarias como un asa remachada en el borde -figura 6.38-. Si comparamos las características de la pasta -mezcla
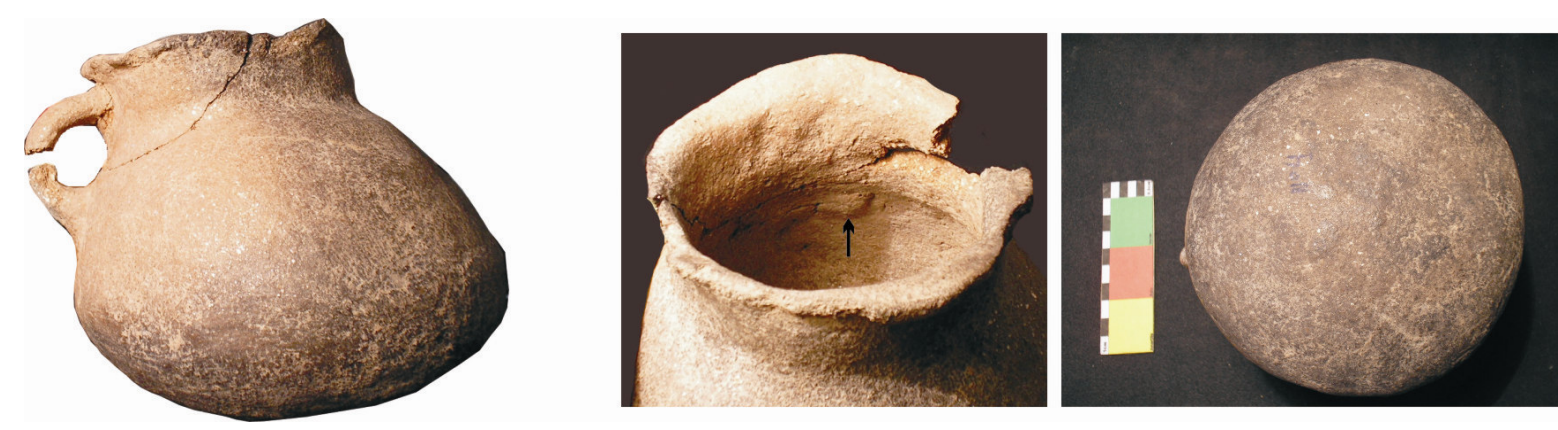

Figura 6.38: se observa la forma de la base de las vasijas calceiforme y la ubicación del asa. A su vez en la fotografía del medio se marca con una flecha donde se observa el remache. 
5- con sus propiedades formales, vemos que, a diferencia de las vasijas descritas anteriormente, éstas son muy adecuadas para ser sometidas al fuego en tanto que, además de la propiedades de resistencia al shock térmico de la pasta y el buen comportamiento térmico de ésta, poseen formas globulares o subglobulares, sin puntos de inflexión marcados o angulares en el cuerpo. En síntesis, podemos decir que son vasijas con volúmenes muy pequeños - bajos si las comparamos con las vasijas de formas "a" o "ab"-, estables, con un índice bajo de accesibilidad, alta transportabilidad, alta resistencia al sock térmico y alta porosidad en la pasta. Dadas estas propiedades se puede decir que son potencialmente aptas para contener, transportar y procesar líquidos y sólidos.

"Otras formas": los volúmenes que presentan estas vasijas son variables, la mitad de los 8 casos medidos se hallan entre los 73 litros y los 80 o 90 litros, y la mitad restante entre los 26 y 37 litros. Con relación a su estabilidad, la altura del centro de gravedad de las vasijas apenas se mantiene en la misma posición cuando las piezas se inclinan, específicamente aquellas que poseen bases convexas; en el caso de las bases cónicas el centro de gravedad desciende; aquellas que presentan patas son muy estables -figura 6.39-. Con respecto a la accesibilidad a los contenidos, de los 17 casos medidos tenemos un promedio de 0,66 con una desviación típica de 0,08 , con un mínimo de 0,37 y un máximo

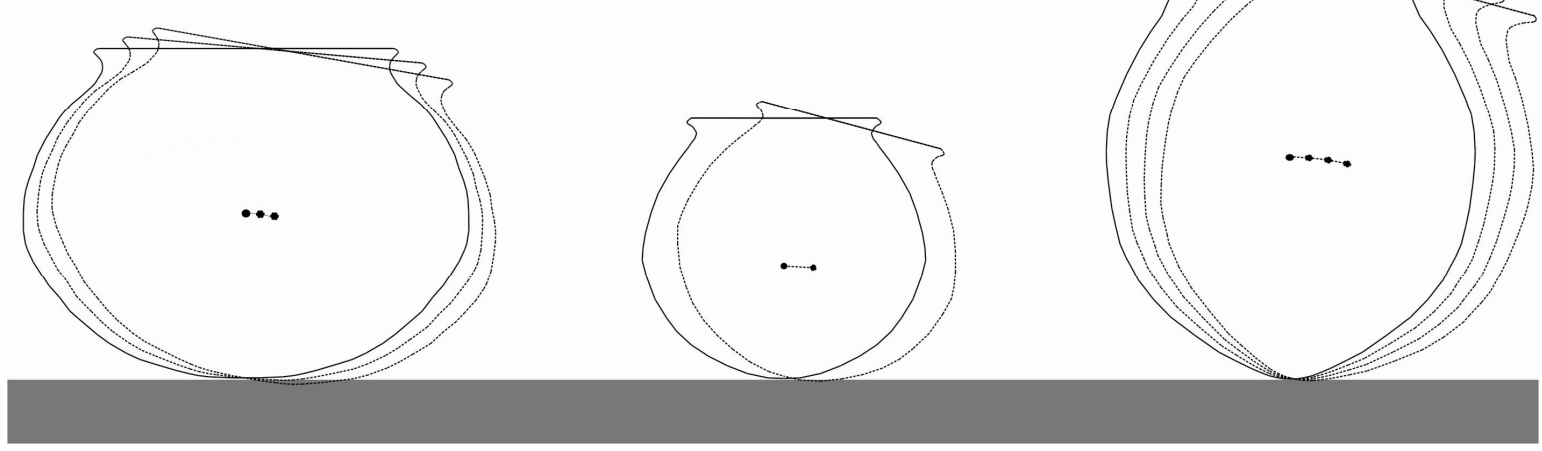

Figura 6.39: dibujos que muestra como el centro de gravedad se mantiene o desciende a medida que la base se vuelve cónica.

de 0,83 . La resistencia al sock térmico y comportamiento térmico en estas vasijas es favorecida no sólo por las características de las pastas con las cuales están confeccionadas en las que la mezcla 5 posee $43,7 \%(n=48)$ - sino también por sus cuerpos globulares sin puntos de inflexión marcados, compartiendo esto con las formas calceiformes. De esta manera, se convierten en las vasijas de porte más grande, con características adecuadas para ser sometidas al fuego. Recordemos que la otra forma que puede presentar volúmenes de más de 40 litros (formas "a") no es adecuada para esta actividad. En síntesis, podemos 
decir que son vasijas con volúmenes variados altos, medios y bajos; según la forma de la base (cónica, convexa o con patas) son más o menos estables, necesitando soportes aquellas que tienen base cónica. Poseen bajo índice de accesibilidad, transportabilidad relativa dependiendo del tamaño y de la presencia de atributos secundarios, alta resistencia al sock térmico y alta porosidad en la pasta. En términos de lo planteado por Rice (1987), estas formas son adecuadas para ejecutar una gran variedad de actividades: dependiendo de los tamaños y la presencia de asas, pueden servir para transporte, transferencia, almacenamiento o procesamiento en frío y caliente.

Platos: cuando analizamos los tamaños de los platos señalamos que pueden dividirse en platos pequeños, con diámetros que rondan los $155 \mathrm{~mm}$ y una altura que no supera los $40 \mathrm{~mm}$ y platos grandes que rondarían de los 400 a los $600 \mathrm{~mm}$ de diámetro y una altura de $140 \mathrm{~mm}$. En relación a los volúmenes, los pequeños no llegan a medio litro, y los grandes según pudimos medir en la pieza con mayor grado de completitud- poseen una capacidad de 14,55 litros. Dada la forma de los platos y la coincidencia de la boca con el diámetro máximo, al índice de accesibilidad es absoluto. En relación a la estabilidad de estos objetos, hemos señalado que los platos chicos poseen bases cónicas y los grandes bases cóncavas -exterior- y convexas -interior- por lo que entre ambos tamaños se presentan diferencias. Teniendo en cuenta la forma de la base, la altura de los platos pequeños y el diámetro de estos, al inclinarlos todo el contenido se derramaría, por lo que se necesitarían soportes para mantenerlos erguidos -figura 6.40-. Podría ser también el caso que se pudieran utilizar como tapas de algún recipiente. Los platos grandes poseen bastante estabilidad no solo por la forma de la base que genera una superficie de apoyo estable, sino que el centro de gravedad se eleva cuando estos son inclinados -figura 6.40-. No poseen formas secundarias de agarre aunque son muy fáciles de transportar. Los más grandes, si bien son un poco más pesados y voluminosos, poseen una gran superficie de paredes

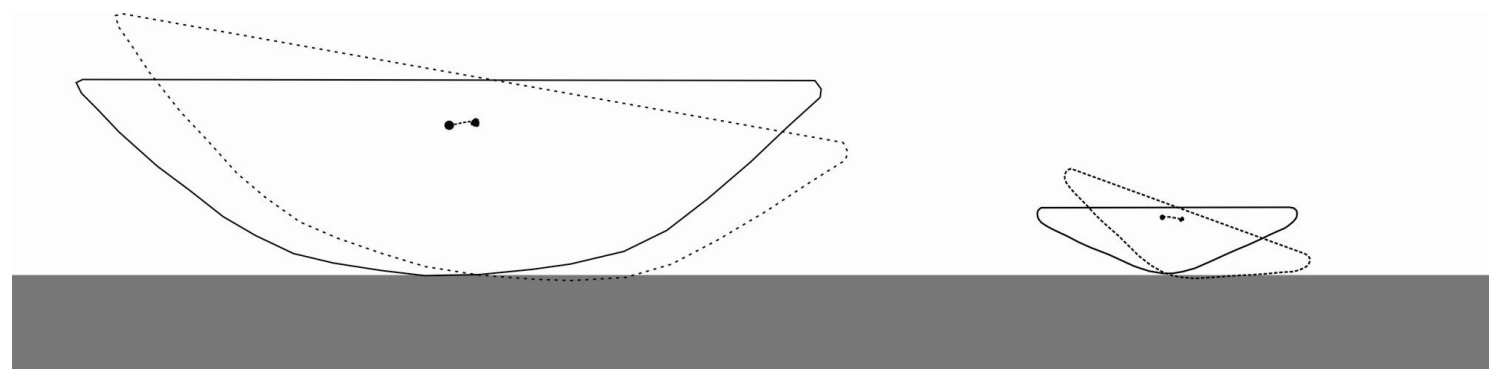

Figura 6.40: se observa, en el primer dibujo, como el centro de gravedad se eleva al inclinarse el plato grande en tanto este presenta una base cóncava convexa. En el caso de los platos pequeños que poseen bases cónicas el centro desciende al inclinarse la pieza 
divergentes, donde pueden ser tomados para transportarlos. Los espesores de los muros varían entre $5 \mathrm{~mm}$ el mínimo y $9 \mathrm{~mm}$ el máximo, y poseen una media de 7,11 $\mathrm{mm}-$ desviación estándar de 1,39 mm- y una moda de $7 \mathrm{~mm}(\mathrm{n}=40)$. En relación al shock térmico y comportamiento térmico, se utiliza una variedad de mezclas para su confección, existiendo en mayor proporción las mezclas 2 y 1 (38,46\% y 30,76 \% respectivamente). El resto de las mezclas se halla por debajo del $15 \%$. Los platos pequeños no presentan puntos de inflexión o angulares marcados en el cuerpo, sí los poseen los platos grandes en la base, que al no ser convexa podrían generar cierto estrés. La amplitud de la boca hace que el calor se pierda rápidamente. En síntesis, los platos chicos son vasijas con volúmenes muy pequeños, inestables, con un índice de accesibilidad absoluto, alta transportabilidad, resistencia al sock térmico y alta porosidad en la pasta. Los platos grandes son vasijas con volúmenes bajos, estables, con un índice de accesibilidad absoluto, alta transportabilidad, poca resistencia al shock térmico y alta porosidad en la pasta. Dadas estas propiedades se puede decir que los platos son potencialmente aptas para contener, transportar, transferir y procesar líquidos y sólidos, sin ser expuestos al fuego.

En cuanto a aquellas formas que tenemos solo un ejemplar: el vaso tiene una alta accesibilidad a los contenidos, es fácilmente transportable y por la mezcla con la cual está realizado y la inexistencia de puntos angulares posee una buena resistencia al estrés térmico. La vasijita de paredes divergentes y base cónica posee un volumen de menos de medio litro, tiene una alta accesibilidad a los contenidos en tanto que el diámetro máximo coincide con el de su boca, y posee resistencia al estrés térmico. La vasija compuesta dependiente de borde evertido posee un índice de accesibilidad de 0,66, y tiene baja resistencia al estrés térmico ya que presenta puntos angulares muy marcados en el cuerpo.

\section{Vasijas de clase A1}

En las vasijas de clase A1 apenas se observa el antiplástico en la pasta; en general se trata de arena y tiesto molido de tamaño muy pequeño con muy baja densidad. Estas características -según la plateado por Tite (1999)- le otorgarían mucha fragilidad a la pasta, desarrollándose fracturas inestables a lo largo de la pieza, no habiendo nada que la absorba, deflecte, etc., por lo que no serían adecuadas para resistir el shock térmico. Por la baja densidad de cavidades al interior de la pasta, podría decirse que son muy poco porosas, y 
por eso muy impermeables, lo que podría variar con la presencia de pulido en su interior. Una propiedad compartida por todas es la estabilidad en tanto presentan bases cóncavas convexas que forman una superficie de apoyo estable y en algunos casos las mismas son planas.

Forma "b": la capacidad de estas vasijas es muy variable. En términos generales va de los 1,5 litros a los 7 litros, existiendo casos aislados de 0,5 litros y 28 litros. Son las vasijas que alcanzan mayores capacidades de contención al interior de las formas de la clase A1. En relación a la accesibilidad a los contenidos, esta es buena, puesto que el índice $(\mathrm{n}=49)$ arroja un valor promedio de 0,83 con una desviación de 0,12 y un mínimo y máximo de 0,627 y 1 . En relación a la transportabilidad, la misma varía según tenga asas o no. Algunas de estas están remachadas. Los espesores de estas vasijas son delgados y homogéneos, alcanzando en el cuerpo los 5 y $6 \mathrm{~mm}$, lo que las hace bastante frágiles a los golpes. Dadas las características de las pastas, estas vasijas son bastante impermeables. En cuanto a la resistencia al shock térmico, las piezas presentan puntos angulares y de inflexión marcados, por lo cual no son aptas para ser colocadas al fuego. En síntesis, podemos decir que son vasijas con volúmenes bajos, aunque son las de mayor capacidad dentro de la clase A1. Son estables, con un alto índice de accesibilidad, alta transportabilidad, fragilidad a los golpes, baja resistencia al shock térmico y alta impermeabilidad.

Forma c: Sus capacidades son variables, desde los 1,80 litros a los 4,93 litros. Si bien su capacidad es menor que la forma "b" compartiría con estas el rango de volúmenes. En relación a la accesibilidad, en los tres casos medidos el índice $(n=11)$ arrojó una media de 0,91 con una desviación de 0,17 y un mínimo y máximo de 0,56 y 1 . Tiene buen índice de accesibilidad a los contenidos, mayor que la forma " $b$ ". Algunas piezas poseen asas remachadas lo que las hace fáciles de transportar, aunque por su tamaño, aquellas que no poseen asas son fácilmente transportables. Los espesores del cuerpo poseen una media de 5 y mínimos y máximos de 3 y 7 , por lo cual son bastante frágiles a los golpes, sumado a las características de la pasta. En relación a la porosidad/permeabilidad son bastante impermeables. En cuanto a la resistencia al shock térmico, presentan puntos angulares y de inflexión marcados, por lo cual no son aptas para soportar el estrés térmico. En síntesis, podemos plantear que son vasijas con volúmenes bajos, estables, con un alto índice de 
accesibilidad, alta transportabilidad, fragilidad a los golpes, baja resistencia al shock térmico y alta impermeabilidad.

Escudillas: Sus capacidades oscilan entre los 1,5 litros y los 2,5 litros. En cuanto al acceso a sus contenidos, el índice arroja $(n=153)$ un valor promedio de 0,99 con una desviación típica de 0,07 y un mínimo y máximo de 0,63 y 1, lo que es decir que poseen una accesibilidad casi absoluta. Aunque no poseen atributos secundarios de agarre, dado su tamaño son muy transportable. A su vez, la parte inferior del cuerpo es divergente, lo que la hace sostenible con la palma de la mano. Dadas las características de la pasta y los espesores homogéneos del cuerpo -de unos $5 \mathrm{~mm}$ - son bastante frágiles. Por otro lado, poseen un punto angular que produce una zona de estrés térmico por lo que no son aptas para colocarse sobre el fuego. Como hemos señalado, la pasta es bastante impermeable, potenciada por el pulido en su superficie interna. En síntesis, podemos decir que son piezas con baja capacidad, accesibilidad absoluta a los contenidos, muy estables, fácilmente transportables y manipulables, alta fragilidad a los golpes, baja resistencia al shock térmico y muy impermeables.

Calceiformes: la capacidad de la pieza es muy baja -menos de medio litro-, poca estabilidad con una base convexa, y poca accesibilidad. Por su pequeño tamaño y la presencia de asa remachada es muy transportable y manipulable. Es poco apta para resistir al shock térmico. El espesor del cuerpo es de $5 \mathrm{~mm}$ por lo cual es bastante frágil a los golpes. A su vez, como el resto de las de clase A1, es bastante impermeable.

“Otras formas": la capacidad de estos recipientes es muy baja, yendo de los 0,07 a los 0,64 litros. En relación a la accesibilidad a los contenidos, el índice $(n=4)$ arroja un valor de 0,75 con una desviación de 0,09 y un máximo y mínimo de 0,66 y 0,88, valores que le otorgan buena accesibilidad. Son muy transportables y manipulables dado el tamaño que presentan. Los espesores del cuerpo oscilan entre los $3 \mathrm{~mm}$ a los $8 \mathrm{~mm}$. Al igual que la forma calceiforme, a pesar de no presentar puntos angulares marcados, dadas las características de la pasta no son aptas para resistir al shock térmico. Son bastante impermeables. En síntesis, estas piezas poseen baja capacidad, alta accesibilidad y estabilidad, alta transportabilidad, fragilidad relativa según los espesores, baja resistencia al shock térmico y alta impermeabilidad. 
Vasos o jarras: en relación a la capacidad de estos vasos, tenemos uno de muy baja capacidad -menos de medio litro- y otros cuatro que van de los 1,5 litros a los 2,19 litros. La accesibilidad a los contenidos es muy alta, teniendo la mayoría una accesibilidad absoluta. Son muy transportables y manipulables, no sólo por su tamaño sino porque poseen un asa vertical. Poseen una alta fragilidad, con espesores de $5 \mathrm{~mm}$ a $6 \mathrm{~mm}$. Poseen poca resistencia al shock térmico por las propiedades de la pasta. En los casos cuadrangulares, se le suma puntos angulares que separan los planos que forman el cubo. Son altamente impermeables, con la superficie interna totalmente pulida. En síntesis, los vasos o jarras presentan de baja a muy baja capacidad, alta accesibilidad, elevada estabilidad, buenas transportabilidad, fragilidad, baja resistencia al shock térmico y muy buena impermeabilidad.

Vasijas restringidas compuestas: Sus capacidades son variables, yendo de los 0,6 a los 1,3 litros con valores extremos de 0,17 litros y 6 litros. Poseen una accesibilidad bastante baja, sólo en una se supera los 0,5 en el resto se halla por debajo de esta medida. A pesar de no poseer formas secundarias de agarre, dado su tamaño son transportables y manipulables. Son frágiles al estrés mecánico, además poseen poca resistencia al shock térmico tanto por las propiedades de la pasta como por la presencia de un punto angular en el cuerpo. Son impermeables dadas las características de la pasta. Si bien poseen un tratamiento de pulido como las escudillas y los vasos o jarras en su interior, éste no llega a cubrir toda la superficie interior. En síntesis, podemos decir que estas piezas poseen baja capacidad, poca accesibilidad, alta estabilidad, transportabilidad, fragilidad a los golpes, poca resistencia al shock térmico y buena impermeabilidad.

Modeladas: La capacidad de estas vasijas no supera el litro, aunque no tengamos cálculos específicos, dada la complejidad de las formas modeladas. Igualmente, la accesibilidad es difícil de calcular, aunque en el caso del rostro modelado con nariz en gancho invertida podemos decir que posee una accesibilidad casi absoluta en tanto que la boca casi coincide con el diámetro máximo. Son muy transportables y manipulables tanto por el tamaño como por las formas. Poseen muy poca resistencia al shock térmico. Dadas las características de la pasta son impermeables, a pesar de que sus superficies internas no están pulidas. En síntesis, podemos decir que las formas modeladas poseen baja capacidad, 
accesibilidad alta o baja dependiendo de la forma modelada, buena estabilidad, son muy transportables, frágiles, con baja resistencia al estrés térmico e impermeables.

Bol: no poseemos mediciones de volúmenes para calcular la capacidad de estas piezas, aunque podrían ser semejantes a las escudillas. La accesibilidad de los contenidos en estas formas es absoluta, coincidiendo el diámetro máximo con el diámetro de la boca. En relación a la transportabilidad, estas piezas no poseen formas secundarias de agarre, aunque dados el tamaño y la forma son fácilmente manipulables y transportables. Teniendo en cuenta los espesores de las paredes de los recipientes $-4 \mathrm{~mm}$ - y las características de las pastas, son piezas muy frágiles a los golpes. Con respecto a la resistencia al estrés térmico, a pesar de no poseer puntos angulares y tener formas simples, si tenemos en cuenta las características de la pasta estos recipientes no son aptos para colocarse sobre el fuego. Al igual que las escudillas, están pulidos en sus superficies internas, con lo que aumentan sus propiedades de impermeabilidad. En síntesis, podemos decir que poseen una capacidad baja de contención, un índice de accesibilidad absoluto, buena transportabilidad, fragilidad a los golpes, poca resistencia al shock térmico, y alta impermeabilidad.

Habiendo caracterizado las propiedades potenciales para ser usadas en determinadas actividades prácticas, nos toca preguntarnos y responder que sucede una vez que se convierten en vasijas: ¿Dónde son distribuidas?; ¿van a otros lugares desde estos sitios residenciales pequeños, medianos y grandes o quedan ahí? ¿Están presentes en todo el valle o solo en algún sector? Además en la siguiente sección responderemos también a otra serie de interrogantes que nos adentrarán en la vida de las vasijas en los sitios analizados: ¿cómo se las usa en los lugares adonde van a parar?; ¿quiénes las usan?; ¿dónde se las usa?; ¿se las almacena en algún lado?, ¿en qué prácticas específicas intervienen? y, al participar en ellas ¿a qué otros objetos y sujetos se vinculan, y de qué manera lo hacen? 


\section{Parte}

\section{Las vasijas una vez terminadas...}

\section{¿Dónde son distribuidas?}

Señalamos a los sitios Martínez 1, Martínez 2 y Martínez 4 como probables lugares donde se fabricaban las vasijas analizadas aquí, particularmente las vasijas realizadas con la clase E. También señalamos que las vasijas confeccionadas con la clase A1, dado los datos que arrojaron los análisis de activación neutrónica, podrían tener algún origen diferente, pero que existían datos para proponer una producción local en los sitios descriptos. Como se habrá notado en la descripción de los contextos productivos de estas vasijas, aparecen especimenes de las mismas clases y formas que están siendo usadas en distintas actividades prácticas. En otros casos se ha señalado la presencia de estas vasijas al interior de los sitios en habitaciones cerradas y techadas junto a cinceles de metal y otras herramientas vinculadas a la producción alfarera (Assandri 1991, Herrero y Ávila 1991; Espósito 2009; Juez 1991), indicando lugares de almacenaje de vasijas terminadas de confeccionar y a la espera de utilizarse en estos sitios o en otro lugar (Assandri 1991, Juez 1991). Estos sitios han sido interpretados como lugares residenciales de tamaño mediano donde además de realizarse actividades artesanales, se habrían realizado otras actividades vinculadas a la reproducción del o los grupo/os doméstico/s que vivían en dichos lugares (Assandri 1991; Juez 1991; Herrero y Ávila 1991; Heredia 1998; Pérez Gollán 1991). Así, las vasijas habrían estado en parte destinadas a ser utilizadas por los mismos artesanos que las fabricaban. Pero además, encontramos estas vasijas en sitios en los que no se han hallado evidencias de producción artesanal vinculada a la cerámica, como en Piedras Blancas o la Rinconada.

Vemos entonces que las diferentes formas y clases tecnológicas de las vasijas analizadas tienen una amplia distribución en el Valle. Se las encuentra tanto en sitios ubicados junto a las terrazas de cultivos en las laderas de la sierra del Ambato y la Graciana, como en el fondo de valle. A su vez, se hallan en sitios de diferentes tamaños. Laguens y Bonnin (2005) señalan que a pesar de lo esperado para una sociedad como la de Ambato, con relaciones sociales con un grado alto de exclusión, estas clases cerámicas se hallan presentes en todos los sitios relevados y excavados, con una amplia distribución, aunque con proporciones diferenciales. Esto lleva a los autores a proponer una participación ambigua de la cerámica en el establecimiento de relaciones sociales, en tanto 
que, por un lado, aparentarían una igualdad en el acceso a determinados bienes, pero por otro lado marcarían las desigualdades debido a las proporciones relativas de estas cerámicas en cada sitio. Por lo pronto, lo que nos interesa señalar aquí en relación a las biografías de estas vasijas es que se distribuían en todo el valle.

Con la descripción hasta aquí realizada, hemos marcado ciertos puntos que, citando a Appadurai (1991) nos acercarán a los intereses que animaron las trayectorias de estas vasijas: la vinculaciones históricas con 'formas de hacer' más antiguas, la alta representatividad de los objetos analizados en el contexto que se consolida a partir del siglo IV/ V en el Valle, la intersección de los contextos productivos de estas vasijas con los contextos reproductivos de los grupos que las fabricaban, entre otros. A su vez, marcamos la amplia distribución de estos objetos en el valle, su acceso generalizado y, podríamos decir, explícitamente generalizado, aunque con la ambigüedad que las proporciones relativas de esas vasijas en los distintos sitios implican. Adentrémonos ahora en la vida de estos objetos una vez fabricados.

\section{Las vasijas haciendo: rastros, huellas, contextos y prácticas...}

Discutiremos a continuación los datos de dos clases de análisis que hemos realizado: los rastros de uso de las vasijas como indicios o huellas de las actividades en las que participaron (ver anexo 4), y los contextos de uso de las mismas. Ambos análisis nos permitirán observar las prácticas en las que estaban comprometidas y las vinculaciones con otros objetos en sus contextos de uso, pudiendo acceder a las convergencias y divergencias de las trayectorias biográficas de las diferentes formas y clases analizadas tanto como al interior de cada una de ellas.

Para la descripción de los rastros de usos nos enfocaremos en describir las huellas que presenta cada una de las formas descriptas, o cada categoría mayor de agrupación como la clase tecnológica o la mezcla, particularmente en el caso de las vasijas de la clase E. La descripción de las huellas para cada forma se realizará en primer lugar sin considerar los contextos en los que dichas operaciones prácticas ocurrían. Esto se debe a que poseemos piezas enteras y fragmentadas que provienen de colecciones, por lo que no poseemos sus contextos de hallazgos. Por otro lado, poseemos piezas provenientes de contextos de descarte como los montículos "basureros". Este acercamiento general nos permitirá obtener la gama de acciones y actividades que podemos inferir a través de las huellas observadas. Una vez descritos los rastros y huellas, profundizaremos en los 
contextos prácticos de acción de estos objetos, lo que será de importancia para conocer los lugares específicos donde se realizaban estas actividades y los objetos a los que se vinculaban de manera práctica, estableciendo diferencias y semejanzas entre ellos.

\section{a) Huellas y Rastros...}

Los objetos de los que analizamos las huellas de uso provienen de los sitios Martínez 1, Martínez 2, Martínez 4 y Piedras Blancas, y de las colecciones de la Dirección de Antropología de Catamarca y del Museo Adán Quiroga de la ciudad de San Fernando del Valle de Catamarca. Los objetos de la colección Rosso que hemos incorporado para el análisis de las formas y tamaños no pudieron ser analizados en relación a sus huellas de uso, por lo que los $n$ manejados en esta sección serán menores a aquellos análisis ${ }^{\mathrm{ix}}$.

\section{Vasijas de clase $E$}

Vasijas de forma " $a$ "

Para el análisis de las huellas de uso hemos dividido las vasijas en ocho zonas -figura 6.41-, describiendo las huellas de la superficie exterior e interior de las mismas.

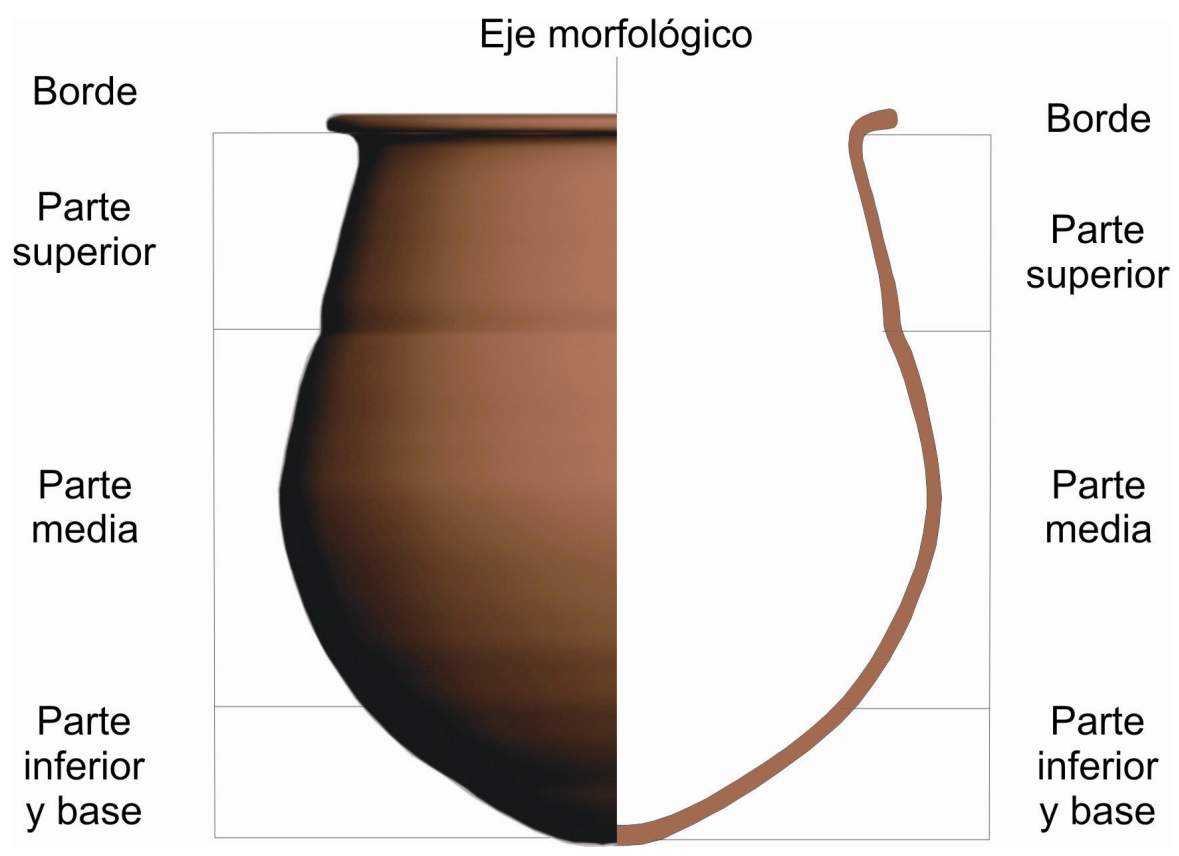

Figura 6.41: zonificación de las vasijas de forma "a" 
De las 7 bases que observamos, 2 de la zona de la superficie exterior presentan lotes -patches-, en 4 de ellas se hallan marcas -hoyuelos y el antiplástico sobresaliente -. En dos de ellas sólo hay antiplástico sobresaliente y en las otras dos se combinan los hoyuelos con antiplástico sobresaliente. En la zona inferior observamos 8 casos en los cuales se presentan antiplástico sobresaliente combinado con hoyuelos y estrías perpendiculares y diagonales al eje morfológico de las piezas, y en dos casos se presentan lotes o patches de marcas de forma rectangular, localizados en algunos sectores sin extenderse por toda la superficie de la zona considerada. En relación a la parte media -gráfico 6.18-, de los 21 casos observados, el 4,8\% presenta lotes en esa zona, que al igual que en la zona inferior son restringidos y localizados. Existe en esta zona un gran porcentaje de marcas: 54,2\%. Las marcas se presentan de la siguiente manera: el $43 \%$ de los 21 casos analizados presentan estrías que corren en diferentes direcciones: presentan mayor porcentaje las perpendiculares al eje morfológico -33\%-, siguiéndoles las diagonales y paralelas con menos de la mitad de ese porcentaje. Es decir que en la parte media hay un predominio de estrías perpendiculares que pueden combinarse con un porcentaje menor de estrías paralelas y diagonales. Los hoyuelos poseen un 52,4\% y el antiplástico sobresaliente un 19\% en los 21 casos. En relación a la parte superior de las vasijas -gráfico 6.18-, de los 44 casos analizados un $10 \%$ puede presentar lotes -patches- localizados y restringidos y un $61,8 \%$ posee marcas. Dentro de las marcas, de los 44 casos $28 \%$ poseen estrías. En general las estrías son perpendiculares al eje morfológico: $22,4 \%$. Las otras direcciones de estrías están en un $6,1 \%$ las diagonales y un $2 \%$ las paralelas. Los hoyuelos también están presentes con un 34,7\%. El antiplástico sobresaliente alcanza el 4,1\%. En relación al exterior del borde, de 40 casos observados el $4,8 \%$ posee lotes o patches y el 45,3\% de los casos poseen marcas. El 9,5\% de los casos presentan estrías. Aquellas que corren perpendiculares al eje presentan un 2,4\%, y las paralelas un 7,1\%. A su vez, en algunos casos se presentan hoyuelos con $2,4 \%$, antiplástico sobresaliente $19 \%$ y astilladuras un $23,8 \%$-figura 6.42 .

En toda la superficie exterior de las vasijas, los lotes o patches presentan un porcentaje bajo. Como hemos señalado, los lotes o patches se producen por la superposición de marcas, lo que no nos permite identificar cuál es la que produjo la erosión. La poca presencia de aquellos nos indica que estas vasijas no han tenido muchos contactos con abrasivos durante el tiempo suficiente para que se produzca este tipo de erosión. Si a esto le sumamos el tamaño de estas vasijas, la inestabilidad que poseen y lo complicado y probablemente riesgoso de su transporte, la baja presencia de lotes o patches nos indica que estas vasijas eran raramente movidas tendiendo en general a permanecer en 


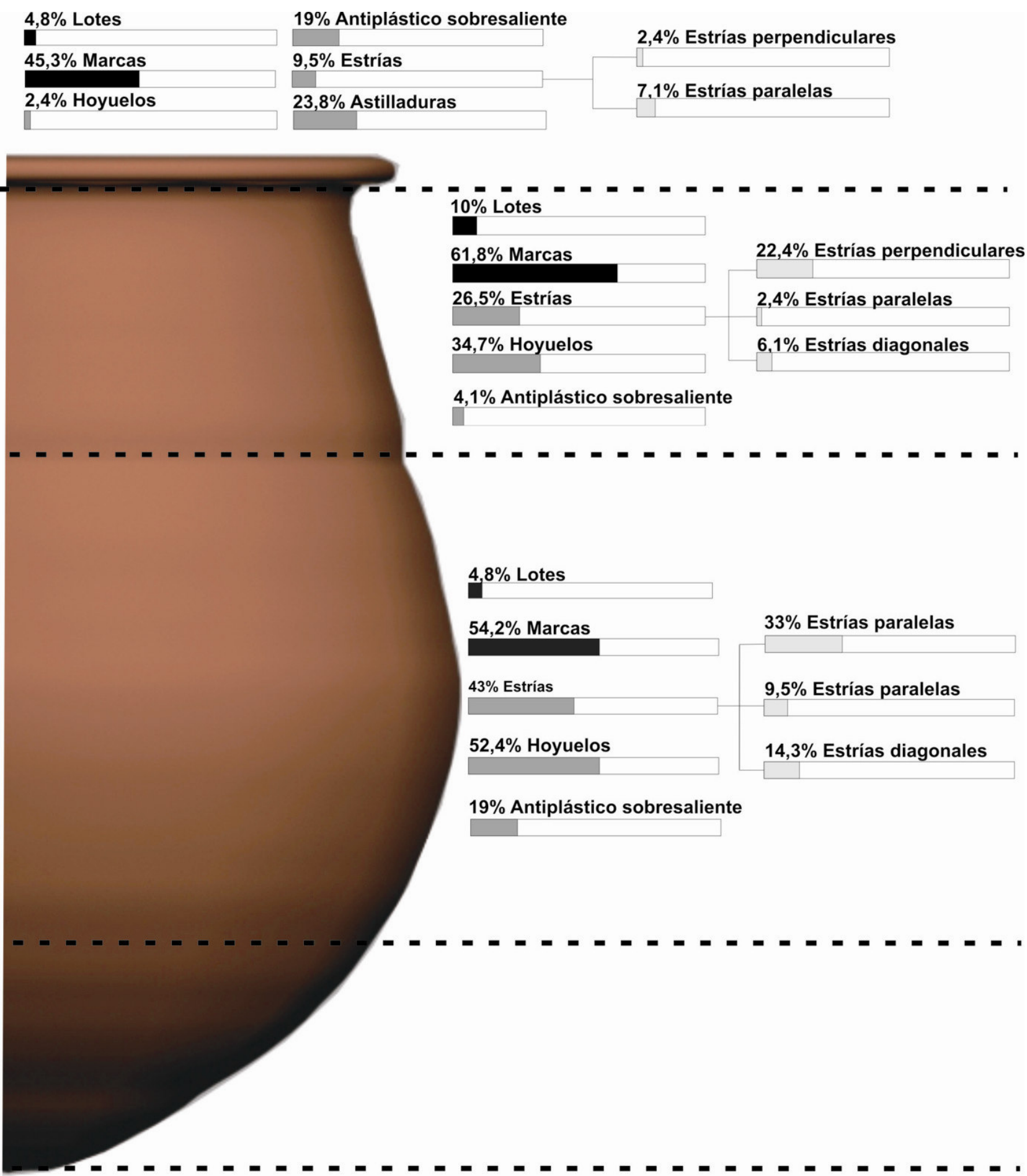

Gráfico 6.18: porcentajes según zonas de lotes y marcas en la superficie exterior de las vasijas de forma "a". Los $\mathrm{n}$ figuran en el texto.

el mismo lugar. Otro patrón de huellas observado, nos está indicando que algunas de las vasijas realizaban ciertos movimientos, y el contacto con variedad de abrasivos, algunos muy finos y otros más gruesos. Los abrasivos finos habrían producido el antiplástico sobresaliente observable en las zonas inferiores y en el borde. Este abrasivo debió ser por 
lo menos de menor grosor que la separación de los antiplásticos que forman parte de la pasta; este tipo de erosión produce la aparición de hoyuelos, en tanto que los antiplásticos, a medida que avanza la erosión, llegan a 'brotar' de la pasta dejando las huellas en la

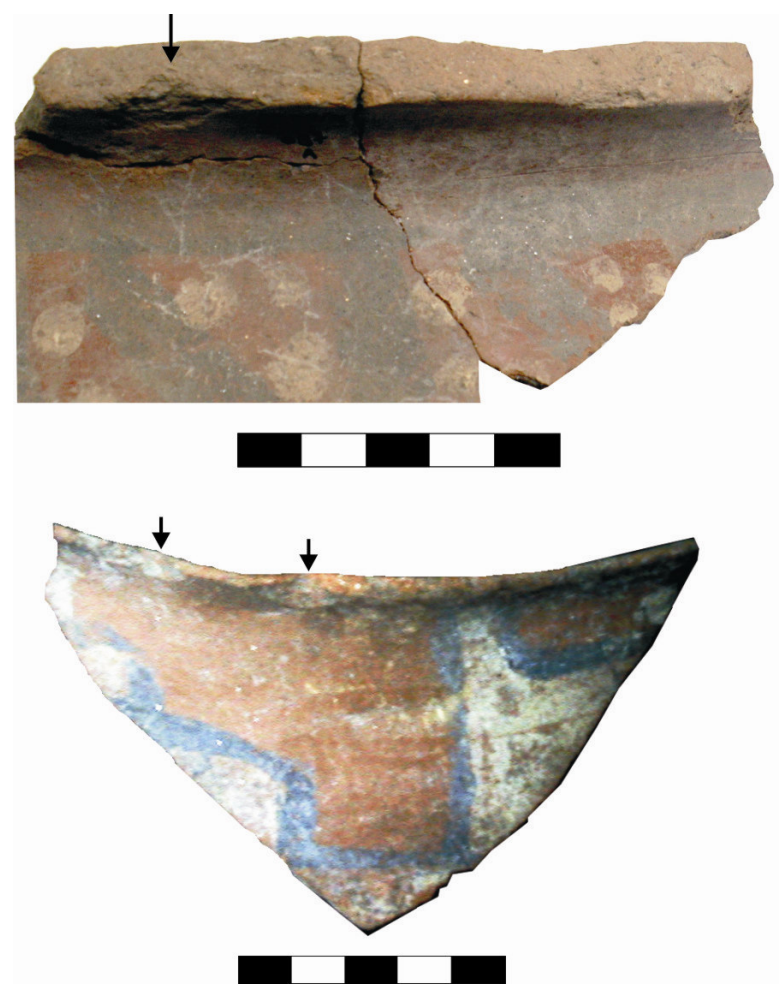

Figura 6.42: zona superior y borde de la superficie exterior de las vasijas de forma "a". Las flechas indican las astilladuras. matriz de la misma. En otros casos, estas vasijas entraron en contacto con abrasivos más gruesos y duros que produjeron la formación de estrías y de hoyuelos. Las estrías nos muestran ciertas direcciones seguidas por el abrasivo en las piezas: tenemos en mayor cantidad abrasivos que recorrieron la superficie en una dirección perpendicular al eje morfológico, pero también hay recorridos diagonales y paralelos. Por otro lado, vemos astilladuras en el borde, en general fracturas hertzianas debidas a golpes. De estos patrones de marcas podemos realizar ciertas inferencias: de las marcas observadas en la base, zona inferior y zona media, podemos señalar el contacto de las base con algún abrasivo fino y gruesos, debido a su fijación en algún soporte, estando quizás apoyadas en los pisos. En segundo lugar, dada la presencia y dirección de las estrías en estas piezas, habrían tenido movimientos perpendiculares al eje, diagonales y paralelos, estando en contacto con abrasivos más duros, existentes en los sedimentos donde fueron apoyadas. Esto nos indicaría movimientos de rotación sobre el eje y de inclinación de la pieza como se muestra en la Figura 6.43. La presencia de lotes o patches en la zona media puede ser producto del contacto con un abrasivo más duro y grueso que la matriz de la pasta, lo que haría producido una fuerte erosión en los lugares de mayor contacto, dejando estrías y hoyuelos en donde existieron contactos más esporádicos.

Las huellas en la zona exterior del borde muestran ciertos patrones interesantes: tenemos la presencia esporádica de lotes -patches-, y marcas. Aisladamente las vasijas presentan estrías perpendiculares, paralelas y diagonales al eje morfológico; apareciendo con mayor frecuencia astilladuras y antiplástico sobresaliente. De estas huellas pueden inferirse ciertos movimientos y posiciones de las vasijas. Cuando describimos la forma de los borde de estas vasijas señalamos que eran marcadamente evertidos y terminaban en un 

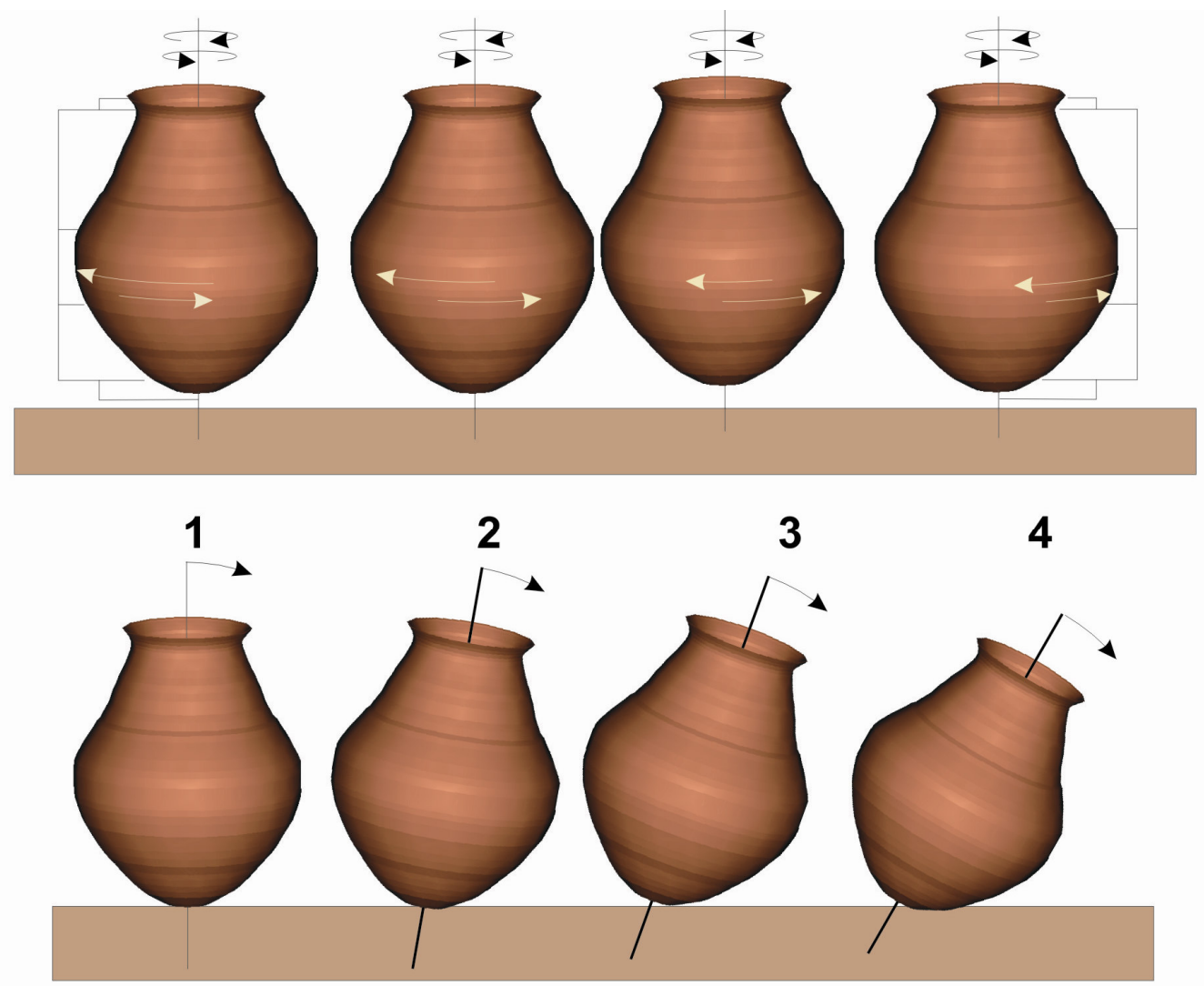

Figura 6.43: movimientos reconstruidos. Superior: giro alrededor del eje morfológico. Inferior: se muestran el grado de inclinación alcanzado representado por los números 1, 2, 3 y 4. Obsérvese que este último no es tan pronunciado.

labio recto. Parte de las huellas observadas pueden ser producto de la intervención de algún instrumento en la extracción o procesamiento de los contenidos que hubiese tenido la vasija. Principalmente las astilladuras y algunas de las estrías perpendiculares, paralelas o diagonales al eje, indicándonos en el caso de las estrías que el material del cual estaba conformado dicho instrumento era igual o más duro que la matriz de las pastas con la cual se confeccionaban las vasijas. A su vez, las astilladuras también podrían ser producto de impactos de un instrumento contra el borde. Asimismo, la existencia de antiplástico sobresaliente, combinado con astilladuras y estrías en distintas direcciones, nos indicaría que algunas de ellas fueron colocadas boca abajo, quizás cuando no se estaban utilizando o a la espera de ser utilizadas.

Pasando ahora a las superficies internas -gráfico 6.19 y figura 6.44-, vemos que en las 8 bases y partes inferiores observadas existen 3 que poseen lotes -patches- y 4 que poseen marcas. Las marcas presentes son antiplástico sobresaliente y hoyuelos -2 cada una-. En relación a la parte media tenemos que de las 21 observadas 33,3\% poseen lotes patches- y $61 \%$ marcas. Las marcas son estrías perpendiculares al eje morfológico en menor cantidad -9\%-. Hoyuelos y antiplástico sobresaliente en mayor cantidad $-42,9 \%$ y un 47,6\% respectivamente-. Con respecto a la parte superior, se observa una disminución 


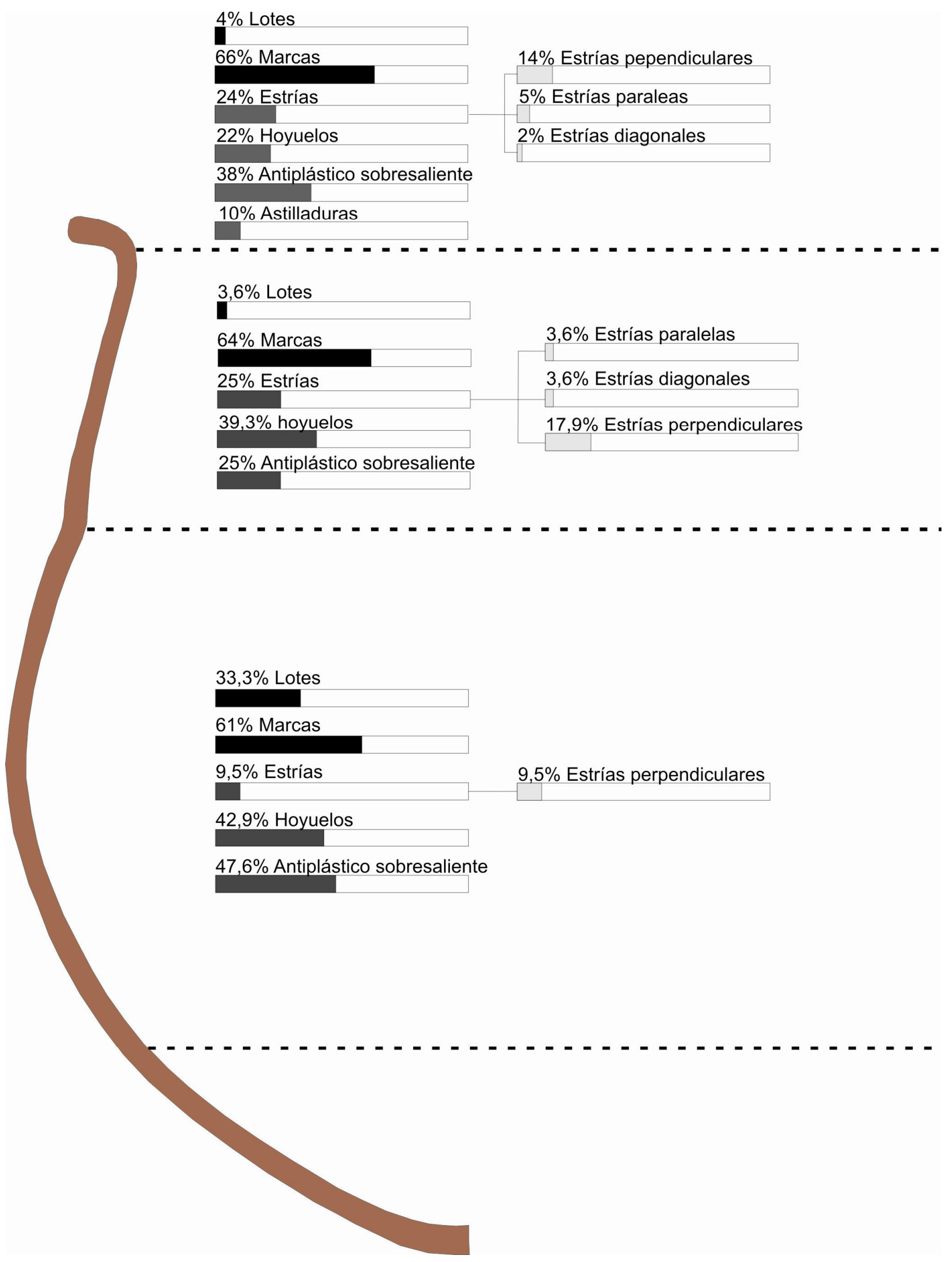

Gráfico 6.19: porcentajes según zonas de lotes y marcas en la superficie interior de las vasijas de forma "a". Los $\mathrm{n}$ figuran en el texto. 
de la presencia de lotes -patches- al 3\% (un caso de los 28 registrados), las marcas alcanzan el $64 \%$. Éstas en general se trata de estrías -25\%-, teniendo mayor representación las que siguen una dirección perpendicular al eje morfológico de la pieza con casi el $18 \%$. Luego se pueden hallar estrías diagonales y paralelas con un 3,6\% cada una. Los hoyuelos alcanzan el 39,3\% y $25 \%$ de antiplástico sobresaliente. La combinación de altas proporciones de antiplástico sobresaliente con estrías hace que aumente la proporción de hoyuelos en tanto ambos procesos erosivos producen esta marca. En el interior del borde y cuello tenemos que de los 50 casos observados vemos un $4 \%$ de lotes -patches- y un $66 \%$ de marcas. En relación a estas últimas, tenemos: estrías en un $24 \%$, teniendo mayor representatividad las perpendiculares con un 14\% -las paralelas y diagonales poseen $5 \%$ y 2\% respectivamente-. En general las estrías de dirección paralelas al eje morfológico se ubican en los bordes. En cuanto a las otras marcas observadas tenemos hoyuelos $-22 \%$ - y antiplástico sobresaliente -38\%-. También en los bordes aparece un 10\% de astilladuras. En ninguna de las zonas presentan huellas de carbonización.

El patrón de distribución, nos está indicando diferentes procesos en la generación de estas marcas. En las bases y el cuello, pero principalmente en el sector medio y superior del cuerpo, hay presencia de patches en bajas cantidades con antiplástico sobresaliente figura 6.44-. Existen estrías en las partes media, superior y cuello, que corren perpendiculares al eje morfológico. Los hoyuelos, ampliamente representados, se correlacionan con la aparición de las estrías y del antiplástico sobresaliente. También tenemos un caso con descascaramiento del baño interno y presencia de antiplástico sobresaliente -figura 6.44-. Señalamos en el anexo IV que el antiplástico sobresaliente podría ser consecuencia de dos procesos erosivos, uno físico como el que describimos cuando analizamos la aparición de esta marca en las superficies exteriores, y otro químico, específicamente triboquímico (Schiffer y Skibo 1989:102-103) -ver anexo IV. Arthur (2002), en sus estudios sobre vasijas utilizadas para la fermentación de bebidas, señala que en la superficie de las vasijas que presentan baños se produce un descascaramiento y una fuerte erosión causada principalmente por el proceso químico de la fermentación de granos. Esto produce que se formen bacterias con ácido láctico, lo que genera que el $\mathrm{Ph}$ se torne muy bajo y se forme un material muy ácido, que produce una fuerte erosión interna en las vasijas, durante el procesamiento y el almacenamiento de diferentes tipos de bebidas fermentadas (Arthur 2002:339). 


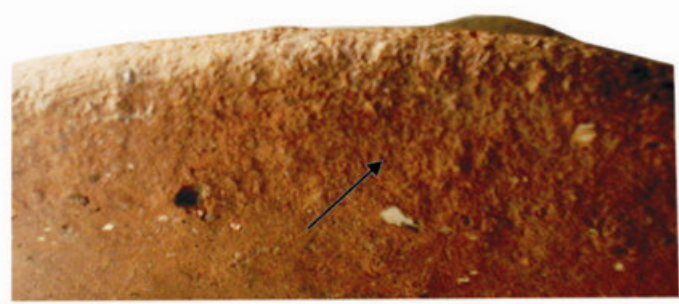

an
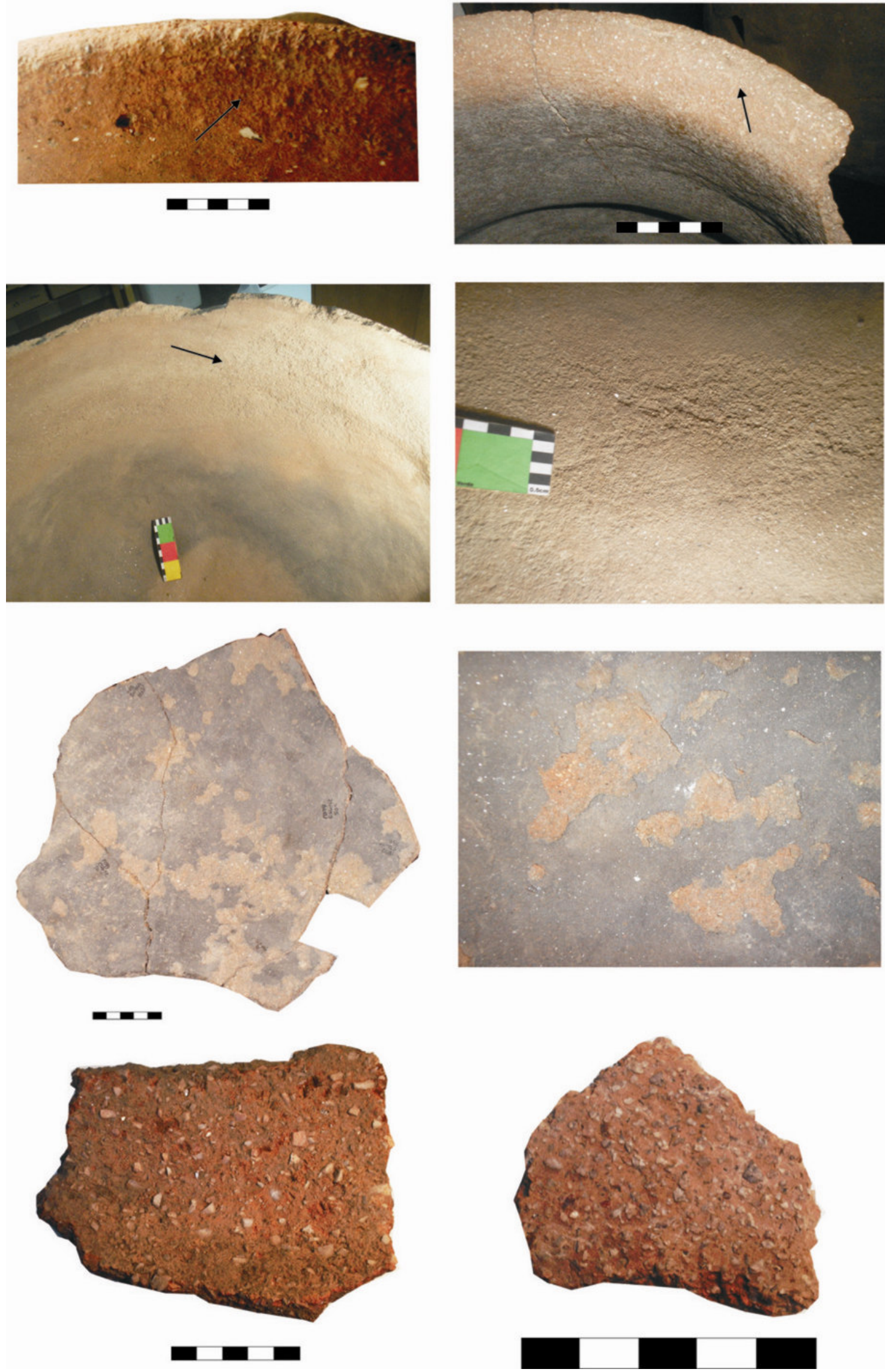

Figura 6.44: fotografías de las diferentes marcas y lotes hallados en las distintas zonas de la superficie interna de las vasijas de forma "a". Se muestran dos tipos de marcas, antiplástico sobresaliente y descascarado de los baños. Ambas se deben al proceso de fermentación de bebidas. 
Mientras realizábamos los análisis de rastros de usos e identificamos estas huellas, teníamos dudas acerca de qué tipo de proceso físico y/o químico podría haberlas producido. Con estas preguntas, el director de esta tesis, junto a Francisco Pazzarelli y Gisela Vargas, quienes habían realizado análisis de residuos orgánicos con reacción a la gota (Pazzarelli 2006), experimentaron con vasijas actuales reproducidas según las características de pasta de la clase E, cocidas en el mismo tipo de atmósfera y a la misma temperatura -oxidante y a $700^{\circ}$ (ver Laguens et al 2007).

Una vez fabricadas, se puso a fermentar en ellas chicha de maíz; aquí retomamos los primeros resultados de 7 semanas de almacenado. Cada semana se fotografió una superficie previamente demarcada para luego comparar el desgaste entre las distintas tomas. Aquí presentamos dos fotos, una al inicio del proceso y otro a la séptima semana ${ }^{\mathrm{x}}$ figura 6.45-. Claramente las huellas que presentan se corresponden con las observadas por nosotros en las vasijas arqueológicas: la matriz arcillosa se erosionó dejando los antiplásticos sobresaliendo a manera de islas, hasta que algunos de ellos se salieron de la matriz dejando un hoyuelo en el lugar en que estaban ubicados. Estos datos nos permiten señalar que las huellas interiores observadas, particularmente aquellas que presentan descascarados y algunos de los lotes -patches- son producto de la utilización de estas vasijas para la fermentación de algún tipo de bebida fermentada, sea de maíz (chicha) o de algún otro vegetal -ej.: algarroba (Aloja).
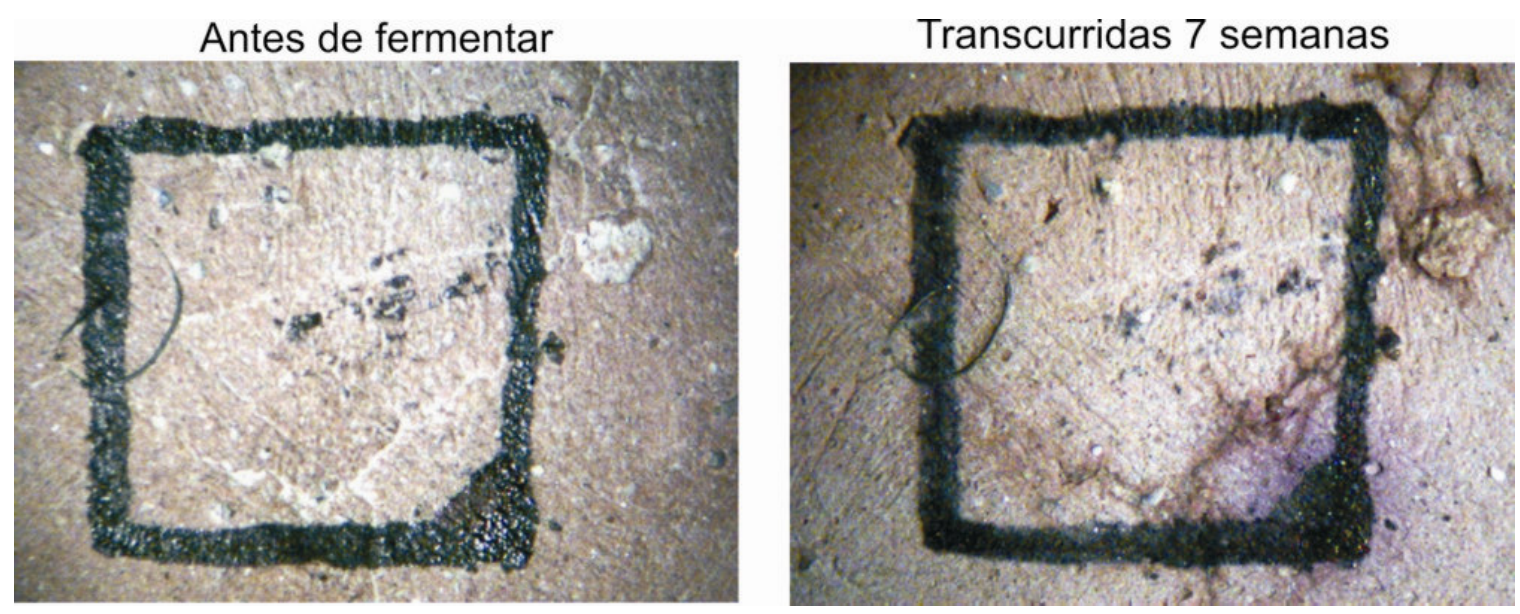

Figura 6.45: imágenes en donde se muestran la superficie interna de una vasija confeccionada con las mismas características de la clase E, donde se puso a fermentar chicha durante 7 semanas consecutivas. El resultado es la erosión de la arcilla y la exposición de los antiplásticos, que quedan sobresaliendo de la pasta. Agradecemos la fotografía a Laguens, Pazarelli y Vargas. 
Las estrías que están presentes en la superficie, tanto las que poseen antiplástico sobresaliente como las que tiene lotes -patches-, podría ser producto del instrumento utilizados para extraer el contenido. En general por la dirección de las estrías indicarían movimientos circulares al eje morfológico, pero también diagonales y paralelos. Pero si observamos los porcentajes de marcas, no todas las vasijas presentan estas huellas por lo que probablemente se usaban para otras cosas que no dejaron rastros visibles. Trataremos de acercaremos a ellas retomando una serie de estudios de residuos orgánicos por reacción a la gota -ver anexo IV-realizados en mas de 500 muestras de vasijas pertenecientes a la clase E (Pazzarelli 2006, 2007). Pazzarelli (2006) pudo determinar dos conjuntos de recursos: carnes (albúmina) y grasas animales y vegetales (ácidos grasos). En el caso de las vasijas que estamos analizando, los resultados obtenidos arrojan que en general predominan los ácidos grasos más que la albúmina. Esto se observa particularmente en fragmentos que, en su interior, presentan huellas de uso que pueden asociarse con efectos químicos producto de la fermentación de bebidas. Por más que exista la predominancia de un tipo de residuo sobre otro, todo esto nos informa que estas vasijas habrían estado en contacto con vegetales, grasas animales y en algunos casos con carne. Por lo que, hasta el momento, los análisis de residuos orgánicos están apoyando las huellas de uso observadas con respecto a la producción de bebidas fermentadas pero muestran la existencia de más actividades prácticas donde intervenían estas vasijas.

Vasijas de forma “ $a b$ ”

Se siguió la zonificación de Skibo (1992) -figura 6.48-. Dado que hemos podido observar pocas de estas vasijas, las expresiones no se realizarán en porcentajes. De las 8 bases observadas, en la zona exterior, cuatro presentan lotes -patchs-, y 6 presentan marcas. Las marcas se tratan de antiplástico sobresaliente -8 casos-, pero además sobre la superficie erosionada en todos los casos se observan estrías perpendiculares al eje morfológico y hoyuelos -figura 6.46-. Los lotes - patch- observados se extienden desde la base unos $15 \mathrm{~mm}$ hacia la zona exterior inferior de la vasija. Lo mismo sucede con las estrías. En la zona exterior inferior -8 casos- también se observaron hoyuelos y estrías que corren en distintas direcciones: paralelas, diagonales y perpendiculares -figura 6.46-. En la parte media de la vasija -6 casos-, las estrías sólo son perpendiculares, observándose también la presencia de hoyuelos. Este patrón continúa en la zona exterior superior de las vasijas. En los bordes, se registraron astilladuras -7 casos-. En la zona interior del borde y cuello de estas vasijas, también se observaron estrías gruesas, perpendiculares y paralelas, 

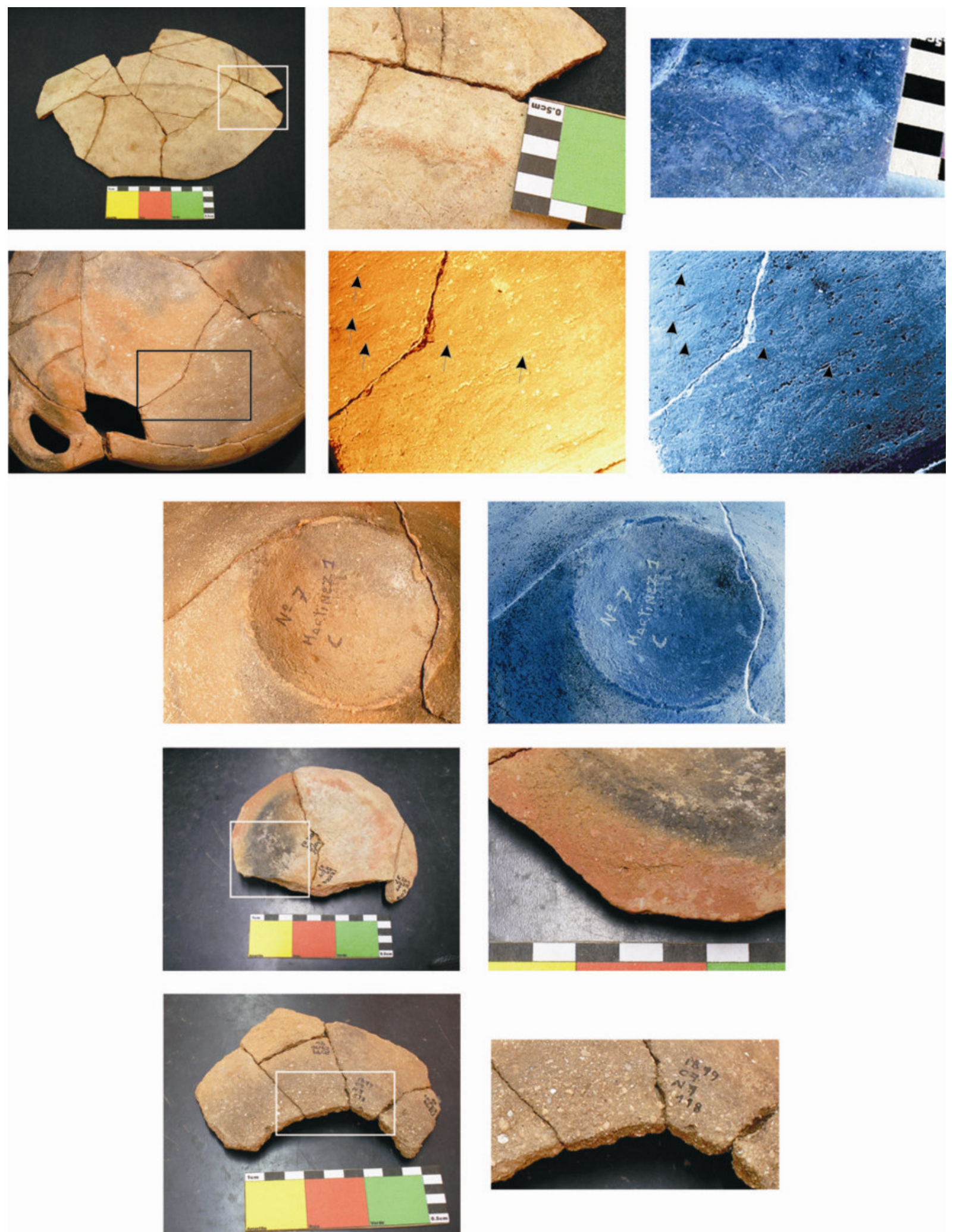

Figura 6.46: fotografías que muestran lotes y marcas en distintas zonas de la superficie exterior de las vasijas de forma "ab". En la primera tira de imágenes se observa un lote en la zona media del cuerpo. La segunda tira muestra estrías diagonales y perpendiculares al eje en la zona inferior de estas vasijas. La tercera, cuarta y quinta muestra la erosión de las bases. Obsérvese la última en donde un abrasivo produjo que el antiplástico quede sobresaliendo. 

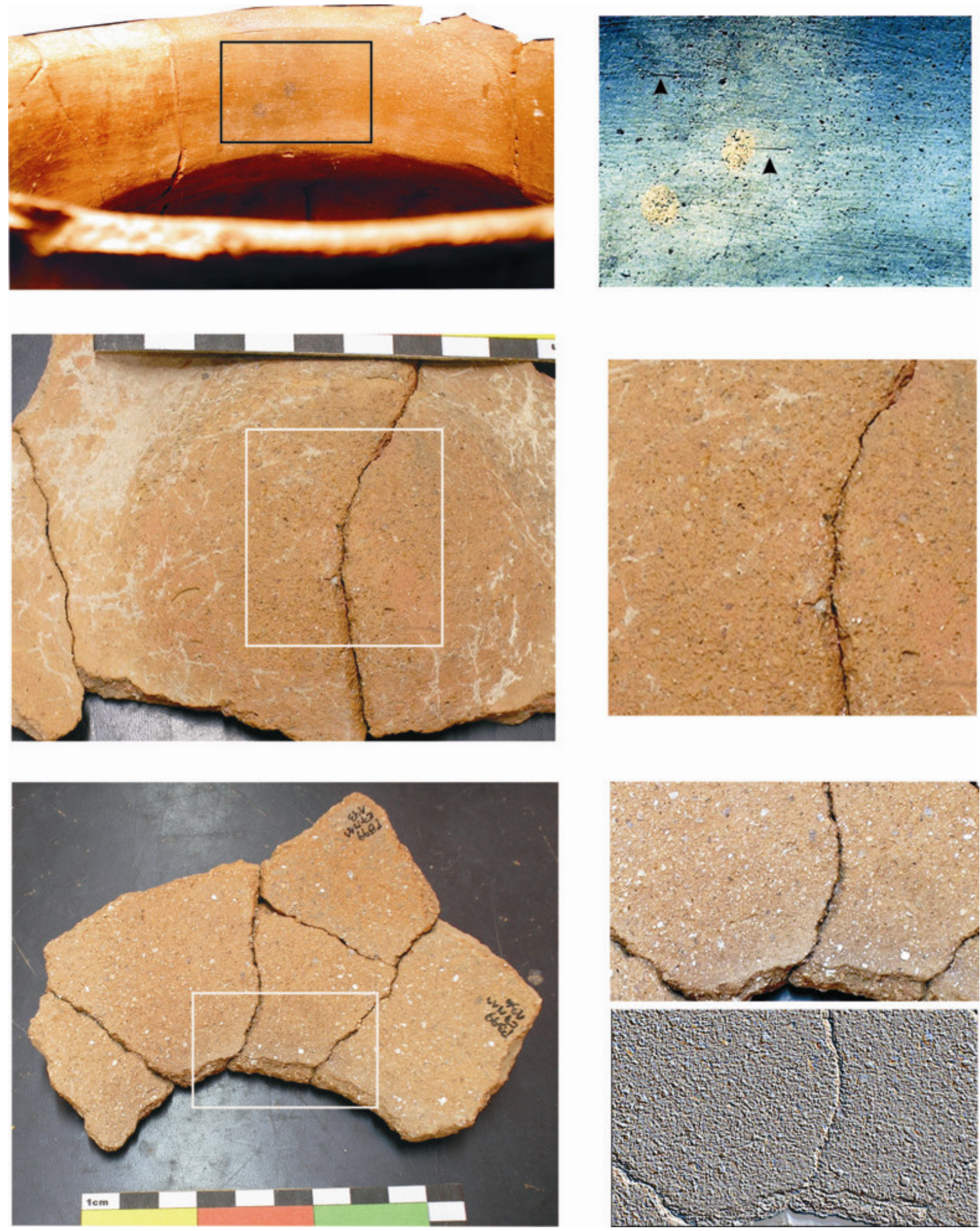

Figura 6.47: fotografías que muestran las marcas observadas en distintas zonas de la superficie interior de las vasijas de forma "ab". En la primera tira de imágenes se observa estrías perpendiculares al eje en la zona interior del borde o cuello -se marca con una flecha negra. En la segunda y tercera tira se muestran casos donde aparece el antiplástico sobresaliente. 
además de hoyuelos y astilladuras -figura 6-47-. En la zona interior, partes superior, media, inferior y base tienen un patrón común de hoyuelos y estrías perpendiculares y diagonales al eje morfológico de la pieza. En algunos casos en las bases aparece el antiplástico sobresaliendo -figura 6.47-. A partir de la observación de estas huellas, se puede inferir el patrón de movimiento siguiente -figura 6.48-: estos objetos habrían realizado movimientos de inclinación, en tanto los lotes - patch-observado en la base y las estrías diagonales y paralelas no se adentran tanto en la zona inferior de la vasija, solo uno $15 \mathrm{~mm}$. Las estrías perpendiculares al eje nos indican movimientos giratorios alrededor del eje morfológico. La forma que presenta la vasija también produce que las marcas se
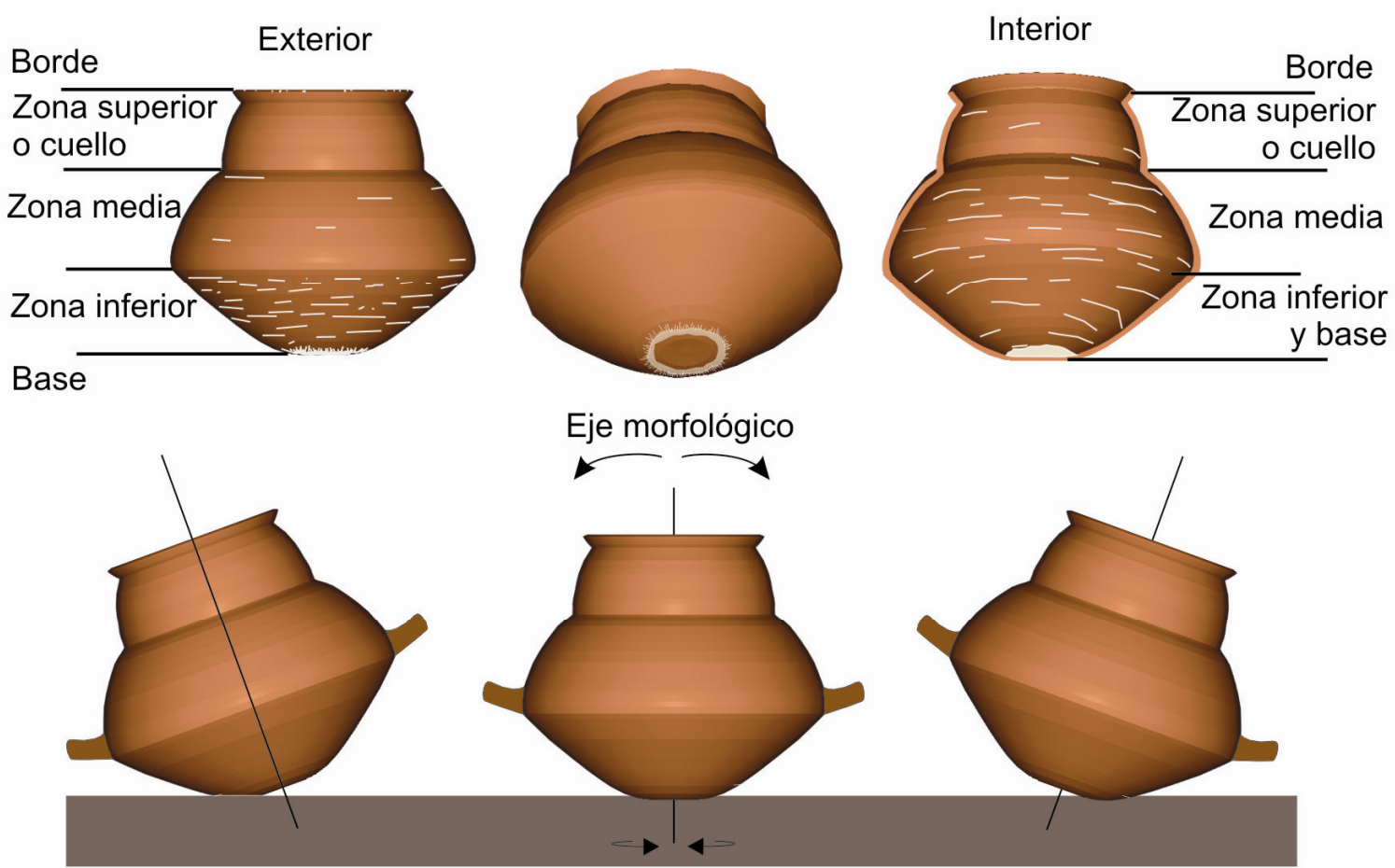

Figura 6.48: en el dibujo superior se muestran las zonas y el patrón de marcas de cada una de ellas. En la primer y segunda vasija se observan estrías perpendiculares, paralelas, diagonales y lotes en la superficie exterior. En la tercera se observa el patrón de estrías perpendiculares en el cuerpo y cuello y, antiplástico sobresaliente en la base de la superficie interior de estas vasijas. El dibujo inferior muestra los movimientos de inclinación, giro y/o combinación de ambos.

concentren en el sector inferior por debajo del punto angular que divide el cuerpo en dos. En el caso de las huellas en el interior, se pude decir lo siguiente: aquellas vasijas que presentan solo estrías perpendiculares y paralelas en sus distintas zonas nos muestra que la extracción de los productos colocados en el interior se realizaba con algún tipo de instrumento que abradió dicha superficie pero no nos dice nada acerca de lo que contenía, en cambio el caso del antiplástico sobresaliente podría corresponder al igual que la forma A al efecto de la fermentación de bebidas en su interior. Además de los análisis de residuos 
orgánicos, otro dato que nos puede alumbrar un poco más sobre lo que contenían estas vasijas proviene de los análisis de pigmentos realizados sobre una sustancia blanquecina hallada como relleno de una de estas vasijas en el recinto sudeste del sito Piedras Bancas ver descripción de contextos más adelante. Los análisis de residuos orgánicos de la sustancia y del raspado de las paredes permiten inferir que estas vasijas habrían entrado en contacto con grasas animales o vegetales y no con albúmina (Pazzarelli 2006). El análisis de la sustancia blanca arrojó que se trataba de un preparado de pigmento de color blanco con alto contenido de calcio y que, la grasa animal o vegetal habría sido utilizado como aglutinante del pigmento (Bertolino comunicación personal ${ }^{\mathrm{xi}}$ ).

En relación a las huellas de atrición por uso observadas en la vasija que contenía pigmento blanco se observó que posee estrías y presencia de antiplástico sobresaliente, lo que nos estaría indicando dos usos diferentes. Dado las características de estos: uno para fabricar bebidas fermentadas, otro para almacenar pigmento blanco no comestible, podemos plantear en ese caso un uso secuencial: primero la fermentación, y en un momento posterior de la vida de la vasijas el almacenamiento de pigmento. Estas vasijas no presentan huellas de carbonización.

\section{Calceiforme}

Para esta descripción se siguió la zonificación de Skibo (1992). Con relación a las huellas de atrición por uso, en esta clase de formas en general casi no se observan. Concretamente el labio, pude presentar astilladuras; en la zona exterior superior y media se pueden presentar lotes -patchs- restringidos y también puede haber presencia de estrías perpendiculares y paralelas al eje morfológico. En la zona interior parte media se han observado algunos hoyuelos y puede presentar sectores muy restringidos con antiplástico sobresaliente. De las huellas observadas no podemos obtener muchas conclusiones respecto de los movimientos que realizaba, pero si observamos los patrones de carbonización nos podemos acercar a su modo de uso concreto. Todas las vasijas calceiformes analizadas presentan huellas de carbonización, cuyo patrón puede ser descrito del siguiente modo -figura 6.49-: en el sector exterior el hollín cubre toda la superficie contraria a donde se ubica el asa, que está adherida al labio de la vasija y posee una posición vertical. En el sector donde se encuentra el asa y hasta cierto punto -marcado por un punto de inflexión- que delimita el cuerpo de la base, no están manchadas de hollín. Si se observa la superficie interior este patrón se vuelve a repetir -figura 6.49-. Se hallan adheridos al muro restos carbonizados del contenido que fue expuesto al fuego, cubriendo 
toda la superficie contraria a la pared del asa. Según este patrón de huellas de carbonización -figura 6.49-, se puede plantear que estas vasijas eran suspendidas sobre el fuego de forma inclinada, probablemente sostenidas por el asa o apoyadas sobre soportes de piedras; tal como fue hallada en el RH de Piedras Blancas ${ }^{x i i}$-ver descripción de contexto más adelante- la segunda vasija observada en la figura 6.49. Las huellas dejadas por este modo de uso específico nos informan que no todo su volumen fue utilizado. Si consideramos un volumen de $2000 \mathrm{~cm}^{3}$, el usado efectivamente sería menor a la mitad. Los análisis de residuos orgánicos a las sustancias adheridas puestas a cocinar en el fuego, arrojaron valores positivos tanto de ácidos grasos como albúmina, indicando así el contacto de estas piezas con grasas animales, vegetales y carne.

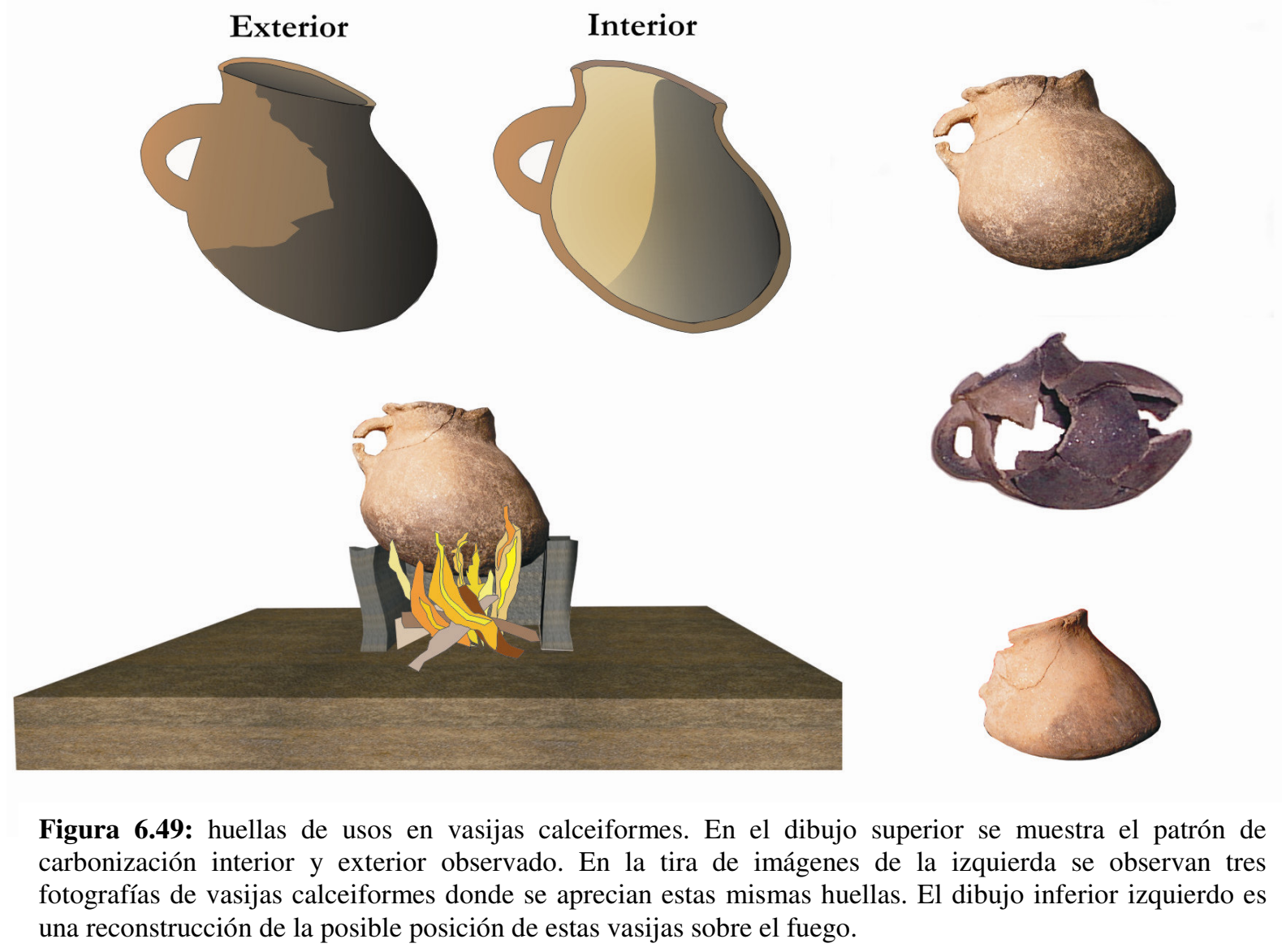

\section{Forma plato no restringido:}

En esta forma no fue usada la zonificación propuesta por Skibo (1992) -figura 6.50, se la dividió en cuatro zonas tanto para la superficie exterior como interior: base, parte inferior, parte superior y borde.

Hemos podido observar solo una base de esta forma que presenta por un lado lotes patch- y por el otro dos variedades de marcas -figura 6.51-: antiplástico sobresaliente y 


\section{Borde}

Zona inferior, media y superior

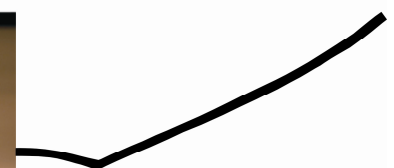

Base

Figura 6.50: zonificación de los platos.
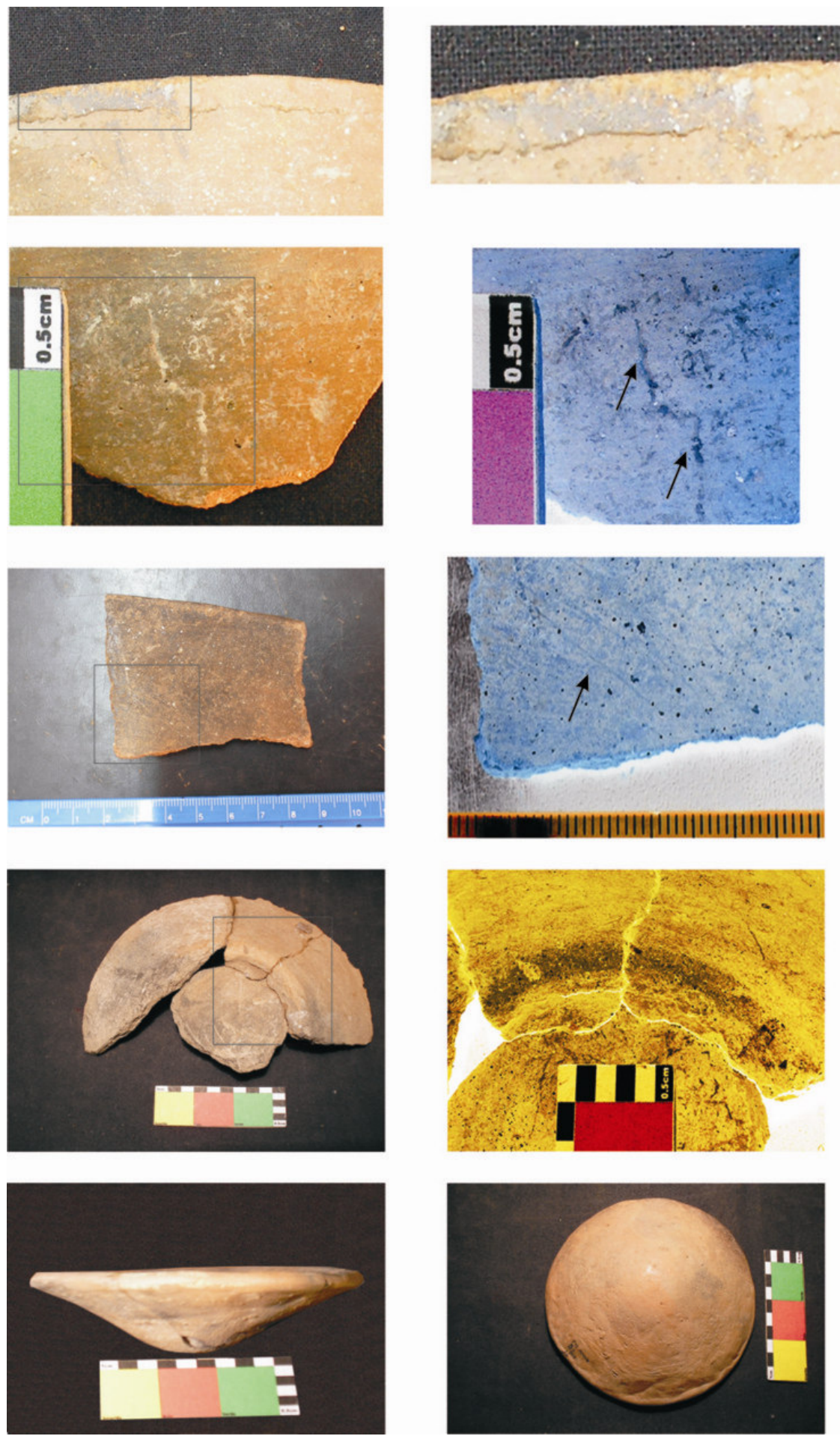

Figura 6.51: fotografías que muestran marcas y lotes en diferentes partes de los platos grandes -primera, segunda, tercera y cuarta tira- y de los platos chicos última tira. En la primera tira se observa lotes en el borde, en la segunda y tercera tira se observan estrías en distintas direcciones -se marcan con una flecha. En la tercera se observa el lote en la base. La última tira muestra un plato chico que no posee casi marcas, características que comparte con los otros platos chicos analizados. Las imágenes de la derecha, salvo la última, fueron sometidas a un proceso digital de inversión de colores para que resalten las marcas y lotes. 
hoyuelos. En la zona inferior de la superficie exterior (2 casos observados) existen estrías perpendiculares y hoyuelos. En la zona superior -gráfico 6.20 y figura 6.51- de los 34 casos observados tenemos 2,9\% de lotes -patches- y $77 \%$ de marcas. Dentro de las marcas las que poseen mayor porcentaje son las estrías y los hoyuelos, 71,4 \% y 20\% respectivamente. También existe antiplástico sobresaliente pero con un muy bajo porcentaje $-5,7 \%$. En cuanto a la dirección de las estrías, si bien las hay diagonales -25,7\%y paralelas $-17,1 \%-$, las perpendiculares son las que poseen mayor porcentaje $-65,7 \%$. En la zona exterior del borde de estas piezas -34 casos- se observan estrías paralelas al eje morfológico y astilladuras. En la superficie interna se observa, al igual que en la zona superior, mayor cantidad de marcas $-67,6 \%$ - que lotes $-5,9 \%$. Dentro las marcas tenemos
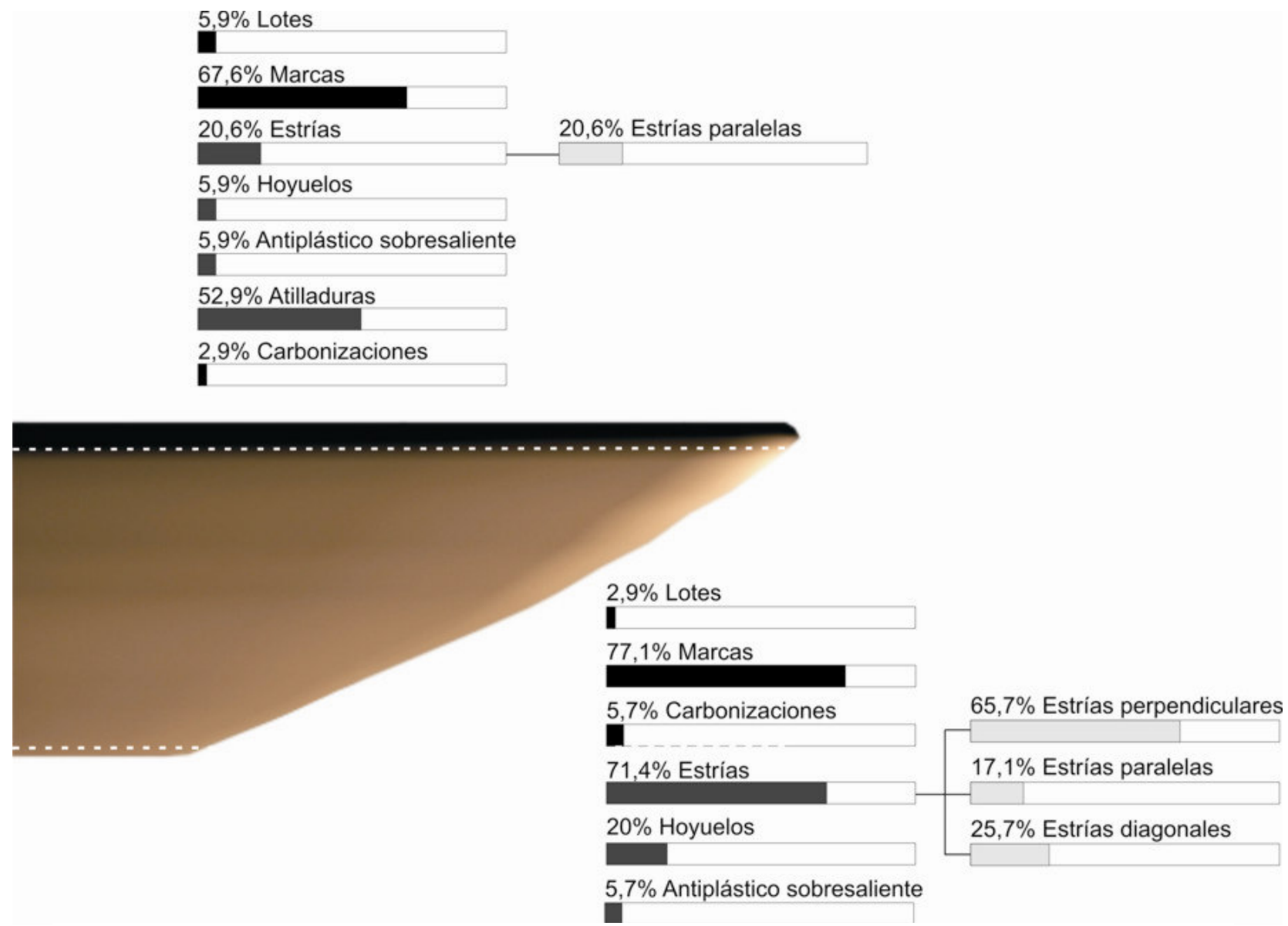

Gráfico 6.20: porcentajes de lotes y marcas en las distintas zonas de la superficie exterior de los platos grandes. Los $\mathrm{n}$ se hallan en el texto.

en mayor porcentaje de astilladuras $-59,9 \%$ - y estrías $-20,6 \%$, pero también hay, aunque en menor medida, antiplástico sobresaliente y hoyuelos $-5,9 \%$ cada uno. Las estrías sólo corren en sentido paralelo $-20,6 \%$.

En el sector interno del borde -34 casos-, también se presentan lotes con el 10\%- y marcas con el $73 \%$-gráfico 6.21 y figura 6.52- . Las marcas se tratan de astilladuras en mayor cantidad -51,4\%-, siguiéndoles las estrías -24,3\%- y los hoyuelos -16,2\%-; el 
antiplástico sobresaliente posee poca representación -5,4\%. Las estrías en mayor cantidad siguen una dirección perpendicular al eje morfológico de la pieza -16,2\%-, las estrías paralelas y diagonales poseen menor porcentaje $-8,1 \%$ y $2,7 \%$ respectivamente. En la zona interior superior de los 34 casos, presenta 2,9\% de lotes y 64,7\% de marcas. Las marcas se reparten de la siguiente manera: las estrías son las de mayor cantidad -47,1\%-, le siguen los hoyuelos -20,6\%- y con menor representación el antiplástico sobresaliente -5,9\%-. En cuanto a las estrías las que se hallan presentes siguen en mayor medida una dirección perpendicular al eje morfológico -41,1\%- y diagonal en menor proporción -23,5\%.

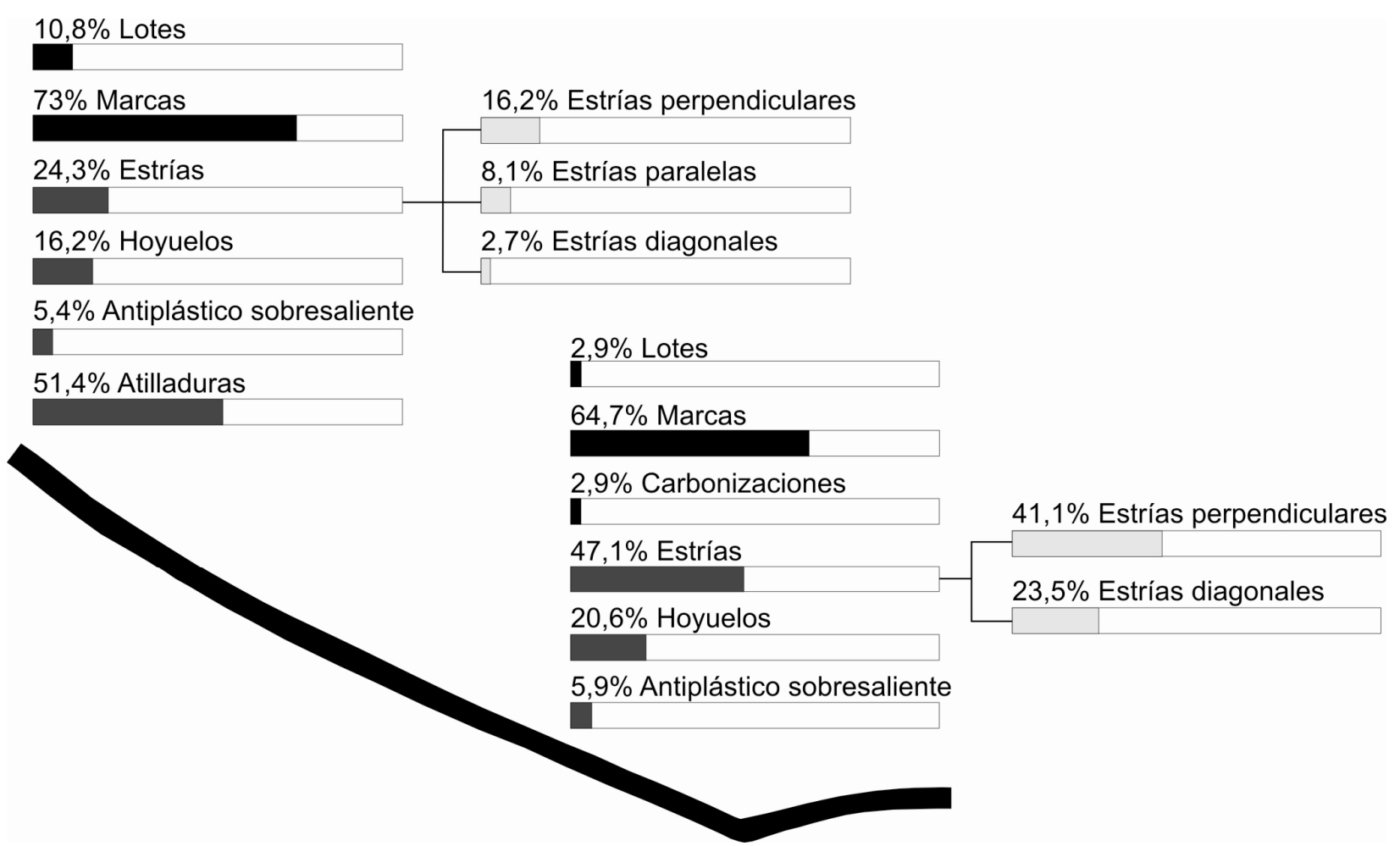

Gráfico 6.21: porcentajes de lotes y marcas en las distintas zonas de la superficie interior de los platos grandes. Los porcentajes de la zona inferior, media, superior y base se encuentran juntos. Los n se hallan en el texto.

Según las marcas observadas, podemos reconstruir los siguientes movimientos figura 6.53A-: las marcas presentes en el exterior indicarían movimientos alrededor del eje morfológico y de inclinación de las piezas en diferentes direcciones. Con respecto a las huellas observadas en la superficie plana del borde recto, tanto exterior como interior, la combinación de estrías perpendiculares, más lotes -patch- y antiplástico sobresaliente-, estaría indicando, al igual que lo señalamos para la forma "a", que algunas de estas piezas fueron colocadas boca abajo, quizá cuando se las guardaba o almacenaba, lo que produjo contacto con tierra o arena fina. Con respecto a las marcas observadas en la superficie interna de estos objetos se puede plantear que las mismas son producto de un abrasivo que habría entrado en contacto con la superficie de estos objetos realizando movimientos al 
rededor del eje morfológico, que podrían vincularse tanto con movimientos de batido o revuelto de lo que se procesaba en estas piezas.
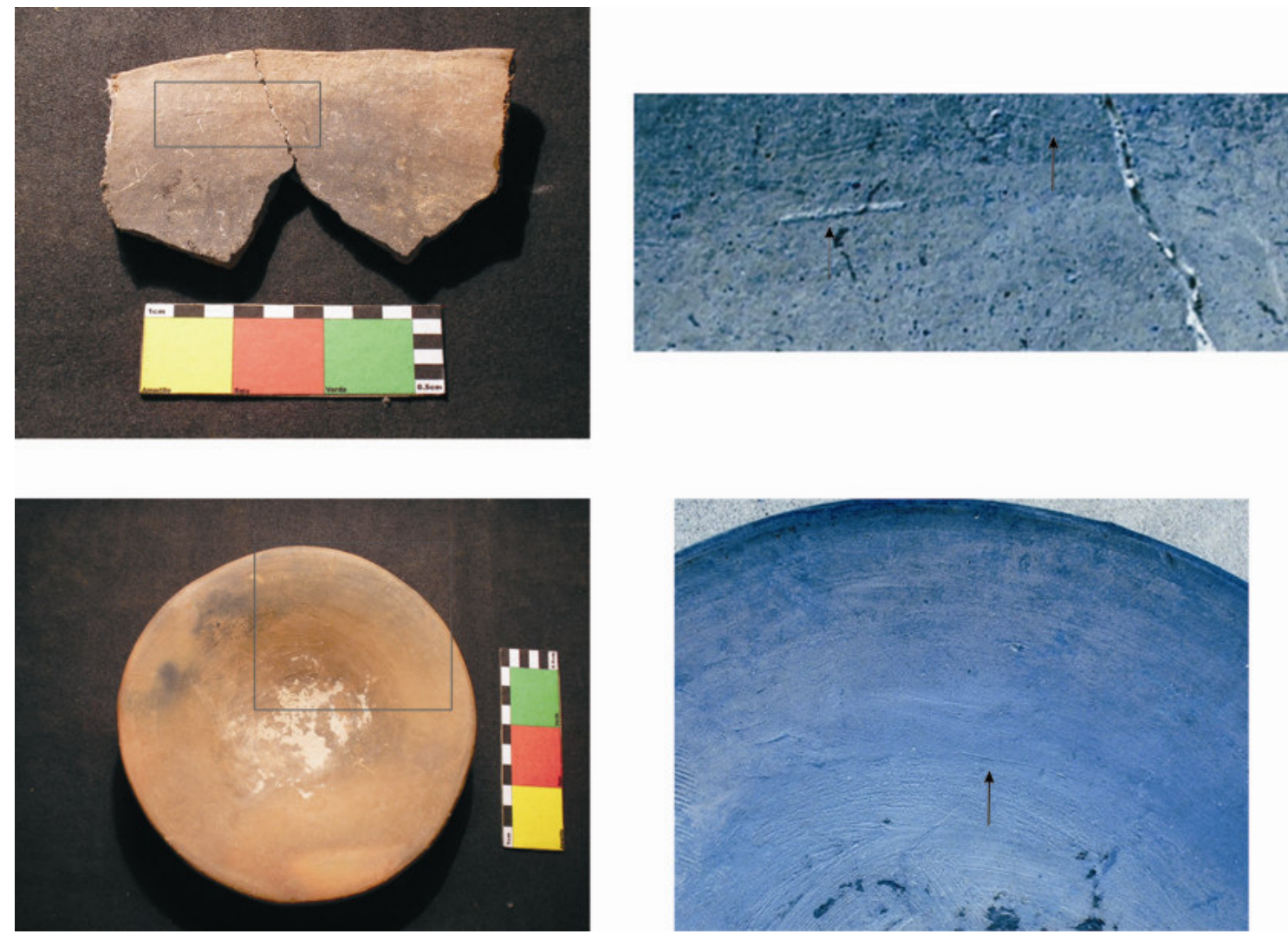

Figura 6.52: fotografías en donde se observan las marcas de la superficie interior de los platos grandes superior- y chicos -inferior. Particularmente se marcan con flechas las estrías perpendiculares. Las imágenes de la derecha fueron sometidas a un proceso digital de inversión de coleros para que resalten las marcas.

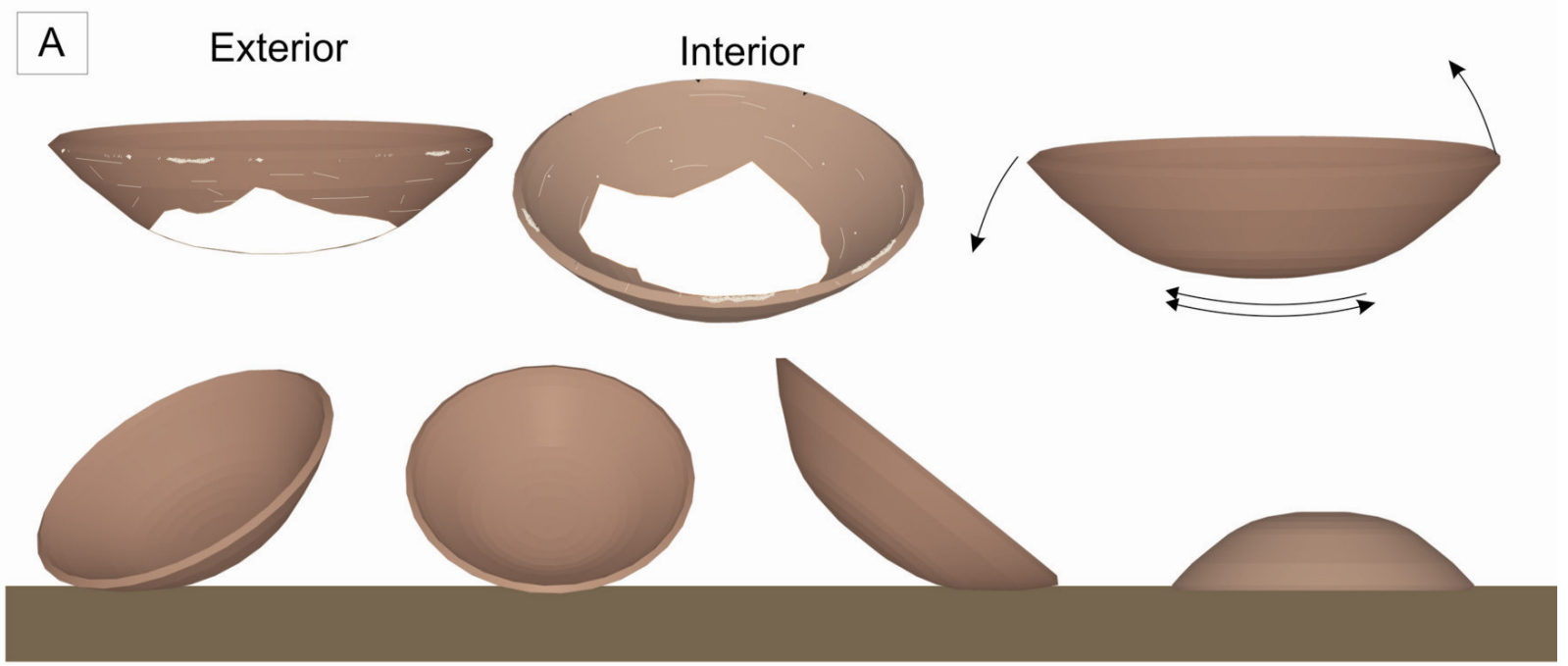

B

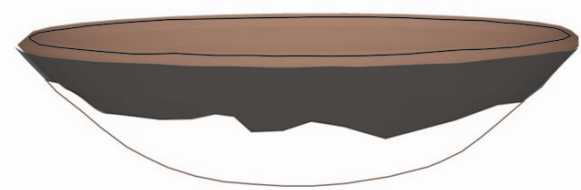

Figura 6.53: en A se observa el patrón de marcas en la superficie exterior e interior de los platos grandes; a su vez, se marcan los distintos movimientos reconstruidos. En B se observa el patrón de carbonización hallado. 
Los análisis de residuos orgánicos realizados arrojan la presencia de ácidos grasos y ausencia de albúmina, lo que significa que tuvieron contacto con grasas animales y/o vegetales, pero no con carne (o por lo menos, no con demasiada frecuencia, Pazzarelli 2006).

Con respecto a las huellas de carbonización, sólo se observaron en la superficie exterior de uno de los casos analizados -figura 6.53B-. El hollín ocupa todo la zona superior externa del recipiente llegando hasta el labio, en la superficie interior no se hallaron huellas de este tipo. En función de este patrón, la zona carbonizada no debió estar en contacto directo con el fuego, ya que si así lo hubiera realizado se abría producido otro tipo de huella: la oxidación de la superficie original o la formación de una coloración más clara -grisácea- (Hally 1983, Skibo 1992). Al no poseer la base sobre la cual observar el patrón de carbonización no podemos saber si esta habría apoyado directamente sobre el fuego o si habría estado por encima de la fuente de calor; pero dado que son recipientes planos y de baja altura -recordemos que la proyección realizada del recipiente con mayor grado de completitud es de $140 \mathrm{~mm}$ y el promedio de los diámetros de las bocas supera los $500 \mathrm{~mm}-$, se podría plantear que la pieza estuvo colocada no directamente en el fuego, sino suspendida a cierta distancia de este, quizás colocada sobre algún/os soporte/es ${ }^{\mathrm{xiii}}$.

\section{Vasijas de "otras formas":}

Para la descripción, al igual que las formas "a", "ab" y calceiforme, se siguió la zonificación de Skibo (1992) -figura 6.56A-.

Las huellas de atrición por uso en esta forma se presentan de la siguiente manera: en las superficies exteriores -gráfico 6.22 y figura 6.54- de la zona de la base pudimos observar 9 casos. La presencia de carbonización en más de la mitad de los casos ocultaba las marcas, pero como estas carbonizaciones no tapaban toda la superficie, se observó la presencia de estrías perpendiculares y hoyuelos. En la zona inferior de la superficie externa -18 casos- pueden presentar lotes - patchs- en muy bajo porcentaje -1\%-y marcas $-56,6 \%$. Las marcas presentes se tratan de hoyuelos en mayor cantidad $-50 \%$ - y en menor porcentaje estrías perpendiculares y antiplástico sobresaliente $-5,6 \%$ cada una. La presencia de carbonizaciones alcanza casi el 57\%. En la parte media no hay presencia de lotes, solo se observan marcas $-60 \%, 30$ casos. Las marcas más abundantes son los hoyuelos $-56,7 \%$ - y las estrías perpendiculares $-26,7 \%$-. También hay presencia de antiplástico sobresaliente pero en un muy bajo porcentaje $-3,3 \%$. Las carbonizaciones en esta zona alcanzan el 46,7\%. En la parte superior -35 casos- sigue el mismo patrón que la 


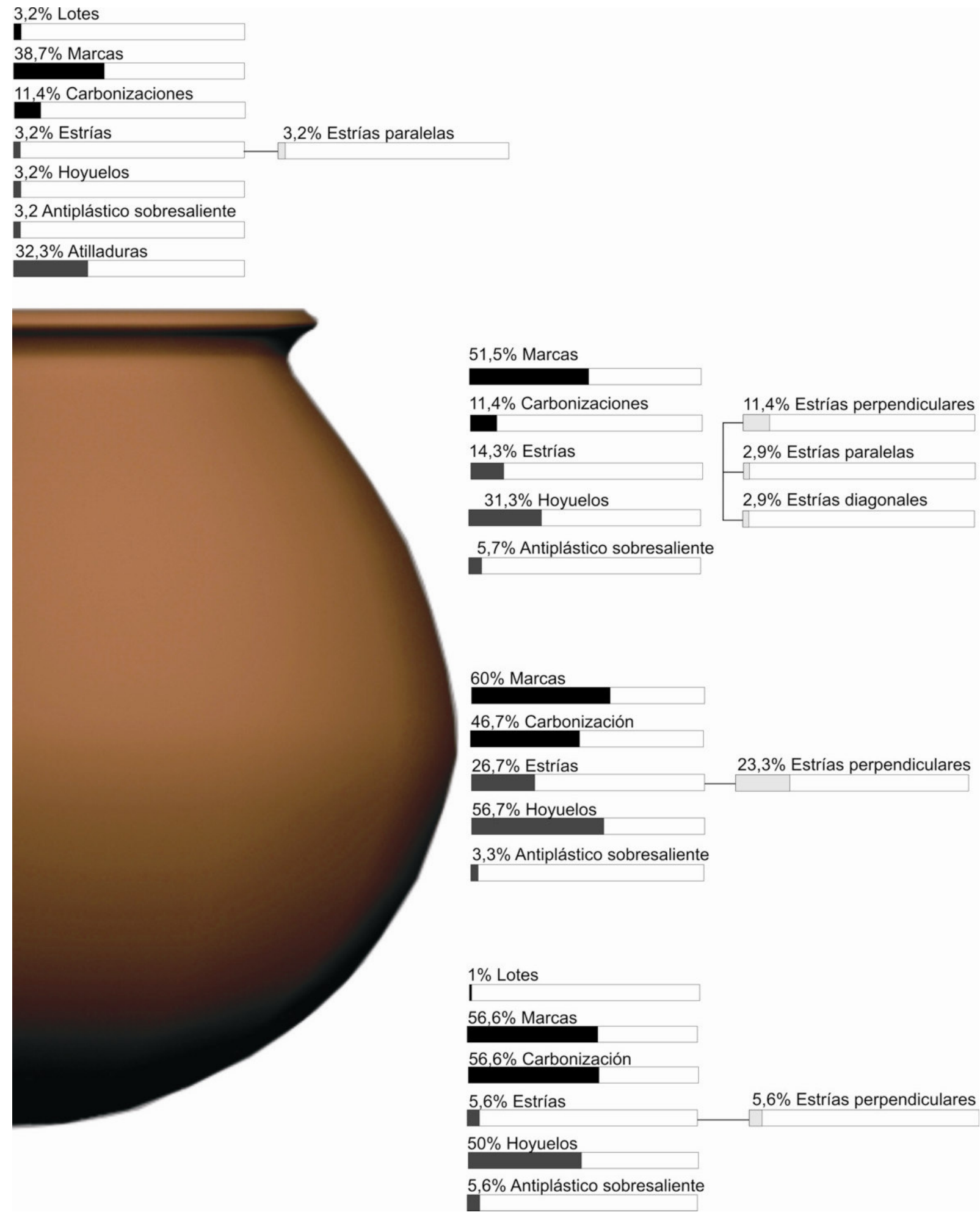

Gráfico 6.22: porcentajes de lotes y marcas en las zona del borde, superior, media e inferior de las vasijas pertenecientes a las "otras formas". Los n se encuentran en el texto. 

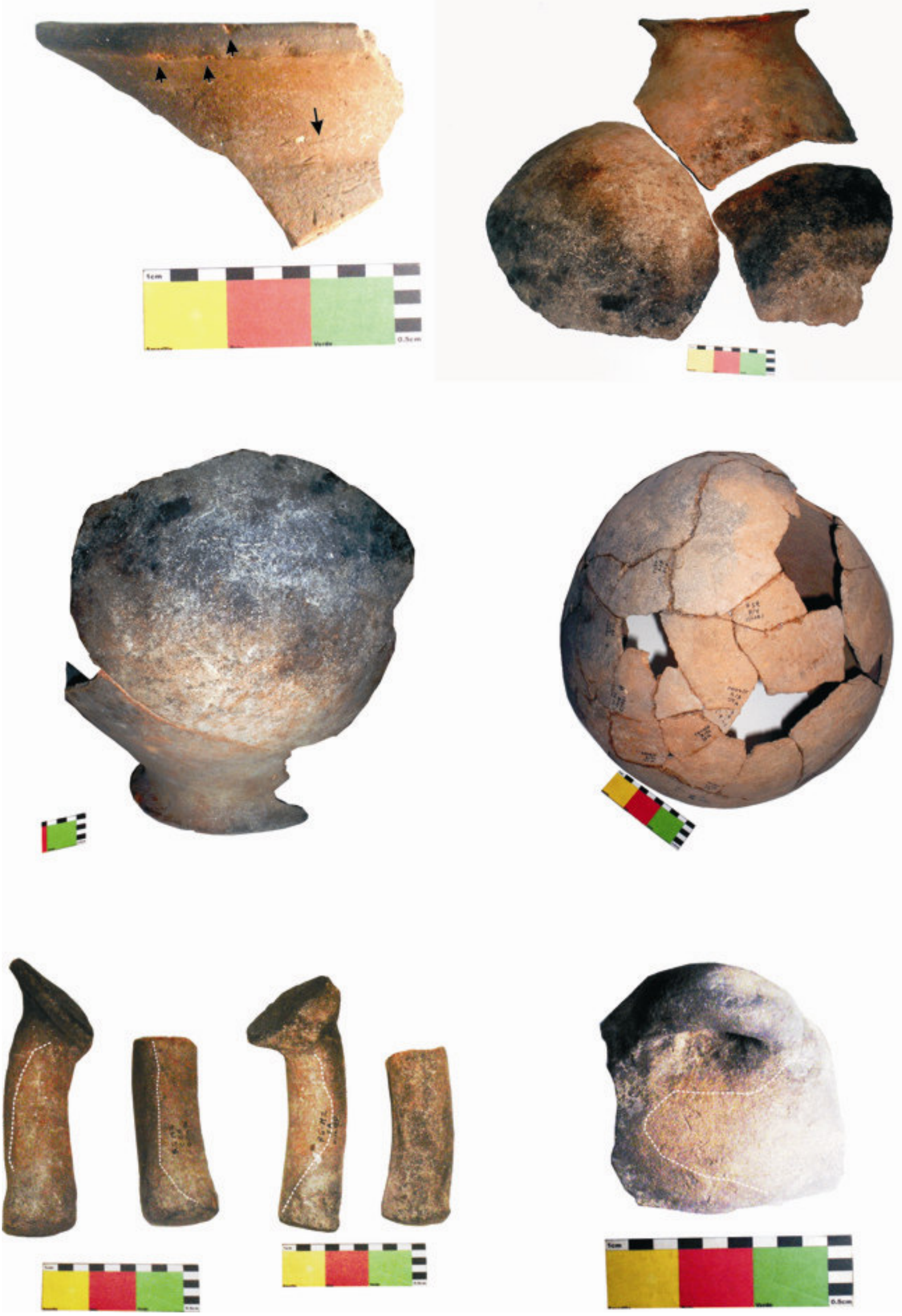

Figura 6.54: fotografías que muestran los patrones de marcas y carbonización observados en la superficie exterior de las vasijas pertenecientes a "otras formas". La foto superior izquierda muestra astilladuras, estrías perpendiculares y hoyuelos. En el resto se puede observar los diferentes patrones de carbonización hallados. En algunas cubre toda la base, parte inferior y media, en otra cubre las misma área pero de un solo lado. Las líneas entrecortadas blancas delimitan el área de extensión de las carbonizaciones en las patas -inferior izquierda- y asas -inferior derecha- 
media, salvo por la presencia en menor medida de carbonización, sólo el 11,4\%. Las marcas alcanzan el 51,5\%. Principalmente se presentan hoyuelos y estrías $-31,3 \%$ y 14,3\% respectivamente- y en menor porcentaje antiplástico sobresaliente $-5,7 \%$. Si bien existe presencia estrías en diferentes direcciones, predominan las perpendiculares con un 11,4\%, mientras que las paralelas y diagonales no alcanzan el 3\%. En la zona del borde -30 casosse observó la presencia de un muy bajo porcentaje de lotes -patchs- con un 3,2\% y un gran porcentaje de marcas con un 38,7\%. La presencia de carbonización se presenta en el mismo porcentaje que la zona superior $-11,4 \%$. Las marcas presentes son en mayor cantidad astilladuras $-32,3 \%-$; se presentan también estrías paralelas, hoyuelos y antiplástico sobresaliente en muy bajo porcentaje $-3,2 \%$ cada uno.

En la superficie interior -gráfico 6.23 y figura 6.55- se observó que en la zona del borde -30 casos- se presentan, al igual que en la zona exterior, lotes -patchs- en muy baja presencia -3,1\%- y marcas con un gran porcentaje -65,6\%-. Las estrías, los hoyuelos y las astilladuras presentan porcentajes semejantes $-25 \%, 21,9 \%$ y $21 \%$, respectivamente- y el antiplástico sobresaliente se halla en menor proporción -12,5\%. En general, las estrías corren perpendiculares al eje morfológico -21,9\%-, aunque también en menor medida se presentan estrías paralelas $-9,4 \%$ - y diagonales $-6,3 \%$. En la parte superior existen, al igual que en el borde, lotes en baja proporción -5\%- y marcas en mayor proporción -60\%. Las marcas presentes se tratan de hoyuelos en mayor cantidad $-45 \%$ - y, de estrías y antiplásticos en menor cantidad $-15 \%$ y $10 \%$ respectivamente-. Las estrías en general siguen una dirección perpendicular y diagonal. En la zona media se presentan lotes -6.7\%y marcas -53,3\%-. Las marcas se componen de hoyuelos en mayor proporción -43,3\%pero también hay estrías y antiplástico sobresaliente $-10 \%$ y $16,7 \%$ respectivamente. Las estrías en general, al igual que en la zona superior, siguen una dirección perpendicular y diagonal al eje morfológico. En la zona inferior y base aumenta el porcentaje de lotes 14,3\%- y siguen en abundancia las marcas -50\%-. Estas últimas se tratan de hoyuelos en mayor cantidad -28,6\%-, siguiéndole en proporción el antiplástico sobresaliente y luego las estrías $-21,4 \%$ y $14,3 \%$, respectivamente. Las estrías, al igual que en la zona superior y media, siguen una dirección perpendicular y diagonal al eje morfológico.

Según lo observado, los movimientos realizados por estas vasijas se podrían describir de la siguiente forma -figura 6.56A-: la presencia de lotes -patch-, de estrías perpendiculares y hoyuelos en la zona inferior de la superficie exterior nos marcan movimientos alrededor del eje morfológico y, al no presentar estrías en otras direcciones, nos indican que estas vasijas no fueron inclinadas. Sin embargo, dada la alta cobertura de 


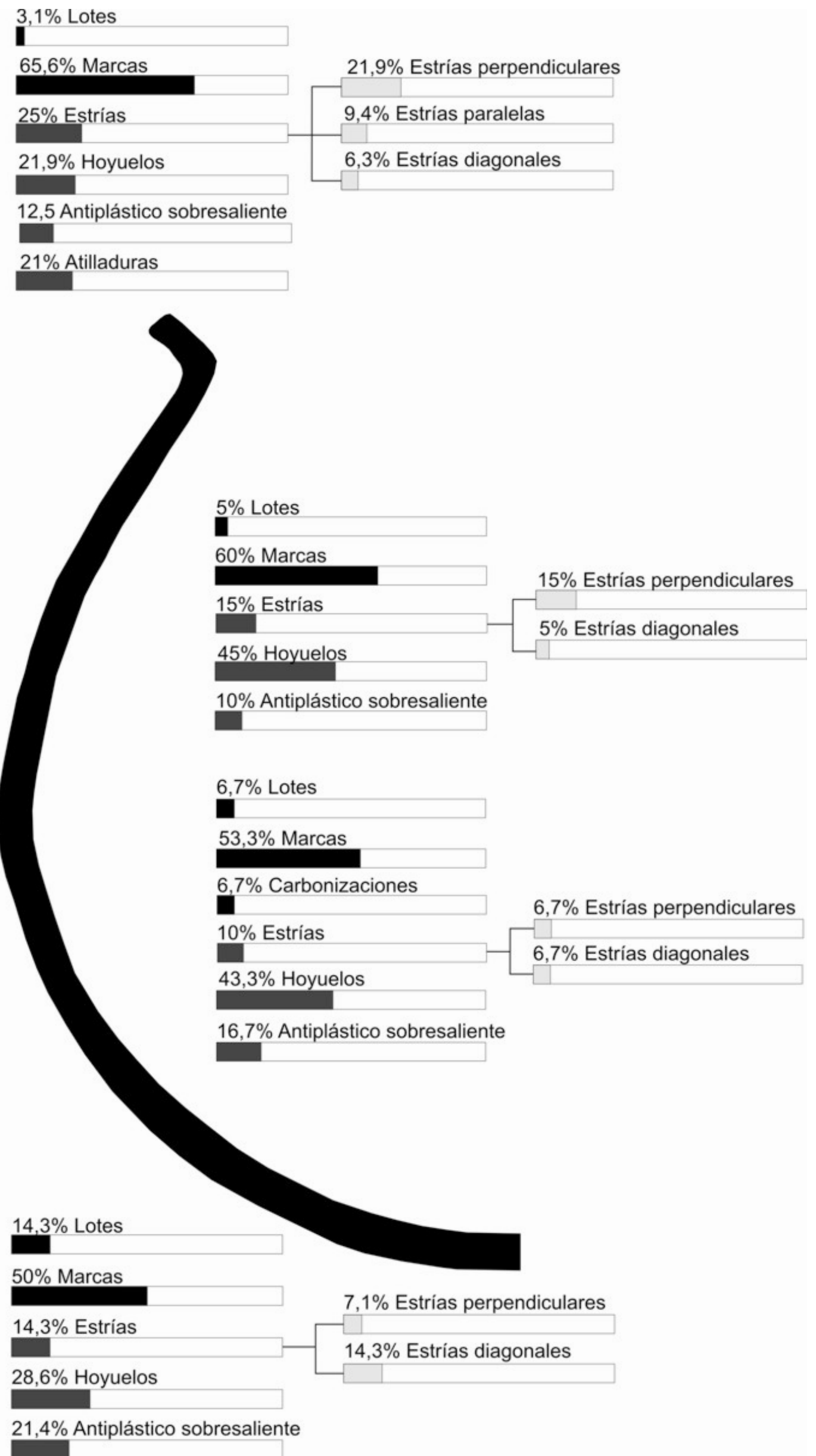

Gráfico 6.23: porcentajes de marcas en el interior del borde, zona superior, media e inferior y base. Los $\mathrm{n}$ se hallan en el texto. 

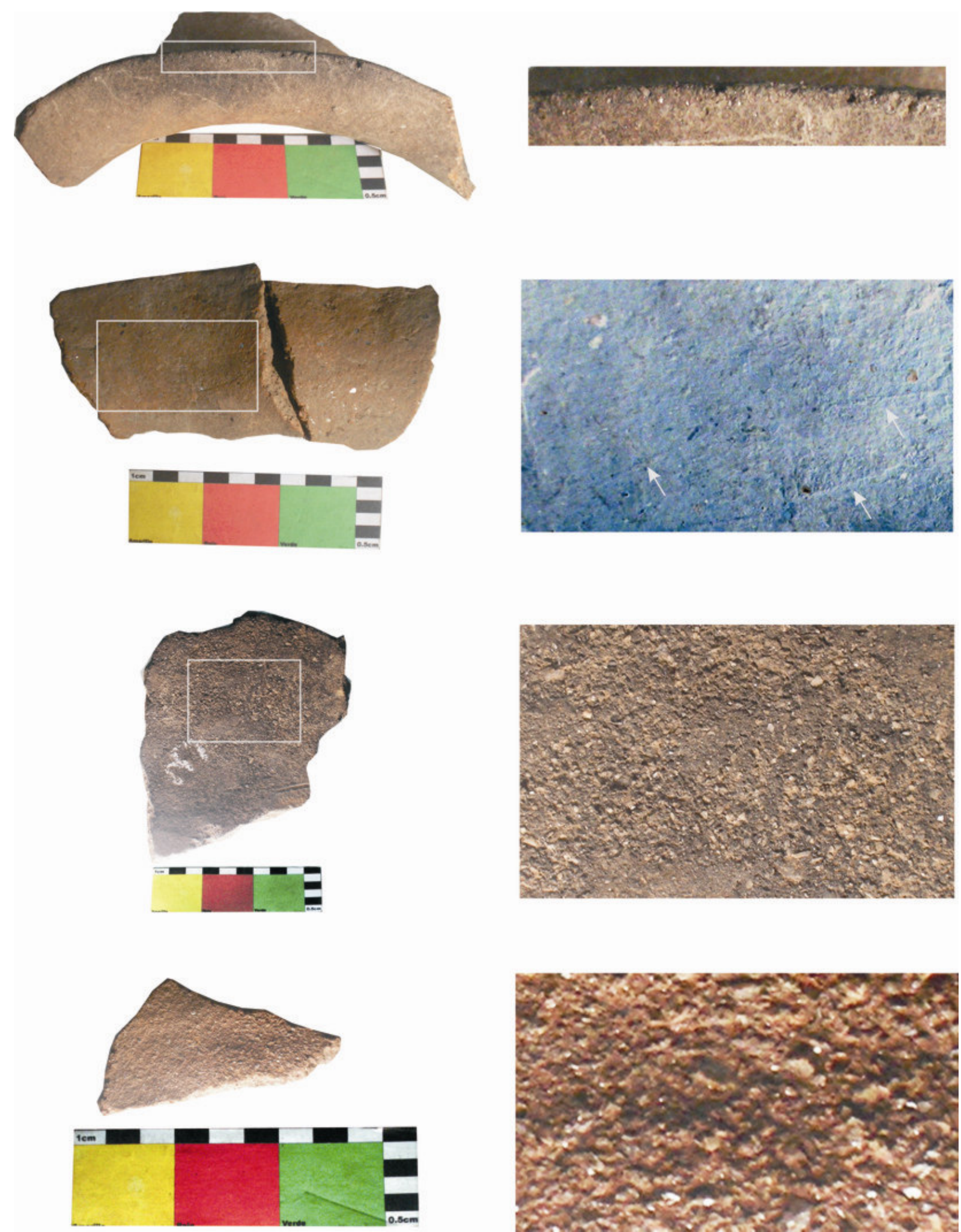

Figura 6.55: fotografías que muestran distintas clases de marcas observadas en las diferentes zonas de la superficie interna de las vasijas pertenecientes a "otras formas". En la primera tira de imágenes de arriba se observa astilladuras en los bordes. En la segunda tira, estrías perpendiculares y diagonales en la zona superior, en las dos tiras que restan se observa el antiplástico sobresaliente en fragmentos de la zona media e inferior. Las fotografías de la derecha son ampliaciones de los sectores marcados por una recuadro blanco. Una de estas imágenes fue sometida a un proceso de inversión de colores para que resalten las marcas. 


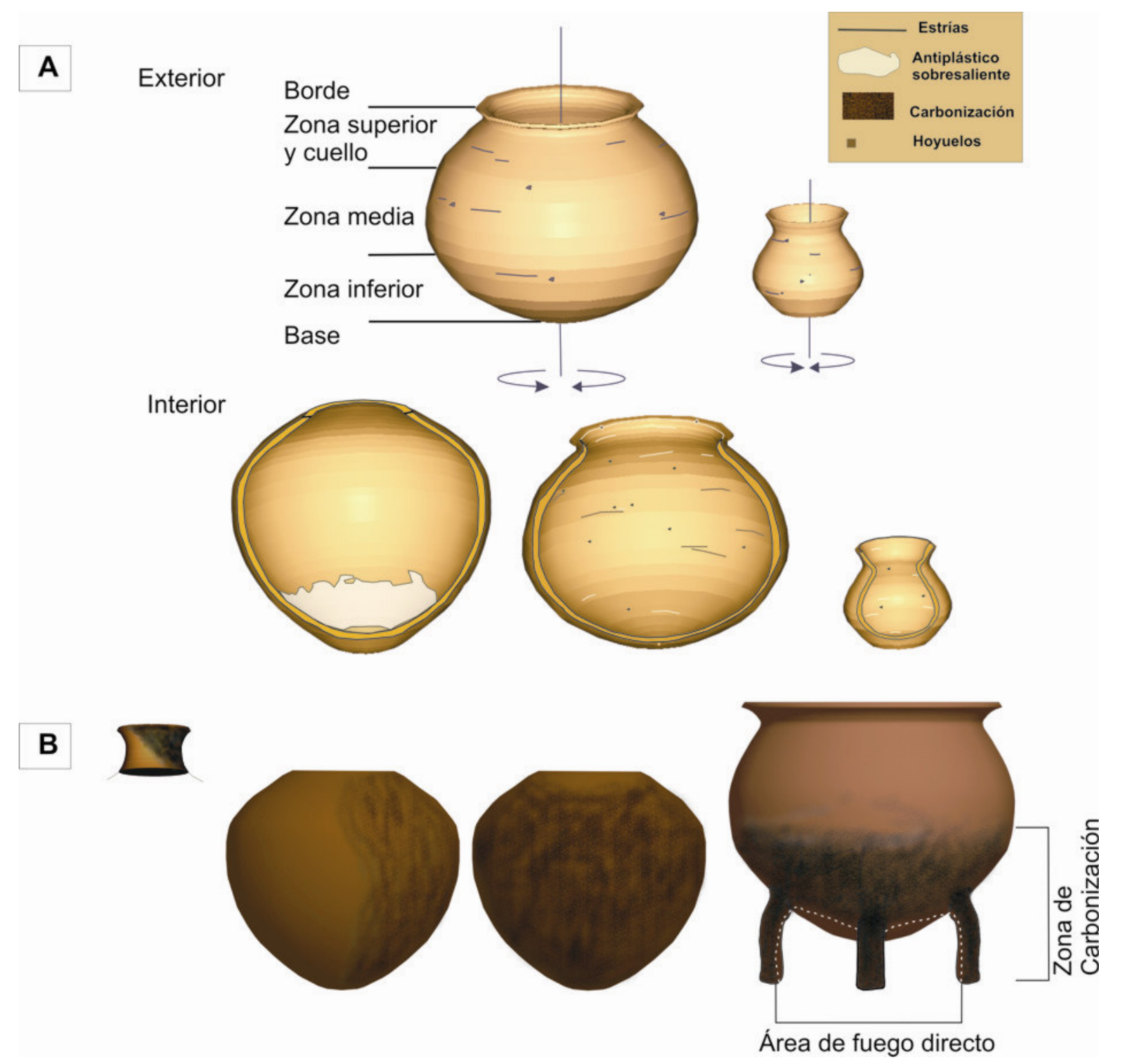

Figura 6.56: A muestra la zonificación de las superficie exterior de las vasijas pertenecientes a "otras formas". La zonificación de la superficie interior es igual a la exterior salvo porque la zona inferior y base forman parte de una misma área. Además se pueden observar patrones de marcas y movimientos reconstruidos. En B se observa distintos patrones de carbonización.

esta zona por las carbonizaciones, cabe la posibilidad de que quedaran dichas marcas ocultas. Lo mismo sucede para la zona inferior y media. Las marcas presentes en la zona superior muestran también movimientos de giro sobre el eje morfológico. La presencia en el borde de astilladuras y estrías paralelas al eje morfológico podrían se productos de instrumentos utilizados para extraer y/o revolver los contenidos que se habrían cocinado en estas vasijas. La presencia de antiplástico sobresaliente en la superficie interior de estas vasijas, con un mayor porcentaje en la base, podría corresponder a procesos de fermentación de bebidas alcohólicas tal como fue observado para las formas "a" y "ab". Recordemos que estas piezas son las que alcanzan mayores volúmenes juntos con la de de 
forma "a". Pero si observamos que en la superficie externa de estas mismas zonas -inferior y base- también hay alta frecuencia de carbonizaciones, nos indican rotación de actividades, en ciertos momentos se las utilizó para la fermentación de bebidas (que no necesita fuego para que ocurra el proceso), y en otro momento se la usó para cocinar alimentos.

La producción de chicha involucra tanto a la fermentación como a la cocción. Sin embargo, en los estudios etnoarqueológicos sobre la zona andina consultados (Cutler y Cárdenas 1985; Menacho 2000; Pazzarelli y Vargas 2008) y, en las entrevistas efectuadas por nosotros, para realizar estos procesos se utilizan dos vasijas distintas (olla y tinaja), y no la misma ${ }^{\mathrm{xiv}}$. En relación a los análisis de residuos orgánicos se observó, en algunas, la presencia de ácidos grasos (contacto con grasas vegetales y animales) y albúmina (contacto con carne) y, en otras, se registró solamente la presencia de ácidos grasos. Esto nos marca ciertas diferencias en los usos concretos de estas vasijas, reforzando por otro lado la posibilidad de intervenir en el proceso de producción de chicha, particularmente aquellas que presentan solo ácidos grasos.

Las huellas de carbonización -figura 6.56B- se presentan con altos porcentajes en casi toda la superficie de las piezas, disminuyendo notablemente hacia la zona superior y el borde. Este patrón generalizado nos podría indicar que la fuente de calor, en general se encontraba alejada de la base, no en contracto directo. Esto se debe las bases se hallan cubiertas de carbonizaciones, al igual que las zonas inferiores. Sólo en un caso con alto grado de completitud -90\%- pudimos observar la presencia en un sector de la base de una fuerte oxidación donde no se depositó hollín, parámetro indicativo de contacto directo con fuego (Hally 1986; Skibo 1992); y en otro caso, aunque la base está ausente, la carbonización se presenta sólo en la parte media, tendiendo a desaparecer en la zona del borde y hacia las zonas inferiores. De las piezas con presencia de carbonizaciones que presentan mayor grado de completitud podemos inferir más exactamente algunas de las formas de colocación de estas vasijas sobre el fuego a la hora de cocinar los alimentos:

a) En las que son tetrápodas, -figura $6.56 \mathrm{~B}$ - la altura de las patas que es de $15 \mathrm{~cm}$ nos indican una distancia relativamente corta a la fuente calor, por lo que el fondo de la vasija que es de forma cónica se hallaría en contacto directo con el fuego. Si observamos el patrón de carbonización en la superficie exterior del fondo cónico de la vasija y de las patas, respalda esta interpretación: se observa que hacia el centro y las caras internas de las patas no presentan tizne, mientras que los sectores exteriores de las patas sí lo hacen, llegando a alcanzar la mitad de la zona media de la vasijas, no observándose ni en la zona 
superior ni del borde. En el caso del fondo de la vasija sólo se observa la superficie color anaranjada sin la presencia de tizne. Dado el espacio de separación de las tres patas y por la altura de estas no debió ser un fuego muy grande; en ese caso, el tipo de carbonización observado adquiriría otro patrón. En otra tetrápoda registrada, en las que se observa sólo un parte de una de las patas y un cuarto del fondo de la vasija, se observa el mismo patrón.

b) En las que no poseen patas se observó lo siguiente -figura 6.56B-: en uno de los casos el hollín cubre desde la base hasta la zona superior de la vasija, en otro cubre hasta el borde -se trata de la vasija que posee menor diámetro de boca- y en el último la carbonización cubre sólo uno de los lados de la pieza; mientras que el otro lado casi no presenta depósito de hollín y la superficie presenta una coloración más clara y anaranjada que la original como si hubiera tenido un proceso de oxidación. De esta observación podemos reconstruir dos formas de colocar estas vasijas sobre el fuego: 1) en el caso de la que presenta sólo un lado carbonizado y el otro oxidado y, a su vez el depósito de hollín llegó hasta la zona superior, habría sido colocado directamente sobre el fuego. El lado que presenta la superficie sin depósito de carbón habría sido apoyado directamente sobre el fuego, ya que se necesita mucha temperatura para que se produzca la oxidación de la zona (Skibo 1992). De ello se deduce que la vasija estaba colocada de costado en el fuego y posiblemente inclinada en tanto que parte de la base posee depósito de carbón mientras que otra parte no. El fragmento de cuello con evidencias de carbonización podría corresponde a la misma forma de ubicar la vasija sobre el fuego, en tanto el depósito de hollín afecta sólo a una parte del cuello. En el otro caso donde se observa el depósito de hollín desde la base hasta la mitad de la vasija, está indicando la colocación por encima del fuego. Es de resaltar que la vasija que posee parte de un lado oxidada fue hallada en el recinto sudeste del sitio Piedras Blancas, al lado de un fogón, aplastada por el techo de la habitación. Este fogón no posee una estructura armada, sino que fue excavado directamente el en piso formando una cubeta de forma irregular -ver descripción de contextos más adelante.

\section{Vasos y Jarras}

Poseemos solo dos ejemplares enteros de esta clase de forma. El más pequeño figura 6.57- que presenta una altura de $40 \mathrm{~mm}$ y $60 \mathrm{~mm}$ de diámetro máximo que coincide con la boca, sólo presenta un hoyuelo alisado en la superficie exterior del cuerpo. En la superficie interior no presenta lotes ni marcas. No poseemos análisis de residuos orgánicos, pero la superficie interna presenta pigmento rojo de forma extendida. El otro ejemplar más grande de base plana presenta en la superficie exterior en su zona media, estrías 
perpendiculares y diagonales al eje indicando movimientos giratorios alrededor del mismo. En su superficie interior no se observan ni marcas ni lotes. Al no poseer más casos u análisis de residuos orgánicos no podemos con los datos que poseemos hasta el momento inferior usos específicos.
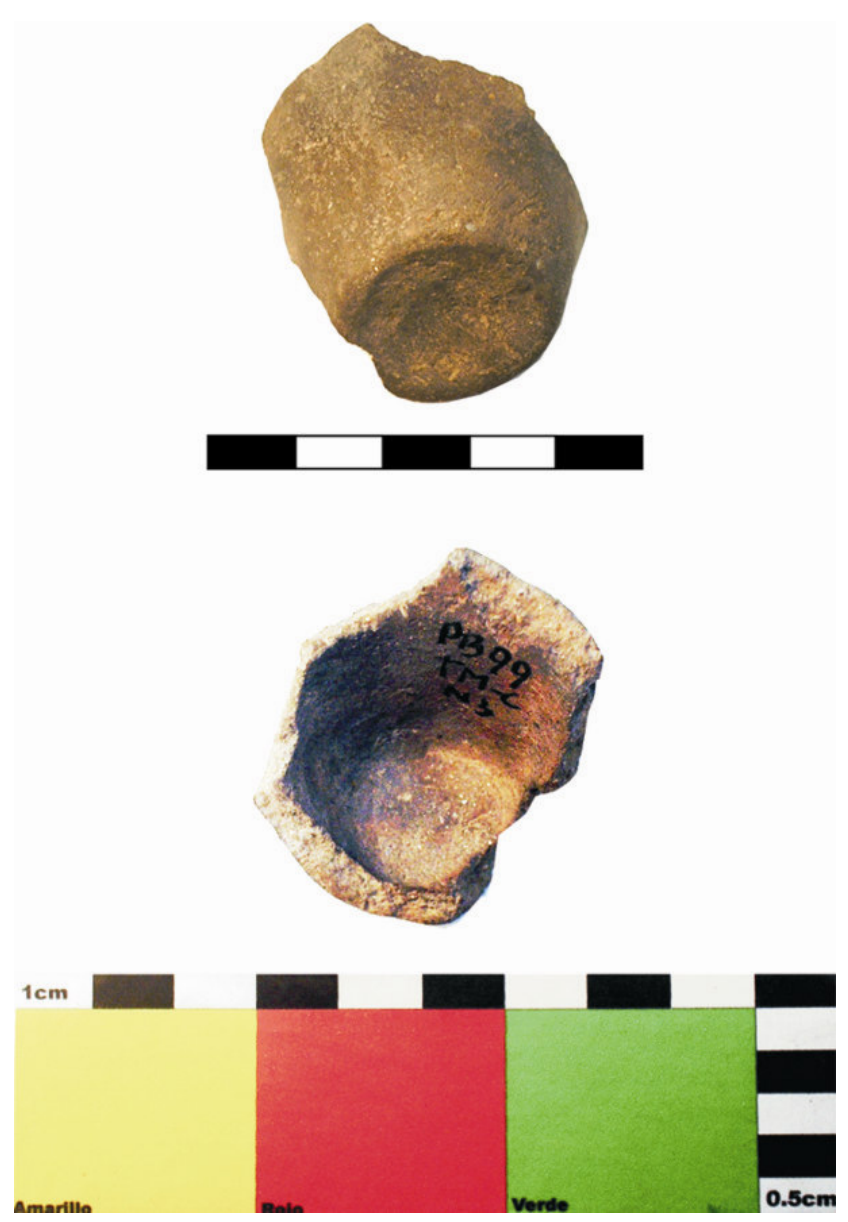

Figura 6.57: vaso pequeños. En la imagen inferior se muestra la superficie interna cubierta irregularmente por pigmento rojo.

\section{Vasija restringida compuesta dependiente de borde evertido}

Esta vasija no se halla completa, por lo que las huellas que pudieran existir en la base pudieron identificarse. En la zona exterior, en la parte inferior se pudieron registrar estrías perpendiculares diagonales. En el resto de las zonas no aparecieron ni marcas ni lotes. Lo mismo ocurre con la superficie interior. Por tanto, podemos decir muy poco sobre los que nos indican las marcas salvo ciertos movimientos alrededor del eje morfológico. Tampoco posemos análisis de residuos orgánicos. Al provenir del montículo de Piedras Blancas, la asociación contextual tampoco nos informa sobre su uso. 


\section{Vasijas de clase A1}

Forma " $b$ ":

La zonificación de esta vasija es la que se observa en la figura 6.58.

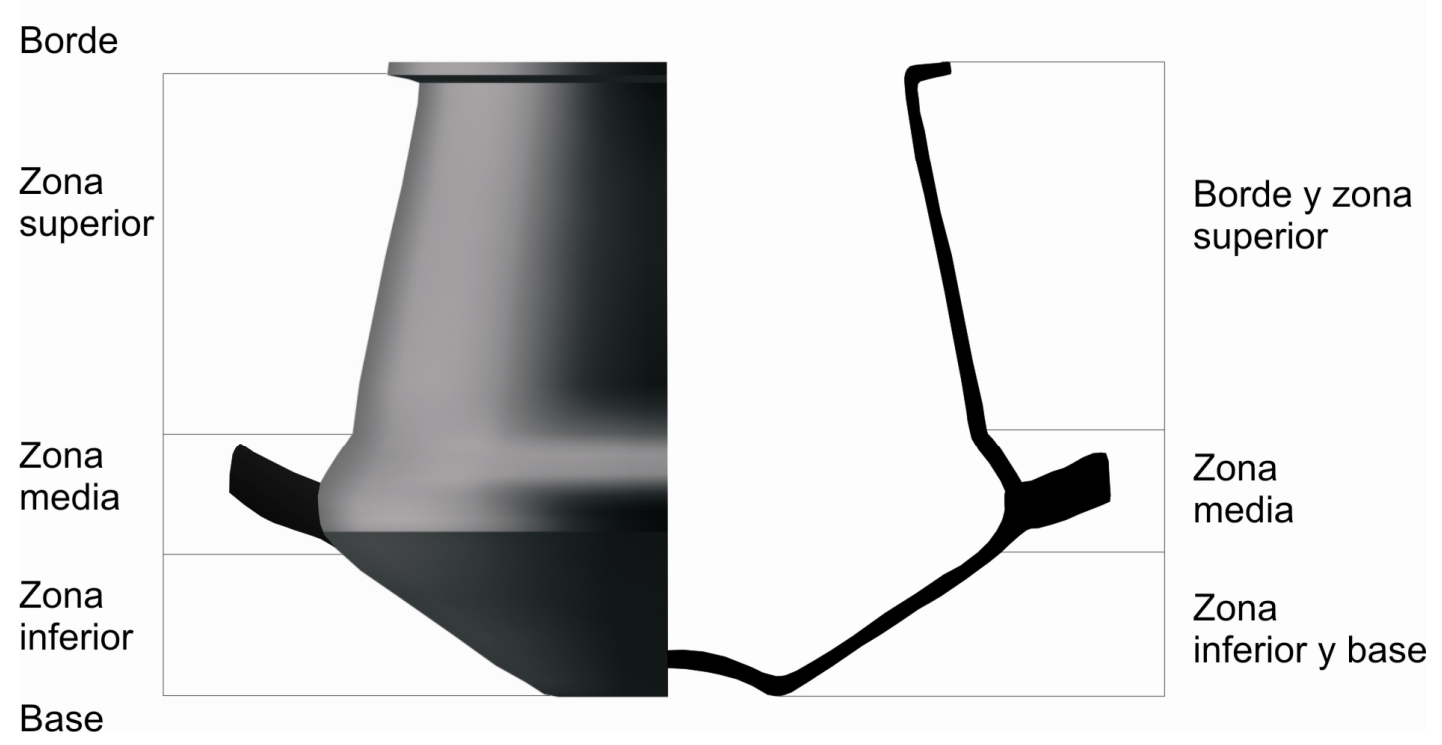

Figura 6.58: zonificación de la superficie externa e interna de las vasijas de forma "b".

En relación a las huellas de uso observadas en la superficie exterior -gráfico 6.24 y figura 6.59- de las bases -26 casos- se presentan lotes -patchs- y marcas en altos porcentajes $-88 \%$ y 76,9\%, respectivamente-. Los lotes en la base ocupan solo la franja que tiene contacto con la superficie de apoyo, observándose la continuación de éstos hacia la zona inferior de las vasijas, no extendiéndose más allá de los $10 \mathrm{~mm}$. En el resto de la base, es decir en la parte cóncava, que no llega a tener contacto con la superficie de apoyo, no se registró la presencia de lotes. Sobre los lotes a su vez se pueden llegar a identificar algunas marcas, principalmente estrías perpendiculares. La erosión que produjeron los lotes patchs-, en algunos casos fue tan intensa que aplanó la superficie convexa que presenta la base en el límite con la zona inferior de la pieza; en otros casos extrajo sólo la superficie pulida dejando expuesta la pasta grisácea. En la zona inferior -34 casos- se registraron lotes y marcas $-61,8 \%$ y $100 \%$ respectivamente-. Los lotes se encuentran justo en el límite entre la zona inferior y la base. En general son la continuación de los lotes observados en la base que penetran hacia la zona inferior uno pocos milímetros -10 mm como máximo-. Las marcas presentes se componen de estrías en un $100 \%$ y hoyuelos en un $26 \%$. Las estrías siguen diferentes direcciones -perpendiculares con $76,5 \%$, paralelas con $76,5 \%$ y 


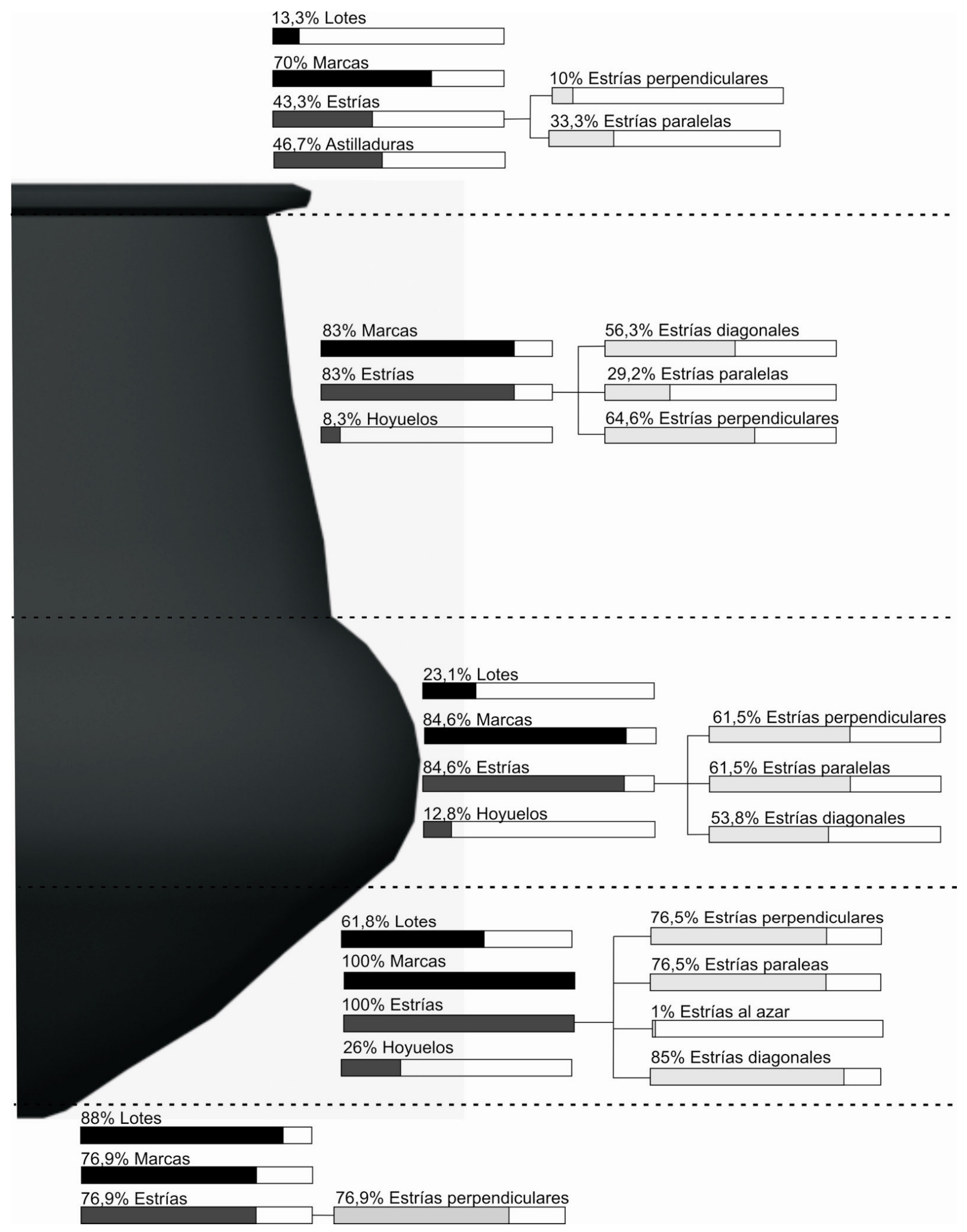

Gráfico 6.24: porcentajes de lotes y marcas en las distintas zonas de las vasijas de forma "b". 
diagonales 85\%-, las estrías paralelas parten casi siempre desde la zona de contacto entre la base y la zona inferior, avanzando aproximadamente hasta unos $20 \mathrm{~mm}$ o $30 \mathrm{~mm}$. En el resto de la superficie de la zona abundan las estrías diagonales y perpendiculares. Los hoyuelos presentes en estas vasijas a diferencia de los de las vasijas de clase E, al no presentar antiplástico observable, no corresponden a la extracción de éstos, sino que se tratan de impactos sobre la superficie que extrajeron material produciendo la formación de un hueco. En algunos casos esto impactos no tuvieron la suficiente fuerza para producir un hueco y en otros el ángulo de impacto, demasiado oblicuo, no permitió que se forme el cono de hertz característico, sino sólo una parte de éste; en estos casos queda expuesta una superficie más bien plana y de mayor extensión, a estos casos lo hemos definido como "cachado" para diferenciarlo de los hoyuelos. En la zona media -39 casos-, disminuye la cantidad de lotes $-23,1 \%$ - y las marcas se mantienen en un alto porcentaje -84,6\%-. Éstas se tratan de hoyuelos y estrías $-12,8 \%$ y $84,6 \%$, respectivamente-. Las estrías corren en proporciones semejantes en diferentes direcciones: paralelas, diagonales y perpendiculares. Lo que cambia es la ubicación de las mismas dentro de la zona de las piezas: las paralelas en general se encuentran en la zona del diámetro máximo de estas vasijas; en las vasijas enteras que hemos podido analizar, las estrías paralelas se hallan en las caras donde no se encuentran las asas, las que casi no presentan huellas. Las perpendiculares y diagonales se hallan repartidas por toda la zona. En la zona superior, en el cuello -48 casos-, los lotes desaparecen y siguen con altos porcentajes las marcas $-83 \%$. Los hoyuelos se presentan en bajos porcentajes y las estrías en mayores $-8,3 \%$ y $83 \%$, respectivamente- Predominan las estrías perpendiculares y diagonales $-64,6 \%$ y $56,3 \%$, respectivamente- y en menor medida aparecen estrías que siguen una dirección paralela al eje morfológico. Ya en el sector externo del borde -31 casos- vuelven a aparecer los lotes -13,3\%-y las marcas continúan con alto porcentaje $-70 \%$. No hay presencia de hoyuelos, predominando las estrías con $43,3 \%$ y las astilladuras con 46,7\%. En relación a la dirección de las estrías tenemos en mayor cantidad paralelas y en menor cantidad perpendiculares $-33,3 \%$ y $10 \%$, respectivamente. No presentan huellas de carbonización, lo que nos indica que éstas no fueron sometidas al fuego, recordemos que las propiedades de performance potencialmente indicaban que no eran aptas para soportar el estrés térmico.

Si analizamos los porcentajes de los lotes y las marcas en las distintas zonas, puede observarse que, en general, se presentan en mayor abundancia en las zonas inferiores y medias que en las del cuello y el borde. Particularmente los lotes se hallan presentes en la base y la zona inferior en contacto con ésta. En relación a los porcentajes y distribución de las marcas, tenemos una alta representación de estrías paralelas en la zona de contacto 

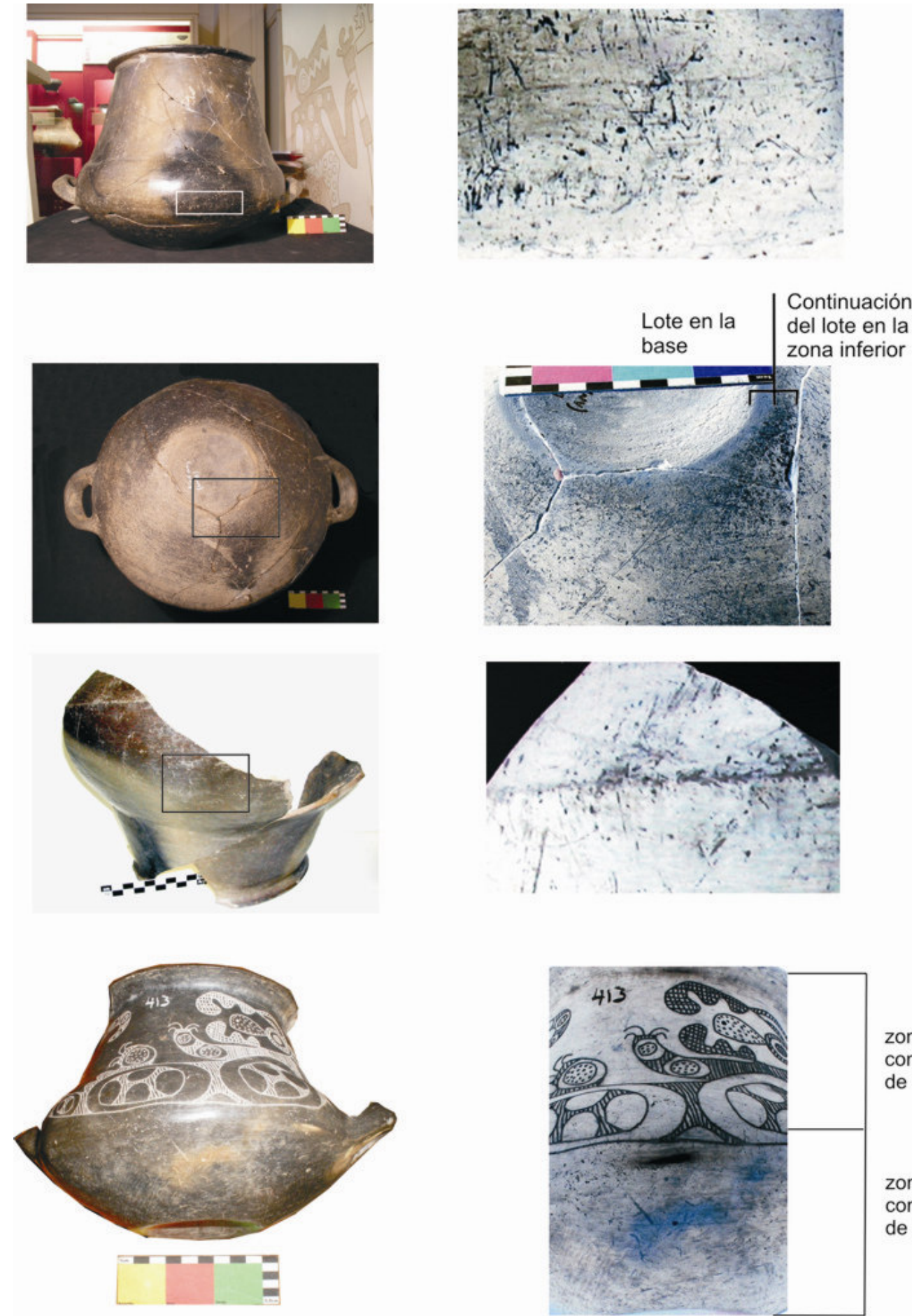

zona de menor concentración de marcas

zona de mayor concentración

de marcas
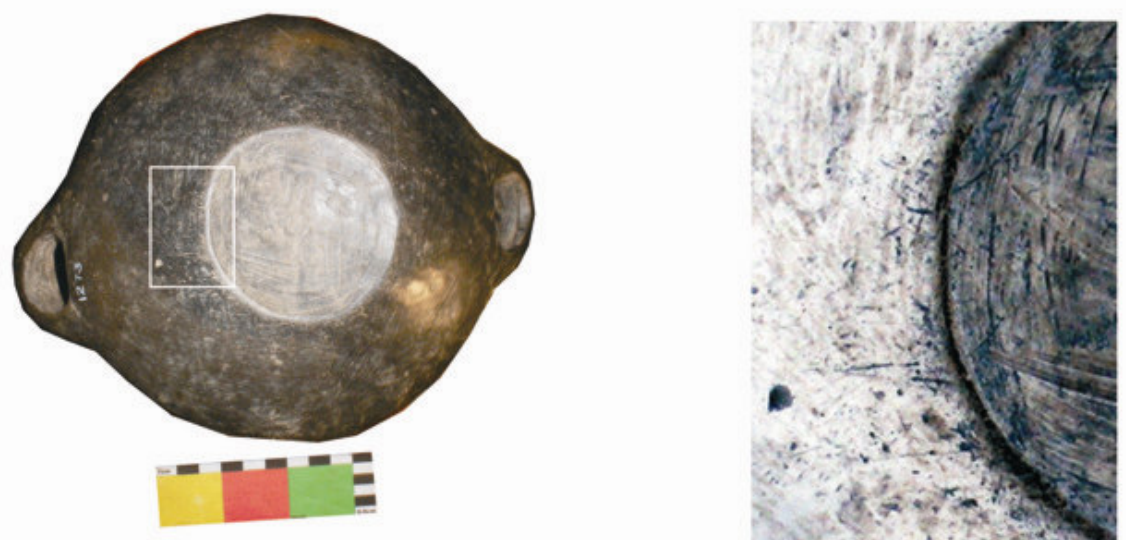

Figura 6.59: fotografías que muestran lotes y marcas en distintas zonas de la superficie exterior de las vasijas de forma "b". En la primera, tercera y cuarta tira de imágenes se observan estrías en diferentes direcciones y lotes en la zona media. En la segunda y quinta tira se muestran lotes y estrías en las bases. 
entre la base y la parte inferior de la vasija y en las zonas de máximo diámetro en la parte media. También aparecen, en menor proporción, en el cuello y el borde. Las estrías perpendiculares y diagonales poseen una alta representación en casi todas las zonas, pero principalmente en las inferiores. Según este patrón, podemos señalar en primer lugar una alta movilidad de estas piezas, dada la frecuencia de aparición de marcas y lotes, que produjo el contacto con variedad de abrasivos. Particularmente esto se observa en la recurrencia de lotes en las bases y las zonas de contacto entre ésta y la parte inferior del cuerpo de las vasijas que, dependiendo del grado de desgaste, que en algunos casos llegó a aplanar la superficie, nos estaría marcando una frecuencia de uso más elevada, o un tiempo más largo tiempo de utilización. La presencia de hoyuelos y "cachaduras" en todas las zonas nos indica contactos con abrasivos en diferentes ángulos de incidencia y con diferente fuerza de impacto.

Los movimientos que podemos reconstruir son los siguientes -figura 6.60-: inclinación en un ángulo no muy pronunciado, que produjo el desgaste en la base y zona de contacto con la parte inferior del cuerpo de las vasijas, probablemente vinculado a la extracción de los contenidos; y giros alrededor del eje morfológico. La presencia de
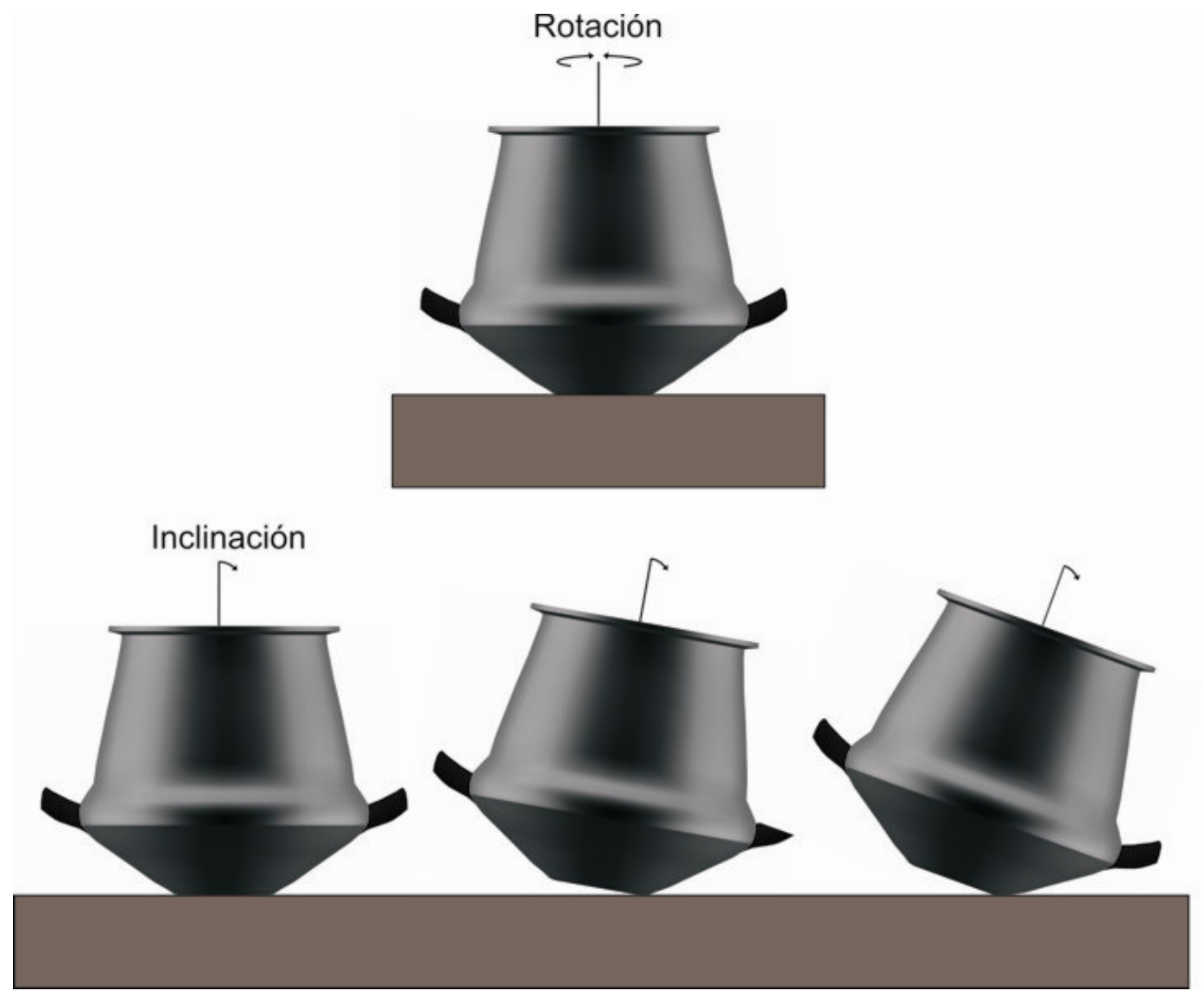

Figura 6.60: movimientos reconstruidos según los patrones de lotes y marcas de la superficie exterior de las vasijas de forma "b" 
cachaduras y estrías paralelas en las zonas de máximo diámetro del cuerpo pueden haber ocurrido por contacto o golpes, probablemente con otras vasijas u objetos; al ser levantadas o colocadas en distintos lugares. En el caso de las marcas del borde la presencia de lotes, podría indicar que en algunos casos estas vasijas fueron colocadas boca bajo, las estrías perpendiculares están apoyando esta propuesta. La frecuente presencia de astilladuras podría ser producto tanto de la operación mencionada anteriormente, cómo del contacto con algún instrumento que golpeó el filo del borde. La frecuencia de estrías paralelas, estarían apoyando está última interpretación.

En la superficie interior -gráfico 6.25 y figura 6.61-, en la zona del borde y cuello 40 casos-, se presentan lotes en bajo porcentaje $-2,5 \%$ - y marcas con una mayor representación $-77,5 \%$. Estas últimas se tratan de estrías, en mayor medida -70\%-, siguiéndole las astilladuras $-20 \%$ - y, con menor representación, los hoyuelos -7,5\%. Las estrías siguen una dirección perpendicular y paralela $-40 \%$ y $50 \%$ respectivamente-, y en menor medida una dirección diagonal al eje morfológico -22,5\%. Las paralelas, en general, se hallan ubicadas en el borde. En la zona media -34 casos- se presentan, al igual que en el cuello y el borde, lotes en menor proporción -2,9\%- y marcas en mayor porcentaje -50\%. Todas ellas se tratan de estrías perpendiculares $-44,1 \%$ - y diagonales $-29,4 \%$. En la zona inferior y base -31 casos- no se presentan lotes, pero sí marcas con un $71 \%$ de representación. En esta zona se presentan estrías en mayor cantidad $-71 \%$ - y hoyuelos en menor medida $-19,4 \%$. Las estrías siguen en mayor medida una dirección perpendicular al eje morfológico y, en menor medida, diagonal -61,3\% y 45,2\%, respectivamente-.

En el patrón de huellas observado en las superficies interiores predominan las marcas, existiendo muy poca frecuencia de lotes. La presencia de hoyuelos en las bases, zonas inferiores y el cuello; la alta frecuencia de estrías perpendiculares y diagonales tanto en las zonas inferiores, medias y superiores, nos indican que los instrumentos que entraron en contacto con la superficie siguieron un movimiento alrededor del eje morfológico en un plano perpendicular o diagonal a este. Existe muy baja presencia de lotes por lo cual nos estuvieron sometidas a fuertes procesos erosivos.

La inexistencia de huellas de carbonización, sumada a la poca resistencia al estrés térmico en relación con las pastas y forma, nos indican que no sólo no son aptas para su sometimiento al fuego sino que tampoco fueron utilizadas para la cocción. Si tenemos en cuenta la presencia de asas remachadas que permiten su manipulación segura y la alta movilidad estas piezas sugeridas por las marcas observadas -inclinaciones no muy pronunciadas, rotaciones al rededor del eje morfológico, etc.-, podemos decir que se están 


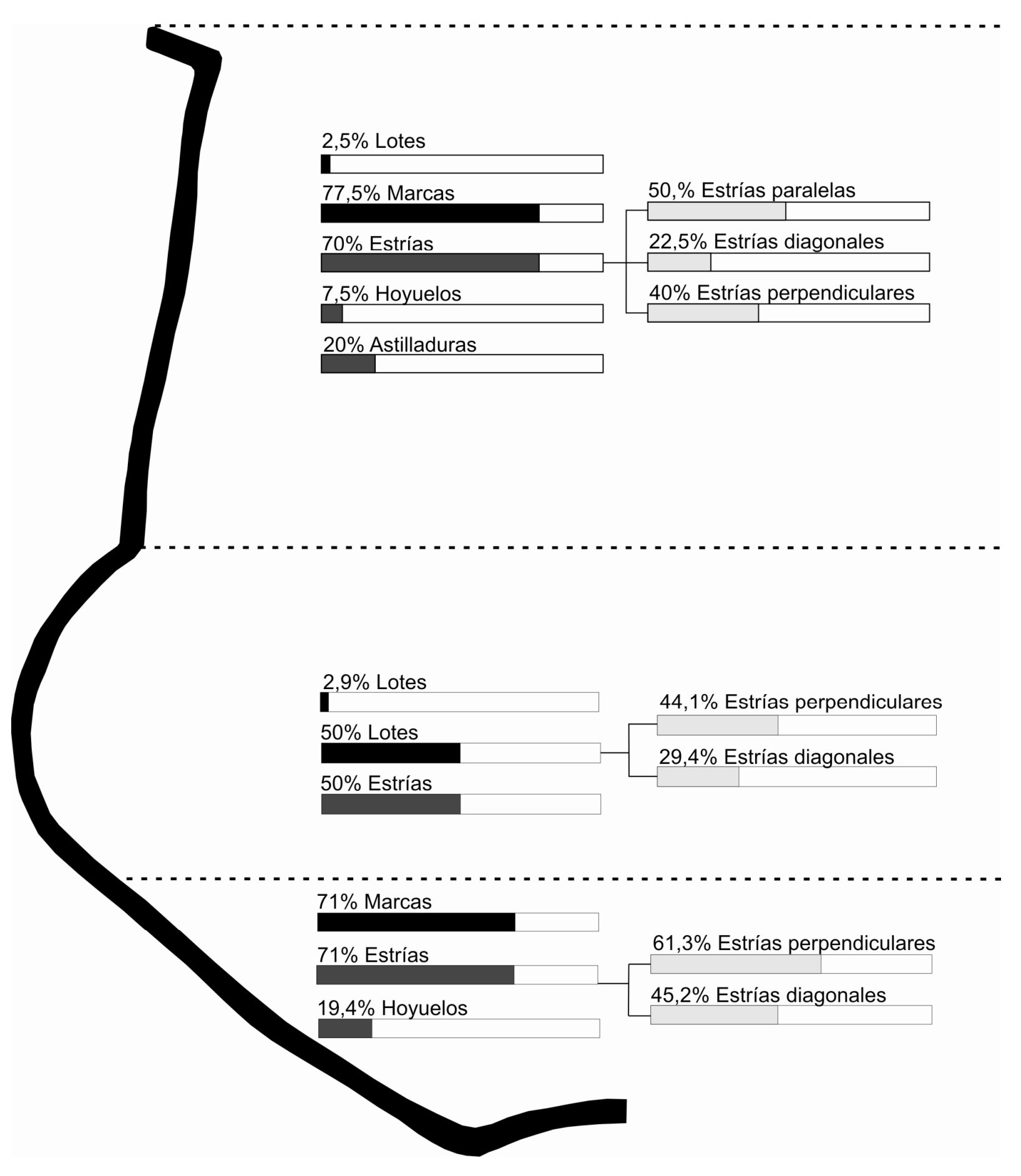

Gráfico 6.25: porcentajes de lotes y marcas en las diferentes zonas de la superficie exterior de la forma "b". Los n se hallan en el texto.

utilizando para transportar y manipular distintos productos. Al no poseer análisis de residuos orgánicos en estas vasijas no podemos aproximarnos aún a los contenidos. Por otro lado las huellas observadas no nos permiten precisar cuales fueron estos, pero sí indirectamente nos aportan algunos datos al respecto: si la fermentación de bebidas actividad en la que participan algunas de las vasijas de forma "a", "ab" y "otras formas"- 
produce un desgaste característico en el caso de las clases E, ¿que tipo de huella produciría en esta clase de vasijas de pasta fina y muy pulidas? Según lo observado por Arthur (2002) en vasijas de pastas finas, que presentan una superficie pulida y que fueron utilizadas para contener bebidas fermentadas de arroz, el proceso químico también produjo la desintegración de la arcilla. Arthur (2002) observa en el interior de estas vasijas zonas donde el pulido no existe y parte de la pasta fue extraída, pero nosotros no hemos observado patrones semejantes en estas vasijas. Por lo que o no entraron en contacto con este tipo de bebidas, o el tiempo de contacto con ellas fue relativamente corto impidiendo que el proceso de fermentación produzca la desintegración de la arcilla.
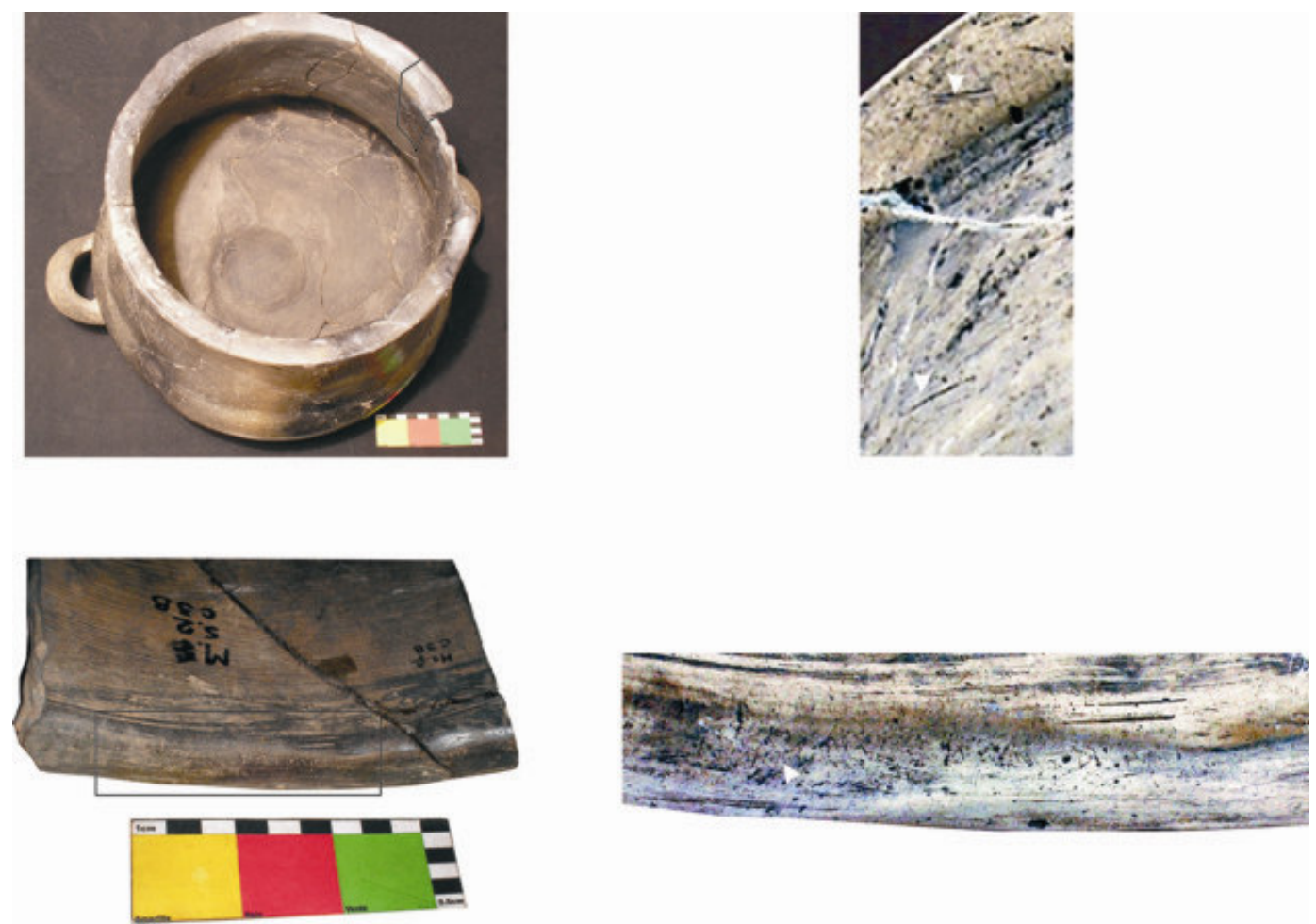

Figura 6.61: fotografías que muestran las marcas en la zona del borde y cuello de la superficie interior de las vasijas de forma "b". Se observan estrías y lotes -inferior-. Las estrías se marcaron con flechas blancas -superior derecha. Las imágenes de la derecha son ampliaciones de los recuadros de la izquierda que fueron sometidas a un proceso de inversión de colores para resaltar las marcas.

Hemos registrado tres casos particulares: dos fragmentos de bases y parte del cuerpo inferior de las vasijas y en un borde y cuello, que en toda la superficie interior se encontraba disperso un pigmento color rojo -figura 6.62. Lo interesante es que no se hallaba ni en las fracturas ni en las superficies exteriores, por lo que inferimos que el pigmento se adhirió a la superficie interior antes de su rotura. Esto también coincide con la 
utilización de las vasijas de forma "ab" para guardar pigmento blanco descrito anteriormente.
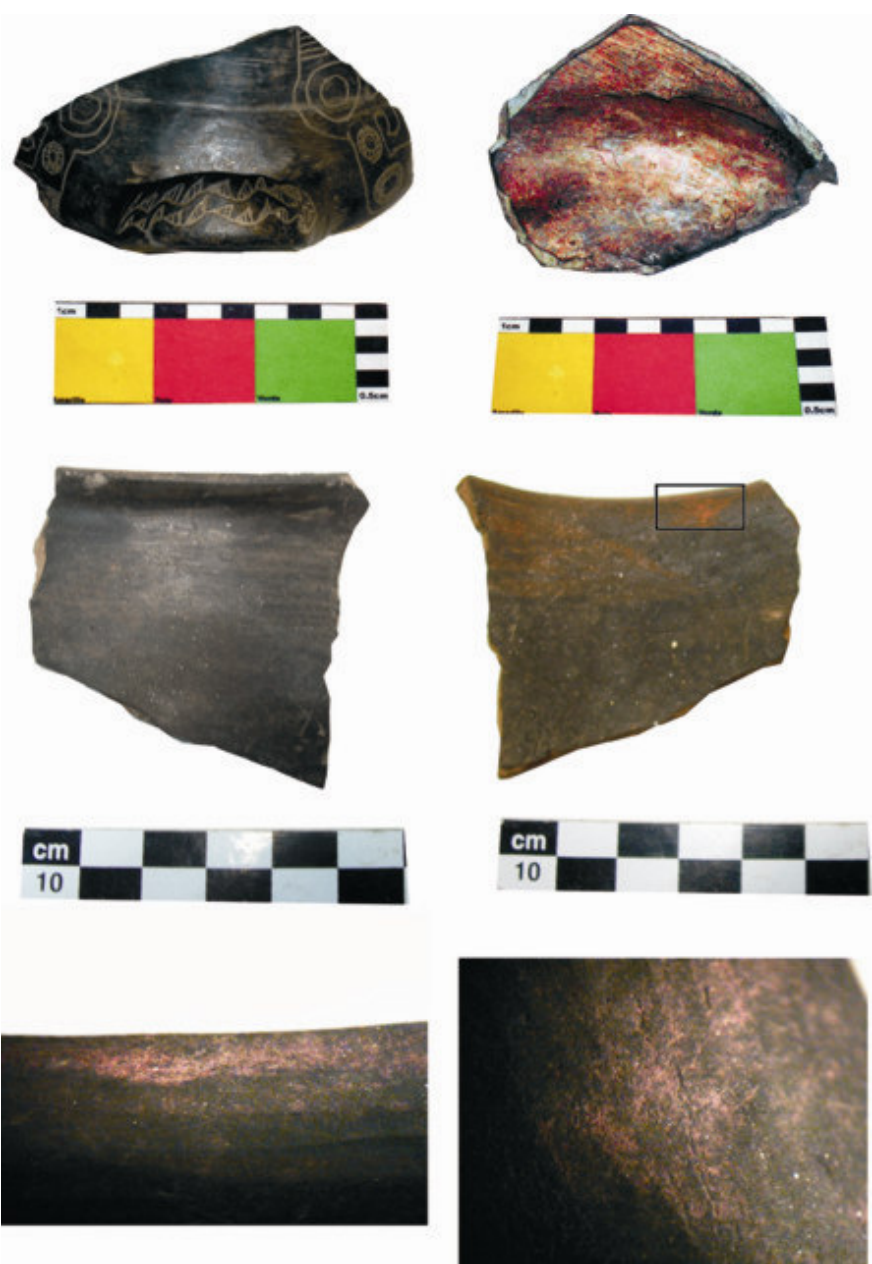

Figura 6.62: fotografías de las superficies internas de vasijas de forma "b" donde se observa pigmento color rojo. Las dos fotografías inferiores son ampliaciones de zonas del recuadro de la figura del centro.

Si tenemos en cuenta la variedad de tamaños presentes en estas vasijas y su alta transportabilidad, es probable que se utilizaran para un amplio rango de actividades; principalmente la manipulación, transporte, almacenamiento o servido. Dada la forma compleja que poseen estos recipientes, su utilización para ciertas operaciones de procesamiento, como el batido, que requieran cierta libertad en la manipulación de los instrumentos y que el contenido pueda ser mezclado homogéneamente, o el amasado, etc., serían menos propicias. 


\section{Escudillas}

La zonificación de las escudillas fue la siguiente: en la superficie exterior se dividió en base, parte inferior, parte media, parte superior y exterior del borde -figura 6.63-. La superficie interior se dividió en borde, parte superior e inferior y base -figura 6.63-.

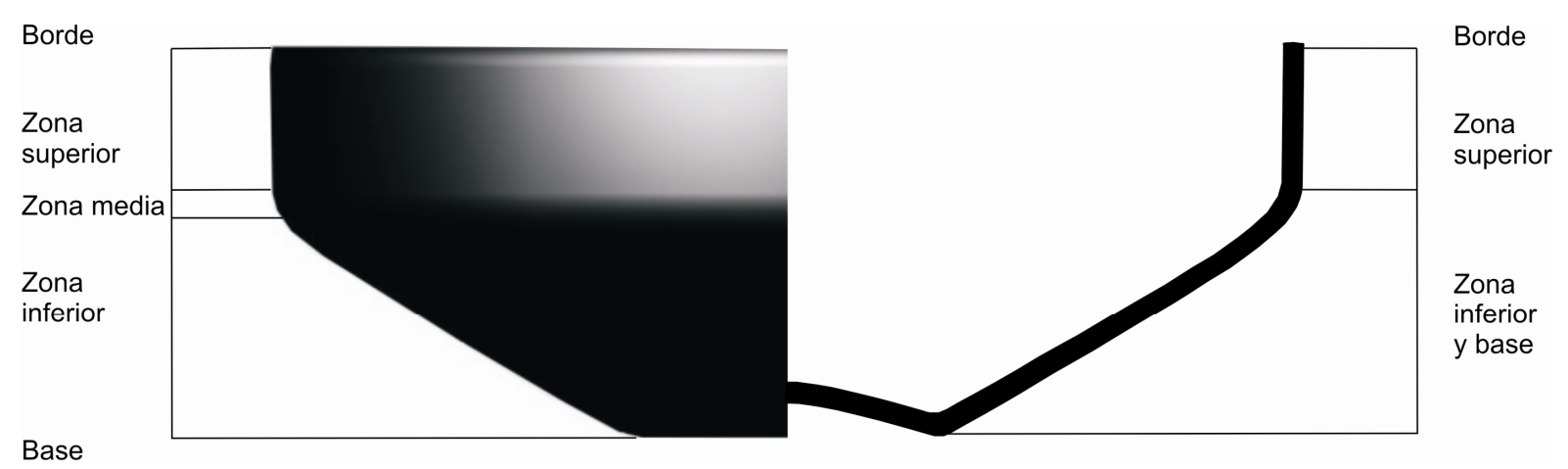

Figura 6.63: zonificación de la superficie exterior e interior de las escudillas.

Las huellas de atrición presentes en la superficie exterior son las siguientes -gráfico 6.26 y figura 6.64-: en la zona de la base -52 casos-, al igual que hemos observado para la vasijas de forma "b", se presentan lotes y marcas $-86,5 \%$ cada uno. Los lotes en general cubren una superficie que recorre todo el arco de circunferencia de la base, justo en la zona de apoyo. No penetra en la parte más cóncava de la base. En esta última zona solo se observan algunas estrías. Los lotes, dependiendo del grado de desgaste, forman un anillo más ancho o más fino. Cuando el desgaste en esa zona es muy pronunciado, la superficie de contacto, que en general es convexa, queda aplanada tal cual lo observamos para las bases de las vasijas de forma "b" -figura 6.64. A su vez los lotes penetran en la zona inferior hasta unos $10 \mathrm{~mm}$ como máximo. Las marcas presentes en la zona se tratan de estrías perpendiculares. En la zona inferior -120 casos-, se observan lotes en menor cantidad que la base $-34,2 \%$ - y marcas $-91,7 \%$. Los lotes se ubican en la zona de contacto de esta parte y la base, en general se tratan de la continuación de los lotes de la base. Desde esta zona parten estrías paralelas y diagonales hasta unos 15 a $20 \mathrm{~mm}$. También se presentan estrías paralelas -65,8\%-, perpendiculares -62,5\%-y diagonales -80,8\%. Existe un caso en que se observa un astillado térmico, que es producto de la cocción del ceramio. En la zona media también se presentan lotes $-16,6 \%$ - y en mayor cantidad marcas $-81,8 \%$. Las marcas se componen exclusivamente de estrías, las más representadas son las paralelas $-57,6 \%$ - y las diagonales $-51,5 \%$-; las perpendiculares presentan menor porcentaje $-37,1 \%$. En la zona media también se presenta lo que hemos denominado "cachadura", que se 
produce por golpes en ángulos muy oblicuos a la superficie. En la zona superior -132 casos-, se presentan lotes con bajos porcentajes $-5,8 \%$ - y marcas $-79,6 \%$. Las marcas son todas estrías. Los porcentajes de las estrías paralelas y perpendiculares casi se invierten con respecto a la zona media $-24,2 \%$ y $60,6 \%$, respectivamente-, mientras que las diagonales siguen casi en la misma proporción $-52,6 \%$. A pesar de que en todas las zonas existen estrías, en un gran porcentaje de los casos la cantidad dentro de una misma pieza varía. En general siempre hay mayor cantidad en las zonas inferiores que en las partes medias y superiores; particularmente disminuyen en los paneles donde se realizan los grabados, que en estas piezas siempre se hallan en la zona superior. En cuanto a los bordes en su sección externa, que en las escudillas son rectos o redondeados -137 casos-, se presentan lotes en bajos porcentajes $-8 \%$ - y marcas $-72,6 \%$. Las marcas se tratan en mayor medida de estrías paralelas -47,8\%-, siguiéndoles las diagonales -10,6\%-y luego las perpendiculares -8,8\%-; se presentan también astilladuras $-32,7 \%$.

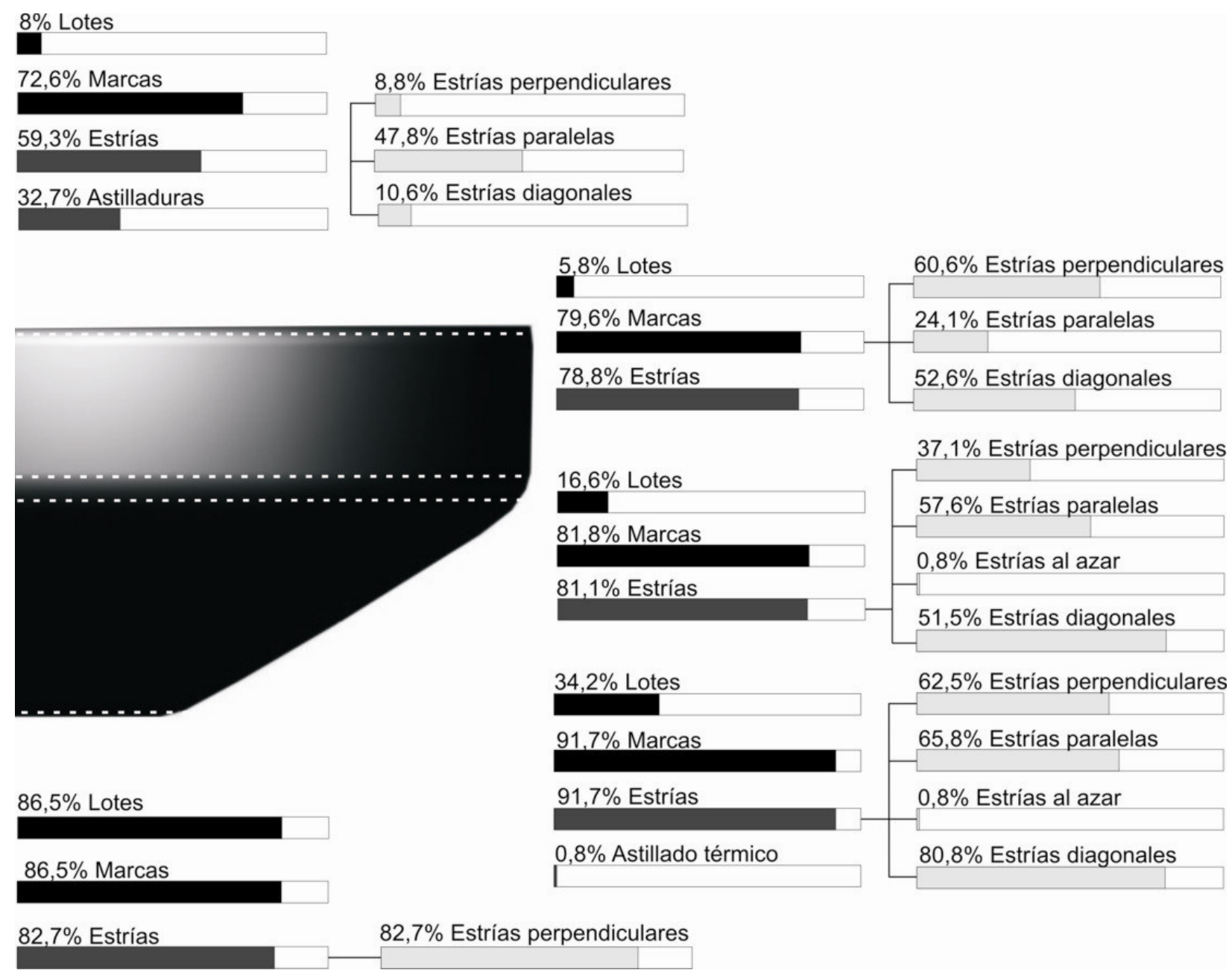

Gráfico 6.26: porcentajes de lotes y marcas de las diferentes zonas de la superficie exterior de las escudillas. Los $\mathrm{n}$ se hallan en el texto. 

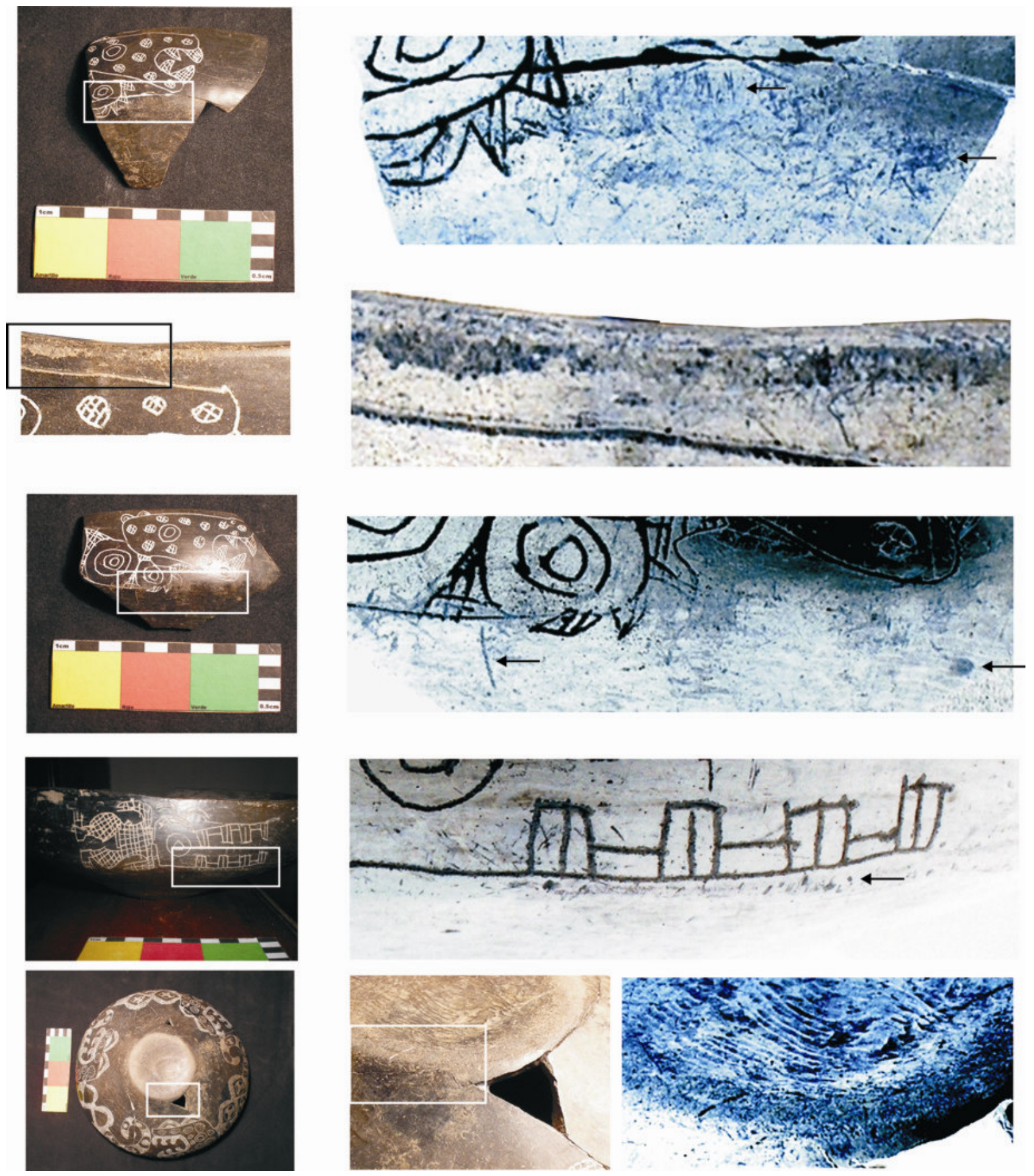

Figura 6.64: fotografías que muestran las marcas y lotes en distintas zonas de la superficie exterior de las escudillas. Se observan estrías y lotes en las zonas medias y bordes. A su vez también se muestran lotes y estrías en la base.

De los patrones observados se pueden reconstruir los siguientes movimientos $\mathrm{y}$ acciones -figura 6.65-: los de la base y parte de contacto entre ésta y la zona inferior nos indican movimientos de inclinación y rotación sobre el eje morfológico. Dependiendo de la frecuencia de contacto con el/los abrasivo/s, en algunos casos se llegó a aplanar la 
convexidad que en general presenta la zona de apoyo. La inclinación de las escudillas, según la altura a la que llegan las estrías paralelas que salen desde esta zona, no habría superado el ángulo que se muestra en la figura 6.65 B. Adentrándonos más en la zona inferior, se observan patrones combinados de direcciones de estrías; las estrías diagonales responderían a dos patrones: o un abrasivo que recorrió la superficie oblicuamente al eje morfológico, o movimientos de la pieza que implicaron, en la misma acción, inclinación y rotación. Los que son perpendiculares al eje son productos o de un abrasivo que recorrió una dirección perpendicularmente al eje, o de movimientos de rotación sin inclinación. La presencia de "cachaduras" y hoyuelos que ha sido registrada cercana a las zona media,

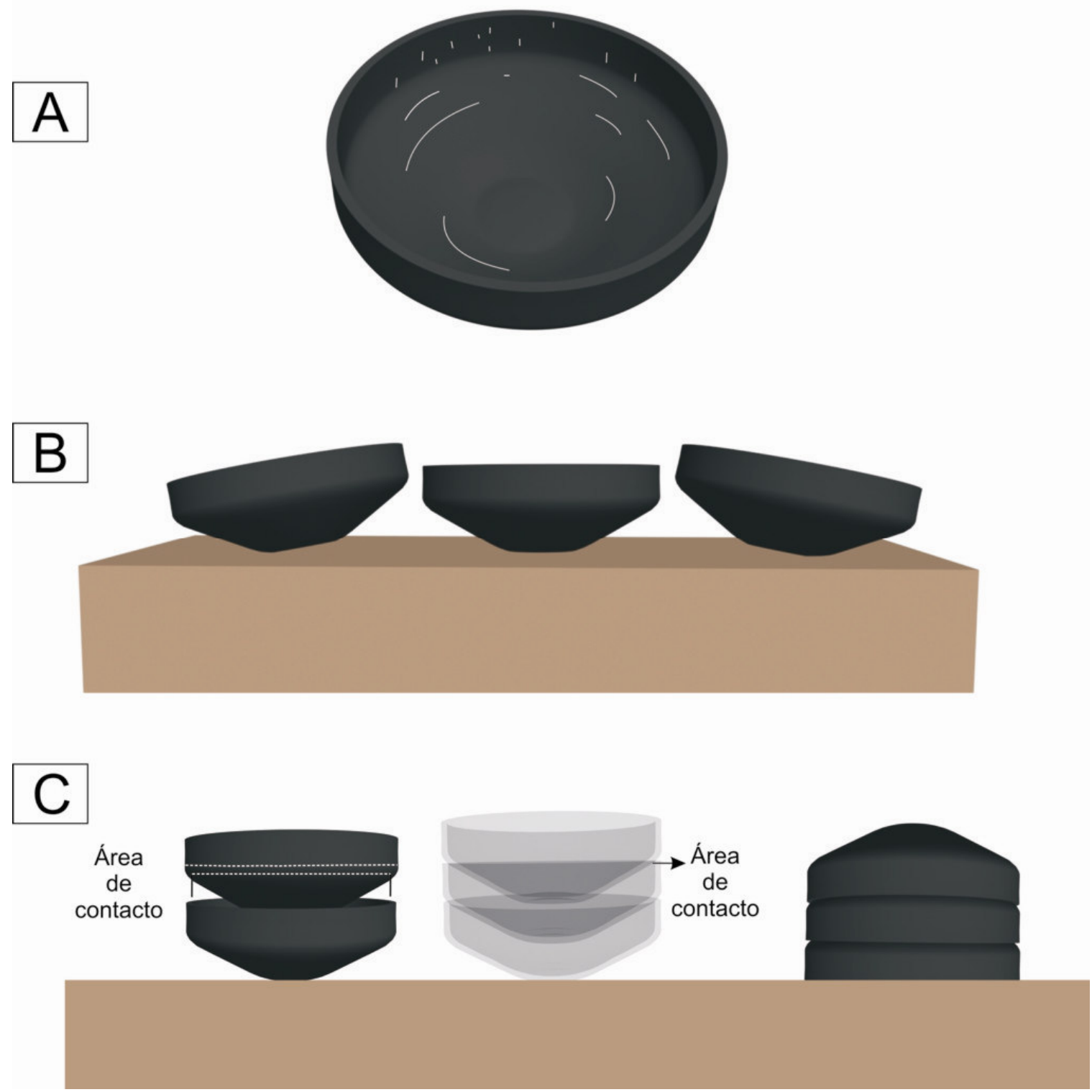

Figura 6.65: en A se muestra el patrón de marcas -estrías- en la superficie interior. En B se muestran los movimientos de inclinación y rotación reconstruidos. En C se muestran posibles formas de almacenado de estos objetos.

próximas al punto angular, podría corresponder a golpes en ángulos muy oblicuos con superficies duras. Una posibilidad, dada la forma de algunas de las escudillas -"escudilla a" y “b”, Bedano et al (1993)- que son las que posee mayor representación $-86 \%$ n=188- y en 
donde las paredes de la zona superior no convergen sino que son rectas o casi rectas, podrían corresponder a la forma de guardarlas unas dentro de otras. Si observamos el porcentaje de astilladuras en los bordes y particularmente en la zona interior de éstos, sumado a la ya comentada presencia de hoyuelos, "cachaduras" y estrías paralelas en la zona media -figura 6.64 y $6.65 \mathrm{C}$-, podríamos suponer un almacenamiento de este tipo.

Pero dado que, cuando piezas del mismo diámetro son encajadas una encima de otra la zona interior del borde no llegan a tener contacto con el punto angular, algunas de estas estrías, hoyuelos y cachaduras corresponderían a las acciones que ejecutaban las piezas cuando fueron usadas. Particularmente, se observan movimientos paralelos y de contacto lateral con otra superficie dura. A su vez la presencia de estrías perpendiculares en el borde, más los lotes, quizás nos indican contactos con abrasivos que recorrieron la superficie en dirección perpendicular al eje morfológico, lo que puede explicarse por el contacto con un algún instrumento -como en el caso de estrías paralelas-, o por su colocación boca abajo sobre una superficie abrasiva. Podríamos pensar en que estas piezas fueran encajadas una dentro de otra y colocadas boca abajo -figura 6.65-.

En cuanto a la zona interior del borde -gráfico 6.27 y figura 6.66-, presenta lotes en menor cantidad -9,3\%- y marcas en mayor proporción -57,6\%-. Las marcas se componen de estrías $-48,3 \%$ - y astilladuras $-16,1 \%$. Las estrías predominantes son las perpendiculares y las paralelas $-26,3 \%$ y $22,9 \%$, respectivamente-, las diagonales poseen menor representación $-11,1 \%$. En la zona superior aparecen lotes en bajo porcentaje -4,9\%- y marcas en mayor medida $-73,9 \%$. Las marcas son exclusivamente estrías: perpendiculares y diagonales $-64,1 \%$ y 49,8\%, respectivamente- en mayor proporción; y paralelas con muy bajo porcentaje $-2,4 \%$. En la zona inferior y la base se presentan lotes en muy bajo porcentaje $-4,5 \%$ - y marcas $-82,1 \%$. Todas las marcas presentes se tratan de estrías, perpendiculares principalmente $-71,4 \%$ - y diagonales $-57,1 \%$-, teniendo las paralelas baja representación $-5,4 \%$.

En todas las escudillas, las marcas en la zona interior poseen patrones comunes. Predominan las estrías perpendiculares y diagonales, y poseen muy baja presencia las estrías paralelas y los lotes -ver patrón en figura 6.65 A. Tanto las perpendiculares como las diagonales son producto del contacto con un abrasivo, probablemente un instrumento, que realizó movimientos giratorios alrededor del eje. Las estrías paralelas corresponden a movimientos paralelos al eje, esto es más observable en la zona superior en tanto las paredes son rectas. En cambio en la zona inferior tienden a ser movimientos más perpendiculares o en un plano levemente inclinado respecto al eje. 


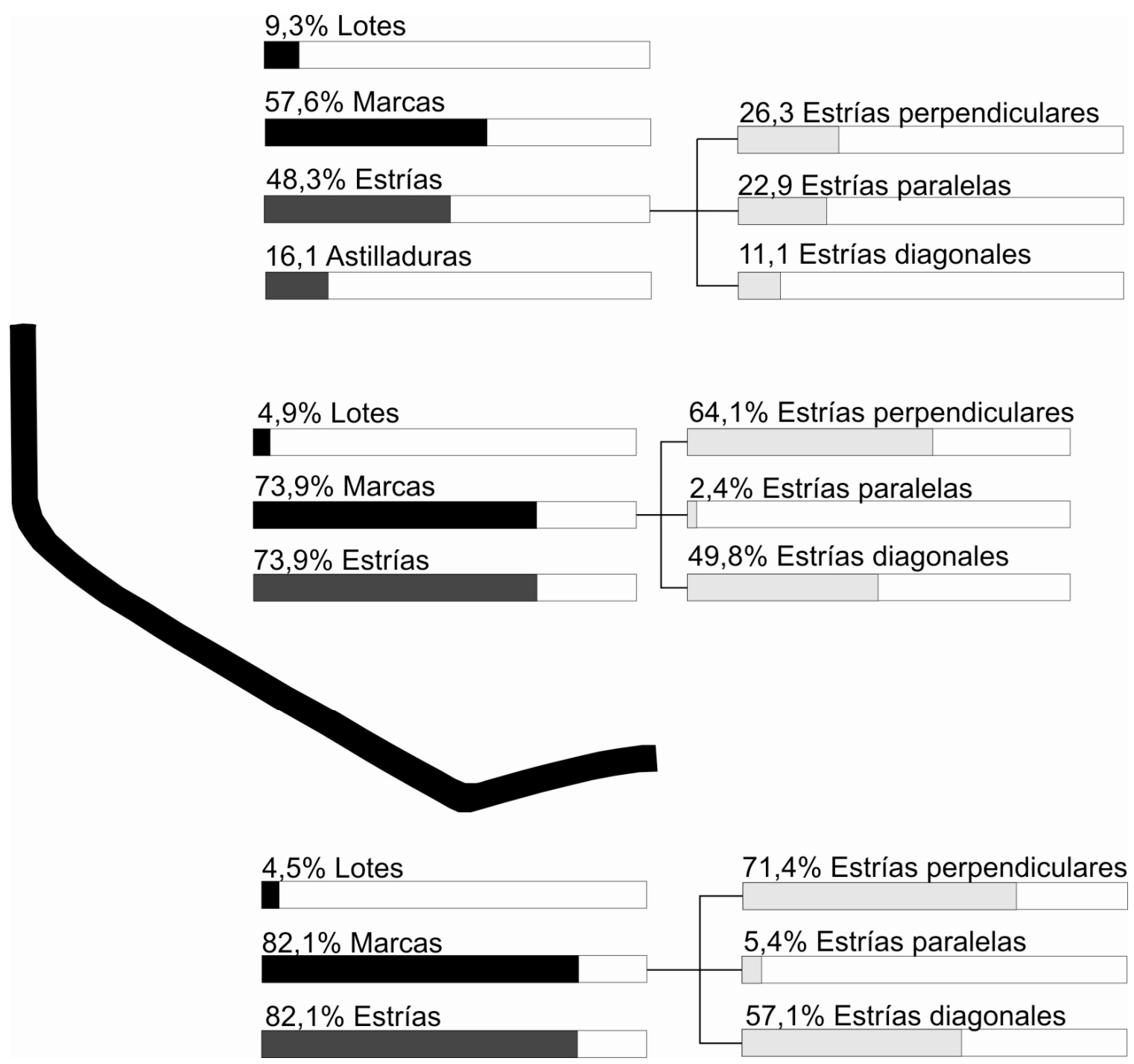

Gráfico 6.27: porcentajes de lotes y marcas en la superficie interior de las escudillas. Los n se hallan en el texto.

En cuanto a los análisis de residuos orgánicos se realizaron solo en dos casos, ambos arrojaron presencia de ácidos grasos y no de albúmina. Si tenemos en cuenta la impermeabilidad de estos recipientes, en tanto la superficie interna se halla totalmente pulida, sería muy apta para contener líquidos, sea bebidas o comidas como sopas, etc. Dada sus propiedades de accesibilidad que casi es absoluta, sus tamaños variables, sus posibilidades de fácil transporte y manipulación, son muy buenos para servir por ejemplo alimentos, o tomar alguna bebida, agua, chicha etc. ${ }^{\mathrm{xv}}$.

Pero esto no limitaría su uso en otras prácticas, por ejemplo aquellas vinculadas a la preparación de pigmentos, ya que en cuatro casos se observó en las superficies internas la presencia de pigmento color rojo que se extendía por toda la zona. Al igual que en las observaciones realizadas para la forma $\mathrm{b}$-figura 6.67-, el pigmento no se presentaba en las 

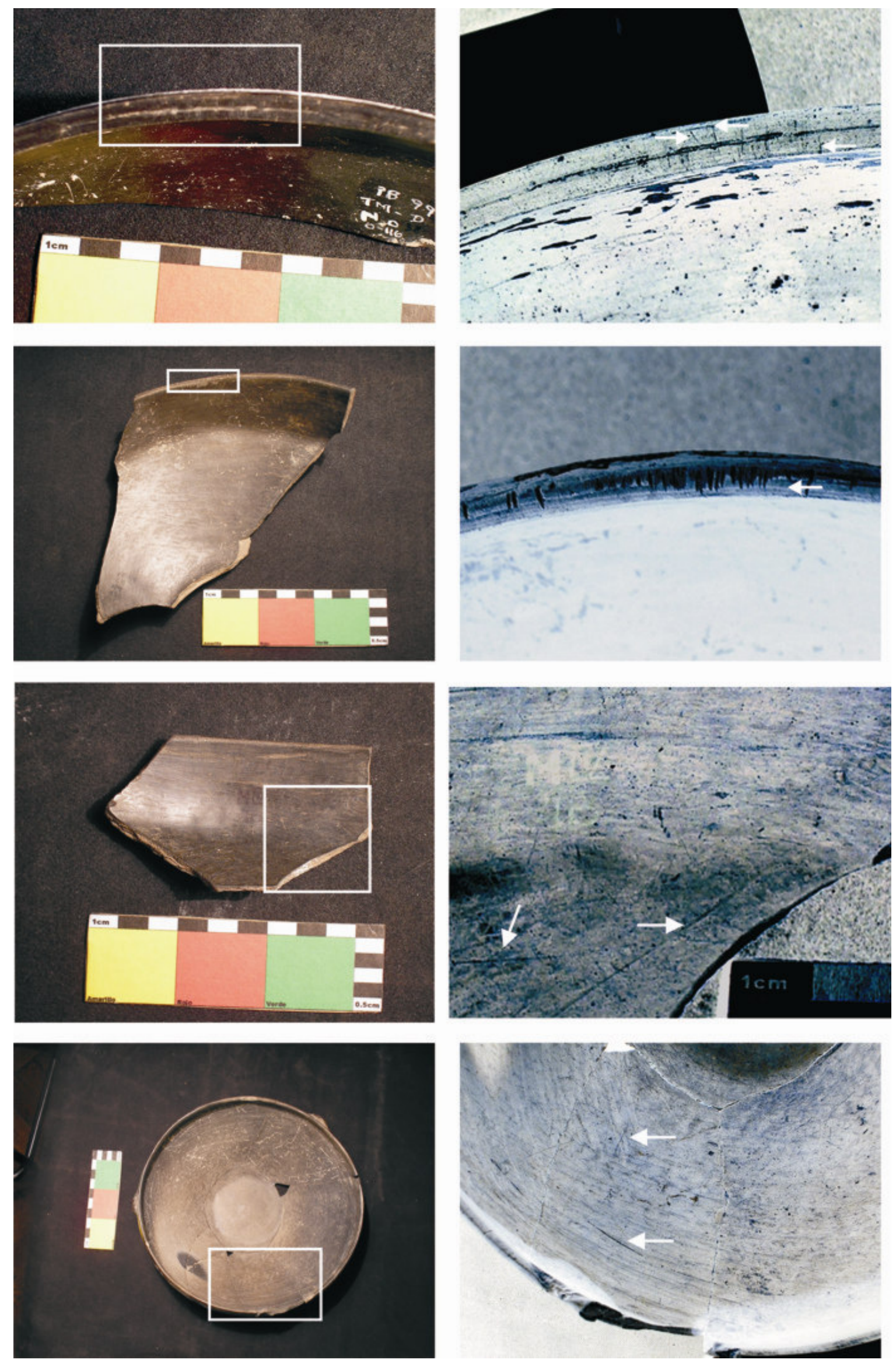

Figura 6.66: fotografías de marcas de las distintas zonas de la superficie interior. Particularmente de estrías en distintas direcciones. Las fotografías de la derecha son ampliaciones de los recuadros de la izquierda sometidas a un proceso de inversión de colores. 
fracturas ni en la zona exterior sino sólo en el interior, por lo que probablemente la adherencia de éste a la superficie de las piezas fue anterior a su rotura. Los fragmentos, al igual que los de las formas "b", proviene de distintos sitios y lugares, tanto recintos como montículos basureros. Según las huellas observadas, los análisis de residuos orgánicos y la presencia de pigmento en su interior, nos vinculan estas piezas con las de forma "b" en tanto que se relacionan con actividades semejantes. Si las vasijas "b" se utilizan como intermediarias entre las más grandes, las escudillas serían los recipientes finales desde donde se consumiría las bebidas y comidas, o, en el caso de los pigmentos, conformaba el recipiente desde el cual se extraía el pigmento para ser aplicado a lo que se quería pintar.
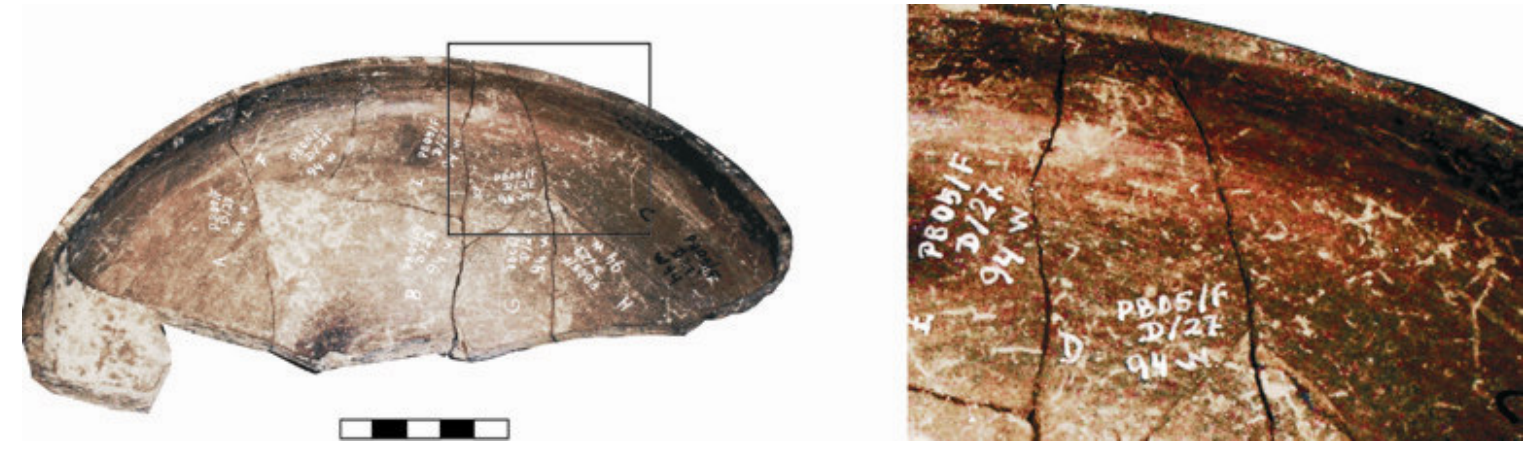

Figura 6.67: escudilla con pigmento rojo en la superficie interior. La foto de la derecha es una ampliación del recuadro negro de la izquierda.

Bol

La superficie exterior e interior de estos recipientes fue zonificada de la siguiente manera -figura 6.58-: la exterior en tres sectores: base, cuerpo y borde; y la interior en dos borde, cuerpo y base.

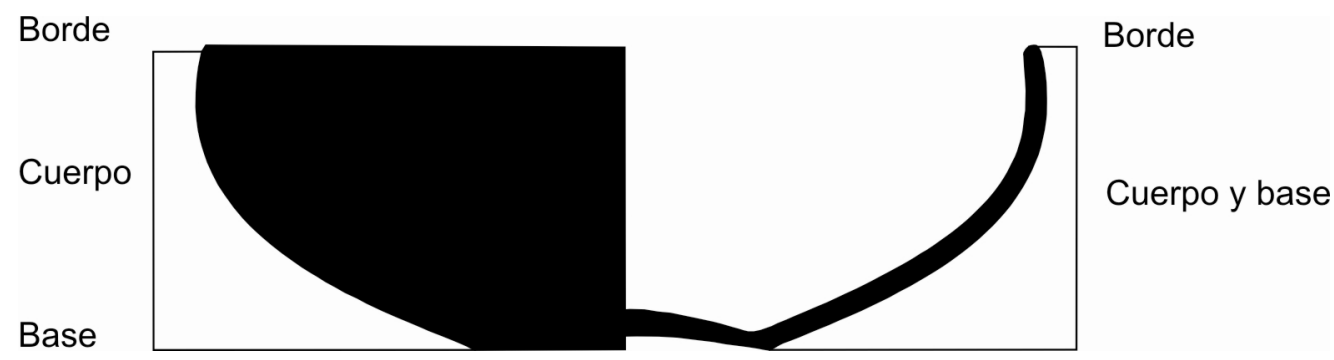

Figura 6.58: zonificación de la superficie exterior e interior de los bols. 
Las marcas observadas son las siguientes. En la superficie exterior de la base se observan lotes -2 únicos casos- y presentan marcas que se tratan de estrías perpendiculares. Los lotes forman un anillo justo en el punto de apoyo de la base. Las estrías se observan impresas sobre los lotes, y algunas entre esta región y el comienzo de la zona cóncava de la base. Las huellas se asemejan mucho a las observadas para las bases de las vasijas "b", escudillas y vasijas "c". Del cuerpo tenemos más casos representados -26- en estos se observan los siguientes patrones -gráfico 6.28 y figura 6.59-: los lotes se presentan en bajos porcentajes $-7,1 \%$ - mientras que las marcas están más representadas $-82,1 \%$. Los lotes se hallan en la zona de contacto entre la base y el cuerpo, desde este sector, al igual que en las escudillas, parten estrías paralelas en general hacia arriba, no más de $10 \mathrm{~mm}$. Las marcas se tratan de estrías en mayor proporción -78,6\%- y hoyuelos en menor medida 14,3\%. Las estrías presentes siguen en general una dirección perpendicular al eje morfológico de las piezas -67,9\%-, siguiéndole en proporción las direcciones diagonales con $46,4 \%$ y las paralelas con $25 \%$. En la zona exterior del borde -26 casos- se observan lotes en bajos porcentajes 7,4\%, y marcas en mayor cantidad -66,7\%. Las marcas se componen de astilladuras en mayor proporción $-51,9 \%$ - y estrías en menor medida $-37 \%$. Las estrías más frecuentes son las paralelas -29,6\%-, siguiéndole con muy bajos porcentajes las perpendiculares y diagonales $-3,7 \%$ cada una.
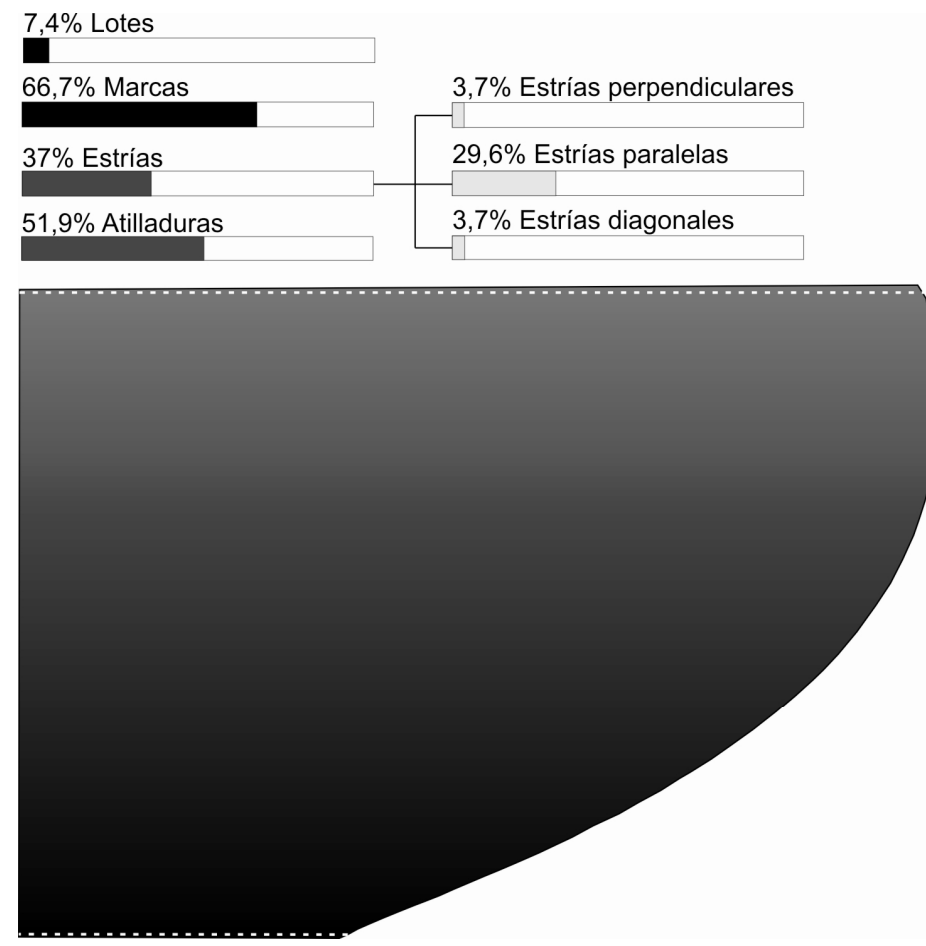

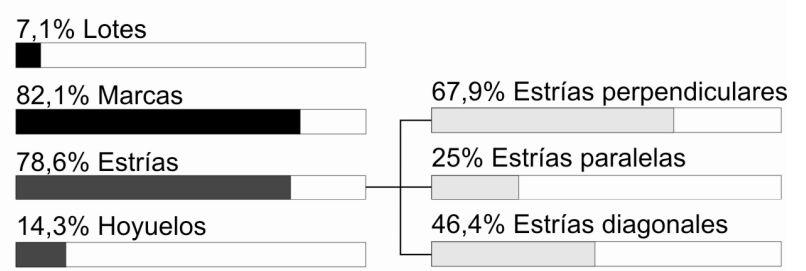

Gráfico 6.28: porcentaje de lotes y marcas en el borde y la zona media y superior del cuerpo. Los n están en el texto. 

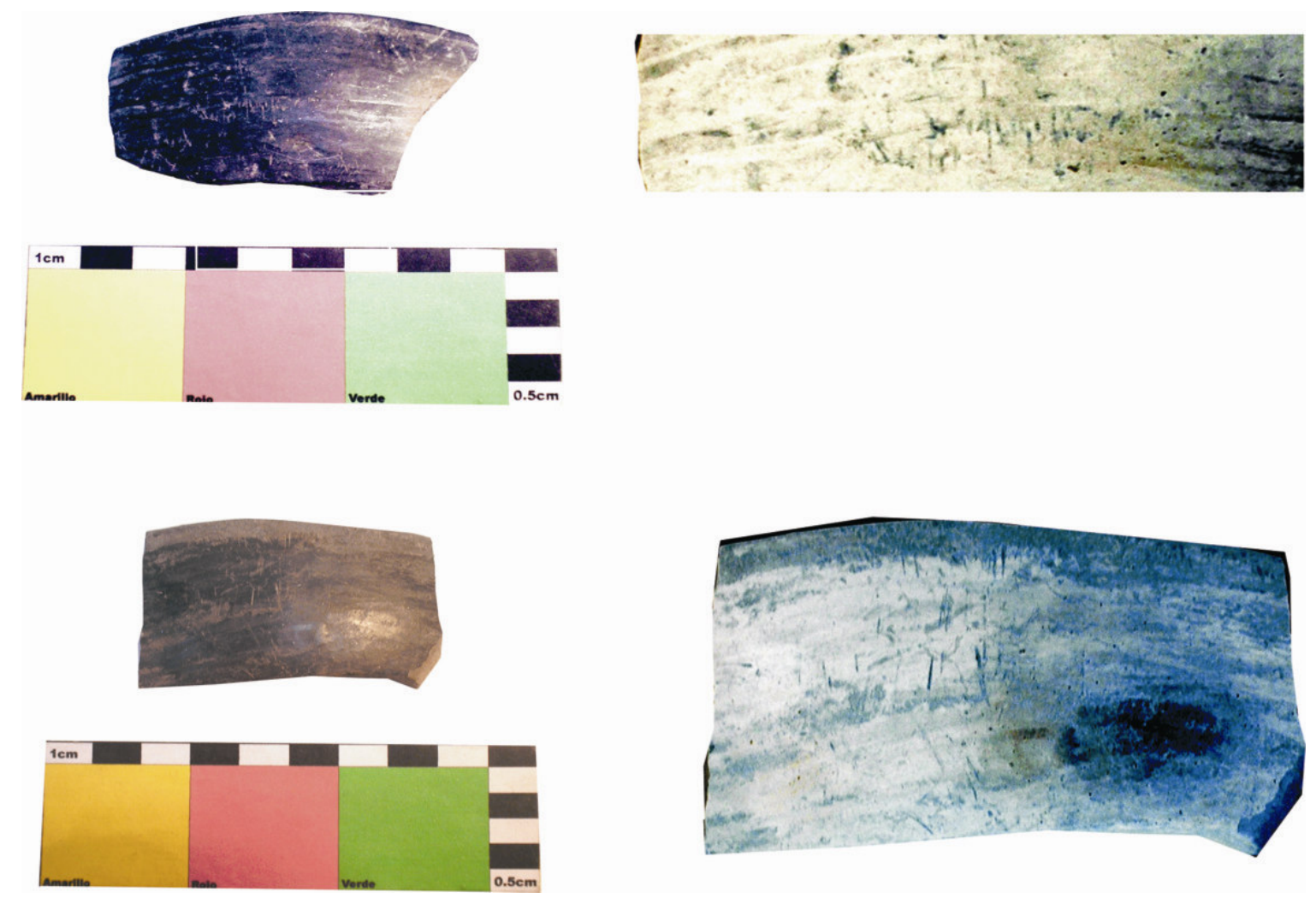

Figura 6.59: fotografías que muestran lotes y marcas en la la zona del borde y cuerpo del los bols. Las imágenes de la derecha sufrieron un proceso de inversión de colores.

De los patrones observados podemos inferior los siguientes movimientos -figura 6.60-: de la base, fricción con superficies abrasivas que produjo lotes en la zona de contacto. De la zona de contacto del cuerpo y la base, la presencia de lotes y estrías paralelas nos indican inclinación del bol hasta el ángulo que se observa en la figura 6.60. La presencia en todo el cuerpo de estrías diagonales y perpendiculares en mayor medida nos muestra rotación sobre el eje morfológico de las piezas y, al igual que las escudillas, movimientos que en la misma acción combina inclinación y rotación. Las estrías paralelas y la presencia de cierta frecuencia de hoyuelos nos podrían indicar movimientos paralelos, por ejemplo cuando son alzados y vueltos a asentar o de contacto lateral con otras piezas figura 6.60. Quizás si lo comparamos con la presencia de un alto porcentaje de astilladuras en los bordes, al igual que ciertas formas de escudilla, correspondan a la forma en que se los guardaba: encajándolos uno dentro de otro. Estos patrones de marcas muestran una alta frecuencia de contactos con variedad de abrasivos en diferentes direcciones, indicando una alta movilidad y diversidad en las actividades a la que fueron sometidas. 

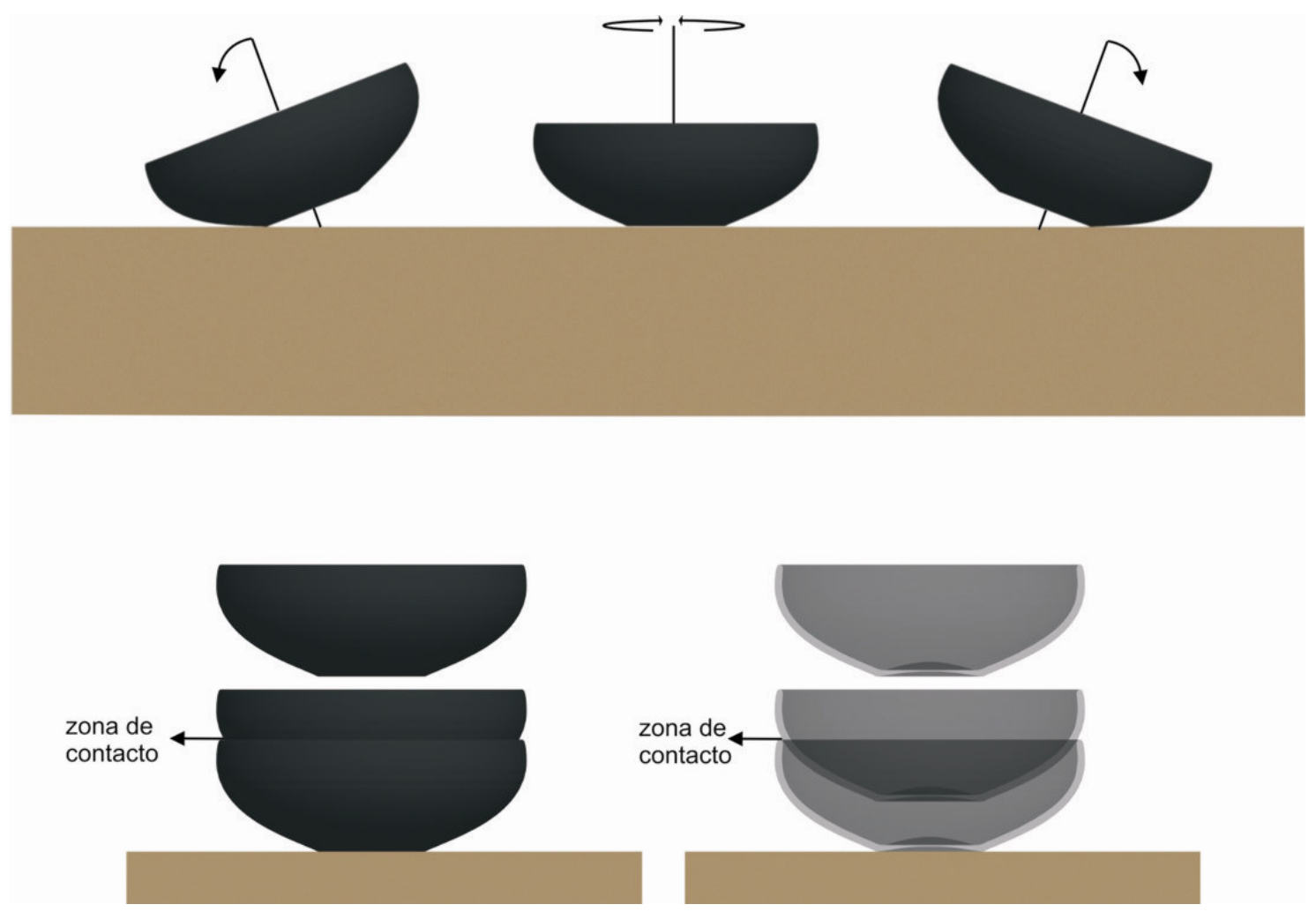

Figura 6.60: se muestran los movimientos reconstruidos -superior- y una posible forma de almacenado de los mismos -inferior-

En relación a la zona interior se observan los siguientes patrones -gráfico 6.29 y figura 6.61-: en el borde -26 casos- se presentan lotes con el mismo porcentaje que en el sector exterior del borde $-7,4 \%$-, aunque las marcas disminuyen un poco -44,4\%. El 40,7\% de las piezas presentan estrías en diferentes direcciones, tenemos paralelas en las zonas del filo del borde -11,1\%-, perpendiculares y diagonales con un porcentaje levemente mayor 18,5\% cada una. Las astilladuras también se encuentran pero en menor medida que en la zona exterior, invirtiéndose las relaciones entre estrías y astilladuras respecto del lado exterior. Con respecto a la zona interior del cuerpo -26 casos- se presentan lotes $-7,1 \%$ - y marcas en mayor medida $-64,3 \%$. Éstas se tratan en todos los casos de estrías, que siguen en general una dirección perpendicular -46,4\% y diagonales -39,3\%-, estando representadas las estrías que corren paralelas al eje morfológico en muy bajo porcentaje respecto de las dos anteriores $-3,6 \%$.

Las huellas de atrición observadas en la zona interior del borde muestran, a diferencia de la zona exterior, disminución de las astilladuras y las estrías paralelas y un crecimiento de las estrías perpendiculares y diagonales. Esto nos podría marcar la posibilidad de que en algunos momentos estas piezas fueron colocadas boca abajo. Las estrías paralelas y las astilladuras podrían corresponder, tanto a la forma de guardarlos, 
$7,4 \%$ Lotes

a

$44,4 \%$ Marcas

40,7\% Estrias

$18,5 \%$ Estrías perpendiculares

40,7\% Estrias

$18,5 \%$ Atilladuras

$18,5 \%$ Estrías paralelas

$18,5 \%$ Atiladuras

$11,1 \%$ Estrías diagonales

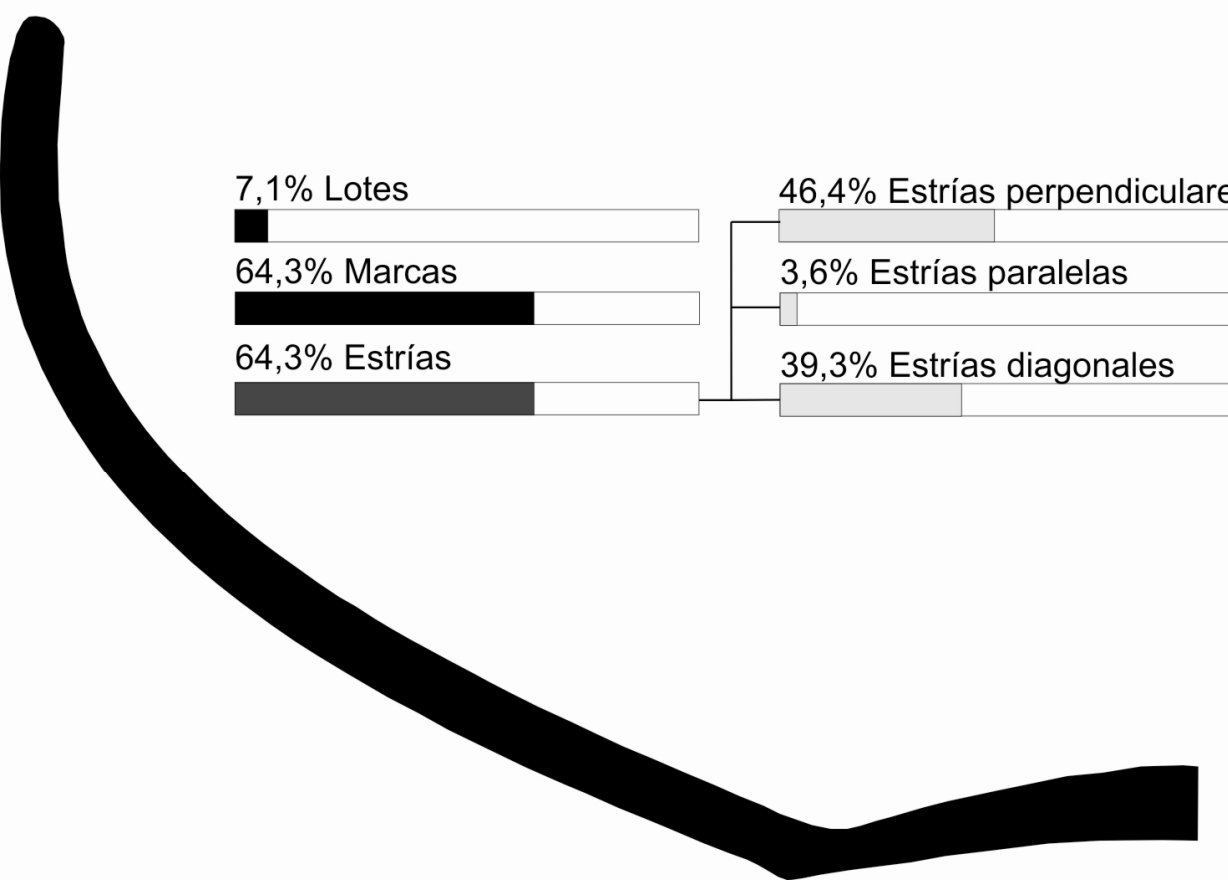

Gráfico 6.29: porcentaje de lotes y marcas de las distinta zonas de la superficie interior de los bols. Los $\mathrm{n}$ se expresan en el texto.
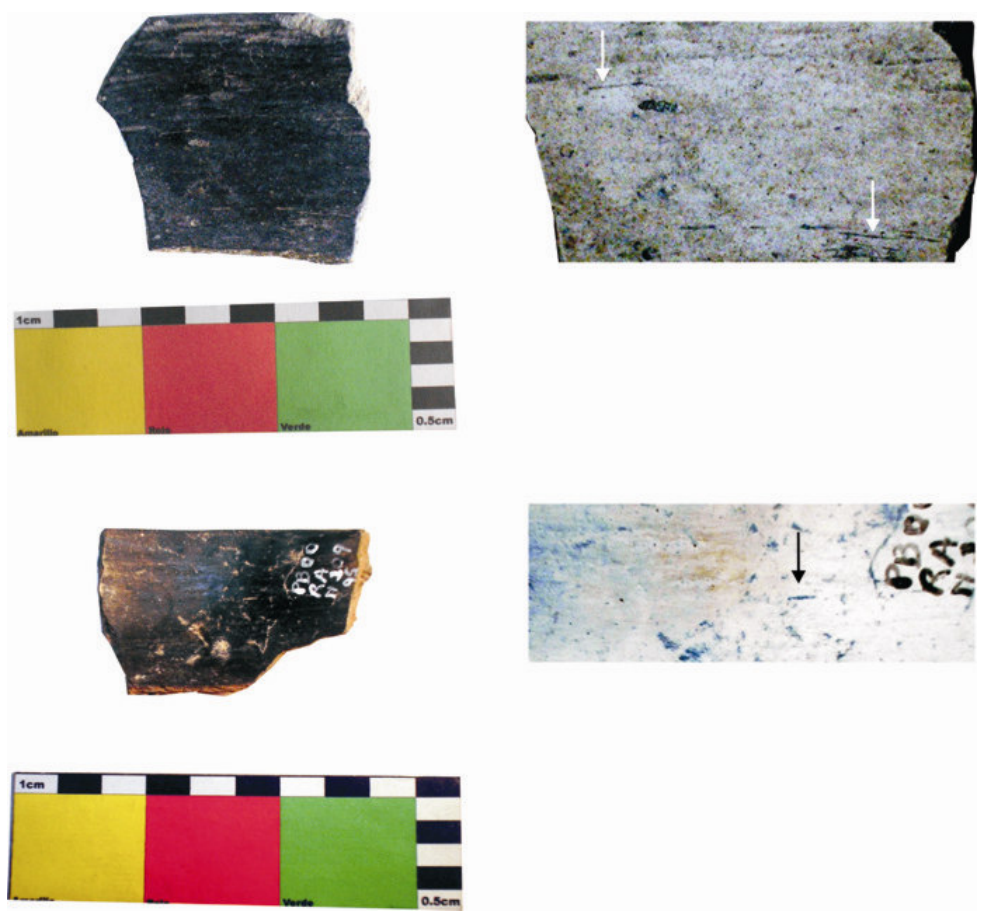

Figura 6.61: fotografías que muestran las marcas -estrías- de la superficie interior. Las mismas se hallan marcadas con flechas. Las fotografías de la derecha son ampliaciones de las de la izquierda y fueron sometidas a un proceso de inversión de colores. 
encajándolos uno dentro del otro, como a la utilización de un instrumento para acceder a los contenidos, que produjo también el patrón de marcas interiores semejantes a las escudillas, que muestran principalmente movimientos alrededor del eje morfológico de la pieza.

No poseemos análisis de residuos orgánicos para esta forma, pero juntos con las escudillas y los vasos o jarras son las únicas que presentan la superficie interior completamente pulida o bruñida, que le suman impermeabilidad a las propiedades que ya poseía por el tipo de pasta con el que son confeccionados. En este sentido serían también aptos para contener líquidos y comidas más líquidas. Tampoco se han hallado rastros de pigmentos que indiquen su vinculación con esta actividad, como fue identificado para otras piezas. La alta movilidad que muestra el patrón de huellas de atrición, la variabilidad de tamaños, el hecho de que puedan ser fácilmente manipuladas y transportadas, sumado a la accesibilidad absoluta a sus contenidos, nos señalan que, al igual que las escudillas, podían ser utilizadas para actividades de procesamiento, que según las huellas observadas podrían ser mezclar y revolver, así como para servir y consumir.

\section{Vasos o Jarras:}

Hemos descrito dos formas de vasos, una subcilíndrica de contorno simple con asa lateral en cinta adosada, de base plana y, otra subcuadrangular de contorno simple, sin asa y también con base plana. La presencia de éstos en la muestra es muy baja, por lo que no realizamos gráficos de porcentajes para cada forma sino que vamos a describir las huellas de atrición en los que pudimos observarlas. La zonificación de ambas clases de vasos se realizó de la siguiente manera: al lado exterior se lo subdividió en base, cuerpo y borde y; la superficie interior de igual manera.

Los vasos o jarras de forma subcilíndrica -figura 6.62-, al igual que los de forma cuadrangular, presentan (cuatro casos para cada una de las formas) lotes y marcas en tres de las bases. En el caso de los de forma subcilíndrica se observan en dos casos y en los cuadrangulares en los cuatro casos. Los lotes en los que se presentan se tratan de sectores de formas irregulares que extrajeron el pulido y parte de la pasta de las bases planas. En ninguno de los casos la abrasión extrajo toda la superficie, sólo en sectores localizados. Las marcas son estrías perpendiculares al eje morfológico de la pieza. La zona del cuerpo (de los 6 casos analizados en las vasos de forma subcilíndrica) presentan lotes en dos casos, éstos son muy restringidos y se encuentran en los sectores inferiores del cuerpo -cercanos 


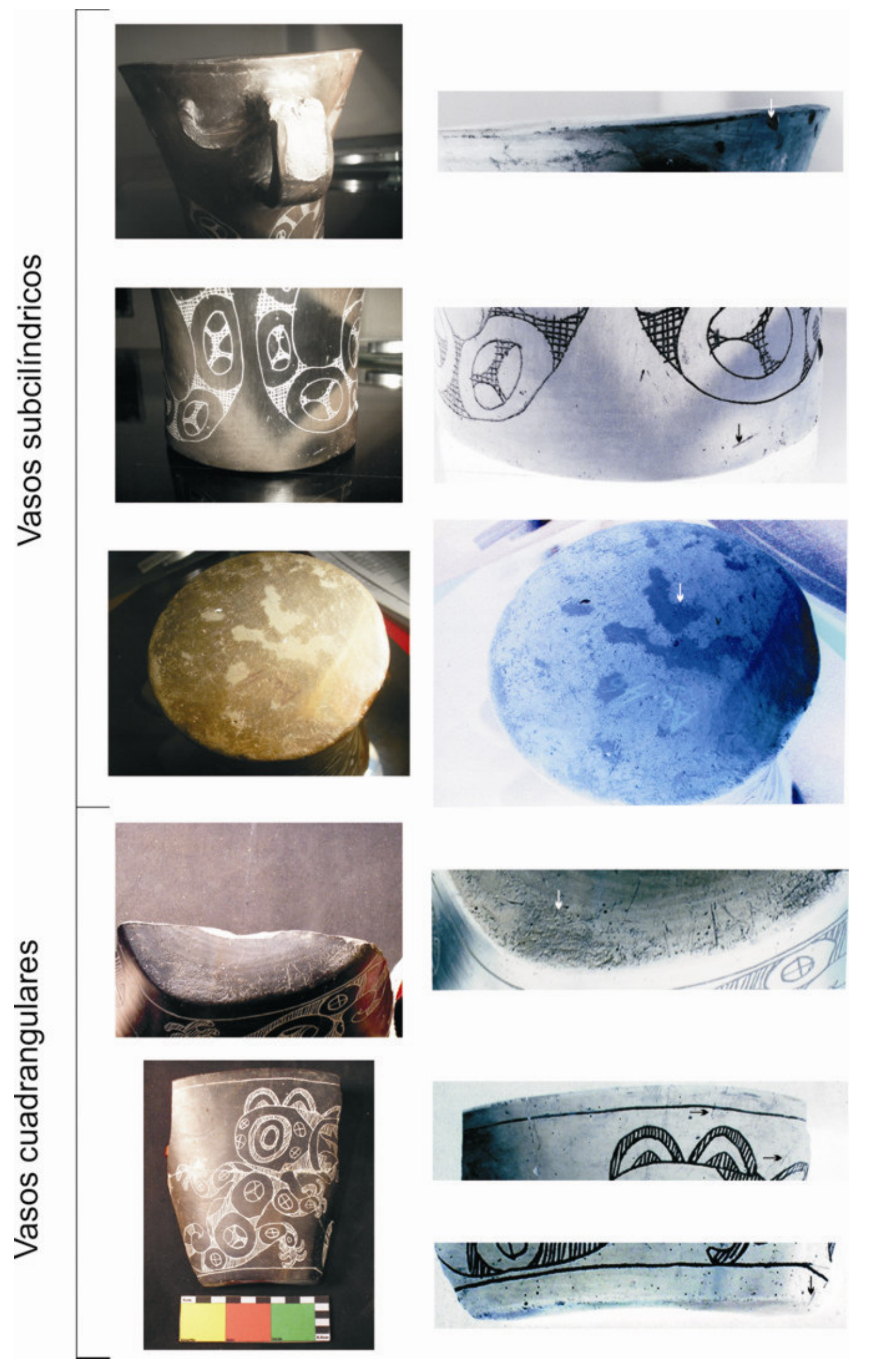

Figura 6.62: fotografías de las marcas y lotes de distintas zonas de los vasos. Las imágenes de la derecha son ampliaciones de zonas de las fotografías de la izquierda. Se indican con flechas las marcas y lotes. Las imágenes de la derecha sufrieron un proceso de inversión de colores. 
al punto terminal que divide la base y el cuerpo. En el caso de los cuadrangulares -figura 6.62-, de los cuatro casos analizados uno presenta un lote restringido en misma zona que los subcilíndricos. En relación a las marcas, en ambos se compone de estrías en todos los casos y hoyuelos sólo presente en un caso en ambas formas. En los de formas subcilíndrica en todos se presentan estrías perpendiculares, en tres de ellos se combinan con diagonales y paralelas. En los de forma subcuadrangular tenemos la combinación de estrías perpendiculares y paralelas en dos casos y en uno se le suman las diagonales. En relación a los bordes, en los subcirculares -cuatro casos observados- solo uno presenta un lote muy restringido y una marca. En los cuadrangulares -solo dos casos- no presentan lotes y sólo un presenta una marca. En ambas formas las marcas se tratan de astilladuras.

En función de las huellas de atrición observadas, podemos señalar los siguientes movimientos y acciones que habría realizados estos recipientes. En primer lugar debemos resaltar la relativa baja erosión que presentan las bases que, al ser planas, apoyarían totalmente sobre la superficie abrasiva. Si la comparaos con la erosión de las zonas de contacto de las escudilla, bol, u otra vasijas que poseen procesos erosivos pronunciado, quizás nos indique menor movilidad de estas piezas y menor frecuencia de contacto con superficie abrasivas. Por otro lado, el proceso erosivo que produjo los lotes en las base no continúa hacia las zonas inferiores del cuerpo, ni siquiera logró aplanar el ángulo casi recto que forma la base con el cuerpo. Este hecho nos indica que si se los inclinaba, este movimiento se lo realizaba en el aire, o sobre algo que impidiera el contacto con una superficie abrasiva. Lo mismo se observa en los sectores del cuerpo, donde las estrías se presentan de forma aislada al igual que los hoyuelos. En el borde hay muy pocas marcas y cuando aparecen son aisladas. Si pensamos en la forma de estos recipientes cilíndrico o cuadrangulares, la altura de las piezas supera ampliamente el diámetro máximo que en general coincide con la boca, sumado eso a la presencia de asas verticales, que si bien aisladas se hallan presentes, nos indica movimientos de aprensión a través del asa para luego volver a apoyarlo, además de ciertos movimientos rotatorios alrededor del eje morfológico.

En la superficie interior, en los bordes de todos los casos de la forma subcuadrangular no presentan ni marcas ni lotes. En el caso de la subcircular, presenta en un caso lotes y en otro una marca (estrías paralelas). En cuanto al cuerpo, en los subcirculares no existe la presencia de lotes -seis casos- y en cuatro se presentan marcas, específicamente estrías: en tres de ellos estrías perpendiculares se combinan con paralelas y en otros tres solo aparecen paralelas. En los de forma cuadrangular -cuatro casos- no 
presentan lotes, tres presentan estrías y sólo uno hoyuelos. Las estrías se presentan muy alisadas en la superficie, y pueden seguir direcciones perpendiculares, combinadas con diagonales y paralelas. En relación a la base en los cuadrangulares -cuatro casos- no se observan ni lotes ni marcas. En los subcirculares -cuatro casos observados- en un caso tenemos presencia de un lote muy restringido y en tres de marcas, específicamente de estrías perpendiculares.

No poseemos análisis de residuos orgánicos que nos acerquen a los contenidos, y como veremos más adelante los contextos de hallazgos tampoco no indican al respecto. Pero si tenemos en cuenta las formas y los movimientos descriptos anteriormente, a lo que sumamos que las superficies internas (al igual que las escudillas y bol) se presentan totalmente pulidas favoreciendo la impermeabilización, y tenemos en cuenta la relación altura/diámetro máximo (que impide realizar determinadas actividades en el interior) podemos suponer que se hallarían más vinculados a servir, transferir o beber algún tipo de líquido. Las marcas no nos permiten inferir que tipos de líquidos; sólo podemos decir que (al igual que en las escudillas) si fuera chicha no llegó a dejar algún tipo de erosión producto del proceso de fermentación, probablemente porque si la bebida entró en contacto con la superficie del vaso o jarra tuvo poco tiempo de permanencia en ella. Pero tampoco podemos descartar que se las utilizara para beber agua u algún otro tipo de líquido.

\section{Forma "c":}

Poseemos muy pocos casos registrados de cada zona, por lo que para las descripciones no nos manejaremos con porcentajes, sino con cantidades. La zonificación realizada de esta forma se corresponde con la de las vasijas "b" -ver figura 6.63-.

La única base registrada presenta en la superficie exterior lotes, que al igual que las vasijas " $b$ " se encuentra en el sector donde la base apoya sobre la superficie de contacto. Las estrías se observan en la zona donde comienza la concavidad de la misma. Hacia la zona inferior que entra en contacto con la base, de los 6 casos observados solo en 1 se observa lotes, que provine de la base y avanza unos pocos milímetros en esta zona, combinándose con estrías paralelas y diagonales. En los 5 casos restantes se observan marcas. Se tratan de estrías, principalmente diagonales y perpendiculares. En la zona media el patrón se repite pero las estrías predominante son las perpendiculares y las paralelas. En la zona del cuello, de 12 casos registrados solo 1 presenta un lote muy restringido, el resto presenta marcas. Estas se tratan exclusivamente de estrías -10 de 12-, que en general son perpendiculares -10 de $12-$, y en menor medida diagonales -5 de $12-$ y 

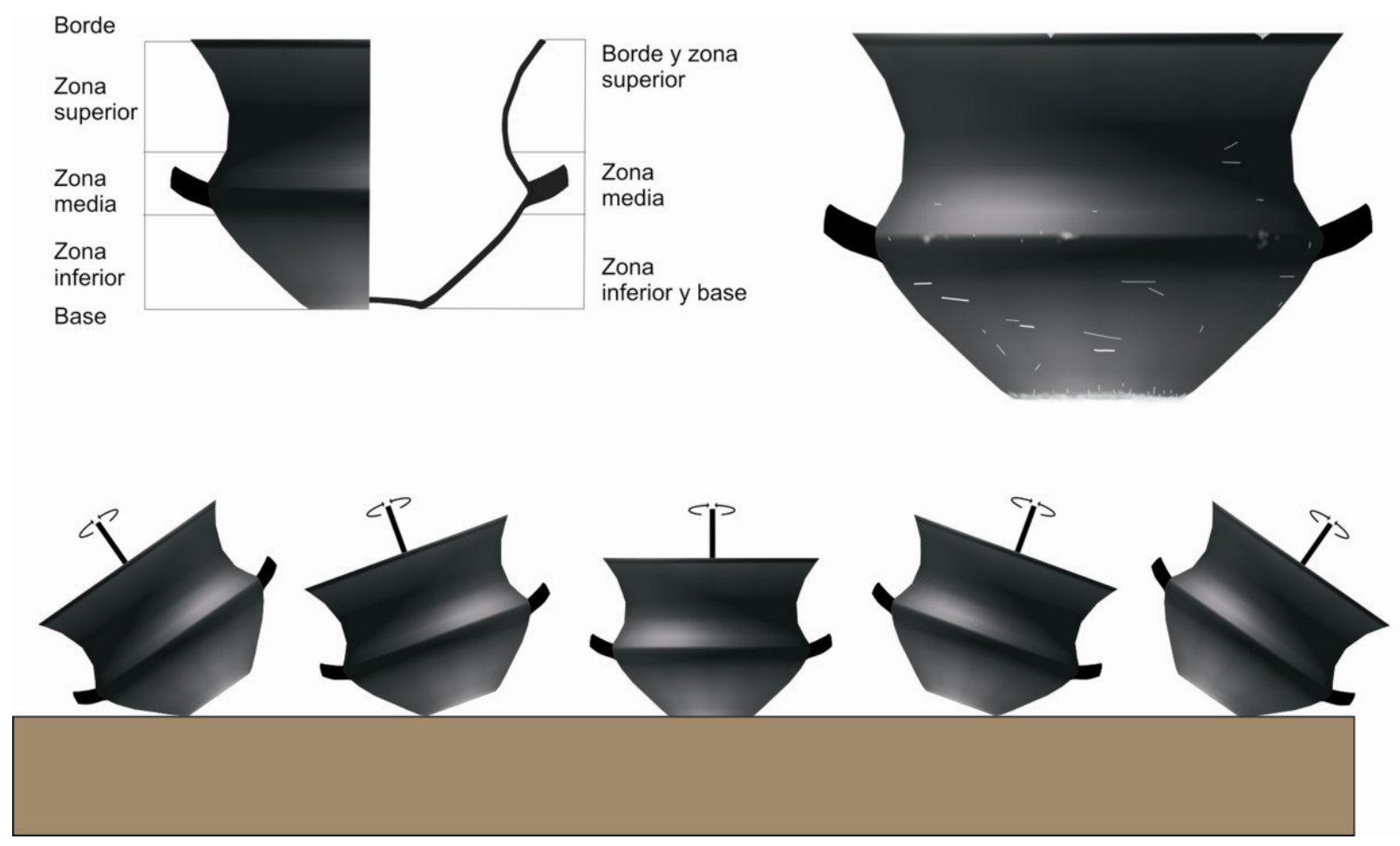

Figura 6.63: se muestra la zonificación de la superficie interior y exterior de estas vasijas -superior izquierda-. Se observan los patrones de marcas y lotes en las distintas zonas de la superficie exterior superior derecha. A su vez, se muestran los movimientos reconstruidos según el patrón de marca observado -inferior.

paralelas -2 de12-. En el borde, de 10 casos registrados ninguno presente lotes, 6 presenta marcas, que en general se trata de estrías perpendiculares -2 de $10-$, paralelas -3 de 6- y diagonales -4 de 10-, también se presentan astilladuras -4 de 6-. De los patrones observados podemos realizar algunas inferencias de movimientos de inclinación leve, y giro sobre el eje de la pieza -figura 6.63-. También combinación de movimientos de giro e inclinación, tal cual lo hemos observado para las de forma "b". El caso de las estrías paralelas observadas en la zona media, donde se encuentra el diámetro máximo, podría indicar movimiento de inclinación sin rotación.

En la superficie interior en la zona del borde y parte de cuello no existen lotes y sí se presentan marcas -9 de 10; en el borde existen estrías paralelas -3 de 10- y astilladuras -3 de 10- y en el cuello se tratan de estrías perpendiculares -6 de 10- y diagonales -6 de 10-. En la parte media de la superficie interior y en la zona de la base - 6 casos registrados cada una- no se observan lotes y si se presentan marcas que en general se tratan de estrías perpendiculares principalmente en la base y diagonales. Los patrones observados muestran el contacto de un abrasivo que recorrió la superficie con movimiento giratorios alrededor de la pieza, probablemente se trate del instrumento para manipular o extraer los contenidos de las vasijas. La forma del cuello, de paredes divergentes, permite una accesibilidad mayor a los contenidos y una manipulación de los mismos. No poseemos análisis de 
residuos orgánicos por lo que no podemos acercarnos por el momento a qué tipo de contenidos se colocaban y manipulaban en su interior. En ninguno de los casos, como lo hemos hecho para otras vasijas de clase A1 se halló presencia de pigmento.

\section{Vasijas restringidas compuestas}

La zonificación realizada de esta es semejante a la de las escudillas: base, parte inferior, media (punto angular), superior y borde. La superficie interior las hemos dividido en borde, parte superior, inferior y base -figura 6.64 a-. Al igual que en las de forma "c" poseemos muy pocos casos registrados de cada zona, por lo que para las descripciones no nos manejaremos con porcentajes, si no con cantidades absolutas.

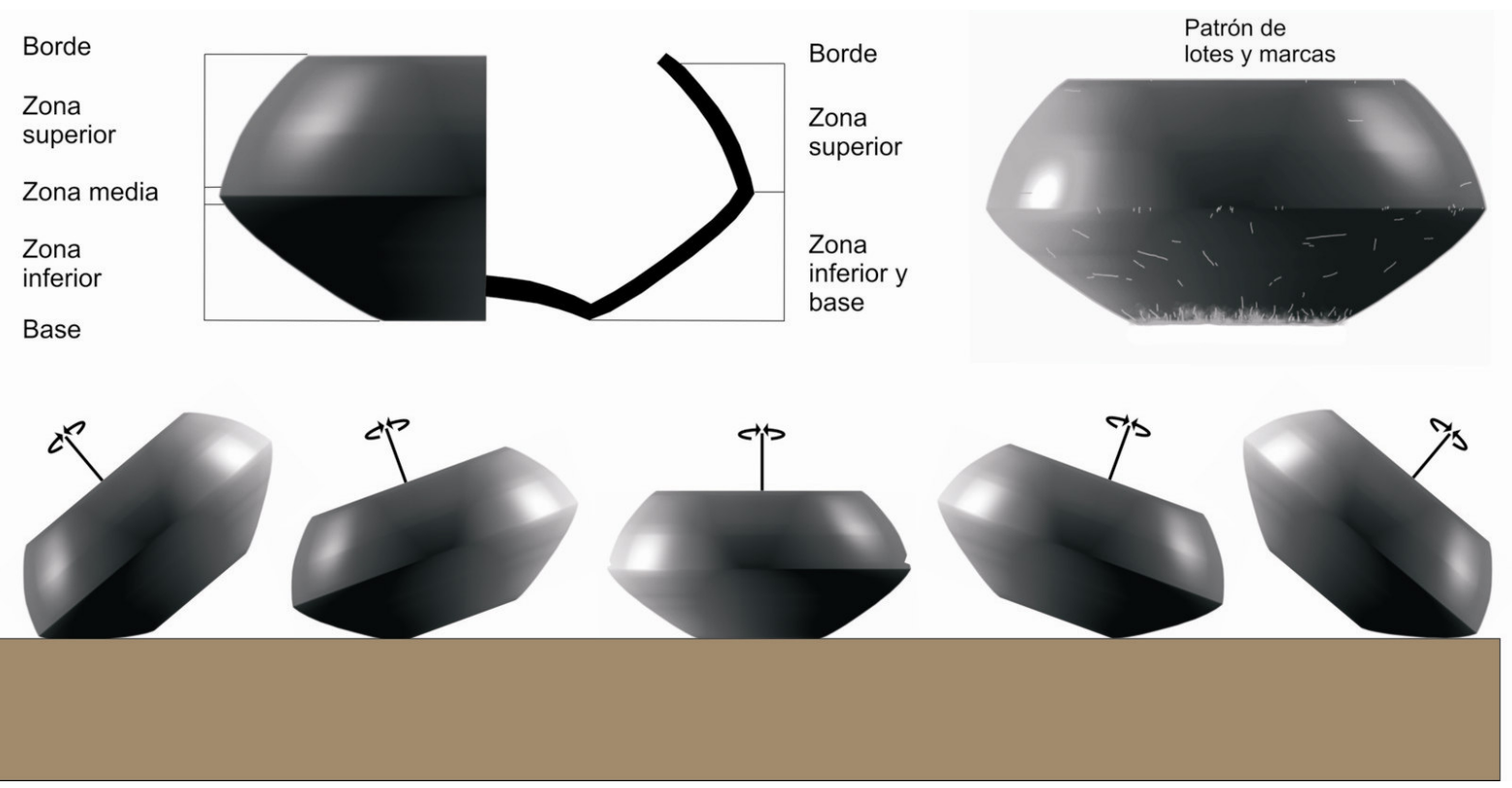

Figura 6.64 a: se muestra la zonificación de la superficie exterior e interior de las vasijas restringidas compuestas. Se observa el patrón de lotes y marcas y los movimientos reconstruidos.

En la superficie exterior de las bases se registra la presencia de lotes en la zona de contacto de la base cóncava con la superficie de apoyo -figura 6.64 b-. También se registran estrías perpendiculares, específicamente donde la comienza la concavidad de la base. En la parte inferior de la zona de contacto con la base, en los 3 casos observados los lotes continúan unos pocos milímetros, en esta zona se combinan con estrías paralelas y diagonales. En el resto de la parte inferior se observan lotes restringidos y estrías en distintas direcciones perpendiculares, paralelas y diagonales. En el punto angular, de los 6 casos observados, no se presentan lotes y sí marcas, en 5 casos que se tratan de estrías paralelas y diagonales. En la superficie exterior parte superior, entre el borde y el punto angular, en un caso se presenta un lote restringido y en cuatro algunas estrías aisladas 

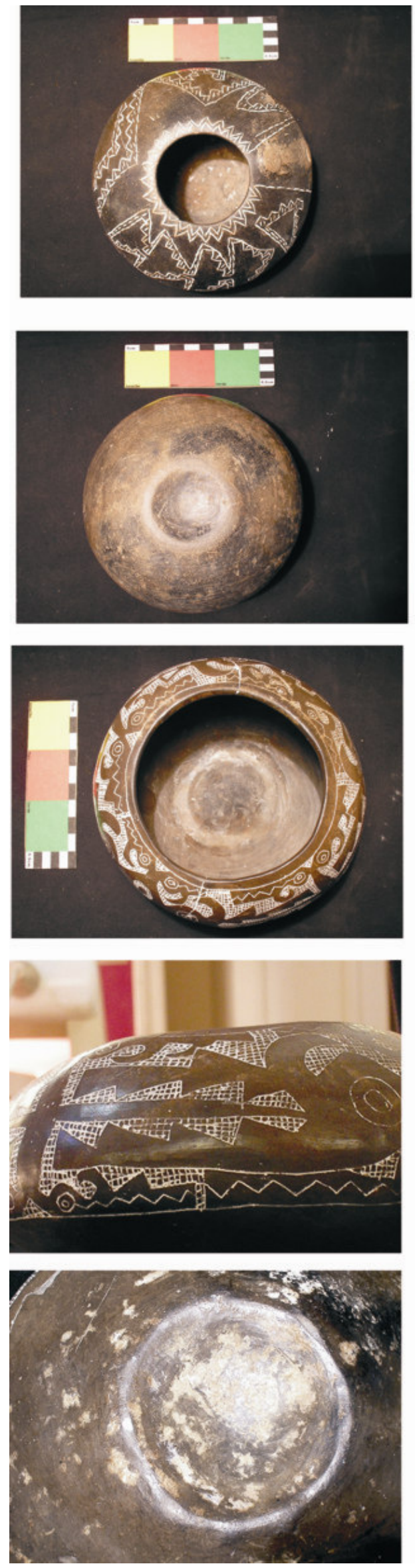

Figura 6.64 b: fotografías en donde se observan marcas y lotes en distintas zonas de la superficie externa de las vasijas restringidas compuestas. Se observa astilladuras en el borde, la casi ausencia de marcas en la zona superior y la mayor cantidad de lotes y marcas en la zona inferior y base. Las fotografías de la izquierda se sometieron a un proceso de inversión de colores.
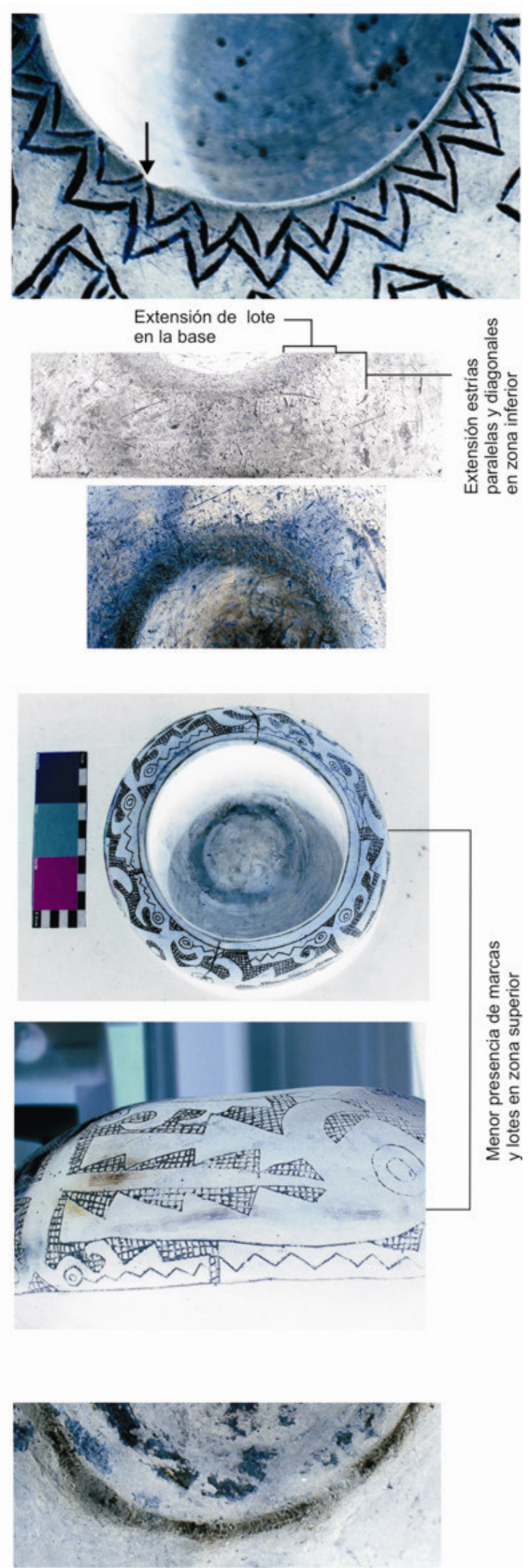
perpendiculares, diagonales y también paralelas. En la zona del borde no se presentan lotes, sí marcas que en los en 3 de los seis casos registrados son estrías paralelas y en uno perpendiculares y diagonales. También en dos casos se presentan astilladuras. El patrón de huellas observado muestra mayor cantidad de marcas en la zona inferior y media, teniendo en general una presencia aislada en la zona superior por encima del punto angular donde se encuentra el panel decorativo. Las marcas muestran un contacto frecuente y en direcciones variadas con abrasivos, particularmente en la zona de la base y parte inferior, movimientos de inclinación, rotación y giro -figura 6.64 a-. La inclinación, dada la presencia de estrías paralelas y diagonales en la zona del punto angular, debió ser importante -figura 6.64 a. Este patrón de marcas se repite en la zona interior del borde. En la zona interior parte superior casi no se observan ni lotes ni marcas, salvo en un caso aislado se observan una estría perpendicular. En la zona inferior, no se presentan lotes y aparecen algunas estrías perpendiculares y diagonales. Aunque poseen una boca muy restringida y de difícil acceso a los contenidos, la presencia de astilladuras y estrías paralelas en el borde denotan la introducción de algún instrumento en el interior. Lo mismo podemos decir de la marcas en la zona superior, inferior y base. En un caso, que apareció como ajuar del enterratorio de un niño -ver más adelante descripción de contextos del Recinto $\mathrm{H}$ del sitio Piedras Blancas-, en el interior se hallaban panes de pigmento rojo y blanco. No poseemos análisis de residuos orgánicos, pero quizás este hallazgo nos aproxime a lo que estas vasijas pudieron haber realizado cuando se hallaban aún en uso.

\section{Modeladas}

Dado que la forma varía de pieza a piezas describiremos las huellas por cada una. Tenemos una solo pieza entera de clase A1 modelada en forma de sapo -figura 6.65-, que proviene de la colección del Museo Adán Quiroga. Esta presenta el exterior pulido y el interior solo alisado. La piezas, presenta lotes en el lugar donde las cuatro patas del sapo apoyan sobre la superficie, la erosión llegó a aplanar la superficie. En la boca se observan astilladuras tanto del lado interno como externo. Y sobre el lomo se observan solo dos estrías que recorrieron la superficie perpendicularmente al sentido más largo de la pieza. En el interior no presenta marcas ni lotes. A su vez tenemos registrados tres fragmentos más que no podemos reconstruir exactamente la forma modelada, pero pertenecen a esta clase de vasijas, en general presentan el exterior pulido y grabado y el interior solo alisado, no presentan marcas observables ni en el exterior ni en el interior, pertenecen a fragmentos de un borde y dos de cuerpos. Un fragmento de borde presenta pigmento rojo extendido en 

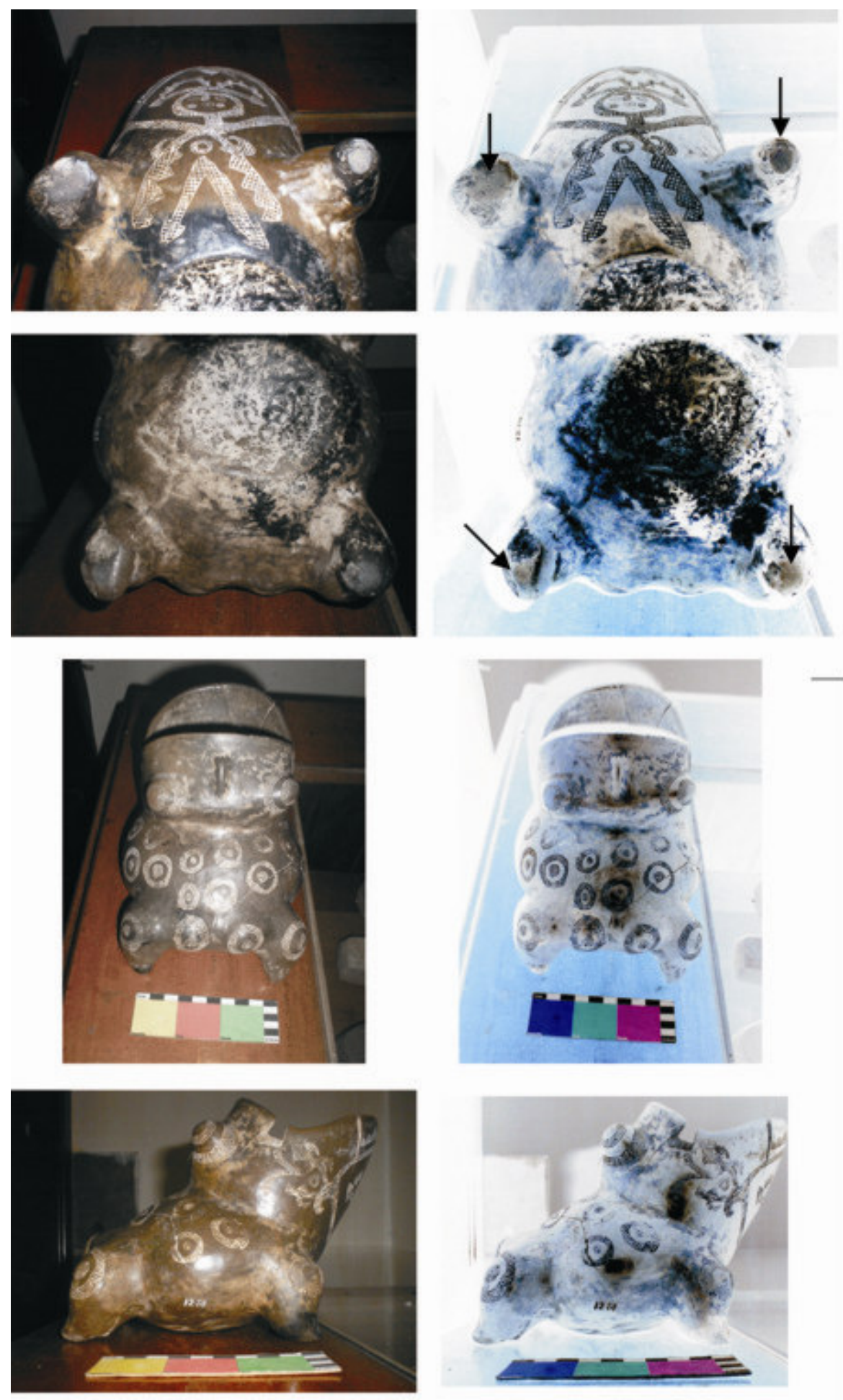

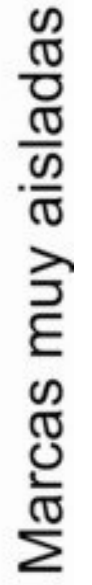
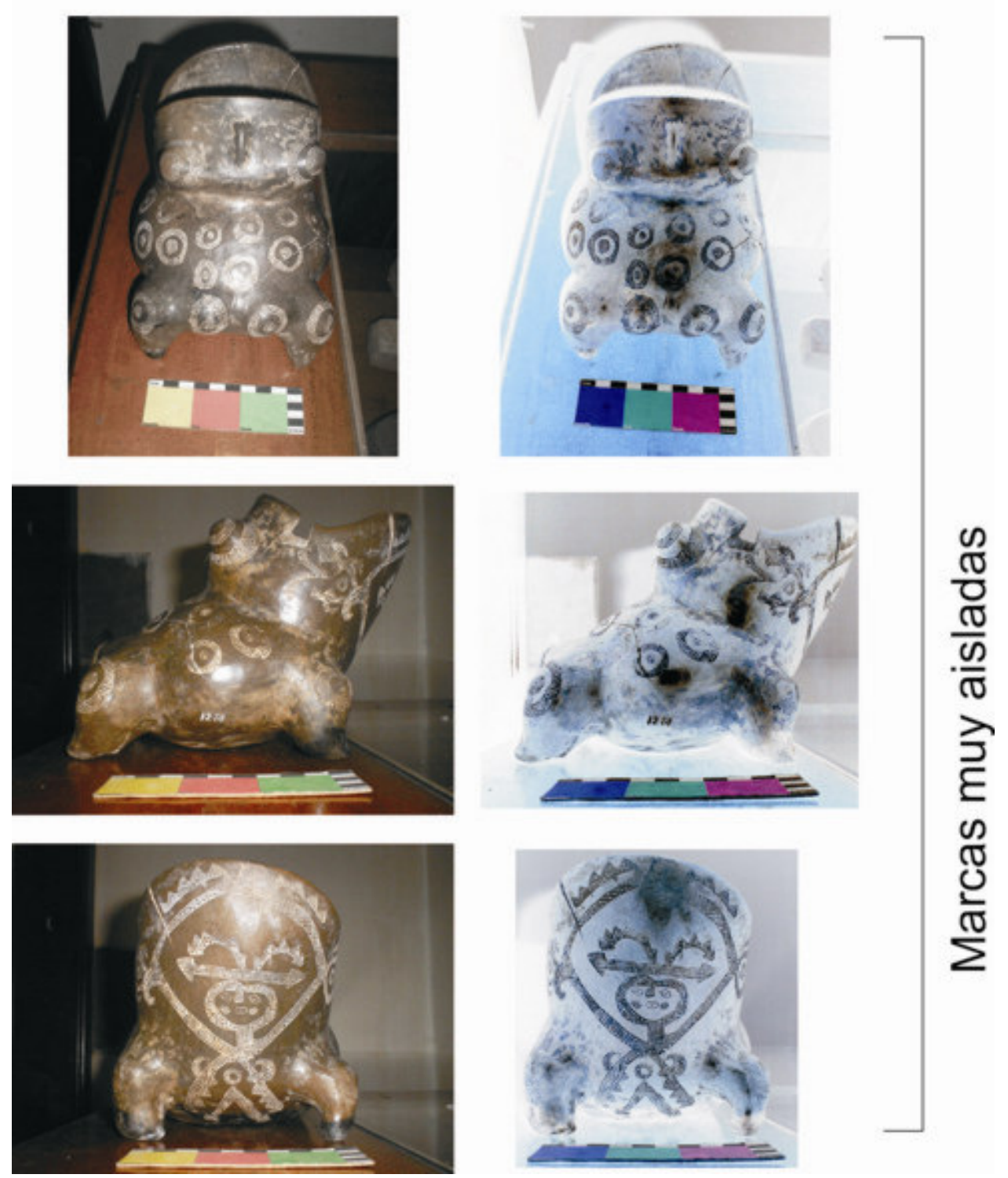

Figura 6.65: fotografías de una vasija modelada en forma de sapo. Se muestran los lotes en la zona de las patas y la ausencia de marcas y lotes en el resto de la superficie exterior. Las imágenes de la derecha se sometieron a un proceso de inversión de colores. Colección M.A.Q. 
su interior, en gran parte de la superficie. Además registramos dos fragmentos de vasijas aparentemente pequeñas, modeladas con rostros antropomorfos -figura 6.66-, semejantes a los esbozados al pastillaje en las vasijas de clase E forma "a". Ambas poseen superficies pulidas. Estos al igual que los otros fragmentos registrados casi no presentan marcas, una estría muy aislada en la parte interna de una de ellas. A su vez, la que presenta base plana solo está levemente desgastada -figura 6.66. Si bien es relativamente poca la información que tenemos de estas piezas y su presencia en la muestra es escasa, tenemos que todas las piezas analizadas -5 vasija distintas-, enteras y fragmentos con pocas huellas o marcas.
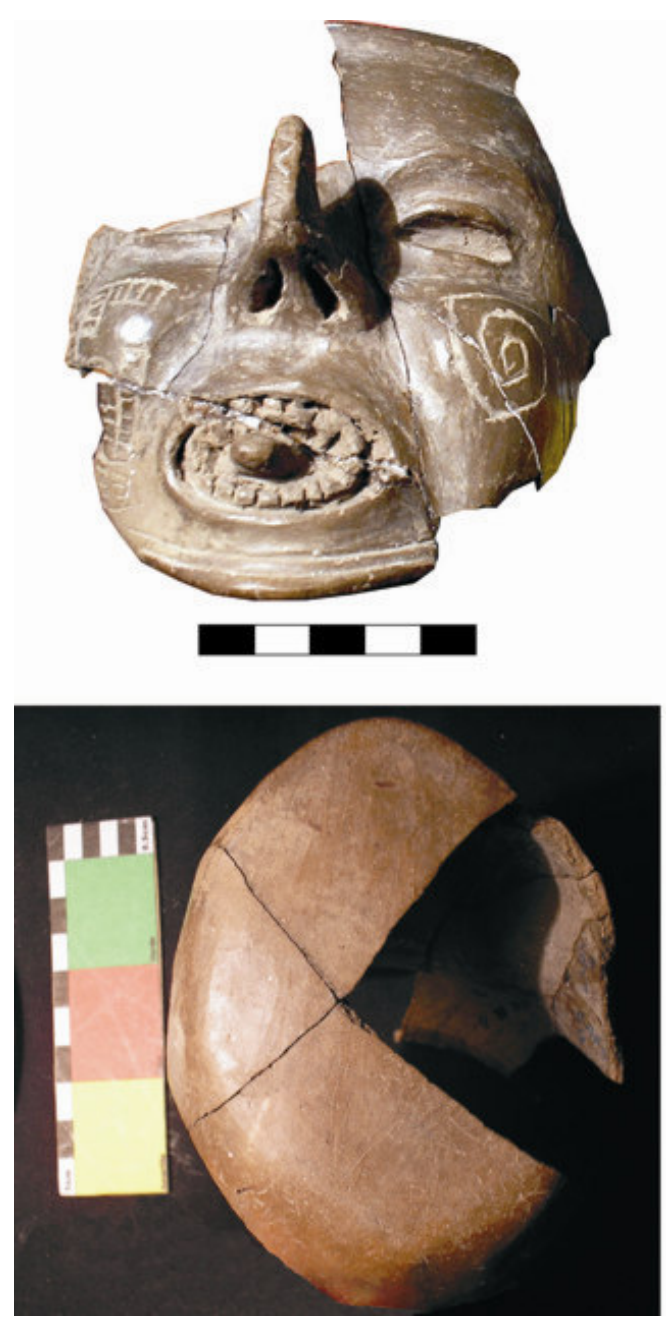
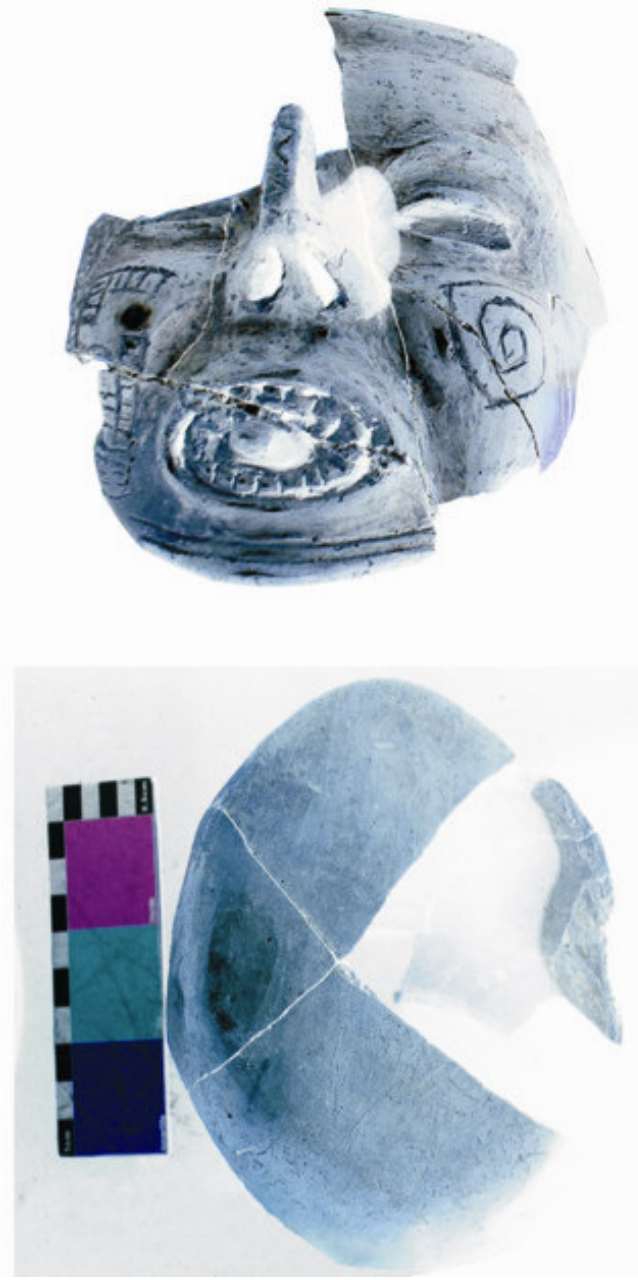

Figura 6.66: fotografías de una vasija modelada en forma rostro con nariz en gancho invertida. Se muestran las marcas aisladas en la zona de la base y la ausencia de marcas y lotes en el resto de la superficie exterior. Las imágenes de la derecha se sometieron a un proceso de inversión de colores.

Debemos tener en cuenta que el sapo proviene de una colección por lo cual no conocemos el tratamiento que ha recibido durante su trayectoria desde que fue hallado por lo que la erosión de la patas podría corresponder a este tiempo. Si embargo, lo que coincide con aquellas de las que sí conocemos la trayectoria y provienen de excavaciones y con un tratamiento de conservación adecuado, se correlacionan con la poca presencia de huellas. 
La erosión de la superficie de apoyo de las patas del sapo contrasta con la poca erosión del resto de la pieza; si confiamos en que gran parte de esta erosión proviene del contexto de uso nos indicaría un contacto frecuente de esta superficie con un abrasivo, y de contacto infrecuente con el resto de la pieza. Uno de los casos nos muestra la utilización de esta pieza para contener pigmentos.

La vasija calceiforme y las pertenecientes a las "otras formas" no presentan lotes ni marcas en su superficie exterior salvo en la zona de la base que presentan lotes pero muy leves. En la superficie interior no se observaron marcas ni lotes. Por otro lado no poseemos análisis de residuos orgánicos por lo que se hace muy difícil hipotetizar su forma de uso.

Habiendo descrito las huellas de uso observadas para cada una de las formas identificadas pasaremos ahora a analizar los contextos de usos en las cuales estas vasijas fueron halladas.

\section{b) Contextos y Prácticas}

La descripción de los contextos de uso donde se hallaron las vasijas analizadas, no solo nos permite observar en que otras prácticas, además de las ya inferidas, pudieron haber intervenido estos objetos, sino que también nos posibilita enmarcarlas en los lugares en donde éstas se desarrollaban. Además, nos facilita observar las relaciones entabladas con otros objetos y vasijas en dichos espacios. Para la descripción de los contextos de uso recorreremos los diferentes sitios de donde provienen los objetos analizados. A su vez, incorporamos los contextos de uso de otro sitio que ha sido excavado por otro equipo de investigación en el valle y que nos permitirá comprender aún más profundamente a estos objetos: La Rinconada o Iglesia de los Indios (Gordillo 2009).

Antes de continuar debemos realizar ciertos comentarios sobre la particularidad de la estratigrafía de los sitios analizados, específicamente de las habitaciones y de los espacios abiertos o galerías ${ }^{x v i}$. Es recurrente encontrar contextos bastante claros del final de la ocupación de los sitios, en tanto éstos acabaron incendiándose y la techumbre que se derrumbó debido al incendio aplastó todos los objetos que se estaban utilizando antes de la caída. A su vez, estos objetos en general se encuentran apoyando en pisos en algunos casos muy consolidados, como los hallados en los sitios Martínez 1, Martínez 2, Martínez 4 y el recinto $\mathrm{F}$ del sitio Piedras Blancas. En general los contextos que vamos a describir corresponden a la estructuración espacial existente antes del derrumbe de la techumbre. Por debajo de estos pisos, en general, disminuye notablemente la aparición de hallazgos, 
salvo un caso que analizaremos más adelante -el recinto $\mathrm{H}$ del sitio Piedras Blancas. Volveremos sobre esto en el penúltimo capítulo, particularmente en relación a la discusión de las interfacies de período (Harris 1991) y la configuración de geografías espaciotemporales que articulan las rutinas en las que las vasijas y los sujetos participan cotidianamente. Describimos los contextos para cada uno de los sitios excavados, empezando por los más pequeños Martínez 1 y Martínez 4, luego con sitios más grande como el sitio Martínez 2 y Piedras Blancas y, por último, los contextos del sitio Iglesia de los Indios. Esta forma de descripción nos permitirá realizar comparaciones entre sitios del mismo tamaño o entre éstos y los mayores.

\section{Los contextos del Sitio Martínez I}

Dentro de la clasificación realizada por Assandri (2007) se trata de un sitio mediano -clase M-. En un primer momento se lo caracterizó como una elevación de $0.50 \mathrm{~m}$ sobre el nivel del terreno, con un diámetro aproximado de $28 \mathrm{~m}$-figura 6.67-. Consta de una unidad-habitación y de un montículo basurero (Assandri 1991). Las excavaciones se realizaron en dos sectores de la unidad, detectándose en el sur parte del muro perimetral y del patio, y una habitación en el norte. En el sector sur el muro perimetral está construido con diversas técnicas arquitectónicas: barro batido en la cara externa, y piedra en la interna, combinando piedras planas aplicadas en forma vertical sobre el muro de barro, a modo de revestimiento, cantos rodados superpuestos y unidos por mortero de barro formando columnas que refuerzan el muro, y grandes piedras planas en la base de la pared con su eje mayor en sentido vertical (Assandri 1991). En el sector norte se delimitó una habitación de

aproximadamente $7 \mathrm{~m}$ de largo por $5 \mathrm{~m}$ de ancho, identificándose en los muros las técnicas constructivas ya descriptas. La ubicación de pozos de poste en el centro de la habitación y de restos de techos quemados reforzaría la hipótesis de un techado a 2 aguas o quizás a 4 aguas. Este sitio cuenta con un fechado radiocarbónico, realizado sobre carbón correspondiente a una estructura de techo, de $1770 \pm 90$ años C14 AP.

En total se abrieron 11 cuadrículas de 4m de lado: las cuadrículas 5A, 5a, 5b, 6a y 6B corresponden a la habitación techada; mientras que las cuadrículas 1a, 1B, 1C, 1D, 1E y 2a a sector de patio.

Durante la excavación de las cuadrículas 5 a y 5 B, a los 0,65 m aparecen los troncos quemados de la techumbre. Aplastados por éstos se hallan diversidad de objetos, entre ellos algunas de las vasijas aquí analizadas. Estos objetos están apoyados en un piso que 


\section{Sitio Martínez 1}

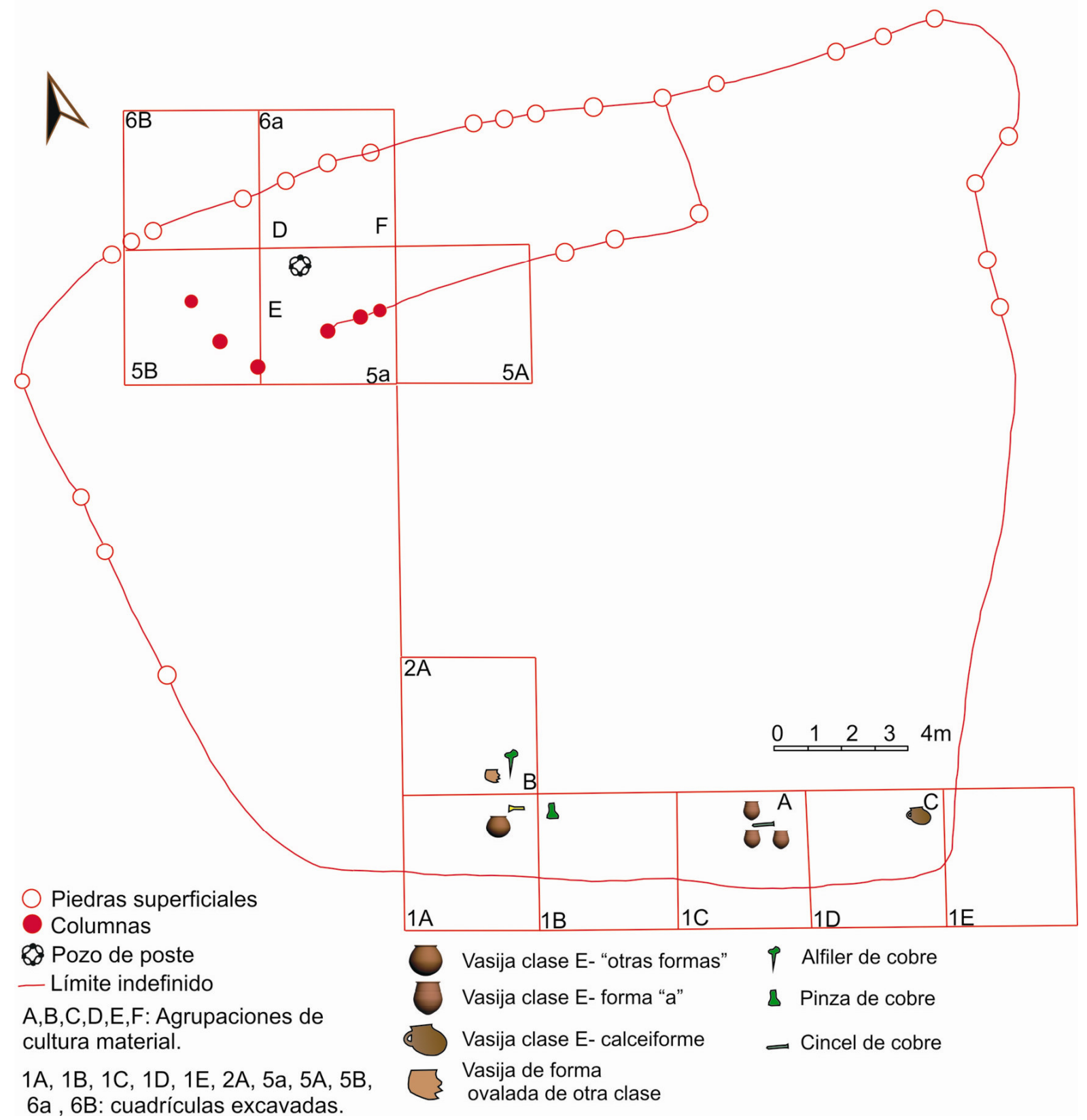

Figura 6.67: plano del sitio Martínez 1.

está conformado por un sedimento muy consolidado (Assandri 1991), que se encuentra a unos $0,20 \mathrm{~m}$ por debajo del piso hallado en el sector sur del patio, es decir que para ingresar a la habitación debe ser transpuesto un escalón. Esta característica la comparte con habitaciones techadas de otros sitios como son Martínez 2 y Piedras Blancas. La entrada a este recinto no fue identificada. Hacia el este contra el muro que divide las dos habitaciones aparece una banqueta de barro de baja altura de unos 0,50 $\mathrm{m}$ de ancho (Assandri 1991). En el sector central de la habitación se halló una estructura de sostén de poste con el poste carbonizado aún en su interior -figura 6.68-. Apoyando en el piso, se encontró gran cantidad de material: principalmente escudillas -algunas de ellas de clase 
A1-, vasijas globulares de clase E -"otras formas", forma "a" y "ab"-; e instrumentos de hueso, metal y piedra. En términos generales, del calco de las plantas que realizamos de las libretas de campo, más las descripciones realizadas por Assandri (1991) puede observarse que la mayor cantidad de material descrito y dibujado, así como los objetos de cerámica tanto pequeños como de mayor porte se encuentra concentrados en el sector central-oeste de la habitación, es decir desde la estructura de poste hacia la pared oeste -figura 6.68. No solo el material se concentra en esta zona si no que también las actividades vinculadas con el fuego, en tanto que se halló un fogón que se ubica hacia el SO de la estructura de poste. Desde el centro de la habitación hacia el este casi no se registran hallazgos de materiales sobre el piso, salvo contra el muro este, posiblemente apoyados sobre la banqueta. Dada la cercanía y asociación de los hallazgos, Assandri (1991) los agrupó en tres concentraciones de materiales que se denominaron con letras: d, e y f -figura 6.68-. La concentración d que se definió muy cercana a la estructura de poste hacia el noroeste de la misma, pero en el sector central de la habitación, se compone de una vasija de grandes dimensiones asociable a las "otras formas", esta vasija no presenta huellas de carbonización exteriores y las marcas presentes tanto en la superficie interior y exterior son hoyuelos. Si bien no conocemos la altura, en tanto no pudo reconstruirse completamente, posee un diámetro de boca $380 \mathrm{~mm}$. Junto a esta vasija se halló una escudilla de paredes divergentes de otra de las clases cerámicas definidas por Fabra (2008) -clase A3, ante lisa pulida- de unos 75 mm de altura y $190 \mathrm{~mm}$ de diámetro de boca. Hacia el este aparecen fragmentos de una vasija clase A1 con rostro modelado. Junto a estas tres vasijas se hallaron tres cinceles de metal, un pulidor de piedra y dos espátulas confeccionadas sobre una escápula de camélido y una estatuilla de cerámica antropomorfa fragmentada sin cabeza. La concentración E ubicada en la esquina suroeste de la habitación es la que presenta mayor cantidad de material. En la descripción realizada por Assandri (1991) se señala la presencia de dos escudillas entre las que se pudo reconstruir una negra gris grabada clase A1 de forma "d" (Bedano et al 1993) -no se pudo ubicarla espacialmente dentro de la concentración E-, esta pieza presenta el patrón de huellas característico observado que hemos descrito para todas las escudillas. También se registró otra escudilla ante pulida clase A3, -escudilla de forma "a" (Bedano et al 1993)- no se pudo ubicarla espacialmente dentro de la concentración E-. Una vasija de forma "b", ante pulida de clase A3 -tampoco se pudo ubicar en la concentración E-, y fragmentos que no llegan a formar una vasija entera, pero se reconstruye gran parte de la misma de una vasija perteneciente a las "otras formas" de clase E4 -mezcla 1-. También en la misma concentración aparecen fragmentos de una vasija de forma "b" clase A1 con las típicas huellas observadas y fragmentos de una vasija modelada con nariz en gancho. 
Además apareció un hornillo de pipa y un tubo fragmentado de pipa, tres espátulas de hueso -dos realizadas sobre escápulas de camélidos y una sobre un hueso largo-, un núcleo de cuarzo, una mano, un pulidor de piedra, tres fragmentos de pizarras con retalla y retalla bifacial, un tortero y dos fichas de cerámica -las pizarras y el tortero no se pudieron ubicar dentro de la concentración E-.

En el sector noreste de la habitación, posiblemente sobre la banqueta que corre paralela al muro este que divide este recinto del otro, se encuentra la cuarta concentración. En esta no se hallaron vasijas cerámicas, componiéndose de algunas herramientas realizadas en hueso, específicamente dos espátulas realizadas con escápulas de camélido, una lanzadera de telar confeccionada de material óseo, un pan de pintura rojo y dos cuentas de collar. Es de resaltar que en las libretas de campo confeccionadas por Assandri (19731974) se señala que una vez excavado el piso consolidado donde apoyaban la mayoría de los hallazgos, la frecuencia de aparición de hallazgos es muy aislada. Este hecho, como se verá a medida que continúe la descripción, se repite en la mayoría de los sitios analizados.

En la habitación techada tendríamos entonces: presencia de grandes vasijas clase E4 - mezcla 1- pertenecientes a las "otras formas" que poseen muy pocas marcas -sólo aparecen hoyuelos en la superficie interior-; asociadas a escudillas clase A1 -variedad d Bedano et al 1993- con evidencias de utilización, que muestran los típicos movimientos de las escudillas: inclinación, giro sobre el eje, astilladuras en los bordes, estrías perpendiculares y diagonales en la superficie interna vinculadas éstas últimas con actividades de revolver o mezclar. También en otro sector aparecen asociadas esta misma clase de vasijas a objetos de cerámica pertenecientes a otras clases tecnológicas: una escudilla de paredes divergente y una vasija de forma "b" -ambas de clase A3-. Es de resaltar que una de estas vasijas -“otras formas"- fragmentada aparece junto a un fogón, asociada a fragmentos de una vasija clase A1 con cara modelada. Sin embargo, la vasija de "otra forma" no presenta huellas observables de carbonización en su superficie externa. Lo que podemos observar hasta aquí un patrón recurrente de asociación de una o dos vasijas grandes de clase E -“otras formas"- junto a vasijas de menor tamaño -sean de clase A1 o de otra clase tecnológica cómo la A3-: escudillas y vasijas de forma b, que las hemos caracterizado como intermediarias en actividades de transferencia y servido, pero también de procesamiento. En las dos concentraciones donde aparecen estos conjuntos asociados también se encuentran herramientas como cinceles de metal y espátulas de hueso. También alfileres de metal y láminas de pizarra con retalla y retoque marginal (Aschero 1975), pulidores de piedra y placas de mica. 
De la excavación de las cuadrículas 2A, 1A, 1B, 1C, 1D y 1E en la zona del patio, se pudo observar la presencia del muro perimetral que rodea al sitio. Está construido en este sector con la técnica de tapia con columnas de piedras distribuidas regularmente, combinado en algunos sectores con mampuestos de piedra planas como revestimiento (Assandri 1991). El muro divide a las cuadrículas 1A, 1B, 1C, 1D y 1E en dos sectores, uno interno al sitio, que conformaría un espacio abierto, que es definido como patio (Assandri 1991) y otro externo al sitio. La cuadrícula 2A se halla completamente dentro del patio. En los sectores de las cuadrículas que dan hacia dentro del patio, Assandri (1991) encuentra que a los 0,70 $\mathrm{m}$ de profundidad $-0,20 \mathrm{~mm}$ sobre el piso de la habitación techada al norte- aparece un piso consolidado sobre el que apoyan variedad de objetos cerámicos una vasijas de forma calceiforme clase E2 -mezcla 5-, una vasijas de "otras formas" de grandes dimensiones, clase E4 -mezcla 1-, dos vasija de clase E4 -mezcla 1- forma "a" pintadas, una con rostro modelado al pastillaje, herramientas de metal de cobre -cinceles, pinzas, alfileres- y de hueso -punzón-, materia primas como placas de mica y panes de pintura roja. La distribución y asociación de materiales les permite distinguir tres sectores diferentes de concentración de material que les denomina a, b y c $\mathrm{c}^{\mathrm{xvii}}$-figura 6.67-.

La concentración "a" se distribuye entre la esquina NE de la cuadrículas $1 \mathrm{C}$ y la equina NO de la cuadrícula 1D. Se encontraron tres vasijas de grandes dimensiones de clase E1 -mezcla 1-. Una de $1000 \mathrm{~mm}$ de alto, que posee en el cuello un rostro modelado con la típica nariz en gancho a su vez está pintada de negro y blanco sobre rojo. El modelado y la pintura forman un personaje antropomorfo que porta posiblemente en una mano un arma y en la otra un escudo. La segunda vasija que también es de forma "a", es de menor altura y volumen, que al no estar completa (sólo el 40\%) no pudo determinarse con precisión su altura. Esta última también posee la superficie pintada, aunque no presenta modelado al pastillaje. La pintura dibuja una línea blanca con puntos negros justo en la unión del cuerpo con el cuello. La tercera vasija, está muy fragmentada y es también de forma "a" pero no posee decoración alguna, sólo está alisada. Junto a estas tres vasijas aparecen asociados un estatuilla de forma zoomorfa que representa un felino, discos de cerámica -fichas-, un punzón de hueso o lanzadera, un fragmento de tubo de pipa de cerámica pulida y materias primas como placas de mica y dos panes de pintura roja.

La concentración "b" se distribuye en el rincón SE de al cuadrícula 2A, en el rincón NE de la cuadrícula 1A, y en el rincón NO de la cuadrícula 1B. Se compone de: en el ángulo $\mathrm{SE}$ de la cuadrícula $2 \mathrm{~A}$ aparecen fragmentos que remontan de una vasija de sección ovalada de clase A3 (Fabra 2008) de $270 \mathrm{~mm}$ de diámetro por $180 \mathrm{~mm}$ de alto. (Assandri 
1991). En la esquina NE de la cuadrícula $1 \mathrm{~A}$ aparecen fragmentos que remontan de una vasija clase E4 -mezcla 1- pertenecientes a las "otras formas" de grandes dimensiones, posee una altura de $460 \mathrm{~mm}$, un diámetro máximo de $625 \mathrm{~mm}$, un diámetro de boca de 423 $\mathrm{mm}$ y un volumen de 100 litros. Posee muros espesos de unos $12 \mathrm{~mm}$ en el cuerpo y 9 en el borde. En relación a las huellas, se observan en la zona exterior parte media solo algunos hoyuelos, en la zona interior del borde, justo en el ángulo o filo de este se observa el antiplástico sobresaliendo, lo que indicaría dada la forma evertida del borde que entró en contacto con un abrasivo mas fino que la separación de los antiplástico, probablemente por ser colocada boca abajo sobre el piso. Quizás estuviera colocada de esta forma antes de romperse. En los sectores superiores, medios e inferiores de la superficie interna de la vasija sólo se observan algunos hoyuelos. No presenta huellas de carbonización. Junto a estas dos vasijas se hallaron un cincel de metal, 1 alfiler de metal, una laja de pizarra con retoque, dos discos de cerámica y una cuenta de colar de valva (Borus oblongus).

La Concentración "c" que se encuentra cerca de la esquina que forma al E el muro perimetral entre la esquina NE de al cuadrícula 1D y el sector NO de la 1E. La misma se compone de una vasija calceiforme clase E2 -mezcla 5- que posee huellas de carbonización tanto en la superficie interna como externa, dada la distribución de éstas, al igual que el resto de calceiformes analizadas, para que se produzca dicho patrón debió ser colocada sobre el fuego de forma inclinada. Posee alrededor de un litro de volumen, una altura de unos $150 \mathrm{~mm}$, un diámetro de boca de unos $120 \mathrm{~mm}$ y un diámetro máximo de unos $160 \mathrm{~mm}$. Asociado a esta vasija aparece un pulidor de piedra y una piedra de honda.

En el sector exterior al muro perimetral, específicamente de las cuadrícula 1B se halló una gran cantidad de cerámica fragmentada (732 fragmentos) pertenecientes a vasijas de distintas clases tecnológicas, estatuillas zoomorfas y antropomorfas y torteros (Assandri 1991). Este lugar es interpretado por la autora como de descarte de material cerámico vinculado a prácticas artesanales de confección de alfarería, que se llevarían a cabo del otro lado del muro, ya afuera del sitio.

Unos $28 \mathrm{~m}$ al E, muy cercano al paleocauce, se encuentra la que se denomina montículo basurero. Se excavó una cuadrícula de 4 metros de lado y de 0,90 de profundidad (Assandri 1991:65). De este lugar se obtuvieron restos malacológicos, de material óseo, metal y cerámico. Ente los cerámicos predomina los de clase A1 y los de clase E (Assandri 1991). Las formas más representadas son las escudillas, las vasijas b y las de forma "a" y "otros formas". Si pensamos en, la baja tasa de frecuencia de aparición por debajo de los pisos en la habitación excavada, la correlación de los materiales hallados 
en el montículo y los hallados al interior del sitio, nos estaría indican cierta dinámica vinculada al descarte de los objetos utilizados en el sitio en el montículo.

Cómo también lo observa Assandri (1991:69), existe una diferencia entre el sector de área abierta al sur -patio- con el sector norte -recinto cerrado y techado-. Es en el interior del recinto techado el único lugar -salvo sector de descarte por fuera del sitio y en montículo basurero- donde se registra la presencia de escudillas o vasijas modeladas o de forma b -clase A1 y A3-, pulidas y en algunos casos decoradas -pintadas e incisas; remontables en gran medida.

En el sector Sur junto al muro perimetral se observa cierto patrón diferencial: de forma separada aparecen, una vasija perteneciente a las "otras formas" junto a otra vasija ovalada. Por otro lado, tres vasijas de forma "a", dos de ellas pintadas y otra modelada y en un rincón una vasija de forma calceiforme con huellas de carbonización, que probablemente fueron producidas en otro lugar ya que en dicho rincón no hay evidencias de un fogón. Como veremos más adelante, estas vasijas, aparecen asociadas a pequeños fogones y piedras -lajas o rodados- que se utilizaban de soporte para colocarlas inclinadas por encima del fuego para cocinar o calentar el contenido que, como hemos señalado a parir de los análisis de residuos orgánicos, combinaba vegetales y carne. El preparado en general no alcanzó a ocupar todo el volumen que podía contener la olla. En este caso, dado que el volumen de la vasija es de un litro, sería de aproximadamente la mitad. Asociados a estas concentraciones aparecen herramientas de metal -cinceles y agujas-, panes de pintura -color rojo- y placas de micas. En el caso de la calceiforme aparece asociada a un pulidor de piedra y a un proyectil de honda. Como hemos señalado más arriba no existe la asociación observada en el recinto techado de vasijas grandes con otras más pequeñas, de otras clases tecnológicas. Si tenemos en cuenta la presencia de materias primas utilizadas en la fabricación de cerámica -mica como antiplástico-, la pintura color roja, más la presencia de herramientas como cinceles y espátulas, que servirían para proceso de desbastado y alisado de las vasijas (Espósito 2006, 2009) de forma "a" y "otras formas", y sumamos a ello la presencia de un espacio de descarte de material cerámico al otro lado del muro, la interpretación realizada por Assandri (1991), de que en este espacio abierto se habrían ejecutado actividades artesanales vinculadas a la alfarería, cobra fuerza. No obstante, como hemos señalado al identificar los probables lugares de fabricación de vasijas -tales como el sitio Martínez 2 y Martínez 4-, en este sitio no se hallaron panes de arcilla cruda o piezas no cocidas o con evidencia de fallos en su manufactura o cocción. Pero la presencia de contextos semejantes de asociación entre herramientas, materias 
primas y piezas cerámicas, hallados en aquellos sitios donde poseemos cierta información que permite entrever la realización de estas actividades podría apoyar la hipótesis de Assandri (1991). Esta última autora, también señala la posibilidad de que en estas vasijas se realizaron actividades de almacenamiento, particularmente en las de forma "a". Sin embargo si bien existe la posibilidad de que ese fuera el caso, los contextos en donde se han hallado gran número de estas vasijas almacenando algunas veces vegetales como chañar, que describiremos más adelante, se dan o en espacios abiertos pero techados como las galerías -sitios La Rinconada y Piedras Blancas- o en recintos cerrados y también techados -Martínez 2, Martínez 4, Piedras Blancas, La Rinconada-. En el espacio excavado en el sector sur de Martínez 1 no se han hallado evidencia de la existencia de techos, como lo fue en el recinto cerrado excavado en el sector norte. Por lo que si se encontraban almacenando lo estaría haciendo a la intemperie. Si a este hecho lo pensamos en relación a que los contextos de uso de estas vasijas en otros sitios (que describiremos más adelante), junto a sus huellas de uso y a los resultados de los análisis de residuos orgánicos, todo ello apunta a actividades que necesitan espacio más resguardados, como los que requiere la fermentación de chicha y el almacenado de productos vegetales y animales; en este sentido, el hecho de que se encuentren almacenando a la intemperie pierde sustento.

Por otro lado la autora señala que las concentraciones halladas en el recinto techado junto al muro norte, serían el lugar para guardar herramientas y materias primas vinculadas a las actividades artesanales, particularmente por la asociación de herramientas como los cinceles y las espátulas de hueso sea que estas últimas estén asociadas a las vasijas o guardas sobre la banqueta ubicada al norte. Pero también señala la realización de otras actividades domésticas como almacenamiento de alimentos e incluso el almacenamiento de las vasijas que se hubieren confeccionado en el sector externo al sur del sitio. Es sugerente al respecto que las vasijas grandes pertenecientes a las "otras formas" solo presenten hoyuelos aislados en su interior, es decir pocas marcas, y que aquella hallada junto a un fogón no presentara huellas de carbonización. Si pensamos en la distribución y asociación de estas vasijas con otras de tamaños más pequeños, que sí presenta huellas, y que esta agrupación es recurrente, a lo que sumamos que en la zona donde se concentran aparece un fogón y material óseo principalmente de huesos largo de camélidos fragmentados (pertenecientes a los cuartos traseros del animal, con huellas de descarne, cuereo o cortes longitudinales en la diáfisis), todo ello nos indica y refuerza que estas vasijas participaban de otro tipo de actividades vinculadas con el consumo de animales, además de las artesanales ya referidas. 


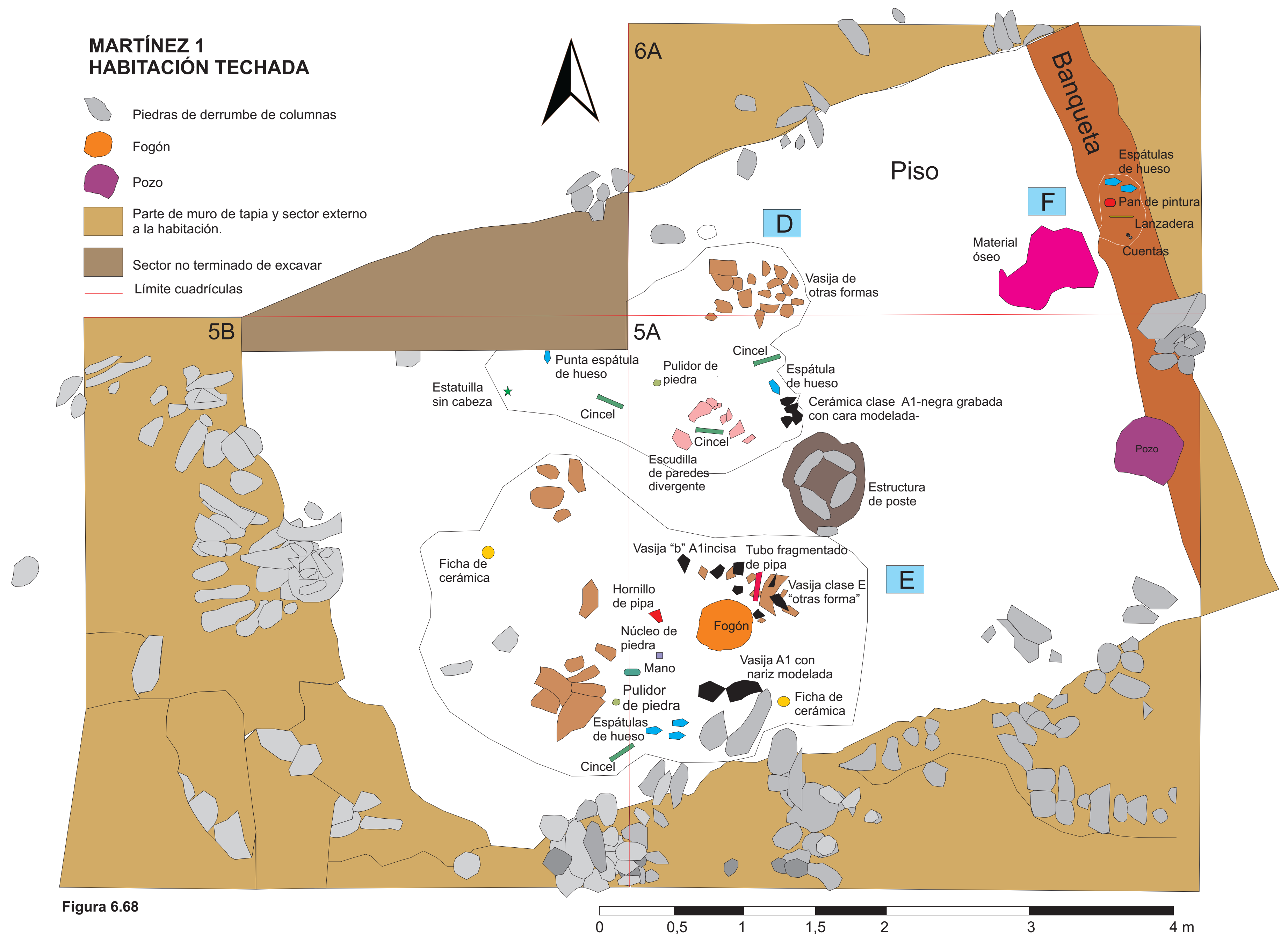




\section{Los contextos del sitio Martínez 4}

Este sitio es de forma trapezoidal de unos $170 \mathrm{~m}^{2}-10 \mathrm{~m}$ en sentido este-oeste y $17 \mathrm{~m}$ en sentido norte-sur (Herrero y Ávila 1991) -figura 6.69. Dentro de la categoría de Assandri (2007) es un sitio pequeño. Al mismo lo conforman una unidad-habitación y un área de galería o patio que se integran espacial y temporalmente al sitio Martínez 2 (Herrero y Ávila 1991, Juez 1991). El sector de habitación se delimita por paredes de barro amasado y columnas de piedras superpuestas, mientras que el área de mayor tamaño de la galería o patio se adosa hacia el este de la habitación en un sentido mayor este-oeste, estando abierto hacia el norte y existiendo probablemente otro recinto hacia el sur del patio, en un sector no excavado.

Se cuadriculó todo el sitio en cuadrículas de $4 \mathrm{~m}$ de lado. Se excavaron en el sector sur del sitio cuatro cuadrículas: 1B, 2B, 3B y 4B -figura 6.69-. De la excavación de estas cuadrículas se pudieron distinguir tres sectores diferentes: una habitación cerrada y techada -A- en el sector suroeste -Cuadrículas 4B y sector oeste de la cuadrícula 3B-, una galería techada -B- hacia el este de la habitación abierta hacia el norte, que corre en sentido esteoeste -sector este de la cuadrícula 3B, cuadrículas 2B y cuadrícula 1B-. Según los autores alrededor de los 0,60 m y 0,70 m de profundidad en la habitación se halló un piso sobre el que se disponían la mayoría de los hallazgos realizados. En el caso de la galería, éste se hallaba entre $\operatorname{los}$ 0,50 $\mathrm{m}$ y $\operatorname{los}$ 0,60 $\mathrm{m}$ de profundidad. En ambos casos aparecen cenizas, trancos quemadas y enramada, en algunos casos, los restos del techo estaban aplastando a los objetos que se hallaban apoyados sobre el piso. Un caso mencionado por los autores es el de una vasija clase E perteneciente a las “otras formas" que se encontró en la cuadrícula 1A aplastada por un tronco quemado -figura $6.69, \mathrm{n}^{\circ} 18$.

Existe cierta sectorización en la disposición y asociación de hallazgos sobre el pisos tanto en la galería, como en el recinto techado. En el caso del recinto techado observamos que la mayoría de los hallazgos se realizaron en el sector oeste de la habitación -mitad este de la cuadrícula 4B- En este sentido coincide con los observado en el recinto techado del sito Martínez 1. A su vez dentro de esta área, en el caso de las vasijas poseen cierta distribución diferencial en el espacio y cierta asociación a determinados elementos, particularmente restos óseos humanos. En relación a la distribución, si observamos el plano, se apreciará que las vasijas de clase E 1 y E4 -mezcla 1- aparecen hacia el este. A su vez tenemos que existe un conjunto al norte y otro cercano al muro sur de la habitación. Al norte existe una vasijas clase E1 -mezcla 1- pertenecientes a las "otras formas" de gran 
tamaño y con tres patas -figura 6.69, $\mathrm{n}^{\circ}$ 24-, la misma posee el patrón de huellas observado en los otras con estas características, específicamente nos referimos a las huellas de carbonización en la superficie exterior. En la zona si bien aparece lo que los autores denominan ceniza, no se registra un fogón. Asociados a esta vasija aparecen algunas astillas de huesos largos de camélido -figura 6.69, $\mathrm{n}^{\circ} 17$-. Cercana a esta vasija tetrápoda, a unos $0,60 \mathrm{~m}$ al sur oeste, aparece una vasija grande - figura $6.69, \mathrm{n}^{\circ} 1$ - aunque de menor tamaño que la que es tetrápoda. Probablemente esta vasija sea de forma "a", en tanto que, si bien, en esta zona solo se halló gran parte de un cuerpo globular clase E1 -mezcla 1-, más al sur, se halló una parte de un cuello y borde de una vasijas de forma "a" con el rostro modelado al pastillaje - figura 6.69, fragmento color marrón cercano a ${ }^{\circ} 3$ - que, si bien no remonta con la anterior, es de la misa clase y pertenece a una vasija de un tamaño semejante a la que puede inferirse del cuerpo reconstruido. El cuerpo remontado se asociada a restos humanos, específicamente fragmentos de huesos largos -figura 6.69, $\mathrm{n}^{\circ} 25$ - y fragmentos de cráneos - figura $6.69, \mathrm{n}^{\circ} 2$ - de por lo menos dos individuos. Las huellas observadas en la parte interna de las vasijas solo se presentan como hoyuelos, al igual que en la externa. En el borde, particularmente en sector interior del labio antiplástico sobresaliente que podría estar indicando que esta vasija fue en algún momento colocada boca abajo. En el sector sur oeste de la cuadrícula, junto al muro sur de la habitación aparece otra vasija clase E4 -mezcla 1- tetrápoda - figura $6.69, \mathrm{n}^{\circ} 5$ - que sólo presenta como huellas unos hoyuelos en la superficie exterior zona inferior y nada en la superficie interior. Muy cercano a esta vasija se encontró un punzón de hueso - figura 6.69, n ${ }^{\circ}$-. Hacia el oeste más cercano al muro oeste de la habitación se hallaron fragmentos de por lo menos tres escudillas negras gris grabadas $-n^{\circ} 3$ en plano- de $120 \mathrm{~mm}$ de diámetro de boca, que presentan los patrones típicos de huellas observadas para esta clase de formas de vasijas. Asociadas a estas escudillas aparecen resto de huesos largos de humanos. Más al sur, un vaso negro grabado con motivos antropomorfos clase A1- figura 6.69, $\mathrm{n}^{\circ} 4$-. Cercanos a esta concentración aparece una vasija de forma b clase A1 y una jarrita o vaso perteneciente a otra clase tecnológica pintada en negro sobre rojo -fragmentos color negro rincón sur oeste de cuadrícula 4B-. Los autores también señalan que por debajo de lo que se definió como piso aparece escaso material cerámico, en este sentido es semejante a lo observado por Assandri (1991) en la habitación techada del sitio Martínez 1.

En el sector de galería se pude realizar cierta sectorización interna según la distribución de los hallazgos. En general las vasijas de clase E que son de gran tamaño pertenecientes a la "otras formas" aparecen junto a los muros. Dos de ellas al este de al cuadrícula 3B, junto al muro que divide este sector del recinto. También aparece una de 
ellas, la que fue aplastada por los troncos al derrumbarse la galería del techo se halla en el rincón sur este de la galería. En esta zona, donde aparecen los fragmentos de la vasija, se menciona que también se hallaron restos de parte de un maxilar superior humano y astillas de huesos largos. Hacia el centro de la galería en sentido norte sur y en sentido este oeste cuadrícula 2B- aparecieron apoyando en el piso cinceles de metal - figura $6.69, \mathrm{n}^{\circ} 9$ y 8-, una espátula de huesos con un felino modelado en ambas caras en el extremo del cabo figura 6.69, $\mathrm{n}^{\circ} 7-, 5$ instrumentos de filita con filo retocado - figura $6.69, \mathrm{n}^{\circ} 15$ - y también algunas astillas de huesos largos de camélidos, una escápula y dos diáfisis. Según Herrero y Ávila (1991) al norte de la galería -rincón NE de cuadricula 2B, n 11 en figura 6.69, -, cercana al borde de la misma, se encontró una concentración de fragmentos de por lo menos 19 escudillas: 16 de clase A1 -12 con decoración incisa- y 3 de otras clases tecnológicas. También se halló una vasija $b$, un bol y una compuesta de paredes divergentes pertenecientes a otras clases tecnológica. En el relevamiento realizado de los materiales en la Dirección de Antropología de Catamarca no pudimos hallar las escudillas de clase A1 que habrían aparecido en este sector, por lo que no poseemos datos de tamaños y huellas. Si nos guiamos por la descripción realizada por los autores y por los patrones generales de huellas observados por nosotros podría conformar un sector de almacenaje de estas piezas. Siendo el área donde fueron hallados relativamente pequeña -1 a 1,5 $\mathrm{m}^{2}$ - nos indicaría que las escudillas podrían haber estado apiladas una encima de la otra. Recordemos que cierta huellas que aparecen recurrentemente en las escudillas -cachaduras y estrías paralelas en la zona media en inferior- las hemos referenciado a esta posibilidad. Sin embargo no podemos confirmarlo. Hacia el sur de la cuadrícula B contra el muro sur de la galería aparece cierta asociación particular de materiales, tenemos dos molinos planos de piedras, y entre ambos una mano de moler. Hacia el norte, muy cercano a la concentración de herramientas del centro de la cuadrícula, se encontró un pan de pintura roja $-n^{\circ} 12$ en figura 6.69; ocre hematítico, según Herrera y Ávila (1991)-, un pan de arcilla cruda y, fragmentos de clase E, probablemente de algunas d la vasijas de "otras formas" halladas contra el muro sur. Al este de uno de los morteros se encuentra una vasijas clase $\mathrm{A} 1 \mathrm{de}$ forma $\mathrm{b}-\mathrm{n}^{\circ} 14$ en figura 6.69-. Hacia el oste de donde aparece esta vasija también se encontró un instrumento realizado en material óseo - n 16 figura 6.69-. 
SITIO MARTÍNEZ 4

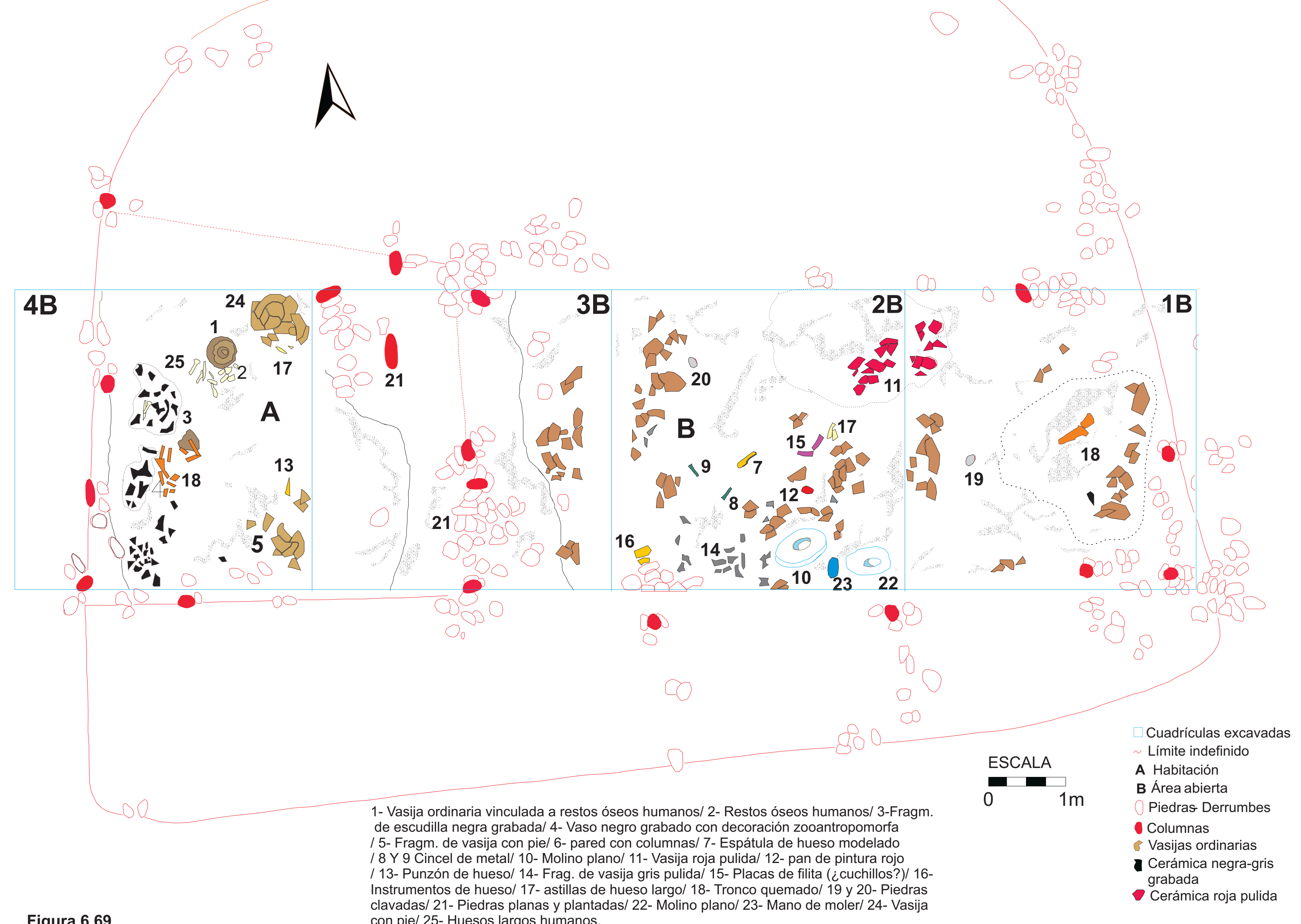




\section{Los contextos del sitio Martínez 2}

El sitio Martínez 2, que se encuentra unos $50 \mathrm{~m}$ al sur de Martínez 4 y a $100 \mathrm{~m}$ del río de Los Puestos, corresponde a un sitio grande dentro de la clasificación de Assandri (2007).

Presenta un muro perimetral de pirca doble, que encierra un espacio de forma subtrapezoidal de unos $716 \mathrm{~m}^{2}$-figura 6.70-. Internamente, a su vez, presenta dos sectores de habitaciones, uno ubicado al este y otro al oeste separados por un patio central.

El sector Oeste se trataría de tres habitaciones ubicada en sentido norte-sur. Adosada al este de dichas habitaciones corre una galería techada abierta hacia el este, de unos 2,5 m de ancho.

El sector este se compone de al menos tres habitaciones y posiblemente un cuarta, que corren en sentido norte-sur, que a su vez al igual que las del sector oeste presentan una galería techada abierta al este.

Las excavaciones se concentraron en ambos sectores tanto en las galerías abiertas como en algunos de los recintos techados. En todos los casos se observa una diferencia en la profundidad donde aparece lo que fue definido como piso, que en general, según la señala Juez (1991), en el interior de las habitaciones es bastante consolidado. En las habitaciones se presenta a $0,90 \mathrm{~m}$ de profundidad y en las galerías a $0,70 \mathrm{~m}$ de profundidad. Es decir que al igual que lo observado en el sitio Martínez 1 existe un desnivel de unos $0,20 \mathrm{~m}$, por lo que las habitaciones se hallan más unidas que los patios debiendo trasponer un escalón para ingresar a las mismas. Los fechados radiocarbónicos realizados sobre restos de carbón, señalaron una antigüedad de 1690 (+- 80) años BP para el Sector Oeste, y de 1510 años (+- 70) BP para el Sector Este (Laguens y Bonnin 1996:70).

Con respecto a la distribución de las vasijas a las que les trazamos las biografías podemos realizar cierta sectorización: entre sectores de recintos techados y galerías. Las vasijas de clase A1 -escudillas, vasijas de forma b y vasos o jarros, bol- se encuentran mayormente representadas en al interior de las habitaciones y no en las galerías. Mientras que las de clase E -vasijas de "otras formas" tetrápodos o de base cónica o convexa, calceiformes, vasijas de forma "a", "ab"- aparecen tanto al interior como en las galerías. A su vez podemos distinguir según los contextos de aparición de las vasijas de clase E, pero también de algunas de clase A1, en dos sectores: en uno estas se hallan almacenadas o 
guardadas a la espera de su utilización y en otros se hallan realizando alguna actividad particular. Al interior de las habitaciones encontramos cierta sectorización en relación a los

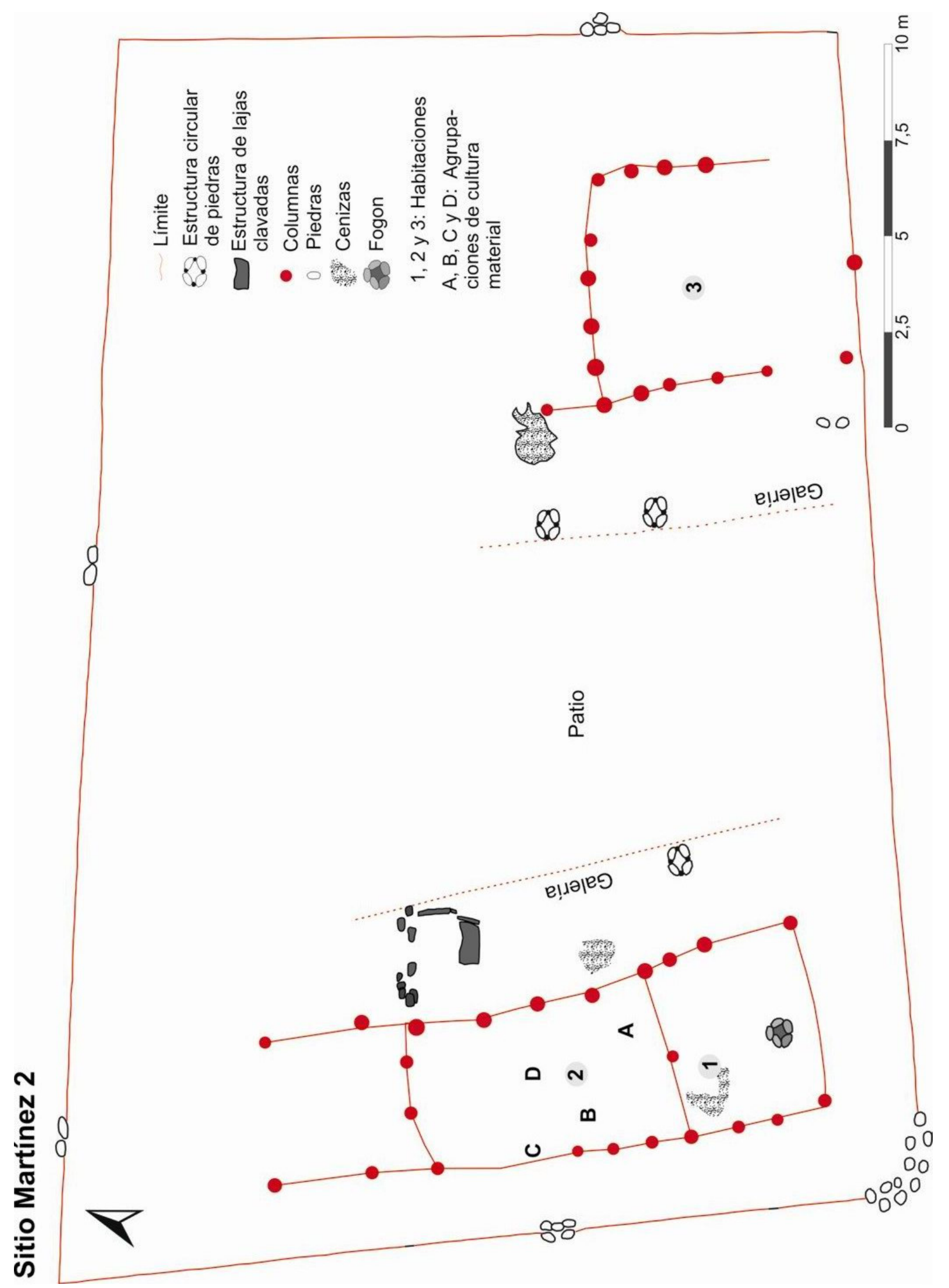

Figura 6.70: plano del sitio. 
lugares utilizados para realizar actividades y en relación a donde se encuentran las mayores distribuciones de hallazgo y de vasijas. Al igual que en el sitio Martínez 1 y Martínez 4 se concentran hacia los sectores centrales y sur oeste, dejando espacios vacío en el sector E y N. Ya sean esto para sectores de circulación o de descanso.

Sector Oeste. En la habitación 1 -figura 6.71, H1- se encontraron, alrededor de una estructura de piedra que delimita un fogón, varias vasijas de clase E2 y E5 -pertenecientes a las "otras formas" dos de ellas con patas-, algunas escudillas de clase A1, junto a una vasijas "b" y escudillas de otras clases cerámicas. Las vasijas se hallaban dispuestas y asociadas de la siguiente forma: $\mathrm{Al}$ este de la estructura, a unos 0,60 m de esta según las descripciones realizadas por Juez (1991), las fotografías tomadas y las plantas calcadas y reconstruidas de las libretas de campo por nosotros, se halló una vasija de "otras formas" figura 6.72-, clase E2 -mezcla 5- con asas horizontales remachadas en la zona media inferior de la vasija, asociada a restos humanos, entre ellos un cráneo muy fragmentado, con algunos elementos quemados y partes de una pelvis. Las huellas de carbonización se distribuyen en la base que es cónica y hasta la zona donde se hallan las asas. Las que a su vez presentan carbonización en la zona inferior y no en la superior. Además en la inferior y base sólo de un lado de la vasija se observa la presencia de antiplástico sobresaliente, lo que evidencia la fricción con una superficie que poseía abrasivos más finos que la separación de los antiplásticos. Las huellas de carbonización a su vez muestran que la vasija no habría estado apoyada directamente sobre el fogón sino sobreelevada. Con respecto a las huellas interiores se presentan de dos clases: en la zona media y parte inferior antiplástico sobresaliente, que lo señalamos como producto de la fermentación de bebidas en el interior de las vasijas. Y además en la zona inferior y base se observa la presencia adherida y carbonizada de una sustancia probablemente parte de lo que se cocinó en la vasija. Los análisis de residuos orgánicos sobre residuos adheridos (Pazzarelli 2006) señalan que la misma poseía presencia tanto de albúmina como de ácidos grasos. Es decir que estuvo en contacto tanto con grasas animales, grasas vegetales y carne. El tipo de huella observado, más el contexto de asociación a restos humanos concuerdan con estos análisis. Es interesante resaltar a la hora de pensar la biografía de estas vasijas pertenecientes a las "otras formas", que en este caso nos marca alternancia en prácticas distintas, algunas vinculadas con las cocción en donde participaban los humanos como ingredientes al igual que vegetales y otras prácticas vinculadas a la fermentación de bebidas. Al oeste de la estructura se halló otra vasija -figura 6.73- clase E5 (mezcla 4), recordemos que esta subclase presenta una baño negro interno, perteneciente a las "otras formas", posee un diámetro de boca de $260 \mathrm{~mm}$, una altura de unos $400 \mathrm{~mm}$ y un diámetro 
de $500 \mathrm{~mm}$. Esta presenta en las zonas medias marcas de carbonización que comienzan a difuminarse hacia las zonas inferiores y superiores, si bien no pudo observarse la zona de la base, aparentemente esta no poseía carbonización. En las zonas interiores no se observan marcas ni lotes. El patrón de huellas de carbonización observado nos marcan que la vasija probablemente halla sido colocada directamente sobre el fuego, lo que produjo que no se carbonizara la zona de la base y la zona inferior y sí la media ${ }^{\text {xiii }}$. Hacia el NO de esta vasija se señala la presencia de cenizas, pero no se habla de que estas constituyeran un fogón, sino deducimos que probablemente pertenezcan a parte de la techumbre incendiada y posteriormente derrumbada. A su vez entremezclados con los fragmentos de esta vasija se hallaron restos humanos, otro cráneo fragmentado con algunos elementos quemados, huesos largos de por lo menos tres individuos de diferentes edades -dos fémures, una tibia, un húmero, un cubito y un radio-, metacarpos y fragmentos de costillas. Al norte de la estructura aparece una vasija tetrápoda de clase E2 -mezcla 5- con una altura de unos 600 $\mathrm{m}$ un diámetro de boca de $460 \mathrm{~mm}$ y un diámetro máximo de $520 \mathrm{~mm}$. El volumen de la vasija es de unos 70 litros. Presenta en su superficie exterior huellas de carbonización típicas de las que poseen patas -ver gráfica más arriba-, en su interior se observan solo como marcas hoyuelos. Posee residuos adheridos en el fondo -base- de la vasija. Estos arrojaron presencia de ácidos grasos y ausencia de albúmina. Es decir contacto con grasas animales o vegetales y no con carne (Pazzarelli 2006). Asociadas a estas vasijas aparecen según fragmentos de por lo menos cuatro escudilla gris grabadas, de las que nosotros pudimos registra solo una de ellas, que es una escudilla "a" (Bedano et al 1993). Esta posee un diámetro de boca de unos $240 \mathrm{~mm}$, y aunque no pudo ser reconstruida por completo tendría una altura de unos $80 \mathrm{~mm}$, siendo el volumen aproximado de 2 litro. El patrón de estrías en la superficie externa e interna son las típicas observadas para estas escudillas mostrando movimientos de inclinación, rotación y una que combina a la vez rotación y traslación. No posee cachaduras en la zona media, sí algunas estrías paralelas. En el borde presenta un lote que produjo la extracción del pulido, por lo que nos puede indicar que en algún momento estuvo boca abajo. A su ve no presenta astilladuras en esta zona. La zona interior también presenta las típicas marcas asociadas a movimientos circulares de algún abrasivo, posiblemente algún tipo de instrumento. Cercano a ésta Juez señala la aparición de fragmentos de por lo menos tres escudillas pintadas negro sobre ante de otras clases tecnológicas, y una jarra pintada de negro sobre engobe rojo. A su vez, nosotros registramos la presencia de una vasija de forma "b", clase a1, sin decoración. Posee un diámetro de boca de unos $240 \mathrm{~mm}$ y un diámetro máximo de unos $360 \mathrm{~mm}$. Las huellas presentes son las típicas presentadas por las vasijas de forma "b". Inclinación y 
rotación sobre el eje de la pieza. En este caso en el sector inferior de la base presenta muchas estrías paralelas y diagonales, que podría estar indicando que la inclinación de la pieza fue mayor del patrón observado en el resto llegando a entrar en contacto las asas con el piso. Vuelve a presentarse en esta habitación la asociación entre grandes vasijas de "otras formas", algunas con patas junto a escudillas de varias clases tecnológicas y una vasija de forma "b". En este caso a diferencia del sitio Martínez 1, todas las vasijas se hallan o con evidencias de utilización en actividades de cocción en las que habrían participado como ingredientes individuos humanos. Así mismo la cocción de vegetales y la fermentación de bebidas. A diferencia de los contextos significativos de asociación de la habitación techada en sitio Martínez 1, la habitación 1 no presenta asociación de estas vasijas con herramientas y materias primas.

La habitación 2 -figura 6.71, H2-, ubicada la norte de la 1, separada por un muro de tapia con columnas de la anterior, posee unos 4,5 m de ancho y unos $7 \mathrm{~m}$ de largo. No se conoce exactamente donde se ubica la entrada a la habitación. Por la distribución de materiales, si es que se entraba desde una de las habitaciones, debió ser desde la tercera, al norte de la habitación 2 y, si no podría ser el caso, cómo ha sido registrado en otros sitios Piedras Blancas, recinto F- podría entrarse desde la galería. El piso al igual que la habitación 1 se halla 0,20 m por debajo del definido en la galería. En esta habitación Juez (1991) señala la presencia de cuatro concentraciones de material, que configura un espacio de agrupación mayor ubicado más hacia el sur oeste del recinto, existiendo menos presencia de material en los sectores norte y este. En este sentido es semejante a la sectorización del la habitación 1. Según al distribución y asociación de materiales Juez (1991) determinó cuatro concentraciones de materiales diferente: A, B, C y D -figura 6.71, H2-. En todas ella aparecen las vasijas analizadas aquí.

La concentración " $A$ ” que se ubica en el sector sur de la habitación junto al muro sur, sector centro-oeste de la habitación se compone dos vasijas de clase E de gran tamaño pertenecientes a las "otras formas" de unos $700 \mathrm{~mm}$ de altura que se asociaban a restos óseos humanos -pelvis y falanges- y de camélidos -extremidades-. Y cercana a estas una vasija de forma "b" sin asas clase A1. Asociados a estas tres vasijas y restos óseos se encontró también: tres pequeñas lajas de filitas con retoque marginal, un núcleo de cuarzo, una placa de mica, un cincel de metal y un pan de pintura blanca. Al sur este de la habitación a 1m aproximadamente de la concentración “a”, Juez (1991) señala la presencia de fragmentos de tres vasijas dos de ellas de otras clases tecnológicas y una de clase A1 forma "b" con motivos grabados. El motivo es un personaje antropomorfo que lleva en sus 
brazos a otro que presenta rasgos felínicos, como dientes bien marcados y vestimentas con representación de manchas. Esta última presenta muchas marcas y lotes en la superficie externa, que disminuye en el área donde se desarrolla el grabado. Las marcas indican inclinación, probablemente pronunciada dado la presencia de estrías paralelas y cachaduras, recurrentes en la línea del diámetro máximo y un poco por debajo de este. A su vez también las marcas indican giros alrededor del eje morfológico. En el borde se observan estrías paralelas y lotes, lo cual podría estar indicando que en algún momento fue colocada boca abajo y entró en contacto con algún tipo de abrasivo. En el interior presenta solo estrías paralelas en el borde y no presenta marcas en el resto de la superficie. La otras dos se tratan de una vasija incompleta de forma " $b$ " pintadas una negros y blanco sobre engobe rojo y, la otra una escudilla pintada de negro sobre engobe ante. Ambas poseen decoración un geométrica y la otra una cabeza de un felino con las fauces bien abierta.

En la concentración “ $B$ " Juez (1991) describe la presencia de fragmentos pertenecientes a dos vasijas grandes pintadas negro y blanco sobre rojo, nosotros no hemos podido relevarlas en la colección que se encuentra en los depósitos de la dirección de Antropología de la Provincia de Catamarca. Probablemente, aunque no lo mencione la autora sean de forma "a" en tanto que son las únicas vasijas grandes de clase E. Estas se encontraron asociadas a fragmentos óseos de humanos y de camélidos. En algunos huesos de camélidos como astrágalos, metapodios, vértebras caudal, falanges, se observan según la autora huellas de descarne. A su vez se presentan astillas de huesos largos con posible fractura intencional. Los huesos humanos consisten en partes de una pelvis, una falange, un tarsiano y fragmentos de costillas. La pelvis presentaría huellas de descarne. Específicamente de estas vasijas no poseemos registro de huellas ni medidas, en tanto no pudieron ser identificadas en la colección del sitio. Recordemos que en esta misma concentración aparece una escudilla no cocida con falla de fabricación que hemos descrito cuando analizamos los contextos de producción de vasijas en este sitio.

La concentración " $C$ ” junto al muro oeste a un metro más al norte de la concentración "b", que está formada por una vasija "a" muy fragmentada que posee pintura negra y blanca sobre rojo que se halla asociadas a restos fragmentados de humanos y camélidos. También aparecen asociado a la vasija y los huesos un apéndice de cerámica similar a una nariz en gancho típicas de estas formas. Según Juez (1991:29), los huesos de humanos hallados corresponden a dos individuos de diferente edad. Se tratan de una cabeza de fémur de un adulto que posee huellas de descarne y, el resto de huesos que aparecen corresponden a un peroné de niño y varias cosillas. Junto a estos restos aparece 
una epífisis proximal de camélido y astillas de huesos largos con posible fractura intencional. En nuestro relevamiento del material del sitio no hemos podido registrar este fragmento particular que describe Juez, pero sí hemos podido registrar otras partes de esta vasija, específicamente dos fragmentos de bordes, parte del cuello y el cuerpo. Todos están referidos en su rótulo a la concentración c, y al estar esta concentración compuesta por una sola vasija, inferimos que podrían pertenecer a la misma vasija fragmentada descripta por la autora. En uno de los fragmentos de borde se observa una franja diagonal de pintura roja sobre la pasta natural. Los dos fragmentos de borde, cuello y cuerpo pertenecen a la misma clase tecnológica E -mezcla 3- y poseen los mismos radios de boca, por lo cual refirma su pertenencia a una misma vasija. El diámetro de boca de esta vasija es de 280 $\mathrm{mm}$, el cuerpo tendría un diámetro aproximadamente de $530 \mathrm{~mm}$. Las huellas que presentan en la superficie exterior son: en la zona media y superior, hoyuelos y estrías perpendiculares al eje morfológico, en el borde no se observa ningún tipo de marca. Lo cual nos está indicando movimientos giratorios sobre el eje. En las superficie externa tenemos tanto en la zona media como en la superior una combinación de hoyuelos y antiplástico sobresaliente, también existen estrías perpendiculares al eje morfológico. No se observan huellas de carbonización en la superficie. Las marcas interiores nos estarían señalando la utilización de esta vasija para dos prácticas diferentes: aquella que involucra almacenar huesos de humanos y camélidos, o partes de cuerpos humanos de diferentes individuos y de camélidos y, según las huellas observadas, la participación en la fermentación de bebidas fermentadas (ej: chicha o aloja). De los análisis realizados por Pazzarelli (2006) sobre esta pieza arrojó tanto la presencia de ácidos grasos como albúmina, por lo que estuvo en contacto tanto con grasas vegetales, animales y carne.

La concentración " $D$ " ubicada en el centro del recinto, aparecen fragmentos de una vasija de clase E2- de gran porte, pudimos registrar solo el borde completo y parte superior del cuerpo, posee un diámetro de boca de unos $240 \mathrm{~mm}$ y, pertenece a las "otra formas", no presenta huellas de carbonización en la superficie exterior, a su vez en esta zona sólo aparecen algunos hoyuelos aislados y en el bordes no presenta marcas ni lotes. Esta se halló asociada a restos humanos y de camélidos fragmentados. Los huesos humanos según Juez (1991) se tratarían de un peroné, una tibia de infante, tres carpianos, o tarsianos, uno de los cuales presentaría huellas de descarne y un fragmento de pelvis. En cuanto a los huesos de camélidos se presentan astrálagos de dos individuos distintos, una epífisis 
proximal de tibia, un metapodio, una falange y un tarsiano. Todos según la autora presentan huellas de descarne.

En este habitación a diferencia de la Habitación 1 que por los hallazgos realizados se hacían cosas vinculadas con el cocido tanto de vegetales y animales, en la habitación 2 se trataría más bien de un lugar de almacenaje tanto de vasijas, herramientas y algunas materias primas, así como también de almacenaje de productos vegetales y carnes. Podría ser el caso que estos productos pasaran luego a la habitación donde se los cocinaba. O a la inversa ya cocidos eran guardados momentáneamente en esta. En ambas habitaciones encontramos asociación de vasijas grandes de "otras formas" y forma "a" a vasijas más pequeñas ", "ab", "b" y escudillas que las hemos identificados como intermediarias o finales respecto al consumo. Un aspecto interesante de las relación entre los contextos de uso y las vasijas analizadas es que nos permitieron conocer que una misma vasijas participó en más de una actividad, a lo largo de su vida: fermentación, almacenado de vegetales y o carne y cocinado.

Al este de las habitaciones se encuentra una galería techada -figura 6.71, G-, esta presenta dos banquetas - $\mathrm{a}$ y $\mathrm{b}$ - sobre las que se han hallado apoyadas varias vasijas principalmente de clase E de diferentes formas y subclases. En algunos casos sobre las banquetas se hallaron otro materiales como ciertas herramientas y también fragmentos óseos humanos. Sobre la banqueta $A$-figura 6.74- que se dispone al sur contra el muro esta de la habitación 1 y mide unos $0,60 \mathrm{~m}$, se encontraron tres vasijas de diferentes formas de clase E: una pertenecientes a las "otras formas" -figura 6.74, 1-, con un diámetro de boca de $240 \mathrm{~mm}$ y un diámetro máximo de $430 \mathrm{~mm}$, la altura no superaría según las proyecciones de las partes halladas los $500 \mathrm{~mm}$, presenta asas verticales remachadas en la zona superior del cuerpo. En cuanto a las huellas observadas, esta vasija presenta en la zona exterior inferior hasta unos 7 centímetros del diámetro máximo huellas de carbonización en la superficie externa, que se prolongaría casi hasta la base. No observándose otro tipo de marca. En la superficie interior presenta algunas estrías diagonales y perpendiculares, junto a hoyuelos. En el borde solo se presentan algunas estrías paralelas, probablemente de contacto con el instrumento con que se extraían los contenidos sometido al fuego. La análisis de residuos orgánicos indican del cuerpo indican la presencia tanto de ácidos grasos como albúmina. Otra de las vasijas que aparece es una de forma "ab" -figura 6.74, 2- pintada con asas remachadas horizontales, la que presenta en la zona exterior el patrón característico observado para estas vasijas y en el interior estrías perpendiculares junto a hoyuelos. A esta pieza no se le ha realizado análisis de 
residuos orgánicos. Además, en el extremo norte de la banqueta, junto a la vasija de "otras formas" -figura 6.74, 4-, aparece una vasija calceiforme clase E2 -figura 6.74, 3- de un diámetro de boca de unas $100 \mathrm{~mm}$, un diámetro máximo de $180 \mathrm{~mm}$ y un alto de $200 \mathrm{~mm}$; que presenta las huellas típicas de carbonización que suelen posee las vasijas de esta clase de forma. Junto a la vasija aparecen dos piedras de forma subredondeadas descriptas en la libretas como si estuvieran delimitando un fogón. Por lo que quizás esta parte de la banqueta, conformaba no un área de guardado de la vasija como lo parece el sector sur de la misma, si no de un fogón externo al recinto. Si pensamos en las piedras y el patrón de huellas de carbonización de la calceiforme, las que se colocaban inclinadas sobre el fuego necesitando par esto apoyo, estaría apoyando esta última hipótesis. Los residuos orgánicos de esta vasija dieron positivo para vegetales y carnes. Por la forma en que se hallaron estas vasijas estaban dispuesta boca arriba sobre la banqueta probablemente apoyadas contra la pared aquella con bases cóncavas como la que poseen las "otras formas". Al frente de esta banqueta, sobre el borde de la galería que da al patio, se encontraron apoyando sobre el piso una conana y dos manos de molino plano -figuras 6.71 , G y 6.74, 5,6 y 7-. Cercana a estos hallazgos pudimos registrar un fragmento de una vasija con muy bajo porcentaje de arco -5\%-, más que corresponde a uno de los platos grande clase $\mathrm{E} 4$, que posee un diámetro de boca de unos $570 \mathrm{~mm}$. El patrón de huellas presentas es en la superficie externa estrías perpendiculares al eje y un sector circular restringido de antiplástico sobresaliente. En el interior posee estrías perpendiculares al eje. Y en el borde tanto en el exterior como en el interior presenta astilladuras. No podemos señalar que se hallaba entera esta piezas en este lugar, parece ser un fragmento aislado, pero es el primer contexto de los que venimos analizando donde aparece este tipo de piezas, en una galería y cercana a manos y una canana. Recordemos que a este tipo de platos los relacionamos con actividades de procesamiento y que de los análisis de residuos orgánicos, realizados sobre esta forma de vasijas arrojaron presencia de ácidos grasos y no albúmina -carne-

Juez (1991) señala que hacia el norte de la habitación, alineada con la estructura de poste aparece la banqueta $B$-figura 6.71, G, cuadrícula 3G-. Asociada a esta estructura, tanto colocadas sobre la misma o apoyadas en el piso de la galería a lado de la misma, se han encontrado por lo menos 6 vasijas fragmentadas de variedad de formas. Algunas de ella se hallaron asociadas a herramientas y materias primas, tales como pigmento blanco y mica. Concretamente aparecen: una vasija de clase E2 pertenecientes a las "otras formas" con asas remachadas en semianillo horizontal -figura $6.71, \mathrm{G}, \mathrm{n}^{\circ} 1$ - que posee un diámetro de boca de $400 \mathrm{~mm}$ y un diámetro máximo de $500 \mathrm{~mm}$ y unos $570 \mathrm{~mm}$ de alto. Con un volumen de unos 79 litros. Más del 60\% de porcentaje de arco en las zonas de borde, 
cuerpo y base. En la superficie externa presenta huellas de carbonización hasta unos centímetros por encima del diámetro máximo y en la zona de la base, en las asas la carbonización no alcanza a cubrir la parte superior del asa, es decir que la vasija no fue colocada directamente sobre el fuego si no probablemente por encima de este. En el borde, específicamente en el sector que da hacia el interior de la vasija, se observa la presencia de antiplástico sobresaliente, indicándonos que esta zona entró en contacto con abrasivos. Como hemos señalado al analizar el patrón general de huellas que presentan estas vasijas, podría estar indicando su colocación en algún momento boca abajo. En la superficie interior, presenta estrías perpendiculares y diagonales, más hoyuelos. Los fragmentos de esta vasija si se observa la planta se hallan repartidos en la banqueta y debajo de la misma, apareciendo asociadas a un cráneo y un hueso largo de humano. Hacia el norte -figura $6.71, \mathrm{G}, \mathrm{n}^{\circ} 2-$, se halló parte de una vasija de forma "a" de clase E1, con rostro modelado que presenta la típica nariz en gancho asociadas a esta forma. Posee un diámetro de boca de $360 \mathrm{~mm}$ y un diámetro máximo de cuerpo de $440 \mathrm{~mm}$. Se reconstruye gran parte de la vasija, con porcentaje de arco del borde, cuello y parte superior del cuerpo del $100 \%$. En cuanto a las huellas presentes tenemos que en la superficie exterior parte media presenta algunas estrías perpendiculares y paralelas, son bastante aisladas. Esto nos indica movimientos de giro e inclinación. En la zona del borde tanto interna como externa se observa antiplástico sobresaliente, lo cual cómo la vasija anterior nos indica que esta en algún momento fue colocada boca abajo. En la superficie interna del cuello aparece antiplástico sobresaliente y en la zona del cuerpo parte media aparece antiplástico sobresaliente y lotes de forma irregulares. Nos muestra fuertes procesos erosivos probablemente vinculados a la fermentación de bebida. Los análisis de residuos orgánicos muestran que estuvo en contacto solo con grasas animales y/o vegetales y no con carne. Una observación interesante de realizar de esta pieza es que las fracturas, específicamente las inferiores del cuerpo son parejas y forman una superficie plana que podría utilizarse de apoyo para otras vasijas tal como fue hallado por Gordillo (2009) en la Rinconada. Esto nos habla de un proceso posterior al uso de la vasija; la que una vez rota o dejada de usar fue reconvertida en otro objeto, en este caso soporte para otras vasijas. Además nos indica que el resto de las fracturas que posee la vasija fueron posteriores a las fracturas inferiores del cuerpo, en tanto no hay indicios de reparación. Este hecho nos deja dos posibilidades: o, la vasija se fracturó sólo en la sección inferior del cuerpo y la base, por lo que en este caso se reutilizó y reconvirtió la parte sana. O se utilizó una vasija que no estaba rota, pero que ya no se tenía intención de utilizarla para fermentar chicha y, se decidió transformarla en soporte. Al lado de esta vasija, junto a una canana - figura $6.71, \mathrm{G}, \mathrm{n}^{\circ} 3$-, se encontró 
una vasijita calceiforme, clase E2, del mismo tamaño que la hallada en la banqueta A y con las huellas de carbonización típicas de estas vasijas. Los residuos orgánicos arrojan la presencia de ácidos grasos y albúmina (Pazzarelli 2006). Al sur de donde aparece esta concentración -figura 6.71, n5- se halló una vasija de clase E1 de forma "a" pintada de color negro, blanco y rojo sobre pasta natural. Posee un diámetro de boca de $380 \mathrm{~mm}$, la zona del borde y el cuello poseen un porcentaje de arco del 50\%. En relación a las huellas observadas en la zona exterior no presenta marcas ni lotes. En cambio en la interior sí: en el borde zona interior presenta antiplástico sobresaliente, justo en el ángulo recto que forma el labio, esto nos sugiere que en algún momento estuvo boca abajo apoyada sobre una superficie abrasiva. En la zona del cuello aparece antiplástico sobresaliente y hacia la zona más inferior del cuello aparecen lotes con fuerte erosión. De los análisis de residuos orgánicos de las vasijas halladas en la banqueta de esta forma de clase E1, todas arrojan presencia de ácidos grasos y no albúmina. Por lo cual indican contacto con grasas animales y/o vegetales y no con carne. Las huellas observadas más los análisis de residuos orgánicos apuntarían a la fermentación de bebidas. Junto a esta vasija se hallaron apoyando sobre la banqueta huesos humanos -un peroné y dos tarsianos-, junto a un punzón de huesos, una mano de mortero de cuarzo blanco, un pan de pintura blanca y placas de mica. Al lado aparece una vasija de contorno inflexionado perteneciente a otra clase tecnológica cuadrícula -figura 6.71, G, $\mathrm{n}^{\circ} 4$-. Presenta decoración de cabezas romboidales en negro sobre una pintura blanca que según Juez (1991) debió cubrir toda la superficie externa; teniendo la superficie interna negra y muy alisada. En el borde de la banqueta, hacia el sur -figura 6.71, G, $\mathrm{n}^{\circ} 6$-, aparecen aplastado por un derrumbe de columnas fragmentos de una vasija de forma "b" clase A1. Hemos podido registrar parte del cuerpo $170 \mathrm{~mm}-16 \%$ de arco-, presentado asas remachadas en seminalillo horizontales. En la superficie exterior presenta los típicos patrones de huellas descritos para esta forma de vasijas que nos indican movimientos de inclinación y rotación sobre el eje. En el interior no presenta pulimento y no se observan marcas ni lotes. Hacia el este de la galería en el borde, aparecen fragmentos de vasijas de otras clases tecnológicas y fragmentos de una vasija b-figura $6.71, \mathrm{G}, \mathrm{n}^{\circ} 7$-. Posee un diámetro de boca de $200 \mathrm{~mm}$ y un diámetro máximo de $130 \mathrm{~mm}$. Está representada en un $20 \%$ del arco, la base no se ha encontrado. En relación a las huellas observadas presenta en el sector exterior parte media estrías perpendiculares y paralelas específicamente en la zona del diámetro máximo, y en el superior estrías paralelas y perpendiculares más aisladas. Este patrón está de acuerdo con el general observado para estas vasijas. Alrededor de todo el labio presenta lotes bastante pronunciados por lo que puede inferirse que esta vasija fue colocada, en algún momento, boca abajo. En la zona 
interior del cuello presenta estrías perpendiculares, paralelas y diagonales; en la zona interior parte media casi no se observan huellas. Si uno observa los dibujos de planta donde se halla esta vasija se encuentra no solo en el borde de la galería si no alineada con otras vasijas que pertenecen a otras clases tecnológicas.

Si nos dirigimos más al norte de la galería -figura 6.71, G-, aparentemente la banqueta B termina, aunque no se sabe dónde exactamente. Entre la cuadrícula 3C y 3D a $1 \mathrm{~m}$ de distancia al norte de la canana y, sobre el piso se destacan dos concentraciones: una que se compone de una vasija de forma "ab", que no hemos podido identificar, asociada a retos óseos humanos -un parietal, un malar, parte de un conducto auditivo y una epífisis proximal-. Al lado, a unos $0,30 \mathrm{~m}$ a $0,40 \mathrm{~m}$ aparece una pipa fragmentada asociada a fragmentos de huesos largos, un tarsiano humano. Dada la cercanía de la otra vasija de forma $\mathrm{ab}$, probablemente estos restos óseos pertenezcan a ese conjunto. Más al norte a unos $0,70 \mathrm{~m}$ a $0,60 \mathrm{~m}$ aparecen un fragmento de cuerpo y asa -en semianillo horizontal remachada- de una vasija perteneciente a las "otras formas" de clase E2 (mezcla- 5) con un $10 \%$ de porcentaje de arco. Tiene un diámetro máximo de unos $240 \mathrm{~mm}$. Posee huellas de carbonización en su superficie externa que provienen desde la zona inferior. En el asa las marcas de carbonización se encuentran en la zona inferior y no en la superior. En la zona interior del cuerpo esta no presenta marcas. Al norte de ese fragmento aparece un conjunto de fragmentos pertenecientes ana vasija clase E4 -mezcla 4- pertenecientes a las "otras formas" posee asas en semianillo horizontal remachadas. El diámetro de borde es de $240 \mathrm{~mm}$ y el diámetro máximo es de $450 \mathrm{~mm}$, no conocemos la altura por que no hemos podido remontar los fragmentos pero si comparamos con otras vasijas en las que hemos podido proyectar esta medida no superaría los $50 \mathrm{~cm}$ de alto. En relación a las huellas observadas esta en la zona exterior parte inferior y base, aparece antiplástico sobresaliente y hoyuelos; ya en la parte media se presentan hoyuelos y estrías perpendiculares, y en la zona exterior del borde aparecen algunas astilladuras. En la zona interior del borde existen presencia de astilladuras y antiplástico sobresaliente por lo que nos estría indicando que en algún momento esta vasija fue colocada boca abajo. En el interior en distinta zonas -cuello cuerpo -parte media e inferior- aparece antiplástico sobresaliente, típicas huellas que asociamos a la fermentación de bebida. Esta vasija no presenta huellas de carbonización. De los análisis de residuos orgánicos realizados sobre fragmentos pertenecientes a la clase E4 de estas cuadrículas específicamente en sectores de cuerpo, arroja o ausencia de ácidos grasos y albúmina, presencia de sólo ácidos grasos, o presencia de ambos. La única muestra analizada por Pazzarelli (2006) de clase E4, que posee desgaste -antiplástico sobresaliente- como es el caso de la vasija analizada aquí arroja la presencia tanto de 
ácidos grasos como albúmina. Cercano a esta vasija aparece una espátula de huesos. Hacia el centro y Oeste de la cuadrícula, probablemente contra el muro del recinto, pero dentro de la galería, aparece un conjunto de fragmentos de una vasija pertenecientes a las "otras formas" pero tetrápoda de clase E2 -mezcla 5-. Si bien en las libretas se describe que apareció gran parte de la vasija, hemos podido identificar el sector de la base donde salen las patas. El diámetro en este sector es de unos $280 \mathrm{~mm}$, por lo que si lo comparamos con otras vasijas tetrápodos este tendría una altura de unos 600 a $700 \mathrm{~mm}$ incluyendo las patas que en general elevan la base de la vasija unos $0,15 \mathrm{~m}$ del piso. En la zona exterior presenta las típicas huellas de carbonización. Y en la zona interior no presenta huellas. Según los análisis de Pazzarelli (2006) de dos fragmentos analizados de clase E2 en esta cuadriculas ambos poseen presencia de ácidos grasos y albúmina.

Sector Este -figura 6.75-. En este sector los hallazgos fueron más escasos que en el Oeste, probablemente debido a la menor extensión y profundidad de excavación en algunos sectores. Se compone al igual que el área oeste de una galería, en este caso abierta al oeste y de recintos cerrados y techados. En estos se aparecieron muy pocos fragmentos de vasijas. En el interior de la habitaciones aparece en el área de un pasillo de la primera habitación al sur se describe la aparición de algunos fragmentos cerámicos de clase E muy pequeños. En el sector de galería, según Juez (1991), junto a la primera estructura de poste sur, aparecen fragmentos pertenecientes a dos vasijas ordinarias -probablemente de clase E-. Pudimos registrar el cuerpo de una vasija de clase E2 -mezcla 5- que presenta huellas de carbonización en la superficie exterior y poseería un diámetro máximo aproximado de $430 \mathrm{~mm}$. En la zona interior solo presenta hoyuelos. De tres muestras de cuerpo analizadas por Pazzarelli (2006) dos arrojan ausencia de residuos orgánicos y una presencia de ácidos grasos. Al norte de esta vasija cercana a la otra estructura de poste pero más al este aparece los restos de una vasijas clase E2 -mezcla5- forma "a" muy fragmentada. Posee un diámetro de boca de unos $220 \mathrm{~mm}$ y un diámetro máximo de $500 \mathrm{~mm}$. El porcentaje de arco es de $40 \%$. En relación a las huellas observadas esta presenta en la zona interior antiplástico sobresaliente tanto en la zona del cuello y media del cuerpo. En la superficie exterior presenta solo algunos hoyuelos. De cinco muestra analizadas por Pazzarelli (2006) de cuerpo de vasijas de clase E2 en este cuadrícula tenemos que dos no presentan residuos orgánicos, una presenta ambas clases y otra dos solo albúmina. Por lo que podemos decir que según las huellas observadas en el interior y los residuos orgánicos esta vasija ha estado en contacto tanto con carne como con vegetales. Cercana de esta vasija a unos 0,60 a $0,70 \mathrm{~m}$ al norte aparece parte de una mandíbula inferior de humano. 


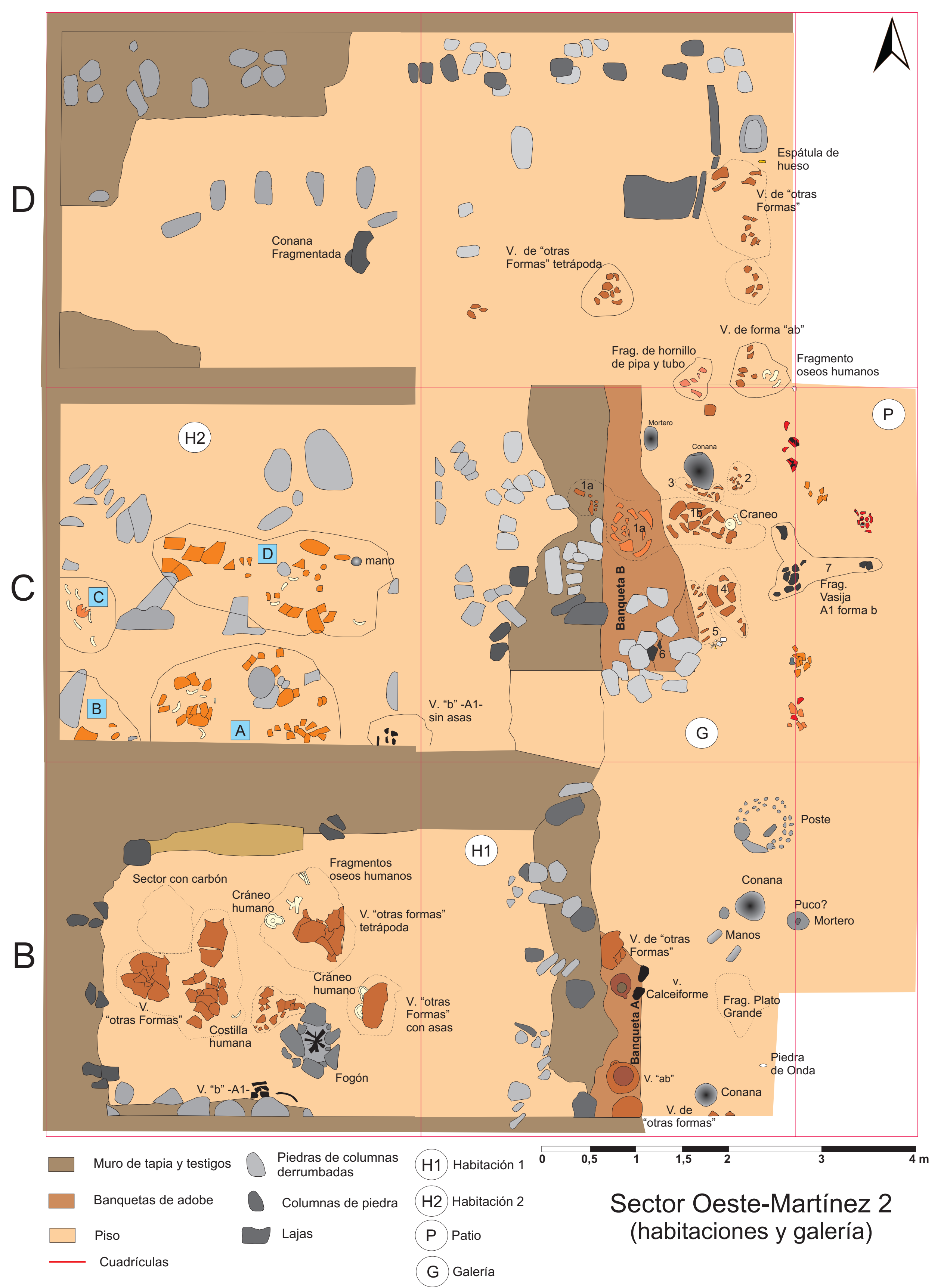

Figura 6.71: planta del sector oeste del sitio Martínez 2. Cubre el sector de Habitación H1 y H 2 y, la galería G que corre al este de estos en sentido norte-sur. 


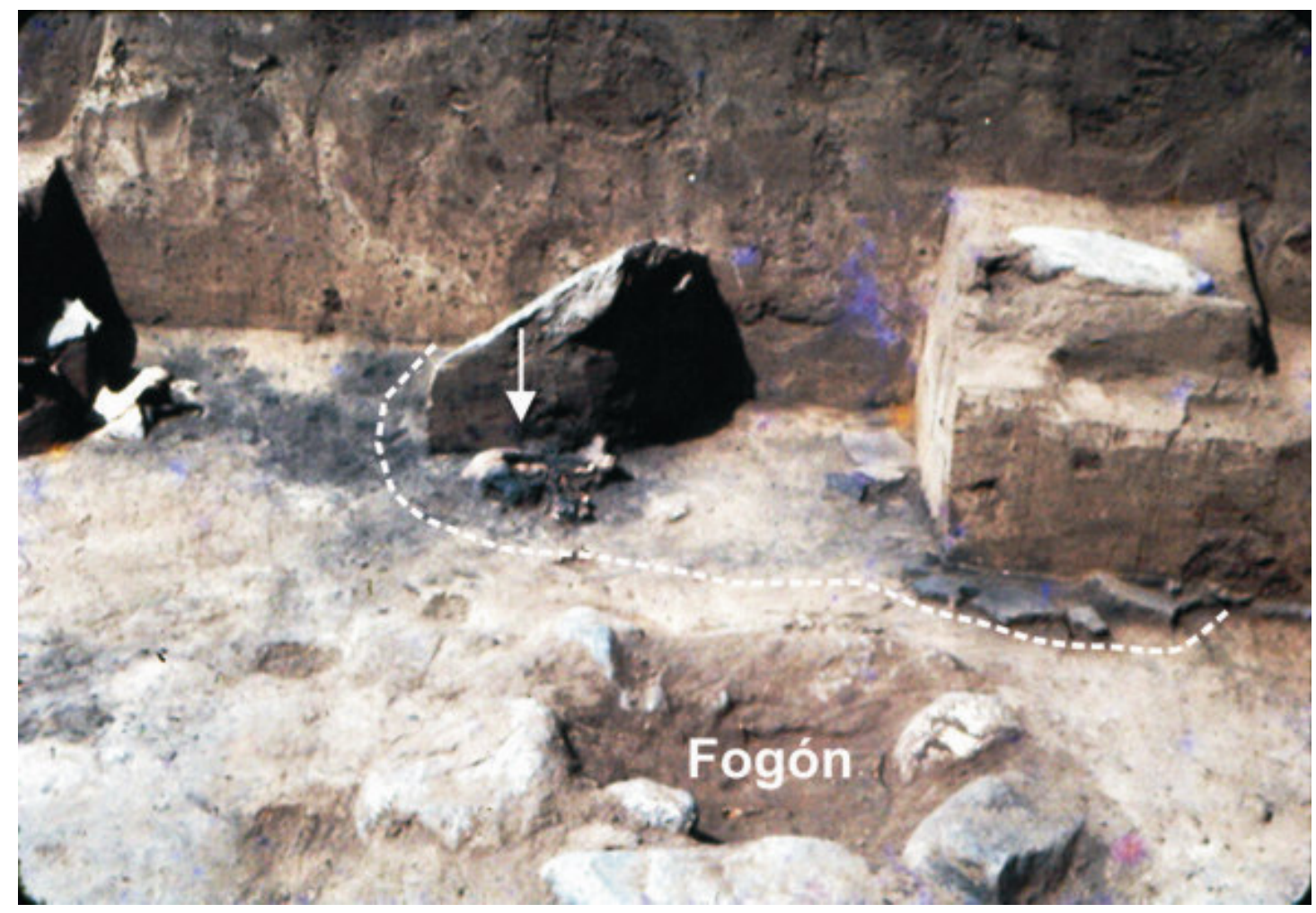

Figura 6.72: fotografía en donde se observa el fogón hallado en la habitación 1 del sitio Martínez 2 y, hacia el oeste, restos carbonizados de una vasija de "otras formas" -con asas remachadas en posición horizontal en el sector medio del cuerpo- y un cráneo humano aplastado.

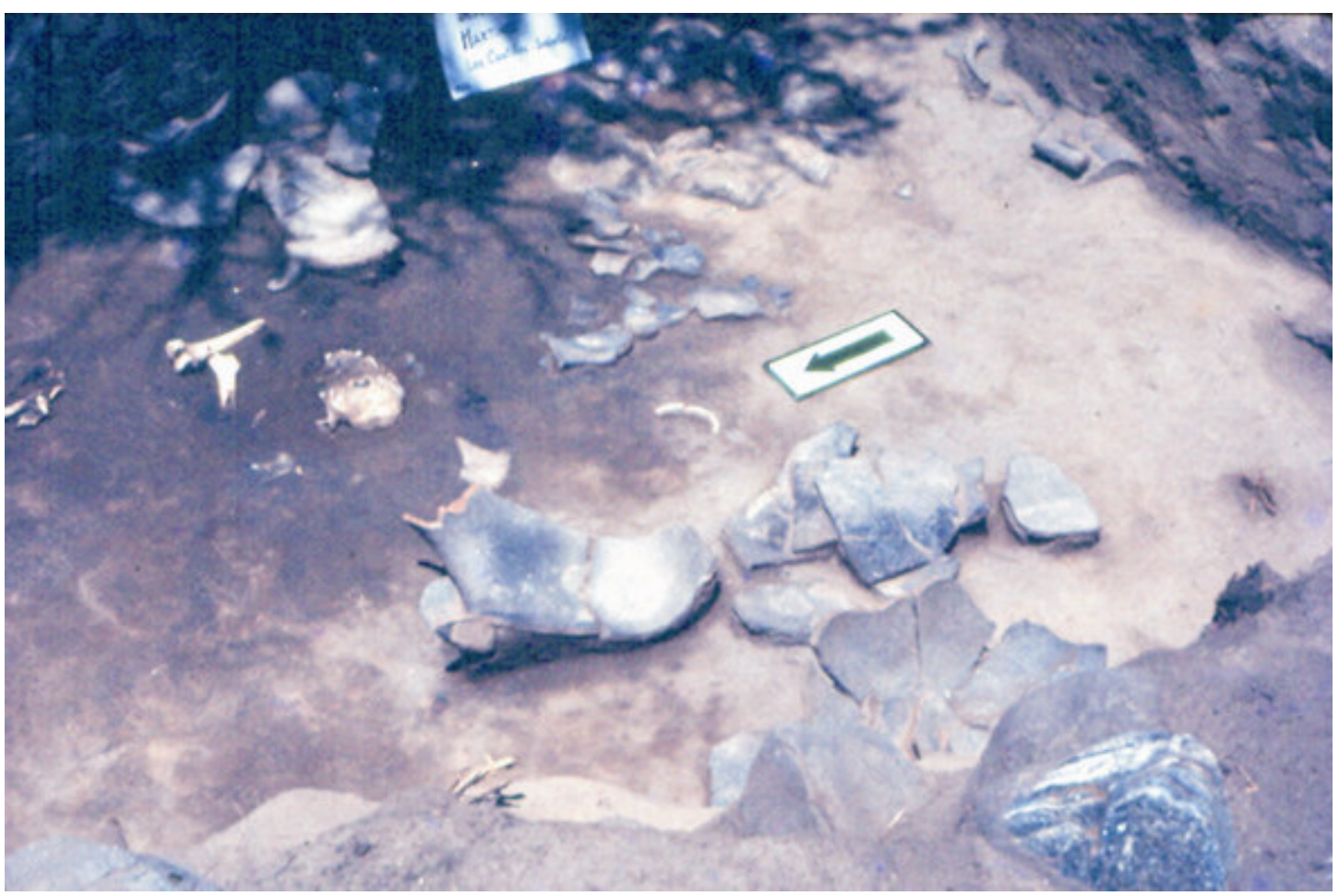

Figura 6.73: fotografía de la habitación 1 del sitio Martínez 2 en donde se observan restos de dos vasijas junto a restos humanos -cráneos, huesos largos u costilla-. El fogón se encuentra en la sección central superior de la fotografía. 

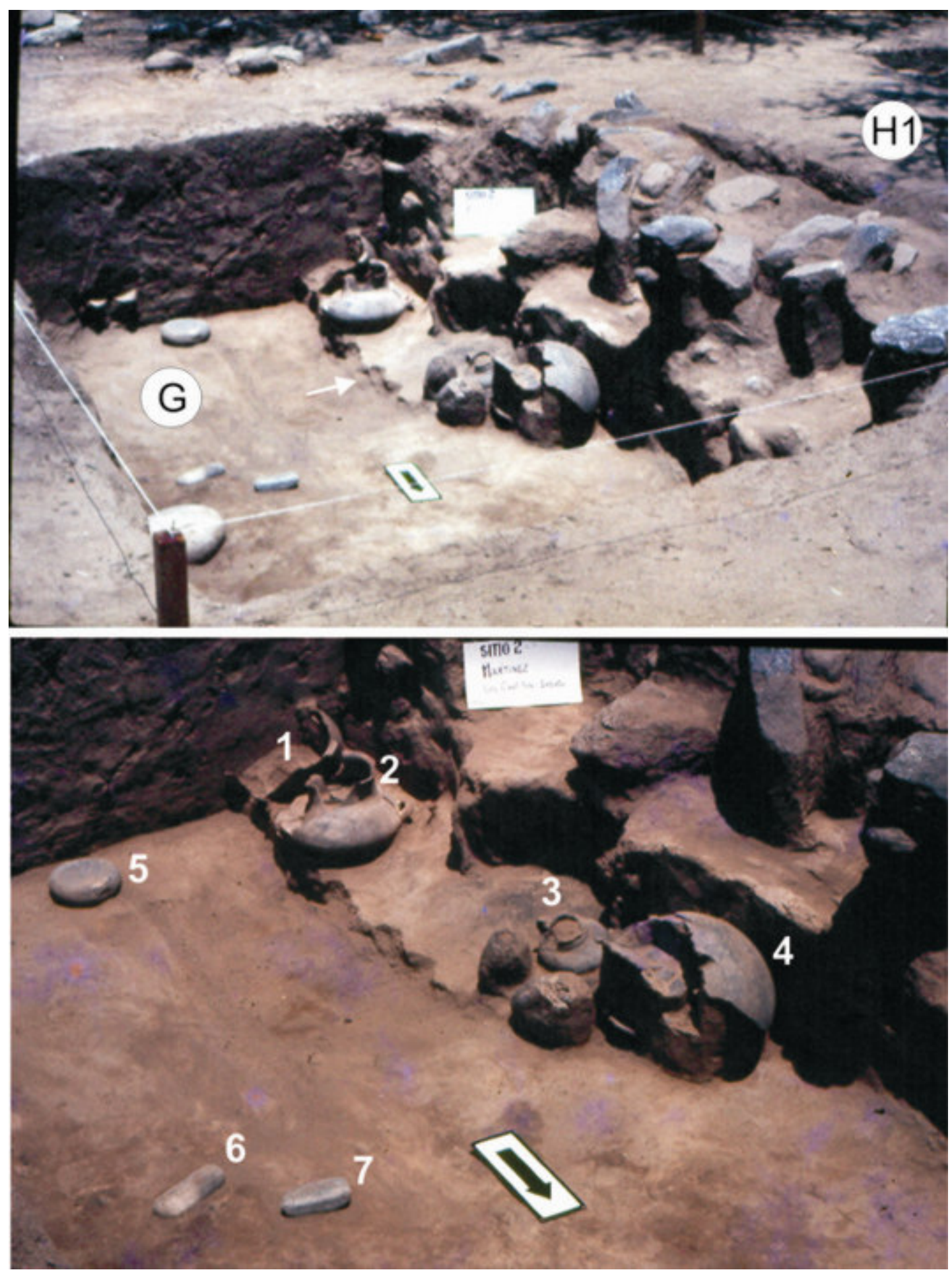

Figura 6.74: fotografías que muestran las vasijas y otros hallazgos hallados sobre la banqueta A y el piso de la galería en sector oeste del sitio Martínez 2. 


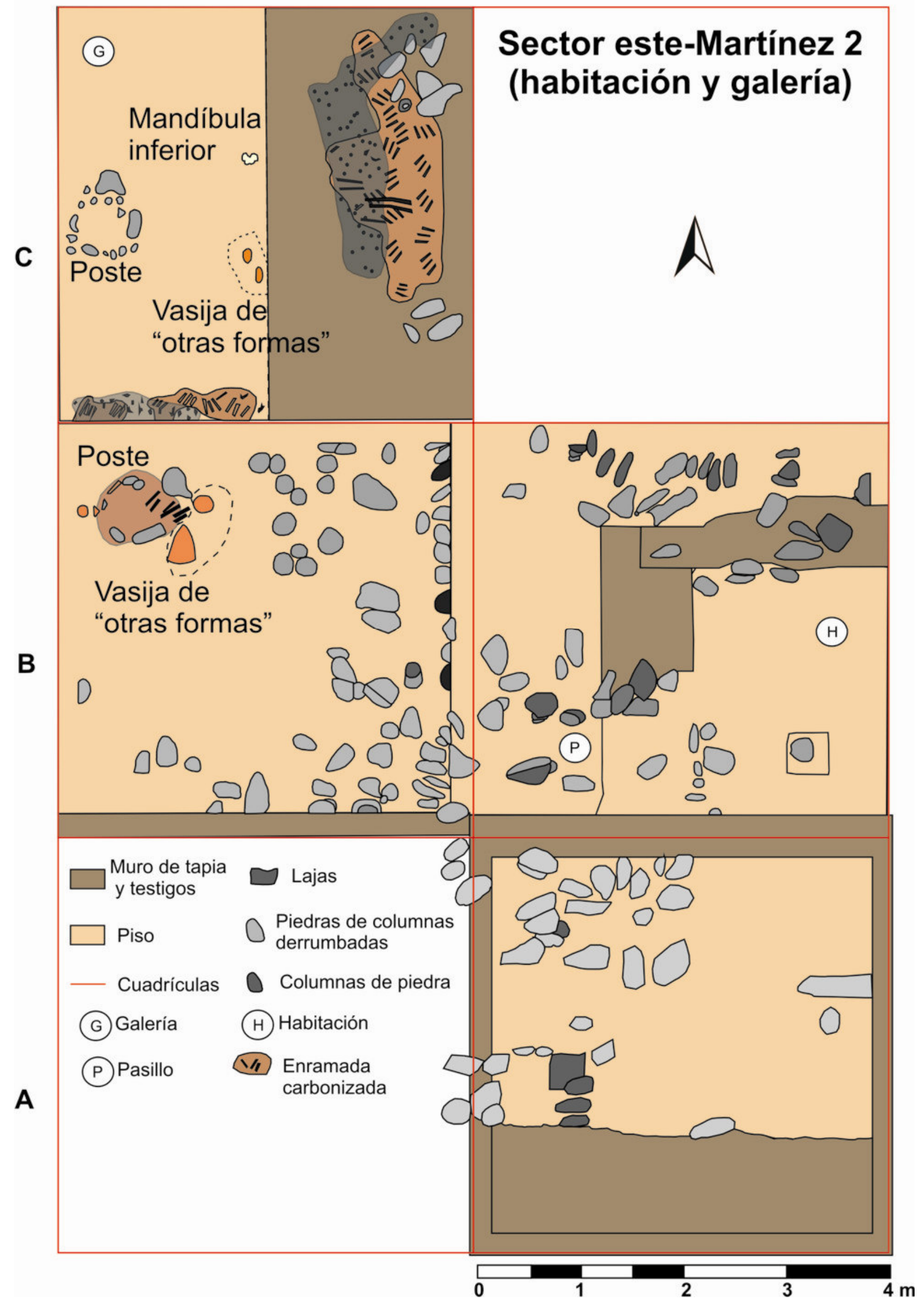

Figura 6.75: planta sector este del sitio Martínez 2 


\section{Los contextos del Sitio Piedras Blancas}

El sitio Piedras Blancas (042) -figura 6.76- se ubica en el fondo del valle, sobre la segunda terraza de la margen derecha del río Los Puestos, a una distancia menor a los 100 m. Por el lado norte, es delimitado, a unos 100 m., por un arroyo temporario. Fue registrado en prospecciones realizadas durante 1993. Es un sitio al aire libre monticular con construcciones, de alta visibilidad y baja obstrusividad, de $100 \mathrm{~m}$. en dirección E-O y 80 m. en sentido N-S, conformando un rectángulo. Dentro de la clasificación de Assandri (2007) se trata de un sitio muy grande -MG-.

El sitio fue dividido en dos partes. El Sector I se ubica hacia el oeste y se trata de una elevación designada como montículo, con una superficie aproximada de $40 \mathrm{~m}$ por $50 \mathrm{~m}$, orientado en dirección Noroeste-Sudeste. Luego, existe un área de transición, entre el montículo y el sector II, tratándose de un área deprimida en donde no se registran restos de estructuras. El Sector II se definió con relación a la presencia de estructuras de paredes de piedra, agrupadas en la sección más cercana al río, en la mitad Este. En él se identificaron siete recintos (C, B, E, F, H, I, J) y tres patios (A, D, G). Entre este sector y el sector de transición existe un muro de piedras de cuarzo blanco canteado, que corre de Norte a Sur por un tramo de $39 \mathrm{mts}$ aproximadamente, con una interrupción en el sector central de unos 7 mts. Esta interrupción se interpreta como el acceso al lugar (Caro 2002).Sus características arquitectónicas permiten pensar en una posible multifuncionalidad del lugar, en la realización de tareas comunales que incluyeran a más de una familia. Es importante también el hecho de que se encuentre a $400 \mathrm{~m}$ de otro sitio complejo con características ceremoniales: La Iglesia de los Indios.

Las excavaciones en Piedras Blancas incluyeron al Sector I y II, mediante apertura de cuadrículas, trincheras y sondeos. Los trabajos se realizaron durante noviembre de 1996, mayo y octubre de 1999, noviembre de 2000, noviembre de 2004, marzo y abril de 2005 y octubre de 2008.

Las vasijas analizadas aquí se presentan tanto en los espacios cerrados y techados recintos $\mathrm{H}, \mathrm{C}$ y F; como en espacios en galerías y espacios abiertos -pátio G-. También se presentan en gran cantidad en el montículo asociado al sitio. Iremos describiendo los contextos donde se hallaban las vasijas en cada uno de los recintos y luego en los espacios abiertos. 


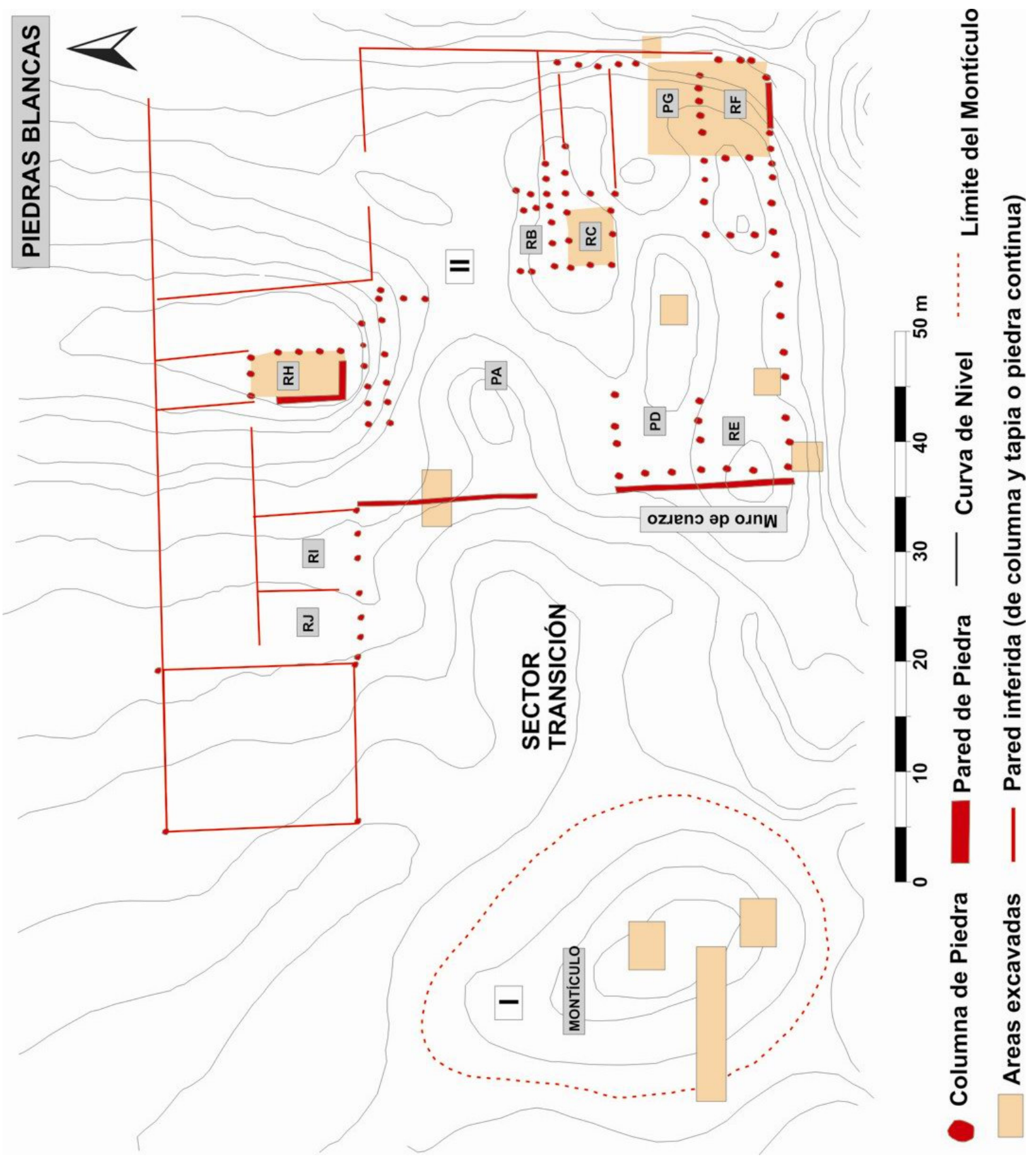

Figura 6.76: plano del sitio.

\section{Recinto $H$}

Las excavaciones en el Recinto $\mathrm{H}$ del sitio Piedras Blancas -figura 6.76, $\mathrm{RH}-$, se realizaron a través de cinco intervenciones, en un lapso temporal de 5 años -noviembre 1996; mayo y octubre de 1999; noviembre 2000 y octubre y noviembre de 2004-. Durante las primeras tres intervenciones, los interrogantes que guiaron las excavaciones se vincularon a establecer cómo era el uso del espacio a nivel intrasitio, tratando de observar si poseían sectores diferenciados a nivel no sólo formal, sino también funcional. La búsqueda de áreas de actividades diferenciadas fue uno de los principales factores por los cuales se decidió 
excavar utilizando el método de decapage, registrándose la posición tridimensional de los hallazgos, y relevándose en planta la superficie expuesta en cada extracción de sedimento. La segunda intervención combinó otra técnica además del decapage, en donde la identificación de estructuras positivas y negativas poseía un interés mayor que la reconstrucción de áreas de actividades. De estas dos excavaciones surgió un interrogante sobre la presencia o no de dos ocupaciones, en tanto en la primera excavaciones se registró una disminución en la taza de depositación en profundidad de los hallazgos y la segunda registró la continuación de la aparición de hallazgos, cuestionando la presencia de un hiatus ocupacional. La tercera excavación continúo hasta llegar al piso estéril, se siguió con la misma técnica aplicada en las primera excavaciones del año 1999. De esta última se pudo determinar la existencia de una segunda o tercera, según si existe o no un hiatus entre las excavaciones del año 1999 y 2000, ocupación evidenciada por un elemento interfacial horizontal -ver anexo 4 y figura 6.10- que muestra aplanamiento del lugar. Esta excavación cortó una antigua habitación de paredes de tapia. Esto se observa claramente porque en la esquina norte del recinto $\mathrm{F}$ se puede ver que el muro de tapia cortado hace una $\mathrm{T}$ dividiendo en tres espacios distintos. Por lo que el recinto $\mathrm{H}$ ocupa parte del espacio perteneciente anteriormente a por lo menos dos o tres habitaciones. Poseemos de esta última excavación un solo fechado, que fue realizado sobre un marlo de maíz carbonizado hallado contiguo al muro de tapia cortado por la interfacie, arroja un fechado de 1438+33BP. Si comparamos con el otro fechados realizados en este recinto -1230+-80BP y 1309+-43BP-, este fechado, junto con uno realizado sobre un diente de un niño enterrado debajo del piso de la habitación -1509+-43BP- son los más tempranos. Probablemente estemos al inicio de la reocupación del lugar. En tanto que los materiales hallados asociados al marlo y a los muros de tapia cortados, en el caso de los cerámicos de clase A1, presenta los típicos motivos ciénagas que aparecen en el sitio el Altillo con gran representación y que corresponden a los primero siglos del primer mileno.

En las primeras reconstrucciones estratigráficas de las excavaciones del año 1996 y 1999, se pudo interpretar a los depósitos excavados como formando un solo nivel de ocupación (Zaburlín 2001). Según esta autora el piso de dicho nivel, a diferencia de lo que venimos viendo en los sitios Martínez, no estaba diferenciado, estructuralmente, ni por un material ni por un tratamiento especial, por lo que se lo identificó por la cantidad y disposición de los materiales y por su asociación a rasgos constructivos (asientos de muros, topes de rasgos, etc.), observándose que el piso no era homogéneo en todo el recinto (Zaburlin 2001). 
Cuando Zaburlín (2001) analizó las tasas de depositación de inclusiones en profundidad y la relación de estas tasas con los ensamblajes cerámicos, fue posible vislumbrar por la autora un buzamiento en el piso de ocupación -figura 6.77-. Según estos datos, el mismo es más alto en la esquina SE del recinto donde se ubica a 0,95 $\mathrm{m}$ de profundidad, manteniéndose junto a la pared sur y sudoeste a $1 \mathrm{~m}$ de profundidad, descendiendo levemente en el centro del recinto a 1,05-1,10 $\mathrm{m}$ de profundidad y bajando a 1,10 a 1,20 m hacia el norte del mismo. En cuanto a la tasa de depositación de fragmentos en profundidad y de remontajes, se observó que las mayores acumulaciones de materiales se registran entre los 0,90 y 1,20 m de profundidad, descendiendo hasta casi desaparecer alrededor de los 1,30 m de profundidad, en lo que se caracterizó como un sedimento estéril -figura 6.78-.

\section{Niveles con mayor densidad de items discriminados por cuadrícula}

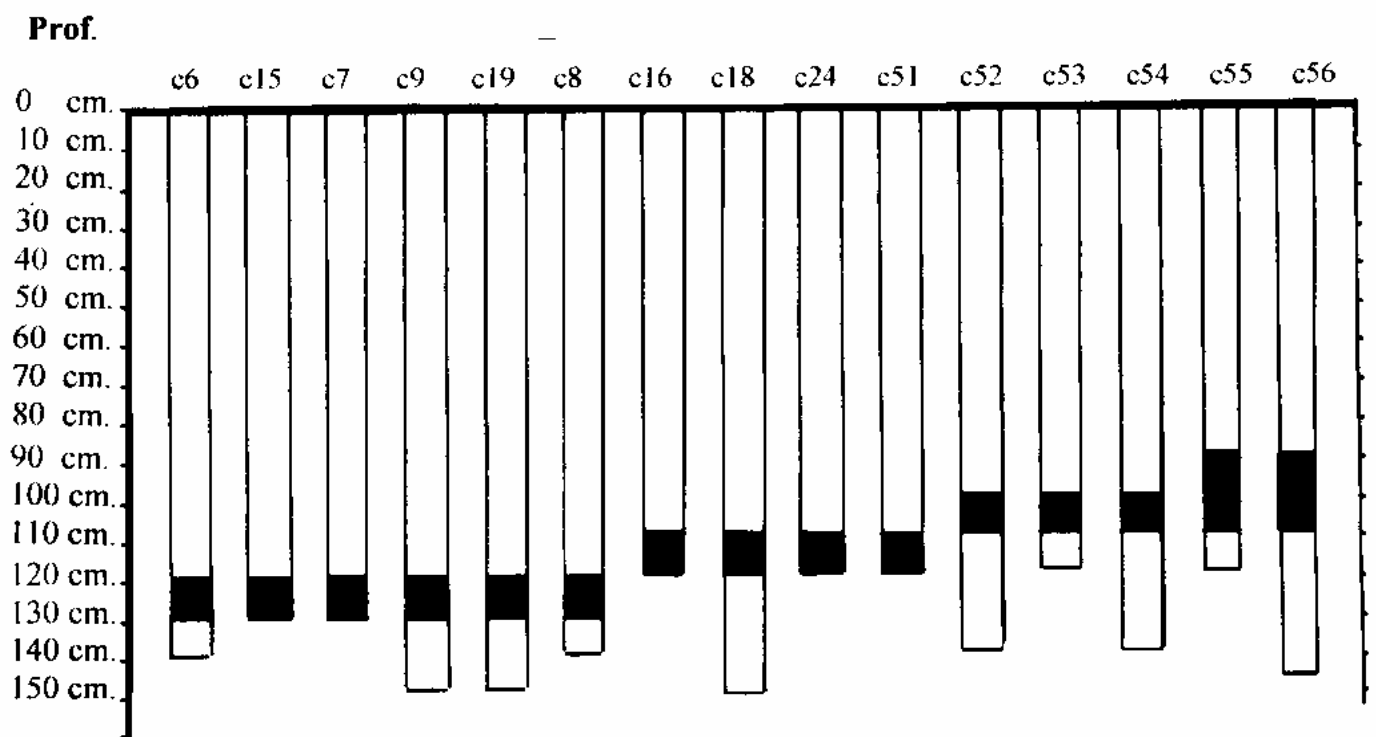

Figura 6.77: se muestra el buzamiento del piso por cuadrículas desde el norte -más alto- hacia el sur -más bajo. Fuente Pérez et al (2000).

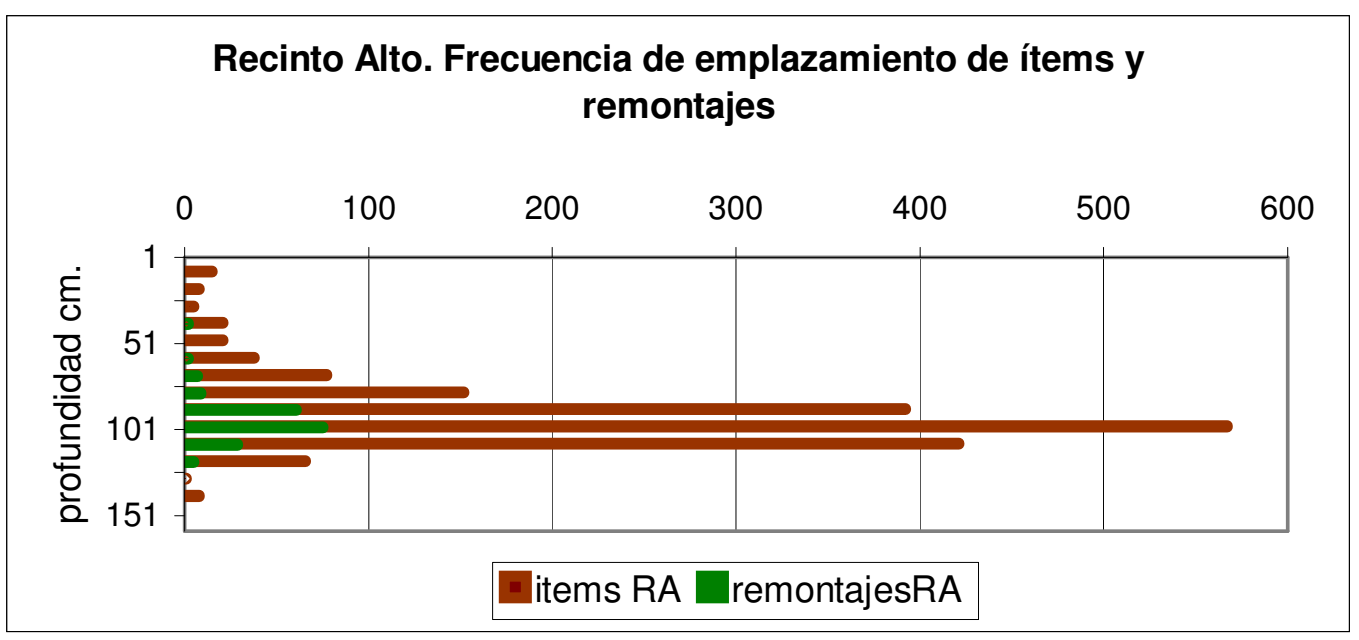

Figura 6.78: obsérvese que la mayor tasa de emplazamiento de ítems se da entre $10 \mathrm{c} 90 \mathrm{~cm}$ y $120 \mathrm{~cm}$ de profundidad. Fuente Zaburlín (2001). 
En el sector norte se detectó un área con enramada carbonizada dispersa, a diferencia de otros sectores del sitio donde aparecen los troncos quemados aquí no fueron hallados figura 6.79, 7-. A nivel de piso se detectaron distintas estructuras: varios pozos -figura 6.79: 1, 2, 3, 4- y dos estructuras de lajas -figura 6.79: 5 y 6-. Son significativos los entierros de individuos infantiles, de diferentes edades, en distintos sectores del recinto por debajo de lo que se identificó como el piso de ocupación -figura 6.79: 8, 9, 10-. Por lo menos tres enterratorios fueron identificados -los describiéremos en detalle en el capítulo siguiente-. Algunas de las vasijas aparecen como ajuar de estos enterratorios. Dos de estos enterratorios probablemente fueron excavados desde el piso. Otro de ellos se halla por debajo del muro este, por lo que la fosa se debió excavar antes de la construcción de dicho muro. Solo uno de los enterratorios presenta como ajuar vasijas -figura 6.80-: específicamente se colocó una vasija restringida compuesta pequeñita -menos de medio litro de volumen- de clase A1, con un asa remachada en posición vertical. La vasija posee huellas de usos en el exterior que indican movimientos en distintas direcciones. En el interior no se observan huellas. El asa se fracturó antes de que fuera colocada la pieza en la tumba, en tanto que la fractura del asa está totalmente alisada y emparejada la superficie. En el interior de esta vasijita aparecieron dos panes de pintura uno de color rojo y otro de color blanco. Es difícil saber el uso de esta vasija antes de que se utilizara como un objeto para acompañar a un difunto, pero lo que sí podemos saber es que las huellas observadas nos muestran que fue utilizada con anterioridad a su participación en dicho contexto. Lo mismo ocurre con la otra vasija que es de forma calceiforme de tamaño pequeño -menos de medio litro de volúmenes- de clase E2 -mezcla. Esta, tanto en la superficie interior como exterior, posee las típicas huellas de carbonización de esta forma. Los resultados del análisis de residuos orgánicos de los contenidos arroja la presencia de, al igual que las otras vasijas analizadas de forma calceiforme, ácidos grasos y albúmina; es decir contacto con grasas vegetales o animales y carne.

Apoyando sobre lo que se identificó como piso, las vasijas aquí analizadas, se distribuyen en todo el recinto presentando cierta distribución espacial diferencial que nos muestran un repertorio de prácticas distintas en las que participan, así como momentos biográficos diferentes. Por un lado tenemos vasijas de tamaño pequeño clase E y A1 -junto a otra clases- probablemente en uso -vinculadas con el consumo de alimentos y la preparación de pigmentos-, por otro lado tenemos vasijas almacenadas -también pequeñasa la espera de ser utilizadas y, por otro lado, tenemos una gran cantidad de fragmentos de vasijas que no remontan o que remontan parcialmente, menos del 50\%-que ingresaron al recinto probablemente ya rotas para se reutilizadas en la confección de otros artefactos - 
platos y fichas- y quizás el molido de alguno de ellos para la preparación de antiplástico para las pastas, hablamos específicamente de las clase A1. Estas vasijas presentan huellas de uso, lotes y marcas que evidencian su utilización en distintas actividades.

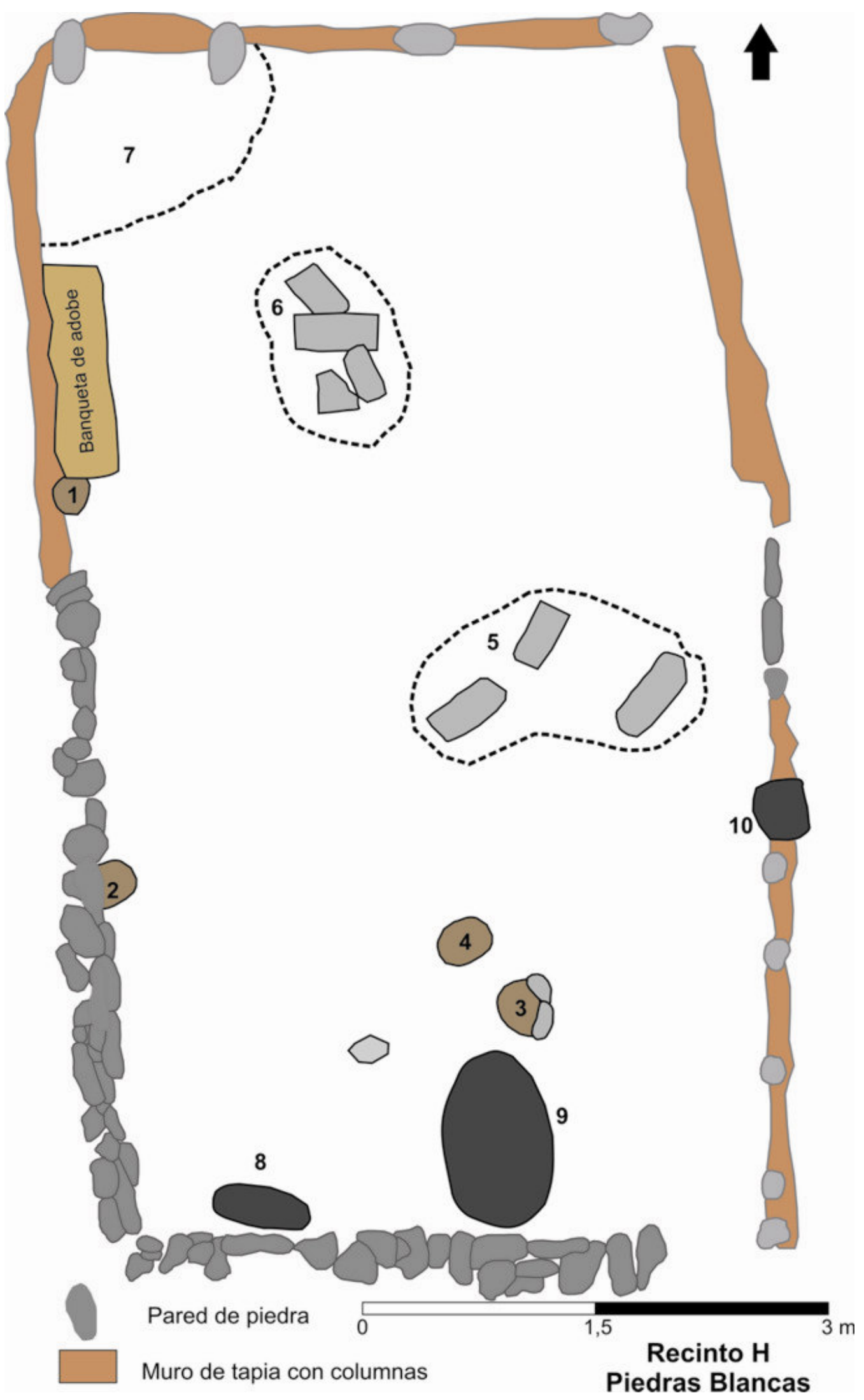

Figura 6.79: planta que muestra el conjunto de estructuras hallados en el recinto $\mathrm{H}$ vinculadas al piso. El detalle de que es cada $n^{\circ}$ ver en el cuerpo del texto. 

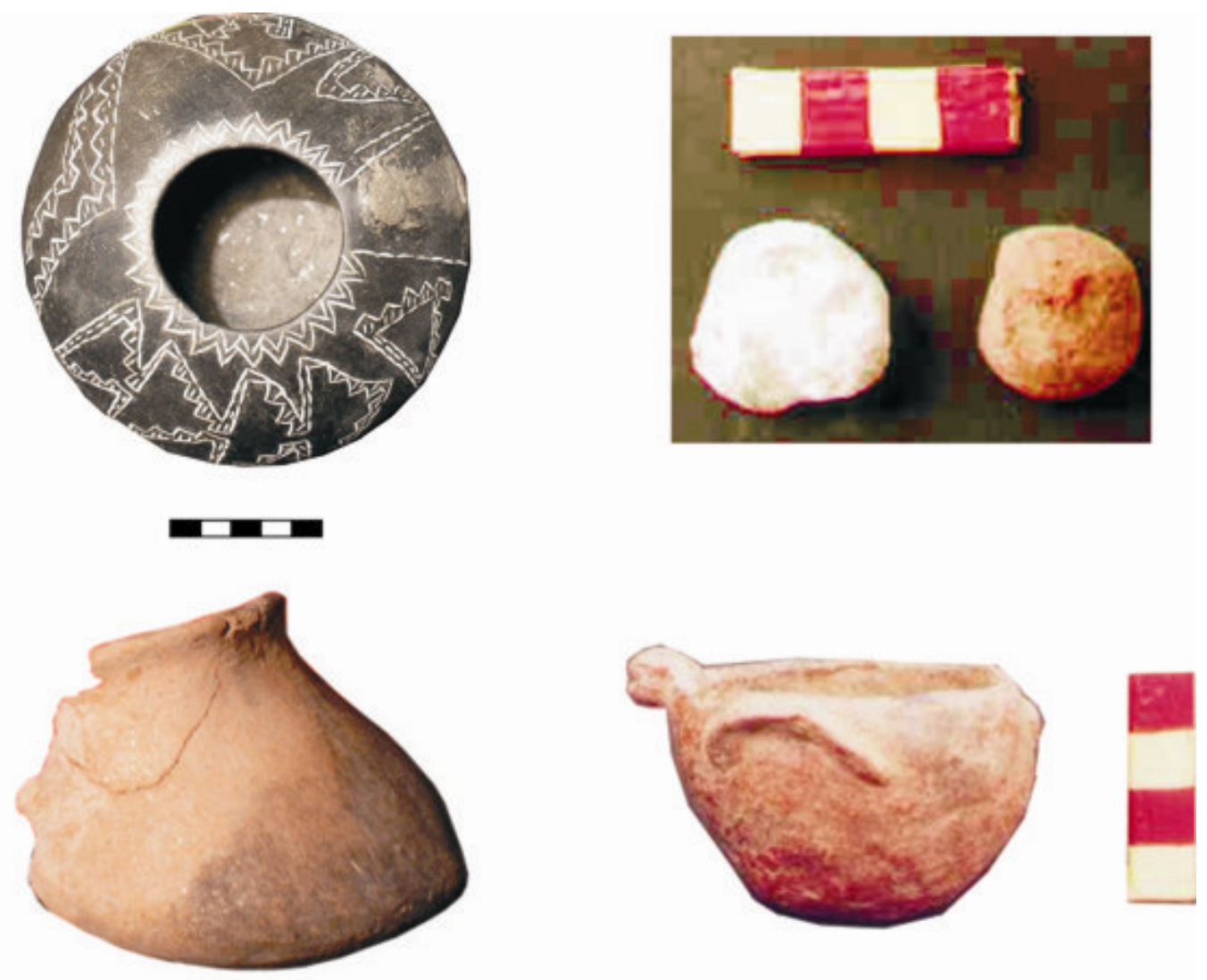

Figura 6.80: fotografías de los objetos de cerámica hallados como ajuar de una de la tumbas. La fotografía superior derecha muestra las bolas de pigmento halladas al interior de la vasija compuesta restringida fotografía superior izquierda-.

Como hemos señalamos, la mayoría de los remontajes de vasijas analizadas -algunas del 100\%, otras con un $90 \%$ y, otras por debajo del 50\%- se hallan apoyando en lo que fue determinado por Zaburlín (2001) como piso de ocupación. Tenemos dos vasijas, que remontan en un 90\%, asociadas a las estructuras de lajas -figura 6.81: 1 y 2-. Estas estructuras probablemente se utilizan para la contención y almacenaje de vasijas, tal cual se observa en el recinto F del mismo sitio -ver más adelante-. La estructura de lajas que se halla más al norte, consisten en 5 lajas, una de forma cuadrangular, una de forma trapezoidal y tres de forma rectangular, todas presentan los bordes cortados prolijamente con un espesor entre los 6 y $4 \mathrm{~cm}$. Estas se encontraron superpuestas horizontalmente y bajo este amontonamiento se encontraba una vasija calceiforme clase E2 -mezcla 4totalmente aplastada que se remontó prácticamente en su totalidad-figura 6.81, 1-. En base a la forma de las lajas y al orden de superposición, es probable que conformaran un tipo de caja. Las lajas que se ubicaban en el tope se registraron a $85 \mathrm{~cm}$. bajo el nivel de la superficie, en cambio las que se ubicaban en la base se registraron a 1,05 m. de profundidad. La vasija posee un diámetro de boca de $110 \mathrm{~mm}$, un diámetro máximo de 200 mm y una altura de $195 \mathrm{~mm}$. El volumen de contención de esta vasija es de unos 2,7 litros. 
En relación a las huella de uso presenta, tanto en la zona externa como internas, la patrones de carbonización típica de esta forma de vasijas. Los análisis de residuos orgánicos sobre muestras provenientes de esta vasija arrojan la presencia de ácidos grasos y albúmina. Probablemente, como lo señala Zaburlín (2001) las lajas estaban formando una caja donde se hallaba contenida esta vasija. La estructura de lajas que se halla más al sur, en la zona central del recinto hacia el este, aparece asociadas a una vasija de clase E4 perteneciente a las "otras formas" de pequeño tamaño -figura 6.81, 2-, con asas en seminalillo remachadas horizontales. Posee un diámetro de boca de $150 \mathrm{~mm}$ un diámetro máximo de $200 \mathrm{~mm}$ y una altura de $240 \mathrm{~mm}$ y 3,46 litros de volumen. En cuanto a la marcas posee en la superficie exterior solo estrías perpendiculares aisladas y la superficie interior algunos hoyuelos, en los borde no presenta lotes ni marcas. Probablemente las lajas hayan formado una estructura de contención de esta vasija. Asociada la estructura aparece otra vasija modelada con forma zoomorfa -camélido- de pequeñas dimensiones que casi se reconstruye en un $90 \%$-figura 6.81, 3-. Cercanos a los muros norte, este y sur aparecen ciertos conjuntos significativos que nos permiten observar reciclaje de las vasijas y su transformación en otro objeto, específicamente platos. Sobre el piso y contra el muro norte, en el mismo sector, aparecen dos fragmentos que remontan de un cuerpo de vasija globular clase E5 (mezcla 4) que a su vez remontan con otro conjunto de fragmentos ubicados a más de dos metros en el sector sur pegado al muro este -figura 6.81: 4, 5 y 6-. El remontaje de todos los fragmentos permite reconstruir el cuerpo globular de una vasija de grandes dimensiones que presenta un baño negro. Por la forma del cuerpo podría llegar a pertenecer a una vasija de forma "a" con un diámetro máximo medido de $600 \mathrm{~mm}$ y un espesor en los sectores de base de $18 \mathrm{~mm}$ y en el cuerpo de $10 \mathrm{~mm}$. El baño negro se halla en las tres partes remontadas de las vasijas con descascaramientos de forma irregular. Además se puede observar perfectamente como los descascaramiento al unirse una vez que fueron remontadas las tres parte de las vasijas como continúan en la otra, por lo que dicho proceso erosivo se produjo anteriormente a la fractura de los mismos. Los análisis de residuos orgánicos arrojan presencia tanto de albúmina como de ácidos grasos. En relación a las huellas observadas en la superficie exterior presenta patches en los sectores cercanos a la base y zona inferior, y hoyuelos en la zona media. No posee erosión en las fracturas que indique un proceso de reformatización de los fragmentos. Pero dado el lugar donde fueron hallados, el tamaño de cada una de las partes que luego fueron remontadas -1:250 X 200 mm; 2-480 mm X 400 mm; 3: 200 X 120 mm- nos indicaría su utilización como un objeto diferente, Zaburlín (2001) los propone como platos. Es decir que el contexto de hallazgo donde aparecen los tres fragmentos pertenecientes a esta vasija, no muestra por un 


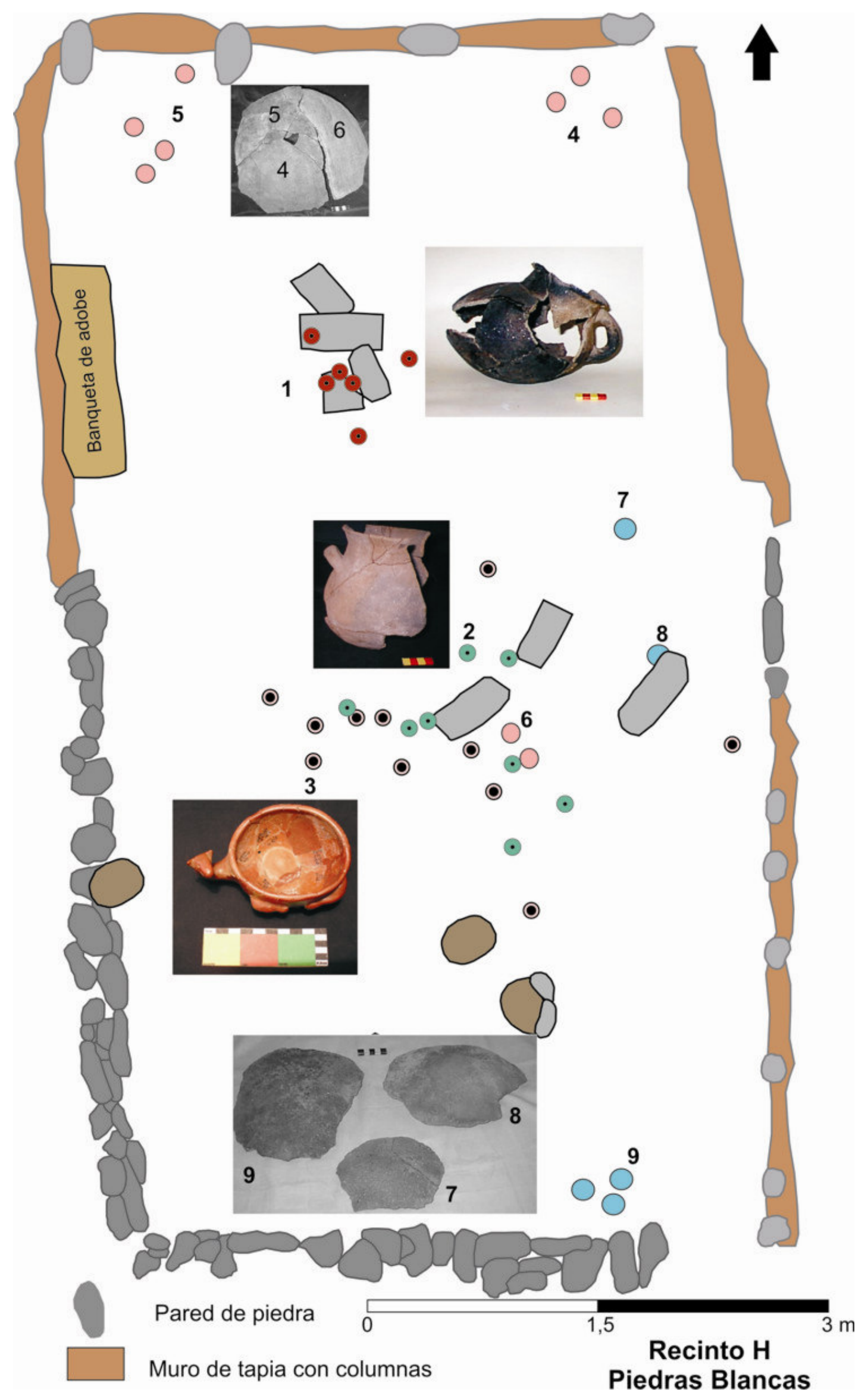

Figura 6.81: planta que muestra las vasijas remontadas en más de un $90 \%$ asociadas a estructuras de lajas. Además se observan fragmentos de cuerpos reciclados de grandes vasijas de clase E. 
lado una reutilización de una vasija que se fracturó o se la fracturó intencionalmente, y su resignificación en otro objeto, un plato. Ya mencionamos que en el sitio Martínez 2 vasijas de la misma forma fueron reutilizadas como soporte de otras vasijas. Esta reutilización de las zonas globulares de vasijas de esta clase y forma se repite en el Recinto H. Otro conjunto significativo hallado semejante al descrito anteriormente la conforman tres fragmentos de vasijas globulares clase E4 (mezcla 4) que podrían pertenecer a una misma vasija -figura 6.81: 7, 8 y 9-, pero que no remontan. Los radios máximos medidos están entre los $200 \mathrm{~mm}$ y los $225 \mathrm{~mm}$, por lo que, las vasijas, tendrían unos diámetros máximos entre los $400 \mathrm{~mm}$ a $450 \mathrm{~mm}$. No podemos determinar con exactitud la/as forma/s a la/s que pertenece/n, pero al tratarse de partes de cuerpos de vasijas globulares pueden ser o de forma "a" o pertenecer a las "otras formas". A diferencia de la vasija anterior los fragmentos en la superficie interna no presentan descascarado, solo poseen hoyuelos aislados. En la superficie exterior presenta solo hoyuelos. En relación a los análisis de residuos orgánicos arrojan ausencia de ácidos grasos y albúmina. El tamaño de cada fragmento es de alrededor de $200 \mathrm{~mm}$ de diámetro, posee una forma subcircular y su márgenes se encuentran desgastados, e intencionalmente se les confirió una forma redondeada. Coincidimos con Zaburlín (2001) que podrían conformar platos o cuencos confeccionados con sectores globulares de grades vasijas de clase E. Estos conjuntos nos indican la existencia de reciclado y reformatización de partes de vasijas para transformarse en otros objetos.

La reutilización de fragmentos de vasijas en este recinto también está dada por la presencia de seis fichas confeccionadas de distintas clases tecnológicas: dos de clase A1, 2 de clase $\mathrm{E}$ y dos confeccionadas con otra clase pero de pasta fina -clase A5- . La realizadas con la clase A1 presentan ambas caras pulidas por lo pertenecen a sectores de escudillas o bols, a su vez poseen unos $20 \mathrm{~mm}$ de diámetro. La de clase E y las de clase A5 se hallan en proceso de formatización.

Desde la mitad del recinto hacia el sur se distribuyen la mayoría de los remontajes parciales -figura 6.82-, entre el 50\% y menores a este, tanto de vasijas de clase A1 como de clase E, así como también de otras clases tecnológicas; existiendo mayor proporción de clase A1. En este sector encontramos escudillas de clase A1, fragmento de vasijas de forma b de clase A1, bases y sectores inferiores de vasijas de forma "ab" de clase E2, fragmentos de platos grandes E3. Todas ellas poseen marcas de uso y lotes por lo que conforman fragmentos de vasijas que han sido utilizada. Es el sector sur el que presenta también la mayor concentración de fragmentos cerámicos del recinto -figura 6.83-. Para Zaburlín 


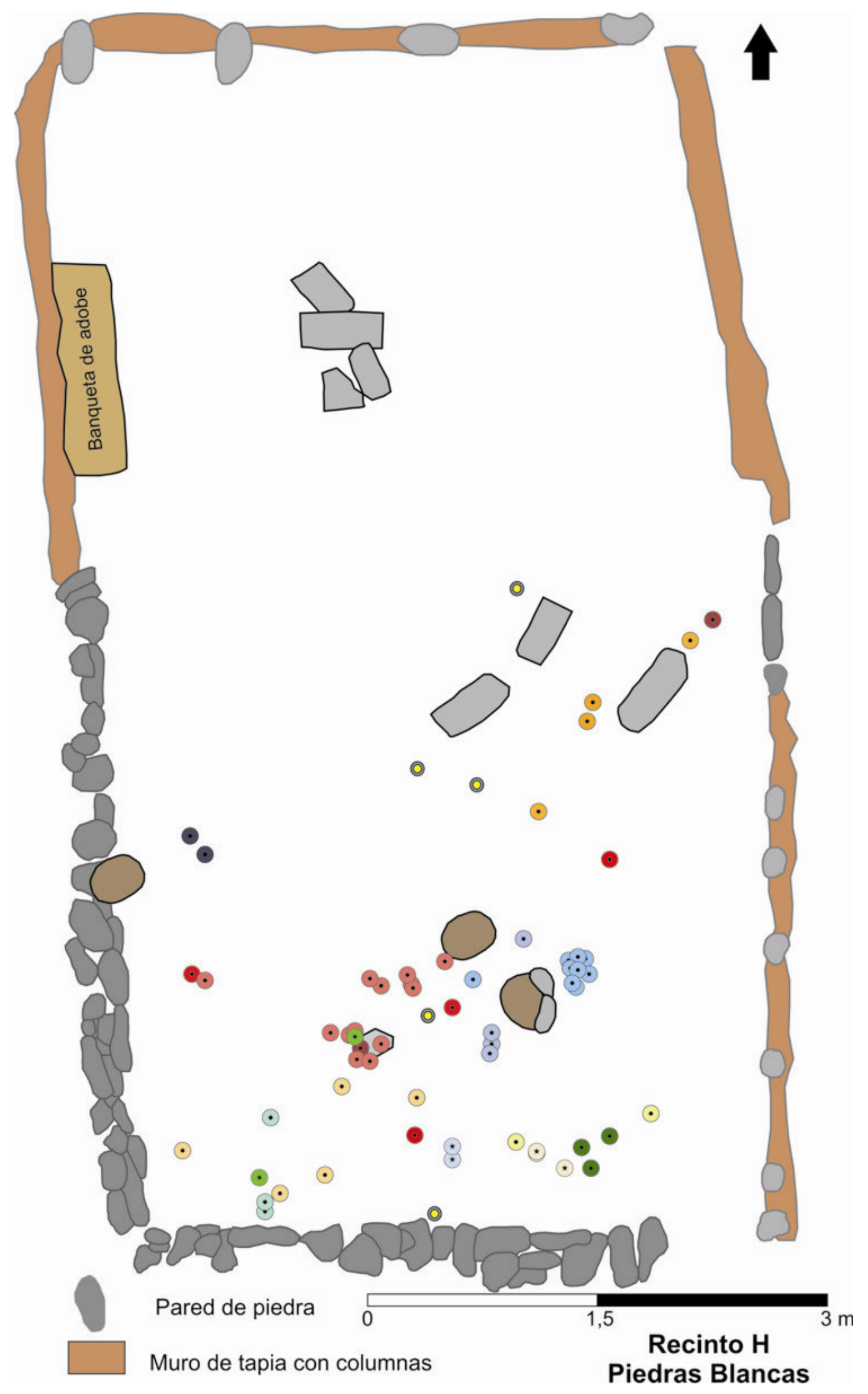

Figura 6.82: se muestran la distribución de remontajes de menos del 50\% que se concentran en el sector sur. Los fragmentos que remontan poseen los mismos colores. 


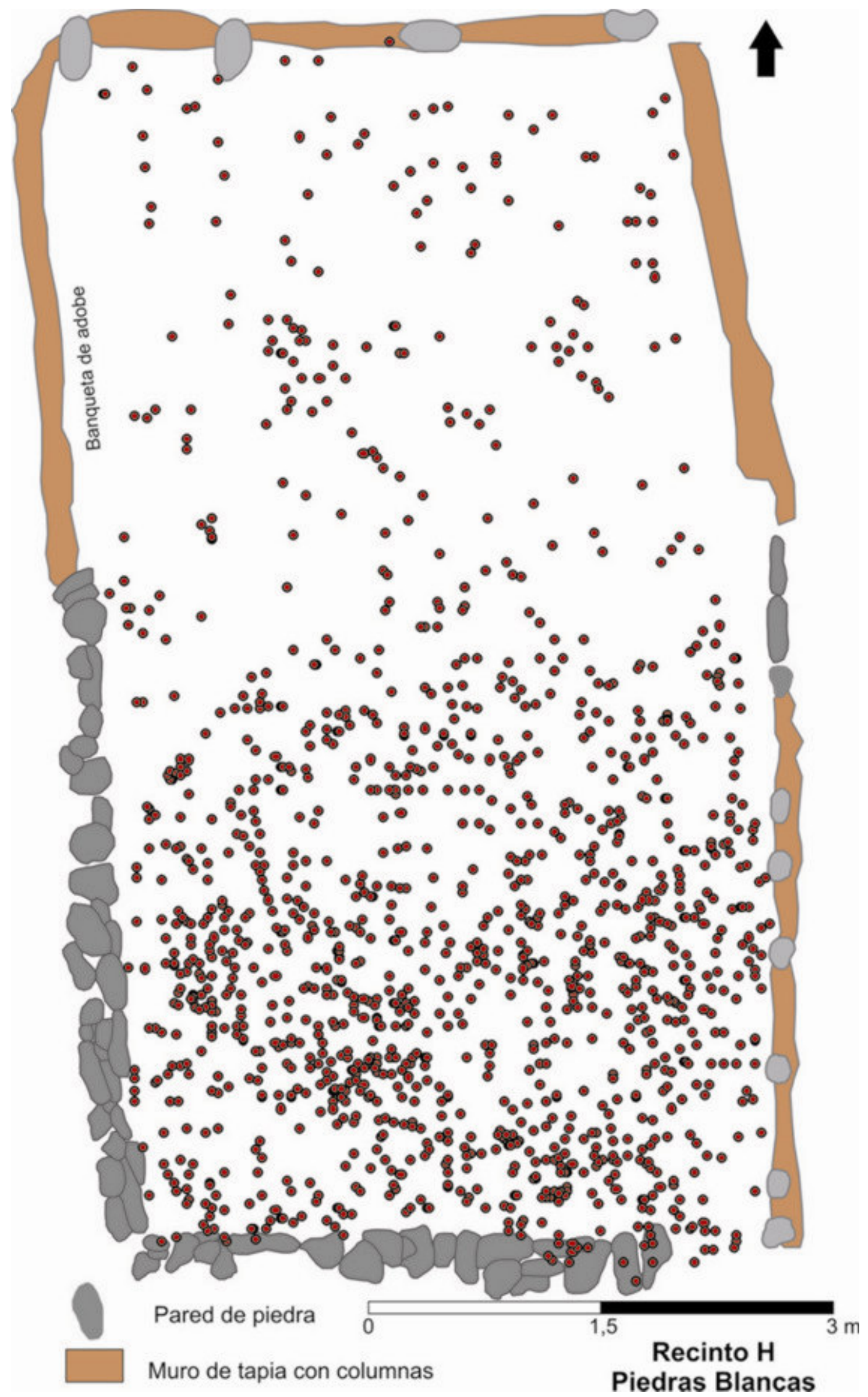

Figura 6.83: se muestran la distribución de fragmentos cerámicos vinculados al piso. Obsérvese la mayor concentración hacia la mitad sur de la habitación. 
(2001) la distribución de los fragmentos cerámicos indicaría la posibilidad de que en el sector sur del recinto, contra el muro sur se ubique un depósito de desecho secundario. Esto se refuerza con la distribución de piezas remontadas con baja representación de su contorno las cuales se ubican principalmente en la esquina sudeste. Es en la mitad sur del recinto -figura 6.84- en donde, también, se concentra la aparición de pigmentos de color rojo y blanco. Las placas de mica halladas también se distribuyen en esta zona. Así como los panes de arcilla cruda. El material lítico posee una distribución homogénea en el recinto específicamente está compuesto de 11 instrumentos de molienda -manos- que se distribuyen por todo el recinto, algunas de ellas presenta pigmento rojo; 5 artefactos de filita con retoque marginal que forman un filo activo, una punta de proyectil confeccionada en cuarzo cristalino y, lascas y debris de cuarzo.

Con los datos de las dos primera excavaciones se pueden configurar dos espacios distintos: la mitad norte del recinto que estaría techada y la mitad sur del recinto que sería a cielo abierto, teniendo posiblemente el acceso desde la equina sureste del recinto. Según la distribución de los distintos materiales, tendríamos contra el muro sur un lugar de concentración de materiales cerámicos que Zaburlín (2001), siguiendo a (Schiffer 1987:5859), clasifica como desecho secundario: "basura" que ha sido trasladada a un punto específico como desechos fuera del lugar de uso. A su vez coincidimos con Zaburlín (2001) que estos desechos serían provisionales en tanto estarían acumulados momentaneamente, ya sea para ser retirados y llevados en un futuro a un lugar definitivo, o reutilizados más adelante como otro objeto; en este caso podría ser que se hayan guardado para su posterior transformación en platos, fichas, etc. También podría ser el caso, dada la concentración de fragmentos de clase tecnológicas de pasta fina como la A1, que se los reutilizara molido como antiplástico. En la zona central, aún dentro del área sin techar se realizarían actividades vinculadas a la manipulación de pigmentos rojos y blancos, la fabricación de fichas de cerámica y de placas de mica. En esta zona también se emplaza una de las estructuras de lajas de contención de vasijas - una perteneciente a las otras formas y otra modelada-. El sector techado presenta también una estructura de laja de contención de vasijas - una calceiforme y una escudilla- . A su vez tanto en el sector techado como contra el muro este, ya en el espacio abierto, aparecen los platos confeccionados con partes recicladas de vasija globulares deforma "a" y de las "otros formas". Hasta el momento tenemos un fuerte énfasis en la realización de prácticas artesanales vinculadas con la producción y utilización de pigmentos y el reciclado de partes de vasijas para su resignificación en otros objetos. Esta vinculación a prácticas 
artesanales se puede reafirmar con los datos obtenidos de las excavaciones del año 2000, que fueron asociadas a una segunda ocupación.

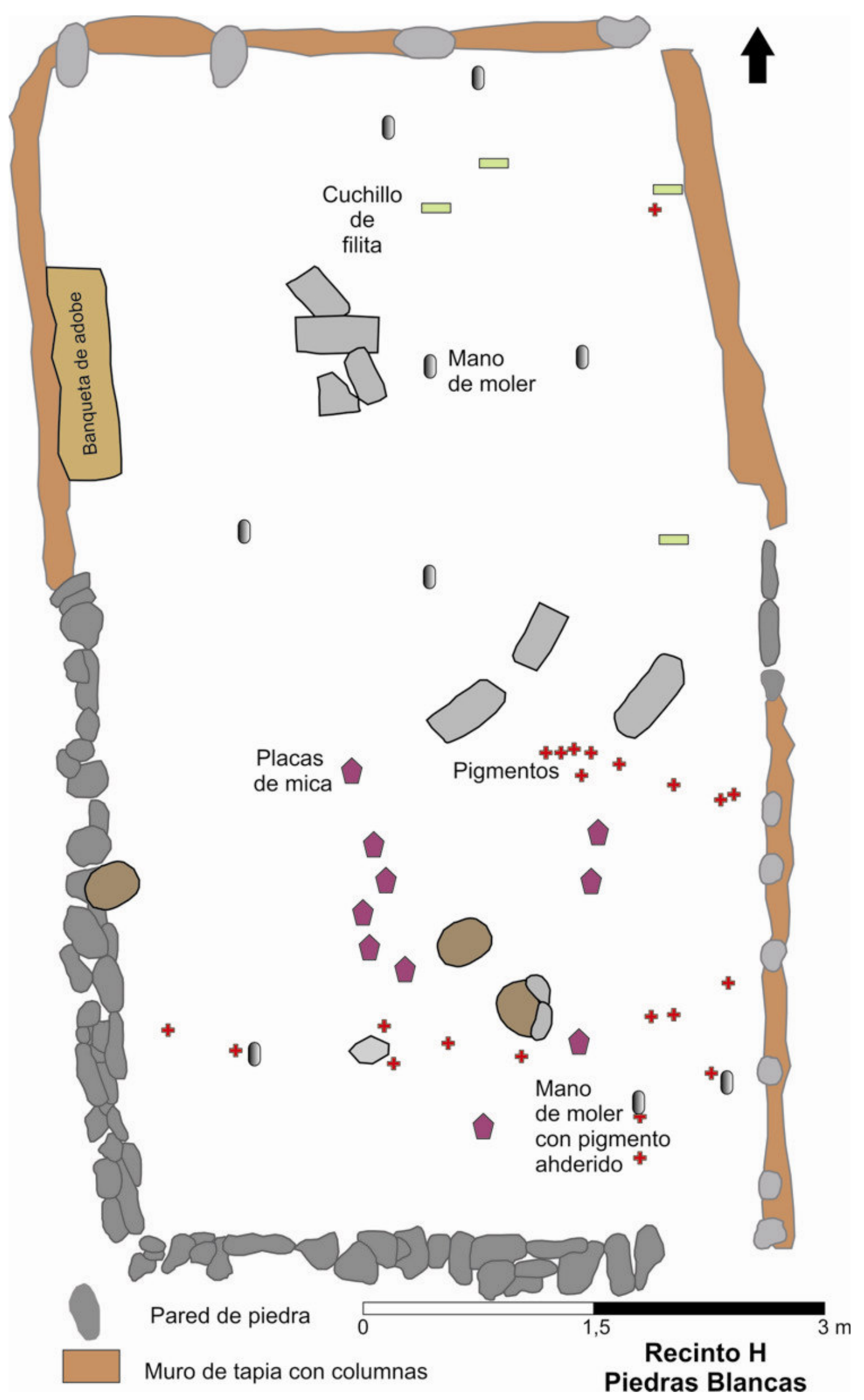

Figura 6.84: distribución de artefactos líticos, pigmentos y placas de mica. 
Durante los trabajos de campo del año 2000 se quiso corroborar la efectiva aparición del estrato estéril que había sido observado por Zaburlín (2001) tanto en el campo como en las gráficas de tasa de distribución en profundidad de los hallazgos. Para ello se limpió la superficie que había quedado expuesta en noviembre de 1999, observándose así la reaparición de material arqueológico. Esto ocasionó ciertos interrogantes acerca de la presencia de una o dos ocupaciones en el lugar, puesto que, aunque aparecía ahora material arqueológico, se había observado una disminución notable del mismo, situación que, junto a esta reaparición de material, podría estar significando un hiatus entre dos ocupaciones. Se decidió así excavar utilizando una combinación de metodologías (Cruz 2005). Además de seguir usando la técnica del décapage, se utilizó otra tendiente a la identificación de estructuras a través de la retención diferencial de humedad. Las áreas que presentaban mayor retención fueron descriptas como posibles estructuras en negativo -por ejemplo pozos-, y se las excavó por separado, mientras que las áreas intersticiales se siguieron excavando con el método de décapage. La variación de la técnica se debía a un interés en tratar de reconstruir eventos de depositación que formaban este supuesto segundo nivel de ocupación. Se terminó de excavar el depósito llegando hasta los 1,60 m de profundidad, pero no se llegó a determinarse el piso estéril.

En la -figura 6.85- se pueden observar las estructuras excavadas en este recinto, que corresponden a lo que parecía ser el segundo piso detectado. Se pudieron identificar cuatro fogones en el sector medio del recinto, evidenciados en el campo por la tierra quemada y la abundancia de cenizas, y nueve estructuras negativas. De las mismas, cuatro de ellas estructuras 8, 2, 5 y 4- se interpretaron como depósitos de basura, tres -estructuras 6, 9 y 7 habrían conformado el sostén de vasijas, una -estructura 3- se interpretó como un gran depósito de carbón de algarrobo -Prosopis sp.- (Marconetto 2008), y la última -estructura 1- consistía en un pozo con evidencias haber sido quemado a altas temperaturas, presentando un alto nivel de rubefacción. Por debajo del nivel de tierra quemada de esta estructura, se encontró el entierro de un camélido juvenil, colocado allí probablemente como ofrenda -figura 6.86-. En este último caso este aparente segundo piso de ocupación, al igual que el anterior, no poseía un tratamiento diferencial por lo que no pudo identificarse a nivel estructural. La interpretación de su presencia se realizó en función del emplazamiento y asociación de las estructuras identificadas, no considerándose la tasa de depositación en profundidad de las inclusiones, como sí lo fue hecho en la primera reconstrucción estratigráfica realizada por Zaburlin (2001). De la aplicación e interpretación de ambas formas de excavación, en principio, obtendríamos el siguiente panorama estratigráfico: parecen existir dos pisos de ocupación en el Recinto H del sitio 


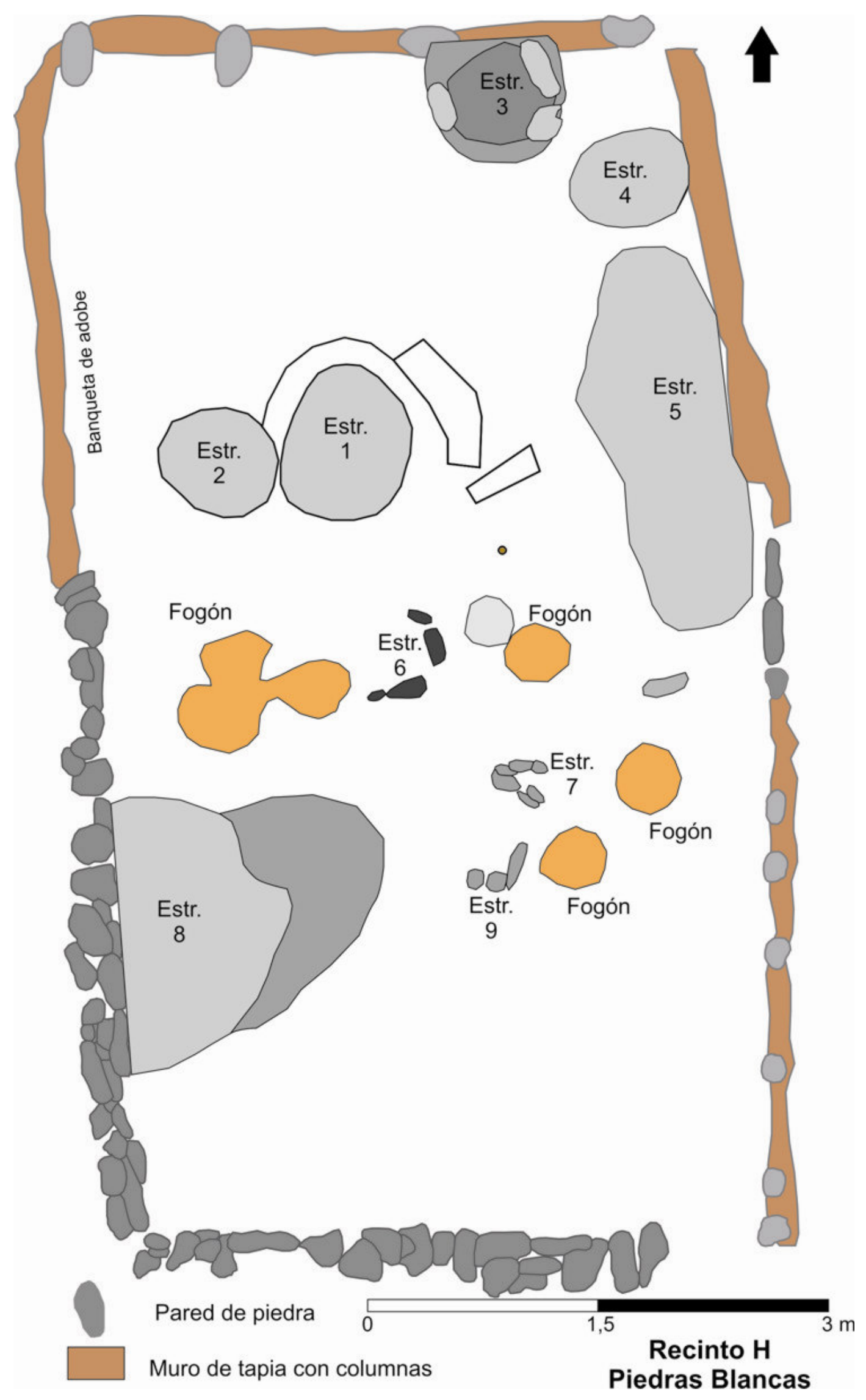

Figura 6.85: estructuras halladas en la campaña del año 2000. Las descripciones de cada una se detallan en el cuerpo del texto. 
Piedras Blancas. Uno se encontraría alrededor de los 0,90 $\mathrm{m}$ de profundidad en el sector sudeste del recinto descendiendo en el norte hasta los 1,20 m de profundidad. Bajo el mismo se encontraron fosas que contenían tres entierros, algunos con ajuar asociado. Las actividades llevadas a cabo dentro del recinto marcarían una diferencia entre el sector norte respecto del sector sur. El segundo piso de ocupación también marca diferencias entre el sector norte del recinto respecto del sector sur. En el sector central norte, se halló una serie de estructuras en negativo que indican actividades vinculadas a la producción de altas temperaturas para la fabricación de objetos de metal -estructura 1- (Espósito y Marconetto 2008). Este sector conformaría un área cerrada, a diferencia del sector sur, que no habría estado techado.

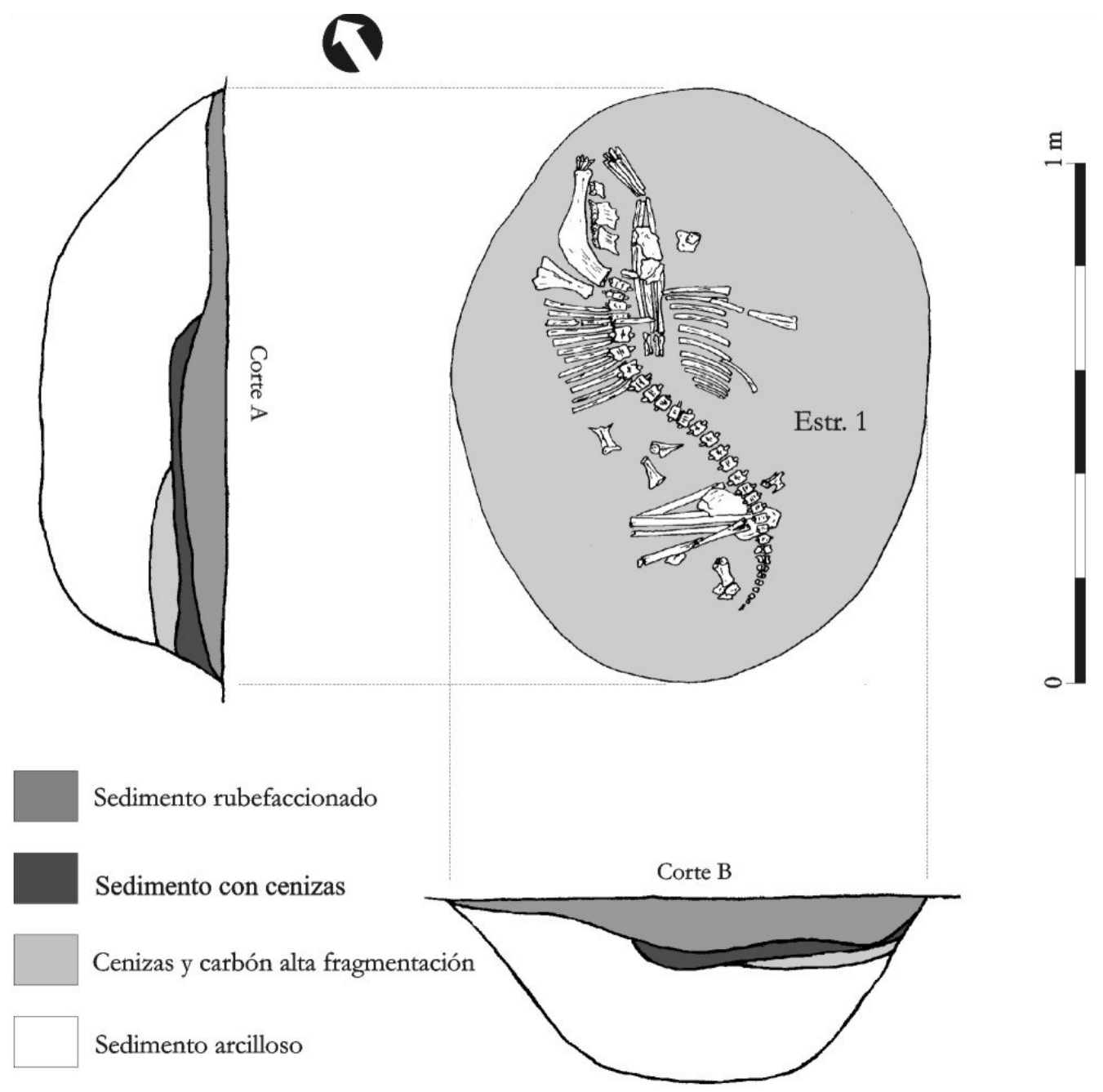

Figura 6.86: contenidos del pozo de la estructura 1 . 
Ahora bien, si tenemos en cuenta lo observado por Zaburlín (2001) respecto a la aparición de un nivel estéril por debajo del piso identificado por ella y la confirmación en la excavación posterior de la continuidad de la aparición de hallazgos en toda la superficie del recinto: ¿estamos hablando de un hiatus ocupacional? Suponiendo que no exista este hiatus, sigue aún existiendo la posibilidad de que se trate de dos ocupaciones; aunque, teniendo en cuenta que se aplicó una variante al método utilizado originalmente: ¿se trata realmente de dos ocupaciones diferentes o es una confusión producto de la aplicación de dos metodologías de excavación distintas? Para la reconstrucción de los contextos depositacionales de las vasijas era un problema el resolver la presencia de dos o tres ocupaciones. Por lo que diseñamos in SIG (sistema de información geográfica) -anexo 5con el objetivo de observar por un lado la existencia de una o dos ocupaciones y por el otro lado, reconstruir al menos secuencias estratigráficas parciales que nos permitan vincular contextos significativos de asociación que, dada los distintas técnicas de excavación aplicadas, quedaban desvinculados no solo espacialmente sino que temporalmente en tanto se asociaban a ocupaciones distintas, por lo que nos podríamos estar perdiendo información contextual importante para determinar los contextos de asociación donde las vasijas se hallaban. De los análisis realizados pudimos determinar la no existencia de un hiatus entre las dos ocupaciones, y que la disminución en la tasa de depositación en profundidad general y por cuadrícula observada por Zaburlín (2001), que mostraban una disminución en la frecuencia de aparición de hallazgos en profundidad, escondía la diversidad de procesos de depositación que fueron modelando la estratigrafía, particularmente los elementos interfaciales verticales -para definición ver anexo 4 y para análisis anexo 5- . El planteo de que se trataba de dos ocupaciones estaba influenciado por dos cosas: por un lado la técnica de decapage aplicada, que al privilegiar las relaciones topográficas en planos superpuestos, no permitía hacer hincapié en las relaciones estratigráficas, por lo que las mismas se perdían. Y, por el otro lado, por el supuesto que poseen los gráficos de tasas de depositación de hallazgos en profundidad, que conciben el espacio al rededor del hallazgo como homogéneo -ver anexo 5 para desarrollo del análisis espacial en el SIG-. EL SIG, además, nos posibilitó la reconstrucción de secuencias estratigráficas parciales que nos permitió asociar estructuras y prácticas que habían sido separadas y asociadas a dos ocupaciones diferentes -ver anexo 5-. Específicamente nos permitió, en el sector norte discernir que la estructura 1 excavada en el año 2000, en realidad se había cortado desde el piso identificado por Zaburlín (2001). Esta estructura se ha definido como un a estructura de combustión dedicada al recocido de metales para la fabricación de objetos de metal por medio de la técnica de martillado (Marconetto y 
Espósito 2008, Espósito 2009). El fogón está compuesto por una pared subcircular de tierra consolidada que se sobresale entre 5 y $10 \mathrm{~cm}$. por encima de la superficie del piso, formando una semianillo que rodea al pozo en su parte norte. Toda la estructura tiene $1 \mathrm{~m}$ aproximadamente de diámetro y de aproximadamente $20 \mathrm{~cm}$ de profundidad, que contiene un sedimento en su base que presenta un alto nivel de termoalteración, apoyado sobre una muy fina capa de sedimento con cenizas y carbón con alto nivel de fragmentación. Por debajo de la base del pozo se encontró el esqueleto de un camélido neonato depositado en un sedimento arcilloso con la cabeza orientada hacia el noroeste. Al respecto de las prácticas en las que pudo haber estado involucrada esta estructura, debemos descartar el uso de esta estructura como fogón de cocina (Marconetto y Espósito 2008 y Espósito 2009). Las características y morfología de los fogones domésticos conocidos en otros sitios del valle y hallados en el mismo recinto difieren de éste en cuanto se trata de fogones planos, de poca potencia con predominancia de cenizas y relativamente poco carbón, sin ninguna estructura de contención perimetral como sí posee esta estructura. Asociados a esta estructura de combustión se encontraron dos objetos significativos, como lo son un yunque y un pulidor líticos. El yunque es una especie de "plato" subcircular de unos $30 \mathrm{~cm}$ de diámetro y aproximadamente $5 \mathrm{~cm}$ de alto confeccionado sobre una laja. Posee los bordes redondeados y su superficie levemente cóncava y con una textura producto del trabajo por abrasión y desgaste por uso. El martillo es un rectángulo de prisma rectangular de unos $15 \mathrm{~cm}$ de largo y de 5 X $5 \mathrm{~cm}$ de ancho, con sus extremos levemente convexos y con rastros de abrasión y micro-fracturas longitudinales sobre la superficie de sus extremos (Espósito 2009: 53-54). A la estructura de combustión se le asocian espacialmente dos estructuras más -figura 6.85-. Contigua a la misma, unos 0,50 a 0,60 m hacia el este contra el muro, se halló la Estructura 5, un pozo alargado de aproximadamente $2 \mathrm{~m}$ y medio de largo por unos $50 \mathrm{~cm}$ de ancho y $30 \mathrm{~cm}$ de profundidad. El sedimento de esta estructura resultó un relleno de cenizas, carbón, fragmentos cerámicos pequeños de variedad de clases, y un conjunto de carbones con alta fragmentación, contexto que se interpretó como el resultado de las acciones de limpieza y barrido realizadas en la estructura de combustión y parte del piso del recinto. Espósito (2009:54) señala que a través del análisis con microscopio óptico se halló que algunos de estos pequeños fragmentos de carbón presentaban incrustaciones verdes iridiscentes a la luz artificial, que por color y morfología podían tratarse de restos de cobre. Por su parte, la Estructura 3 se encuentra adosada al muro norte del recinto y distante un 1 a $1,5 \mathrm{~m}$ de aquella. Consiste en un pozo de aproximadamente $0,50 \mathrm{~m}$ de diámetro y $0,50 \mathrm{~m}$ de profundidad, demarcado por grandes lajas colocadas de canto, y en cuya base se recuperaron sólo grandes fragmentos de carbón, 
sin encontrarse ningún otro tipo de material, de lo que se ha interpretado que se trató de un depósito de carbón vegetal (Marconetto 2008). En esta estructura se recuperó una muestra de 500 g de carbón perteneciente a algarrobo, aunque su capacidad se aproxima a los $125.000 \mathrm{~cm} 3$, es decir, aproximadamente el espacio que ocuparían $20 \mathrm{~kg}$ de carbón fragmentado o $10 \mathrm{~kg}$ de carbón en grandes trozos. A este contexto debemos sumar la estructura de laja que contenía la vasija calceiforme con huellas de carbonización tanto en su interior como exterior que se encontraría a lado de esta estructura hacia el norte de la misma -estructura de laja 6 de figura 6.79- . Una asociación semejante se encontró en el sitio Martínez 1 ya descrito, en la esquina sur este del patio en donde aparece una vasija calceiforme usada con las típicas huellas de carbonización junto a herramientas y objetos en proceso de producción. En este caso el consumo realizado de preparados con vegetales y animales que suelen encontrarse como residuos en estas pequeñas vasijas, se hallan presentes en los mismos lugares donde se realizan actividades artesanales.

En el centro del recinto aparecen estructuras de piedras asociadas a fogones domésticos. Es en esta área donde Zaburlín (2001) encuentra una segunda estructura de laja para contención de dos vasijas casi enteras fragmentadas aplastadas por las lajas. Hacia el oeste, en la excavación del año 2000 se registraron dos pozos -uno está truncado a otro- que se definieron como depósito de basura -estructura 8 en figura 6.85-. El área donde se encuentran estos posos coincide con lo observado por Zaburlín (2001) en cuanto a la acumulación en este espacio sur oeste de desecho. Sin embargo el contenido de los pozos presenta fragmentos pequeños de cerámica pertenecientes a distintas clases junto a otros materiales. Por lo que pueden diferenciarse en este sector el piso de donde se habría excavado y rellenado pozos de acumulación de desecho, probablemente limpieza del lugar, que dado el truncamiento nos muestran que se realizaron en dos momentos distintos, de aquellos fragmentos de cerámicas acumulados en el sector sur y también oeste, que podrían estar a la espera de su resignificación en otro objeto, comenzando a transcurrir otra biografía como otras cosa.

En síntesis, si bien la estratigrafía de este recinto resulta compleja de interpretar podemos señalar que en gran medida las prácticas observadas configuran un espacio donde es recurrente prácticas vinculadas a la producción artesanal de variedad de objetos. Según lo observado por Espósito (2009) se fabricarían o incluso repararían objetos de metal por medio del martillado, tanto herramientas -cinceles, tubos, pinzas- como otros objetos colgantes, anillos, etc.-. Existen ciertas evidencias de la confección de placas de mica, que se encuentran según Zaburlín (2001) en distintos momentos de su producción. Las vasijas 
aquí analizadas participan diferencialmente conviviendo en distintos tiempos biográficos, por un lado tenemos aquellas que ingresan al recinto después de un recorrido que ha dejado su huella en la superficie de las mismas, que serán transformadas en otros objetos como fichas y platos. Por otro lado tenemos objetos ya confeccionados con los restos de estas vasijas en el mismo espacio. Y además tenemos vasijas que participan de otro forma, todavía están en pleno uso, tal es el caso de las vasijas calceiformes, la vasija pequeña pertenecientes a las “otras formas", las escudilla y otra vasijitas como las modeladas y el plato chico. Otras vasijas aún enteras han sido dispuestas en un enterratorio como acompañante del difunto. Existen evidencias de la manipulación de pigmentos blancos y rojos en las que participaban algunas vasijas -escudillas- principalmente como contenedores y manos de piedra probablemente para molerlo. No sobemos si en este lugar se preparaba el pigmento o ya venían preparados -en pancitos- y aquí se lo aplicaba a lo que se quería pintar. El énfasis que se observa en la manipulación de pigmentos en este lugar, así como la participación de pequeñas vasijas de clase A1, queda aún más enfatizado si pensamos que en uno de los enterratorios hallado en el sitio se encontró un pequeña vasijita de clase A1 que contenía dos panes de pigmentos - uno blanco y uno rojo- y el niño hallado en este enterratorio se hallaba apoyado sobre una laja pintada totalmente de rojo. Es sugestivo que no aparezcan las grandes vasijas de forma "a" o de otras "formas", si no que se traten de vasijas más pequeñas de fácil transporte. Cuando, estas últimas aparecen, lo hacen en forma de fragmentos a la espera de su transformación y resignificación posterior en otro objeto. En cierta manera se asemeja al espacio exterior del sito Martínez 1, donde si bien aparecen vasija de gran tamaño estas, aparentemente, no están siendo usada, si no que probablemente se las esté fabricando. Y como en el caso del recinto $\mathrm{H}$ aparecen asociadas herramientas y materias primas vinculadas a la producción artesanal y, vasijas pequeñas con evidencias de uso, tal como la vasija calceiforme hallada en la esquina sur este del muro perimetral que rodea al sitio.

\section{Recinto Chico}

La excavación de este recinto se realizó en el año 1999. Se utilizó como método la técnica de decapage. El área excavada del recinto cubre la mitad oeste del mismo, teniendo unos $6 \mathrm{~m}$ de distancia entre las paredes norte y sur; y a partir de la pared oeste $4 \mathrm{~m}$ en dirección este. Las paredes norte, sur y oeste están confeccionadas con la técnica de tapia y columnas de piedra dispuestas entre sí a una distancia de 0,7 m. En el área excavada no se halló la entrada a este espacio. Al igual que en el Recinto Alto, y a diferencia del recinto 
F y, de los sitios Martínez 1, 2 y 4, el piso no presenta características estructurales o tratamientos especiales. Fue identificado a partir de la ubicación de los rasgos y concentraciones de materiales a $1 \mathrm{~m}$ de profundidad (Zaburlín 2001:19) -figura 6.87-. Estos rasgos se tratan de un escalón de tierra consolidada ubicado en la esquina noroeste del sitio, una estatura de lajas de piedras para contener vasijas, una estructura para sostén de poste, y, un fogón. Los remontajes realizados tal cual lo observa Zaburlín (2001) coinciden con lo que se determinó como piso. Las vasijas a las que les trazamos la biografía aparecen distribuidas diferencialmente sobre el piso del recinto y asociadas a determinados rasgos.

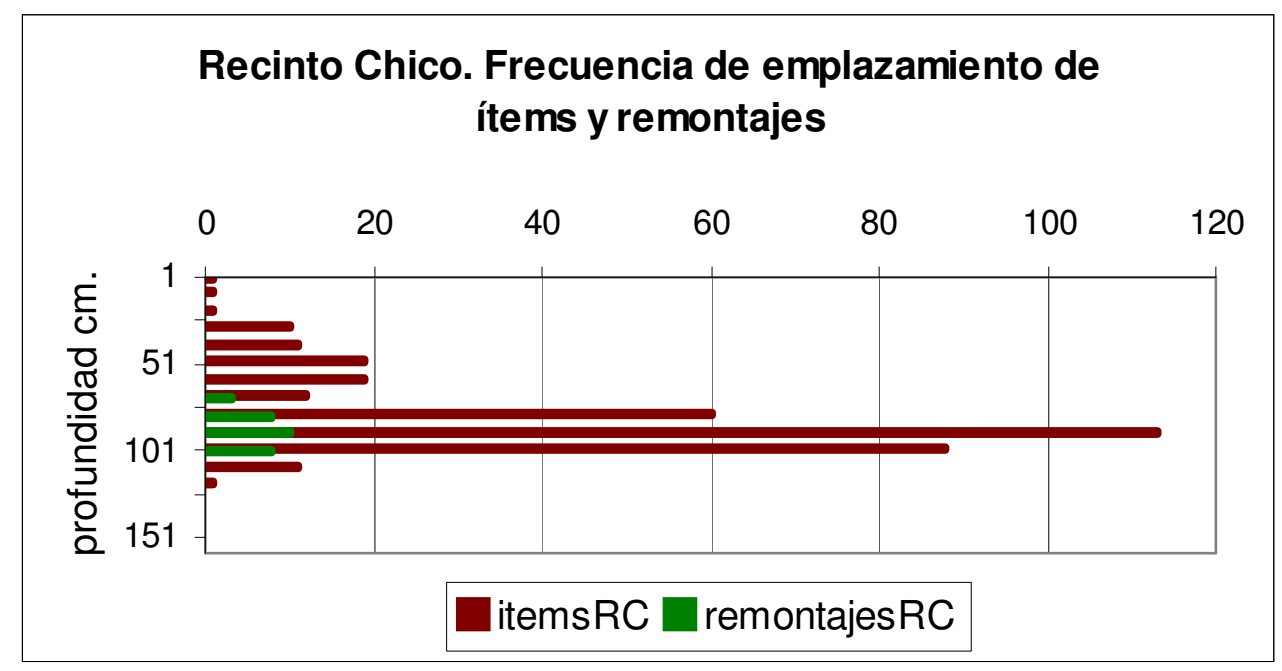

Figura 6.87: obsérvese que la mayor tasa de emplazamiento de ítems se da entre $10 \mathrm{c} 90 \mathrm{~cm}$ y $100 \mathrm{~cm}$ de profundidad. Fuente Zaburlín (2001).

A diferencia del recinto $\mathrm{H}$, se pudieron realizar sólo tres remontajes: uno se trata de una vasija de grandes dimensiones, asociables a las "otras formas" de clase E4 (mezcla-) que remonta en un $70 \%$, se halló fragmentada al lado de una estructura de piedra probablemente utilizada para mantener erguida a esta vasija -figura 6.88, remontaje 1 y figura 6.89-. Solo se encontró el cuerpo casi completo no se halló los fragmentos de las partes superiores -borde-. Pero dado que solo se excavó la mitad de recinto estos podrían estar en la zona no excavada. Posee un diámetro máximo de $680 \mathrm{~mm}$ y una altura relativa unos $600 \mathrm{~mm}$, con un volumen aproximado de 115,7 litros. La estructura de piedra: se ubica a $1,80 \mathrm{~m}$ desde la pared oeste y a $0,75 \mathrm{~m}$ de la pared norte. Consiste en una estructura de contorno rectangular, de $0,72 \mathrm{~m}$. de largo y $0,53 \mathrm{~m}$. de ancho. Está conformada por gruesas lajas y rocas grandes de forma rectangular. Las lajas ubicadas en los lados norte y sur fueron clavadas con una inclinación de $45^{\circ}$ hacia adentro, con lo cual se forma una cavidad con perfil en "V". Si tenemos en cuenta la asociación espacial, el tamaño y la forma cónica de la base de la vasija y, por lo tanto, su inestabilidad, probablemente esta 


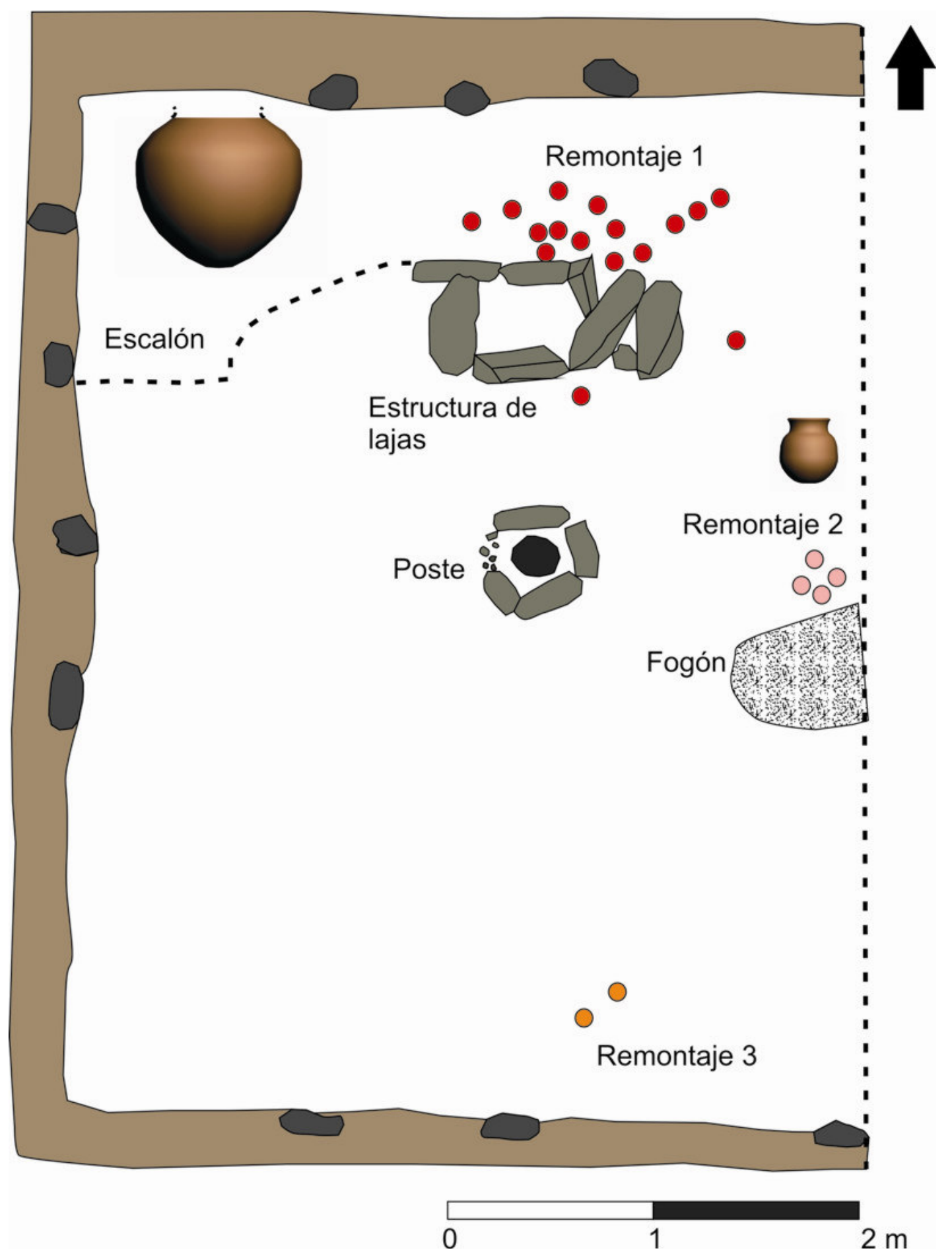

Figura 6.88: planta del recinto $\mathrm{C}$ donde se muestran las estructuras halladas y remontajes de vasijas.

habría estado colocada en la estructura en el momento de abandono del recinto. En relación a las huellas de uso que presenta esta vasija en la zona exterior de la base, hasta el diámetro máximo aparecen huellas de carbonización, en la superficie interior en las zonas de la parte media, inferior y base presenta antiplástico sobresaliente. Y en la zona inferior 

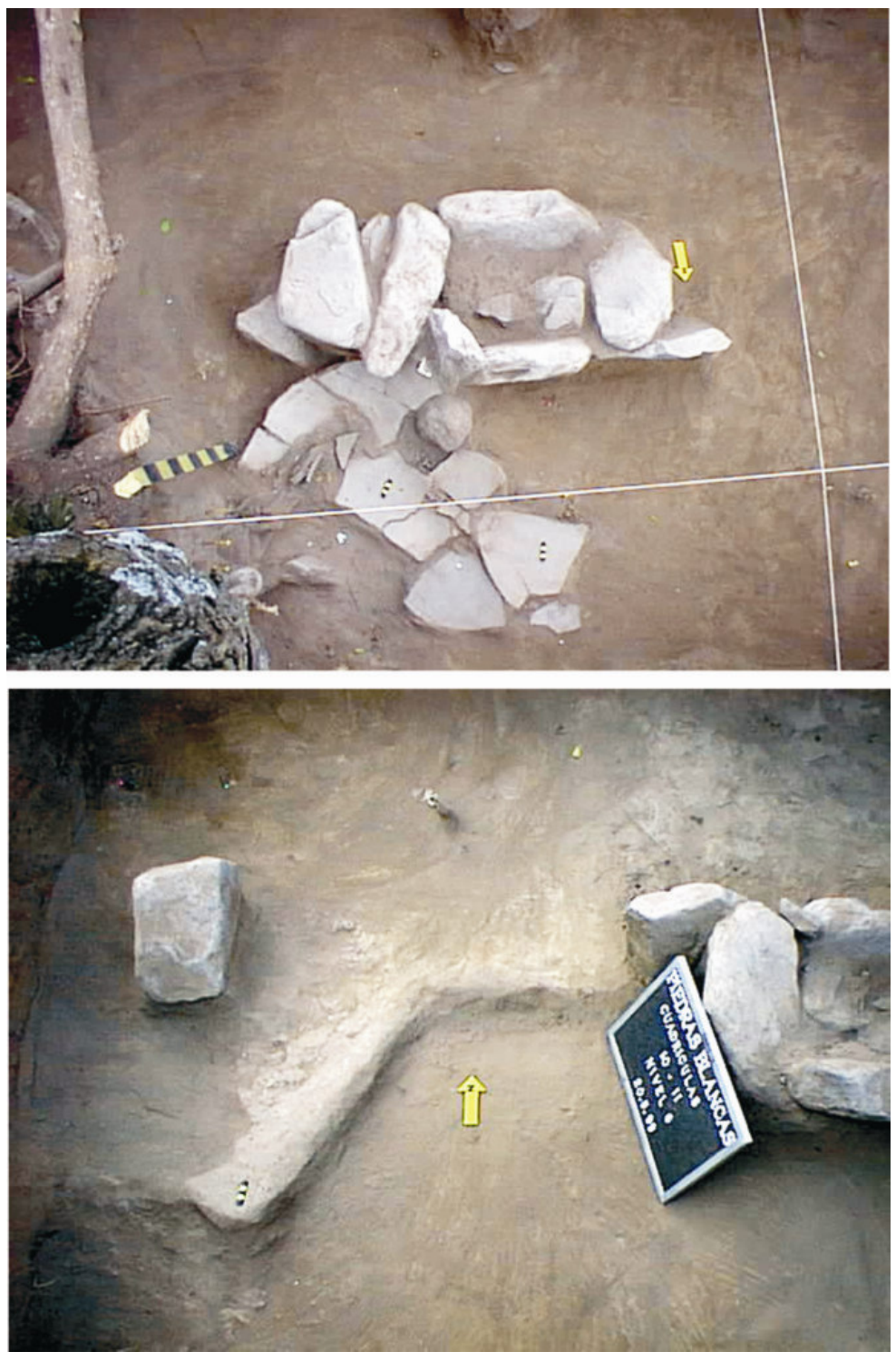

Figura 6.89: la fotografía superior muestra la estructura de contención de vasijas y el remontaje 1; en la inferior se observa el escalón y parte de la estructura de contención de vasijas.

de la superficie interna también se presenta un lote restringido de forma irregular de unos $40 \mathrm{~mm}$ x $30 \mathrm{~mm}$. En relación a los análisis de residuos orgánicos realizados por Pazzarelli (2006), esta vasija arrojó presencia de ácidos grasos y albúmina. Es decir contacto con carnes y posiblemente vegetales. Según estos datos y la presencia de antiplástico sobresaliente $\mathrm{y}$ huellas de carbonización tenemos que esta vasija se está usando para distintas cosas, por un lado fermentar bebidas y por otro cocinar alimentos. Esto hallazgo coincide con otras vasija de gran tamaño pertenecientes a las "otras formas" halladas en los sitos Martínez 1, 2 y 4. Es la primera vasija que presenta huellas de carbonización que está confeccionada con otra mezcla de pasta que no es la que presenta la clase E2 -mezcla 5- por lo que la composición de la clase no es determinante para el sometimiento al fuego de una vasija; pero sí existe una tendencia a preferir las vasijas de esta última clase. Si pensamos que las huellas y residuos nos muestran que la vasija se usó para dos procesos distintos, cocinar y fermentar, y, según el contexto donde la hallamos que nos indica que estaba colocada fija en una estructura de piedra diseñada para sostenerla, nos puede esta indicando ciertas cosas acerca de la espacialidad de las prácticas donde participa: por un lado nos puede indicar el lugar donde eran colocadas algunas de las vasijas para fermentar las bebidas, o también, puede ser el caso que nos indique, que esta vasija en dicho momento no se hallaba en una operación práctica específica como es fermentar, almacenar o cocinar, si no que la vasija se hallaba almacenada a la espera de 
realizar alguna actividad. Pero a su vez la estructura y la vasija guardada dentro de ella, configuran dentro del espacio interno del recinto un fuerte estructurador de donde se deben desarrollar determinadas actividades, en tanto configuran un aspecto fijo, a la manera de un poste, una banqueta, un fogón en uso etc. A unos $2 \mathrm{~m}$ al sur este de la estructura sobre el piso apareció un fogón -figura 6.88-. Asociado a este fogón apareció una vasija pequeña que remontaba en un $50 \%$-figura 6.88, remontaje 2-. Es de clase E1 y pertenece a las "otras formas", posee un diámetro de boca aproximado de $140 \mathrm{~mm}$, un diámetro máximo de $160 \mathrm{~mm}$ y una altura de $200 \mathrm{~mm}$. Tiene un volumen de 3,2 litros. A pesar de estar a lado del fogón no presenta huellas de carbonización. En relación a la marca y lotes, solo presenta hoyuelos aislados en la superficie exterior zona media e inferior. Los análisis de residuos orgánicos arrojan presencia de ácidos grasos y albúmina (Pazzarelli 2006). El tercer remontaje -figura 6.88, remontaje 3- se halla al sur de este último y se, se trata de fragmentos de una vasija b pertenecientes a otra clase tecnológica de las analizadas aquí clase A2-.

Hemos podido registrar más fragmentos sobre el nivel del piso que no remontan, pero que les pudimos reconstruir la forma u asociarlos a una de las ya clasificadas para el valle: aparecen tanto fragmentos de clase E - bordes de vasija "a", bordes de vasijas pertenecientes a las "otras formas", bordes de platos grandes, borde cuerpo y base de vasijas calceiformes-, como fragmentos de la clase A1 -borde, cuerpo y base de escudillas y, borde, cuello y cuerpo de vasijas de forma b-. Todos presentan huellas de utilización, tanto en la superficie externa como interna, que indican su participación en diferentes actividades. Estos en general no remontan, por lo que podrían considerarse como representas de partes de vasijas que pasaron por el lugar, y que se hallan descartadas provisoriamente o como hemos visto en el recinto $\mathrm{H}$ a la espera de su transformación en otro objeto. En este recinto a diferencia del $\mathrm{H}$ no se han hallado objetos reciclados o en proceso de reformatización, por lo que quizás desde este lugar eran trasportados a lugares definitivos de descarte, como los montículos "basureros", o al recinto $\mathrm{H}$ para su posterior reciclado. En términos de Zaburlín (2001) serían desechos secundarios. En relación a la distribución podemos observar cierta espacialización en la ubicación de estos fragmentos, en general se hallan contra los muros norte y oeste, presentándose algunas concentraciones alrededor de los rasgos -huella de poste y soporte de piedra- del área excavada (Zaburlín 2001). Es interesante resaltar algunos de estos fragmentos por la presencia de residuos en su interior y por el hecho que se han realizando análisis de residuos orgánicos: aquellos fragmentos asociables a la forma calceiforme, si bien no remontan son todos de clase E2, y pertenecen a una vasijas de dimensiones semejantes y con las mismas huellas de 
carbonización, por lo que podrían llegar a pertenecer a una misma vasija. Estos se hallaran cercanos a los fragmentos de la vasija grande que remonta en un 70\%. Los análisis de los residuos orgánicos carbonizados en su interior arrojan la presencia de ácidos grasos y albúmina, es decir contacto con grasas animales y/o vegetales y, carne. En uno de los fragmentos de cuerpo y cuello de vasijas de forma b -clase A1- que posee un diámetro de $280 \mathrm{~mm}$, la superficie interna aparece manchada de pigmento rojo que evidencia su contacto con este material. Es semejante a lo que marcamos para otra vasija de la misma clase y forma tanto en los sitios Martínez como el recinto H. Los análisis de residuos orgánicos de la base y parte inferior del cuerpo de una escudilla de clase A1 arroja la presencia de ácidos grasos y ausencia de albúmina. Esta presenta las huellas típicas que hemos asociados a esta forma. Otro fragmento de clase E2 pertenecientes a las "otras formas", con un diámetro de boca de $300 \mathrm{~mm}-17 \%$ de porcentaje de arco-, que presenta como huellas de uso hoyuelos y en la superficie interior parte superior estrías asiladas perpendiculares y diagonales, arrojó como resultados de los análisis presencia de ácidos grasos y ausencia de albúmina.

Si a las distribuciones de material cerámico le sumamos otros materiales se amplia y complementa los contextos de asociación. En la esquina noroeste se ubican una serie de artefactos: una ficha cerámica, dos cuentas de nácar, un fragmento de pinza de metal y un cubo de roca cristalina. Estos elementos podrían estar ubicados en un espacio de almacenaje temporal. En el espacio circundante a la huella de poste, que comprende el área ubicada entre el pozo y el muro oeste, continuándose con el espacio ubicado entre el pozo y el fogón. En este espacio se ubican tanto los artefactos líticos, los desechos de talla y la vasija de otra forma remontada en un 50\%. Probablemente este espacio donde se realizan distintas actividades algunas vinculadas con la cocción y procesamiento de alimentos y si se toman en cuenta las materias primas de las herramientas líticas y de los desechos de talla, es probable que en estos espacios se realizaran actividades vinculadas con la manufactura o mantención de implementos líticos (Zaburlín 2001). No debemos descartar la posibilidad de otras actividades de manufactura donde se manipularan estas herramientas. En cuanto a los restos óseos la autora señala que sin importar sus dimensiones se concentran en el espacio comprendido entre el muro oeste y la línea formada por el soporte de piedra y la huella de poste. Es notable la disminución en los hallazgos en el sector sur del área excavada. En este recinto aunque no se halla excavado completo comparte con los contextos que venimos describiendo la concentración de diversas prácticas, donde las vasijas analizadas se hallan activamente participando, en el sector central y oeste de la habitación. 


\section{Recinto Sudeste}

Este se ubica en la esquina sureste del sitio -figura 6.76-, parte de las paredes que lo delimitan conforman el muro perimetral este y sur del sitio. Es de forma rectangular de unos 7, $5 \mathrm{~m}$ en sentido este-oeste y, unos 6,5 m en sentido norte sur -figura 6.90-. Se lo

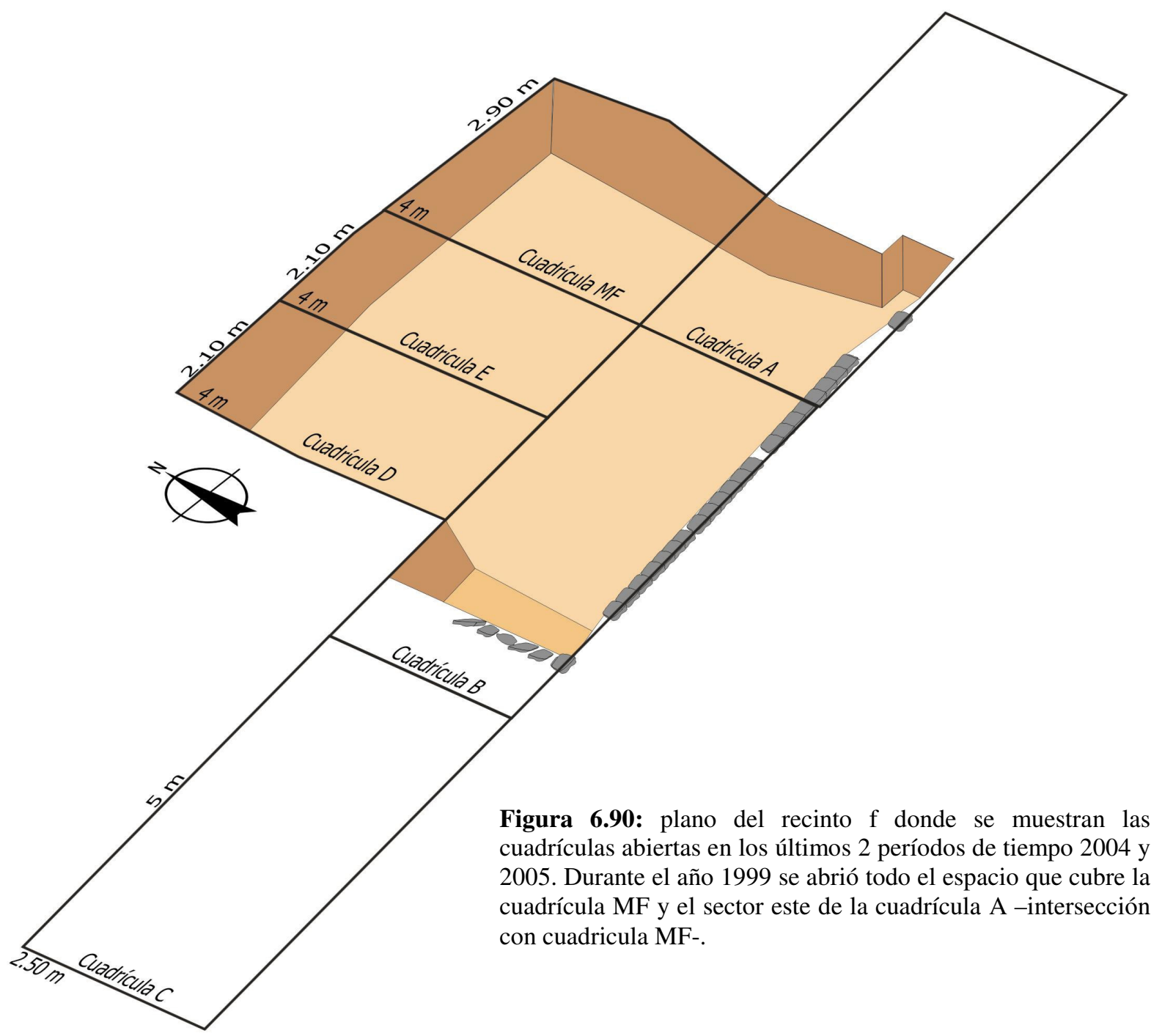

excavó en cuatro períodos de tiempo. Durante la primera excavación que se realizó en el año 1999, se abrió un espacio que cubría el largo del recinto en sentido norte-sur y, 3 m en sentido este oeste -cuadrículas MF y parte de A-. De estas primeras excavaciones se obtuvo el siguiente panorama: se excavo parte del derrumbe de los muros y columna comenzándose a destapar los troncos carbonizados que conformaban tanto la enramada como tirantes de techo -figura 6.91-. La excavación en aquel momento no llegó a determinar la presencia de un piso estructuralmente definido; el mismo fue identificado enexcavaciones subsiguientes. Asociadas al derrumbe del techo y en algunos sectores aplastadas por el techo en la esquina noreste contra el muro norte en un espacio de unos 2 $\mathrm{m}^{2}$ aparecieron repartidos fragmentos de dos vasijas de grandes proporciones: una de 
formaba "a", la otra pertenecientes a las "otras formas". Dada la distribución de los fragmento y el alto porcentaje de de remontaje -más del 70\%- de las vasijas, se pueden suponer que estaban apoyadas contra el muro norte en el rincón de la habitación. La vasija perteneciente a las "otras formas" de clase E2 que se pudo remontar en más de un $50 \%$, por lo que permitió su proyección gráfica para acercarnos al volumen y su dimensiones, posee de diámetro de boca unos $200 \mathrm{~mm}$ y de diámetro máximo unos $330 \mathrm{~mm}$; a su vez presenta una altura de unos $476 \mathrm{~mm}$, siendo el volumen estimado de unos 24 litros. En relación a las huellas de uso, presenta tanto en su superficie externa -parte media y superior- como interna -en las mismas zonas- algunos hoyuelos aislados; en el interior del cuello observamos presencia aislada de estrías perpendiculares. Los análisis de residuos orgánicos, de uno de los fragmentos pertenecientes al cuerpo, arroja presencia de ácidos

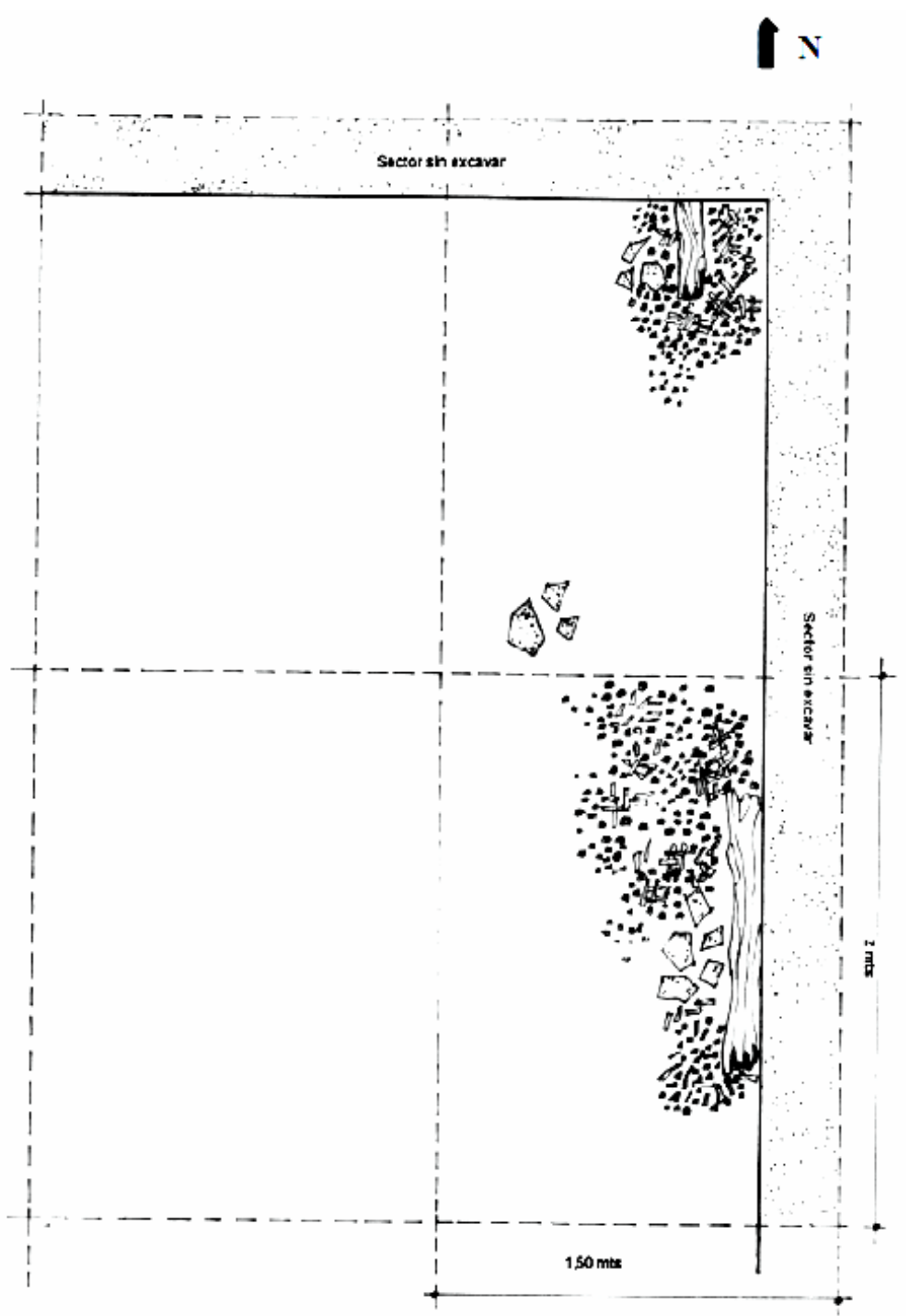

Figura 6.91: planta de excavación del año 1999. Cuadrícula MF en los dos siguientes períodos. Se observan troncos carbonizados, enramada y fragmentos de vasijas aplastados por la techumbre. grasos y ausencia de albúmina. Esto nos indica que la vasija entró en contacto con grasas animales y/o vegetales pero no con carne. La otra vasija que se encuentra dispuesta al lado de esta, hacia el oeste, es de forma "a" de clase E5 -mezcla 4- por lo que presenta en su interior un baño negro. Se puedo remontar el $90 \%$ de esta vasija. Presenta en el cuello un rostro modelado que pose la típica nariz en gancho hacia arriba, además de boca, cejas y ojos. Todos se hallan adosados al pastillaje. A

diferencia de otras vasijas de esta forma en las que también se presentan 
rostros modelados, la hallada en este recinto no se encuentran pintada, como en general los hacen las otras vasijas observadas. Posee una altura de $679 \mathrm{~mm}$ un diámetro de boca de $240 \mathrm{~mm}$ y un diámetro máximo de $440 \mathrm{~mm}$. En relación a las huellas observadas, en la superficie exterior, parte inferior, se observa lotes irregulares combinados con antiplástico sobresaliente; en la parte media y superior solo se observan estrías perpendiculares combinadas con hoyuelos, y en la zona exterior del borde aparecen estrías finas paralelas con antiplástico sobresaliente que nos podría indicar que la vasija en algún momento estuvo boca abajo. En los sectores interiores presenta estrías perpendiculares y hoyuelos. Los análisis de residuos orgánicos realizados sobre varios fragmentos de esta vasija arrojan tanto presencia de ácidos grasos como de albúmina. Las huellas observadas en la superficie exterior muestra un proceso erosivo intenso en un sector restringido en la zona inferior y probablemente la base y, en las zonas medias y superiores, estrías perpendiculares. Esta nos muestra por un lado movimientos giratorios y ausencia casi de movimientos de inclinación. Las marcas y lotes en las zonas inferiores se pueden producir por este tipo de movimiento también. Según las marcas exteriores tenemos dos posiciones: en una la vasija se hallaría boca abajo, situación que produjo el antiplástico sobresaliente en el borde y, otra posición erguida boca arriba que combinó movimientos giratorios alrededor del eje y leves o nulos movimientos de inclinación. Es difícil de determinar en que posición se hallaba esta vasija en el lugar que fue encontrada, pero si analizamos las descripciones de cómo se fueron excavando los fragmentos, hallamos que los fragmentos de borde son los primeros que empiezan a aparecer junto a los primeros troncos carbonizados del techos, por lo que quizás nos esté indicando que ésta se hallaba erguida junto a la otra vasija.

En la segunda intervención -noviembre-diciembre de 2004- se establecieron tres cuadrículas -A, B y C- de $5 \mathrm{~m}$ de largo por 2,5 $\mathrm{m}$ de ancho y una -MF- de $2,90 \mathrm{~m}$ por $4 \mathrm{~m}$ de largo -figura 6.90-. La excavación limitaba hacia el E con el muro perimetral que rodea al sitio. La decisión de realizar cuadrículas rectangulares y disponerlas en la esquina sur/oeste del sitio se debió a que en aquel momento, debido a los hallazgos de la excavación de año 1999, se pensaba que ese espacio conformaba un galería y no un recinto, que corría junto al muro perimetral. En este primer período se excavaron $30 \mathrm{~m}^{2} \mathrm{de}$ los $46 \mathrm{~m}^{2}$ que cubren las cuadrículas A, B, C y MF. En el segundo período -abril/ mayo de 2005- la excavación, en virtud de los hallazgos del período anterior -principalmente la presencia del techos derrumbados carbonizados- se amplío hacia el norte para poder destapar completamente a los troncos carbonizados. Así se establecieron dos cuadrículas más, también de forma rectangular -cuadrículas E y D- -figura 6.90-. Las cuadrículas tenían, cada una, un largo de 4 m y un ancho de 2,10 m. La excavación se amplió unos 16 
$\mathrm{m}^{2}$ más. En total la superficie excavada del recinto es de unos $46 \mathrm{~m}^{2}$. La excavación, tal cual lo hemos expresado en el capítulo tres siguió los lineamientos propuestos por Harris (1997) -ver anexo 5-. Podemos resumir los hallazgos de la siguiente manera: se identificaron 56 unidades estratigráficas, definidas, algunas de ellas, como estratos horizontales y otras como elementos interfaciales verticales -figura 6.92; para una descripción de la unidades estratigráficas identificadas ver anexo 5-. Los estratos horizontales corresponden a eventos de derrumbe de muros de piedras y tapia con columnas, acumulación y mezcla por acción eólica y de roedores, y eventos de caída de techos del recinto, así como pisos consolidados, fogones y cubetas de fogones. También aparecieron unidades estratigráficas verticales, tales como muro de piedra continuo, muro de tapia y muro de tapia con columnas. A su vez se hallaron cuatro estructuras de sostén de poste, con los troncos carbonizados en su interior. La mayoría de las vasijas analizadas, y, específicamente aquellas que remontan en un gran porcentaje -más del 50\%- aparecieron aplastadas por la enramada, los troncos, la torta y los postes de sostén de techo, apoyando en un piso muy consolidad $[17]=[10]=[30]$ - figura 6.93, 6.94; ver anexo 5- o formando parte de unidades que fueron de estructuras emplazadas sobre el piso. Aquellos fragmentos que no remontan se hallaron distribuidos diferencialmente tanto apoyando sobre el piso como formando parte de su matriz. No se hallaron acumulados en un sector particular o específicos si no distribuidos por todo el recinto.

Ya mencionamos a las dos vasijas halladas en la esquina noreste del recinto. Entre las estructuras de poste, en el centro del recinto, en el sector sur de la cuadrícula D, apareció una estructura construida con lajas planas, que fue destruida por la caída del los troncos del techo -[27] en figura 6.94-. La estructura medía unos 1,10 $\mathrm{m}$ de largo por 0,90 a $1 \mathrm{~m}$ de ancho -figura 6.95-. En su interior se hallaron 2 vasijas: una de clase E1, perteneciente a las "otras formas" que remonta en un $60 \%$ y una escudilla A1 con un felino inciso que remonta en su totalidad. La vasija de clase A1 remonta solo el cuerpo nos falta la base y los bordes. Posee un diámetro máximo de $490 \mathrm{~mm}$.

En relación a las huellas observadas, en la superficie exterior desde la zona inferior y probablemente desde la base hasta unos $70 \mathrm{~mm}$ por encima del diámetro máximo, toda la superficie se halla con huellas de carbonización. En esta zona no se pudo observar otras huellas en tanto la carbonización cubre toda la superficie, en la parte superior donde no hay huellas de carbonización no se observa marcas ni lotes. En el interior se observan lotes de forma irregulares tanto en las zonas interiores, medias y superiores, junto a zonas con antiplástico sobresaliente. A su vez desde la zona media hacia la inferior presenta una 


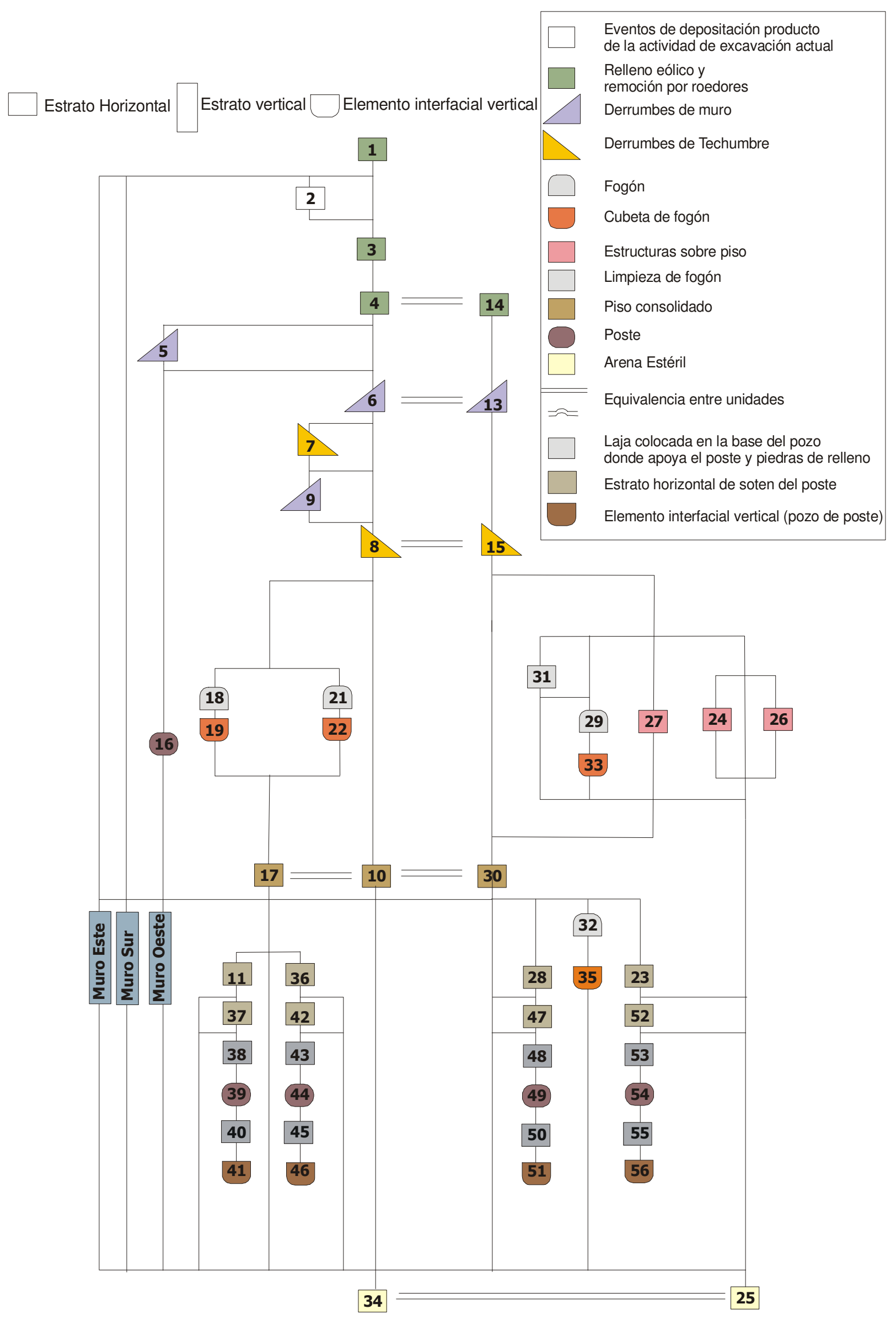

Figura 6.92: matriz estratigráfica del recito F del sitio Piedras Blancas. 

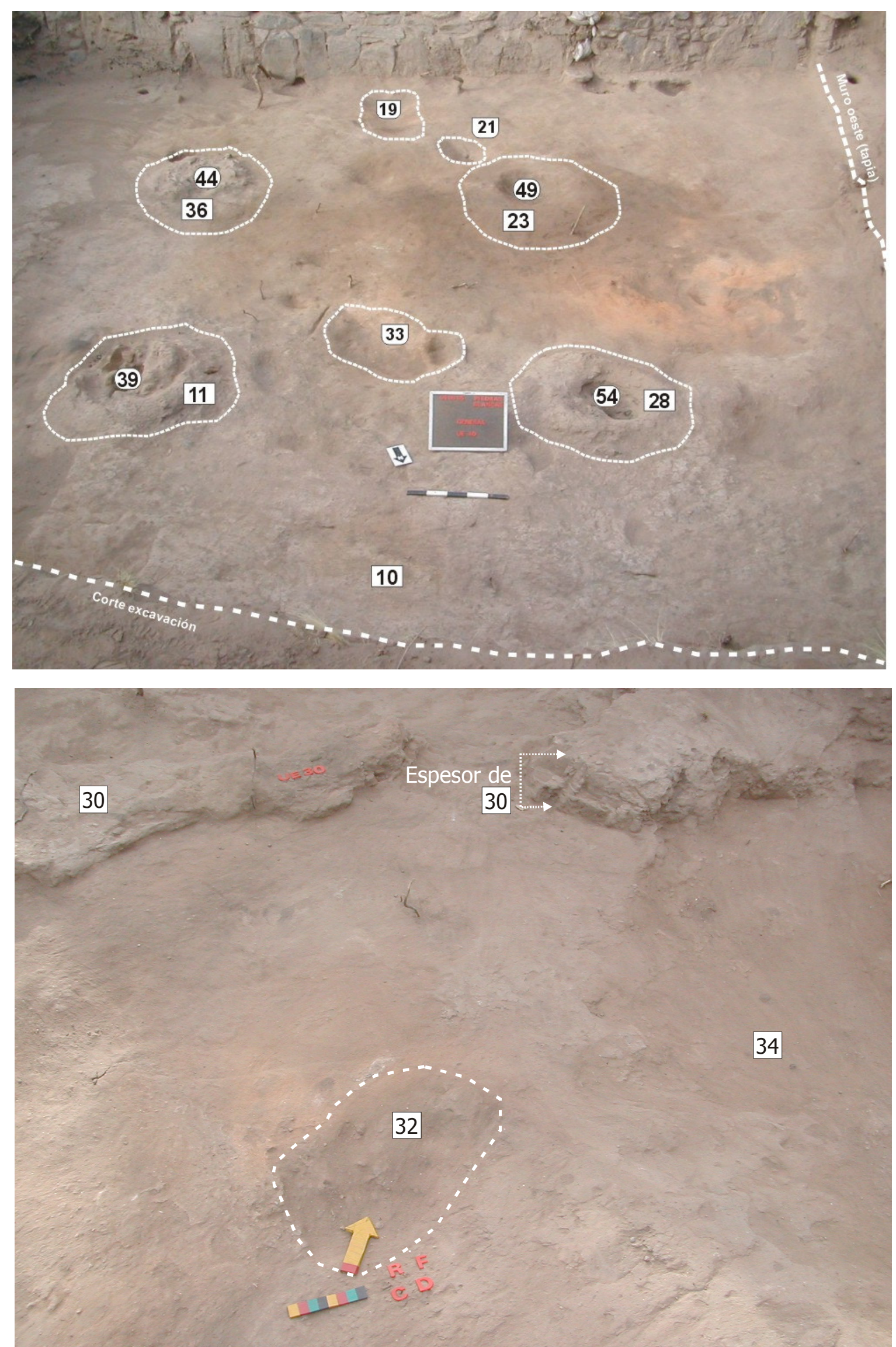

Figura 6.93: piso consolidado $[10]=[30]$ donde apoyaban las vasijas y otros objetos hallados -ver figura 5.94-. A su vez en la imagen superior se observan tres cubetas de fogón -[19], [33] y [21]- y las cuatro estructuras de poste. En la imagen inferior se observa además del piso un primer fogón [32] realizado antes de construir [30] y el sedimento estéril [34\} 


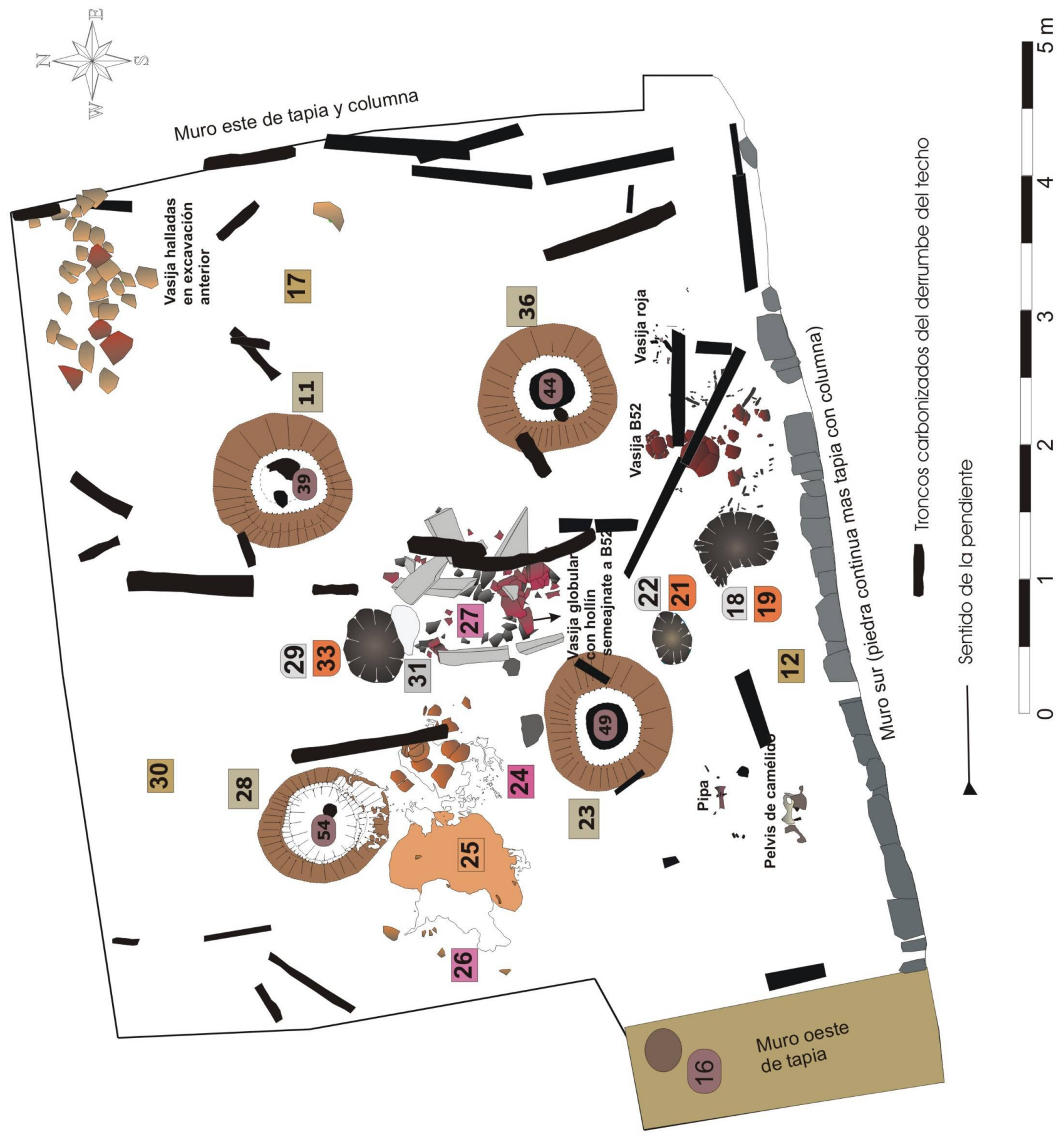

Figura 6.94: se observan los troncos carbonizados, las estructuras, fogones y vasijas que remontan. Todos apoyan sobre [30].

cubierta de un pigmento rojizo. En relación a los análisis de residuos orgánicos, arrojó presencia de ácidos grasos y ausencia de albúmina. Tenemos según lo que venimos describiendo de las marcas, lotes, carbonizaciones y presencia de pigmento por lo menos tres o cuatro actividades a las que fue sometida esta vasija, por un lado lotes y marcas como el antiplástico sobresaliente nos estarían indicando actividades vinculadas a la 
fermentación de bebida, la huellas de carbonización nos indican su colocación en un fogón, por lo que tenemos otra vasija que no es de clase E2 sometida al fuego. Probablemente, dado el patrón de carbonización y ausencia de oxidación, no estuvo apoyada directamente en el fuego si no por encima de este. Además la presencia de pigmento en la zona interior nos indica que esta entró en contacto con este.

Los análisis de residuos orgánicos realizados en esta vasija indican su contacto con grasas, animales y o/vegetales, esta concuerda con sus huellas y también con actividades de cocción de alimentos vegetales. Para el caso de la manipulación de pigmentos, veremos
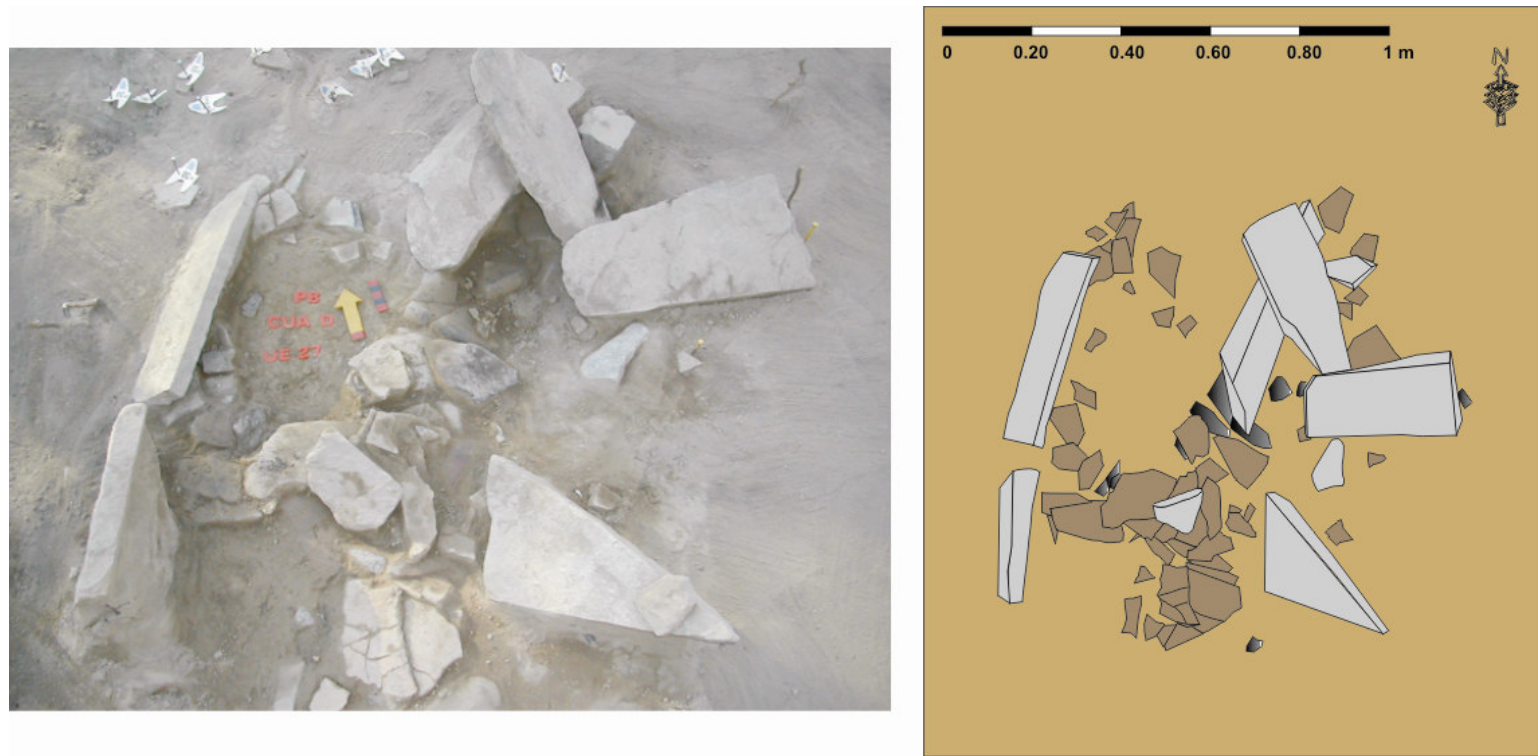

Figura 6.95: estructura de contención de vasijas [27]. Aparecen dos vasijas una de clase E perteneciente a las otras formas y una escudilla grabada de clase A1. Ambas poseen adheridas en la superficie interior pigmento color rojo.

en otro contexto hallado en este recinto que para su preparación se utiliza grasa por lo que los análisis de residuos orgánicos también concordarían con esta actividad. Tenemos entonces una alternancia de actividades distintas que implican procesos y objetos diferentes. En el contexto hallado más que cumplir con algunas de estas actividades, se hallaba posiblemente almacenada, y si pensamos en los residuos y sus huellas probablemente la última actividad en la que participó tuvo que ver con la contención de pigmentos de color rojo y su manipulación. Esta variedad de prácticas en las que estuvo involucrada esta vasija y, que hemos observado para otros casos, nos está marcando parte de la trayectoria biográfica de la misma. Si pensamos en las actividades que ejecuta, el cocido de alimentos, la fermentación de bebida, el almacenaje para la manipulación de pigmentos color rojo, podríamos darle cierta temporalidad al interior del la biografía de este objeto. Si pensamos en la fermentación de chicha y en las diversas etnografías que se 
han realizado tanto en los andes -centrales y meridionales-, en zonas urbanas donde aún se produce chicha (Pazzarelli y Vargas 2008; Menacho 2000, García 1988) ${ }^{\text {xix }}$ las vasijas utilizadas para fermentar la chicha son dedicadas exclusivamente a este proceso, principalmente porque pude llegar afectar el sabor de la misma (Pazzarelli y Vargas 2008). Quizás, la vasija se destinó a cocinar posteriormente a su participación en la fermentación. Este tiempo pudo ser largo si pensamos en el grado de desgaste -lotes y antiplástico sobresaliente- que presenta, aunque también cabe la posibilidad de un tiempo relativamente más corto pero con mayor frecuencia de uso en actividades de fermentación. Y por último se utilizó para contener pigmento de color rojo, la última actividad antes que se rompiera la vasija al caérsele el techo. En cuanto a la escudilla hallada, que se halla fragmentada pero completo pero que remonta en su totalidad, posee una altura de $55 \mathrm{~mm}$ y un diámetro de boca de $185 \mathrm{~mm}$, el diámetro de la base es de $58 \mathrm{~mm}$. En el panel superior por encima del punto angular posee grabado un felino, con líneas bastante rectas diferentes a los felinos que se observan normalmente en esta clase de representaciones que poseen líneas más curvas. En relación a las huellas de uso se presenta al igual que el resto de las escudilla lotes en la zona de contacto de la base con la superficie de apoyo. En la parte inferior presenta estrías paralelas, específicamente en la zona de contacto de esta zona con la base y diagonales y perpendiculares desde el punto angular hacia la base. En la zona media -punto angular- y unos $5 \mathrm{~mm}$ hacia la base presenta estrías en general paralelas. En la zona donde se halla el panel decorativo las estrías disminuyen aunque se observan estrías en distintas dirección: paralelas, perpendiculares y diagonales. En la zona exterior del borde presenta estrías paralelas y astilladuras. En la superficie interior también presenta en la zona del borde astilladuras y estría paralelas. Luego se observan estrías perpendiculares y diagonales por toda la superficie interna. A su vez en la superficie interior se observa la presencia adherida de pigmento color rojo en varios de los fragmentos. Habría que determinar al estar entremezclado con los restos de la vasija grande si esta adherencia no se produjo por el contacto con esta. Sin embargo debemos tener en cuenta que, por un lado, en este caso, se repite la asociación de vasijas de "otras formas" de gran tamaño con escudillas, tal cual lo observamos en los sitios Martínez, y por el otro lado señalamos a estas vasijas como intermediarias, que permiten movilizar y manipular los contenidos que se hallan acumulados en las vasijas más grande. Por lo que quizá las manchas de pigmento rojo observadas no sean accidentales si no producto de su utilización en la manipulación de este. Muy cercano a esta estructura, a unos $0,50 \mathrm{~m}$ al norte se definieron tres unidades estratigráficas -[21, cubeta de fogón], [31, relleno de la cubeta] y [33, limpieza del fogón], ver anexo 5-. 
A un metro hacia el oeste, cercana de la estructuras de poste se definieron dos unidades estratigráficas -[24] y [26], ver anexo 5- que apoyaban sobre el piso, estas estaban compuesta por un sedimento blanquecino que poseía un espesor de unos 0,08 $\mathrm{m}$ y se distribuían en forma de una colada irregular -figura 6.96-. En relación a las inclusiones culturales que presentaban estas dos unidades, aparecieron frecuentes fragmentos cerámicos que se encontraban incrustados en el sedimento en diferentes inclinaciones.

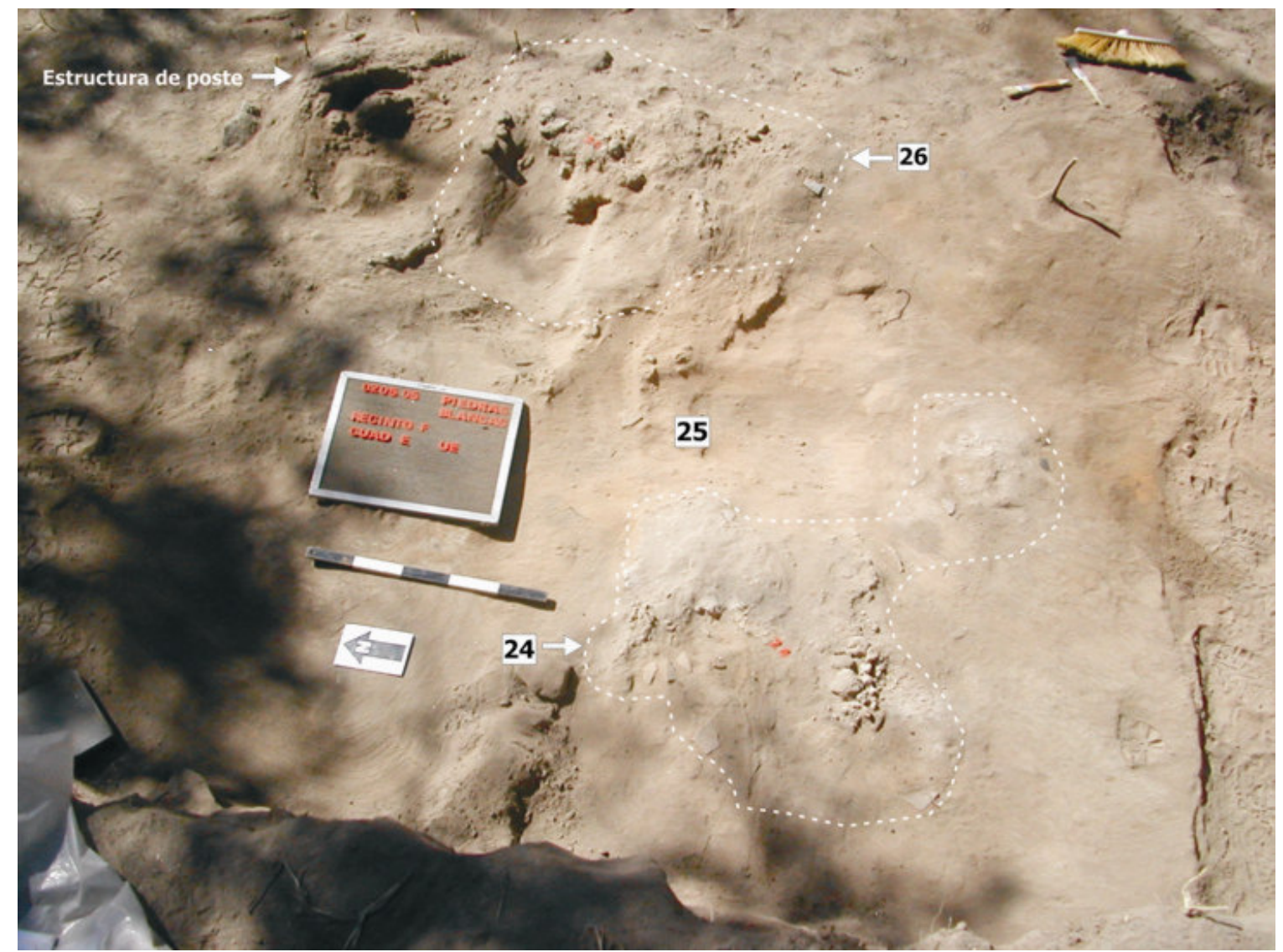

Figura 6.96: unidades estratigráficas [26] y [27]. Se trata de una vasija de forma "ab" que contenía pigmento blanco; que al derrumbarse el techo lo esparció por el lugar.

Algunos debieron ser recolectados en lotes, debido a que, si bien estaban fracturados, se observaba claramente que pertenecían a una misma pieza que se fracturó al caerse el techo. Es sugestivo que se hallaran fragmentos de una base de una vasija, semejantes a los fragmentos que se levantaron como lotes, en posición invertida y con sedimento adherido a ella. Dadas estas características, a este estrato se lo interpretó como el contenido de un recipiente cerámico, que al momento de derrumbarse el techo se rompió desparramando los fragmentos y el contenido de la vasija por el piso [30]. La vasija se trataba de una vasija "ab" que pertenece a otra clase tecnológica de las analizadas (G1), tiene un diámetro máximo de cuerpo de $284 \mathrm{~mm}$ y una altura de $280 \mathrm{~mm}$, con un volumen de unos 5,32 litros. En los primeros análisis de residuos orgánicos realizados tanto al contenido como a 
la vasija se determinó la presencia de ácidos grasos y ausencia de albúmina, por lo que el sedimento blanquecino asociado a la vasijas y esparcido en el piso se pensó que se trataba de un material finamente molido de origen vegetal aunque no se podía determinar cual era éste específicamente. Posteriormente a los análisis realizados, se mandaron muestra a analizar de estos pigmentos y resultó que se trataba de un preparado para producir pigmento color blanco con alto contenido de calcio, donde se había utilizado grasa vegetal $^{\mathrm{xx}}$. En relación a las huellas de uso de las vasijas en la zona exterior presenta en la zona de apoyo de la base antiplástico sobresaliente, en la zona inferior se observan estrías diagonales y perpendiculares, no presenta huellas en la zona superior ni en el borde. En la superficie interior presenta solo hoyuelos aislados. Junto al muro oeste aparece una gran vasija que pertenece a las "otras formas" que posee un diámetro de boca de unos $400 \mathrm{~mm}$ y un diámetro máximo de unos $600 \mathrm{~mm}$, no pudimos remontarla completa, se halla aproximadamente en un 50\%. Es de resaltar que pueden existir fragmentos en el sector que falta de excavar de unos $0,50 \mathrm{~m}$ hacia el oeste hasta llegar al muro de tapia. En cuanto a las huellas observadas solo presenta hoyuelos aislados en la superficie externa. En el borde presenta astilladuras. Ya en la zona del cuello hacia el interior se observa antiplástico sobresaliente, marca asociada con la fermentación de bebidas. Si comparamos esto con los
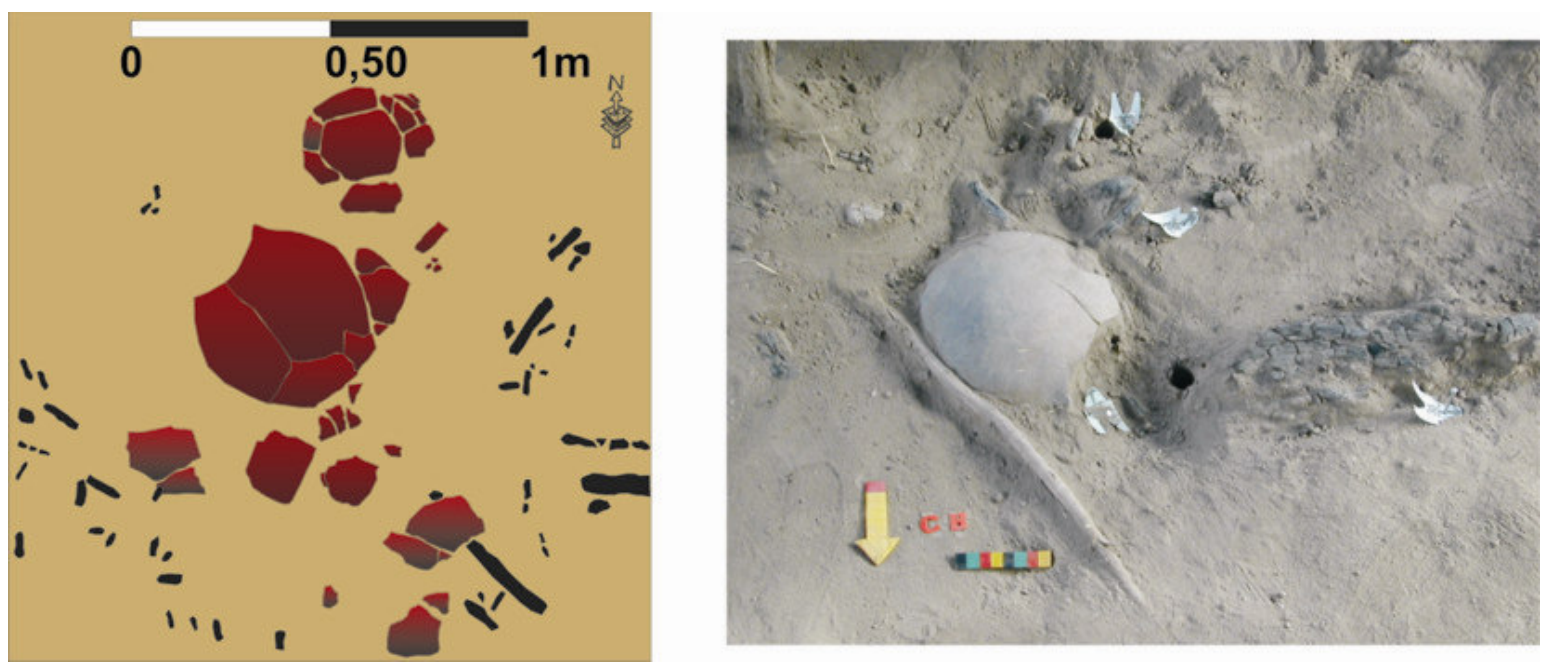

Figura 6.97: se observa una vasija perteneciente a las otras formas que fue aplastada por el techo. En la figura 5,94 aparece como vasija b52.

resultados de los análisis de residuos orgánicos reafirma la posibilidad de que realizara esta actividad en tanto arroja presencia de ácidos grasos y ausencia de albúmina.

Hacia el sur, en el espacio intermedio entre las dos estructuras de poste y el muro sur que es de piedra continua, se hallaron dos fogones muy cercanos separados por unos 0,60 m: a lado de uno de ellos -[18] y la cubeta [19], ver anexo 5- hacia el este, se halló una vasijas de clase E2 perteneciente a las "otras formas" -figura 6.94, vasija B52 y figura 6.97-y, unos 0,50 m al este de la misma se halló un puco de clase A2 y parte de una vasija 
calceiforme E2. La vasija de clase E2, perteneciente a las "otras formas", se encontró totalmente aplastada por uno de los postes que sostenían la enramada del techo, en un área de $1 \mathrm{~m}^{2}$. Se pudo remontar casi el $90 \%$ de la pieza. Lo que falta para remontarla completa es el cuello y el borde. Posee una base cónica, un cuerpo globular que tiene un diámetro máximo de $333 \mathrm{~mm}$ de diámetro, el cuello es restringido, si bien no lo pudimos reconstruir el diámetro en este sector, según la proyecciones que se pueden realizar sería menor de 180 mm. En relación al volumen de contención aproximado de la vasija es de menos 17,4 litros. La vasija en la superficie exterior posee huellas de carbonización que nos permiten además de señalar que fue sometida al fuego, las maneras en que se la colocaba sobre el mismo: el hollín cubre desde la base hasta la zona superior de la vasija, a su vez la carbonización se halla cubriendo solamente uno de los lados de la pieza. El otro lado de la pieza casi no presenta depósito de hollín y la superficie en esa zona se observa con una coloración más clara y anaranjada que la original, como si hubiera sufrido un proceso de oxidación. Estas observaciones nos permiten ver que la misma habría sido colocada directamente sobre el fuego. El lado que presenta la superficie sin depósito de carbón habría sido el que estuvo en contacto directo con las llamas, en tanto se necesita mucha temperatura para que se produzca la oxidación de esta zona (Skibo 1992). De esto se deduce que la vasija estaba colocada de costado sobre el fuego y posiblemente inclinada, en tanto que una parte de la base posee depósito de carbón mientras que otras partes no lo presentan. Es sugerente que se encuentra a lado del fogón el que es de forma irregular alargada y posee una cubeta no muy profunda. El interior de la vasija presenta en la zona inferior y base antiplástico sobresaliente, lo cual nos vuelve a indicar su utilización en más de una actividad y, a su vez, como señalamos para otros casos una secuencia de uso. Los análisis de residuos orgánicos arrojaron presencia de ácidos grasos y ausencia de albúmina. Nos informa que en las actividades de cocción a las que estuvo sometida no intervino la carne, lo cual concuerda con las marcas que la vinculan con la fermentación de la chicha. Del residuo adherido de esta vasija se realizó un fechado por AMS 1281+-33 BP -95,4\% de probabilidad- . Esta fecha concuerda con un fechado realizado en una ramita hallada como inclusión de uno de los rellenos de una cubeta de fogón -[32] ver anexo 5- que arrojo una fecha calibrada de $1273+-49$ BP $-95,4 \%$ de probabilidad-. Este evento es el primer evento realizado, junto con el cavado de los pozos para colocar los postes del recinto y probablemente el levantado de los muros. Se encuentra por debajo del piso consolidado. Quizás nos esté marcando el inicio de construcción del recinto F. Ahora si lo comparamos con los fechados obtenidos de la enramada del techo que se halló por encima de la vasija, que arroja una fecha calibrada con $95,4 \%$ de probabilidad de $920 \pm 70 \mathrm{BP}$, una diferencia 
temporal de un poco más de 300 años se nos presenta entre la construcción del techo y la ocurrencia de las otras acciones. Por lo que la vasija a nivel estratigráfico es contemporánea con las otras cosas realizadas en el piso de la habitación, es decir se halla dentro de un contexto significativo de asociación, pero su participación en actividades de fermentación y cocción de vegetales es coincidente con una temporalidad mayor, es decir que en ese contexto esta vasija se halla probablemente como otra cosa, en otro estado biográfico, en cierta forma representa un tiempo más largo, y a su vez nos permite entrever quizás la larga vida de alguna de ellas.

La vasija calceiforme de clase E2 que se encuentra a $1 \mathrm{~m}$ al este de esta, junto a la pared de piedra, no pudo ser remontada en su totalidad. Solo en un $40 \%$, tiene un diámetro máximo en el cuerpo de $180 \mathrm{~mm}$ y en el borde de unos $140 \mathrm{~mm}$ y una altura de unos 150 mm. A su vez presenta un volumen aproximado de 2,5 litro. En la superficie exterior presenta las huellas de carbonización típica que hemos descrito para esta forma, lo cual nos indica una forma específica de posición sobre el fuego. En su interior presenta las misas huellas de carbonización que las otras analizadas y residuos orgánicos adheridos. De los análisis realizados por Pazzarelli (2006) esta vasija arrojó presencia tanto de ácidos grasos como albúmina. Al norte d esta vasija unos $0,70 \mathrm{~m}$ y a unos $0,50 \mathrm{~m}$ de la vasija de clase E2 perteneciente a las "otras formas" apareció una escudilla de clase A2 entera, sin contenido en su interior aplastada por el techo. A su vez entre este fogón y el otro hallado en la zona, aparecen otro puco de clase A2. Este contexto reafirma la asociación que venimos realizando en contexto de actividades vinculadas con el fuego la asociación entre vasijas de "otras formas" de gran tamaño y escudillas.

Hacia el este de los fogones a 1m de distancia -figura 6.98- aparece un conjunto de
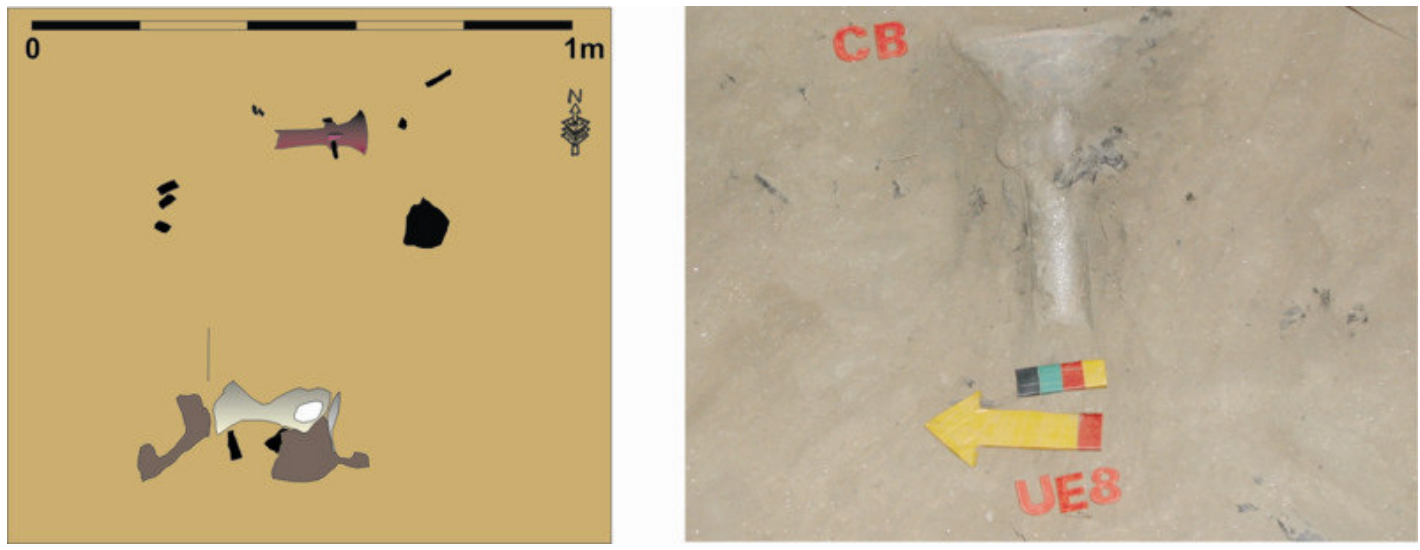

Figura 6.98: conjunto de pelvis de camélido, tubo de pipa y placas de mica. En la figura 5.94, figuran como pelvis de camélido y pipa. 
una pelvis de camélidos, una placa de mica y un hornillo y tubo de pipa. Estos últimos elementos se les encontró aplastados por el techo, si bien no podemos confirmarlo, si pensamos en la fragilidad de la placa de mica, o incluso la pipa, si se la pisa se puede llegar a fragmentar el tubo, quizá no hallan estado apoyados directamente en el piso, si no insertos -guardados- en la enramada del techo.

Toda el área central del recinto, la zona oeste y sur conforma un gran espacio donde se realizan variedad de prácticas distintas tenemos por lo menos aquellas vinculadas con la manipulación de pigmentos blancos y rojos, en este caso aparece una asociación fuerte entre vasijas grandes menos transportables, vasijas de forma "ab" que permiten manipular más fácilmente los pigmentos y escudillas pequeñas. Lo mismo sucede con las actividades de cocción teneos vasijas de clase E2 grandes junto a fogones asociadas a escudillas más pequeñas.

La fermentación de bebida está vinculada a vasijas grandes tanto de forma "a" como pertenecientes a las "otras formas". Por otro lado algunas de las vasijas muestran una alternancia de actividades que pueden ser secuenciadas: fermentación de bebida, cocción de alimentos y luego manipulación de pigmento rojo. Salvo en el rincón noreste del recinto en donde existe un espacio donde hay guardadas vasijas de gran tamaño, algunas vinculadas con la fermentación de chicha otra con la manipulación de vegetales pero sin sometimiento al fuego, en los espacios del este y el norte no es que no se ha hallado material cerámico y otro tipo de material pero este en general no remonta, si no son fragmentos individuales de formas y clase distintas, probablemente residuos de otras actividades realizadas en el lugar. A su vez nos permiten entrever actividades de limpieza.

En octubre noviembre de 2008, se terminó de excavar este recinto y se amplió el área hacia el norte -figura 6.99-. Durante esta excavación se pudo hallar la entrada al recinto que se encuentra en el centro de la pared norte -ver figura 6.100-. Coincide justo con el área donde se encuentran menor densidad de hallazgos. La misma es de unos 0,90 m de ancho, presenta un escalón que ubica al piso del recinto 0,20 metro por debajo del piso del patio y galería que se hallan al norte. En este sentido se comporta de la misma manera que los sitios Martínez 1, Martínez 2 y Martínez 4. La entrada está delimitada por sendas paredes de tapia, de 0,70 $\mathrm{m}$ de ancho, que poseen una especie de revoque o estucado color blanquecino. No poseemos análisis de este que nos informe de su composición pero se diferencia de otras paredes de tapia halladas en el sitio. Heredia (1998) señala que una de las habitaciones en el sector este del sitio Martínez 2, parte de lo que se idéntico como bloques de derrumbe de muro de tapia, presentaba un revoque color rojizo. Lo mismo fue 
señalado para la excavación de dos cuadrículas (cuadrículas 3 y 4) contra el muro de entrada al sitio Piedras Blancas, que del lado interior se halló que poseía un revoque color rojizo. Es interesante de pensar la posible vinculación entre el pigmento hallado en el recinto $\mathrm{F}$ color blanco que se hallaba contenido en las vasija y la aplicación de pintura en las paredes.

Al traspasar esta entrada, se excavó un área de unos $52,5 \mathrm{~m}^{2}$. En esta área se abrieron tres nuevas cuadrículas -figura 6.99-. Se pudieron determinar dos sectores diferentes, en los que se hallaron una gran cantidad de vasijas fragmentadas pero que la mayoría

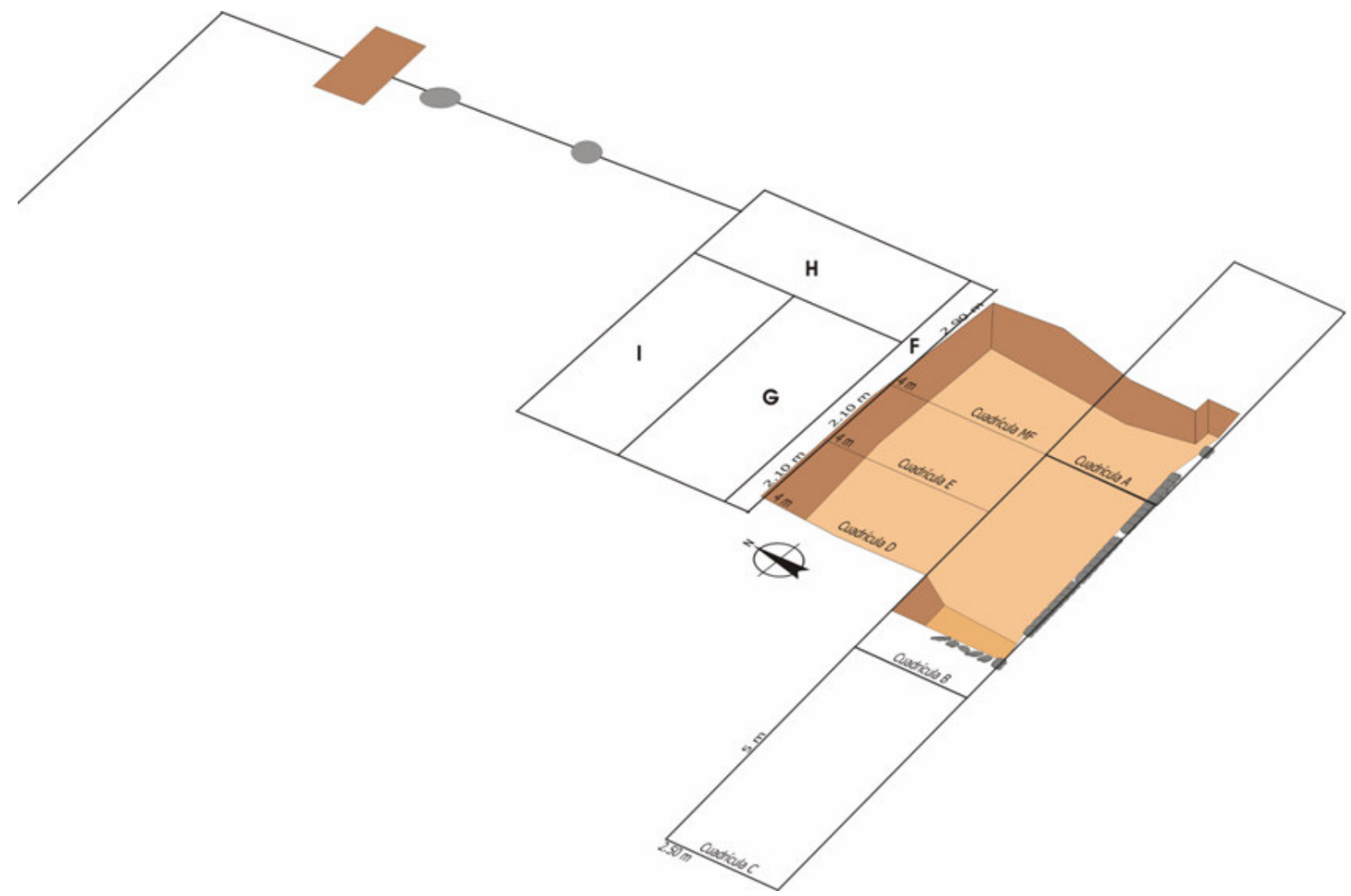

Figura 6.99: cuadrículas ampliadas hacia el norte del recinto F. Cubren el área de patio G.

remontan casi en su totalidad. Si bien aún no se han llevado acabo análisis de estos materiales, de los registros de campo se pueden determinar más de 15 vasijas diferentes. La mayoría de ellas corresponde a vasijas de clase E de gran tamaño: de forma "a" con rostros modelados - con nariz en gancho o común-, de "otras formas" y de forma "ab". Muchas de estas presentan marcas, específicamente antiplástico sobresaliente; algunas de ellas en las partes externas presentan huellas de carbonización, o en la superficie interna residuos orgánicos. Solo una vasija de forma "b" de clase A1 fue hallada en este espacio. 


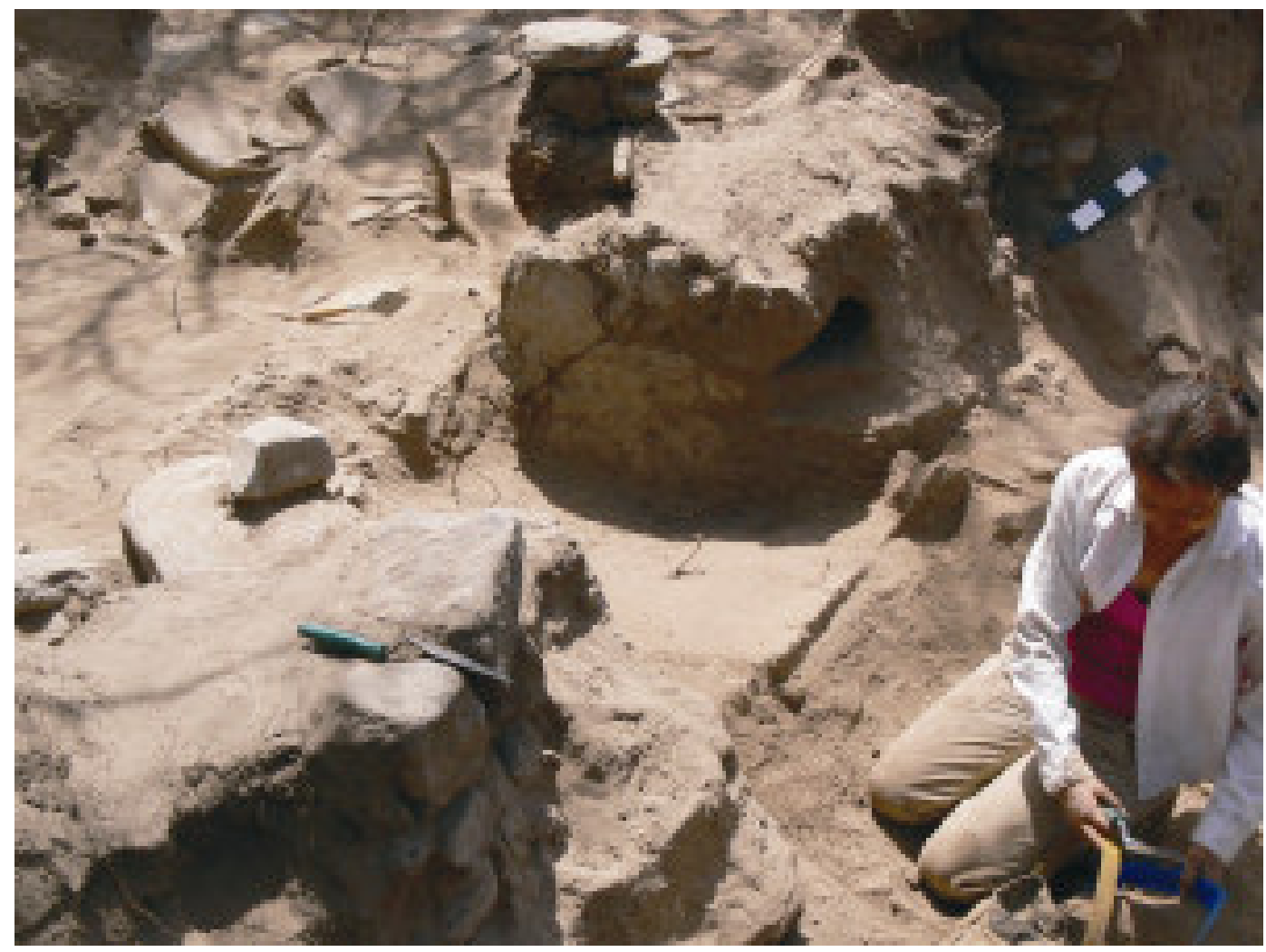

Figura 6.100: entrada al recinto F desde el norte. Obsérvese la existencia de un escalón de unos 0,20 m para entrar al recinto.

En la zona exterior del recinto se pudieron determinar dos grandes áreas -figura 6.101-, una que conforma una galería que corre en sentido norte sur contra el muro perimetral este, y un sector de patio abierto hacia el oeste de esta galería. La entrada al recinto que da al espacio abierto, hacia el este, posee una banqueta de adobe delimitada en su parte superior con piedras de caras planas, sobre la que probablemente se hallaban las vasijas que se encontraron fragmentadas al pie de la misma. El otro sector donde se disponen las vasijas es debajo del techo de la galería. Según lo observado en el campo y los registros en plantas habría una línea de vasijas contra el muro este y sur de la galería, y luego otra línea de vasijas en el borde de la misma dejando un espacio de circulación entre ambas filas de vasijas. Según los datos preliminares que posemos, algunas de ellas estaban vacías, probablemente guardadas a la espera de ser utilizada en un momento posterior. Es un contexto semejante a la galería del sitio Martínez 2, descripta anteriormente. Pero, además se halló una vasija ubicada al borde de la galería junto al poste, que gracias al incendio, logró conservar el contenido que poseía la misma antes del derrumbe del techo figura 6.102-. Esta se trata de una vasijas de clase E4 de forma "a" aparentemente de tamaño grande y una "ab" de tamaño mediano, que al derrumbarse el techo de la galería y el poste de sostén del mismo, y fracturarse las mismas desparramaron uno 900 frutos de 
chañar carbonizado. Más adelante veremos que un contexto semejante fue hallado por Gordillo en una galería del sitio Iglesia de los Indios (Gordillo y Ares 2005). Este contexto nos permite observar como hemos visto para los sitio Martínez 1, 2, que en los espacios de galería predominan las vasijas de clase E de diferentes formas. Son espacios no solo donde estas se hallan almacenadas, si no también se hallan realizando actividades como el almacenaje de frutos de chañar. Mientras que en los espacios internos de las habitaciones aparecen con mayor frecuencia las escudillas, vasijas b, bol de clase A1 y también de otras clases cerámicas, junto a vasijas de clase E.

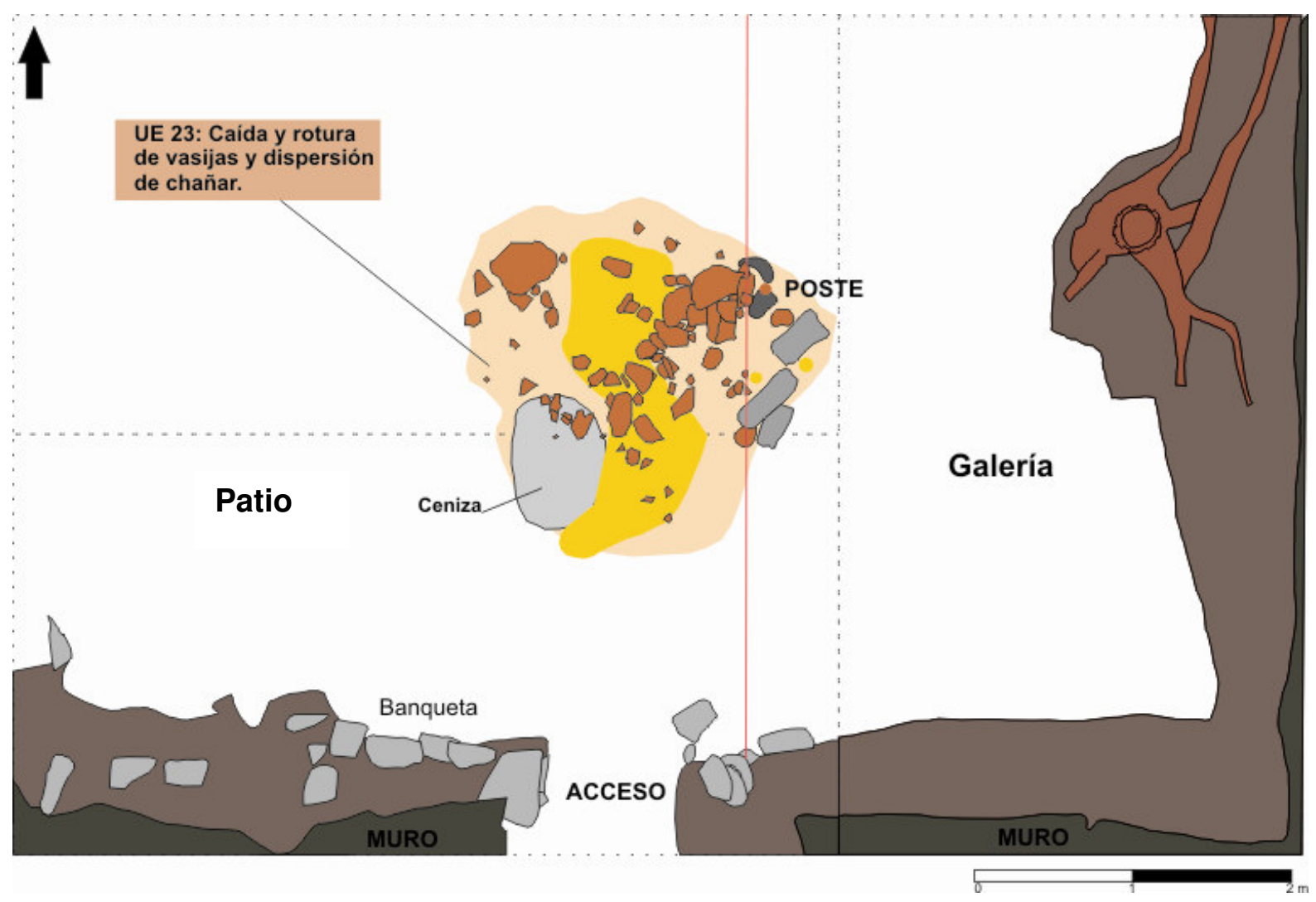

Figura 6.101: sectores identificados en el patio G. Además se observa uno de los contextos donde aparece una vasija de forma "a" de clase E, conteniendo frutos de chañar carbonizados. 


\section{Los contextos del sitio Iglesia de los Indios}

Este asentamiento entra en la categoría de los sitios complejos -MGS- según Assandri (2007), consiste en un espacio abierto o plaza, con un montículo ceremonial o
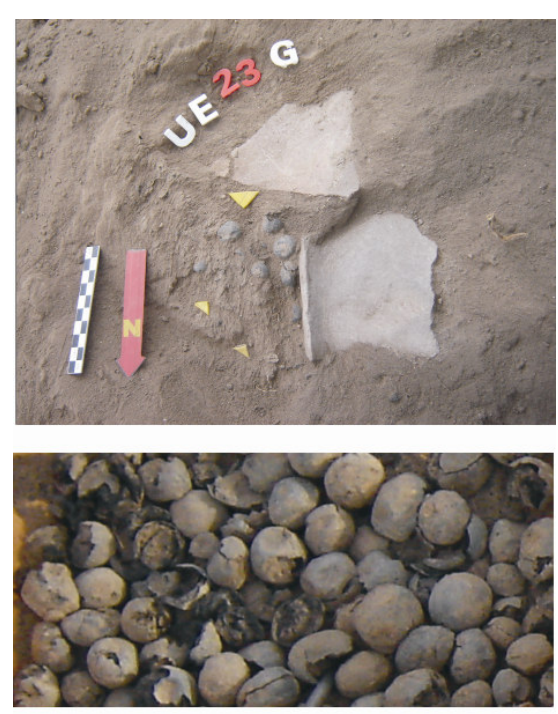

Figura 6.102: se muestra la vasija con los chañares carbonizados.

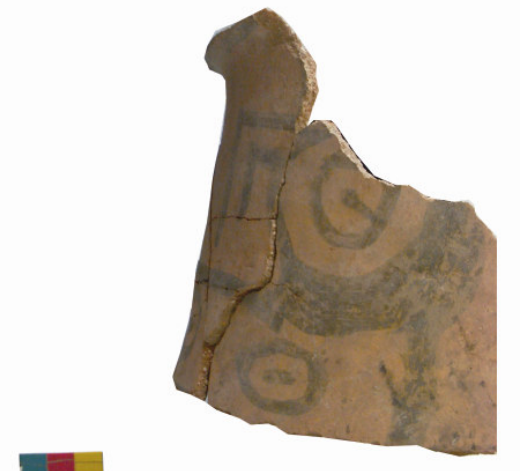

plataforma, y recintos que rodean la plaza, de dimensiones variadas Gordillo (1995, 2006). Estos forman una $U$ abierta hacia el Oeste, delimitada por rampas que dan acceso a la plataforma, en el sector sur y a pequeñas terrazas en el sector Norte -figura 6.103-. Sus dimensiones son $130 \mathrm{~m}$. N-S por $120 \mathrm{~m}$. E-O (Gordillo 1995). Se identificaron áreas de actividad ritual (la plataforma con rampas hacia su sector Sur), de concurrencia o reunión (la plaza o espacio central abierto hacia el Oeste) y residenciales y de actividad doméstica (unidades habitacionales en los sectores Norte y Este), así como remodelaciones y ampliaciones a las estructuras a lo largo de su ocupación. La construcción más notable es la plataforma, consistente en un montículo artificial de $3.60 \mathrm{~m}$. de altura y de $23 \mathrm{~m}$. por $13.5 \mathrm{~m}$. de ancho, compuesto por material arqueológico diverso (cerámica en abundancia, de estilo Ciénaga, Condorhuasi y Ambato tricolor, material óseo humano y faunístico, carbón, cenizas, material lítico, de metal, etc.), sedimentos amarillentos, limo-arcillosos, carbón y ceniza, rodeado por muros de piedra y una rampa de acceso en su lado Norte. Su secuencia de construcción parece haber sido relativamente rápida, en las siguientes etapas: a) descarte de materiales, b) construcción de los 4 muros de piedra que la rodean, c) construcción del muro Norte y las rampas de acceso. Hay una intención evidente por destacar el terreno en esta plataforma, por el cuidado y la inversión de trabajo en las técnicas constructivas y la sobreelevación del mismo. Volveremos sobre este aspecto, cuando analicemos los montículos en el penúltimo capítulo

Otro espacio para destacar es la gran plaza de $75 \mathrm{~m}$. de lado, ubicada frente al montículo, y abierta hacia su lado Oeste, delimitado por múltiples estructuras situadas en 


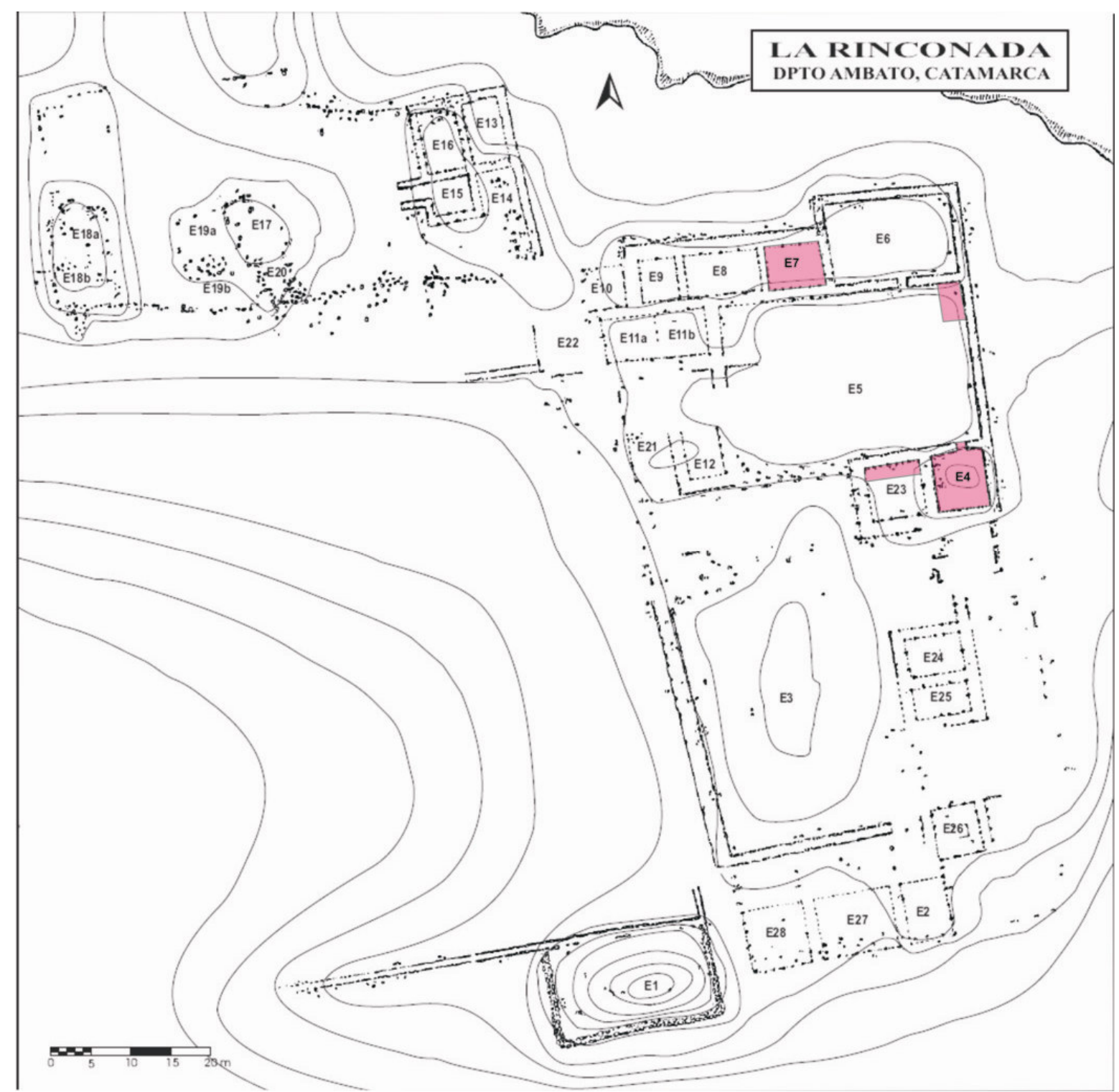

Figura 6.103: plano de La Rinconada. Se colorean con rosa las áreas que se describen. Modificado de Gordillo (2009)

núcleos en los lados Norte y Este. Según Gordillo se podría definir a La Rinconada desde su organización espacial como un sitio con 3 sectores claramente delimitados: a) áreas de actividad ritual -montículo -, b) áreas de concurrencia y reunión -gran plaza -, c) áreas residenciales -núcleos estructurales Norte y Este- y d) espacios libres entre las habitaciones (Gordillo 1995). La Rinconada cuenta con 11 fechados correspondientes a diferentes sectores del sitio y realizados sobre distinto tipo de material (troncos, frutos, hueso), siendo el más temprano $1800 \pm 80$ años C14 AP, y el más tardío $840 \pm 55$ años C14 AP (Gordillo 2005).

Las diferentes excavaciones realizadas en el sitio La Rinconada o Iglesia de los Indios (Ares 2006; Gordillo 1995, 2009; Gordillo y Ares 2005), nos permiten ampliar los contextos de asociación donde se encuentran las vasijas analizadas aquí. Estas se han hallado como inclusión de la matriz de la plataforma, al interior de habitaciones techadas, 
en galerías y patios asociados a estas habitaciones. Si bien la clasificación a nivel formal de las vasijas difiere de la utilizada por nosotros, en tanto que la autora utiliza en general la propuesta de Balfet et al (1992), dado que en (Gordillo 2009) se presenta las formas que aparecen en cada una de las excavaciones realizadas podemos asociarlas con la clasificación formal retomada por nosotros. A nivel tecnológico sólo podemos acercarnos a las grandes categorías clasificadas por Fabra (2008): clase E y A1.

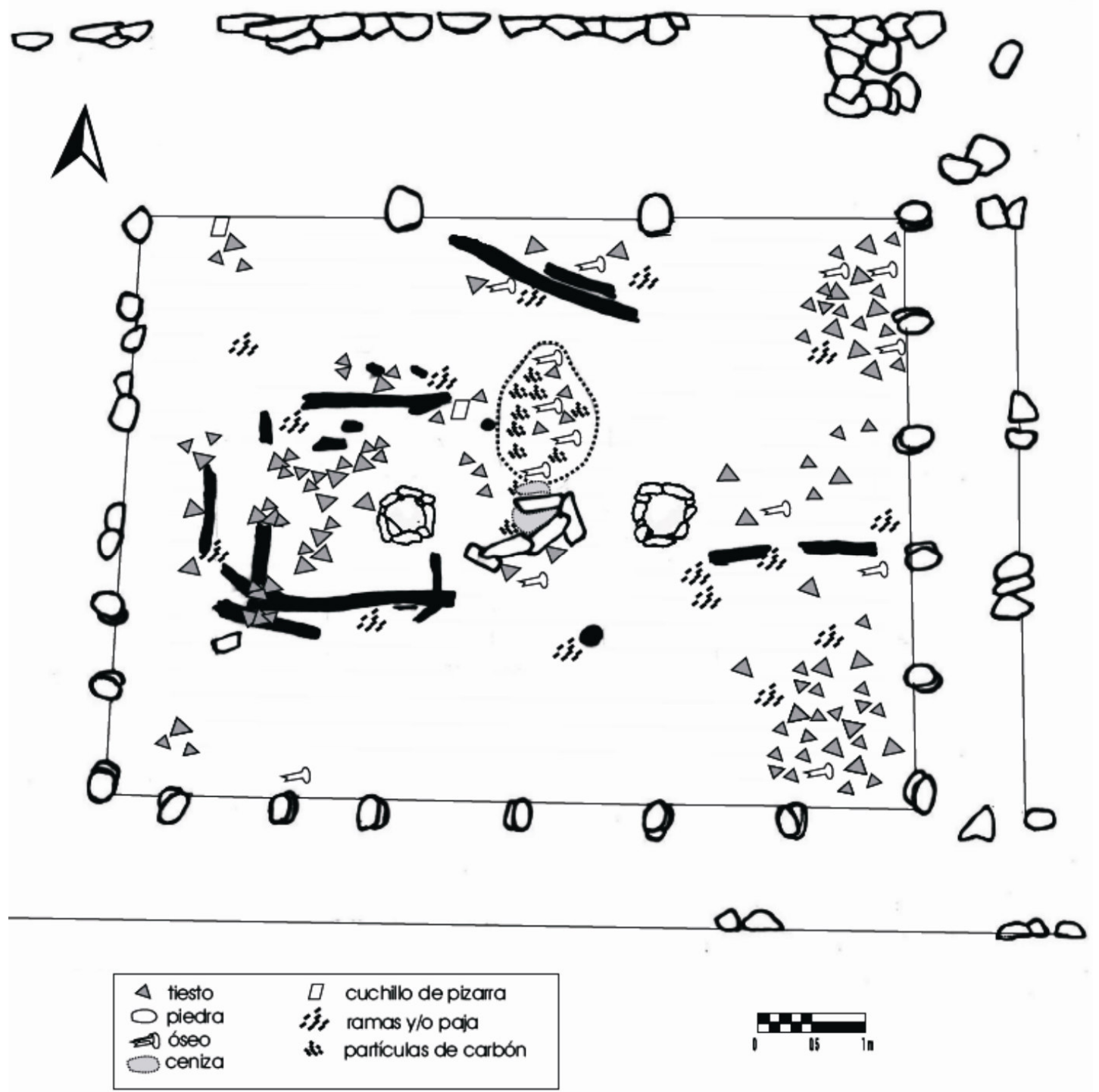

Figura 6.104: planta de la estructura 7 de La Rinconada. Tomada de Gordillo (2009).

\section{Recintos techados}

La estructura 7 -figura 6.104-, se trata de un recinto techado de forma ligeramente trapezoidal de unos $7 \mathrm{~m}$ en sentido este oeste y unos 5,40 m norte sur (Gordillo 2009). Presenta cuatro muros dobles y rectos. Al igual que otros recintos que aparecen en el valle las paredes internas son de tapia con columnas. A nivel estratigráfico Gordillo (2009:64) 
señala la presencia de un gran depósito postocupacional (hasta $-0,75 \mathrm{~m}$ ). El depósito ocupacional fue dividido en dos niveles $(-0,85 /-0,95 \mathrm{~m})$ que formado por los restos de techumbre depositados -troncos, torta, paja- sobre el piso; y el inferior $(-0,85 /-0,95 \mathrm{~m})$ que corresponde al piso de ocupación. Este no posee un tratamiento especial si no que se determinó por el emplazamiento de rasgo -asientos de muros, bases de postes, etc.- La techumbre quemada, presenta varios troncos de hasta $1,80 \mathrm{~m}$ de longitud y unos $15 \mathrm{~cm}$ de diámetro que, en algunos casos se hallan aplastando las vasijas que apoyaban en ele piso (Gordillo 2009:64-65). Presenta a su vez dos estructuras de sostén de poste ubicadas en el eje central longitudinal en sentido este-oeste, equidistante de las paredes del mismo y entre sí alrededor de 2,30 m. Es de resaltar que en el recinto Sudeste del Sitio Piedras Blancas

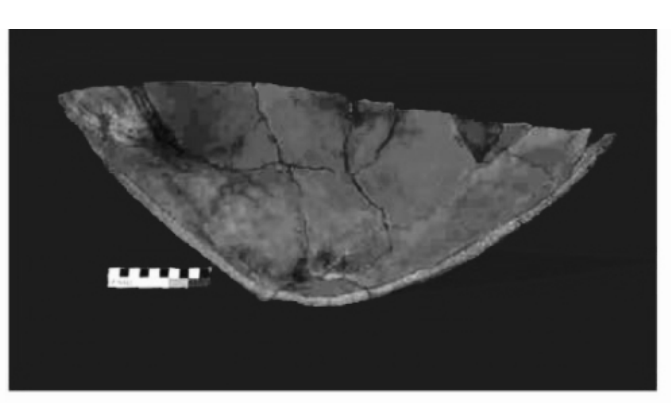

Figura 6.10: Escudilla grande procedente de E7
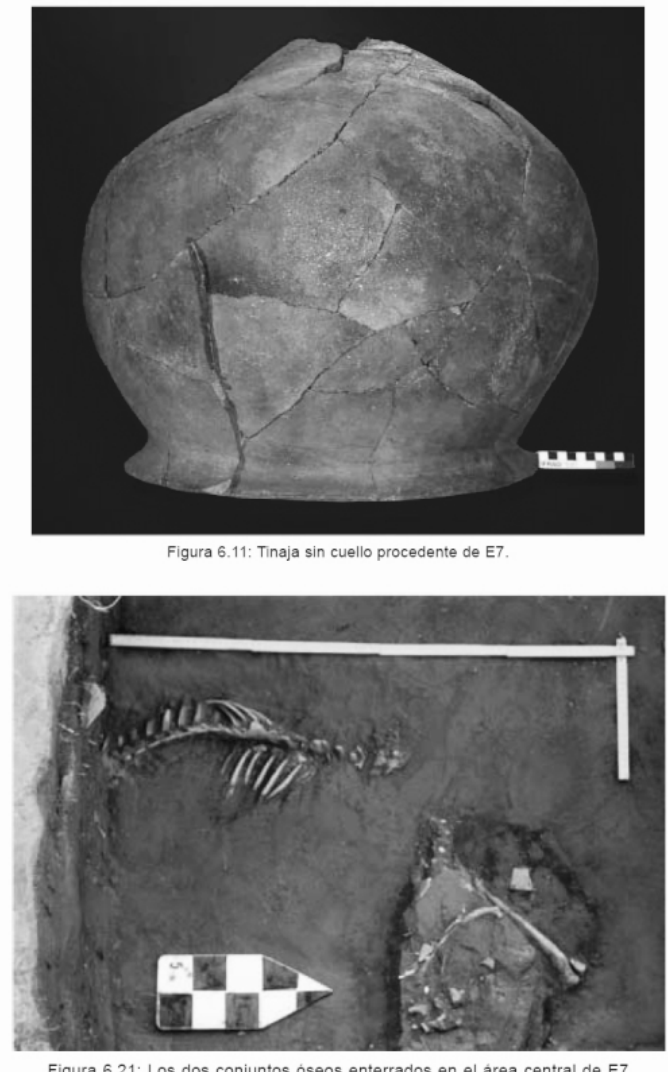

Figura 6.21: Los dos conjuntos oseos enterrados en el area central de E7

Figura 6.105: algunos hallazgos realizados en la Estructura 7 de la Rinconada. Fuente Gordillo (2009). los postes también se hallaban equidistantes de las paredes y entre ellos existía casi la misma distancia observada en este recinto por Gordillo (2009). Si bien no se halló el acceso, la autora señala que dado las características constructivas, la relación con otras unidades y la distribución de los rasgos internos y la residuos sobre la superficie de ocupación sería en el ángulo SE, dando acceso a la estructura abierta 5- En el centro del recinto se halló un fogón, con una estructura de piedra que rodea parcialmente el área de ceniza, partículas de carbón y tierra quemada (Gordillo 2009). En relación a la distribución de los restos alfareros la autora señala que es diferencial, incrementándose su frecuencia sensiblemente en el sector este, donde se hallaría más de la mitad de tiestos correspondientes a la superficie de ocupación y se localizarían unas ocho vasijas. Fuera de esta área se hallarían unos picos de concentración que obedecen a la presencia de vasijas rotas principalmente de pasta ordinaria de gran tamaño -clase E para nosotros- y según las formas reconstruidas por Gordillo (2009) se tratarían de vasijas de forma 
"a" y pertenecientes a las "otras formas" -tinajas y ollas según Gordillo (2009)-, también se han hallado platos grandes -escudillas grandes según Gordillo (2009)- -figura 6.105-. Se tratarían en general de materiales de facto y algunos de descarte provisorio. Además de las vasijas de clase E, aparecen escudilla, vasos, ollas simples, con cuellos y cerradas indeterminadas -forma "b", forma "c" de Bedano et al 1993. También según las descripciones de Gordillo (2009) aparecería de otras clases tecnológicas. Volvemos a encontrar una asociación entre vasijas grandes de clase $\mathrm{E}$ y vasijas mas pequeñas que poseen atributos secundarios que permiten la manipulación y el transporte, junto a escudilla de distintos tamaños. A su vez al igual que en otros sitios aparecen sectores dentro del recinto, algunos contra los muros, donde se hallan vasijas almacenadas, y otros en sectores centrales cercanos al fogón donde se desarrollan variedad de actividades. Asociados a los restos de vasijas y distribuidos por todo el recinto aparecen restos humanos -fragmentos de: maxilar superior derecho mandíbulas, maxilar superior izquierdo, maxilar inferior derecho y pequeños fragmentos de cráneos quemados (Gordillo 2009:72). También distribuidos en el recinto aparecen pocos restos óseos entre los que se destacan un camélido y un roedor. A su vez también aparecen distribuidos por el piso siete fragmentos de filitas -cuchillos-, fragmentos de manos de moler y otros artefactos rectangulares pulidos planos. A contiguo al fogón aparece un pozo de residuos que poseían algunos fragmentos cerámicos, fragmentos óseos entre otras cosas. Resalta que por debajo del piso aparecieron dos entierros -figura 6.105-: de camélidos uno y otro de partes de camélidos y humanos, que los describiremos en el capítulo siguiente cuando analicemos los sujetos como artefactos. Salvo por las estructuras de pozo para poste, la de desechos y los dos enterratorios por debajo de 1 piso aparecen muy poco material. En cuanto a los fechado que posee la estructura 1260+/-40 años radiocarbónicos AP y 1230 +/- 40 años radiocarbónicos AP. Son contemporáneo con el fechado del fogón por debajo del piso del recinto $\mathrm{F}$ del sitio Piedras Blancas y con el fechado del resido orgánico realizado sobre la vasija pertenecientes a as "otras formas" en el mismo recinto.

La estructura 4 -figura 6.106- es otro de los recintos techados excavados completamente. Este se vincula con la estructura 5 a través de un pasillo ubicado en el centro del muro norte del recinto. Todos sus muros, fueron realizados de piedra contigua canteada. Al igual que en la estructura 7 , se halló el techo carbonizado derrumbado sobre el piso de la habitación aplastando en algunos casos los objetos apoyados en el piso antes del incendio, entre ellos vasijas de clase E y A1, así como de otras clases tecnológicas. 


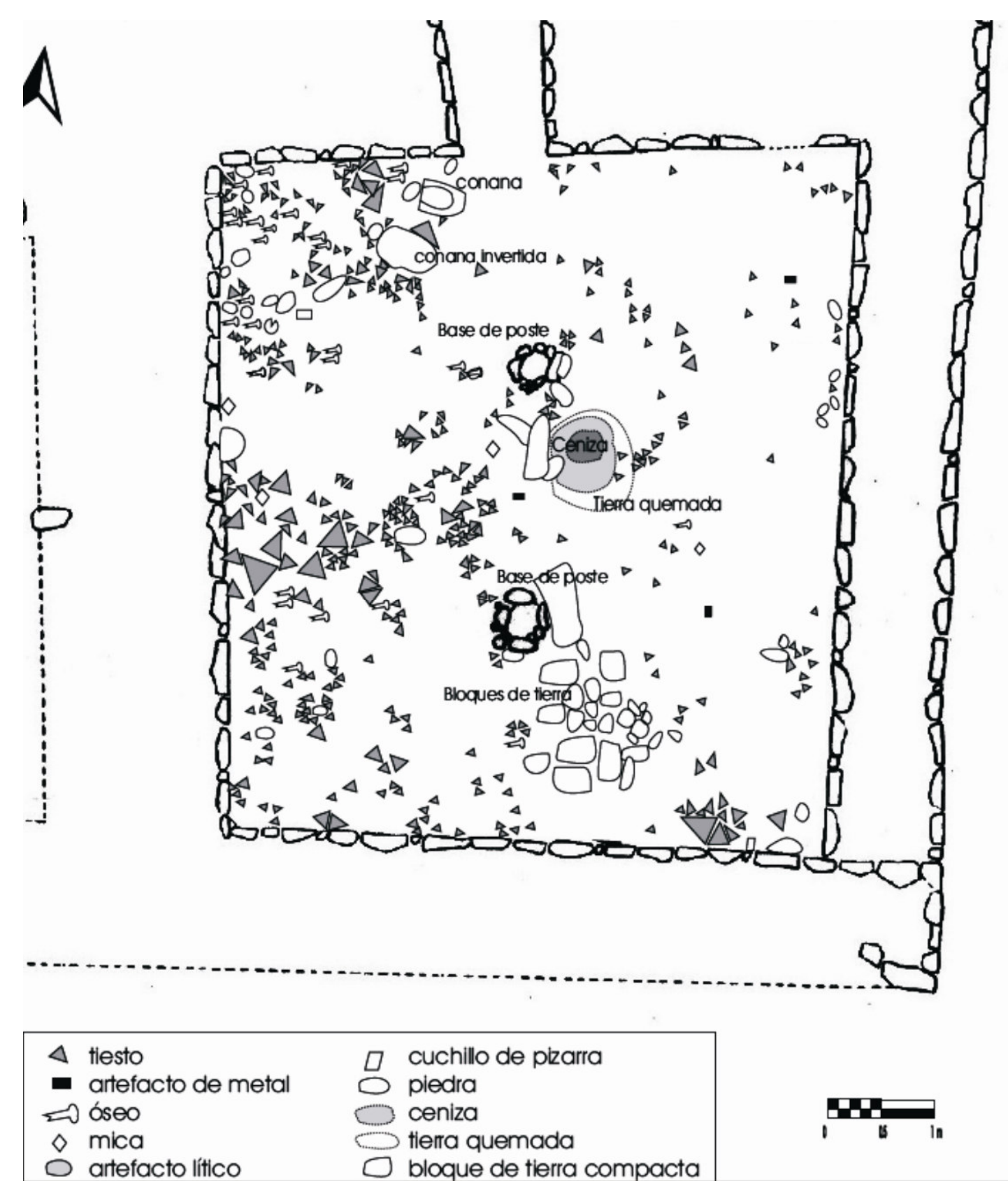

Figura 6.106: planta del piso de la Estructura 4. Tomada de Gordillo (2009).

Presenta dos huellas de poste en el sector de la línea central norte sur y un fogón casi en el centro del recinto. Según la autora el conjunto cerámico hallado en este recinto está constituido en su totalidad por fragmentos, no aparecen piezas enteras. Sin embargo, señala que le fue posible agrupar muchos de los tiestos por su correspondencia a una misma piezas -familia de fragmentos-, algunas de la cuales alcanzarían el 100\% (Gordillo 2009: 81). Hay un sector bien definido donde se congregan las actividades realizadas en este recinto, el lado oeste, dejando espacios relativamente vacíos al este y noreste. En total la autora, considerando todos los tiestos que ingresaron al piso de la vivienda a la largo de su historia, define un número mínimo de 61 vasijas entre las cuales la mayoría se trataría de escudillas, ollas y tinajas, 
además encuentra 2 vasos, una jarra y dos cuencos (Gordillo 2009: 88). A su vez señala que de la totalidad de tiestos hallados en el nivel antrópico, casi el $70 \%$ proceden de la mitad oeste, especialmente del centro y noroeste de la habitación (Gordillo 2009:88). Las clases tecnológicas representadas serán tanto vinculadas a la clase E de Fabra (2008), A1 y otras clases. Según la autora existirían doce vasijas de facto y partes de otras siete que serian descarte provisorio producto de las actividades realizadas. Así señala que: "en la mitad oeste se abrían desarrollado las actividades vinculadas al uso de la alfarería en tanto que en dicho lugar están localizadas todas las vasijas. A su vez señala que la cerámica fina -entre estas las d clase A1- se distribuiría en distintos puntos a lo largo de una franja de $2 \mathrm{~m}$ adyacente al muro, mientras que la cerámica ordinaria -clase E- aparecería en el sector central y norte de aquella unidad. Además algunas de las ollas -otras formas en nuestra clasificación- presentan huellas de hollín, lo que evidenciaría su colocación al fuego. En general señala que las vasijas sugieren una variedad de usos y actividades tales como preparar comida, con o sin cocción, contener y o almacenar sustancias líquidas o sólidas, servir y consumir alimentos (Gordillo 2009:89). Dentro del recinto a su vez contra el muro sur apareció un contexto donde se encontró separada del área antes señalada una vasija calceiforme que remonta completamente de grandes dimensiones. En relación a los otros materiales la autora señala que el material faunístico son abundantes concentrándose en el área noroeste del recinto, se trataría de camélidos -Lama sp.- en mayor cantidad, hallándose todas las partes esquelétales representadas, pero también aves -cáscara de huevos y huesos de Rhea sp. A su vez se halló una calota humana sobre un fragmento de olla que yacía junto al sector central del muro oeste. En este sentido, encontramos al interior de las viviendas la asociación entre vasijas grandes de clase E junto a huesos de humanos, y animales. También en distintos sectores del recinto aparecen herramientas de metal -cincel, espátula y hachita de bronce-. En síntesis la autora propone que todas las actividades vinculadas a la preparación de carnes y otros alimentos parecen haber tenido lugar en la mitad oeste del recinto, especialmente en las áreas noroeste y centro oeste. En la primera de ellas se asocian ollas de cerámica, artefactos de molienda, con restos óseos que presentan atributos antrópicos. También en este sector aparece una olla tricolor de gran tamaño -vasijas "a"- posiblemente usada para almacenar. En el área centro Oeste se ubicarían varias vasijas ordinarias, que por sus características y restos de hollín se utilizarían para cocinar en el fogón central. En cuanto a lo que denomina vajilla fina escudillas, jarras, vasos y ollas- donde entran la clase A1 analizada aquí mostrarían una distribución no tan acotada como las otras, pero se hallaría siempre en la mitad oeste de 1 recinto. Esto contexto nos vuelve a remarcar 1 asociación entre vasijas grandes tanto de 
otras formas como de forma a de clase E, junto a escudillas, vasijas de forma $b$, participando de los mismos espacios y actividades.

La estructura 23 se trata de un recinto que se halla al oeste de la estructura 4, este no fue excavado en su totalidad si no solo un área rectangular en la porción norte del mismo (Gordillo 2009). En, el espacio excavado no se observó la presencia de techo carbonizado, ni hallazgos de facto. Sí se identificó en la esquina noreste del recinto un contexto en el que aparece un círculo de ceniza y tierra quemada, en el que se halló un cráneo de camélido adulto aparentemente expuesto durante un tiempo prolongado al fuego. Se les asocian una masa arcillosa con antiplástico, circular de sección aplanada, un instrumento cuadrangular de pizarra, un pequeño artefacto ovoide de cuarzo, una placa de mica recortada, un perforador en posición horizontal y varias cuentas de collar. Según Gordillo (2009:108) "este grupo de elementos cuidadosamente colocados uno sobre o junto a otros, parece corresponder a la expresión material de un ritual doméstico que relaciona simbólicamente a este animal con la manufactura cerámica y los bienes suntuarios. La asociación de los camélidos con actividades artesanales la hemos visto en el recinto alto, pero vinculada a la elaboración o reparación de objetos de metal. Sin embargo cercana a la estructura que hemos asociado a donde se mezclaba la arcilla, que pertenecería a una ocupación anterior al del período formativo, aparece enterado un camélido joven, que si bien se halla despojado de objetos, podría establecerse cierta relación con las actividades vinculadas con la producción de alfarería. La diferencia es que en el recinto alto estos cuerpos primero aparecen enteros y segundo son de jóvenes.

\section{Patio}

La estructura 5 -figura 6.107- se trata de un espacio abierto con una galería en la esquina noreste del patio (Ares 2006; Gordillo y Ares 2005; Gordillo 2009). Este espacio más la otras unidades que lo compone constituyen según Gordillo y Ares (2005:212) el ámbito residencial, que se halla claramente diferenciado del las áreas públicas y construcciones de carácter público-monumental que se extiende por el centro y sur del sitio. En al esquina noreste de este espacio, debajo del techo incendiado y derrumbado de la galería se halló un $\mathrm{n}^{\circ}$ mínimo de vasijas de 14 piezas de la cuales once de ellas corresponderían a la clase tecnológica E, una a otra de clase -Allpatauca- y dos a clase A1. Las vasijas de clase E corresponderían tanto a grandes vasijas de forma "a" y "otras formas" algunas bicolor o tricolor otras sin decoración. También habría dos vasijas de 
forma calceiformes. El volumen que poseen las grandes vasijas se hallaría entre 80 litros y 250 litros. Estas vasijas se encontraron alineadas contra el muro y algunas de ellas estaban contenido frutos de chañar, los endocarpios de Geoffroea sp se hallaron tanto dentro de las

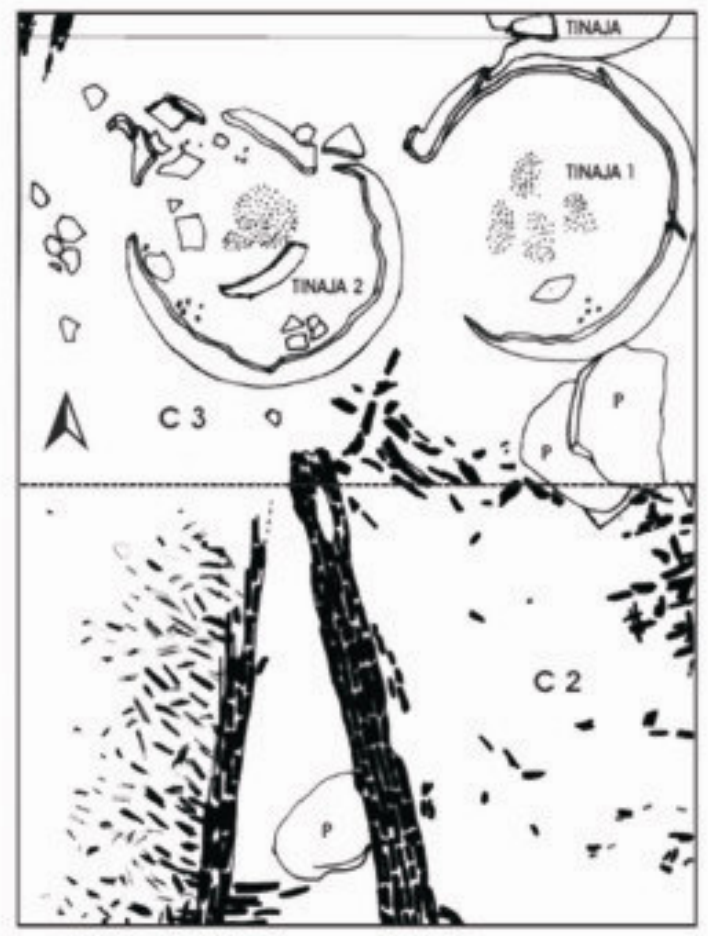

Planta a $\cdot 0,55 \mathrm{~m}$

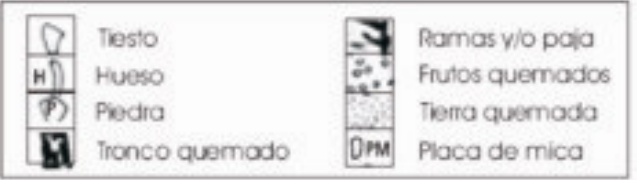

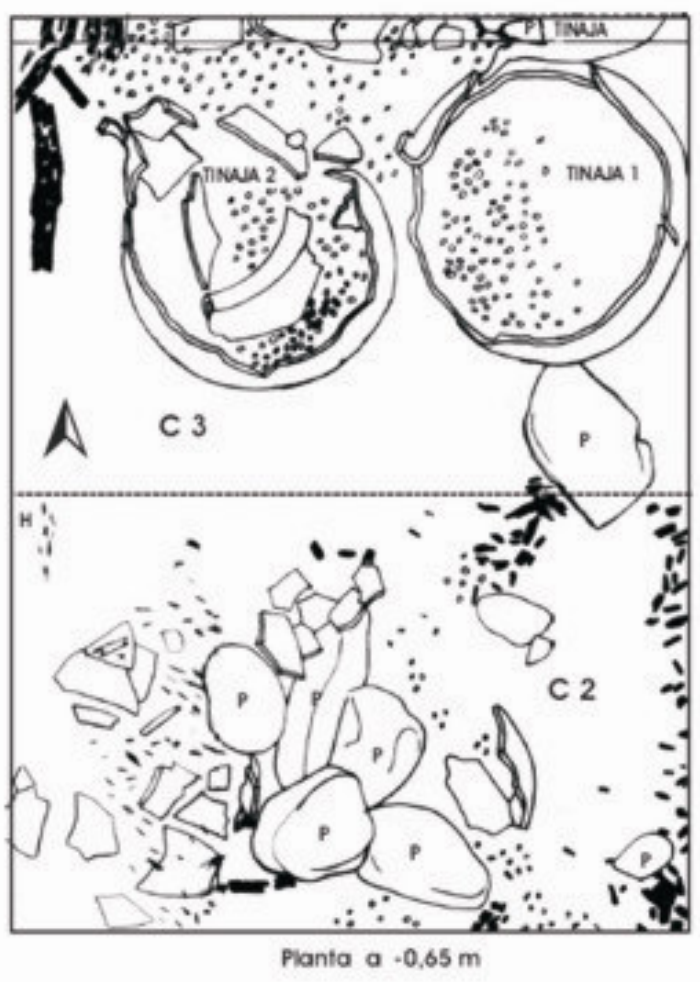

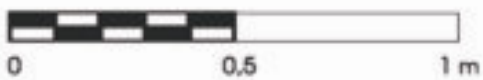

Figura 6.107: planta de la Estructura 5 de La Rinconada. Tomada de Gordillo (2009).

vasijas como esparcidos por el lugar debido a la rotura de esta al caerse el techo -figura 6.108-. Es resaltar que además se encontró la parte superior de una vasija "a" -bicolorque al romperse habría pasado a cumplir una función de soporte tras haber regularizado la línea de fractura. También cercano a la base de unas de esas vasijas aparecen un fragmento de hornillo y tubo de pipa fragmentado que se habría utilizado para estabilizar uno de estas vasijas. Pudimos analizar una de estas grandes vasijas que contenía frutos de chañar que se hallaba depositada en la dirección de Antropología de Catamarca ${ }^{x x i}$. La vasija no se encuentra entera pero posee gran parte del cuerpo de la misma. Es de clase E2 -mezcla 5pintada con motivos geométricos en rojo y blanco sobre la pasta natural. Pose un diámetro máximo de $580 \mathrm{~mm}$. No podemos sacar la altura de la pieza pero la parte representada 

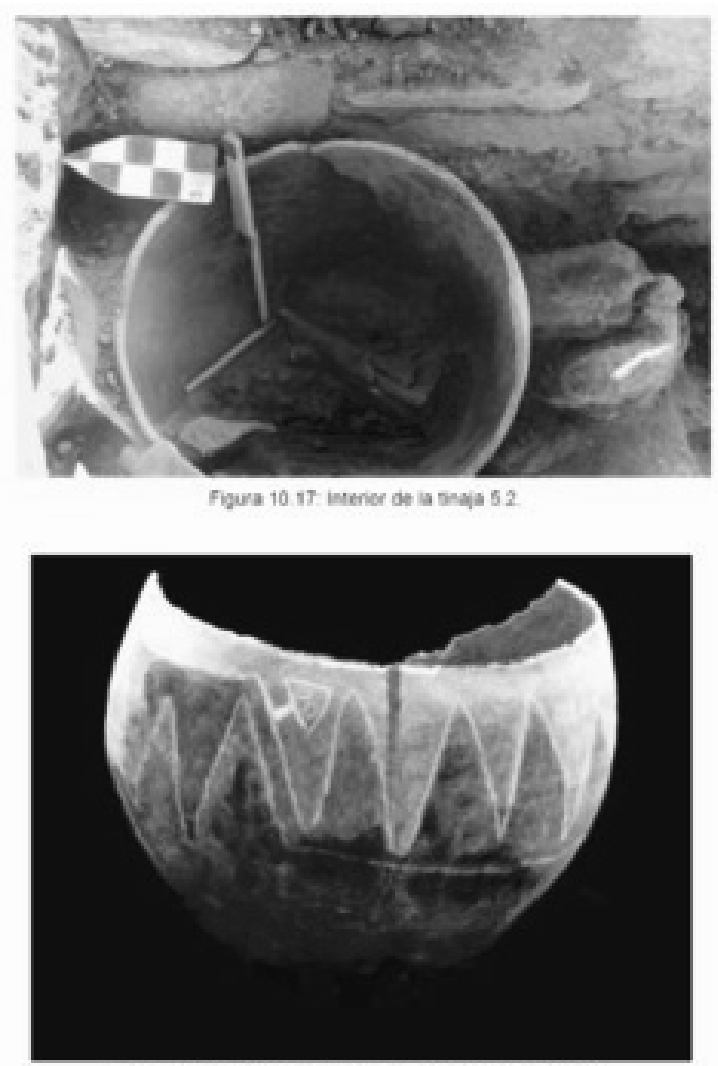

Foura 10: A: Cuerpo de is tinajs 5.2 con decoracion tricolior

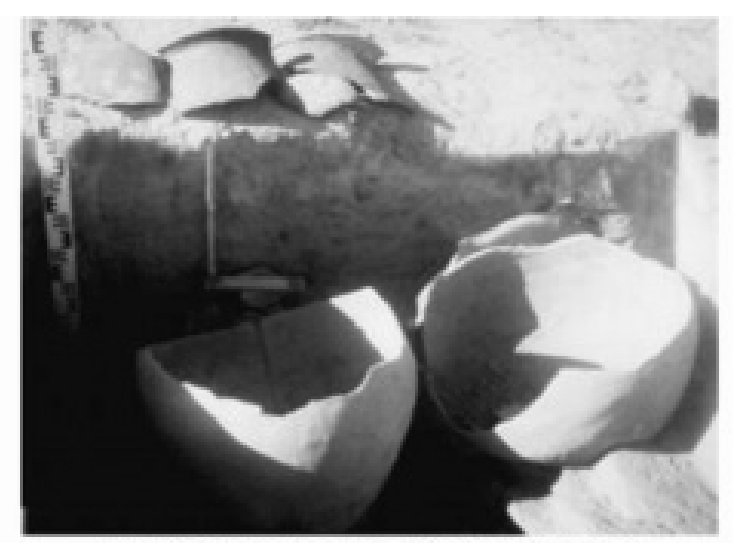

Figura 10.16: Tinajas en la cuadrioula 3 de ia excavacion de Es

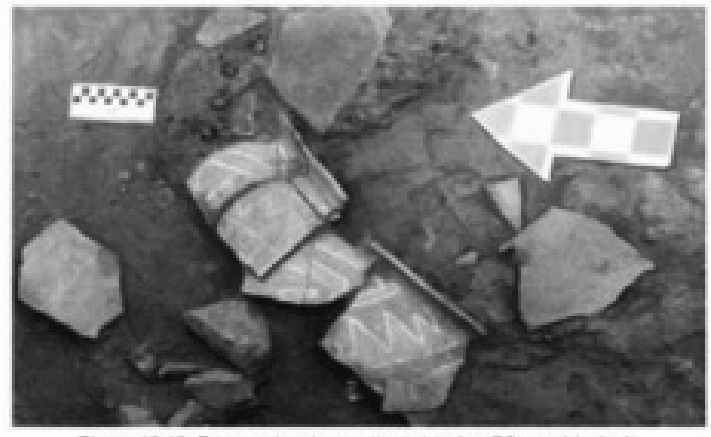

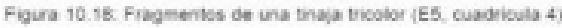

Figura 6.108: vasijas de clase E forma "a", halladas conteniendo chañar en la Estructura 5. Fuente Gordillo (2009)

mide $530 \mathrm{~mm}$, por lo que la pieza superaría ampliamente esta altura. Sería una de las pieza más grande halladas en este sector. En relación a las marcas en la superficie exterior presenta en la base antiplástico sobresaliente, en la zona inferior algunos lotes de forma irregulares; por debajo del diámetro máximo presenta también en la zona media lotes. Esta vasija al ser tan grande debió, se movida muy poco, las huellas observadas mostrarían que las marcas de la base se realizan en una superficie con un abrasivo fino, sin tanto movimientos, y lo lotes podrían a los soportes utilizados para sostenerla y posiblemente a la inclinación de esta, sin embargo no se observó la presencia de estrías indicativas de este tipo de movimientos. En la zona interior, se presenta solo marcas, en la zona media se observa en una gran proporción de la misma antiplástico sobresaliente mezclado con hoyuelos. Este marca que hemos asociado a la fermentación de la bebida, si pensamos que se la halló contenido y asociada a frutos de chañar, volveríamos a encontrar alternancia en las actividades en las que participaba. Aparecieron dos piezas pequeños modeladas, una de clase A1 incisa con motivos geométricos y otra roja -posiblemente clase A2- modelada con un rostro humano. A su vez repartido en lo que se definió como piso aparecen fragmentos que no remontan de varias clase y formas que según Gordillo y Ares (2005) correspondería a desechos primarios de la actividades llevada sen el lugar. En relación a 
otra materiales en el área parecen material lítico, específicamente una mano de un mortero y una mano fragmentada con restos de pigmento color rojo. Aparecen palcas de micas formatizadas que presentan agujeros de perforación probablemente para colgantes y cuentas de collar. A su vez se encontraron tres objetos de metal: un tubo, un alfiler y una cuenta (Gordillo y Buono 2005). En relación a la presencia de restos óseos, las autoras señalan que la mayor parte de la biomasa fue aportada por Artyodactilos principalmente camélidos complementados con cérvidos y fauna menor como aves (Gordillo y Ares 2005). Del género Lama se asocian según las autores parte de bajo y alto rinde predominando estas últimas, lo cual podría indicar actividades concurrentes en ese espacio. Además señalan que en los recintos prevalecen las partes de buenos rendimientos por lo que según las investigadores podría representar que en los patios se llevaran acabo actividades de procesamiento ingresando en las habitaciones las partes ya trozadas (Gordillo y Ares 2005:220).

\section{Recapitulando: vasijas, contextos y prácticas}

Según las huellas de usos y los contextos de hallazgos las vasijas analizadas aquí habrían participado de manera diferencial en variedad de prácticas: almacenamiento, preparación, cocido y consumo de productos vegetales y de carnes; preparado, fermentación, almacenamiento y consumo de bebidas fermentadas y, manipulación, almacenamiento y probable aplicación de pigmentos blancos y rojos. La participación en estas prácticas no implicaba la no intervención en otra, tanto las huellas como los contextos de uso nos marcan la inserción de una misma vasija en mas de una práctica distinta, es decir una misma vasija que fue utilizada para fermentar, puede posteriormente ser utilizada para almacenar y luego cocinar, etc. pero, en ciertos casos, esos cambios de actividades y de prácticas pueden ordenarse en una secuencia de temporalidad relativa, en donde la primera actividad realizada es la fermentación, luego el almacenaje y o la cocción de vegetales y/o partes corporales de animales y de camélidos, e inclusive una combinación de estos y; por último, el almacenaje de pigmento blanco o rojo.

Elaboración y consumo de chicha: esta práctica es un proceso que requiere varios pasos y en general implica a más de un objeto. El único proceso que hemos podido determinar con bastante precisión que realizarían estas vasijas es el de la fermentación y transferencia de esta bebida. En general, esta actividad conforma la primera operación que ejecutan las vasijas grandes de "otras formas" y las vasijas grandes de forma "a". Las 
vasijas de forma "ab" que evidencia su participación en actividades de fermentación, probablemente hayan sido utilizadas como intermediarias, en tanto que en general las vasijas de forma "a" y algunas de las "otras formas", se movilizaban muy poco, estas otras vasijas de menor volumen, con asas remachadas, permitían trasladar la bebida a los espacios de consumo, cuando no coincidían con la ubicación de las vasijas grandes, así como fraccionarla en el caso que se quisiera. En cuanto a los recipientes utilizados para beber o consumir la chicha, es más difícil de determinar. A su vez, en estas vasijas, el traslado y acumulación de chicha sería la primera de las actividades realizadas. No existe una asociación clara entre recipiente que podrían ser utilizados para beberla, tales como escudillas, los vasos y jarras, las vasijas modelados o inclusive los bols, con esta actividad, en tanto no existen asociaciones contextuales registradas entre vasijas que se hallan almacenando y fermentando la chicha, con estos otros recipientes. Sí hemos registrado estas asociaciones para otras prácticas. Quizás participaban otros objetos de materiales perecederos que no se han conservado. Evidencias de estas actividades se han registrado en todo los sitios analizados, tanto los pequeños, los medianos, los grandes, los muy grande y muy grande con sectores. Las vasijas que presentan estas huellas en general aparecen o en el interior de las habitaciones contra los muros, en las esquinas, o en soportes de piedras y; en las galerías, aunque probablemente, en estos últimos casos más que estar fermentando hayan estado siendo guardadas. Además, algunas de las que presentan huellas de fermentación en la galería se hallan almacenando chañar, como hemos visto en el sitio La Rinconada y Piedras Blancas.

Almacenamiento de vegetales y de carnes: en relación al almacenamiento de vegetales, según los contextos conservados hallados en La Rinconada y en Piedras Blancas, se trataría de chañar, aunque no podemos descartar otros como maíz que se halla representado en las excavaciones y otros aún no determinados. El almacenamiento de chañar es realizado exclusivamente en las vasijas de forma "a" conformando la primera o segunda actividad. Según los contextos de hallazgos, esta práctica ocurre en las galerías estando las vasijas ubicadas o contra los muros de las mismas o, en el borde de estas junto al sostén de poste del techo. En relación al almacenamiento de partes trozadas de humanos y camélidos todos juntos: suele conformar la primera o, si la vasija se utilizó para fermentar chicha la segunda actividad de las grandes vasijas de forma "a", "otras formas" y forma "ab". Según los contextos se ejecutarían en el interior de habitaciones, algunas veces cercana a las áreas de mayor actividad donde se encuentran los fogones, en otros casos en habitaciones donde no hay fogones, pero también hemos registrado vasijas almacenando 
estas partes en las galerías. Esta distribución variada de los lugares, podrían mostrarnos la espacialidad de las prácticas de trozamiento y preparado de las partes corporales, que comprenderían las galerías o patios y las habitaciones. Asociadas a estas vasijas, y, en algunos casos, conteniendo los mismos productos, se hallaron escudillas y vasijas de forma "b" tanto de clase A1 como de otra clase tecnológicas.

Procesamiento de vegetales: si bien este se pudo realizar en varias vasijas de diferentes formas, una de las vasijas que puede relacionarse directamente con este, son los platos grandes, los que según los análisis de residuos orgánicos solo entraron en contacto con vegetales. Estos platos han aparecido tanto al interior de las habitaciones como en las galerías, en este último caso asociados a conanas planas y manos de moler.

Cocción de vegetales y carnes: las vasijas que participan aquí son las de "otras formas" tetrápodas y no, y los platos grandes. En el caso de las "otras formas" sin patas esta actividad suele ser la segunda actividad realizada, mientras que la primera fue fermentar la chicha, en el caso de las vasijas con patas y los platos grandes puede ser la primera. Para cocinar carnes -camélidos pero también humanos- junto a vegetales, se utilizan las vasijas grandes de "otras formas" y las "calceiformes" de clase E2. Se trataría en el caso de la calceiforme de la primera y única actividad, en el caso de las otras formas en la segunda actividad. En general, esta clase de actividades se ejecutan en el interior de los recintos techados, en el centro de las habitaciones. Concentrándose las vasijas alrededor del fogón. En estas actividades, particularmente aquellas que implican la utilización de vasijas de otras "formas" se vinculan a vasijas de forma b y escudillas tanto perteneciente a la clase A1 como a otras clases tecnológicas.

Servido y consumo de los diferentes preparados: más allá de las formas de consumo que pueden variar, según los tipos de comidas, en algunos casos no necesitándose recipientes intermediarios que permitan consumir o distribuir los contenidos, hemos encontrado en estrecha vinculación y en los mismo espacios donde las vasijas de formas "a" y "otras formas", se hallan cocinando o almacenando, vasijas de forma "b" y escudillas, no solo de clase A1, si no que también de otras clase tecnológicas y de diversidad de tamaños. Probablemente estas participen en la extracción, movilización de los que se cocinaba o almacenaba e inclusive como recipiente final antes del consumo de los alimentos y preparados. Particularmente estas asociaciones se dan al interior de los 
recintos, por lo que quizás también nos informe sobre los espacios de consumo más frecuente de las comidas.

-Preparado, Almacenado y Manipulación de Pigmentos Rojos y Blancos. De los análisis de pigmento tenemos en el caso de los blancos por lo menos dos clases de pigmentos diferentes, que se diferencian a su vez del pigmento utilizado para pintar las vasijas antes de cocinarlas. Uno de estos es el que se utiliza para pintarlas postcoción, pero no coincide con los blancos hallados tanto en al interior de una vasija restringida compuesta junto aun pan de pigmento rojo que formaban parte de un ajuar de un enterratorio de un niño en el recinto $\mathrm{H}$ del sitio Piedras Blancas. Ni con la vasija conteniendo pigmento blanco hallada en el recinto sudeste del mismo sitio. En el caso de los pigmentos rojos que en general se vinculan a vasijas de "otras formas", vasijas "b", escudillas, vasos pequeños y vasijas restringidas compuestas, lo hemos hallado aplicado a una laja sobre la que se dispuso un niño enterrado. Así tenemos la participación de distintas formas de vasijas en la preparación y manipulación de pigmentos utilizados para diferentes prácticas que implicaron la aplicación de pintura de color blanca sobre las incisiones o grabados de vasijas de clase A1 ya cocida, pigmento color rojo en lajas que sirvieron de apoyo a los cuerpos de los difuntos, quizás también la aplicación en los muros de las habitaciones o de los patios que pueden estar pintados de rojos y blancos, e inclusive, quizás en pinturas corporales. Los lugares de hallazgo y donde se observa la manipulación de estos pigmentos y la participación de las vasijas varían: se hallan en las galerías muchas veces junto a morteros y manos teñidas de color rojo, en otros casos en áreas donde se ejecutan otras prácticas artesanales como el martillado de metales, el reciclado de partes de vasijas cerámicas y su transformación en otros objetos, la fabricación de placas de micas y fichas, etc. En otros al interior de los recinto, junto o cercanos a los fogones. Esta variedad de contextos muestran quizás la espacialidad diferencial de las prácticas de pinturas donde fueron sometidas estas vasijas. En el caso de las vasijas de "otra formas" conformó la tercera actividad a las que fueron sometidas; en el caso de las de forma "ab" pudo ser la primera o la segunda, si ésta antes fermentó chicha. En el resto de formas y clases que participan es difícil de determinar esta secuencia. 


\section{Parte}

\section{Las Vasijas al romperse...}

No conocemos los tiempos de vida esperados de las vasijas analizadas, quizás estos hayan sido diferenciales. A través de las análisis de las huellas de uso, residuos orgánicos y contextos de uso hemos visto que algunas de las vasijas de clase E, especialmente las grandes vasijas pertenecientes a las "otras formas", a la forma "a" y a la forma "ab" se utilizaron para más de una actividad: fermentar chicha, almacenar vegetales y partes corporales de camélidos y humanos, cocinar vegetales y carnes, contener pigmentos. Sobre la serie de actividades en las que participaron, puede ser establecidas una secuencia: primero fermentaron chicha, luego se utilizaron para cocinar o almacenar vegetales y carnes y, en algunos casos como última actividad se la utilizó para almacenar pigmentos rojos o blancos. Esta secuencia nos representan etapas en al biografía de estas vasijas; parafraseando a Kopytoff (1991), quizás, una "vida bien vivida" de una vasija implicara su participación no solo en practicas distintas, si no en una secuencia particular. Pero a su vez esta secuencia nos puede estar representando un lapso de tiempo muy prolongado de uso de las mismas. Las vasijas de forma "a" y "otras formas", son de gran porte, poseen muros espesos, algunas de ellas han permanecido fijas en determinados lugares sin realizar muchos movimientos por lo que quizás estuvieron sometidas a menores peligros de caída, golpe etc. En el caso de las de forma "ab" poseen una movilidad mayor. A su vez cuando no participaban de una actividad concreta se colocaban en lugares diseñados específicamente para guardar a estos objetos, en algunos casos sobreelevados de los piso sobre banquetas de adobes construidas para tal fin, o contra los muros alejados de las zonas de circulación y concentración de actividades. Un caso interesante que nos muestra la participación de una vasijas en por lo menos dos actividades distintas y su continuación durante un tiempo prolongado dentro de los circuitos donde participaba, lo conforma la vasija de "otras formas" de clase E2 hallada en el recinto sudeste, apoyada al lado de un fogón contra la pared de piedra ubicada al sur de la habitación. Esta vasija como vimos se encontró totalmente aplastada por uno de los postes que sostenían la enramada del techo, en un área de $1 \mathrm{~m}^{2}$. Se pudo remontar casi el $90 \%$ de la pieza. Lo que falta para remontarla completa es el cuello y el borde. Se trata de una vasija mediana con muros espesos. Posee una base cónica, un cuerpo globular que tiene un diámetro máximo de $333 \mathrm{~mm}$, el cuello es restringido. Si bien al diámetro de este sector no lo pudimos reconstruir, según la proyección que se pueden realizar sería menor de $180 \mathrm{~mm}$. En relación al volumen de contención aproximado de la vasija es de menos 17,4 litros. La vasija en la superficie 
exterior posee huellas de carbonización que nos muestran además de su sometimiento al fuego, la manera específica en que se la colocaba sobre el mismo: de costado y posiblemente inclinada. Es sugerente que se encuentre a lado de un fogón el que es de forma irregular alargada y posee una cubeta no muy profunda. En el interior de la vasija presenta en la zona inferior y base marcas, principalmente antiplástico sobresaliente, lo cual nos indica su utilización en actividades de fermentación antes de su sometimiento al fuego y que produjo que se le adhirieran residuos del proceso de cocido. Primero participó en la fermentación de bebidas y luego cocción de vegetales, en tanto los residuos orgánicos, arrojaron presencia sólo de ácidos grasos y no de albúmina. A su vez señalamos que del residuo adherido de esta vasija se realizó un fechado por AMS 1281+-33 BP 95,4\% de probabilidad-. Esta fecha concuerda con un fechado realizado en una ramita hallada como inclusión de uno de los rellenos de una cubeta de fogón -[32] ver anexo 5que arrojo una fecha calibrada de $1273+-49$ BP -95,4\% de probabilidad-. Este evento es el primer evento realizado, junto con el cavado de los pozos para colocar los postes del recinto y probablemente el levantado de los muros. Se encuentra por debajo del piso consolidado. Quizás nos esté marcando el inicio de construcción del Recinto. Ahora si lo comparamos con los fechados obtenidos de la enramada del techo que se halló por encima de la vasija, que arroja una fecha calibrada con 95,4\% de probabilidad de 920 $\pm 70 \mathrm{BP}$, una diferencia temporal de un poco más de 300 años se nos presenta entre la construcción del techo y la ocurrencia de las otras acciones. Por lo que tenemos que a nivel estratigráfico la vasija forma parte de la interfacie de período donde se hallan las otras vasijas, fogones y estructuras hallados, es decir es contemporánea con las otras cosas realizadas en el piso de la habitación, se halla dentro de un contexto significativo de asociación; pero las huellas y residuos adheridos, dado el fechado obtenido, podríamos decir su participación en actividades de fermentación y cocción de vegetales es coincidente con una temporalidad mucho más amplia, aquella del primer fogón y probable primer evento de combustión, vinculado con la construcción y ocupación del recinto. Así esta vasija posee un recorrido biográfico muy largo, probablemente trascurrido durante varias generaciones, pero dada su posición estratigráfica, es absolutamente contemporánea con las otras vasijas halladas apoyando sobre el piso. Volveremos sobre esta conjunción de temporalidades distintas, y el rol de las interfacies de período en dichas intersecciones, en el penúltimo capítulo cuando analicemos las cartografías. Por el momento estos datos nos marcan una temporalidad muy larga de vida de algunas de estas vasijas.

Sin pretender realizar una analogía directa con contextos sociales y temporales distantes, se ha mencionado que las piezas dedicadas a la elaboración y fermentación de 
chicha en ciertos lugares de los Andes meridionales poseen una vida muy larga, superando incluso al tiempo de vida de una persona particular, siendo utilizadas por varias generaciones (Vargas y Pazzarelli 2008). Estos autores señalan, a partir de entrevistas con chicheras provenientes de la zona de Cochabamba en Bolivia, que a las vasijas utilizadas para fermentar chicha se las cuida mucho, utilizándolas en muchas ocasiones como metáforas de una vida prolongada, aconsejándose a personas jóvenes que deben cuidarse tal como se cuidan las vasijas para que puedan vivir mucho tiempo. Nosotros mismo realizamos algunas entrevistas con integrantes de la Comunidad Indígena Colla de Finca Tumbaya en la Quebrada de Humahuaca -Provincia de Jujuy-, donde para la elaboración de la chicha se utilizan vasijas cerámicas, las que según nos señalaban no solo se adquiría o eran objetos de regalos cuando una familia nueva se formaba, si no que en general se heredaban pasando de mano en mano por varias generaciones. Más allá de estos contextos etnográficos, lo expuesto anteriormente nos muestra que algunas de las vasijas de clase $\mathrm{E}$ de "otras formas", probablemente también algunas de forma "a" y "ab" trascendían la temporalidad de la vida de una persona y duraban más de una generación. Con respecto a las vasijas de clase A1, a diferencia de las de clase E, sus propiedades tecnológicas las hacen objetos muy frágiles a los golpes, una vez que comienza a producirse una fractura, no existe nada que la detenga. Si a esto le sumamos que las huellas de uso muestras una alta movilidad y variedad de movimientos realizados con ellas, estas vasijas deben haber estado expuestas a más peligros que las otras. Por lo que quizás se rompían con más frecuencia y duraban menos tiempo. Aunque este hecho dependerá de las formas de cuidado, frecuencia e intensidad de uso de la mismas. Dentro de las de clase A1 ciertas consideraciones pueden ser realizadas respecto a las huellas observadas y las formas: mientras que la forma "b", escudilla, forma c, vasija restringida compuesta, las huellas muestran variedad de movimientos y procesos erosivos fuertes en bases, y zonas inferiores, las vasijas modeladas, vasos y jarras lo hacen en menor medida, ya sea debido al tipo de uso que se le daba o al cuidado que estas recibían. Por lo que quizás estos se rompían con menor frecuencia y duraban más tiempo que las otras. Sin embargo a pesar de estas tendencias que nos informan quizás de los tiempos esperados de vida de cada una de las vasijas, no quiere decir que las vasijas no se hayan roto antes, o que se decidiera sacarlas de su participación en las prácticas donde solían involucrarse antes de su rotura.

En general podemos señalar que, una vez rotas las vasijas, no hay intenciones en prolongar la vida de las mismas utilizando métodos de reparación de la pieza tales como el cocido. En el caso de las vasijas de clase E, no hemos registrado ningún caso que presente agujeros de reparación. En el caso de las de clase A1 de todas las piezas enteras, 
parcialmente remontadas y fragmentos analizados (386) solo cuatro presentan hoyuelos de reparación, es decir el 1\%: un borde de vasija de forma b, un fragmento de escudillas, un fragmento de vaso o jarra, y una fragmento de cuerpo de una vasija restringida compuesta. Este hecho, no solo nos indica la intención de no prolongar la vida de una vasija por medios de métodos de reparación, si no que a su vez nos muestra el instante final, intencionalmente concebido, en que una vasija, sin importar la clase, formas, prácticas y contexto en la que participó deja de ser ese objeto que almacenaba chañar, pigmento rojo o blanco, partes corporales de humanos y camélidos, o que fermentaba chicha, o que se utilizaba para cocinar preparados de vegetales y carnes, o que permitían transportar, servir y consumir, los preparados y las bebidas, o aplicar la pintura. Es decir ese instante es muy significativo, en tanto el objeto comienza un proceso de transformación y resignificación importante. En ese momento cada vasija se disgrega, no solo porque se rompe y se fragmenta $y$, no es vuelta a unir, si no que a su vez con los fragmentos pueden ocurrir varios procesos distintos que los vinculan a prácticas, espacios y tiempos diferentes. Cuando estas se rompían, los fragmentos no eran dejados en el lugar, si no que intervenían prácticas de limpieza. Es a través de estas prácticas que se produce una resignificación de las vasijas y de los fragmentos. Estas prácticas producían que algunos grupos de fragmentos o partes de vasijas, por algún tiempo, no sabemos cuanto, quedaran almacenados contra los muros de las habitaciones techadas, tales como hemos señalado contra la esquina noreste y muro sur de Recinto Chico, contra el muro este del Recinto Sudeste; o en ciertos sectores de las galerías, como en el sitio Martínez 4. Pero estas prácticas a su vez producían otra cosa, no todo los fragmentos eran acumulados en estos lugares en tanto que solo existen parte de ellos y casi no remontan. Por lo que algunos de los fragmentos que fueron extraídos de sus lugares de rotura, eran trasladados a otros espacios fuera del recinto techado y de los contextos de la práctica donde acabaron rompiéndose. Desde estos lugares podrían ser llevados a otro espacio donde con ellos se confeccionaban otros objetos, tal como lo hemos analizada para el Recinto $\mathrm{H}$ del sitio Piedras Blancas. En este lugar, las partes de vasija fracturadas, eran acumuladas en el sector sur del recinto contra los muros. En esos espacios no sabemos cuanto tiempo permanecían acumulados, pero a algunos de ellos en dicho lugar se los transformaban en otros objetos. Con los cuerpos de las grandes vasijas globulares de forma "a" y "otras formas", que presentan marcas de uso tales como antiplástico sobresaliente o descascaramiento de los baños interiores vinculadas a la fermentación de chicha que visiblemente se les produjeron antes de su rotura, se confeccionaron platos. Con los sectores de boca y cuello de vasijas de forma "a", aquellos que quedaban enteros, las 
fractura inferiores eran completamente alisadas con el objetivo de estabilizar la pieza fragmentada y de formar un soporte estable para sostener erguidas otras vasijas de clase $\mathrm{E}$ de forma "a" de base cónica tal como se observa en la estructura 5 de La Iglesia de los Indios, en donde la porción superior de una vasija de forma "a" que presenta las factura inferior alisada estaba sosteniendo a una vasija de forma "a" que almacenaba chañar. $\mathrm{O}$ como la encontrada en la galería oeste del sitio Martínez 2 al pie de la banqueta B junto a un mortero plano, que se trataba de una vasija "a" con el rostro modelado y la nariz en gancho con la fractura aplanada. A su vez, con partes de cuerpos de escudillas, de bols y vasijas "b" se confeccionaron fichas de diversos tamaños e inclusive torteros. Además, muchas de los fragmentos de clase A1 y otras clases tecnológicos de pasta fina que no presenta antiplástico visible se los volvía a moler para su incorporación en las pasta para confeccionar vasijas de la misma clase. En todos estos procesos la unidad significativa deja de ser el objeto entero, las vasijas, pasando a cobrar sentido los fragmentos de estas. Pero no en todos los casos se las reutiliza como otro instrumento o se confeccionaba otros objetos. En el valle de Ambato, una estructura recurrente es una serie de montículos que se hallan adosados o cercanos a las viviendas, que fueron definidos como "basureros" o plataformas, en caso de presentar paredes de piedra conteniéndolos. En estas estructuras se han hallado gran cantidad de fragmentos de estas vasijas, tanto de clase E como A1 y de las distintas formas analizadas. Del total de fragmentos analizados 218 provienen del montículo de Piedras Blancas. En estos espacios no solo aparecen objetos de cerámica si no restos de otros objetos: restos de animales consumidos -camélidos-, fragmentos de huesos humanos, pigmentos, semillas, instrumentos líticos, fragmentos de vasijas de otras clases tecnológica, pipas, fragmentos de objetos de metal, e inclusive lingotes de este material etc. La formación de estos lugares se realizó a través de depositaciones periódicas y de la acumulación progresiva de los desechos arrojados en ellos. Digamos por ahora, que en los montículos se halla un compendio de la variedad de objetos utilizados y prácticas ejecutadas en el Valle, entre ellas las vasijas analizadas. Pero también existen casos donde las vasijas analizadas, así como otros objetos fueron extraídos de las rutinas donde se movían enteros, y fueron incorporados como acompañante del entierro de niños por debajo de los pisos y paredes de algunos recintos, tal como los entierros hallados por debajo del piso del recinto $\mathrm{H}$. 


\section{Parte}

\section{Sintetizando: sus biografías...}

Las distintas biografías que tuvieron las vasijas analizadas permiten entrever en ellas la confluencia parcial de diferentes escalas sociales, temporales y espaciales. La convergencia de estas escalas, implica que no se pueda establecer una biografía "ideal", para cada clase o forma específica, aunque sí es recurrente encontrar biografías comunes.

La vinculación de estas vasijas con una tradición tecnológica más antigua, relaciona a todas los objetos analizados, con temporalidades que exceden sus tiempos biográficos particulares, relacionándose con "formas de hacer" que perduran en el tiempo, al menos desde comienzos del primer milenio de la era. Mientras que varias clases tecnológicas del Período Formativo, en los inicios del Período de Integración Regional -siglos V a IV de la era- desaparecen y se dejan de usar; las vasijas de clase E y A1 continúan fabricándose y utilizándose, pero no solo podemos observar su continuidad si no que, además, en el nuevo contexto social, se produce un aumento de la representatividad de estas clases respecto del período anterior. En el caso de la clase A1 el aumento es del $33 \%$ y, en el caso de la clase E, el aumento es mucho más alto, del 100\%. Por lo dicho, las vasijas confeccionadas con estas clases en el nuevo contexto social adquieren mayor popularidad. Podríamos decir que en la historia más larga que representa todo el primer milenio, se logran imponer como objetos altamente "deseados" o "requeridos". Esta puede ser una de las razones que permite comprender su alta distribución y presencia en todos los sitios del valle, sin importar el tamaño, complejidad y ubicación, e inclusive su presencia fuera del valle.

A diferencia de las vasijas de la clase E, que perduran de la misma manera, en el caso de las vasijas de la clase tecnológica A1 (Negro Pulido) si bien continúa produciéndose de la misma forma, que las clases Gris Negro Pulido y Negro Pulido del Período Formativo, sufre una modificación en relación a la decoración de la superficie externa en tanto que se le incorpora por medio de la técnica de incisión y/o grabado el repertorio iconográfico clásico del estilo Aguada de la zona de Ambato (Bedano et al 1993; Fabra 2008; González 1998; Gordillo y Kush 1987; Laguens 2002).

Para confeccionar amabas clases se utilizó un mezcla de arcilla roja con una proporción de arcilla blanca. La primera en tanto posee buenas cualidades plásticas y la segunda como antiplástico. En el caso de la clase E probablemente estas arcillas fueron extraídas de canteras locales como las halladas en el arroyo Los Escobales, aunque faltan realizar análisis de AMS para confirmar los otros análisis realizados -difracción de rayos 
$\mathrm{X}$ - que así lo sugieren. Estas canteras se hallan formando parte de las barrancas de los arroyos que circulan por el valle específicamente en sectores donde afloran relictos de rocas sedimentarias del terciario y sedimentos del cuaternario. El acceso a estas canteras no habría sido restrictivo por lo menos, como vimos, dichas restricción no fue demarcada materialmente. Lo mismo sucede con los antiplásticos que se mezclan con la arcilla -arena, cuarzo y mica- los que son abundantes en el valle, por lo que tampoco implicaría la existencia y posibilidad de imponer restricciones en el acceso a estos. En relación a la Clase A1, hasta el momento no han aparecido fuentes de arcilla al interior del valle que se correlacionen con los estudios de AMS. Existe un grupo de alta homogeneidad, probablemente producido con arcillas provenientes de una sola fuente, pero también existen otros grupos provenientes de otras fuentes. A su vez este grupo con alta homogeneidad aparece representado fuera del valle: hacia el noreste en la zona de Alberdi -Tucumán-, al sureste al pie de la serranía del Ancasti y al suroeste en la Quebrada del Tala, justo cuando esta desemboca en el valle central de Catamarca. Estos además de marcarnos cierta interacción entre los habitantes del valle y estas regiones en donde los objetos fabricados, con la clase A1, se hallaban inmersos, vinculan a algunas de estas vasijas con espacialidades y relaciones sociales más amplias que las que se dan al interior de lo sitios y del mismo valle. Aparentemente según los datos de AMS obtenidos hasta el momento estos objetos se vinculan más a los sectores sureste-Babiano, pie del Ancasti y noreste -Alberdi, Tucumán- en tanto que la mayor representatividad en las muestras analizadas de estos lugares la posee el grupo de referencia de Ambato. A su vez, aunque falte confirmación, el grupo de referencia posee vinculaciones con una cantera de arcilla ubicada al otro lado de la sierra del Ambato al noroeste del valle, al pie del cerro Aconquija, Potrero de Santa Lucía. Esto nos podría estar hablando de interacciones entre este lugar y el Valle. Hasta el momento, si este fuera el caso, no conocemos si los objetos provendrían ya confeccionados desde este lugar o si por el contrario solo la arcilla de esta fuente fue requerida por los habitantes del valle. En caso que esta hipótesis se confirme, dado que en primer lugar, las características de la pasta de la cerámica confeccionada con la clase A1-muy frágil- podrían poner en problemas la integridad de la pieza al tener que viajar a través de largas distancia, y en segundo lugar, en el Valle se han hallado contextos significativos que evidencias proceso de producción de alfarería, apareciendo además de herramientas y materias primas, piezas sin cocinar, se habría traído la arcilla. Aunque no podemos descartar la circulación de objetos enteros. En el caso del Valle de Ambato debemos recordar que otras clase de materiales, no solo eran buscados a gran distancia, si no que también se los traía en forma de materia prima, tal es el caso del metal que 
ingresaba al valle como lingote (Espósito 2009). O maderas para construcción de los techos que era buscadas a más de $50 \mathrm{~km}$ del valle hacia el este (Marconetto 2008). Los otros grupos que pertenecen a otras fuentes, no a la del grupo más homogéneo, como es el caso de los fragmentos del Sitio Martínez 3 -un montículo basurero cercano a sitios de tamaño pequeño (Martínez 4) y grande (Martínez 2)-, nos indican que probablemente circulaban objetos o arcillas provenientes de otros lugares y también de canteras diferentes aun no halladas en el valle. Esto nos abre un gran abanico de posibilidades al inicio de las trayectorias biográficas de esos objetos, particularmente las vasijas confeccionadas con la clase A1, vinculándolos a lugares distintos fuera del valle, y a lugares en el interior del mismo valle. A su vez aquellos objetos que habrían venido de fuera del valle, poseen una biografía anterior a la llegada y a su inserción activa en la vida de valle. No sabemos si venían recién confeccionados o con un recorrido anterior, si este fuera el caso, según las huellas observadas, que en general permiten desentrañar ciertos patrones de uso generales, dicho recorrido no sería tan distinto a los que podemos interpretar que se realizaba con ellos en el valle. En el caso que fueron "nuevos" o sin "uso", el inicio de las biografías de estos objetos se hallarían mediadas por relaciones más amplia y distintas a las que podemos desentrañar de su participación en las prácticas en las que fueron involucrados en el valle. Por otro lado a pesar de existir varias posibilidades en cuanto a la proveniencia de las arcilla y/o los lugares de fabricación de la cerámica, tenemos por el contrario cierta homogeneidad en los proceso de producción no solo a nivel de ciertas arcilla más utilizadas, como las que se usan en el grupo de alta homogeneidad, si no que también en la utilización principalmente de arcilla rojas y blancas, así como también en la estandarización de algunos tipos de formas como las escudillas (Laguens y Juez 1999, Fabra 2008). Estas "formas de hacer" que perdura y se popularizan en el período de integración regional, entra de lleno en el terreno de la constitución de determinados habitus de producción y reproducción. Pero además al considerar que dentro de estas largas tradiciones existe, posibilidades iniciales distintas, tales como la procedencia de las arcillas e inclusive de los objetos, pero como señalamos algunas poseen más preeminencia que otras, debemos también pensar en la posibilidad que se instalen en determinados espacios sociales sentidos hegemónicos de preferencias en las "formas de hacer las vasijas". A pesar de estas posibilidades biográficas iniciales diferentes, según lo que venimos desarrollando a lo largo de este capítulo el decurso de la vida de objetos que pudieron haber tenido un origen distinto no fue diferente.

Si bien señalamos la posibilidad de que pudieran venir objetos provenientes de lugares distantes, hemos aportado argumentos para plantear la existencia de una 
producción local de vasijas de clase E y también de clase A1 en sitios de tamaño Pequeños (Martínez 4), Medianos (Martínez 1) y Grandes (Martínez 2), no existiendo evidencias para sitos Muy Grandes (Piedras Blancas) y Muy grande con Sectores (Iglesia de los Indios o La Rinconada). Desde diferentes investigaciones realizadas en el valle (Fabra 2005, 2008, Laguens y Juez 1999), se ha señalado la existencia de cierta tendencia a la especialización en la producción cerámica, pero la misma no sería especializada si no semiespecializada. Esto va de acuerdo con las escalas espaciales y sociales donde son producidas estas vasijas en el valle y los otros objetos de cerámica vinculados a ellas, las que están enmarcadas por los espacios de reproducción social cotidiana de estos artesanos, es decir las vasijas se confeccionan en los lugares donde estos grupos vivían, no existiendo centros o espacios dedicados exclusivamente a la producción cerámica.

Las rutinas seguidas en la producción de vasijas en estos sitios pequeños, medianos y grandes, producen cierta espacialización al interior de los mismos y, a su vez, vincula a estos sitios, espacios y prácticas artesanales, así como las personas que las realizaban y vivían allí, con espacios y relaciones sociales más amplias que aquellas delimitadas al interior de los mismos. Para el aprovisionamiento de las arcillas, no se observa la existencia de una restricción en el acceso a las canteras -lo mismo podríamos decir de los antiplásticos utilizados y quizás también de los pigmentos- por lo que, la rutina de salir de la casa e ir a buscar o elegir las arcillas, extraer arena, cuarzo y placas de mica, vincularía a los espacios donde las vasijas se confeccionaban y a las personas que las realizaba y que vivían en ellos, con ámbitos en los que median relaciones sociales vinculadas con la construcción de colectividades mayores y más inclusivas a las que se articulaban al interior de estos sitos. En este sentido quizás compartan y se encuentren dentro del mismo espacio de construcción y negociación donde se hallan las formas de apropiación del combustible, particularmente la leña, para la cocción de las vasijas. A esta última práctica la hemos vinculado a la apropiación de lo que siguiendo a Marconetto (2008) señalamos como el "monte". Las casas, y particularmente las analizadas aquí, están insertas en el monte, este las rodea. En este sentido, la rutina de proveerse de los materiales necesarios para la fabricación de vasijas activaría las relaciones sociales que mediaban las formas de acceso y apropiación de dichos elementos y espacios, en donde como hemos señalado, debieron jugar un importante rol las agrupaciones mayores a las cuales pueden vincularse los distintos sitios, las aldeas relativamente dispersas inferidas por Assandri (2007). Pero también si pensamos en la posibilidad de que además de la leña fina de la poda natural del monte, se habría utilizado guano para la cocción de estas vasijas, la producción de las mismas se vincularía a otras clases de relaciones espaciales y sociales, donde también 
participan las casas y los habitantes de ellas. Particularmente nos referimos a la posibilidad de utilización de guano. A este debemos vincularlo con la gestión de los camélidos, única fuente de obtención de este elemento. La crianza de estos animales en el valle, tal cual lo muestra el emplazamiento de los corrales ubicados al lado de los campos y terrazas de cultivo y; las formas de alimentación que recibían estos, que en gran parte consistía en maíz o en los rastrojos de este (Figueroa et al 2009), es virtualmente imposible de desvincularla del paisaje que construye y delinea la particular forma de apropiación del agua de escorrentía y de las vertientes que hemos descrito en el capítulo cuatro, que como dijimos estructura no solo las prácticas agrícolas, si no también el emplazamiento de las viviendas. Por lo que la obtención del guano, se vincula con la lógica en las que la apropiación del agua, la tierra y los productos de estas se realizaba. En este sentido las rutinas seguidas para la confección de vasijas se enlazan y a la misma vez enlazan, a las formas de relación y construcción de espacios que superan a las relaciones y espacios delimitados al interior de las casas.

La secuencia de producción que realizarían los artesan@s para confeccionar vasijas de estas clases y formas, ocurren en parte en los espacios abiertos y más luminoso, como los patios y las galerías: tales como la mezcla de la arcilla, el molido de los minerales, o de los tiestos, la preparación de las mezclas, y el levantado de la piezas, así como la pintura e incisión. A su vez en las habitaciones techadas, que son espacios más internos, restringidos, hundidos y menos luminosos, son lugares donde se guardan los instrumentos y materias primas, piezas recién terminadas o a la espera de ser cocidas e incluso algunas mal fabricadas, almacenadas contra los muros de las habitaciones y sobre banquetas adosados a estos. Así tenemos cierta dinámica y regionalización del espacio al interior del muro perimetral producido por estas prácticas. Pero a su vez en tanto que la transformación en objetos, en vasijas, ocurre en ellos, es decir en las habitaciones, galerías y patios, estos espacios no solo quedan implicados en esas otras espacialidades y relaciones sociales más amplias que hemos referido en el párrafo anterior, si no que además por este mismo hecho, se hallan activamente definiendo uno de los locus donde las mismas se producen y reproducen. Así tenemos que las prácticas artesanales de fabricación de estas vasijas, que ocurren en los sitios de tamaño pequeños, medianos y grandes, produce no solo que ciertas "formas de hacer", que perduran al menos mil años en el valle -in-corporadas como habitus- sean actualizadas desde el pasado y desactualizadas al momento de que determinados sujetos específicos dentro del espacio social particular del Valle de Ambato artesanos semi-especializados (Bourdieu 1977, 1988; Laguens 2006b) las producen; si no que también en esas mismas prácticas y los espacios delimitados por las rutinas implicadas 
en la recolección de la arcilla, el antiplástico, la leña, el guano etc., vuelven a actualizar y desactualizar, a in-corporar y, por ellos reproducir las formas y espacios, podríamos decir en el sentido que le hemos atribuido en el capítulo cuatro, el paisaje, que definen la apropiación del monte y del agua, y, a través de ellos, no solo la definición de los colectivos que median a dichas lógicas, si no que también el lugar ocupados por las personas que habitan dichos sitios, en ellos.

Las vasijas, una vez confeccionadas, en los espacios y por las personas señaladas, comienzan a circular por varios lugares y a vincularse a distintas prácticas. Señalamos que las personas que confeccionaban las vasijas no eran especialistas de tiempo completo, por otro lado dijimos que no se hallaron lugares o sitos especiales para realizar esta actividad, por lo que en los mismos lugares donde estas vasijas se producían, se realizaban otras prácticas vinculadas a la reproducción social del grupo que vivía ahí. Las distintas actividades realizadas por estos grupos, implicaron la participación de las mismas vasijas que ellos confeccionaban y, quizás de algunas otras vasijas provenientes de otros lugares. Por lo que algunas de las vasijas que eran confeccionadas quedaban en los mismos espacios donde eran producidas, y, a su vez eran utilizadas por1@s mism@artesan@s que las producían. Mientras que en los patios o galerías se estaban confeccionado las vasijas, en los recintos techados se hallaban vasijas grandes de "otras formas" cocinando vegetales y carnes. Había escudillas y vasijas de forma "b" de clase A1, junto a vasija de otras clases transportando o sirviendo lo que se cocinaba. En los pisos de las galerías, junto a morteros donde se molieron probablemente granos u otros productos vegetales, los grandes platos se hallan procesando o conteniendo esos mismos productos. Junto a otros morteros donde se molía pigmento existían vasijas de forma "b" y escudillas conteniendo el polvo de color rojo o blanco extraído del molido; a su vez, las banquetas soportaban el peso de las vasijas usadas o nuevas a la espera de su inserción o reinserción en alguna de las prácticas mencionadas; por lo que los tiempos biográficos de estas otras vasijas que se hallan participando de varias prácticas distintas, quedan vinculados con los tiempos productivos de las vasijas que se están haciendo en dichos lugares. Es decir las vasijas se hacen y "nacen" en espacios fuertemente connotados, por los derroteros de otras vasijas, por su inserción en prácticas específicas. Así, a las vasijas que se están produciendo y las que están almacenando, cocinando, guardando, o procesando, es imposible ubicarlas como momentos distintos de una secuencia lineal de producción y uso, en tanto en ese espacio, las prácticas de procesamiento, almacenamientos y cocción de partes de camélidos y humanas o solo vegetales, la acumulación de pigmentos, la fermentación de bebida y las prácticas de producción de objetos cerámicos, así como los mismos objetos producidos, los 
artesanos, se hallan al mismo tiempo y por ello en tanto prácticas sociales relacionados recursivamente (Bourdieu 1977, 1988). Algunas vasijas desde estos lugares se dirigen hacia otros sitios más grandes donde no se han hallado evidencias de su fabricación, tales como Piedras Blancas y La Rinconada. No sabemos si también estas vasijas desde los sitios pequeños trascendían los cerros que delimitan el valle, por el momento es difícil saber si alguna de las piezas de clase A1, halladas fuera del valle, tanto las confeccionadas con el grupo de alta homogeneidad como las que no, se habrían confeccionado en alguno de estos sitios, pero aunque no podamos corroborarlo no debemos descartarlo.

Las vasijas fueron confeccionadas con variedad de mezclas, formas, tamaños, que les confieren ciertas propiedades técnicas y formales, que de manera potencial podrían influir su utilización en diferentes actividades específicas. Estas propiedades, no restringieron su participación futura en alguna actividad particular, pero sí produjeron ciertas diseminaciones y encuentros en las vidas de estos objetos. Es decir que en el momento en que estos objetos son fabricados, existen ciertas apreciaciones por 1@s artesan@s sobre las posibilidades futuras de uso. Estas influyen en los modos en que las vasijas se insertaban en prácticas concretas: tales como aquellas que fueron dedicadas a realizar determinadas actividades de cocción que en la mayoría de los caso están confeccionadas con la clase $\mathrm{E}$ mezcla 5, la que posee tamaño de antiplástico mediano y pequeños con una mayor cantidad de mica que el resto, la que justamente señaláramos con mejores propiedades de resistencia al shock térmico y estrés térmico. A su vez ninguna vasija de clase A1 se utilizó para esta actividad. Esto también se observa con respecto a algunas formas dentro de la clase E: las vasijas de "otras formas" y las "calceiformes" son las que en general se utilizan para cocinar, a su vez son estas formas las que presentan propiedades formales que les permiten resistir el shock y estrés térmico de mejor manera. Es decir que existe cierta correlación en los tamaños de molidos de los antiplásticos, el agregado de mica, las formas de las vasijas y prácticas en donde se necesita la cocción. Las vasijas calceiformes son en las que más puede observarse esta correlación, en tanto no hemos registrado vasijas de esta forma de la clase $\mathrm{E}$ que no se hayan confeccionado con otra mezcla que no sea la 5 y que no presenten huellas de carbonización en la superficie exterior. En el caso de las "otras formas" que son tetrápodas ocurre lo mismo que las calceiformes. Pero en otros casos, de vasijas pertenecientes a las "otras formas", la correlación con actividades que necesiten su colocación en el fuego, es más potencial, en tanto que no todas las que son de otras formas se utilizan para cocinar y además no todas aquellas vasijas que pertenecen a esta forma y poseen la mezcla 5 se han sometido al fuego. Si bien la mezcla no es absolutamente determinante para una vasija en relación a las actividades de cocción, en tanto tenemos 
vasijas de mezcla 1 y mezcla 3 que se han utilizado para cocinar, existe una tendencia a preferir vasijas de mezcla 5 para someterlas al fuego, en tanto que los otros son casos aislados. Existen algunas propiedades formales, además de la clase tecnológica y mezcla que también restringen cierta trayectoria futura con respecto al uso: aquellas vasijas que presentan puntos angulares y de inflexión muy marcados, como las vasijas de forma "a" y "ab" -las últimas a su vez con bases cóncavas-convexas-, no han sido sometidas al fuego. El resto de propiedades, estabilidad, accesibilidad, porosidad, transportabilidad, etc., predisponen a las vasijas para facilitar ciertas operaciones ejecutadas con ellas, tales como el transporte y manipulación, ya sea por su tamaño o presencia de atributos secundarios como asas, que en general son remachadas tales como las presentan las vasijas de forma "ab", "b", "c", alguna de las "otras formas". Para acceder y manipular más fácilmente los contenidos tales como las escudillas, bols, platos chicos o grandes. O que presenta más estabilidad por lo cual no necesitan de soporte o sostenimiento para quedar erguidas. Todas estas propiedades más que determinar su participación en una práctica diferente, produce su inserción diferencial en ellas, es decir estas propiedades más que diferenciarlas, en algunos casos, produce su encuentro como participantes que ocupan diferentes roles en una misma práctica. Dada la asociación recurrente de vasijas de tamaños, clases -E, A1 y otras- y formas distintas -forma "a", "otras formas", forma "b", escudillas y vaso o jarrasen contextos de acción particulares -almacenado y cocido de vegetales y carne y almacenado de pigmentos- probablemente debamos ampliar a un nivel más amplio de agrupación a todo este grupo de objetos, que ya no depende necesariamente de la forma, tamaño, propiedades técnicas, decoración, características de performance, si no de su participación en prácticas específicas que los vinculan a sentidos y significados específicos. Este hecho plantea no un problema pero sí un desafío a la perspectiva biográfica, principalmente respecto de donde se coloca el límite de un objeto, para decir que uno está reconstruyendo la biografía de este objeto particular, siendo que en algunas instancias o momento los objetos se mueven en grupos como si fueran un mismo objeto, desafiando la posibilidad de su separación.

Las prácticas que hemos podido desentrañar donde se involucran diferencialmente las vasijas se vinculan algunas, con la preparación y consumos de comidas: trozamiento, almacenamiento, cocido y probable consumo de carnes -animal y humana-. Almacenamiento, procesamiento, cocido y consumo de alimentos vegetales: chañar, probablemente maíz y otros. Otras se relacionan con el preparado, mezcla y fermentación de chicha. Pero también se hallan fuertemente vinculadas a otras prácticas no relacionadas directamente con la preparación y consumo de alimentos y bebidas, si no con el preparado, 
almacenado, manipulación y aplicación de pigmentos rojos y blancos. Toda esta variedad de prácticas en las que están inmersas estas vasijas y en las que una misma vasija llega a estar a lo largo de su vida, nos informa de que los ritmos temporales de las intervenciones activas de las vasijas tenían por lo tanto diferentes implicancias en la interacción con las biografías de otras vasijas y objetos, así como las biografías de los sujetos y grupos humanos. En general todas las vasijas de diferentes formas y clases tecnológicas, participaban en más de una práctica, ocuparon roles diferentes en la realización de estas, salvo por las vasijas calceiformes que se utilizaron para una actividad muy específica. Pero, a su vez hemos visto que en varios casos estas prácticas pueden llegar a secuenciarse de la siguiente manera: fermentación y almacenado de chañar en vasijas de forma "a"; fermentación y almacenado de pigmento en vasijas de forma "ab"; fermentación y almacenado de partes corporales de camélidos y humanos en vasijas de forma "a" y "otras formas" de clase E; fermentación y cocción de vegetales en vasijas de "otras formas" de clase E; fermentación y cocción de partes corporales de camélidos y humanos en vasijas de "otras forma" de clase E; fermentación, cocción de vegetales y almacenamiento de pigmentos color rojo en vasijas de "otras formas" de clase E. En el caso de vasijas de clase A1, tanto de la forma "b", "escudillas", "vasos o jarras" "modeladas", probablemente "bols" y "vasijas restringidas compuestas", se las han hallado acompañando en todas las actividades señaladas, salvo durante el proceso de fermentación, a vasijas de formas "a" y "otras formas". Aunque en estos casos debido a la ausencia de marcas distintivas y falta de análisis químicos, no podamos saber si una misma vasija alternaba entre estas prácticas o si seguía la misma secuencia que las otras vasijas. Sin embargo, la recurrente asociación de estas vasijas en los mismos contextos de ejecución de estas prácticas, inclusive algunas teniendo los mismos contenidos que albergaban las vasijas de formas "a", "ab" y "otras formas" de clase E asociadas a estas, son muy sugestivos y podrían llegar a apuntar a un derrotero semejante que las otras vasijas que las acompañan. Así tenemos que el tiempo de vida de algunas de las vasijas, se halla segmentado a través de su inserción secuencial en prácticas diferentes. Estos segmentos o etapas quizás nos muestren parafraseando a Kopytoff (1991) "edades" o "períodos" reconocido en la vida de estas vasijas, de hecho ciertas actividades dejan sus huellas visibles en ellas, rastros de su devenir que permanecen indeleblemente presentes en sus cuerpos, inclusive posteriormente a su fragmentación. Las huellas y rastros dejados por la fermentación, la cocción, el pigmento, conforman marcadores, elementos mnemónicos de prácticas pasadas y de las historia acumuladas por ellas. Así parte de la biografía de estas vasijas en donde llegan a convivir, las distintas espacialidades que cada práctica implicaba, así como los objetos a los cuales se 
relacionaron en ella y los mismos sujetos con los cuales se vincularon quedan impresas materialmente y por lo tanto fijadas en sus cuerpos. A su vez el que una vasijas transcurriera por cada uno de estos segmentos de duraciones probablemente variables de pieza a pieza, y de práctica a práctica, podría conformar la encarnación de una "exitosa" carrera social de estos objetos, como una vida bien vivida (Kopytoff. 1991:91). Ahora la duración de lo que podríamos llamar ese tiempo intermedio entre el "nacimiento" de estas vasijas y la "muerte" cuando se fragmenta, en el cual se hallan implicados estos otros tiempos secuénciales, es difícil de determinar. Pero la misma secuencia de uso nos puede estar indicando tiempos de duración prolongados, o por lo menos expectativas de una larga duración. A su vez en la vida de esto objetos, existen momentos y lugares específicos donde las vasijas se guardan. En estos espacios, ya sea en las banquetas de las galerías, o en áreas marginales al desarrollo de las actividades en el interior de las habitaciones, permanecen inmóviles -no sabemos por cuanto tiempo- a lado de otras vasijas, algunas con las huellas de su participación e inicio de recorrido, memorias de su paso por una o quizás dos etapas, otras aún sin nada, se hallan a la espera de su inserción o reinserción en alguna de estas prácticas. Por lo que a los ritmos temporales de sus inserciones activas en alguna de las prácticas que estructuran la vida de estos objetos debemos sumar estos otros tiempos donde las vasijas esperan. Una pista al respecto de la duración de algunas de las vasijas es el caso que hemos discutido anteriormente de la vasija de clase E, pertenecientes a las "otras formas" hallada en el Recinto Sudeste del sito Piedras Blancas. La que muestras un recorrido de unos 300 años. Probablemente esta duración no halla sido lo más frecuente, pero sumado a lo dicho anteriormente, nos permite entrever que algunas vasijas, aquellas que no se rompieron y lograron perdurar, trascendieron la vida de una persona, vinculándose a más de una generación.

Al no poder determinar cuando se decidía que la vasija debía, por ejemplo, dejar de cocinar y empezar a almacenar pigmento, no podemos saber los mecanismos y procesos que intervenían en el traspaso de etapa en etapa, de práctica a práctica, o de una "edad" a "otra". Quizás mediaban ciertos procesos de transición, a la manera de cómo la ha establecido Arnol Van Genep y lo ha extendido al resto de la vida social Turner (1980:103104), para los diferentes momentos de transición en la vida de las personas -nacimiento, adolescencia, casamiento y muerte-, definiéndolos como "ritos de paso", los que presentan tres etapas: separación, travesía por las márgenes -limen- y reagregación. A lo mejor esos lugares donde se las guardaba, eran espacios transaccionales, luego de la separación de una práctica, en ellos permanecían junto a otras vasijas, a la espera de su reagregación. Según las prácticas en las que fuere a participar y de la etapa biográfica en la que se hallaba, 
podrá compartir el derrotero con ciertas vasijas y dejarán atrás antiguos derroteros, aunque las huellas de ese devenir permanezcan, como dijimos, marcadas indeleblemente en la superficie de sus cuerpos, inclusive posteriormente a su fragmentación final. Existe un momento donde es más visible esta serie de pasos, este cambio de estado, y resignificación: es en el momento que la vasija se rompe, este instante es el momento donde se concibe el final de la vasija como ese objeto. Por más que sólo halla recorrido parte de la secuencia, digamos ejecutado una de las prácticas esperada, cuando se rompen no las reparan, no se les prolonga la vida, no se les permite continuar como esos recipientes que eran. Es decir una vasija que se rompe mientras fermenta chicha, tranquilamente si se la cose, pude almacenar otras cosas, por ejemplo chañar, pigmento, etc., sin embargo no se concibe esa posibilidad. En ese momento la vasijas se disemina, se la separa, no quedan en los lugares donde se rompen, estos son limpiados, barridos, los fragmentos son recogidos y trasladados a otro lugar. En este sentido podríamos decir que se da una de las primeras etapas un proceso de separación en el que las prácticas de limpieza y traslado tienen un rol muy importante. En esa instancia los fragmentos comienzan a realizar una especie de travesía por los márgenes, se lo coloca durante un tiempo en los rincones o contra los muros de las habitaciones, junto a otros fragmentos de vasijas rotas, pequeños fragmentos invisibles quedan incorporados como inclusiones de los pisos de tierra en los mismo lugares donde se rompía. En ese sentido pasan a una instancia liminar, por lugares donde normalmente no transcurrían sus vidas, o se asocian a objetos que con los que no compartían los mismos espacios, se transforman en una especie de sujetos transicionales, ya no son vasijas, solo son partes de vasijas rotas y aún no han sido reagregados, en una nueva condición o estado. Este tiempo liminar, son instancias interestrcutrales donde los fragmentos y las vasijas junto con sus biografías, sus historias acumuladas e inscritas en sus cuerpos, pasan por un momento transicional de liminaridad hasta que se completa la travesía al nuevo estado, durante este instancia que puede ser de tiempo variable -largo o muy corto-, las biografías de las vasijas, los fragmentos y las posibilidades futuras de estos, no son ni una cosa ni otra; o tal vez son ambas al mismo tiempo, no están allí ni aquí o incluso no están en ningún sitio de los reconocidos por las topografías culturales, y están entre y mitad de todos los puntos reconocibles del espacio-tiempo de las clasificaciones estructurales (Turner 1980:108) ${ }^{x x i i}$. Pero estas travesías por los márgenes, esta permanencia en la liminaridad, son temporales, siempre están dirigidas a volver a espacios o estados conocidos y reconocidos: en algunos casos ese estado de liminaridad y ubicuidad es resignificado al pasar a otro espacio, lugar donde habitan temporalmente estos "seres" transicionales, como el recinto $\mathrm{H}$ del sitio Piedras Blancas, son lugares dedicados, entre 
otras cosas, a retransformar parte de esos fragmentos en otros objetos: soportes, platos, fichas, torteros o polvo para confeccionar nuevas vasijas, etc., en esa instancia esos otros fragmentos comienzan a transcurrir una biografía distinta, como otro objeto. Aquellos a los que no se transformaba en otros objetos o sustancias, transitaban a lugares espaciotemporales que poseen una ubicación precisa en las topografías culturales, se depositaban, como la mayoría de los demás objetos utilizados en el valle, en los montículos asociados a los sitios. En esta instancia, las trayectorias biográficas individuales de estas vasijas comienzan a vincularse con las trayectorias individuales de otras vasijas también arrojadas allí y con las historias de los otros objetos rotos o enteros también depositados en esos lugares. De esta manera, sus biografías quedan relacionadas a un tiempo muy prolongado, el de la formación de los montículos, cuyo proceso de sedimentación, en algunos casos, supera los mil años de antigüedad. En estas estructuras de larga duración, la fusión de trayectorias particulares, coloca a las vasijas en una categoría mayor de objeto, ya no vinculada a la intervención de cada una de ellas en prácticas de fermentación y consumo de bebidas fermentadas, el almacenamiento de vegetales, camélidos y humanos, de pigmentos, o la cocción de estos productos, sino a la historia de todas ellas, puesto que, a la vez que sedimentaban sus significados, diluían la contextualidad de su agencia, de su trayectoria de vida particular, en marcos temporales mucho más amplios. Se trata de una transición a otra categoría de objeto y como veremos a un espacio sin tiempo. Si pretendiéramos resumir a las biografías de estas vasijas en un diagrama de flujo clásico, lo único que estaríamos realizando sería una abstracción poco útil para comprender a las mismas, puesto que el flujo que se intenta reconstruir en ese tipo de trayectoria, visto desde las sendas biográficas reconstruidas aquí, no es continuo, sino que posee otro carácter. Analicemos ahora a los sujetos como si fueran artefactos, lo que nos abrirá, luego, la posibilidad de comprender aún más profundamente el carácter fragmentado, disperso, relacional y dialéctico de las sendas biográficas seguidas por estas vasijas. 


\section{Notas}

i Los métodos experimentales aplicados para la determinación mineralógica fueron: 1) por difracción de rayos X (XRD) -difractómetro PW1710-, 2) uso de microscopios de barrido electrónico (SEM) -Jeol 6400 y Leica 360- y 3) uso de microscopio electrónico -Hitachi H-800- (TEM-STEM) para partículas individuales menores a 2 micrones (Bertolino y Fabra 2003, Fabra 2008).

ii Los análisis se realizaron en el Reactor de Investigación de la Universidad de Missouri. Para una descripción detallada del tratamiento recibido por las muestras ver Laguens et al (2006).

iii Este sitio es uno de los más grandes del valle, posee un montículo central como el del sitio la Rinconada y habitación alrededor (Herrero y Ávila 1993, Pérez Gollán 1991; Pérez G. y Heredia 1975,)

iv Ambas canteras son utilizadas por artesanos ceramistas del valle Central de Catamarca, para reproducir muy buenas réplicas de la típica cerámica Aguada de Ambato negra gris grabada -clase A1-.

${ }^{v}$ La estandarización de las escudillas o pucos vinculadas con Aguada fue planteada más recientemente por Zagorodny et al (2005). El análisis fue realizado sobre escudillas -pucos- de La Aguada Orilla Norte depositadas en el Museo de la Plata, sobre un total de 813 piezas. Ver también Balesta et al (2009).

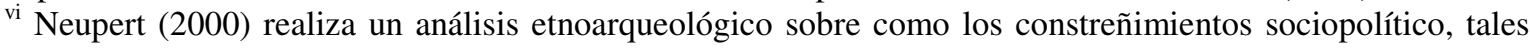
como las luchas faccionales restringen el acceso a las fuentes de arcilla. Su trabajo señala el límite de los modelos que ponen demasiado énfasis en que la elección de una fuente depende solo de aspectos vinculados a lo económico o tecnológico, siendo la distancia una de las variables principales. Ella muestra cómo los factores sociales o políticos se hallan irremediablemente influyendo en dichas decisiones.

${ }^{\text {vii }} \mathrm{La}$ diferencia entre el $\mathrm{n}$ de radios de borde y el $\mathrm{n}$ de los espesores del borde se debió a que hemos incorporado al análisis algunos fragmentos que podían ser asociados a una forma específica pero dado la pequeño que eran no se podía tomarles el radio y sí otros atributos como el espesor.

viii Idem nota $\mathrm{V}$.

${ }^{\text {ix }}$ La colección desde el año 2004 se hallaba embalada, no expuesta. Dicho depósito que se encontraba en la ciudad de la Falda fue robado. La colección está baja proceso judicial; hallándose parte bajo custodia del Museo de Antropología de la Facultad de Filosofía y Humanidades de la UNC y parte en la Dirección Provincial de Cultura.

${ }^{x}$ Agradecemos a Laguens, Pazzarelli y Vargas por facilitarnos las fotografías.

${ }^{x i}$ El análisis del Pigmento se realizó en el marco de un proyecto financiado por la Agencia Nacional de Promoción Científica y Tecnológica dirigido por la Dra. Bertolino e integrado por nosotros, en el que se están investigando por diferentes tipos de análisis las clases de pigmentos utilizados en la cerámica Aguada del Valle de Ambato y aquella asociada al estilo Portezuelo.

xii Zagorodny y Balesta (2001: 59) observan un patrón semejante de carbonización en piezas calceiformes provenientes del Valle de Hualfin pertenecientes a la colección Muñiz Barreto del museo de la Plata, asociadas también a la cultura de la Aguada.

xiii Actualmente, en la zona de estudio se utilizan pailas de metal de formas muy abiertas y planas -semejante a los platos grandes- para hacer arrope de chañar (Figueroa y Dantas 2006). Estas pailas son colocadas, no directamente sobre le fuego, si no sobre un soporte realizado en adobe en forma de U cerrada de unos $50 \mathrm{~cm}$ de alto aproximadamente, que presenta un hueco en el que es apoyada la paila. Las huellas de carbonización en la paila que se observa en la fotografía son muy semejantes a las observadas por nosotros en estos platos.

${ }^{\text {xiv }}$ La preparación de chicha de maíz, es un proceso largo en donde intervienen no solo un tipo de vasijas si no por lo menos tres: Olla, Virque y Tinaja. Las tinajas son en las que se pone a fermentar la chicha, es en ésta instancia en que la fermentación puede producir las huellas antes mencionadas. Transcribimos a continuación una de las recetas registradas por nosotros con una chichera, doña Tomasa, de la comunidad Indígena Colla de Finca Tumbaya en la Quebrada de Humahuaca durante los trabajos etnográfico realizado por Espósito en los años 2007, 2008 y 2009; en el marco de sus investigación doctoral sobre el proceso de conformación de la comunidad indígena. Para $15 \mathrm{Kg}$. de harina de maíz:

Preparación de la levadura: para hacer la levadura se utilizan 1,5 kg. de harina. Con ésta se hacen bollos (del tipo de los que se hacen para hacer pan). Se los cocina al horno hasta que estén bien doraditos no quemados, mientras más dorados estén mejor. Luego a estos bollitos cocidos se los muele hasta hacerlos harina. Luego a la harina hecha de bollos se la pone en una olla (de barro) se la mezcla con agua y se "mece" (mezcla) hasta que queda una especie de masa (no seca si no más vale húmeda). Luego se la pone cerca de algo que de calor (por ejemplo debajo de la cocina a leña) para que se levante, para que leude. Según lo que señalaba doña Tomasa, algunas veces cuando la masa leuda llena la olla. Una vez que leudó la levadura ya está lista. Según contaba don Pablo -esposo de doña Tomasa-, su mamá hacía mucha chicha, y a la levadura la hacía "muqueada", doña Tomasa señaló que ahora ya no se hace más así y a ella le da un poco de "asco", pero señala que no hace nada porque "todos los contenidos que hubiera tenido la saliva, al estar hirviendo tanto tiempo se van". Don Pablo llama "chicha muqueada", a la chicha en la que la levadura se realizó por medio 
del muqueado. Este consiste en: se hacen los bollitos de harina, se los cocina en el horno hasta que estén doradito, luego se los despedaza en pequeñas partes, cada una de esas partes, la persona que está haciendo la chicha, en este caso la mamá de Pablo, se la daba a los que estaban ayudando, el participó cuando era chico, al pedacito se lo colocaba en la boca y se lo masticaba, volviéndolo una masa húmeda (impregnada de saliva) luego se lo escupía dentro de la olla, según Pablo y también su esposa de esta forma la levadura leudaba más rápido.

La chicha: (según lo expresara Tomas ahora pasamos a la chicha en sí o propiamente dicha no recuerdo exactamente los términos que utilizó pero marcó una diferencia entre hacer la levadura y hacer la chicha)

Se tiene prendido un fuego, yo pregunté como era el fuego me dijeron semejante a donde se prepara la tijtincha. Ahí se pone en una olla a hervir agua. Para 15 kilos de harina se utilizan unos 50 a 80 litros de agua. El agua se coloca a hervir primero en las ollas, una vez que hierve se la coloca en una tinaja (es el agua de reserva) se la tapa para que no se enfría y al ser de barro el calor se conserva bien, al igual que el frío. Una vez hervida el agua y colocada en las tinajas, se pone a hervir más agua, mientras tanto, en el virque (según la cantidad de chicha se usan de diferentes tamaños, se coloca el resto de la harina, una vez colocada se hecha la levadura y se empieza primero a "mecer", se revuelve con una cuchara de madera (nunca se usa de metal según lo marcaran ambos) hasta que se vaya mezclando bien la harina y la levadura, también se la va amasando, con los puños cerrados, realizando una trabajo de empujar hacia abajo la masa primero con una mano y luego con la otra. Una vez que se mezcla bien la levadura con la harina se le va agregando el agua que se había puesto a hervir -aún se guarda el agua hervida que había sido colocada en la tinaja de reserva-. A medida que se le agrega el agua se va meciendo con la cuchara de madera (doña Tomasa expreso que cuando se le empieza agregar el agua hirviendo se sigue amasando con las manos y señaló que este movimiento hace que los nudillos de las manos se pelen por lo que ellos ahora solo la mecen con la paleta de madera) el virque se llena hasta casi el borde, y se mece con la cuchara de madera hasta que casi se deshaga la harina. Una vez que esta bien mecida el agua la harina y la levadura. Se realiza el bautismo de la Chicha que consiste en echar sal en forma de cruz y hojas de coca adentro de la preparación del virque, según lo que menciona doña Tomasa en el bautismo se pide a la pachamama para que no les haga mal la chicha (según la forma en que le expresó, riéndose, se refería a que no los machara tanto la chicha). En el proceso de mecido del contenido del virque se va separando lo que denominan arrope crudo, es un agua blanquecina, que queda en la parte de arriba del virque, esta se va sacando toda y se la va poniendo en ollas, las que luego son colocadas en el fuego para realizar el arrope que queda como si fuera dulce de leche según lo expresara don Pablo. La cantidad de arrope crudo que se extrae es muchísima, y se la va poniendo en diferentes ollas, una de ellas se coloca en el fuego y a medida que se va reduciendo y evaporándose el agua se le va agregando arrope crudo de las otras vasijas. De las varias ollas llenas de arrope crudo, queda solo un poco de arrope cocido, según lo señalara don Pablo con sus manos formando una especie de bollo de unos 15 a $20 \mathrm{~cm}$ de diámetro -Don Pablo no mencionó cantidad alguna, solo fue una apreciación con las manos-. El arrope tiene que hervir muchas horas, Don pablo señaló que para la cantidad de harina que mencionamos - $15 \mathrm{~kg}$ - unas 24 hs, pero doña Tomasa señaló que esa cantidad de horas no alcanzaban, pero no dijo cuantas horas más, señalo que hasta que esté el arrope. Una vez extraído del virque el arrope crudo, por debajo de este queda la Chulla, la que es bien blanquecina y más espesa que el arrope crudo. Y a su vez por debajo de este está el anchi ...... (y algo más en quichua) que son las impurezas de anchi que se usa para comerlo como postre, agregándole un poco de azúcar, este es la parte más gruesa de la harina que se deposita en el fono del virque, por encima de esta está el anchi ....... Que son la impurezas que no se come, alguno se los dan a los pichichos y otras veces, cuando se percibe que puede faltar la chulla, se los hace bollitos y se los cocina, luego se lo muele y se lo mezcla con agua y se lo mece, de ahí se puede extraer más chulla, pero aparentemente no es lo más común. Para extraer la chulla, al líquido blanco cremoso que se encuentra por debajo del arrope crudo se lo cuela en una tela que no debe tener la trama ni muy cerrada, ni muy abierta, a la chulla se la pasa a las tinajas, una vez que se cuela todo, se extrae casi toda la chulla que se la va colocando en las tinajas, queda un poco de ella sobre anchi que tiene impurezas, unos $10 \mathrm{~cm}$ por encima de este, en ese momento se le agrega el agua ya hervida que estaba en las tinajas como agua de reserva. Se vuelve a mecer para que se mezcle bien y se extrae más arrope crudo, que se agrega al que se está cocinando en el fuego y también, se extrae más chulla, la que se coloca en las tinajas. Esta son bien tapadas, con papel madera de las bolsas de azúcar o pan y una tela por encima y luego se las ata bien por el cuello de la tinaja, estas ya se colocan a fermentar. A todo esto, en el virque queda aún el anchi (con impurezas) y el (anchi que se usa de postre), estos se extraen. En ese momento el virque se deja de usar. El arrope aún se está hirviendo, en algunos casos se le hecha pedazos de fruta como banana y particularmente Tomasa Sajama le agrega cuando casi está listo azúcar quemada, o caramelizada porque le da un gustito especial. Cuando se va cocinando el arrope en la parte superior se va concentrando un aceite, el aceite del maíz, según Tomaza algunas personas lo van extrayendo y lo van guardando en una ollita. Ella dice que no lo saca si no que lo deja porque cuando la chicha estás lista queda mejor se ve el aceitito de maíz como que le deja una mejor textura. Las personas que lo sacan lo que hacen es que cundo alguien viene y le pide chicha, le agregan el aceite en ese momento para que quede con esa textura linda que le deja el aceite. La mezcla del arrope ya cocido y la chula que se puso a fermentar no se 
hace inmediatamente, si no que, por ejemplo según lo comentara Tomasa, si queremos tener chicha para el sábado que viene, la empezamos hacer el sábado anterior, la chicha tiene que fermentar unos 5 días para que esté lista, se puede dejar más días, dependiendo si hace calor o no porque si hace calor fermenta más rápido, pero en invierno si pasan más de 5 días la chicha ya empieza a machar. A la chulla y el arrope, si a la chicha la queremos tomar el sábado, lo mezclamos el jueves, así termina de fermentar bien, pero la chulla ya está fermentando desde antes, según Tomasa cuando la chulla ya está casi lista uno se acerca a la tinaja y la chuclla habla, dice shhhhhhhhhhhh, como que está saliendo gas, como una cerveza dice...

${ }^{\mathrm{xv}}$ Existen ejemplos etnográficos que muestran que para beber la chicha no sólo se utilizan vasos o jarros como los pares de queros típicos de la zona andina en épocas del Incario y también durante Tiahuanaco; si no que también, por ejemplo, los Ashuar del Ecuador (Descolá 1987, 2005; Bowser 2000) consumen la chicha de mandioca en bols -denominado pininkia (Descolá 2005:72)-, u otras formas abiertas y planas semejantes a las escudillas. En distintas zonas de los andes bolivianos, en general se utilizas un porongo -Lagenaria siceraria- que se usa como cucharón para extraer la chicha, y se bebe directamente de este; correspondiendo a una medida de chicha, aproximadamente un litro (Pazarelli y Vargas 2008).

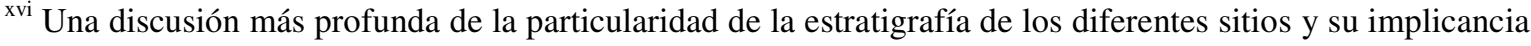
en las trayectorias biográficas de las vasijas analizadas se realizará en el penúltimo capítulo.

xvii Las plantas que quedaron de estas cuadrículas no permiten confeccionar un dibujo como lo hicimos para la habitación techada. Por lo que las referencias se hacen al plano general del sitio.

xviii A su vez en la zona inferior se observa, donde no se encuentra cubierto por carbonizaciones, que la superficie de la vasijas se ha craquelado, es decir se le ha formado superficialmente una red de microfracturas, en general con un patrón exagonal. Probablemente esta no tengan que ver con su colocación al fuego durante el uso de la misma, si no que sea producto del efecto de la cocción. Rye (1981:111) señala este tipo de patrón de fractura producto de un rápido calentamiento durante el proceso de cocción de la vasija, en este caso dada la composición de la pasta con antiplástico de cuarzo y mica de tamaño variado permitió que la pieza, no llegara a fragmentarse atrayendo y deflectando las líneas de fractura produciendo la red observada.

${ }^{x i x}$ En entrevistas realizadas por nosotros con personas que fabrican chicha en la Comunidad Aborigen Colla de Finca Tumbaya en la Quebrada de Humahuaca, estas personas señalaron que las vasijas utilizadas para mezclar y fermentar (tinaja y virque) sólo se utilizan para esas actividades, incluso cuando no se está fabricando la chicha permanecen en lugares guardadas boca abajo.

${ }^{\mathrm{xx}} \mathrm{El}$ análisis se realizó en el marco del proyecto dirigido por la Dra. Bertolino sobre el estudio de los pigmentos utilizados en la cerámica Aguada de Ambato y Portezuelo.

xxi Agradecemos a la Dra. Inés Gordillo que nos ayudara en el acceso a esta pieza cuando analizamos el material de los sitios Martínez que se hallaba en los depósitos de la Dirección de Antropología de la Provincia de Catamarca. Por supuesto a la Directora, Lic. Natalia Ponferrada, al Jefe del Departamento de Arqueología, Lic. Sergio Álvarez, el habernos posibilitado el laboratorio y el acceso a los materiales. Además a todos los que fueron compañeros de trabajo cuando realicé en dicha institución una pasantía de trabajo en convenio con la Universidad Nacional de Catamarca.

xxii Volveremos a retomar esta instancia cuando nos adentremos en las geografías espacio-temporales y las interfacies de período en las que analizaremos de que manera en Ambato dialogaron contingencia y estructura. 


\section{CAPÍTULO 7}

\section{PERSONAS COMO COSAS: LOS CUERPOS COMO OBJETOS}

Pensar a las personas como objetos nos permitirá desvincularnos de aquellas perspectivas en las cuales la identidad de la persona se constituye sólo a través de su subjetividad, en relación a determinados marcos de significados discursivos o simbólicos, insertos en un particular contexto socio-histórico, más allá de sus intervenciones en el mundo. Pondremos atención en este capítulo a los cuerpos como lugares centrales tanto en un sentido genético (socialización) como crónico (práctica cotidiana) en la subjetivación de las personas. Señalamos con Butler (2002) que haríamos hincapié en los procesos productivos, de materialización de éstos, más que en dar por sentado un cuerpo biológico, natural, sobre lo cual se inscribe lo cultural. Para nuestro caso de estudio es fundamental que tomemos una posición en la que no se de por sentado un cuerpo ya formado, con límites definidos. Una de las características más sobresaliente señalada por todos aquellos investigadores que se han dedicado a estudiar la iconografía Aguada y particularmente de Aguada de Ambato, cuando en las vasijas aparecen motivos figurativos de humanos y no humanos -sea de forma modelada, aplicada al pastillaje, pintada, incisa o grabada- es la capacidad de transformación de los cuerpos, la metamorfosis, la mutación, los cambios de estados, de formas y de sustancias (Balesta y Zagorodny 2002; Bedano et al 1993; Gonzáles 1961, 1974, 1977, 1998; González y Baldini 1991; Gordillo 2009, Gordillo y Kusch 1987; Laguens y Gastaldi 2008, Kusch 1982, 1990) Ya hemos descrito las representaciones que suelen aparecer grabadas o incisas en cerámicas de clase A1 o, pintadas en las grandes vasijas de forma "a" y "ab" de clase E: humanos convirtiéndose en felinos, o a la inversa, pájaros transformados en felinos, camélidos mutando a felinos o a la inversa, ofidios felinizados o a la inversa, figuras multiformes como las "draconianas" compuestas por parte de varios animales distintos y también humanos, etc. Es como si los cuerpos no estuvieran fijos si no en un continuo proceso de transformación; por más que como la han señalado algunos autores ocupen ciertas posiciones corporales en las representaciones (Kusch 1982, 1990; Kusch y Valko 1997; Gordillo 2009), tales como la representación de frente respecto de los cuerpos humanos o de perfil de los felinos, que se vinculan a ciertos modelos de lo humano y lo no humano; y que, además, en los paneles decorativos estos motivos ocupen ciertos lugares específicos, situación que probablemente ordene y establezca ciertas reglas a la hora de plasmar estos procesos de trasformación corporal en las vasijas; todos ellos son cuerpos inestables, pasan de un estado a otro, de una forma a otra, se intercambian sustancia, fluidos, partes, etc. En este sentido se acerca 
bastante a la definición que diera Alberti (2006) siguiendo a Vilaça (2005) para caracterizar a la cerámica San Francisco y Candelaria: cuerpos crónicamente inestables. Esta poética de los cuerpos que nos muestran las representaciones iconográficas plasmadas en las vasijas, que también es una política del mismo, nos permite hacer hincapié y repensar otras series de prácticas que ocurrieron en Ambato y que se vinculan con las vasijas a las que les trazamos las biografías, las que en gran medida poseen estas mismas representaciones.

Estas prácticas se refieren a ciertos tratamientos que recibieron los cuerpos al momento de la disolución del individuo como tal, al momento de su muerte. Esos tratamientos, se vinculan con procesos de transformación de los cuerpos, son prácticas preformativas que producen no solo la permanencia de ciertos cuerpos y con ellos de determinados sujetos, si no también la disolución de estos y probablemente con ellos de los sujetos muertos. Es decir en este caso la poética implicada en los tratamientos corporales también es una política del establecimiento y permanencia de determinados cuerpos y, la mezcla, disolución y diseminación de otros. Pero además, ambas prácticas, logran en su ejecución, también producir un tensión muy fuerte al interior de la perspectiva naturalista moderna occidental con la que nos movemos muchas veces los arqueólogos, en tanto que seres que para esta última perspectivas son taxonómicamente diferentes a los humanos, como los camélidos, en estos contextos prácticos de la acción, conforman categorías casi imposible de separarse ${ }^{\mathrm{i}}$.

En el valle de Ambato se han hallado por lo menos dos formas diferentes en el tratamiento de los cuerpos de los individuos al morirse. Por un lado, el cuerpo se conserva anatómicamente unido y, por otro lado, el cuerpo es dislocado y/ o fragmentado (Baffi y Torres 1996; Cruz 2005, 2007; Gordillo 2009; Gordillo y Solari 2009; Juez 1991, Herrero y Ávila 1991; Pérez Gollán et al. 2000).

\section{Fragmentando los cuerpos}

Los fragmentos de cuerpos aparecen en casi todos los sitios analizados: sitio Martínez 2, Martínez 4, La Rinconada y Piedras Blancas. Dentro de cada uno de estos sitios, los fragmentos se hallaron en varios tipos de lugares: por un lado formando parte del relleno de los montículos, tanto aquellos que fueron transformados en plataformas -La Rinconadacomo en los que no -Piedras Blancas- y, por otro lado, sobre los pisos de las galerías, apoyados en las banquetas de adobe o en el interior de recintos habitacionales, sea 
guardados en el interior de las vasijas de forma "a", "ab" y de "otras formas", o a punto de ser cocinados, o incluso ya cocidos, en esta última forma de vasijas. En otros casos aparecieron distribuidos y apoyados sobre los pisos de las habitaciones o como inclusión de pozos como en el sitio La Rinconada.

En el caso del sito Martínez 2, estos restos óseos aparecen en las galerías y en las habitaciones techadas. Algunos se hallaron solos, apoyados directamente en el piso, como el caso de un fragmento de mandíbula inferior que apareció en la galería este contra el muro de los recintos techado de ese sector. En otros casos, en las galerías y habitaciones, tal como hemos descrito a la analizar los contexto de hallazgos de las vasijas analizadas de este sitio, aparecen varios fragmentos pertenecientes a distintos huesos, de más de un individuos, de edades diferentes y sexo biológico "femenino" como "masculino" anatómicamente definidos- almacenados en vasijas de clase E de "otras formas", forma "a" y forma "ab", en varios casos junto a huesos de camélidos también pertenecientes a distintos individuos, de diferentes edades, con huellas de haber sido sometido a acciones semejantes: descarne, calcinado, etc. En el caso de la habitación 1 hemos señalado la asociación de huesos humanos fragmentados a 2 vasijas pertenecientes a las otras formas, que se encuentran alrededor de un fogón delineado por piedras. Ambas vasijas presentan huellas de carbonización en su superficie externa que responden a distintas posiciones tomadas en los eventos de cocción en relación al fuego, una directamente apoyada sobre este y otra levantada sostenida por algún soporte quizás las piedras que rodeaban al fogón. Ambas vasijas fueron aplastadas por la techumbre incendiada que se les derrumbó encima. Antes de este evento estas vasijas estaban conteniendo: una un cráneo muy fragmentado con algunos elementos quemados y parte de una pelvis. La otra también almacenaba un cráneo fragmentado con elementos quemados, en el que parte de la apófisis craneal presenta huellas de fractura intencional, como un "rebanado" producido por un elemento cortante con anterioridad a que el hueso se quemara (Juez 1991:90). Además fragmentos de huesos largo de por lo menos tres individuos distintos de diferentes edades: dos fémures, una tibia, un húmero, un cúbito y un radio. En la habitación 2 hemos detallado siguiendo las descripciones de Juez (1991) y las libretas de campo confeccionadas por esta misma autora durante las excavaciones, la presencia de vasijas almacenado huesos de humanos y también de camélidos. Dos vasijas de "otras formas" cercanas al muro sur, en su posición central, aparecieron sus fragmentos entre fragmentos de pelvis y falanges de humanos y fragmentos de huesos de las extremidades de camélidos. En la esquina suroeste, 
dos vasijas de forma "a" tricolores se encontraron asociadas a fragmentos óseos de humanos y de camélidos. En algunos huesos de camélidos como astrágalos, metapodios, vértebras caudal, falanges se observan según la autora huellas de descarne. A su vez se presentan astillas de huesos largos con posible fractura intencional. Los huesos humanos consisten en partes de una pelvis con huellas de descarne, una falange, un tarsiano y fragmentos de costillas. Más al norte contra el muro oeste hemos descrito la presencia de una vasija de forma "a" pintada tricolor con rostro modelado en nariz en gancho, asociada a huesos humanos pertenecientes a dos individuos de diferente edad. Se trata de una cabeza de fémur de un adulto que posee huellas de descarne, un peroné de niño y varias costillas. Junto a estos restos aparece una epífisis proximal de camélido y astillas de huesos largos con posible fractura intencional. Al centro del recinto aparece una vasija pertenecientes a las "otras formas" asociadas a restos humanos de distintos edades y también huesos por lo menos de dos individuos de camélidos, que presentan huellas de descarnes. Los huesos humanos según Juez (1991) se trata de un peroné, una tibia de infante, tres carpianos, o tarsianos y un fragmento de pelvis. En cuanto a los huesos de camélidos se presentan astrálagos de dos individuos distintos, una epífisis proximal de tibia, un metapodio, una falange y un tarsiano. En el caso de la galería oeste, aparecen en la zona de la banqueta B y más al norte tres vasijas junto a hueso de humanos fragmentados: una de "otras formas" con huellas de carbonización que indican su colocación por encima del fuego asociada a un cráneo y fragmentos de huesos largo de humanos. Otra vasija de forma "a" tricolor aparece asociada a un peroné y dos tarsianos humanos. Más al norte una vasija de forma "ab" aparece junto a un parietal, un malar, parte de un conducto auditivo y una epífisis proximal de tibia.

En total en el sitio Martínez 2 se recuperaron 318 restos óseos humanos -figura 7.1(Cruz 2005:368) pertenecientes a un número mínimo (NMI) de 7 individuos (Cruz 2005; Juez 1991): tres niños/as y cuatro adultos femeninos y masculinos. Además Juez (1991) señala que los siete individuos se identificaron con huesos post-craneales, mientras que se rescataron solo dos cráneos y un maxilar inferior de un tercer individuo. Por lo que hay más representación del esqueleto post craneal. Esto quizás indique prácticas diferentes con las distintas partes del cuerpo. Según Cruz (2005:368) el 38\% de los restos humanos identificados presentan alguna o varias huellas producidas por acciones humanas. Las huellas relevadas por este autor se relacionan con las siguientes acciones: fractura intencionale principalmente en las costillas cuando el hueso aún estaba hidratado, quemaduras principalmente sobre huesos del cráneo, largos y planos, calcinado principalmente en huesos largo, pintura en parietales de cráneo y huellas de corte -figura 
7.2 y 7.3. Estas últimas a su vez se presentan en tres formas distintas: unas son en ángulo

\section{Representación gráfica de restos óseos identificados}

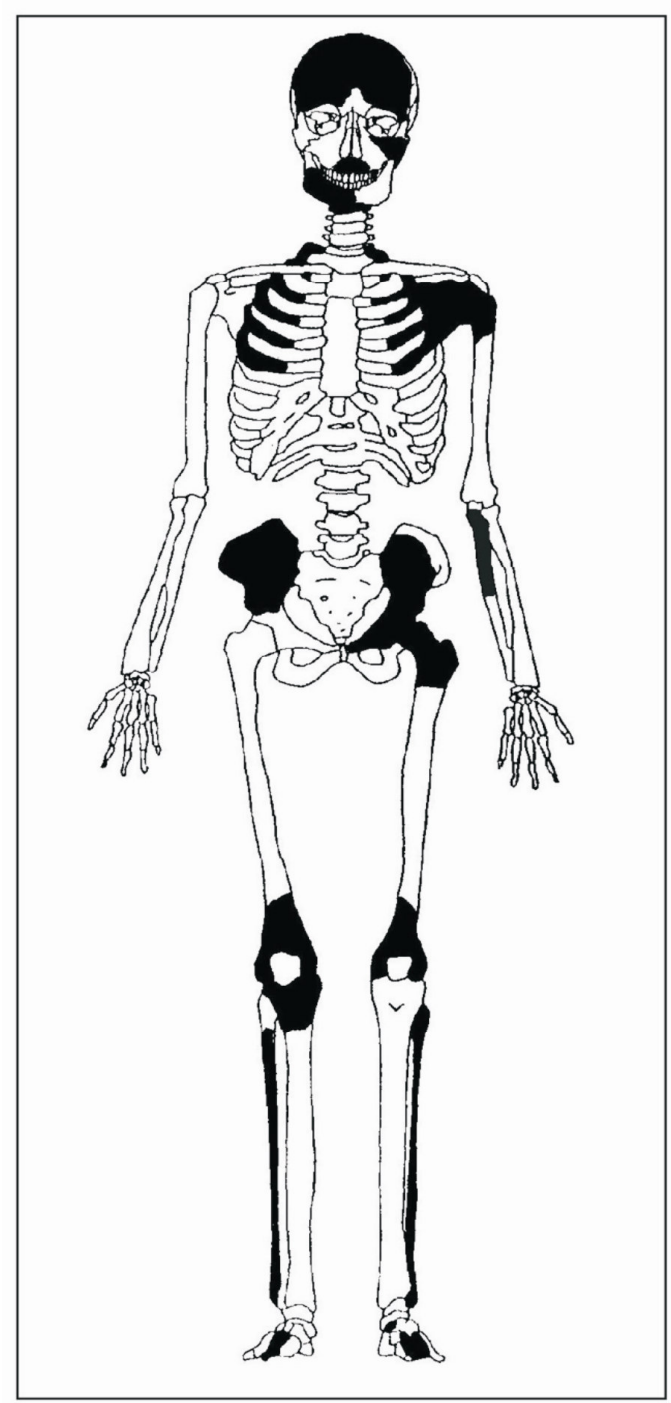

152- fragmentos de huesos largos (diáfisis y epífisis)

22- fragmentos de huesos planos

31- fragmentos de costillas

1 - vértebra torácica y 2 cervicales

32- fragmentos de huesos craneales

1- fragmento de mandíbula

2- incicivos y 1 premolar

3- escápulas

1- fragmento de epífisis proximal de humero

4- fragmentos de diáfisis de cúbito

15- fragmentos de coxis

2- fragmentos de epífisis proximal de fémur

3- epífisis distal de fémur

1 - fragmento de epífisis proximal de tibia

13- fragmentos de fíbula

11- falanges

1- metacarpo

4- metatarsos

Figura 7.1: huesos identificados en el sitio Martínez 2. Fuente Cruz (2005).

recto y se concentran en la zonas de las articulaciones, otras poseen un ángulo oblicuo y no están asociadas a un área específica y, por ultimo, huellas de impacto violento particularmente en partes del cráneo -margen supraorbital izquierdo-. Estas marcas permiten observar diferentes acciones realizadas sobre los huesos que acercan a las maneras en que estos cuerpos fueron trozados. Estas acciones son desmembramiento de las piernas de la pelvis, esto fue observado a través de marcas de cortes en ángulo recto presentes en una epífisis proximal de fémur con cuello y cabeza femoral de un individuo adulto femenino (Cruz 2005: 371). A su vez este autor señala que dado el emplazamiento de las marcas de cortes que se encuentra sobre la parte delantera del hueso, el desmembramiento ha sido realizado desde la región inguinal -sin rastro de previo descarnado- y no a partir de las nalgas del individuo, la parte más carnosa y musculosa (Cruz 2005:371-372). A su vez esta acción de desmembramiento, que implica el corte de 

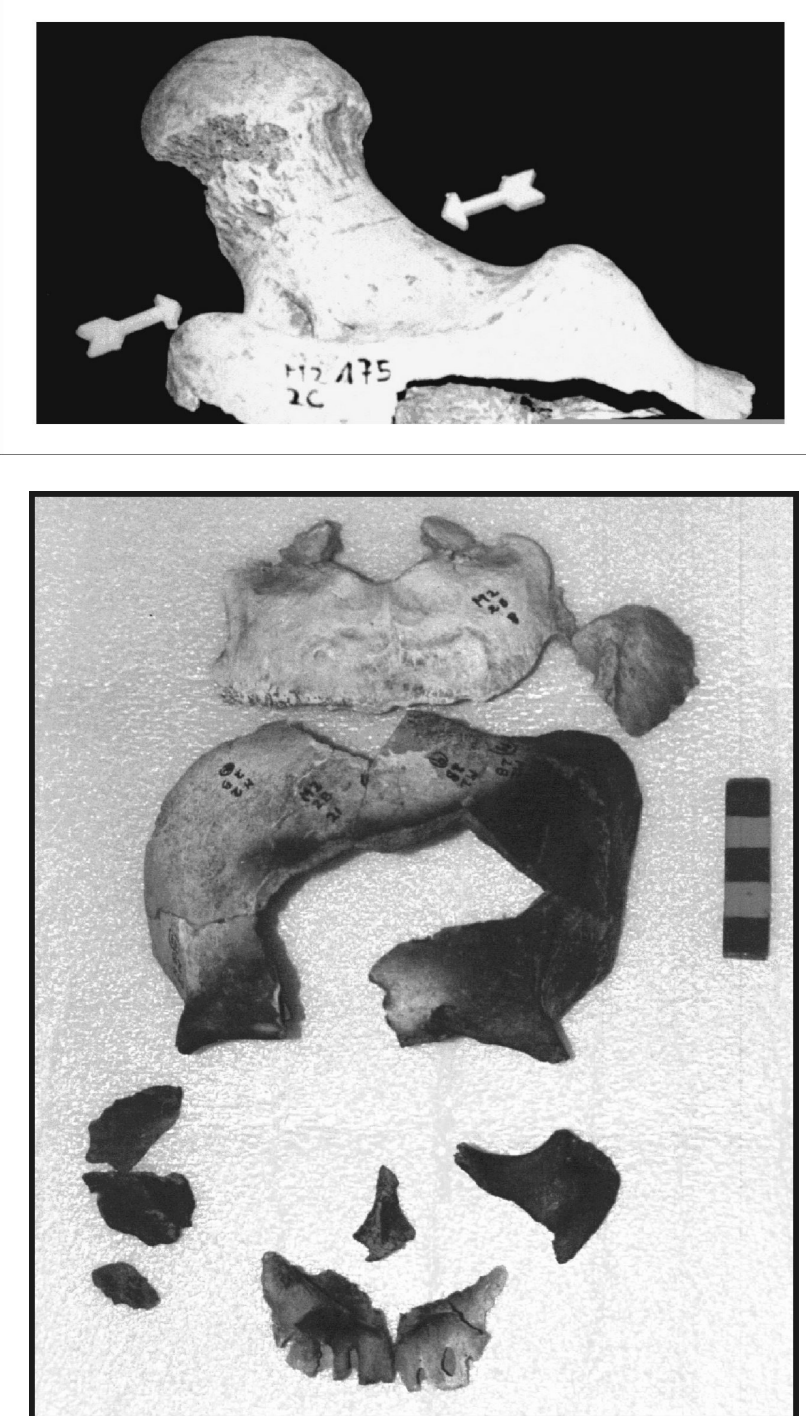

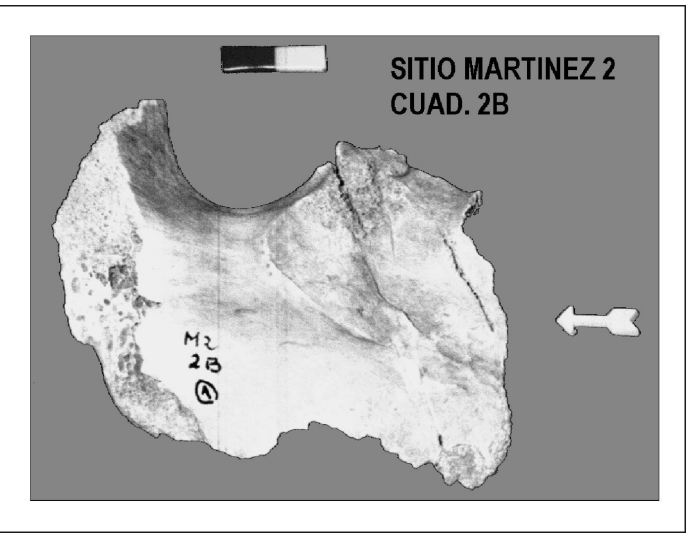

Figura 7.2: imagen izquierda arriba huellas de corte en un femoral, imagen izquierda abajo cráneo modificado por actividad humana e imagen derecha arriba, huella de corte en un coxis. Fuente Cruz (2005).

venas, arterias y de ligamentos asociados con esta parte del cuerpo, si se la ejecutara sobre un individuo vivo lo arrastraría, producto de la hemorragia, rápidamente a la muerte (Cruz 2005:372). Desmembramiento de la pelvis de la columna precedido de una acción de descarne y extracción de vísceras: las marcas de corte han sido observadas sobre un fragmento de hueso coxal de un individuo femenino muerto en su juventud (Cruz 2005:372). Según este autor la localización de las cortes en esta región del hueso indican que el objetivo buscado era la desarticulación del hueso coxal y del hueso sacro y la separación de la pelvis de la columna. A su vez la disposición de los rastros en la región interna de la pelvis parece indicar que los individuos han sido vaciados de sus entrañas antes de ser desarticuladas. Descarne de un omóplato: el fragmento óseo presenta una única marca, en una región que no está en relación con una articulación; a su vez además de esta característica, la marca es oblicua indicando una acción de descarne o limpieza de los tejidos (Cruz 2005:374). Impactos violentos sobre los cráneos y sometimiento al fuego 


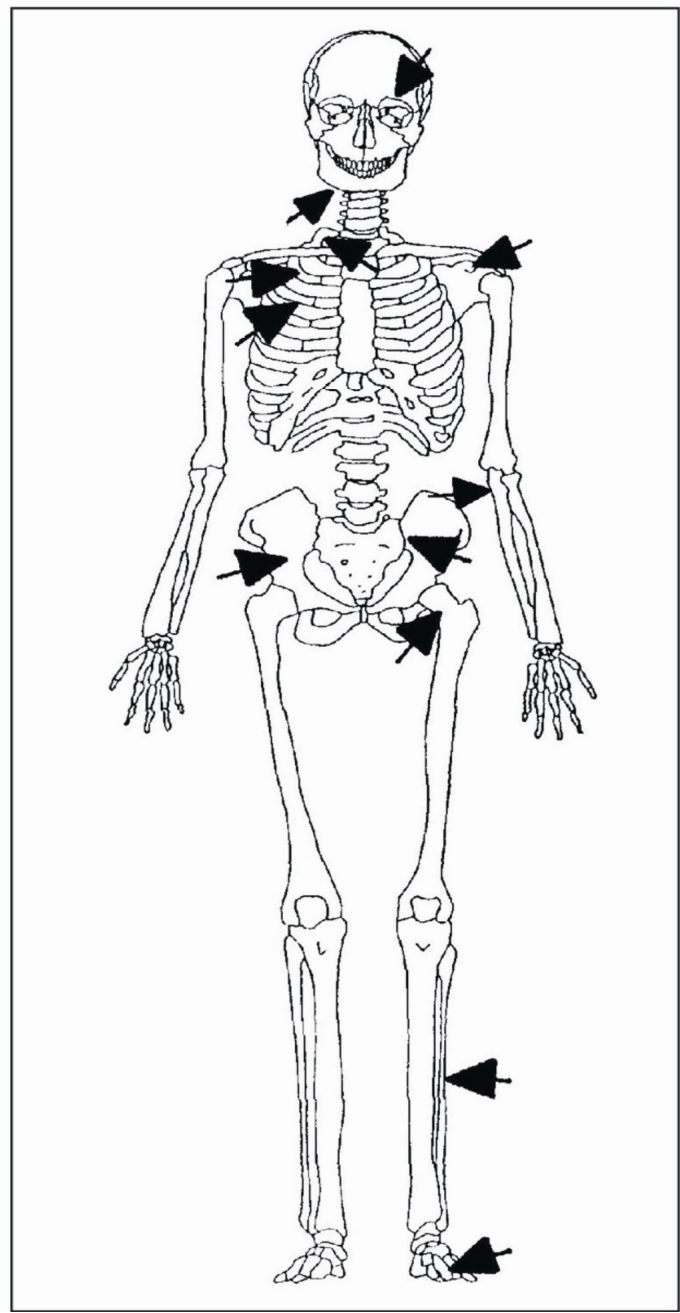

Figura 7.3: lugares donde se observan las marcas de cortes y otras acciones. Tomado de Cruz (2005)

de manera directa: uno de los cráneos hallados en la habitación 1 de este sitio, particularmente el que se asocia a la vasija de otras formas hallada al este del fogón que presenta huellas de carbonización en su exterior que evidencia su colocación directamente sobre el fuego; que pertenece a un individuo femenino adulto presentan marcas de corte sobre el margen supra orbital izquierdo, además de quemaduras. Juez (1991:92) consultando con el Dr. Laguens profesor de la cátedra de Patología II, de la Facultad de ciencia Médicas de la UNLP-, ha asociado los tipos de quemadura presentes en este cráneo y la multifragmentación que posee el mismo al sometimiento de un fuego intenso cuando aún poseía partes blandas (piel, carne, cerebro) que produjo el estallido del mismo. Por lo que señala cierto tratamiento diferencial de los cráneos respecto a las partes postcraneales. También se han hallado vértebras cervicales quemadas solo en ciertos sectores.

Pintura de cráneos: en las paredes externas de un fragmento del cráneo, específicamente de la calota, que pertenece a un individuo joven, se observa la presencia de un círculo pintado de color negro que parece haber sido realizado con los dedos sobre el cráneo ya limpiado de sus tejidos (Cruz 2005: 375). Juez (comunicación personal) quien ha estudiado ampliamente la colección Rosso nos ha señalado que este coleccionista poseía dos cráneos pintados uno de negro y otro de rojo, también con círculos rellenos como si fueran lunares o manchas, que los había extraído de las excavaciones realizadas en Ambato por el mismo. Una de las vasijas analizadas por nosotros de forma asimétrica de clase E2 (mezcla 5) posee en la zona del cuerpo, pintados en negro, círculos rellenos que parecen lunares o manchas, semejante a las que presentan los cráneos.

En el caso de los huesos de camélidos que se encontraron asociados a los huesos humanos, siempre se tratan del esqueleto post-craneal del animal, no se señala la presencia 
de fragmentos de cráneos de camélidos en estos contextos de asociación. Juez (1991) señala que se determinó la misma cantidad de individuos que los humanos, es decir siete del género Lama. Tres individuos adultos y cuatro individuos jóvenes. En este sentido de la misma forma que los humanos las edades de los cuerpos trozados son distintas. Además, la autora, realiza cierta consideración respecto a las prácticas de trozamiento que nos permite entrever la espacialidad y rutinas ejecutadas de: 3,32\% de las piezas óseas identificadas, se corresponden a huesos pertenecientes a extremidades, por lo que señala que solo se abrían trasladado a los contextos donde aparecen -habitaciones y galerías- solo los cuartos y que el primer trozamiento se abría realizado en otro lugar. Además señalan la ausencia de falanges unguinales las que según Mengoni Goñalons y Silveira (1976 citado en Juez 1991:93) se explicaría por la forma en que fue cuereado el animal, de manera tal que quedaron en el cuero cuando este fue quitado del mismo. Así tendríamos un primer trozamiento y cuereo del animal fuera de las habitaciones y las galerías. No sabemos si se lo realizaba en el patio en tanto que este solo fue excavado en una pequeña porción o fuera de los muros que encierran el sitio.

En el sitio Martínez 4 los fragmentos de cuerpos aparecen tanto en las habitaciones como En las galerías, también corresponde a individuos de diferentes edades y sexo biológico femenino y masculino. En algunos casos como en el sito Martínez 2 se asocian a huesos fragmentados de camélidos. En total fueron encontrados un número mínimo (NMI) de 7 individuos (Baffi y Torres 1996:60): cuatro adultos, dos de sexo biológico masculino, uno femenino y otro indeterminado, dos de edades subadultas y un niño, todos de sexo biológico indeterminado. En la galerías, se asocian específicamente a dos vasijas y a su vez están distribuidos por el piso. Con respecto aquellos que aparecen asociados a las vasijas, que los podrían haber estado conteniendo antes de la caída del techo son los siguientes: entre los fragmentos de una vasija de "otras formas" de gran porte de clase E, se encontró un fragmento de maxilar superior derecho de adulto, junto a tres fragmentos de costillas de uno o varios individuos adultos. A su vez junto al muro sur más cercana de la pared que divide la galería del espacio techado, aparece una vasija de clase A1 de forma "b", asociada restos humanos de adultos: epífisis de un peroné, tres fragmentos de costillas quemados, un fragmento de diáfisis de hueso largo, dos fragmentos de vértebras cervicales y una indeterminada, 1 fragmento de malear y maxilar derecho y, 5 astillas de hueso largo que presentan una punta aguzada, que según las autoras podrían ser utilizadas como instrumentos (Baffi y Torres 1996:58). Luego repartidos por el piso se describen otros 
fragmentos: desde fragmentos de costillas, astillas de huesos largos, distintas partes del fémur, distintas vértebras y fragmentos de maxilares tanto superior e inferior. En este sentido es muy semejante a lo hallado en el sitio Martínez 2. En el sector que más se concentran los fragmentos según las autoras es en la cuadrícula $2 b$, zona central de la galería, pero también aparecen en la 1a contra el muro este y en la 3 b contra el muro de la habitación. Al interior del recinto techado: se halló un contexto significativo de una vasija de forma "a", con rostro modelado en nariz en gancho, junto a varias escudillas de clase A1, asociadas a restos óseos humanos, una diáfisis de tibia derecha fragmentada en tres partes, la que parecía según las autoras haber sido intencionalmente partida en sección longitudinal, además poseía un lascado realizado cunado el hueso aún estaba hidratado (Baffi y Torres 1996:58). También sugieren la extracción de la medula del mismo. También aparecen un fragmento de frontal, un fragmento de epífisis distal de fémur, dos huesos de tarso, un peroné, tres costillas con aparentes marcas, la diáfisis de radio y cubito derecho en las que también señalan la extracción de la medula ósea, un fragmento de ileon y 9 fragmentos indeterminados.

Tres acciones son identificadas por las autoras: extracción de médula ósea: observada principalmente en fragmentos de huesos largos, en tanto que se presentan sin el tejido esponjoso por lo que suponen la extracción del mismo mientras el hueso estaba fresco. Calcinado: particularmente observado en fragmentos de huesos largos. Trasformación y utilización como instrumentos: una diáfisis de hueso largo se halló con una muesca y brillo en la cara externa que según las autoras podría corresponder a su utilización como sobador. Además de las cinco fragmentos de huesos largos con punta hallados en la galería.

En el sitio Piedras Blancas, los fragmentos óseos humanos se hallaron particularmente en el montículo: aparecieron algunos fragmentos de un esqueleto de niño, particularmente un fémur y algunos fragmentos de cráneos (Pérez Gollán et al 1997). En este montículos también se han registrado una gran cantidad de huesos de camélidos tanto fragmentados como enteros.

En el sitio La Rinconada, fueron encontrados fragmentos óseos humanos en la plataforma aunque en menor cantidad que en las galerías y recintos techados donde suelen aparecer también. Particularmente en este último sector se han hallado en la estructura 7, 4 y 5. En el caso de la plataforma aparecen algunos dientes, un fragmento de mandíbula, un 
fragmento de falange y un fragmento de cráneo, correspondientes a uno o más individuos adultos, no registrándose huellas de manipulación humana evidente (Gordillo y Solari 2009:35). En el caso de la estructura 7 se hallaron en distintos contextos al interior de la habitación, la mayoría se disponía sobre el piso y otros, como rellenos de pozos. Los que aparecen en el piso se tratan de maxilares superiores e inferiores de adultos y pequeños fragmentos de cráneos quemados y un occipital fracturado aparentemente según las autoras por un impacto violento. Estos fragmentos corresponderían a un número mínimo de 2 individuos como dijimos adultos. Otro contexto donde aparecen estos fragmentos de cuerpos, es en un pozo excavado en el sector central del recinto -figura 7.4-, en este aparecieron fragmentos óseos de más de un especie de camélido además de fragmentos humanos (Gordillo 2009, Gordillo y Solaris 2009:37). De cada taxón según las autoras se reconocieron los siguientes huesos: de humanos: un húmero, un radio y un fragmento de mandíbula con dientes; de vicuña: falanges, metatarso, metacarpo, radio y hueso largo de vicuña; y de Lama sp.: radio, metapodio, costillas y hueso largo (Gordillo y Solaris
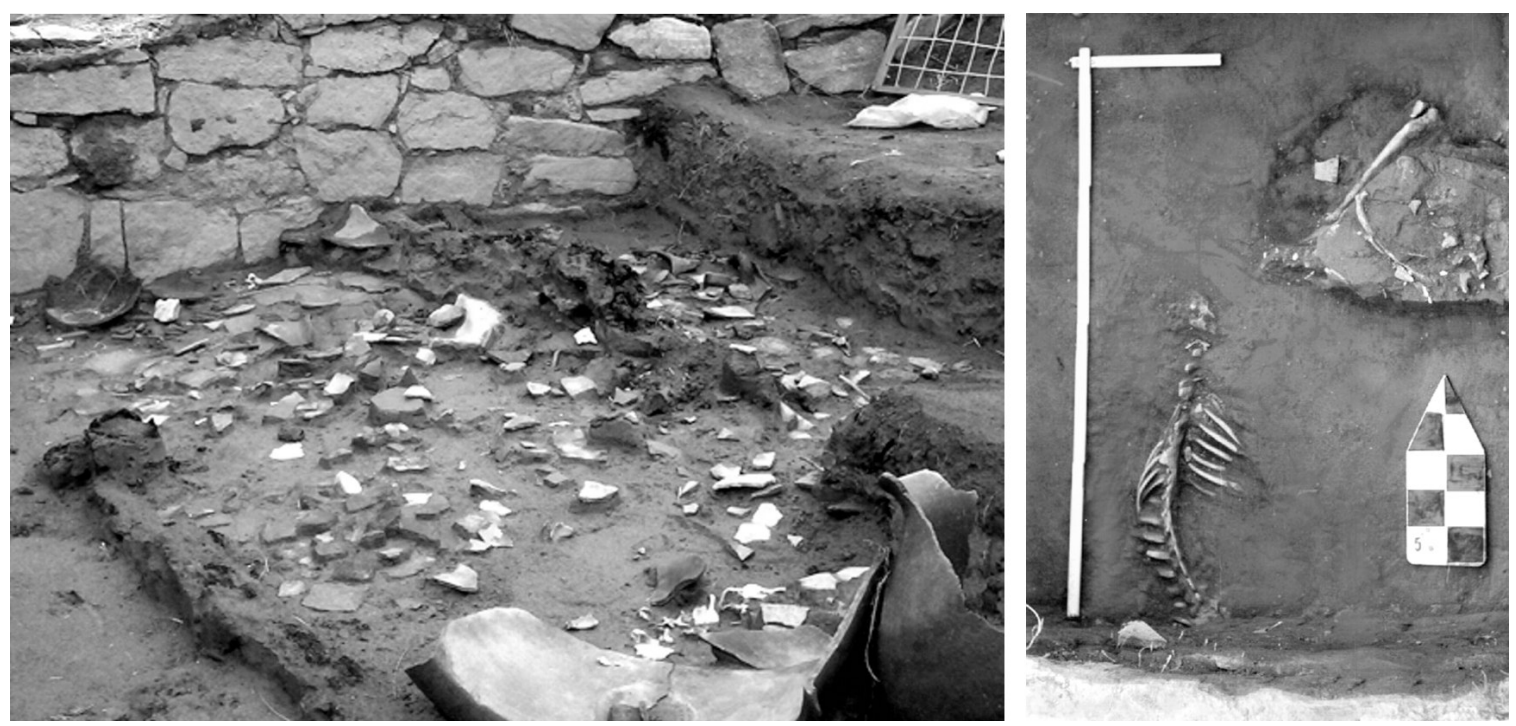

Figura 7.4: En la imagen izquierda se observa un sector del piso de ocupación de E5, con cráneos y otros materiales altamente fragmentados. En la imagen de la derecha se muestra el entierro de un camélido articulado y en la esquina superior derecha de la imagen el pozo donde se enterraron fragmentos de huesos humanos y de camélidos debajo del piso de E7. Fuente Gordillo y Solari (2009)

2009:37). En la estructura 4 aparecen un fragmento frontal de cráneo apoyado sobre una gran fragmento de olla - de "otra forma" clase E-, quemado pero sin otras marcas de manipulación. En La estructura 5, un espacio de galería techada, aparecieron muy cercanas al conjunto que hemos descrito de vasijas de forma "a" que aparecieron conteniendo frutos carbonizados de chañar, exclusivamente fragmentos de cráneos y uno cráneo entero sin la mandíbula -figura 7.4 y 7.5. Se identificaron un número mínimo de 6 individuos. El cráneo entero se halló tapado por una vasija abierta, de base cóncava-convexa de clase E, 
probamente un "plato grande" -cuenco para Gordillo 2009-. En otros casos se registró la presencia de marcas de corte en la rama izquierda de una mandíbula que evidenciarían su desarticulación del resto del cráneo y, a su vez, presentaba señales de pulido indicando algún tipo de manipulación continua sobre el hueso seco (Gordillo y Solaris 2009:38). En otras casos estas autoras señalan la presencia en los fragmento de cráneos de varios grados de exposición al fuego y en uno en particular una mancha oscura en el endocráneo, que no han podido determinar a qué corresponde pero, sugieren la posibilidad de que sea producto de un uso anterior.
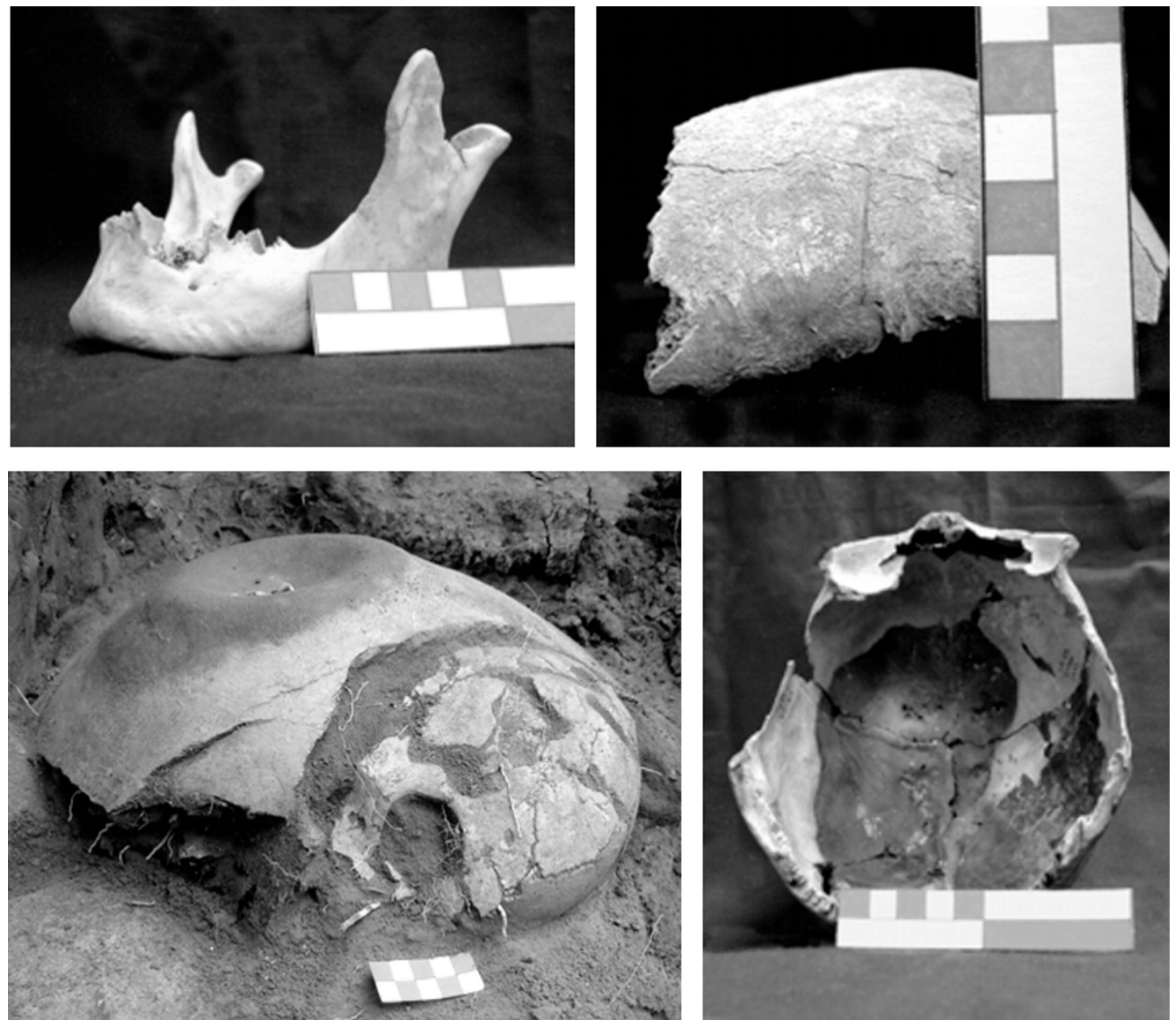

Figura 7.5: restos de cráneos procedentes de E5. Arriba: mandíbula y parietal con marcas. Abajo: cráneo sin mandíbula al interior de un cuenco (izquierda) y mancha endocraneal de otro ejemplar quemado (derecha). Fuente Gordillo y Solari (2009)

En otro fragmento de cráneo de individuo de sexo masculino y edad adulta, que también mostró diversos grados de exposición al fuego se registró una marca de corte intencional en el parietal izquierdo, esta huella de corte parecería haber sido realizada según las autoras con un golpe con un objeto contundente y cortante de filo metálico. Así tendríamos, representados en las galerías mayormente cráneos, y en el interior de los recintos también aparecerían cráneos pero en algunos casos junto a otras partes 
esqueletales tal como los hallados en el pozo excavado por debajo del piso en la estructura 7 , en este último caso con partes esqueletales de camélidos -Lama sp y vicuña-. Las acciones evidencian, en el caso de los cráneos la ejecución de cortes y desarticulación del resto del cráneo, junto con uso o manipulación continua sobre el mismo hueso en estado seco. Por otro lado golpes sobre parietales con probables herramientas metálicas. Además no descartan la utilización para alguna actividad aún no definida del cráneo con la mancha negra muy intensa en la zona del endocráneo.

De las partes corporales representadas y de los tratamientos recibidos se pude reconstruir cierto proceso para trozar los cuerpos de los individuos muertos. Es muy difícil hasta el momento determinar las causas de muerte, existen ciertas marcas como los golpes de elementos cortantes aparentemente de metal, en la partes supraorbitales, que son perimorten, es decir ocurrieron en un momento muy cercano a la muerte, en tanto no se observan procesos de regeneración de tejidos, etc. Pero no se puede determinar si la persona murió por esta acción o no. Sí podemos, aunque fragmentariamente, reconstruir proceso posteriores, que son verdaderas prácticas de trozamiento, desmembramiento y descarnado de los cuerpos. Aparentemente, hay un primera instancia, que es la extracción de las visceras, luego se procedería, según lo observado por Cruz (2005), a la separación de las piernas de la pelvis, desde la zona desde la región inguinal, aparentemente antes del descarnado y no desde las nalgas del individuo. También, se separaría la pelvis de la columna a través de la desarticulación del hueso coxal y el hueso sacro. Al cráneo, según lo observado por Gordillo y Solari (2009), se le extraería la mandíbula, y probablemente dado que luego aparecen solos los cráneos o fragmentos de estos, se lo desarticularía de la columna. Así tenemos al menos cuatro partes: miembros inferiores, parte media del cuerpo, cráneo y mandíbula. No conocemos el resto de los procesos de desmembramiento y desarticulación, pero probablemente dada la fragmentación posterior también se ejecute con los miembros superiores y otras partes. Luego vendría el descarnado que fue observado en distintas partes del cuerpo.

La fragmentación del cuerpo, produce que las partes desmembradas, desarticuladas se diseminen, hay una dispersión de los cuerpos; no se han recuperado contextos donde se encuentren representados, aunque fragmentados, individuos completos, solo se hallan partes de estos. Esto puede indicar, como ya lo hubiera percibido Juez (1991) prácticas de distribución de partes, tanto al interior de los integrantes de una unidad, como quizás con otros, vecinos, parientes, etc. Más allá de ésto, que por la información hasta ahora 
recopilada resulta sumamente difícil de determinar, sí es importante el proceso de desarticular del cuerpo: desmembrarlo, extraerles las visceras, sacarle la carne etc., son acciones que desarman un cuerpo, despojándolo, ya no es un cuerpo son solo fragmentos. No conocemos los lugares donde se ejecutaban estas prácticas de trozamiento. En el caso de los camélidos según lo observado por Juez (1991) en Martínez 2, ocurriría en distintos espacios, lo mismo señala Gordillo (2009) para La Rinconada. Lo que sí conocemos son los espacios y recipientes donde las partes trozadas de las personas fueron almacenadas durante algún período de tiempo. Una vez trozado el cuerpo y dispersados los distintos fragmentos del mismo, éstos últimos, comienzan a vincularse y tener por lo menos durante algún tiempo un recorrido semejante a fragmentos o partes de otros cuerpos que fueron también trozados. A las distintas partes trozadas se las almacena temporalmente -en las habitaciones techadas y algunas veces en la galerías-, en las vasijas de forma "a" y "otras formas"-, teniendo esta instancia de contención temporaria una característica específica: la asociación y mezcla de fragmentos de cuerpos, tanto con partes del mismo individuo, como con fragmentos y trozos de varias personas, y también fragmentos de varios camélidos, pero además, de diferentes edades, y "sexos" distintos. Esta característica produce el encuentro, conjunción y mezcla de distintas partes de cuerpos. Así tenemos que el proceso de diseminación de los cuerpos en fragmentos y su dispersión, es el que inicia y propicia en Ambato la posibilidad de encuentro futura de las distintas partes en las vasijas. A su vez desde estos lugares de almacenamiento temporal, pasan a otros espacios, en el caso del sitio Martínez 2, desde una de las habitaciones techadas -habitación 2- donde se los almacenaba, pasan a otra habitación contigua -la habitación 1-, donde hay un fogón y donde son sometieron a procesos de cocción, utilizándose vasijas de "otras formas" de clase E . En esta instancia de traspaso y movilización debieron cumplir un rol importante como intermediarias las vasijas de forma "ab" y "b", recordemos que ésta no sólo presentan asas remachadas y tamaños que permiten su fácil movilidad, y que las huellas de usos también muestran estos movimientos, sino que se las ha hallado conteniendo partes de estos fragmentos. Por otro lado dijimos que las vasijas "a" son menos transportables y suelen permanecer fijas o con poca movilidad, lo mismo para grandes vasijas de "otras formas". En este momento, e incluso antes del almacenado, las distintas partes corporales pueden recibir tratamientos distintos, particularmente el cráneo, que por lo observado por Juez (1991) y, Gordillo y Solari (2009) podrían haber seguido caminos distintos del esqueleto post craneal. Juez (1991) señala la posibilidad de que algunos de los cráneos habrían sido colocados al fuego directamente, sin previo descarnado, ni extracción de cerebro, ojos, etc. lo que haría que estos exploten y se multifragmenten. Quizás luego, 
algunas de estas partes de cráneos, eran agregadas, junto con el resto de fragmentos, como ingredientes del preparado que se estaba por cocinar o cocinando en dichos lugares. A su vez, el cocido en las vasijas de estas partes, según las huellas observadas, se lo realizó de distintas maneras: alguna de las vasijas, como vimos, se las colocaba por encima de la llama, sobre algún soporte y otras, eran apoyadas directamente al fuego; ambas prácticas, nos muestran movimientos y maneras específicas para cocinarlos. En esta instancia, la asociación de partes que hemos descrito, cobra un sentido más que de asociación y conjunción, de fusión de cuerpos, o por lo menos partes de cuerpos, en tanto ingredientes, junto a vegetales, de un preparado particular. Cocinar o preparar una comida, que en general requiere seguir determinados procedimientos, recetas, etc., de cómo debe ser preparada, es una instancia altamente preformativa: hay cambios de estado, las sustancias se alteran adquieren texturas y colores distintos, intercambian sus fluidos, componentes, etc. Si pensamos en procesos de cocción prolongados tanto las carnes, grasas y vegetales, en muchos casos llegan a unirse, a formar parte de un mismo caldo, etc. Por lo que esta fusión, cobra un sentido más literal que metafórica. Así, las prácticas de trozado, desmembramiento y descarnado, conforman parte de una coreografía que hace del cuerpo, fragmentos, partes que ya no están juntas, ni remiten necesariamente a un cuerpo o al cuerpo conocido antes. Por más que se conociera a la persona muerta, por más que se tuviera memoria de ellas, los fragmentos de su cuerpo que se diseminan y se juntan a otros fragmentos de otros cuerpos, de otras personas y animales, sean estos huesos descarados, o huesos que aún conservan la carne, cráneos descarnados o sin mandíbulas, o incluso partes de estos, visceras, etc., diluye casi toda posibilidad de reconocimiento de lo que fue: pensemos en el cráneo de Martínez 2, que fue colocado con piel, cabellos, ojos, es decir la cara de una persona visible, pero fue colocado directamente al fuego, este proceso hace que no sólo las marcas que aún podía haber llevado esta persona en su rostro, tatuajes, pintura, o peinado etc., se consuma en el fuego, si no que se lo deja hasta el punto de hacer estallar el cráneo o parte de este. O incluso en aquellos cráneos que se guardan, relativamente enteros, aparentemente por mucho tiempo, pero también han sufrido proceso de calcinado, y descarnado.

Como lo han señalado Cruz (2005) y Gordillo y Solari (2009) estos procesos son partes de prácticas antropofágicas, por medio de las cuales esa conjunción de partes de cuerpo terminar siendo reincorporada a otros cuerpos. Todo esta comensalidad es un proceso de transformación, de cambio, resignificación que por medio de la fragmentación de cuerpos de distintos sujetos, produce la posibilidad de su reagrupación en una especie de collage armado con varias partes de personas y animales, es casi la transformación, la 
metamorfosis de cuerpos en un forma multiforme, a la manera de las representaciones "draconianas", pero sin el felino. Este mismo proceso además no sólo logra reagrupar estos fragmentos o colocarlos en combinaciones variadas a nivel de partes del cuerpo, de individuos, de edades y "sexos" distintos, si no que fusiona o pone en un plano semejante en ese mismo instante a los camélidos, que también sus partes representan a distintitos individuos y edades diferentes. En ese espacio y en esa coreografía humanos y camélidos son partes de un mismo universo, en esos contexto y como veremos a continuación, en otros también separarlos apelando a las grandes categorías de humano y animal, o camélido y humanos, pierde su sentido.

Estos fragmentos también poseen una vida posterior, en tanto que algunos se transforman en instrumentos, tales como las astillas de huesos humanos con punta hallados en el sector central de la galería del sitio Martínez 4, cercano al área donde hemos señalado la posibilidad de realización de prácticas artesanales, entre las que se encuentra la confección de alfarería. O también en Martínez 4, aunque no asociado a un contexto como las astillas, aparece un fragmento de huesos largo en el que uno de sus bordes está pulido, probablemente debido al uso como sobador del mismo. Una mandíbula inferior, presenta también una zona muy pulida. Este pulimento fue realizado cuando el hueso estaba ya seco, lo que evidencia la permanencia de algunos de ellos, en dichos lugares, por algún tiempo. O el cráneo al que se le pintó manchas redondas de color negro en el sitio Martínez 2, e inclusive los cráneos hallados por Rosso, también pintados con manchas redondas negras y rojas. En otros casos, han quedado ciertos fragmentos en el piso de las galerías. Con los huesos de los camélidos también se realizan instrumentos: con las escápulas se confeccionan espátulas, con algunos huesos largos se fabrican instrumentos de viento, cucharas, torteros, etc.

Cruz $(2005,2007)$ ha señalado la posibilidad de que algunos de los fragmentos de cuerpos humanos conservados hayan sido reliquias, que rememoran a un antepasado muerto, o alguien con cierta distinción social. La reliquia es entendida por el autor como la conservación por parte de los vivos de un elemento rememorativo que se hallaría fuertemente cargado de eficacia simbólica (Cruz 2007). En este sentido su preservación afirmaría la entidad de una presencia, que engendraría una devoción a un antepasado particular o bien un personaje jerarquizado por la sociedad que se manifiesta después de la muerte como un intermediario entre lo humano y lo divino (Cruz 2007). A esta situación la relaciona con los ritos observados en el área andina denominados mallquis, donde según el autor el cuerpo del difunto se convierte en un poder generativo similar al de una semilla; 
jugando, los antepasados y los muertos, un papel muy importante en la fertilidad de los campos y de los animales (Cruz 2007). Pero en el caso de los mallquis, es el cuerpo reconocible del difunto, transformado en antepasado, el que pude ser retirado de su tumba, incluso paseado por los campos, etc. (Pérez Gollán 2000a). Sin embargo, si pensamos esta proposición en relación al proceso de producción de ese collage, y su vida posterior, si fueron trasformados posteriormente en especies de reliquias, mas que rememoración de un antepasado o una persona individual, serían representantes en todo caso de sujetos más genéricos $^{\text {ii }}$. Lo que sí queda claro y fuertemente enfatizado en el caso de Ambato es la disolución del cuerpo, de "un" cuerpo, de límites de edades, de límites "sexuales", de límites de "especies", etc.

\section{Conservando los cuerpos}

Como dijimos, el otro tratamiento dado a los sujetos al morirse es la conservación del cuerpo totalmente articulado. Se hallaron cuatro casos de este tipo de tratamiento. En general se trata de entierros en fosas que fueron excavadas en la tierra: tres enterratorios individuales de niños, algunos con ajuar asociado, fueron hallados en una habitación del sitio Piedras Blancas (Cruz 2005, 2007; Pérez Gollán et al. 2000; Zaburlín 2001); un enterratorio de un adulto en una un sitio pequeño -Cárcava 1- de paredes de piedra a unos $400 \mathrm{~m}$ al sur del sitio Piedras Blancas. Cruz (2005) además menciona un enterratorio colectivo de cuerpos enteros de humanos y de camélidos no asociada aun sitio particular, en la ladera oeste del Ambato, sin embargo no es clara la contemporaneidad de este enterratorio con el resto, no apareciendo material diagnóstico, por lo que por el momento lo dejamos en suspenso.

En el sitio Piedras Blancas -figura 6.76-, específicamente en el Recinto H -figura 7.6- se han hallado tres enterratorios de humanos, dos de ellos se tratan de fosas que se hallan por debajo del piso de este recinto. Los tres enterratorios se ubican en la mitad sur del recinto. Uno debajo de la pared este, los otros dos contra el muro sur por debajo del piso.

El enterratorio 1 (Pérez Gollán et al 2000) -figura 7.7-: se ubica junto a la pared sur a una distancia de $48 \mathrm{~cm}$. de la esquina Oeste, se lo halló a una profundidad de $1 \mathrm{~m}$ de la superficie, apenas por debajo del piso. Recordemos que en esta zona, apoyados sobre el 
Sitio Piedras Blancas- Recinto $\mathrm{H}$

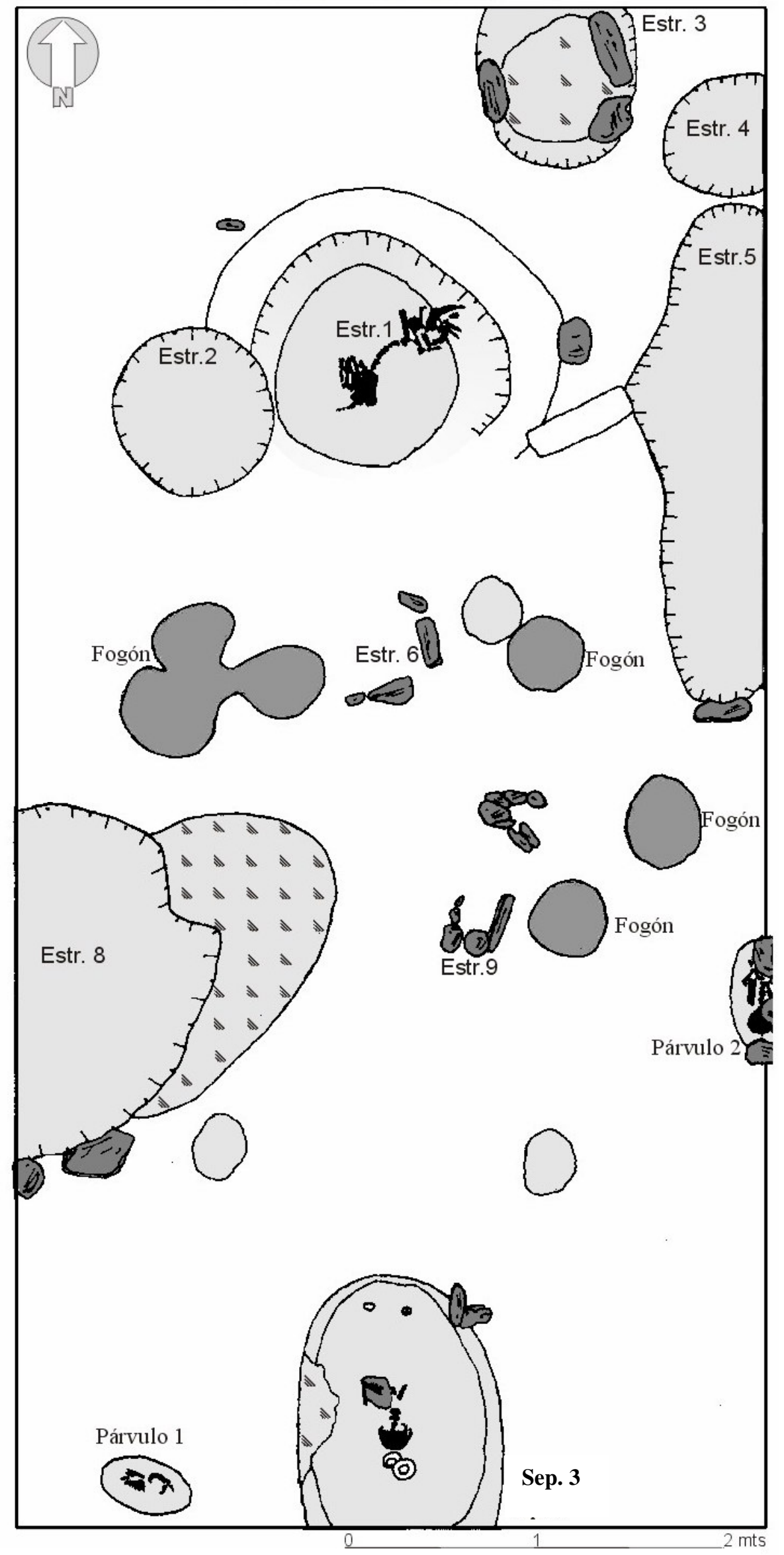

Figura 7.6: planta donde se muestran los tres enterratorios hallados. 

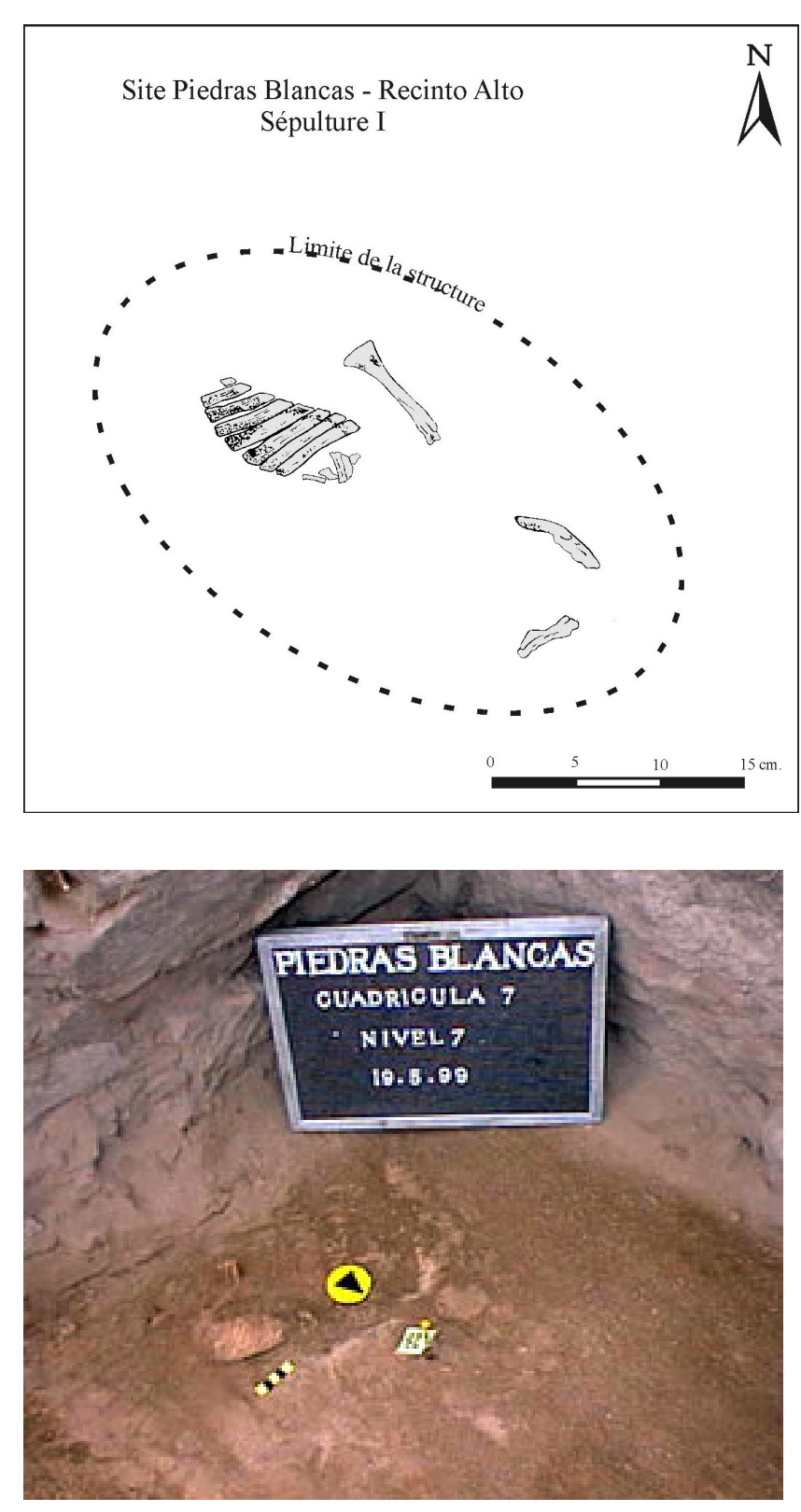

Figura 7.7: sepultura 1. El niño se halla enterrado directamente sobre el piso. piso aparece una concentración de fragmentos de vasijas de clase A1 de varias formas que hemos asociado junto con Zaburlín que se hallaban almacenadas como fragmentos a la espera de su participación en alguna de las actividades artesanales que se realizan en el lugar con estos objetos, transformación en fichas, torteros, e inclusive el molido para su incorporación como antiplástico a las pastas de nuevas vasijas de clase A1. El entierro consiste de un elemento interfacial vertical, una fosa, que fue excavada en un sedimento más claro que el que la rellenaba y cubría el esqueleto hallado en su interior. Este pertenece a un individuo infantil. Los restos óseos presentan una conservación regular, a excepción de los huesos del cráneo que se recuperaron sólo algunos fragmentos. El esqueleto se ubica en posición genuflexa con apoyo latero dorsal izquierdo con la cabeza orientada hacia el sudeste, y la espalda orientada hacia el interior del recinto. Asociados al cuerpo no se halló ningún objeto, es decir que el cuerpo fue enterrado solo o con materiales precederos no conservados.

El enterratorio 2 (Pérez Gollán et al 2000) -figura 7.8-: se ubica junto a la base de la sexta columna de la pared este, a una profundidad de un metro. Se trata de un elemento interfacial vertical, que cortó un sedimento más compacto y más claro que el relleno que cubría el esqueleto. El corte en planta del elemento interfacial presenta una forma relativamente irregular de uno $0,50 \mathrm{~m}$ de diámetro, de unos $0,20 \mathrm{~m}$ a $0,30 \mathrm{~m}$ de profundidad. El esqueleto se ubica en posición genuflexa con apoyo latero dorsal derecho, con la cabeza orientada hacia el sur y la espalda hacia el este, es decir hacia afuera del 
recinto. En este caso se hallaron elementos asociados: en la base del cráneo se hallo un tiesto, directamente apoyado sobre la nuca, y a la altura del cuello se hallaba una astilla de hueso incrustada que atravesaba la columna en la zona cervical de lado a lado. Como posible ajuar se hallaron en las proximidades y junto con los restos óseos, cuatro falanges
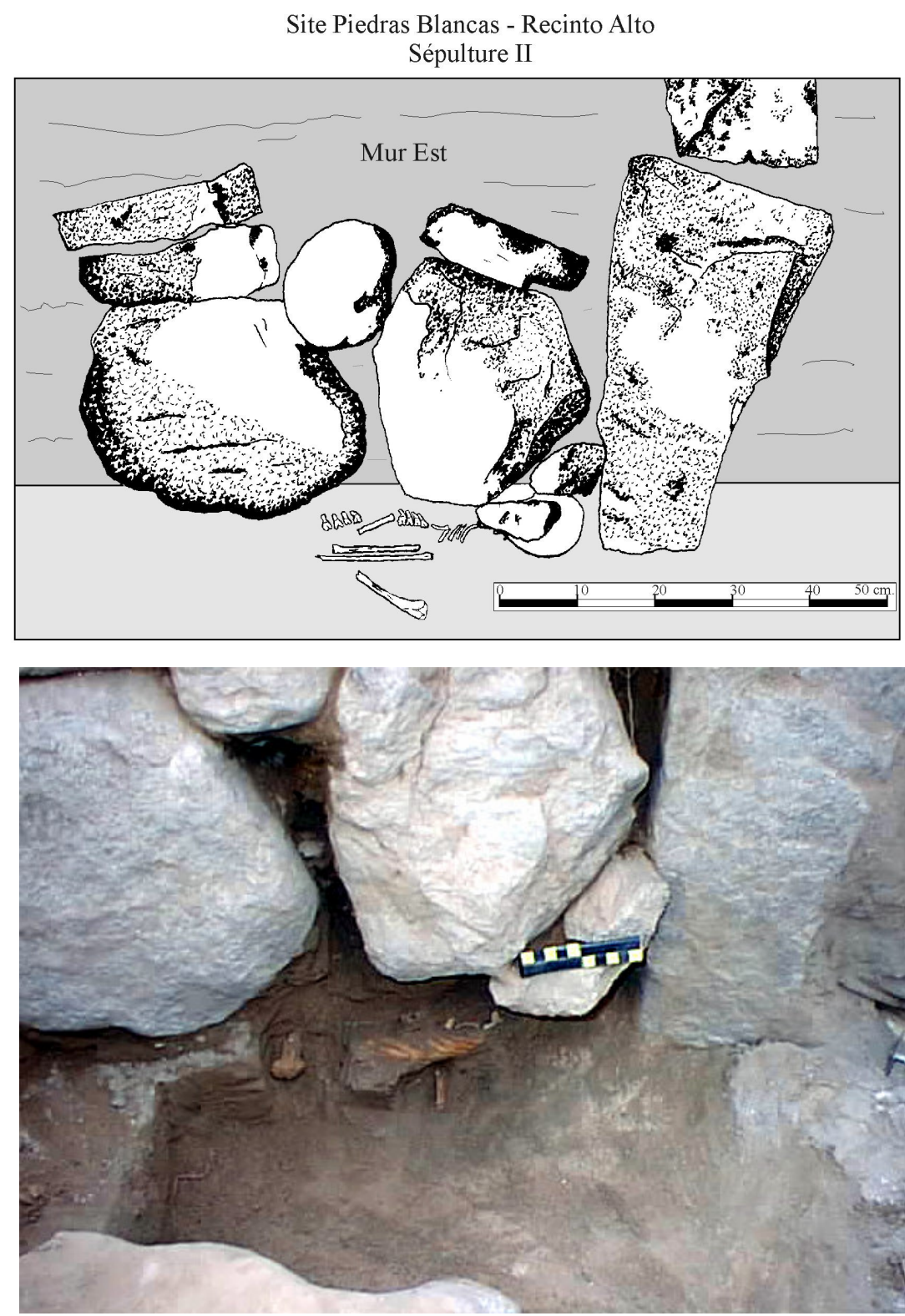

Figura 7.8: sepultura 2 realizada por debajo del muro. ungueales de felino; un anillo de metal en la base de la excavación, una hoja de mica con restos de pigmento rojo, una estatuilla zoomorfa de cerámica representando un camélido, una cuchara de hueso realizada sobre una costilla y fragmentos cerámicos dispersos.

El enterratorio 3 -figura 7.9-: se compone de un elemento interfacial vertical -fosaque presenta en planta una forma ovalada de aproximadamente $1,10 \mathrm{~m}$ de ancho por $1,28 \mathrm{~m}$ de largo, presentando en el centro una profundidad de $0,44 \mathrm{~m}$. La misma se ubica a $2 \mathrm{~m}$ del muro Oeste y está adosada al muro Sur (Pérez Gollán et al 2000). En este pozo se ubicó en el fondo del mismo una laja irregular la que antes de colocarla fue pintada de rojo. Sobre la misma se dispuso el cuerpo de un niño de 2 a 4 años en posición dorsal y extendida, con la cabeza mirando al sur. Luego por detrás del cráneo se dispusieron: una vasija restringida compuesta de clase A1 de pequeñas dimensiones, la que originalmente presentaba un asa remachada entre el borde y el punto angular en posición vertical. Esta se abría roto antes del entierro en tanto que la zona de fractura fue desgastada logrando alisarla hasta que apenas sobresalgan dos 


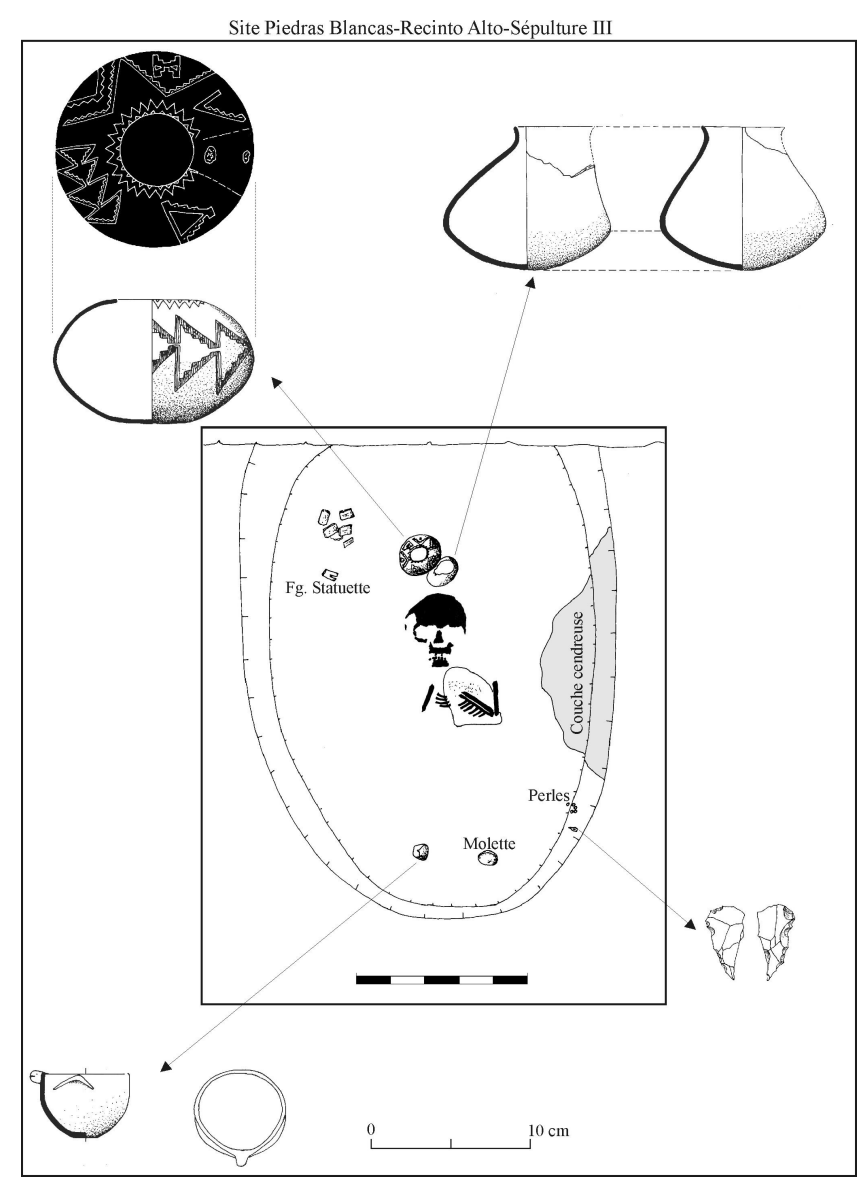

pequeños domos que evidencian el remachado del asa. La vasija presenta una serie de incisiones con motivos geométricos no asimilables a ningún estilo conocido para la zona o para la cultura Aguada. A su vez esta vasija presenta en su interior dos panes de pinturas: uno de forma rectangular de color rojo, y otro en forma de bollo de color blanquecino. A su vez, también atrás del cráneo, al lado derecho -hacia el este- de la vasija antes descripta, se dispuso otra vasija calceiforme pequeña, que presenta el asa remachada arrancada o rota. A su vez posee las mismas huellas de carbonización que las otras vasijas

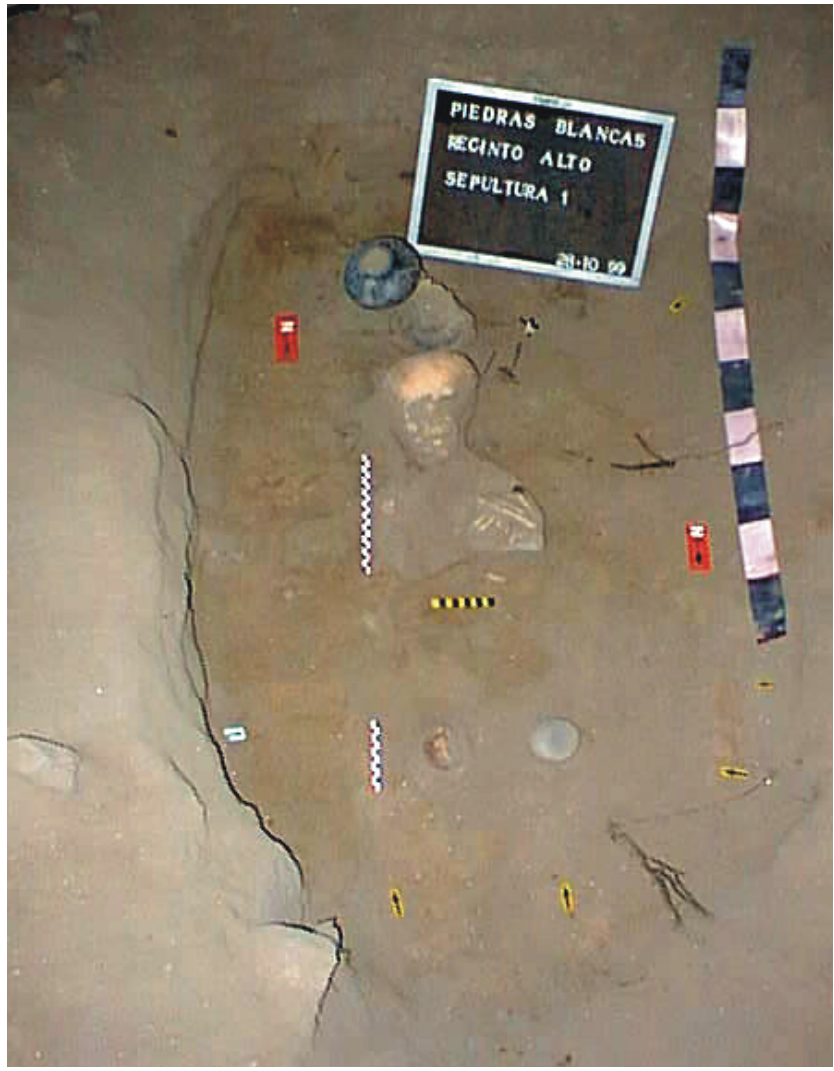
calceiformes halladas en el sitio, que indican su utilización en la misma clase de prácticas, a su vez de los análisis de residuos orgánicos de los restos adheridos en su interior arroja al igual que en el caso de las otras vasija ácidos grasos y carne. Debemos decir que ambas vasijas son las más pequeñas que hemos registrado para cada forma. A la altura donde debían localizarse los pies del niño (no encontrados), se hallaron otros materiales: a la derecha, una pequeña vasija modelada sobre el borde y cuerpo brindándole un aspecto zoomorfo. A la izquierda, se halló Figura 7.9: sepultura 3 . una pequeña mano de conana. A su vez, es de resaltar, que hacia el este entre el cuerpo y la pared de la fosa se colocó un 
fragmento de la parte inferior - piernas- de una estatuilla antropomorfa de cerámica que presenta atributos sexuales masculinos y femeninos. Es sugerente la ausencia de los pies y la presencia sólo de las piernas de la estatuilla y ausencia de la parte superior de la misma. Otros objetos que se hallaron son: un perforador de cuarzo y una cuenta de turquesa.

En el sitio Cárcava 1, se halló una fosa excavada directamente en el piso de habitación de un sitio pequeño de paredes de piedra, en la fosa se colocó un individuo adulto, que estaba aparentemente en posición extendida y dorsal, con sus extremidades inferiores orientadas al noroeste (Cruz 2005 y 2007).

En el sitio 099, Cruz (2005) halló por debajo del piso de una de las habitaciones una caja rectangular confeccionada con lajas que en su interior no contenía nada. En ese momento la asocia a una estructura de almacenaje. Sin embargo como puede ser observado en otros lugares no muy lejanos del valle, en la localidad de El Rodeo, al suroeste del valle, vinculadas a Aguada (Kriscautzky et al 2005), se halló un enterratorio dentro de estas cajas con ajuar asociado. Por lo que quizás en Ambato también podría conformar una forma de entierro.

En el sitio La Rinconada o Iglesia de los Indios, no se hallaron cuerpos enteros de humanos como en el caso del sitio Piedras Blancas pero, sí se halló en la estructura 7 figura 7.4-, en el centro del recinto, cercano al pozo que contenía fragmentos óseos de varios individuos pertenecientes a vicuña, Lama sp. y humano; un enterratorio de un individuo adulto de vicuña, que fue enterrado por debajo del piso. Se encontraba en posición extendida y se le asociaba un hacha de metal -cobre- que, según Gordillo (2009), podría conformar el instrumento con el que se le dio muerte.

Este hallazgo nos lleva a que describamos dos entierros más que se hallaron en el recinto $\mathrm{H}$ del sitio Piedras Blancas. Estos no son enterratorios de niños humanos, sino que son cuerpos de camélidos neo-natos -asimilables a edades muy parecidas a la de los niños humanos- que aparecen enterrados en fosas en el mismo espacio que los otros y de la misma manera. Uno se trata de una fosa que fue excavada desde el piso -figura 6.86-, una vez realizado esto, se depositó en su interior un camélido joven que apareció totalmente articulado, sobre este se depositaron tres estratos más, uno de ceniza con espículas de carbón, otros que posee menor cantidad de ceniza, y también presenta espículas de carbón 
y por último un sedimento que se encuentra rubefaccionado probablemente por las estructura construida encima utilizadas por el recocido de metales (Espósito 2009). El otro individuo joven de camélido, apareció enterrado en una fosa excavada directamente en el piso, aunque dado la presencia de un elemento interfacial horizontal, que nos indica que esta superficie fue cortada para construir el recinto $\mathrm{H}$, nos es difícil determinar desde donde se excavó la fosa. El camélidos también está totalmente articulado, no hallándose ningún objeto asociado -figura 7.10-.

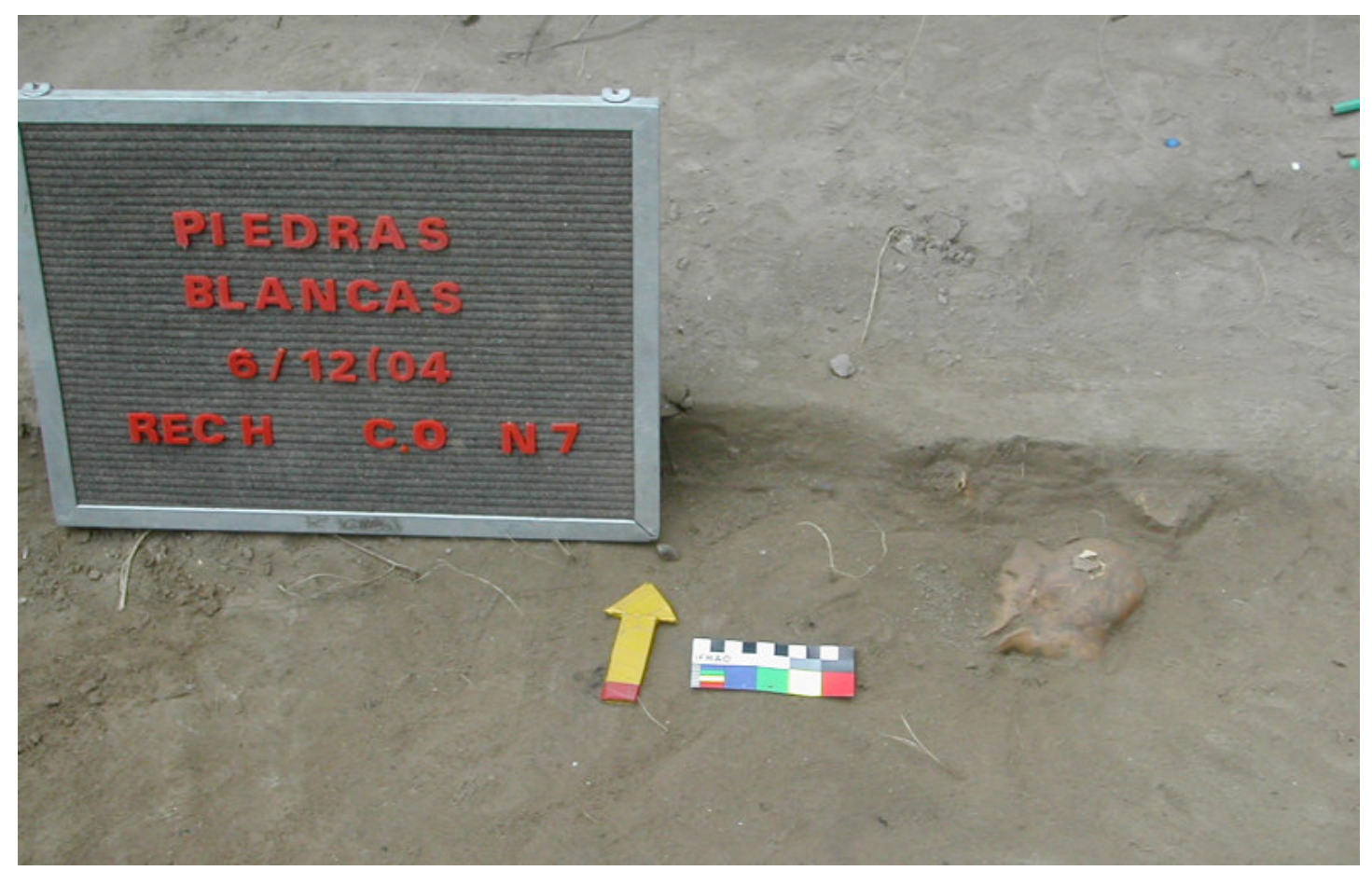

Figura 7.10: camélido joven enterrado directamente en el piso. Se observa el cráneo.

A diferencia de las prácticas de fragmentación de los cuerpos, en esta otra actitud, existe un fuerte énfasis recibido por los mismos durante el proceso ritual de entierro. No se los colocaba de cualquier forma, es decir no fueron arrojados a la fosas y luego enterrados; todos fueron dispuestos de una manera específica, o boca arriba totalmente extendidos o en posición genuflexa. La fosa se excava directamente en la tierra, adquiriendo en general una forma ovalada o subcircular y de poca profundidad $-0,40 \mathrm{~m}$ a $0,50 \mathrm{~m}$ o podría ser el caso, si se confirma, de la utilización de lajas para conformar el espacio de entierro. Todo $\boldsymbol{e l}$ evento ritualizado de entierro se concentra y gira alrededor del cuerpo entero del difunto. De hecho cuando se colocan objetos en su interior, estos poseen ubicaciones determinadas muy precisas como vimos en uno de los entierros del sitio Piedras Blancas.

Las dos clases de tratamiento que recibían los cuerpos de las personas y de los camélidos al momento de su muerte (ya sea inflingida o natural), coloca en el centro de la escena a los cuerpos, como actores y vehículos fundamentales de las formas en que las 
personas en Ambato representaron sus disoluciones como tales, o por lo menos la manera en que los vivos, aquellos mismas personas que habitaban los sitios, representaron a los muertos y por lo tanto a los sujetos que fueron. Ambas formas de representación, tanto aquella que, podríamos decir que destila los cuerpos volviéndolos fragmentos para fusionarlos en un collage de partes, y aquella otra que conserva los cuerpos enteros por medio de su entierro, ocurrían en los mismos espacios, es decir al interior de los sitios donde las personas habitaban, e inclusive en las mismas habitaciones donde se desarrolla normalmente la vida social. Pero en esos espacios, ambos llegaron a habitar lugares diferentes, unos permanentes, otros temporarios, unos fijos otros móviles.

El lugar habitado por los cuerpos conservados enteros de los muertos conformó parte del sustrato donde se desarrollaba la vida, se ubicaron por debajo de los pisos de las habitaciones, e inclusive en algunos casos fueron soporte estructural de una pared. El lugar de los fragmentos de cuerpos en cambio, tanto durante el proceso de destilación, como en su vida posterior, fue en al interfacie del piso, es decir permanecen en un espacio dinámico y móvil, no están fijos, perduran en circulación durante algún tiempo en la vida de los vivos, son visibles para éstos, se los manipula, a diferencia de los otros que quedan invisibilizados. Esta invisibilidad no solo esta dada por los sedimentos que se les tira encima y que conforma, después de un tiempo, la argamasa que permite la conservación del cuerpo articulado reconocibles hasta hoy día, y posteriormente sobre ellos la construcción del piso e inclusive de una pared por encima de estos; sino que, además se siguen desarrollando otras actividades por encima de estos lugares. Así ambas prácticas sobre los cuerpos, marcan no solo posibilidades y forma particulares de representar la muerte de ciertos sujetos, podríamos decir el devenir de los vivos, si no que también delinean, a través de ciertas rutinas que zonifican el espacio interior de las viviendas, un espacio-tiempo intermedio donde las personas que habitaron el valle desarrollaban su vida como sujetos sociales, antes de la muerte. Nos es difícil de determinar las distintas trayectorias biográficas que siguieron en vida dichos sujetos -enteros o fragmentados-, como en el transcurrir de las mismas no sólo fueron produciendo dichos cuerpos si no en la manera en que en cierta forma llegaron a prescribir el devenir de esos cuerpos unas vez muertos. Pero, de esas biografías, tenemos ante nosotros algo muy claro y muy visible: su final. Este es representado en Ambato de dos maneras distintas y en cierta forma opuestas, que implican definiciones de sujetos y relaciones diferentes: la aniquilación del cuerpo entero y su destilación o resignificación, junto a otros cuerpos, en un nuevo conjuntos que no refiere a un solo sujeto, sino a varios, forma el límite, la frontera, en la cual aquellos cuerpos y sujetos enteros enterrados reconocen su existencia. Quizás este punto y el que 
los espacios habitados por estos nuevos sujetos no sea totalmente concluyente, nos de un lugar preciso para pensar la producción del cuerpo y las biografías de los sujetos vivos. Desarrollaremos esto en el capítulo siguiente cuando delinearemos las cartografías de encuentro y desencuentro entre las personas y las cosas.

La asociación contextual de los camélidos y los humanos recibiendo ambos el mismo tratamiento corporal, nos informa que no podemos pensar a la construcción de las subjetividades de los individuos humanos y a sus cuerpos, tomando a lo "humano" como una categoría distinta de la de "animal". En este caso, dicha dicotomía, que nos asocia a clasificaciones taxonómicas modernas, se diluye. Aquí, la definición de los sujetos humanos fragmentados, se vincula y diferencia, así como se opone tanto con la de los cuerpos humanos enteros enterrados solos o acompañados de objetos, como con las de los camélidos enterrados solos o también acompañados de objetos. Ambos grupos discontinuos, sujetos "singularizados" y sujetos "no singularizados", trasformados en collage, se definen mutuamente a través de las coreografías posteriores a la muerte que enfatizan o el cuerpo entero o hacen de él solo fragmentos. Las vasijas aquí analizadas, tuvieron a lo largo de sus vidas, un rol importante en este proceso, pasemos a considerar ahora, las intersecciones en las cuales las biografías de sujetos, y de las vasijas analizadas se vinculan, se unen o disgregan.

\section{Notas}

\footnotetext{
${ }^{\text {i }}$ En un trabajo anterior (Laguens y Gastaldi 2008) propusimos, siguiendo la propuesta de Philip Descolá (2001), para el caso de la cultura Aguada de Ambato, la posibilidad de transformación entre humanos y no humanos -animales, plantas y objetos- mostrando cómo en Ambato podía estar operando principalmente un esquema "animista", en el sentido que le otorga este ultimo autor, que modelarían las relaciones entre humanos y no humanos. En este esquema, los humanos y los animales comparten la misma interioridad "alma", esencias, cultura, etc.-, es decir los animales se comportan según las reglas sociales de los humanos, pueden existir entre ellos relaciones de parentesco, se pueden casar, o realizar transacciones económicas, etc.; pero se diferencian en su exterioridad, fiscalidad -aspectos físicos, sustancias corporales, uñas, piel etc.-, en este sentido se opone al modelo que le denomina "naturalista" de las sociedades modernas occidentales en donde lo compartido es la naturaleza, en tanto todos tenemos, ADN, átomos, etc. y, lo que nos diferencia es la cultura. Así en estos esquemas animistas donde es compartida la cultura, lo que permite establecer diferencia son los aspectos exteriores, a maneras de ropajes, pero son intercambiables. Este cambio ontológico donde se desdibuja la categoría Naturaleza-Cultura, permite un alto grado de trasformaciones corporales, metamorfosis entre humanos y no humanos. Otra perspectiva semejante a la de Descolá, es la del Antropólogo brasilero Viveiros de Castro (1996, 2002), quien desde sus estudios etnográficos, a planteado una teoría no solo para repensar las relaciones entre los humanos y no humanos, si no la misma categoría de sujeto. Esta perspectiva fue denominada por él como Perspectivismo Amerindio. En donde hay un cambio notable del lugar ocupado por la naturaleza. Es casi una oposición inversa a lo que se concibe en las sociedades occidentales, en donde hay una sola naturaleza y múltiples culturas, en este caso hay múltiples naturalezas y una cultura compartida. Por lo tanto cada sujeto no tiene una naturaleza fija, si no que cambia según el punto de vista que ocupe en ese momento.

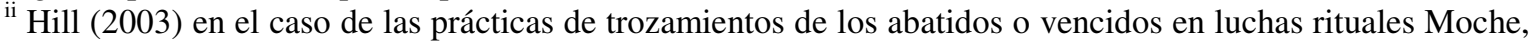
más que un proceso de destrucción, observa el desmembramiento como un proceso generativo de inscripción de significados, en tanto estos fragmentos son transformado en mercancías sagradas, en el que la reliquia conservada, más que representar a la persona a la que pertenecía, era depositaria del poder sacrificial, una suerte de nuevo significado.
} 


\section{CAPÍTULO 8}

\section{CARTOGRAFÍAS: INTERSECCIONES Y DISEMINACIONES, ENCUENTROS Y DESENCUENTROS ENTRE LAS PERSONAS Y LAS COSAS}

En este capítulo iremos entrelazando las distintas sendas seguidas par los sujetos, con las biografías seguidas por las vasijas, haciendo hincapié no solo en las intersecciones o diseminaciones entre estas, y sus implicancias en la constitución de ambos, si no que también discutiremos las geografías espacio-temporales que estos encuentros y desencuentros delinean en el valle.

Los tiempos de vida esperados de las distintas formas y clases de vasijas analizadas fueron diferentes; señalamos que para alguna de las vasijas como las de forma "a" y "otras formas" de clase E, pudieron ser largos, incluso trascendiendo la vida de varias personas. En cambio para algunas formas de la clase A1, tales como las escudillas, los bols, las vasijas "b" y las "c" señalamos que pudieron haber tenido tiempos más cortos; mientras que para las modeladas, los vasos y jarras su vida también pudo ser un poco más larga. Esto hace que los encuentros entre estas vasijas y determinadas personas sean diferenciales. Así algunas vasijas a lo largo de sus vidas llegaron a vincularse a distintas personas trascendiendo en algunos casos la muerte de las mismas; a su vez, una persona, llegó a vincularse con vasijas que se hallaban en distintos momentos de sus biografías, compartiendo solo en parte la vida con ellas. Puntualizamos que en la mayoría de las formas -salvo las calceiformes y algunos de los platos grandes- una misma vasija llegó a participar en más de una práctica y, que a su vez, podían llegar a secuenciarse: siendo una de las primeras la fermentación de chicha, la segunda el almacenamiento, procesamiento y/o cocido de vegetales y carnes y, la última, el almacenado, preparación y aplicación de pigmentos. Este hecho, probablemente no haya pasado desapercibido por quienes las utilizaban, no solo por la memoria que pudiera trasmitirse de persona a persona sobre estos objetos, si no que en los cuerpos de estos contenedores, se hallaban superpuestas e impresas las marcas visibles y distintivas que rememoran y narran su derrotero. Por lo que en las relaciones entabladas entre personas y vasijas, sean al momento de su fabricación o de su participación en una práctica específica, confluyen temporalidades, especialidades y relaciones sociales que trascienden el momento del encuentro.

Las rutinas seguidas por 1@s artesan@s para fabricar estas vasijas implicaron ciertos recorridos que tuvieron como punto de inicio la casa donde estos vivían. Así desde las casas se dirigieron a las barrancas donde se hallarían la fuentes de arcilla, quizás en el 
camino recogieron leña de los sectores del monte circundante a las viviendas, para luego volver a la casa. Desde ésta también fueron a buscar placas de mica y cuarzo en la falda de los cerros de la sierra de Ambato, dirigiéndose hasta la zona de los corrales para aprovisionarse de guano, que en el caso de los sitios analizados, implicaría desandar el camino que recorre el agua -tanto de escorrentía como de las vertientes- para bajar a los sectores de fondo de valle; para luego, al igual que con la arcilla y la leña, volver a la casa donde se emprendería la confección de las vasijas. En estas rutinas que tuvieron como punto de partida y llegada las viviendas, a través de las cuales los artesanos se proveyeron de los materiales y recursos necesarios para confeccionar las vasijas, quedaron implicadas las formas y lógicas de apropiación de lo que en un sentido amplio denominamos el monte y el agua, en la que incluimos la tierra, sus producto y los camélidos. En este sentido estas rutinas no solo se ejecutaron sobre ese paisaje, a manera de escenario, si no que es en la práctica repetitiva y rutinaria donde éstas llegaron en cierta forma a producirlos y reproducirlos. Pero además, estas rutinas, que confluían en el momento de hacer y cocinar estas vasijas en las casas donde estos sujetos vivían, establecían un lazo muy fuerte, entre las viviendas, como espacios de vida y reproducción de estos grupos, y esos paisajes mayores; conformando uno de los locus de definición del lugar ocupado por dichos grupos en las relaciones con sus vecinos y con colectivos más amplios, tanto al nivel del valle, como probablemente de las agrupaciones menores o aldeas observadas por Assandri (2007). Pero estas rutinas, y los saberes puestos en acción a la hora de producir estos recipientes son herederos, como hemos visto, de una tradición tecnológica más antigua, que vincula tanto a las vasijas como los artesanos con temporalidades que exceden sus tiempos biográficos particulares, vinculándose con "formas de hacer" que no sólo logran perduran en el tiempo, al menos desde comienzos del primer milenio de la era, sino que se popularizan en el período analizado, respecto de otras formas que desaparecen.

A su vez, en los mismos sitios donde estas personas vivían, en sus casas se desarrollaban otras prácticas además de las artesanales, vinculadas con la reproducción social del grupo que vivía allí, donde también participaban estos recipientes: la fermentación de bebidas o el almacenado, procesado, cocido de carnes y vegetales con todas su implicancias en la definición de los cuerpos de los sujetos; o el almacenado, manipulación y aplicación de pigmentos en variedad de objetos, inclusive en los cuerpos. Así las vasijas "nacían" en contextos fuertemente estructurados y connotados por el derrotero de otras vasijas. Por lo que tanto las nuevas vasijas que serán incorporadas a la vida social en estos sitos, como aquellas dirigidas a otros lugares, y los mism@s artesan@s que ejecutaron las prácticas y rutinas en ellos, quedan implicados en esas otras 
temporalidades, especialidades y relaciones sociales que los trascienden. Las antiguas vasijas que ya han tenido un recorrido social en estos espacios y que portan en sus cuerpos las marcas de esa historia, en cierta manera restringen el inicio de las nuevas trayectorias biográficas, e influyen en la inserción de las nuevas vasijas a la vida social. Si pensamos en las secuencia de vida que hemos reconstruidos para alguno de estos objetos, la incorporación de una nueva vasija requiere el traspaso o la transición de vasijas más viejas a otros estadios de su trayectoria biográfica, de estas forma en cierta manera no sólo prescriben la participación inicial de una vasija nueva, si no también de las mismas personas que se disponen a usarlas, en tanto que la historia sedimentada en sus cuerpos limitan las acciones futuras realizadas con éstas.

A medida que va transcurriendo la vida de las vasijas, y se involucran en prácticas distintas, llegaron a establecer relaciones con espacios, objetos y sujetos diferentes. Una de las prácticas más preformativa en la cuales, gran parte de las vasijas estuvieron involucradas, y de las que, dado los contexto hallados y la información obtenida, nos permiten comprender mejor su intervención en la constitución de los sujetos, son aquellas por medio de las cuales los cuerpos devinieron fragmentos y collage. Prácticas, que sin la participación de varias de las formas y clases analizadas, no podrían haber tenido lugar. Para muchas de estas vasijas estas prácticas conformaron una etapa intermedia en sus trayectorias, habiendo participado antes en otras, tales como la fermentación y consumo de chicha y posteriormente algunas en el almacenamiento, manipulación y aplicación de pigmentos. Más allá de las vinculaciones significativas entre estas tres prácticas y su orden secuencial, que hasta el momento con la información que poseemos nos es difícil de determinar, nos muestra como las vasijas a lo largo de sus vidas fueron acumulando, historias y relaciones diferentes con objetos, espacios y sujetos distintos. En el caso de la fermentación de bebida, que se vincula con el consumo de chicha, sabemos que ciertas vasijas como las de clase E de forma "a" y "otras formas", en general ocuparon durante ese momento ciertos espacios menos dinámicos, como son los rincones de las habitaciones, o contra los muros de las mismas y que se llegaron a vincular a vasijas de forma "ab" las que permitían trasladar o transferir la bebida a otros lugares, pero no es tan clara su vinculación con vasijas de clase A1 como las escudillas, los vasos o jarras; por lo que quizás para el consumo intervinieron otros recipientes de material perecedero. Pero además sabemos que la preparación de la chicha requiere la participación de otros objetos y varias acciones, antes de que se ponga a fermentar (Cultler y Cárdenas 1985; Pazarelli y Vargas 2008), que no necesariamente dejan huellas, para los que se necesitarían análisis más finos para llegar a determinarlas. Por lo que las vasijas que fermentan probablemente llegaron a vincularse a 
otras, tales como los platos grandes donde se procesan vegetales. El consumo de chicha como práctica, es frecuente y común en muchas de las sociedades andinas y de tierras bajas, tanto prehispánicas como actuales (Arnold 1998; Cutler y Cárdenas 1985; Descolá 2005; Pazarelli y Vargas 2008; Randall 1993). Esta puede ser preparada a base de maíz, mandioca, maní, algarroba, quínoa, etc. Aunque en Ambato aún no tengamos estudios que nos permitan conocer con precisión con que se la preparaba, la presencia de marlos de maíz en las habitaciones, nos podría indicar su utilización. No obstante la utilización de la algarroba tampoco puede ser descartada dada la presencia de algarrobales en el valle. Beber chicha en el mundo andino y en el de las sociedades de tierras bajas, suele ser una práctica cotidiana, e inclusive se señala como una fuente de nutrientes muy importantes, base de la alimentación de algunas de ellas (Descolá 2001; Cutler y Cárdenas 1985, Pardo 2004). Suele ser un elemento infaltable en diferentes fiestas y celebraciones de carácter más restringido o colectivo donde se encuentra condensando según los contextos donde se la toma múltiples sentidos sociales, simbólico, cósmicos, genealógicos etc. En Ambato, por lo que pudimos observar la chicha parece beberse cotidianamente en tanto que aparecen vasijas con sus marcas en todos los sitios. En algunos de ellos, particularmente en los más grandes con sectores, las prácticas de bebida, tuvieron vinculaciones con la reproducción de colectividades mayores. Si retomamos lo planteado por Gordillo y Ares (2005) para La Rinconada -e inclusive podría ser extendido para otros sitios semejantes, como Bordo de los Indios y Huañumil-, algunas de las prácticas donde llegaron a participar las vasijas halladas en la estructura 5, que almacenaban grandes cantidades de chañar, o inclusive aquellas con marcas de fermentación con volúmenes que alcanzan los 250 litros, el mayor encontrado en el valle, estaban destinado a un consumo más amplio que el familiar, e incluso al de la población residente en el sitio donde fueron halladas. Además plantearon que dicho consumo pudo ser destinado a las reuniones que se realizarían periódicamente en el lugar, en el espacio más amplio a manera de "plaza" que presenta el sitio; por lo que estas vasijas cuando fermentan chicha o almacenan el chañar, no solo quedan implicadas en escalas sociales, temporales y espaciales distintas, más amplias, si no que también a los ritmos temporales que impondrían esas celebraciones.

Para el caso de la manipulación de pigmentos y su aplicación, sabemos que conforma la última de las etapas en las que suelen participar las vasijas, por lo menos que hayan dejado una marca identificable. Éstas almacenan y manipulan distintos colores, rojos y blancos. En estas prácticas se utilizan vasijas de "otras formas" de clase E y A1, de forma "ab", escudillas y modeladas. Aparecen asociadas a objetos tales como conanas y manos. Los espacios donde se las ejecuta comprenden tanto los recintos techados, como las 
galerías y espacios abiertos que no llegan a conformar verdaderos patios, como es el caso del recinto $\mathrm{H}$ del sitio Piedras Blancas. A su vez se utilizaron no solo colores distintos si no pigmentos del mismo color pero de composiciones distintas. De los análisis realizados, los pigmentos asociados a estas vasijas no serían los que se usan en la pintura de las vasijas antes de cocinarlas, sino más bien pintura post cocción, particularmente pigmento blanco colocado en las incisiones de las vasijas negras de clase A1. En este caso lamentablemente no podemos saber en que momento se lo aplicó si al inicio de su trayectoria o posteriormente y si se vinculaba a una resignificación de esos objetos, un cambio de estado en la biografía de los mismos. Además, el pigmento se utilizó para pintar las paredes tanto de las habitaciones como de los muros perimetrales, los hay rojos y blancos. También como hemos señalado cuando analizamos los fragmentos de cuerpos, algunos cráneos aparecían pintados con manchas negras o rojas, lo que nos habla de la participación del pigmento en los proceso de trasformación de estos fragmentos. Pero también el pigmento, participó en el entierro de los cuerpos enteros. Esto nos lleva a que nos adentremos en la etapa intermedia.

La etapa intermedia entre estas práctica como dijimos se vinculó con el almacenamiento, procesamiento, manipulación, cocido y consumo de carnes y vegetales. Es decir con prácticas culinarias, entre las que se encontraban las antropofágicas. En el capítulo anterior señalamos que estas prácticas junto con aquellas que conservan el cuerpo entero implicaron en su ejecución que los cuerpos de ciertas personas perduraran, aunque de manera invisible, en el sustrato donde se desarrollaba la vida social y; por otro lado, que los cuerpos de otras personas, por medio de su dislocación, desmembramiento y descarnado, se disolvieran, como parte de un proceso generativo, genésico de un cuerpo nuevo, sin forma, sin límites precisos, indefinido; los diferentes sujetos o partes de ellos, junto con sus edades o trayectorias biográficas particulares de duración variable, devinieron un collage (de camélidos y humanos), una amalgama que los fusionó y resignificó en un cuerpo “otro". Este proceso, a su vez, permitió transformaciones futuras de las partes fragmentadas, en tanto que habilitó, no solo su perduración como fragmento, si no también su modelado como instrumento, o su trasformación en otro objeto; hasta que al final fueron incorporados donde iban a parar la mayoría de las cosas al término de sus trayectorias biográficas, a los montículos. Estos nuevos sujetos multiformes y, esto nuevos objetos, habitaron el espacio más dinámico, permanecieron visibles, fueron manipulables. Ambas prácticas no distinguieron patrones de edad. Así la experiencia cotidiana de los vivos -sus biografías-, sean estos niños, jóvenes, adultos o viejos, transcurrió en un espacio-tiempo, en la interfacie donde limitaron, se opusieron, se excluyeron y definieron 
mutuamente aquellos cuerpos enteros y los que devinieron fragmentos. Pero además ambas prácticas implicaron espacios que no están totalmente superpuestos. Aquellos sujetos enterrados enteros, no sólo fueron habitantes del sustrato donde se llevó a cabo la vida social, si no que además habitaron el sustrato de los espacios más restringido de los sitios, sea en las habitaciones techadas o en recintos no techados pero de acceso mas restrictivo; no se adentraron en los patios que, como lo señalara Ares (2006) son espacios intermedios entre esferas semi-públicas o semi-domésticas. Ni tampoco trascendieron a estos, penetrando en un espacio aún más externo, trasponiendo, los muros perimetrales que rodean a los sitios pequeños, medianos, grande y muy grandes, donde suelen emplazarse los montículos basureros o; aquellos muros que en los sitios muy grandes con sectores delimitan los patios de un espacio más público como la plaza, donde se encuentran las plataformas -antiguos montículos basureros-. En el caso de los sitios pequeños, medianos, grandes y muy grandes el lugar ocupado por el montículo, conforman un área en cierta forma exterior a estos; un espacio que no posee una demarcación con lo que podríamos decir el "más allá" del sitio, por lo menos materialmente marcada. Lo mismo puede ser planteado para las plataformas de sitios como La Rinconada, en tanto que el espacio central a manera de plaza, no posee muros que restrinjan su acceso, su lado oeste está totalmente abierto, es permeable e invita a la visita. Pero, en cambio, todos los sitios sin importar el tamaño, poseen muros y vanos que limitan el acceso al o los patios. Esta área "mas externa" donde están los montículos y las plataformas, es una suerte de región liminal entre el espacio que es compartido por los que habitan el sitio y aquel otro compartido entre estos con los "vecinos" que refiere a relaciones y colectividades mayores de las que habitan el mismo y, que median la articulación de estos grupos al paisaje mayor que señaláramos en el capítulo cuatro. Es justamente en ese espacio liminal donde los nuevos sujetos indefinidos, armados con partes distintas y de sujetos diferentes, se adentran en zonas en las cuales dominan relaciones sociales más colectivas, pero que explícitamente, por medio del montículo, como desarrollaremos en profundidad más adelante, condensan las prácticas de grupos más restringidos. Es en este sentido que estos "nuevos sujetos" forman parte de los diálogos materiales a través de los cuales, los distintos grupos domésticos de carácter más restringido en Ambato se llegaron a autodefinir como tales y por medio de esto definieron su relación con grupos mayores, tales como las aldeas (Assandri 2007).

Así la vida de las personas en Ambato, sus biografías, transcurre en esa geografía, sus cuerpos desde su nacimiento e incorporación a la vida social hasta su muerte, se hallan interpelados por ambas actitudes corporales, sus devenires se dirimen a través de ellas, y en 
ellas encuentran sus lugares de pertenencia, su constitución como sujetos sociales. No existe lugar visible en el espacio colectivo para "un" cuerpo fijo, no transformado en un collage, no metamorfoseado; pero a su vez, este proceso que si no se lo controla puede llegar a producir la aniquilación o disolución de los sujetos y con ellos de los grupos de pertenencia, en tanto abre la posibilidad de transformaciones y resignificaciones continuas; llegó a ser limitado, suturado, y amenazado, por la fijación en espacios más restringidos "menos colectivos" de cuerpos enteros de "un" solo individuo, de un sujeto, algunas veces solo, otras junto a objetos que, en sus cuerpos, llevaron las marcas de sus trayectorias biográficas y que narran las relaciones que los mismos entablaron con los sujetos enterrados, a lo largo de sus vidas en dichos espacios.

Las vasijas como hemos visto no sólo llegaron a acompañar a estos sujetos enterrados, sino que también junto a ellos, antes de su muerte, y junto los otros, que luego devinieron fragmentos, transitaron por las mismas geografías espacio-temporales y fueron partícipes en sus producciones.

Las vasijas que participaron en dichas prácticas ocupando diferentes roles fueron las de clase E de forma "a", de "otras formas", de forma "ab" y, las de clase A1 -aunque también participaron objetos pertenecientes otras clases tecnológicas- de forma "b", de forma "c" y las escudillas. Estas vasijas se utilizaron para realizan distintas acciones sobre los cuerpos. En primer lugar los almacenan ya dislocados, desmembrados, descarnados y mezclados -partes de distintos individuos y como dijimos de edades, especies y ell@s diferentes-. En segundo lugar participan en la transferencia de estos a lo lugares donde se los cocina, en las habitaciones techadas y; en tercer lugar, se las utiliza para cocinarlos y luego para consumirlos. Es decir que están implicadas desde el inicio de este proceso. Una de las características de los procesos en los cuales intervienen es que son temporarios, están dirigidos siempre hacia un momento posterior. En este sentido la vinculación de estas vasijas con los procesos preformativos de lo cuerpos es temporal, en tanto que el contenido almacenado o cocido, siempre abre a otro proceso, sea el consumo o la posibilidad posterior de los fragmentos de cuerpos de trasformarse en instrumentos o en otros objetos. En este sentido el tiempo de vinculación entre las trayectorias biográficas de esas vasijas, con las trayectorias biográficas de los sujetos presentes que están siendo contenidos o cocinados en estas, es corto y siempre vinculado a un momento posterior, el de sacar ese contenido hacia fuera y permitir su transformación. Si pensamos esta acción de contención temporaria, estas vasijas, en esa etapa biográfica pueden ser vinculadas y contrapuestas con otros contenedores que están almacenando a los individuos, también humanos y camélidos, 
de edades distintas, solos o acompañados de objetos, aunque de una materialidad diferente: las fosas, donde aquellos sujetos y objetos fueron depositados especialmente.

La fosa cumple en este caso el rol de acoger tanto a los objetos como a los individuos. En este sentido, acoge de la misma forma que las vasijas. Sin embargo, este acoger de la fosa, que en algunos casos como hemos visto fue excavada en los pisos de las habitaciones, y en otros por debajo de los muros, puede ser diferenciado del acoger de las vasijas. Las fosas, indican eventos más cerrados, en los que los objetos e individuos allí dispuestos quedan recluidos, pensemos en la fosa que fue excavada por debajo del muro de uno de los recintos del sitio Piedras Blancas en la que su apertura requeriría romper parte del mismo. Por su parte, el sentido de acoger de las vasijas refiere, como hemos mencionado, a un ambiente de contención temporaria, siempre dirigidos a un proceso posterior, trasformativo. Así, la masa de fragmentos de individuos almacenados, procesados, cocidos o a punto de ser ingeridos en las vasijas, en algún momento es extraída de ellas. La vasija, en tanto recipiente que los acoge, produce y reproduce, en cierta manera, estos sujetos multiformes $y$, por medio de este proceso, las discontinuidades que mencionáramos arriba, aunque de una manera temporal. Así, en el momento biográfico donde estas vasijas almacenan, transportan, cocinan etc., se transforman en agentes, en tanto producen y reproducen las discontinuidades, entre sujetos fragmentados y no fragmentados. La fosa, en cambio, como acogedora, perpetúa e inmoviliza las relaciones que allí son puestas en juego. Tanto el individuo como los objetos allí depositados ocupan un lugar determinado en ese espacio discreto, habiendo sido colocados de cierta manera y no de otra. Recordemos al niño dispuesto sobre una laja pintada de rojo con su cuerpo en posición extendida en sentido norte-sur, así como la vasija de aspecto zoomorfo y la mano de conana ubicadas, cada una de ellas, a la derecha y a la izquierda respectivamente de donde debían localizarse sus pies. Al igual que el camélido enterrado en el sitio La Rinconada, dispuesto totalmente extendido junto a una placa cuchillo con la que probablemente se le dio muerte. Todos los integrantes dispuestos en la fosa, se encuentran realizando una coreografía lenta y casi inmutable, imprimiéndose en esa perpetua pantomima de muertos una individualidad a cada uno de ellos -en tanto ocupan una posición fija y determinada- imposible de pensarse sin esa delimitación precisa de sus disposiciones relacionales. En este sentido, los objetos de las fosas como las vasijas, al igual que los individuos enterrados en ellas, entablan relaciones de oposición, a la distancia, con los individuos fragmentados colocados en las vasijas y no con las vasijas que permiten el proceso. Así, las identidades relacionales que se ponen en juego al interior de la fosa entre distintas individualidades reconocibles, entre el cuerpo de un sujeto y objetos 
-inextricablemente conjugados-, se vinculan y oponen a las identidades fusionadas de los distintos sujetos introducidos dentro de las vasijas. Fosas y vasijas se vinculan en tanto son acogedoras y reproductoras de dichas discontinuidades. Sin embargo, los tiempos diferentes en que los individuos fragmentados son almacenados, transportados y cocinados, por las vasijas, y los individuos enteros contenidos por las fosas- uno muy corto y otro muy largo-, produce que las fosas y las vasijas se distancien. El que la fosa, en cierta forma fije el significado de los objetos como de los sujetos incorporados en ellas, nos lleva a que en el capítulo que sigue, analicemos las intersecciones posibles de realizar entre las trayectorias de los otros sujetos y objetos, no incorporados en las fosas, con las estructuras, que al igual que las fosas pretenden inmovilizar determinados significados e identidades, los montículos basureros hallados en el valle, algunos de ellos transformados en plataformas ceremoniales.

Pero antes de llegar a ellos, debemos realizar un paso más y mostrar de qué forma se produce el tránsito entre las temporalidades contingentes de los encuentros que venimos describiendo, en el cual toda práctica ocurre, y temporalidades más largas como las que condensan los montículos, es decir debemos preguntarnos de que manera en Ambato dialogaron contingencia y estructura.

Para reflexionar sobre este diálogo, nos situaremos en un lugar específico, el recinto F del sitio Piedras Blancas y en un momento específico, cuando lo estábamos excavando. Este emplazamiento espacio-temporal se debe a que fue durante la excavación cuando muchas de las vasijas aquí analizadas junto con otros objetos que empiezan a aparecer en el recinto comienzan a interpelarnos sobre ciertos supuestos con los que encaramos la excavación, que se vincularon con los principios de estratigrafía arqueológica propuesto por Harris (1991) -capítulo 3 y anexo IV-: algunos de estos objetos, como hemos visto en el capítulo seis, estaban apoyando en la interfacie de un "piso" muy consolidado en algunos sectores, y otros, en las interfacies de diferentes estratos -como los fogoncitos o braceritos excavados desde ese "piso"- o asociados a estos. Entonces, un interrogante comenzó a cuestionar aquellos primeros supuestos referidos a la propuesta con la que habíamos emprendido la excavación: ¿a qué estrato debían asociarse estos objetos? Si seguíamos el lineamiento de la excavación por unidades estratigráficas debían ser asociados al estrato donde apoyaban, pero perdíamos, en cierta forma, las relaciones que entre sí mantenían en un momento determinado de su historia como objetos. Estas relaciones trascendían de alguna manera las relaciones estratigráficas de superposición o subyacencia, en tanto todos formaban parte de un escenario significativo, donde se 
desarrollaba la vida cotidiana de los que vivían en este sitio. Esta inquietud nos comenzó a trazar un sendero de reflexión que nos condujo a discutir críticamente el lugar ocupado por los objetos en la teoría de Harris y a evaluar la importancia de las interfacies e interfacies de período para aprehender otros tipos de relaciones -además de las estratigráficas-. Es en este espacio donde se producían los encuentros o diseminaciones de las biografías de los objetos y sujetos, es decir la trama de las geografías espacio-temporales. Además nos permitió identificar y especificar cómo en Ambato, a través de las prácticas de limpieza de los pisos de las habitaciones, las vasijas, los cuerpos fragmentados y demás objetos pasaban a incorporarse a temporalidades más larga.

\section{Mediaciones entre contingencia y estructura: las interfacies como limen}

Quien conozca la propuesta Harris podría preguntarse el por qué interrogarnos, sobre el lugar de los objetos en la misma, siendo que dicho autor le otorga un lugar determinado, con límites bien precisos. La misma persona podría invocar la palabra de Harris para precisar ese lugar diciendo que el establecimiento de la secuencia estratigráfica de un yacimiento se realiza sin referencia alguna al material que contiene, y que los análisis artefactuales no pueden cambiar las relaciones estratigráficas en tales secuencias. Con lo cual nosotros acordaríamos completamente. Además, podría agregar que en palabras de Harris (1991: 176) "el objetivo principal de todo estudio artefactual es proporcionar una datación a cada estrato y elemento individual [y que] sin los hitos cronológicos que nos proporcionan los artefactos, la secuencia estratigráfica de los yacimientos arqueológicos carecerían de valor histórico cultural. [Además], el análisis de los restos aparecidos en una excavación debe basarse en la secuencia estratigráfica del yacimiento ya que ésta muestra la posición relativa en la que fueron hallados." (Harris 1991:164). Con lo cual nosotros también acordaríamos. Entonces, esa misma persona, una vez delimitado el lugar, y advirtiendo nuestra conformidad sobre el mismo, volvería a cuestionaros el por qué preguntarse aún por el lugar que ocupan los objetos en la interpretación de la estratigrafía de un sitio arqueológico, específicamente haciendo referencia a la propuesta de Harris.

Para aclarar esta pregunta, vamos a describir la manera en que dicho interrogante fue corporizándose como un problema que debía ser discutido. Esto nos lleva a situarnos en un lugar y un tiempo específicos, esto es, en la habitación mientras desarrollábamos la excavación. 


\section{Durante la excavación...}

Luego de la primera intervención realizada en 1999, en el recinto sudeste, en la que como ya señalamos se siguió el método de decapage, se continuaron las excavaciones en dos períodos de trabajo 2004 y 2005.

Primer período: se planteó la excavación con una serie de cuadrículas rectangulares de $5 \mathrm{X}$ 2,5 m en el sitio Piedras Blancas, tratando de cubrir la esquina SO del sitio, ya que se suponía que se trataba de un sector de galerías techadas. Así las cuadrículas conformaron una L, la parte más corta de la L -ubicada contra el muro este- se superponía a la cuadrícula excavada la vez anterior -cuadrículas B, A y MF de figura 6.90-. En la excavación anterior, sólo en un sector -SO de la cuadrícula MF- se había alcanzo el techo carbonizado. En el resto de la cuadrícula MF y Sector O de la cuadrícula A, no se había llegado aún al techo, habiéndose levantado los derrumbes del muro E -de columna y tapiay parte del derrumbe del muro sur, -también formado por columnas de piedras y tapia-. Una vez establecidas las cuadrículas comenzamos a excavar siguiendo los principios del método estratigráfico. Durante este primer período de excavación se definieron 10 unidades estratigráficas -figura 8.1-: seis unidades corresponden a derrumbes de muro y a rellenos -por acarreo eólico y fluvial- posteriores a los derrumbes. Dos corresponden al derrumbe del techo incendiado: la unidad [7] se definió como la torta del techo y la unidad [8] como la mezcla de la paja, enramada y los troncos del techo. La unidad [9] corresponde a un lavado de un muro de tapia y la última, [10], a un piso consolidado. Durante este período no se terminó de excavar [8] ni se pudo definir completamente los límites de [10]. Durante la excavación de [8], comienzan a aparecer ciertos hallazgos -una vasija cerámica globular, una pipa, una pelvis de camélido, placas de mica, entre otros objetos -figura 8.2-, que estaban apoyando en una superficie muy consolidada, posteriormente definida como [10]. En ese momento fue interpretado como un piso consolidado sobre el cual se habría derrumbado el techo. Los troncos y ramas que formaban parte del techo se encontraban aplastando a los objetos que apoyaban en [10]. Hasta ese momento, estos hallazgos no nos generaban ningún interrogante sobre el lugar que debían ocupar en la estratigrafía; de hecho, siguiendo los principios de estratigrafía arqueológica, fueron asociados al estrato donde apoyaban, es decir, al piso consolidado [10]. Al final de este período y en virtud de observar que los troncos del techo quemado se extendían hacia el norte, sobrepasando el límite de la excavación, se decidió ampliar la misma hacia esa dirección a fin de destapar completamente los troncos carbonizados del techo. 


\section{Matriz Estratigráfica del primer período Recinto F}

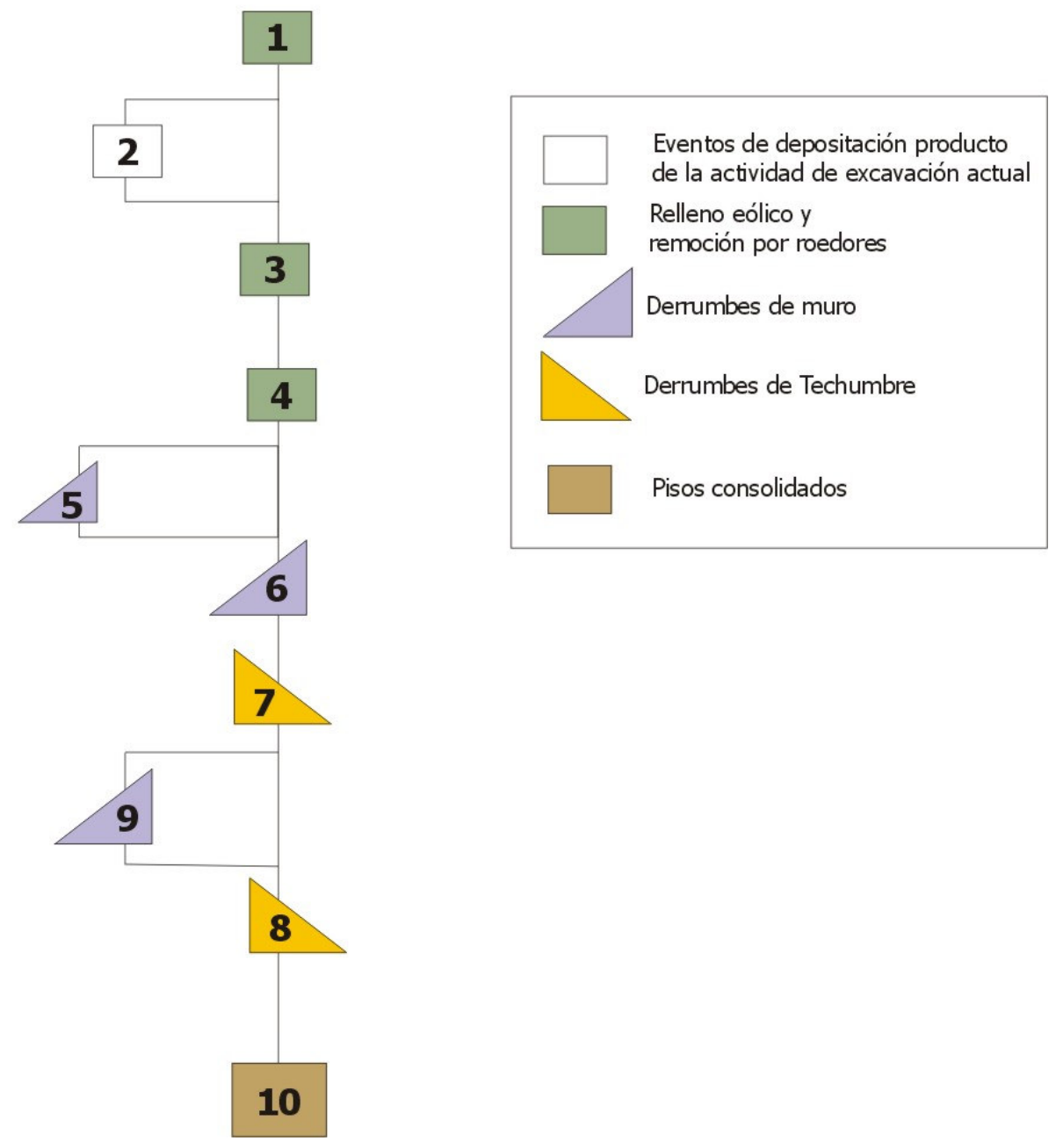

Figura 8.1: matriz estratigráfica del primer período de excavación del recinto F del sitio Piedras Blancas.

Segundo Período: se concretó unos meses más tarde. Con el objetivo de excavar todos los troncos del techo carbonizado, se definieron dos cuadrículas más-cuadrículas E y D- de 4 por 2,10 m, pasando a tener la excavación una superficie de $46 \mathrm{~m}^{2}$-figura 6.90-. Es durante este segundo período donde comienzan a surgir ciertas dudas e interrogantes, particularmente en relación a los hallazgos del período anterior que fueron incluidos en [10]. Durante este período de excavación se definieron 46 unidades estratigráficas más, algunas de ellas equivalentes con las identificadas en el período anterior -figura 6.92-. Aparecieron más estratos de relleno y derrumbes de muro de tapia y columna, mientras que lo que se comenzó a definir en el período anterior como [10] -figura 6.93-, se extendió al resto de la superficie excavada. Sobre éste, apoyaba en toda su superficie la unidad [8] figura 6.94 -troncos carbonizados, enramada y paja-, que no conformaba, como se hubiera supuesto, el techo incendiado y derrumbado de una galería, sino la techumbre incendiada y 
derrumbada de un recinto cerrado. Esto quedó aún más claro cuando se hallaron cuatro estructuras de sostén de poste en el centro del recinto con los postes carbonizados en su interior -figura 6.94 [39], [44], [49] y [54]-. También se definió una serie de estratos y elementos interfaciales verticales que se clasificaron como fogones de pequeño tamaño

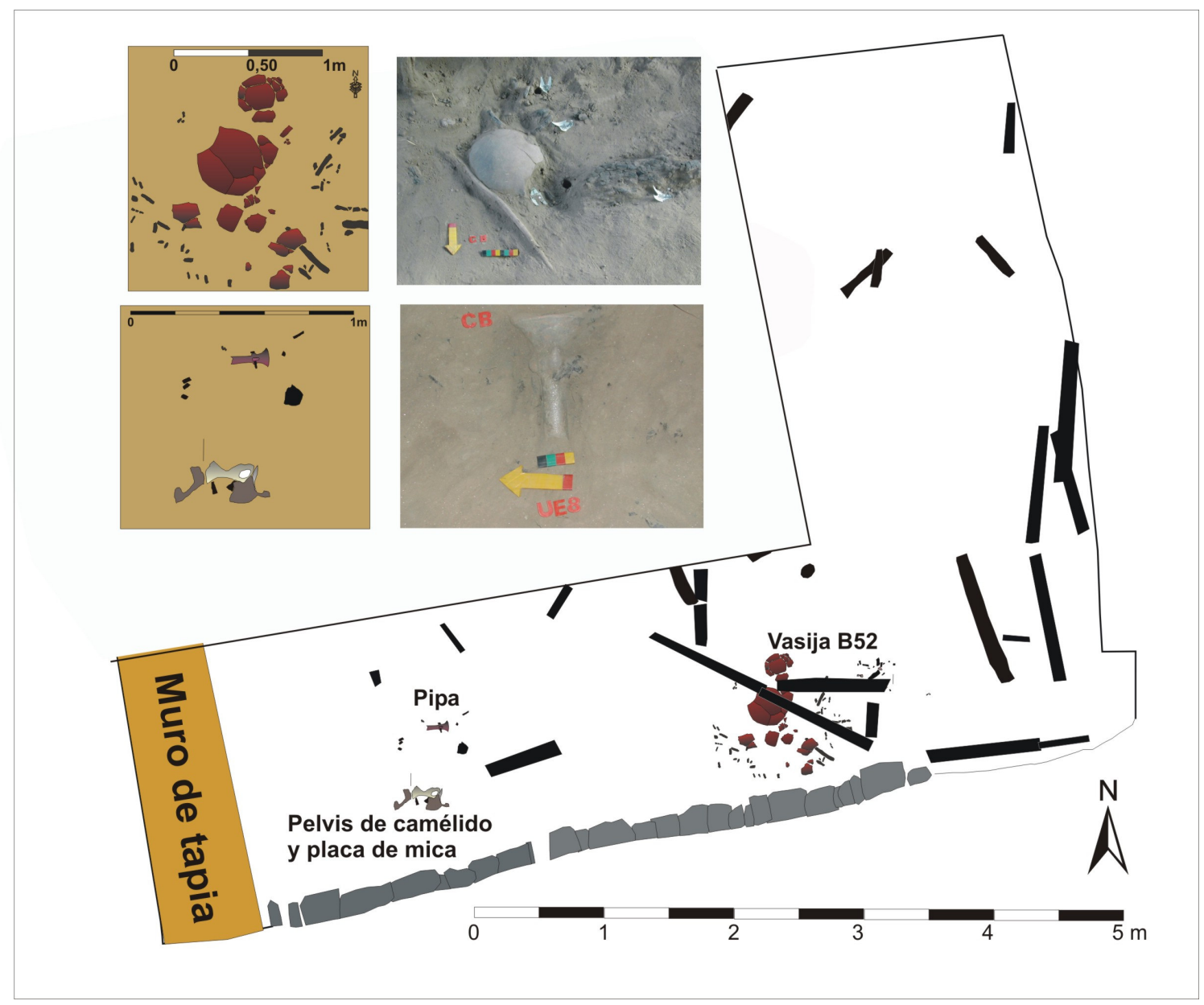

Figura 8.2: hallazgos durante el primer período de excavación.

repartidos por distintos lugares de la habitación -figura 6.94 [18], [22], [29]-. Las cubetas de los fogones -los elementos interfaciales verticales- se excavaron desde [10] -[19], [21], [33]-, y también se halló un estrato horizontal apoyando en el relleno de uno de las cubetas de fogón, que fue definido como producto de la limpieza del fogón [31]. A su vez, apoyando sobre [10], se halló una estructura de piedra que contenía en su interior tres vasijas -rotas por el derrumbe del techo- que se definió como [27] -figura 6.94 y 5.95-. También apoyando sobre [10] se identificaron dos estratos horizontales más, [24] y [26] figura 6.94 y 5.96-. Ambos estaban conformados por el contenido de dos vasijas que fueron rotas por el derrumbe del techo, y sus contenidos esparcidos en la inmediatez de las mismas. Estos estratos apoyaban en [10], pero también apoyaban en otro estrato [25] que, una vez extraídos [24], [26] y [10] se observó que conformaba la superficie natural desde la cual se construyó el recinto y sobre la cual se depositó [10]. En esta zona, el techo 
derrumbado apoyaba directamente sobre [25], no pudiéndose hallar [10]. Apoyando en [10] ,además de los objetos hallados en el primer período, se encontraron otros, también aplastados por el derrumbe del techo: una vasija roja de pequeñas dimensiones totalmente fragmentada pero posible de ser remontada completamente -figura 6.9, vasija roja-, un puco de color negro gris grabado, una segunda pipa rota, dos cucharas de madera fragmentadas, etc. Son estos hallazgos aplastados por el techo y apoyando en [10], los que, luego de ser levantados y comenzado a excavar [10], nos empiezan a marcar una duda, que era escrita de esta manera en nuestra libreta de campo:

\section{5-04-05}

“...se terminó de extraer la enramada (...) Una vez terminada la tarea se relevó la superficie que quedó expuesta. Esta conformaría el lugar donde estaban apoyando las cosas halladas (vasijas y pipas) que denominamos 10. Esta superficie podría conformar el piso donde se pisaba."

\section{6-04-05}

“...se empezó a excavar 10. Al sacar la primera extracción se observan hallazgos no horizontales de pequeño tamaño que no remontan entre sí, y los que, a diferencia de los otros hallazgos, no presentan huellas de carbonización en su superficie. Lo que podría indicar que conforman parte de otro estrato..."

En este momento una serie de interrogantes comenzaron a cuestionar aquellos primeros supuestos: ¿a qué estrato debían asociarse los objetos que habían sido aplastados por el derrumbe del techo y que se hallaban apoyando en [10]?

Si seguíamos los lineamientos de la excavación por unidades estratigráficas, los objetos debían ser asociados al estrato donde apoyaban, es decir [10]. Ahora si considerábamos como "inclusiones" de [10], tanto a los objetos que apoyaban en su superficie, como aquellos que comenzaron a aparecer al empezar a excavar dicho estrato nos surgían otros interrogantes: ¿no estaríamos creando relaciones significativas entre objetos que quizá no las tenían?, ¿no estaríamos perdiendo otras relaciones quizás más significativas que hubieran tenido estos objetos con, por ejemplo, la estructura de piedra y 
las vasijas contenidas en ella, o con los fogones que aparecieron sobre [10], o con [24] y [26] antes de que las vasijas se rompan y el contenido se esparciera?

\section{Los objetos y las unidades estratigráficas}

Como ya mencionamos, Harris señala que "el análisis de los restos aparecidos en una excavación debe basarse en la secuencia estratigráfica del Yacimiento, ya que ésta muestra la posición relativa en la que fueron hallados. La secuencia estratigráfica se forma sin referencia alguna al material que contendrá, por ello, los análisis artefactuales no pueden cambiar las relaciones estratigráfica halladas en las secuencias."(1991:165-166) Por otro lado, señala que el hecho de que los objetos incluidos en un estrato puedan clasificarse en originales -contemporáneos de la formación del estrato-, infiltrados -posteriores a la formación del estrato- o residuales - manufacturados en una época anterior a la formación del estrato- no afecta al registro de los artefactos:

“...el principal método para documentar el punto exacto del hallazgo de los artefactos es el registro tridimensional, de esta forma el punto del hallazgo se fija en el espacio y se emplaza en una secuencia de tiempo relativo a través del método estratigráfico, que lo remite al estrato en el que fue hallado. La asignación del número de estrato a todos los hallazgos a de ser axiomático, ya que así también se fijan los objetos en el espacio, que viene dado por los límites del depósito” (1991:170).

El objeto, entonces, adquiere identidad: por un lado por características intrínsecas que lo definen como un objeto de determinada época, y por el otro, al interior de la secuencia, por su inclusión dentro de un estrato, el que le otorga una ubicación en la matriz y un tiempo secuencial relativo. A su vez, nosotros redefinimos a la unidad estratigráfica como representativas de determinadas prácticas sociales, las que nos proporcionarían un marco para acceder -conjuntamente con otros tipos de análisis de los objetos- a los significados sociales que estos tuvieron en un momento determinado de su historia. De esta forma, los artefactos como inclusiones de una unidad estratigráfica, adquieren significatividad temporal y de sentido en función de su inclusión dentro de una unidad que si bien no es completamente cerrada, conforma por lo menos en la instancia analítica e interpretativa una unidad con ciertos límites, es decir, las inclusiones conforman con ella una especie de pequeño mundo cerrado de significación, quedando fuera de esto las relaciones que estos objetos pudieron haber mantenido con otros objetos - con los cuales no tenían relaciones estratigráficas significativas- durante un momento determinado de su historia. Esto nos 
trae de nuevo a los interrogantes con que finalizamos el acápite anterior. Si tomábamos a los objetos que apoyaban en [10] como inclusiones de éste, perdían en cierta forma las relaciones que podrían haber mantenido con otros objetos (como por ejemplo los de [27], [24], [26]) en un momento determinado de su historia. Estas relaciones trascienden las relaciones estratigráficas de superposición o subyacencia, en tanto todos formaban parte de un escenario significativo, donde se desarrollaba la vida cotidiana de los que vivían en este sitio del Valle de Ambato. ¿Cuál es este escenario?

\section{Los objetos y las interfacies}

En el campo, como se lee en la libreta, tomamos la siguiente decisión respecto al dilema que se nos presentaba:

"Se decidió separar estos hallazgos (los que surgieron al comenzar a excavar [10]) poniéndolos como inclusión de otro estrato [12]. La unidad 10 pasó conformar la superficie de apoyo de aquellos materiales (vasijas, ollitas, pipas etc.) que fueron aplastados por el techo."

Así [12] pasó a conformar el piso consolidado, es decir el lugar que le había sido otorgado a [10]. Este hecho nos hizo reflexionar sobre el rol de una de las categorías analíticas que Harris propone para comprender mejor la dinámica de formación de los depósitos estratificados: las interfacies. Esta categoría nos permitió abrir la posibilidad de observar relaciones entre unidades estratigráficas que en la matriz no poseen relaciones estratigráficas directas, y también poder establecer relaciones entre unidades y objetos, más allá de considerar a estos últimos como inclusiones de aquellas.

Harris define a las interfacies como la superficie de las unidades estratigráficas, siendo uno de los elementos más importantes que permiten identificarlas, conformando aquello que permite dividir la tierra en dos, diferenciar dos acciones o conjuntos de ellas y establecer las relaciones estratigráficas. Las interfacies se clasifican como elementos interfaciales -horizontales o verticales- si son de destrucción de un depósito, o interfacies de estrato -horizontales y verticales- si son productos de la depositación. Las interfacies de estrato horizontal son las superficies de estratos que se han creado o depositado más o menos horizontalmente, teniendo una extensión igual a la del estrato. Las interfacies de estratos verticales forman la superficie de un estrato vertical, generalmente un muro. 
Cuando un grupo de estas interfacies conforman una gran superficie se habla de interfacie de período.

En función de lo anterior, hasta el momento, [10] conformaría la interfacie de estrato de [12], que junto con las interfacies de estrato de [27], [26], [24], [25], [18], [21], [31], [29], constituirían una interfacie de período. Pero esto hace que nos volvamos a preguntar ¿a qué unidad asociamos los objetos que están apoyando en el piso [12]? Según Harris, las interfacies de períodos son el equivalente a la suma de las interfacies de estratos horizontales y verticales que conformaron niveles de uso coetáneos (Harris 1991:100). Por lo que a las interfacies de estrato que ya mencionamos debemos agregar las interfacies de estrato vertical de los muros sur, norte, este y oeste. Pero además nos queda por sumar otra interfacie de estrato que completa la interfacie de período mencionada y que redefine [10]: la interfacie de estrato formada por la superficie del techo que se derrumbó y aplastó los objetos. Esta interfacie de estrato, al estar aplastando a: 1) los objetos que apoyaban en [10]; 2) los objetos contenidos por [27] que apoyan en [10]; 3) a [24]; 4) a [26], nos vincula no sólo la totalidad de las otras interfacies, sino que además nos determina un momento específico de uso coetáneo -figura 8.3-. Probablemente, algunos de los objetos que apoyan en [10] (como la pipa, placas de mica y un conjunto de cuentas de collar) se hallaban insertos entre la enramada al momento de derrumbarse el techo. Por lo que [10], no sólo sería la superficie donde apoyaban los objetos aplastados por el techo, sino que conformaría un espacio liminar en donde los objetos que apoyaban en el piso, las cosas insertas en el techo, los fogones, las vasijas con sus rellenos, la estructura de piedra con sus vasijas, compartirían relaciones en un espacio significativo condensador de múltiples relaciones además de las estratigráficas. ¿Cuáles serían esas relaciones?

\section{Las interfacies y otras relaciones:}

A [10], lo hemos definido como una interfacie de período. En este sentido [10] nos marca un tiempo y un espacio de uso común y coetáneo. La duración del segmento de tiempo de la interfacie de período es difícil de determinar, pero en nuestro caso tenemos herramientas que nos permiten definir no cuánto duró el período de tiempo de usos en común de ese espacio, sino un evento específico de ese tiempo, marcado por una unidad estratigráfica y su interfacie: el derrumbe del techo. Ese evento y sus consecuencias -la rotura tanto de los objetos insertos en la enramada como de los que apoyaban en el piso de la habitación, así como la estructura de contención de vasijas- nos sitúa en un momento de corta duración, quizás un día o unas horas en las vidas de los que vivieron en dicha 


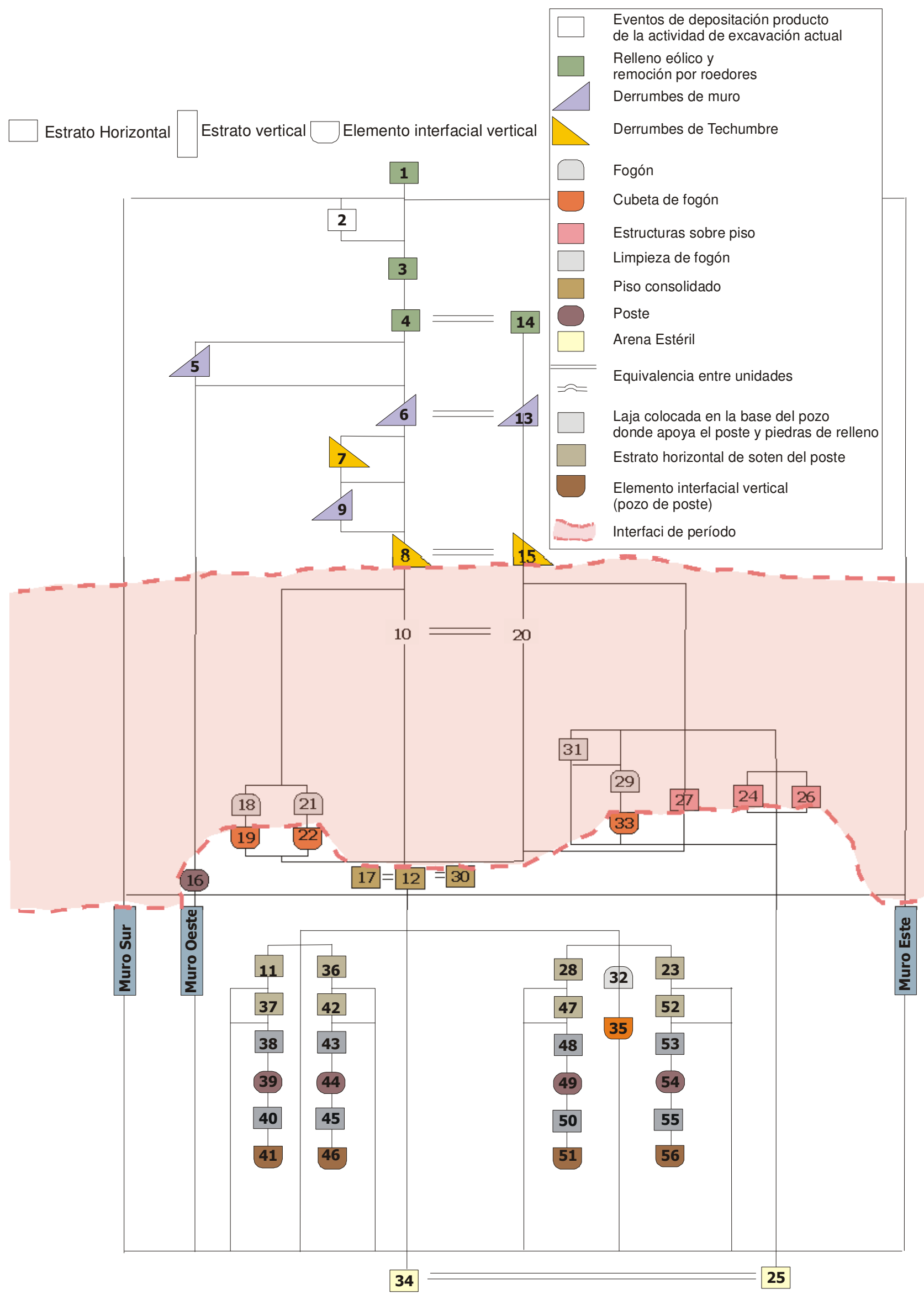

Figura 8.3: matriz estratigráfica del recinto f reinterpretada. La zona de color roza transparente se tarta de una interfacie de período. 
habitación. No sabemos el tiempo en el que los objetos dispuestos entre la enramada, apoyados en el piso o almacenados en la estructura de piedra, fueron ocupando, cada uno, el lugar que poseían antes de derrumbarse el techo, pero lo que sí podemos saber es que todos ellos se hallaban presentes en un momento determinado, aquél previo al incendio y derrumbe del techo. En este sentido cobra relevancia la separación de los objetos aplastados por el techo, de aquellos que se hallan incluidos en [12]. A [12] lo definimos como un piso, los que en general se asocian con acciones tales como barrido, pisoteo, extracción e inclusión de material (D’Amore 2002, Haber 2006). Por lo que los pisos de tierra, a pesar de que presenten un alto grado de consolidación, no son unidades totalmente impermeables, pudiendo contener inclusiones producto de las acciones descriptas anteriormente. En ese sentido las inclusiones de [12] representarían una parte de todas las acciones llevadas a cabo en el lugar. Por lo que si poníamos como inclusión de [12] tanto a los objetos que apoyaban en él, antes de derrumbarse el techo, como los que se habrían hallado insertos en las enramada del techo, hubiéramos perdido la posibilidad de vincular estos con otras unidades y objetos con los que mantenían relaciones significativas en tanto formaban parte de la geografía de la casa en un "día" determinado: tal como el caso de la vasija B52 -figura 6.94- -pertenecientes a las "otras formas" con huellas de carbonización en su superficie- que se hallaba al lado del fogón [18], y una de las vasijas almacenadas en [27] -perteneciente a la misma clase tecnológica "E" y forma que la B52- que presentaba, también, huellas de hollín en su superficie evidenciando su colocación sobre el fuego. Ambas vasijas mantenían relaciones que trascendían a las estratigráficas. Incluso pensemos en la vinculación entre el fogón [18] y B52, mucho más significativa, que la relación que tendría B52 con las inclusiones de [12]. Esto no quiere decir que las inclusiones del piso [12] no formasen parte de esta geografía, pero el piso y sus inclusiones, a diferencia de [10] nos remite a un tiempo más prolongado, en el que se condensa parte de la historia ocurrida en el lugari. Si comparamos el número de inclusiones registradas en [12], con el número de inclusiones registradas en [10], observamos una gran discordancia entre la cantidad y variedad de objetos utilizados diariamente, y lo que quedó de ellos como inclusión del piso [12] (del total de inclusiones registradas en la excavación, el $65.61 \%$ corresponde a [10] y sólo el $17 \%$ a [12]). Este hecho nos informa de una práctica de limpieza continua del piso de la habitación y de la extracción de las cosas rotas fuera de la misma. Por lo que las prácticas de limpieza están también demarcando fuertemente esa geografía cotidiana, y a su vez, produce que los objetos que apoyaban en la interfacie de [12], aplastados por el techo, y los fragmentos incluidos en [12], es decir aquellos que las limpiezas del piso no lograron barrer, se vinculen en otro plano. Los últimos son 
representantes de objetos que estructuraron otras geografías cotidianas sucedidas en la habitación, y que, al incorporarse a esta otra geografía -[10]- como inclusión del piso, expresa un proceso de más larga duración. Este hecho, a su vez, nos abre la posibilidad de vincular este lugar con otro ámbito del sito, vinculado a una temporalidad más larga que la que nos está marcando la geografía cotidiana de [10], en tanto posiblemente la esté fijando más allá de la contingencia en la cual lo cotidiano se produce y reproduce. Me refiero al montículo que forma parte del sitio donde se halla la habitación -figura 6.76-, cuya relación con ésta se hallaría mediada por las prácticas de limpieza de los pisos de la habitación: los "desechos" extraídos a través de las cotidianas limpiezas en la habitación, habrían sido arrojados -depositados-, en el montículo.

Esta estructura alcanza una altura de unos 2 metros, es de forma ovalada teniendo un largo de aproximadamente $25 \mathrm{~m}$ por unos 15 de ancho. Si bien en dicha estructura no se han realizado excavaciones siguiendo los principios de estratigrafía propuestos por Harris, por lo que no poseemos una secuencia estratigráfica en formato de matriz, se realizaron sondeos y trincheras que nos permiten aproximarnos a la historia de formación de los mismos a través del análisis de las secciones de estas intervenciones. La figura 8.4, muestra el dibujo del perfil sur de una trinchera realizada al montículo en sentido E-O -ver zona rectangular de excavación del montículo en figura 6.76-. En este perfil se puede observar la superposición estratigráfica de diferentes estratos, por lo menos unas 22 unidades estratigráficas. La disposición de dichas unidades presenta un buzamiento hacia el E lo que nos está indicando el sentido de la pendiente de la superficie donde se depositó cada una de ellas. Las 22 unidades son indicativas de una variedad de acciones que le fueron dando a este lugar la forma de una estructura monticular. Algunas de estas unidades poseen mayor volumen de sedimento que otras, las unidades [2], [4], [19], [18], [15], [20] y [14] son de mayor volumen, mientras que los depósitos de ceniza y carbón [21], [5], [6], [7], [8], [9], [3], [13] y [16], y el sedimento compacto [11] posen un volumen de sedimento menor. En la matriz estratigráfica construida de esta sección, se pueden apreciar las relaciones estratigráficas entre las distintas unidades. Estas relaciones, al indicarnos una cronología relativa de depositación de las mismas, nos permiten observar la recurrencia de algunas acciones en la formación del montículo, tales como la depositación de sedimento ceniciento y carbonoso, como la depositación de sedimento con fragmentos de muro de tapia derrumbado. Estos depósitos pueden vincularse con lo registrado en la habitación, como por ejemplo, la unidad estratigráfica [31], que conforma los restos de una de las limpieza del fogón [29], o los fragmentos de muro de tapia derrumbados hallados mientras se extraía el derrumbe del techo, semejantes a aquellos hallados en distintas unidades 
Sitio Piedras Blancas-Montículo

Trinchera M- Sección Pared Sur y Matriz Estratigráfica

W

W

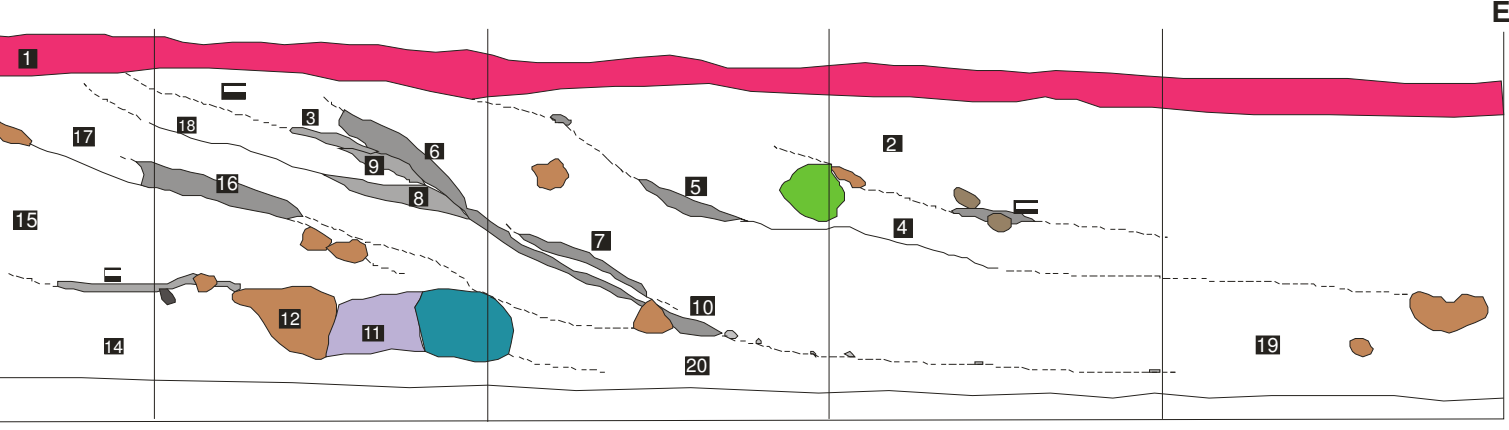

Remoción actual de sedimentos por laboreo de la tierra

Sedimento con ceniza y carbón

Sedimento muy consolidad (fragmento de muro de tapia)

Sedimento de relleno

Sedimento Compacto

Cueva de Roedor

Roca

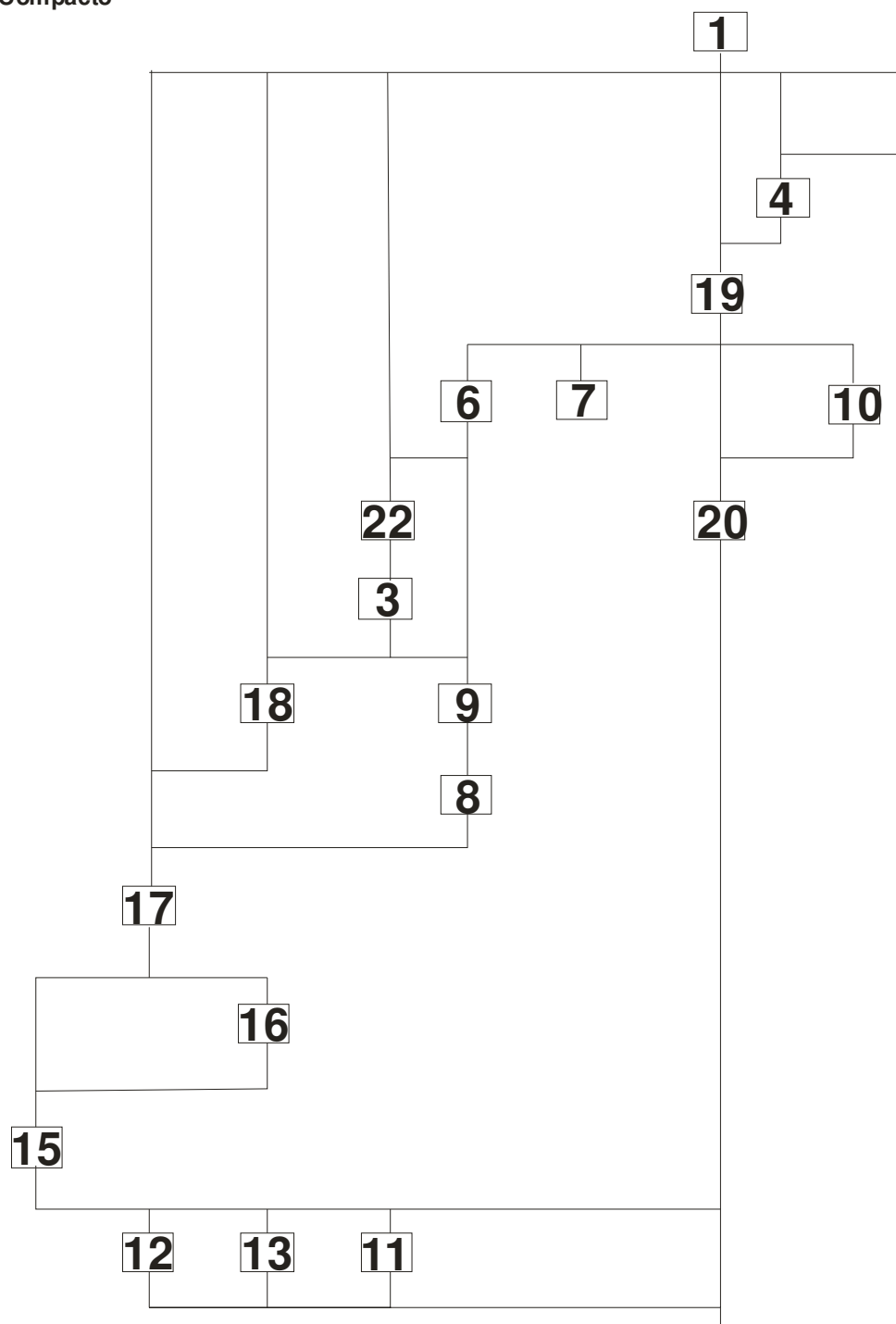

14

Figura 8.4.: dibujo de la sección sur de la trinchera realizada al montículo del sitio Piedras Blancas y la matriz estratigráfica reconstruida. 
estratigráficas del montículo. Por otro lado, las inclusiones que contienen los diferentes estratos que componen el montículo son representativas de gran parte de las cosas usadas en el sitio: restos de animales consumidos - en su mayoría de camélidos-, fragmentos de huesos humanos -que suelen aparecer como inclusión de los pisos-, pigmentos, semillas, instrumentos líticos -específicamente de cuarzo-, fragmentos de vasijas cerámica -entre ellas las analizadas aquí-, fragmentos de pipas, fragmentos de platos y demás objetos elaborados en cerámica, fragmentos de objetos de metal, e inclusive pequeños lingotes de cobre arsenical, etc. Sumado a esto, la temporalidad del uso de esta estructura es contemporánea con la del sitio. Esta estructura posee una temporalidad larga de conformación, con dos fechados radiocarbónicos provenientes del montículo (Marconetto 2008): el más antiguo 1340+ 40 B.P.-PB montículo (1)- y el más tardío 1040+50 B.P. -PB montículo (2)-, en años radio-carbónicos nos indica unos 300 años de diferencia. Si los comparamos con las fechas que provienen de otras habitaciones del sitio donde la más antigua es de $1370+70$-PB Rec C- y la más tardía es de 920 +70 B.P -PB Rec F (la habitación de la que damos cuenta en este trabajo), estas fechas nos permiten correlacionar el tiempo de uso del montículo con el tiempo de uso de las habitaciones. Al montículo, entonces, habrían ido a parar gran parte de las cosas que eran extraídas de la habitación por medio de las prácticas de limpieza. Así, las prácticas de limpieza de los pisos se conforman como prácticas que median entre los objetos que se hallan estructurando la geografía de la habitación en un día determinado, y aquellos objetos, que, en parte, quedaron incorporados como inclusión de [12], representantes de otras geografía cotidianas y que en parte fueron incorporados al montículo, comenzando a participar de esta manera de una temporalidad mucho más larga, la de formación del montículo, con una temporalidad de por lo menos 300 años. Los objetos son participantes activos en la estructuración de los espacios liminares definidos por Harris como interfacies de período. En estos espacios, los objetos aún no se hallan incluidos dentro de una unidad estratigráfica específica, sino que forman parte de esa aparente "superficie" donde se desarrollan las prácticas sociales, esa geografía espacio temporal, que se halla indisolublemente relacionada y constituida por la secuencia estratigráfica. Son las prácticas de limpiezas, las mediadoras entre contingencia y estructura. Es a través de su ejecución coreográfica, que las vasijas, los cuerpos fragmentados, y demás objetos transcurren y se desplazan desde un espacio-tiempo contingente, el de las interfacies, hacia un espacio tiempo estructural, al tiempo de la larga duración, es decir al montículo. Pasaremos ahora a observar las implicancias de este traspaso, y el rol de los montículos en la fijación de los significados en el largo término. 
Notas

i Pazzarelli (2006) llama a esto "historia de la ocupación". 


\section{CAPÍTULO 9}

\section{MEMORIA Y SENTIDO COMÚN: LOS MONTÍCULOS Y LA FIJACIÓN DE SIGNIFICADOS EN EL LARGO TÉRMINO}

Los montículos y especialmente las plataformas, como hemos visto en el capítulo 1 conformaron uno de los elementos, a los cuales se apeló como evidencia del proceso de integración ideológica y centralización del poder político-religioso en el noroeste argentino (NOA) durante el Período de Integración Regional. Forman y definen en parte a los llamados "centros ceremoniales" (González 1977, 1992, 1998; Gordillo 1990, 1995; Pérez Gollán 1986, 1991, 2000a), complejos arquitectónicos hallados en diferentes sitios del NOA, como el Valle de Ambato -La Rinconada, Bordo de los Indios, Huañumil-, y el Valle de Catamarca -Choya 68 (González 1998), Pueblo Perdido (Kriscautzky 1996-97); en la Rioja La Cuestecilla (Calegari 2006) ${ }^{\mathrm{i}}$. Estos complejos se componen en términos generales de una gran plataforma piramidal de varios metros de alto, dispuesta en algunos casos al lado de una plaza más hundida, rodeada de recintos habitacionales, adquiriendo el complejo una forma de U. Esta escenografía, que para muchos investigadores le otorga un aspecto monumental, más la presencia de huesos humanos fragmentados en los rellenos de las plataformas, que suelen asociarse a prácticas sacrificiales, completa el panorama que permite pensar a dichos lugares como complejos dedicados a la realización de ceremonias públicas. Además de la escenografía de estos centros, la iconografía de la cerámica Aguada hallada en estos lugares, en la que aparecen ciertos personajes ataviados que poseen en una mano un hacha y en la otra una cabeza cercenada -denominado el "sacrificador" (González 1998)- reafirmaría la realización de dichos rituales y ceremonias. Así, la presencia en estos edificios de carácter público-religioso -pirámide-, de áreas de concurrencia -plaza- y, por lo general de sectores residenciales, permitió diagnosticarlos como "CentrosCeremoniales" (González 1998; Gordillo 1990, 1995; Pérez Gollán 1991). Las interpretaciones realizadas sobre este tipo de arquitectura "monumental", como hemos referido en el capítulo 1 se encuadran en cierto marco según el cual "...los "monumentos" más prominentes en los Andes Centrales y Andes Meridionales, tales como las plataformas piramidales, es la arena donde se ejerce la violencia ritual o simbólica de las elites. El poder sagrado está focalizado en el centro, axis mundi del complejo ritual, que es activado por la elite para la realización de ritos de consumo que se juzgan cruciales para el éxito agrícola y la reproducción del orden socio cósmico" (Swenson 2003:257, la traducción es nuestra. 
En este capítulo discutiremos el rol histórico que le fue otorgado a los montículos ceremoniales como escenarios monumentales donde, a través de la puesta en escena de ciertos rituales se produciría la legitimación del poder político y religioso de las elites. Creemos que la importancia de estos montículos no se restringe a ser sólo soporte monumental de una dramaturgia diseñada para reproducir las relaciones de poder, sino que también, y fundamentalmente, son estructuras que, por la dinámica de su formación, las inclusiones materiales halladas y su larga temporalidad, muestran aquellos lugares donde determinadas prácticas sociales -no sólo aquellas vinculadas con aspectos del ceremonial religioso, sino también con las relaciones sociales de producción, las construcción de los grupos sociales y de los sujetos- pretendieron ser ahistorizadas, es decir naturalizadas, conformando parte del "sentido común" de los que vivieron allí.

Para comprender el lugar que ocuparon estas estructuras en el Período de Integración Regional, debemos situarnos en el proceso mismo a través del cual aparecen las sociedades campesinas, puesto que es ahí donde la conformación de determinadas relaciones sociales de producción y reproducción, enmarcó como posibilidad la construcción de los montículos del Valle de Ambato.

Para Vicent García (1991a), lo verdaderamente relevante de la agricultura es que implica la inversión de trabajo de rendimiento diferido, por lo que el problema no es sólo asegurar el éxito técnico de ese esfuerzo, sino garantizar el acceso a sus resultados.». El modo de vida campesino exige la institucionalización de la apropiación, tanto en lo que se refiere a la producción, como en lo relativo a los medios de producción. Así, las economías domésticas, además de la reproducción del ciclo productivo, tienen que lograr la reproducción de las células productivas y de las relaciones sociales de producción. En palabras de Meillasoux: «La posibilidad [que tiene la unidad doméstica] de beneficiarse en el futuro de su trabajo pasado y presente, está subordinada a su capacidad para reproducir las relaciones de producción, para crear la organización social de acuerdo a un esquema repetitivo y según las mismas estructuras.» (1984: 67). Así, a diferencia de sociedades con economía de caza y recolección donde predominan relaciones de reciprocidad generalizada dentro y fuera de los grupos sociales, por lo que son fundamentales las alianzas, en las sociedades campesinas se comienzan a restringir las alianzas intergrupales y se va abandonando la reciprocidad generalizada, institucionalizándose relaciones con mayor grado de exclusión en la apropiación de los recursos y el acceso a la tierra (Hernando 2002, 
Vicent García 1991b y 1991b) ${ }^{\text {ii }}$. Este cambio de una reciprocidad generalizada a una más restringida con respecto a otros grupos, implica no sólo poder legitimar dicha restricción, sino también la existencia de cambios en las relaciones de parentesco, de forma tal que cambie la estructura de los vínculos y obligaciones entre grupos (Hernando 2002:152). Este cambio, para Meillasoux (1984) implica el paso de un parentesco clasificatorio a uno genealógico. Así, la reciprocidad se limita al círculo definido por la unidad de parentesco, que constituye un segmento social autónomo y representa el sujeto de apropiación de los medios de producción: no es el individuo el que se apropia de éstos sino el grupo, el segmento de parentesco en su conjunto. El cambio de un parentesco clasificatorio a otro genealógico implica la entrada del tiempo, específicamente un tiempo pasado, es decir un tiempo genealógico vinculado a los antepasados. Como señala Criado Boado (1991:104) para la "racionalidad campesina [...] no sólo es la tierra de la que se deben apropiar a través del tiempo, sino que en el retorno cíclico de las estaciones agrícolas, bajo la necesidad de almacenar para más tarde, cobra cuerpo la dimensión temporal y la sociedad se acostumbra a pensar, no ya en un tiempo social paralelo a un tiempo mítico, sino en un tiempo social que ya tiene pasado, presente y futuro [...] Es más, los antepasados se convierten en la condición de posibilidad de la sociedad, ya que ellos representan mejor que nadie la tradición que sostiene la comunidad" iii . En este marco, veremos a continuación cómo, en el proceso de apropiación de los medios de producción por parte de las sociedades campesinas, en las que se comenzó a restringir la reciprocidad generalizada al interior del grupo de parentesco, los montículos del Valle de Ambato adquirieron su sentido como dispositivos a través de los cuales la construcción de un tiempo pasado se convirtió en una parte fundamental de la producción y reproducción de las relaciones sociales del grupo que vivió en el Ambato.

\section{Los montículos del Valle de Ambato y la apropiación del pasado.}

\section{I: Los montículos y su dinámica de formación:}

Los montículos del Valle de Ambato son en principio estructuras de tierra, que se elevan del espacio circundante hasta una cierta altura, llegando algunas a alcanzar los $3 \mathrm{~m}$ de alto. En el Valle de Ambato se han hallado por lo menos once de estas estructuras repartidas en diferentes sectores del fondo del valle -figura 9.1- siempre asociadas a cursos de agua, ya sea al lado del cauce principal que atraviesa el valle -Río de los Puesto- o cercanos a los arroyos tributarios de este último. Se presentan en dos modalidades, algunos 
están incorporados a los sitios de habitaciones -figura 9.2- y otros se hallan aislados a una cierta distancia de los sitios, a unos 50m aproximadamente.

Todos los montículos hallados hasta el momento en el valle, comparten por lo menos tres características:

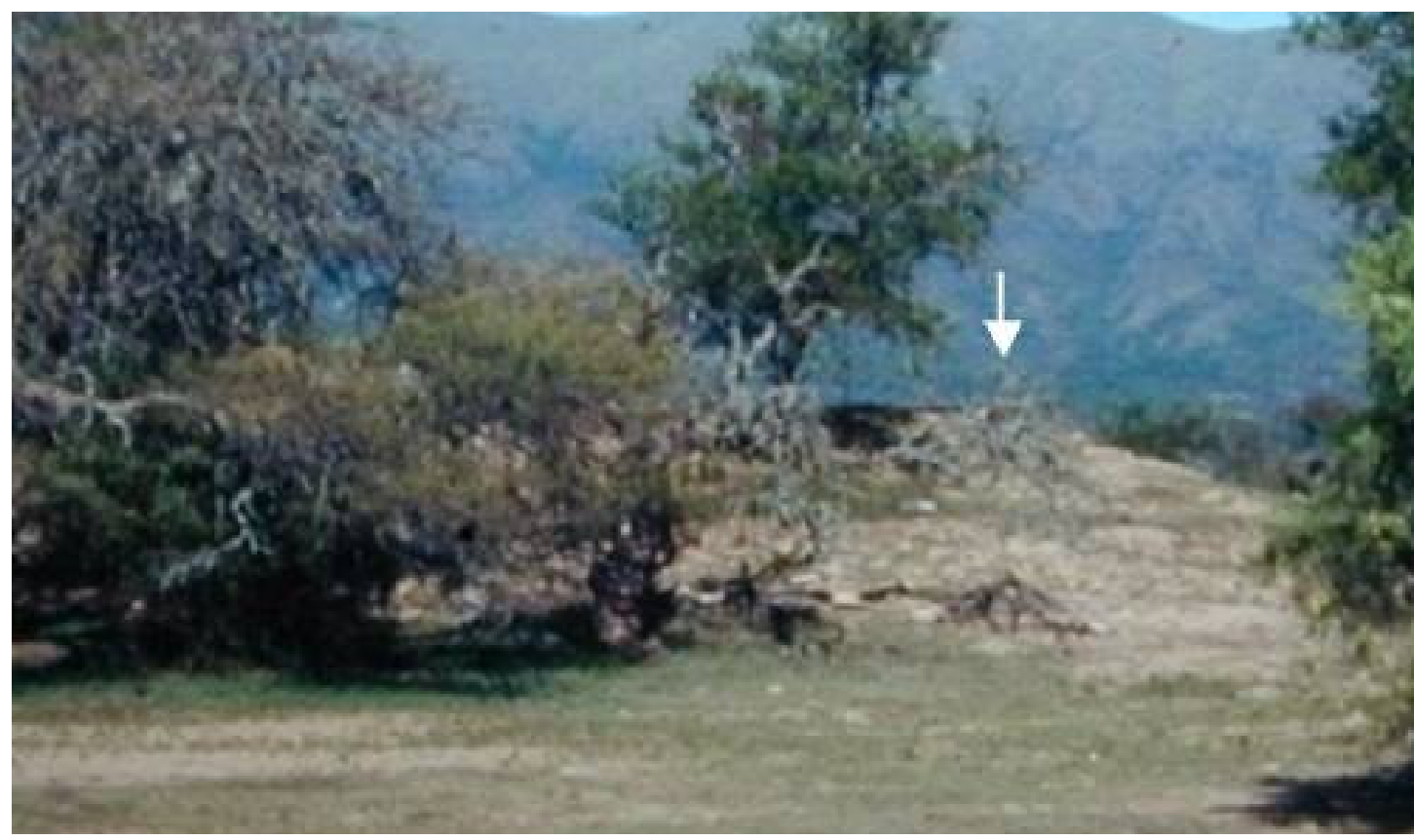

Figura 9.1: montículo ceremonial -plataforma- del sitio La Rinconada

\section{Primero: no parecen haber sido construidos de una sola vez, sino que su construcción} se llevó a cabo en diferentes momentos y progresivamente, por sucesivas depositaciones. Ya hemos visto el proceso de formación del montículo del sitio Piedras Blancas, en el que solo en un perfil de una trinchera pudimos registrar más de 22 unidades estratigráficas superpuestas -figura 8.4-. Otro de los casos es el del montículo del sitio Iglesia de los Indios -figura 6.103-. La rama sur está constituida por una estructura monticular artificial o "plataforma" de $21 \mathrm{~m}$ por 13,5 m que presenta una altura de mas de $3 \mathrm{~m}$ de alto. Se halla rodeada por cuatro muros de piedra. Además, en la parte norte la "plataforma", posee, a diferencia del la parte sur, el muro realizado de piedras planas, canteadas, y ensamblada con mucha precisión. La parte inferior de dicho muro está formada por una hilera de lajas dispuestas verticales coronadas con hileras de lajas dispuestas horizontalmente. En contraste, las paredes Sur, Este y Oeste, fueron confeccionadas con piedras redondeadas e irregulares. Posee dos rampas que probablemente sirvieron para el acceso: una se extiende $35 \mathrm{~m}$ hacia el oeste y la otra es más pequeña y conecta la plaza con la estructura por su lado norte. Según Gordillo (1990), no fue una estructura levantada de una vez, sino que tuvo reparaciones y agregados -tales 


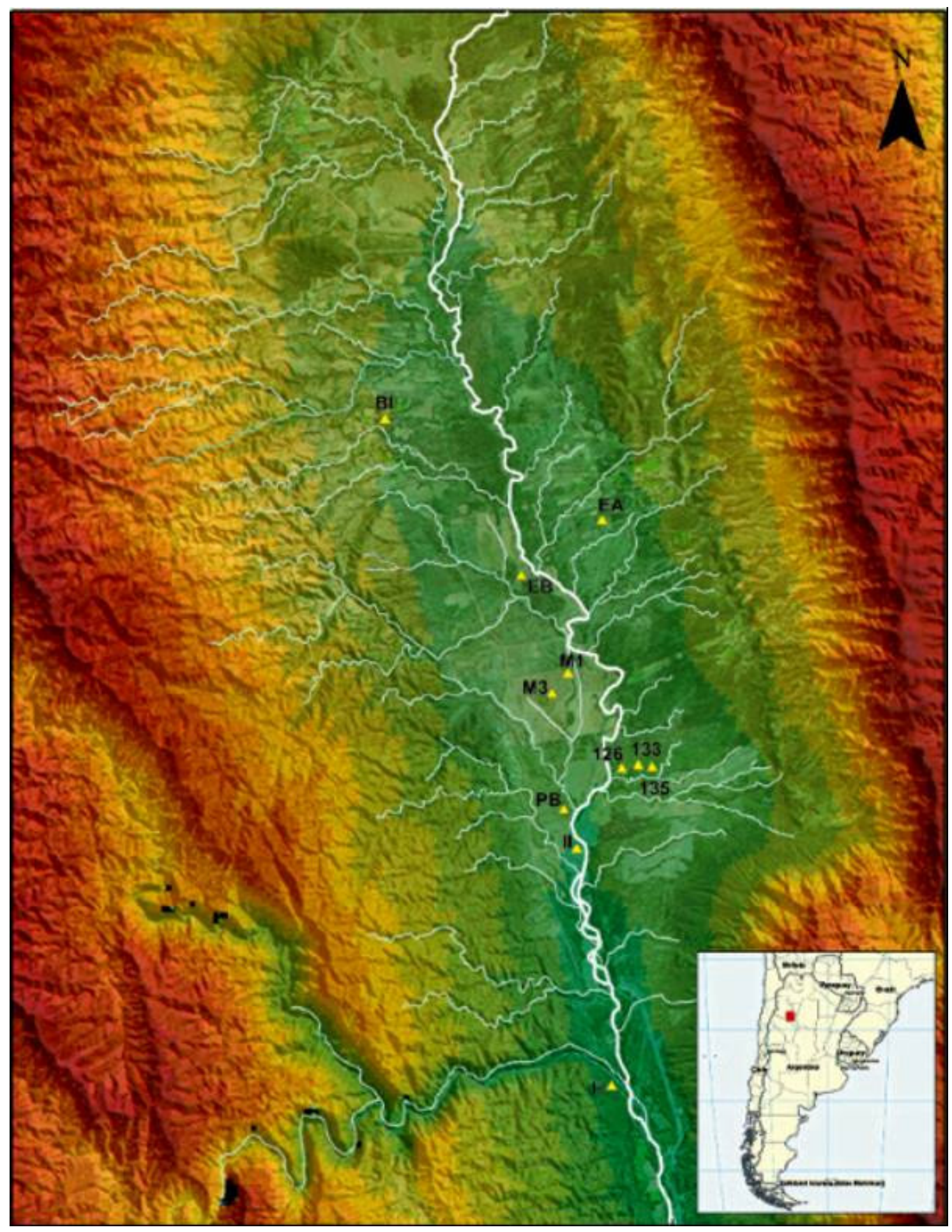

Figura 9.2: Los Cambios de coloración en el mapa indican cambios en la altitud, se puede observar que los montículos están en el mismo piso altitudinal en el fondo del Valle. Por otro lado la disposición en el espacio es cercana a los cursos de agua. Las abreviaturas indican el nombre de los sitios: BI (Bordo de los Indios), EB (El Bañado), EA (El Altillo), M1 (Martínez 1), M3 (Martinez3), II (Iglesia de los Indios), PB (Piedras Blancas), H (Huañumil). En el caso de los sitios 126, 133, 135, el número indica el nombre del sitio. 
como las rampas y muros que la rodean- a lo largo de su vida, es decir, su fisonomía "monumental" debió ser adquirida a través de una serie de intervenciones periódicas. E inclusive señala que dicha estructura se abría realizado aprovechando y resignificando una antigua área de acumulación de residuos (Gordillo 2006). Es decir sobre un montículo basurero, probablemente del estilo del sitio Piedras Blancas. En otro de los montículos hallados en el valle -sitio Martínez 3-, se identificaron al menos tres grandes capas de depositación que evidenciarían diferentes momentos en la conformación del mismo. Lo mismo sucede con el montículo de otro de los sitios excavados -El Altillo- en el que fueron identificados al menos cuatro grandes eventos de depositación de material.

\section{Segundo: todos los montículos poseen en su matriz inclusiones materiales semejantes.}

En el caso de los montículos de sitios como El Altillo, Martínez 1 y Martínez 3, la composición matricial de los mismos, junto con las características del material que los compone: restos de animales consumidos, fragmentos de huesos humanos, pigmentos, semillas, instrumentos líticos, fragmentos de vasijas, pipas, platos y demás objetos elaborados en cerámica, fragmentos de objetos de metal, etc., hizo que se los interpretara como depósitos de basura, como basurales que se habrían convertido en montículo debido a la acumulación continua de desechos. En el caso del sitio arqueológico Iglesia de los Indios, los restos encontrados también se hallan fragmentados, y hay huesos de animales consumidos, que, si bien evidencian para algunos investigadores actividades "rituales" -como los restos humanos trozados hallados en la matriz del montículo- la mayor cantidad de material hallado -además de los huesos, carbón, ceniza y abundantes fragmentos cerámicos- ha sido interpretada como "material de desperdicio": "basura". Ahora bien "la basura", que como categoría es una construcción actual y sería erróneo extrapolarla directamente al pasado, nos remite a las prácticas cotidianas en las que estaban insertos los objetos antes de que se los deposite en estos lugares, es decir a sus biografías. En el caso de las vasijas analizadas a todo su recorrido biográfico. Así, en algún momento estos objetos se dejaron de usar, ya sea porque se rompieron o porque se decidió dejar de usarlos. Estos objetos no fueron arrojados en cualquier lugar, por ejemplo en los campos de cultivos, sino que se los depositó en determinados lugares, en los montículos.

El tiempo de adquisición de la fisonomía monticular varió de montículo en montículo. Los fechados nos muestran una escala larga de formación de los mismos. Si observamos los gráficos 2 y 3 podemos apreciar esta larga duración. De los fechados obtenidos de las excavaciones realizadas (Laguens y Bonnin 1996, Marconetto 2008) - 
gráfico 9.1-, como el caso del montículo el Altillo el fechado más antiguo -EA nivel 17- es de 1990+70 B.P. y el más tardío es de 1390+ 80 -EA nivel 10-, es decir que en años radiocarbónicos nos indica un lapso temporal de unos 600 años de formación del montículo. En el caso del montículo del sitio Piedras Blancas poseemos dos fechados: el más antiguo del montículo 1340+ 40 B.P.-PB montículo (1)- y el más tardío 1040+50 B.P. -PB montículo (2)-, en años radio-carbónicos nos indica unos 300 años, pero si comparamos con las fechas que provienen del resto de habitaciones del sitio la más antigua es de $1370+70$-PB Rec C- y la más tardía es de 920 +70 B.P -PB Rec F-, es decir que en años radiocarbónicos tendría unos 450 años de formación. Existen otros sitios que presentan montículos asociados que arrojaron fechas que marcan también una prolongada formación de estas estructuras. El caso del sito Iglesia de los Indios posee fechados que van del 1800 +80 B.P. -LR muestra 6- al 840 +55 -LR muestra 8-, es decir que en años radiocarbónicos la ocupación del sitio es de uno 960 años de duración, lapso en el que el montículo se fue formando. Otro caso es el del sitio Martínez 2, donde el fechado más temprano que posee es de 1690+80 -M2 sec W(1)- y el más tardío 990+ 70 B.P. -M2 sec W(2)-, es decir unos 600 años. Los otros dos montículos que poseen fechados son Martínez 3 con una fecha radiocarbónica de 1700+60 B.P. y Martínez 1 1770+90 B.P., aunque al poseer sólo un fechado no podemos saber hasta cuándo se estuvieron formando. En el

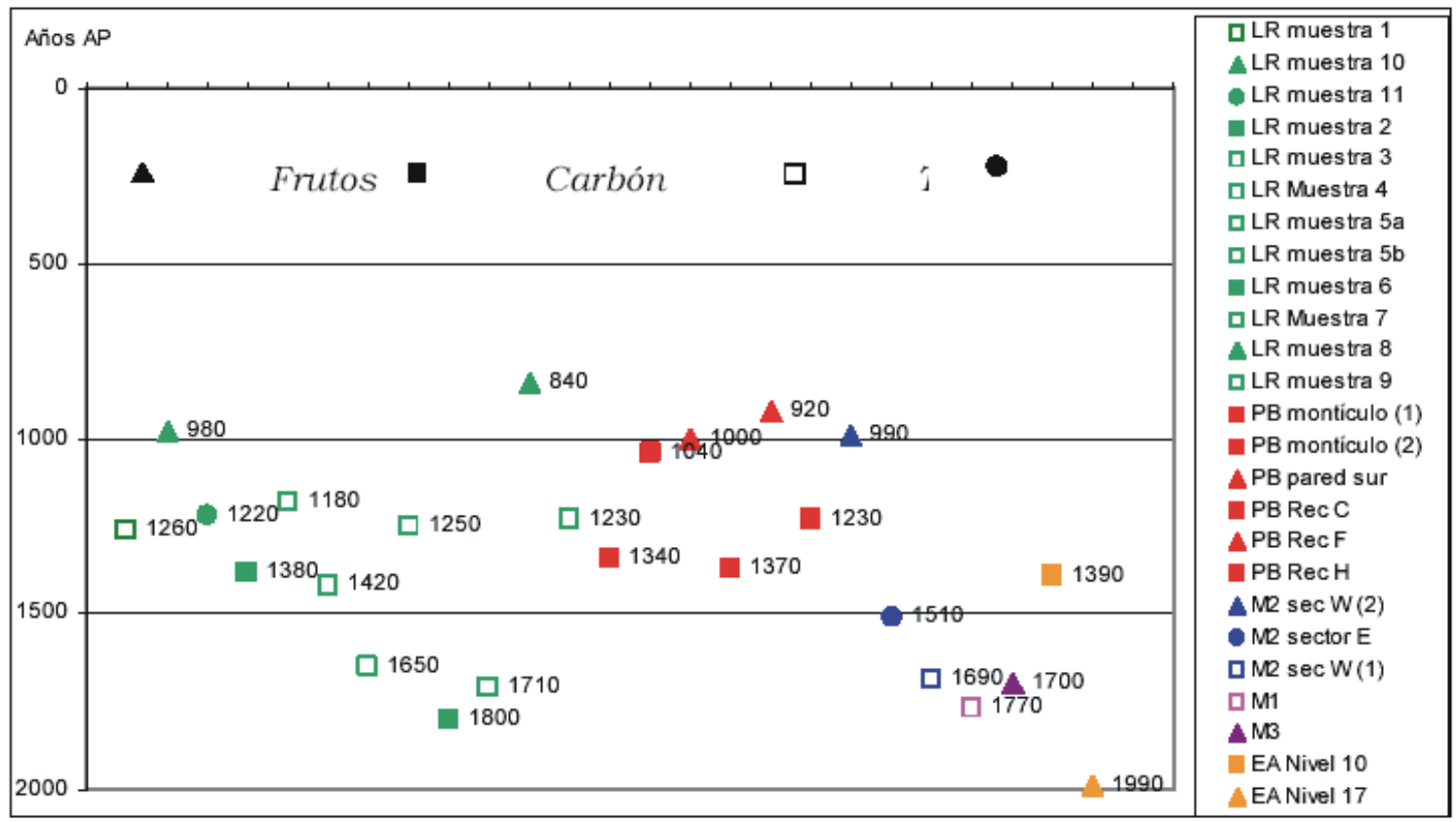

Gráfico 9.1: cuadro con los fechados del Valle (fuente, Marconetto 2008). 
gráfico 9.2 se pueden apreciar de manera más clara los lapsos temporales de formación de todos los montículos que poseen fechados.

En función de lo expuesto, podríamos decir que, en algunos casos, la formación del montículo nunca fue un proceso totalmente acabado. Los fechados más tardíos corresponden a una serie de eventos que muestran que alrededor del final del primer milenio e inicios del segundo milenio de la era, las aldeas del Valle de Ambato se incendiaron, lo que no sólo produjo que la formación de los montículos se detuviera, sino que el valle se deshabitara hasta tiempos más tardíos.

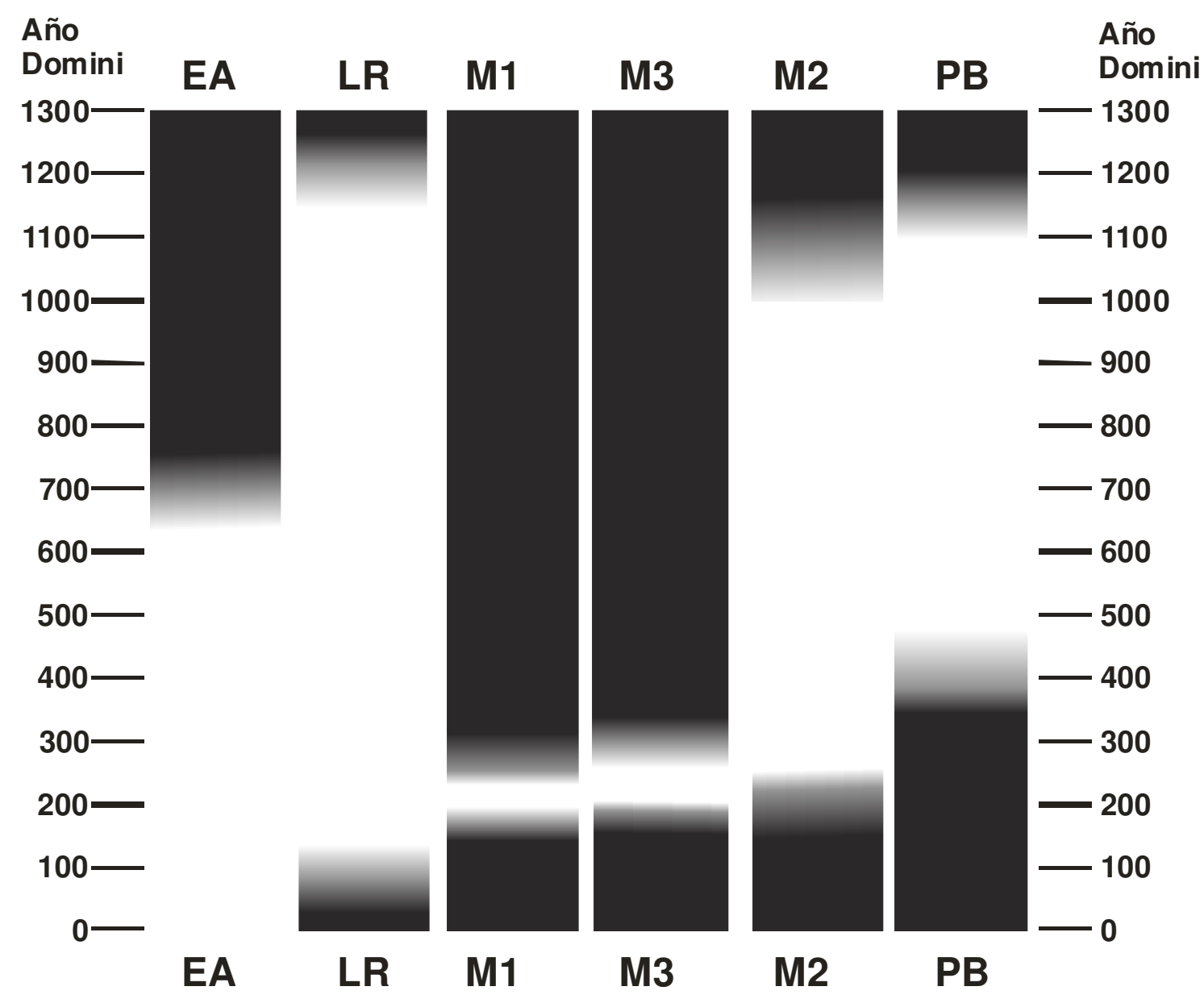

Gráfico 9.2: gráfico que muestra los períodos de formación de las estructuras monticulares de las que se posee información cronológica. Lo blanco indica ocupación, lo negro desocupación.

Tercero: algunas de las primeras acciones de depositación que comenzaron a formar los montículos se realizaron sobre recintos de piedra ya existentes. Estas estructuras son de forma circular realizadas con muro de piedra continuo. En el caso del sitio El Altillo -figura 9.3-, se observa una estructura circular de paredes de piedras de grandes dimensiones -unos 15m de diámetro aproximadamente-. En el caso del montículo del sitio de Piedras Blancas, la estructura hallada también posee una forma circular y es de muro de 
piedra continua al igual que el sito anterior, aunque en este caso no se pudieron determinar sus dimensiones puesto que la disposición de la trinchera de excavación no lo permitió. Los fechados más tempranos de los montículos hasta ahora conocidos, provienen de unidades estratigráficas que se hallan por encima de estas estructuras, por lo que podríamos suponer que éstas son más antiguas. Un caso interesante al respecto es el hallazgo de una ocupación anterior en el sito Piedras Blancas. En la excavación del recinto $\mathrm{H}$ de este sitio figura 6.76- -contemporáneo al recinto F-, se pudo observar que el mismo se levantó sobre unas habitaciones de muro de tapia ya existentes en el lugar -figura 6.10-. Quizás la construcción circular sobre la cual se empezaron a depositar los materiales que comenzaron a formar el montículo del sitio Piedras Blancas sea contemporánea a esta otra ocupación, que como hemos mencionado corresponda al Período Formativo.

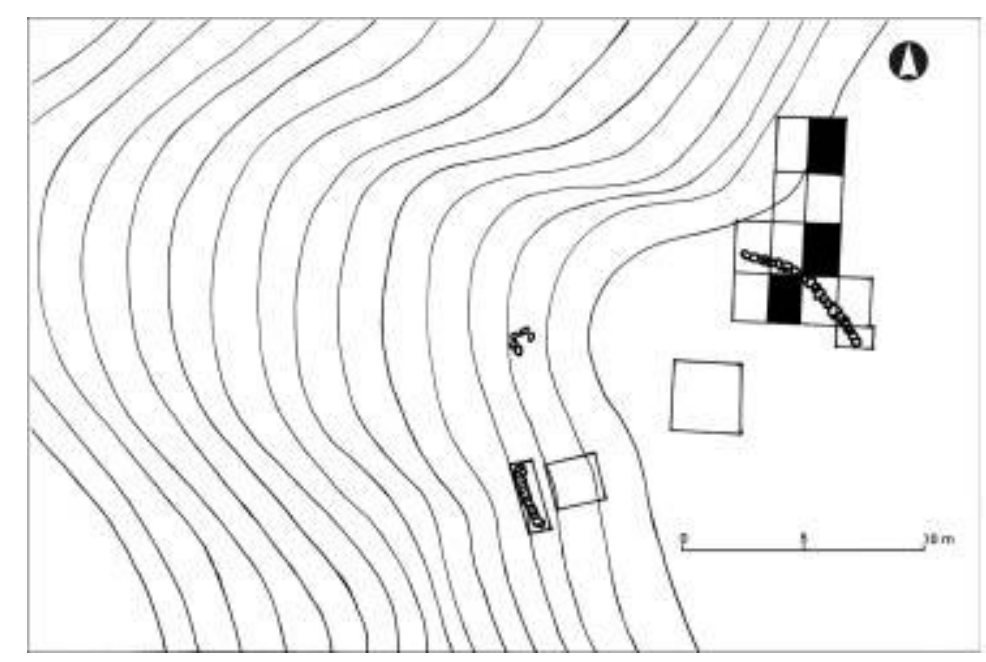

Figura 9.3: estructura hallada en la base del montículo el Altillo. Fuente Fabra (2007)

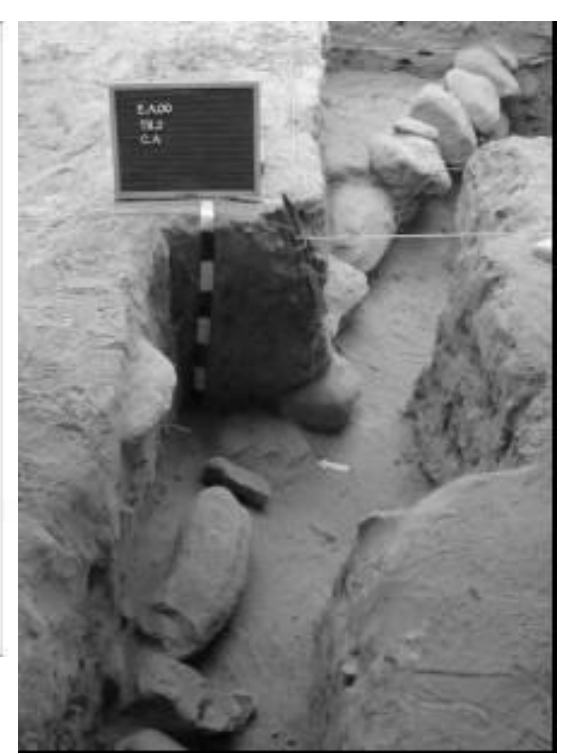

En resumen, podemos decir que la construcción de los montículos como estructuras sobreelevadas no fue ejecutada de una sola vez sino que requirió de intervenciones periódicas y continuas, durante las cuales y por largo tiempo les fueron siendo incorporados los diversos elementos que los fueron constituyendo como tales. En segundo lugar, los materiales que los iban transformando en montículos son representativos de las diferentes actividades realizadas en los sitios asociados a ellos. Y por último, algunas de las primeras acciones de depositación que comenzaron a formar los montículos se realizaron sobre recintos de piedra ya existentes.

En función de estas tres características que comparten todas las estructuras monticulares excavadas en el Valle de Ambato, podemos plantear que los montículos son 
aquellos lugares $^{\mathrm{iv}}$ (Giddens 1995) donde se intersectan y conjugan una multiplicidad de significados diferentes que nos refieren a los circuitos cotidianos donde los diversos objetos depositados allí y las personas que los depositaron estaban insertos. Además, es donde estos circuitos cotidianos pasan a formar parte indisoluble de una temporalidad muy larga vinculada a la historia de formación, podríamos decir de "sedimentación", de estas estructuras. Así, los montículos se fueron formando por una superposición progresiva de esas historias cotidianas, a la vez que dichas historias pasaban a formar parte de ese largo proceso de sedimentación, que es el montículo, que las trascendía y que tenía, en forma aparente, la traza de un tiempo inmutable.

\section{II: Los Montículos: sedimentación, visualización y monumentalización de un paisaje}

Señalamos que los montículos se disponían en el fondo del valle, cercanos a los cursos de agua que lo surcan. Dijimos también que podían estar incorporados al interior de un sitio, o a cierta distancia de ellos y que se comenzaron a depositar sobre antiguas habitaciones. Además señalamos en el capítulo anterior que, sea que formen parte de un sitio pequeño, mediano, grande, muy grande o muy grande con sectores, éstos se ubican o: por fuera de los muros perimetrales que delimitan los sitios o, en el caso de los sitios muy grandes con sectores, por fuera de los muros que delimitan los patios internos. En el primer caso tenemos por ejemplo el montículo del sitio Piedras Blancas, el que a su vez se emplaza en frente de la entrada al sitio. También ocurre lo mismo con el montículo del sitio Martínez 1 y el montículo Martínez 3 asociado al sitio Martínez 2 o 4. En el Caso de La Rinconada la plataforma, emplazada al sur del sector definido como plaza, se halla por fuera de los patios interiores, a los que solo se puede acceder atravesando un vano. El acceso a la plaza, a diferencia de los patios, no fue restringido materialmente, su lado oeste es totalmente abierto. Es decir tal cual lo expresamos en el capítulo anterior el montículo se adentra en espacios menos restringidos, por lo menos no materialmente. En este sentido, ocupa un espacio liminar entre el espacio compartidos por las personas que habitan los sitios y el espacio habitados por los vecinos en los cuales median relaciones sociales más amplias que las delimitadas al interior de los sitios.

A su vez señalamos en el capítulo cuatro, que en parte, la estructuración del paisaje del valle, se dio en relación a la apropiación del agua de vertiente y escorrentía en el que se producía una fuerte vinculación entre grupos que comparten el agua que baja desde las laderas hacia el río. Pero además señalamos que estos grupos podían al menos ser 
agrupados en tres grandes concentraciones o aldeas (Assandri 2007). Y que al interior de estas observábamos un estructuración particular: cada una de estas agrupaciones presentaría un sitio MGS, seguidos de vecinos de primer orden de tamaño $G$, luego por vecinos de segundo orden de tamaño M y de tercer orden de tamaño P. A su vez, al interior de cada una de las concentraciones, pueden distinguirse agrupaciones más pequeñas de sitios $\mathrm{P}$ en relación a sitios $\mathrm{M}, \mathrm{G}$ y MG, vinculados a determinadas torrenteras o arroyos. Por otro lado hemos señalado según las prácticas de recolección observadas en el valle, tales como la gestión de los recursos forestales, el monte, el que se halla rodeando a las casas, debieron cumplir un rol importante las aldeas a la hora de definir las formas de apropiación de esto. Recordemos que algunas prácticas de recolección de leña, como aquellas vinculadas al trabajo de metales podrían causar presión sobre el monte circundante, por lo que si bien a diferencia de a lógica de apropiación del agua de vertiente y escorrentías, es más difícil restringir el acceso a estos recursos del monte y por otro lado según las evidencias materiales no parecen haber sido restringidos. ¿Qué rol cumplieron los montículos en este particular paisaje?

El montículo es un lugar de ambivalencia espacio-temporal, en tanto que es producto de la reiteración de prácticas cotidianas, pero a la vez es también el lugar donde lo cotidiano se incorpora como sedimento a la larga duración y por ello sale de la cotidianidad. En este sentido, el montículo vuelve a ubicar en un plano de la naturaleza lo producido culturalmente, en tanto éste se vive como natural, puesto que siempre estuvo allí: es la expresión de una memoria que, dada la dilatada temporalidad de la misma, es en cierta forma inmemorial. El montículo como estructura en proceso de formación, también está en un continuo proceso de visibilización respecto del espacio circundante, adquiriendo de esta forma una monumentalidad que se expresa no sólo visualmente sino también temporalmente, convirtiéndose así en monumento. ¿Pero monumento de qué?. Dijimos que lo que ingresa en el montículo es representación de la variedad de prácticas realizadas por las personas en el valle: en el montículo se intersectan diferentes circuitos por donde las cosas depositadas allí pasaron, circuitos que se emplazan dentro de ese paisaje particular que predominó varios siglos. Es decir que en cierta manera los montículos son sedimento y monumento del paisaje del Valle de Ambato. Esta monumentalización queda más clara si pensamos la ubicación de los montículos en las partes altas de las barrancas con respecto a los arroyos. 


\section{Los Montículos y El Período de Integración Regional}

Retomando la discusión sobre la manera en que las sociedades campesinas deben apropiarse del tiempo pasado para su reproducción social, diremos que en los montículos se está corporizando una dimensión de lo temporal, comienza a visibilizarse en el espacio una noción de pasado, pero que a su vez vuelve a ser incorporada como parte de la naturaleza que no cambia, que es inmutable. Creemos que los montículos como estructuras monumentales producen no sólo la legitimación en la restricción del acceso a los lugares productivos de un grupo en tanto monumentaliza las prácticas llevadas a cabo en el lugar, sino que también delinea la estructura de los vínculos y obligaciones al interior del grupo y entre los grupos. En Ambato no podemos observar la construcción de un parentesco genealógico respecto de uno clasificatorio, hecho que en otros lugares se presenta como de fundamental importancia a la hora de delinear la estructura de los vínculos y obligaciones al interior del grupo y entre grupos. La muerte no se visibiliza, no hay visibilidad pública de los lugares donde son enterrados los muertos. Los antepasados parecen desaparecer del espacio social visible en tanto aparecen enterrados por debajo de los pisos de las viviendas, o son desarticulados y almacenados junto a los animales -camélidos- en grandes vasijas para luego ser consumidos y arrojados como otra inclusión dentro del montículo ${ }^{\mathrm{vi}}$. A diferencia de lo que sucede en otras partes de los Andes donde se construyeron monumentos funerarios, tales como los chullpares hallados en diferentes partes de Bolivia realizadas en adobe y en piedra alcanzando algunos más de $10 \mathrm{~m}$ de alto -un ejemplo de esto son las chullpas de Sillustani al lado del lago Umayo cerca del Titicaca, 1100 a 1450 d. C. (figura 9.4)-; donde puede observarse una monumentalización de la muerte, en tanto se inscribe visiblemente en el paisaje ${ }^{\text {vii }}$. En el valle de Ambato durante el período de integración regional, no se observa este proceso; quizás, como lo señaló Pérez Gollán (2000b), los suplicantes sean formas de rememorar a los antepasados y referenciar a un pasado genealógico viii. Pero esto en el Valle aún no está totalmente claro, todavía no han sido hallados ninguno de estos objetos. El grupo social como sujeto de apropiación, entonces, no se delinearía a través de la construcción de una serie genealógica y su inscripción en el paisaje a manera de monumentos. Creemos, no obstante, que el montículo como condensador de las prácticas llevadas a cabo en el valle, es la estructura a través de la cual el grupo se posiciona como sujeto de apropiación. En este sentido, el montículo se convierte en metáfora de lo social y por ello de lo real, a la vez que se emplaza como un ordenador temporal, como constructor de una memoria. Pero dicha memoria en el largo término del proceso de sedimentación, visualización y monumentalización del montículo, 
se incorpora como natural, y de esta forma, el montículo es emplazado en la naturaleza como símbolo metonímico que expresa continuidad y a-temporalidad. Es en este preciso lugar de ambigüedad donde el montículo cobra todo su sentido como estructura a través de la cual se produjo y reprodujo no sólo el paisaje del valle de Ambato del primer milenio, sino que, junto aquel, las relaciones sociales que entablaron las personas que vivieron en él.
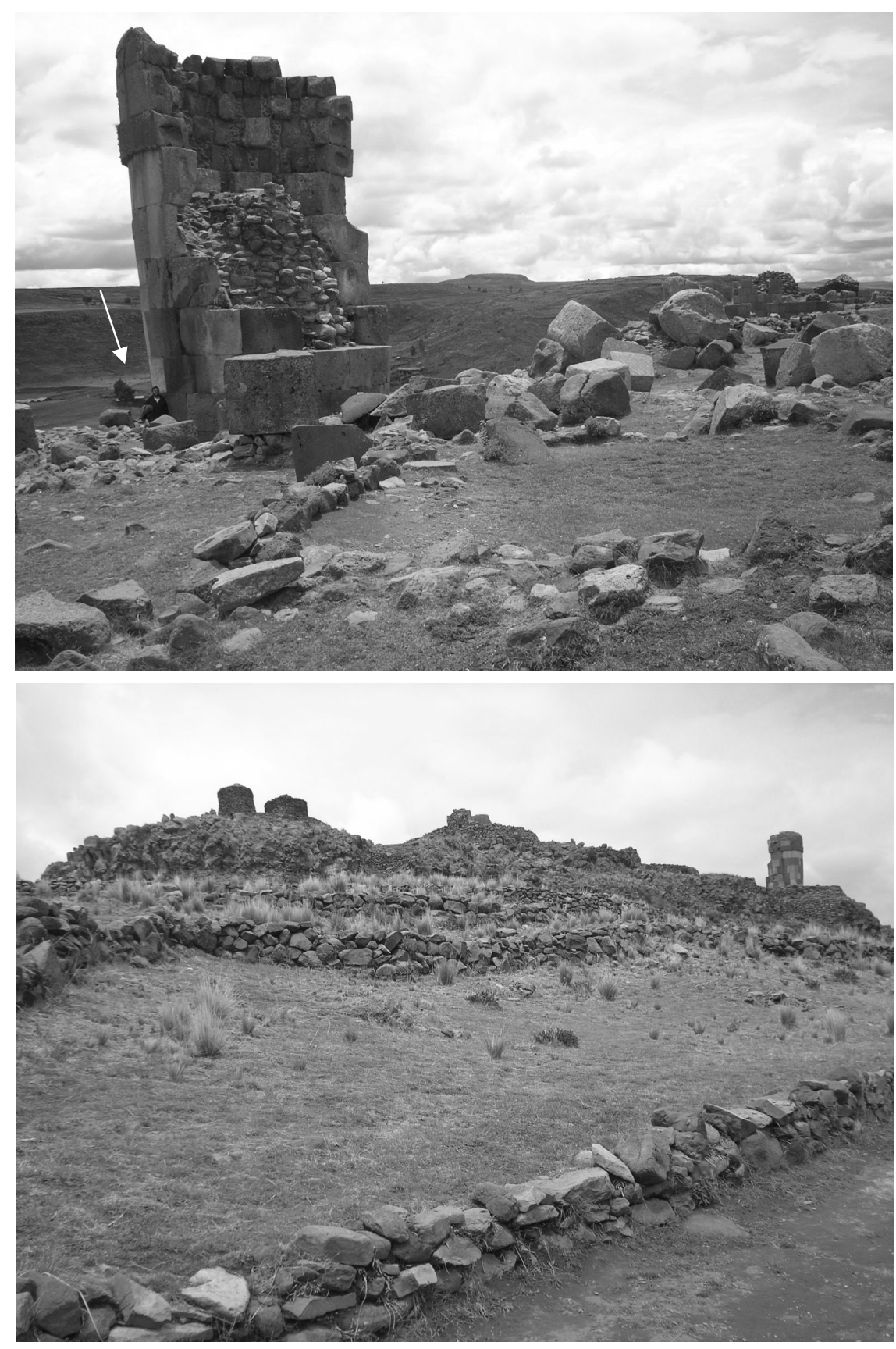

Figura 11: Chullpas de Sillustani, obsérvese como escala la persona que se halla en la parte inferior izquierda de la Chullpa que figura en la fotografía superior. 
Nos queda realizar una consideración respecto del proceso histórico de conformación y utilización de las estructuras monticulares. El sitio Iglesia de los Indios, como ya mencionamos, no fue construido de una sola vez. Según los fechados que hemos analizado, este montículo posee un largo proceso de formación del 100 d.C. al 1200 d.C. aproximadamente. A diferencia de otros montículos, que, como ya mencionamos, no presentan un proceso acabado - tal puede ser el caso de montículo el Altillo o Piedras Blancas-, sino que están en continua formación, al montículo de la Rinconada, en algún momento de esos 11 siglos de duración, se lo inmovilizó, construyéndole cuatro paredes a su alrededor que contenían su relleno, además de levantar dos plataformas de piedra que dan acceso a su cima y una plataforma de piedra que lo coronaba. Todos estos elementos constructivos funcionaron como dispositivos que a manera de cápsula pretendieron contener la memoria acumulada en dicho lugar y frenar la dinámica de sedimentación y monumentalización que lo transformó en montículo. Debemos tratar ahora, para comprender más profundamente este proceso, la manera en que determinados significados particulares pretenden ser universalizados y así fijados indefinidamente.

\section{Lo particular universalizado: la fijación de un pasado y la constitución de "una" memoria social.}

Como señala Laclau (1996:53), lo universal no es otra cosa que un particular que en cierto momento subvierte su estado y pasa a ser dominante. "Si (...) una objetividad [en nuestro caso la fijación de "una" memoria social] logra afirmarse parcialmente, sólo lo hace reprimiendo lo que la "amenaza", aquellos otros particulares que quedaron fuera de dicha construcción. Aquí debemos explicitar lo que entendemos por ideología, hegemonía y sentido común. Retomaremos para esto los planteos realizados por Isla (2002) sobre el concepto de hegemonía de Gramsci y las consideraciones que realizaron de sus planteos Jean y John Comaroff.

Según Isla (2002:21), para Gramsci "la ideología, alcanza en un proceso su significado más alto como concepción del mundo que se manifiesta implícitamente en el arte, el derecho, la actividad económica, y en todas las manifestaciones de la vida individual y colectiva". A su vez, señala que Gramsci distinguía en el "hombre común" una conciencia contradictoria implícita que lo sitúa como hombre de su época con una conciencia histórica, compartiendo una cultura. En este sentido dice que la comprensión crítica de sí mismo se da entonces a través de la lucha de hegemonías políticas para arribar a una elaboración superior de la propia concepción de la realidad. Este hecho para Gramsci 
no sería mecánico, sino el producto de un proceso histórico, por el cual la ideología que predomina se transforma en el desarrollo político de la hegemonía en sentido común. De esta forma, los textos de Gramsci, según Isla (2002:22) permiten distinguir la ideología, que como concepción del mundo en su fase inicial de predominio lucha con otras en términos discursivos y de las prácticas para alcanzar el predominio del sentido común que en otro plano, repleto de concepciones estéticas, valores, normas de vida trata de ser impregnado y remodelado por aquella. Triunfante este aparato hegemónico, crea un nuevo terreno ideológico, como reforma de la conciencia, que implica una nueva concepción del mundo y un nuevo sentido común. Si embargo en este proceso hay una lucha permanente por ampliar o reducir la hegemonía en el sentido común, es una lucha por la apropiación del sentido común y por ello del significado de la historia, del presente y del provenir. Gramsci dirá que es una lucha cultural donde el triunfo, o la hegemonía, nunca será completa, donde siempre habrá resistencia (Isla 2002:22). En una reinterpretación del sentido dado a estos conceptos por Gramsci, según Isla (2002:23) los Comaroff opondrán en su interpretación, los conceptos de Ideología y Hegemonía. Para ellos la Ideología no es sólo, como señala Gramsci, una concepción del mundo, sino la concepción dominante, la "verdad histórica" y "Universal". Luego la Hegemonía será ese orden de signos y prácticas, relaciones y distinciones, imágenes y saberes-inscriptos en un campo cultural situado históricamente, que es concebido como una imagen dada y naturalizada del mundo y de los habitantes del mismo. Isla comparte esta definición. Sin embargo, prefiere denominar a este proceso como "sentido común", visto como prácticas rutinarias o (rutinizadas), hábitos enmarcados en la tradición. Reservando el concepto de Hegemonía para una situación más dinámica de luchas de proceso de imposición de prácticas y sentidos como de su resistencia. Es así que para Isla, la hegemonía es algo nunca terminado, donde partes se contestan o resisten a la subordinación, otras se concensúan, otras se ignoran. Para este autor la hegemonía será el proceso de inscripción y conformación de los hábitos, proceso que se enriquece con las luchas que se producen en su interior.

En general, en los trabajos que trataron los fenómenos ideológicos ocurridos durante el Período de Integración Regional, la ideología, como desarrollamos en el primer capítulo, se halla más asociada a la definición de la misma como mistificación, en tanto enmascaraba diferencias sociales existentes. Es por eso que el despliegue de una dramaturgia en los escenarios monumentales se plantea como fundamental para reproducir las relaciones de poder. Así como la utilización de bienes que reflejan estatus y poder, tales 
como las placas metálicas con el personaje de las manos vacías o Punchao o la utilización de alucinógenos.

Creemos que lo que sucedió en algún momento del período de integración regional en el sitio La Rinconada, fue el intento de un particular de conquistar el sentido común de los que vivían allí y establecer una nueva "verdad histórica", un universal. Este hecho se vincula a un cambio del lugar de los montículos que en cierto momento fueron incorporados dentro de los poblados. Quizás esta doble inmovilización de los montículos, por un lado su incorporación a los poblados y por otro su encapsulamineto, fueron los mecanismos que permitieron fijar un determinado significado sobre ellos. Si observamos otros lugares del NOA donde han aparecido plataformas ceremoniales, tal como el sitio Choya 68, podemos observar, según nuestra interpretación, la consolidación de este nuevo sentido común. En el sector suroeste del valle de Catamarca, se han localizado cuatro estructuras que se interpretan como ceremoniales. Todas forman montículos de entre 3 y 6 m de alto. El montículo del sitio Choya 68 “...es de forma troncocónica, con la cúspide plana. La base es circular y tiene $25 \mathrm{~m}$ de diámetro. Su altura media desde la base de la construcción es de cerca de $6 \mathrm{~m}$ de alto, pero esa base se halla por debajo de la superficie del terreno actual (...) Este se halla muy lejos de ser una acumulación informe de rodados y sedimentos. Por el contrario muestra una cuidadosa planificación y construcción progresiva desde la base a la cúspide (González 1998:34-35)" Este montículo, a diferencia de los que estuvimos reseñando, fue construido en un solo momento, su emplazamiento se realizó de una vez, no existiendo un proceso de sedimentación y monumentalización creciente. Asociados a este montículo, aparecieron algunos fragmentos de cerámica típica de Ambato -negra gris grabada- y, en mayor cantidad, cerámica portezuelo. La cerámica portezuelo ha sido señalada como la última fase de Aguada (González 1998). Si observamos los fechados realizados en el montículo refirmarían esta interpretación, puesto que se ubican la mayoría por encima del 1000 d. C., correspondiendo los más tempranos alrededor del 800 d.C. En este momento, en el Valle de Ambato, específicamente en el sitio de la Rinconada, pero probablemente también en otros sitios -Bordo de los Indios, Huañumil, entre otros-, el proceso de fijación de "una" memoria ya se habría establecido, por lo que estas nuevas estructuras levantadas de una vez, podrían corresponder a ese nuevo sentido común, consolidado como ideología. Sin embargo, la conquista del sentido común, la fijación de "una" memoria, o de la "verdad histórica" como señala Isla no es un proceso totalmente acabado. Es decir, ese particular que se vuelve dominante, encubriendo a otros particulares que quedan afuera, no logra eliminarlos. Por un lado no hay "hegemonía" perfecta, puesto que ésta no logra que todos los contenidos normativos y 
orientativos de la cultura sean "no dichos", ni contestados, ni siquiera en el pensamiento íntimo de los sujetos (Isla 2002). Y por otro lado, el "particular" en el proceso de devenir "universal" realiza lo que varios autores desde posiciones psicoanalíticas llaman "efecto frontera" (Laclau 1996, Hall 2003). Esto lo hemos referido en las perspectivas que tomamos para comprender a las identidades sociales.

Siguiendo a Hall (2003) señalamos que la constitución de una identidad nunca es un proceso totalmente acabado. Los cierres que produce y la aparente unidad que proclama, sólo es ficticia, siempre hay un margen, algo que queda fuera. Este margen no puede ser incorporado totalmente, puesto que le es fundamental a su constitución, para su marcación de "lo que no es", por lo que es continuamente desestabilizada y amenazada por aquél. Es decir que siempre pueden existir nuevos procesos de suturación de significados. Pero creemos que existen determinados objetos, que como dispositivos materiales, logran producir un efecto de "desplazamiento de la contingencia". Si bien son producto de ella, en tanto que es en el marco de las prácticas de producción y reproducción social en que se forman y mantienen, lo visible es su larga temporalidad, su inmutabilidad. Así, producen un aparente quiebre, una discontinuidad en el fluir constante de las cadenas de significación por donde los sujetos se desplazan, en las que siempre puede haber una nueva condensación. Esta discontinuidad, que sólo es un transcurrir más lento de ese desplazamiento, produce un cierre de la cadena, pero que es aparente, temporal, puesto que nunca logra incorporar totalmente al margen que la amenaza y la desequilibra, aquellos particulares que dejó de lado. En este caso aquellas otras memorias que se encontraban en pugna al momento en que los montículos fueron encapsulados.

En el Valle de Ambato, poseemos información que nos permite ver estos procesos de contestación y resistencia. Algunos de los montículos que hemos analizados, al momento de consolidarse el proceso de Integración Regional, estando activos y consolidados ya varios de los “centros ceremoniales" -como La Rinconada- con sus montículos encapsulados, les siguieron arrojando objetos, es decir los siguieron monumentalizando. Tal es el caso del sitio El Altillo, uno de los montículos más tempranos hallados en el valle, donde las capas superiores contienen fragmentos de cerámica típica de la utilizada durante el Período de Integración Regional, como la negra gris grabada, junto a restos de alimentos y demás objetos. Lo mismo sucede con el montículo del sito Martínez 3. Estos hechos quizás produjeron que el margen que aquella memoria institucionalizada establecía respecto de otras posibles se tornase demasiado visible, y que el efecto de desplazamiento de la contingencia que producían los montículos ahora encapsulados, 
volviesen al lugar de donde fueron desplazados y, con ello, que ese transcurrir más lento se acelerase en una nueva condensación de significados, en una nueva lucha hegemónica por el sentido común. Quizás en algún momento del siglo XI o XII, en el Valle de Ambato, el margen, el exceso, se hizo tan visible, que el desplazamiento de lo contingente fue anulado, abriéndose un nuevo espacio para las disputas por el pasado, espacio para nuevas condensaciones de significados. Fue en ese momento que los conglomerados aldeanos fueron incendiados y luego abandonados.

\section{Notas}

${ }^{\mathrm{i}}$ Las estructuras monticulares artificiales también se han identificados en otras partes del NOA en períodos como el formativo: tales son los casos de los Sitios de Alamito (Núñez Regueiro 1998; Tartusi et al 1993), y Taif del Valle (Berberián y Nielsen 1988; Gonzáles 1977). En el caso de las de Alamito se han hallado en tres terrazas aluviales a diferentes alturas una serie de unidades que tiene forma de anillo que están compuestos por una depresión central, rodeado por una serie de montículos que forman un anillo. Estas estructuras no son todas iguales sino que: un de ella es un montículo más grande que el resto. Uno de los montículos excavados posee unos 3 metros de alto por 47 de longitud y 36 de ancho, se halla rodeado por su lado oriental de una pared de contención realizada con rodados superpuestos dejando un lienzo desparejo, el relleno se componía de variedad de objetos, gran cantidad de fragmentos cerámicos, huesos de animales fragmentados -algunos quemados-abundantes desechos líticos, lentes de cenizas, espículas de carbón y también huesos y un cráneo humano, por estos hallazgos ha estos montículos los llamaron "basureros". Hacia el este dos plataformas rectangulares revestidas en piedras forman un pasillo que desemboca en la depresión antes mencionada. El resto de los montículos son recintos que se utilizaron para diferentes actividades talleres metalúrgicos, cobertizo y habitaciones-, en las plataformas y los montículos mayores se habrían realizado rituales, el hallazgo de restos humanos en los materiales de los estas estructuras, junto con otros materiales (tallas líticas, objetos de metal etc.), así lo indicarían. Las habitaciones mayores habrían sido alojamiento de las personas que oficiaban el culto o ritual (jefes-shamanes) y los recintos que han servido como talleres o habitaciones menores, para los artesanos especializados, que integrarían la población de cada centro ceremonial (Núñez Regueiro 1998: 253). Los emplazamientos de Alamito fueron interpretados (Tartusi et al 1993; Núñez Regueiro 1998) como centro cúlticos de Condorhuasi, existiendo una metalurgia de carácter local firmemente desarrollada. Según este autor estos centros habrían desempeñado un papel significativo en la distribución de bienes, especialmente relacionados con el culto, hacia sitios de otras regiones, tanto en forma directa como de tráfico caravanero (Núñez Regueiro 1998:259). Aún más tempranos que estos sitios de Alamito, pero en cierto momento contemporáneo, en Tafí del Valle, se han hallado otro conjunto de montículos. Estas estructuras están compuestas fundamentalmente por rocas pequeñas y medianas. Sus dimensiones varían desde 30 a $40 \mathrm{~cm}$ de altura hasta $4 \mathrm{~m}$ de alto y decenas de $\mathrm{m} 2 \mathrm{de}$ extensión. En estos últimos casos se encuentran a veces estructuras simples pequeñas construidas en superficie. Son en general resultado del despedre de los campos previos al cultivo, y en ocasiones han sido empleados a su vez como basurales (como se desprenden de la abundancia de fragmentos cerámicos y líticos en superficie) (Berberián y Nielsen 1988:30). Estas estructuras están asociadas a estructuras del típico patrón margarita (Raffino 1988) que Berberián y Nielsen (1988) denomina unidades circulares compuestas que constan de uno o más recintos circulares grandes (a cuyos muros se adosan uno o más recintos circulares pequeños o medianos. También, estos montículos se asocian a varias de estos tipos de estructuras que conforman una especie de aldea. Uno de ellos, el más grande denominado El Mollar arrojó una fecha muy temprana 2296+-70 A.P., es decir al inicio del período formativo, a su vez conforma parte de estas aldeas. Al parecer este Montículo se hallaba rodeado un tipo especial de esculturas líticas -menhires- situados alrededor del mismo. González (1977:108) interpreta esta conformación arquitectónica como centro ceremonial que en determinado momento del año debió congregar en ritos y ceremonias buena parte de la población del Valle y de las zonas aledañas.

ii Vicent García (1991a), retomando los planteos de Childe realiza una reinterpretación del origen del neolítico y de las economías de base campesina. El planteo de esta autor es que la adopción de la agricultura es un proceso lento. Los cazadores recolectores -durante el cambio del pleistoceno al holoceno en la península ibérica-, al hallarse en un medio altamente cambiante e impredecible, optan por estrategias más conservadoras, que permitan aumentar la predicibilidad de la producción y por lo tanto la seguridad del 
grupo con un coste social mínimo, es decir introduciendo el menor número posible de cambios en las relaciones sociales. Los cazadores recolectores altamente especializados del paleolítico superior, se adaptan a las condiciones del Holoceno diversificando al máximo sus fuentes de subsistencia tanto en el tiempo como en el espacio, recurriendo a recursos de alta productividad -tales como las semilla, frutos, plantas de tamaño pequeño, pesca etc.- (Vicent García 1991a:18). El punto débil de tales sistemas de "amplio espectro" es que la fuerte indeterminación de los ciclos climatológicos ejerce una presión permanente sobre los grupos humanos a través de la percepción del "riesgo". Esta percepción favorecería por un lado, la tendencia a incrementar la inversión de trabajo y la complejidad de los sistemas de gestión de los recursos, y, por otro a la adopción de soluciones parciales, tendientes a dotar a los grupos de reservas para hacer frente a la escasez. Los cereales cultivados y los animales domésticos son especialmente eficientes desde este punto de vista (Vicent García 1991a:18-19). El propio éxito de las estrategias de subsistencia produce contradicciones en el largo plazo que se relacionan con la reducción del radio de movilidad del grupo contradiciendo así la diversificación geográfica de la obtención de recursos, y limita la gran flexibilidad de las respuestas en casos de crisis que constituyen el aspecto más ventajoso de las economías de amplio espectro. En este sentido el principal efecto de este proceso, que para las posiciones mas tradicionales sería la progresiva sedentarización de los grupos humanos, no sería exactamente así: en ausencia de otras presiones, la agricultura no implica sedentarización, de la misma forma que qué la caza y recolección tampoco la excluye. Es así que el "modo de vida campesino" no sería una mera consecuencia mecánica de la fijación de las comunidades derivada del incremento de la agricultura. Lo verdaderamente relevante de la agricultura es que implica la inversión de trabajo de rendimiento diferido. Este sistema crea sus propios problemas: por un lado, la aparente disminución de la incertidumbre que implica las prácticas agrícolas, esconde en realidad una concentración de riesgos, esta concentración de los riesgos asumidos puede ser uno de los factores que lleva a lo que se ha llamado "trampa agrícola". Por otro lado aparece el problema de la apropiación de los recursos llevándonos directamente al interior de la conformación de las relaciones sociales en los grupos que entraron dentro de dicha trampa. La reproducción de las unidades campesinas «...depende de la inversión de un esfuerzo de rendimiento diferido, por lo que el problema no es sólo asegurar el éxito técnico de ese esfuerzo, sino garantizar el acceso a sus resultados.» (Vicent García: 1991a:45). En este lugar se sitúa uno de los principales aspectos dinámicos de "la revolución neolítica" y por otro lado en términos dialécticos el conflicto que viene a resolver es hacer aceptable socialmente dentro de las sociedades cazadoras recolectoras donde hay un predominio de la reciprocidad generalizada, formas de "reciprocidad" menos generalizadas. Tales como limitar la reciprocidad generalizada al grupo de parentesco, dejando formas de reciprocidad negativa para los que no lo son. Esto vincula, para el autor, directamente el problema con una de las cuestiones centrales de la teoría social contemporánea y particularmente dentro de tendencia materialistas históricas: el origen de la desigualdad social.

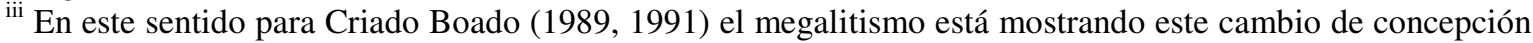
del espacio y el tiempo, en tanto el megalito es una marca temporal y a su vez es un monumento mortuorio colectivo que estaría marcando esta nueva concepción donde le tiempo cobra cuerpo en el monumento y a su vez los muertos de la comunidad cobran relevancia como antepasados.

iv Tal como lo expresamos en el capítulo 3 definir a los montículos como "lugares" nos permite alejarnos de una concepción moderna del espacio y el tiempo. La separación del espacio y el tiempo es una de las principales características de la modernidad (Giddens 1995). A su vez esta separación es acompañada de un vaciamiento de estas categorías en tanto se alejan de la especificidad de la localización El mapa mundi en el que no existe un lugar privilegiado -puesto que es una proyección universal-, es el correlato simbólico del reloj en el vaciamiento del espacio (Giddens 1995: 29). La categoría de lugar nos permite salirnos de esta posición moderna al poder vincular el espacio y el tiempo mediante una localización, en nuestro caso el montículo como categoría espacio-temporal.

v Aquí el paisaje se utiliza no como categoría natural sino como un producto socio-cultural, creado por la objetivación en el medio, y en términos espaciales de la acción social tanto de carácter material como imaginario (Criado Boado 1989, 1991, 1995; Ingold 1993; Thomas 2001; Tilley 1994)

${ }^{v i}$ El culto de los antepasados está muy extendido en los Andes, tratándose de la creencia en que los espíritus de los muertos desempeñan un papel activo y crucial en el mundo de los vivos. En muchas regiones del mundo andino se veneraban y veneran aún como protectores a los antepasados de los clanes locales, y sus cuerpos eran tratados como objetos sagrados, se les realizaban sacrificios, se les renovaban las ofrendas etc. (Conrad y Demarest 1988).

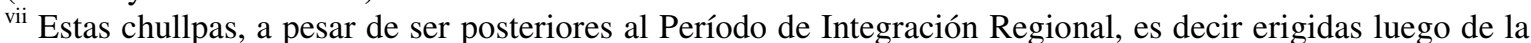
caída de Tiahuanaco y antes que comience el Tawantinsuyo, es un caso muy claro de lo que se ha dado en llamar culto a los antepasados. Estas se interpretan como los sepulcros monumentales de los gobernantes Lupacas: por un lado, estaría la posibilidad de que las chullpas hubieran funcionado como marcadores territoriales, y por otro poseerían una función ceremonial ligada a segundos funerales a ceremonias anuales en honor de los difuntos nivel familiar o de ayllu, o dentro de la política administrativa de los gobernantes Lupacas (Hyslop 1977). Todas poseen acceso a los espacios donde están enterrados los muertos, lo que concuerda con aquellos que señalan que los muertos eran extraídos de sus lugares para reverenciarlos o 
pasearlos por los campos de cultivo. En el caso de Ambato, por el tratamiento que reciben los muertos y los cuerpos, no se habría dado la rememoración de los antepasados de esta forma.

viii Según Pérez Gollán, los suplicantes hallados en el NOA serían las representaciones de los antepasados hechos piedra. Esta interpretación se fundamenta en parte en el análisis de las crónicas españolas donde se menciona: "Adoran los indios dos géneros de ídolos, unos fijos, como los cerros y peñascos y cumbres altas de la sierra nevada, y al sol, luna y las estrellas, [...] y al trueno y rayo, y á la mar y á los manantiales; otros son móviles, de los cuales unos tienen en sus chacras y labranzas en medio, como abogados de los que en su lengua llaman guanca, [...]Adoran también a sus progenitores gentiles, cuyos huesos tenían en mucha veneración y los guardan en unos sepulcros de piedra y les ofrecían sacrificios de conejos [cuyes] y corderos de la tierra [llamas] y ofrendas de chicha y coca." "Declaran los viejos que antiguamente hubo indios que tenían por oficio hacer y labrar estos dioses con las figuras referidas, y fundidores que los fundían de plata, oro y cobre, [...] Adoran otros ídolos de piedra, por decir que eran los fundadores o patrones de los pueblos, a quien llaman marcayoc, ó marca oparac, [...]"(Pérez Gollán 2000a:4). Los suplicantes del Noroeste se habrían hallado en los campos de cultivos que: “.... la manera de un mapa, podían ser considerados como objetos visuales y, a la vez leídos como un texto. Informaban sobre la genealogía e historia del grupo, su dominio territorial y las transformaciones del paisaje. En pocas palabras constituían la memoria, pero también eran la imagen, el doble del antepasado.” (Pérez Gollán 2000b:32). 


\section{CAPÍTULO 10}

DESANDANDO CAMINOS

El objetivo general que guió esta investigación doctoral fue comprender las maneras específicas de participación de la cultura material en los procesos de construcción de identidades sociales en la segunda mitad del primer milenio de la era en el Valle de Ambato Catamarca, Argentina-. Este interrogante se vinculó a problemáticas mayores que desde hace al menos 30 años el Proyecto Arqueológico Ambato viene desarrollando, relacionadas con el surgimiento en el valle -alrededor del cuarto o quinto siglo del primer milenio- de relaciones sociales con mayor grado de exclusión que las formas organizativas anteriores, lo que habrían producido la institucionalización de desigualdades sociales inéditas para la región y la época (Heredia 1998; Pérez 1991, 1994; Laguens y Bonnin 1996; Laguens 2002, 2005, 2006). Concretamente, en este contexto, nos interesamos en dilucidar las formas específicas en que la cultura material participó en la constitución, legitimación y reproducción de la identidades sociales surgidas como parte del proceso de transformación social mencionado. La necesidad de focalizarnos en la participación de aquella en los procesos de construcción identitaria respondió a la inquietud de que la misma no sólo conforma el registro visible con el que trabajamos los arqueólogos, sino que podía ser considerada un elemento activo -y podríamos plantear un "agente" más- de dicho proceso (Dobres 2000; Gastaldi 2007b, 2007c, 2007d; Haber y Gastaldi 2006; Hodder 1990; Ingold 1999; Laguens 2007; Laguens y Pazzarelli 2007; Shanks y Tilley 1987). Esta posición nos llevó a marcar ciertas limitaciones, pero también retomar los aportes del lugar históricamente ocupado por la cultura material en las investigaciones que se abocaron a estudiar los procesos de cambio señalados en el Valle de Ambato.

Así nos adentramos en las maneras en que fue considerada la cultura material en las distintas investigaciones realizadas en el Valle. Para realizar esta tarea tomamos una perspectiva de largo alcance, comenzando desde el período formativo de la disciplina, particularmente observando el lugar que ocuparon aquellos materiales que luego pasaron a conformar parte del patrimonio de la cultura de la Aguada, visiones que influyeron en el comienzo de las investigaciones en el Valle y en el lugar otorgado por éstas a la cultura material y, junto a ella, a los sujetos que lo habitaron. De estos análisis hemos podido caracterizar tres grandes formas de definir a la cultura material:

En la primera forma estos restos aparecen como símbolos que podían aún ser leídos en la actualidad, en tanto que en las tradiciones folclóricas, que aun persistían en diferentes 
partes del NOA, se hallaban las cláusulas de los convenios a través de los cuales los mismos fueron creados. El arqueólogo solo debía conocer las costumbres y leyendas para poder acercarse a sus significados. En la segunda forma, estas convenciones se rompen, los arqueólogos, ya no podían ni debían leer y descifrar esos símbolos. Lo draconiano pasó a ser definido como reflejo de pueblos o civilizaciones más avanzadas provenientes de las áreas nucleares de los Andes. Lo que debía hacer el arqueólogo era rastrear el origen de esas influencias, ver las relaciones, contactos y migraciones que fueron modelando las culturas del NOA y que dieron origen a la cultura de la Aguada. En este último caso la cultura material fue el reflejo claro y sin distorsión de la cultura, de la raza o de la civilización según quién lo propusiera. La cultura desde esta perspectiva fue definida como conjunto de normas compartidas, las que se expresan en todas las cosas de la vida humana, entre ellas la cultura material. En esta mirada, al definir a la cultura como una especie de envase de rasgos, normas y valores compartidos, se desdibujaba el sentido del concepto de sociedad, reificando a la cultura como una identidad propia que parece existir más allá de las personas que la sustentan. La cultura material, entonces, pasaba a trasformarse en el significante del grupo de personas que la poseía. Así un recipiente cerámico que, por ejemplo, porte las figuras felínicas o draconianas, se transformaba en el significante de la Cultura de la Aguada; sus rasgos, su estilo, su carácter etc., lo reflejan, adquiriendo así este recipiente identidad por sí mismo, al diferenciarse de otros significantes-recipientes que reflejaban a otra cultura. Las personas y sus representaciones en esta perspectiva quedaban por fuera de la relación especular entre cultura y cultura material. Así, el recipiente se transformaba en una entidad autónoma y su naturaleza expresada objetivamente.

Esta forma de definir a la cultura, a las personas que la integran y a la cultura material, marcó los inicios de las investigaciones en el valle. En tanto que los materiales que aparecían en él permitían caracterizar una facie de Aguada aún no conocida. Pero a medida que se profundizaron las investigaciones en el valle esa primera visión comenzará a erosionarse. Los materiales hallados en las prospecciones y excavaciones realizadas comienzan a mostrar, por un lado, una mayor antigüedad de las "manifestaciones aguadas" que en otras regiones del NOA. Por otro lado, la aparición de arquitectura monumental, como las plataformas piramidales, formando parte de complejos residenciales con un sector público a manera de plaza, señalaba la aparición de centro ceremoniales diferentes a los conocidos para Alamito, los que eran más antiguos y de carácter familiar. Estas diferencias permitían entrever un cambio en los rituales desde una organización familiar a una supra doméstica, y con ello, la aparición de especialistas que coordinaban dichas actividades. Estos cambios serán 
interpretados como producto de una transformación interna de las relaciones sociales, mas que como influencias directas o indirectas de las áreas nucleares de los andes.

La nueva interpretación coloca en la discusión tres temas que conforman en parte la fuente de los interrogantes que dan sustento al objetivo general planteado:

En primer lugar la importancia dada a la producción local de las transformaciones sociales y su vinculación con un proceso de larga duración en el cual hunde sus raíces; conformando parte, por supuesto, de un proceso más amplio donde el valle se transforma en un punto de articulación importante en la conformación de un espacio regional integrado, en el que el flujo de ideas y bienes con un alto valor simbólico jugará un papel fundamental.

En segundo lugar, se plantea un quiebre en la noción de cultura con la cual se encaró las primeras investigaciones. Los planteos irán incorporando conceptos provenientes del materialismo histórico, lo que producirá que ésta ya no sea considerada homogénea, compartida de igual forma por todos, y reificada en la cultura material, en tanto que se vivirá de diferentes maneras, la ideología tendrá un rol muy importante en este proceso en tanto será mediadora de estas diferentes maneras de vivirla. La religión, las representaciones iconográficas, etc. dejarán de ser la expresión simbólica de la relación con la naturaleza, será a través de ésta y por medio de ella que las nuevas relaciones sociales de poder lograrán consolidarse y reproducirse, transformándose en superestructura.

En tercer lugar, vinculado a esto último, los objetos -vasijas, discos de metal-, las edificaciones -casas, plataformas, montículos- etc. dejarán de ser patrimonio de la facie Aguada de Ambato para transformarse en "evidencias", "indicios", "huellas" de procesos de cambios internos en las relaciones socioeconómicas y del surgimiento de una ideología dominante, fuertemente arraigada en tradiciones anteriores. La transparencia que poseían los símbolos para Lafone y Quiroga; la claridad de la imagen especular entre cultura y cultura material de Debenedetti, Boman y Greslebin, Casanova, Leviller, Bennett y González se comenzarán a opacar. Lo draconiano y las representaciones plasmadas en la cerámica o los objetos de metal, etc., pasarán a transformarse en productos ideológicos que sustentan relaciones de dominación. Así la cultura material irá perdiendo su poder reflectivo de la cultura, tempranamente otorgado por Debenedetti, y adquirirá más visiblemente su rol de indicador de procesos de cambios internos en las relaciones sociales de los grupos que habitaron el Valle. Si bien al principio la interpretación de los cambios estará fuertemente asociada a posiciones neoevolucionistas, en tanto que la sociedad que habitó el valle será definida como un señorío, posteriormente se criticará esta primera visión, desplazando la interpretación a una posición no tipológica de estas trasformaciones. Dos variables 
aparecerán en escena que permitirán señalar el grado de complejización de la sociedad: heterogeneidad y diferenciación. Las sociedades complejas serán entendidas como sistemas sociales caracterizados por patrones marcados e institucionalizados de desigualdad y heterogeneidad. La cultura material ya no será considerada un indicador directo de estos cambios, si no que, definida como registro arqueológico se trasformará en fuente de preguntas y expectativas que permitirán contrastar el grado y alcance de dichas variables en el valle.

Tomando estos tres temas, la primera pregunta que nos surgió, se vinculó a que si teníamos en cuenta los cambios y transformaciones sociales señaladas por las distintas investigaciones realizadas- aparición y conformación de nuevos grupos sociales, de nuevas relaciones sociales de poder, paso de rituales domésticos a rituales supradomésticos, lo cual implicaba construcciones de grupos de pertenencia más amplios que los familiares, etc.- ¿Por qué en ninguna de las investigaciones aparecía como un interés estudiar los procesos a través de los cuales estos grupos se llegaban a definir como tales respecto de otros?, en otras palabras, que nunca se había atendido a los procesos de construcción identitaria necesarios para las nuevas formas de articulación social. Es decir, ¿de que manera, los diferentes grupos llegaron a articularse entre sí, a diferenciarse, negarse, etc.?. Ante nuestros ojos se nos presentaba, como un vacío ineludible y aún no indagado analizar los procesos y mecanismos a través de los cuales los sujetos y grupos de pertenencia en el valle llegaron a definirse.

Responder a este interrogante requería en un primer momento un replanteo de la noción de cultura y de los sujetos que la integran. Debíamos extraerla del esencialismo donde habitó por mucho tiempo en las interpretaciones de los materiales que estudiábamos. Debíamos dejar de hablar de "una identidad", para pensar en plural, en identidades. En tanto que no podíamos partir de pensar a la cultura como homogénea, compartida de igual forma por todos, cerrada sobre sí misma, como una fuerza centrípeta. Debíamos volver a poner a los sujetos como partícipes en la definición de los grupos e identidades. Gran parte de este recorrido lo teníamos allanado gracias a las anteriores investigaciones, en tanto ya se habían replanteado alguno de estos temas, como señalamos anteriormente. Pero, además del vacío sobre los procesos de construcción identitaria, si queríamos comprender en profundidad las transformaciones debíamos replantear en parte dos cuestiones más: una vinculada con la relación entre la constitución de los sujetos sociales y la ideología; otra, vinculada con lo anterior y de fundamental importancia para una perspectiva arqueológica, la concepción de cultura material y el lugar ocupado por ésta en la explicación de los procesos de cambio señalados. 
La primera cuestión, se vinculó a la necesidad de replantear la definición de ideología utilizada, sin abandonar su característica principal como sustentadora de relaciones de dominación, pero que permitiera correrla un poco de su definición como mitificación de la realidad, en el sentido de falsa conciencia; ya que se trasformó en una especie de concepto vacío, que permitía por sí mismo explicar la legitimación y reproducción de las diferencias. Al ser una categoría tan amplia y abstracta, su problema radica en la generalidad, el tratamiento por ejemplo de los bienes y prácticas exóticas como funcionalmente prestigiosos, no da cuenta del carácter sociohistórico específico de esos objetos y prácticas; concretamente de qué manera específica intervienen en la reproducción de determinadas relaciones en ese lugar y contexto específico. En este sentido debíamos replantearnos la idea de ideología. Como señalamos no pretendíamos extraerla de donde Marx la colocó, y donde la colocaron las investigaciones en el valle, es decir vinculada a la sustentación de los proceso de dominación, puesto que es su característica fundamental, pero sí debíamos realizar cierta consideración sobre la misma que nos permitieran pensar en cómo los sujetos llegan a definirse como tales en relación a ella, de qué manera éstos a través de sus prácticas la van estructurando y reproduciendo y, en relación a esto, que relaciones podemos establecer entre ésta y la constitución de las identidades sociales en el valle.

Uno de los principales problemas que observábamos de la noción de ideología más clásica era la posibilidad de distinguir entre realidad social y falsa conciencia, en tanto que la ideología no solo sometía a los sujetos si no que los llegaba a crear. Esto ya nos habría una puerta y nos permitía pensar en los procesos de creación de los sujetos en Ambato. En este sentido se nos hacía pertinente para pensar, por más que el autor no hablara de ideología, la noción de habitus y doxa de Bourdieu. En términos de este autor podíamos pensar a la ideología como naturalizada, como evidente en sí misma, "no reconocida" y tomada como dada en tanto, a través del habitus -la incorporación de lo social en los cuerpos-, llegaba a entallar una "fe práctica", una conformidad prerreflexiva, ingenua y natural, con las presuposiciones fundamentales de un modo de vida dado. Así la ideología y con ella la constitución de los sujetos, operaba más efectivamente en la rutina, en los niveles no discursivos de la práctica humana. A través de esta discusión surgía la segunda cuestión a replantear, la que no sólo tenía que ver con el interés arqueológico sobre la cultura material, en tanto es con los que nos enfrentamos cotidianamente los arqueólogos, sino con el lugar que ésta podía ocupar en esos procesos. En las tres posiciones que caracterizamos anteriormente ésta había tenido un lugar pasivo: fue reflejo, indicador, fuente de preguntas; es decir participó marginalmente de la producción y reproducción de las transformaciones sociales y con ellas de los sujetos y grupos en el valle. 
Esto nos llevó a que dentro de un panorama teórico más general discutamos aquellas posiciones esencialistas, materialistas y constructivistas de la construcción de las identidades y su relación con las cosas, en las que los objetos y sujetos quedaron ubicados en laderas opuestas. En este sentido, pudimos extraer a los objetos de aquellos marcos según los cuales éstos se transforman en espejos de esencias reificadas -la cultura en las posiciones normativas-; de aquellos donde éstos adquieren sentido sólo en relación al plexo funcional donde participan, siendo sólo productos de necesidades de los individuos que los preceden posiciones materialistas vinculadas a la Nueva Arqueología- y de aquellos enfoques que pretenden encontrar al sujeto detrás del artefacto, siendo este último solo producto de un red intersubjetiva de significados -visiones constructivistas-. Retomando la serie de investigaciones producidas recientemente en el Valle de Ambato (Espósito 2006; Gastaldi 2007b, 2007c, 2007d; Gordillo 2006, 2009; Haber et al 1996-97; Laguens 2002, 2005, 2007; Laguens y Pazzarelli 2007; Pérez Gollán 2000) donde la cultura material fue adquiriendo cada vez más un rol activo, pudimos plantear una posición alternativa donde sujetos y objetos se coproducen activamente en el tiempo. Así planteamos que tanto objetos como sujetos no pueden ser entendidos si no es en relación de unos con otros. No se puede comprender acabadamente a los objetos si estos no son analizados en el marco de las prácticas sociales en las que participan, ya que es en éstas donde adquieren significados (Gastaldi 2007d, Shanks y Tilley 1987, Miller y Tilley 1996). Y, por otro lado, no se puede entender la constitución del sujeto si no es en relación con los objetos con los cuales convive durante su vida (Gosden y Marshall 1999; Haber y Gastaldi 2006, Ingold 1999; Thomas 1996, 2001).

Para poder abordar estos problemas, a nivel metodológico, realizamos una inversión de perspectiva: los objetos fueron analizados como si fueran personas con particulares trayectorias biográficas (Gastaldi 2007d, 2007b; Gosden y Marshal 1998; Kopytoff 1991) y los sujetos se analizaron como si fueran artefactos, haciendo énfasis en la producción del cuerpo (Butler 2002; Treherne 1995). Ambas perspectivas por sí solas resultaron insuficientes para comprender los procesos de construcción de identidades sociales y su vinculación con la cultura material, por lo que finalmente, estas dos perspectivas invertidas fueron imbricadas construyendo una serie de cartografías donde se observaron los encuentros, conjunciones y diseminaciones de estas biografías y los sujetos a los cuales dichos objetos se vincularon.

Para la primera fase de análisis nos concentramos en una categoría de objeto particular, vasijas cerámicas, pertenecientes a dos grandes clases tecnológicas E y A1. Ambas poseían una historia larga en el valle, provenían desde los inicios de la ocupación del mismo, es decir que eran representantes de una larga tradición. Pero a su vez observábamos que a 
partir del siglo IV o $\mathrm{V}$ ambas sufrieron algunos cambios importantes: aunque continuaron fabricándose casi de las misma manera, particularmente las de clase E, los que nos permitía entrever la existencias de antiguas formas de hacer que se consolidaban y perduraban durante todo el primer milenio, su representación en los distintos sitios respecto de momentos anteriores aumentaba notablemente: $100 \%$ la clase E y $30 \%$ la clase A1. Este hecho sumaba un punto interesante, no sólo que esas formas de hacer llegaron a consolidarse, si no que se popularizaron respecto de otras formas que desaparecen tal cual lo había observado Fabra (2008) en su investigación. A su vez en el caso de la clase A1, si bien seguían fabricándose casi de la misma manera, se les incorporaba otra iconografía diferente, apareciendo las figuras draconiformes, o felínicas, típicas de lo que se conoce como Aguda Ambato y que habían sido asociados a la consolidación de una nueva ideología. Nos propusimos así reconstruir las biografías de las vasijas confeccionadas con estas clases, con el objetivo de que a medida que trascurriéramos por las distintas vidas seguidas por estos objetos podríamos ir analizando la manera en que estos no sólo se llegaron a constituirse en objetos significativos en su intervención en determinadas prácticas sociales, sino que también hasta qué punto en esa dinámica llegaron a construir, producir o crear a los sujetos mismos que las fabricaban, utilizaban y convivían con ellas.

Así nos adentramos en caracterizar en primer lugar los procesos productivos a través de los cuales estos recipientes se convirtieron en vasijas. Esto nos llevó a observar los posibles lugares de fabricación de las mismas y de proveniencia de las arcillas utilizadas. Dado lo observado en relación al origen de las arcillas, existen varias posibilidades, lo mismo para los lugares de fabricación. O bien entraban algunas arcillas de otros lugares y se fabricaban en el valle o, se fabricaban con arcilla locales aún no identificadas u ocurrían ambas cosas. En este sentido hemos aportado argumentos para plantear la existencia de una producción local de vasijas de clase E y también de clase A1 en sitios de tamaño Pequeños (Martínez 4), Medianos (Martínez 1) y Grandes (Martínez 2), no existiendo evidencias para sitios Muy Grandes (Piedras Blancas) y Muy grande con Sectores (Iglesia de los Indios o La Rinconada). Observamos además que a pesar de existir varias posibilidades iniciales que nos hacían entrever inicios biográficos diferentes de estos objetos, teníamos por el contrario cierta homogeneidad en los procesos de producción no sólo a nivel de ciertas arcilla más utilizadas, como las que se usan en el grupo de alta homogeneidad, sino que también en la utilización principalmente de arcilla roja y blanca, así como también en la estandarización de algunos tipos de formas como las escudillas (Laguens y Juez 1999, Fabra 2008). Estas "formas de hacer" que perduran y se popularizan en el período de integración regional, nos marcan procesos de constitución de determinados habitus de producción y reproducción. Pero 
además, al considerar que dentro de estas largas tradiciones existen posibilidades iniciales distintas, tales como la procedencia de las arcillas e inclusive de los objetos pero, como señalamos, algunas poseen más preeminencia que otras, debemos también pensar en la posibilidad que en determinados espacios sociales se hallan instalados sentidos hegemónicos de preferencias sobre determinadas "formas de hacer las vasijas" respecto de otras. Pero esto también implica la convivencia de sentidos superpuestos, y quizás en tensión sobre estos objetos; por lo menos al inicio de sus biografías. Sin embargo a pesar de estas posibilidades biográficas iniciales diferentes, según lo que fuimos desarrollando a lo largo de la investigación, el decurso de la vida de objetos que pudieron haber tenido un origen distinto en el valle no tuvo grandes diferencias.

Si bien en el valle existe una tendencia a la estandarización en la producción cerámica, la misma no sería especializada si no más bien semiespecializada (Fabra 2008, 2005; Laguens y Juez 1999). Esto va de acuerdo con las escalas espaciales y sociales donde son producidas estas vasijas en el valle y los otros objetos de cerámica vinculados a ellas; las que están enmarcadas por los espacios de reproducción social cotidiana de est@s artesan@s, es decir las vasijas se confeccionan en los lugares donde estos grupos vivían, no existiendo centros o espacios dedicados exclusivamente a la producción cerámica.

Si pensamos en las rutinas seguidas en la producción de vasijas en los sitios pequeños, medianos y grandes, las mismas, producen cierta espacialización al interior de los mismos y, a su vez, vincula a estos sitios, espacios y prácticas artesanales, así como las personas que las realizaban y vivían allí, con espacios y relaciones sociales más amplias que aquellas delimitadas al interior de los mismos. Estas rutinas, implicaron recorridos que tuvieron como punto de inicio la casa donde estos vivían. Así desde las casas se dirigieron a las barrancas donde se hallarían la fuentes de arcilla, probablemente compartidas con otros vecinos, en tanto no se halla por lo menos materialmente restringido su acceso, quizás en el camino recogieron leña de los sectores del monte circundante a las viviendas, para luego volver a la casa. Desde ésta también fueron a buscar placas de mica y cuarzo en la falda de los cerros de la sierra de Ambato, dirigiéndose probablemente, si aceptamos la hipótesis de la utilización de una combinación de combustibles para su cocción, hasta la zona de los corrales para aprovisionarse de guano, que en el caso de los sitios analizados, implicaría desandar el camino que recorre el agua -tanto de escorrentía como de la vertientes- para bajar a los sectores de fondo de valle; para luego, al igual que con la arcilla y la leña, volver a la casa donde se emprendería la confección de las vasijas. 
Así, en las rutinas a través de las cuales los artesanos se proveyeron de los materiales y recursos necesarios para confeccionar las vasijas, que tuvieron como punto de partida y llegada las viviendas, quedaron implicadas las formas y lógicas de apropiación de lo que en un sentido amplio denominamos el monte y; también, el agua articuladora en parte de la ocupación del valle, la gestión agrícola y, dada la vinculación de esta prácticas con la gestión de los camélidos, podemos decir que en parte, de estos últimos también. En este sentido estas rutinas no sólo se ejecutaron sobre ese paisaje, como si este conformara un escenario, sino que también en la práctica repetitiva y rutinaria de las mismas, en la activación y ejercicio de las relaciones que median el acceso a esos recursos, llegaron en cierta forma a producirlo y reproducirlo. Además, estas rutinas, que confluían en el momento de hacer y cocinar estas vasijas en las casas donde estos sujetos vivían, establecían un lazo muy fuerte, entre las viviendas, como espacios de vida y reproducción de estos grupos, y esos paisajes mayores; conformando uno de los locus de definición del lugar ocupado por dichos grupos en las relaciones con sus vecinos y con colectivos más amplios, tanto al nivel del valle, como probablemente de las agrupaciones menores o aldeas observadas por Assandri (2007).

Pero a su vez en los mismos lugares donde estas vasijas se producían, se realizaban otras actividades vinculadas a la reproducción social del grupo que vivía ahí, en donde las mismas tenían un rol fundamental: fermentación de bebidas, almacenado, procesado y cocido de carnes y vegetales con todas su implicancia en la definición de los cuerpos de los sujetos; almacenado, manipulación y aplicación de pigmentos en variedad de objetos, inclusive en los cuerpos. Así, las vasijas "nacían” en contextos fuertemente estructurados y connotados por el derrotero de otras vasijas. De este modo los tiempos biográficos de estas otras vasijas que se hallaban almacenando, quedaron vinculados con los tiempos productivos de las vasijas que se estaban haciendo en dichos lugares. Estas vasijas no solo fueron utilizadas por aquellos que las fabricaron, si no que también desde estos lugares, trascendieron a otros donde no hay evidencia de su fabricación. Estas clases, se hallan conspicuamente representadas en todos los sitios del valle teniendo una amplia distribución.

De los análisis de performance, atrición por uso, de residuos orgánicos y contextuales, hemos podido acercarnos a reconstruir no solo la variedad de prácticas realizadas, con estos recipientes, si no que también hemos podido conocer que algunas de las vasijas analizadas, a lo largo de su recorrido biográfico participaron en más de una de las prácticas señaladas y, lo hicieron de manera secuencial.

Las vasijas fueron confeccionadas con variedad de mezclas, formas, tamaños, que les confieren ciertas propiedades técnicas y formales. Estas propiedades, no restringieron su 
participación futura en alguna actividad particular, pero sí produjeron diseminaciones y encuentros en las vidas de estos objetos. Es decir que en el momento en que estos objetos son fabricados, existen ciertas apreciaciones realizadas por 1@s artesan@s sobre las posibilidades futuras de uso. Tales como algunos tipos de mezclas de la clase E -mezcla 5- y forma de vasijas -calceiformes, "otras formas" y platos- que permiten una mejor performance en actividades de cocción respecto de otras que no la tienen; no solo por el tipo de mezcla, como en el caso de la vasijas de clase A1, si no por la forma que poseen -vasijas a, ab, b, c, escudillas, modeladas, etc-. O la presencia de ciertos atributos secundarios y tamaños, que permiten su manipulación y facilitan la realización de actividades que requieran el transporte de las vasijas, etc. Pero todas estas propiedades más que determinar su participación en una práctica diferente, produce su inserción diferencial en ella, es decir estas propiedades, en algunos casos, más que diferenciarlas, producen su encuentro como participantes que ocupan diferentes roles en una misma práctica. Tal es el caso por ejemplo de la asociación recurrente que hallamos de vasijas de diferentes tamaños, clases -E, A1 y otras- y formas distintas forma "a", "otras formas", forma "b", escudillas y vasos o jarras- en contextos de acción particulares -almacenado y cocido de vegetales y carne y almacenado de pigmentos-. Esta asociación nos plantea un nivel más amplio de agrupación de todo este grupo de objetos. Dicho nivel ya no depende necesariamente de la forma, del tamaño, las propiedades técnicas, la decoración, o las características de performance, si no de su participación en prácticas específicas que los vinculan a sentidos y significados específicos. Lo que plantea, no un problema, pero sí un desafío interesante y una mayor riqueza a la perspectiva biográfica, principalmente respecto a dónde se coloca el límite de un objeto, para decir que uno está reconstruyendo la biografía de este objeto particular, siendo que en algunas instancias o momentos, -como en estos casos- los objetos se mueven en grupos como si fueran una unidad, desafiando la posibilidad de su separación. Esto nos lleva a considerar la posibilidad de que en ciertos momentos, y a medida que iban transcurriendo sus vidas, algunas vasijas llegaron a articularse en categorías más amplias de objetos o familias de objetos. Pero, también debemos pensar a esta clase de articulación, en relación a las biografías generales que hemos reconstruidos de cada uno de ellas. En tanto que, por ejemplo, en el caso de algunas vasijas, estos momentos de encuentro se dan ya transcurrido un tiempo, suele ser la segunda prácticas o la tercera; por lo que esas vasijas poseen una historia previa, distinta a las otras. Y posteriormente pueden llegar a articularse de otra manera.

Es decir que estas categorías más amplias, se definen en la operacionalidad misma de la práctica que se ejecuta. Pero en tanto la vida de los objetos siguen transcurriendo y llegan a participar en otras prácticas y, de esta forma adquieren otros sentidos, la biografías de cada 
una de estas vasijas adquiere una relevancia fundamental, en tanto que es en ellas donde se condensan esas historias, las que según lo que hemos visto quedan impresas en las superficie de su cuerpos, a manera de capas de sedimentos que forman una verdadera estratigrafía de sentidos superpuestos. Si ponemos en juego esta "etapas" en la vida de estos objetos, la incorporación de una nueva vasija requiere el traspaso o la transición de vasijas más viejas a otros estadios de su trayectoria biográfica. De esta manera las viejas vasijas llegaron a prescribir la inserción de una vasija nueva en una práctica específica y, de esta forma, se hallaban activamente estructurando también a las personas que se disponen a utilizarlas, en tanto que la historia sedimentada en sus cuerpos, su biografía, limitan las acciones futuras realizadas con estas.

Hemos analizado las distintas prácticas en las que se involucraron las vasijas y las personas. Una de las más visiblemente preformativas, en relación a la construcción de los sujetos, son aquellas vinculadas a la dislocación, fragmentación y fusión de cuerpos y la producción de nuevos sujetos. Esta suele ser la segunda actividad en la que suelen participar las vasijas, antecedida y precedida por la fermentación de bebidas y el almacenamiento de pigmentos. Las vasijas participaron ocupando diferentes roles, utilizándolas para realizar distintas acciones sobre los cuerpos. En primer lugar, las vasijas fueron utilizadas para almacenarlos ya dislocados, desmembrados, descarnados y mezclados -partes de distintos individuos y como dijimos de edades, especies y ell@s diferentes-. En segundo lugar participaron en la transferencia de estos a lo lugares donde se los cocina, en las habitaciones techadas y; en tercer lugar, se las utilizó para cocinarlos y luego para consumirlos. Es decir conformaban uno de los objetos sin los cuales dichas prácticas hubieran sido casi imposibles realizarlas.

Las prácticas de trozamiento de individuos, es imposible pensarlas sin las otras prácticas que se realizaron sobre los cuerpos, en donde estos se mantienen enteros. Ambas, en su ejecución, llegaron a producir y reproducir sujetos distintos, a su vez implicaron y vincularon a los objetos y sujetos participantes con escalas temporales, sociales y espaciales diferentes. Estas prácticas, junto con aquellas que conservan el cuerpo entero, implicaron en su ejecución que los cuerpos de ciertas personas perduraran, aunque de manera invisible, en el sustrato donde se desarrollaba la vida social, es decir, enterrados debajo de los pisos de las habitaciones e inclusive de algunas paredes y; por otro lado, que los cuerpos de otras personas, por medio de su dislocación, desmembramiento y descarnado, se disolvieran, como parte de un proceso generativo, genésico de un cuerpo nuevo, sin forma, sin límites precisos, indefinido; en donde los diferentes sujetos o partes de ellos, en donde sus edades o 
trayectorias biográficas particulares de duración variable, en donde ell@s, en donde los camélidos y los humanos, devinieron un collage, una amalgama que los fusionó y resignificó en un cuerpo "otro".

Este proceso, a su vez, permitió transformaciones futuras de las partes fragmentadas, en tanto que habilitó, no solo su perduración como fragmento, si no también su modelado como instrumento, o su trasformación en otro objeto; hasta que al final fueron incorporados en los montículos, estos últimos receptores de la mayoría de los objetos utilizados. Tanto los nuevos sujetos multiformes como los nuevos objetos fabricados con partes de éstos, habitaron, un espacio diferente, al ocupado por los que fueron conservados enteros. Estaban presentes en la superficie más dinámicas de las habitaciones, galerías y patios, es decir permanecieron visibles, se los manipulaba y se realizaban cosas con ellos. Por otro lado además de vivir mundos separados superpuestos, los límites del espacio habitados por ambas clases de sujetos, no son coincidentes. Los sujetos enterrados enteros, no solo habitaron el sustrato donde la vida social ocurría, si no habitaron los sustratos más restringidos de las viviendas, por ejemplo en las habitaciones techadas. No llegaron, o no le fue concedido por los vivos, la posibilidad de adentrarse en espacios intermedios entre esferas semipúblicas o semidomésticas o incluso más allá de estas, tales como los patios y montículos que sí fueron ocupados por los otros sujetos fragmentados. Es justamente en ese espacio liminal, donde están emplazados los montículos, donde los nuevos sujetos indefinidos, armados con partes distintas y de sujetos diferentes, se adentran en zonas en las cuales dominan relaciones sociales más colectivas, pero que explícitamente, por medio del montículo condensan las prácticas de grupos más restringidos. No existe lugar visible en el espacio colectivo para "un" cuerpo fijo, no transformado en un collage, no metamorfoseado; pero a su vez, este proceso que si no se lo controla puede llegar a producir la aniquilación o disolución de los sujetos y con ellos de los grupos de pertenencia -en tanto abre la posibilidad de transformaciones y resignificaciones continuas-; llegó a ser limitado, suturado, y amenazado, por la fijación en espacios más restringidos, "menos colectivos", de cuerpos enteros de "un" solo individuo, de un sujeto, algunas veces solo, otras junto a objetos que, en sus cuerpos, llevaron las marcas de sus trayectorias biográficas y que narran las relaciones que los mismos entablaron con los sujetos enterrados, a lo largo de sus vidas en dichos espacios.

Así la vida de las personas en Ambato, sus biografías, transcurre en esa geografía; sus cuerpos desde su nacimiento e incorporación a la vida social hasta su muerte se hallan interpelados por ambas actitudes corporales, sus devenires se dirimen a través de ellas, y en ellas encuentran sus lugares de pertenencia, su constitución como sujetos sociales. 
En relación a lo anterior, hemos vinculado a las vasijas participantes de estos procesos, con otros contenedores, las fosas, que al igual que aquellas, guardaban y acogían a los sujetos, aunque específicamente aquellos conservados enteros. Pero hemos señalado también que mientras las fosas fijaban las relaciones puestas en juego en su interior, la contención de las vasijas estaba dirigida a un momento posterior, por lo que era temporal. Es decir las biografías de las personas que eran transformadas en un collage se vincularon solo temporalmente con las biografías de las vasijas que permitían que dicha trasformación se produjera. En este sentido vasijas y fosas, se diferenciaban en tanto participaban en temporalidades contrapuestas, pero ambas se hallaban estrechamente vinculadas en tanto que activamente se involucraban, las primeras, en la fragmentación, trasformación y fusión de los cuerpos de ciertos sujetos; las segundas, en la conservación y fijación de los cuerpos enteros. Pero la vida de las vasijas, a diferencia de las fosas continuaron, no culminaron con la ejecución de este proceso. Como hemos visto, se esperaba de ellas que participaran posteriormente en otras prácticas, tal como el almacenado y manipulación de pigmentos. Por lo que ese momento temporal de encuentro, donde permitían el proceso de transformación de los sujetos en collage, conforma una de las etapa en la vida de estos objetos, que pasará a formar parte de la historia acumulada por ellas.

Los tiempos de vida esperados de las distintas formas y clases de vasijas analizadas, fueron diferentes; señalamos que para alguna de las vasijas como las de forma "a" y "otras formas" de clase E, pudieron ser largos, incluso trascendiendo la vida de varias personas. En cambio para algunas formas de la clase A1, tales como las escudillas, los bols, las vasijas "b" y las "c" señalamos que pudieron haber tenido tiempos más cortos; mientras que para las modeladas, los vasos y jarras su vida pudo ser un poco más larga. Esto hace que los encuentros entre estas vasijas y determinadas personas sean diferenciales. Así, algunas vasijas a lo largos de sus vidas llegaron a vincularse a distintas personas, trascendiendo en algunos casos la muerte de las mismas; a su vez, una persona, llegó a vincularse con vasijas que se hallaban en distintos momentos de sus biografías, compartiendo sólo en parte la vida con ellas. Este desplazamiento temporal de los tiempos de vida, donde algunas de las vasijas como hemos visto pudieron perdurar más de una generación, sumado a las biografías específicas seguidas por éstas que, a manera de una estratigrafía, se superponen y densifican los cuerpos de las mismas, producen que aquellos sujetos que inician su recorrido biográfico, al igual que las nuevas vasijas que se están confeccionando o se incorporan a la vida social, queden fuertemente vinculados, entrelazados y estructurados en parte por estas historias. 
La culminación de las biografías de las vasijas, está determinada por el momento en que la vasija se rompe; este instante es el momento donde se concibe el final de la vasija como ese objeto. Por más que sólo halla recorrido parte de la secuencia, digamos ejecutado una de las prácticas esperada, cuando se rompen no las reparan, no se les prolonga la vida, no se les permite continuar como esos recipientes que eran. Por ejemplo, si una vasija se rompe mientras fermenta chicha puede cosérsela y almacenar otras cosas, por ejemplo chañar, pigmento, etc.; sin embargo, no se concibe esa posibilidad. En ese momento la vasijas se diseminan, se las separa, no quedan en los lugares donde se rompen, éstos son limpiados, barridos, los fragmentos son recogidos y trasladados a otro lugar. Las prácticas de limpieza, no sólo ocurren con las vasijas sino como hemos visto en el capítulo ocho, los pisos en general son continuamente limpiados. En el caso de las vasijas, es a través de la coreografía de la limpieza y traslado de los fragmentos rotos desde los espacios donde se rompieron hacia el lugar donde se emplazaban los montículos, que a su vez, implica transitar desde espacios más restringidos a espacios más colectivos, que pasan a formar parte de temporalidades más largas que la de sus tiempos biográficos particulares. Continuamente las prácticas de limpiezas no sólo actualizan las interfacies donde ocurre la vida social, si no que median la articulación entre contingencia y estructura, en tanto es a través de ellas que los objetos pasan como sedimento a la larga duración, al ser incorporados a los montículos.

En estos lugares las vasijas, sus historias también sedimentadas en sus cuerpos, se unen a otras historias de otras vasijas: se produce la fusión de las distintas biografías de estos objetos. En estas estructuras de larga duración, la fusión de trayectorias particulares coloca a las vasijas en una categoría mayor de objeto, ya no vinculada a la intervención de cada una de ellas en prácticas específicas, sino a la historia de todas ellas, puesto que, a la vez que sedimentaban sus significados, diluían la contextualidad de su agencia, de su trayectoria de vida particular, en marcos temporales mucho más amplios. Pero el montículo como fuerza centrípeta atrae también a la mayoría de los otros objetos y restos de prácticas realizadas en dichos sitios. Continuamente, estas estructuras son alimentadas por ellas, de tal forma que a lo largo de sus vidas, que en algunos casos alcanzan casi los mil años de antigüedad, se van trasformando en monumento, adquiriendo visibilidad. De a poco, los montículos van apropiándose de un espacio que en sí, en tanto productos de prácticas más restringidas, no representan: es decir comienzan a apropiarse de un espacio más colectivo, aquel compartido con los vecinos. Pero al mismo tiempo, al ser representantes de una larga temporalidad, vuelven a ubicar en un plano de la naturaleza lo producido culturalmente, en tanto estos se viven como naturales, puesto que siempre estuvieron allí: son la expresión de una memoria que, dada la dilatada temporalidad de la misma, es en cierta forma inmemorial. Si volvemos a 
pensar en las biografías de las vasijas y su vinculación con las dos formas de tratamiento corporal, en las que por la corta temporalidad de almacenamiento de los individuos fragmentados contenidos por ellas, se alejaban de las fosas, se volvían a vincular cuando ingresaban en los montículos. En tanto montículos y fosas lograban inmovilizar las relaciones entre los sujetos y los objetos al vincularlos con lugares espacio-temporales que parecen existir fuera de la contingencia donde dichas relaciones se producen y reproducen. Pero los montículos, a diferencias de las fosas que implican un evento único y cerrado, están en continua formación, podemos decir que fueron un proceso nunca acabado. Pero hemos visto como a partir del siglo quinto o sexto, algunos de ellos particularmente los emplazados en los sitios muy grandes con sectores, fueron cancelados, clausurados. En ese proceso la posibilidad de ir acumulando nuevas historias, nuevos sedimentos y nuevos sentidos fue anulada, y al mismo tiempo la historia acumulada, fue apropiada. Pero a pesar de esto, otros montículos siguieron creciendo, e incluso viejos montículos provenientes del formativo como el Altillo, en el que gran parte de sus sedimentos proviene de ese momento, se le siguieron arrojando materiales que ponen en evidencia la tensiones en juego, que son objetivadas en dichas prácticas.

La violencia simbólica (Bourdieu y Wacquant 1995) involucrada en la clausura de una estructura que por "naturaleza" implica la acumulación progresiva y "nunca acabada" de las historias a través de las cuales las identidades de los sujetos y de los distintos grupos de pertenencia en el valle llegaron a definirse, y que a su vez provocó la apropiación y la "universalización" de algunos significados dejando fuera otros, fue limitada, amenazada, en tanto otros montículos, no clausurados siguieron siendo alimentando. Estos, así como los sujetos y grupos que participaron en dichas prácticas, se trasformaron en el afuera constituido (Hall 1996) de las nuevas resignificaciones y construcciones de sentidos. Es así que en el Valle de Ambato a medida que trascurre el primer milenio, pero principalmente a partir del siglo V o VI de la era, comienza a vislumbrarse una tensión cada vez más fuerte entre la construcción y definición de las identidades de grupos de pertenencia más restringidos a nivel doméstico y su articulación a grupos mayores, en donde priman relaciones y construcciones más colectivas. Los sujetos, desde su nacimiento e incorporación a su grupo de pertenencia y a la vida social, se encuentran interpelados por ambas construcciones. Sus cuerpos habitan la interfacie donde, los sujetos de cuerpo entero y los sujetos convertidos en collage forman parte de los diálogos entre ambas clases de construcción, donde las vasijas con su biografías sedimentadas en sus cuerpos y las fosas son agentes imprescindibles en este proceso, donde la ambivalencia del montículo como representante de prácticas más restringidas y habitante de espacios más colectivos; como naturaleza y cultura al mismo tiempo, logra fijarlas en el largo 
término. Esto nos lleva a plantear que: ni los cuerpos enteros y cuerpos fragmentados, ni las vasijas y las fosas, ni los grupos de pertenencia más restringidos y colectividades mayores, ni los montículos clausurados y no clausurados, ni los camélidos, ni los humanos, pueden comprenderse si no es en relación de unos con otros. Es justamente en el lugar, en el punto de intersección, de encuentro, donde las materialidades y las funciones, las objetividades y las subjetividades, las prácticas y las agencias de humanos y no humanos, cuerpos fragmentados y no fragmentados, grupos restringidos y grupos más colectivos, vasijas, fosas y montículos, en el Valle de Ambato, llegaron a constituirse mutua, heterogénea, fluida y activamente en el tiempo. 


\section{Bibliografía}

Alberti, B.

2006-07 Destabilizing Meaning in the Antrhropomorphic Forms From Northwest Argentina. En Overcoming the Modern Invention of Material Culture. Editado por Vítor Oliveira Jorje y Julian Thomas. Journal of Iberian Archaeology, Special Issue Vol: 9/10: 209-229. ADECAP, Portugal

Althusser, L.

2003 Ideología y aparatos ideológicos del estado. En Ideología: Un Mapa de la Cuestión, editado por S. Zizek pp.115-155. Fondo de Cultura Económica de Argentina S.A., Buenos Aires.

Ambrosetti, J. B.

1906. El hacha de Huaycama. Anales del Museo Nacional de Buenos Aires. T.XVI, $\left(\operatorname{Ser} .3^{o}\right.$, t.IX).

Appadurai, A.

1991 Introducción. Las mercancías y la política del valor. En La Vida Social de las Cosas. Perspectiva Cultural de las Mercancías. Editado por A. Appadurai, pp.1787. Traducido por A. Castillo Cano. Grijalbo. México.

Arenas, P.

2003 Etnografía y alimentación entre los Toba-Nachilamole\#ek y Wichi-Lhuku'tas del Chaco Central (Argentina). El autor, Buenos Aires..

Ares, L.

2006 De patio en patio. Una mirada a los patios del Noroeste argentino prehispánico, desde La Rinconada de Ambato. Tesis inédita. Facultad de Filosofía y Letras, Departamento de Ciencias Antropológicas, Universidad de Buenos Aires.

Ardissone, R.

1941. La instalación humana en el valle de Catamarca. Estudio antropogeográfico. Biblioteca de Humanidades T. XXVII. Ed Facultad de Humanidades y Cs de la Educación, UNLP. La Plata.

Arfuch, L.

2005 Problemáticas de la identidad. En Identidades, Sujetos y Subjetividades, editado por L. Arfuch. Prometeo Libros. Buenos Aires.

Arnold, D. Y. (edit)

1998 Hacia un orden andino de las cosas. Tres pistas de los Andes meridionales. Hisbol/ILCA, Bolivia. 
Arnold, D.

1985 Ceramic Theory and Cultural Process. New Studies in Archaeology. Cambridge University Press, Cambridge

Arthur, John W.

2002 Pottery Use-Alteration as an Indicator of Socioeconomic Status: An Ethnoarchaeological Study of the Gamo of Ethiopia. Journal of Archaeological Method and Theory, Vol. 9, No. 4.

Aschero, C. A.

1975 Ensayo para una clasificación morfológica de artefactos líticos aplicada a estudios tipológicos comparativos. Informe manuscrito presentado al Consejo Nacional de Investigaciones Científicas y Técnicas (CONICET).

Assandri, S. B.

1991 Primeros resultados de la excavación en el sitio Martínez 1 (Catamarca, Argentina). Publicaciones del CIFFyH 46:53-85.

2007 Procesos de complejización social y organización espacial en el Valle de Ambato, Catamarca. Tesis de Maestría en Arqueología Social. Publicaciones Tesis. Formato Digital. Universidad Internacional de Andalucía, España.

Assandri S., A. Ávila, R. Herrero y S. Juez

1991 Introducción a la biogeografía y arqueología del Valle de Ambato (Provincia de Catamarca, Argentina). Publicaciones del CIFFYH Arqueología Vol. 46.

Assandri, S. y A. Laguens

1999 Asentamientos aldeanos Aguada en el Valle de Ambato. Actas del XIII Congreso Nacional de Arqueología Argentina, Córdoba. En prensa.

Baffi, E. I. y Torres, M, F.

1996 Los Restos Humanos del Sitio Martinez 4 (Ambato, Catamarca). En Arqueología $\mathrm{N}^{\circ}$ 48: 55-63. Publicaciones del CIFFYH.

Balesta, B y N. Zagorodny

2002 Los frisos antropomorfos en la cerámica funeraria de La Aguada de la Colección Muñiz Barreto. En Estudios Atacameños No 24: 39-50.

Balesta, B y N. Zagorodny y C. Valencia

2009 Evidencias de estandarización en la manufactura de cuencos de La Aguada Orilla Norte (Argentina). En Estuudios Atacameños ํ37: 79-98 .

Balfet, H., Fauvet-Berthelot, M y S. Monzón

1992 Normas para la descripción de vasijas cerámicas. Centre Ètudies Mexicanes et Centreamèricanes. Mexico. 
Barale, A.

2006 Organización del trabajo en contextos de diferenciación social. El Valle de Ambato,

Catamarca. Silos $I V$ al $X \quad d$. C. Tesis de Licenciatura inédita, Escuela de Arqueología, Universidad Nacional de Catamarca, Catamarca.

Barba, L.; R. Rodríguez; J.L. Córdoba.

1991 Manual de técnicas microquímicas de campo para la arqueología, Instituto de investigaciones antropológicas, UNAM, México

Bedano, M.C, Juez, M.S. y Roca, M.D.

1993 Análisis del material arqueológico de la colección Rosso procedente del Departamento de Ambato, Provincia de Catamarca. Publicaciones 7, Instituto de Arqueología, Universidad de Tucumán

Bennett W. C, Bleiler E. F y Sommer F. H.

1948 Northwest Argentine Archeology. Yale University Publications in Anthropology $\mathrm{N}^{\circ} 38$. Yale University Press, New Haven.

Berberian E. E. y Nielsen A. E.

1988 Sistemas de asentamineto prehispánicos en la etapa formativa del Valle de Tafí (Pcia. De Tucumán-República Argentina). En Sistemas de Asentamiento Prehispánicos en el Valle de Tafí, compilado por Berberián E. E., pp 21.53. Editorial Comechingonia, Córdoba.

Bertolino S. R. Y Fabra M.

2003 Provenace and Technology of Pot Sherds From Ancient Andean Cultures at the Ambato Valley, Argentina. En Applied Clay Science 24: 21-34.

Bianciotti, A.

2005 Alberto Rex González: La imagen y el espejo. Arqueología Sudamericana Vol. 1 $\mathrm{N}^{\circ} 2: 155-184$.

Bibby, D. V.

1993 Building Stratigraphic Sequences on Excavations: an Example From Konstanz, Germany. En Practices of Archaeological Stratigraphy, editado por

Edward C. Harris, Marley R. Brown III, and Gregory J. Brown: 104-121. Academic Press, London.

Binford, L.

1962. Archaeology as Anthropology. American Antiquity 28:217-225.

1965 Archaeological Systematics and the Study of Culture Process. American Antiquity 31:203-210. 
Bintliff, J.

1991 The Contribution of an Annaliste/Structural History Approach to Archaeology. En The Annales School and Archaeology, editado por J. Bintliff, pp. 1-33. Leicester University Press, Londres y Nueva York

Blanton, R.

1995 "The Cultural Foundations of Inequality in Households", en Foundations of Social Inequality, editado por D. Price y G. Feinman. Plenum Press, New York.

Boman , E y H. Greslebin

1923 Alfarería de estilo draconianao de la Región Diaguita (República Argentina). Editorial Ferrari S. A. Buenos Aires.

Bonnin, $\mathrm{M}$

2007 Cultura Aguada: Ambato 73/76. En Sesiones y Resúmenes, de la. IV Reunión Internacional de Teoría Arqueológica en América del Sur Universidad Nacional de Catamarca y World Archaeological Congreso. San Fernando del Valle de Catamarca.

Bourdieu, P.

1977 [1972] Outline of a Theory of Practice. Traducido por R. Nice. Cambridge University Press, Cambridge.

1988 [1987] Cosas dichas. Traducción de M. Mizraji. Gedisa, Barcelona.

1991 El sentido práctico. Taurus, Madrid.

Bourdieu, P. y L. Wacquant

1995 Respuestas. Por una antropología reflexiva. Traducido por H. Levesque Dion. Grijalbo, México.

Bowser, B.

2000. From Pottery to Politics: an Ethnoarchaeological Study of Political Factionalism,

Ethnicity, and Domestic Pottery Style in the Ecuadorian Amazon. Journal of Archaeological Method and Theory, Vol. 7, ํ3:219-248.

Braudel, F.

1980 [1968] La historia y las ciencias sociales. Traducido por J. Gómez Mendoza. Alianza, Madrid.

Braun, D.

1983. Pots as tools. En Archaeological Hammers and Theories, editado por Moore, J. A., and Keene, A. S., Academic Press, New York, 
Bregante, Odilla

1926 Ensayo de clasificación de la cerámica del Noroeste Argentino. Ángel Estrada y Cía. Editores, Buenos Aires.

Bronitsky, G. y R. Hamer

1986 Experiments in Ceramic Technology: The Effects of Various Tempering Materials on Impact and Thermal-Shock Resistance. En American Antiquity, Vol. 51, No. 1: 89101

Butler J.

2002 Cuerpos que importan. Sobre los límites materiales y discursivos del "sexo".

Editorial Paidós-Argentina

Callegari, A.

2006. La complejidad social, el paisaje construido y los ritos de convalidación del poder en La Cuestecilla. La Rioja (depto.de Famatina). Actas de la IV Mesa Redonda "La Cultura de La Aguada y su dispersión", pp. 137-150. Instituto de Investigaciones Arqueológicas y Museo, Universidad Católica del Norte, San Pedro de Atacama.

Carandini, A.

1997 Historias en la tierra. Manual de excavación arqueológica. Traducido por X. Dupré Raventós. Editorial Crítica (Grijalbo Mondadori), Barcelona.

Caro M.

2002 Desigualdad social y su registro arquitectónico en el sitio arqueológico Piedras

Blancas. Publicación digital. http://www.ffyh.unc.edu.arl secretarias/cyt/jor2002/IIIjor.htm en Marginalidad social y vulnerabilidad: diversidad, desigualdad y pobreza

Casanova, E.

1930 Hallazgos arqueológicos en el cementerio Indígena de Huiliche (Dto. De Belén.

Prov. de Catamarca). Archivos del Museo Etnográfico n 3, pp.5-25. Universidad de Buenos Aires.

Clark, D. L.

1984 Arqueología analítica. 2da. edición. Traducido por Bellaterra. Editorial Bellaterra S.A., Barcelona.

Cobb, C. R. y P. H. Garrow

1996 Woodstock Culture and the Question of Mississippian Emergence. American Antiquity 61(1):21-37.

Conrad G. W y Demarest A. A

1988. Religión e imperio. Dinámica del expansionismo Azteca e Inca. Alianza Editorial y Sociedad Quinto Elemento. América Monografías. Madrid. 
Corominas J y Pascual J. A.

1992 [1980] Diccionario crítico etimológico castellano e hispánico. Volumen III.

Editorial Gredos. Madrid

Criado Boado, F.

1989 “We, the Post-megalithic People ...". En The Meanings of Things. Material Culture

and Symbolic Expression, editado por I. Hodder, pp. 79-89. Harper Collins Academic,

Londres.

1991 “Tiempos prehistóricos y espacios modernos". En Historia y Crítica: 85-108.

1995 The Visibility of the Archaeological Record and the Interpretation of Social

Reality. En Interpreting Archaeology. Finding Meaning in the Past, editado por I.

Hodder, M. Shanks, A. Alexandri, V. Buchli, J. Carman, J. Last y G. Lucas, pp. 194-

204. Routledge, Londres.

Cruz P.

2005 Archéologie de la mort dans la Vallée d'Ambato. Homme et milieu dans le Bassin de Los Puestos (Catamarca-Argentine) durant la Période d'Intégration Régionale (IV $V^{e} X^{e}$ siècles après J.-C.). Tesis Doctoral inédita. La Sorbona. Francia

2007 La muerte y sus manifestaciones en el valle de Ambato. Actas de la IV Mesa redonda La Cultura La Aguada y su dispersión. Universidad Católica del Norte. Instituto de Investigaciones Arqueológicas y Museo. San Pedro de Atacama. Chile.

Cutler, C. y M. Cárdenas

1985 [1947] Chicha un cerveza indígena sudamericana. En La Tecnología en el mundo andino, editado por H. Lechtmann; A. M. Soldi. Imprenta de la UNAM, pp: 247-259. México.

D’Amore, L.

2002 Secuencia de estratigrafía arqueológica y prácticas sociales. Historia de una unidad doméstica del oasis de Tebenquiche Chico. Tesis de Licenciatura inédita, Escuela de Arqueología, Universidad Nacional de Catamarca, Catamarca.

2007 Narrar las prácticas del pasado: el potencial de la estratigrafía arqueológica como representativa de prácticas sociales. En Intersecciones en Antropología N8: 101-119. UNCPB, Argentina.

De la Orden A., y A. Quiroga

1997. Fisiografía y vegetación de la Cuenca del Río Los Puestos, Departamento de Ambato,Catamarca. Revista de Ciencia y Técnica Vol. IV, N 4 , año 3. UNCA 
Debenedetti, S.

1912 Influencias de la Cultura Tiahuanaco en la Región del Noroeste Argentino (Nota preliminar). Publicaciones de la Facultad de Filosofía y letras $N^{\circ}$ II. Buenos Aires.

1931 L'ancienne Civilisation des Barreales. Ars Americana 2, París.

Descola, P.

1987 Las selva culta: Simbolismo y praxis en la ecología de los Achuar. Abya-Yala. Ecuador.

2001 Construyendo naturalezas, ecología simbólica y práctica social. En Naturaleza y sociedad. Perspectivas antropológicas, editado por P. Descola y G. Pálsson, traducido por S. Matrangelo. Siglo XXI, Madrid.

2005 La lanzas del crepúsculo. Relatos jíbaros. Alta amazonia. Fondo de Cultura Económica. Buenos aires.

Dobres, M. A

2000 Technology and Social Agency. Blackwell Publishers: Oxford y Masachusetts

Dobres, M y C. R. Hoffman

1994 Social Agency and the Dynamics of Prehistoric Technology. Journal of Archaeological Methodand Theory 1(3):211-258.

1999 The Social Dynamics of Technology. Practice, Politics, and World Views. Smithsonian Institutions Press: Washington and London.

Donkin, R.

1979 Agricultural Terrasing in the Aboriginal New World. University of Arizona Press. Tucson.

Escolar, D

2007 Los dones étnicos de la Nación. Identidad Huarpe y modos de producción de soberanía en Argentina. Prometeo Libros, Buenos Aires.

Espósito G.

2006 Ni utilitarios ni suntuarios. Los cinceles de metal del sitio Martínez 1, valle de Ambato, Catamarca, siglos VI al XI DC. La Zaranda de Ideas. Revista de Jóvenes Investigadores en Arqueología 2:9-18. Buenos Aires.

2009 De clasificaciones y categorizaciones: Los objetos de metal del Valle de Ambato, Catamarca, $600-1200$ d. C. BAR Internacional Series, Oxford

Espósito, G. y M. B. Marconetto

2008. Metalurgia y recursos forestales en el Valle de Ambato (Pcia. de Catamarca). Problemáticas de la Arqueología Contemporánea. Tomo II. Editado pro A. Austral y M. Tamagnini. Editoral de la Universidad de Río Cuarto. 
Fabra, M.

2005 Tecnología cerámica y cambio social en sociedades agrícolas prehispánicas. Valle de Ambato, Catamarca. En La Cultura de la Aguada y sus Expresiones Regionales, editado por Martín S., M.E. Gonaldi, S. R. Ferraris y A. R. Giordano, pp. 15 a 22. EUDELAR, La Rioja.

2008 Producción tecnológica y cambio social en sociedades agrícolas prehispánicas (Valle de Ambato, Catamarca). BAR International Series. Oxford.

Federici, L.

1991 "Alfarería del sitio El Altillo (ScatAmb 337), Valle de Ambato, Provincia de Catamarca". En Publicaciones 46: 131-142. CIFFyH.

Fernández Cobas, M. I y Martínez Prieto M. P.

1998 Criterios y convenciones para el tratamiento de la cultura Material mueble. CAPA

7. Grupo de Investigaciones en Arqueología del Paisaje, Universidad de Santiago de Compostela.

Figueroa G.

2007 Sistema de producción agrícola en la vertiente occidental del valle de Ambato, Catamarca, siglos VII a XI d.C. Informe inédito.

2008 Los sistemas agrícolas del Valle de Ambato, Catamarca, siglos VI a XI d.C. En Intersecciones en Antropología $\mathrm{N}^{\circ}$ 9: 313-317.

Figueroa, G. y Dantas M.

2006 Recolección, procesamiento y consumo de frutos silvestres en el noroeste semiárido argentino. Casos actuales con implicancias arqueológicas. En La zaranda de ideas $\mathrm{N}^{\circ} 2: 35-50$.

Figueroa, G. G., M. Dantas y A. G. Laguens

2009 Agropastoral Practices and Innovations in the Production of Plants and Animals in the Southern Andes. Ambato Valley, Argentina, First Millennium AD. Current Anthropology, en evaluación.

García L. C.

1988 Etnoarqueología: manufactura de cerámica en Alto Sapagua. En Arqueología Contemporánea argentina. Actualidad y perspectivas, editado por H. D. Yacobaccio, L. A. Borrero, L. C. García, C. A. Aschero y C. Bellelli pp: 33-58. Ediciones Búsqueda, Buenos Aires. 
Gastaldi, M. R.

2007a El lugar de los objetos en la teoría estratigráfica de Edgard C. Harris: Reflexiones desde una habitación del Valle de Ambato, Argentina. Ponencia expuesta en el $I V$ Taller Internacional de Teoría Arqueológica Sudamericana Inter World Archaeological Congress.

2007b Intersectando biografías: Prácticas de almacenamiento, vasijas y personas en el Valle de Ambato. I milenio AD. Ponencia expuesta en el IV Taller Internacional de Teoría Arqueológica Sudamericana Inter World Archaeological.

2007c Fijando sentidos. Montículos y proceso de integración regional: reflexiones desde el Valle de Ambato. Ponencia expuesta en el XVI Congreso Nacional de Arqueología Argentina

2007d Tecnología y Sociedad: Biografía e Historia Social de Las Palas del Oasis de Tebenquiche Chico. Bar. Internacional Serie. Oxford, Inglaterra.

Gerristen, F.

1999 To Build and To Abandon. The Cultural Biography of Late Prehistoric Houses and Farmsteads in the Southern Netherlands. En Archaeological Dialogues 2.

Giddens, A.

1991 [1987] El estructuralismo, el post-estructuralismo y la producción de la cultura. En La teoría social, hoy, editado por A. Giddens y J. Turner, pp. 254-289. Traducción de J. Alborés. Patria, México.

1995 [1984] La constitución de la sociedad. Bases para una teoría de la estructuración. Amorrourtu. Buenos Aires

Gnecco, C.

2006 Territorio y alteridad étnica: fragmentos para una genealogía. En (Des) territorialidades y (NO) lugares: procesos de configuración y transformación social del espacio, editado por Gómez D. H. y Piazzini Suárez, pp. 221-246. La Carreta Editores E.U. Medellín.

2004 La Indigenización de las arqueologías Nacionales. En Teoría arqueológica en América del Sur, editado por Politis G. G. y R. D. Peretti, pp 119-128. INCUAPA, UNICEN.

González, A. R.

1950-55 Contextos culturales y cronología relativa en el área central del NOA. Anales de Arqueología y Etnología. Tomo IX: 16-29. Universidad de Cuyo, Mendoza.

1961-64 «La Cultura de La Aguada del N. O. Argentino», Revista del Instituto de Antropología $\mathrm{N}^{\circ} 2$ et 3 Universidad Nacional de Córdoba.

1974 Arte, estructura y arqueología. Análisis de figuras duales y antrópicas del N.O. Argentino. En Nueva Visión, Colección Fichas 35. Buenos Aires. 
[Continuación de González, A. R.]

1977 Arte precolombino de la Argentina. Introducción a su historia cultural. Buenos Aires: Filmediciones Valero.

1979 La dinámica cultural del N.O. Argentino. Evolución e historia en las culturas del N.O. Argentino. Antiquitas $\mathrm{N}^{\circ}$ 28/29:1-15 Buenos Aires.

1992 Las placas metálicas de los Andes del Sur. Contribución al estudio de las religiones precolombinas. Materialien zur Allgemeinen und Vergleichenden Archäologie, Band 46. Verlag Philipp von Zabern, Mainz am Rheim.

1998 Cultura La Aguada. Arqueología y diseños. Filmediciones Valero, Buenos Aires.

González, A. R. Y Baldini, M. I.

1991 Función y significado de un ceramio de la Cultura La Aguada: Ensayos de interpretación. En Boletín del Museo de Arte Precolombino $\mathrm{N}^{\circ}$ 5: 23-52, Santiago de Chile.

González, A. R. y Pérez Gollán J. A:

1976 Argentina indígena. Víspera de la Conquista. Paidos. Buenos Aires

González Bonorino, F

1978 Descripción geológica de la Hoja 14f, San Fernando del Valle de Catamarca. Servicio Geológico Nacional, Buenos Aires.

Gordillo, I

1990 Ambato: entre pirámides y jaguares. En Revista Ciencia Hoy 2(8): 19-24. Buenos Aires

1995 Arquitectura y religión en Ambato. Organización socio espacial del ceremonialismo. Publicaciones del CIFFyH 47:55-110. Córdoba.

2005 Dimensión temporal del sitio La Rinconada. Su interpretación y aporte a la historia del Período Medio. En La Cultura de la Aguada y sus expresiones regionales, editado por Martín S., M.E. Gonaldi, S. R. Ferraris y A. R. Giordano, pp. 159 a 171. EUDELAR, La Rioja.

2006 Espacio y rito. Aproximaciones a la construcción del paisaje Aguada. Actas de la IV mesa Redonda de la Cultura de la Aguada y Su dispersión. Universidad Católica del Norte. Instituto de Investigaciones Arqueológicas y Museo San Pedro de Atacamas. Chile

2009 El Sitio ceremonial de la Rinconada: Organización socio espacial y religión en el Valle de Ambato (Catamarca, Argentina). BAR Internacional Series, Oxford.

Gordillo, I. y Ares, L.

2005 Ingresando a los patios de La Rinconada (Ambato, Catamarca). En La Cultura de la Aguada y sus Expresiones Regionales, editado por Martín S., M.E. Gonaldi, S. R. Ferraris y A. R. Giordano, pp. 211 a 225. EUDELAR, La Rioja. 
Gordillo, I. y Buono, H.

2005 La metalurgia Aguada en el sitio La Rinconada. En La Cultura de la Aguada y sus expresiones regionales, editado por Martín S., M.E. Gonaldi, S. R. Ferraris y A. R. Giordano, pp. 141 a 152. EUDELAR, La Rioja.

Gordillo, I. y M. F. Kusch

1987 La Aguada: por una aproximación iconográfica. Revista de Antropología, 3: 40-52, Buenos Aires, Argentina.

Gordillo, T. y Solari A.

2009 Prácticas mortuorias entre las poblaciones del Valle de Ambato (Catamarca, Argentina). En Revista Española de Antropología Americana Vol. 39 N 1: 31-51.

Gosden, C.

1994 Social Being and Time. Blackwell Publishers, Oxford.

2001 Postcolonial Archaeology: Issues of Cultural, Identity, and Knowledge. En Archaeological Theory Today, editado por I. Hodder, pp: 241-261. Polity Press, Cambridge.

Gosden C. y Y. Marshall

1999 The Cultural Biography of Objects. World Archaeology 31(2):169-178.

Granizo, M. G.

2001 La cerámica en Tebenquiche: Una propuesta de interpretación categorial. Tesis de

Licenciatura inédita. Escuela de Arqueología, Universidad Nacional de Catamarca, Catamarca.

Haber, A. F.

1994 Supuestos teórico-metodológicos de la etapa formativa de la Arqueología de Catamarca (1875-1900). Publicaciones Arqueología 47:31-54. C.I.F.F y H. Universidad Nacional de Córdoba.

1996 La estrategia y la construcción del tiempo en arqueología. Comentarios sobre la teoría de Harris. Shincal 5: 27-34.

2006 Una arqueología de los oasis puneños. Domesticidad, interacción e identidad en Antofalla, primer y segundo milenios d.C. Universidad del Cauca y Jorge Sarmiento, Córdoba.

2004 Arqueología de la naturaleza/ naturaleza de la Arqueología. En Hacia una arqueología de las arqueologías sudamericanas, editado por Alejandro Haber, pp. 15-31. Ediciones Uniandes, Bogotá.

Haber, A. F. y D. D. Delfino

1995-1996 Samuel Lafone Quevedo and the Construction of Archaeology in Argentina.

Revista de História da Arte e Arqueologia 2:31-43/405-413. 
Haber A. F. y M. R. Gastaldi

2006 Vida con palas. En Antípodas. Revista de antropología y arqueología. Volumen 2: 275-302.

Haber A., Laguens A. y Bonnin M.

1996-97 Montículo y casa. Elementos retóricos en la cultural material Ambato, en Shincal. Revista de la Escuela de Arqueología, № 6, Catamarca, p 59 a 64.

Hall, S.

2003 Introducción ¿Quién necesita identidad?. En Cuestiones de identidad cultural, Editado por Hall S. y Du Gay P., pp: 13-39. Amorrortu editores.

Hally, David. J.

1983. Use alteration of Pottery Vessel Surfaces: an Important Source of Evidence for the Identification of Vessel Function. North American Archaeologist 4: 3-26.

1986 The Identification of Vessel Function: A Case Study from Northwest Georgia. American Antiquity 51:267-295.

Harris, E. C.

1991 [1989] Principios de estratigrafía arqueológica. Traducido por E. Junyent. Editorial Crítica, Barcelona.

Heidegger

1994 La cosa. En Conferencias y artículos. Traducido por Eustaquio Barjau. Barcelona, Ediciones del Serbal.

Heredia O.

1976 Investigaciones Arqueológicas en los Castillos -Dpto. Ambato Provincia de Catamarca. Informe inédito. Documentación Proyecto Arqueológico Ambato.

1998 "Proyecto: investigaciones arqueológicas en la región del Valle de Ambato (dto. Ambato, provincia de Catamarca)", en Estudios, $\mathrm{N}^{\circ}$ 10, Centro de Estudios Avanzados de la Universidad Nacional de Córdoba.

Hernando, A

2002 Arqueología de la identidad. Akal editores. Madrid.

Herrero, R. Y Ávila, A.

1991 Excavaciones en la unidad residencia ScatAmb 004 (Martínez 4) del Período de Integración Regional. En Arqueología №46: 111-130. Publicaciones del CIFFYH.

1993 Aproximación al estudio de los patrones de asentamiento en el valle de Ambato. Publicaciones 6, Investigaciones 4. Tucumán

Hill, E.

2003 Sacrificing Moche Bodies. En Journal of Material Culture Vol. 8(3): 285-299. SAGE, London. 
Hyslop, J.

1977. "Chulpas of the Lupaca zone of the Peruvian high plateau". Journal of Field Archaeology 4: 149-170. Boston.

Hodder, I.

1982 Symbols in Action. Ethnoarchaeological Studies of Material Culture. Cambridge University Press, Cambridge.

1987a Archaeology as Long-Term History. Cambridge University Press, Cambridge.

1987b The Contribution of the Long Term. En Archaeology as Long-Term History, editado por I. Hodder, pp. 1-8. Cambridge University Press Cambridge, Cambridge.

1988 [1986] Interpretación en arqueología. Corrientes actuales. Traducción de M. E. Aubet. Crítica, Barcelona.

1989 Post-Modernism, Post-Structuralism and Post-Processual Archaeology. En The Meanings of Things. Material Culture and Symbolic Expression, editado por I. Hodder, 64-78. Harper Collins Academic, Londres.

1990 The Domestication of Europe. Structure and Contingency in Neolithic Societies. Basil Blackwell, Oxford.

1992 Theory and Practice in Archaeology. Routledge, Londres Ingold, $\mathrm{T}$.

1993 The Temporality of the Landscape. World Archaeology 25: 152-174.

1999 Foreword. En The Social Dynamics of Technology. Practice, Politics and World Views. Editado por Marcia- Anne Dobres y Christopher R. Hoffman. Smithsonian Institution Press. Washington and London.

Isla A.

2002 Los usos políticos de la identidad. Indigenismo y Estado. Editorial de las Ciencias. Buenos Aires.

Izeta, A.D., A.G. Laguens, M.B. Marconetto y M.C. Scattolin

2009 Camelid Handling in the Meridional Andes During the First Millennium AD: a

Preliminary Approach Using Stable Isotopes. International Journal of

Osteoarchaeology 19(2):204-214.

Jones, S.

1997 The Archaeology of Ethnicity. Constructing Identities in the Past and Present. Routledge: Londres y Nueva York. 
Juez, S.

1991 Unidad arqueológica Rodeo Grande, Valle de Ambato: excavaciones en el sitio Martínez 2. En Arqueología, N 46: 87-110. Publicaciones del CIFFYH

Kopytoff, I.

1991 La biografía cultural de las cosas: La mercantilización como proceso. En La vida social de las cosas. Perspectiva cultural de las mercancías. Editado por A. Appadurai, pp.89-142. Traducido por A. Castillo Cano. Grijalbo. México.

Kriscautzky, N

1996-1997 Nuevos aportes en la arqueología del Valle de Catamarca. En Shincal, Revista de la Escuela de Arqueología de Catamarca, Nro 6:27-31.

Kriscautzky, N., Lomaglio, D, Morales F. y Puentes H.

2005 Comentarios acerca del hallazgo de un entierro múltiple en un sitio de Aguada inicial en el Rodeo, Dpto. Ambato, Catamarca. En La Cultura de la Aguada y sus expresiones regionales, editado por Martín S., M.E. Gonaldi, S. R. Ferraris y A. R. Giordano, pp. 299 a 306. EUDELAR, La Rioja.

Kusch, F.

1982 Propuesta metodológica para el análisis de los diseño de las piezas Aguada. (MS) Fondo documental Proyecto Ambato.

1990 La representación de la figura Humana en el N. O. Argentino. En Revista de antropología. Una Búsqueda del Hombre desde el tercer Mundo, Año 5(9). Buenos Aires.

Kush, F. y Valko, Marcelo L.

1997 Los sistemas simbólicos y sus transformaciones. La Aguada después de la Aguada. Actas del XII Congreso Nacional de Arqueología Argentina, Tomo II: 108-115.La Plata.

Laclau, E.

1996. Universalismo, particularismo y la cuestión de la identidad. En Emancipación y diferencia. Ariel, Buenos Aires.

Lafone Quevedo, S. A.

1888 Londres y Catamarca. Imprenta y Librería Mayo. Buenos Aires.

1905 Viaje Arqueológico en la región de Andalgalá 1902-1903. Revista del Museo de la Plata XII:3-38.

1914 Los indios del Valle de Catamarca. Estudio histórico por el Padre A. Larrouy. Revista de la Universidad de Buenos Aires, XXVII:359-371 
Laguens, A. G.

2002 Desigualdad social y cultura material en contextos arqueológicos. El caso del Valle de Ambato, Catamarca. Publicación digital. http://www.ffyh.unc.edu.ar/secretarias/cyt/jor2002/IIIjor.htm en Marginalidad social y vulnerabilidad: diversidad, desigualdad y pobreza

2005 "Contextos materiales de desigualdad social en el Valle de Ambato, Catamarca, Argentina, entre el S. VII y X d.C.", Relaciones de la Sociedad Argentina de Antropología, vol XXIX.

2006a Continuidad y ruptura en procesos de diferenciación social en comunidades aldeanas del valle de Ambato, Catamarca, Argentina. Chungara Vol.38 N²: 211222. Arica, Chile.

2006b "Campo y espacio social en el estudio arqueológico de la desigualdad". En Contra la tiranía tipológica en arqueología: Una visión desde suramérica. Editado por Cristóbal Gnecco y Carl Henrick Langebaek. Facultad de Ciencias Sociales, CESO, Universidad de los Andes. Ediciones Uniandes.

2007 "Objetos en objetos: Hacia un enfoque relacional de lo estético en Arqueología". Ponencia presentada en el IV Taller Internacional de Teoría Arqueológica Sudamericana Inter World Archaeological

Laguens A. G. y Bonnin M.

1996 Evaluación de series de fechados radiocarbónicos del valle de Ambato, Catamarca" en Publicaciones Arqueología N48:65-101, C.I.F.F y H. Universidad Nacional de Córdoba.

2005 "Recursos Materiales y Desigualdad Social en la Arqueología de AmbatoCatamarca", en La Cultura de la Aguada y sus expresiones regionales, editado por Martín S., M.E. Gonaldi, S. R. Ferraris y A. R. Giordano, pp. 23 a 33. EUDELAR, La Rioja.

Laguens G. y Gastaldi M.

2008 Registro material, fisicalidad, interioridad, continuidad y discontinuidad: posiciones y oposiciones frente a la naturaleza y las cosas. En: Puentes hacia el pasado: reflexiones teóricas en arqueología. Sociedad Chilena de Arqueología pp. 169189.Santiago de Chile.

Laguens A.. Dantes M., Figueroa G., Gastaldi M. R., Juez S. y Pazzarelli F.

2007 Vasijas + pucos con huesos + agua no son solo sopa: la cerámica de uso doméstico en el siglo IX d. C. en el Valle de Ambato, Catamarca y sus relaciones con otros entramados sociales y materiales. En Número Especial de Pacarina. IV Congresos Nacional de Arqueología Argentina. 
Laguens A., Giesso M., Bonnin M., Speakman R., Glascock M., Manasse B. y Kriscutzky N.

2004 Estudio y distribución de la cerámica gris-negra grabada del Valle de Ambato (CA.

300 - 1000 D. C.. Ponencia presentada en el XV Congreso Nacional de Arqueología Argentina. Río Cuarto.

Laguens, A., M. Giesso, J. Speakman y M. Glascock.

2006. Provenance Analysis of Gray-Black Incised Ceramics. Ponencia presentada el Society for American Archaeology Meeting, San Juan, Puerto Rico.

Laguens, A. G. y S. Juez

1999 Especialización en la manufactura cerámica de pucos Aguada. Actas del XIII Congreso Nacional de Arqueología Argentina, Córdoba. 2001.

Laguens A. G. y F. Pazzarelli

2007 “'Manufactura, uso y descarte? o acerca del entramado social de los objetos cerámicos" IV Taller Internacional de Teoría Arqueológica Sudamericana Inter World Archaeological. Manuscrito.

Latour, Bruno

1996 On Interobjectiviy. Mind, Culture and Activity, 3 (4): 228-245

1998 On actor-network theory: a few clarifications. fttp://amsterdam.nettime.org/ Lists-

Archives/nettime-1-9801/msg00019.html, 1-9 and 1-5

Law, John

1992 Notes on the Thoery of the Actor network: Ordering, Strategy and Heterogeneity.

Publicado por el Center for Science Studies, Lancaster University, Lancaster LA1

4YN, en http://www.comp.lancs.ac.uk/sociology /papers/Law-Notes-on-ANT.pdf

Lechtman, $\mathrm{H}$.

1993 Technologies of Power: the Andean Case. En Configurations of Power. Holistic Anthropology in Theory and Practice, editado por J. S. Henderson y P. J. Netherly, pp. 244-280. Cornell University Press, Ithaca y Londres.

Lechtman, H. y A. N. Soldi

1985 La Tecnología en el mundo andino. Runakunap Kawsainimkupaq Rurusquankunaqa, Vol 1:Subsistencia y Mensuración. Editado por H. Lechtman y A. N. Soldi. Universidad Nacional Autónoma de México, México

Lemonnier, $\mathrm{P}$.

1992 Elements for an Anthropology of Technology. Museum of Anthropology, University of Michigan, Ann Arbor.

Leroi-Gourhan, A.

1984 Las raíces del mundo. Traducido por M. Vassallo. Ediciones Juan Granica, Barcelona. 
Leviller R.

1927 Nueva crónica de la conquista del Tucumán. Tomo I: 1542-1563. Editorial Sucesores de Riva de Neyra. Madrid.

Llamazares, A. M. y Slavutsky, R

1990 Paradigmas estilísticos en arqueología: del normativismo culturalista a las alternativas postsistémicas. En: Boletín de antropología americana 22: 21-43.

Lorandi, A. M.

1967 Vasijas de Catamarca con caracteres excepcionales en la Zona. Anales de Arqueología y Etnología. XII. Mendoza.

Lumbreras, L. G.

1984 La Arqueología como ciencia social. Casa de las Américas, La Habana, Cuba.

2006 Arqueología social latinoamericana. En Problemáticas de la Arqueología Contemporánea, Tomo I., editado por A. austral y M. Tamagnini pp.47-55. Universidad Nacional de Río Cuarto. Río Cuarto, Córdoba.

Manzanilla, L. (editora)

1986 Unidades habitacionales mesoamericanas y sus áreas de actividad, UNAM, Imprenta Universitaria, México

Marconetto, M.B.

1999 Analyse des Restes de Charpentes Carbonisées de la Vallée d'Ambato (Catamarca, Argentine). BAR International Series, Oxford, en prensa.

2008 Recursos Forestales y el Proceso de Diferenciación Social en Tiempos Prehispánicos en el Valle de Ambato, Catamarca. BAR International Series, Oxford.

Marconetto, M. B y V. Mors.

(Sin fecha). Casas en el monte y el monte en la casa. Análisis antracológico de las estructuras de construcción del Valle de Ambato (Catamarca, Argentina). Boletín de la Sociedad Chilena de Arqueología Chilena; de próxima aparición.

Mariot V., A. Tenchini, A. Reuter, F. Zubrinic

2001. Relevamiento cartográfico y geomorfológico de los procesos erosivos de las cuencas de los Ríos Ambato y Huaniomil - Pcia. de Catamarca. Revista de Ciencia y Tecnica de la UNSE. (En prensa)

Marx, K.

1978 El capital. Crítica de la economía política. Tomo I. Fondo de Cultura Económica, México. 
McGuire, R.

1983 Breaking Down Cultural Complexity: Inequality and Heterogeneity. En Advances in archaeological Method and Theory, editado por M. Schiffer p 91 - 142.

Meillassoux, C.

1984 Mujeres, graneros y capitales, 6ta. edición. Traducido por O. del Barco. Siglo XXI Editores, México.

Menacho, K. A.

2000 Trayectoria de vida de vasijas cerámicas y modo de vida pastoril. Tesis de Licenciatura inédita, Facultad de Humanidades y Ciencias Sociales, UNJu.

Meskell, L.

2001 Archaeologies of Identity. En Archaeological Theory Today, editado por I. Hodder, pp: 187-213. Polity Press, Cambridge.

Miller, D. y C. Tilley

1996 Editorial. Journal of Material Culture 1(1):5-14.

M.O.L.A.S.

1994 Archaeological Site Manual. Museum of London Archaeology Service. Londres. Inglaterra

Montani, R.

2004 Categorías materiales y formas sociales entre los Wichís de Los Baldes (Salta, Argentina). Tesis de Licenciatura Inédita. Escuela de Antropología, Facultad de Humanidades y Artes, Universidad Nacional de Rosario.

Neupert, M. A.

2000 Clays of Contention: an Etnoarchaeological Study of Factionalism and Clay Composition. Journal of Archaeological Method and Theory, Vol. 7, №3:249272.

Núñez Regueiro, V. A.

1974 Conceptos instrumentales y marco teórico en relación al análisis del desarrollo cultural de Noroeste Argentino. En Revista del Instituto de Antropología $\mathrm{n}^{\circ} \mathrm{V}: 169-190$.

1998 Arqueología, historia y antropología de los sitios de Alamito. Ediciones Interdea. San Miguel de Tucumán.

Nuñez Regueiro, V. y M. Tartusi.

1990. Aproximaciones al Estudio del Área Pedemontana de Sudamérica". Cuadernos: 12. I.N.A., Buenos Aires.

Orton, C; Tyers, P y Vince A.

1997 [1993] Crámica en arqueología. Editorial Crítica, Barcelona. 
Palavecino, E

1944 Alfarería Chaqueña. Relaciones de la Sociedad Argentina de Antropología, IV: 231245.

Pardó, Oriana

2004 "Las chichas en el Chile precolombino". Chloris Chilensis. Revista chilena de flora y vegetación, Año 7 Nº 2. URL: http://www.chlorischile.cl.

Pazzarelli F.

2006 Prácticas domésticas de almacenamiento y consumo en contextos arqueológicos de desigualdad social. Tesis inédita presentada para optar por el grado de licenciado en Historia de la Faculta de Filosofía y Humanidades de la Universidad Nacional de Córdoba.

2007 Notas para una arqueología de la comida. En La Zaranda de Ideas. Revista de Jovenes investigadores en arqueología, N4:157-162

Pazzarelli, F y G. Vargas

2008 ¿Cómo hacer chicha en Córdoba? Reflexiones acerca de las implicancias políticas y materiales de la producción de chicha por inmigrantes bolivianos. En Revista del Museo de Antropología. Vol. 1 n. 1 p.29-40

Pérez Gollán, J. A.

1981 Introducción. En Presencia de Vere Gordon Childe. Editado por Pérez Gollán J. A. pp. 17-78. Instituto Nacional de Antropología e Historia, México.

1986 Iconografía religiosa andina en el noroeste argentino. Boletín del Instituto Francés de Estudios Andinos XV(3-4):61-72.

1991 La cultura de La Aguada vista desde el Valle de Ambato. Publicaciones del CIFFYH. Arqueología 46:157-173.

1994 El proceso de integración en el valle de Ambato: complejidad social y sistemas simbólicos. Rumitacana 1(1):33-41.

1999 Arte y arqueología de La Aguada. Artinf 103/104:12-14.Buenos Aires.

2000 a "El jaguar en llamas (La religión en el antiguo Noroeste Argentino)". En Nueva

Historia Argentina Tomo I, Los Pueblos Originarios y La Conquista. Compilado por

Miriam Tarragó. Buenos Aires, Sudamericana, pp 229-256.

2000 b "Los suplicantes una cartografía social". En Arte Prehispánico Creación,

Desarrollo y Persistencia. Temas de la Academia. Academia Nacional de Bellas Artes. Buenos Aires. 
[Continuación de Pérez Gollán, J. A.]

2007 Comentarios mesa 3: la noción de complejidad en la arqueología del NOA y Andes

Centro -SUR. En Sociedades Precolombinas Surandinas. Temporalidad, Interacción y Dinámica Cultural del NOA en el Ámbito de los Andes Centro-Sur. Editado por V. I. Williams, B. N. Ventura, A .B. M. Callegari y H. D. Yacobaccio. Taller Internacional de Arqueología del NOA y Andes Centro-Sur. Buenos Aires.

Pérez Gollán, J. A., S. Assandri, M. Bonnin, M. Caro, P. Cruz, M. Fabra, J. Hierling, S. Juez, A. Laguens, M. A. Zaburlin.

2000 Proyecto Arqueológico Ambato: Excavaciones en el sitio Piedras Blancas, Valle de Ambato, Catamarca. Informe inédito.

Pérez Gollán, J. A., S. Assandri, M. Bonnin, M. Caro, J. Hierling, S. Juez, A. Laguens

1997 Excavación arqueológica en el sitio Piedras Blancas, La Rinconada, Valle de Ambato, Catamarca. Informe inédito

Pérez Gollán, J. A., M. Bonnin, A. Laguens, S. Assandri, L Frederich, M Gudemos, J Hierling, S. Juez.

1996-97 "Proyecto Arqueológico Ambato: un estado de la cuestión"; en Shincal, Revista de la Escuela de Arqueología de Catamarca, Nro 6, 1996- 1997:115-123.

Pérez Gollán, J. A y Heredia, O. R.

1975 Investigaciones arqueológicas en el departamento Ambato, Provincia de Catamarca.

Relaciones de la Sociedad Antropología, IX (nueva serie). Buenos Aires, Argentina.

1987 Hacia un replanteo de la Cultura de la Aguada. En Cuadernos Instituto Nacional de Antropología $\mathrm{N}^{\circ} 12$ : 161-178. Buenos Aires, Argentina.

Pérez Gollán, J. y A. Laguens

2001 "Les Cultures Tiahuanacu et Aguada: anciennes et nouvelles lectures". En Dossiers d Archeologie, Nro. 262, Avril.

Pierce, Ch. S.

2005 [1893-1903] El ícono, el índice y el símbolo. Traducido por S. Barrera. http://www.unav.es/gep/IconoIndiceSimbolo.html

Politis G. y Pérez Gollán, J. A.

2004. Latin American Archaeology: between colonialism and globalization. En L.

Meskell y R. Preucel (eds.) A Companion to Social Archaeology. Pp. 353-373.

Blackwell Publishing, UK

Primera Convención Nacional de Antropología. Primera Parte.

1966 Publicaciones. Instituto de Antropología. Facultad de Filosofía y Humanidades.

Universidad Nacional de Córdoba. 
Quesada, M. N.

2000 Tecnología agrícola y producción campesina en la Puna de Atacama, I milenio D.C. Tesis de licenciatura inédita, Escuela de Arqueología, Universidad Nacional de Catamarca, Catamarca.

2007 Paisajes Agrarios del Área de Antofalla. Procesos de trabajo y escalas sociales de la producción agrícola (Primer y segundo milenios d.C.). Tesis de doctorado inédita, Facultad de Ciencias Naturales y Museo, Universidad Nacional de la Plata.

Quiroga, A.

1977 [1901] La cruz en América. Ediciones Castañeda, Buenos Aires.

Randall, R.

1993. Los dos vasos. Cosmovisión y política de la embriaguez desde el incanato hasta la colonia. En Borrachera y memoria. La experiencia de lo sagrado en los Andes. Editado por Saignes, T pp: 73:112. Hisbol/IFEA, La Paz

Raffino, R. A.

1988 Poblaciones indígenas de la Argentina. Tipográfica Editora Americana, Buenos Aires.

Ravines, R.

1989 Arqueología práctica. Los Pinos, Lima.

Real Academia Española de lengua

2001 Diccionario de lengua española. Vigésima segunda edición. http://www.rae.es/rae.html

Renfrew, C y P. Bahn

1993 [1991] Arqueología. Teorías, métodos y práctica. Traducción de M. J. Mosquera Rial. Akal, Madrid.

Restrepo E.

2004 Teorías contemporáneas de la etnicidad. Stuart Hall y Michel Foucault. Editorial Universidad del Cauca. Colombia.

Rice, P. M.

1987. Pottery Analysis. A Sourcebook, University of Chicago Press, Chicago.

Rivera Cusicanqui, S.

1884. Oprimidos pero no vencidos. Luchas del campesinado aymara y qhechwa de Bolivia, 1900-1980. La Paz: Hisbol-CSUTCB, 1984.

Rodríguez J. C.

2002 La Alfarería de Casira. Las artesanías y el proceso de transformación en su integración a mercados urbanos. Editorial Universidad Nacional de Jujuy, San Salvador de Jujuy. 
Roskams, S.

2003 Teoría y práctica de la excavación. Traducido por María Ruiz del Árbol. Editorial Crítica. Barcelona.

Rye Owen S.

1988. Pottery Technology. Principles and Reconstruction. Manuals on Archaeology 4. Washington D. C.: Taraxacum.

Sahlins, M.

1983 Economía de la edad de piedra, 2da. edición. Traducido por E. Muñiz y E. R. Fondevila. AkalEditor, Madrid.

Saunders, N. J.

1999 Biographies of Brilliance: Pearls, Transformations of Matter and Being c. AD 1492.

En World Archaeology 31(2): 243-257. Routledge, Londres.

Schlanger, N.

1994 Mindful Technology: Unleashing the Chaine Operatoire for an Archaeology of Mind. En TheAncient Mind. Elements of Cognitive Archaeology, editado por C.

Renfrew y E. B. W. Zubrow,pp. 143-151. Cambridge University Press. Cambridge.

Shanks, Michael

2006 From a Postprocesual to a Symmetrical Arcaheology. http://traumwerk. stanford.edu:3455/Symmetry $/ 822$

Shanks, M. y C. Tilley

1987 Re-constructing Archaeology. Theory and Practice. Cambridge University Press, Cambridge.

Schiffer, M. B.

1972 Archaeological Context and Systemic Context. American Antiquity 37(2):156-165.

1987 Formation Processes of the Archaeological Record. University of New México Press. Albuquerque.

1995 Behavioral Archaeology. First Principles. University of Utah Press. Salt Lake City.

1990 Te Influence of Surface Treatment on Heating Effectiveness of Ceramic Vessels. Journal of Archeological Science 17:373-381.

Schiffer, Michael B. y James M. Skibo

1987. Theory and Experiment in the Study of Technological Change. Current Anthropology 17 (5):595-622

1989 A Provisional Theory of Ceramic Abrasion. American Anthropologist 91 (1): 101115 
Shennan, S (editor)

1994. Archaeological Approaches to Cultural Identity. Routledge, Londres.

Shepard Anna O.

1976 [1956] Ceramic for Archeologist. Washington D.C.: Carnegie Institution of Washington.

Sillar, B.

1996 The Dead and the Drying: Techniques for Transforming People and Things in the Andes. Journal of Material Culture. $\mathrm{N}^{\circ} 1(3): 259 \pm 89$.

2000 Dung by Preference: the Choice of Fuel as an Example of how Andean Pottery Production is Embedded within Wider Technical, Social, and Economic Practices. En Archaeometry $\mathrm{N}^{\circ}$ 42: 43-60.

Sillar, B., and Tite, M. S.

2000 The Challenge of 'Technological Choices for Materials Science Approaches in Archaeology. Archaeometry, $\mathrm{N}^{\circ}$ 42: 2-20.

Skibo, J.

1992 Pottery Function. A Use-Alteration Perspective. Plenum Press, New YorK and London

Spector, J. D.

1996 What this Awl Means: Toward a Feminist Archaeology. En Contemporary Archaeology in Theory. A Reader, editado por R. Preucel y I. Hodder, pp. 485-500. Blackwell Publishers, Oxford y Cambridge (Massachusetts).

Swenson E. R.

2003 "Cities of Violence: Sacrifice, Power and Urbanization in the Andes" Journal of Social Archaeology 3: 256-296. SAGE Publications. EE UU.

Tartusi, M. R. A. y Núñez Regueiro V.

1993 Los centros ceremoniales del Noroeste Argentino. Publicaciones N5, Serie Ensayos $N^{\circ} 1$. Instituto de Arqueología, UNT, Tucumán.

Thomas, J.

1996 Time, Culture and Identity. An Interpretive Archaeology. Routledge, Londres y Nueva York.

2001 Archaeology of Place and Landscape. En Archaeological Theory Today, editado por Ian Hodder, pp, 165-186. Polity: Cambridge.

Tilley, C.

1989 Interpreting Material Culture. En The Meanings of Things. Material Culture and Symbolic Expression, editado por I. Hodder, pp. 185-194. Harper Collins Academic, Londres.

1994 A Phenomenology of Lansdcape. Places, Paths and Monuments. Berg Publishers, 
Oxford y Providence.

Tite M.

1999 The Role of Strengt, Toughness and Thermal Shock Resistance in Determining the Choice of Temper in Ceramic- AN Overview. Ponencia presentada en el World Archaeological Congress 4, Cape Twoun, Sudáfrica.

Tite M., KiliKoglou V. y Vekinis G.

2001 Strength, Toughness and Thermal Shock Resistance of Ancient Ceramic, and Their influence on Technological Choice'. En Archaeometry 43 (3):301-324.

Treacy, J.

1994 Las chacras de Coporaque. Andenería y riego en el valle de Collca. Instituto de Estudios Peruanos. Lima

Treherne, P.

1995 The Warrior's Beauty: the Masculine Body and Self-Identity in Bronze-Age Europe. Journal of European Archaeology 3(1):105-144.

Trigger, B.

1994 Historia del pensamiento en arqueología. Crítica. Barcelona Tringham, R.

1995. Archaeological Houses, Households, Housework and The Home. En The Home: Words, Interpretations, Meanings, and Environments editado por D. N. Benjamin, Stea D. Y Saile D. pp 79-107.Aldershot, Avebury.

Turner, V.

1980 La selva de símbolos. Aspectos del ritual Ndembú. Siglo XIX editores, Madrid. Ulhe, Max

1912 Las Relaciones prehistóricas entre el Perú y la Argentina. Actas del Congreso Internacional de Americanistas. Tomo XVII. Buenos Aires.

Vicent García, J. M.

1991a El Neolítico. Transformaciones sociales y económicas. Boletín de Antropología Americana 24:31-61.

1991b "Fundamentos teórico-metodológicos para un programa de investigación arqueogeográfica". En El cambio Cultural del IV al II Milenios a.C. en la Comarca Noroeste de Murcia. Volumen I, editado por P. López García, pp.31-117. Consejo Superior de Investigaciones Científicas, Madrid

Vilaça A.

2005 Chronically Unstable Bodies: Reflections on Amazonian Corporalities. En Journal of the Royal Anthropological Institute. Vol: $11 \mathrm{~N}^{\circ} 3$ : 455-64 
Viveiros De Castro, E.

1996 Os Pronomes cosmológicos e o Perspectivismo Ameríndio. En Mana 2(2):115-104.

2002 A Inconstancia da Alma Salvagem. Cosac \& Naify, Sâo Pablo.

Webmoor, Timothy

2006 Un giro más tras el "giro social". El Principio de la Simetría en Arqueología. http://traumwerk.stanford.edu:3455/Teotihuacan/090

Witmore, Christopher

2006 "A Past no Longer Past." Some Implications for a Symmetrical Archaeology. http://traumwerk.stanford.edu:3455/Symmetry/1040

Yoffe, $\mathrm{N}$.

1993 Too Many Chiefs? (or, Safe Texts for the 90`s). En Archaeological Theory: Who Sets the Aagenda? Editado por K. Flannery. Academic Press, New York.

Zaburlin, M. A.

2001 Informe final. Análisis de áreas de actividad en el sitio Piedras Blancas. Valle de Ambato. Informe Final de Beca de Iniciación, Fondo Nacional para la Ciencia y la Tecnología, Buenos Aires, Argentina.

Zagorodny Nora y Bárbara Balesta

2001 La Construcción de grupos de referencia como herramienta en la investigación ceramológica. En: Cristina Diez Martín (editora) Actas del XII CNAA. Tomo II: 55-62. La plata: Universidad Nacional de la Plata.

Zagorodny N., B. Balesta, G. Ávalos, Valencia C. y Gómez Ferreiro M. J.

2005 Homogeneidad y permanencia de los pucos de la Aguada Orilla Norte. en La Cultura de la Aguada y sus Expresiones Regionales, editado por Martín S., M.E. Gonaldi, S. R. Ferraris y A. R. Giordano, pp. 129-140. EUDELAR, La Rioja 


\section{EXCAVACIONES POR UNIDAD ESTRATIGRÁFICA EN EL RECINTO F Y EN EL RECINTO G DEL SITIO PIEDRAS BLANCAS}

Hemos señalado, en el capítulo dos, que para la reconstrucción de las cartografías de intersección era de suma importancia acceder a las ambientaciones y los contextos de co-presencia, es decir aquellos contextos donde las vasijas entraban en relación con otros objetos y personas, y en cuyo marco adquirieron significados. Por esto, se decidió en el Proyecto Marco donde se desarrolla la investigación utilizar otro método de excavación, diferente a los que fueron implementados con anterioridad vinculados a la técnica del decapage (Leroi-Gourhan 1984), la que permitía limitadamente esta reconstrucción, así se optó por seguir los principios de estratigrafía arqueológica propuestos por E. C. Harris (1991) (Gastaldi 2007a). Esta elección se fundamente en que, como hemos señalado en el capítulo dos, éste nos permitía acercarnos a la noción de práctica social tal cual se la comprende desde la teoría social contemporánea (D’Amore 2002, 2007; Haber 1996; Roskams 2003). Veamos que diferencia a ambos métodos, y las limitaciones del primero para la reconstrucción de los contextos de co-presencia tal cual los hemos definido en el capítulo dos.

En principio tres posiciones generales pueden ser resumidas con respecto a los métodos de excavación (Carandini 1997; Harris 1991; Ravines 1989; Renfrew y Bahn 1993; Roskams 2003). En la primera, el método de excavación por niveles arbitrario, la unidad elemental de análisis e interpretación es el artefacto. En esta perspectiva se privilegia la recuperación de las inclusiones sin tener en cuenta la matriz que las contiene, y en donde se fijan niveles arbitrarios de excavación. Como señala Carandini (1997) esto produce una simplificación de la complejidad estratigráfica del depósito ${ }^{\mathrm{i}}$. En una segunda perspectiva, el método de excavación por unidad estratigráfica (Bibby 1993; Carandini 1997; D’Amore 2002, 2007; Harris 1991; Roskams 2003), las unidades fundamentales son las matrices donde se hallan las inclusiones, recuperándose las unidades estratigráficas, las que son consideradas eventos únicos de depositación que representan una acción o un conjunto de ellas (Carandini 1997:56-57). Según este punto de vista, cada unidad estratigráfica adquiere significado no sólo por sus propias características, sino por las relaciones estratigráficas que mantiene con el resto de las unidades, a la vez que el significado de las inclusiones se da principalmente en relación a la matriz que las contiene. Así, se intenta reconstruir una secuencia de estratigrafía arqueológica, interpretándose las 
unidades al momento de su recuperación durante la excavación (Carandini 1997; D’Amore 2002; 2007; Gastaldi 2007a; Haber 1996; Harris 1991; Roskams 2003). La tercera posición intenta acceder a una visión etnográfica del registro arqueológico, a partir de la búsqueda de las huellas materiales dejadas por las actividades cotidianas realizadas en el pasado, método denominado decapage (Leroi-Gourhan 1984). Este método consiste en seguir ciertas características físicas de composición, coloración, compactación, etc. del sustrato arqueológico respetando cuidadosamente los vestigios en el lugar que cada uno ocupa. Se privilegia la relación topográfica en planos, cortando la superficie en planos superpuestos. Las unidades de análisis son los vestigios, entre ellos las inclusiones culturales, y no las unidades estratigráficas, persiguiéndose como objetivo la búsqueda de pisos en los cuales la abundancia y la organización de los restos justificaran la existencia de áreas de actividades específicas. La reconstrucción de estas actividades se realiza principalmente en el laboratorio, a través de relacionar los distintos registros de inclusiones o hallazgos y los rasgos identificados en dibujos de plantas. Con este método se logran reconstruir grandes acontecimientos arqueológicos, como pueden ser la identificación y caracterización de pisos y niveles de ocupación. Sin embargo, al no registrarse la sucesión de acciones que produjeron estos depósitos, es decir, las unidades estratigráficas y sus mutuas relaciones, este método permite observar limitadamente el proceso de formación de los mismos (D'Amore 2002, 2007; Haber 1996, 2006).

Los interrogantes y los métodos utilizados en ocasiones anteriores a las realizadas a partir del 2004 apuntaron a reconstruir áreas de actividad diferenciales a nivel intrasitio e intersitio que permitieran realizar un análisis comparativo de las actividades realizadas en distintos contextos del sitio Piedras Blancas, con el objetivo de identificar grupos socialmente diferenciados (Zaburlín 2001:1). Esta idea se sustentó en que "la complejización en las estructuras sociales también implica una diferenciación en el uso de los espacios dentro del asentamiento. En consecuencia es de esperar que el registro material de los contextos habitacionales reflejen un rango de actividades variadas: tareas cotidianas de elaboración de alimentos, actividades productivas, como así también actividades rituales. A la vez que la segregación espacial de dichas actividades permitiría diferenciar las áreas de vivienda de los grupos de elite y las áreas de vivienda de las unidades domésticas bajo su control, y también las de posibles actividades rituales y de especialistas" (Zaburlín 2001:1). Las áreas de actividad como concepto operativo hace referencia a “(...) la concentración y asociación de materias primas, instrumentos o desechos en superficies o volúmenes específicos que reflejen actividades particulares (Manzanilla 1986:11). Y si bien, el área de actividad se la considera como “...unidad 
básica de análisis del registro arqueológico, (...) es reflejo de acciones particulares repetidas, de carácter social, con un trasfondo social específico..." (Manzanilla 1986:11), nos acerca más a espacios de configuración de actividades específicas -tal cual Zaburlín (2001) pretende discernir en el sitio Piedras Blancas-, o las cuatro variedades generales de áreas que define Manzanilla (1986:11) -"la producción, el uso o consumo, el almacenamiento y la evacuación"-, que a prácticas sociales como las hemos definido en el capítulo dos. Estos espacios de configuración tienen un componente más sincrónico y dan una imagen instantánea, en cambio la unidad estratigráfica, la secuencia estratigráfica y las interfacies no hablan de procesos temporales, de sedimentación, de estructuración de dichos espacios en términos de rutinas diarias que van produciendo y reproduciendo las relaciones puestas en juego en esos lugares.

Al procedimiento de excavar estratigráficamente le subyace, como mencionáramos, el supuesto teórico de que cada una de las unidades estratigráficas que se identifica considerada la unidad elemental de la excavación- puede interpretarse como una acción o un conjunto de acciones. Al hablar de unidades elementales identificables en una excavación, nos referimos a aquellas unidades estratigráficas, tanto horizontales como verticales, que representan el conjunto de eventos que forman la vida sedimentaria de un depósito; esto es, la estratificación original de un sitio arqueológico.

Los estratos horizontales son aquellos que tienden, en diferentes grados, a la horizontalidad, como pueden ser los pisos de ocupación, los rellenos de pozos, los derrumbes o las depresiones. Los estratos verticales hacen referencia exclusiva a acciones humanas de estratificación, que “...complican el modelo de estratificación arqueológica y su proceso de excavación e interpretación..." (Harris 1991:77); tal es el caso de los muros. Las interfacies equivalen a las superficies espaciales totales de los estratos, y marcan el límite de su constitución, por lo que conforman un elemento de suma importancia a la hora de distinguir las distintas unidades estratigráficas, aunque cabe aclarar que en su registro durante la excavación, no se diferencian de sus respectivos estratos horizontales o verticales, puesto que poseen sus mismas relaciones estratigráficas. Los elementos interfaciales representan una acción negativa y destructiva de la estratificación; los elementos interfaciales horizontales son generalmente invisibles, por el hecho de constituir, por ejemplo, una acción de limpieza de la ocupación anterior al momento de reocupar un recinto. Los elementos interfaciales verticales, son aquellos cortes producidos por extracción y excavación de pozos y depresiones en el sedimento. Aunque poco usuales, las interfacies de período indican un período de uso común de estratos, interfacies y 
elementos interfaciales, mientras que las interfacies de destrucción hacen referencia a aquellos niveles y áreas de destrucción de estratos sometidos a excavación y remoción.

En la excavación se identifican y excavan por separado las unidades estratigráficas que componen el depósito, observando y estableciendo las vinculaciones estratigráficas de subyacencia o suprayencia- entre ellas. El registro de las unidades estratigráficas debe ser suficiente para poder establecer su posición estratigráfica y su relación con otras estructuras en el sitio, establecer procesos implicados en su formación, proveer una interpretación útil dentro de las limitaciones de la excavación y permitir fecharla relativamente (M.O.L.A.S. 1994, Museum of London Archaeology Service). Por ello debe seguirse un procedimiento que permite obtener dicha información.

El registro de la excavación se realizó adaptando los planteos del Manual de Arqueología de Sitio del M.O.L.A.S. (1994) a nuestro caso de estudio. En este sentido, se adaptaron algunas de las planillas publicadas en dicho manual y se diseñaron otras.

Cada unidad identificada durante la excavación, se registra en una planilla destinada a tal efecto -Registro de unidad estratigráfica-, en donde se detalla su ubicación planialtimétrica, sus relaciones estratigráficas con los estratos de los cuales se distingue, la composición sedimentaria que presenta y las características de los hallazgos culturales a ella asociados. Además, se realiza una primera interpretación del por qué se identificó la unidad como tal. Las inclusiones culturales se describen y registran tridimensionalmente en planillas de hallazgos.

El procedimiento de excavación se realiza de la siguiente manera: Primero se define la unidad a excavar, luego se la dibuja en planta -escala 1:20- en la planilla de planta diseñada para tal efecto, después se mapea el relieve de dicha unidad tomándole cotas de tal manera que sean representativas de la topografía del estrato. La reconstrucción topográfica de la superficie de cada uno de los estratos nos permite reconstruir secciones estratigráficas en distinto lugares de la excavación, sin necesidad de contar con un perfil en el campo. Inmediatamente después del levantamiento topográfico se la fotografía y filma. Una vez realizado este registro, se comienza con la excavación de la misma y se empieza a llenar la planilla de registro de unidad estratigráfica. Los hallazgos que se van encontrando son mapeados tridimensionalmente en una planilla diseñada específicamente para ello. El sedimento es cribado completamente, tomándose mientras se excava diferentes tipos de muestras, algunas de manera sistemáticas, como son las de flotación, sedimentológicas, para fechar -C14-, y otras que se determinan según las características particulares de cada estrato excavado. 
Notas

${ }^{\mathrm{i}}$ Ver las siete críticas realizadas por Carandini (1997: 50-52) al método Wheeler. 
ANEXO II:

DESCRIPCIÓN DE LOS ATRIBUTOS Y ESTADOS DE ATRIBUTO DE LA

CLASIFICACIÓN DEL MATERIAL CERÁMICO

Atributos y estados de atributo para la identificación de los fragmentos a clases cerámicas

Clase -grupo-:

- Período de Integración Regional (Fabra 2002)

- A1 (Negro Pulido)

- A2 (Rojo Pulido)

- A3 (Alisado/Pulido)

- A4 (Naranja Alisado)

- A5 (Rojo Alisado/Pulido)

- B (Castaño Alisado/Pulido)

- C (Castaño Pulido)

- D (Castaño/Rojo Alisado)

- E1 (Tosco)

- E2 (Tosco)

- E3 (Tosco)

- E4 (Tosco)

- E5 (Tosco)

- E6 (Tosco)

- F (Castaño Alisado)

- G (Crema Alisado -Allpatauca-)

- I (Gris Claro Alisado)

-Periodo Formativo (Fabra 2002)

- A (Ordinario con mica dorada)

- B (Ordinario con mica plateada)

- C (Negro pulido)

- D (Castaño Alisado/Pulido sin engobe)

- E (Alisado con engobe rojo)

- F (pulido con engobe rojo)

- $\mathrm{G}$ (Tosco)

- I (Castaño Pulido con engobe)

- J (Castaño Pulido sin engobe)

- $\mathrm{K}$ (Ordinario con engobe)

- L/C (Gris/ Negro Pulido)

- L/N (Gris/ Castaño Pulido)

- M (Negro Alisado/ Pulido)

- N (Castaño Pulido)

- (Ante Pulido)

- N/O (Ante/Castaño Pulido)

- P (Ante Alisado - "Alpatauca"-)

- Q (Naranja Alisado/ Pulido)

- R (Alisado sin engobe, con pintura externa) 
- S (Alisado /Pulido sin engobe)

- T (Alisado/ Pulido con engobe y pintura externa)

- U (Alisado con engobe negro)

- $\mathrm{V}$

- W (Ordinario con mica dorada y plateada)

- X (Negro Alisado)

- Y (Castaño Alisado/Pulido)

- AA (Castaño Pulido con engobe rojo)

- BB (Castaño Pulido/Alisado con baño negro)

- CC (Castaño Tosco/ Pulido)

- DD (Pulido con engobe rojo en ambas)

- EE (Grsi Alisado/Pulido)

- FF (Negro Alisado/ Pulido)

- GG (Gris Alisado)

- HH (Castaño Pulido con engobe rojo en ambas)

- II (Alisado con baño negro interno)

- JJ (Castaño Alisado)

- KK (Castaño Pulido con engobe rojo)

- LL (Pulido/Alisado con engobe castaño)

- MM (Negro Alisado /Pulido -oxidante-)

- $\mathrm{NN}$ (Castaño/Negro Pulido)

- OO (Negro/Rojo Pulido con engobe rojo)

- PP (Alisado con baño blanco)

- QQ (Negro/castaño Pulido)

- RR (Negro Pulido/Alisado)

Atributos y estados de atributo para la realización del catálogo de formas y tamaños representados:

Tipo de Vasija:

- Vasija A

- Vasija AB

- Vasija B

- Vasija C

- Escudilla A

- Escudilla B

- Escudilla C

- Escudilla D

- Vasijas asimétricas

- Vasijas restringidas de forma subglobular

- Vasijas no restringidas de contorno compuesto

- Vasos subcilíndricos de contorno simple

- Otra

\section{Forma global de la Vasija:}

- Simple abierta (hemisférico)

- Simple abierta (ultrahemisférico)

- Simple abierta (tronco abierto) 
- Simple cerrada (ovoide)

- Simple cerrada (esférico)

- Simple cerrada (globular)

- Simple cerrada (cilindro)

- Simple cerrada (troncocónico cerrado)

- Compuesta abierta (troncocónico invertido)

- Compuesta abierta (perfil en S)

- Compuesta cerrada (perfil en S)

- Compuesta cerrada (perfil quebrado)

- Compuesta cerrada (bitroncocónico)

- Anejas (geminado)

- Anejas (trilobulares)

- Anejas (tetralobular)

\section{Borde:}

\section{-Labio}

- Recto

- Redondeado

- Engrosado Externo

- Engrosado Interno

- Engrosado Ambas Caras

- Recto-Redondeado

- Recto-Engrosado Externo

- Inclinado-Engrosado Externo

- Inclinado Redondeado

-Angulo del Borde

- Recto

- Agudo

- Obtuso

-Corte del borde

Dibujo de la sección del borde

Cuello:

-Cuello simple

- Recto

- Evertido

- Invertido

- Recto evertido

- Recto invertido

- Convexo

- Cóncavo

-Cuello compuesto

- Recto-evertido

- Recto-invertido

- Recto-recto evertido

- Recto-recto invertido

- Recto-convexo

- Recto-cóncavo 
- Evertido-recto

- Evertido-invertido

- Evertido-recto evertido

- Evertido-recto invertido

- Evertido-convexo

- Evertido-cóncavo

- Invertido-recto

- Invertido-evertido

- Invertido-recto evertido

- Invertido-recto invertido

- Invertido-convexo

- Invertido-cóncavo

- Recto evertido-recto

- Recto evertido-evertido

- Recto evertido-invertido

- Recto evertido-recto invertido

- Recto evertivo-convexo

- Recto evertido-cóncavo

- Recto invertido-recto

- Recto invertido-evertido

- Recto invertido-invertido

- Recto invertido-Recto evertido

- Recto invertido-convexo

- Recto invertido-cóncavo

- Convexo-recto

- Convexo-evertido

- Convexo-invertido

- Convexo-Recto evertido

- Convexo-recto invertido

- Convexo-cóncavo

- Cóncavo-recto

- Cóncavo-evertido

- Cóncavo-invertido

- Cóncavo-recto evertido

- Cóncavo-recto invertido

- Cóncavo-convexo

Asa:

-Asa con doble inserción

- Doble adherida

- Labio adherida

- Doble remachada

- Labio remachada

- Simple remachada 
-Asa de inserción única

- Adherida

- Remachada"

-Sección del Asa

- Circular

- Rectangular

- Cuadrangular

- Trapezoidal

- Subcircular

- Subrectangular

- Subcuadrangular

- Subtrpezoidal

-Tipo de Asa

- Arco retorcida

- Arco lisa

- Arco trenzada

- Arco de correa

- Maciza mamelonar

- Maciza otomorfa

- Maciza troncocónica

- Maciza zoomorfa

- Maciza en botón

-Posición del asa

- Horizontal

- Vertical

- Oblicua

- $N^{o}$ de Asa

Cantidad de asas que posee la vasija.

\section{Cuerpo:}

-Nacimiento del cuerpo

- Directo (no se observa)

- Directo

- Directo Indirecto

-Forma del cuerpo

- Paredes curvas simples

- Paredes curvas compuestas

- Paredes rectas simples

- Paredes rectas compuestas

- No se observa

-Puntos del cuerpo

- No presenta (tiesto recto)

- Punto de tangencia vertical convexo

- Punto de tangencia vertical cóncavo

- Punto de inflexión

- Punto angular

- Puntos terminal y angular 
- Puntos terminal y de tangencia vertical cóncavo

- Punto terminal y de tangencia vertical convexo

- Punto terminal

- No se observa

-Perfil del tiesto

- Recto

- Convexo

- Cóncavo

- Angular

- Cóncavo-Convexo

- Recto cóncavo

- Recto convexo

-Corte del cuerpo

Dibujo de la sección del cuerpo.

Base:

-Forma exterior de la base

- Plana

- Cóncava

- Convexa

-Forma interior de la base

- Plana

- Cóncava

- Convexa

-Espesor de la base

Es el espesor máximo que posee la base expresado en milímetros.

-Diámetro de la base

Es el diámetro máximo que posee la base expresado en milímetros.

-Corte de la base

Dibujo de la sección de la base.

Medidas:

Piezas enteras o con alto grado de completitud:

-Altura de la pieza: expresada en milímetros.

-Altura de las asas: expresada en milímetros.

-Altura de los apéndices: expresada en milímetros.

-Diámetro 1, Diámetro 2, Diámetro 3: se toman para caracterizar más detalladamente vasijas que debido a su forma necesitan ser ilustradas con diferentes diámetros. Estos se expresan en milímetros.

-Altura del diámetro 1, Altura del diámetro 2 y altura del diámetro 3: especificación en milímetros de los tres diámetros anteriores respectivamente.

Para fragmentos orientados:

-Radio: es el radio del fragmento orientado según la posición original en la pieza expresado en milímetros. 
-Porcentaje de Arco: es el porcentaje de arco de circunferencia representado por el fragmento medido en porcentaje.

Atributos y estados de atributo para caracterizar las etapas de descarte y reactivación del material cerámico

\section{Reactivación:}

\section{-Cantidad de perforaciones}

Se expresa el número de perforaciones o "costuras que posee el fragmento o la pieza analizada.

\section{-Observaciones}

Campo memo donde se escribe las observaciones acerca de las prácticas de reactivación de las piezas.

\section{Descarte:}

\section{-Pintura postcocción}

Campo lógico donde se coloca si posee o no pintura.

-Color

- Amarillo

- Rojo

- Blanco

- Ocre

-Extensión de la pintura

- Puntual

- Restringido

- Extendido 


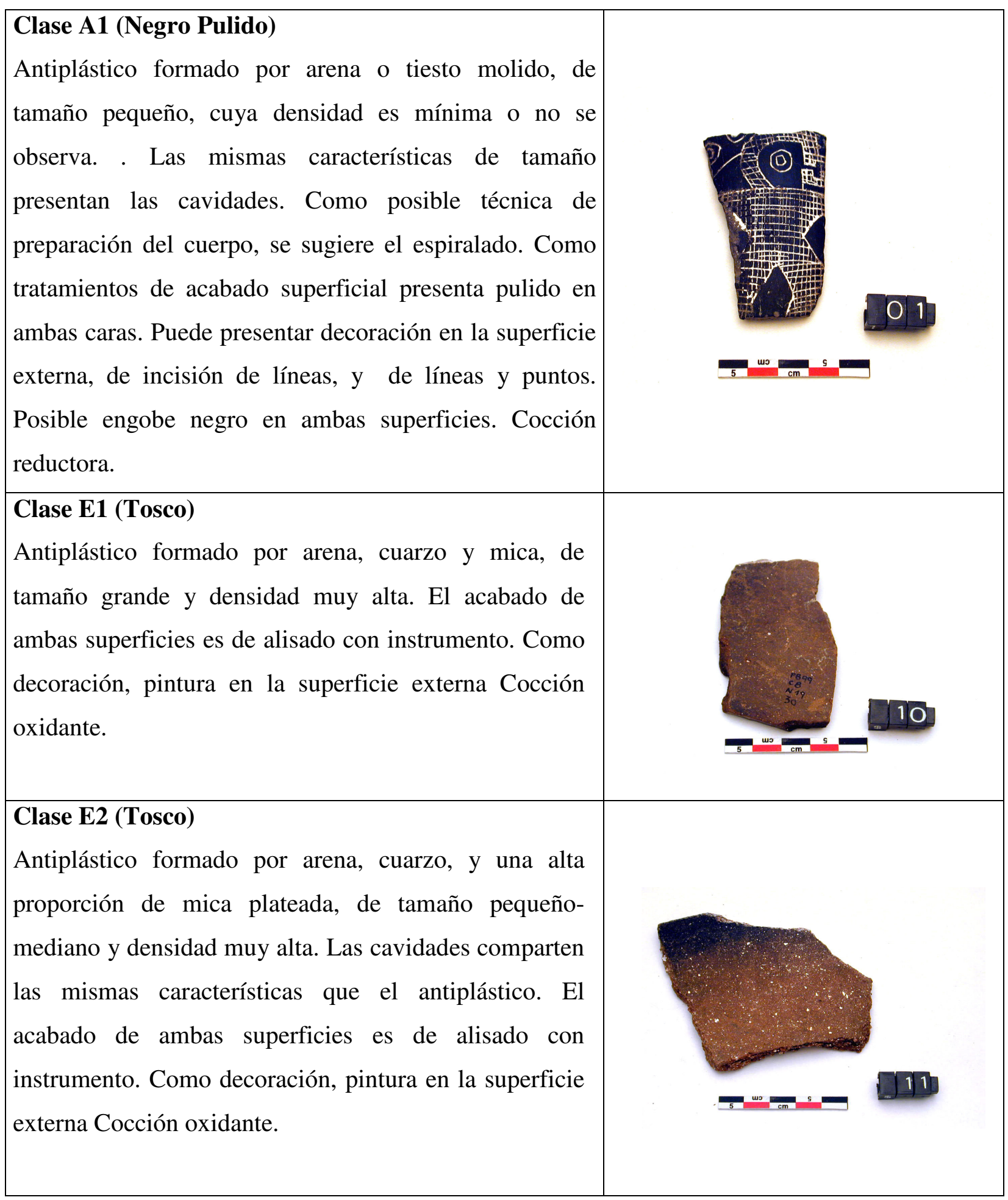




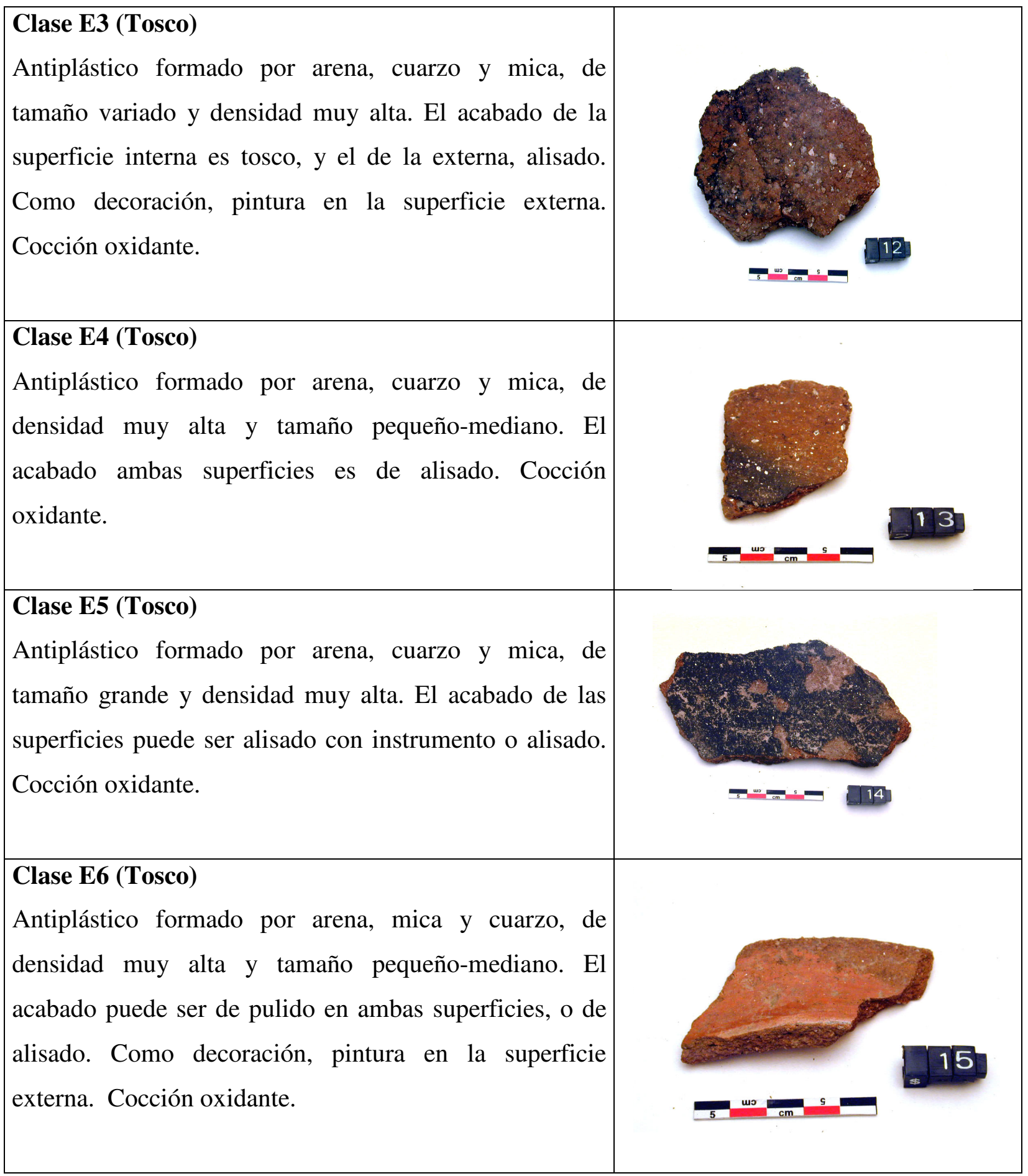

Modificado de Apéndice 8 de Fabra (2008) 


\section{ANEXO IV \\ VARIABLES PARA LA DESCRIPCIÓN DE LOS MODOS DE USO DE VASIJAS CERÁMICAS: INTENCIONES FUNCIONALES (PERFORMANCE) Y USOS \\ CONCRETOS (RASTROS)}

\section{Variables tomadas en el primer plano de análisis: vasijas y performance}

En este ámbito se pueden situar los estudios vinculados tanto a los análisis de la forma y dimensiones de las vasijas, como los estudios tecnológicos de propiedades y composición de los objetos cerámicos (Braun 1983; Hally 1986; Rice 1987; Rye 1981; Schiffer y Skibo 1987, 1989; Tite 1999; Tite et al 2001). Braun (1983: 108) señala que las características mecánicas de performance de una vasija afectan la efectividad de la misma para ejecutar tareas particulares, dichas características son condicionadas por atributos tales como las técnicas de manufactura, la forma de la vasijas y la composición de la pasta. Rice (1987) señaló que las vasijas cerámicas en su rol de herramientas serían un subconjunto de una categoría mayor de artefactos materiales y tecnológicos llamados "facilities" (Rice 1987: 208). Los "facilities" contienen o retienen el movimiento de sus contenidos e incluye en esta categoría "cosas" tales como corrales, graneros, cestas, así como también cerámica. Para este autor, las funciones de los contenedores de cerámica doméstica tomarían lugar en tres amplios dominios: almacenar, transformar o procesar, y transferir o transportar (Rice 1987: 208). Para acercarse a la función de las vasijas como contenedores, Rice señala dos conjuntos de características que deben tenerse en cuenta: por un lado, la forma de la vasija y las propiedades de uso relacionadas con ella -la capacidad, la estabilidad, la accesibilidad y la transportabilidad. Y por otro lado, la composición y propiedad de la cerámica -espesor, resistencia al shock térmico, comportamiento térmico y permeabilidad /porosidad /densidad.

La capacidad de un contenedor cerámico depende de la forma y el tamaño de la vasija. Puede ser medida a través del volumen que posee la misma. La estabilidad, es la habilidad de la vasija para sostenerse erguida sobre una superficie plana (Hally 1986:278), estando determinada por la forma, la distribución de su peso, y el ancho de su base (Shepard 1976: 236). Según esta autora, el grado de estabilidad se relaciona con la posición del centro de gravedad: "un cuerpo está en equilibrio estable si su centro de gravedad es elevado cuando es inclinado, inestable si el centro de gravedad desciende" (Shepard 1976.237-238) 
${ }^{1}$. La propiedad de accesibilidad a los contenidos, que mide la dificultas de acceso al contenido de la vasija, puede ser calculada a través de un índice que mide la relación entre diámetro máximo y diámetro mínimo por encima del máximo. Si la relación se acerca a uno, la accesibilidad es mayor, de lo contrario es menor. En cuanto a la propiedad de transportabilidad, depende de la forma, el tamaño y el peso, pero también de las cualidades de agarre-presencia o ausencia de formas secundarias: asas o agarres- (Rice 1987).

Con respecto al espesor, las paredes gruesas se vincularon a la necesidad de sostén estructural, y se ha sugerido que para almacenar ciertos productos, los espesores gruesos mantienen la humedad fuera de la vasija (Rice 1987). Este mismo autor señala que para determinados tipos de procesamientos las paredes gruesas son más resistentes a golpes durante el batido, agitado o mezclado. Pero por otro lado, en actividades de transferencia, muros espesos retardan la conducción del calor desde los contenidos hacia fuera, manteniendo el exterior templado, además de ser recipientes pesados para movilizarlos. El espesor también se vincula con la resistencia al Shock térmico y el comportamiento térmico. En relación a la resistencia al shock térmico, dos características se vinculan directamente a éste y completan el rango de posibilidades de las vasijas para retener sus contenidos y sobrevivir a impactos y cambios rápidos de la temperatura sin quebrarse: rigidez y dureza (Tite 1999). En relación a esto, Tite (1999) señala que las vasijas deben responder a dos clases de fracturas: una inestable y otra estable. En el caso de una fractura inestable y quebradiza, una vez que comienza a formarse, ésta se propaga rápidamente, resultando en la fractura total de la vasija. En el caso de una fractura estable, al iniciarse es rápidamente absorbida, por lo que necesita una energía mayor para que logre propagarse y romper la pieza. Kilikoglou et al. (1998, citado en Tite 1999)- señala que en las arcillas con un porcentaje menor al 10\% de concentración por volumen de cuarzo se producen fracturas inestables, en cambio con porcentajes mayores a $20 \%$ se producen fracturas estables. También la forma del antiplástico es de fundamental importancia. Formas planas, tales como la mica, si se combinan con la red de microfracturas que produce una alta concentración de cuarzo, hace que la pasta posea una mayor rigidez y dureza. Según Tite (1999) las vasijas en las que se producen fracturas estables resisten mejor los cambios de temperatura rápida. Sin embargo, la resistencia al shock térmico no depende sólo de la rigidez y dureza de la pieza, sino que también afecta dicho comportamiento la expansión térmica de los antiplástico presentes en las pastas. La forma de la vasija afecta también a estas propiedades, el stress decrece si los cuerpos de las vasijas son globulares, a 
diferencia de aquellas otras formas que poseen puntos angulares o de inflexión marcados (Tite 1999). Con relación a las propiedades de porosidad, permeabilidad y densidad, Rice (1987) señala que si bien estas propiedades nos son equivalentes, están muy vinculadas en sus constricciones y acciones. La permeabilidad hace referencia a la penetración de la humedad en las paredes de la vasija por efecto de la apertura de los poros, pudiendo ser manipulada modificando la superficie interna o externa de la vasija. A su vez, la permeabilidad se halla vincula con la porosidad: presencia de poros o espacios vacíos dentro de la pared. La densidad -el peso de un objeto por unidad de volumen- es la inversa de la porosidad. Para evaluar estas características un punto importante son el tamaño y densidad de las cavidades. Las propiedades de usos derivan de relacionar la permeabilidad con la porosidad: pastas muy porosas y permeables no son deseable en vasijas utilizadas para almacenar a largo plazo, particularmente líquidos (Rice 1987). En cambio, para períodos cortos de almacenaje de agua, la porosidad podría resultar ventajosa ya que la evaporación la mantiene fresca. Pastas muy porosas han sido señaladas como negativas para hervir agua en tanto tarda mucho más en hervir que pastas menos porosas (Skibo 1992).

\section{Variables de tomadas en el segundo plano de análisis: vasijas y usos concretos}

En el segundo plano se encuentran los estudios de alteraciones por uso de la cerámica tanto a nivel físico como químico (Hally 1983, Schiffer 1990, Schiffer y Skibo 1987, 1989, Barba et al 1991, Skibo 1992, Arthur 2002). Skibo (1992:42) coloca a estos estudios dentro de un ámbito mayor que denomina "alteración cerámica" -“ceramic alteration"- que incluiría todos los cambios en la cerámica (en la superficie o sub-superficialmente) resultado de procesos químicos y físicos que causan adición, extracción o modificación del material. Las alteraciones por uso requieren que las vasijas o fragmentos de una vasija participen en una actividad humana, mientras que alteraciones que no se vinculan al uso implica que las trazas observadas se formaron mientras la cerámica no participa en una actividad de usos particular ${ }^{2}$. Para reconstruir los usos concretos se realizaron tres tipos de análisis, siguiendo la propuesta de Skibo (1992): estudio de la atrición (erosión por uso) con bajos aumentos -lupa binocular-, análisis de residuos orgánicos y, análisis de depósitos de carbón. Con respecto a los análisis de residuos orgánicos, aquí solo haremos referencias generales que nos permitan combinar los tres tipos de análisis para acercarnos a los usos específicos. 
La abrasión (erosión) fue definida como un rastro producto de la remoción o deformación del material de la superficie cerámica por contacto mecánico, específicamente por deslizamiento, raspado, o en algunos casos por golpe de un abrasivo (Schiffer y Skibo 1989:102). Los mecanismo de abrasión descriptos por estos autores son ocho. En este trabajo vamos a describir sintéticamente, sólo aquellos que nos sirven para comprender las marcas observadas en los objetos analizados: uno de estos procesos son los mecanismos triboquímicos, que producen procesos abrasivos por cambios químicos (Schiffer y Skibo 1989:102-103). Por ejemplo, la fermentación de granos produce que se formen bacterias con ácido láctico, lo que causa que el $\mathrm{Ph}$ se torne muy bajo y se forme un material muy ácido, lo cual hace que durante el procesamiento y el almacenamiento de diferentes tipos de bebidas fermentadas, se produzca una fuerte erosión en el interior de las vasijas (Arthur 2002:339). Otro tipo de mecanismo abrasivo es el surcado -"plowing"- que involucra la remoción de material a lo largo de trazos lineares o curvilíneos como resultado del contacto tangencial de un abrasivo. Estos trazos dependen de las fracturas intergranulares (Schiffer y Skibo 1989:103). Conjuntamente con estos trazos, se pueden producir hoyuelos por extracción de antipláticos que dejan un espacio vacío (Skibo 1992). Otro mecanismo es el microastillado (microchipping), la remoción de pequeñas astillas producto de una fractura hertziana (Schiffer y Skibo 1989:103). El último mecanismo considerado en este trabajo es el "pedestaling", en el que el abrasivo remueve preferentemente granos pequeños, dejando el antiplástico como protuberancia (Schiffer y Skibo 1989:103). Teniendo en cuenta estos mecanismos, para el análisis de la atrición al principio de la investigación se siguieron los lineamientos del estudio actualístico realizado por Skibo (1992) con la cerámica Kalinga proveniente de Filipinas. Este autor definió nueve regiones, en las vasijas Kalinga, donde se aprecian distintas marcas: 1Exterior de la base, 2- Lado exterior bajo, 3-Lado exterior medio, 4- Lado exterior superior, 5Borde, 6- Interior del borde y del cuello, 7- Lado interior superior, 8- Lado interior medio, 9Lado interior bajo y de la base (ver figuras IV.1). Una vez que fuimos avanzando en el análisis de los rastros, las zonas se fueron adecuando a las formas que teníamos representadas en los materiales analizados ${ }^{3}$. 


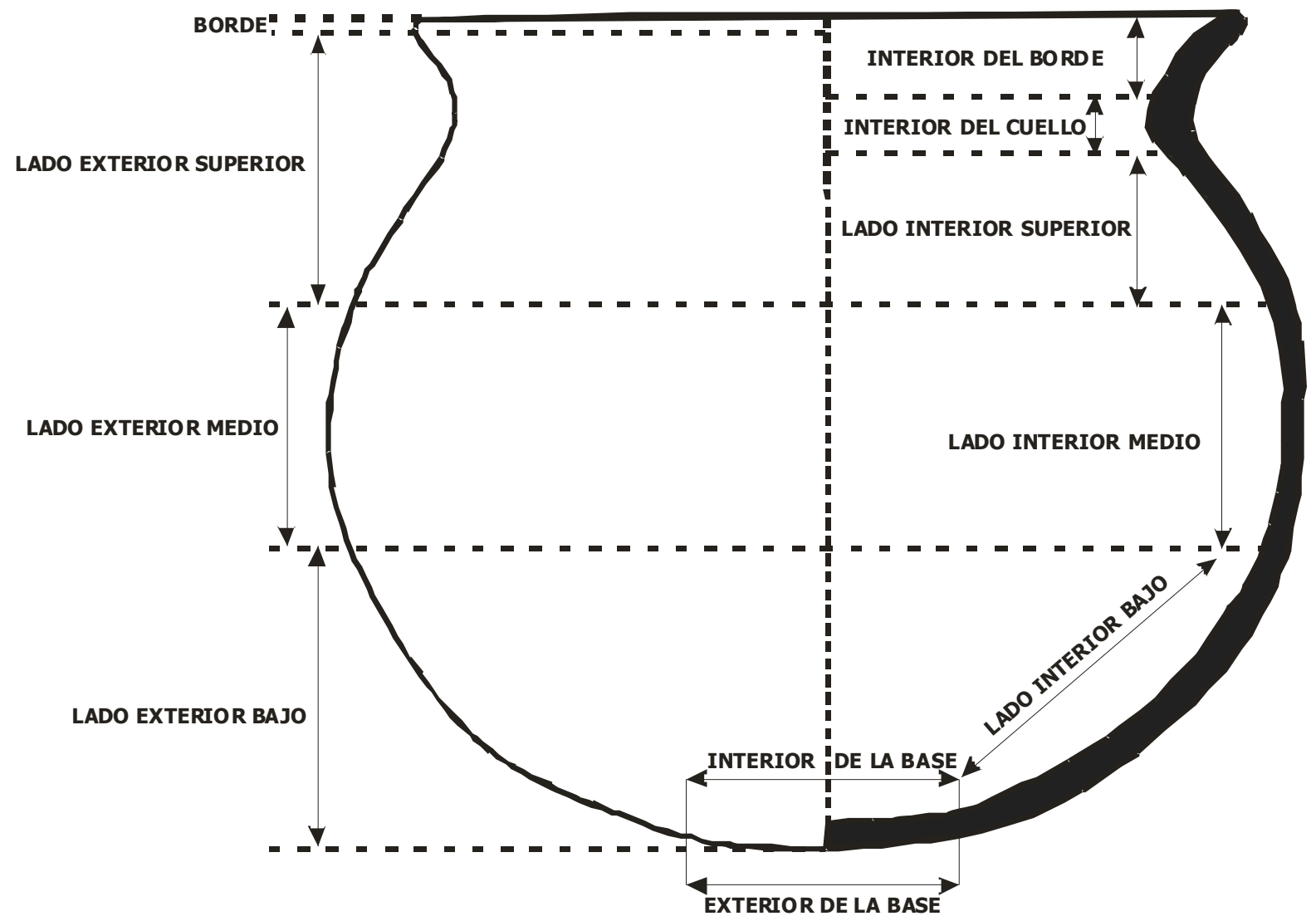

Figura IV.1: zonificación realizada por Skibo (1992). Nosotros retomamos esta zonificación y en algunos casos la adaptamos dependiendo de la forma particular de la vasija analizada

Los rastros hallados en estas áreas pueden ser de dos tipos: a) Marcas (marks), que son el resultado de un único evento de erosión (atrición). Es el nivel más bajo de huellas de erosión por uso (use-attrition trace). Éstas pueden tomar la forma de estrías (scratch) (figura IV.2a), hoyuelos (pits) (figura IV.2b ), antiplástico sobreelevado (pedestalled temper) (figura IV.2c) y astilladuras (chip) (figura IV.2d) (Skibo 1992: 111). También este investigador identificó astilladuras térmicas. En una misma región o zona pueden existir varios tipos de marcas. En el caso de las estrías, sumamos al análisis propuesto por Skibo otras variables como son la dirección que siguen respecto a un eje vertical que atravesaría, imaginariamente, la vasija cuando está erguida. Esto nos acerca a los movimientos de las vasijas y al recorrido realizado por el abrasivo. b) Lotes -patches-, que es el conjunto de marcas producto de una actividad de uso repetida, donde las marcas individuales no pueden identificarse y la superficie está completamente removida (Skibo 1992: 111). 

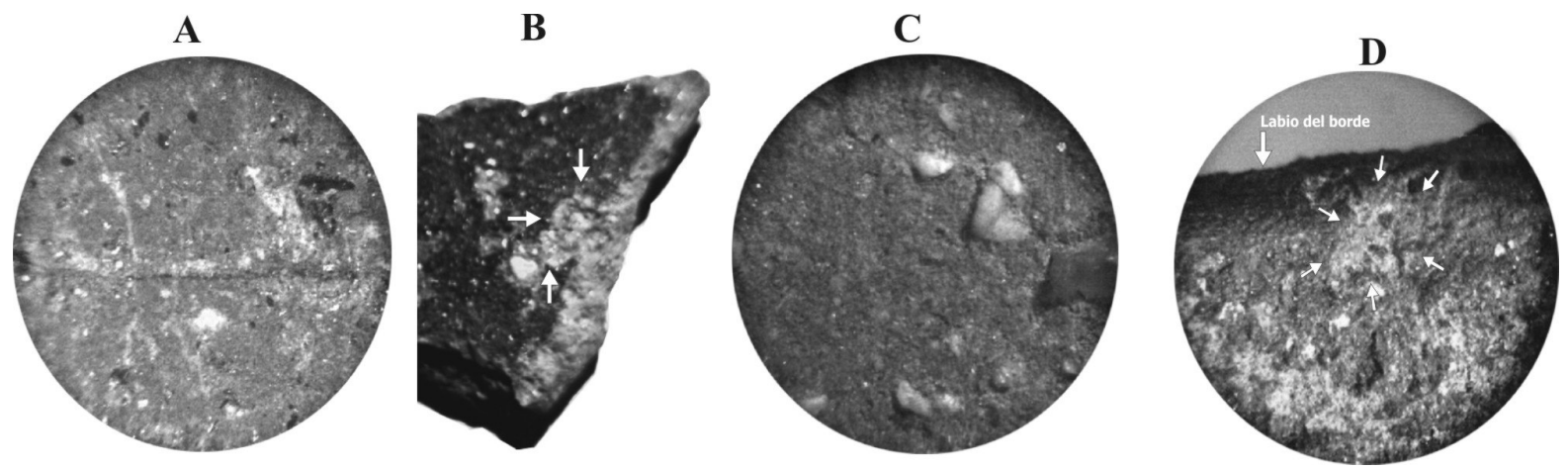

Figura IV.2: Imágenes de las huellas identificadas en la cerámica procesada del Recinto $\mathrm{H}$ del sitio de Piedras Blancas. Para tomar las fotografías se utilizó una lupa binocular, una fuente de iluminación con fibra óptica dual flexible, 1 cámara digital modelo CMOS 1/2", MOTIC 1000 con adaptadores de distintos diámetros para colocar en oculares de Lupa Binocular. Resolución: 1280 x 1024 pixels c/ salida directa USB 2.0. Las medidas tomadas sobre las imágenes se realizaron con el módulo de análisis morfométrico que trae el Software Motic Images Plus 2.0 para manipulación avanzada y análisis de imagen. A): estría tomada a 14X. B) Imagen macro de fragmento de cuerpo con hoyuelo. Las flechas delimitan la huella. C) Imagen tomada a 14X. Nótese que entre los dos antiplásticos la matriz fue erosionada por un elmento más fino que la separación entre ellos. D) Imagen tomada a 14X. Se trata de una astilladura observada en el labio de un fragmento de borde. Las flechas más pequeñas delimitan la huella.

Con respecto a las huellas de carbonización, retomamos los experimentos realizados por Hally (1983) y Skibo (1992) sobre vasijas arqueológicas. A su vez realizamos una experiencia que nos permitió ajustar nuestras observaciones. Hally demostró que la distancia a la fuente de calor afecta el patrón de carbonización. Así, identificó dos clases de depositaciones según la distancia entre las paredes de la vasija y la fuente de calor: a) se trata de una capa negra opaca, que se produce si la vasija es apoyada directamente en el fuego, siendo probablemente carbón sólido, y b) un depósito más lustroso hallado en los lados y en los bordes. Esta capa, a diferencia de la primera, no es removida cuando se la frota. También este autor observa que en la zona de contacto con la llama, en caso que la vasija esté apoyada directamente en el fuego, se puede producir una oxidación del área expuesta al fuego, quedando más clara y anaranjada que el resto de la superficie original de la pieza, no conservándose depósito de carbón en esa zona. Skibo (1992) observa en sus experimentos lo mismo en relación al depósito de carbón y la oxidación, aunque señala que cuando la misma vasija es colocada directamente sobre el fuego con agua para que hierva, la oxidación no se produce nunca puesto que no llega a la temperatura necesaria, y sí se deposita carbón. Observa también que se forman dos capas de depósito de carbón: una, muy espesa, que pude llegar hasta el borde de la vasija, pudiéndose lavar fácilmente. La otra resiste el lavado, siendo menos espesa. Teniendo en cuenta estas observaciones se procedió a observar presencia o 
ausencia de carbonizaciones, en caso de la presencia huellas de carbonización se las describía siguiendo en primer lugar que parte cubría de la vasija (cuello, cuerpo, base, asas), a su vez se realizaba una descripción cualitativa de cómo se repartía la misma en la superficie de la vasija y se confeccionó un dibujo esquemático de la misma.

\footnotetext{
${ }^{1}$ Para el cálculo de la altura del centro de gravedad se utilizó una función del programa Autocad (2004) que permite calcular el centroide en sólidos de revolución. El centroide o baricentro de un objeto X que pertenece a un espacio n-dimensional es la intersección de todos los hiperplanos que dividen a $\mathrm{X}$ en dos partes de igual nvolumen con respecto al hiperplano (http://es.wikipedia.org/wiki/Centroide). Es decir el centroide conformaría el promedio de todos los puntos X. El centroide, equivale en algunos casos con el centro de masa y el centro de gravedad, siempre y cunado la gravedad sea estable, el sólido uniforme y la distancia que consideremos no sean estelares. En el caso de los objetos cerámicos pueden ser considerados equivalentes. Por lo que el valor del centroide arrojado por Autocad equivale al centro de gravedad de la pieza.

${ }^{2} \mathrm{Si}$ bien las alteraciones producto de factores no vinculados al uso pueden tornar difícil la tarea de estudiar los otros tipos de alteraciones, no los anula, algunas consideraciones deben tenerse en cuenta: primero tomar a la vasija como un todo, y no trabajar sólo con fragmentos sino con vasijas enteras si existieran o con alto grado de completitud. Por otro lado estudios etnoarqueológicos como los realizados por Skibo (1992) permiten tener marcos de comparación sobre patrones de marcas y trazas que refieren a actividades específicas de uso, posibles de desvincularse de las marcas y trazas producidas fuera de una actividad de uso concreta.

${ }^{3}$ Para apreciar las distintas zonificaciones aplicadas ver el capítulo V.
} 
ANEXO V

\section{Parte: Reconstrucción de Contextos Depositacionales en el RH}

En esta sección describimos las actividades llevadas a cabo para reconstruir la estratigrafía de uno de los recintos del sitio Piedras Blancas -Recinto H- (figura V.I-1) de donde provienen parte de los objetos que analizamos.

La reconstrucción de la estratigrafía arqueológica depende fundamentalmente de los métodos de excavación utilizados. Estos métodos, lejos de ser sólo un procedimiento técnico-mecánico dentro de la planificación de un diseño de investigación arqueológica, implican decisiones epistemológicas, teóricas y metodológicas de la naturaleza de aquello que se excava. Los métodos de excavación suponen seguir determinados procedimientos para disgregar aquello que se nos presenta homogéneo ante nuestros ojos, la tierra a excavar (Carandini 1997). El proceso de disgregación involucra a su vez otro proceso unido a éste, el de agrupación. Las decisiones de por qué, cómo y dónde disgregar/ agrupar constituyen desde ese instante una especie de armazón estructural donde la interpretación posterior de los depósitos puede ser ubicada. Pero este armazón estructural producido por los métodos de excavación aplicados en función de determinadas preguntas de investigación, ¿es inamovible, o permite, por el contrario, que sus elementos puedan ser disgregados y reagrupados cuando surgen nuevos interrogantes en torno a los cuales construir nuevas narrativas acerca de los depósitos excavados?. Este es uno de los primeros interrogantes que surgió al analizar el material espacial disponible y las metodologías de excavación aplicadas en el sitio. Las excavaciones en el recinto $\mathrm{H}$ se realizaron durante un período de 5 años donde no sólo los métodos aplicados fueron cambiando durante el lapso que duraron la excavaciones, sino que los interrogantes que nos realizamos hoy en relación a los significados que los objetos hallados tuvieron en relación a las prácticas sociales en las que intervinieron, requieren una nueva disgregación y reagrupación, en otras dimensiones, de los depósitos excavados, esto es, la reconstrucción de las unidades estratigráficas que los conforman. 
Para poder observar las limitaciones con que nos hallamos para la reconstrucción estratigráfica del recinto, empezamos determinando los límites y posibilidades de las diferentes métodos de excavación existentes para reconstruir la estratigrafía de los depósitos excavados.

\section{Los Métodos de Excavación arqueológica y sus implicancias en la reconstrucción estratigráfica}

Tres posiciones pueden ser resumidas. En la primera, la unidad elemental de análisis e interpretación es el artefacto, perspectiva que privilegia la recuperación de las inclusiones sin tener en cuanta la matriz que las contiene, y en donde se fijan niveles arbitrarios de excavación. En una segunda perspectiva, las unidades fundamentales son las matrices donde se hallan las inclusiones, recuperándose las unidades estratigráficas, las que son consideradas eventos únicos de depositación que representan una acción o un conjunto de ellas. Según este punto de vista, cada unidad estratigráfica adquiere significado no sólo por sus propias características, sino por las relaciones estratigráficas que mantiene con el resto de las unidades, a la vez que el significado de las inclusiones se da principalmente en relación a la matriz que las contiene. Así, se intenta reconstruir una secuencia de estratigrafía arqueológica, interpretándose las unidades al momento de su recuperación durante la excavación (D’Amore 2002; Harris 1991; Carandini 1997). La tercera posición intenta acceder a una visión etnográfica del registro arqueológico, a partir de la búsqueda de las huellas materiales dejadas por las actividades cotidianas realizadas en el pasado, método denominado décapage (Leroi-Gourhan 1984). Esta metodología consiste en seguir los movimientos del suelo arqueológico, respetando cuidadosamente los vestigios en el lugar que cada uno ocupa. Se privilegia la relación topográfica en planos, cortando la superficie en planos superpuestos. Las unidades de análisis son los vestigios, entre ellos las inclusiones culturales, y no las unidades estratigráficas, persiguiéndose como objetivo la búsqueda de pisos en los cuales la abundancia y la organización de los restos justificaran la existencia de áreas de actividades específicas. La reconstrucción de estas actividades se realiza principalmente en el laboratorio, a través de relacionar los distintos registros de 
inclusiones y los rasgos en plantas. Con este método se logran reconstruir grandes acontecimientos arqueológicos, como pueden ser la identificación y caracterización de pisos y niveles de ocupación. Sin embargo, al no registrase la sucesión de acciones que produjeron estos depósitos, es decir, las unidades estratigráficas y sus mutuas relaciones, este método permite observar limitadamente el proceso de formación de los mismos. Describamos ahora los métodos de excavación utilizados en Piedras Blancas.

\section{Las Excavaciones en el Recinto H: identificando y caracterizando pisos de ocupación}

Las excavaciones en el Recinto $\mathrm{H}$ del sitio Piedras Blancas, se realizaron a través de cuatro intervenciones, en un lapso temporal de 5 años (noviembre 1996; mayo y octubre de 1999; noviembre 2000). Durante las primeras tres intervenciones, los interrogantes que guiaron las excavaciones se vincularon a establecer cómo era el uso del espacio a nivel intrasitio, tratando de observar si poseían sectores diferenciados a nivel no sólo formal, sino también funcional. La búsqueda de áreas de actividades diferenciadas fue uno de los principales factores por los cuales se decidió excavar utilizando el método de décapage, registrándose la posición tridimensional de los hallazgos, y relevándose en planta la superficie expuesta en cada extracción de sedimento.

En las primeras reconstrucciones estratigráficas realizadas de las excavaciones de los años 1996 y 1999, se utilizó como herramienta fundamental de análisis el soft de mapeo Surfer 6.0. (Zaburlin 2001). Con los datos obtenidos en este primer acercamiento a la estratigrafía del recinto, se pudo interpretar a los depósitos excavados como formando un solo nivel de ocupación. El piso de dicho nivel no estaba diferenciado estructuralmente, ni por un material ni por un tratamiento especial, por lo que se lo identificó por la cantidad y disposición de los materiales y por su asociación a rasgos constructivos (asientos de muros, topes de rasgos, etc.), observándose que el piso no era homogéneo en todo el recinto.

Cuando se analizaron las tasas de depositación de inclusiones en profundidad y la relación de estas tasas con los ensamblajes cerámicos, fue posible vislumbrar un buzamiento en el piso de ocupación. Según estos datos, el mismo es más alto en la esquina SE del recinto donde se ubica a $0,95 \mathrm{~m}$ de profundidad, manteniéndose junto a la pared sur 
y sudoeste a $1 \mathrm{~m}$ de profundidad, descendiendo levemente en el centro del recinto a 1,051,10 m de profundidad y bajando a 1,10 a 1,20 m hacia el norte del mismo. En cuanto a la tasa de depositación de fragmentos en profundidad, se observó que las mayores acumulaciones de materiales se registran entre los 0,90 y 1,20 m de profundidad, descendiendo hasta casi desaparecer alrededor de los 1,30 m de profundidad, en lo que se caracterizó como un sedimento estéril (Figura V.I-2).

A nivel de piso se detectaron numerosas estructuras (pozos de poste, estructuras de contención, fogones). Con respecto a la distribución de los materiales arqueológicos, se observó una tendencia que diferencia los sectores norte y sur del recinto: los restos cerámicos, óseos y de mica se distribuyen de manera similar, presentando una mayor densidad en el sector sur y menor presencia en el norte; los restos de pigmentos se concentran en cercanías de la pared este; los restos líticos presentan una distribución homogénea en todo el recinto. En cuanto al material cerámico, se puede agregar que aquel decorado (cerámica Negro Pulido con incisiones en motivos Ciénaga-Ambato y Aguada Ambato, y cerámica pintada con los mismos motivos, incluyendo Ambato Tricolor) se concentra en el sector sur del recinto; mientras que la cerámica no decorada se distribuye en todo el recinto, particularmente en el sector norte (Zaburlin 2001). Los entierros de individuos infantiles, en este recinto como hemos visto en el capítulo 8 son significativos.

Durante los trabajos de campo del año 2000 se quiso corroborar la efectiva aparición del estrato estéril que había sido observado tanto en el campo como en las gráficas de tasa de distribución en profundidad de los hallazgos. Para ello se limpió la superficie que había quedado expuesta en noviembre de 1999, observándose así la reaparición de material arqueológico. Esto ocasionó ciertos interrogantes acerca de la presencia de una o dos ocupaciones en el lugar, puesto que, aunque aparecía ahora material arqueológico, se había observado una disminución notable del mismo, situación que, junto a esta reaparición de material, podría estar significando un hiatus entre dos ocupaciones.

Se decidió así excavar hasta llegar al sedimento efectivamente estéril, utilizando una combinación de metodologías. Además de seguir usando la técnica del décapage, se utilizó otra tendiente a la identificación de estructuras a través de la retención diferencial de humedad. Las áreas que presentaban mayor retención fueron descriptas como posibles 
estructuras en negativo -por ejemplo pozos-, y se las excavó por separado, mientras que las áreas intersticiales se siguieron excavando con el método de décapage. La variación de la técnica se debía a un interés en tratar de reconstruir eventos de depositación que formaban este supuesto segundo nivel de ocupación. Se terminó de excavar el depósito llegando hasta $\operatorname{los}$ 1,60 m de profundidad, donde apareció la capa estéril.

En la Figura V.I-3 se pueden observar las estructuras excavadas en este recinto, que corresponden a lo que parecía ser el segundo piso detectado. Se pudieron identificar cuatro fogones, evidenciados en el campo por la tierra quemada y la abundancia de cenizas, y nueve estructuras negativas. De las mismas, cuatro de ellas (estructuras 8, 2, 5 y 4) se interpretaron como depósitos de basura, tres (estructuras 6, 9 y 7) habrían conformado el sostén de grandes ollas globulares, una se interpretó como un gran depósito de carbón de algarrobo -Prosopis sp.- (Marconetto 2004), y la última (estructura 1) consistía en un pozo con evidencias haber sido quemado a altas temperaturas, presentando un alto nivel de rubefacción. Por debajo del nivel de tierra quemada de esta estructura, se encontró el entierro de un camélido juvenil, colocado allí probablemente como ofrenda. En este último caso este aparente segundo piso de ocupación, al igual que el anterior, no poseía un tratamiento diferencial por lo que no pudo identificarse a nivel estructural. La interpretación de su presencia se realizó en función del emplazamiento y asociación de las estructuras identificadas, no considerándose la tasa de depositación en profundidad de las inclusiones, como sí lo fue hecho en la primera reconstrucción estratigráfica realizada por Zaburlin (2001)

Vemos así que se utilizaron dos métodos de excavación en el recinto $\mathrm{H}$ de Piedras Blancas, uno atendiendo a la identificación de pisos y niveles de ocupación, y el otro atendiendo a la identificación de estructuras positivas y negativas. De la aplicación e interpretación de ambas formas de excavación, obtenemos el siguiente panorama estratigráfico: parecen existir dos pisos de ocupación en el Recinto H del sitio Piedras

Blancas. Uno se encontraría alrededor de los 0,90 $\mathrm{m}$ de profundidad en el sector sudeste del recinto descendiendo en el norte hasta los 1,20 m de profundidad. Bajo el mismo se encontraron fosas que contenían tres entierros, algunos con ajuar asociado. Las actividades llevadas a cabo dentro del recinto marcarían una diferencia entre el sector norte respecto del sector sur. El segundo piso de ocupación también marca diferencias entre el sector norte del 
recinto respecto del sector sur. En el sector norte se halló una serie de estructuras en negativo que indican actividades vinculadas a la producción de altas temperaturas para la fabricación de objetos de metal (Espósito y Marconetto 2005). Este sector conformaría un área abierta, a diferencia del sector sur, que habría estado techado.

\section{Disgregando niveles de ocupación: hacia el establecimiento de secuencias estratigráficas parciales}

Atendiendo a nuestro objetivo de reconstruir las secuencias de formación de los depósitos estudiados, y teniendo presente las limitaciones que poseen las técnicas utilizadas para la reconstrucción de matrices estratigráficas completas optamos por utilizar una herramienta de análisis espacial muy potente los Sistemas de Información Geográfico (SIG). La utilización del SIG se convirtió en una herramienta fundamental para cumplir nuestro objetivo, puesto que no sólo nos permitió vincular las dos formas de excavación utilizadas, sino también trascender las limitaciones de dichos métodos, permitiéndonos establecer el origen de los depósitos que conforman la estratigrafía del Recinto $\mathrm{H}$. El programa utilizado es el Arcview 8.3. EL SIG se diseñó sobre:

A- Bases de datos existente: como la confeccionada por Zaburlin (2001) para la reconstrucción estratigráfica de las primeras tres intervenciones. Esta base de datos se compone de datos de coordenadas X,Y y Z, del tipo de material, y, en el caso de la cerámica, de la clase tecnológica y la vinculación de esta clase a un estilo conocido dentro de los definidos para el Noroeste Argentino.

B- Una nueva base de datos, la que se llenó con la información espacial de la excavación realizada en el año 2000. La nueva se compone de X, Y y Z, del tipo de material. No posee información acerca de las clases cerámicas puesto que los datos se tomaron desde las planillas de registro de hallazgos llenadas en el campo. Por otra parte el procesamiento del material cerámico esta aún en proceso. La confección de la nueva Base de datos requirió de las siguientes actividades:

-Digitalización de las planilla de hallazgos de la campaña del años 2000. 
-Conversión de las coordenadas geográficas en coordenadas ortogonales.

Ambas bases de datos se unificaron, y para esto se utilizó el programa Microsoft Excel (versión 2000). Desde Microsoft Excel, los datos se guardaron en formato DBF IV, los que luego se incorporaron al SIG como tabla.

Con estos nuevos datos, utilizamos el SIG para observar, en primer lugar, las tendencias generales de depositación y distribución de los hallazgos, tratando de inferir si las observaciones realizadas por Zaburlin (2001) en el campo, y la tasa de depositación en profundidad de las inclusiones, podían mantenerse indicando un hiatus en la ocupación y corroborando la presencia de dos pisos de ocupación.

\section{Análisis de Tendencia en la depositación de Inclusiones}

Para inferir las tendencias, se utilizaron primero análisis de frecuencia de depositación de hallazgos en $\mathrm{X}, \mathrm{Y}$ y Z a través de gráficos de histogramas utilizando el análisis estadístico exploratorio que brinda la extensión Geostatistical Analyst de Arcview

\subsection{Estos Histogramas permiten observar que:}

1-Cuando realizamos un histograma de frecuencia tomando como variable el eje Y (dirección norte-sur del recinto) las tendencias de depositación de inclusiones son más abundantes en el sector norte del recinto disminuyendo fuertemente hacia el sur como se observa en la figura (Figura V.I-4). Esto también había sido observado en las primeras reconstrucciones estratigráficas realizadas por Zaburlin (2001).

2- Al realizar el histograma tomando como variable el eje X (dirección este-oeste del recinto) no existe una tendencia en la depositación, manteniéndose constante en todo el ancho del recinto (Figura V.I-5).

3- Con respecto a la taza de depositación de inclusiones tomando como variable $\mathrm{Z}$ (profundidad) en los gráficos de histogramas se observa claramente una distribución 
diferencial. Posee una curva con dos modas, una principal y otra subsidiaria. Es notable la baja de la depositación de hallazgos hacia los 1,23 m de profundidad (Figura V.I-6)

Las tendencias en la frecuencia de depositación de inclusiones en $\mathrm{X}$ e $\mathrm{Y}$ son reforzadas cuando aplicamos el Density Analyst que provee la extensión Spatial Analyst del programa utilizado, para comparar las densidades y distribución de los hallazgos entre los sectores norte y sur de recinto $\mathrm{H}$. Esta herramienta permite crear una imagen raster de la distribución de los hallazgos, obteniendo una superficie continua que muestra, a través de distintas coloraciones, las concentraciones de hallazgos: en el norte del recinto existe menor concentración de hallazgos que en el sur del mismo (Figura V.I-7)

En cuanto a la diferencia en la taza de depositación respecto a la profundidad a través de los análisis espaciales de Densidad, se observa una disminución de la taza, aunque menos representada. Si comparamos las imágenes raster obtenidas se observa que:

1-Cuando aplicamos el análisis a la distribución de hallazgos en Y y Z, la baja de depositación de inclusiones aparece apenas marcada, y se observa más en la mitad sur que en la mitad norte. (Figura V.I-8)

2-Cuando aplicamos la técnica a las distribuciones de hallazgos en $\mathrm{Z}$ y $\mathrm{X}$ aparece dicha diferencia un poco más marcada, aunque no tanto como en el gráfico de frecuencias observado. (Figura V.I-9)

Estas observaciones nos informan que la probabilidad de que exista un hiatus en la depositación de objetos es bastante baja. Y que esa tendencia esconde, tal como se observa en las imágenes raster, la variabilidad de dicha depositación en el espacio. Es decir, hay sectores donde se observa una concentración de las inclusiones en relación a la profundidad, tal cual lo marca la cobertura raster del análisis de densidad.

Si tenemos en cuenta el leve descenso en la taza de depositación de material marcada por el histograma, las observaciones realizadas en el campo sobre la disminución de la aparición de hallazgos, y las interpretaciones de la aparente existencia de dos pisos de ocupación, los depósitos, analíticamente, pueden ser divididos en dos grupos. El grupo A se compondría de todos los hallazgos registrados y recuperados de las campañas anteriores al año 2000, puesto que coincide con la merma en la aparición de las inclusiones -primer piso de ocupación- mientras el grupo B, estaría compuesto por el resto de los hallazgos - 
segundo piso de ocupación-. Estos grupos arrojan diferencias notables si se interpolan las profundidades de los hallazgos utilizando el IDW (Inverse Distance Weighted) para generar un modelo predictivo de la superficie de los depósitos.

El raster obtenido del análisis del grupo A permite observar que en relación a la profundidad, el modelo predictivo para este grupo es menos variable. Se observan tres coloraciones distintas que dominan toda la superficie, observándose una tendencia hacia intervalos más profundos en el sector norte del recinto y menos profundos hacia el sector sureste del mismo (Figura V.I-10).

El raster del grupo B muestra, a diferencia del anterior, mucha más variedad de coloraciones, lo que indicaría una distribución mucho menos homogénea de los hallazgos en relación a sus profundidades (Figura V.I-11). Esto es refirmado si recordamos que en el campo, durante las excavaciones en el 2000, fue identificado un conjunto de estructuras negativas que marcan una depositación no homogénea del material arqueológico, marcando así una diferencia entre los dos grupos.

Hasta este punto confirmamos las diferencias entre los sectores norte y sur del recinto ya observadas en anteriores reconstrucciones. Pudimos observar que el hiatus de ocupación no puede ser confirmado en relación a la tasa de depositación de los hallazgos, aunque sí se observan diferencias en las relaciones entre los hallazgos del grupo A y el grupo B, mucho más variables en este último grupo.

\section{Reconstrucción de Secuencias Estratigráficas Parciales}

Hasta aquí tomamos el espacio como si fuese un elemento homogéneo. Y las características principales de los depósitos provinieron del análisis de las distribuciones de las inclusiones. Trataremos ahora de ver, a través del análisis de una de las estructuras registrada en el sector norte del recinto durante la campaña del 2000, si las diferencias observadas en relación a las tazas de depositación de objetos en profundidad pueden sostenerse en este sector, lugar donde se observa una diferencia notable entre el grupo A y el grupo B. Este análisis fue posible puesto que el SIG nos permitió relacionar la estructura 
identificada (estructura 1 de la Figura V.I-3) con los hallazgos que se encontraban inmediatamente por encima de la estructura, y que podrían haber llegado a formar parte del relleno de la misma al proyectar el corte del pozo hacia arriba (Figura V.I-12).

La vinculación se realizó superponiendo en planta y secciones el límite de la estructura y las inclusiones que contenía, con las distribuciones en planta y secciones de los hallazgos que, si bien no estaban vinculados contextualmente con ella, se ubicaban inmediatamente por encima de la misma. Observando la distribución espacial de los hallazgos en relación a su concentración por encima del corte en planta, se pudo determinar el quiebre de pendiente de la estructura. Este quiebre de pendiente conforma la superficie desde la cual dicha estructura se habría cortado, y se determinó observando el lugar desde donde los hallazgos comienzan a distribuirse espacialmente de forma dispersa sin concentrarse sobre el corte de la estructura ${ }^{1}$. Así, observamos que por encima de la estructura se hallaron veintidós artefactos pertenecientes al grupo A.

La estructura poseía cuatro estratos horizontales diferentes, el primero de ellos un sedimento arcilloso donde se encontró un esqueleto de camélido joven totalmente articulado. Se hallaba en contacto con dos estratos: uno con cenizas que sólo contenía espículas de carbón y astillas de material óseo, y otro conformado por un sedimento con carbón. El cuarto estrato consiste en un depósito de tierra altamente rubefaccionada. Al superponer la cobertura de distribución de hallazgos en $\mathrm{Y}$ y $\mathrm{Z}$ encontrados en la estructura, con los hallazgos que se encuentran por encima de ella pertenecientes al grupo A (Figura V.I-13 sección A), observamos que parte de los veintidós hallazgos se encuentran en directa vinculación topográfica con la estructura, y podrían estar relacionados con el último estrato descrito, el sedimento rubefaccionado. Lo mismo sucede en la sección Y y Z de la sección B (Figura V.I-13). Esto se observa más claramente si a la cobertura anterior le sumamos la cobertura de densidad de depositación y distribución de hallazgos en Y y Z (Figura V.I-14). Vemos así la densidad de hallazgos en directa relación topográfica -15 de los 22 objetos- sobre el corte de la estructura, y los siete objetos restantes, por encima de este sector de mayor densidad. El corte del pozo de la estructura 1, entonces, se habría realizado desde más arriba desde donde fue identificada en el año 2000. Los siete hallazgos que no se encuentran vinculados a ella pertenecerían a estratos superiores, que en ese sector del recinto corresponderían a los derrumbes de muros observados por Zaburlin (2001) en 
los niveles superiores de la excavación. De lo anterior obtenemos la matriz estratigráfica parcial de la figura V.I-15. Si analizamos esta matriz vemos que lo que antes se asociaba a una primera ocupación, invirtió su posición en tanto que se observó que el piso identificado por Zaburlin (2001) era la superficie desde la cual se cortó para realizar el pozo [5] que luego fue rellenado con [4], [3], [2] y [1]. Esto nos permite plantear que las tendencias de distribución de hallazgos observadas, sin tener en cuenta la heterogeneidad de la matriz que los contiene, y las relaciones que se establecen entre los distintos estratos que la conforman, esconden la diversidad de formas de depositación que implica la estratificación arqueológica del recinto. Donde se ubica la estructura en negativo que analizamos, las tendencias observadas en la tasa de depositación en profundidad de los hallazgos representadas a través de histogramas, no pueden ser mantenidas. En este sentido cada uno de los grupos analizados (el grupo A y el grupo B) no conforman un conjunto homogéneo sino que es un agregado de diferentes acciones culturales y naturales que deben ser identificadas y disgregadas. Todo parece indicar que aquello que en un primer momento se interpretó como un hiatus ocupacional y que nos hacía pensar en dos posibles niveles de ocupación, no se puede sostener, al menos, en el sector norte del recinto. Por otro lado, a nivel de secuencia estratigráfica nos permitió acercarnos a matrices parciales que nos permitan en momentos posteriores de análisis comprender las prácticas sociales en las que los objetos analizados estuvieron involucrados.

\section{Notas}

\footnotetext{
${ }^{1}$ Metodología propuesta por D’Amore (2002) para determinar, por un lado, el quiebre de pendiente de una serie de pozos hallados en el Oasis de Tebenquiche Chico, en la Puna de Atacama, y por otro, para poder realizar la reconstrucción de la secuencia estratigráfica del recinto. Este autor no utiliza la tecnología SIG para la reconstrucción estratigráfica.
} 


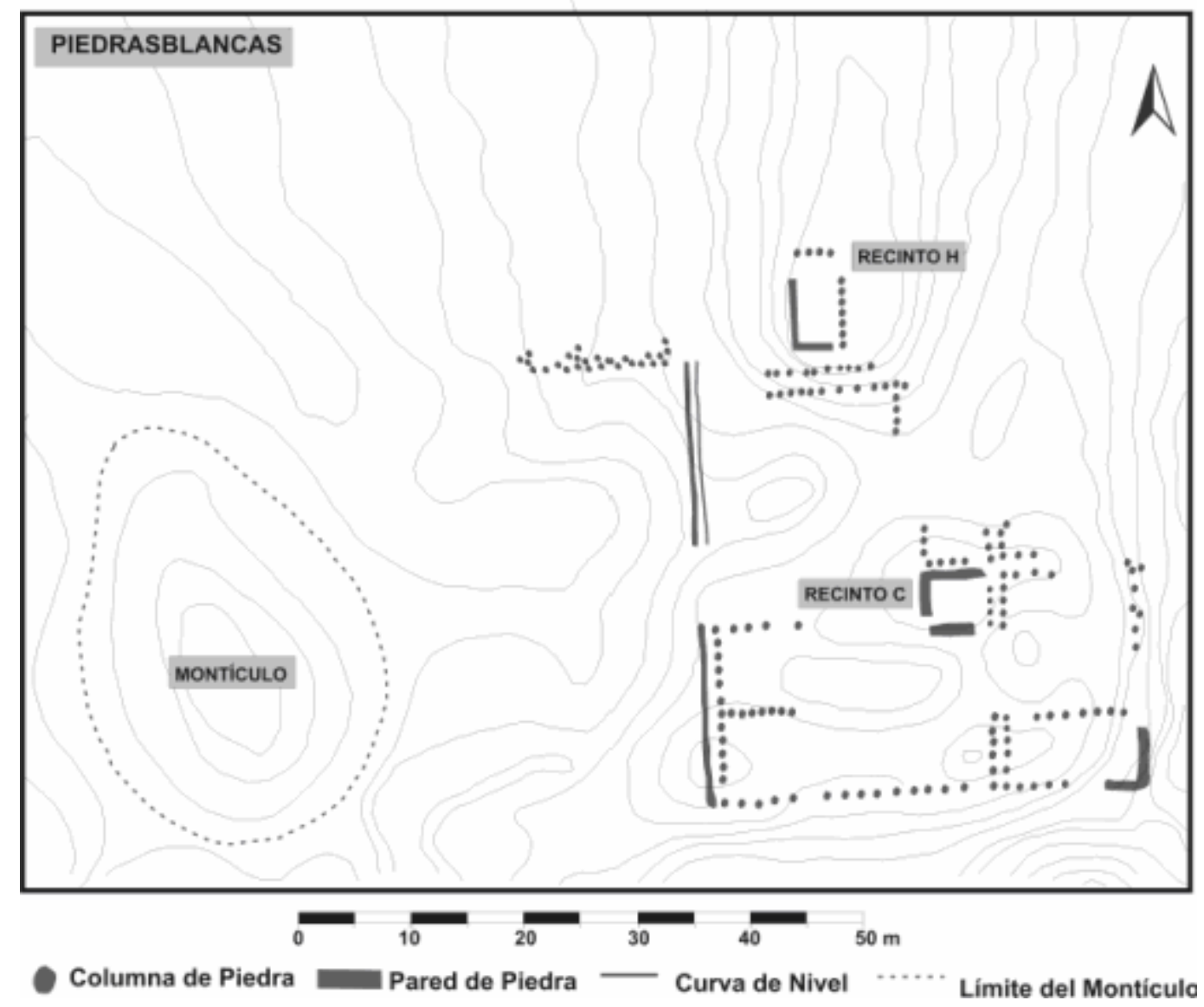

Figura V-I-1

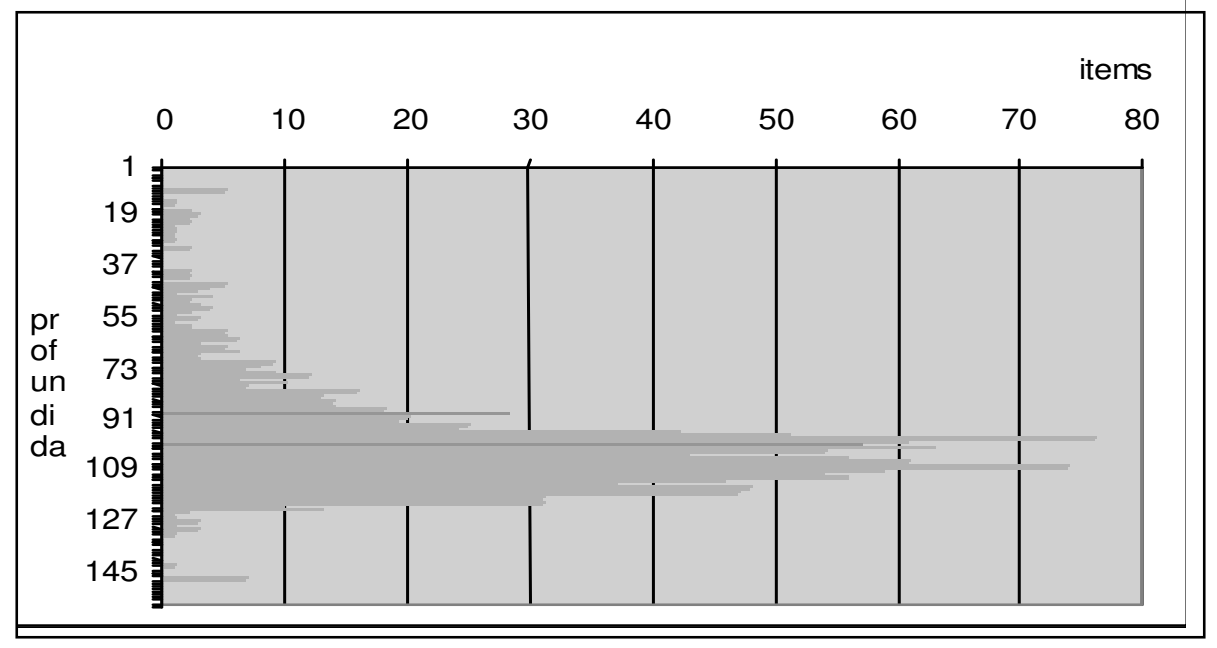

Figura V.I-2 


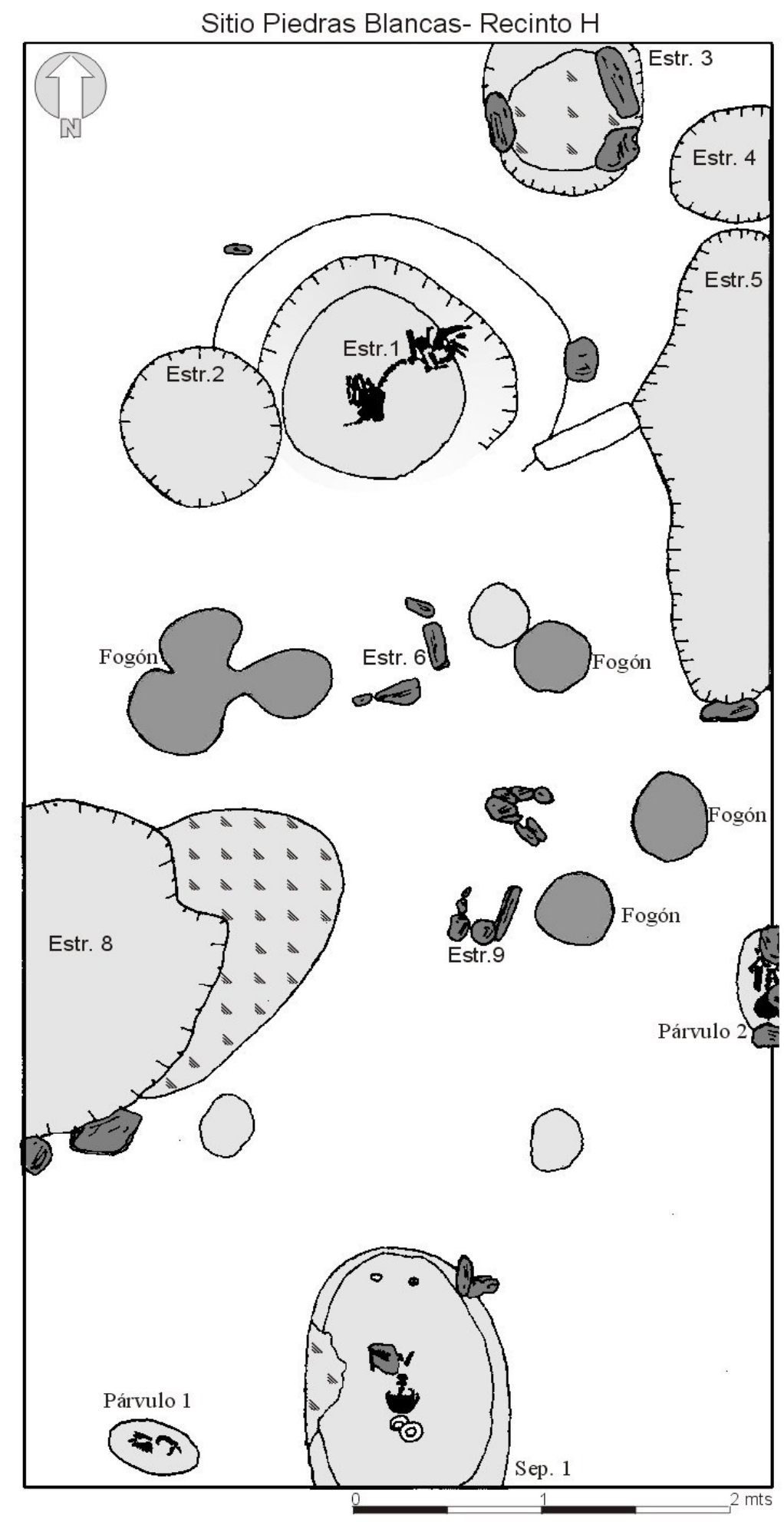

Figura V.I-3 


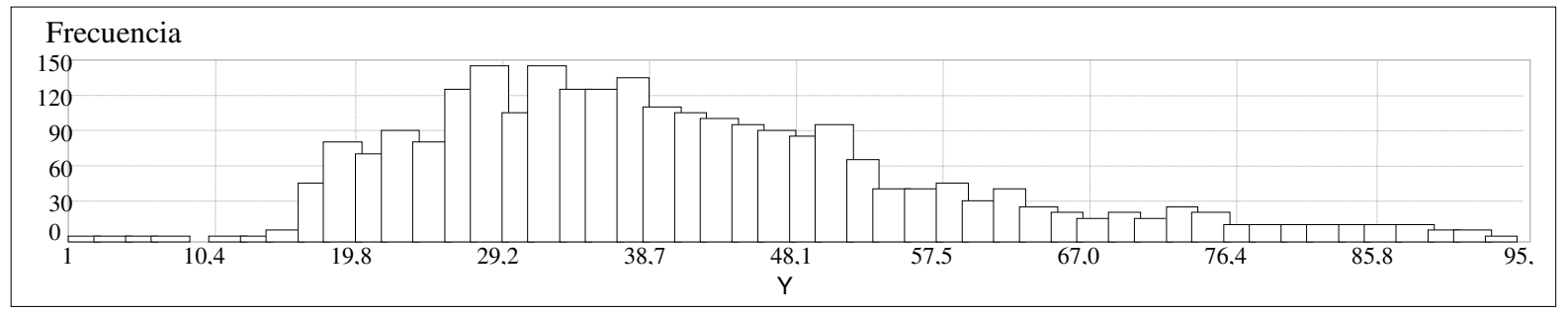

Figura V.I-4

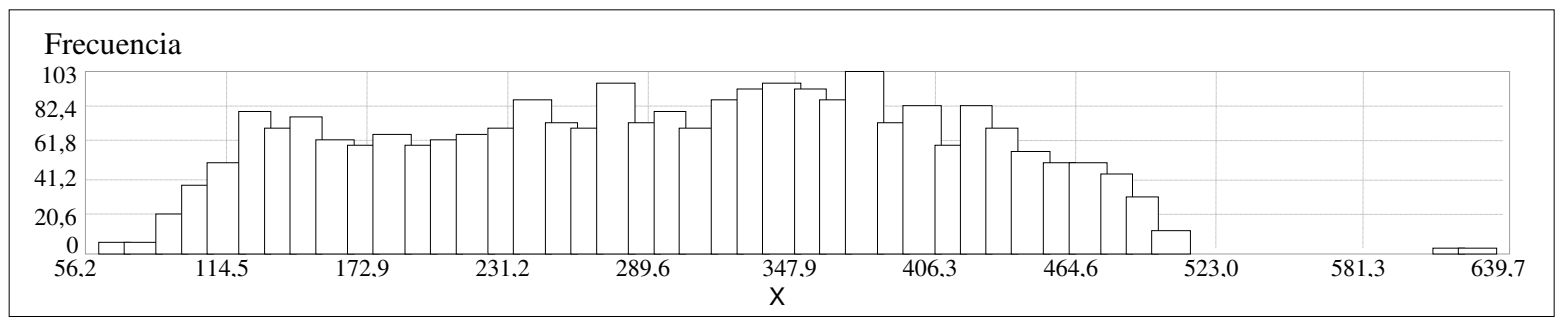

Figura V.I-5

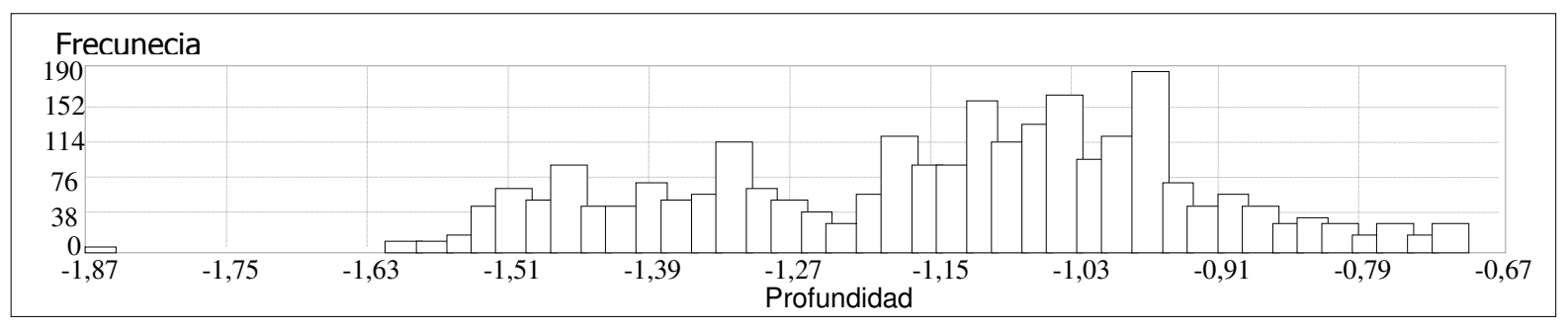

Figura V.I-6 


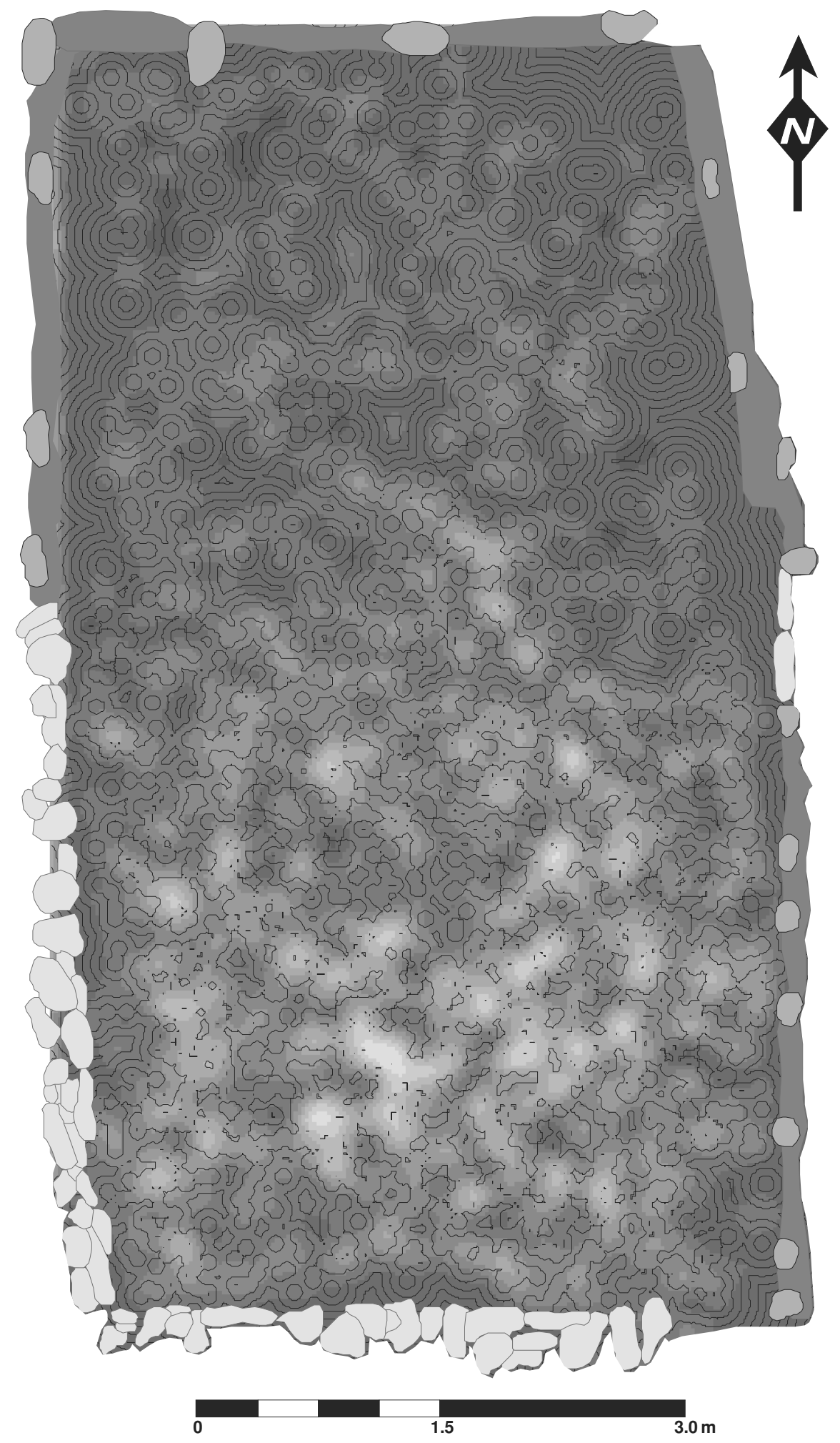

Figura V.I-7 


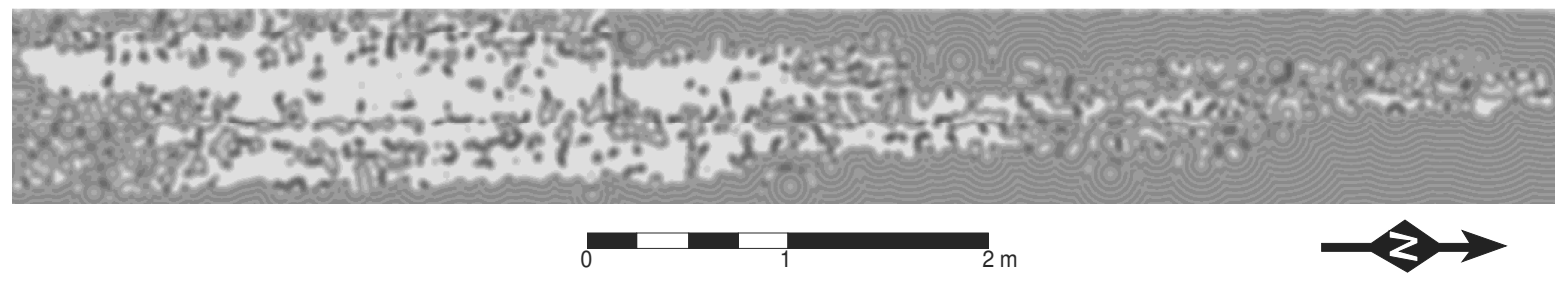

Figura V.I-8

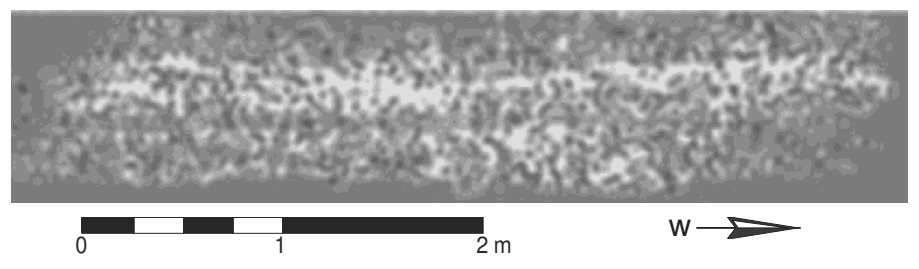

Figura V.I-9 


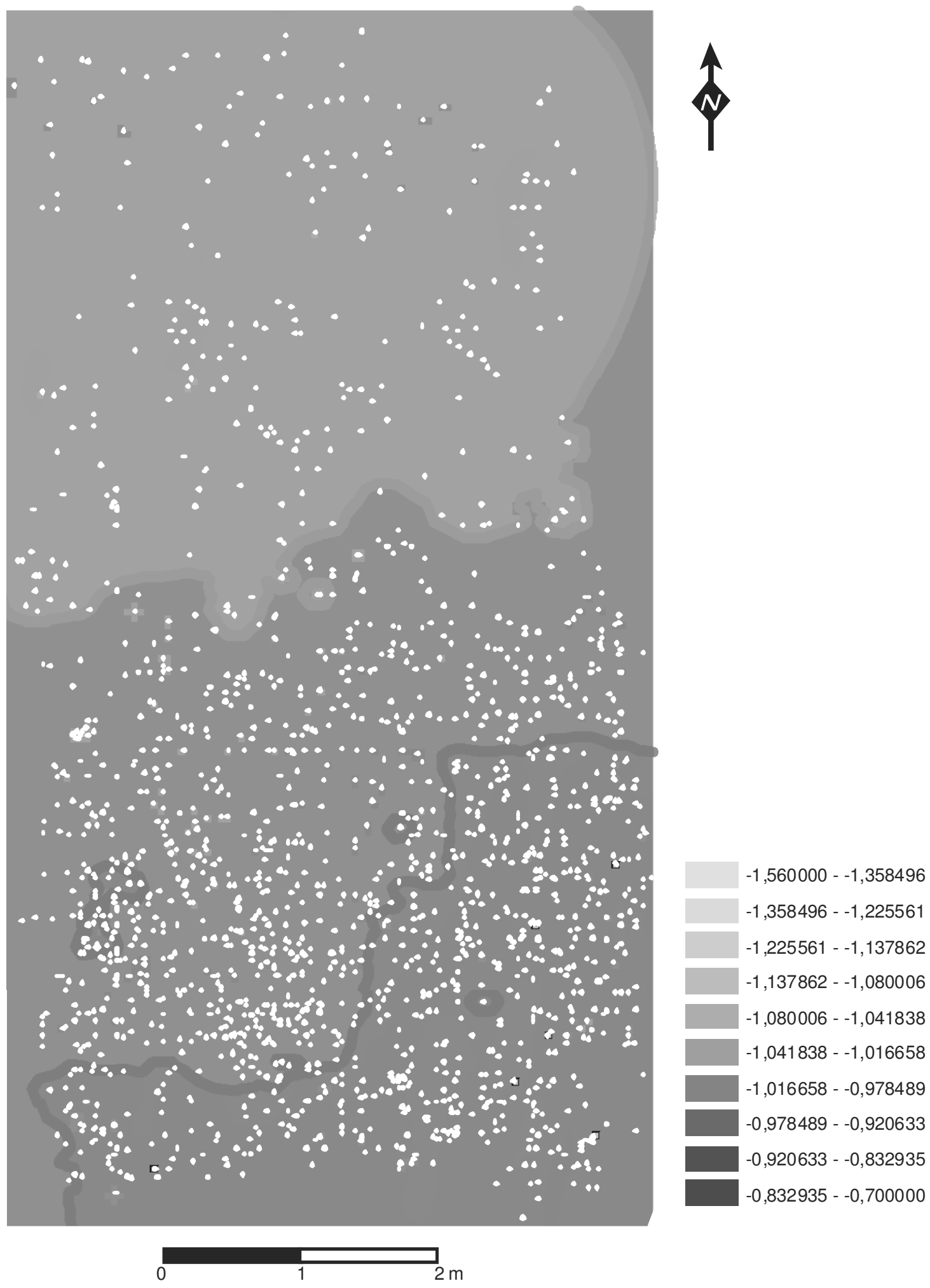

Figura V.I-10 


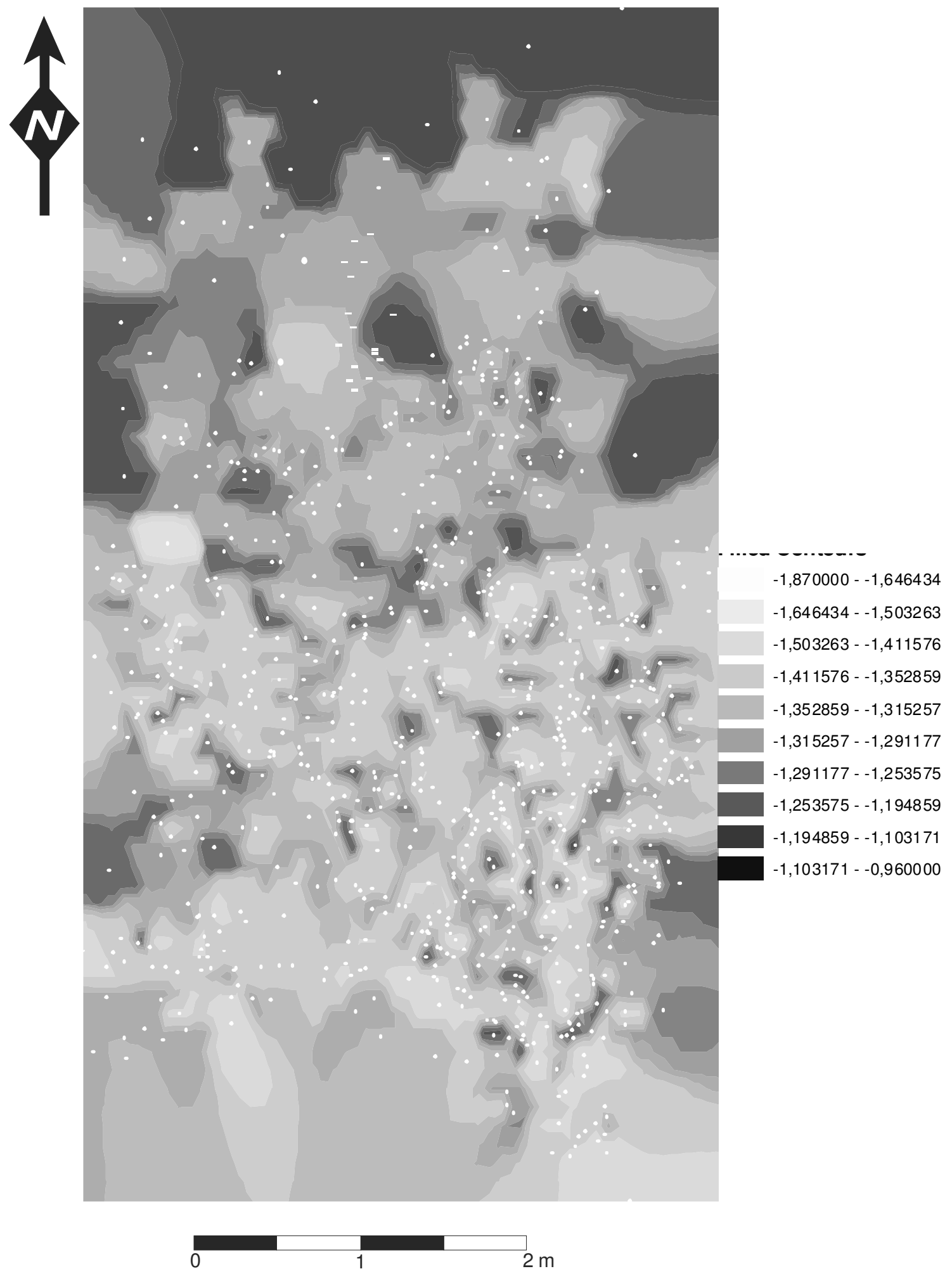

Figura V.I-11 


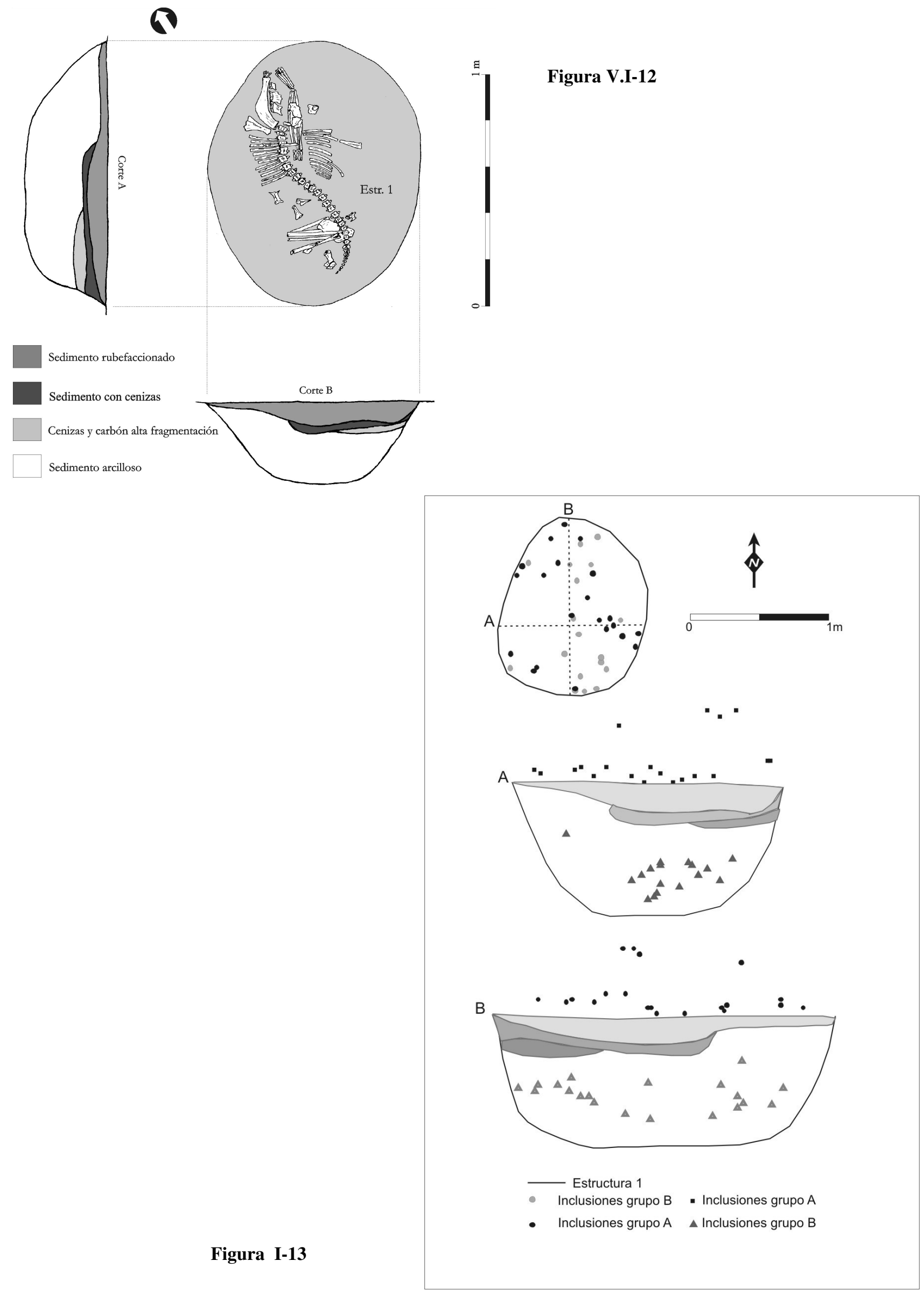




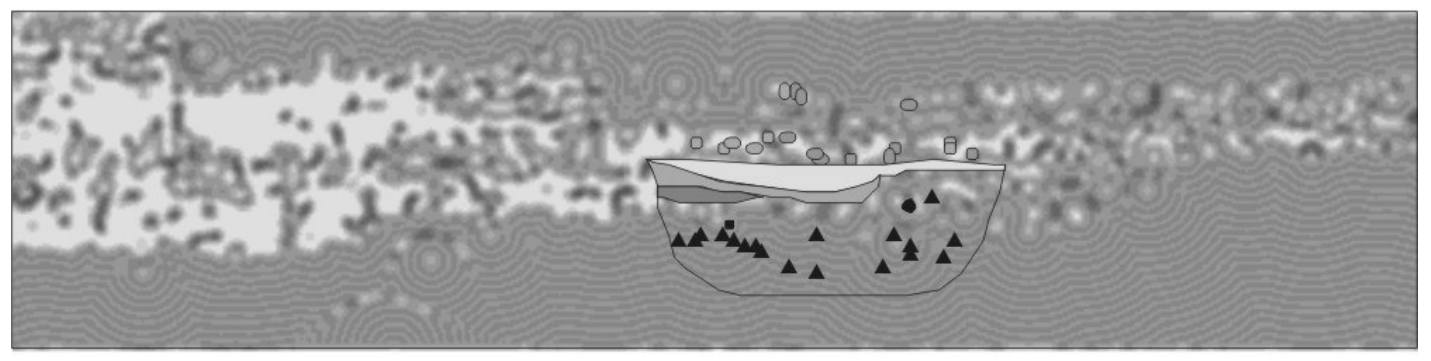

Figura V.I-14

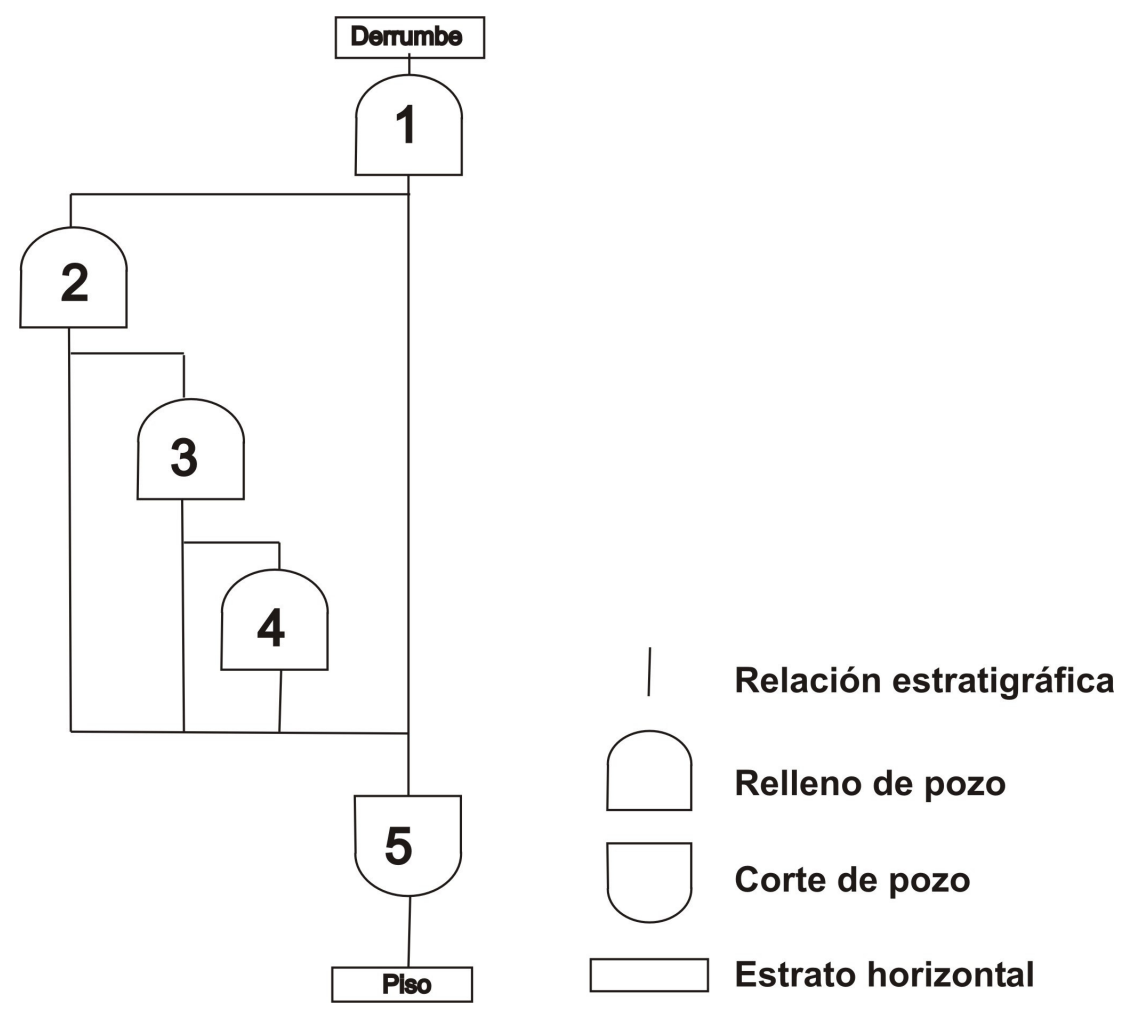

Figura V.I-15 


\section{Parte}

\section{Reconstrucción de la Estratigrafía del Recinto F}

En la última semana de noviembre y las dos primeras de diciembre del año 2004, y durante las dos últimas semanas de abril y la primera de mayo del 2005 se realizaron una serie de excavaciones, utilizando el método estratigráfico en el sitio Piedras Blancas -anexo I-. El sector que se excavó fue el Recinto F, ubicado en el sector suroeste del sitio (Figura V.I-1). La elección de excavar este recinto se debió a que en el año 1999 se había comenzado a excavar en el lugar, habiendo quedado las excavaciones inconclusas, por lo que era necesario continuarlas para evitar los inconvenientes que genera dejar expuesta una excavación ya comenzada durante un lapso prolongado de tiempo.

La excavación se realizó en dos períodos de tiempo. En el primer período -noviembrediciembre de 2004- se establecieron tres cuadrículas -A, B y C- de $5 \mathrm{~m}$ de largo por $2.5 \mathrm{~m}$ de ancho y una -MF- de 2.90 x 4 m de largo (Figura V.II-1). La excavación limitaba hacia el E con el muro perimetral que rodea al sitio. En este sector se encontraba el pozo de excavación realizado en el año 1999, la mitad Este de la cuadrícula A y toda la cuadrícula MF se superpusieron a la excavación realizada durante ese año. El límite sur de la excavación corría contra el muro perimetral sur del sitio. El límite norte era un límite arbitrario dispuesto a 2,5m del muro perimetral. La decisión de realizar cuadrículas rectangulares y disponerlas en la esquina sur/oeste del sitio se debió a que en aquel momento, debido a informaciones obtenidas en las anteriores excavaciones, se pensaba que ese espacio conformaba un galería que corría junto al muro perimetral. En este primer período se excavaron $30 \mathrm{~m} 2$ de los $46 \mathrm{~m} 2$ que cubren las cuadrículas A, B, C y MF. En el segundo período -abril/ mayo de 2005- la excavación, en virtud de los hallazgos del período anterior -principalmente la presencia del techos derrumbados carbonizados- se amplío hacia el norte para poder destapar completamente a los troncos carbonizados. Así se establecieron dos cuadrículas más, también de forma rectangular -cuadrículas E y D- (Figura V.II-2). Las cuadrículas tenían, cada una, un largo de $4 \mathrm{~m}$ y un ancho de $2.10 \mathrm{~m}$. La excavación se amplió unos $16 \mathrm{~m} 2$ más. En total la superficie excavada del recinto es de unos $46 \mathrm{~m} 2$.

El procesamiento de la información obtenida durante las excavaciones se encuentra aún en proceso. Pero podemos resumir los hallazgos de la siguiente manera: se identificaron cincuenta y seis (Figura V.II-3) unidades estratigráficas, definidas, algunas de ellas, como estratos horizontales y otras como elementos interfaciales verticales. Los estratos horizontales 
corresponden a eventos de derrumbe de muros de piedras y tapia, acumulación eólica y mezcla por acción de roedores, y eventos de caída de techos del recinto, así como pisos consolidados, fogones, cubetas de fogones, etc. También aparecieron unidades estratigráficas verticales, tales como muro de piedra continuo, muro de tapia y muro de tapia con columnas. Empecemos describiendo sintéticamente a cada uno de los estratos identificados

Unidad [1]. Es el primer estrato definido. Cubre toda la superficie de las cuadrículas C, B y una parte muy pequeñas de la $\mathrm{A}$, puesto que ya se lo extrajo en ese sector durante la excavación del año 1999 (Figura V.II-4). Se trata de un sedimento de grano fino suave, de color gris amarronado claro. En su composición presenta arena fina (80\%), arena mediana y gruesa $(15 \%)$ y grava fina (5\%). La grava dentro de la matriz sedimentaria se encuentra bien distribuida y tiene forma de subangular a subredondeada. En relación al grosor es bastante irregular -la diferencia de cota inferior y superior es de $0.20 \mathrm{~m}$ - y el límite con el estrato siguiente es claro. Posee muchas raicillas de pasto, y raíces más grandes provenientes de árboles modernos y antiguos. En relación a las inclusiones culturales que presenta sólo aparecen ocasionales fragmentos de cerámica. A este se lo interpreta como un sedimento de relleno, producto de la erosión eólica. En algunos sectores este sedimento apoya y se introduce entre las piedras del derrumbe de columnas de piedras de los muros.

Unidad [2]. Se ubica justo en el límite entre la cuadrículas A y B. Se trata de un sedimento compacto de color marrón claro. Está compuesto de limo (100\%). No posee inclusiones culturales. Posee un grosor máximo 0,002m. El límite con la unidad subyacente es neto. Se la caracterizó como una superficie expuesta dejada por la excavación anterior del recinto. Posiblemente este sedimento por ser muy fino y por la ausencia de partículas en su matriz corresponda a material de zaranda. Además el emplazamiento de la unidad coincide con la fila de tierra dejada en el lugar antes de la limpieza de la superficie a excavar.

Unidad [3]. Es semejante a la unidad [1] (Figura V.II-5). Se extiende homogéneamente por todas las cuadrículas -A, B y C-. Se trata de un sedimento de grano fino suave, de color marrón mediano. Se compone de arena limosa con presencia de mucha mica (90\%) y 10\% de grava gruesa. La grava se encuentra bien distribuida en la matriz, y es de forma subangular. Las inclusiones culturales se componen de moderados fragmentos cerámicos y frecuentes espículas de carbón. El grosor es irregular -la diferencia de cota inferior y superior es de 0.14 
m-. En este estrato al igual que [1] aparecen muchas raicillas y raíces. Se lo identifica como un sedimento de relleno, producto de la erosión cólica. Este estrato podría ser equivalente a [1] debido a que presenta casi las mismas características, siendo los límites entre los estratos muy poco claros. Se los dividió originalmente por un lado, por el cambio en la coloración -aunque probablemente dicha coloración se deba a un cambio en la humedad del suelo, más que a un cambio en las propiedades sedimentológicas y de origen del estrato- y por otro por la presencia de espículas de carbón y la intercalación del estrato[2] entre ambos. Sin embargo, este estrato probablemente se encuentre por encima de [1], si contemplamos que se lo interpretó como sedimento de zaranda producto de las excavaciones del año 1999.

Unidad [4]. Se extiende en toda la superficie que ocupan las cuadrículas B y A. Se diferencia de la anterior unidad porque presenta un sedimento de grano fino friable, mucho más suelto y polvoriento de color marrón agrisado claro. Está compuesto por limo en un 100\%. En la matriz sedimentaria aparecen moderados fragmentos cerámicos, moderadas espículas de carbón, ocasionales fragmentos óseos y una mano de mortero (Figura V.II-10). En relación al grosor que posee, el estrato es muy irregular por lo que no podemos dar una medida del espesor del miso. En un primer momento, debido a la suavidad semejante al talco, se lo interpretó como un probable producto de la erosión eólica; pero luego, a medida que se profundizaba la excavación, comenzaron a aparecer cuevas de roedores -ututucos- excavadas en un sedimento mucho más compacto que el [4] y que aparecía por debajo de este, estando el [4] rellenando las cuevas. Las cuevas se interconectaban, alcanzando algunas de ellas mucha profundidad -hasta $50 \mathrm{~cm}$-. En función de esto la interpretación del mismo sufrió modificaciones y se lo definió, además de teniendo un aporte eólico, como producto del remoción realizada por los roedores al excavar los túneles de las madrigueras. Las inclusiones culturales se encontraban formando parte del relleno de las cuevas, e incluso muchas de ellas se hallaban en la entrada de las mismas, por lo que probablemente estas inclusiones provengan de estratos más profundos que cortaron las cuevas (Figura V.II-6 y II-8).

Unidad [5]. Este estrato posee una extensión reducida. Se ubica en la esquina sur oeste de la cuadrícula B. Se compone de un sedimento de grano fino duro de color marrón oscuro. Se trata de limo (60\%), mica (20\%) y arena mediana (20\%). No posee inclusiones. En relación al grosor es irregular, existiendo una diferencia entre la cota inferior y superior de $0.292 \mathrm{~m}$. Se lo interpreta como un derrumbe de partes de muro de tapia, debido a que el estrato presenta una 
pendiente que baja desde el muro sur hacia el norte, además de los grandes bloques endurecidos que aparecen en la matriz, que conforman parte del muro de tapia derrumbado (Figura II-7)

Unidad [6]. Se extiende en todas las cuadrículas B y A (Figura V.II-8). Se trata de un sedimento de grano fino rígido, de color marrón mediano. Se compone de arena mediana (20\%), limo (70\%) y mica (5\%), mientras que el resto lo componen grandes piedras que van de $200 \mathrm{~mm}$ a $400 \mathrm{~mm}$. El grosor del estrato es irregular pero posee más potencia junto a la pared sur del recinto, afinándose hacia el norte. En relación a las inclusiones posee ocasionales fragmentos cerámicos, ocasionales fragmentos óseos y ocasionales espículas de carbón. El miso está totalmente perforado por las cuevas de los roedores, tal como se observa en la figura anterior. En algunos sectores este sedimento se mezcló con el proveniente del interior de las cuevas - producto del derrumbe de los techos de los túneles-. Se lo interpreta como el derrumbe de muro de tapia y muro de piedra continuo, debido a que en su interior se hallaron grandes piedras, las que se disponían siguiendo la pendiente del derrumbe (Figura V.II-9). Se puede observar la dirección en que se produjo el derrumbe debido a que presenta una pendiente desde el muro sur hacia el norte -igual que [5]-. Muchas de las piedras insertas en el sedimento también presentan esta pendiente. La mano de canana hallada mientras se excavaba el estrato [4] (Figura V.II-10), probablemente pertenezca a este evento de derrumbe, debido a que apoyaba en este sedimento más consolidado y presentaba una pendiente en el sentido del derrumbe. Por otro lado, el peso que presenta la misma hace dudable su transporte hasta allí por los roedores, por lo que este instrumento habría estado apoyado o formando parte del muro que se derrumbó.

Unidad [7]. Sedimento de Grano fino suave de color marrón grisáceo claro -semejante a [6] pero menos compacto- (Figura V.II-11). Esta compuesto de grava fina, mediana y gruesa (25\%), limo (40\%) y arena fina mediana y gruesa $(25 \%)$. La grava dentro de la matriz se encuentra moderadamente distribuida, los tamaños de la misma van de $10 \mathrm{~mm}$ a $25 \mathrm{~mm}$ y es de forma angular a subangular. El grosor de la unidad es muy irregular por lo que no podemos dar una medida exacta del espesor. Por debajo de este estrato aparece paja carbonizada apoyada sobre troncos finos probablemente pertenecientes a la enramada del techo. Presenta ocasionales inclusiones de cerámica y lítico. Se lo interpreta por su posición -apoyando en las ramas derrumbadas del techo - como por su composición diferencial respecto de la unidad [6], 
como la torta del techo derrumbada. Algunas de la inclusiones se encuentran insertas en la torta como si estuviesen formando parte del barro con el que se torteó (Figura V.II-12 y II-13). El estrato posee una pendiente en sentido sureste. La torta del techo, sólo en pocos sectores pudo ser diferenciada del derrumbe del techo, por lo que en alguno sectores se la tomó como $[8]=[15]$.

Unidad [8] = [15]. Sedimento de grano fino suave, marrón anaranjado mediano, está compuesto de arena fina, mediana y gruesa (60\%), limo (20\%) y grava fina y mediana $(20 \%)$. La grava se encuentra moderadamente distribuida en la matriz y posee un tamaño que va desde los $10 \mathrm{~mm}$ a los $20 \mathrm{~mm}$, siendo su forma angular a subredondeada. En este estrato, en las cuadrículas A, B y MF, D y E, aparece la techumbre carbonizada, lográndose observar la composición de la techumbre. Aparecen troncos que por su tamaño y largo parecen conformar los principales sostenes del techo (Figuras II-14 y II-15), troncos más finos y cortos que podrían conformar los secundarios (Figuras II-16), la enramada (Figuras II-17 y II-18), y la paja que cubría a ésta (Figura V.II-19). En este estrato la frecuencia de aparición de material arqueológico aumenta considerablemente, aparecen frecuentes fragmentos cerámicos, recuperándose varios lotes de fragmentos pertenecientes a vasijas que fueron rotas al caerse el techo. En muchos casos estas se encuentran aplastadas por los troncos o la enramada del techo (Figuras II-21 y II-22). Posteriormente a los hallazgos que se encontraban apoyados en el piso al momento de derrumbarse el techo se los asoció a otra unidad, la [10] $=[20]$, puesto que permite un mejor entendimiento de la formación de la estratigrafía del sitio. A la unidad [8] se la definió como una mezcla de torta, troncos, enramada y paja, fragmentos de muro de tapia y piedras producto del derrumbe de la techumbre al incendiarse. La excavación de este estrato se continúo en abril-mayo del 2005, en el que se observó que se extendía al resto de las cuadrículas, ocupando la techumbre toda la superficie del recinto. La extensión de la techumbre a todo el recinto hace que la hipótesis de la galería deba ser modificada y se considere a este espacio totalmente techado.

Unidad [9]. Se encuentra en la cuadrícula MF, su extensión es restringida y se ubica junto al muro E del recinto, compuesto de columnas y tapias (Figura V.II-20). A nivel sedimentológico se lo describe como un sedimento de grano fino suelto y suave, color marrón agrisado mediano, se compone de arena limosa (50\%) y arena fina (50\%). Posee un grosor máximo de unos 0.05. No posee inclusiones culturales. Se lo interpretó como una colada de barro 
producto del lavado por la lluvia del muro de tapia. El estrato se componía de varias láminas delgadas que se superponían una a otra, intercaladas por arena muy fina de un espesor no mayor de $5 \mathrm{~mm}$.

Unidad $[\mathbf{1 0}]=[\mathbf{2 0}]$. Se extiende por todo el recinto. No posee una matriz sedimentaria, puesto que se trata de aquellos objetos enteros $y$ fragmentados que al momento de derrumbarse la techumbre estaban apoyando sobre la superficie del piso (estratos [17], [12] y [30]), o estaban colgados de la techumbre, y que producto del/ los derrumbe/ s se rompieron y se esparcieron por toda el piso. Algunos de los objetos asociados a [8], tales como el conjunto B57 (Figura V.II-21), una pipa (Figuras II-22 y II-23) y una vasija antropomorfa, deberían ser incluidos dentro de este estrato, ya que se disponían totalmente horizontales, estaban aplastados por la enramada y troncos que componen el techo, y apoyaban en la superficie que posteriormente se definió como piso (ver figuras II-24, II-25, II-26, II-27 y II-28 para observar como aparecen otros objetos rotos y apoyados horizontalmente sobre el piso). Cabe hacer una aclaración en relación a la separación realizada entre [10]=[20] de lo que se interpretó como un piso $-[17]=[12]=[30]-$ : si bien los hallazgos se asocian a las unidades estratigráficas en función de donde apoyan, por lo que los objetos que componen a [10]=[20] deberían se incluidos dentro de $[17]=[20]=[30]$, es posible realizar una división interna que facilita la comprensión de la secuencia y de los eventos formadores de la estratigrafía original del sitio. La superficie de apoyo de estos objetos corresponde a una interfacie, esto nos acerca a la superficie donde se pisaba y circulaba. Dicha superficie posee los mismos límites del estrato definido como piso, situación que nos permite dividirla del piso, que como tal, corresponde a una fase, y las inclusiones que contiene nos relaciona más a un proceso continuo de acumulación, extracción, pisoteo y limpieza.

Unidad [11], [23], [36], [28], [37], [38], [39], [40],[42], [43], [44], [45], [46], [47], [48], [49], [50], [52], [52], [53], [54], [55] y [56] forma las cuatro estructura de postes de sotén de techo (Figura V.II-29, imagen inferior derecha) todas presentan las mismas características (Figura V.II-29 imágenes media y superior derecha) por lo que vamos a describir solo una de ellas. Los vamos a describir en función de sus secuencias de formación (Figura V.II-29, esquema de la derecha). Primero desde [34] se excava un pozo cilíndrico de unos $0.50 \mathrm{~m}$ de ancho por unos $0.40 \mathrm{~m}$ a $0.50 \mathrm{~m}$ de profundidad, correspondiendo al elemento interfacial vertical [41]. Luego en el fondo del pozo se coloca una laja plana [40] sobre la que se apoya el tronco [39], 
y luego el espacio que queda entre el tronco y las paredes del pozo se rellena con piedras y pedregullo [38]. Una vez levantado el poste y rellenado el pozo se forma por encima de él un domo [37], probablemente para que reparta el peso del tronco. Este domo se compone de un sedimento con arena sin grava de unos $0.10 \mathrm{~m}$ a $0.15 \mathrm{~m}$ de espesor y por encima de él se coloca un sedimento compuesto de grava y arena gruesa de un espesor que varía de unos 0.05 $\mathrm{m}$ en las bordes del domo a unos $0.10 \mathrm{~m}$ junto al poste, conformando el estrato [11].

Unidades [12]=[17]. Se extiende por las cuadrículas A, B y MF. Sin embargo, en algunos sectores restringidos de estas cuadrículas, no aparece, tal es el caso del sector oeste de la cuadrícula A y el sector noreste de la MF. Se trata de un sedimento de grano fino débilmente sementado, de color marrón mediano, compuesto de grava fina y mediana en un $15 \%$, arena gruesa en un $40 \%$ y limo en un $15 \%$. Presenta como inclusiones a diferencia de [10] moderados fragmentos cerámicos y ocasionales fragmentos óseos. Sobre la superficie de los estratos se observan algunas manchas de sedimento termoalterado. Fueron definidos como un piso consolidado, debido a que no sólo los objetos rotos descritos como [10] apoyaban sobre ellos, sino que además su superficie es horizontal y poseen una dureza considerable probablemente producto de la preparación del suelo y el pisoteo (Figura V.II-30).

Unidad [13]. Es equivalente a [5] y a [6]. Cuando se extendió la excavación, durante el período abril-mayo de 2005 a las cuadrículas D y C, apareció junto a las paredes Este y Norte del recinto un derrumbe de muro de tapia junto con piedras que poseían un buzamiento hacia el interior del recinto al igual que los estratos [5] y [6]. Se trata de un sedimento grueso fuertemente cementado, de color marrón agrisado claro, compuesto por arena gruesa (30\%), arena mediana $(10 \%)$, arena fina $(10 \%)$, limo $(40 \%)$ y grava fina (10\%). En relación a las inclusiones culturales presenta ocasionales fragmentos cerámicos y ocasionales fragmentos óseos. Se encuentran conformando parte de la matriz algunas piedras de columnas derrumbadas.

Unidad [14]. Se extiende en toda la superficie de las cuadrículas C y D. Se trata de un sedimento de grano fino muy suave, de color marrón mediano, compuesto por arena fina, mediana y gruesa (40\%), limo (50\%) y piedras (10\%). Las piedras van desde los 200 a 300 mm. Por la disposición que poseen (Figura V.II-31) parecen conformar un derrumbe de columnas de la esquina noreste del recinto. En relación a las inclusiones culturales aparecen 
ocasionales gasterópodos y ocasionales fragmentos cerámicos. El límite con la unidad siguiente es claro. Se lo definió como un sedimento de relleno acumulado por encima de los derrumbes de muro y techo, producto de la erosión eólica y la alteración producida por roedores que excavaron sus madrigueras en él, tanto como del derrumbe definido como [13]. Es equivalente a [1] y a [3].

Unidad [16]. Es un elemento interfacial vertical, definido como una huella de poste excavada en el muro de tapia este del recinto (Figura V.II-32). Se encuentra alineado con las dos estructuras de postes ubicados al sur del recinto. A diferencia de los demás postes hallados, en este no aparecieron los restos del poste quemado. La conformación de la estructura de poste es diferente a las otras halladas, estando ésta conformada por un pozo de unos 10 a 15 centímetros de diámetro, por lo que el poste habría sido mas fino que los otros. Al igual que las otras estructuras, en la base del pozo se colocó una laja donde apoyaba el poste. Luego, el espacio entre el poste y las paredes del pozo, se rellenó con pedregullo y piedras. No posee un domo alrededor como las otras estructuras, probablemente porque el sostén se lo da el propio muro al estar inserto dentro del él.

Unidad [18]. Se encuentra en la cuadrícula B. Se trata de un sedimento de grano fino suave, gris amorronado claro, posee arena fina, mediana y gruesa $(30 \%)$ y ceniza y carbón en un (70\%), no presentando inclusiones culturales. Se lo interpreta como un fogón. Esta mancha se había empezado a observar cuando se definió [12]=[17], apareciendo con un color grisáceo rodeado por una coloración anaranjada típica de un sedimento termoalterado (Figura V.II-33) .

Unidad [19]. Es un elemento interfacial vertical ubicado en la cuadrícula B. La forma del elemento en planta es irregular, no posee esquinas y el quiebre de pendiente en la cima es gradual. Posee los lados y la base cóncavas, por lo que el quiebre de pendiente en la base es imperceptible. La dirección del elemento interfacial es en sentido E-O. Lo rellena el estrato [21] definido como fogón. A este elemento se lo interpreta como una cubeta de fogón. Es un corte realizado desde el estrato [17] para realizar la cuenca donde se realizó el fogón. Se pudo diferenciar claramente el sedimento que componía el relleno, de las paredes que lo contenían. Estas últimas, a diferencia del fogón [21] (ver descripción mas adelante] que poseía ceniza y carbón en un $80 \%$, se componían totalmente de arena que presentaba una coloración anaranjada típica de un sedimento expuesto a altas temperaturas (Figura V.II-39). 
Unidad [21]. Se encuentra en la cuadrícula B. Se compone de un sedimento de grano fino suave, de color gris amarronado claro, compuesto de arena fina, mediana y gruesa en un $20 \%$ y carbón y ceniza en un $80 \%$. El límite con el estrato siguiente es neto. Al igual que [18] éste se comenzó a observar desde que se empezó a definir [17], y aparecía como una mancha bien definida de color grisácea rodada por una aureola de color anaranjada. Cuando se la empezó a excavar se observó que se encontraba acumulada en una cuenca de depositación, definida luego como [19], que presentaba las paredes totalmente termoalteradas. Estas características nos permitieron interpretarlo como un fogón (Figura V.II-33).

Unidad [22] se trata de un elemento interfacial vertical hallado en la cuadrícula B. La forma del corte del elemento en planta es circular. El quiebre de pendiente en la cima es gradual y sus lados son cóncavos al igual que la base. Lo rellena el estrato [18]. Posee una dimensión de $0.43 \mathrm{~m}$ de diámetro y una profundidad máxima de $0.11 \mathrm{~m}$. Se trata de un corte realizado desde el estrato [17] para realizar la cuenca donde se realizó el fogón. Al igual que en el caso de la cubeta [19], se pudo diferenciar claramente el sedimento que componía el relleno de las paredes que lo contenían. Estas últimas, a diferencia del fogón [18] que poseía ceniza y carbón en un $70 \%$, se componían totalmente de arena que presentaba una coloración anaranjada típica de un sedimento expuesto a altas temperaturas (Figura V.II-39).

Unidad [24] Se encuentra junto a la pared Este en la cuadrícula E. Se trata de un sedimento de grano grueso compacto, es de color blanco amarillento claro. Se compone de una arena? de color blanquecina (10\%) y ceniza? (80\%). Aún no hemos realizado ningún tipo de análisis que nos permita conocer que tipo de material es exactamente (Figura V.II-34). Presenta un grosor en el centro de unos $0.08 \mathrm{~m}$. En relación a las inclusiones culturales aparecen frecuentes fragmentos cerámicos que se encontraban incrustados en el sedimento en diferentes inclinaciones. Algunos debieron ser recolectados en lotes, debido a que, si bien estaban fracturados, se observaba claramente que pertenecían a una misma pieza que se fracturó al caerse el techo. Es sugestivo que se hallaran fragmentos de una base de una vasija, semejantes a los fragmentos que se levantaron como lotes, en posición invertida y con sedimento adherido a ella. Dadas estas características, a este estrato se lo interpretó como el contenido de un recipiente cerámico, que al momento de derrumbarse el techo se rompió desparramando los 
fragmentos y el contenido de la vasija por el lugar. Por otro lado, [24] apoya sobre lo que se definió posteriormente como un piso consolidado [30].

Unidad [25] Es un sedimento que se encuentra por debajo de [24] y [26]. Se trata de un sedimento de grano fino friable, color marrón rojizo claro, compuesto de arena fina (100\%) (Figura V.II-34). Presenta ocasionales fragmentos óseos y cerámicos. El espesor de la arena es variable y no posee un límite claro con el estrato siguiente. Es semejante a una arena fina que aparece por debajo de [17] en el sector noreste de la cuadrícula MF, pero la única diferencia con ella es el color, anaranjado en el caso de [25] y marrón claro en el otro caso. Dada la coloración del sedimento, parece haber estado expuesto a un fuego muy intenso, aunque sin embargo, los pocos materiales hallados en su interior no presentan huellas de haber sido quemados, salvo por una astilla de hueso totalmente calcinada. Tampoco aparecen evidencias de ceniza y carbón, por lo que se habría limpiado totalmente la superficie donde se realizó el fuego. Estratigráficamente este estrato se encuentra en algunos sectores por debajo de [24], [26] (ver descripción siguiente) y en otros por debajo de [30] (piso consolidado). Las unidades [30], [24] y [26] no presentan evidencias en este sector de haber estado sometidas a altas temperaturas, por lo que interpretamos que el fuego que produjo esta alteración en la arena, se habría realizado en momentos anteriores a la depositación de esos estratos.

Unidad [26]. Posee la misma composición que [26], y también se encuentran las inclusiones cerámicas incrustadas en él (Figura V.II-35), que debieron ser levantadas algunas en lotes puesto que formaban parte de una misma vasija. Aparecieron bases de vasija conteniendo este mismo sedimento (Figura V.II-36), por lo que se lo interpreta de la misma forma que [24]. Espacialmente se encuentran a cada lado del estrato [25] (Figura V.II-34).

Unidad [27] Se encuentra en el sector sur de la cuadrícula D. Es una estructura de piedras lajas que contenía en su interior por lo menos tres vasijas enteras que estaban apiladas. Se observa claramente cómo los troncos del techo rompieron la estructura y las vasijas que se encontraban dentro (Figura V.II-37 y II-38)

Unidad [29] se ubica en el centro de la cuadrícula D. Se trata de un sedimento de grano fino suave, morrón agrisado claro, se compone de ceniza (30\%), arena fina (50\%) carbón un (20\%). Posee un grosor de uno 0.19 m en el centro afinándose hacia los costados. En relación 
a las inclusiones culturales aparecen ocasionales fragmentos cerámicos y óseos. Este estrato aparece como una mancha en el sedimento de color grisácea con un aureola de color anaranjada. Al empezar a excavarlo se observa que se encuentra rellenando una cuenca de depositación [33], cuyas paredes están totalmente termoalteradas (Figura V.II-39).

Unidad [30]. Se esparce por todas las cuadrículas E y D (Figura V.II-39). Es un sedimento de grano fino duro, de color marrón blanquecino claro, se compone de grava fina (2\%), limo arcilloso $(80 \%)$ y arena fina en un (18\%), La grava posee una forma y redondeamiento subangular. Posee un grosor de unos 0.06 a $0.10 \mathrm{~m}$ de espesor. La superficie del estrato es totalmente lisa y se observa como si se hubiese realizado una especie de enlechado. Al realizar un corte del estrato (Figura V.II-40), éste se compone de varias finas capas superpuestas de muy pocos milímetros de espesor, como si el tratamiento de alisamiento lo hubiesen realizado en varias ocasiones. Incluso este enlechado cubre la superficie de los domos de los postes ubicados en estas cuadrículas. En relación a las inclusiones culturales, aparecen frecuentes fragmentos cerámicos, apoyados horizontalmente, al igual que frecuentes fragmentos óseos también dispuesto de manera horizontal, frecuentes cuentas de collar de hueso, ocasionales semillas y ocasionales fragmentos líticos de cuarzo. Se lo interpretó como un piso consolidado, semejante a [17] y [12], aunque más consolidado que estos últimos y con un tratamiento de las superficie diferente. Sobre este piso se encontraban apoyando las vasijas que contenían el sedimento blancuzco definido como [24] y [26]. En algunos sectores de las cuadrículas D y E, principalmente debajo de la estructura [27] y donde aparecía la arena rubefaccionada [25], no pudo encontrarse esta superficie consolidada. Desde [30] se cortó la cubeta de fogón [33].

Unidad [31] se encuentra ubicada por encima del fogón [27]. Se trata de un sedimento de grano fino suave, de color gris blanquecino claro, compuesto de ceniza y carbón (70\%) y arena fina y limo (30\%). Aparece un fragmento óseo calcinado. Posee un espesor de unos 0.05 m. Se observa que esta concentración de ceniza y carbón apoya sobre el fogón [29], pero se extiende más hallá de los límites de la cubeta y el sedimento rubefaccionado, apoyando sobre [30]. Podría corresponder a la limpieza del fogón [29]

Unidad [32]. Se encuentra en el sector medio de la cuadrícula E. Se trata de un sedimento de grano fino suave, de color marrón agrisado claro, compuesto de ceniza (40\%), carbón (20\%) y 
arena mediana y fina (40\%). Posee un grosor de unos $0.10 \mathrm{~m}$, sin inclusiones culturales. El sedimento se encontraba contenido en una cuenca de depositación, excavada en una arena fina semejante a [25] tanto en su composición y color. Este estrato se encontraba cubierto por el piso consolidado [30] (Figura V.II-41), es decir que el sedimento se expuso al fuego anteriormente a la confección del piso.

Unidad [33]. Es un elemento interfacial vertical que contiene de relleno a [29]. La forma en planta de este elemento es oval, posee un largo de $0.80 \mathrm{~m}$ y un ancho de $0.56 \mathrm{~m}$ y una profundidad de $0.19 \mathrm{~m}$. El quiebre de pendiente en la cima es gradual, sus lados y base son cóncavos, y posee una orientación este oeste. En el lado oeste se encuentra delimitado con dos piedras planas, clavadas verticalmente (Figura V.II-39). Se lo interpretó como la cubeta de fogón de [29], no sólo porque lo contenía, sino que las pares estaban totalmente rubefaccionadas. Este estrato se encuentra excavado desde [34].

Unidad [34]. Todavía no se la destapó del todo, puesto que no se excavaron por completo las estructuras de postes y los muros, pero se trata de una arena fina que parece conforma el estrato estéril desde donde se construyó el recinto. Esta es equivalente a [25], puesto que [25] corresponde sólo a la alteración térmica sufrida por la arena en contacto con el fuego (Figura V.II-42).

Además de estas unidades estratigráficas horizontales, interfaces y elementos interraciales ya descritos, durante la excavación aparecieron unidades estratigráficas verticales: el muro sur, el muro este, y parte del muro oeste. Estas unidades aún no fueron destapadas en su totalidad, por lo que las vinculaciones estratigráficas con estratos horizontales, interfaces y elementos interraciales, aún quedan por establecerse. Pero vamos a realizar una descripción de los mismos según los datos que poseemos hasta el momento y una primera aproximación tentativa para el establecimiento de su vinculación con las otras unidades identificadas.

Muro Sur: en un primer momento se creía que se trataba de los típicos muros de tapia y columnas que aparecen en Ambato. Sin embargo, a medida que avanzaba la excavación, se descubrió que la construcción combinaba dos técnicas, en el sector este muro de tapia y columnas de piedras, y en el sector medio y oeste muro continuo de piedras (Figura V.II-43). 
La sección realizada con piedras es semejante al muro suroeste del recinto $\mathrm{H}$ del sitio, aunque sin embargo presenta una característica que lo diferencia no sólo de este último, sino de todos los muros de piedra hasta ahora encontrados en el sitio: la presencia de postes de madera dividiendo paneles de mampostería. Presenta dos postes, uno ubicado en el extremo oeste del muro, junto al muro de tapia oste, y otro a la mitad del muro, que dividen al muro de piedra continuo en dos paneles de mampostería. Cuando se excavó el sector donde se encontraban los postes, se encontró la madera de los postes carbonizada. Ésta presentaba las fibras orientadas en sentido vertical, lo que indica que el poste se encontraba parado. Donde apoyaban los postes aparecieron piedras planas tipo laja y, a los costados de los postes, entre éstos y los paneles, se colocaron lajas o piedras chatas para sostenerlo (Figura V.II-43, ver imágenes de la derecha). Ambos postes están alineados con otros de sostén del techo. El poste oste se encuentra alineado con [16], y el poste ubicado en el medio se encuentra alineado con la estructura de poste suroeste. Los paneles se componen de piedras canteadas y cantos rodados seleccionados con una cara plana. Las caras planas miran al interior del recinto. Entre los bordes de los bloques que componen el mampuesto no existe ningún tipo de argamasa que los ligue, por lo que se identifica a la técnica constructiva como pirca seca. En cuanto a la dimensión de los paneles de mampostería, el panel Este tiene un largo de $3.50 \mathrm{~m}$ aproximadamente, y el panel oeste $2.30 \mathrm{~m}$. La sección del muro que presenta columnas y tapia mide aproximadamente unos $1.70 \mathrm{~m}$ de largo. En total el muro sur mide unos $7.50 \mathrm{~m}$ de largo. No sabemos qué alto llegó a tener el muro, aunque si tenemos en cuenta el derrumbe [6], probablemente se halla levantado unos cuantos centímetros más arriba de lo que puede hoy ser observado. Al no terminarse de excavar completamente el muro, aún no se ha podido establecer concretamente los diferentes estratos verticales que pudieron componer los dos paneles de mampuesto. Aún no podemos establecer completamente la vinculación del muro con los estratos horizontales, pero sin embargo, sí podemos establecer una vinculación de subyacencia entre el muro y los estratos [17] y [12], unidades que fueron definidas como un piso consolidado sobre el que apoyaban los objetos que rompieron el techo al derrumbarse, definidos como [10] $=[20]$. Parece ser que los muros se hunden en la arena fina definida como [34], aunque queda por saber si poseen o no cimiento y las características de éstos. La vinculación con el muro de tapia este y oeste aúno no puede ser establecida.

Muro Oeste: se identificó bajo el derrumbe [5]. Se compone totalmente de tapia, habiéndose podido identificar gracias a que cuando se derrumbó el techo, las ramas que componían la 
enramada del mismo se dispusieron en forma paralela al muro, y conformó un límite o tope para el derrumbe (Figura V.II-44). La excavación en la cuadrícula E no llegó a alcanzarlo, por lo que aún no se lo destapó completamente, sólo se lo pudo seguir en los $2.5 \mathrm{~m}$ de ancho que posee la cuadrícula B. El muro presenta unos $0.70 \mathrm{~m}$ de ancho. En su interior se encuentra la estructura de poste [16]. Su altura aún no puede ser establecida, hasta donde se lleva excavado posee unos 0.50 a $0.60 \mathrm{~m}$ de alto. Esta subyaciendo a [12] y se hunde en la arena fina definida como [34].

Muro Este: el muro Este ya había sido destapado en la campaña de 1999. Se trata de un muro de tapia con columnas de piedras superpuestas. En total se identificaron tres columnas, dos de ellas ubicadas en el sector sur del muro, separadas entre ellas unos pocos centímetros. El espacio entre columnas se encuentra alineado con la estructura de poste [11], la estructura de poste sur oeste y la estructura [16] ubicada dentro del muro de tapia oeste. Entre las columnas no se ha hallado madera carbonizada que indique la presencia de algún poste. A pesar de que en la excavación del año 1999 ya habían aparecido las columnas derrumbada que mencionamos, el muro de tapia fue identificado durante la excavación de abril-mayo de 2005. Se encuentra unos $0.30 \mathrm{~m}$ más al Este de las columnas derrumbadas y de las piedras de columnas que aún no se han derrumbado. Posee una inclinación de unos $3^{\circ}$ a $4^{\circ}$ respecto del norte. Las vinculaciones estratigráficas con los otros estratos verticales y horizontales aún no pueden ser establecidas completamente. Sin embargo, el segmento descubierto en la esquina suroeste, se encuentra subyaciendo al estrato [17] y se hunde en la arena fina definida como [34]. 


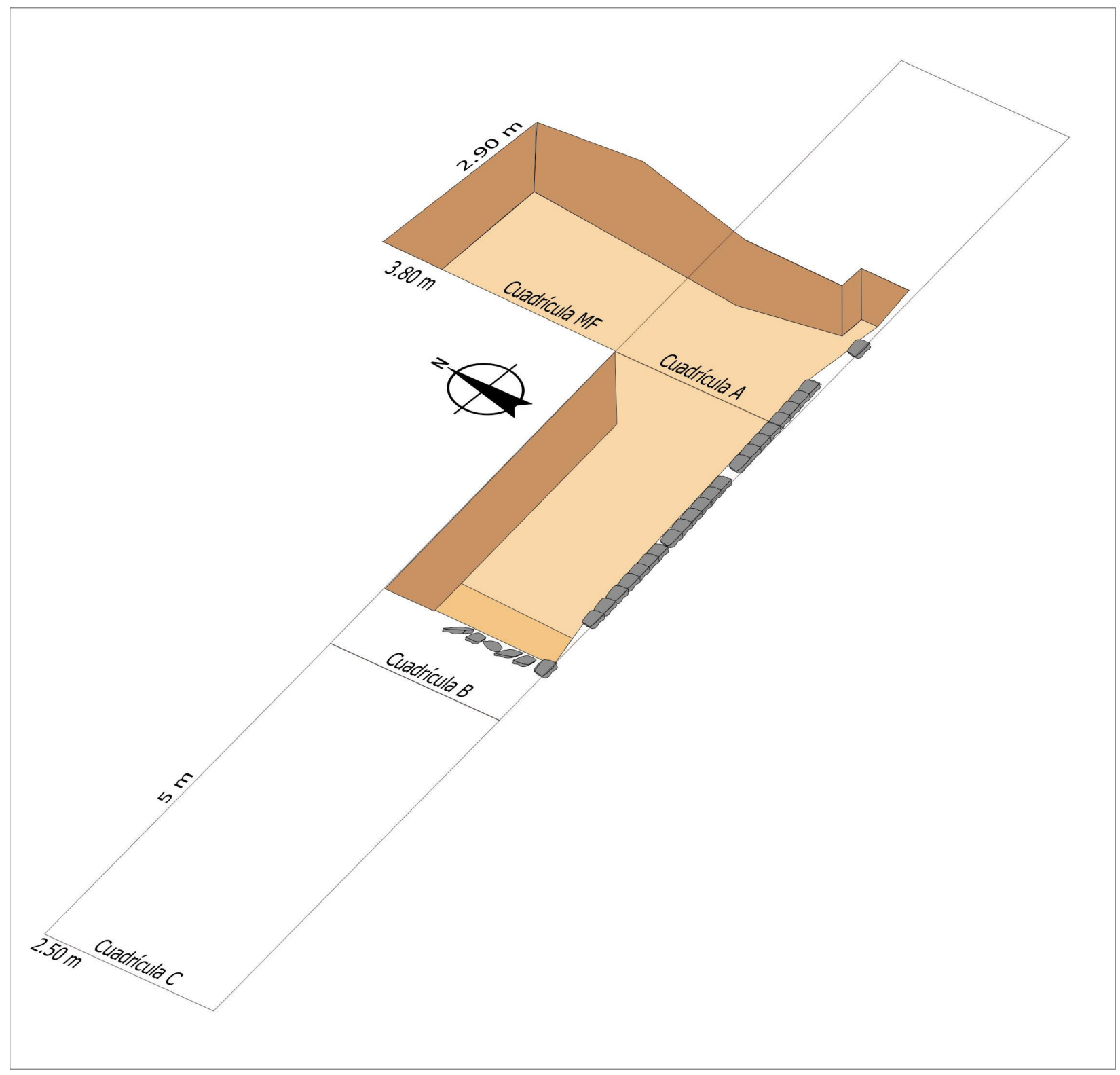

Figura V.II-1 


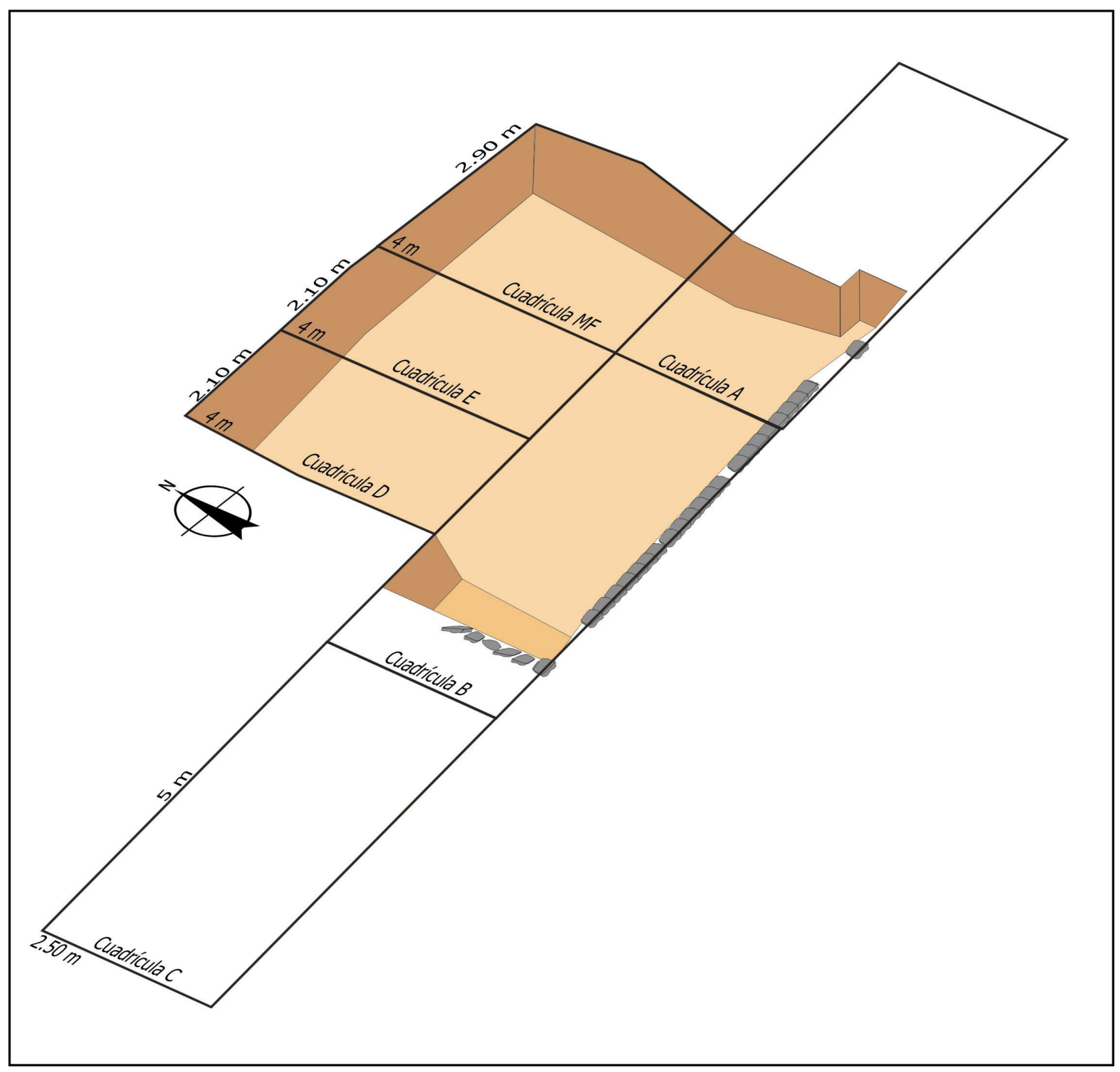

Figura II-2 


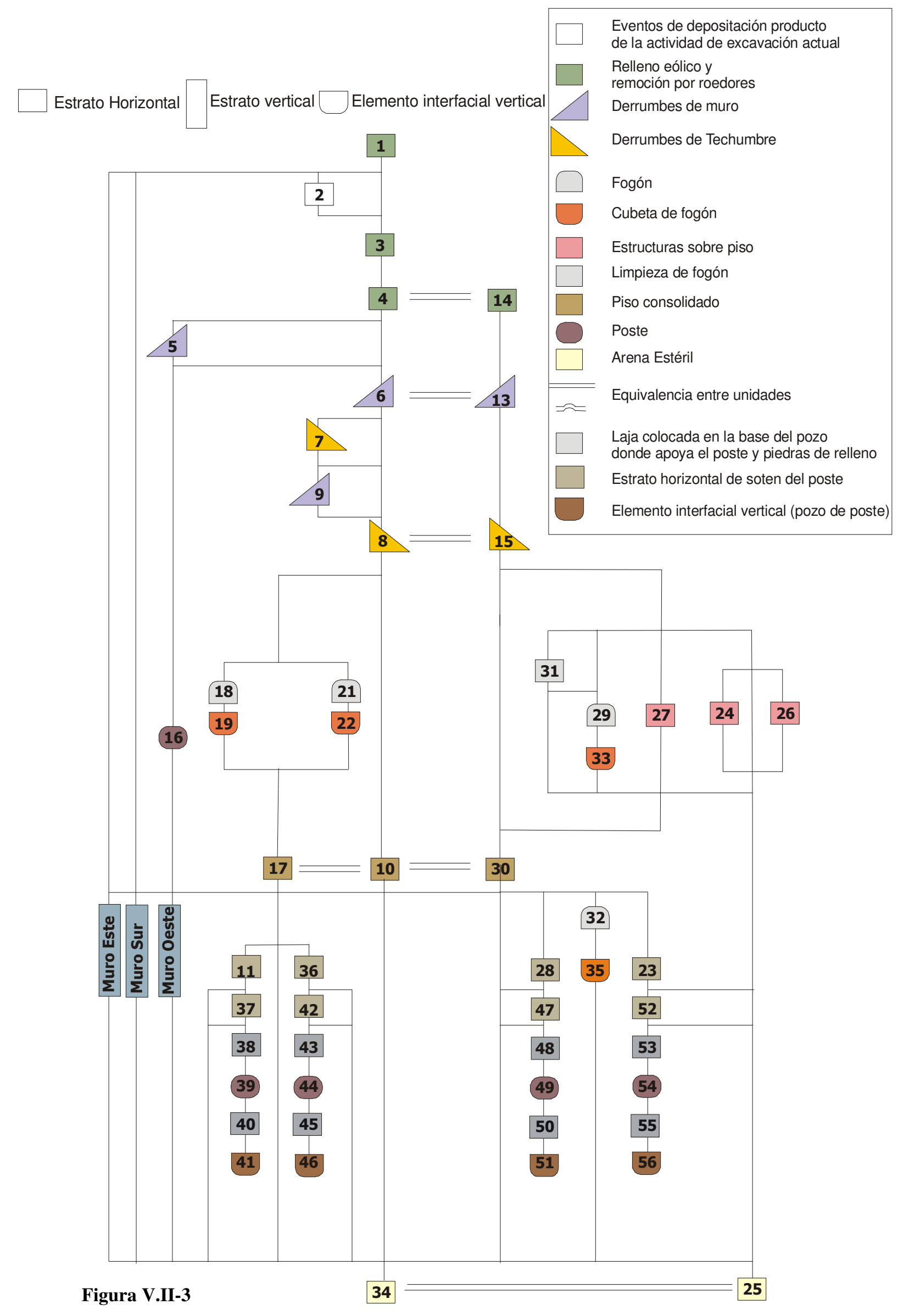




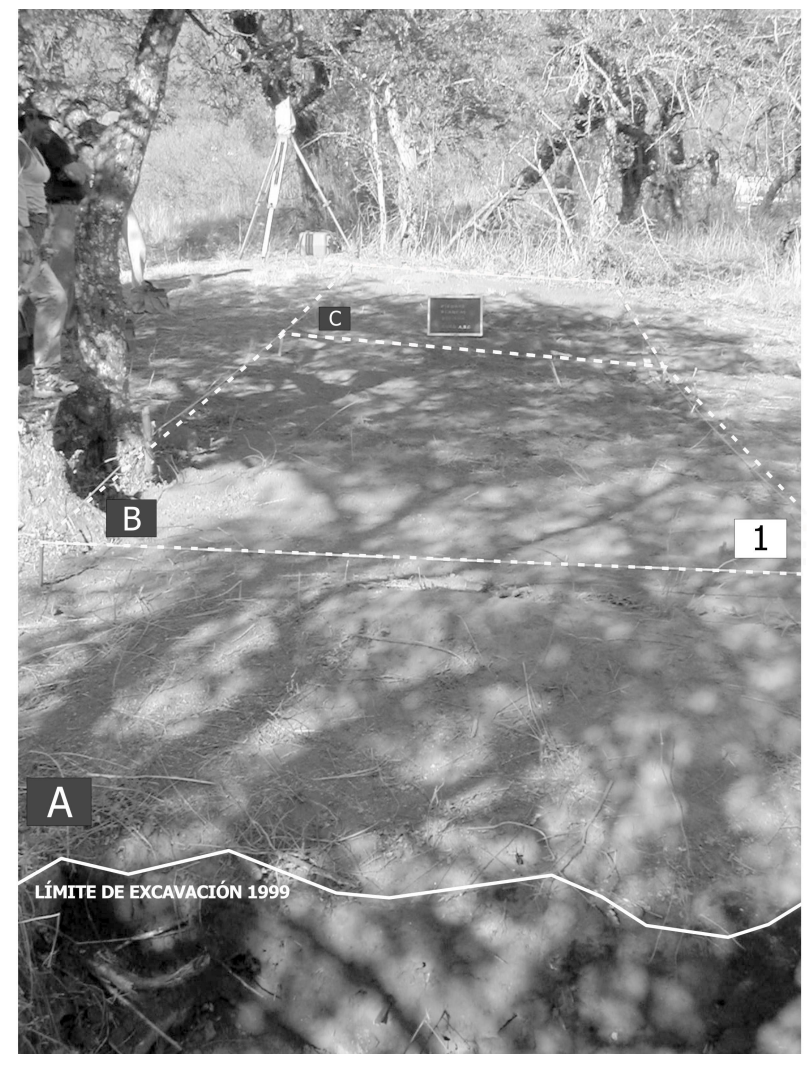

Figura V.II-4

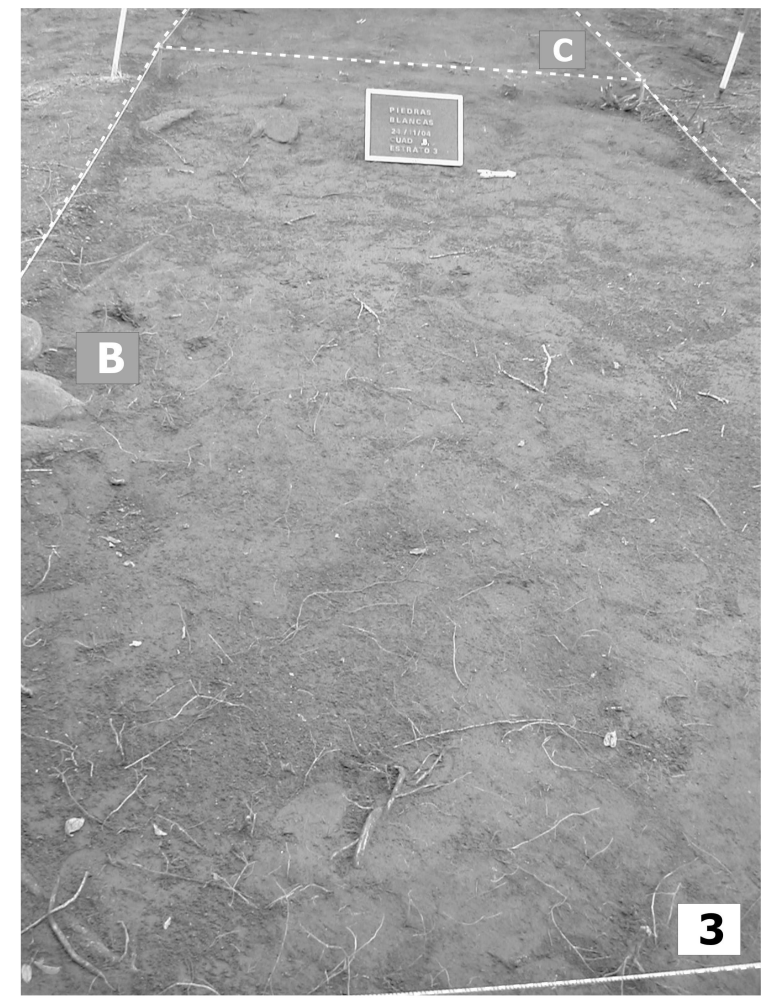

Figura V.II-5 


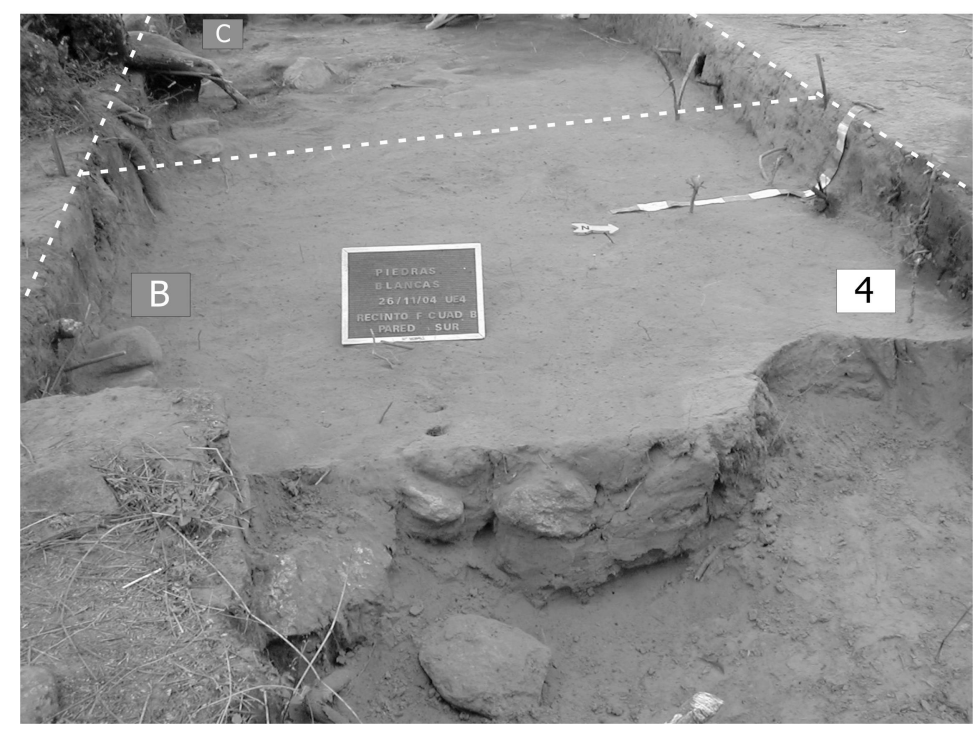

Figura II-6

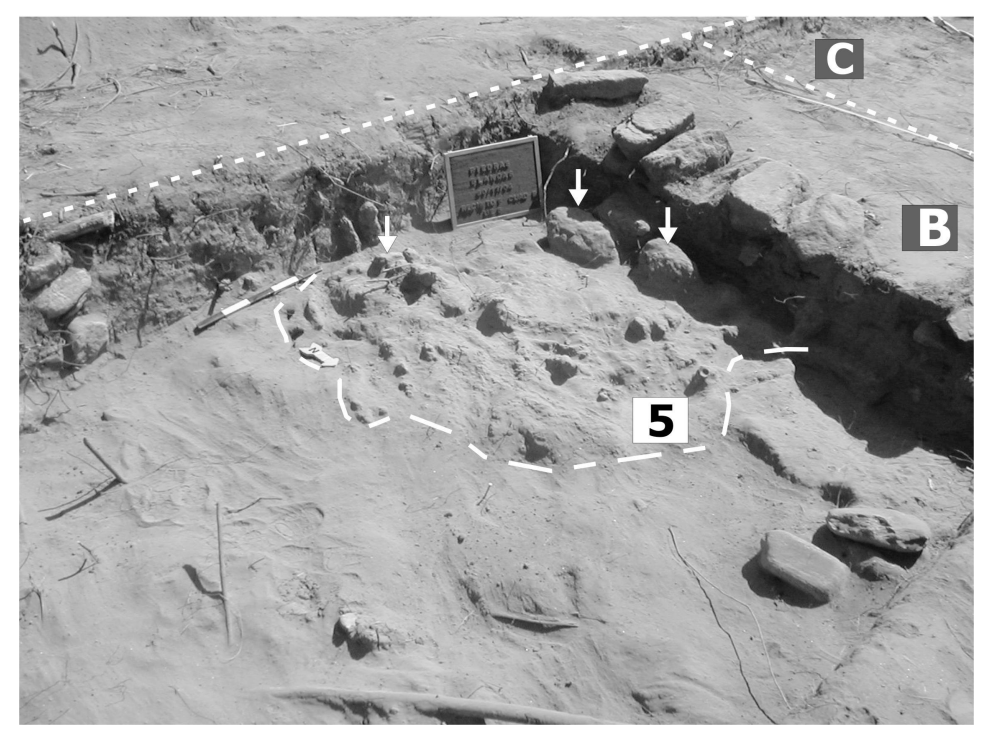

Figura II-7

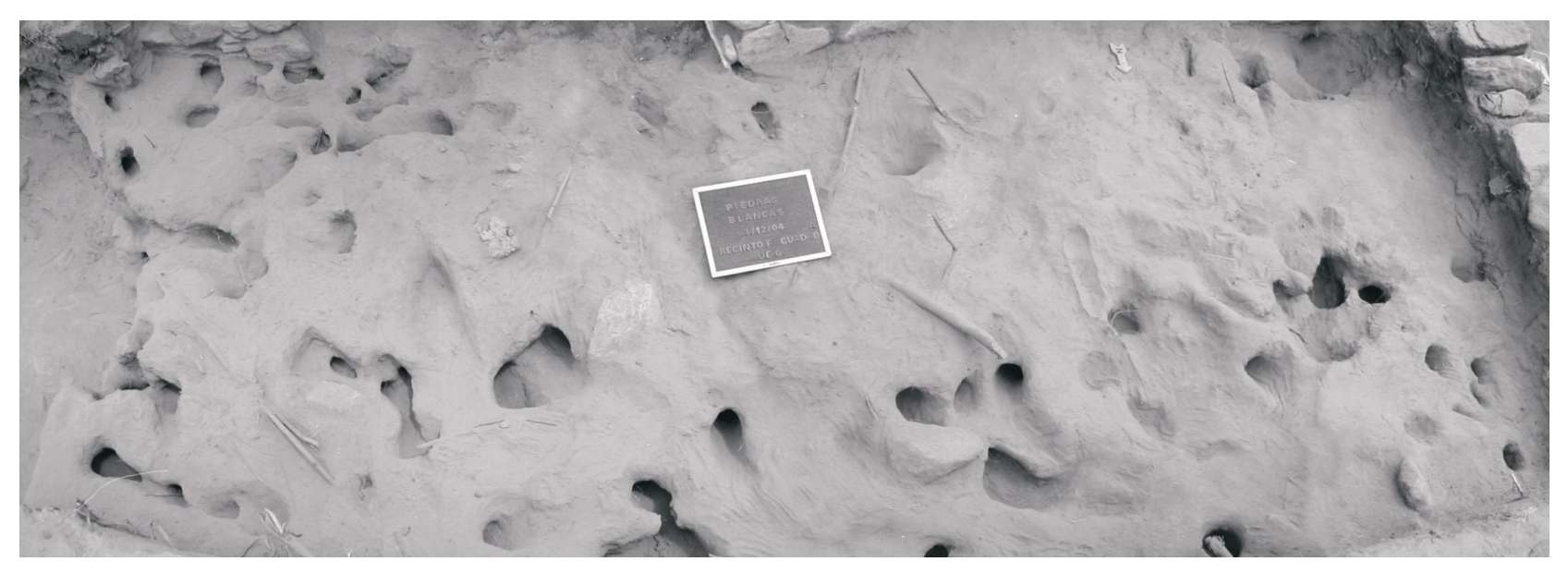

Figura II-8 


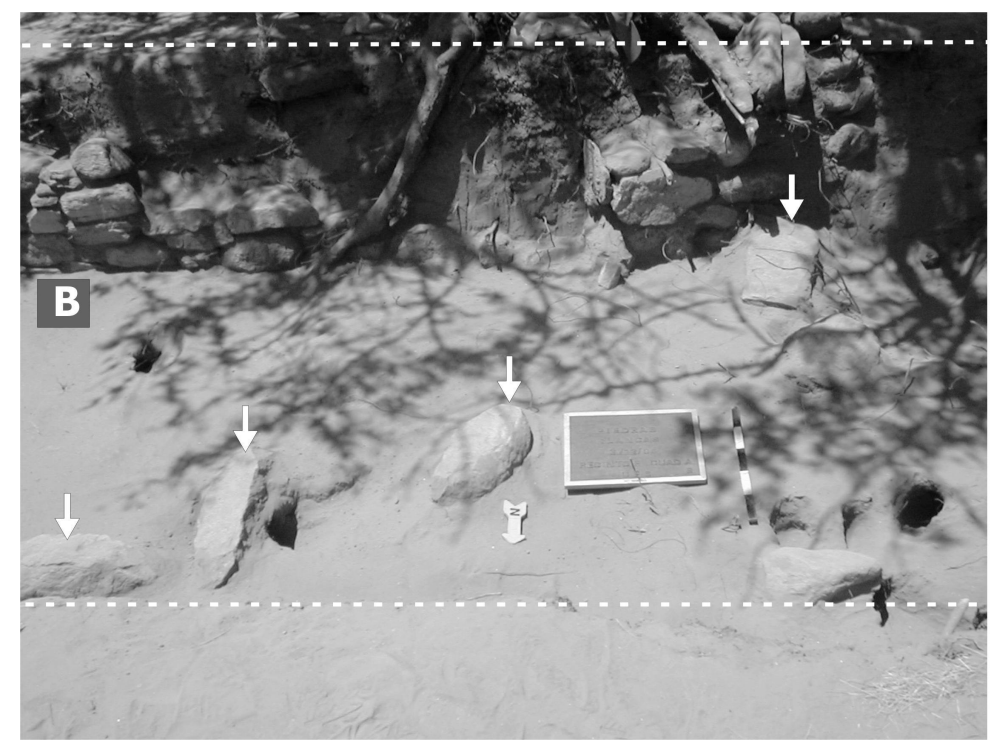

Figura V.II-9

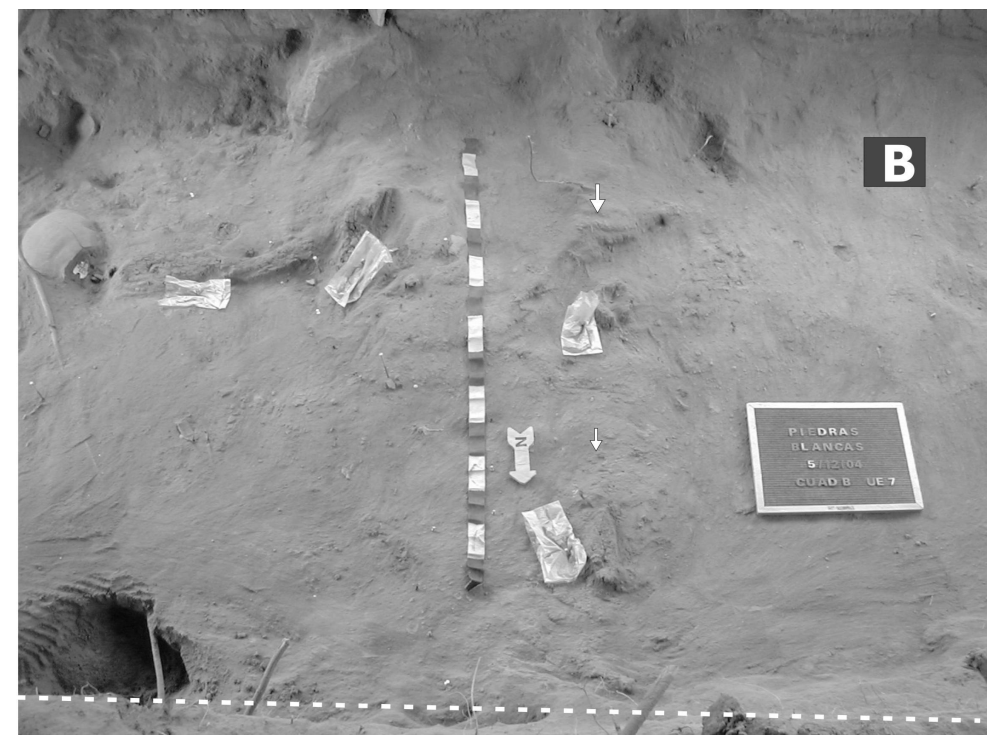

Figura V.II-10

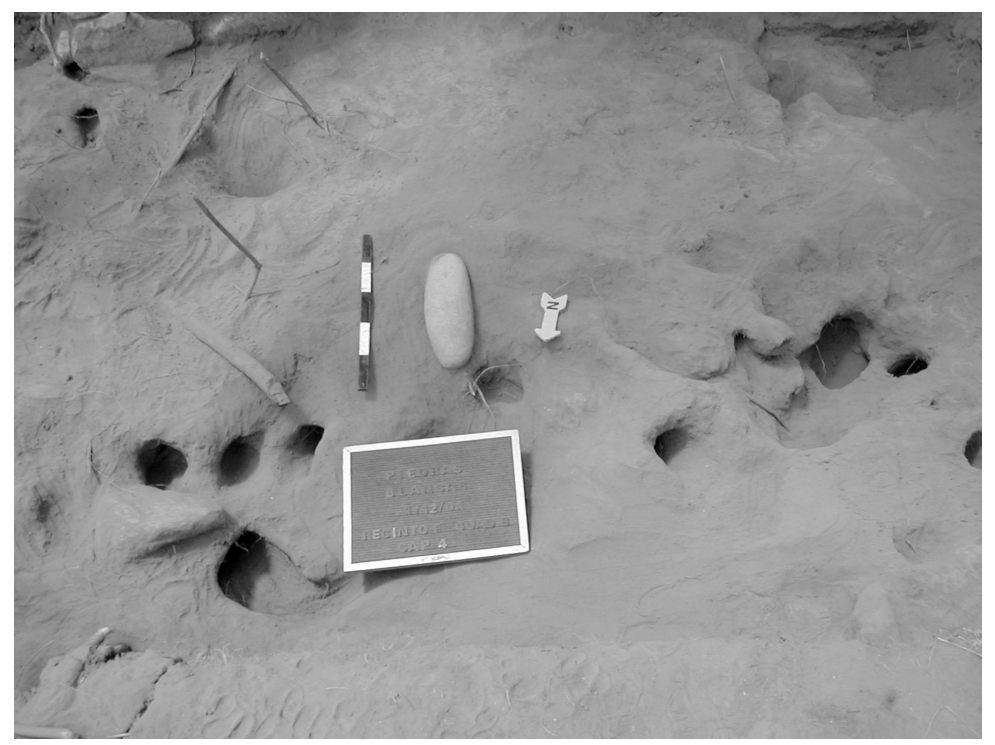

Figura V.II-11 


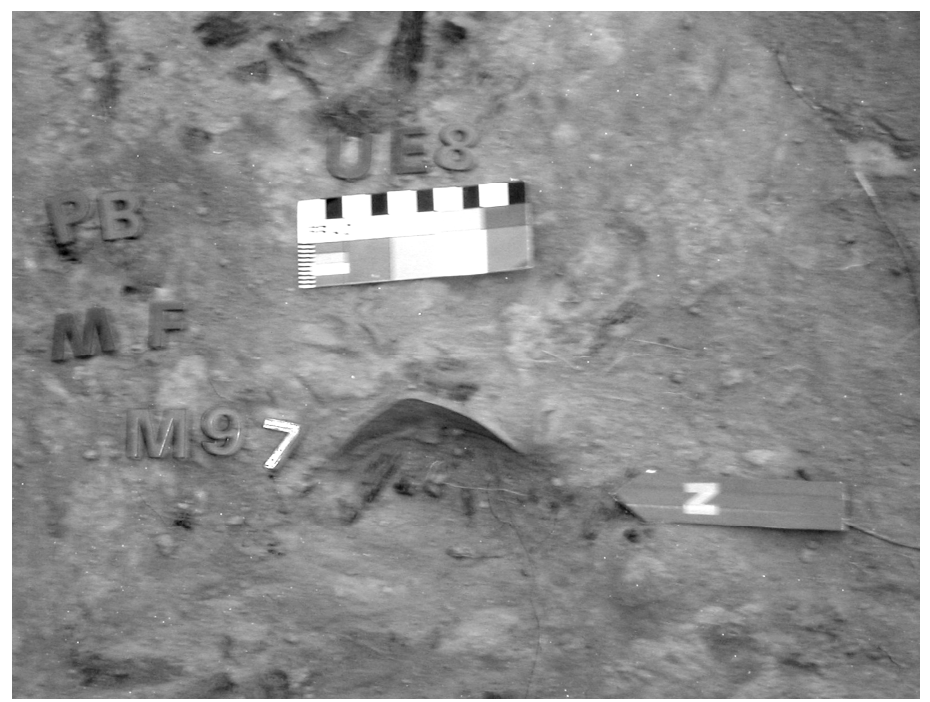

Figura V.II-12

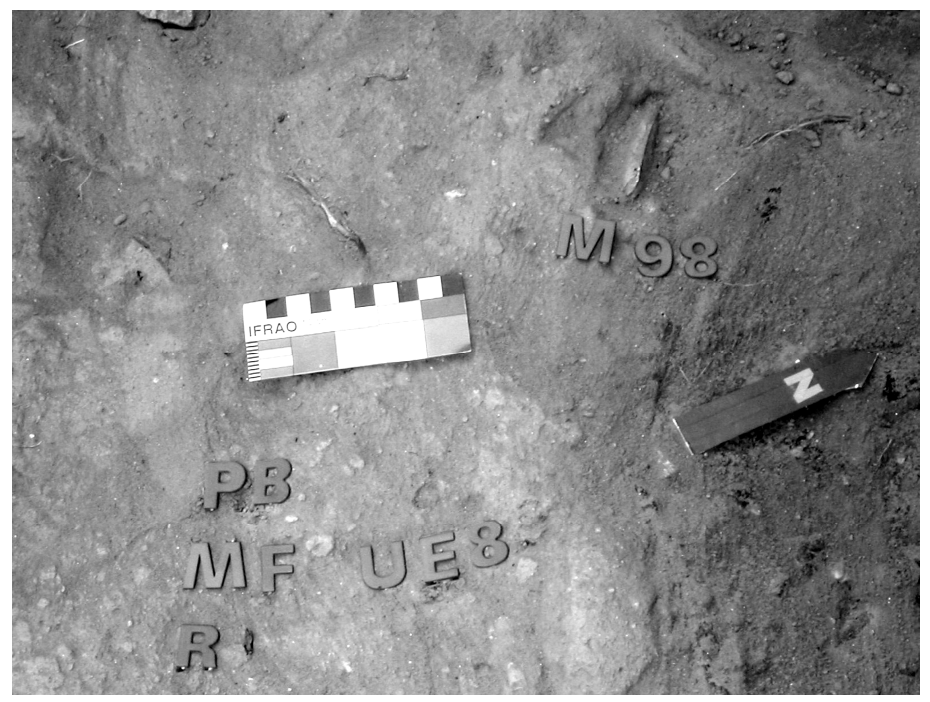

Figura V.II-13

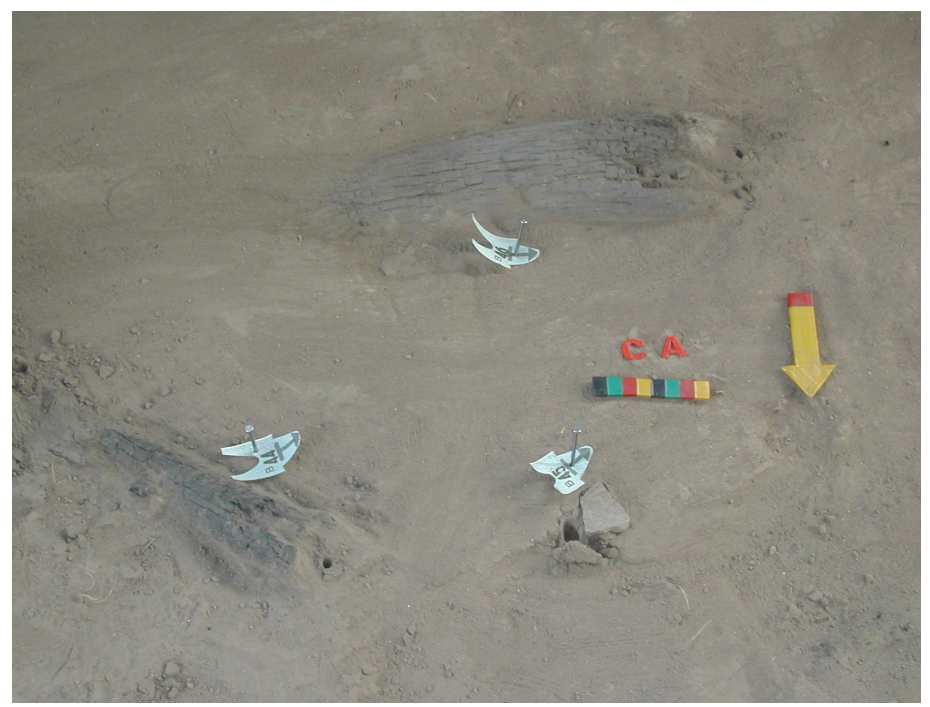

Figura V.II-14 


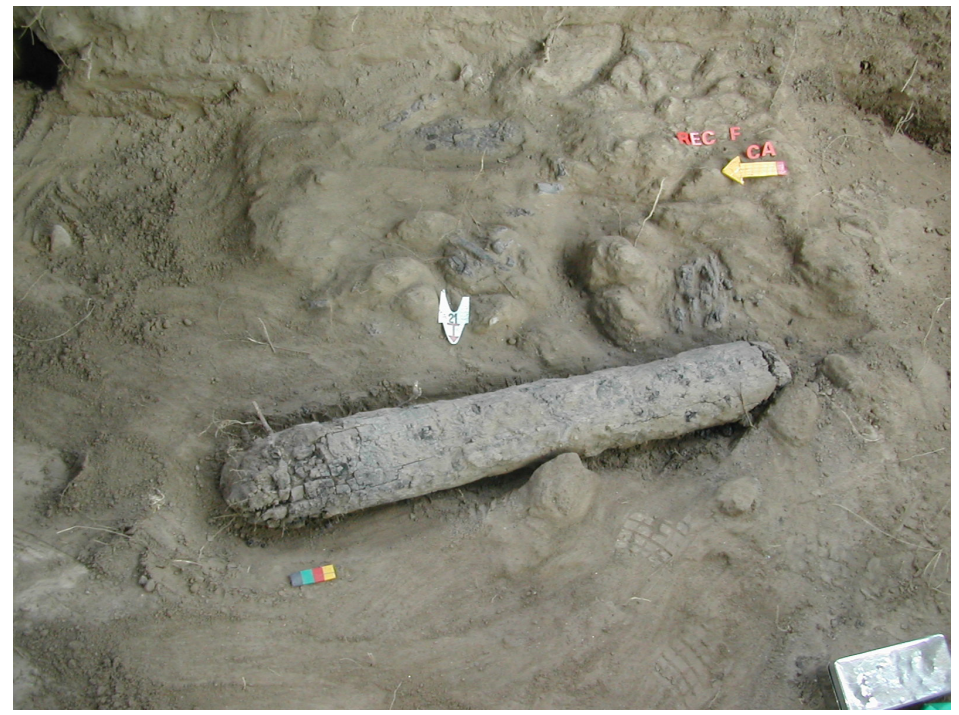

Figura V.II-15

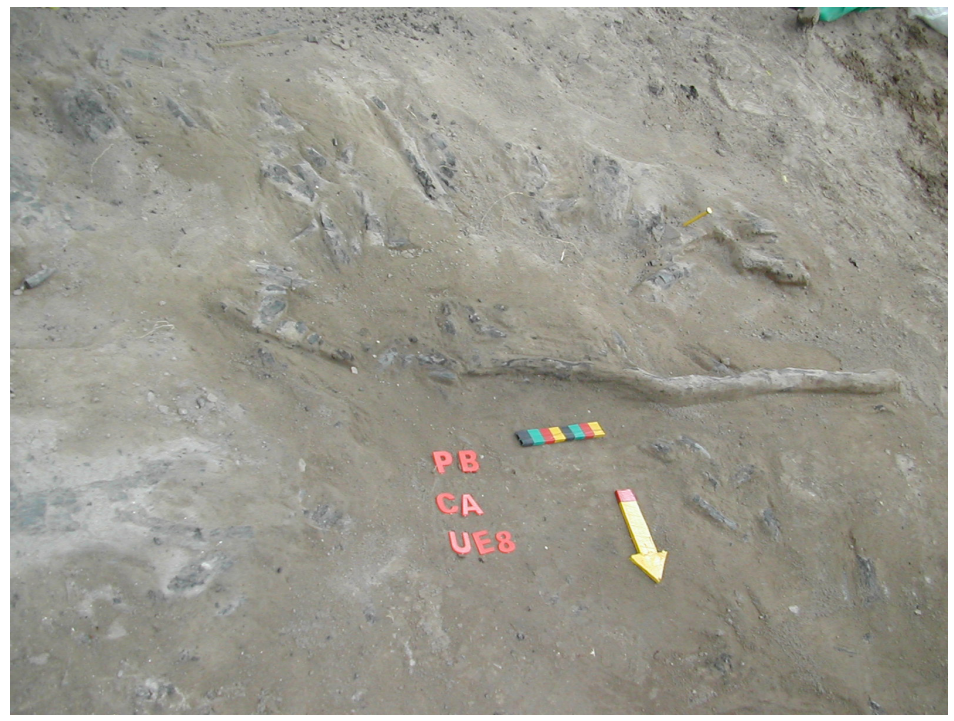

Figura V.II-16

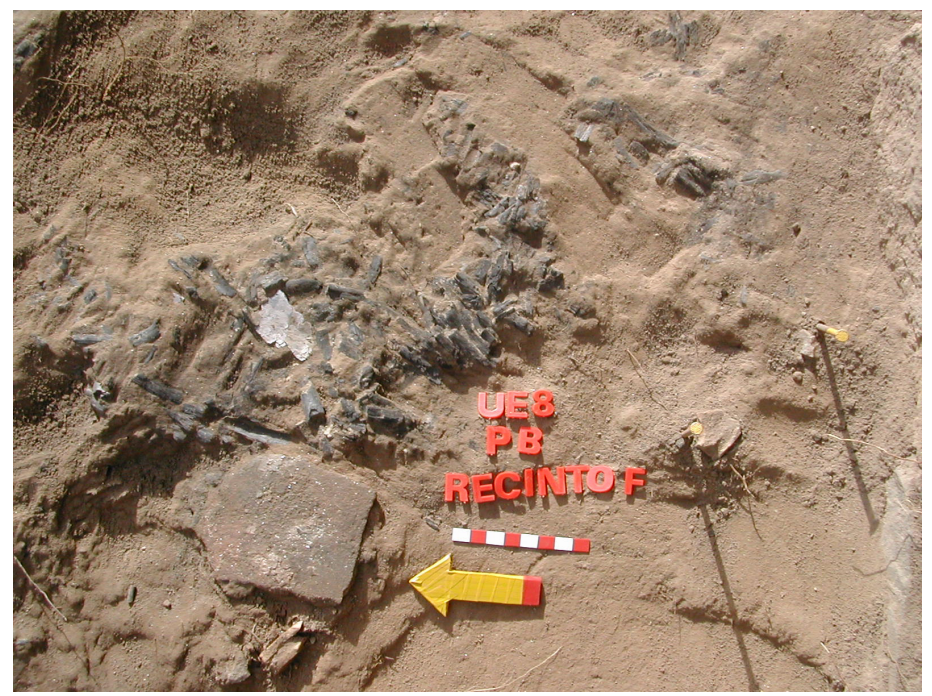

Figura V.II-17 


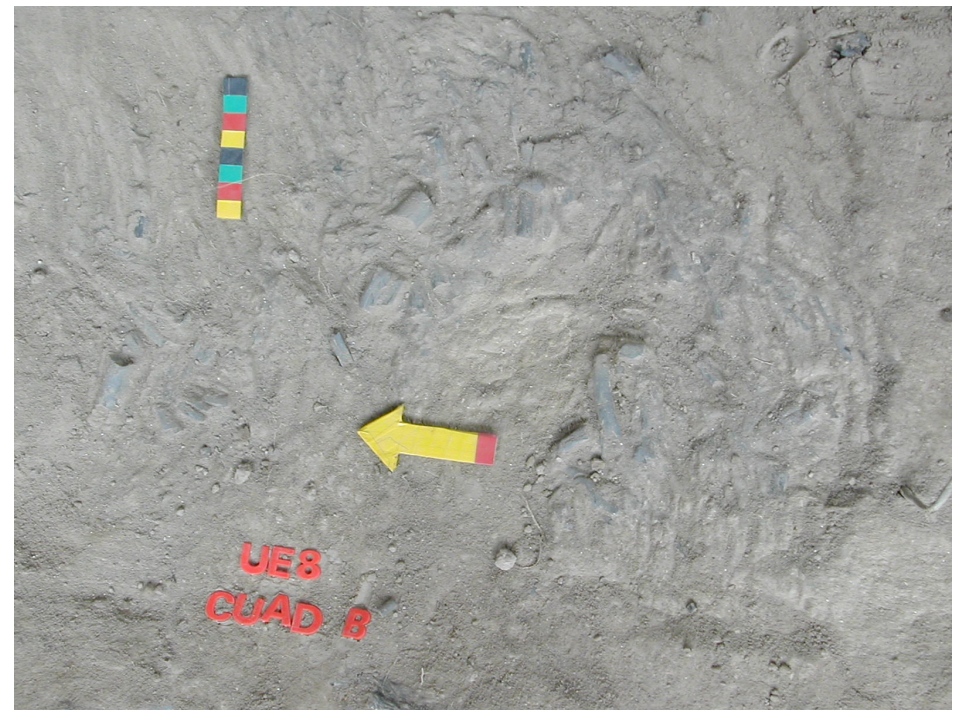

Figura V.II-18

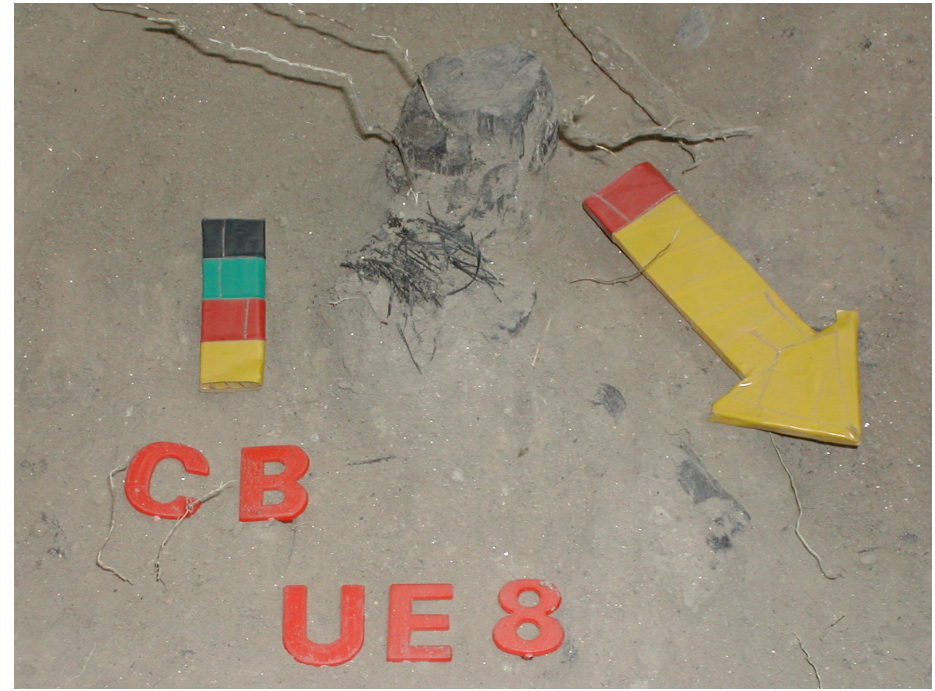

Figura V.II-19

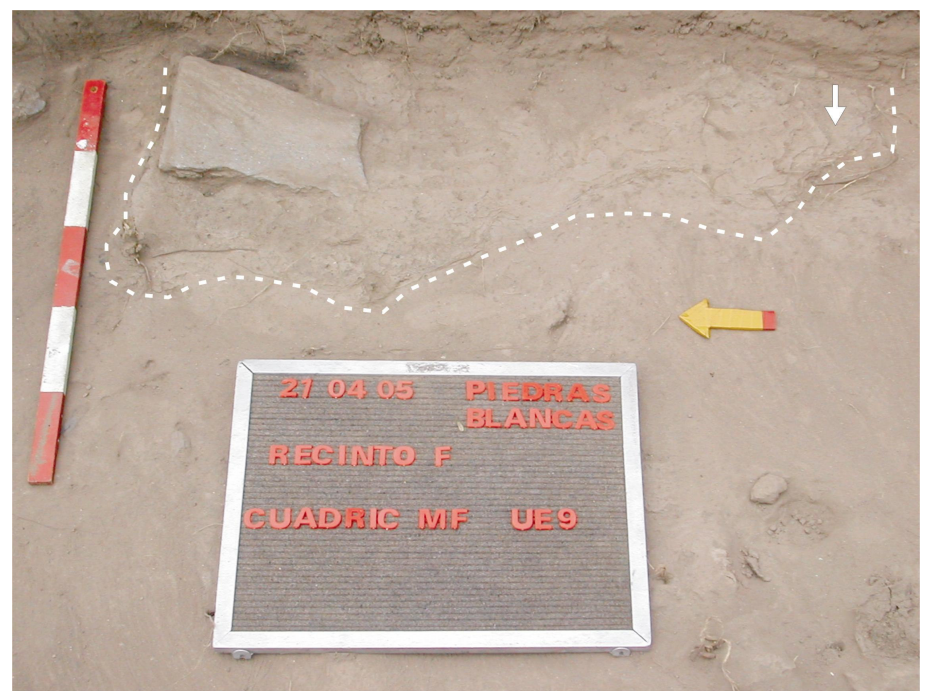

Figura V.II-20 


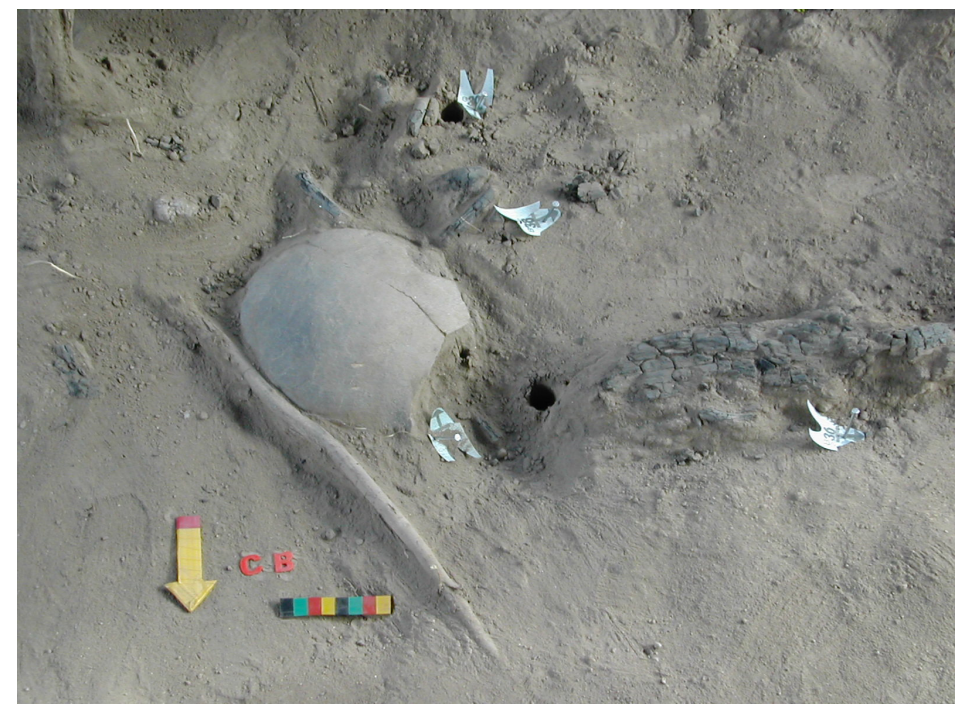

Figura V.II-21

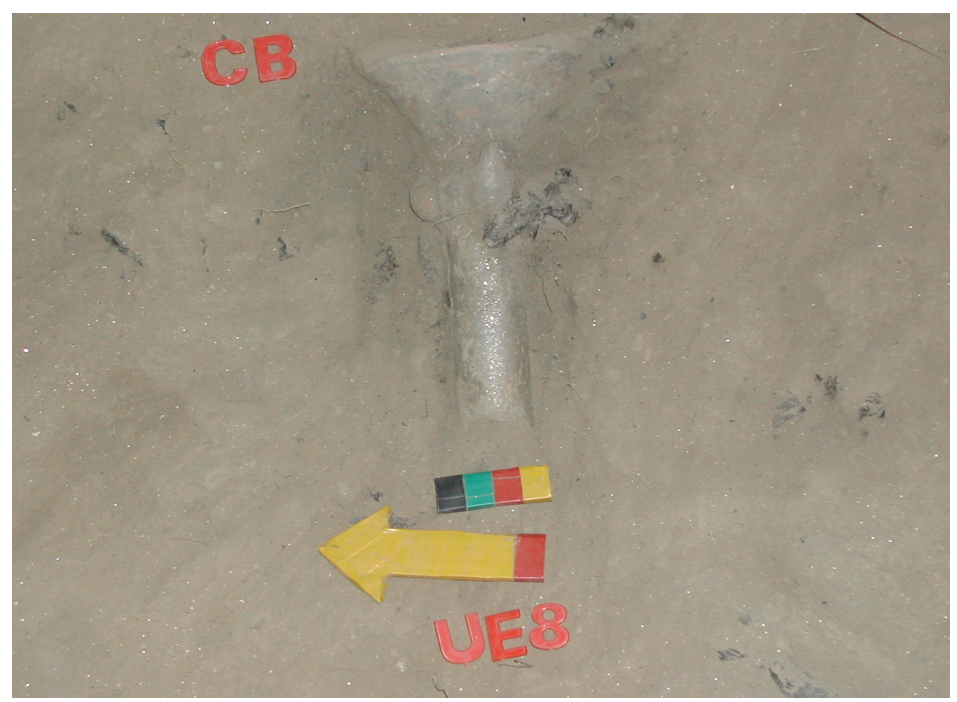

Figura V.II-22

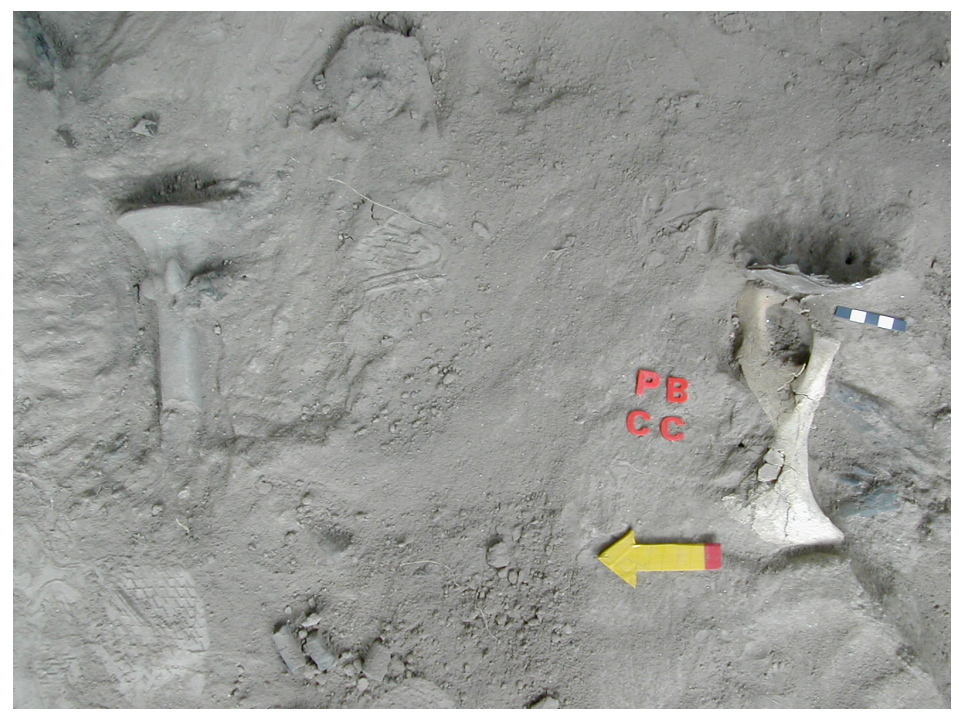

Figura V.II-23 


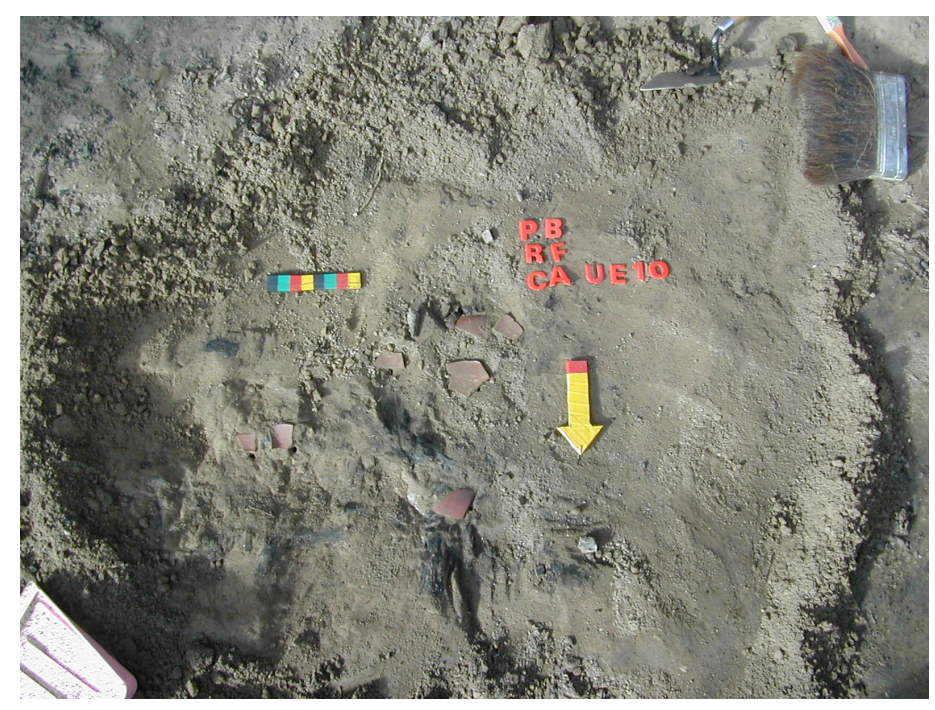

Figura V.II-24

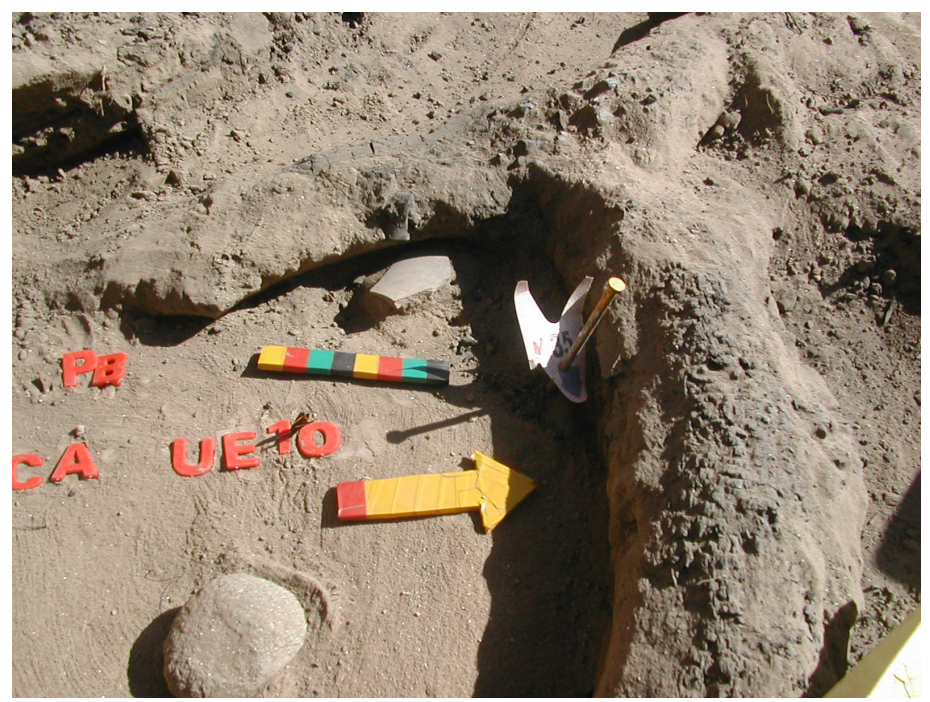

Figura V.II-25

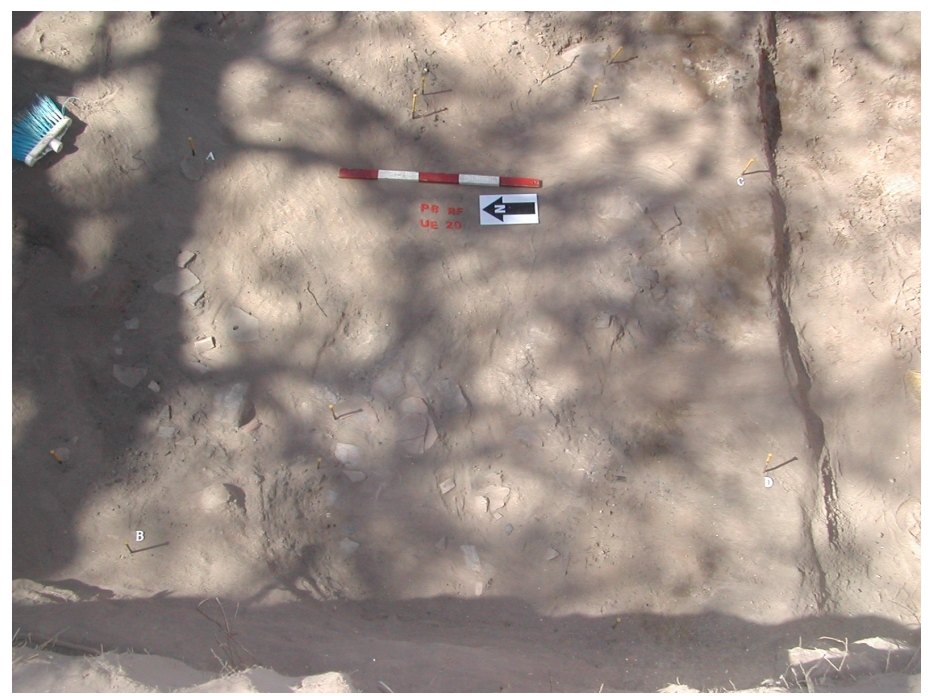

Figura V.II-26 


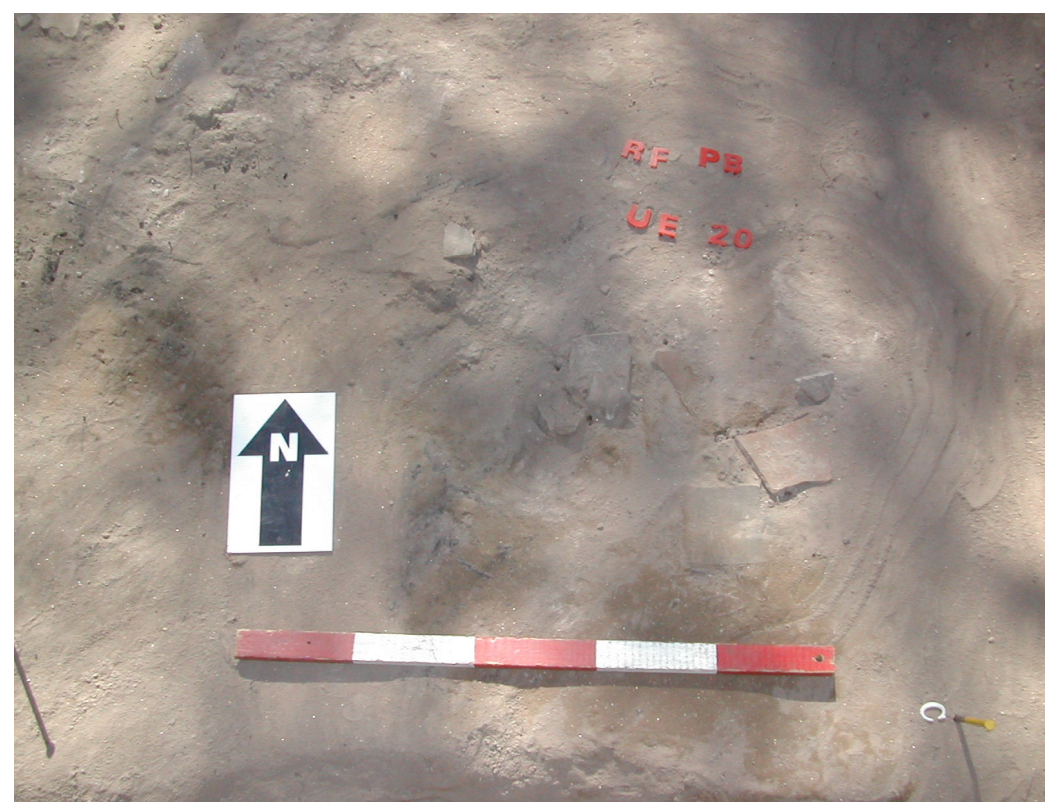

Figura V.II-27

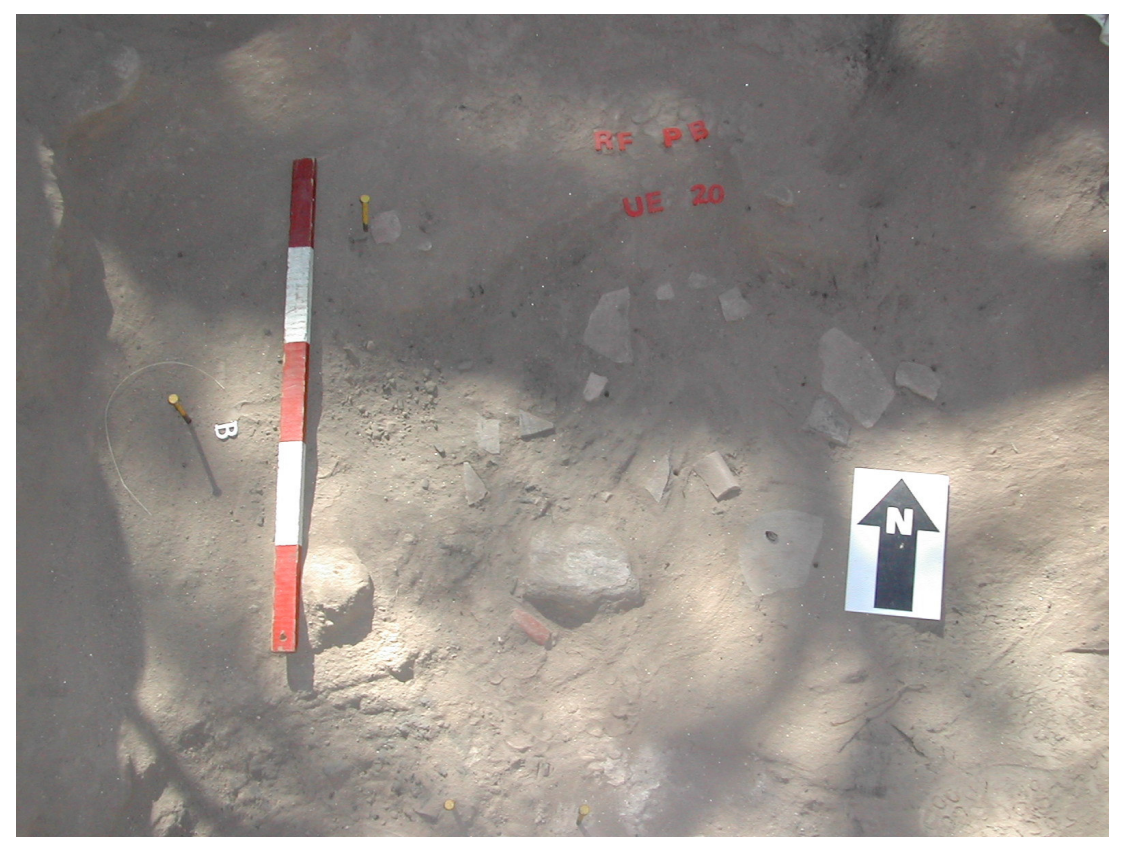

Figura V.II-28 


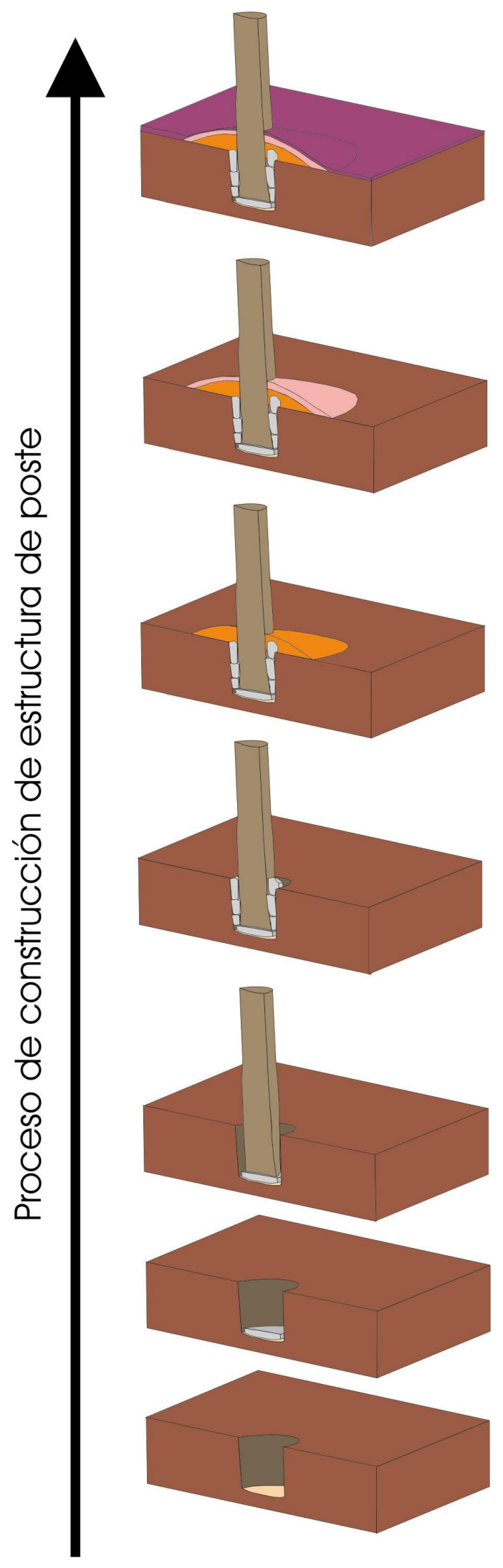

Figura V. II-29
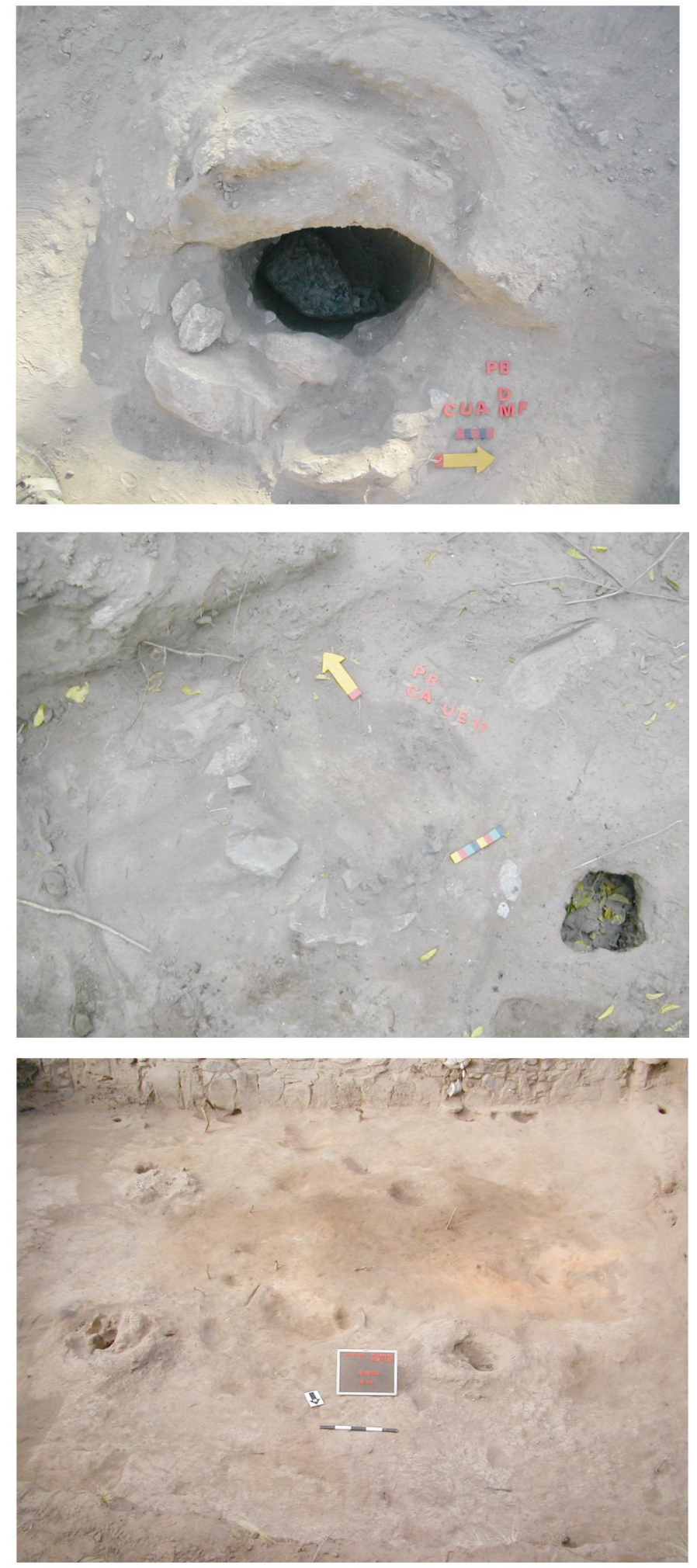


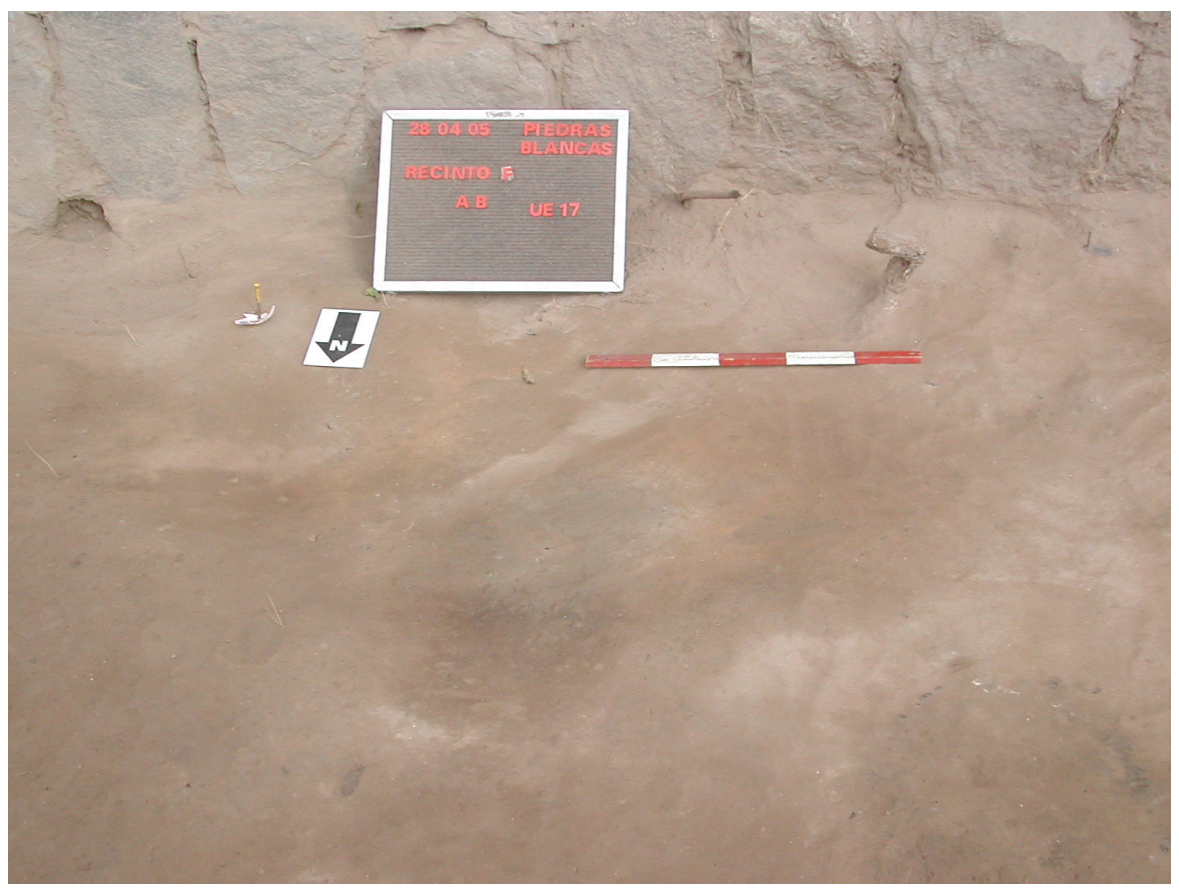

Figura V.II-

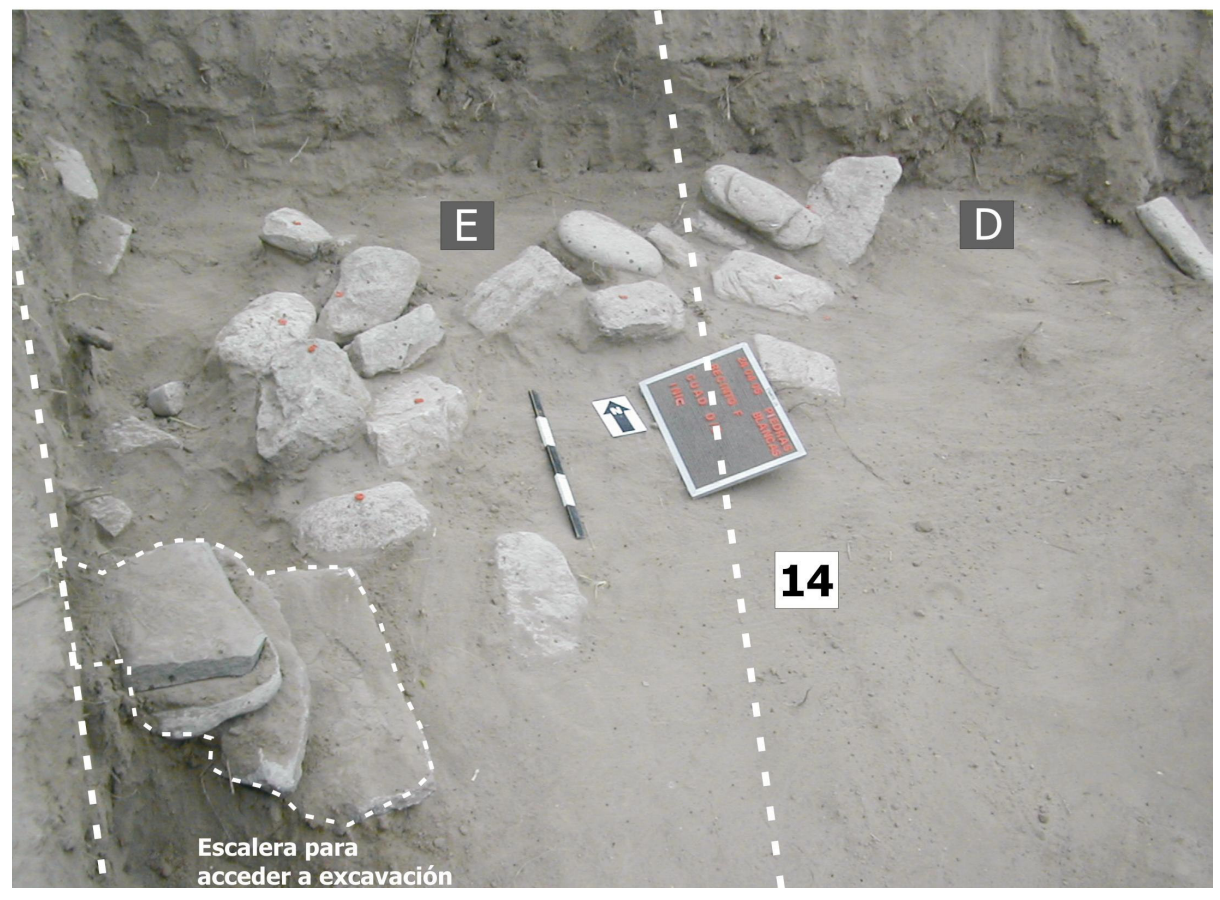

Figura V.II-31 


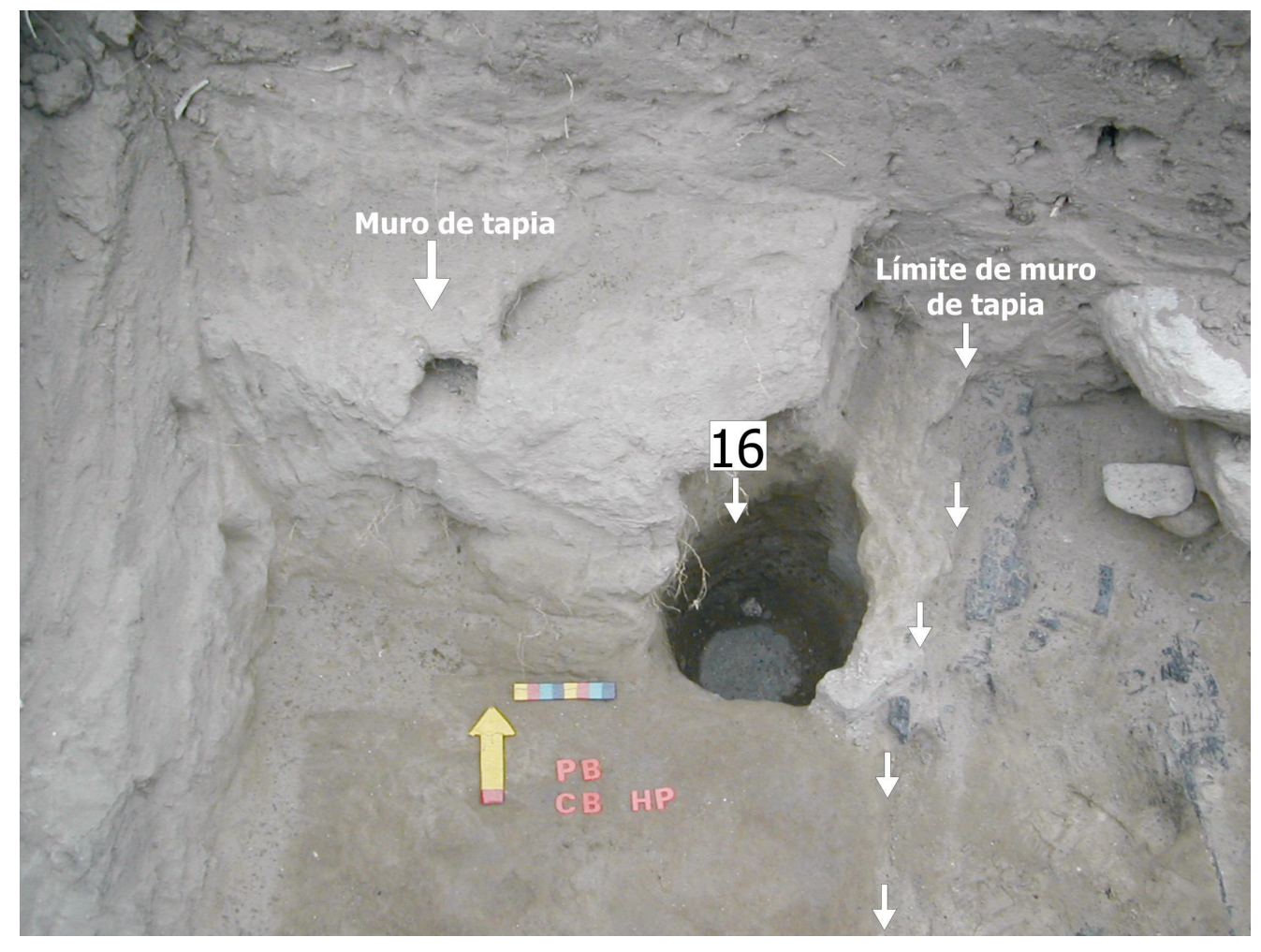

Figura V.II-32

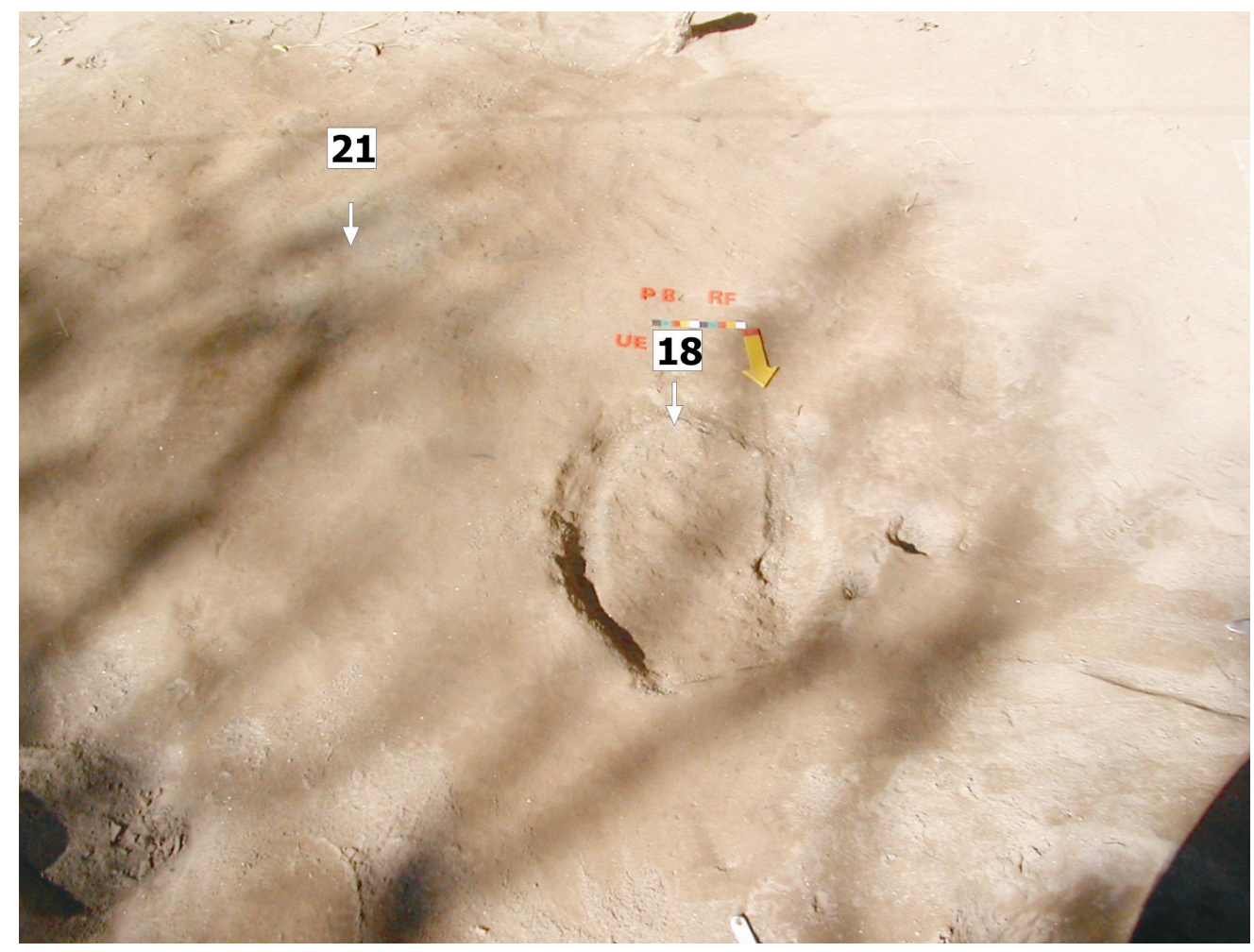

Figura V.II-33 


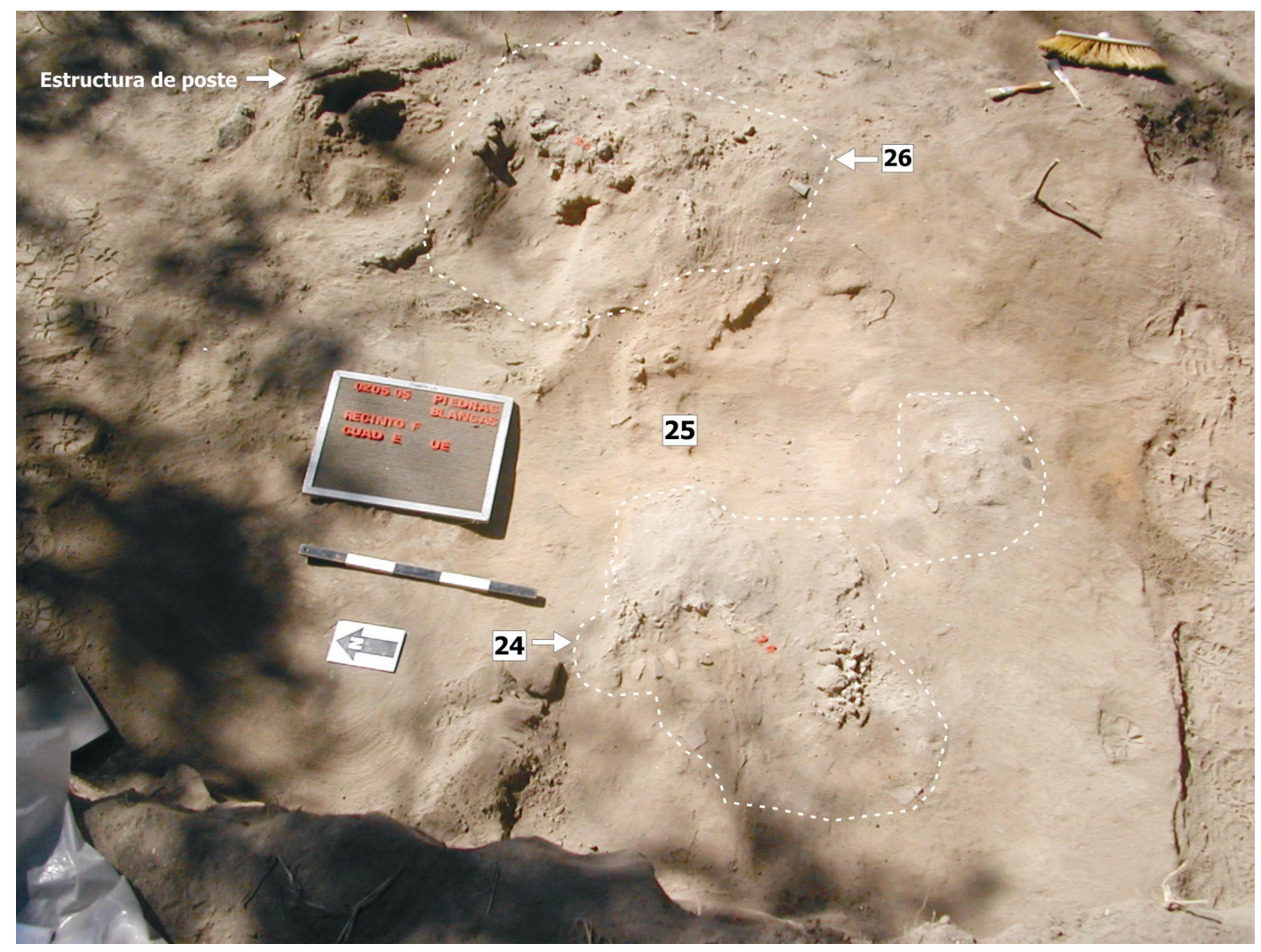

Figura V.II-34

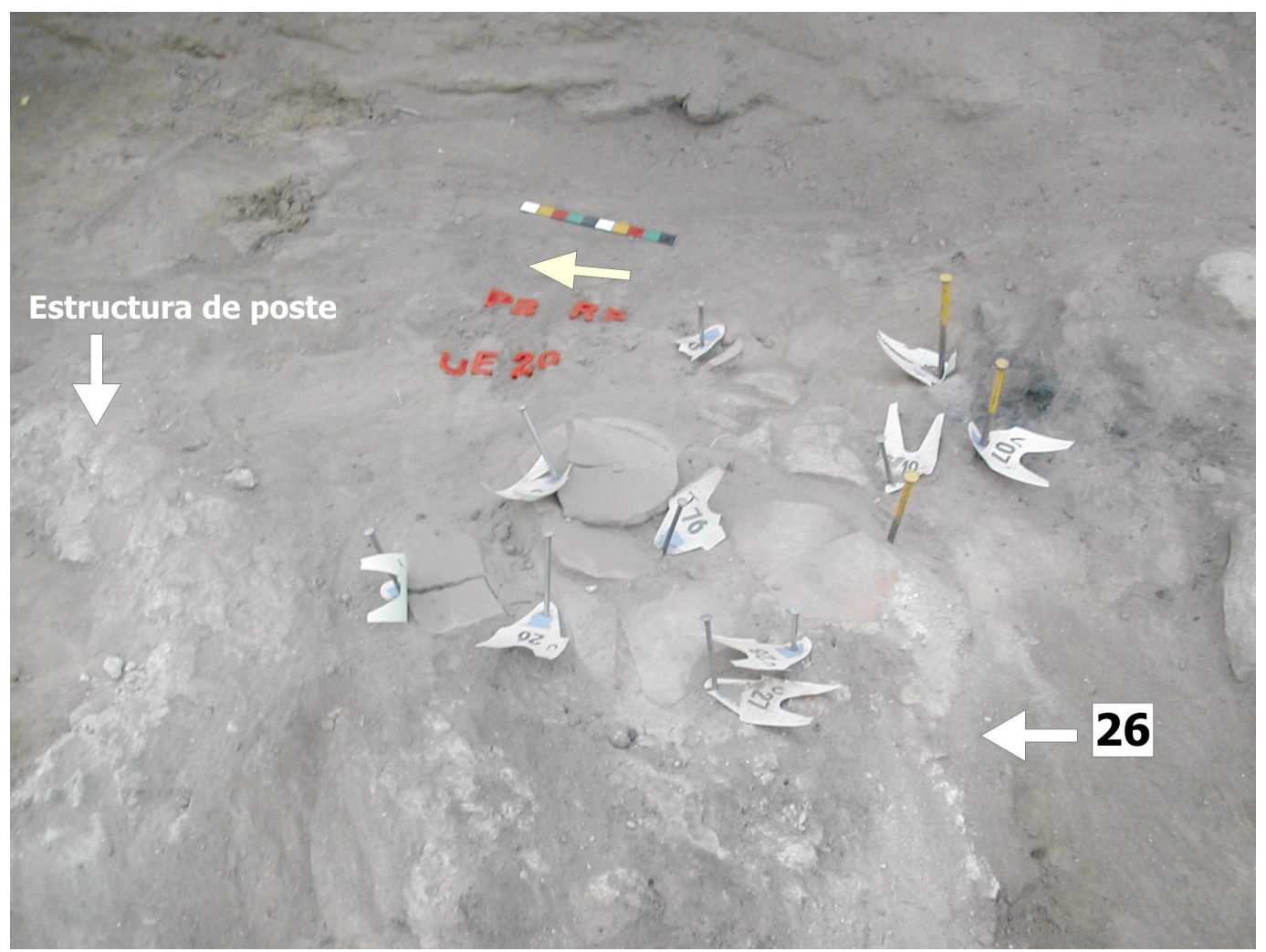

Figura V.II-35 


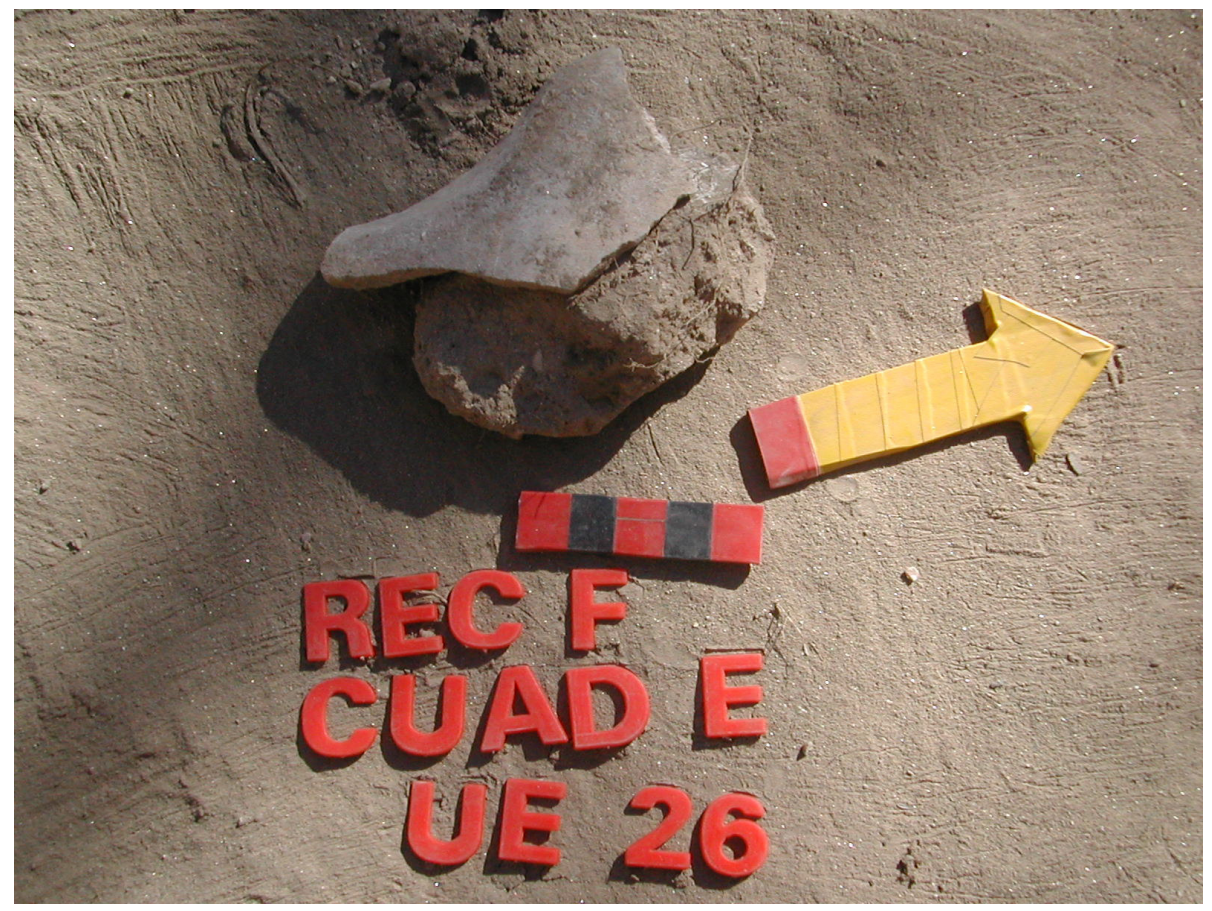

Figura V.II-36

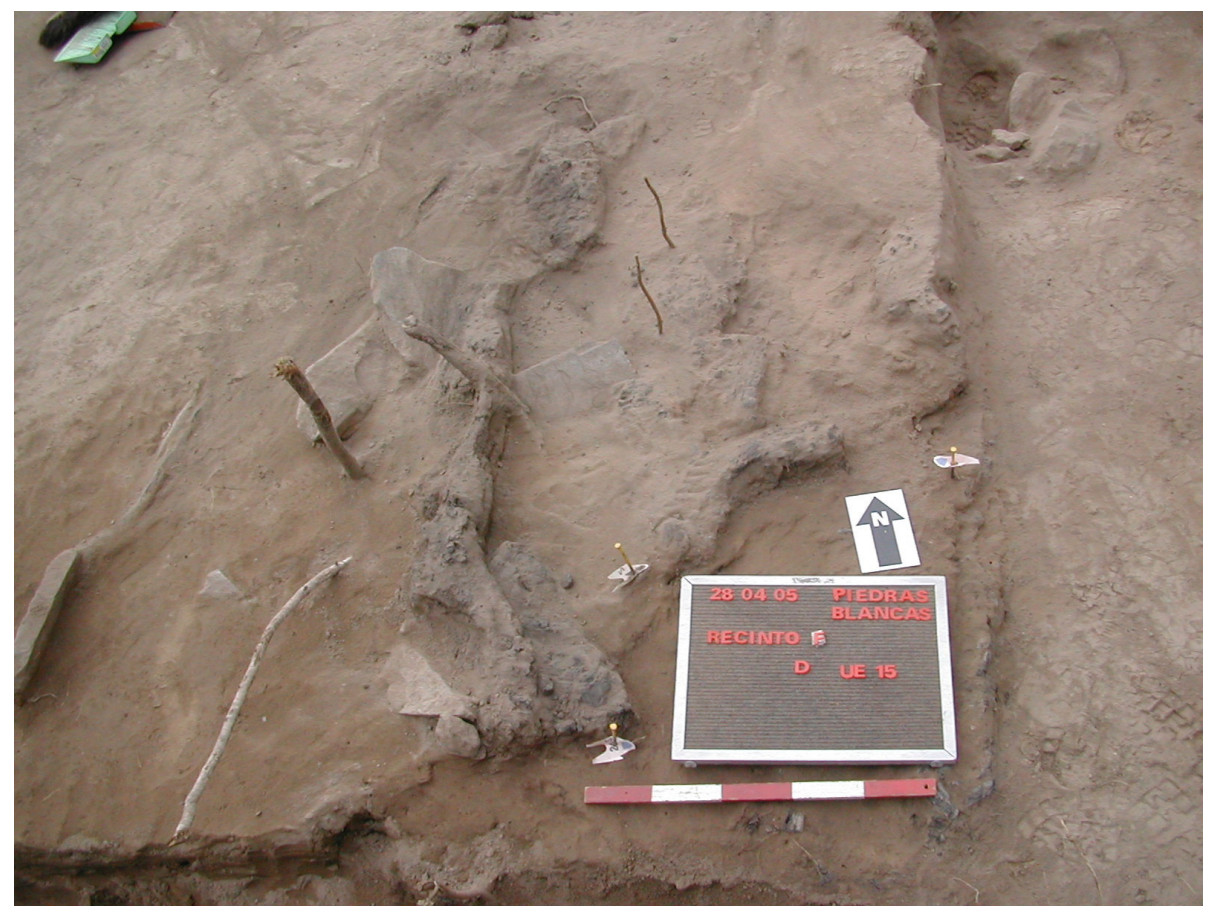

Figura V.II-37 


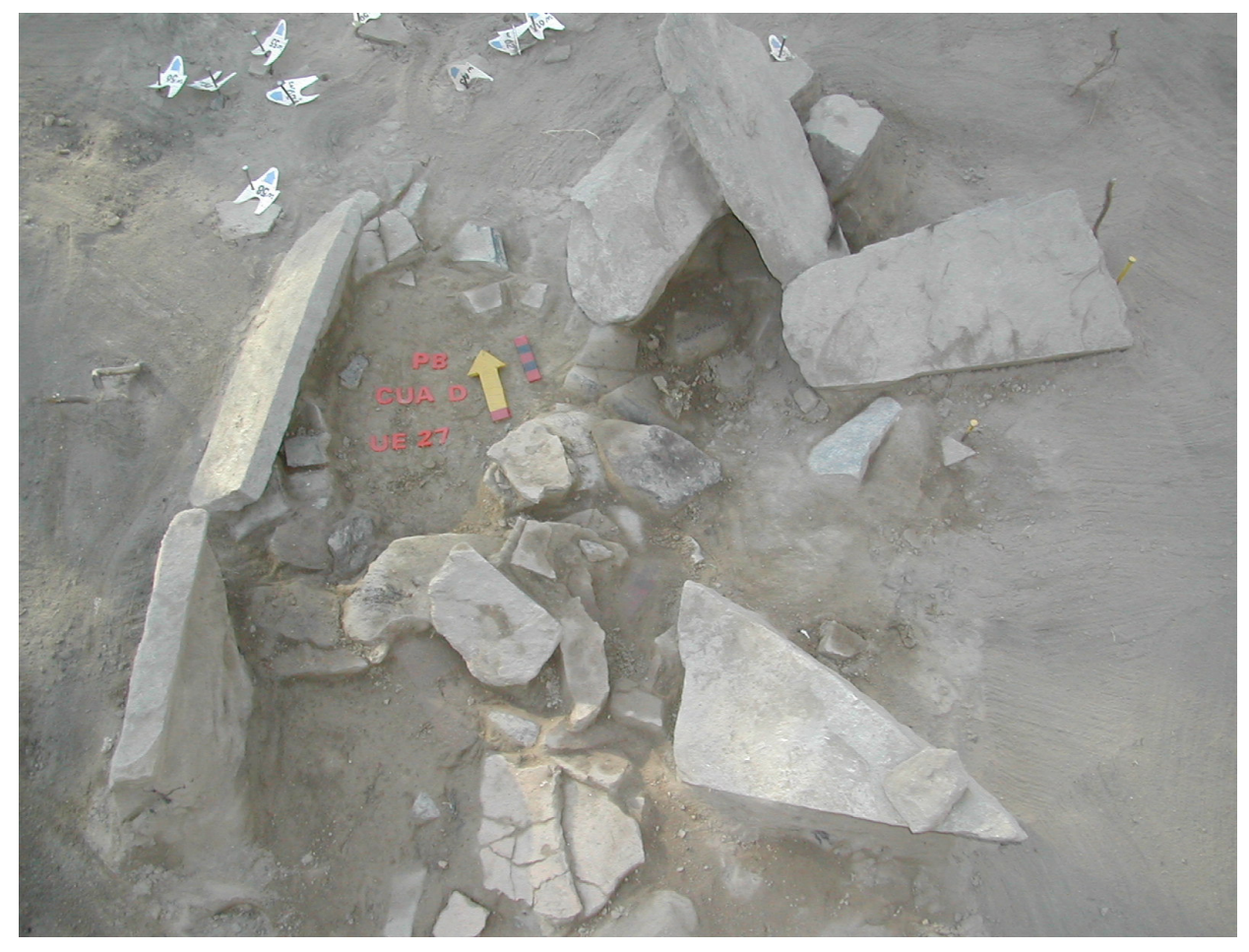

Figura V.II-38

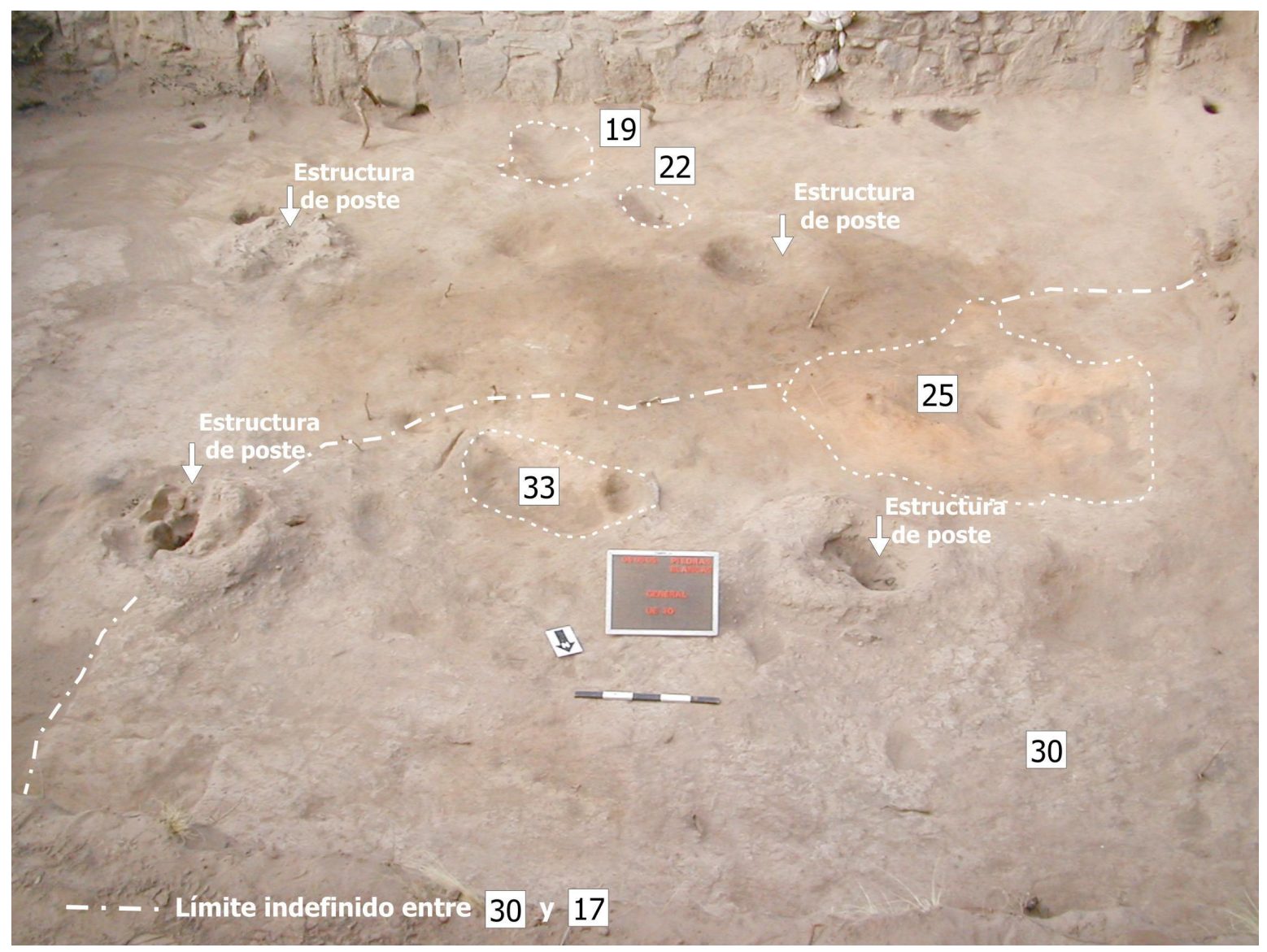

Figura V.II-39 


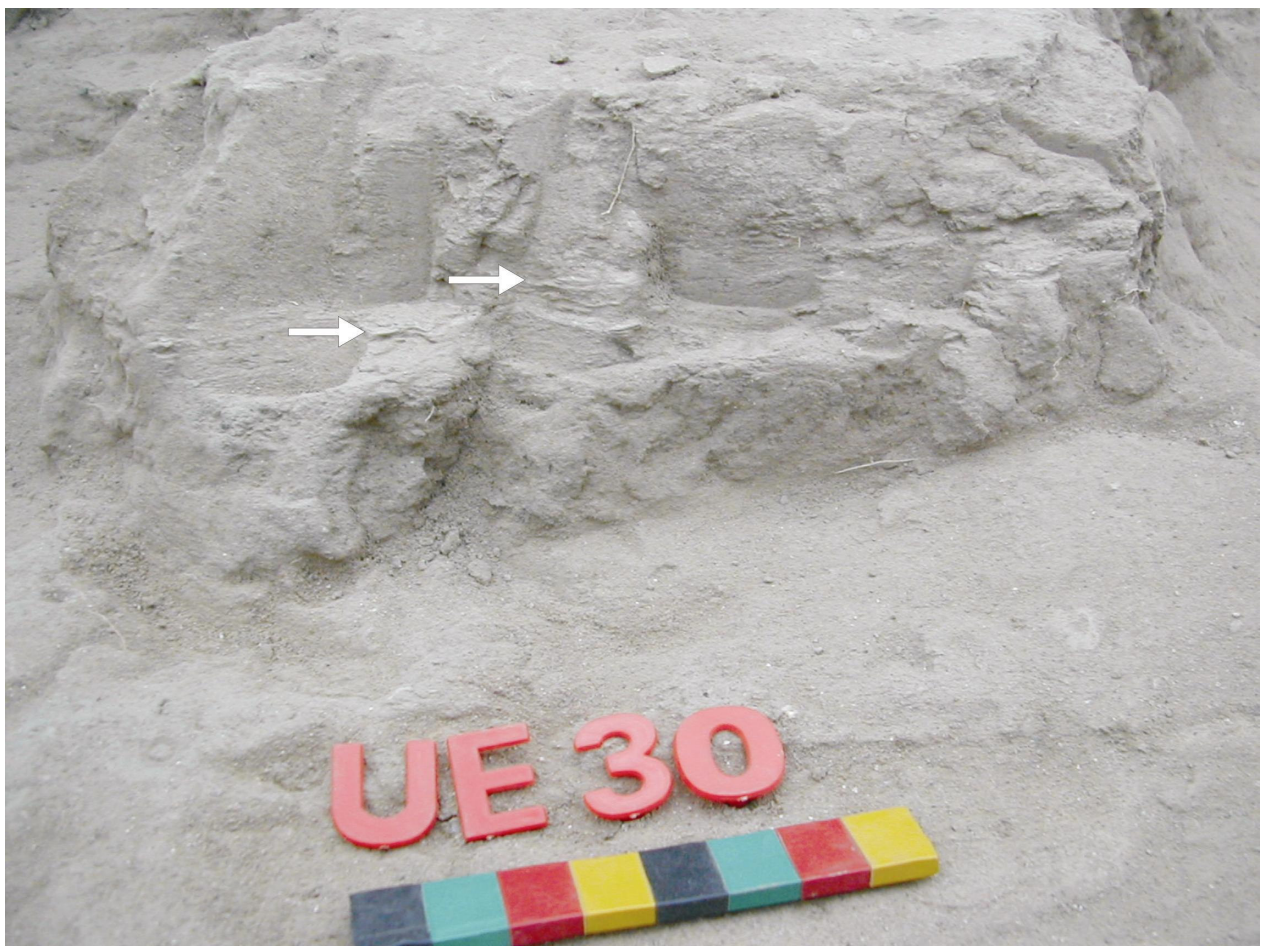

Figura V.II-40

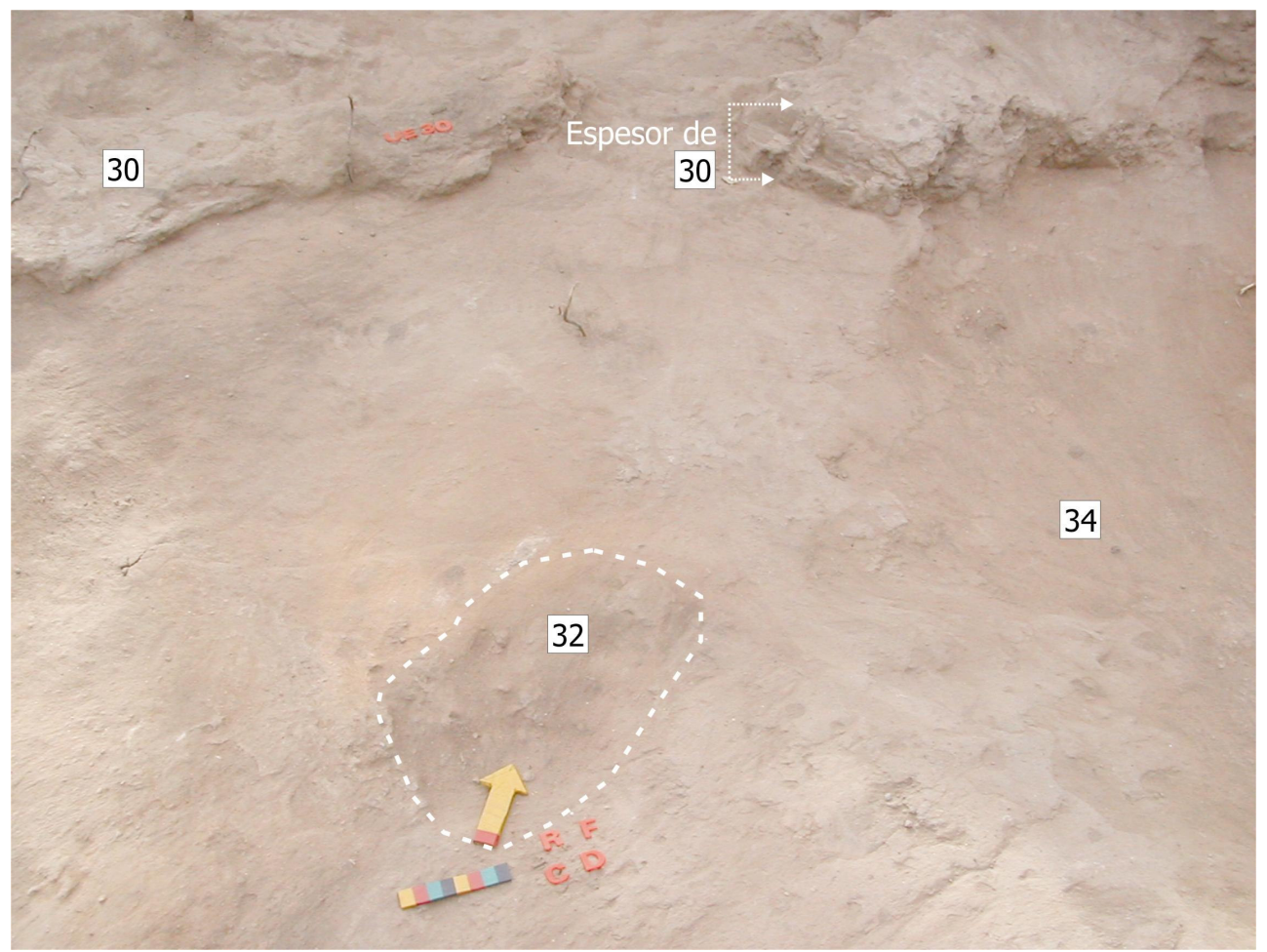

Figura V.II-41 


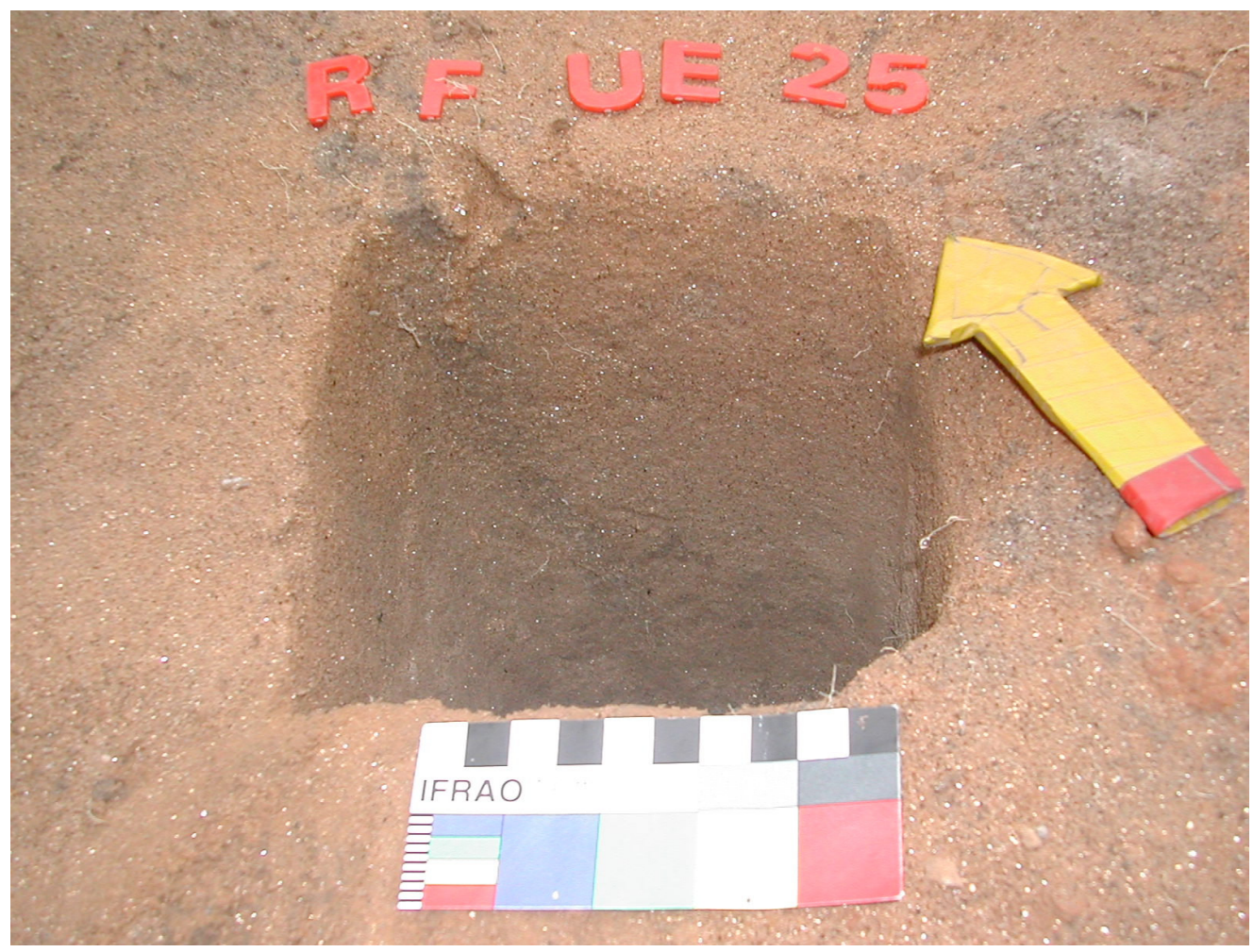

Figura V.II-42

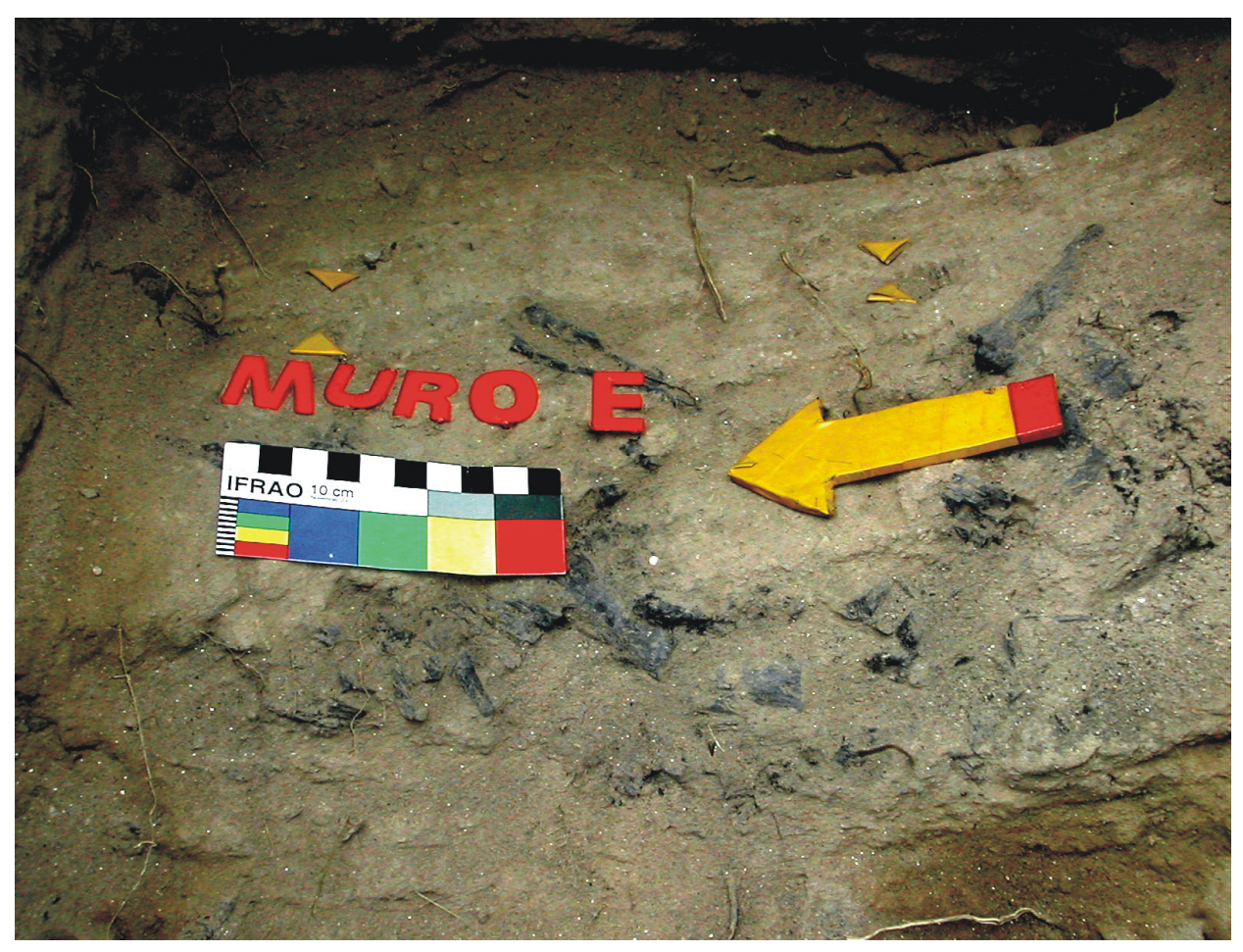

Figura II-43 

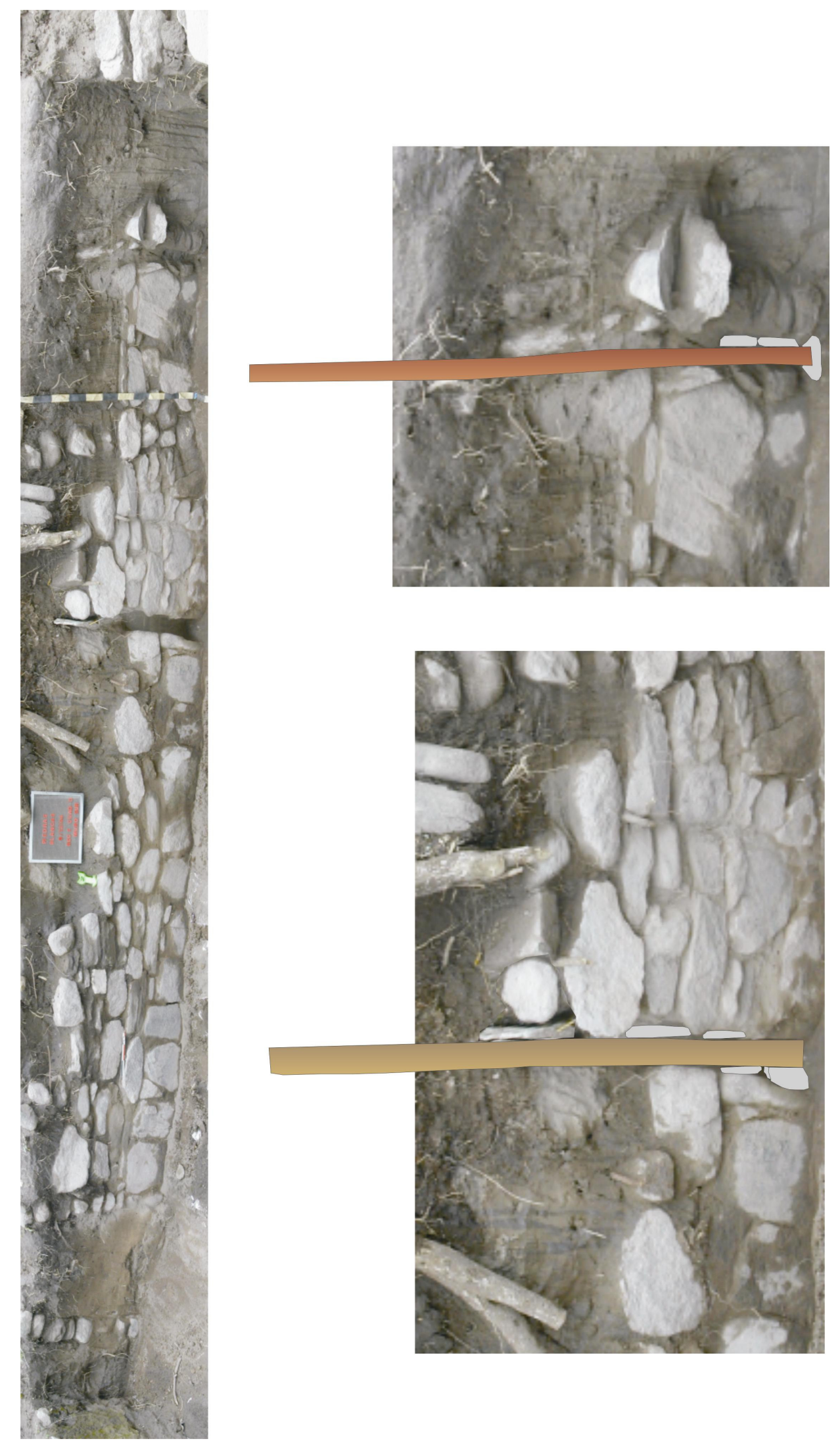

Figura V.II-44 